UNIVERSIDADE DE SÃO PAULO

INSTITUTO DE QUÍMICA DE SÃO CARLOS

QUÍMICA ORGÂNICA E BIOLÓGICA

BARBARA BERNARDIM DE SOUZA

NOVAS METODOLOGIAS EM SÍNTESE ORGÂNICA EMPREGANDO

O REARRANJO DE WOLFF EM DIAZOCETONAS INSATURADAS

TESE DE DOUTORADO

SÃO CARLOS

2017 


\section{NOVAS METODOLOGIAS EM SÍNTESE ORGÂNICA EMPREGANDO O REARRANJO DE WOLFF EM DIAZOCETONAS INSATURADAS}

Tese apresentada ao Instituto de Química de São Carlos da Universidade de São Paulo como parte dos requisitos para a obtenção do título de doutor em ciências.

Área de concentração: Química Orgânica e Biológica

Orientador: Prof. Dr. Antonio Carlos Bender Burtoloso

\section{Exemplar revisado}

O exemplar original encontra-se em ACERVO RESERVADO NA BIBLIOTECA DO IQSC-USP

\section{SÃO CARLOS}


Com amor e carinfo.

Dedico este trabalho a minha mãe, Cirlene Bernardím. 


\section{AGRADECIMENTOS}

Muito obrigada a Deus que em verdes pastagens me fez repousar e me conduziu a águas tranquilas (Salmo 23). A luz que me guiou foi mais forte do que as dificuldades que me cercaram.

Ao meu orientador, Prof. Antonio Burtoloso. Obrigada por me receber em seu laboratório em fevereiro de 2011 para o mestrado, e em fevereiro de 2013, pelo aceite para o doutorado. Foram 6 anos de convivência diária cercada de excelentes e marcantes momentos, com muitas dicas, puxões de orelha, conselhos, alegrias e discussões saudáveis. Admiro muito o seu compromisso com a educação, a forma como conduz a ciência, com muita ética, profissionalismo e seriedade. Aprecio seu otimismo e a maneira como consegue ver o lado bom da vida. Palavras são poucas para agradecer a atenção e orientação que recebi. Levarei todo o aprendizado comigo para onde for.

Ao Prof. Gonçalo Bernardes, pela maravilhosa oportunidade de passar 1 ano em seu laboratório na Inglaterra. Tive um dos melhores anos da minha vida em Cambridge, sendo recebida com muito respeito e consideração. Sou extremamente grata pela chance que me foi dada. Admiro muito seu dinamismo, entusiasmo e energia com a ciência e com a vida.

A minha família, em especial minha mãe Cirlene Bernardim que sempre soube apoiar as minhas escolhas. Pela compreensão em todas as vezes que precisei estar ausente me dedicando ao doutorado. Por tudo, meu muito obrigada, eu não teria chegado até aqui sem o seu apoio! O mesmo agradecimento a minha avó querida Maria de Lurdes, a dona Nenê.

Aos colegas do laboratório "Warner Bruce Kover": Gabriela, Rafael Mafra, João Victor, Edson, Rafael Gallo, Camila, Patrícia, Annes, Meire, Nikolas, Larissa, Lucas, Alexander, Juliana, Ives, Isac, Leonardo, Gustavo, Yuri, Daniel, Fernanda e Ketllyn; e os técnicos Marília e João Pedro. Agradeço muito pelos bons momentos, as discussões sobre química e os cafezinhos após o almoço! Vocês são incríveis e 
sentirei muita saudade da nossa rotina no laboratório!!! Agradeço também à Edvania por todo o carinho e amizade.

Aos colegas de Cambridge (UK), GBernardes Lab: Maria J. Matos, Benjamin, Annabel, Shuang, Russel, Ester, Bruno, Jean, Omar, Núria, Lavinia, Paco, Pedro, Maria Maneiro e Claudia. Whiffen Lab, Phipps Group e ITC: Philip, Georgi, JSP, Szabo, Madalina, Holly, Fabio, Ricardo, Daniel, Claudio, Bruna, José, Lorène, Michael, Stephen, Juan, Elena, Victor, Maria Gonzales, Myeong, Jim, Andreas, Grazia, Francesco, Timo, Swapna, Kat, Gina e Giulia. Espero poder tomar um pint com vocês novamente! Muito obrigada por tornar o dia a dia no laboratório tão divertido! Agradeço em especial ao Philip Murray por ter ajudado a corrigir a minha tese sem mesmo falar português e à Maria J. Matos por toda amizade e companheirismo.

Aos colegas do Mattson Group (USA): Erica, Veronica, Andi, Tom, Josh, Allie, e Tyler e em especial a Prof. Anitta Mattson pela oportunidade e por me receber em seu grupo de pesquisa em Ohio.

Aos amigos da UNICENTRO: Bruna, João, Tiago, Daniele e Silvano. Obrigada por fazerem parte da minha vida desde que nos conhecemos na graduação, em 2007! Vocês são da minha família.

Aos colegas do Laboratório de Biocatálise, em especial ao Prof. André Porto por todo o apoio e pelos potes de sorvetes e doces doados ao nosso grupo. Agradeço também os demais colegas do IQSC.

A todos os professores que participaram e incentivaram a minha formação acadêmica, em especial ao meu orientador de iniciação científica Mauro Chierici Lopes e ao responsável pelo meu interesse e ingresso na área de síntese orgânica, Kleber Thiago de Oliveira.

À Central de Análises Químicas e Instrumentais (CAQI) do IQSC, da Universidade Federal de São Carlos, e da Universidade de Cambridge. Obrigada Sylvana e André por atender as análises de RMN. 
À Universidade de São Paulo, em especial ao Instituto de Química de São Carlos, por todo apoio técnico e institucional. Agradeço ao pessoal da secretaria de pósgraduação, Andréia, Gislei, Gustavo, Daniela e Silvia, vocês são sensacionais!

Um agradecimento especial à Fundação de Amparo à Pesquisa do Estado de São Paulo (FAPESP) pela concessão da bolsa de doutorado (2012/22274-2), estágio BEPE (2015/07509-1) e pelo suporte financeiro aos projetos do grupo. Agradeço também pelo apoio técnico e pela aprovação da bolsa de pós-doutoramento (2016/18771-1).

Em geral, agradeço a todos que contribuíram de alguma forma para que eu chegasse até aqui. 
"We cannot expect in the immediate future that all women who seek it will achieve full equality of opportunity in science. But if women are to start moving towards that goal, we must believe in ourselves or no one else will believe in us; we must match our aspirations with the competence, courage and determination to succeed."

Rosalyn Yalow, Nobel Prize in Physiology or Medicine (1977)

"Life is not easy for any of us. But what of that? We must have perseverance and above all confidence in ourselves. We must believe that we are gifted for something and that this thing must be attained."

Marie Curie, Nobel Prize in Chemistry (1911) and Physics (1903) 


\section{RESUMO}

BERNARDIM DE SOUZA, Barbara. Novas metodologias em síntese orgânica empregando o rearranjo de Wolff em diazocetonas insaturadas, 2017. 445 páginas. Tese (Doutorado em Ciências com ênfase em Química Orgânica e Biológica) - Instituto de Química de São Carlos da Universidade de São Paulo. São Carlos, 2017.

Entre os diferentes tipos de substratos diazocarbonílicos encontrados na literatura, as diazocetonas $\alpha, \beta$-insaturadas têm mostrado promissoras aplicações como intermediários multifuncionais. Este trabalho de tese foi dividido em três capítulos e visou expandir as aplicações das diazocetonas $\alpha, \beta$-insaturadas em química e bioquímica. No primeiro capítulo, quatro exemplos de diazocetonas insaturadas (5456) foram apresentadas como plataformas para a síntese direta de amidas e ésteres $\beta, \gamma$-insaturados (17 exemplos, 61-77) via Rearranjo de Wolff em 64-92\% de rendimento. Quando diazocetonas derivadas de amino-aldeídos foram utilizadas, isósteros peptídicos foram obtidos como demonstrado na síntese rápida e eficiente do nitróxido JP4-039. No mesmo capítulo, um estudo aprofundado comprovando a eficiência de diferentes lâmpadas comerciais (CFL e LED) para promover o Rearranjo de Wolff é apresentado, representando uma alternativa sustentável. Neste estudo, cinco exemplos de diazocetonas insaturadas $(1,86-88)$ foram convertidas em 27 exemplos das respectivas amidas (100-108), ésteres e ácidos carboxílicos (78-85 e 89-98) com rendimentos entre 50 e 99\%. O segundo capítulo é voltado a expansão da química das diazocetonas insaturadas para o estudo de reações de cicloadição [2+2] e [4+2]. Foi demonstrado o preparo de 13 exemplos (141-153) ésteres precursores para reações de cicloadições via rearranjo de Wolff na presença de álcoois alílicos e as tentativas que culminaram na síntese de um cicloaduto de DielsAlder $( \pm)$ 171. O capítulo 3 foi dedicado ao emprego das diazocetonas $\alpha, \beta$-insaturadas para a modificação química específica de proteínas. As diazocetonas foram aplicadas com sucesso para este fim, assim como inspiraram o desenvolvimento de um novo método promissor de bioconjugacão seletiva para cisteínas.

Palavras-chave: Diazocetonas insaturadas. Rearranjo de Wolff. Cicloadições. Bioconjugação. Proteínas. 


\begin{abstract}
BERNARDM DE SOUZA, Barbara. New methodologies in organic synthesis using the Wolff rearrangement from unsaturated diazoketones. 445 pages. Thesis (Doutorado em ciências com ênfase em Química Orgânica e Biológica) - University of Sao Paulo - São Paulo. São Carlos, 2017.
\end{abstract}

Among the various types of diazocarbonyl substrates found in the literature, $\alpha, \beta-$ unsaturated diazoketones have shown a number of promising applications as multifunctional intermediates. This thesis is divided into three chapters, aimed at expanding the reactivity of such $\alpha, \beta$-unsaturated diazoketones for synthetic chemistry and chemical biology applications. In the first chapter, unsaturated diazoketones (5456) are presented as platforms for the direct synthesis of $\beta, \gamma$-unsaturated amides and esters (17 examples, 61-77) via a Wolff rearrangement reaction (64-92\% yield). When diazoketones derived from amino-aldehyde are substrates, peptidic isosters are obtained, as demonstrated in the efficient synthesis of the nitroxide drug, JP4-039. In the same chapter, a study demonstrating the efficiency of several commercial light sources (CFL and LED) to promote the Wolff rearrangement was described, representing a sustainable alternative to UV lamps for this interesting reaction. Four examples of unsaturated diazoketones $(1,86-88)$ were converted in 27 examples of amides (100-108), esters and carboxylic acids (78-85 and 89-98) with yields between 50 and $99 \%$. The second chapter sought to expand the chemistry of unsaturated diazoketones for the study of intramolecular [2 + 2] and [4 +2] cycloaddition reactions. The preparation of the precursor esters (13 examples, 141-153) for cycloaddition reaction was demonstrated by the Wolff rearrangement in the presence of allylic alcohols, and the attempt then culminated in the synthesis of a Diels-Alder cycloadduct $( \pm)$ 171. Chapter 3 was devoted to the use of $\alpha, \beta$-unsaturated diazoketones for the sitespecific chemical modification of proteins. These have been successfully demonstrated for this purpose, as well as inspiring the development of a promising new method for selective bioconjugation of cysteines.

Keywords: Unsaturated diazoketones. Wolff rearrangement. Cycloaddition. Bioconjugation. Proteins. 


\section{LISTA DE ESQUEMAS}

Esquema 1 Diversos métodos empregados no preparo de compostos diazocarbonílicos. a) acilação do diazometano; b) transferência de diazo; c-f) outras metodologias.

Esquema 2 Formação de pirazolinas a partir de cloretos de ácidos $\alpha, \beta$-insaturados e diazometano. 29

Esquema 3 Preparação de diazocetonas insaturadas por Wotiz e Buco...........................................30

Esquema 4 Preparação de $\alpha$-diazocetonas $\alpha, \beta$-insaturadas por Chapman e Rosenquist...................30

Esquema 5 Método de transferência de diazo desformilativa, descrito por Regitz e Gupta................31

Esquema 6 Mecanismo de transferência de diazo desformilativa descrita por Regitz. .......................31

Esquema 7 Metodologia descrita por Danheiser a partir de metil-cetonas $\alpha, \beta$-insaturadas. ...............32

Esquema 80 método descrito por Aller para a síntese de diazocetonas, utilizando iminofosforanas.

Esquema 9 a'-Diazocetonas $\alpha, \beta$-insaturadas como dienos em reações de Diels-Alder e síntese de cliclopentenonas.

Esquema 10 Reação de benzanelação e síntese total do produto natural Maesanina a partir de diazocetonas insaturadas. .34

Esquema 11 Diazocetonas insaturadas aplicadas em reações de polimerização. ..............................35

Esquema 12 Sintese de butirolactonas a partir de diazocetonas insaturadas. ..................................... 35

Esquema 13 Diazocetonas insaturadas em reações multicomponentes. ............................................36

Esquema 14 Adição de aza-Michael na diazocetona insaturada 25 ..................................................37

Esquema 15 Adição de aza-Michael na diazocetona insaturada 28..............................................

Esquema 16 Reagentes de olefinação 31 e 32 de HWE desenvolvidos por Burtoloso. ......................39

Esquema 17 Preparação dos diazofosfonatos 31 e 32 por Burtoloso e colaboradores........................40

Esquema 18 Síntese da preussina a partir da diazocetona insaturada 20 .......................................4

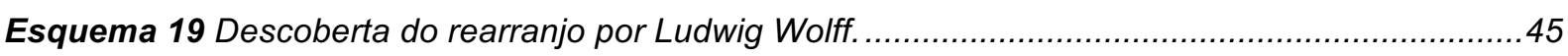

Esquema 20 Conversão de diazocetonas em cetenos e seus derivados via Rearranjo de Wolff. ......46

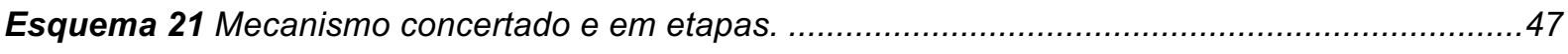

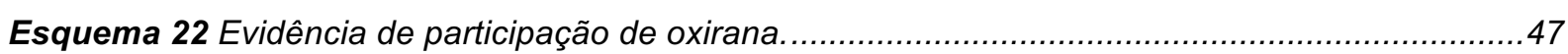

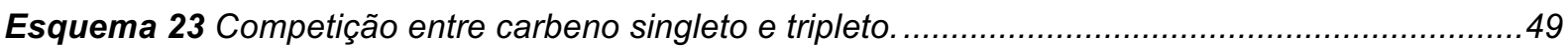

Esquema 24 Reação de Homologação de Arndt-Eistert e contração de anéis. .................................50

Esquema 25 Homologação de Arndt-Eistert aplicada na síntese de produtos naturais. .....................51

Esquema 26 Objetivo 1 e 2: Metodologia para a síntese de amidas, ciclobutanos e cicloexenos. .....53

Esquema 27 Conceito-chave: rearranjo de Wolff a partir de diazocetonas $\alpha, \beta$-insaturadas permitindo

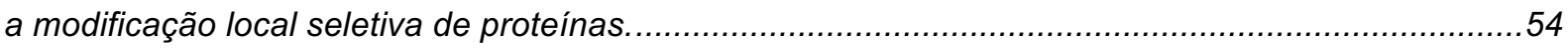

Esquema 28 Síntese em 6 etapas do composto JP4-039 por Wipf. ...............................................57

Esquema 29 Síntese de diazocetonas $\alpha, \beta$-insaturadas a partir de aldeídos. .......................................58

Esquema 30 Síntese das amidas $\beta, \gamma$-insaturadas a partir das diazocetonas $\alpha, \beta$-insaturadas 55 e 56.

Esquema 31 Síntese do nitróxido JP4-039 em duas etapas a partir do (S)-N-Boc-Leucinal 60..........64 
Esquema 32 Dois exemplos mostrando aquecimento e excesso de catalisador ou de sais de prata. 65

Esquema 33 Lâmpadas CFL aplicadas no rearranjo de Wolff. ......................................................66

Esquema 34 Rearranjo de Wolff fotoquímico a partir da diazocetona 1 na presença de diferentes

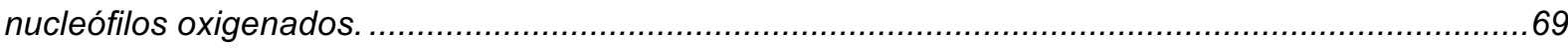

Esquema 35 Disposição experimental do Rearranjo de Wolff usando lâmpadas de LED...................70

Esquema 36 Amidas obtidas usando lâmpada LED para promover o rearranjo de Wolff. ...................71

Esquema 37 Síntese do composto JP4-039 usando lâmpada LED e de alta pressão de mercúrio....72

Esquema 38 Expansão da química das diazocetonas insaturadas para a síntese de cliclobutanos e

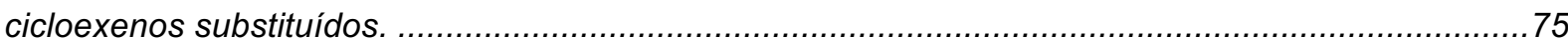

Esquema 39 Exemplos de produtos naturais contendo ciclobutanos e cicloexanos. .........................75

Esquema 40 Cicloadição [2+2] intramolecular descrito por Padwa e Colaboradores.........................77

Esquema 41 Diazocetonas insaturadas preparadas para o estudo de cicloadição [2+2] e [4+2] ........78

Esquema 42 Diazocetona 53 obtida a partir da reação de HWE a partir do fenilglioxal 121 ..............79

Esquema 43 Preparo do fenilglioxal 121 a partir da oxidação da acetofenona $122 \mathrm{com} \mathrm{SeO} \mathrm{O}_{2}$..........80

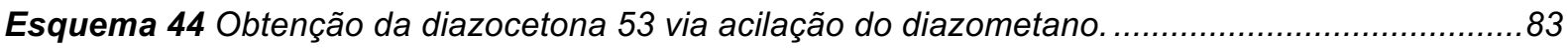

Esquema 45 Rotas alternativas para a obtenção da diazocetona 53 a partir dos aldeídos 127 e 128.

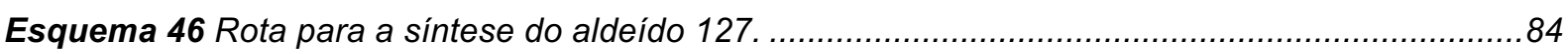

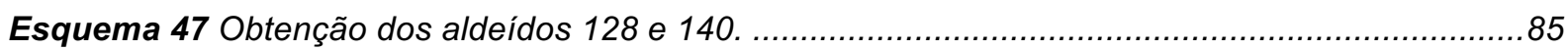

Esquema 48 Ésteres insaturados 141-533 obtidos através do rearranjo de Wolff na presença dos

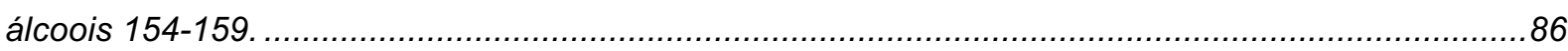

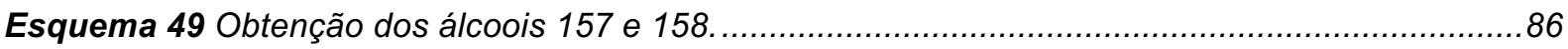

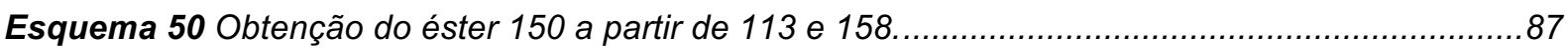

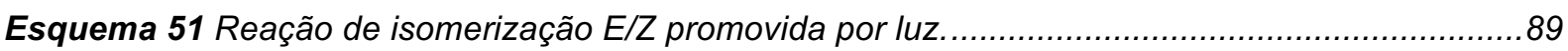

Esquema 52 Substratos explorados por Padwa em fotocicloadições [2+2] ..................................93

Esquema 53 Tentativa de Rearranjo de Wolff a partir da diazocetona 53.........................................93

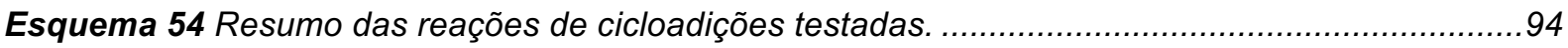

Esquema 55 Substratos da série G-J a serem testados nas reações de Diels-Alder. .........................97

Esquema 56 Reação de Diels-Alder a partir de 150: produtos endo-171 e exo-171.........................99

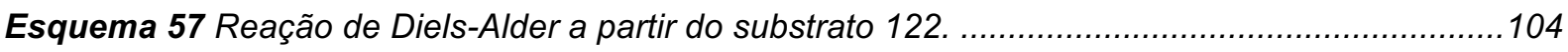

Esquema 58 Compostos carbonilacrílicos como reagentes para modificação específica de proteínas.

Esquema 59 Métodos para bioconjugação de cisteínas. ..........................................................110

Esquema 60 Reação do éster carbonilacrílico 174 com cisteína 173 e lisina 174 ..............................111

Esquema 61 Adição de Michael nas posições $\alpha$ e $\beta$ do reagente carbonilacrílico...............................113

Esquema 62 Adição de N-Boc-Cis-OMe 173 nos reagentes carbonilacrílicos 178-180 ..................114

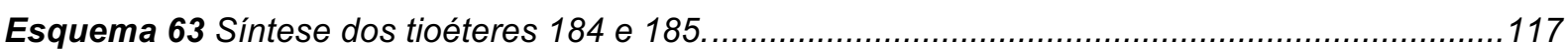

Esquema 64 Estabilidade do aduto de Michael 179 na presença de glutationa 186.......................118

Esquema 65 Comprovação de seletividade através do reagente de Ellman's $187 . \ldots \ldots \ldots \ldots \ldots \ldots \ldots \ldots \ldots . . . . .122$

Esquema 66 Síntese dos reagentes carbonilacrílicos funcionalizados 194 e 195.............................124 
Esquema 67 Bioconjugação da Annexina V, C2Am e albumina com os reagentes 194 e 195. 124

Esquema 68 Diazo-lisozima empregada em reações de cicloadição 1,3-dipolar com ciclooctinos...131

Esquema 69 Exemplos de diazocompostos aplicados na modificação de proteínas. 132

Esquema 70 Reações bioortogonais a partir de diazocompostos. 132

Esquema 71 Reação de adição de cisteína 173 na diazocetona 53. 133

Esquema 72 Reação entre a diazocetona 1 e N-Boc-Cis-OMe 173 em acetonitrila.. 135

Esquema 73 Testes químicos de Ellman's com os conjugados de Annexina V-53. 136

Esquema 74 Condições testadas para a inserção de benzilamina na Annexina V-53. 138

Esquema 75 Tentativa de obtenção do aduto 196 via acilacão do diazometano com ácido 201. 139 


\section{LISTA DE FIGURAS}

Figura 1 Exemplos de transformações mediadas por compostos diazocarbonílicos. .........................27

Figura 2 Versatilidade das diazocetonas insaturadas.

Figura 3 Exemplos de diazocetonas $\alpha, \beta$-insaturadas preparadas pela metodologia desenvolvida por Burtoloso e colaboradores empregando aldeídos e os diazofosfonatos 31 e 32.

Figura 4 Conversão de diazocetonas insaturadas em heterocíclios nitrogenados

Figura 5 Diazocetonas insaturadas como blocos de construção para a síntese de heterocíclicos de nitrogênio.

Figura 6 Estrutura de um carbeno singleto e tripleto.

Figura 7 Exemplos de produtos naturais sintetizados por contração de anel via Rearranjo de Wolff. 52 Figura 8 a) JP4-039 inspirado no agente protetor XJB-5-131 com base na estrutura molecular do antibiótico gramicidina $S$. b) isóstero (E)-alceno. .57

Figura 9 Espectro de $R M N^{1} \mathrm{H}$ e expansão do espectro de IV obtido para a diazocetona 56 a partir do aldeído 60 (mistura de rotâmeros) em $\mathrm{CDCl}_{3}, 500 \mathrm{MHz}$.

Figura 10 Espectro de $\operatorname{RMN}^{1} \mathrm{H}$ e expansão do espectro de IV obtido para o ester $\beta$, $\gamma$-insaturado 62 a partir da diazocetona 56 após rearranjo de wolff na presença de anilina.

Figura 11 Estudos de HPLC quiral. A: composto racêmico; B: composto quiral a partir de N-Boc-Lleucinal.

Figura 12 Síntese de várias amidas $\beta, \lambda$-insaturadas em duas etapas a partir de aldeídos. ................63

Figura 13 Espectro de $R M N{ }^{1} \mathrm{H}$ e ${ }^{13} \mathrm{C}$ para a diazocetona 1 e o éster 56 68

Figura 14 Uso de diferentes nucleófilos de oxigênio e diferentes diazocetonas para o rearranjo de Wolff usando $L E D$

Figura 15 Diferentes substratos propostos para a reação de Cicloadição [2+2] e [4+2] .....................76

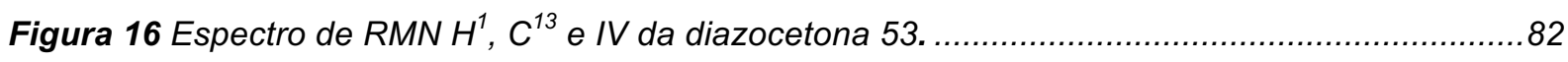

Figura 17 Espectro de $R M N{ }^{1} H$ para o isômero $Z$ 123.............................................................. 82

Figura 18 Espectro de $\mathrm{RMN}^{1} \mathrm{H}$ obtido para o ester $\beta$, $\gamma$-insaturado 145 a partir da diazocetona 1 após

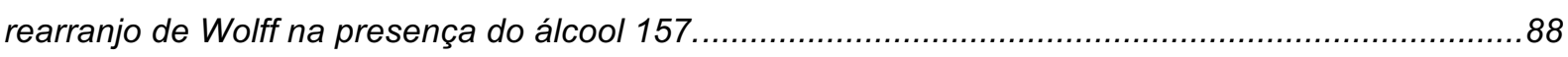

Figura 19 Espectros de RMN dos produtos de isomerização E/Z..................................................90

Figura 20 Espectro de $R M N^{1} H$ do produto 146, de isomerização 167 e 167a antes e após fotólise..92 Figura 21 Diagrama de energia para a a) reação de isomerização $E / Z$ b) dimerização ou

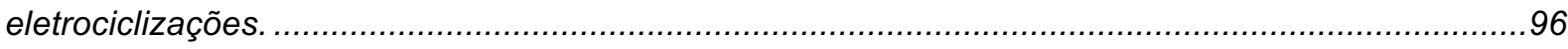

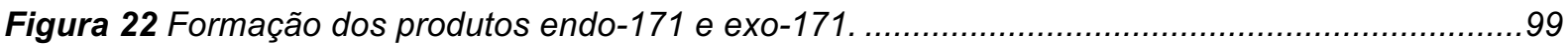

Figura 23 Análise de GC-MS: endo/exo 171 (m/z 286) em uma proporção de 1:1 .........................100

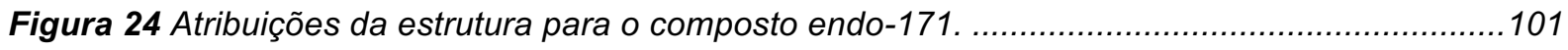

Figura 25 Espectro de ${ }^{1} \mathrm{H}$ e ${ }^{13} \mathrm{C}$ para o éster 150 e o produto de Diels-Alder 171 ............................102

Figura 26 Expansão região dos hidrogênios olefínicos do espectro de $\mathrm{RMN}^{1} \mathrm{H}$ do trieno 150 .........102

Figura 27 Análise esteroquímica relativa dos produtos endo-171 e exo-171...............................103

Figura 28 Adição conjugada de metil tiolato na maleimida e nos reagentes carbonilacrílicos...........112 
Figura 29 Velocidade de reação relativa calculada e resultados experimentais da adição de SMe- nos

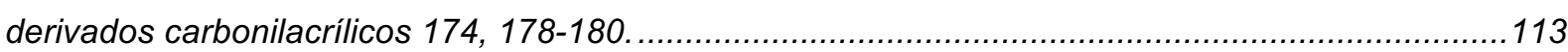

Figura 30 Determinação experimental da constante de velocidade de segunda ordem...................115

Figura 31 Experimento de competição de adição entre 174, 179 e N-metilmaleimida em 173. ........116

Figura 32 Comparação de estabilidade dos derivados 184 e 185. ................................................118

Figura 33 Reação de bioconjugação entre a Annexina V e a amida 179. ......................................120

Figura 34 Proteínas avaliadas para bioconjugação com 179.................................................121

Figura 35 Análise da estabilidade do conjugado albumina-179 e avaliação das propriedades de ligação da albumina modificada e não modificada com do receptor neonatal FcRn via SPR. ...........123

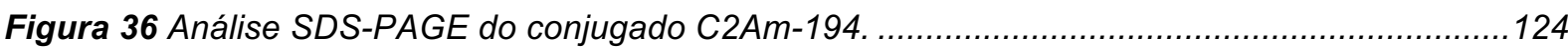

Figura 37 Imagens fluorescentes das células HEK293 apoptóticas e não apoptóticas (controle) após marcação com o conjugado Annexina V-194.

Figura 38 Bioconjugação quimioseletiva e equimolar do Trastuzumab com 179 e 194. Espectro de massas para a cadeia leve do anticorpo antes e após conjugação

Figura 39 Curvas BLI para o Trastuzumab-179, não modificado e as constantes $K_{D}$ obtidas.

Figura 40 Percentagem de células reveladas (filtro FITC) após o tratamento das células com o

Trastuzumab fluorescente e não fluorescente.

Figura 41 Espectro de $\mathrm{RMN}^{1} \mathrm{H}$ e de IV do aduto de Michael 196. ...............................................134

Figura 42 Espectro de $R M N{ }^{1} \mathrm{H}$ para a reação entre a diazocetona 1 e N-Boc-Cis-OMe 173...........135

Figura 43 Bioconjugação da Annexina V com a diazocetona 53. ...............................................136

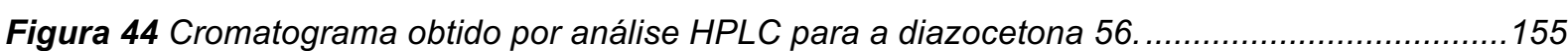

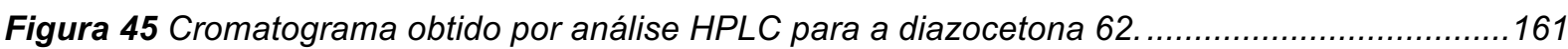

Figura 46 Cromatograma obtido para a separação dos isômeros endo/exo 171 por HPLC..............221

Figura 47 Experimento de competição entre 174, 179 e maleimida. .............................................229

Figura 48 Estabilidade por $R M N{ }^{1} H$ do aduto de Michael 179 na presença de GSH 186.................231

Figura 49 Estabilidade por HRMS do aduto de Michael 179 na presença de GSH 186 ..................232

Figura 50 Comparação de estabilidade dos derivados cromogênicos 184 e 185 .............................235

Figura 51 Análise de LC-MS obtida para as reações de bioconjugação (exemplo albumina)...........241

Figura 52 Análise LC-MS para a Annexina V-Cis316 ............................................................242

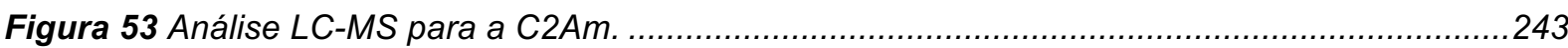

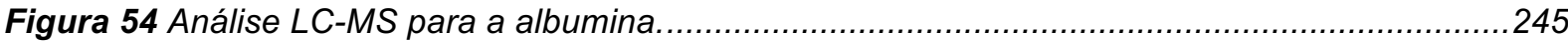

Figura 55 Análise LC-MS da reação entre a Annexina V e 174 após 27 h e 3 dias. ........................246

Figura 56 Análise LC-MS da reação entre a Annexina V e 178 após 27 h e 3 dias. .......................247

Figura 57 Análise LC-MS da reação entre a Annexina V e 179 após 27 h.....................................248

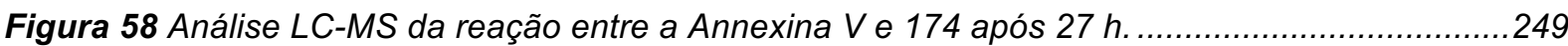

Figura 59 Análise LC-MS da reação entre Annexina V-Cis316 com o reagente de Ellman's 187.....250

Figura 60 Análise de LC-MS da reação entre Annexina V-CisEllman's 316 com 179.......................251

Figura 61 Análise LC-MS da reação entre Annexina V-Cis-179 com o reagente de Ellman's 187....252

Figura 62 Análise LC-MS da reação da C2Am-Cis-78 com 179................................................253

Figura 63 Análise de MSMS para o conjugado C2Am-179.........................................................25 
Figura 64 Análise LC-MS da reação da albumina com 179.

Figura 65 Estabilidade do conjugado de albumina-179 em plasma humano.

Figura 66 Experimento de SPR mostrando a afinidade de ligação da albumina não modificada e albumina-179 com o receptor FcRn. 259

Figura 67 Reação da albumina com o fluorescente 194. 260

Figura 68 Reação da albumina com o reagente PEG-195...............................................261

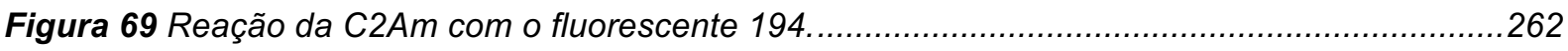

Figura 70 Reação da Annexina V com o fluorescente 194. 263

Figura 71 ESI-MS da cadeia pesada do trastuzumab (50594) após redução com 10 equiv. de TCEP. 265

Figura 72 ESI-MS da cadeia leve do Trastuzumab após a reação com 179 por $1 \mathrm{~h}$ em RT. 266

Figura 73 ESI-MS da cadeia pesada do Trastuzumab (50595) após a reação com 179 por $1 \mathrm{~h}$ em $R T$. 266

Figura 74 Determinação da atividade de ligação do anticorpo com o receptor HER2 por ELISA. ...268

Figura 75 Determinação da constante de ligação $\left(K_{D}\right)$ do anticorpo.......................................269

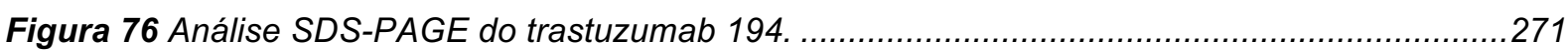

Figura 77 Análise SDS-PAGE do conjugado C2Am-194 ...................................................272

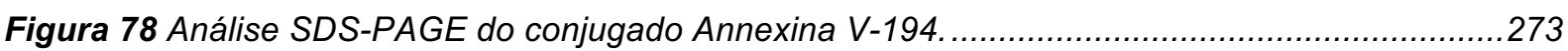

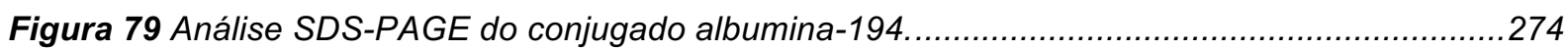

Figura 80 Bioconjugação da Annexina V-Cis316 com a diazocetona 53...................................277

Figura 81 Reação do conjugado de Annexina V-CisEllman's-187 com a diazocetona 53...............278

Figura 82 Reação do conjugado Annexina V-Cis316-53 com o reagente de Ellman's $187 . . . . . . . . . . .279$

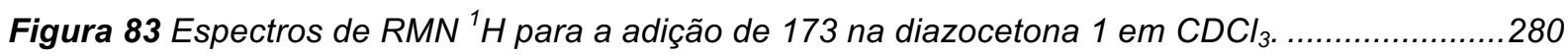

Figura 84 Espectros de $R M N{ }^{1} \mathrm{H}$ para a adição de 173 na diazocetona 1 em $C D C l_{3} / \mathrm{NaP}_{i}(p H 8.0,50$ $m M)$ deuterado 281

Figura 85 Estruturas calculadas (menor energia) para os compostos 174, 178-180 e maleimida. ...283 


\section{LISTA DE TABELAS}

Tabela 1 Rearranjo de Wolff usando lâmpadas CFL e LED como fontes luminosas. 67

Tabela 2 Condições de HWE estudadas a partir do cinamaldeído 119. ...........................................78

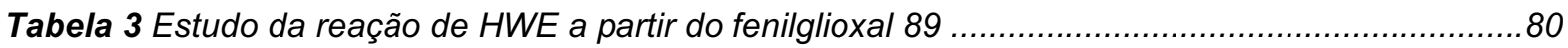

Tabela 4 Isomerização de 141 e 146 em meio básico. ............................................................91

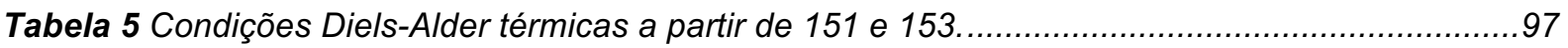

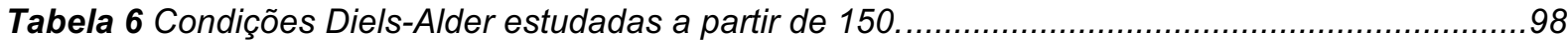

Tabela 7 Condições da reação de Diels-Alder catalisada por ácido de Lewis. ...............................104

Tabela 8 Bioconjugação de cisteínas em proteínas com 174, 178-180....................................119

Tabela 9 Condições testadas para a ciclopropanação da Annexina V-53. ..................................138

Tabela 10 Energias, entropias e frequências das estruturas calculadas de menor energia. ${ }^{a}$.............284 


\section{LISTA DE ABREVIATURAS, SIGLAS E ACRÔNIMOS}

$[\alpha]$ - Rotação específica (deg.mL/g.dm)

ADC - Antibody-drug-conjugate

$\mathrm{AcOH}$ - Ácido acético

AcOEt - Acetato de etila

AlBN - 2,2'-azobis(isobutironitrila)

aq. - Aquoso

Atm - Atmosfera

ATR - Attenuated total reflectance

BLI - Biolayer interferometry

Bn - Benzil

BSA - Albumina de soro bovino

$\mathrm{Cbz}$ - Carbobenzil

Boc - Tert-butóxicarbonil

$\mathrm{Bu}-$ Butil

$t$-Bu - Tert-butil

$\mathrm{cm}^{-1}$ - Número de onda

C2Am - C2A domain of Synaptotagmin-I

$\mathrm{CCl}_{4}$ - Tetracloreto de carbono

CDI - 1,1'-Carbonildiimidazol

CFL - Compact fluorescent lamp

CG - Cromatografia gasosa

COSY - Homonuclear correlation spectroscopy

D - Densidade

$\mathrm{d}$ - Dubleto (RMN) ou $d$ (deuterado)

DBU - 1,8-diazabiciclo[5.4.0]undec-7-eno

DBN - 1,5-diazabicyclo(4.3.0)no-5-eno

DCC - $N, N$-dicicloexilcarbodiimida

dd - Duplo dubleto

ddd - Duplo duplo dubleto

DFT - Density functional theory

DIBAL - Hidreto de diisobutilalumínio 
dhAA - Ácido dehidroascórbico

DIPEA - N,N-Diisopropiletilamina

DMAP - 4-(dimetilamino)piridina

DMEM - Dulbecco's Modified Eagle's Medium - high glucose (meio de cultura celular)

DMF - N,N-dimetilformamida

DMP - Periodinana de Dess-Martin

DMSO - Dimetil sulfóxido

DNA - Ácido deoxiribonucleico

dt - Duplo tripleto

EDTA - Ácido etilendiaminotetraacético

El - Ionização por impacto de elétron

ELISA - Enzyme-linked immunosorbent assay

Equiv. - Equivalentes

Et - Etil

ET - Estado de transição

$\mathrm{Et}_{2} \mathrm{O}$ - Éter dietílico

ESI - Ionização por electrospray

$\mathrm{eV}$ - Elétron volt

FBS - Fetal Bovine Serum

FITC - Isotiocianato de fluoresceína

g- Grama(s)

GSH - Glutationa

$\mathrm{h}$ - Hora(s)

HEK293 - Human Embryonic Kidney 293 cells

$\mathrm{Hz}-$ Hertz

HPLC - High-performance liquid cromatography

HRMS - High-resolution mass spectrometry

HOMO - Highest occupied molecular orbital

HOBt - 1-Hidróxibenzotriazól

HPR - Enzima Horseadish peroxidase

HWE - Horner-Hadsworth-Emmons

$\mathrm{Hz}-\mathrm{Hertz}$

IBCF - Isobutil cloroformato

ICS - Intersystem crossing 
IEF - Integral equation formalism

lgG - Immunoglobulin $G$

IV - Infavermelho

K - Quilo(s)

$\mathrm{L}$ - Litro(s)

LDA - Diisopropilamida de lítio

LED - Light-emitting diode

LUMO - Lowest unoccupied molecular orbital

$J$ - Constante de acoplamento (em RMN)

$\mathrm{MHz}$ - Megahertz

$\mathrm{M}-\mathrm{mol}^{\mathrm{L}-{ }^{-}}{ }^{\text {(mol por litro) }}$

$m / z$ - razão massa/carga

$\mathrm{M}^{+}$- Parent molecular ion

m-CPBA - ácido meta-cloroperbenzóico

Maj - Majoritário

Me - Metil

Min - Minoritário

$\mathrm{m}$ - Multipleto

Me -Metila

$\mathrm{MHz}$ - MegaHertz

$\mathrm{NaP}_{\mathrm{i}}$ - Tampão de fosfato de sódio

$\mathrm{NMO}$ - N-metilmorfolina-N-óxido

NBS - N-Bromosuccinimida

nOe - Nuclear Overhauser effect

$\mathrm{Nu}$ - Nucleófilo

PBS - Tampão fosfato salino

PCC - Piridínio clorocromato

PCM - Polarizable continuum model

$\mathrm{Ph}-$ Fenil

ppm - Partes por milhão

PPTS - $p$-Toluenosulfonato piridina

i-Pr - Isopropril

Py - Piridina

P.F - Ponto de fusão 
$\mathrm{R}_{\mathrm{f}}-$ Fator de retenção

RMN de ${ }^{13} \mathrm{C}$ - Ressonância magnética nuclear de carbono 13

RMN de ${ }^{1} \mathrm{H}$ - Ressonância magnética nuclear de hidrogênio

$\mathrm{s}-$ Singleto

SDS-PAGE - Sodium Dodecyl Sulphate-Polyacrylamide Gel Electrophoresis

sl - Singleto largo

SPR - Surface Plasmon Ressonance

$\mathrm{t}$ - Tripleto

t.a - Temperatura ambiente

TBS - Terc-butildimetilsilil

TCEP - (tris(2-carboxietil)fosfina)

td - Tripleto de dubletos

THF - Tetraidrofurano

TMB - 3,3',5,5'-Tetrametilbenzidina

TMS - Trimetilsilil ou tetrametilsilano

TOF - Time of flight

TLC - (analítica) Thin Layer Chromatography

Tris $\mathrm{HCl}$ - Tampão de hidrocloreto de Tris

Tween - Detergente de lavagem polissorbato

UV - Ultravioleta

$\delta$ - Deslocamento químico em ppm relativo ao solvente prótico

$v$ - Número de onda

Vis - Visível

A representação utilizada para a separação decimal nesta tese foi o ponto. 


\section{Sumário}

1 Introdução .......................................................................................................25

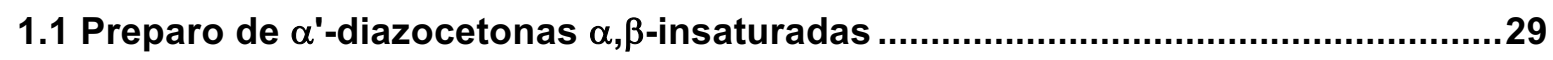

1.2 Aplicações das Diazocetonas $\alpha, \beta$-insaturadas....................................................33

1.3 Recentes avanços na síntese de $\alpha^{\prime}$-diazocetonas $\alpha, \beta$-insaturadas........................38

1.3.1 Diazofosfonatos como novos reagentes de olefinação..........................................39

1.4 Diazocetonas $\alpha, \beta$-insaturadas como blocos de construção em síntese ..............42

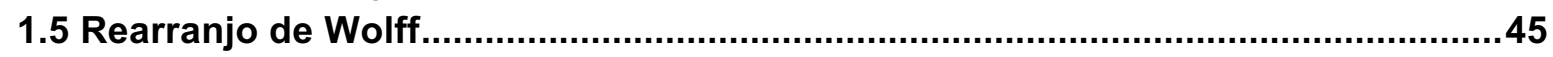

1.5.1 Aspectos mecanísticos do Rearranjo de Wolff...................................................4 46

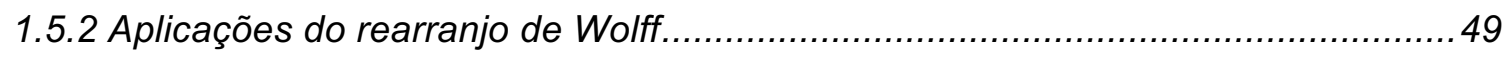

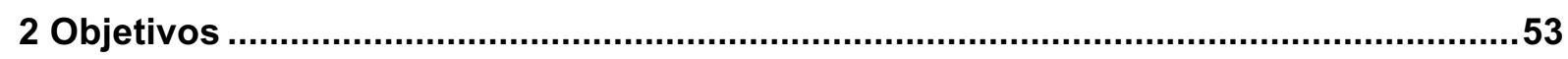

3 Diazocetonas insaturadas como substratos para o rearranjo de Wolff ......................55

3.1 Agente bioprotetor JP4-039...............................................................................56

3.1.1 Sintese das amidas $\beta, \gamma$-insaturadas e do composto JP4-039 ...........................58

3.2 Rearranjo de Wolff promovido por diferentes fontes luminosas ..........................64

3.2.1 Avaliando a fonte luminosa: síntese de amidas e ésteres ...................................66

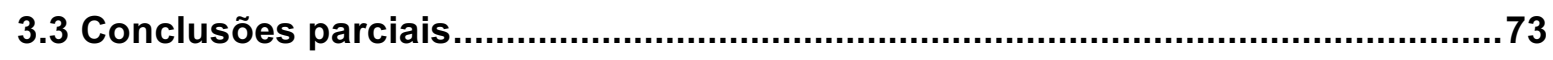

4 Diazocetonas insaturadas como precursoras de reações de cicloadições [2+2] e [4+2] ..........................................................................................................74

4.1 Preparo dos substratos para as cicloadições [2+2] e [4+2] ..................................77

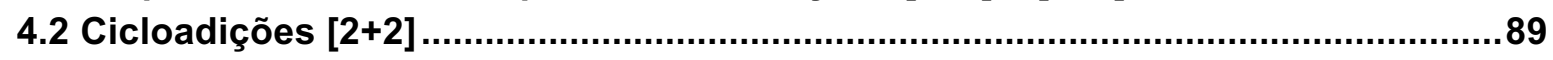

4.2.1 Aspectos mecanísticos da fotoisomerização $E / Z$................................................94 
4.3 Cicloadições [4+2]

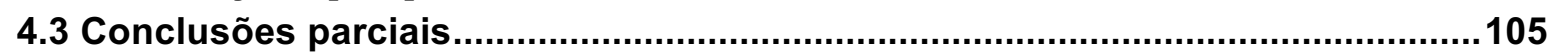

5 Diazocetonas insaturadas como reagentes para modificação de proteínas ............106

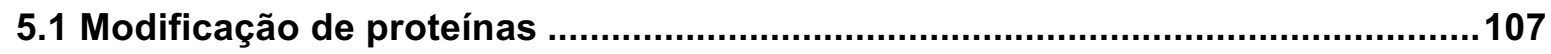

5.1.2 Estratégias para bioconjugação de proteínas ...................................................108

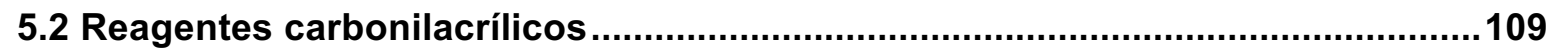

5.2.1 Construção de modelos de aminoácidos ........................................................ 110

5.2.3 Otimização da reação de bioconjugação de proteínas ........................................118

5.2.4 Bioconjugação de anticorpos com derivados carbonilacrílicos ........................... 126

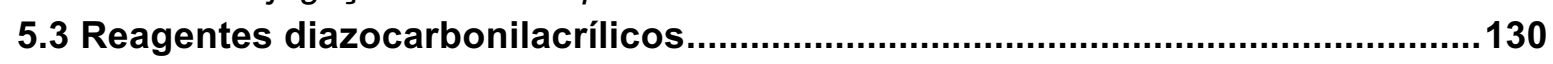

5.3.1 Adição de tio-Michael no reagente diazocarbonilacrílico ................................... 133

5.3.2 Bioconjugação de proteínas com o reagente diazocarbonilacrílico 53 ............... 135

5.3.3 Reações bioortogonais mediadas por carbeno/carbenóide .............................. 137

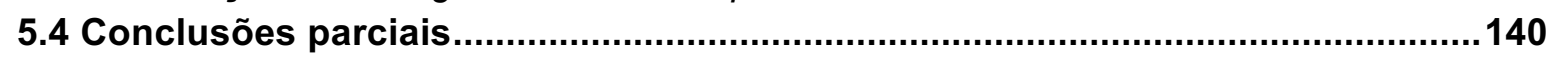

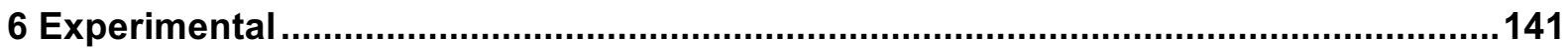

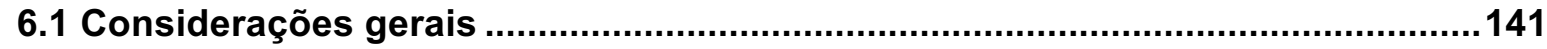

6.2 Procedimento para o preparo do diazofosfonato 32 ........................................145

6.3 Procedimento geral para a reação de Horner-Wadsworth-Emmons .....................146

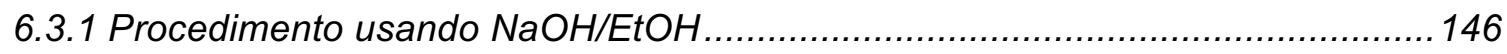

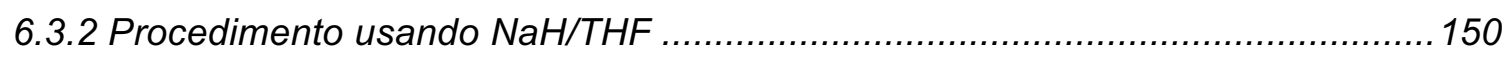

6.3.3 Procedimento usando DIPEA/LiCl............................................................. 156

6.4 Procedimento geral para o rearranjo de Wolff na presença de aminas (lâmpada

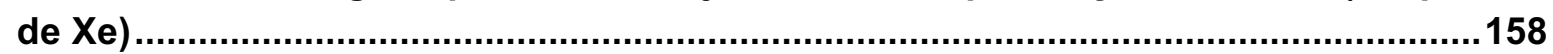

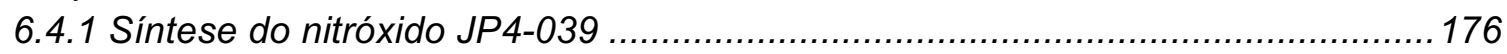

6.4.2 Procedimento para redução do JP4-039 com ácido ascórbico ...........................177

6.4 Procedimento geral para Rearranjo de Wolff usando lâmpada de LED..............182

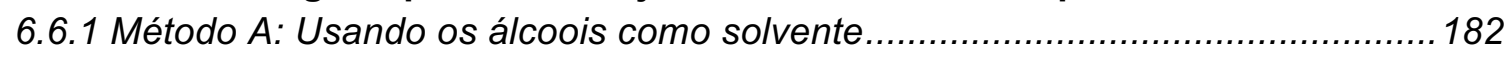

6.6.2 Método B: Usando acetato de etila como solvente ............................................... 193

6.6.3 Método C: Usando álcoois alílicos em acetonitrila (LED ou Xenônio) .................205

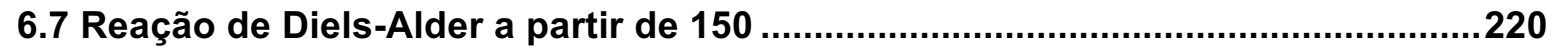

6.8 Síntese dos reagentes carbonilacrílicos..........................................................222

6.9 Procedimento geral para a adição de Michael.................................................225

6.10 Estudos de seletividade.............................................................................228

6.11 Experimento de competição entre 174,179, $\mathrm{N}$-metilmaleimida .........................229

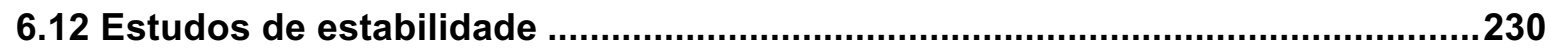

6.12.1 Estabilidade na presença de glutationa (GSH) ............................................2 230

6.12.2 Análise de retro-Michael por UV-VIS.......................................................23

6.12.3 Procedimento para avaliação de estabilidade dos compostos 184 e $185 \ldots \ldots . . .235$

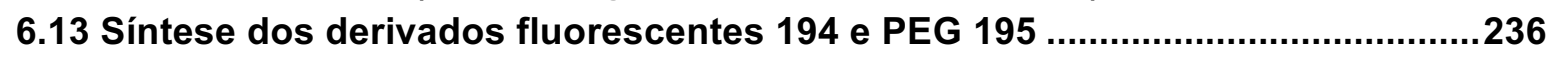

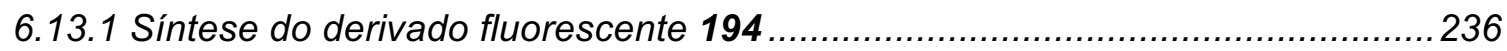

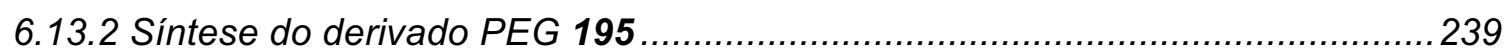

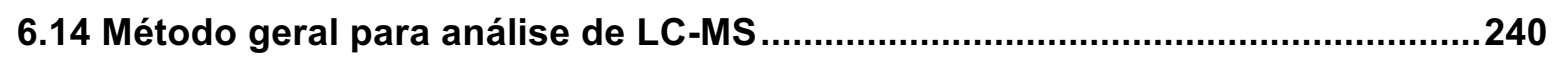

6.15 Análise do produto de conjugação de proteínas usando LC-MS .....................241

6.16 Proteínas utilizadas: Annexina V, C2Am e albumina .......................................242

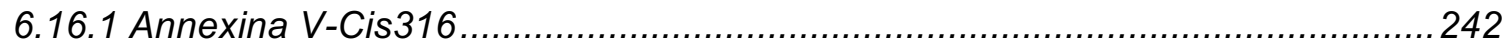

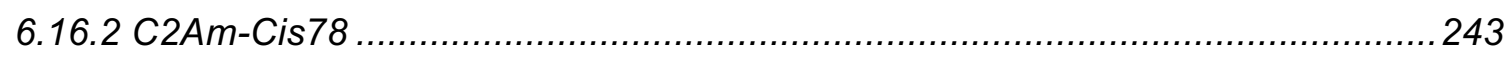

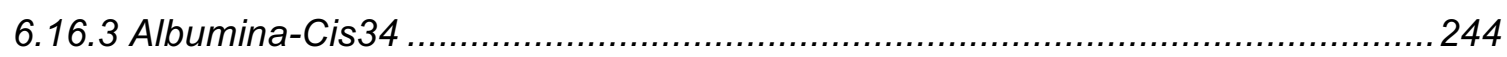


6.17 Procedimento para a bioconjugação com Annexina V-Cis316 .........................246

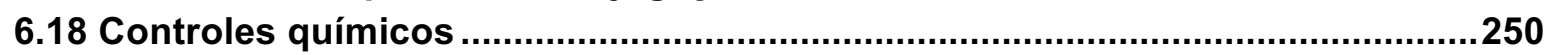

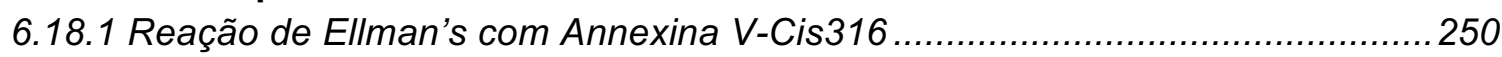

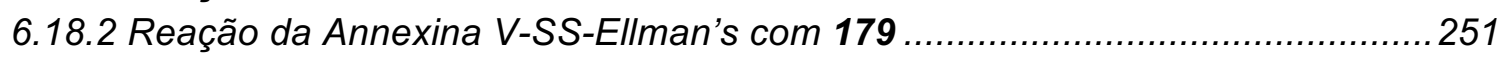

6.18.3 Reação do Conjugado Annexina-179 com o reagente de Ellman's ...................252

6.19 Procedimento para bioconjugação de C2Am-Cis78 ..........................................253

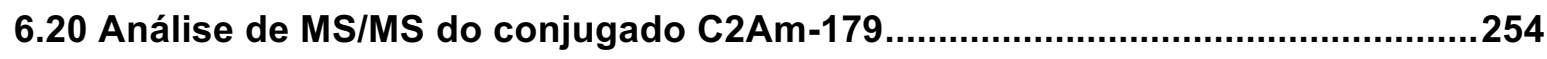

6.21 Procedimento para bioconjugação da Albumina-Cis34 ..................................256

6.22 Estabilidade do conjugado albimina em plasma.............................................257

6.23 Afinidade de ligação da albumina-179 com o receptor FcRn ..........................258

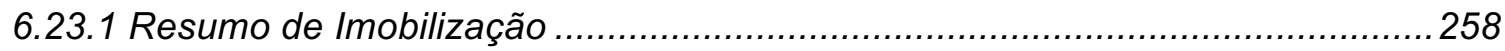

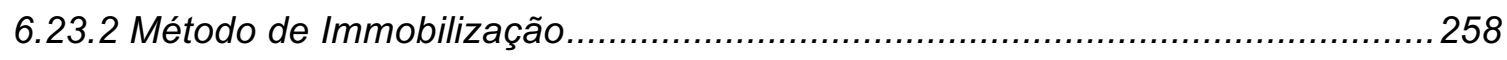

6.23.3 Método de análise de ligação em pH 5.5 ....................................................259

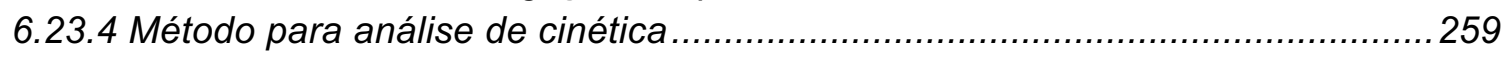

6.24 Reação de bioconjugação entre albumina e o composto fluorescente $194 \ldots . .260$

6.25 Reação de bioconjugação entre albumina e o reagente PEG $195 \ldots . . . \ldots \ldots . . . . . . . .261$

6.26 Reação de bioconjugação entre C2Am e o reagente fluorescente 194 ...........262

6.27 Bioconjugação da AnnexinA V-Cis316 com o reagente fluorescente 194.......263

6.28 Procedimento para bioconjugação do Trastuzumab............................................264

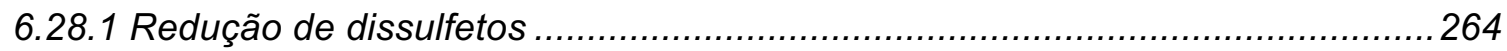

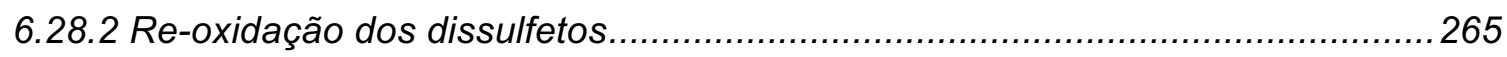

6.28.3 Reação de bioconjugação com 179 .........................................................26

$\mathbf{6 . 2 9}$ Citometria de fluxo .......................................................................................267

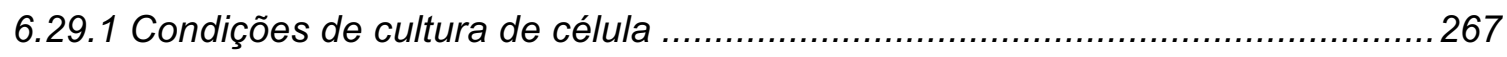

6.29.2 Determinação da especificidade do Trastuzumab-194 …...............................267

6.30 Experimento de ELISA ...............................................................................268

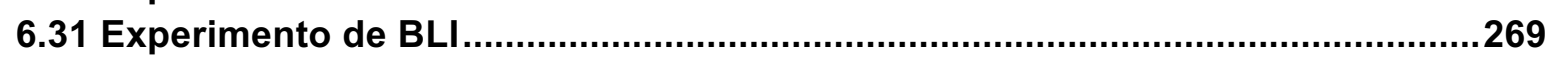

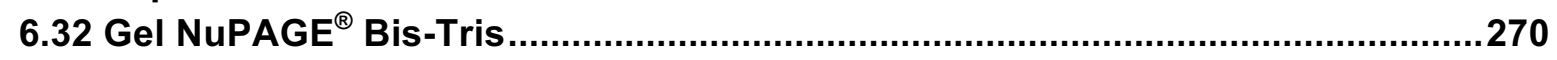

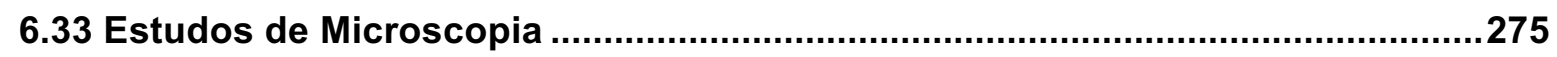

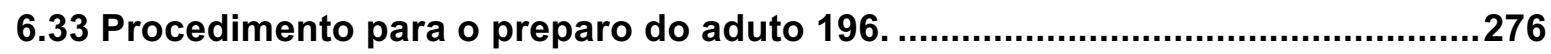

6.34 Procedimento para bioconjugação da Annexina V com a diazocetona 53.......277

6.36 Reação da Annexina V-88 com o reagente de Ellman's 187 .............................279

6.37 Reações de adição de Michael acompanhadas por RMN ${ }^{1} \mathrm{H}$..............................280

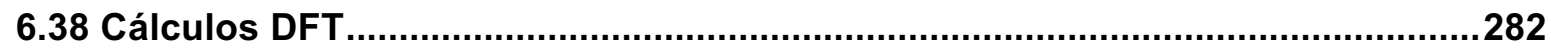

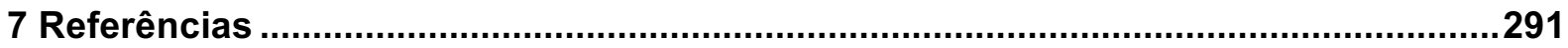

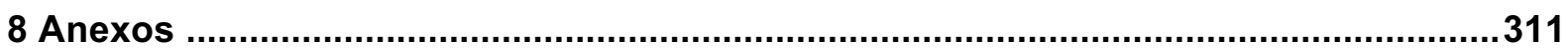




\section{Introdução}

Desde a síntese do diazoacetato de etila, primeira substância alifática contendo o grupo diazo em 1883 por Curtius, ${ }^{1}$ mais de um século se passou e a química dos compostos diazocarbonílicos continua progredindo e avançando nas mais diversas áreas da química. Múltiplos são os relatos descritos na literatura no que diz respeito ao seu preparo, propriedades físicas e químicas, bem como em suas numerosas e variadas aplicações.

Embora descobertos em 1883 por Curtius $^{1}$ e aplicados em 1912 por Ludwig Wolff $^{2,3}$ no rearranjo que hoje leva seu nome, os compostos diazocarbonílicos passaram despercebidos até 1927, ano em que Arndt e Eistert ${ }^{4}$ desenvolveram o primeiro protocolo geral para o seu preparo envolvendo a acilação do diazometano com cloretos de acila. Com o desenvolvimento concomitante do uso de anidridos mistos como agentes acilantes, este protocolo se tornou a rota mais importante para síntese de a-diazocompostos terminais a partir de ácidos carboxílicos (Esquema 1, a). Alguns anos mais tarde, com a necessidade de sintetizar os derivados cíclicos (bem como alguns sistemas acíclicos não acessados pelo método tradicional), a técnica de transferência diazo foi então desenvolvida por Regitz. ${ }^{5}$ Esse método, que envolve o uso de compostos carbonílicos com relativa acidez na posição a (por exemplo, compostos 1,3-dicarbonilados e compostos carbonílicos/carboxílicos com grupos aril na posição $\alpha$ ), uma base e uma sulfonil azida, leva a vantagem de ser brando e de evitar o uso de diazometano (Esquema 1, b). Outros métodos menos usuais (Esquema 1, c-f, respectivamente), embora não menos importantes, incluem a reação de Forster, diazotação de aminocetonas e aminoésteres, desidrogenação e decomposição de tosil-hidrazonas (reação de Bamford-Stevens). Algumas variações destas metodologias surgiram ao longo dos anos envolvendo basicamente a modificação dos protocolos experimentais e a utilização de reagentes alternativos.

\footnotetext{
' Páginas 25 - 44: reproduzido em partes com permissão a partir de Burtoloso, A. C. B.; Dias, R. M. P.; Bernardim, B. $\alpha, \beta-$-Unsaturated Diazoketones as Useful Platforms in the Synthesis of Nitrogen Heterocycles. Acc. Chem. Res. 2015, 48 (4), 921-934.

Pages 25 - 44: reproduced in part with permission from A. C. B.; Dias, R. M. P.; Bernardim, B. $\alpha, \beta-U n s a t u r a t e d$ Diazoketones as Useful Platforms in the Synthesis of Nitrogen Heterocycles.

Acc. Chem. Res. 2015, 48 (4), 921-934

Copyright 2015 American Chemical Society.
} 
a Acilação do diazometano

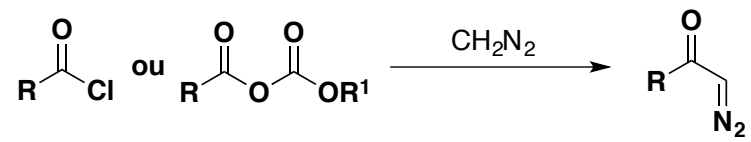

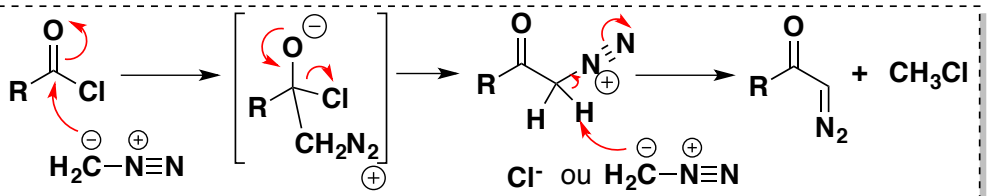

b Transferência de diazo
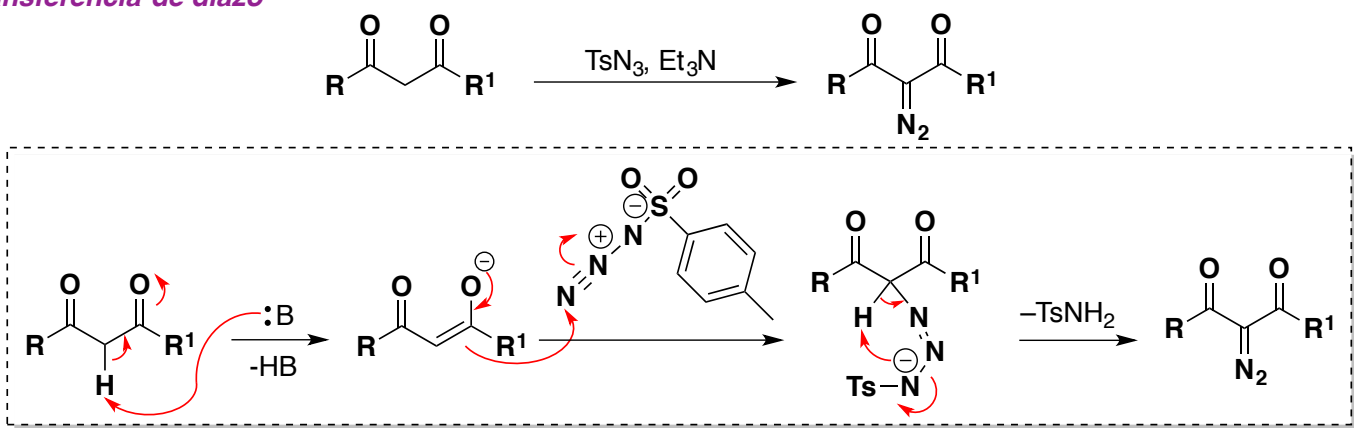

c-f Outras metodologias

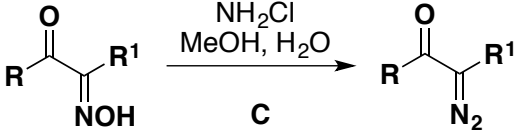

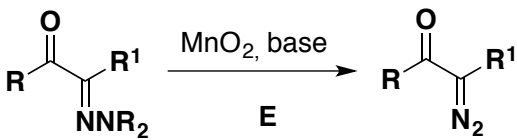

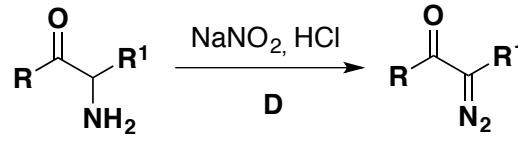

base,

solvente

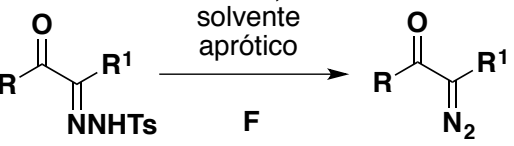

Esquema 1 Diversos métodos empregados no preparo de compostos diazocarbonílicos. a) acilação do diazometano; b) transferência de diazo; c-f) outras metodologias.

Após o desenvolvimento dos dois principais protocolos para a síntese de um composto diazocarbonílico (acilação do diazometano e transferência de diazo), o desenvolvimento da química foi rápida e um crescimento exponencial de novas metodologias e aplicações emergiu na literatura. ${ }^{6-12}$ Conforme representado na Figura 1, inserção de ligações polares $(\mathrm{O}-\mathrm{H}, \mathrm{N}-\mathrm{H}, \mathrm{P}-\mathrm{H}, \mathrm{S}-\mathrm{H}$, Se-H) e não polares $(\mathrm{C}-\mathrm{H}, \mathrm{Si}-\mathrm{H})$ catalisadas por metais de transição, homologação de cadeia e contração de anel através do rearranjo de Wolff, ciclopropanações, formação de ilídeos e cicloadições são algumas de uma infinidade de transformações que os compostos diazocarbonílicos podem mediar (Figura 1). 


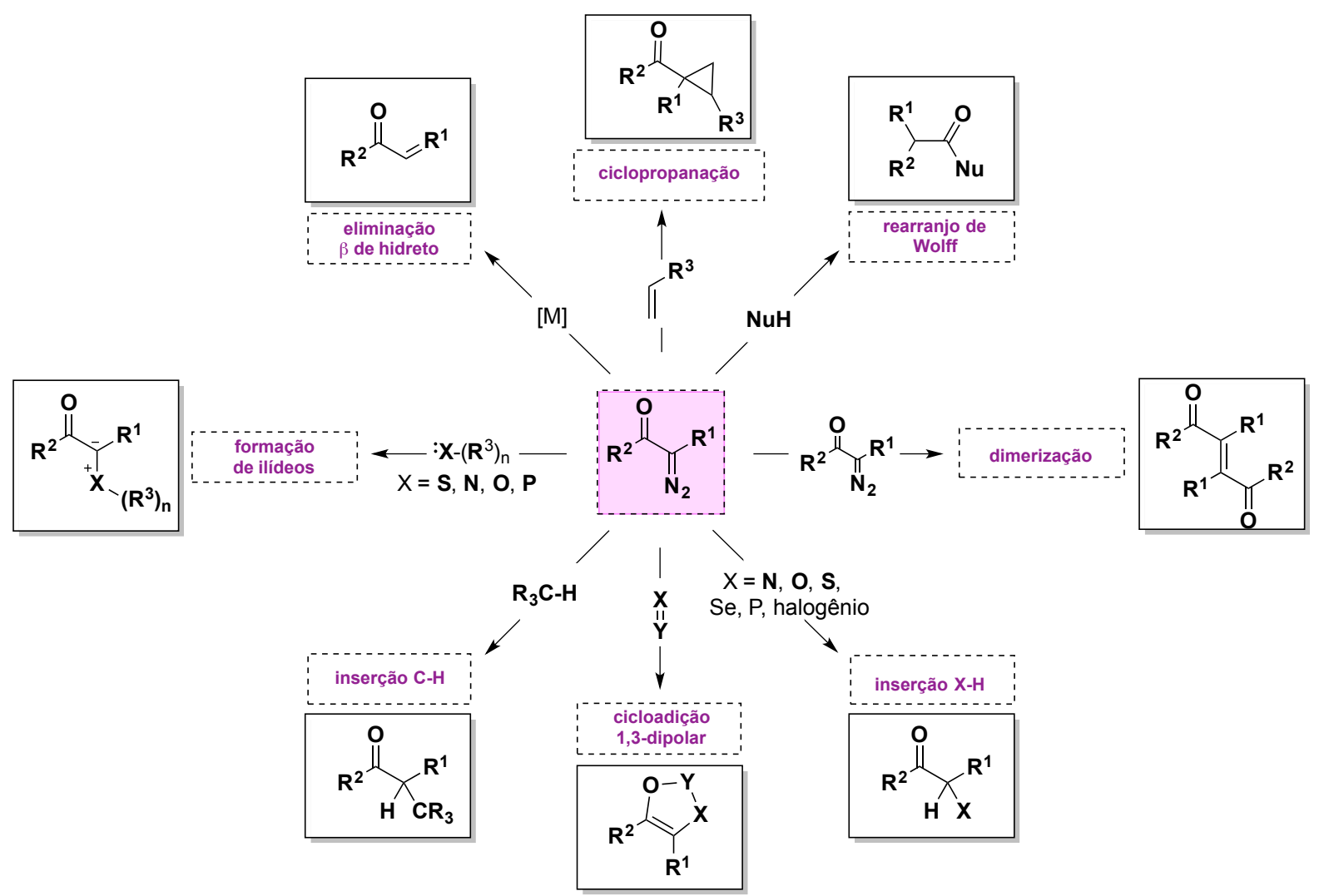

Figura 1 Exemplos de transformações mediadas por compostos diazocarbonílicos.

Embora uma grande variedade estrutural possa ser alcançada atualmente a partir dos protocolos de transferência diazo e acilação de diazometano, uma lacuna ainda existe no que se refere aos casos mais peculiares, como por exemplo, as versáteis diazocetonas $\alpha, \beta$-insaturadas. Este tipo de composto diazocarbonílico pode desempenhar um papel promissor como reagentes multifuncionais. Contendo uma ligação dupla, uma cetona e uma função diazo na mesma molécula, estes substratos podem atuar como importantes blocos de construção em síntese orgânica. Além de todas as reações pertinentes aos compostos carbonílicos (redução, adição nucleofílicas entre outras), a insaturação pode ser funcionalizada, por exemplo, através de reações de diidroxilação, aminodiidroxilação, epoxidação, adições de Michael e em reações de Diels-Alder (Figura 2). Neste caso, a função diazo pode ainda mediar todas as reações pertinentes aos compostos diazocarbonílicos previamente descritas na Figura 1 da presente introdução. 


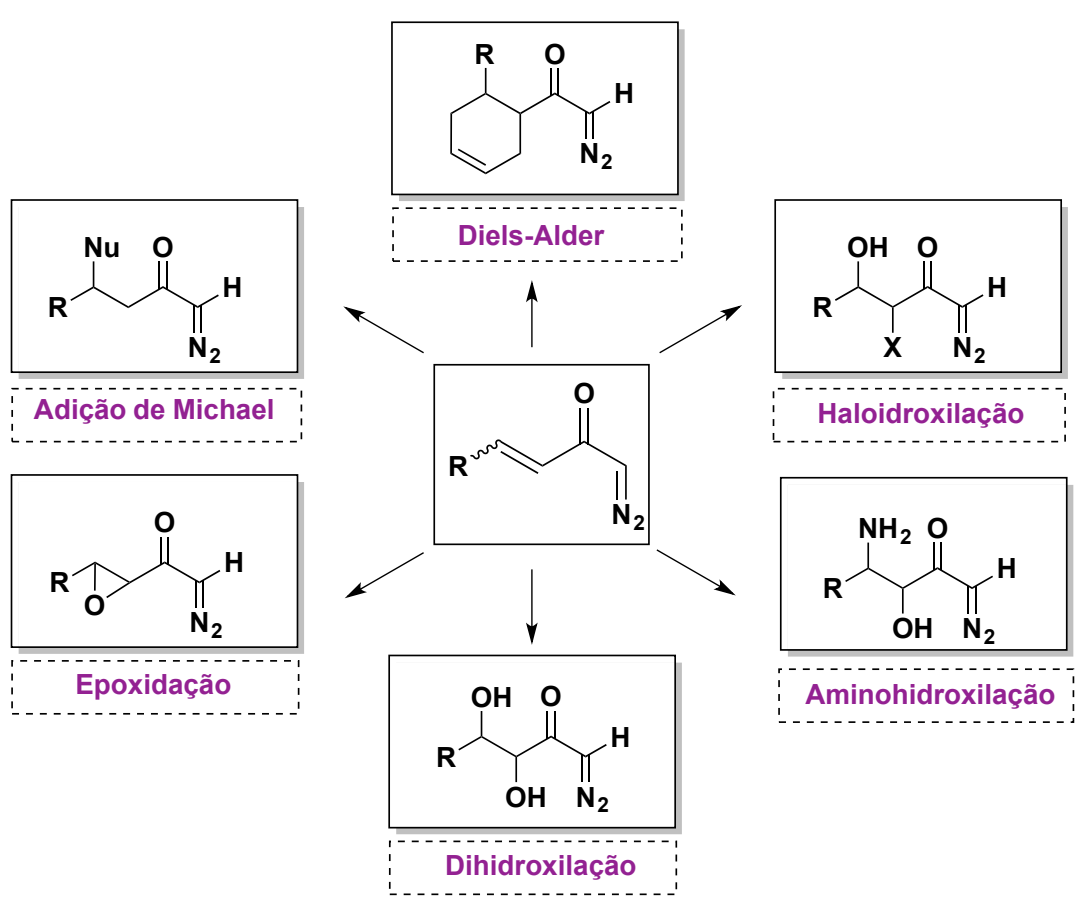

Figura 2 Versatilidade das diazocetonas insaturadas.

Considerando a grande variedade de transformações que os compostos diazocarbonílicos insaturados podem propiciar, métodos que forneçam estes substratos de forma eficiente e com vasta diversidade estrutural são de grande valia. Enquanto a literatura descreve milhares de exemplos envolvendo a síntese e aplicação de diazocetonas saturadas e aril-diazocetonas, ${ }^{6,8,13}$ apenas alguns estudos têm se dedicado aos seus derivados insaturados. Basicamente, este fato se deve à grande dificuldade em sua síntese. Por exemplo, ao menos que sejam utilizados cloretos de acila ou anidridos mistos insaturados substituídos na dupla ligação, a preparação de diazocetonas insaturadas pela clássica acilação do diazometano fornece rendimentos pouco satisfatórios. Neste caso, pirazolinas são formadas como produtos principais provenientes de uma cicloadição 1,3-dipolar entre o diazometano e a ligação dupla conjugada (Esquema 2).

$\mathrm{Na}$ seção que se segue, um breve histórico será apresentado ilustrando a evolução dos métodos para a preparação de diazocetonas $\alpha, \beta$-insaturadas. 


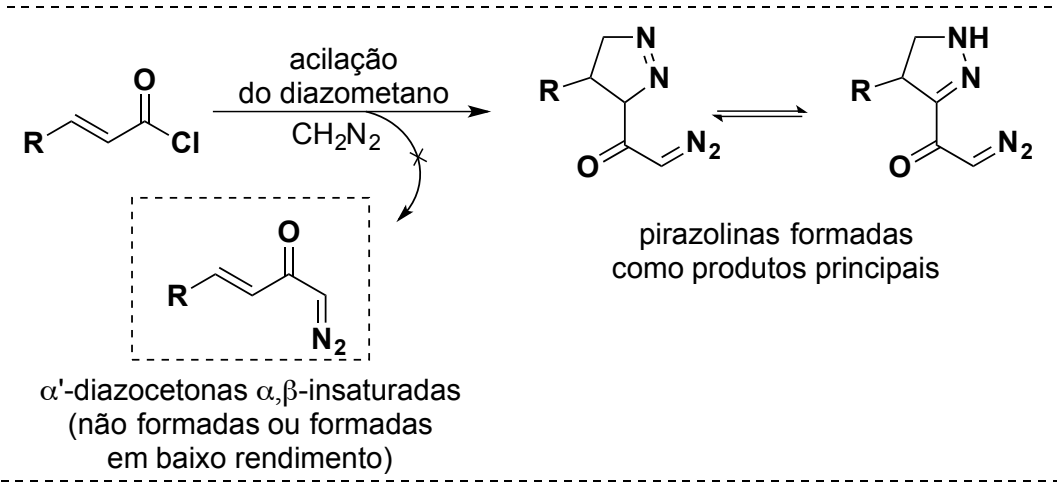

Esquema 2 Formação de pirazolinas a partir de cloretos de ácidos $\alpha, \beta$-insaturados e diazometano.

\subsection{Preparo de $\alpha^{\prime}$-diazocetonas $\alpha, \beta$-insaturadas}

A partir de 1936, ano em que Grundmann ${ }^{14}$ reportou a primeira tentativa de se preparar uma diazocetona $\alpha, \beta$-insaturada a partir da reação entre diazometano e cloretos de ácidos $\alpha, \beta$-insaturados, a química destas promissoras diazocetonas permaneceu durante muito tempo ligada essencialmente aos derivados pirazolínicos (Esquema 2). Embora a funcionalidade "diazocetona" tenha sido formada, a ligação dupla reage completamente com o diazometano utilizado. Contendo um cloreto de ácido e uma dupla ligação conjugada na mesma molécula, os derivados $\alpha, \beta-$ insaturados possuem dois sítios reativos frente diazoalcanos, levando à formação de misturas isoméricas de pirazolinas provenientes da reação de cicloadição [3+2]. Esta observação inspirou Wotiz e Buco ${ }^{15}$, em 1955, para o desenvolvimento de um estudo mais aprofundado da mesma transformação utilizando cloretos de ácidos derivados do ácido cinâmico ( $\left.p-\mathrm{H}, p-\mathrm{OMe}, p-\mathrm{NO}_{2}\right)$ (Esquema 3). Novamente pirazolinas foram formadas como produtos principais. Entretanto, usando-se soluções bastante diluídas, um rendimento de $24 \%$ da diazocetona insaturada $1(p-\mathrm{H})$ foi obtido. No caso do substrato ( $p$-OMe), a diazocetona 2 não pôde ser formada. No mesmo ano, Moore ${ }^{16}$ avaliou a estabilidade e as características das pirazolinas derivadas de diazoacetatos e diazocetonas $\alpha, \beta$-insaturadas, bem como a viabilidade de suas reações subsequentes na presença de $\mathrm{HCl}$ e benzoato de prata/MeOH para o Rearranjo de Wolff. 


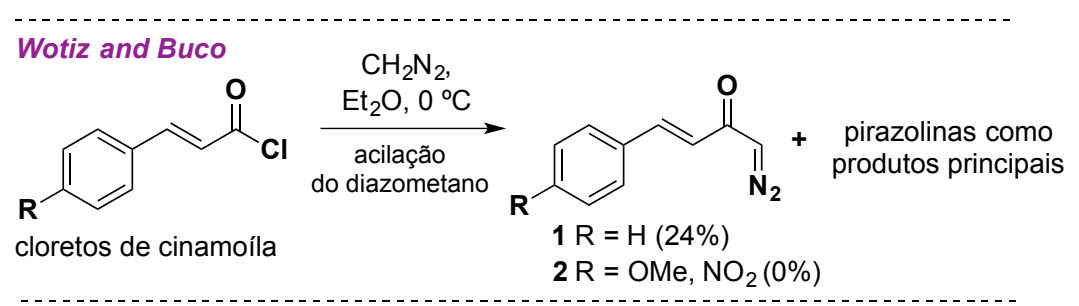

Esquema 3 Preparação de diazocetonas insaturadas por Wotiz e Buco.

Uma maneira interessante de se evitar a formação das pirazolinas foi descrita em 1976 por Chapman e Rosenquist. ${ }^{17}$ A ligação dupla, previamente "protegida", foi formada posteriormente à formação da diazocetona. Neste trabalho, a acilação do diazometano na presença de cloretos de ácido contendo um átomo de bromo na posição $\beta$, seguida de eliminação na presença da base $D B U$, forneceu quatro exemplos de diazocetonas insaturadas em rendimentos variando entre 32 e $77 \%$ (Esquema 4).

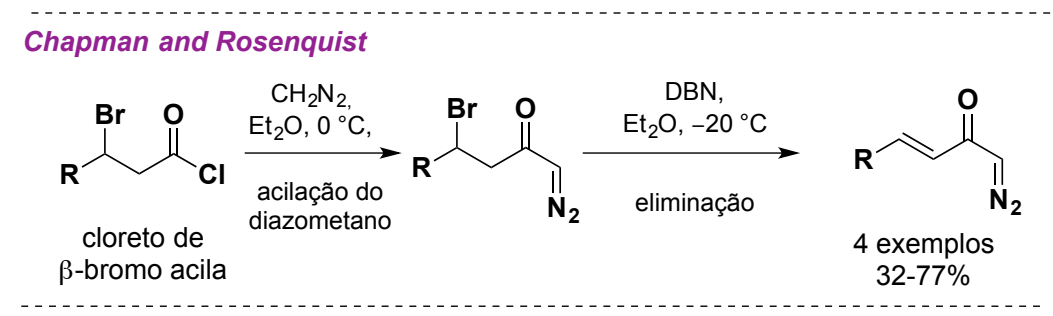

Esquema 4 Preparação de $\alpha^{\prime}$-diazocetonas $\alpha, \beta$-insaturadas por Chapman e Rosenquist.

No que diz respeito à formação de diazocetonas $\alpha, \beta$-insaturadas via transferência de diazo, o primeiro trabalho relatado neste sentido foi publicado por Regitz $^{18}$ e colaboradores em 1970 (Esquema 5). Neste trabalho, várias cetonas $\alpha, \beta-$ insaturadas foram ativadas na presença de formiato de etila 3 para fornecer compostos 1,3-dicarbonilados após uma condensação de Claisen (Esquema 5). Estes compostos 1,3-dicarbonilados foram convertidos nas respectivas diazocetonas após uma reação de transferência diazo e subsequente desformilação através da fragmentação de um intermediário triazolínico (Esquema 6). Cabe frisar, que esta transferência de diazo desformilativa, inicialmente descrita por Regitz em 1964 para diazocetonas saturadas, ${ }^{5,19,20}$ foi uma importante contribuição porque cetonas simples geralmente não reagem diretamente com sulfonil azidas. Quatro anos mais tarde, Gupta $^{21}$ propôs a substituição do formiato de etila por oxalato de dietila na etapa de condensação de Claisen. Esta modificação permitiu uma melhora nos rendimentos 
obtidos. Como por exemplo, a obtenção da diazocetona 1 ( $R=P h)$ em $75 \%$ de rendimento.

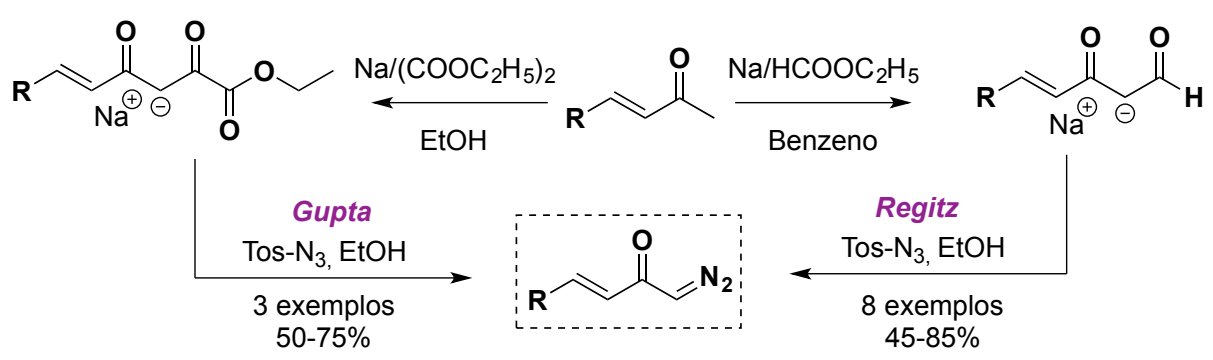

Esquema 5 Método de transferência de diazo desformilativa, descrito por Regitz e Gupta.

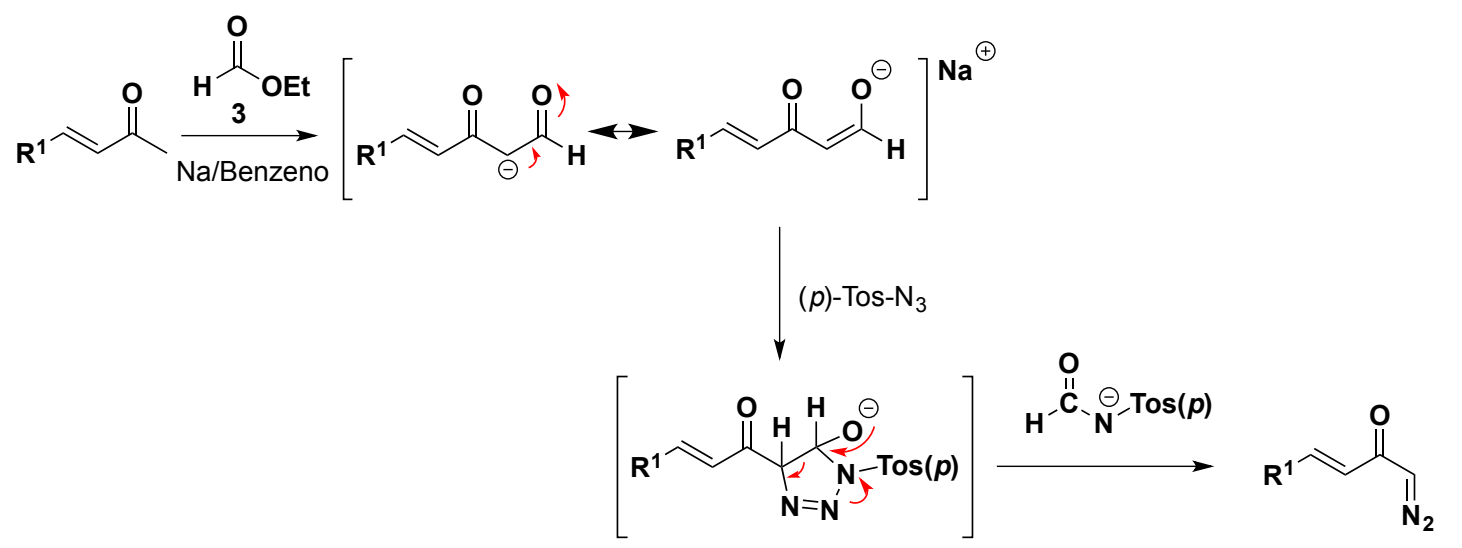

Esquema 6 Mecanismo de transferência de diazo desformilativa descrita por Regitz.

Embora o método desenvolvido por Regitz e Gupta tenha representado um grande avanço no preparo das diazocetonas $\alpha, \beta$-insaturadas, esta metodologia deformilativa não foi muito difundida na literatura devido principalmente às condições reacionais drásticas empregadas ( $\mathrm{Na}, \mathrm{EtOH}$ ou benzeno, temperatura ambiente, 1248 horas), bem como pela baixa regiosseletividade na formação dos enolatos antes da condensação de Claisen (neste caso, refere-se aos derivados saturados). Em 1990, muitas das limitações mencionadas acima foram solucionadas com o desenvolvimento da metodologia proposta por Danheiser. ${ }^{22,23}$ Este método, um tipo diferente de transferência de diazo destrifluoracetilativa, é eficiente tanto para sintetizar diazocetonas saturadas como insaturadas. Esta modificação do método do Regitz consiste em empregar condições cinéticas (LiHMDS, $-78^{\circ} \mathrm{C}, 30$ minutos) para gerar enolatos de metil-cetonas e o uso trifluoroacetato de 2-trifluoroetila como o agente de acetilação (Esquema 7). Na verdade, esta transferência de diazo 
destrifluoracetilativa foi descrita anteriormente por Doyle em um único exemplo, ${ }^{24}$ embora usando LDA como base e não se estendendo para diazocetonas insaturadas. Com a modificação de Danheiser seis exemplos (4a-f, Esquema 7) foram preparados, provando ser um protocolo superior e mais geral para a preparação de $\alpha^{\prime}$-diazocetonas $\alpha, \beta$-insaturadas.

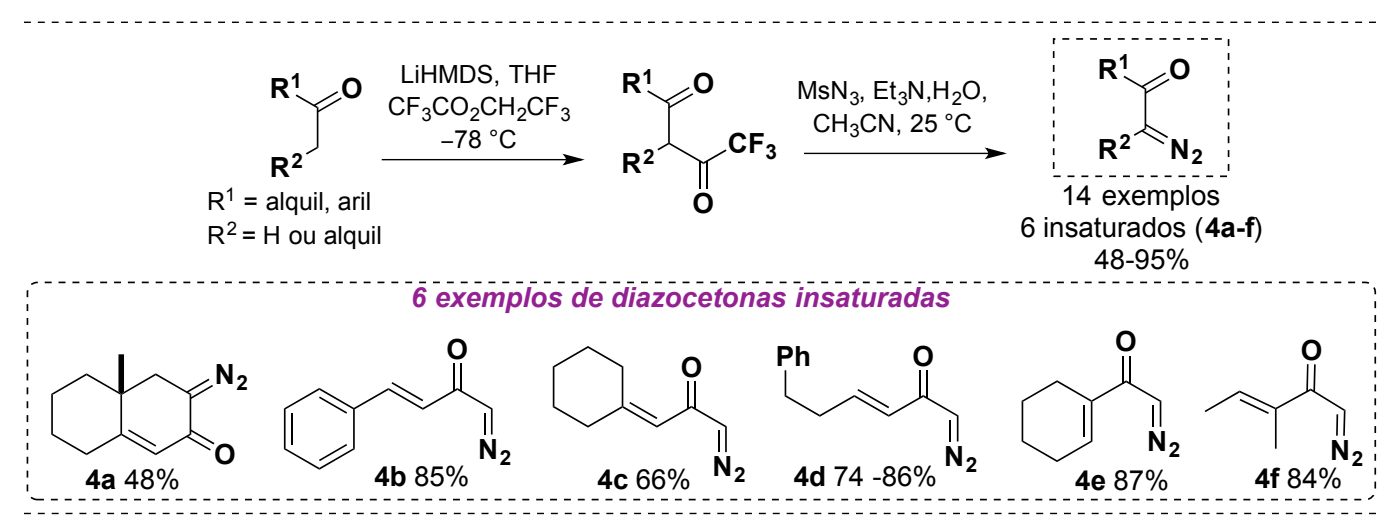

Esquema 7 Metodologia descrita por Danheiser a partir de metil-cetonas $\alpha, \beta$-insaturadas.

Outro método interessante para se alcançar diazocetonas sem a necessidade de utilização de diazometano ou azidas foi descrito por Aller ${ }^{25}$ e colaboradores em 2000 (Esquema 8). O método consiste na acilação de uma cianoiminofosforana com cloretos de acila, que após hidrólise, leva a formação de cloretos de hidrazoílas. Estes cloretos, em seguida, são convertidos em diazocetonas após o tratamento com cloreto de tosila catalítico. Embora um único exemplo para a síntese da diazocetona $\alpha, \beta-$ insaturada 1 ( $R=\mathrm{Ph}, 75 \%$ de rendimento) foi descrito, o método é interessante e tem potencial para ser estendido a outras diazocetonas insaturadas.
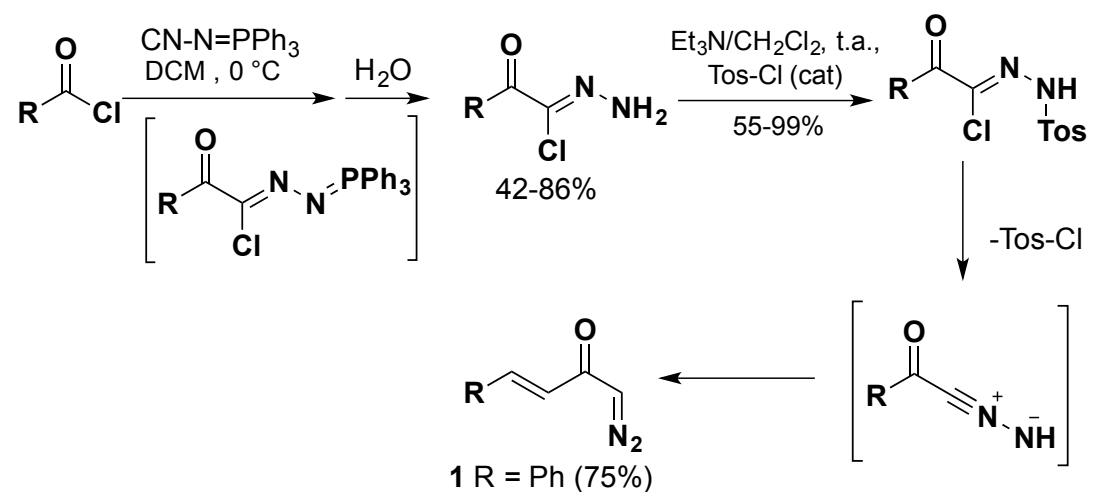

Esquema 8 O método descrito por Aller para a síntese de diazocetonas, utilizando iminofosforanas. 


\subsection{Aplicações das Diazocetonas $\alpha, \beta$-insaturadas}

Conforme mencionado anteriormente, em contraste com as diversas aplicações sintéticas encontradas na literatura a partir de diazocetonas saturadas ou aril-diazocetonas, poucos são os exemplos envolvendo seus derivados insaturados. ${ }^{26-43}$ Os esquemas 9-15 ilustram de forma resumida e esquemática os principais exemplos onde essas diazocetonas são empregadas como plataformas em síntese. A primeira aplicação sintética de uma diazocetona insaturada como substrato foi descrita em 1981, quando Regitz aplicou a diazocetona 5 como dieno em reações de Diels-Alder (Esquema 9). ${ }^{26}$ Embora a função diazocetona não tenha sido posteriormente modificada, este exemplo merece ser citado devido ao fato de ter sido o primeiro a fazer uma transformação a partir destes compostos multifuncionais. Wenkert $^{29}$ empregou diazocetonas $\alpha, \beta$-insaturadas ( $\beta, \beta$-dialquiladas), como por exemplo a substrato 8, na preparação direta de ciclopentenonas. Empregando como catalisador o acetato de ródio, ciclopentenonas foram obtidas em $47-65 \%$ de rendimento após uma reação de inserção C-H (Esquema 9).

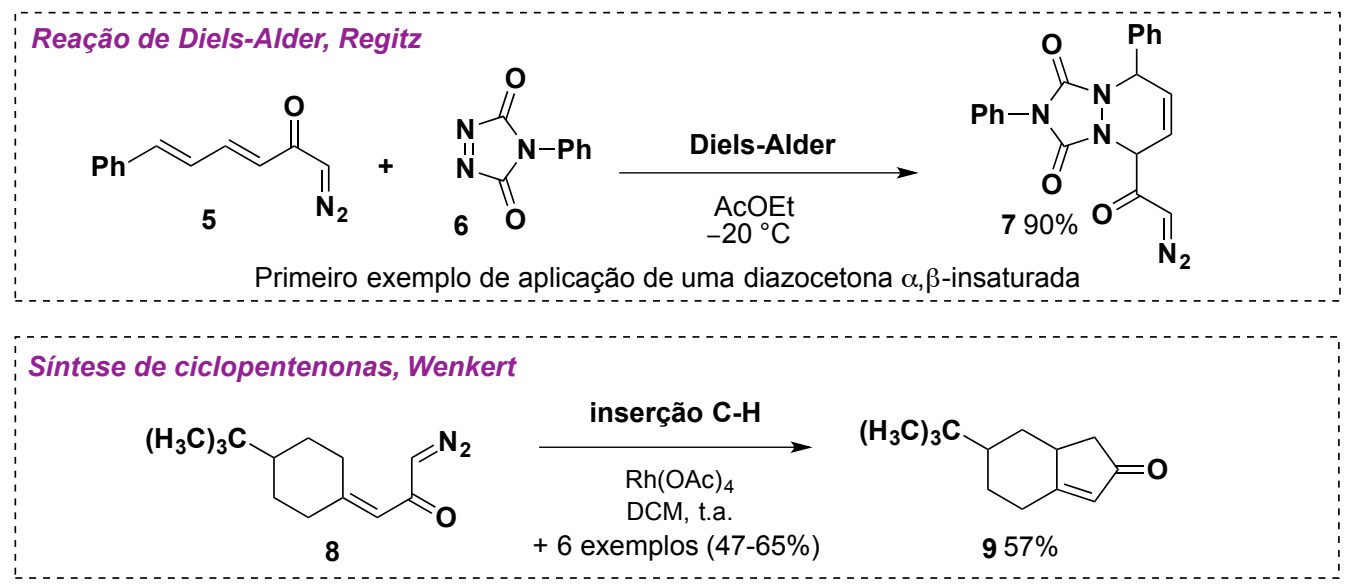
Esquema 9 a'-Diazocetonas $\alpha, \beta$-insaturadas como dienos em reações de Diels-Alder e síntese de
cliclopentenonas.

Danheiser empregou diazocetonas insaturadas para preparar vinilcetenos que, após captura por alcinos, levou a uma reação de benzanelação em cascata (Esquema 10). ${ }^{31}$ Esse método permitiu a preparação de vários anéis aromáticos com um alto grau de substituição, principalmente fenóis. Em uma publicação posterior, o problema associado com a instabilidade de alguns vinilcetenos foi contornado por uma sililação na posição a do grupo diazo destas diazocetonas insaturadas, o que forneceu 
vinilcetenos mais estáveis. ${ }^{32}$ Danheiser ainda aplicou uma anelação aromática similar como etapa chave para a síntese total da Maesanina 10 a partir da diazocetona insaturada 12 (Esquema 10). ${ }^{44}$ Neste caso, a irradiação da diazocetona $\alpha, \beta$ insaturada 12 produz o vinilceteno 13 que desencadeia uma série de transformações pericíclicas fotoquímicas em cascata, terminando com a síntese do fenol substituído 11. A clivagem do grupo de proteção silil éter e a oxidação do fenol 11 utilizando $\mathrm{O}_{2}$ levou a síntese do produto natural Maesanina 10 em uma única etapa (Esquema 10).

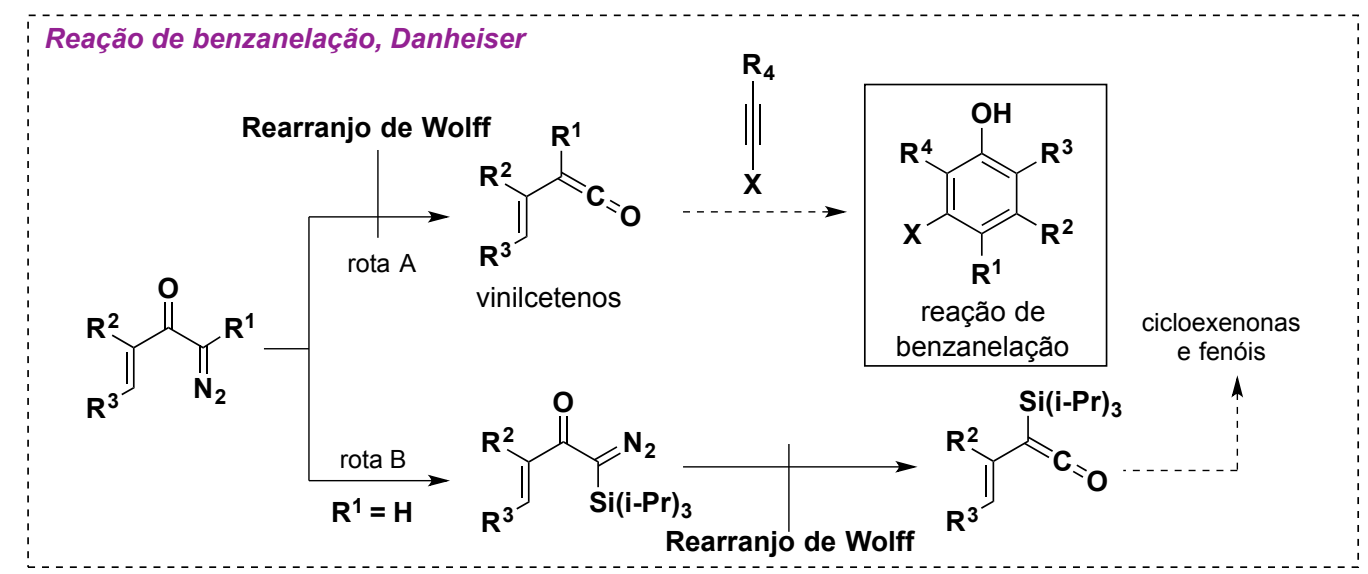

Síntese total Maesanina, Danheiser

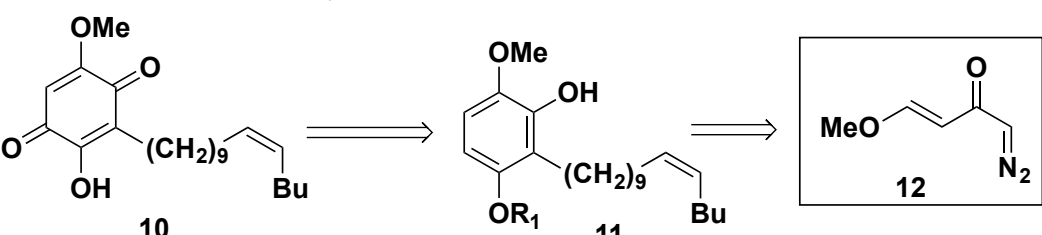

Rearranjo de Wolff fotoquímico

Maesanina

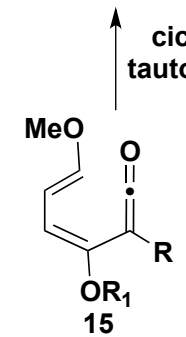

ciclização e tautomerização

MeO

15

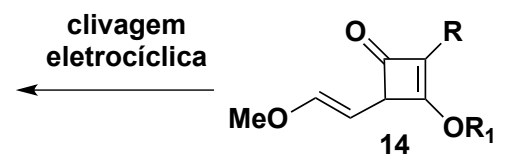

$\mathrm{R}=\left(\mathrm{CH}_{2}\right)_{9} \mathrm{CHCH}\left(\mathrm{CH}_{2}\right)_{4}$

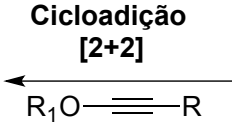

$\mathrm{R}_{1}=\mathrm{Si}(i-\mathrm{Pr})_{3}$

Esquema 10 Reação de benzanelação e síntese total do produto natural Maesanina a partir de diazocetonas insaturadas.

Diazocetonas insaturadas (substrato 16, Esquema 11) também foram empregadas em reações de polimerização (síntese de metilenos polisubstituídos) na presença de catalisadores de $\mathrm{Pd}$, onde a dupla ligação $\alpha$ à carbonila é crucial para o sucesso do processo. A possibilidade de polimerização com a unidade de um carbono 
(ao invés de duas unidades na polimerização vinílica clássica) faz com que o método seja interessante (Esquema 11). ${ }^{34}$

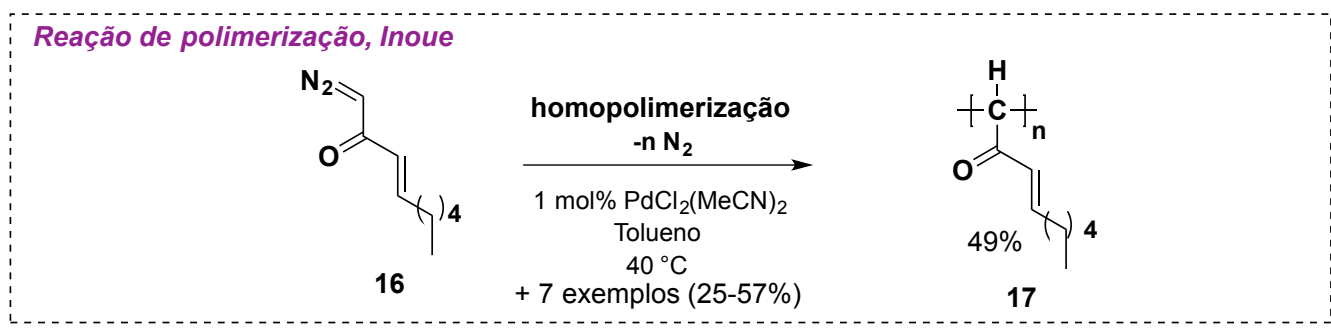

Esquema 11 Diazocetonas insaturadas aplicadas em reações de polimerização.

Brückner e colaboradores descreveram uma abordagem direta para a construção de lactonas após um rearranjo de Wolff, diidroxilação e lactonização. ${ }^{35}$ (Esquema 12). É interessante mencionar que Brückner preparou as diazocetonas pelo método clássico de acilação de diazometano. Neste caso, obrigatoriamente, os haletos de ácidos $\alpha, \beta$-insaturados empregados precisaram estar dissubstituídos na dupla ligação a fim de se evitar a formação de pirazolinas. Mesmo assim, os rendimentos obtidos foram de moderados a bons.

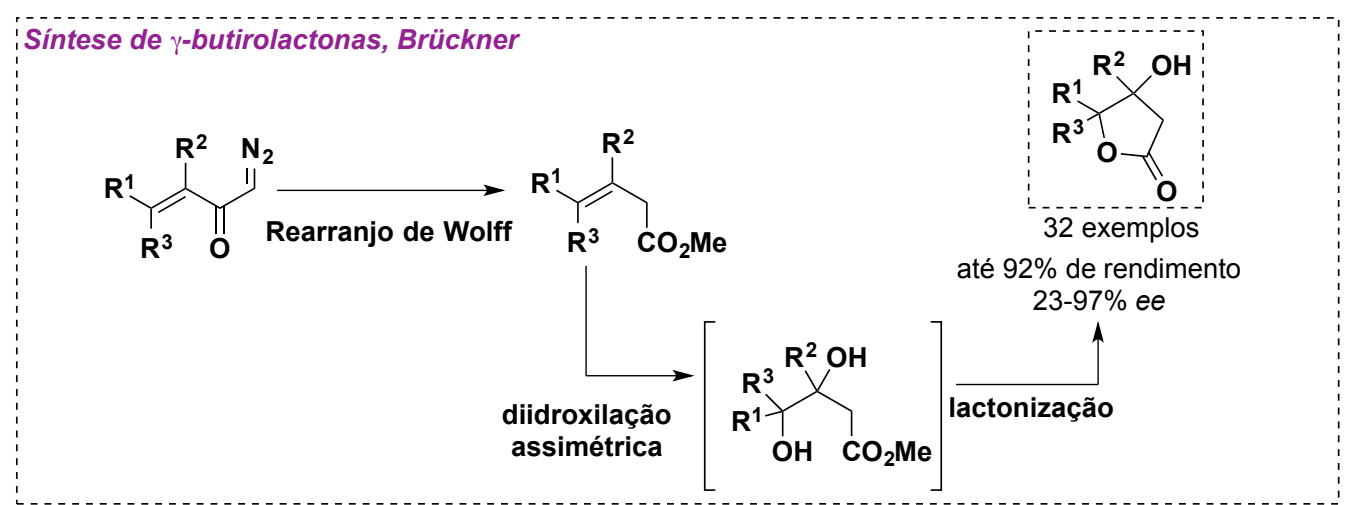

Esquema 12 Síntese de butirolactonas a partir de diazocetonas insaturadas.

Tang empregou as diazocetonas insaturadas (substrato 18, Esquema 13) para preparar ilídeos de fósforo que, na presença de alenos, levam à formação de ciclopentenonas (em uma sequência de olefinação de Wittig e ciclização de Nazarov). ${ }^{38}$ Outro exemplo envolve uma interessante reação multicomponente e foi descrita por Hu na síntese de dióis. ${ }^{39} \mathrm{~A}$ síntese envolve o uso de água, uma catálise dupla na presença de ródio e zinco, glioxal 20 e o composto diazo 1 (Esquema 13). Basicamente esta reação multicomponente envolve a adição à carbonila do glioxal 20 
pela diazocetona 1 catalisada por triflato de zinco, seguida de uma reação de inserção O-H catalisada por acetato de ródio. Mais tarde, uma reação similar pôde ser realizada na presença de iminas derivadas do glioxal, levando a formação de amino-álcoois. ${ }^{41}$ Neste caso, uma combinação de acetato de ródio e a troca do triflato de zinco por ácidos fosfóricos quirais forneceu amino-álcoois com muito boas diastereo e enantiosseletividades (Esquema 13).

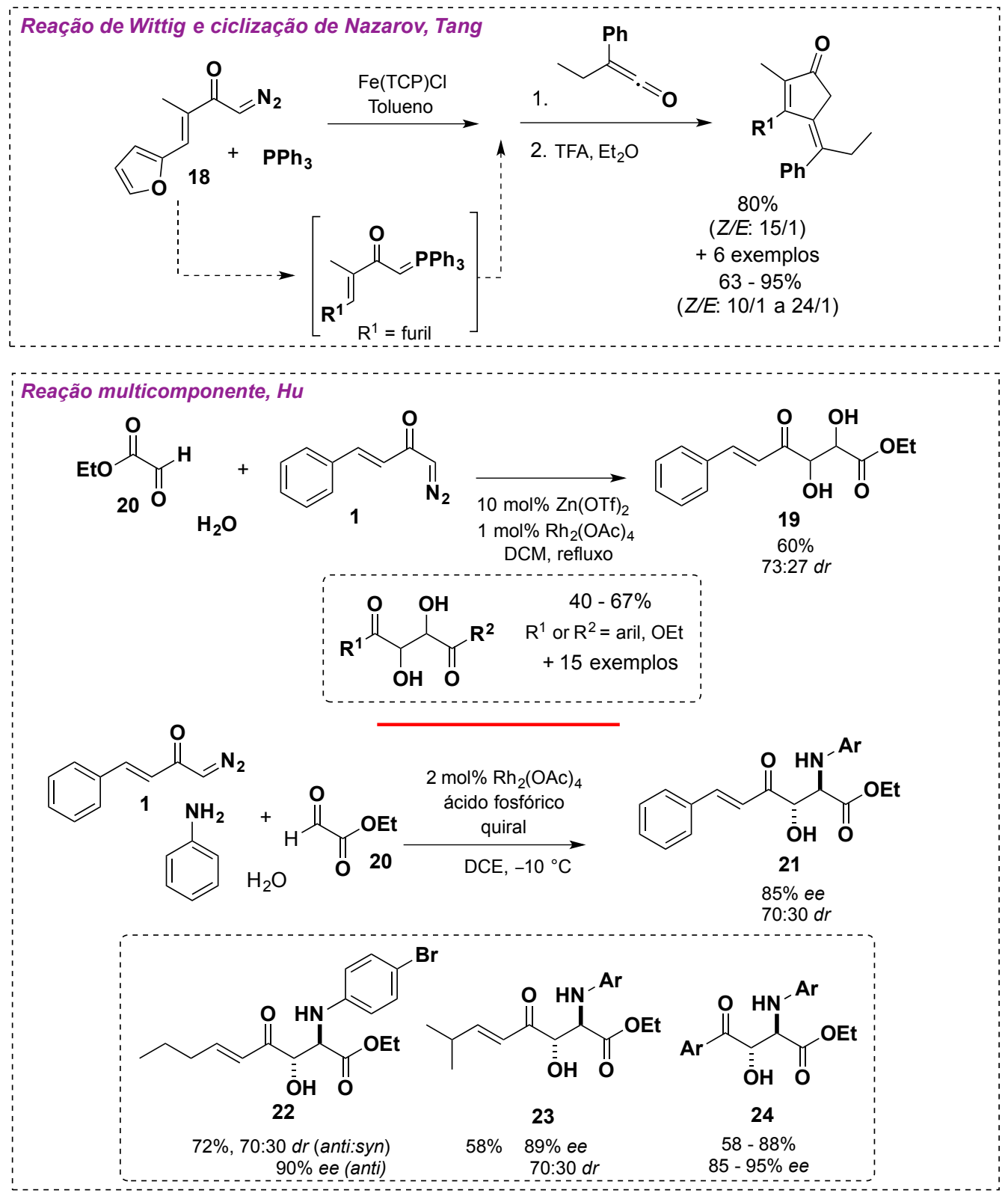

Esquema 13 Diazocetonas insaturadas em reações multicomponentes. 
Seguindo o trabalho de Regitz, ${ }^{26}$ que descreveu a primeira aplicação de uma diazocetona insaturada na preparação de um heterocíclico nitrogenado (Esquema 14), Danishefsky empregou estes compostos na preparação de diidropiridin-4-onas por uma reação de anelação aza-Robinson. ${ }^{27}$ Neste trabalho, uma típica reação bem utilizada na química de enonas (a adição de aza-Michael) foi aplicada à diazocetona 25, o tipo mais simples de uma $\alpha$-diazocetona $\alpha, \beta$-insaturada (Esquema 14). Após a adição conjugada de tiolactamas ( $12-95 \%$ de rendimento, 26a-e), seguida de uma reação entre a função tiocarbonil e um carbenóide de ródio e redução, diidropiridin-4onas (27a-e) foram formadas em $65-73 \%$ de rendimento. Nos casos em que a adição de aza-Michael forneceu baixos rendimentos, utilizou-se um protocolo mais geral: adição de aza-Michael com acrilato de metila, hidrólise, formação de anidrido e acilação com diazometano.

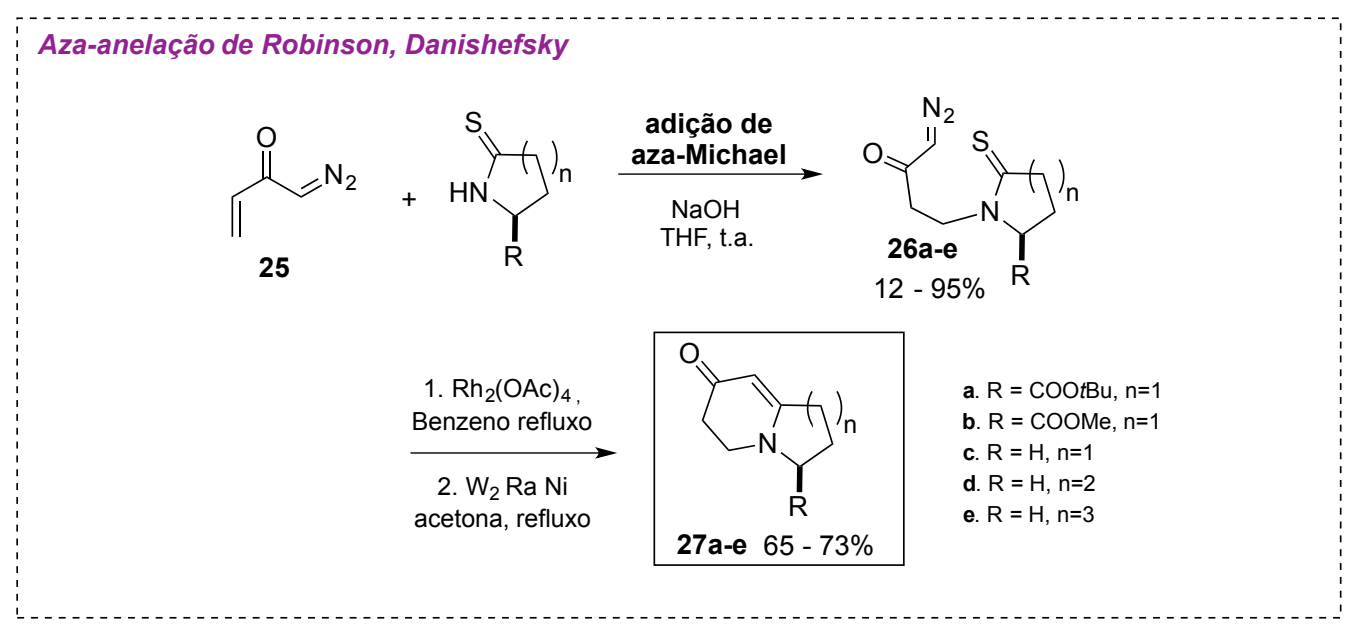

Esquema 14 Adição de aza-Michael na diazocetona insaturada 25.

Alguns anos mais tarde a síntese de aminas cíclicas através de rearranjos sigmatrópicos [2,3], empregando sais de amônio, foi descrita por Clark. ${ }^{28}$ A química também envolveu uma adição de aza-Michael em uma diazocetona insaturada (substrato 28, Esquema 15) nas etapas iniciais. No trabalho de Clark, a adição de alilaminas em uma diazocetona insaturada, seguida de formação de ilídeo e rearranjo sigmatrópico [2,3] forneceu pirrolidinonas 2,5-substituídas (30a-b). Embora direto, o método forneceu as pirrolidinonas com diastereosseletividades baixas $(\leq 2: 1)$. Apesar da estereoquímica relativa não ser determinada, a exposição prolongada dessas misturas em sílica gel enriqueceu um dos diastereoisômeros. Recentemente, Doyle também descreveu a síntese de uma pirrolidina 2,5-disubstituída 
(diastereosseletividade de 2.5:1), empregando diazoacetoacetato enonas ${ }^{45}$ (adição de aza-Michael na presença de anilina e $\mathrm{Sc}(\mathrm{OTf})_{3}$, seguida por uma inserção $\mathrm{N}-\mathrm{H}$ intramolecular.

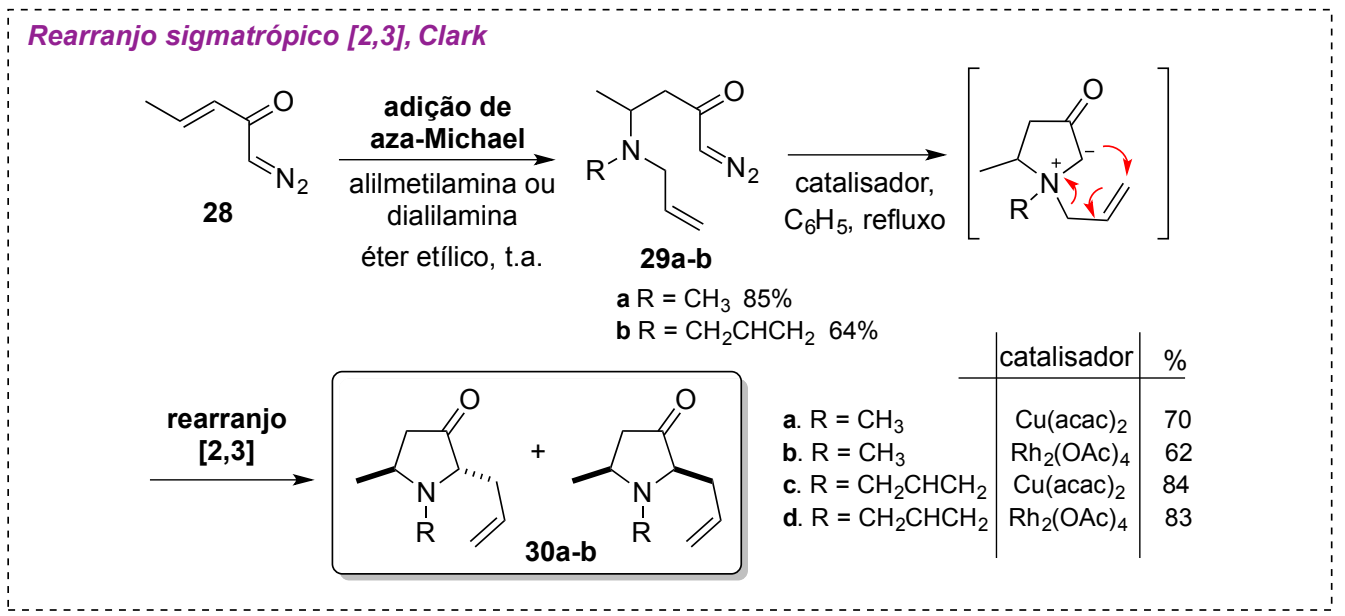

Esquema 15 Adição de aza-Michael na diazocetona insaturada 28.

\subsection{Recentes avanços na síntese de $\alpha^{\prime}$-diazocetonas $\alpha, \beta$-insaturadas}

Embora o estabelecimento do método de Danheiser permitiu o acesso a várias diazocetonas $\alpha, \beta$-insaturadas que não eram preparadas eficientemente pelos métodos clássicos, algumas lacunas ainda demandavam a necessidade de avanços nos protocolos experimentais. Por exemplo, a síntese de diazocetonas insaturadas mais complexas, bem como os derivados com centros estereogênicos epimerizáveis nunca havia sido descrita. Outra limitação está relacionada com a geometria da ligação dupla nestes compostos, onde praticamente todos os métodos levam a apenas geometrias $E$ (provenientes do substrato de partida). Por exemplo, a síntese de diazocetonas com geometria $Z$ exige metil cetonas e/ou cloretos de acila com geometria $Z$ na insaturação, os quais não são facilmente preparados ou comercialmente disponíveis. Além disso, a isomerização da dupla ligação para as diazocetonas $E$ - $\alpha, \beta$-insaturadas também poderia ser um problema em alguns dos protocolos existentes. 


\subsubsection{Diazofosfonatos como novos reagentes de olefinação}

Visando as limitações descritas acima, em $2011^{46}$ e $2013^{47}$ nosso grupo de pesquisa desenvolveu um novo protocolo para a síntese de diazocetonas $\alpha, \beta$ insaturadas. O método emprega aldeídos e um novo reagente de olefinação (diazofosfonatos 31 e 32, Esquema 16) de Horner-Wadsworth-Emmons (HWE). Estes reagentes, facilmente obtidos a partir a reação entre diazometano e os ácidos fosforilacéticos 33 e 34 correspondentes (Esquema 16), permitiram o acesso direto a várias diazocetonas $\alpha, \beta$-insaturadas com configuração $E$ da dupla ligação. Uma simples modificação do ácido fosforilacético inspirado no fosfonato de Ando foi realizada para se obter olefinas de configuração $Z$ com excelente seletividade (Esquema 16). É importante mencionar, que no caso de aldeídos quirais, não se observou qualquer racemização do centro estereogênico a partir das condições desenvolvidas.

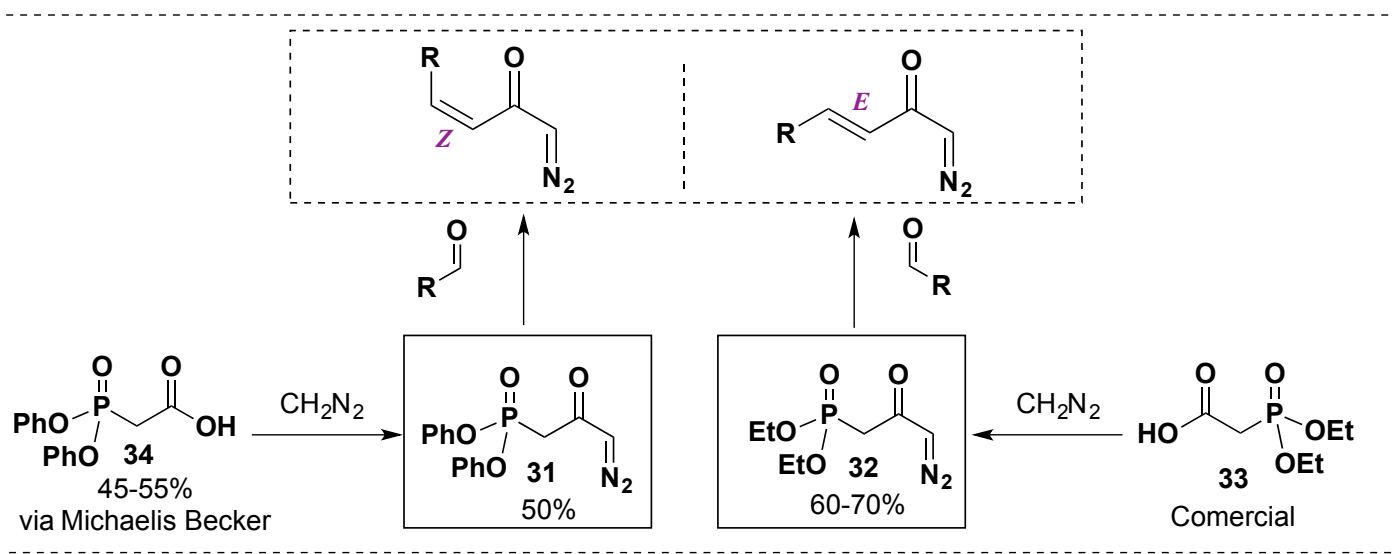

Esquema 16 Reagentes de olefinação 31 e 32 de HWE desenvolvidos por Burtoloso.

Os diazofosfonatos 31 e 32 são facilmente preparados entre 50 e $70 \%$ de rendimento a partir dos correspondentes ácidos fosforilacéticos 33 e 34 após reação com cloreto de oxalila e acilação do diazometano (Esquema 17). Embora comercialmente disponível, o ácido 2-(dietoxifosforil)acético 33 também pode ser preparado pela hidrólise básica a partir do reagente fosfonoacetato de trietila. ${ }^{48}$ Por outro lado, o ácido 2-(difenoxifosforil)acético 34 (e qualquer outro derivado com grupos arilas) é preparado em duas etapas a partir do difenilfosfito, seguindo um procedimento adaptado de Ando (Esquema 17). ${ }^{49-52}$ Cabe mencionar também que a síntese do diazofosfonato $\mathbf{3 6}$ também foi investigada. Este tipo de fosfonato, inspirado 
no clássico reagente de Still-Gennari, ${ }^{53}$ também é conhecido por fornecer duplas ligações com geometrias $Z$ a partir da reação de HWE. $O$ ácido bistrifluoroetilfosfonoacético 35 necessário à preparação do diazofosfonato 36 foi obtido por um protocolo descrito recentemente em nosso laboratório. ${ }^{54}$ Entretanto, após inúmeras tentativas, não foi possível a obtenção deste fosfonato. Outro ponto importante a ser enfatizado é a estabilidade dos diazofosfonatos 31 (sólido amarelo) e 32 (óleo amarelo), podendo ser armazenados por meses sem que ocorra qualquer degradação.

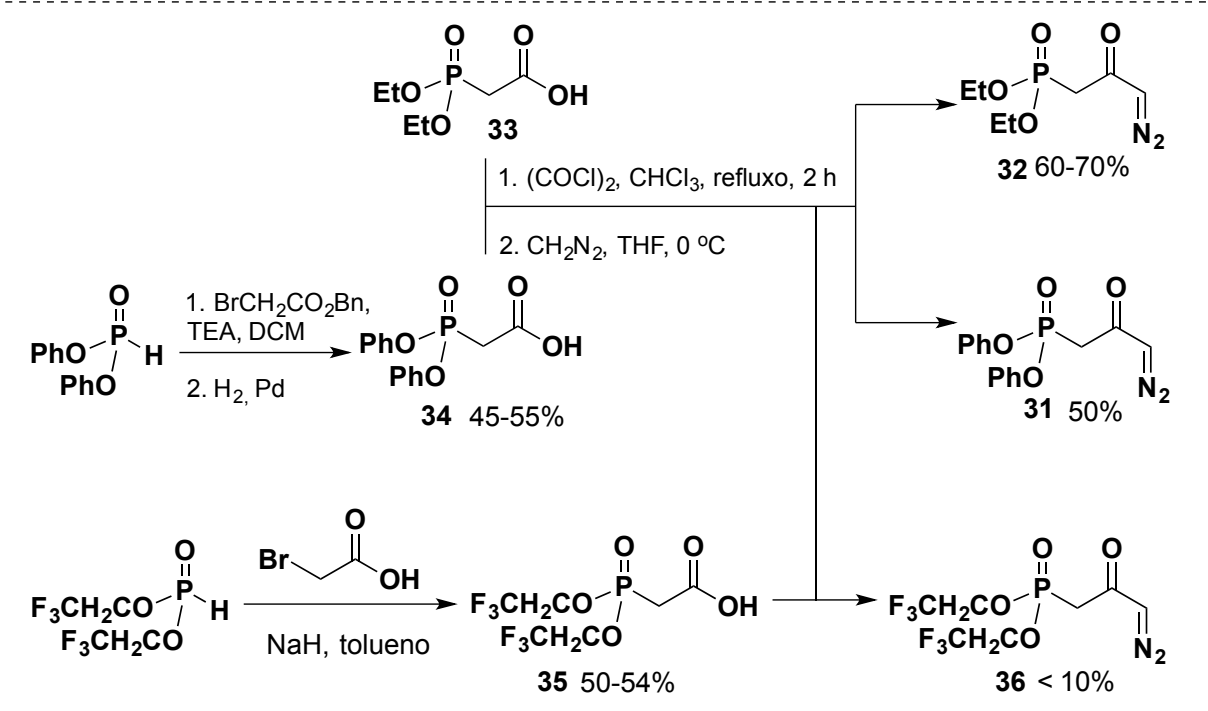

Esquema 17 Preparação dos diazofosfonatos 31 e 32 por Burtoloso e colaboradores.

Após o desenvolvimento dos reagentes de olefinação 31 e 32, várias $\alpha$ diazocetonas $\alpha, \beta$-insaturadas puderam ser preparadas por esta metodologia, incluindo diazocetonas complexas e enantiomericamente puras. ${ }^{55} \mathrm{~A}$ Figura 3 reúne todas as diazocetonas insaturadas preparadas até o momento empregando estes novos reagentes de olefinação. É interessante mencionar que embora preparadas em escalas de até 1.0 grama, nada impede que o método seja estendido para escalas ainda maiores. Em suma, vale ressaltar que o método é direto e utiliza aldeídos, os quais possuem fácil preparo e ampla disponibilidade comercial. 


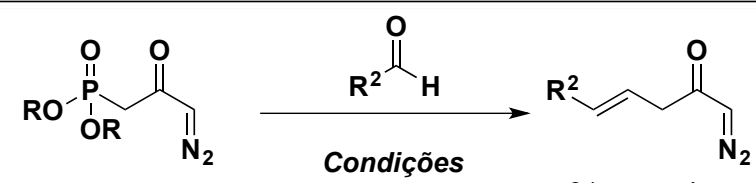

31 ou 32

31 exemplos $40-92 \%$

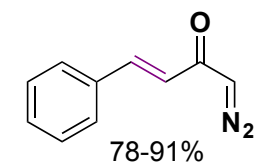

$\overbrace{50 \%}^{O}$<smiles>CNC(O)C=Cc1ccc([N+](=O)[O-])cc1</smiles><smiles>N=CC(=O)/C=C/c1ccco1</smiles><smiles>CCCCCCCCC/C=C/C(=O)C=N</smiles><smiles>CCC/C=C/C(=O)C=[W]</smiles>

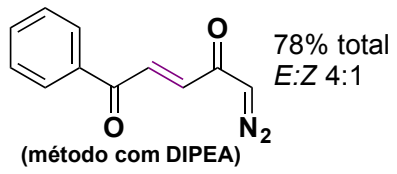<smiles>CC(C)/C=C/C(=O)C=N</smiles>

$67 \%$

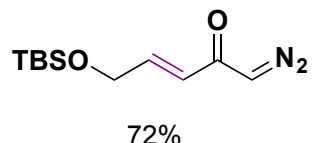

$72 \%$<smiles>CC(C)CC(/C=C/C(=O)C=[W])NC(=O)OCc1ccccc1</smiles>

$83 \%$<smiles>O=C(C=[W])C=CCNC(=O)O[Na]</smiles><smiles>N=CC(=O)C=CC1CCCN1</smiles>

(+/-) $\mathrm{Cb}$<smiles>CN1CCCCC1C=CC(=O)CC#N</smiles><smiles>N=CC(=O)/C=C/C1CCCN1</smiles>

$81 \%$<smiles>N#CC(=O)/C=C/CNC(=O)c1ccccc1</smiles>

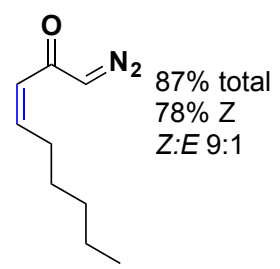

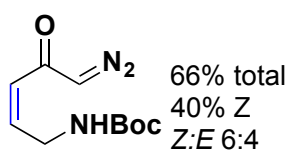<smiles>N#CC(=O)C=CCN</smiles>

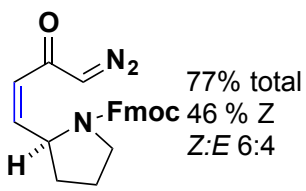

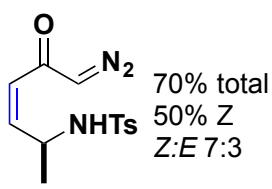<smiles>N=CC(=O)C=CC(Cc1c[nH]c2ccccc12)Nc1ccccc1</smiles><smiles>N#CC(=O)/C=C\C(=N)c1ccccc1</smiles><smiles>[13CH3]OCC(/C=C\C(=O)C#N)CO[18OH]</smiles>

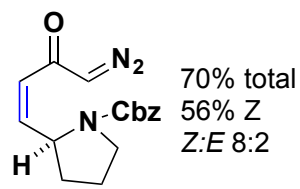

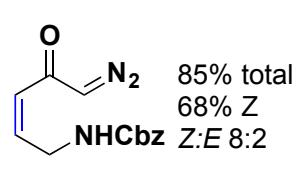

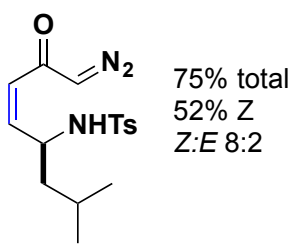

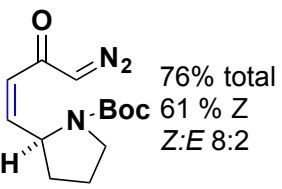

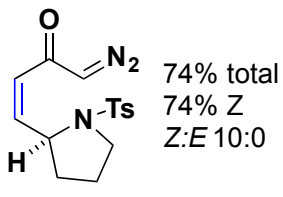<smiles>N=CC(=O)/C=C\c1ccc([N+](=O)[O-])cc1</smiles><smiles>COc1ccc(/C=C\C(=O)C=N)cc1</smiles><smiles>N=CC(=O)/C=C\c1ccccc1</smiles>

Figura 3 Exemplos de diazocetonas $\alpha, \beta$-insaturadas preparadas pela metodologia desenvolvida por Burtoloso e colaboradores empregando aldeídos e os diazofosfonatos 31 e 32 . 


\subsection{Diazocetonas $\alpha, \beta$-insaturadas como blocos de construção em síntese}

Uma das aplicações das diazocetonas desenvolvidas por Burtoloso e colaboradores foi a sua conversão em compostos heterociclos nitrogenados. Com o átomo de nitrogênio já incorporado no substrato diazocarbonílico (oriundo da reação de HWE entre amino-aldeídos e o diazofosfonato 31 e 32, Figura 4), ${ }^{56,57}$ a síntese de diversos heterociclos pôde ser alcançada de forma direta. Neste sentido, uma diazocetona com geometria $E$ ou $Z$, como representado na Figura 4, contem todos os átomos de carbonos necessários para a construção de anéis heteroclíclos de seis membros. No caso da diazocetona com geometria $E$, uma etapa chave para esta transformação seria o rearranjo de Wolff fotoquímico na presença de metanol para levar a síntese do éster $\beta, \gamma$-insaturado bastante versátil (Figura 4). Este intermediário pôde ser funcionalizado, por exemplo, através de reações de dihidroxilação ou epoxidação seguida de abertura. A remoção do grupo de proteção seguida de uma ciclização intramolecular levou a preparação de piperidinas, indolizidinas e quinolizidinas quando aldeídos derivados de aminoácidos acíclicos, derivados de prolina e do ácido pipecólico foram empregados, respectivamente. ${ }^{56-58}$ No que se refere a diazocetona com geometria $Z$ da dupla ligação, elas podem ciclizar sem a necessidade de prévia manipulação da ligação dupla, por exemplo, via inserção N-H intramolecular. Esta transformação levou ao esqueleto básico de dihidropiridi-3-onas em apenas duas etapas a partir de aldeídos. Este esqueleto, após redução da cetona seguida de reação de diidroxilação da dupla ligação levou a síntese de piperidinas

hidroxiladas de forma bastante rápida eficiente. ${ }^{47,59}$ 


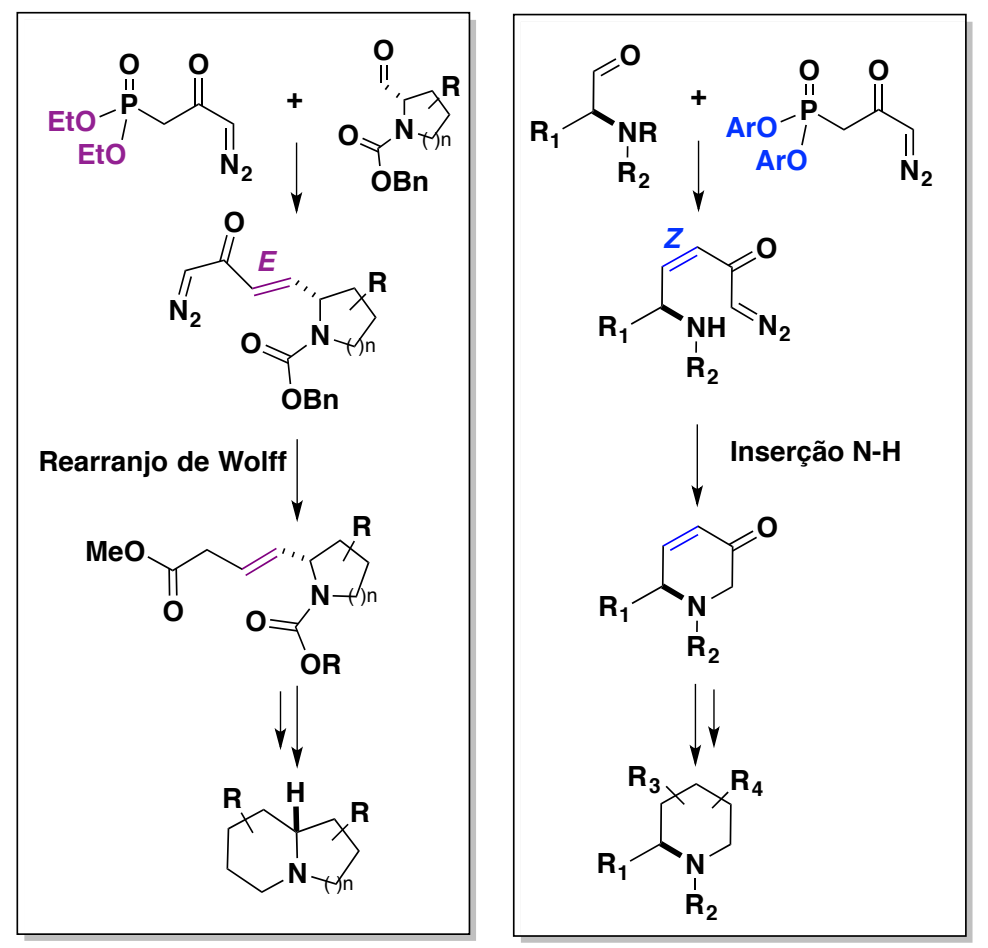

Figura 4 Conversão de diazocetonas insaturadas em heterocíclios nitrogenados

Uma outra estratégia explorada em nosso grupo de pesquisa foi o uso das diazocetonas insaturadas como substratos propícios às reações de Michael. A adição de aza-Michael, por exemplo, posiciona um grupo amino na posição $\beta$ destas diazocetonas, o qual, por sua vez, pode reagir com o grupo diazo para formar heterocíclos de 5 membros (Esquema 18). Um trabalho concluído recentemente pelo nosso grupo de pesquisa envolve o rearranjo de Stevens para a construção de pirrolidinonas cis-2,5-disubstituídas e sua aplicação na síntese total altamente diastereosseletiva do alcalóide preussina em três etapas a partir do decanal (Esquema 18). Os substratos para avaliar o rearranjo de Stevens foram preparados pela adição de aza-Michael (reação entre diazocetonas insaturadas e aminas secundárias). ${ }^{60}$

Como pode ser observado na Figura 5, vários são os exemplos de alcaloides e seus derivados indolizidínicos, piperidínicos, pirrolidínicos e quinolizidínicos preparados a partir das diazocetonas $\alpha, \beta$-insaturadas sintetizadas pela metodologia descrita por Burtoloso e colaboradores. 


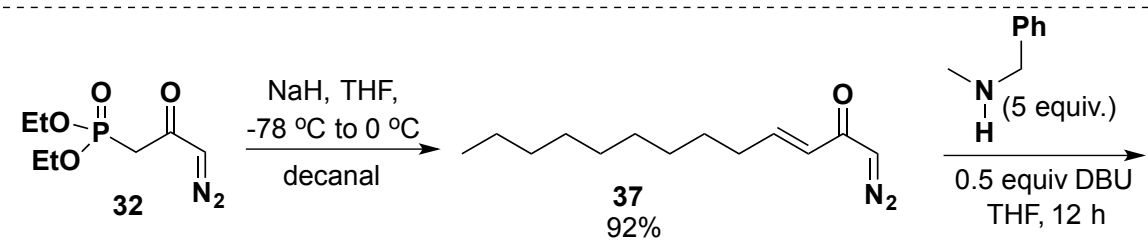

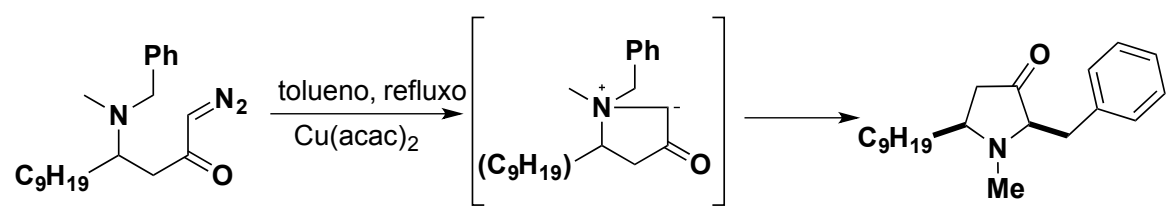

38

$97 \%$

Rearranjo 1,2 de Stevens

tolueno, refluxo, $\mathrm{Cu}(\mathrm{acac})_{2}$. Então:

$-78^{\circ} \mathrm{C}$ e adição de L-selectride

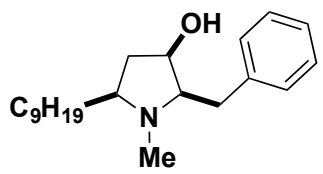

$46 \%$ Rendimento Global, $d r=10: 0$

preussina

40
39

único isômero, $58 \%$

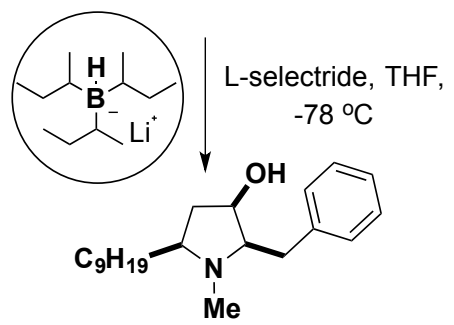

$80 \%, d r=10: 0$

preussina

40

Esquema 18 Síntese da preussina a partir da diazocetona insaturada 20.

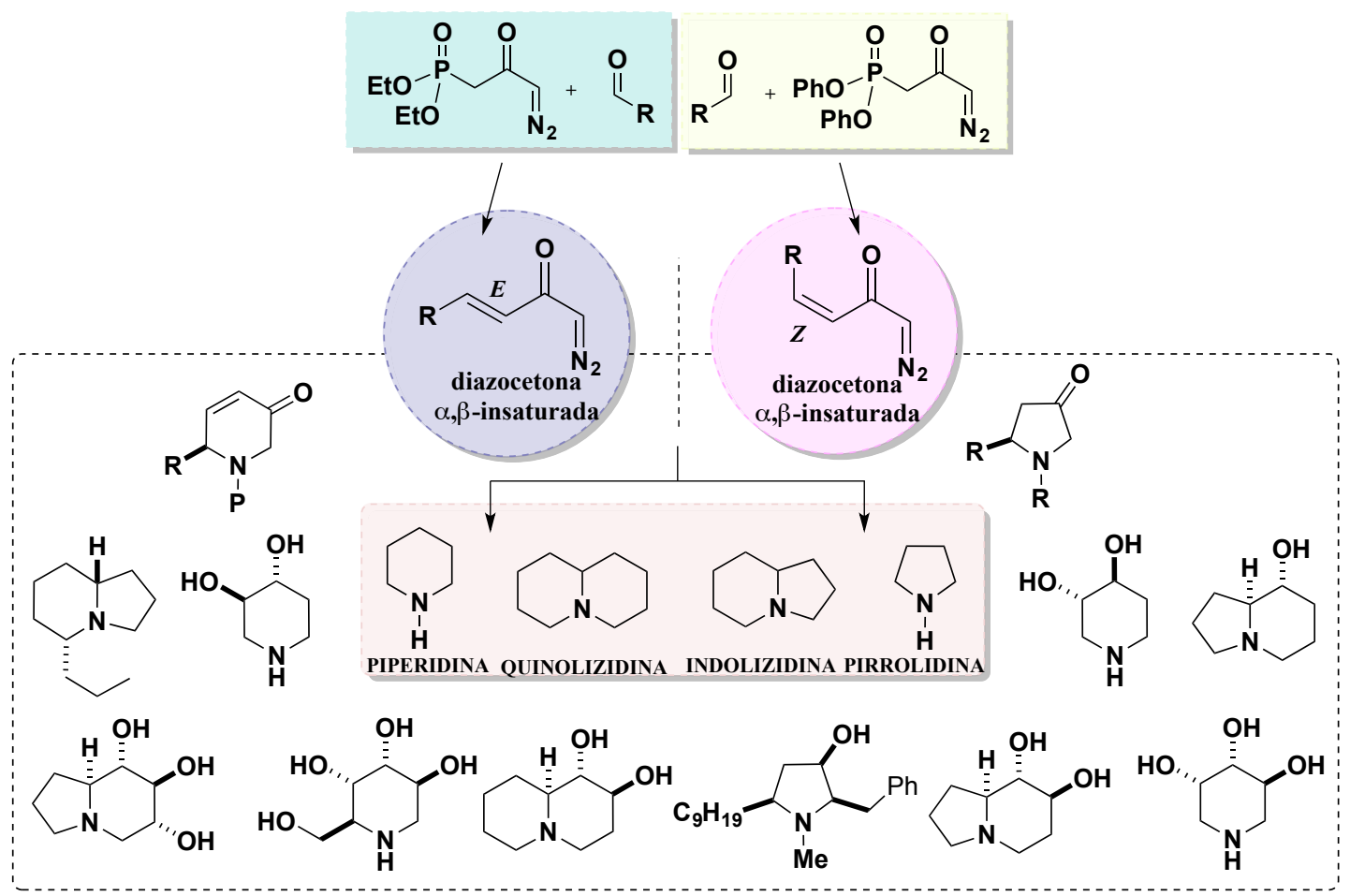

Figura 5 Diazocetonas insaturadas como blocos de construção para a síntese de heterocíclicos de nitrogênio. 


\subsection{Rearranjo de Wolff}

O rearranjo de Wolff foi nomeado após as descobertas de Ludwig Wolff ao tentar preparar a $\alpha$-hidroxicetona 42 a partir $\alpha$-diazo cetona $41 .{ }^{3} \mathrm{O}$ aquecimento do composto diazocarbonílico 41 na presença de água levou a formação do éster 45 , que após hidrólise, forneceu o ácido carboxílico 43 (Esquema 19).

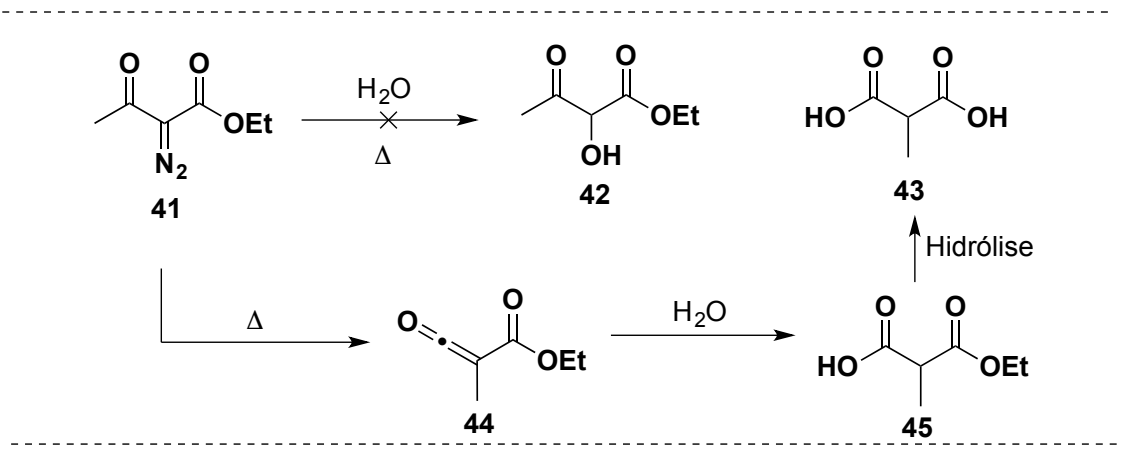

Esquema 19 Descoberta do rearranjo por Ludwig Wolff.

O rearranjo de Wolff consiste basicamente na conversão de diazocetonas em cetenos e seus derivados. $O$ aquecimento de $\alpha$-diazocetonas com sais de prata, ${ }^{61}$ ou sua exposição à luz ${ }^{62}$ leva à extrusão de nitrogênio e migração 1,2 do grupo $\alpha$ carbonila, levando a formação de um intermediário ceteno (Esquema 20). De forma geral, esse mecanismo pode ocorrer de forma concertada, ou passando pela formação de um intermediário $\alpha$-cetocarbeno. ${ }^{62}$ o ceteno é uma espécie extremamente reativa que pode ser capturada por nucleófilos, duplas ligações ou mesmo alquinos para formar ciclo-derivados ou derivados de ácido carboxílico. $\mathrm{Na}$ presença de água, álcoois ou aminas, pode-se gerar ácidos carboxílicos, ésteres ou amidas (Esquema 20). Algumas características gerais do Rearranjo de Wolff são: 1) a reação pode ser iniciada termicamente, fotoquimicamente, ou por catálise através de metal de transição; 2) condições térmicas podem degradar os substratos além de desencadear reações competitivas, como por exemplo, o deslocamento direto do grupo diazo sem que ocorra o rearranjo; 3) o uso de complexos de metal de transição não apenas reduz consideravelmente a temperatura necessária para a reação em comparação com o processo térmico, mas também altera a reatividade do intermediário a-cetocarbeno; 4) óxido de prata (I) ou benzoato prata (I) são os mais utilizados; 5) a reação realizada fotoquimicamente evita o uso de altas temperaturas; 
6) a estereoquímica do material de partida permanece inalterada (retenção líquida de configuração); 7 ) diazocetonas $\beta$, $\gamma$-insaturadas sofrem o rearranjo de Wolff vinílogo. ${ }^{63}$

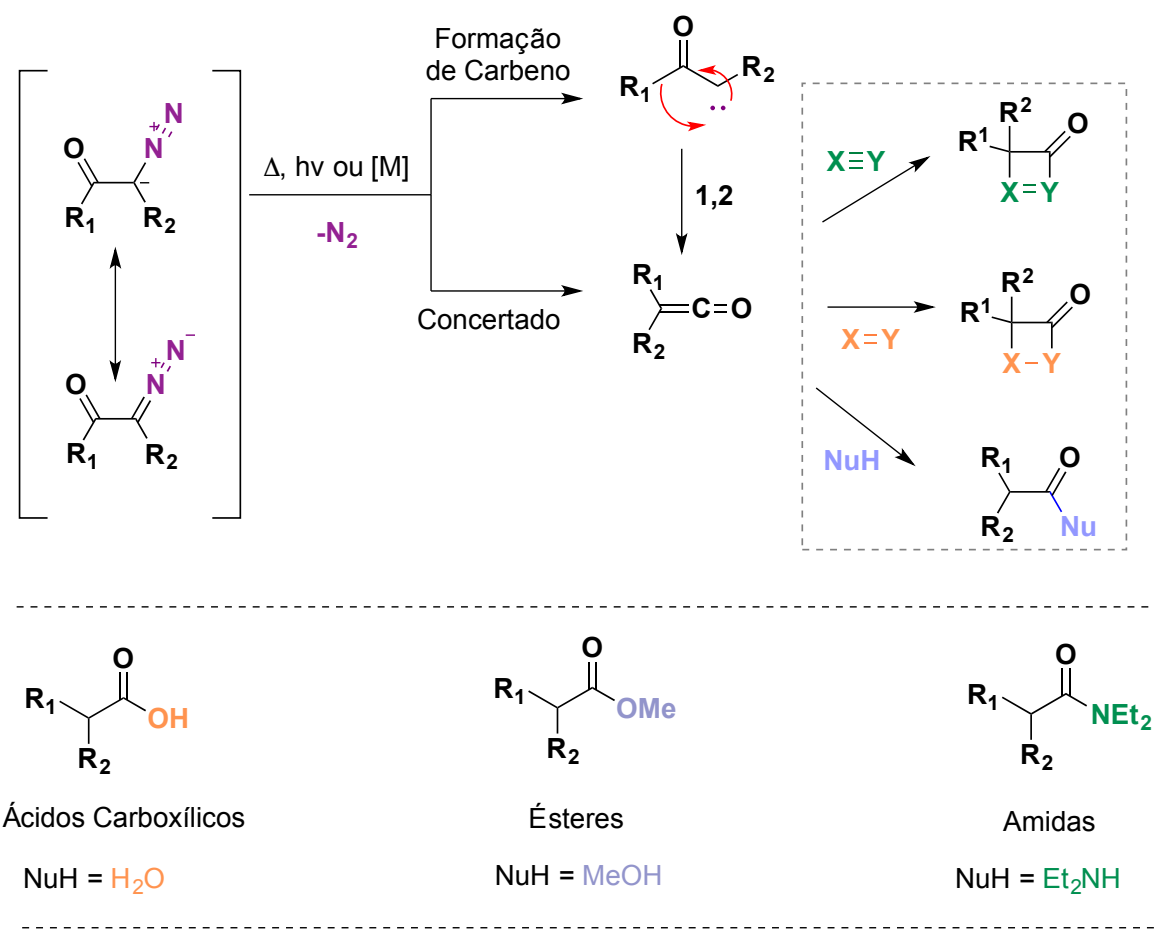

Esquema 20 Conversão de diazocetonas em cetenos e seus derivados via Rearranjo de Wolff.

\subsubsection{Aspectos mecanísticos do Rearranjo de Wolff}

Como resultado da grande aplicabilidade das diazocetonas frente ao rearranjo de Wolff, muito esforço tem sido realizado para compreender os aspectos mecanísticos desta transformação. Vários são os possíveis intermediários reacionais, a destacar os carbenos, cetenos e espécies atuando no estado excitado. Conforme ilustrado no Esquema 20, tanto o mecanismo concertado quanto o proposto em etapas, ainda que tópico de muita discussão, foram confirmados a partir de precursores diazocarbonílicos cíclicos e acíclicos. ${ }^{64}$ Compostos diazocarbonílicos existem em um equilíbrio entre os confôrmeros s-cis e s-trans, sendo a sua distribuição afetada tanto por fatores estéricos $\left(R_{2} \neq H\right)$ quanto por interações eletrostáticas entre a carga negativa do oxigênio e o nitrogênio catiônico (Esquema 21). ${ }^{62}$ Quando a diazocetona possui conformação $s$-Cis (como nos casos cíclicos ou em equilíbrios favorecidos pela atração de cargas), o grupo de saída $\left(N_{2}\right)$ e o grupo migrante $\left(R_{1}\right)$ assumem uma configuração antiperiplanar que favorece o mecanismo concertado. 
Neste caso, a extrusão de nitrogênio ocorre simultaneamente com o rearranjo 1,2alquílico. ${ }^{65}$ No que se refere as diazocetonas s-trans, a relação antiperiplanar entre o grupo de saída e o grupo migrante não é observada, sendo o mecanismo nestes casos preferencialmente em etapas. Alguns argumentos favorecem este mecanismo, como por exemplo, a observação de dependência entre as constantes de velocidade com a estabilidade do carbeno formado. Entretanto, a evidência mais persistente envolvendo este mecanismo surgiu com experimentos de ${ }^{13} \mathrm{C}$ marcado. Diazocetonas marcadas no carbono carboxílico rearranjam para formar cetenos que possuem a marcação em ambos os átomos de carbono (Esquema 22). ${ }^{66,66,67}$

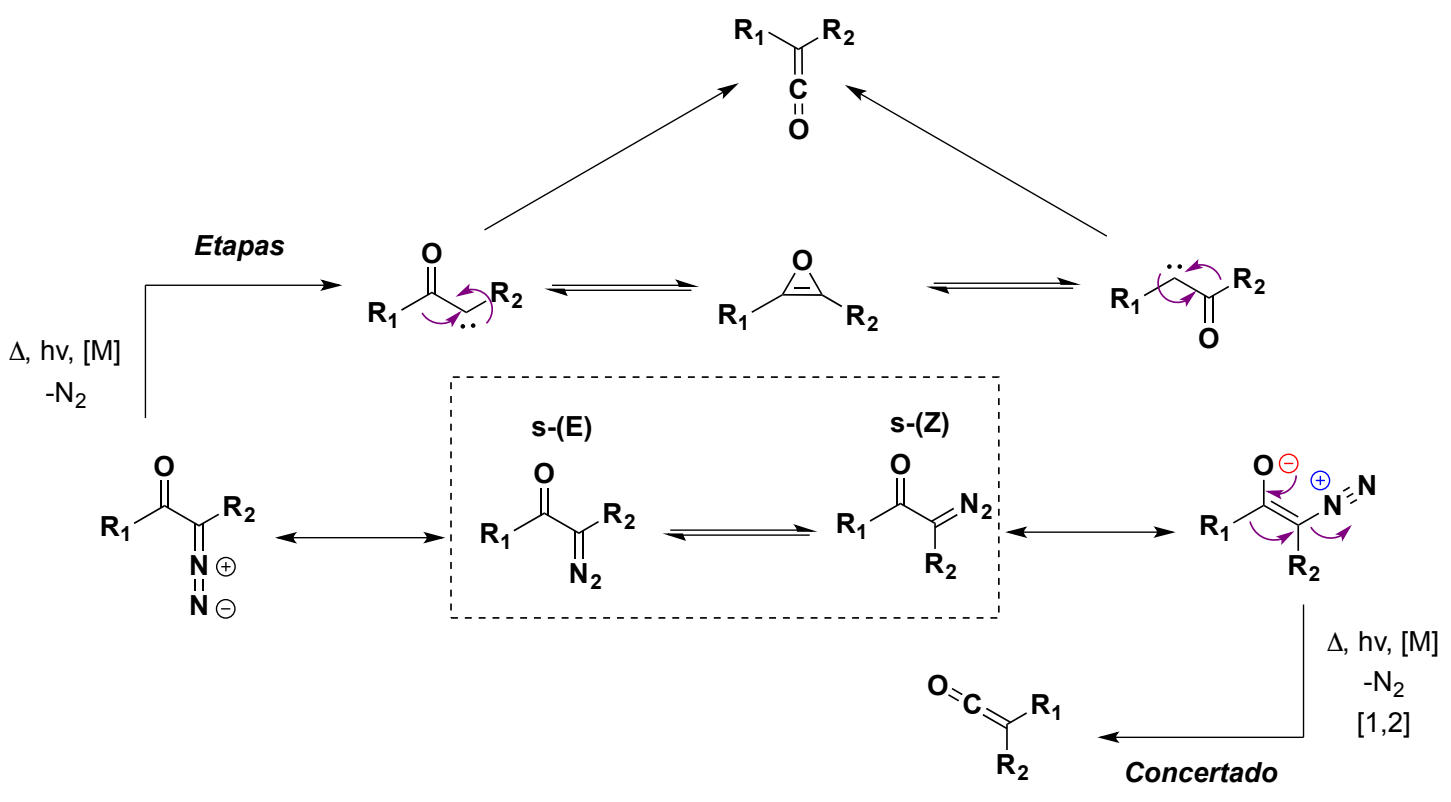

Esquema 21 Mecanismo concertado e em etapas.

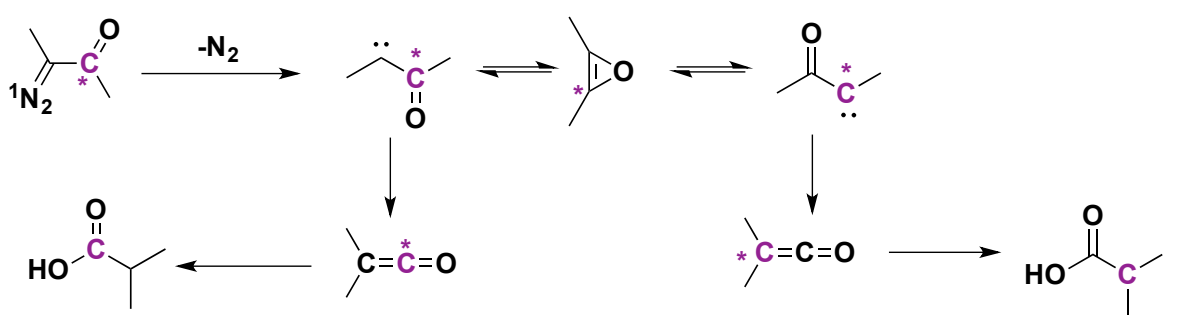

Esquema 22 Evidência de participação de oxirana. 
Outro aspecto importante do mecanismo diz respeito a reatividade singleto vs tripleto do carbeno gerado. O carbeno é uma espécie divalente neutra contendo um átomo de carbono com seis elétrons na camada de valência. Os dois elétrons não ligantes podem estar emparelhados (singleto, ${ }^{1} \sigma^{2}$ ) ou desemparelhados (tripleto, ${ }^{3} \sigma^{1} p^{1}$ ) como ilustrado na Figura 6 . Enquanto carbenos tripletos exibem reatividades do tipo radicalar, os carbenos singleto assumem tanto características nucleofílicas como eletrofílicas devido a presença de um par de elétrons e de um orbital vazio.

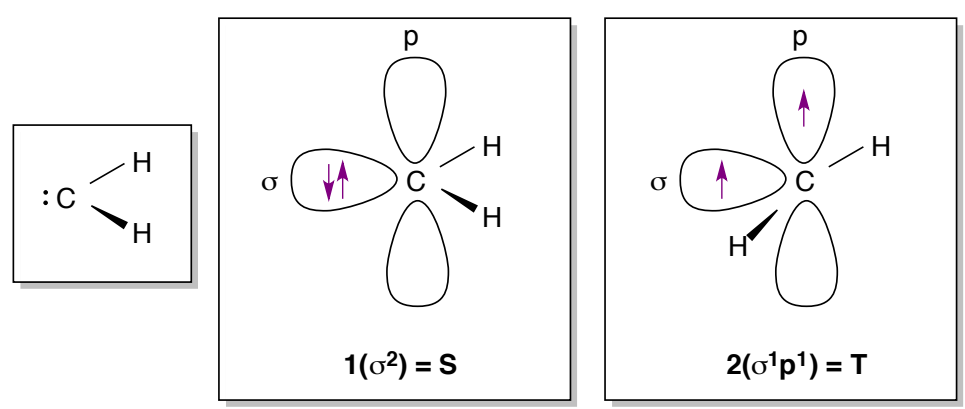

Figura 6 Estrutura de um carbeno singleto e tripleto.

Estudos prévios indicam o estado singleto como sendo majoritário no rearranjo de Wolff. ${ }^{62,68-72}$ Tomioka e colaboradores realizaram experimentos complementares a partir da fotoexposição do diazoacetato 46 (Esquema 23). ${ }^{71,72}$ Neste estudo, foi demonstrado que a fotólise direta de 46 produz um estado excitado singleto $\left({ }^{1} 46^{\star}\right)$ que passa por uma extrusão de nitrogênio para gerar o ceteno (48), o carbeno $\left({ }^{1} 47\right)$, ou ainda um cruzamento intersistemas (intersystem crossing - ISC) para levar ao diazoester no estado tripleto $\left({ }^{3} 46^{*}\right) .{ }^{73}$ O ceteno e o carbeno singleto são então capturados por um álcool para levar a dois produtos (49 e 50, respectivamente). 0 produto de redução 51 é proveniente das espécies tripleto $\left({ }^{3} 46^{*}\right)$ e $\left({ }^{3} 47\right)$. O rendimento do produto 51 é aumentado quando uma fotólise tripleto-sensitizada é utilizada, e suprimido quando um finalizador de espécies tripleto 52 (piperilena) é utilizado previamente a fotólise direta. O produto de inserção $\mathbf{5 0}$ ainda é observado quando o diazoester 46 é tripleto-sensitizada, demonstrando a capacidade de interconversão do carbeno tripleto $\left({ }^{3} 46^{*}\right)$ no carbeno singleto $\left({ }^{1} 46^{*}\right)$. 


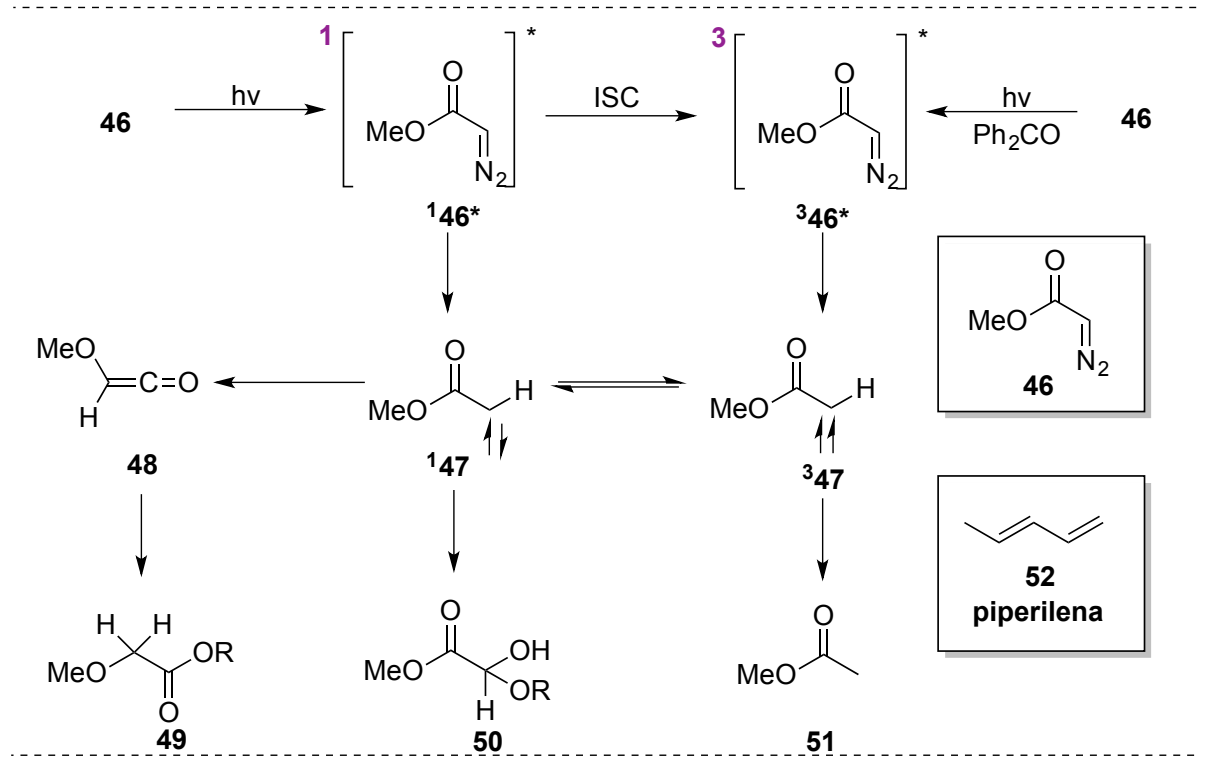

Esquema 23 Competição entre carbeno singleto e tripleto.

\subsubsection{Aplicações do rearranjo de Wolff}

O rearranjo de Wolff é amplamente empregado em reações de homologação de Arndt-Eistert, contração de anel e de cicloadição (Esquema 24). É a etapa chave na reação de homologação de Arndt-Eistert, a qual leva o aumento de um carbono na cadeia de um ácido carboxílico. Essa homologação ocorre pela ativação de um ácido carboxílico (via cloreto de ácido ou anidrido misto), acilação do diazometano e decomposição da diazocetona formada (na presença de aquecimento, luz ou de sais de prata) para o ceteno reativo. Com o ataque de um nucleófilo, o rearranjo 1,2 leva ao derivado carboxílico com o aumento de um átomo de carbono na cadeia (Esquema 24). ${ }^{4,74}$ O rearranjo de Wolff é também aplicado em reações de contração de anéis a partir de diazocetonas cíclicas, primeiramente descrito em 1955 por Horner e Spietschka $^{75}$ (Esquema 24). Neste caso, devido a conformação S-Cis, esta transformação é realizada pela decomposição direta de a-diazocicloexanonas de forma concertada sem que ocorra a formação do carbeno (Esquema 24). 

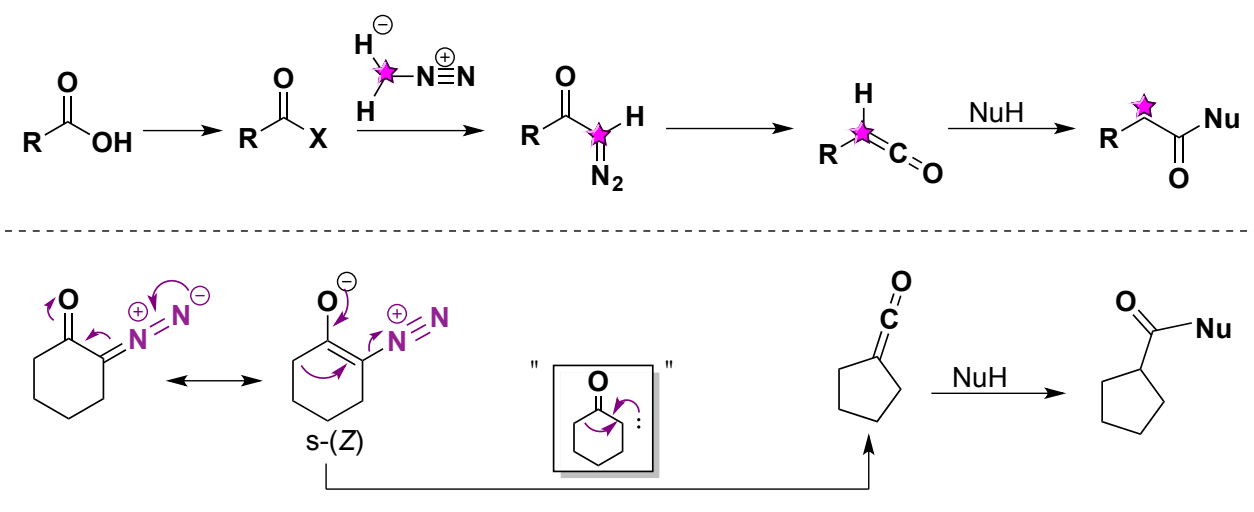

Esquema 24 Reação de Homologação de Arndt-Eistert e contração de anéis.

A homologação de Arndt-Eistert tem sido amplamente explorada na preparação de $\beta$-aminoácidos a partir de $\alpha$-aminoácidos, possuindo importante aplicação principalmente na modificação e síntese total de produtos naturais. ${ }^{76}$ Alguns exemplos incluem a síntese de macrolídeos tais como a Carbonolida $\mathrm{B},{ }^{77}$ alguns alcalóides, como exemplificado pelo ácido $(+)$ - $\alpha$-Kainico, ${ }^{78}$ terpenos e esteróides, tais como (Z)-4-oxo- $\beta$-ionona ${ }^{79}$ e peptideos cíclicos como descrito na síntese da (+)Jasplakinolida $^{80}$ (Esquema 25). Um exemplo recente da aplicação da homologação de Arndt-Eistert na síntese de um intermediário do produto natural (+)-Salvileucalina B é descrito por Sarah Reisman ${ }^{81}$ (Esquema 25). 


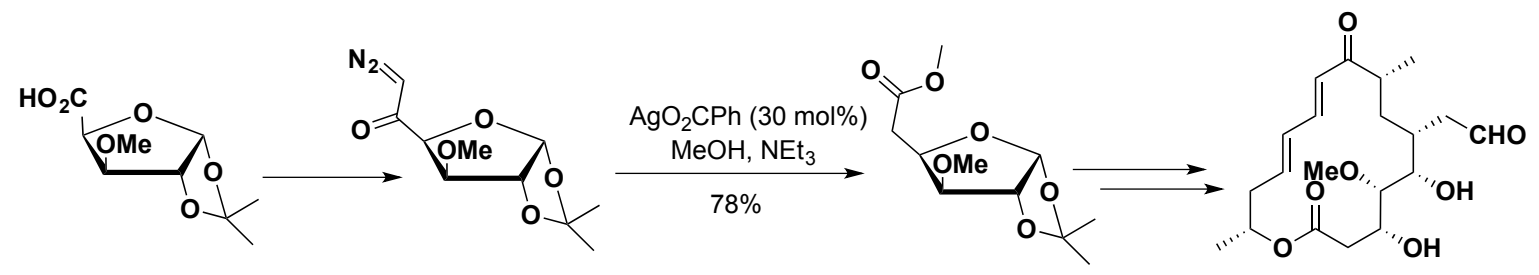

Carbonolida B

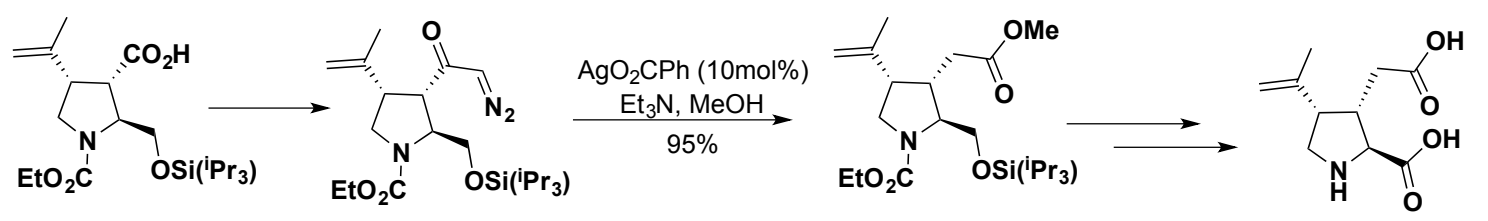

Ácido Kainico

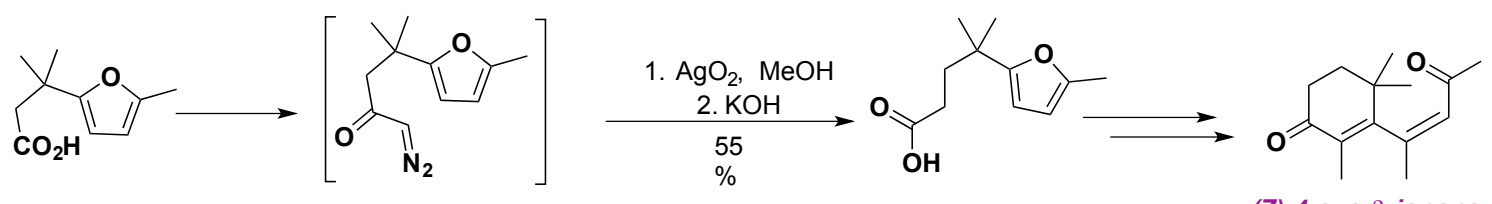

(Z)-4-oxo-p-ionona

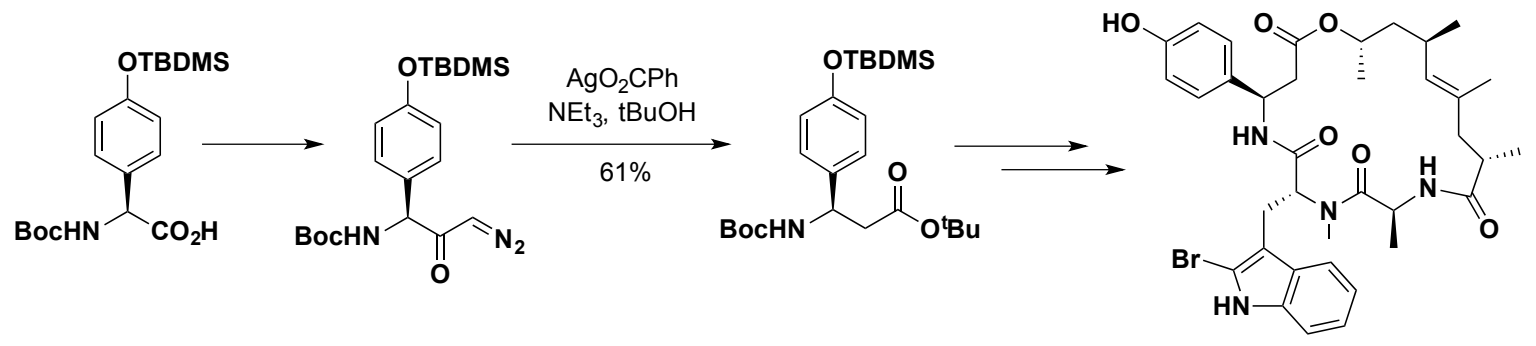

(+)-Jasplakinolida
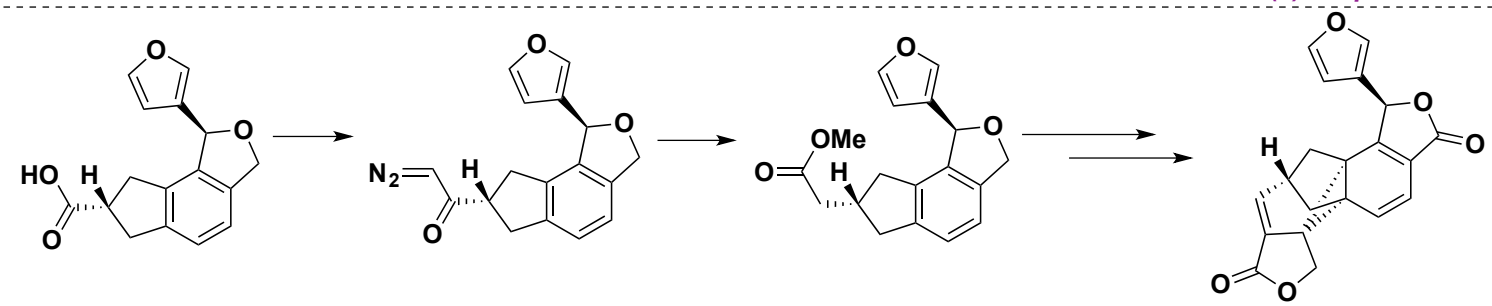

(+)-Salvileucalina B

Esquema 25 Homologação de Arndt-Eistert aplicada na síntese de produtos naturais.

A reação de contração de anéis reação possui especial eficácia na síntese de compostos cíclicos tensionados. ${ }^{82}$ Existem muitos exemplos em que o rearranjo de Wolff é utilizado para contrair ciclopentanonas a ciclobutanos ${ }^{70,83-85}$ e ciclobutanos para ciclopropanos. ${ }^{86}$ O rearranjo é também comumente utilizado para formar sistemas bicíclicos. A Figura 7 ilustra alguns produtos naturais que foram sintetizados fazendo o uso de contração de anel via Rearranjo de Wolff com destaque para o anel construído com esta metodologia. 


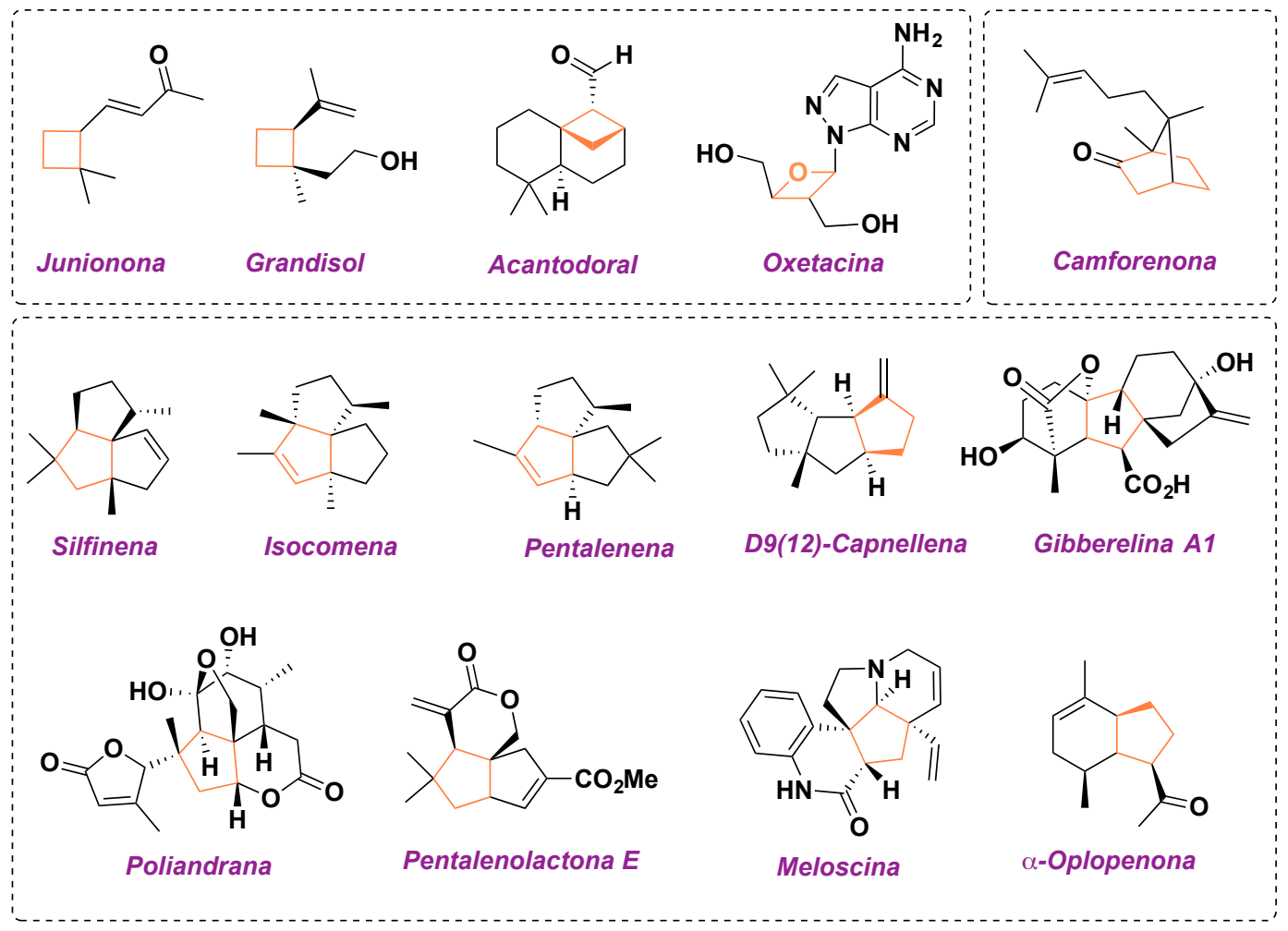

Figura 7 Exemplos de produtos naturais sintetizados por contração de anel via Rearranjo de Wolff. 


\section{Objetivos}

Visando aumentar o escopo de aplicações das diazocetonas $\alpha, \beta$-insaturadas utilizando o Rearranjo de Wolff como etapa chave, os objetivos desta tese de doutoramento são:

1) O estudo do rearranjo de Wollf com diazocetonas $\alpha-\beta$ insaturadas na presença de diversas aminas e posterior aplicação na síntese total do composto JP4-039 e análogos (rota B, Esquema 26).

2) A realização do rearranjo de Wolff com diazocetonas insaturadas na presença de álcoois mais complexos, como por exemplo os álcoois alílicos com o intuito de se estudar reações de cicloadição [2+2] e [4+2] intramoleculares (rota A, Esquema 26).

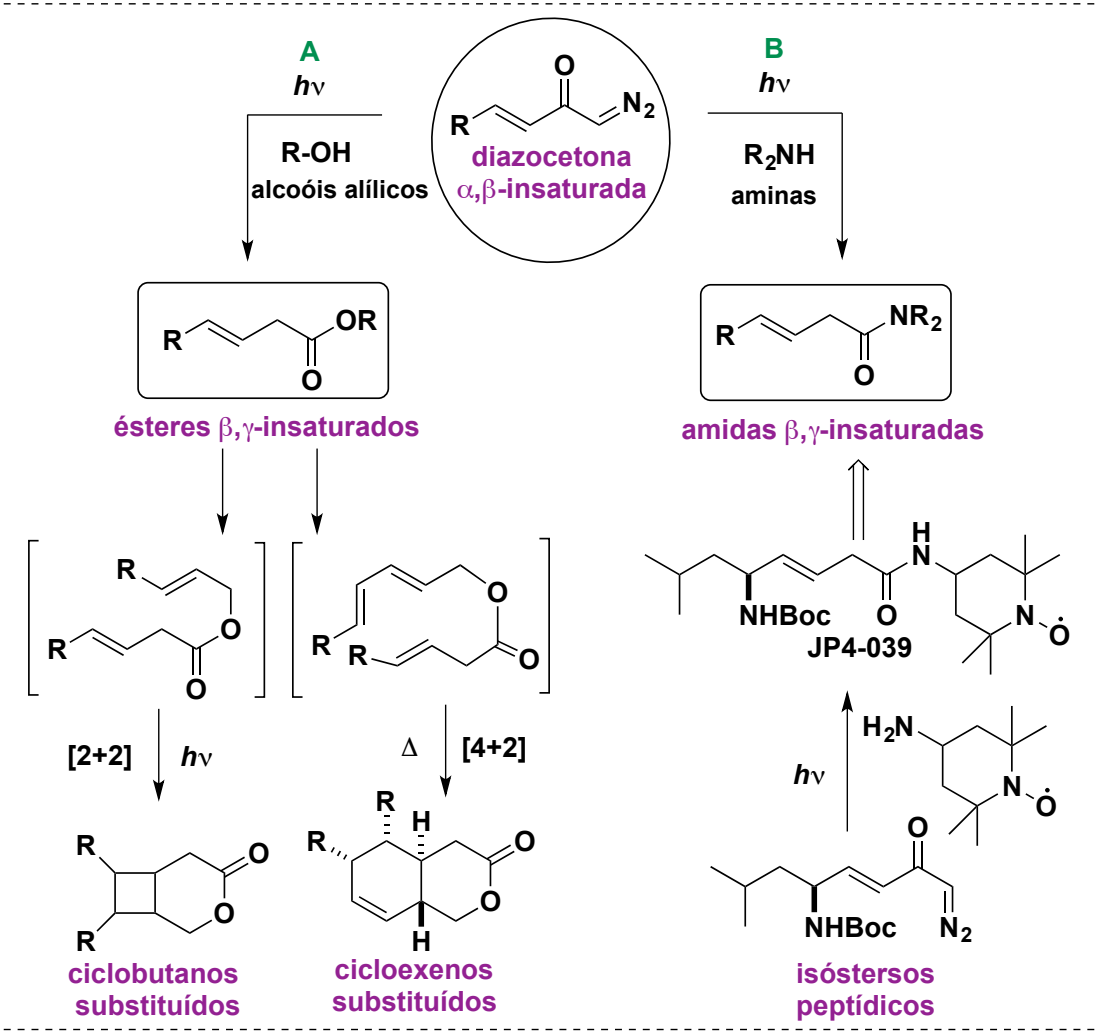

Esquema 26 Objetivo 1 e 2: Metodologia para a síntese de amidas, ciclobutanos e cicloexenos. 
3) Expandir a química das diazocetonas insaturadas (53, Esquema 27) como aceptores de Michael em sistemas ainda mais complexos, como por exemplo, aplicadas na modificação seletiva de proteínas. O conceito-chave do objetivo é ilustrado no Esquema 27.

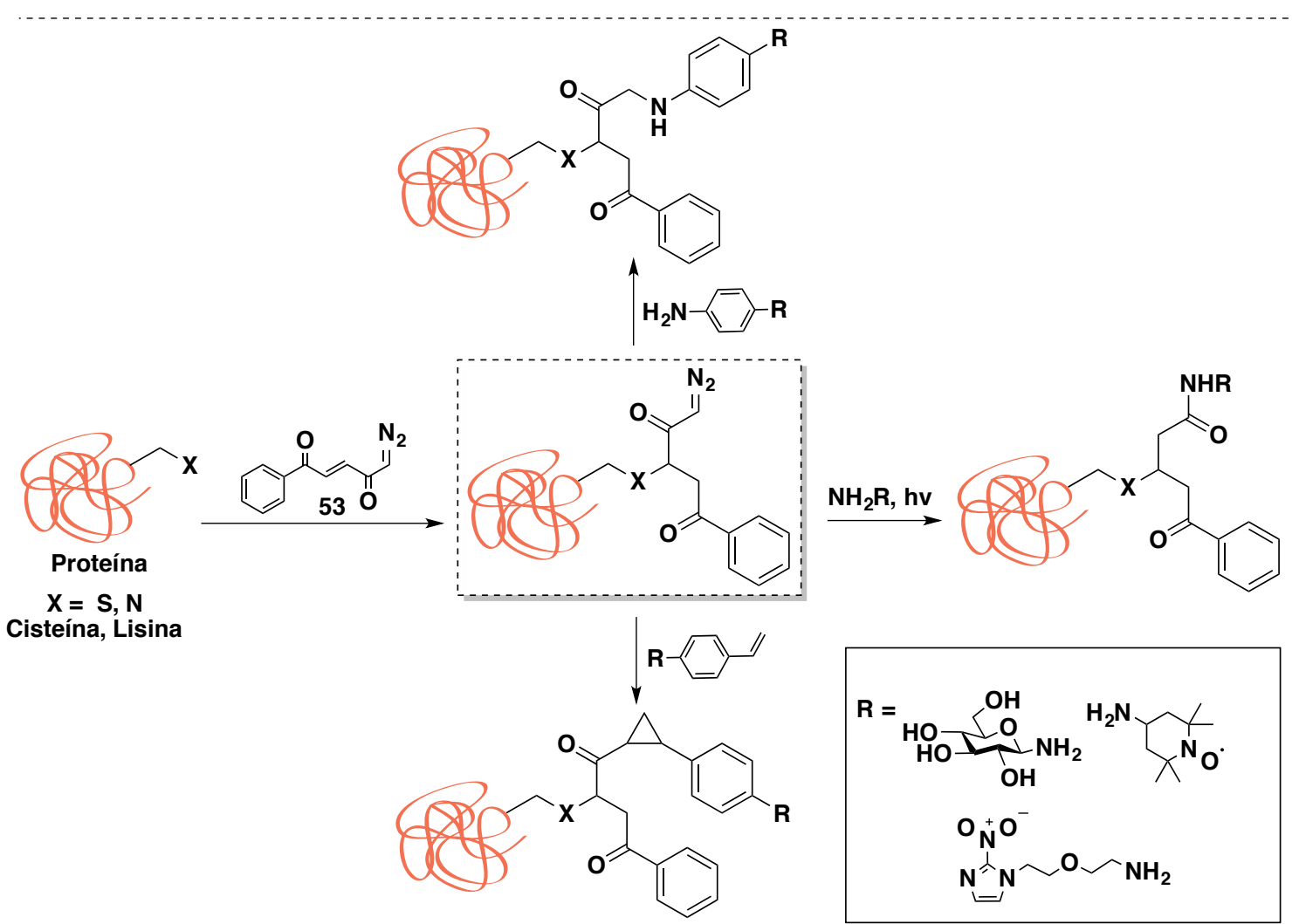

Esquema 27 Conceito-chave: rearranjo de Wolff a partir de diazocetonas $\alpha, \beta$-insaturadas permitindo a modificação local seletiva de proteínas. 


\section{Capítulo I}

\section{Diazocetonas insaturadas como substratos para o rearranjo de Wolff}

Neste capítulo, as diazocetonas $\alpha, \beta$-insaturadas serão apresentadas como plataformas para a síntese direta de amidas e ésteres $\beta, \gamma$-insaturados. Quando diazocetonas derivadas de amino-aldeídos são utilizadas, isósteros peptídicos são obtidos como demonstrado na síntese rápida e eficiente do nitróxido JP4-039. Cabe ressaltar, que a síntese por nós descrita para este importante agente bioprotetor representa a rota mais curta relatada até o momento. Será também discutido um estudo comprovando a eficiência de diferentes lâmpadas comerciais (CFL e LED), em variadas potências, aplicadas no rearranjo de Wolff a partir de diazocetonas saturadas e insaturadas, representando uma alternativa sustentável ao rearranjo de Wolff fotoquímico e térmico. 


\subsection{Agente bioprotetor JP4-039}

Durante muito tempo os raios-X têm sido utilizados como forma de diagnóstico e tratamento de pacientes com diferentes tipos de câncer. ${ }^{87}$ Uma das utilidades da radiação é a radioterapia, a qual atua danificando o DNA de células cancerígenas, levando à sua morte. Embora as células normais também possam ser danificadas após exposição da irradiação ionizante (em menor escala), sabe-se que o microambiente modula o seu reparo sob condições que inibem a divisão celular. Um importante mecanismo de morte celular durante a radioterapia envolve a formação de espécies reativas de oxigênio (ROS) na mitocôndria após a sua radiação. ${ }^{88}$ Neste contexto, moléculas que são capazes de se concentrar e realizar a remoção destas espécies reativas de oxigênio na mitocôndria podem ser de extrema importância como protetores contra radiação. ${ }^{89,90}$

O composto JP4-039 (Figura 8), o qual foi inspirado pelo agente protetor XJB5-13, que por sua vez teve sua estrutura proposta a partir dos farmacofóricos mínimos do antibiótico gramicidina $S$, é um nitróxido que tem demonstrado extrema eficácia na remoção de ROS tais como superóxidos e óxidos nítricos. ${ }^{91}$ Por exemplo, quando comparado no controle das células irradiadas, este nitróxido reforça a reparação e sobrevivência celular por uma ordem de 5-13 vezes. ${ }^{92,93}$ O JP4-039 também é conhecido como um isóstero do peptídeo ${ }^{94}$ leucina-glicina (Figura 8). Considerando a característica de que os peptídeos são facilmente hidrolisados in vivo por peptidases, derivados E-alcenos (isósteros contendo um fragmento amina alílica) vêm demonstrando interessantes atividades quando utilizados na indústria químicabiológica. $^{94}$ ii

\footnotetext{
ii Páginas 56 - 63: Reproduzido em partes a partir de Bernardim, B.; Burtoloso, A. C. B. A Two-Step Synthesis of the Bioprotective Agent JP4-039 from N-Boc-L-Leucinal. Tetrahedron 2014, 70 (20), 3291-3296 com permissão da Elsevier. 
a)

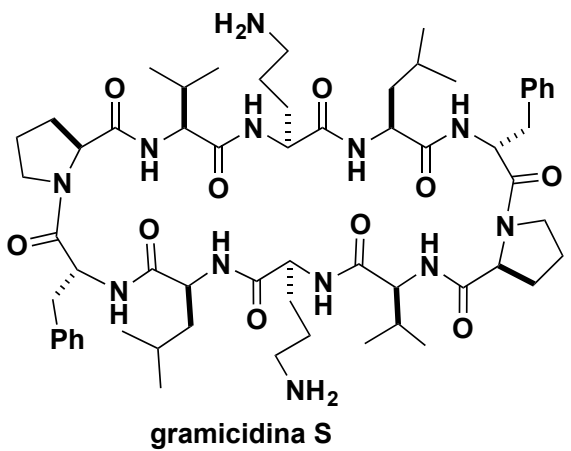<smiles>C/C=C/CC(=O)NC1CC(C)(C)N(Cl)C(C)(C)C1</smiles><smiles>CC(C)CC(/C=C/C(Cc1ccccc1)C(=O)N1CCCC1C(=O)NC(C(=O)NC(CCCNC(=O)OCc1ccccc1)C(=O)NC1CC(C)(C)N(O)C(C)(C)C1)C(C)C)NC(=O)OCc1ccccc1</smiles>

XJB-5-131

JP4-039

b)

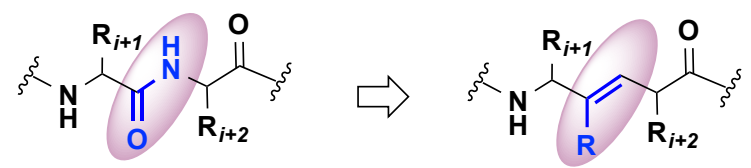

ligação peptídica padrão

isóstero $(E)$-alceno

Figura 8 a) JP4-039 inspirado no agente protetor XJB-5-131 com base na estrutura molecular do antibiótico gramicidina S. b) isóstero (E)-alceno

Em relação ao seu preparo, apenas uma síntese é descrita na literatura. ${ }^{95}$ Durante os últimos anos, o grupo de pesquisa do Prof. Peter Wipf vem demonstrando um grande envolvimento com a síntese e avaliação biológica de vários nitróxidos eficazes na remoção de ROS, entre eles, o agente bioprotetor JP4-039. ${ }^{88,89,91-100}$ A abordagem sintética descrita por Wipf envolve a adição de uma sulfinimina quiral em uma reação de hidrozirconação-transmetalação one-pot como etapa chave. 0 composto JP4-039 é obtido em seis etapas a partir da imina quiral (Esquema 28).

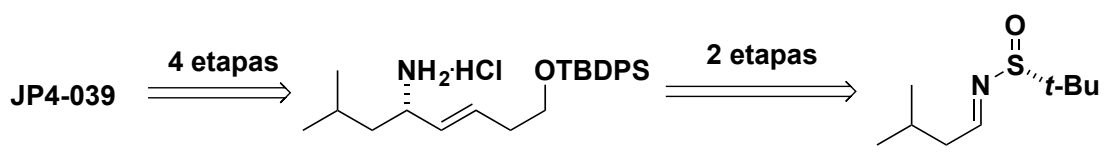

Esquema 28 Síntese em 6 etapas do composto JP4-039 por Wipf. 
Para o desenvolvimento da rota sintética proposta na etapa 1 dos objetivos, inicialmente foram preparadas quatro diazocetonas insaturadas estruturalmente diferentes a fim de avaliar o rearranjo de Wolff na presença de aminas como nucleófilos. Empregando a metodologia de olefinação descrita recentemente por nosso grupo de pesquisa, ${ }^{46}$ as diazocetonas 1,54-56 foram sintetizadas com rendimentos entre 64 e 92\% (Esquema 29). Estes quatro exemplos representam diazocetonas insaturadas contendo grupos alifáticos, aril, aminas acíclicas e cíclicas, respectivamente (Esquema 29). Ao contrário do butiraldeído e benzaldeído, os aminoaldeídos empregados neste estudo não são comercialmente disponíveis e foram facilmente preparados a partir dos respectivos aminoácidos $N$-protegidos (57 e 59, Esquema 29) após redução com borana e oxidação de Swern ${ }^{101,102}$ ou ParikhDoering $^{103,104}$ (58 e 60, Esquema 29). No caso da diazocetona 56, estudos de HPLC quiral mostraram que não ocorreu qualquer racemização durante a etapa de olefinação de Horner-Wadsworth-Emmons.

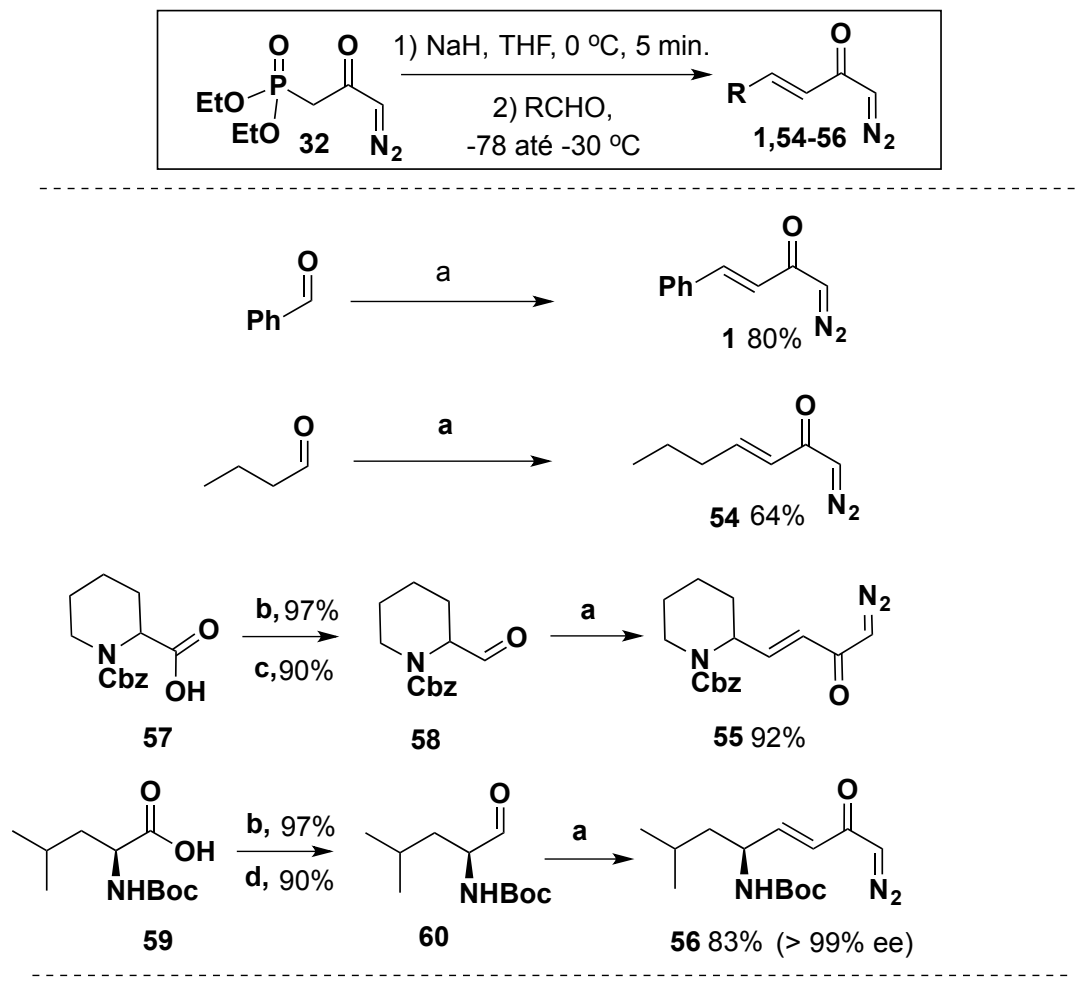

Esquema 29 Síntese de diazocetonas $\alpha, \beta$-insaturadas a partir de aldeídos.

Reagentes e condições a) diazofosfonato $32, \mathrm{NaH}$, THF, $5 \mathrm{~min}$., $0^{\circ} \mathrm{C}$. Depois, aldeído, THF -78 até $-30(55)-40^{\circ} \mathrm{C}$ (56) $0{ }^{\circ} \mathrm{C}$ (1 e 54); b) $\mathrm{BH}_{3} . \mathrm{SMe}_{2}$, THF, $25^{\circ} \mathrm{C}, 12 \mathrm{~h}$; c) Oxidação de Swern; d) Oxidação de Parikh-Doering. A reação de HWE foi realizada com $1.81 \mathrm{mmol}$ dos aldeídos empregados. 
Todas as diazocetonas $\mathbf{1 , 5 4 - 5 6}$ foram obtidas com total seletividade para a olefina de configuração $E$ com constante de acoplamento de $15.3 \mathrm{~Hz}$ entre os hidrogênios do sistema $\alpha, \beta$-insaturado. A formação e geometria das diazocetonas foram confirmadas pela técnica de $\mathrm{RMN}{ }^{1} \mathrm{H},{ }^{13} \mathrm{C}$ e por infravermelho. Uma análise típica é ilustrada na Figura 9. A ausência do singleto $\boldsymbol{d}$ em 9.59 ppm referente ao aldeído do $(S)-N$-Boc-Leucinal 60 , a presença de dois núcleos olefínicos em $\delta 6.66$ (a, $\mathrm{dd}, J=15.4,5.9 \mathrm{~Hz}, 1 \mathrm{H})$ e $6.06(\boldsymbol{b}, \mathrm{d}, J=15.4 \mathrm{~Hz}, 1 \mathrm{H})$, bem como o singleto em 5.31 ppm referente ao hidrogênio $\boldsymbol{c}$ da porção diazocarbonílica corroboram a estrutura. $O$ alargamento dos sinais pode ser justificado pela presença de isômeros rotacionais (rotâmeros) provenientes do grupo de proteção Boc (espectro adquirido em $25^{\circ} \mathrm{C}$ ). As diazocetonas apresentam bandas características em $2100 \mathrm{~cm}^{-1}$ nos espectros de infravermelho respectivas ao estiramento da ligação $\mathrm{C}=\mathrm{N}=\mathrm{N}$ (Figura 9).

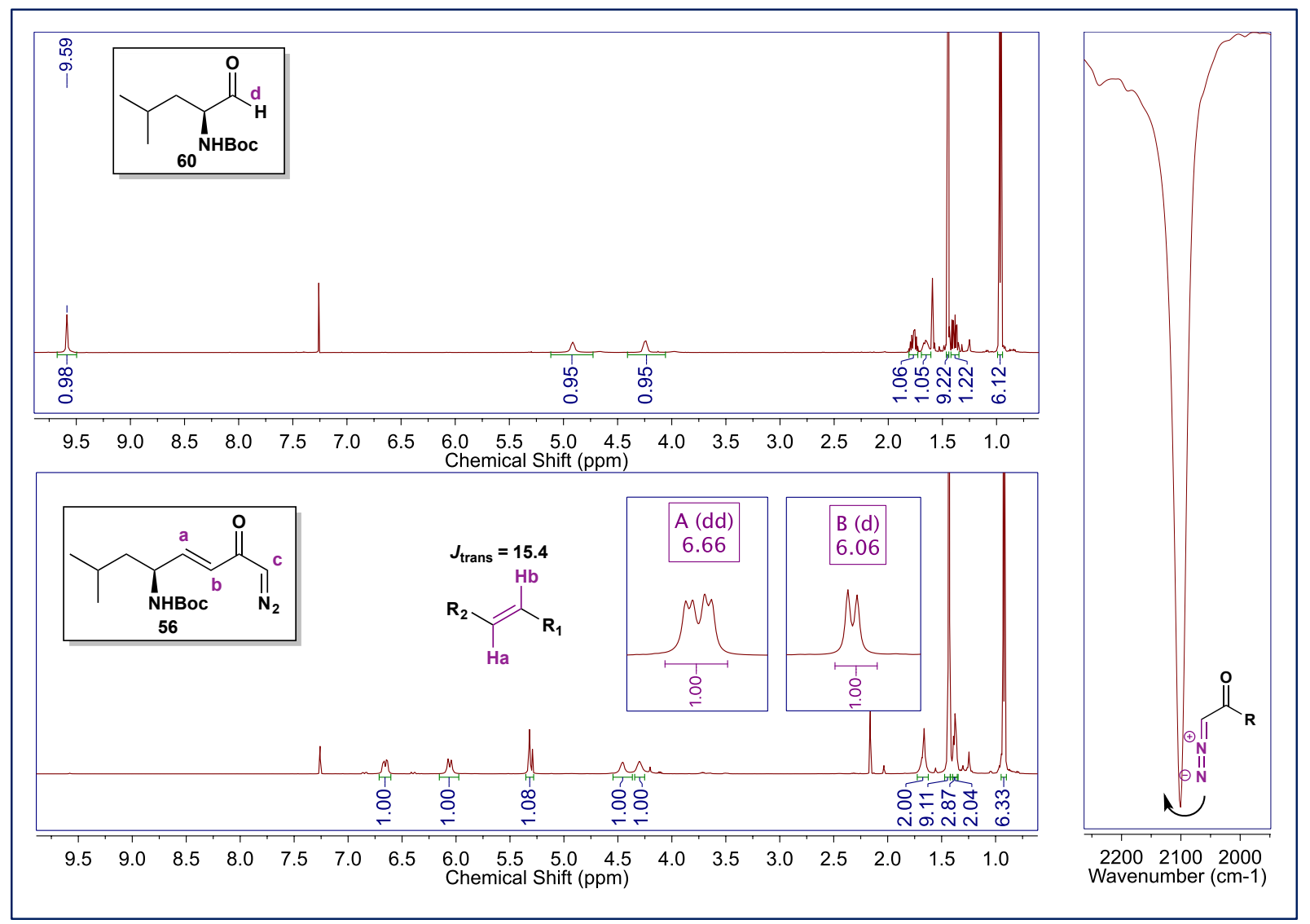

Figura 9 Espectro de RMN ${ }^{1} \mathrm{H}$ e expansão do espectro de IV obtido para a diazocetona $\mathbf{5 6}$ a partir do aldeído 60 (mistura de rotâmeros) em $\mathrm{CDCl}_{3}, 500 \mathrm{MHz}$. 
Após sintetizadas, as diazocetonas foram submetidas ao rearranjo de Wolff fotoquímico na presença de diferentes aminas como nucleófilos. Aminas primárias, secundárias e aromáticas foram avaliadas para este fim. Ainda que seja possível encontrar vários exemplos de rearranjos de Wolff (tanto térmicos como fotoquímicos) a partir de diazocetonas saturadas utilizando aminas como nucleófilos, ${ }^{105-110}$ nenhum exemplo é encontrado na literatura para seus derivados $\alpha, \beta$-insaturados. Na verdade, fomos curiosos sobre o comportamento de tais diazocetonas, especialmente no caso do exemplo quiral 56, na presença dessas bases devido à presença de um próton ácido na posição Y carbonila. Positivamente, a irradiação (lâmpada de arco de Xenônio Osram 150) de uma solução da diazocetona 55 em acetonitrila contendo um equivalente de benzilamina durante $20 \mathrm{~min}$ a $25^{\circ} \mathrm{C}$ forneceu a amida $\beta, \gamma$-insaturada 61a em 98\% de rendimento sem a necessidade de purificação (Esquema 30). Um resultado semelhante foi obtido quando a diazocetona quiral $\mathbf{5 6}$ foi tratada com anilina.

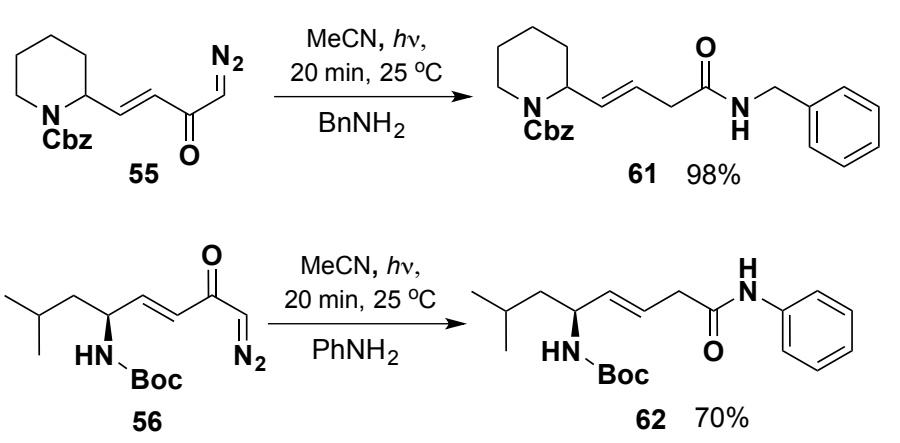

Esquema 30 Síntese das amidas $\beta, \gamma$-insaturadas a partir das diazocetonas $\alpha, \beta$-insaturadas 55 e 56.

A caracterização do produto de Wolff 62 é apresentada da Figura 10. A análise do espectro de RMN ${ }^{1} \mathrm{H}$ corrobora a estrutura pelos sinais olefínicos em $\delta 5.79$ (a, dt, $J=14.8,7.5 \mathrm{~Hz}, 1 \mathrm{H}), 5.56(\boldsymbol{b}, \mathrm{dd}, J=15.4,7.0 \mathrm{~Hz}, 1 \mathrm{H})$, pela ausência do hidrogênio $\alpha$-diazocarbonílico em $5.32 \mathrm{ppm}$ e pela presença de um dubleto em $3.15 \mathrm{ppm}(\boldsymbol{d}, \mathrm{d}, J$ $=7.0 \mathrm{~Hz}, 2 \mathrm{H})$ referente aos hidrogênios $\alpha$-carboxila $\left(-\mathrm{CH}_{2}-\right)$. Uma outra análise importante para a comprovação estrutural diz respeito ao espectro de infravermelho, agora com a ausência da banda intensa em $2100 \mathrm{~cm}^{-1}$ referente ao estiramento $\mathrm{C}=\mathrm{N}=\mathrm{N}$ do grupo diazo. Análises de $\mathrm{RMN}{ }^{13} \mathrm{C}$ e de espectrometria de massas de alta resolução ratificam a estrutura e são apresentados na seção experimental. 


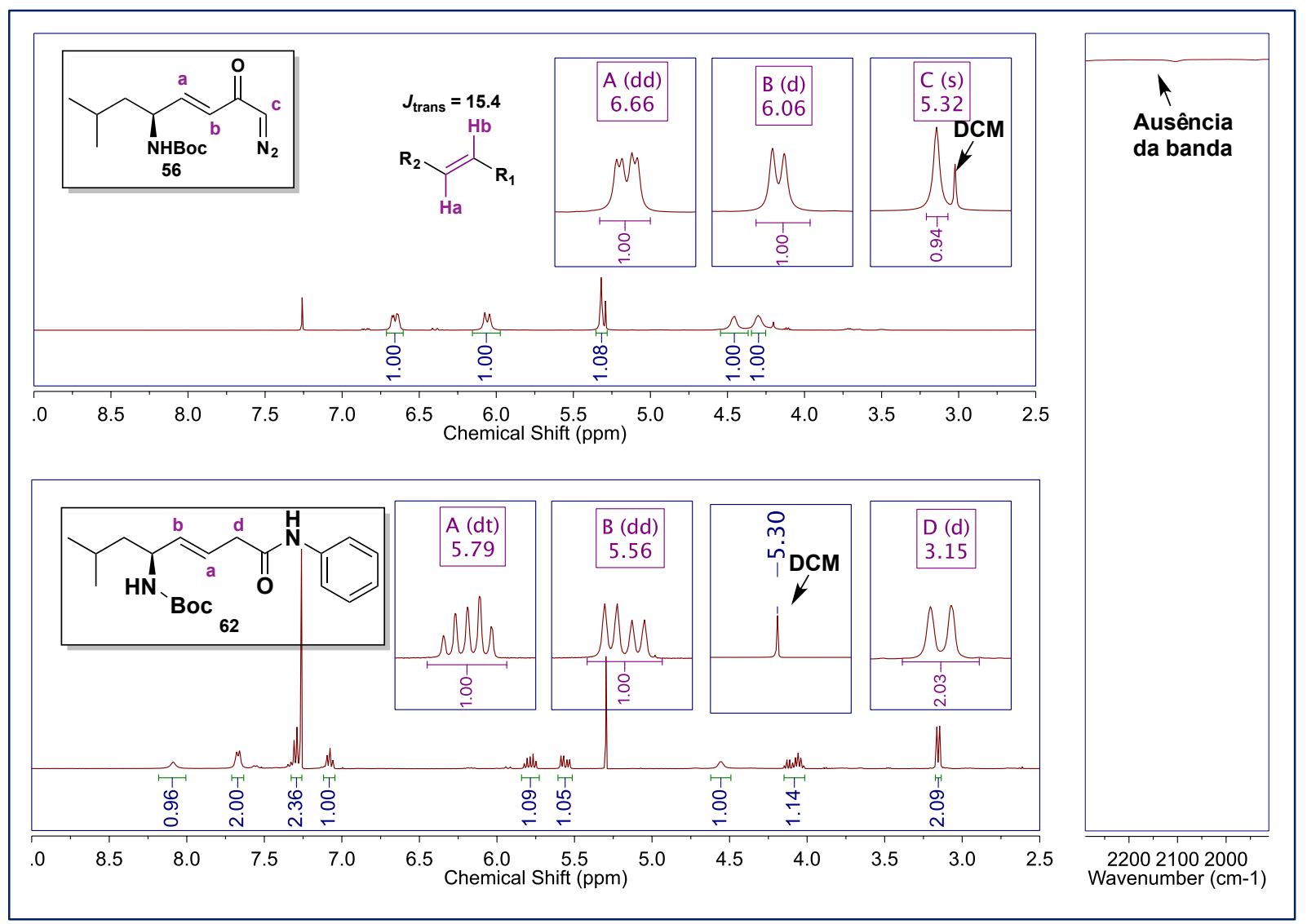

Figura 10 Espectro de RMN ${ }^{1} \mathrm{H}$ e expansão do espectro de IV obtido para o ester $\beta, \gamma$-insaturado 62 a partir da diazocetona $\mathbf{5 6}$ após rearranjo de wolff na presença de anilina.

Os produtos racêmicos $( \pm)-61 \mathrm{~b}$ e $\mathbf{6 1 b}$ foram analisados por HPLC mostrando que não houve qualquer epimerização durante a formação da diazocetona 56 e posteriormente do rearranjo de Wolff nas condições aplicadas (Figura 11). 
mAU

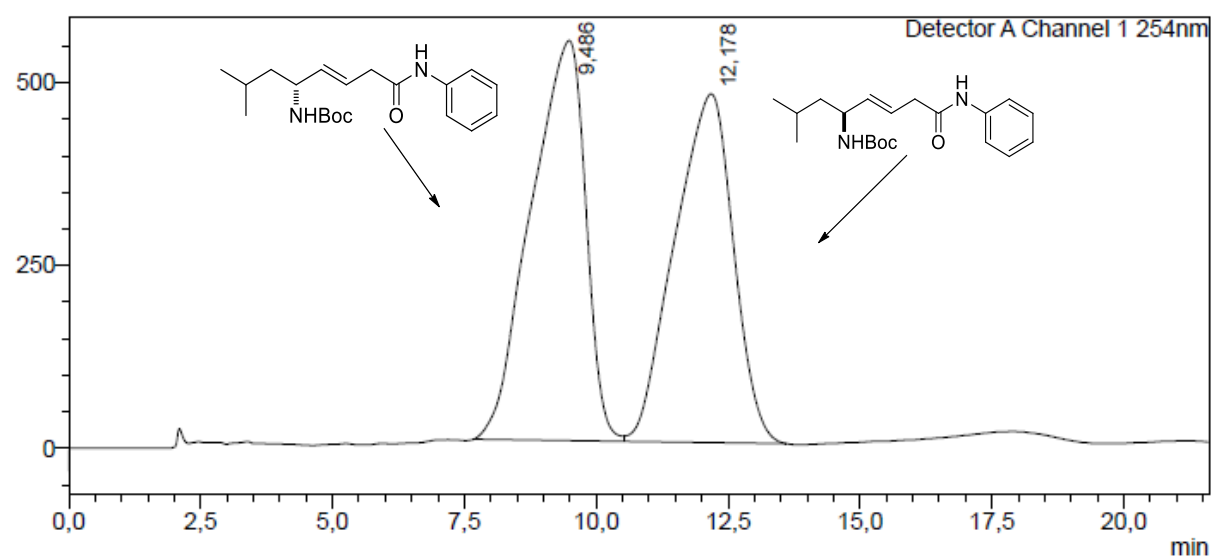

mAU

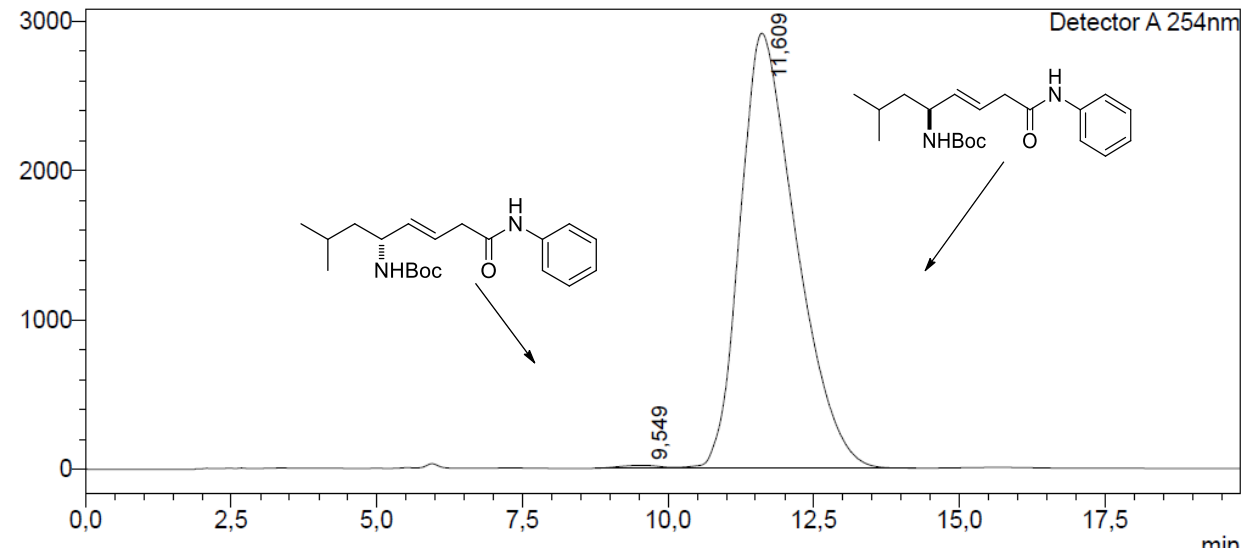

<Peak Table>

Detector A 254nm

Peak\# Ret. Time

reak\# Ret. Time Area

\begin{tabular}{r|r|r|r}
2 & 11,609 & 195578036 & 2915194 \\
\hline Total & & 196553337 & 293529 \\
\hline
\end{tabular}

\begin{tabular}{l|r|}
196553337 & 2935292 \\
\hline
\end{tabular}

Conc.
99,496
99,504

99,504

\begin{tabular}{l|l|l} 
Unit & Mark & Name
\end{tabular}

Figura 11 Estudos de HPLC quiral. A: composto racêmico; B: composto quiral a partir de $N$-Boc- $L-$ leucinal.

O escopo desta transformação foi avaliado a partir das diazocetonas 1,54-56 irradiadas na presença de benzilamina, anilina, p-metóxi-anilina, dialilamina e ciclohexilamina para fornecer amidas $\beta, \gamma$-insaturadas 61-77 com rendimentos variando entre 50 e 98\% (Figura 12). Ao contrário das reações fotoquímicas envolvendo as diazocetonas $\mathbf{5 4 - 5 6}$, as reações realizadas a partir da diazocetona insaturada 1 forneceram misturas entre os produtos de isomerização $E$ e $Z$ da dupla ligação. Os rendimentos indicados na Figura 12 são referentes ao produto $E$ isolado por cromatografia. 


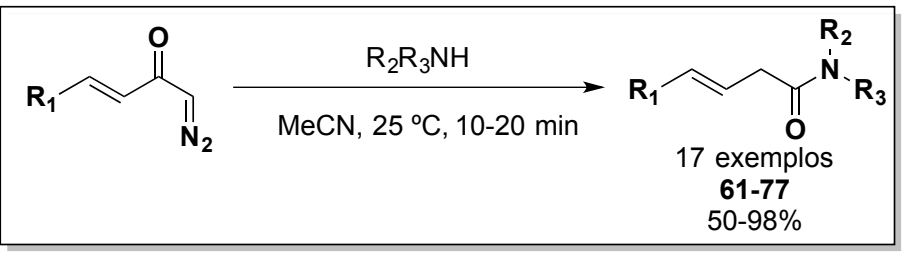

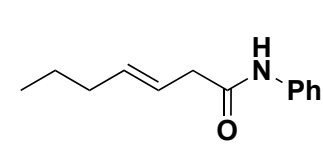

$6376 \%$<smiles>CCC/C=C/CC(=O)Nc1ccc(OC)cc1</smiles>

$6450 \%$<smiles>CCC/C=C/CC(=O)NCc1ccccc1</smiles>

$6590 \%$<smiles>CCC/C=C/CC(=O)NC1CCCCC1</smiles>

66 95\%<smiles>C=CCN(CC=C)C(=O)C/C=C/CCC</smiles>

$6793 \%$<smiles>O=C(C/C=C/C1CCCCN1)Nc1ccccc1</smiles>

68 83\%<smiles>C=CCN(CC=C)C(=O)C/C=C/C1CCCCN1[18O]</smiles>

$6998 \%$<smiles>O=C(C/C=C/C1CCCCN1)NC1CCCCC1</smiles>

70 98\%<smiles>COc1ccc(NC(=O)C/C=C/c2ccccc2)cc1</smiles>

$7150 \%$<smiles>C=CCN(CC=C)C(=O)C/C=C/c1ccccc1</smiles>

$7563 \%$<smiles>O=C(C/C=C/c1ccccc1)Nc1ccccc1</smiles>

72 64\%<smiles>CC(C)CC(/C=C/CC(=O)NCc1ccccc1)NC(=O)OC(C)C</smiles>

$7670 \%$<smiles>O=C(C/C=C/c1ccccc1)Nc1ccccc1</smiles>

73 64\%<smiles>O=C(C/C=C/c1ccccc1)NC1CCCCC1</smiles>

74 66\%

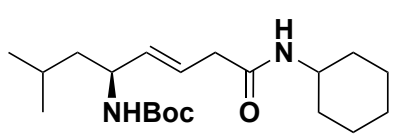

77 96\%

Figura 12 Síntese de várias amidas $\beta, \lambda$-insaturadas em duas etapas a partir de aldeídos.

Finalmente, para mostrar a aplicabilidade do presente método, a diazocetona 56 foi convertida no agente bioprotetor JP4-039 em 65\% de rendimento após irradiação na presença de 4-amino-TEMPO (Esquema 31). Todos os dados espectroscópicos estão em completo acordo com os relatados na literatura por Wipf. ${ }^{95}$ Para esta transformação, o aminoácido comercialmente disponível N-Boc-L-leucina 38a foi primeiramente reduzido na presença do complexo de borana e dimetil sulfeto para gerar $\mathbf{3 8 b},{ }^{110}$ seguido por oxidação com $\mathrm{SO}_{3}$.Py para fornecer o $\mathrm{N}$-Boc-L-Leucinal 38c. ${ }^{103,104} \mathrm{~A}$ reação de olefinação entre $38 \mathrm{c}$ com o ânion diazofosfonato de sódio 14 em -78 a $-40{ }^{\circ} \mathrm{C}$ forneceu a diazocetona $38 \mathrm{com} 83 \%$ de rendimento (> $99 \%$ ee). Em seguida, o rearranjo de Wolff fotoquímico na presença do radical comercialmente disponível 4-amino-TEMPO forneceu o agente bioprotetor JP4-039 em 65\% de rendimento). 


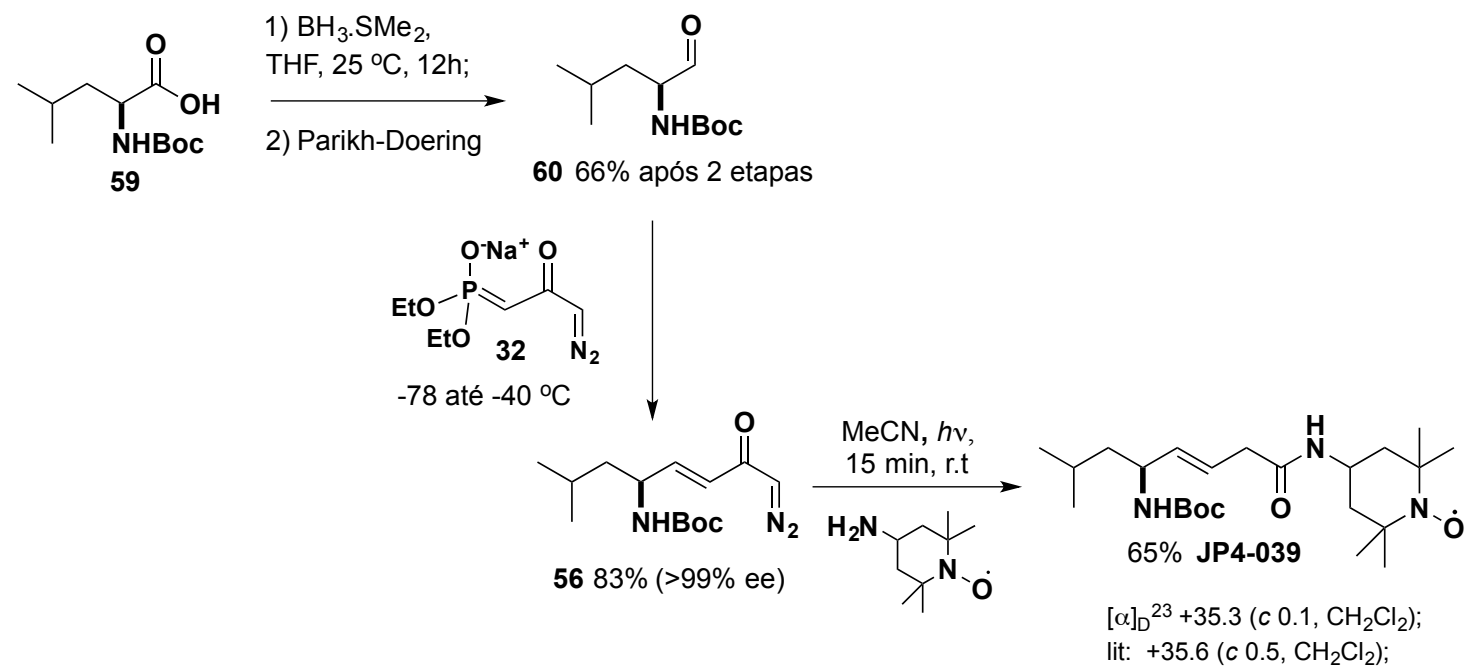

Esquema 31 Síntese do nitróxido JP4-039 em duas etapas a partir do (S)-N-Boc-Leucinal 60.

\subsection{Rearranjo de Wolff promovido por diferentes fontes luminosas}

Como apresentado na introdução da presente tese, o rearranjo de Wolff é uma transformação bastante útil em síntese orgânica. Inicialmente, Ludwig Wolff verificou que o aquecimento de soluções de diazocetonas a temperaturas acima de $100^{\circ} \mathrm{C},{ }^{2}$ ou uso de óxido prata(I) em meio básico, ${ }^{2}$ eram formas apropriadas para o sucesso da transformação. Atualmente, a termólise é geralmente evitada, uma vez que não pode ser aplicada a substratos sensíveis e é geralmente acompanhada pela formação de muitos subprodutos indesejados. Como resultado, sais de prata (I) 111-119 (particularmente benzoato de prata) e a fotólise ${ }^{31,120-128}$ têm sido os métodos comumente adotados como escolha. No caso de sais de prata, a principal desvantagem é o custo e necessidade de altas cargas de catalisador (20-50 mol\%). Protocolos experimentais também podem exigir a adição lenta do catalisador juntamente com aquecimento para o total consumo do substrato. Em alguns casos, quantidades estequiométricas ou quantidades elevadas dos sais de prata devem ser empregues, tal como descrito nos trabalhos de Nicolaou ${ }^{129}$ e Burtoloso ${ }^{58}$ (Esquema 32 , a e b, respectivamente). ${ }^{\text {iii }}$

\footnotetext{
iii Pages 64 - 72: reproduced in part from Bernardim, B.; Hardman-Baldwin, A. M.; Burtoloso, A. C. B. LED Lighting as a Simple, Inexpensive, and Sustainable Alternative for Wolff Rearrangements. RSC Adv. 2015, 5 (18), 13311-13314 with permission from Royal Society of Chemistry.
} 


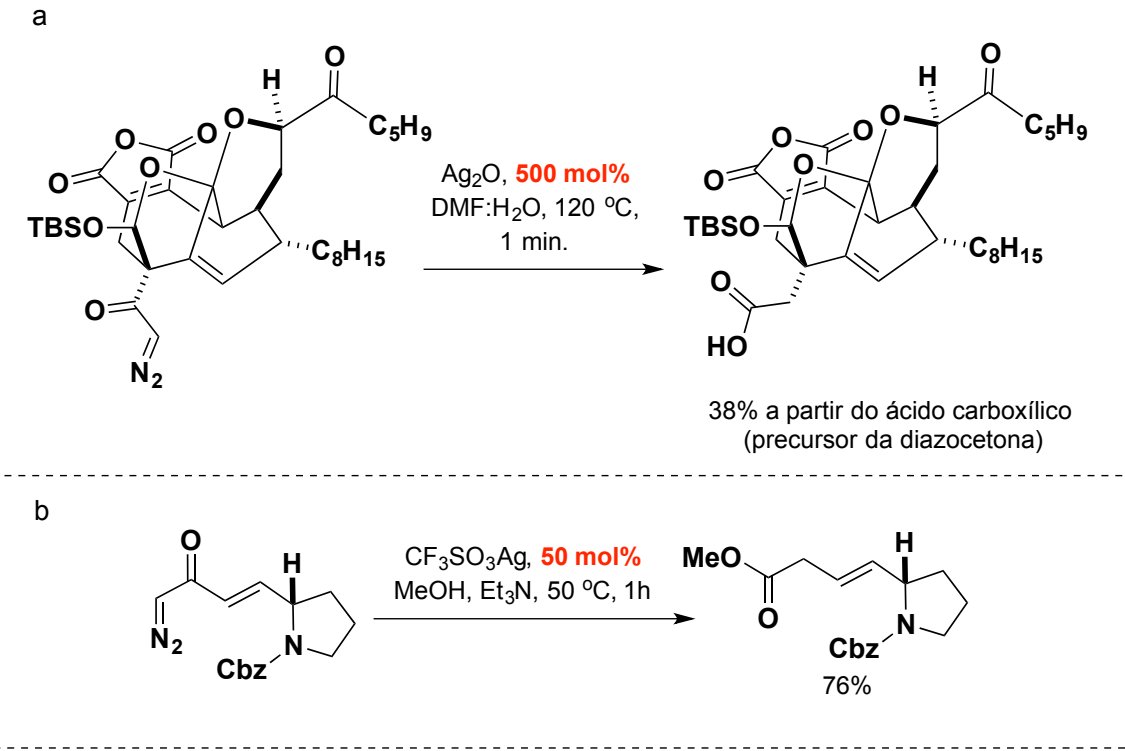

Esquema 32 Dois exemplos mostrando aquecimento e excesso de catalisador ou de sais de prata.

Contrariamente às reações com catalisadores de prata, condições de fotólise costumam apresentar reações mais limpas, com pouco (muitas vezes nulos) subprodutos, além de permitir rendimentos elevados para os produtos do rearranjo de Wolff. $^{62}$ No entanto, a principal limitação da fotólise é a utilização de lâmpadas especiais de xenônio de média e alta pressão assim como lâmpadas de vapor de mercúrio. Estas lâmpadas, além de possuírem alto custo, exigem alto consumo energético além de emitir grandes quantidades de calor, a qual reflete diretamente no rendimento no caso de substratos sensíveis a temperatura.

Uma alternativa sustentável para o rearranjo Wolff fotoquímico utilizando fontes de luz disponíveis no mercado ainda não foi investigado em detalhe. Embora dois exemplos $^{121,126,130}$ individuais são descritos na literatura para o rearranjo Wolff empregando uma lâmpada compacta fluorescente (CFL) em sistemas de fluxo (Esquema 33), com o melhor de nosso conhecimento, nenhum estudo é descrito usando lâmpadas diodo emissor de luz (LED). Nos últimos anos, o uso de lâmpadas LED está aumentando exponencialmente como uma fonte de luz durável e de grande economia energética, ${ }^{131}$ quando comparadas as tradicionais lâmpadas fluorescentes compactas e incandescentes. 


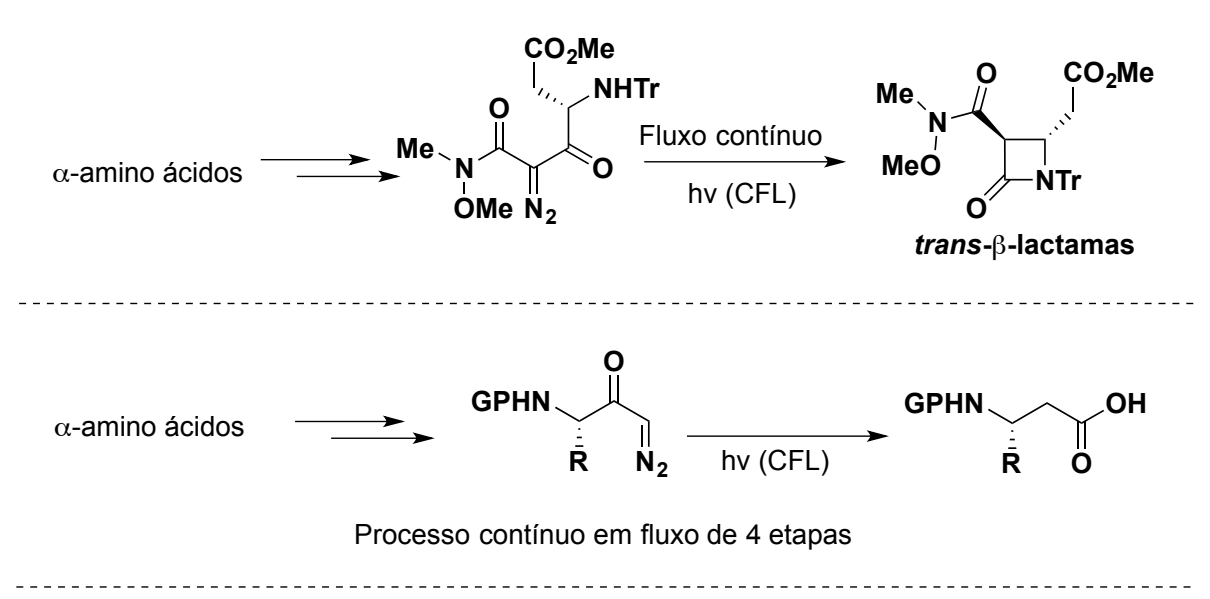

Esquema 33 Lâmpadas CFL aplicadas no rearranjo de Wolff.

Durante o curso dos estudos envolvendo a fotólise das diazocetonas, verificouse uma lacuna de trabalhos aprofundados no que diz respeito ao rearranjo de Wolff em presença de outros tipos de lâmpadas (não somente as lâmpadas de xenônio e mercúrio). Decidiu-se, então, investigar as lâmpadas CFL e LED. Não só para demonstrar que estas fontes de luz são eficientes para promover este rearranjo, mas também que este método pode ser aplicado a vários substratos estruturalmente diferentes sob condições suaves com uma execução simples e prática no laboratório.

\subsubsection{Avaliando a fonte luminosa: síntese de amidas e ésteres}

O trabalho foi iniciado avaliando a capacidade de cinco diferentes lâmpadas brancas CFL e LED para realizar o rearranjo de Wolff. O preparo do éster metílico 78 foi obtido via Homologação de Arndt-Esitert a partir da diazocetona 1 (Tabela 1). Esta diazocetona foi escolhida como um substrato modelo para o estudo de otimização uma vez que é conhecida por proporcionar bons resultados quando as condições clássicas (usando sais de prata) para o rearranjo de Wolff são empregadas ${ }^{35,56}$ (entradas 1 e 2, Tabela 1). Além de permitir uma comparação justa entre os métodos, esta diazocetona também é o substrato modelo adotado para os estudos de cicloadição do presente projeto. Tal como representado na Tabela 1, lâmpadas CFL e LED de média potência são necessárias para o total consumo de 1 e para proporcionar rendimentos quantitativos do éster 78 após 24 h (Entradas 4 e 7 , respectivamente). Também é importante notar que, enquanto as lâmpadas fluorescentes compactas levam a um aquecimento considerável da solução reacional, 
isso não foi observado quando as lâmpadas LED foram empregadas. Este resultado é bastante importante ao utilizar substratos sensíveis.

Tabela 1 Rearranjo de Wolff usando lâmpadas CFL e LED como fontes luminosas.

\begin{tabular}{|c|c|c|c|c|c|}
\hline Entrada & Condições & $\begin{array}{l}\text { Temp. de } \\
\text { Corr }^{c}\end{array}$ & Tempo & $\begin{array}{c}78 \\
(\%)^{a}\end{array}$ & $\begin{array}{l}\text { Temp. solução } \\
\text { após } 24 \mathrm{~h}\end{array}$ \\
\hline $1^{35}$ & $20 \mathrm{~mol} \% \mathrm{AgOBz}, \mathrm{Et}_{3} \mathrm{~N}, \mathrm{MeOH}, 50^{\circ} \mathrm{C}$ & - & $1 \mathrm{~h}$ & 63 & - \\
\hline $2^{56}$ & $\begin{array}{l}\text { Lâmpada de arco de } \\
\text { Xe de alta pressão } 300 \mathrm{~W}\end{array}$ & $6000 \mathrm{~K}$ & $1 \mathrm{~h}$ & 98 & $30^{\circ} \mathrm{C}$ \\
\hline $3^{b}$ & Lâmpada CFL branca $15 \mathrm{~W}$ & $6500 \mathrm{~K}$ & $4 \mathrm{~h}$ & 65 & $38^{\circ} \mathrm{C}$ \\
\hline $4^{\mathrm{b}}$ & Lâmpada CFL branca $45 \mathrm{~W}$ & $6500 \mathrm{~K}$ & $4 \mathrm{~h}$ & 92 & $40^{\circ} \mathrm{C}$ \\
\hline $5^{\mathrm{b}}$ & Lâmpada CFL branca $25 \mathrm{~W}$ & $2700 \mathrm{~K}$ & $4 \mathrm{~h}$ & 83 & $39^{\circ} \mathrm{C}$ \\
\hline $6^{\mathrm{b}}$ & Lâmpada LED branca $5 \mathrm{~W}$ & $2700 \mathrm{~K}$ & $4 \mathrm{~h}$ & 10 & $27^{\circ} \mathrm{C}$ \\
\hline $7^{\mathrm{b}}$ & Lâmpada LED branca $18 \mathrm{~W}$ & $2700 \mathrm{~K}$ & $4 \mathrm{~h}$ & 100 & $27^{\circ} \mathrm{C}$ \\
\hline $8^{\mathrm{b}}$ & Sem lâmpada (branco) & - & $24 \mathrm{~h}$ & 0 & $27^{\circ} \mathrm{C}$ \\
\hline
\end{tabular}

${ }^{a}$ Rendimentos determinados por RMN quantitativo usando 1,2,4,5-tetrametilbenzeno como padrão interno;

${ }^{\mathrm{b}} 0.05 \mathrm{M} \mathrm{em} \mathrm{MeOH}$ em $27{ }^{\circ} \mathrm{C}{ }^{\mathrm{C}} \mathrm{A}$ temperatura de cor expressa a aparência de cor da luz emitida pela fonte de luz. A unidade de medida da temperatura de cor é o Kelvin (K). Quanto mais alta a temperatura de cor, mais clara é a tonalidade de cor da luz. Ex.: uma lâmpada de temperatura de cor de $2.700 \mathrm{~K}$ tem tonalidade suave, já uma outra de $6.500 \mathrm{~K}$ tem tonalidade clara

O produto 78 foi caracterizado a partir das técnicas de $\mathrm{RMN}{ }^{1} \mathrm{H},{ }^{13} \mathrm{C}$, bem como por infravermelho de acordo com a análise realizada na seção anterior (Figura 13). O desaparecimento do sinal do hidrogênio ligado ao grupo diazo, em 5.5 ppm indica o consumo da diazocetona. Os principais sinais para o éster 78 podem ser destacados de acordo com o espectro da Figura 13. O duplo dubleto em 3.26 ppm com constante de acoplamento de 7.1 e $1.4 \mathrm{~Hz}$ e integral para dois hidrogênios, é um sinal bastante evidente para a caracterização do produto de rearranjo de Wolff e representa os hidrogênios $\boldsymbol{d}$. Outros sinais característicos da molécula são: singleto em 3.72 ppm, com integral para três hidrogênios, característico da metoxila incorporada no produto c, bem como o deslocamento e o desdobramento dos sinais olefínicos em 6.50 e 6.31 ppm, d e dt, respectivamente. Os hidrogênios olefínicos em 6.50 ppm (a) e 6.31 ppm (b) com constante de acoplamento de $15.9 \mathrm{~Hz}$ confirmam a geometria $E$ da molécula. A ausência da banda em $2100 \mathrm{~cm}^{-1}$ no espectro de infravermelho confirmou o 
consumo da diazocetona 1 para a formação do produto 78. Esta mesma análise foi realizada para todos os ésteres preparados na avaliação do escopo de substratos.

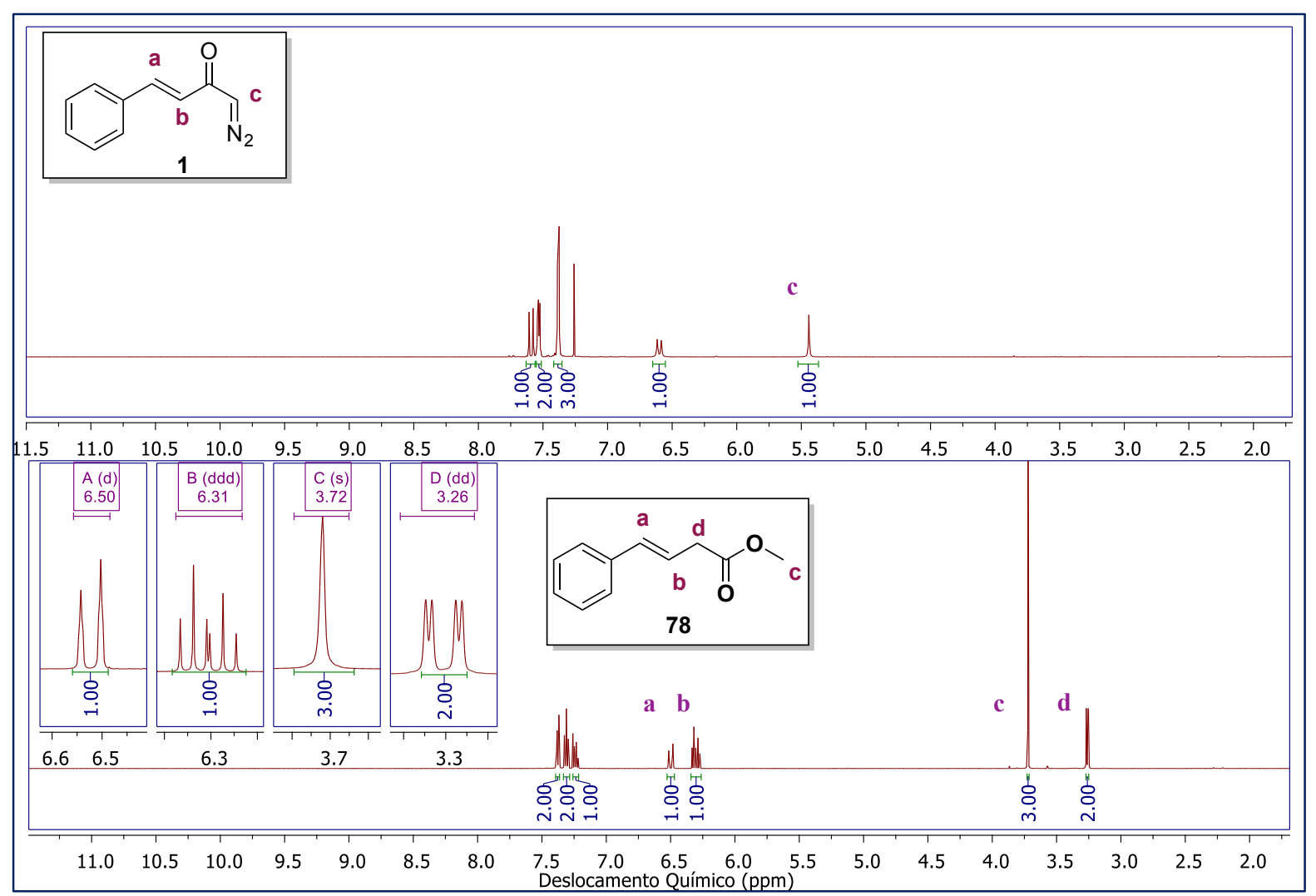

Figura 13 Espectro de $\mathrm{RMN}{ }^{1} \mathrm{H} \mathrm{e}{ }^{13} \mathrm{C}$ para a diazocetona 1 e o éster 56

O escopo do substrato foi avaliado após determinar a lâmpada de LED branca de $18 \mathrm{~W}$ como a melhor fonte de luz para realizar os rearranjos de Wolff. Foi avaliada a reação entre a diazocetona 1 e vários nucleófilos hidroxilados. Isto incluiu exemplos impedidos como isopropil, tert-butil e álcoois mentil, bem como álcool alílico, álcool benzílico, fenol, e água. Como ilustrado no Esquema 34, a reação entre 1 com estes nucleófilos estruturalmente diferentes conduziu a rendimentos isolados dos ésteres 78-85 correspondentes entre 63-100\%. Mesmo quando foram usados fenóis fracamente nucleofílicos e álcoois altamente impedidos como álcool tert-butílico, um rendimento de $63 \%$ foi obtido. 


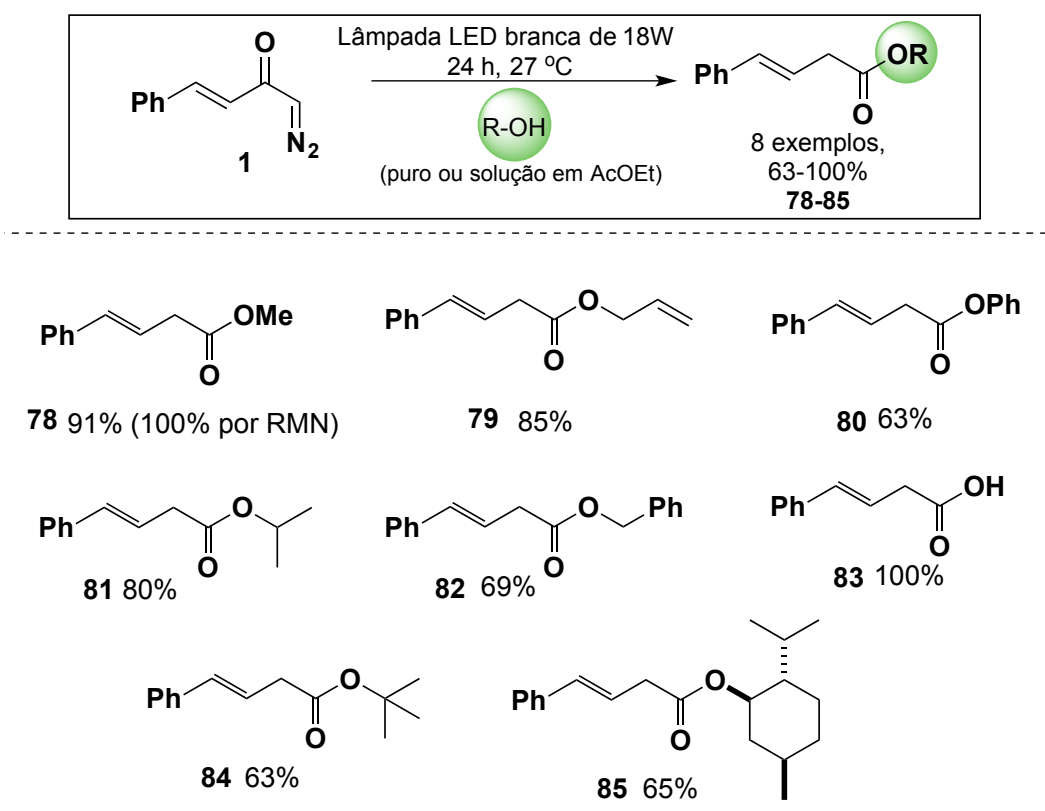

Esquema 34 Rearranjo de Wolff fotoquímico a partir da diazocetona 1 na presença de diferentes
nucleófilos oxigenados.

Com exceção da água e dos exemplos sólidos, em que foi utilizada uma solução do nucleófilo em acetato de etila, as reações foram realizadas utilizando o próprio álcool como solvente e também nucleófilo. Os álcoois são descritos como sendo um dos solventes mais verdes, ${ }^{132}$ além de poderem ser facilmente recuperados a partir da reação, em alta pureza, via destilação. Durante o decurso desta avaliação, um outro estudo revelou que a concentração da solução de reação é crucial para um desempenho elevado da transformação. Por exemplo, um rendimento de $100 \%$ do éster 78 foi obtido quando foram utilizadas soluções da ordem de 0.025-0.05 M, ao passo que apenas $49 \%$ foi obtido em uma solução $0.5 \mathrm{M}$ após 24 horas. Para os processos que empregam acetato de etila como o solvente, 10 equivalentes do álcool é necessário para garantir elevados rendimentos do produto.

Em seguida, investigou-se a utilidade sintética do presente método fotoquímico na presença de outras diazocetonas. Os substratos 86-88 foram preparados e irradiados com LED branca de $18 \mathrm{~W}$ na presença de vários álcoois. Para este estudo, aril-diazocetonas impedidas, diazocetonas quirais e derivadas de aminoácidos foram empregadas, fornecendo os correspondentes ésteres e ácidos 89-98 em 50-89\% de rendimento isolado (Figura 14). É bem descrito que diazocetonas derivadas de $\alpha$ amino ácidos são importantes precursores para a preparação de $\beta$-amino ácidos e ésteres através do rearranjo de Wolff. No é ilustrado a disposição experimental, mostrando a simplicidade e praticidade deste protocolo. Outro ponto que merece 
atenção é que não houve qualquer alteração significativa no rendimento isolado observado com o aumento da escala da reação. Experimentos com 0.2 e $2.0 \mathrm{mmol}$ da diazocetona 86 forneceram $81 \%$ e $78 \%$ de rendimento do composto $\mathbf{8 9}$, respectivamente (Esquema 35).

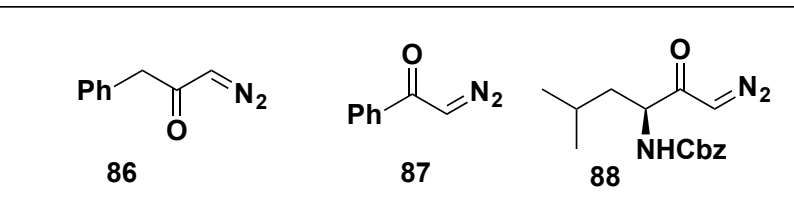

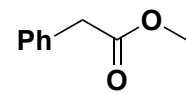

$8981 \%$<smiles>C=CCOC(=O)Cc1ccccc1</smiles>

$90 \quad 75 \%$<smiles>O=C(Cc1ccccc1)Oc1ccccc1</smiles>

$9162 \%$

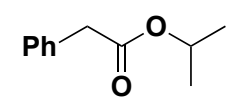

$9263 \%$<smiles>O=C(O)Cc1ccccc1</smiles>

$9378 \%$<smiles>C=CCOC(=O)CCc1ccccc1</smiles>

$9489 \%$<smiles>CC(C)OC(=O)CCc1ccccc1</smiles>

$9570 \%$<smiles>CC(C)(C)OC(=O)CCc1ccccc1</smiles>

96 66\%
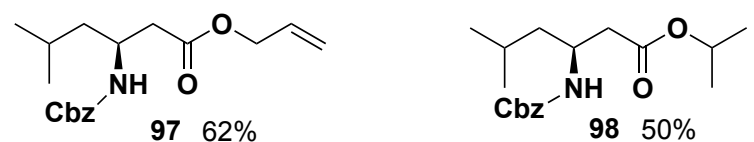

Figura 14 Uso de diferentes nucleófilos de oxigênio e diferentes diazocetonas para o rearranjo de Wolff usando LED

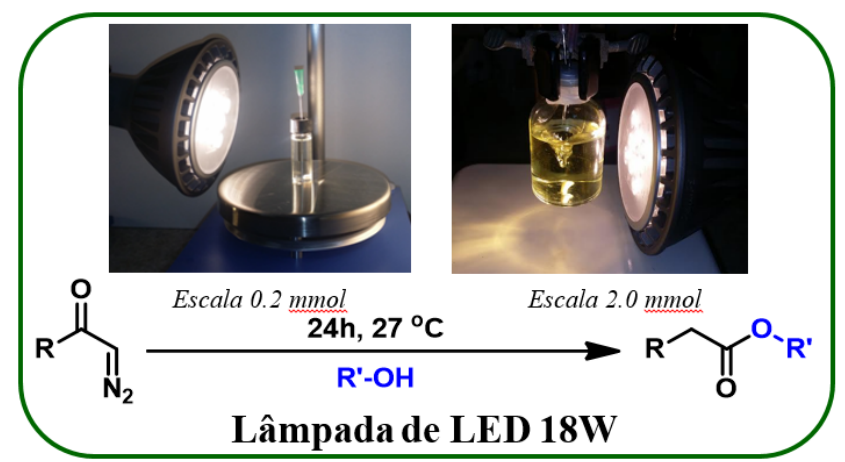

Esquema 35 Disposição experimental do Rearranjo de Wolff usando lâmpadas de LED. 
As mesmas condições reacionais foram então aplicadas nos substratos diazocarbonílicos 87, 88 e 99 na presença de 10 equivalentes de diferentes aminas (Esquema 36). As amidas 100-108 foram facilmente preparadas em excelentes rendimentos variando entre 70 e $99 \%$, sendo que exemplos de diazocetonas bastante impedidas foram utilizadas e ainda foi possível se obter as amidas com rendimentos moderados (exemplo 104, 70\% de rendimento). Por fim, a síntese do composto JP4039 foi comparada utilizando ambas as fontes luminosas a partir da diazocetona 56, com apenas 1 equivalente do nucleófilo 4-amino-TEMPO e o rendimento obtido foi similar (Esquema 37).
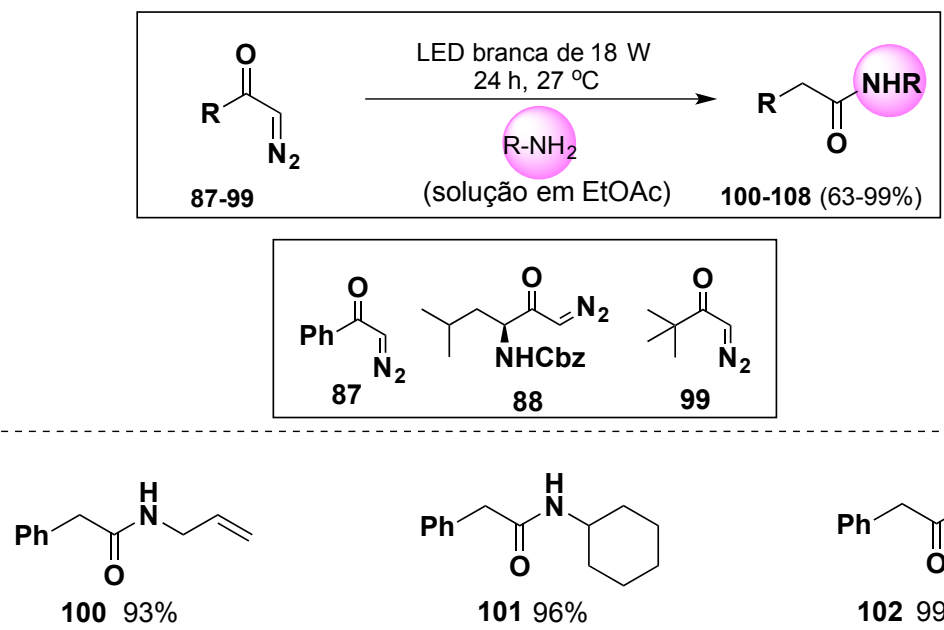<smiles>O=C(Cc1ccccc1)NC1CCCCC1</smiles><smiles>O=C(Cc1ccccc1)NCc1ccccc1</smiles>
$10196 \%$ $10299 \%$<smiles>CCCCNC(=O)Cc1ccccc1</smiles>
$10395 \%$<smiles>C=CCNC(=O)CC(CC(C)C)NCCC</smiles>
$10699 \%$<smiles>C=CCNC(=O)CC(C)(C)C</smiles>
$10470 \%$<smiles>CC(C)CC(CC(=O)Nc1ccccc1)NC(=O)c1ccccc1</smiles>
$10770 \%$ $10563 \%$<smiles>CCCCNC(=O)C[C@H](CC(C)C)NC(=O)OCc1ccccc1</smiles>
$10898 \%$

Esquema 36 Amidas obtidas usando lâmpada LED para promover o rearranjo de Wolff. 


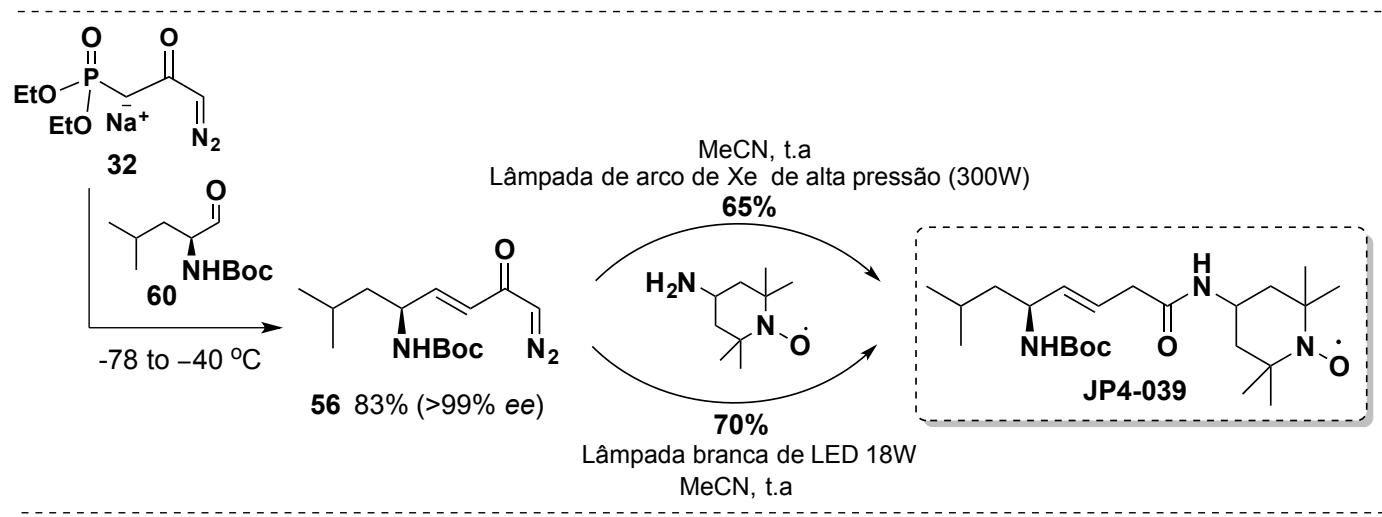

Esquema 37 Síntese do composto JP4-039 usando lâmpada LED e de alta pressão de mercúrio. 


\subsection{Conclusões parciais}

Neste capítulo foi demonstrado o uso das diazocetonas $\alpha, \beta$-insaturadas como interessantes blocos de construção para a síntese direta amidas e ésteres $\beta, \gamma$ insaturados via rearranjo de Wolff fotoquímico promovido por diferentes fontes luminosas. Quatro exemplos de diazocetonas 54-56 foram sintetizadas (rendimentos entre 64-92\%) e convertidas em 17 exemplos de amidas $\beta, \gamma$-insaturadas 61-77 (5098\% de rendimento). Quando diazocetonas derivadas de amino-aldeídos foram empregadas, isósteros peptídicos foram obtidos conforme demonstrado na síntese rápida e eficiente do nitróxido JP4-039. ${ }^{133}$ Cabe ressaltar, que a síntese aqui descrita representa a rota mais curta para o preparo deste composto bioprotetor. Demonstrouse também o uso de simples lâmpadas de LED, disponíveis comercialmente, como uma alternativa prática e sustentável para a realização do rearranjo Wolff. ${ }^{134}$ Este método é amplo no que diz respeito ao nucleófilo e a diazocetona proporcionando rendimentos moderados a excelentes dos produtos desejados. Cinco exemplos de diazocetonas saturadas e insaturadas 1, 86-88 foram convertidas em 27 exemplos das respectivas amidas (100-108), ésteres e ácidos carboxílicos (78-85 e 89-98) com rendimentos entre 50 e $99 \%$. Cabe ressaltar, que em muitos casos não há a necessidade de purificação por cromatografia. Além disso, este método pode ser aplicado a outros nucleófilos, como o procedimento experimental requer apenas a preparação de uma solução da diazocetona e nucleófilo. Este novo protocolo evita o uso de lâmpadas de $\mathrm{Hg}$ e Xe alta pressão, bem como os procedimentos experimentais tediosos que envolvem o uso dos caros sais de prata. 


\section{Capítulo II}

\section{Diazocetonas insaturadas como precursoras de reações de cicloadições [2+2] e $[4+2]$}

Após estabelecer um método que permitiu um acesso rápido e eficiente a vários heterocíclicos nitrogenados e uma extensão para a síntese de isósteros peptídicos como o JP4-039, imaginou-se esses blocos de construção aplicados na síntese de cicloexenos e ciclobutanos substituídos. Por exemplo, ao considerar a dupla ligação estratégica na estrutura da diazocetona, visualiza-se, após o rearranjo de Wolff na presença de álcoois insaturados, um importante substrato para reações de cicloadição [2+2] e [4+2] intramoleculares (Esquema 38). O uso de luz para promover o rearranjo fotoquímico na presença de álcoois alílicos, poderia, em uma única etapa, servir também para promover fotocicloadições [2+2]. Os produtos do rearranjo de Wolff (Esquema 38), poderiam ciclizar de forma intramolecular sem a necessidade prévia de manipulação do substrato em uma única etapa. Isto permitiria a preparação de ciclobutanos altamente substituídos, esqueletos frequentemente encontrados em produtos naturais (Esquema 39). Ao se utilizar álcoois insaturados com duplas ligações conjugadas, o rearranjo de Wolff poderia também promover a síntese de 
substratos para reações de Diels-Alder. Condições térmicas ou catálise com ácidos de Lewis poderiam levar a construção de cicloexenos substituídos, representando uma nova metodologia para acessar essa classe de esqueletos de forma rápida e eficiente (Esquema 38).

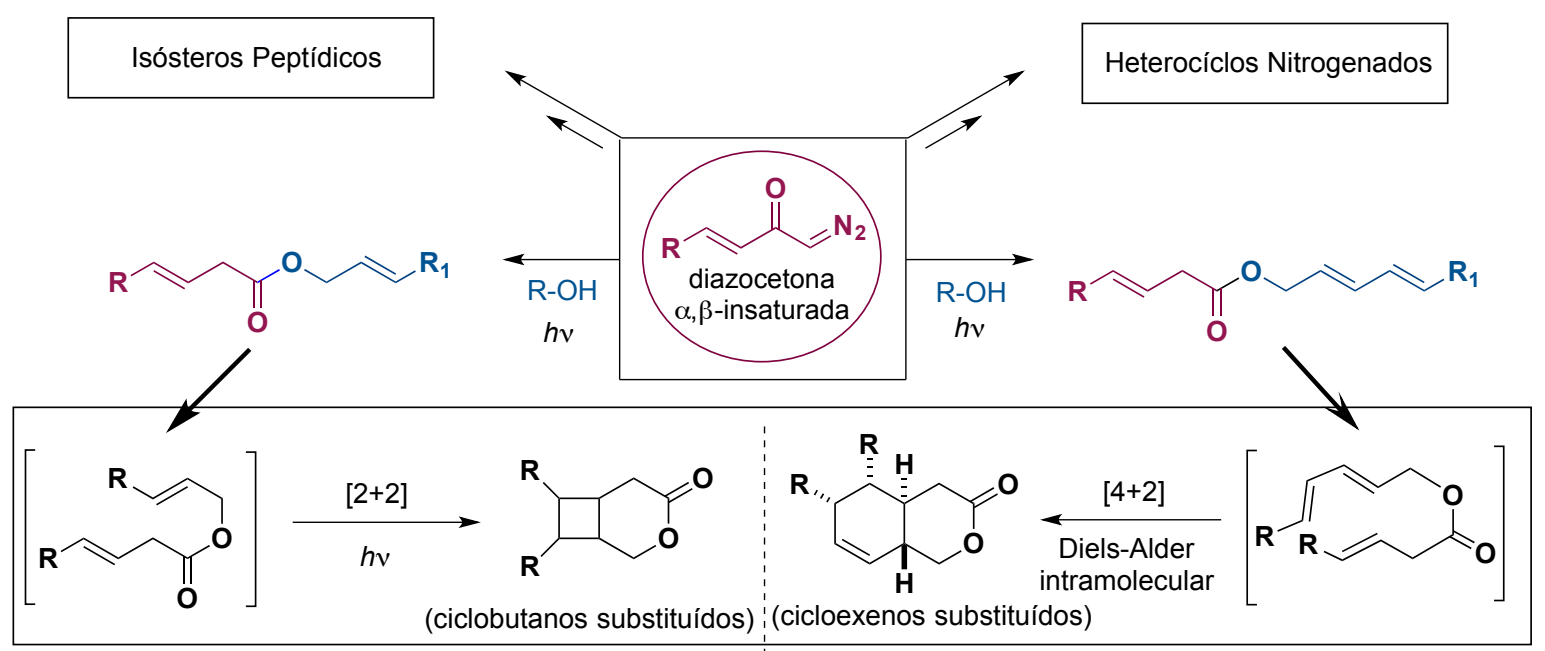

Esquema 38 Expansão da química das diazocetonas insaturadas para a síntese de cliclobutanos e cicloexenos substituídos.

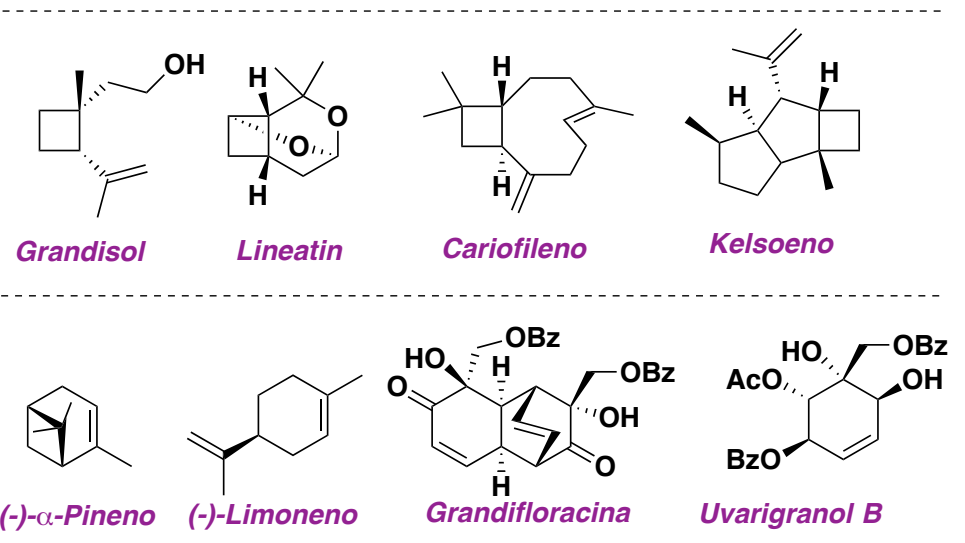

Esquema 39 Exemplos de produtos naturais contendo ciclobutanos e cicloexanos.

Com o intuito de se obter um amplo escopo de precursores, diferentes substratos foram propostos a fim de se estudar as reações de cicloadição [2+2] e [4+2]. Compostos $\alpha, \beta$-insaturados (olefinas conjugadas, deficientes eletronicamente) com alcenos ricos ou levemente ricos em elétrons e o cruzamento entre olefinas com grupos doadores e retiradores foram propostos (Figura 15). Por exemplo, os ésteres precursores (Figura 15, série A-J) poderiam ser sintetizados usando a metodologia clássica de HWE e rearranjo de Wolff a partir das diazocetonas instauradas 
desenvolvidas no grupo do Prof. Antonio Burtoloso. Os substratos com substituintes retiradores de elétrons no anel aromático, como o grupo nitro e acetil (Figura 15, série B e C, respectivamente), poderiam atuar na conjugação da dupla ligação, diminuindo assim a energia do LUMO e permitindo a criação de um ambiente eletrônico distinto entre as duas olefinas. No caso dos ésteres $\alpha, \beta$-insaturados da série $D$, sua síntese poderia ser realizada através de uma reação de isomerização da dupla ligação dos compostos da série A (Figura 15). Já o éster reativo da série $E$, poderia ser obtido a partir da clássica metodologia de HWE fazendo o uso do diazofosfonato 32 e um aldeído como o fenilglioxal, seguido de rearranjo de Wolff na presença de álcoois alílicos. O mesmo raciocínio vale para os precursores da Diels-Alder, trocando apenas a diazocetona (por exemplo, derivada do cinamaldeído - séries I e J, Figura 15) e do álcool insaturado utilizado no rearranjo de Wolff.

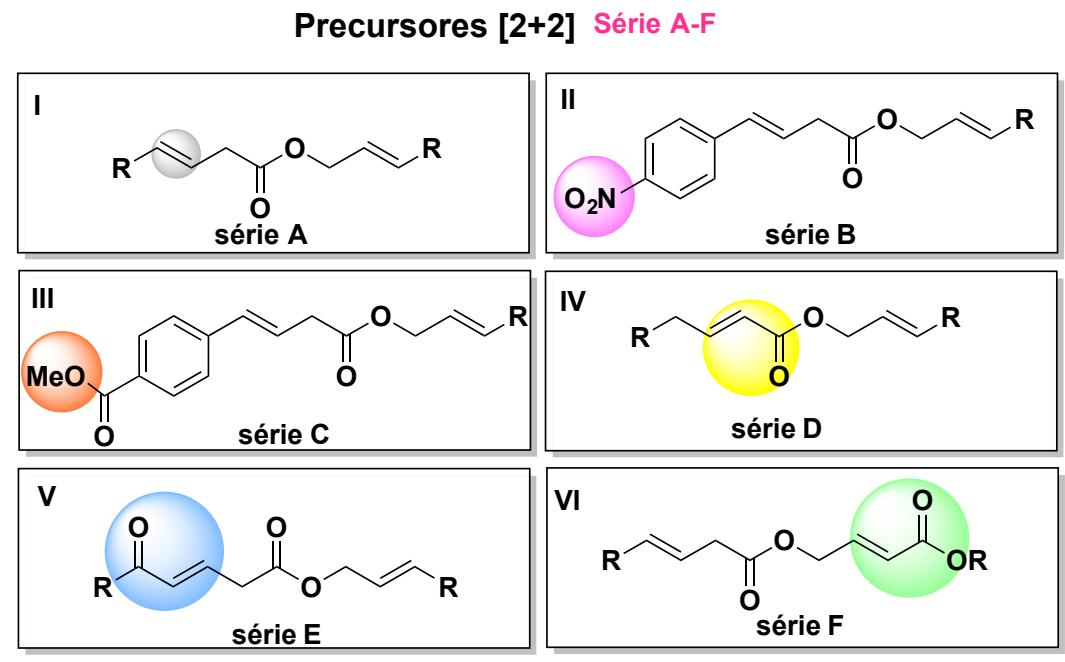

Precursores [4+2] Série G-J

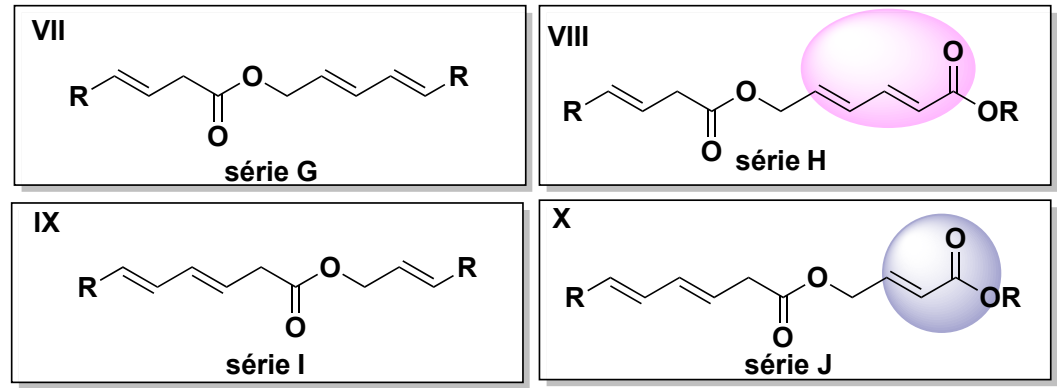

Figura 15 Diferentes substratos propostos para a reação de Cicloadição [2+2] e [4+2]. 
Um trabalho de fotocicloadição publicado por Padwa e colaboradores ${ }^{135}$ serviu como precedente para o encorajamento da proposta de ciclização [2+2]. Dentre os diferentes precursores avaliados, um exemplo em particular 109 (Esquema 40) serviu como base para o início deste estudo. Padwa submeteu uma solução do ciclopropeno 109 em benzeno na presença do fotossensibilizador tioxantona sob a irradiação de uma lâmpada de arco de mercúrio de média pressão (450W, equipada com filtro de Urânio). Após $4 \mathrm{~h}$ de reação, o produto de cicloadição 110 foi isolado em $72 \%$ de rendimento (Esquema 40).

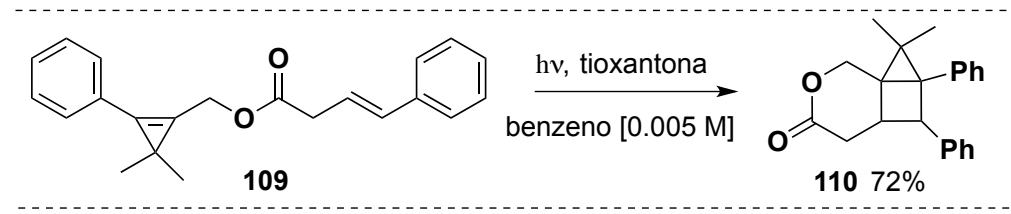

Esquema 40 Cicloadição [2+2] intramolecular descrito por Padwa e Colaboradores.

\subsection{Preparo dos substratos para as cicloadições [2+2] e [4+2]}

O trabalho foi iniciado pelo preparo das diazocetonas $\alpha, \beta$-insaturadas 1,54 , 111-114 segundo um recente protocolo de olefinação desenvolvido por Burtoloso e colaboradores (Esquema 41). Nesta metodologia, 1 equivalente do diazofosfonato 32 é solubilizado em etanol e o aldeído puro adicionado. Uma solução $0.5 \mathrm{M}$ de $\mathrm{NaOH}$ em uma mistura de etanol/água 1:1 é então gotejada durante o período de $1 \mathrm{~h}$ para fornecer as diazocetonas em rendimentos bons a moderados. Cabe ressaltar, que enquanto a metodologia original descrita no capítulo 1 ( $\mathrm{NaH} / \mathrm{THF})$ requer 2 equivalentes de 32 para se obter rendimentos satisfatórios, este protocolo utiliza apenas 1 equivalente do diazofosfonato. Por exemplo, a diazocetona 111 obtida em $90 \%$ de rendimento utilizando $\mathrm{NaH} / \mathrm{THF}$, é sintetizada em $85 \%$ a partir da solução etílica de hidróxido de sódio. O baixo rendimento isolado para a diazocetona 112 está associado a uma reação de hidrólise do éster metílico. Além disso, ao menos que uma solução metanólica seja substituída ao etanol, o produto etílico esterificado de 112 é isolado. No caso da diazocetona 113, derivada do cinamaldeído 119, um rendimento de $30 \%$ foi obtido. Diferentes condições de HWE foram avaliadas, incluindo bases como $\mathrm{NaH}$, DIPEA/LiCl, $\mathrm{K}_{2} \mathrm{CO}_{3}$, $\mathrm{LiOH}$ e $\mathrm{Ba}(\mathrm{OH})_{2}$, e o rendimento obtido, entretanto, não passou de $33 \%$ (Tabela 2 ). 

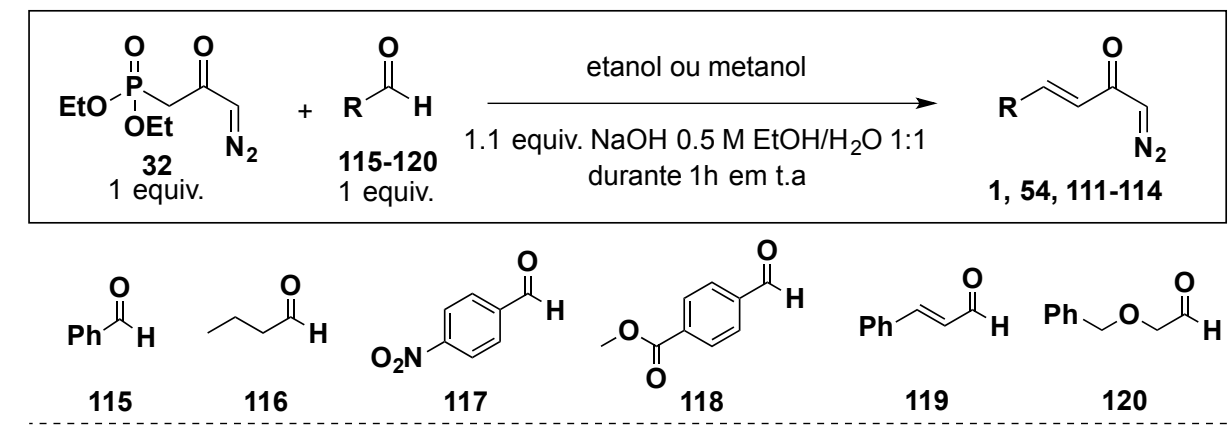

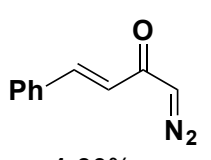

$180 \%$

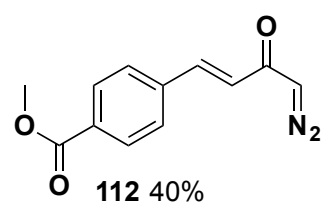<smiles>CCC/C=C/C(=O)C=N</smiles>

$5450 \%$<smiles>N#CC(=O)/C=C/C=C/c1ccccc1</smiles>

$11330 \%$<smiles>N#CC(=O)/C=C/c1ccc([N+](=O)[O-])cc1</smiles>

$11185 \%$

Esquema 41 Diazocetonas insaturadas preparadas para o estudo de cicloadição [2+2] e [4+2].

Tabela 2 Condições de HWE estudadas a partir do cinamaldeído 119.

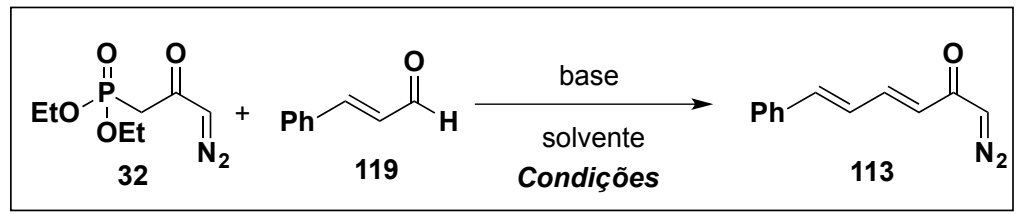

\begin{tabular}{cccccccc}
\hline & $\mathbf{1 1 9}$ & $\mathbf{3 2}$ & Base & base & Solvente & $\mathbf{T}\left({ }^{\circ} \mathbf{C}\right)$ & (\%) $\boldsymbol{E}$ \\
\hline $\mathbf{1}$ & 1.0 & 1.0 & $\mathrm{NaOH}$ & 1.1 & $\mathrm{EtOH} / \mathrm{H}_{2} \mathrm{O}$ & t.a $(0.5 \mathrm{~h})$ & $30 \%$ \\
$\mathbf{2}$ & 1.0 & 2.0 & $\mathrm{NaH}$ & 2.2 & $\mathrm{THF}$ & $0(1 \mathrm{~h})-\mathrm{t} . \mathrm{a}(2 \mathrm{~h})$ & $-\mathrm{b}$ \\
$\mathbf{3}$ & 1.0 & 1.0 & $\mathrm{~K}_{2} \mathrm{CO}_{3}$ & 1.1 & $\mathrm{H}_{2} \mathrm{O}$ & t.a $(24 \mathrm{~h})$ & $30 \%$ \\
$\mathbf{4}^{\mathrm{a}}$ & 1.2 & 1.0 & $\mathrm{DIPEA}$ & 1.0 & $\mathrm{MeCN}$ & $0(1 \mathrm{~h})-\mathrm{t} . \mathrm{a}(24 \mathrm{~h})$ & $-{ }^{\mathrm{b}}$ \\
$\mathbf{5}$ & 1.0 & 1.0 & $\mathrm{LiOH}$ & 1.0 & $i-\mathrm{PrOH} / \mathrm{H}_{2} \mathrm{O}$ & t.a $(24 \mathrm{~h})$ & $30 \%$ \\
$\mathbf{6}$ & 1.0 & 1.3 & $\mathrm{LiOH}$ & 1.5 & $i-\mathrm{PrOH} / \mathrm{H}_{2} \mathrm{O}$ & t.a $(24 \mathrm{~h})$ & $33 \%$ \\
$\mathbf{7}$ & 2.0 & 1.0 & $\mathrm{NaH}$ & 1.0 & THF & $0(1 \mathrm{~h})-\mathrm{t} . \mathrm{a}(24 \mathrm{~h})$ & $\left.-{ }^{\mathrm{b}}\right)$ \\
\hline
\end{tabular}

a 1 equivalente de $\mathrm{LiCl}$ utilizado como aditivo ${ }^{\mathrm{b}}$ produto não foi identificado no bruto reacional.

Uma outra diazocetona explorada foi o exemplo 53 derivado do fenilglioxal 121 (Esquema 42). Além de ser um interessante substrato para as cicloadições [2+2], este substrato poderia abrir um leque de novas aplicações para as diazocetonas $\alpha, \beta-$ insaturadas, como ilustrado no Esquema 42. Além de possuir uma dupla ligação conjugada com a carbonila, a diazocetona 53 também possui excelente reatividade 
frente adições de Michael. $\mathrm{O}$ aduto formado poderia servir como um rápido bloco de construção para a síntese de novos e importantes heterocíclicos de nitrogênio, a incluir 2 e 3-azetidinonas ainda não exploradas no grupo do Prof. Antonio Burtoloso.

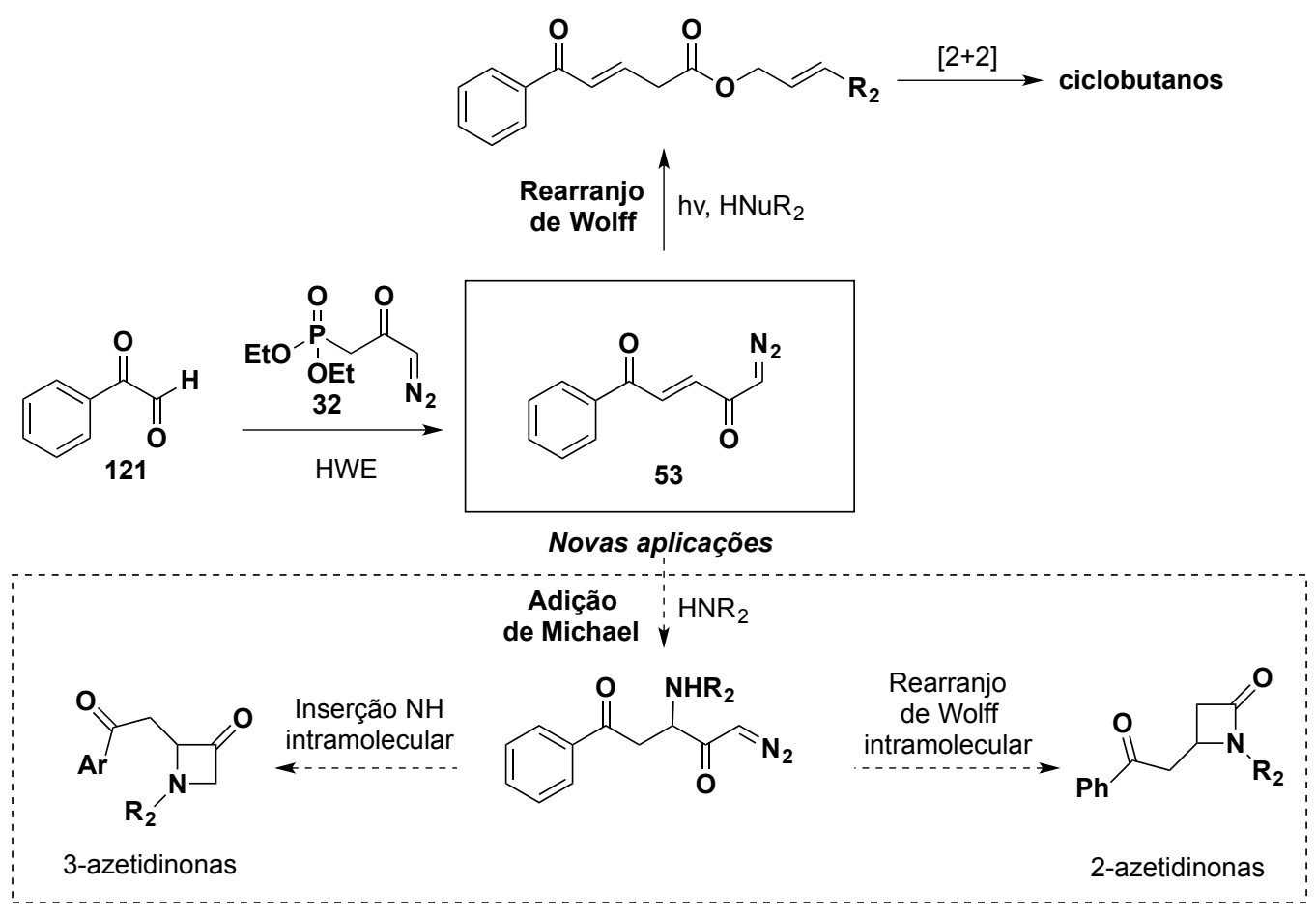

Esquema 42 Diazocetona 53 obtida a partir da reação de HWE a partir do fenilglioxal 121.

Previamente, o preparo e manuseio do reagente fenilglioxal 121 se demonstrou bastante tedioso devido a sua alta instabilidade. Este composto, quando na forma anidra, é conhecido por hidratar-se facilmente com a umidade do ar para permanecer em sua forma mais estável 121.1 $\mathrm{H}_{2} \mathrm{O}$ (Esquema 43), além de espontaneamente sofrer reações de oligo e polimerização rapidamente. ${ }^{136-139}$ Seu preparo é conseguido utilizando dióxido de Selênio $\left(\mathrm{SeO}_{2}\right)$ como oxidante do reagente acetofenona 122 (Esquema 43). ${ }^{137,140}$ A maneira mais eficaz para seu armazenamento é na forma hidratada, a qual pode ser obtida fazendo um refluxo rápido do fenilglioxal 121 anidro em água, o qual irá lentamente cristalizar como um sólido branco na solução. Esta metodologia, entretanto, fornece o glioxal poli hidratado 121. $\mathrm{xH}_{2} \mathrm{O}$.

Os testes de HWE pra se obter a diazocetona $\mathbf{5 3}$ foram realizados com o fenilglioxal 121 adicionado de diferentes formas, a incluir: anidro, hidratado, recém destilado, e ainda, anidro armazenado em uma solução $1.18 \mathrm{M}$ em tolueno ${ }^{140}$ que foi preparada logo após sua destilação (Tabela 3 ). 


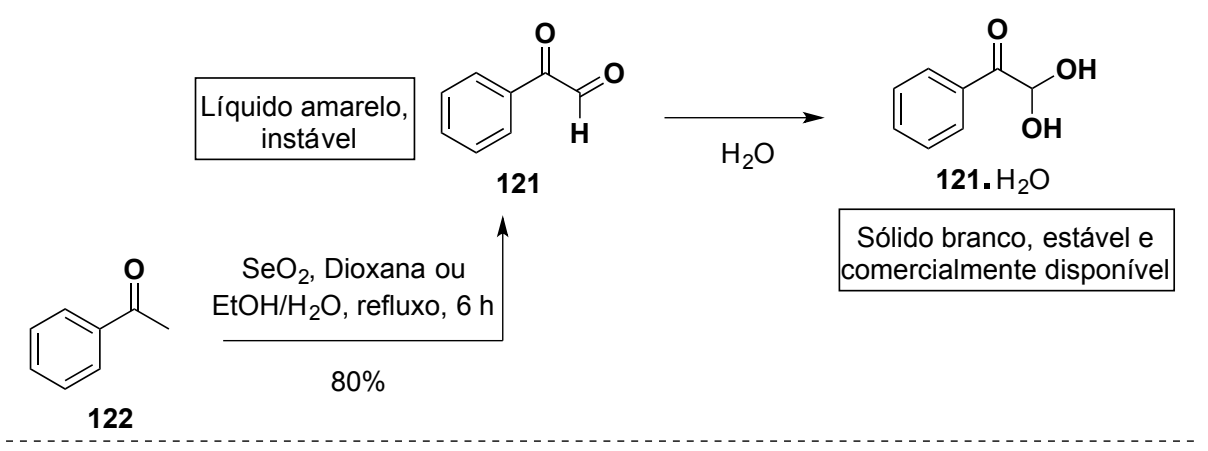

Esquema 43 Preparo do fenilglioxal 121 a partir da oxidação da acetofenona $122 \mathrm{com} \mathrm{SeO}$.

Tabela 3 Estudo da reação de HWE a partir do fenilglioxal 89

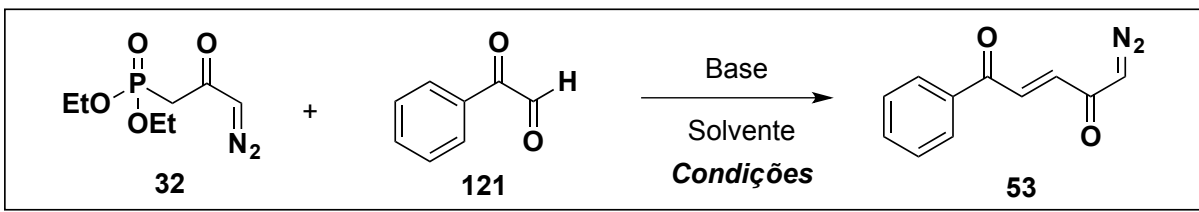

\begin{tabular}{|c|c|c|c|c|c|c|c|}
\hline 121 & 32 & Base & base & Solvente & $\mathrm{T}\left({ }^{\circ} \mathrm{C}\right)$ & $(\%) E+Z$ & $E / Z$ \\
\hline $1^{\mathrm{a}}$ & 1 & $\mathrm{NaOH}$ & 1 & $\mathrm{H}_{2} \mathrm{O}$ & t.a $(0.5 \mathrm{~h})$ & - & - \\
\hline $1^{a}$ & 1 & $\mathrm{NaH}$ & 1.1 & THF & $-78(1 \mathrm{~h})$ até $0(1 \mathrm{~h})$ & 27 & $2: 1$ \\
\hline $1^{a}$ & 2 & $\mathrm{NaH}$ & 2.2 & THF & $-78(1 \mathrm{~h})$ até $0(1 \mathrm{~h})$ & 40 & $1: 1$ \\
\hline $2^{a}$ & 1 & $\mathrm{NaOH}$ & 1 & $\mathrm{H}_{2} \mathrm{O}$ & t.a $(0.5 \mathrm{~h})$ & 0 & - \\
\hline $2^{b}$ & 1 & $\mathrm{NaOH}$ & 1 & $\mathrm{H}_{2} \mathrm{O}$ & t.a $(0.5 \mathrm{~h})$ & 0 & - \\
\hline $1^{a}$ & 1 & $\mathrm{NaH}$ & 1.2 & THF & 0 até t.a (1h) & 5 & $2: 1$ \\
\hline $2^{a}$ & 1 & $\mathrm{NaH}$ & 1 & THF & $-78(1 \mathrm{~h})$ até $-20(2 \mathrm{~h})$ & 15 & $2: 1$ \\
\hline $1^{a}$ & 1 & EtONa & 1 & $\mathrm{EtOH}$ & 0 até t.a $(0.5 \mathrm{~h})$ & 0 & - \\
\hline $1^{a}$ & 1 & $\mathrm{Ba}(\mathrm{OH})_{2}$ & 1.25 & THF & 0 até t.a (24 h) & 47 & $7: 2$ \\
\hline $1^{a}$ & 1 & DIPEA $^{c}$ & 1 & $\mathrm{MeCN}$ & 0 até t.a $(24 \mathrm{~h})$ & 36 & $3: 1$ \\
\hline $1^{a}$ & 2 & $\mathrm{Ba}(\mathrm{OH})_{2}$ & 2 & $\mathrm{MeCN}$ & 0 até t.a(24 h) & 55 & $2: 1$ \\
\hline $1^{a}$ & 1 & $t$-BuOK & 1 & THF & 0 até t.a $(1 \mathrm{~h})$ & 35 & - \\
\hline $1.5^{a}$ & 1 & $\mathrm{Ba}(\mathrm{OH})_{2}$ & 0.8 & THF & 0 até t.a(24 h) & 11 & - \\
\hline $1.2^{\mathrm{b}}$ & 1 & DIPEA $^{c}$ & 1 & $\mathrm{MeCN}$ & 0 até t.a(24 h) & 25 & - \\
\hline $1.2^{\mathrm{b}}$ & 1 & $D B U^{c}$ & 1 & $\mathrm{MeCN}$ & 0 até t.a(24 h) & 33 & - \\
\hline $1^{\mathrm{e}}$ & 1 & $\mathrm{NaH}$ & 1 & THF & $-78(1 \mathrm{~h})$ até $-20(2 \mathrm{~h})$ & 13 & $1: 1$ \\
\hline $1.2^{\mathrm{e}}$ & 1 & DIPEA $^{c}$ & 1 & $\mathrm{MeCN}$ & $0(24 \mathrm{~h})$ & 78 & $3: 1$ \\
\hline $2^{e}$ & 1 & DIPEA $^{c}$ & 1 & $\mathrm{MeCN}$ & $0(72 \mathrm{~h})$ & 54 & $1: 1$ \\
\hline $1^{\text {toug }}$ & 2 & LiHMDS & 2 & THF & $-78(1 \mathrm{~h})$ até -20 & 6 & - \\
\hline
\end{tabular}

${ }^{a} \overline{\text { fenilglioxal anidro, purificado em coluna flash e destilado, armazenado concentrado em freezer }{ }^{b} \text { fenilglioxal hidratado }\left(x \cdot \mathrm{H}_{2} \mathrm{O}\right)^{c}}$ aditivo $\mathrm{LiCl}$ (1 equivalente) ${ }^{\mathrm{d}}$ adição de peneira molecular $3 \mathrm{~A}^{\mathrm{e}}$ Destilado e diluído em tolueno no mesmo dia (1.18 $\mathrm{M}$ ), armazenado em freezer $\left(-20^{\circ} \mathrm{C}\right){ }^{\mathrm{f}}$ monohidrato disponível comercialmente $\left(121.1 \mathrm{H}_{2} \mathrm{O}\right)$ seco por $1 \mathrm{~h}$ utilizando peneira molecular $4 \mathrm{~A}^{\mathrm{g}}$

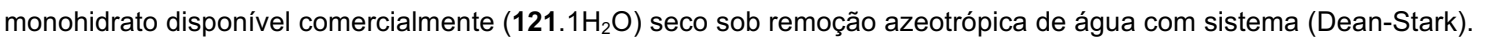


Diferentes metodologias de HWE foram avaliadas para a formação da diazocetona 53. O método inicialmente descrito pelo grupo do Prof. Antonio Burtoloso ( $\mathrm{NaH}$ como base) forneceu o produto desejado com baixos rendimentos (entradas 2 , 3, 6, 7 e 15). Cabe ressaltar, que a partir do diazofosfonato 32, todos os aldeídos empregados na reação de HWE forneceram os produtos de olefinação com $100 \%$ de seletividade para a olefina $E$. Neste caso, partindo de 121, foi observada a formação de misturas com proporções variadas dos isômeros $E / Z$. Na Tabela 3 é destacado que o melhor resultado foi encontrado utilizando-se DIPEA como base e cloreto de lítio (LiCl) como aditivo, quando o fenilglioxal 121 foi empregado a partir de uma solução $1.18 \mathrm{M}$ em tolueno. Neste caso, o rendimento total foi de $78 \%$ e a razão $E / Z 3: 1$ (entrada 16, Tabela 3). Este rendimento, entretanto, demonstrou-se extremamente dependente da escala utilizada, sendo obtido em uma única tentativa e não foi reprodutível posteriormente, variando entre 30 e 50\%. Este resultado pode estar associado com a instabilidade do aldeído utilizado. A caracterização do produto $\mathbf{5 3}$ foi realizada pela técnica de $\mathrm{RMN}$ de ${ }^{1} \mathrm{H}$ e ${ }^{13} \mathrm{C}$ (Figura 16). A constante de acoplamento de $15 \mathrm{~Hz}$ entre os hidrogênios olefínicos confirmam a geometria $E$ da dupla ligação, e $11 \mathrm{~Hz}$ para a geometria $Z$ do isômero cis 123 isolado, Figura 17. A banda característica em $2106 \mathrm{~cm}^{-1}$ nos espectros na região do infravermelho respectivas ao estiramento da ligação $\mathrm{C}=\mathrm{N}=\mathrm{N}$ pode ser observada na Figura 16. 


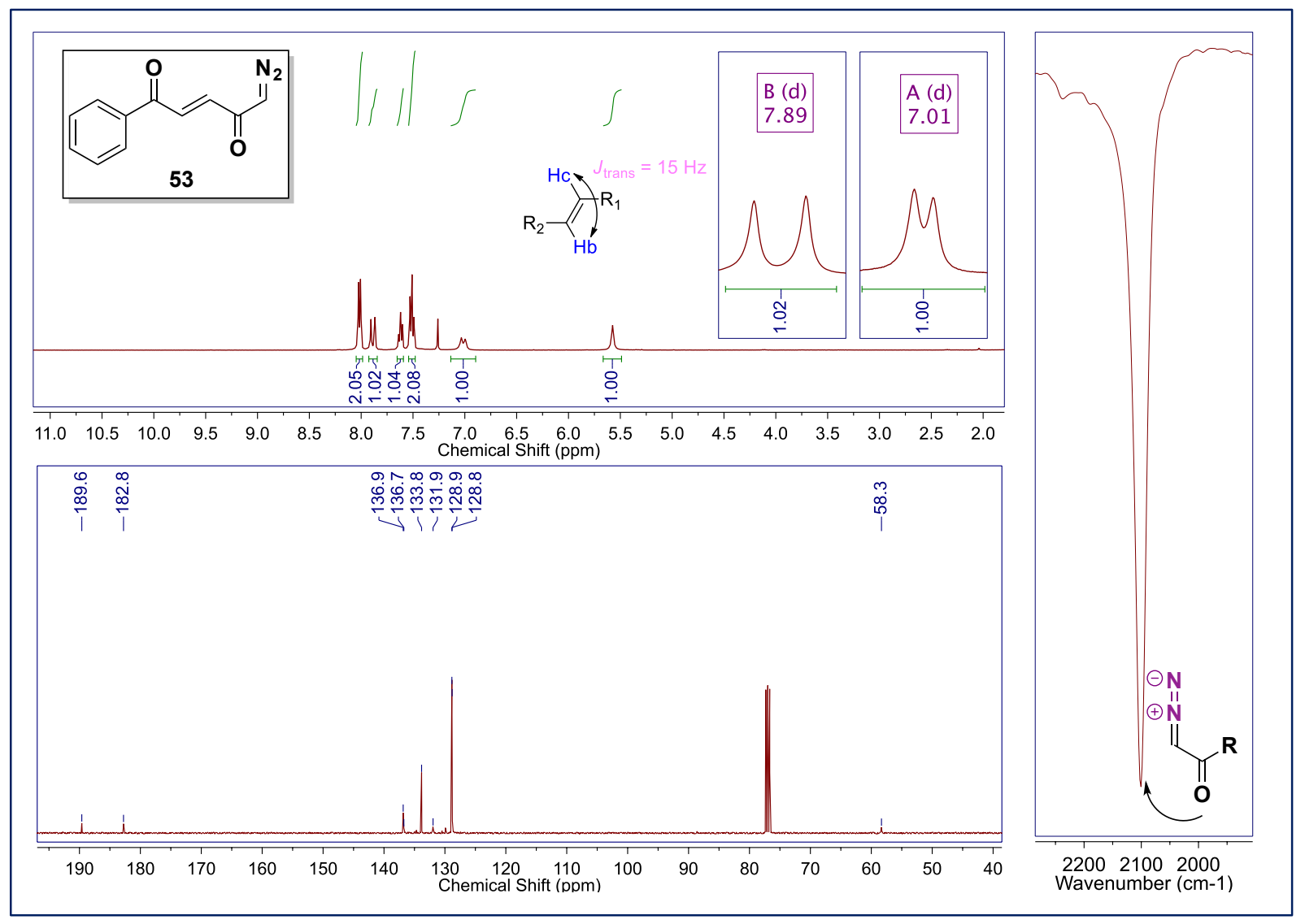

Figura 16 Espectro de $\mathrm{RMN} \mathrm{H}^{1}, \mathrm{C}^{13}$ e IV da diazocetona 53.

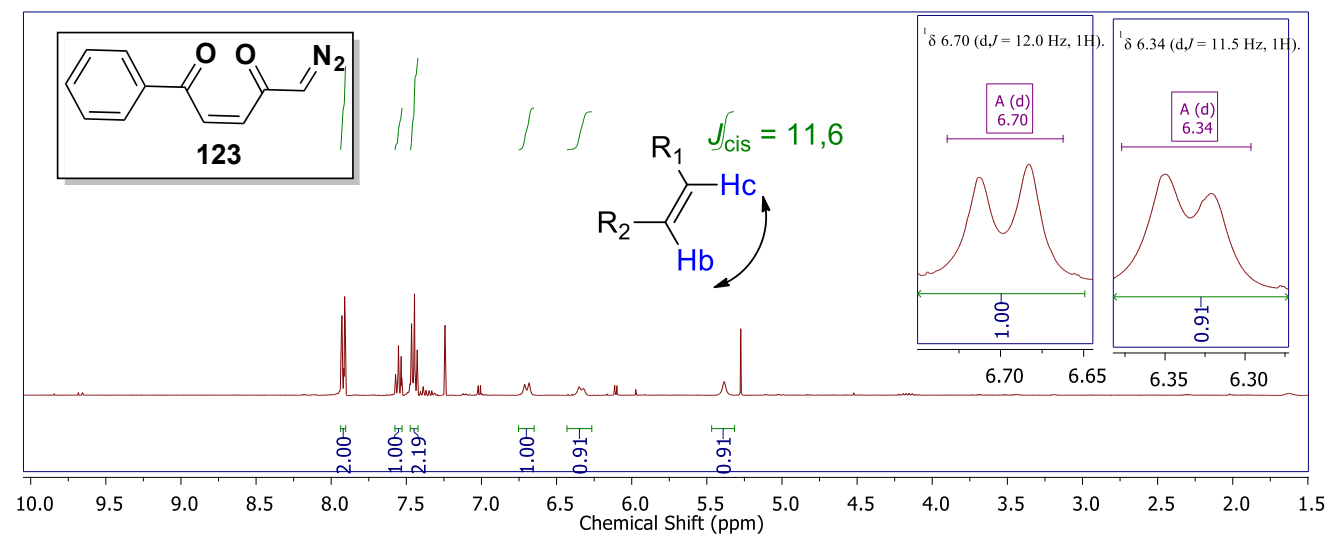

Figura 17 Espectro de RMN ${ }^{1} \mathrm{H}$ para o isômero $Z 123$.

Juntamente com os experimentos de HWE, uma segunda tentativa para se obter 53, ainda que pouco provável de ocorrer satisfatoriamente, foi realizada utilizando o método clássico para formação de diazocetonas (acilação do diazometano na presença de cloretos de acila e anidridos mistos). ${ }^{6,8,13,15,21}$ Esta metodologia funciona muito bem para compostos saturados, ou com duplas ligações bastante impedidas/substituídas. No caso das diazocetonas $\alpha, \beta$-insaturadas, esta metodologia falha uma vez que o diazometano reage paralelamente através de uma reação de 
cicloadição 1,3-dipolar com a dupla ligação, levando a formação de diazopirazolinas assim como anteriormente discutidas na presente introdução. ${ }^{141} \mathrm{O}$ ácido 125 , obtido através da reação entre benzeno e o anidrido maleico 124 via acilação de FriedelCrafts, foi submetido à ativação com cloreto de oxalia ou tionila (ambas as condições foram testadas) para fornecer o intermediário cloreto de ácido 126. A acilação com diazometano em presença de trietilamina como base forneceu um produto majoritário via análise por TLC e nenhum indício do produto desejado 53 (Esquema 44). O resíduo bruto foi enviado para $\mathrm{RMN}^{1} \mathrm{H}$, não sendo possível confirmar a pirazolina (várias misturas isoméricas podem estar presentes e dificultaram a análise).

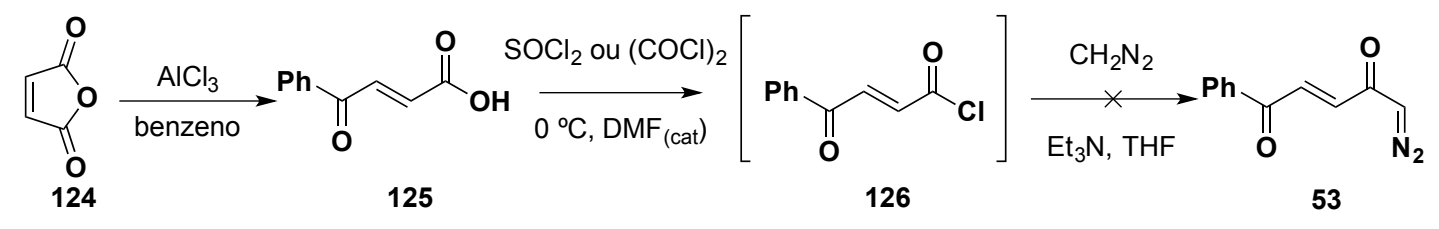

Esquema 44 Obtenção da diazocetona 53 via acilação do diazometano.

Enquanto o fenilglioal leva a síntese da diazocetona 53 de forma direta em apenas uma etapa, outras rotas alternativas foram investigadas sob condições compatíveis com a funcionalidade diazo. Por exemplo, a etapa de olefinação poderia ser realizada com os aldeídos protegidos 127 e 128 e o diazofosfonato 32 (Esquema 45). No caso da reação de HWE com o aldeído protegido 127, a diazocetona 0,0 acetalfenilsulfona 129 poderia ser clivada em condições básicas utilizando DBU para levar a 53. ${ }^{142}$ Por outro lado, o grupo de proteção TBS na diazocetona 130 poderia ser removido usando TBAF para fornecer o álcool 131. A diazocetona 53 seria formada após oxidação de Dess-Martin Periodinona (DMP). É importante mencionar que tanto a desproteção com TBAF $^{143}$ como a oxidação com DMP ${ }^{144}$ foram previamente empregados com sucesso em substratos contendo a funcionalidade diazo. 


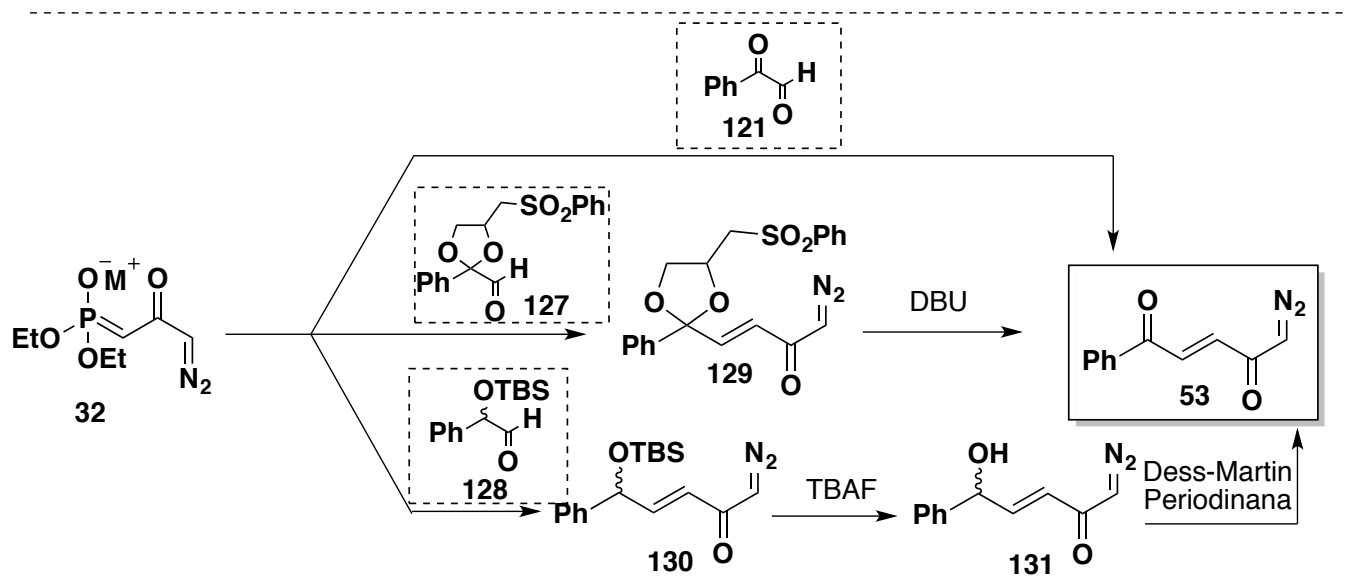

Esquema 45 Rotas alternativas para a obtenção da diazocetona 53 a partir dos aldeídos 127 e 128.

Para o preparo do aldeído 127, uma reação de diidroxilação mediada por tetróxido de ósmio a partir da vinilsulfona comercialmente disponível 132 forneceu o diol 133 com $70 \%$ de rendimento (Esquema 46). Em contraste, os ensaios de proteção da 2-hidroxiacetofenona comercial 135 com 133 mostraram-se tediosos. A preparação da 2-hidroxiacetofenona protegida 134 sob várias condições (com remoção de água via Dean-Stark) utilizando PPTS, $\mathrm{HCl}$ e $\mathrm{pTsOH}$ como fontes ácidas falhou.

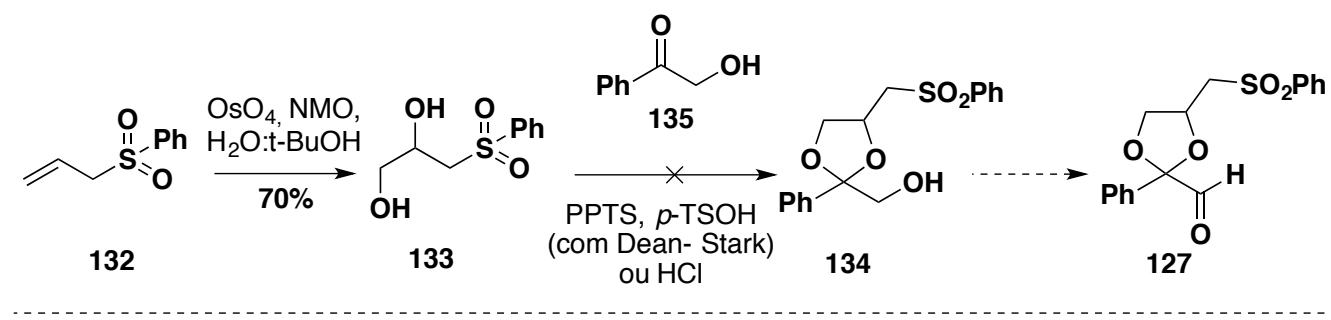

Esquema 46 Rota para a síntese do aldeído 127.

Os Aldeídos 128 e 140 foram obtidos após a proteção do (S)-etil mandelato 136 e (S)-etil lactato 137 com TBS e redução direta do éster 138 e 139 utilizando DIBAL$\mathrm{H}$ em rendimentos quantitativos (Esquema 47). ${ }^{145} \mathrm{O}$ aldeído 128 foi reagido com o diazofosfonato 32 sob condições de olefinação utilizando $\mathrm{NaOH} / \mathrm{EtOH}$. As primeiras tentativas proporcionaram a diazocetona-TBS 130 com $17 \%$ de rendimento. A condição clássica de HWE usando NaH/THF não foi avaliada. Infelizmente, o álcool 131 não foi obtido após tratamento com TBAF/THF proporcionando uma mistura complexa de decomposição após o work-up (Esquema 47). Embora ambas as rotas sintéticas se demonstraram promissoras, os rendimentos obtidos a partir da reação 
direta entre o fenilglioxal 121 anidro e diazofosfonato 32 mostraram-se suficientes para manter o desenvolvimento do projeto.

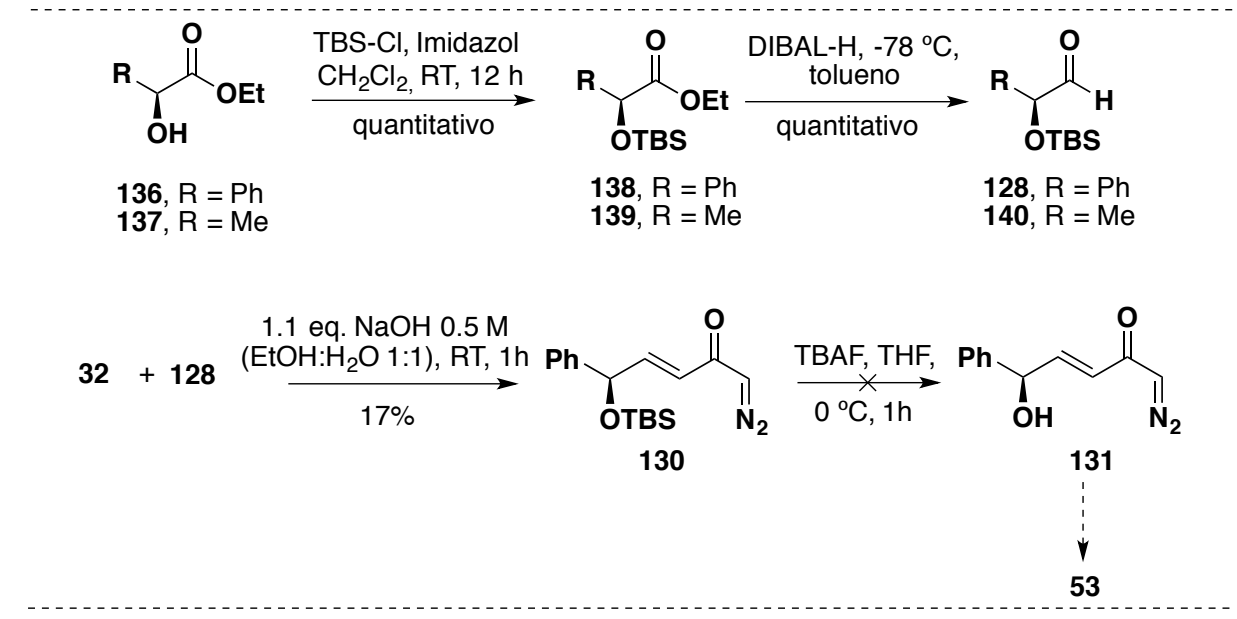

Esquema 47 Obtenção dos aldeídos 128 e 140.

Desta forma, após preparar as diazocetonas, os ésteres $\beta, \gamma$-insaturados 141153 foram obtidos pelo rearranjo de Wolff. O procedimento geral é realizado a partir da fotólise de uma solução $0.02 \mathrm{M}$ da diazocetona em acetonitrila na presença de 110 equivalentes dos álcoois alílicos 154-158 (Esquema 48). Com exceção dos álcoois 157 e 158 (Esquema 49), os outros exemplos são disponíveis comercialmente. Seu preparo é obtido a partir do metil crotonato 160 e do éster 163 (obtido pela esterificação do ácido sórbico 162). A reação de Wohl-Ziegler ${ }^{146,147}$ a partir de 160 e 163 na presença de NBS e um iniciador radicalar (AIBN, peróxido de benzoíla ou UV) fornece os brometos alílicos 161 e 164 em 56 e 50\% de rendimento, respectivamente. Os álcoois alílicos são então preparados após reação na presença de $\mathrm{Ag}_{2} \mathrm{O}$ e $\mathrm{H}_{2} \mathrm{O}$. No caso do brometo 164 , esta mesma transformação pode ser realizada com $\mathrm{NaHCO}_{3}$ (Esquema 49).

Cabe destacar, que a fonte luminosa para realizar o rearranjo de Wolff pode ser tanto uma lâmpada de arco de Xenônio de 260 W quanto uma lâmpada comercial de LED de $18 \mathrm{~W}$ (assim como descrito no capítulo 1). Os rendimentos obtidos são similares, e o tempo reacional varia entre 15 minutos até 4 h (no caso da lâmpada de Xenônio) e 24 h para a lâmpada de LED. 


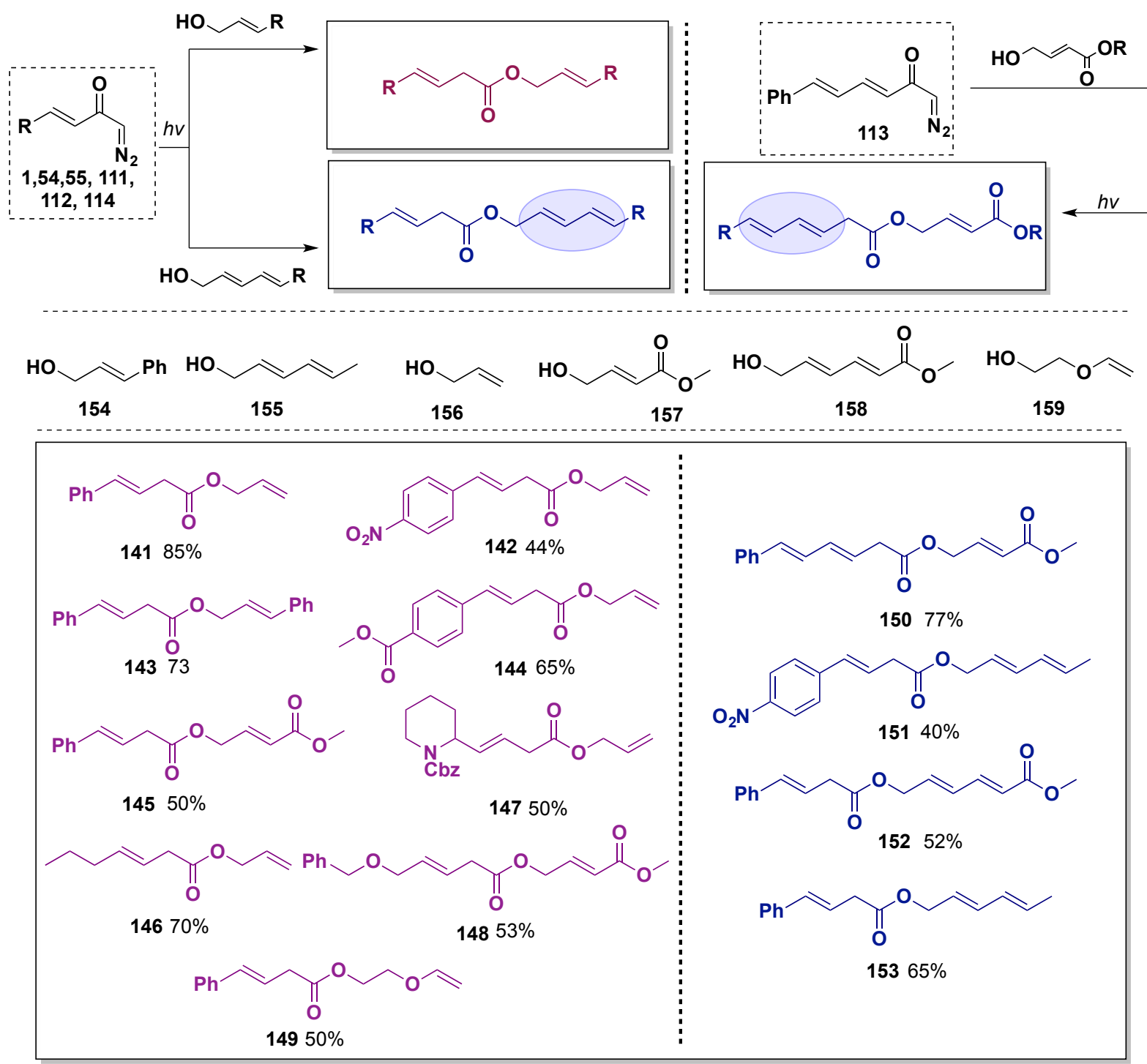

Esquema 48 Ésteres insaturados 141-533 obtidos através do rearranjo de Wolff na presença dos álcoois 154-159.
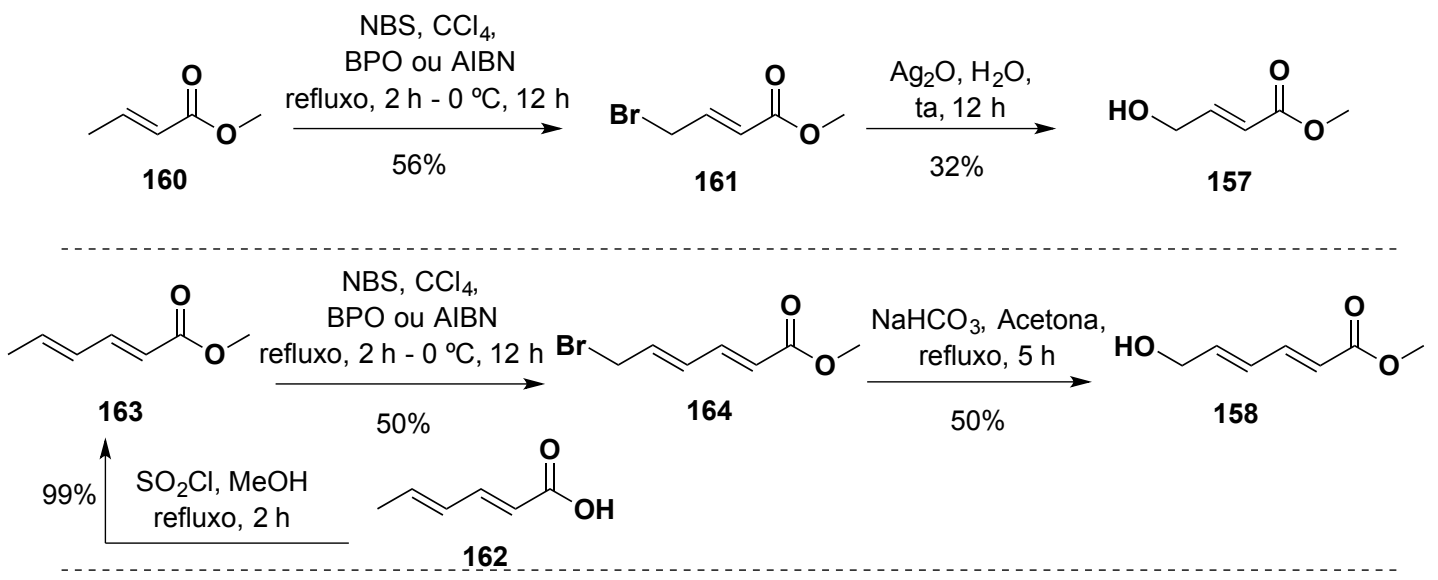

Esquema 49 Obtenção dos álcoois 157 e 158. 
O rearranjo de Wolff a partir de uma solução da diazocetona 113 para obtenção de 150 se demonstrou um pouco mais complicado que o usual (Esquema 50). O melhor resultado encontrado foi utilizando 0.9 equiv. do álcool alílico conjugado em xileno como solvente. A lâmpada empregada foi de LED branco de $18 \mathrm{~W}$ resultando em $77 \%$ de rendimento do produto 150 desejado após $24 \mathrm{~h}$ de reação. Este rendimento, entretanto, não foi reprodutível, possuindo uma diminuição significativa quando a escala reacional foi aumentada. O rendimento obtido ao utilizar $10 \mathrm{mg}$ da diazocetona 113 (0.050 mmol) foi de $77 \%, 60 \%$ foi isolado quando $30 \mathrm{mg}$ de 113 (0.144 mmol) foi empregada, por fim, 40\% de rendimento ao solubilizar $111 \mathrm{mg}$ de 113 (0.577 mmol) nas mesmas concentrações (Esquema 50). Variou-se também o número de equivalentes do álcool alílico conjugado (0.8 e 10 equivalentes) e os solventes ( $\mathrm{MeCN}$, acetona, éter etílico, dicloro, tolueno e xileno) em baixas concentrações (0.02 - $0.004 \mathrm{M})$. O tempo reacional foi acompanhado pelo consumo do material de partida por TLC, e variou entre 24 e 30h para a lâmpada de LED branco (18 W) e 1 - 4 h para a lâmpara de Xe $(260 \mathrm{~W})$. Um teste de rearranjo de Wolff foi realizado a partir da diazocetona 113 em água (Esquema 50). Neste caso, foi possível observar uma mistura de ácidos com diferentes geometrias $E / Z$ provenientes da isomerização do substrato. No caso do substrato 53, não foi possível isolar o produto de Wolff esperado utilizando metanol ou o álcool, tendo a reação resultado em uma mistura complexa de produtos que não pôde ser elucidada.

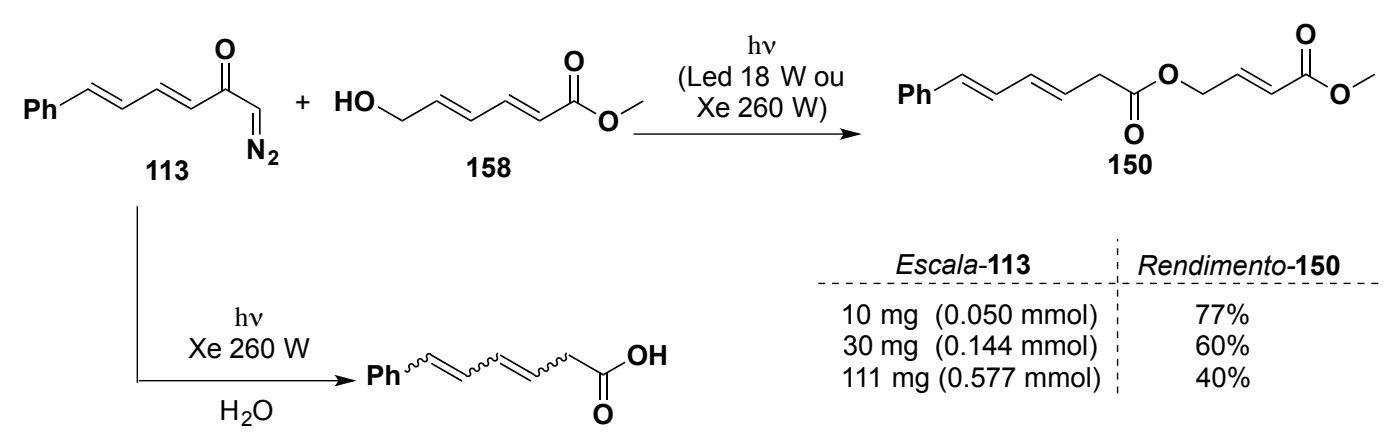

Esquema 50 Obtenção do éster 150 a partir de 113 e 158. 
A caracterização dos produtos de Wolff foi realizada de forma similar ao apresentado no capítulo 1. O espectro de RMN ${ }^{1} \mathrm{H}$ para o substrato 145 é apresentado na Figura 18, corroborando a estrutura pelos sinais olefínicos em $\delta 6.69$ (a, dt, $J=$ 15.8, $4.7 \mathrm{~Hz}, 1 \mathrm{H}), 6.05(\boldsymbol{d}, \mathrm{dt}, J=15.8,1.9 \mathrm{~Hz}, 1 \mathrm{H}), 4.79(\mathrm{e}, \mathrm{dd}, J=4.7,2.0 \mathrm{~Hz}, 2 \mathrm{H}) \mathrm{e}$ $3.75(f, s, 3 H)$, sinais correspondentes ao incorporamento do álcool alílico 127 na estrutura. A ausência do hidrogênio $\alpha$-diazocarbonílico em 5.32 ppm e a presença de um dubleto em $3.32(\boldsymbol{g}$, dd, $J=7.1,1.5 \mathrm{~Hz}, 2 \mathrm{H}$ ) referente ao metileno $\alpha$-carboxila ($\mathrm{CH}_{2^{-}}$) também corroboram a estrutura. Análises de $\mathrm{RMN}{ }^{13} \mathrm{C}, \mathrm{FTIR}$ e de espectrometria de massas de alta resolução ratificam a estrutura e são apresentados na seção experimental.

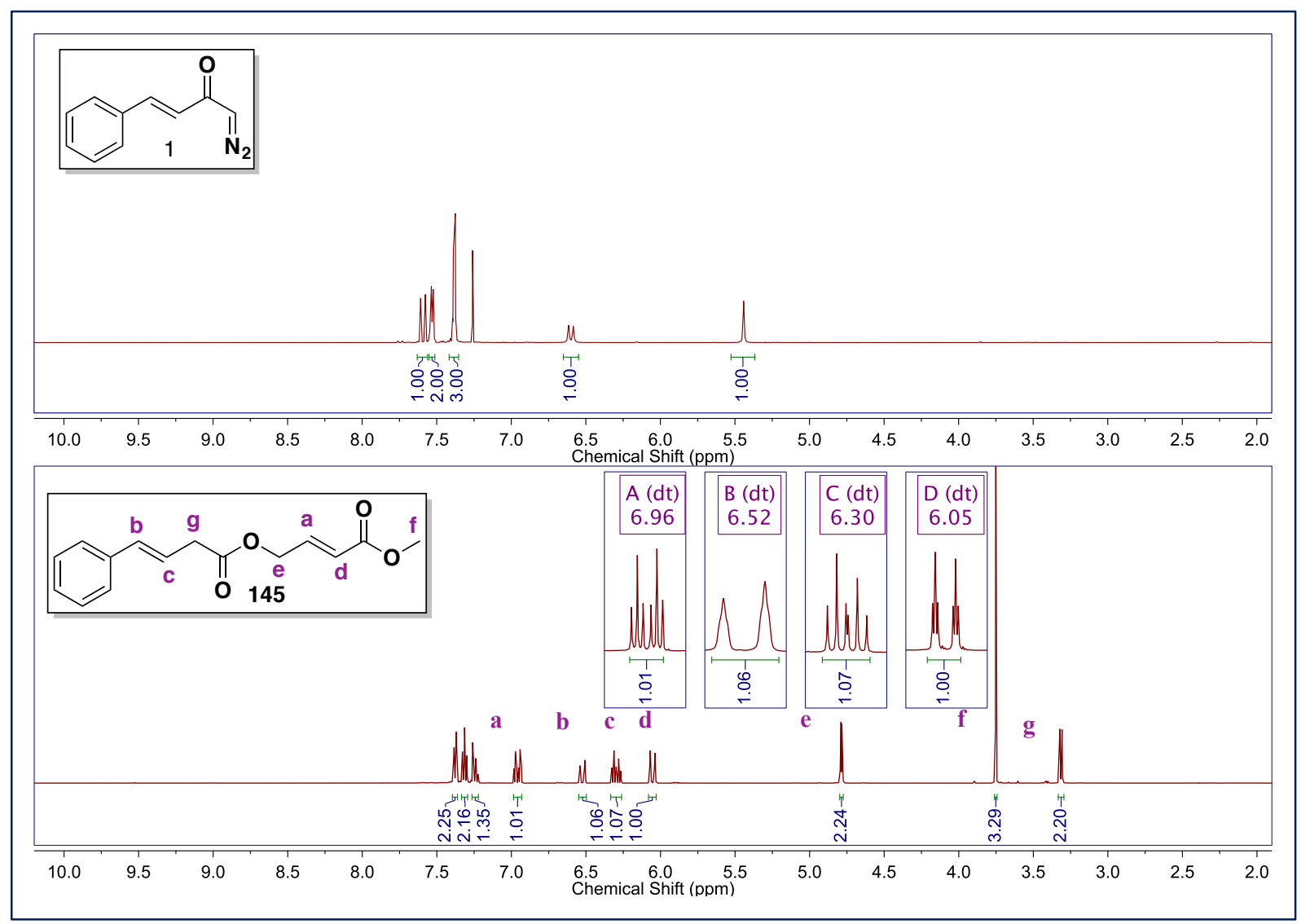

Figura 18 Espectro de $\mathrm{RMN}{ }^{1} \mathrm{H}$ obtido para o ester $\beta, \gamma$-insaturado 145 a partir da diazocetona 1 após rearranjo de Wolff na presença do álcool 157. 


\subsection{Cicloadições [2+2]}

Devido a semelhança estrutural com o substrato estudado por Padwa (Esquema 51), o primeiro precursor escolhido para avaliação das fotocicloadições [2+2] foi o éster 143. O composto puro e isolado foi exposto nas mesmas condições reacionais descritas por Padwa e colaboradores, incluindo concentração, fotossensibilizador e tempo. Uma diferença, entretanto, se refere a fonte luminosa. Padwa utilizou uma lâmpada de média pressão de arco de Mercúrio de 450W, removendo comprimentos de onda abaixo de $330 \mathrm{~nm}$ pelo uso de um filtro de Urânio. Neste experimento, utilizou-se uma lâmpada de alta pressão de arco de Xenônio operando em 260 W disponível em laboratório.

A caracterização do produto formado a partir da irradiação de 143 foi realizada pela técnica de $\mathrm{RMN}{ }^{1} \mathrm{H}$ indicando a formação de dois produtos majoritários correspondentes a um par de isômeros (Esquema 51). A mistura gerada corresponde a uma proporção 1:1 de isômeros com geometria $E 113$ e $Z 165$ da dupla ligação (em ambas insaturações presentes na estrutura, como observado no espectro de RMN ${ }^{1}$ H da Figura 19).

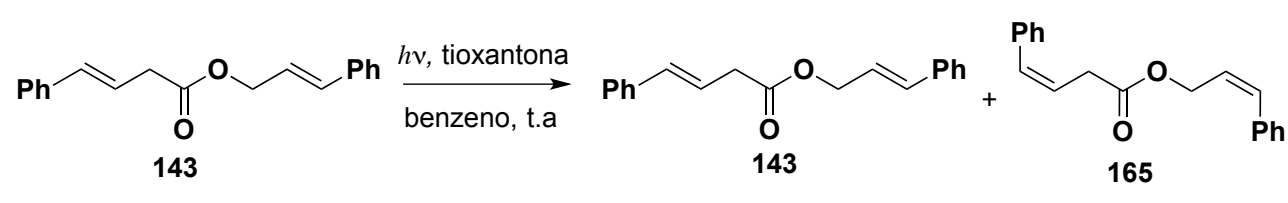

(80\% recuperado com razão $E / Z 1: 1)$

Esquema 51 Reação de isomerização E/Z promovida por luz. 


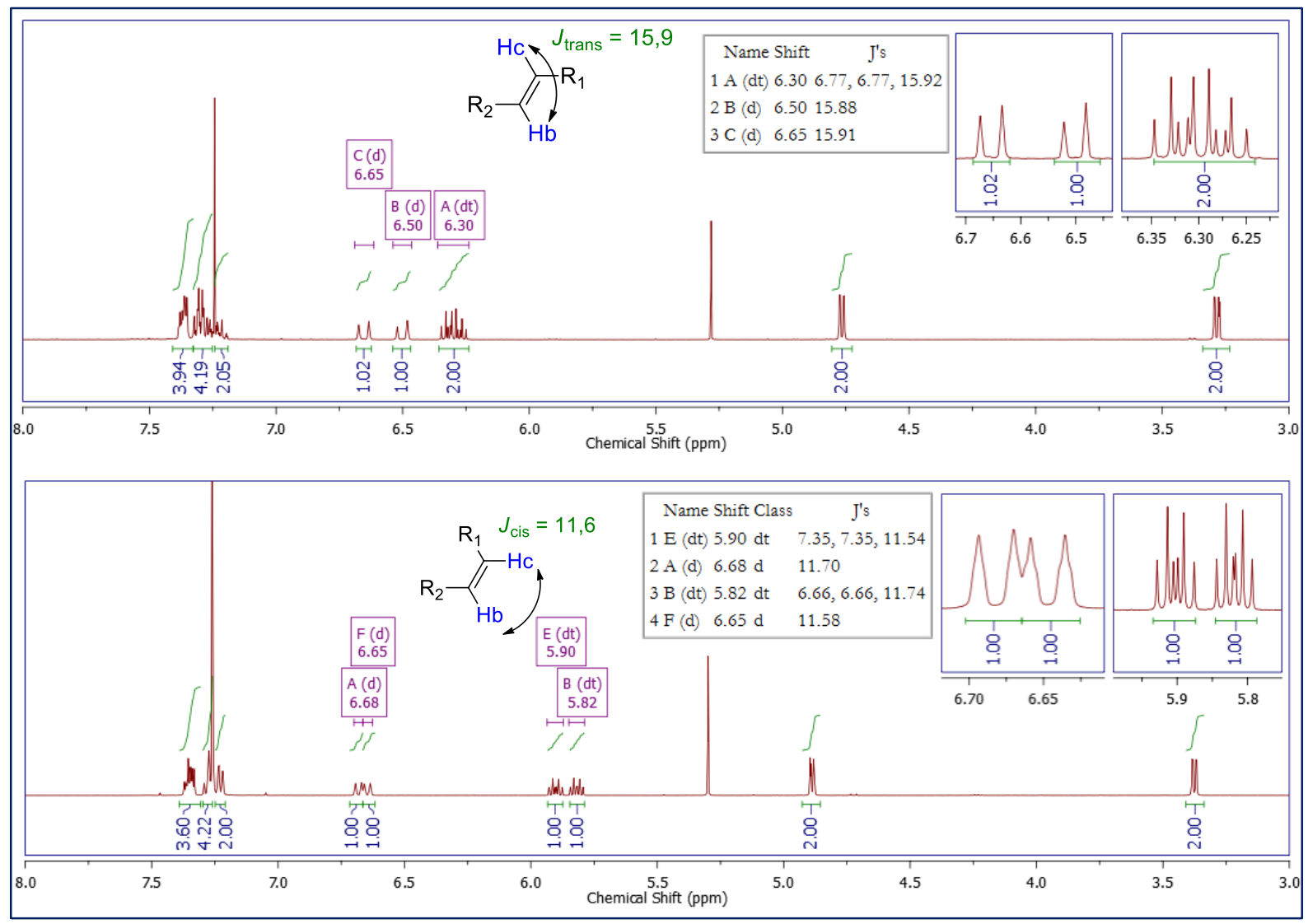

Figura 19 Espectros de RMN dos produtos de isomerização E/Z.

Em todos os casos em que o anel aromático está conjugado com a dupla ligação, os produtos isolados após irradiação foram caracterizados como sendo misturas $E / Z$ em diferentes proporções, sempre tendendo a 1:1. Em nenhum caso foi possível detectar a formação do ciclobutano. Alguns derivados sem a conjugação com anel aromático, exemplos 146, 147 e 148 foram submetidos as mesmas condições reacionais. Nas entradas estudadas, houve a degradação do material de partida e a formação de uma mistura complexa no caso do substrato 147 (análise de RMN ${ }^{1} \mathrm{H}$ do bruto reacional apresentou-se bastante complexa, com sinais de hidrogênios olefínicos semelhantes ao material de partida). Novamente, para os substratos $146 \mathrm{e}$ 148 , a única reação observada consiste na isomerização $E / Z$. Os alcenos simples absorvem a luz na região de $180 \mathrm{~nm}$ e, na ausência de sensibilizadores, sofrem principalmente isomerização $E / Z$. Contudo, os alcenos conjugados (principalmente as enonas que absorvem a comprimentos de onda maiores), costumam formar compostos de cicloadição mais rapidamente. 
Decidiu-se então investigar os ésteres $\alpha, \beta$-insaturados da série $D$ (Figura 15) os quais poderiam ser obtidos através de uma reação de isomerização da dupla ligação dos compostos da série A obtendo-se assim uma enona. Alguns testes de isomerização em meio básico foram avaliados a partir de 141 e 146, como resumidos na Tabela 4. O produto de isomerização a partir de 141 não foi isolado nas condições avaliadas. A dupla ligação é sempre preferencial no sentido da conjugação com o anel aromático. Quando o substrato alquílico 146 foi aquecido (Tabela 4) em condições de refluxo utilizando 1 equivalente de DBU em tolueno, o produto isomerizado 167 foi isolado em $65 \%$ de rendimento após $48 \mathrm{~h}$ de reação.

Tabela 4 Isomerização de 141 e 146 em meio básico.

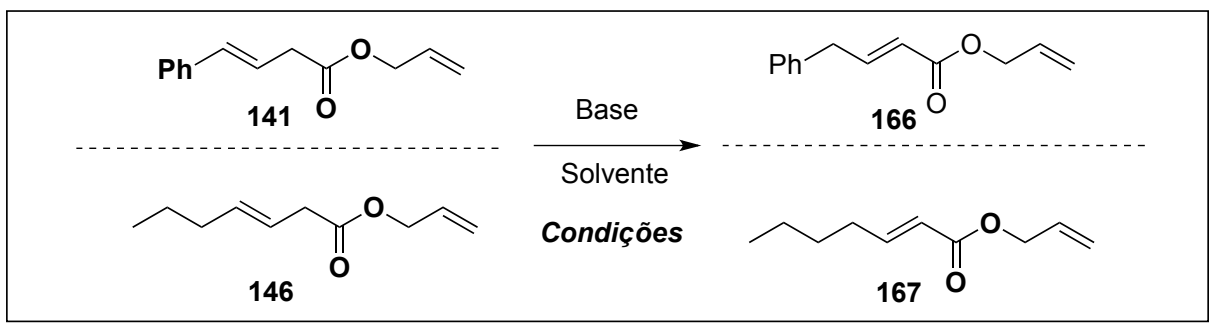

\begin{tabular}{ccccccc}
\hline Composto & Base & Eq. base & Solvente & $\mathrm{T}\left({ }^{\circ} \mathrm{C}\right)$ & tempo & (\%) \\
\hline 141 & $\mathrm{DBU}$ & 0.1 & $\mathrm{CH}_{2} \mathrm{Cl}_{2}$ & t.a & $48 \mathrm{~h}$ & $\mathrm{MR}^{\mathrm{a}}$ \\
141 & $\mathrm{DBU}$ & 0.1 & $\mathrm{THF}$ & $50{ }^{\circ} \mathrm{C}$ & $48 \mathrm{~h}$ & $\mathrm{MR}^{\mathrm{a}}$ \\
141 & $\mathrm{DBU}$ & 0.5 & $\mathrm{CH}_{2} \mathrm{Cl}_{2}$ & t.a & $48 \mathrm{~h}$ & $\mathrm{MR}^{\mathrm{a}}$ \\
141 & $\mathrm{DBU}$ & 0.5 & $\mathrm{Tolueno}$ & refluxo & $24 \mathrm{~h}$ & - \\
141 & $\mathrm{NaH}$ & 1.0 & $\mathrm{THF}$ & $-20^{\circ} \mathrm{C}-\mathrm{t} . \mathrm{a}$ & $30 \mathrm{~min}$ & $\mathrm{MR}^{\mathrm{a}}$ \\
146 & $\mathrm{DBU}$ & 1.0 & $\mathrm{CH}_{2} \mathrm{Cl}_{2}$ & t.a & $48 \mathrm{~h}$ & $\mathrm{MR}^{\mathrm{a}}$ \\
146 & $\mathrm{DBU}$ & 1.0 & $\mathrm{THF}$ & $50^{\circ} \mathrm{C}$ & $48 \mathrm{~h}$ & $\mathrm{MR}^{\mathrm{a}}$ \\
146 & $\mathrm{DBU}$ & 1.0 & Tolueno & refluxo & $48 \mathrm{~h}$ & $65 \%$ \\
\hline
\end{tabular}

${ }^{a}$ material de partida recuperado após o término da reação. ${ }^{\circ}$ rendimento para 167.

A enona 167 foi então solubilizada em benzeno em uma concentração $0.0035 \mathrm{M}$ e submetida as mesmas condições fotoquímicas de cicloadição [2+2], na presença e também na ausência do fotossensibilizador tioxantona. O material de partida não foi totalmente consumido e houve a formação de vários produtos de degradação. Entretanto, o bruto reacional foi enviado para análise de $\mathrm{RMN}^{1} \mathrm{H}$ sendo possível detectar os sinais do produto de isomerização cis 167b juntamente com 167. Novamente, ocorreu isomerização cis/trans como pode ser observado no espectro de RMN ${ }^{1} \mathrm{H}$ da Figura 20 (cabe ressaltar, que a separação entre 146 e 167 foi bastante 
trabalhosa devido a semelhança de $R_{f}$ ). No caso de 167 e 167a, não houve diferença de $R_{f}$ nos diferentes eluentes testados.

De fato, Padwa observou um comportamento similar de isomerização quando utilizou um análogo de cadeia menor 170 (Esquema 52). ${ }^{135}$ Mesmo contendo o ciclopropeno reativo e a enona, apenas isômeros $E / Z$ foram obtidos após irradiar o éster 170. Padwa justifica este resultado com questões de geometria, fazendo com que neste sistema a energia se mantenha localizada na porção cinamato. A irradiação prolongada conduz apenas à isomerização cis-trans em torno da ligação dupla.

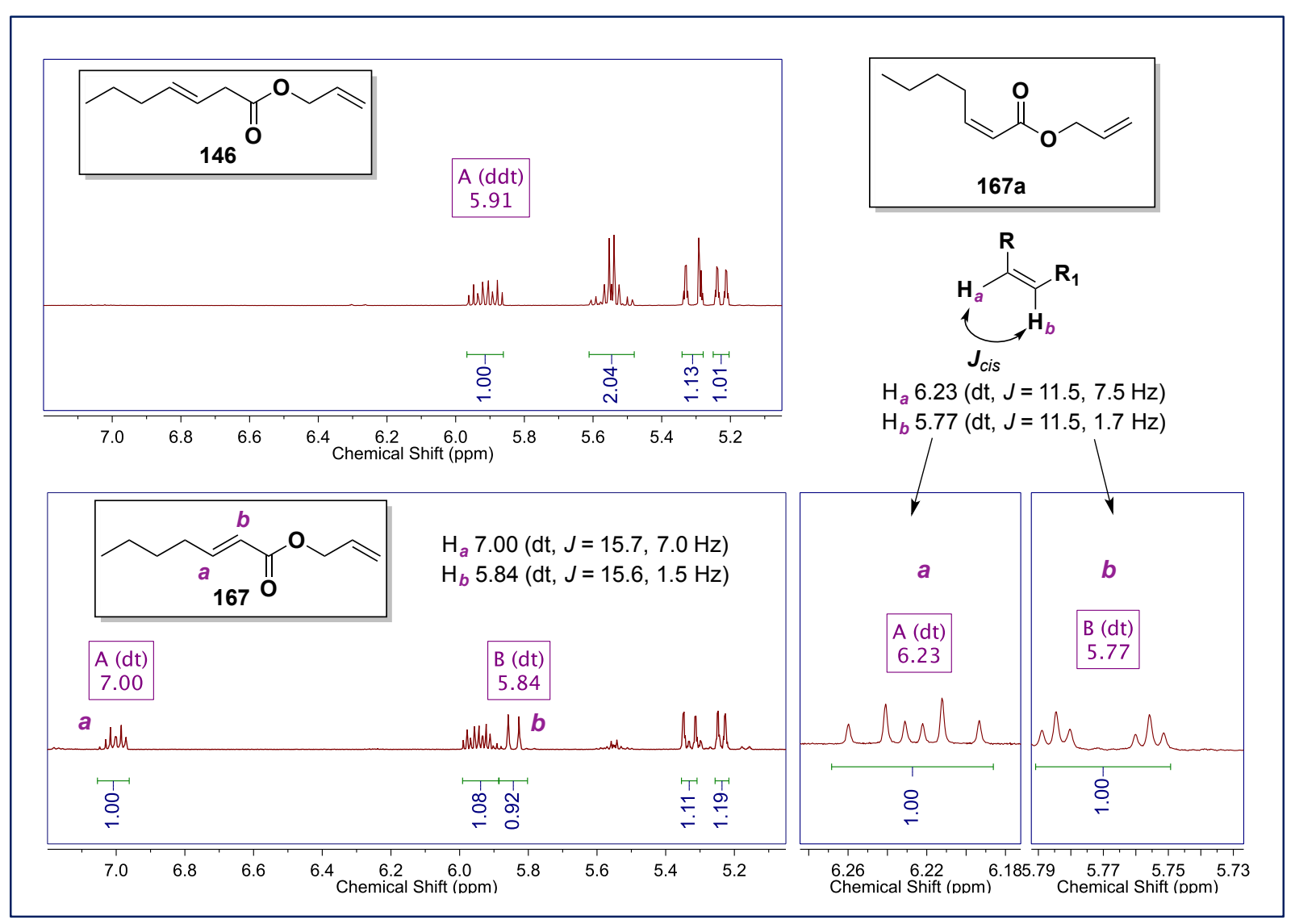

Figura 20 Espectro de RMN ${ }^{1} \mathrm{H}$ do produto 146, de isomerização 167 e 167a antes e após fotólise. 

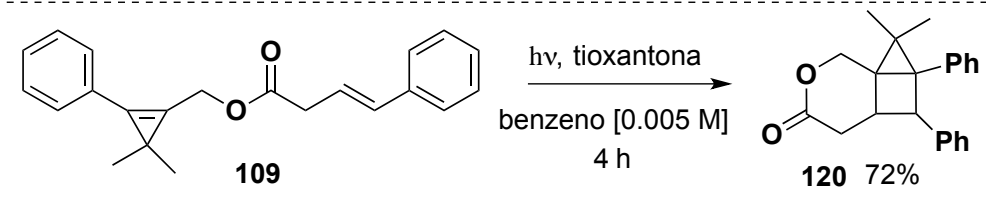

$12072 \%$
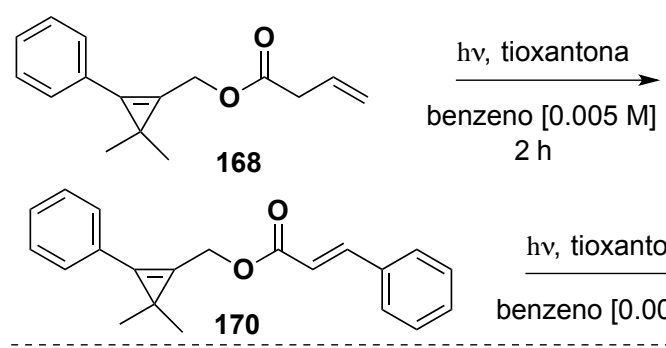

$\mathrm{h} v$, tioxantona

benzeno $[0.005 \mathrm{M}]$

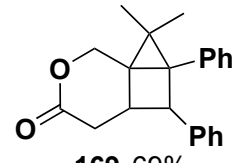

$16969 \%$

$E+Z$

Esquema 52 Substratos explorados por Padwa em fotocicloadições [2+2].

Os esforços foram então voltados para os ésteres da série $E$. Interessantemente, o rearranjo de Wolff a partir da diazocetona $\mathbf{5 3}$ se mostrou muito mais complexo do que geralmente é observado. O produto de rearranjo não pode ser obtido usando de 1-10 equivalentes do nucleófilo álcool alílico em solução de acetonitrila, nem mesmo quando o próprio álcool alílico foi utilizado como solvente (Esquema 54). Este fato pode estar relacionado com a fotosensibilidade do produto formado resultando em reações indesejadas após a formação do éster com tempos de irradiação prolongados. Uma reação teste foi realizada a partir da diazocetona 53 e de metanol como nucleófilo. De forma similar, houve uma grande degradação do material de partida sem que seja possível o isolamento de um produto majoritário.

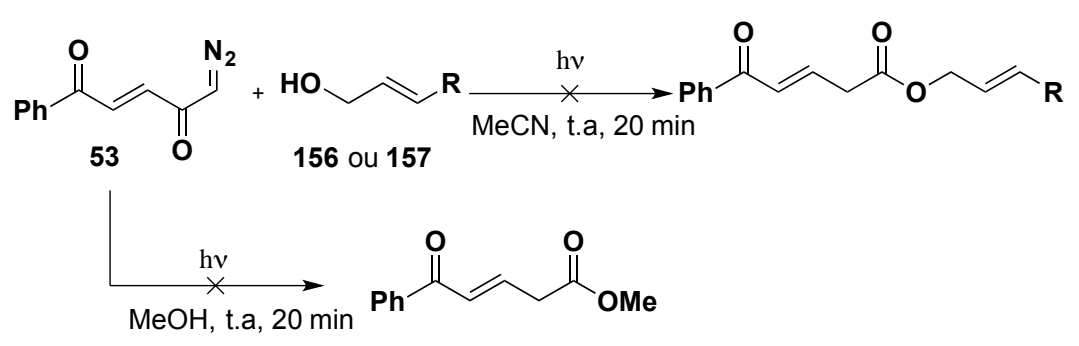

Esquema 53 Tentativa de Rearranjo de Wolff a partir da diazocetona 53.

Outros ésteres das séries B, C e F foram avaliados em diferentes condições, variando a presença ou não de fotossensibilizador, concentração, fonte luminosa, o único resultado obtido foi a isomerização em torno da dupla ligação (em ambos alcenos). O Esquema 54 ilustra um resumo dos dados coletados. Um último éster 149 
sintetizado (série $\mathrm{K}$ ), com a presença de um segundo metileno $\left(-\mathrm{CH}_{2}\right)$ na cadeia que poderia facilitar a ciclização por permitir um maior grau de liberdade na geometria da molécula foi estudado. Entretanto, o mesmo resultado de isomerização foi observado.

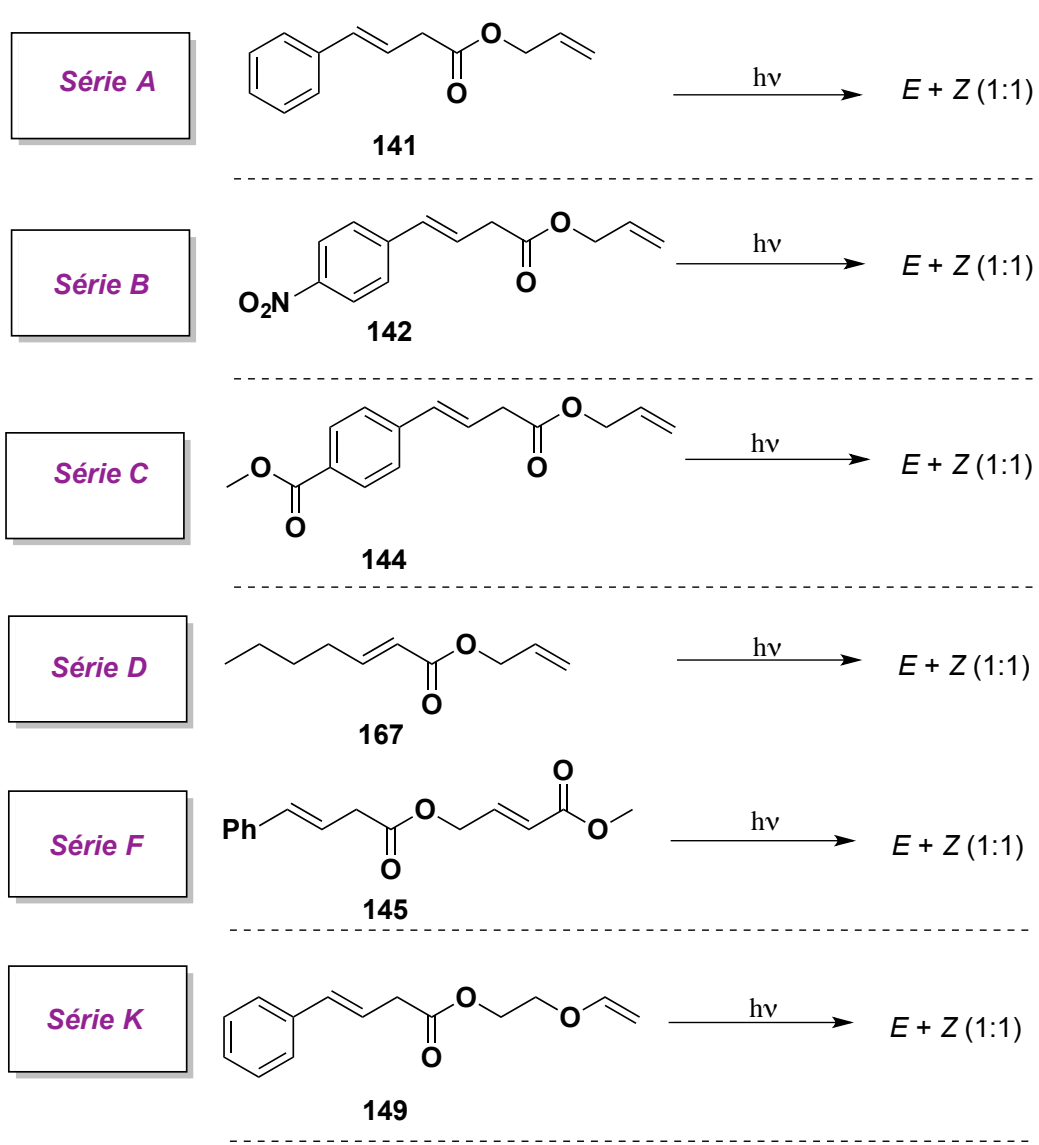

Esquema 54 Resumo das reações de cicloadições testadas.

\subsubsection{Aspectos mecanísticos da fotoisomerização $E / Z$}

Um exemplo de isomerização fotoquímica cis-trans é mostrado no diagrama da Figura 21. A absorção de luz visível ou ultravioleta por uma molécula leva a estados excitados com energia suficiente para quebrar ou reorganizar a maioria das ligações covalentes. Uma reação fotoquímica ocorre quando o relaxamento de um estado excitado conduz a um isômero do substrato inicial ou quando sofre uma adição intermolecular de outra molécula (ou ainda intramolecular). Os estados excitados podem ser classificados como singleto $(\uparrow \downarrow)$ ou tripleto $(\uparrow \uparrow)$, com base no seu momento angular de spin eletrônico. No caso dos alcenos simples, existe uma grande diferença energética entre o estado singleto $\left(\pi, \pi^{*}\right)^{1}$ e o correspondente estado tripleto $\left(\pi, \pi^{*}\right)^{3}$, fazendo com que um cruzamento entre sistemas seja ineficiente. Esta grande 
diferença em energia somada as características de spin eletrônico levam a diferentes tipos de reações ao se irradiar diretamente um alceno (singleto $\rightarrow$ singleto) e ao fazer o uso de fotosensibiliadores $\left(S_{t}\right)$ que induzem o estado tripleto $\left(S_{\uparrow \uparrow}+M_{\uparrow \downarrow} \rightarrow S_{\uparrow \downarrow}+M_{\uparrow \uparrow}\right)$. Enquanto ligações duplas isoladas requerem $180 \mathrm{~nm}$ de energia para promover a transição $\pi \rightarrow \pi^{*}$, a conjugação com substituintes fenil, dienos ou polienos reduz a energia necessária para cerca de $300 \mathrm{~nm} .^{148}$

Quando um alceno absorve um fóton, ambos isômeros cis e trans sofrem excitação $\Pi \rightarrow \Pi^{*}$ levando a um estado excitado $\left(S_{1}{ }^{c}\right.$ e $\left.S_{1}{ }^{t}\right)$ que retem a geometria do material de partida (Figura 21). No estado fundamental $\left(\mathrm{S}_{0}{ }^{\mathrm{c}}\right.$ e $\left.\mathrm{S}_{0}{ }^{\mathrm{t}}\right)$, a barreira energética de rotação em torno da ligação dupla produzida pela ligação $\pi$ é de aproximadamente $60 \mathrm{kcal} / \mathrm{mol}$ (para o estilbeno, por exemplo). Nos estados excitados $\mathrm{S}_{1}{ }^{\mathrm{c}}$ e $\mathrm{S}_{1}{ }^{\mathrm{t}}$, entretanto, esta barreira energética rotacional é inexistente uma vez que não existe uma ligação $\pi$ real (linha pink no diagrama da Figura 21). Esses estados então podem relaxar rapidamente a um estado de energia inferior $\left(S_{1}\right)$ que não possui qualquer informação de esteroquímica. Após este ponto, a conversão interna deste estado $S_{1}$ conduz a região do estado de transição do estado fundamental $S_{0}$ (ET no diagrama), que decai igualmente para os estados fundamentais dos isômeros cis e trans. Acompanhando o estado de energia $\mathrm{S}_{1}{ }^{\mathrm{c}}$ (próximo a $\theta=0^{\circ}$ ) é possível observar que aproximadamente $70 \%$ (no caso so estilbeno) das moléculas neste estado relaxam para o estado $S_{1}$ (Figura 21). Os $30 \%$ restantes podem passar por um rearranjo eletrocíclico levando a subprodutos, esta etapa ocorre de forma bastante lenta. Outra reação comumente observada é a dimerização dos alcenos via cicloadição [2+2]. Cabe ressaltar, que isomerizações $E / Z$ podem ser realizadas tanto com irradiação direta tanto com o uso de fotossensibilizadores levando a diferentes proporções dos isômeros desejados. 


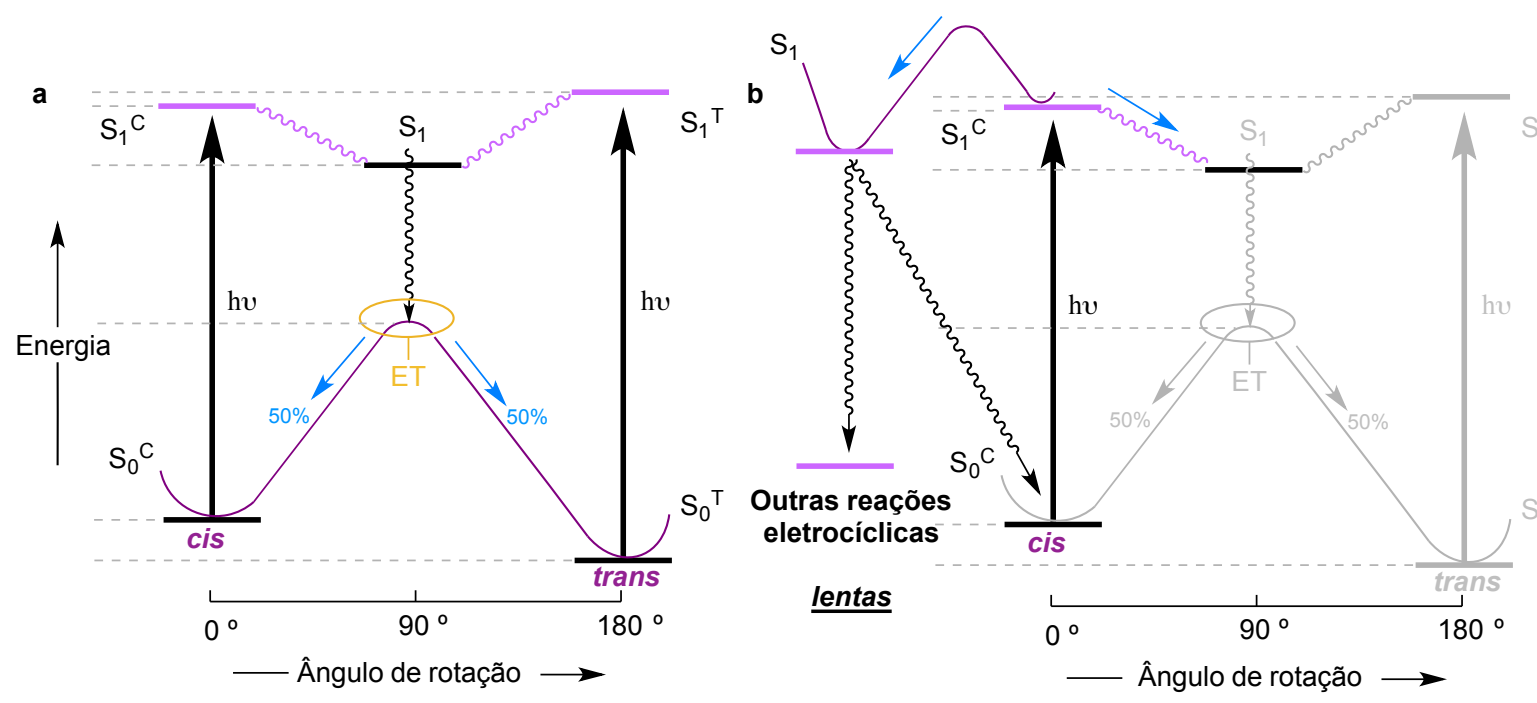

Figura 21 Diagrama de energia para a a) reação de isomerização $E / Z$ b) dimerização ou eletrociclizações.

O que os resultados indicam é que a presença do ciclopropeno no substrato estudado por Padwa pode estar favorecendo a reação de duas formas: elevada reatividade do ciclopropeno e impossibilidade de isomerização, tornando este substrato bastante particular. A energia do ciclopropeno (54.1 kcal $/ \mathrm{mol})$ atribuída em grande parte à deformação angular é aliviada ao perder a hibridização $\mathrm{sp}^{2}$ para formar as ligações $\mathrm{sp}^{3}$ do ciclobutano. ${ }^{149}$ Nos substratos estudados da série A-G, questões de geometria podem estar fazendo com que a irradiação prolongada conduza apenas à isomerização cis-trans em torno da ligação dupla.

\subsection{Cicloadições [4+2]}

No que diz respeito as reações de Diels-Alder, como mencionado anteriormente, idealizou-se as séries G-J como precursores principais a serem investigados (Esquema 55). A primeira série de substratos avaliados foi a G. Uma solução do substrato 153 em benzeno foi agitada em temperatura ambiente por $48 \mathrm{~h}$, recuperando-se o material de partida após este período (Tabela 5). A solução foi então aquecida no ponto de ebulição do solvente benzeno, tolueno e xileno por $48 \mathrm{~h}$, recuperando-se $>99 \%$ do material de partida no caso com benzeno. Com tolueno e xileno houve degradação do material de partida. Já no caso do substrato 151 , as mesmas condições reacionais de aquecimento levaram a uma mistura complexa de degradação (Tabela 6). 


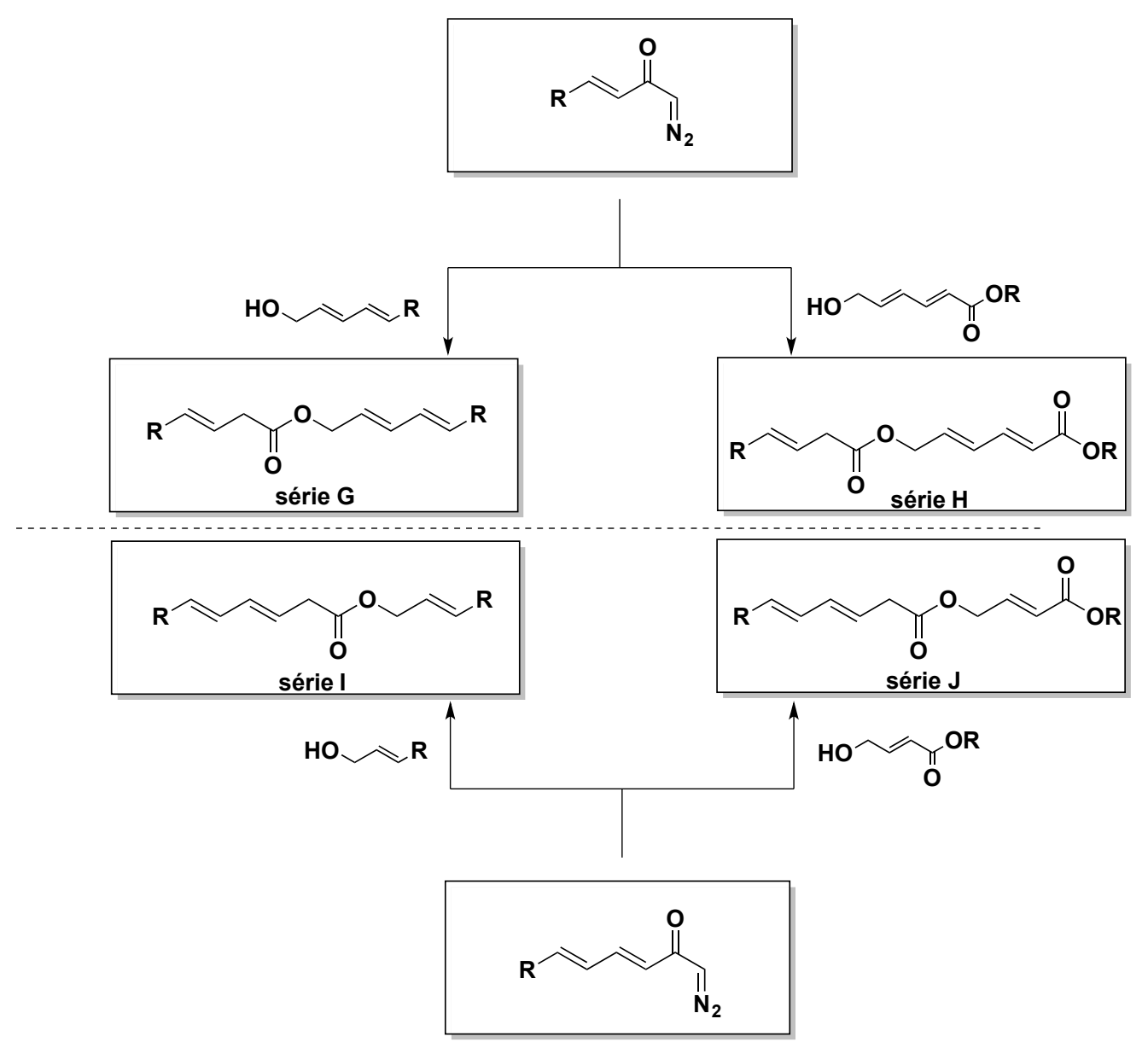

Esquema 55 Substratos da série G-J a serem testados nas reações de Diels-Alder.

Tabela 5 Condições Diels-Alder térmicas a partir de 151 e 153.

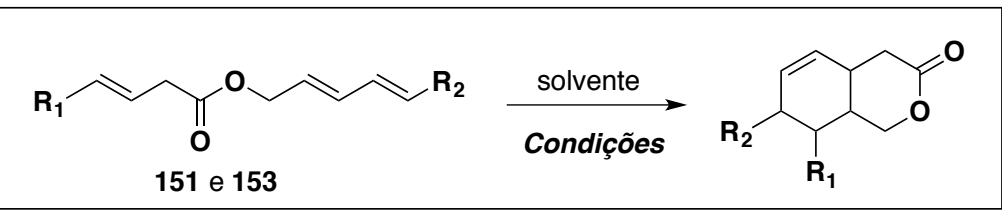

\begin{tabular}{ccccc}
\hline Composto & Solvente $^{\mathrm{b}}$ & $\mathrm{T}\left({ }^{\circ} \mathrm{C}\right)$ & Tempo & $\mathbf{( \% )}$ \\
\hline $151^{\mathrm{a}}$ & benzeno & ambiente & $48 \mathrm{~h}$ & $\mathrm{MR}^{\mathrm{a}}$ \\
$151^{\mathrm{a}}$ & benzeno & refluxo & $48 \mathrm{~h}$ & $\mathrm{MR}^{\mathrm{a}}$ \\
$151^{\mathrm{a}}$ & tolueno & refluxo & $48 \mathrm{~h}$ & degradação \\
$151^{\mathrm{a}}$ & xileno & refluxo & $12 \mathrm{~h}$ & degradação \\
$153^{\mathrm{a}}$ & benzeno & ambiente & $48 \mathrm{~h}$ & $\mathrm{MR}^{\mathrm{a}}$ \\
153 & benzeno & refluxo & $12 \mathrm{~h}$ & degradação \\
\hline
\end{tabular}

${ }^{a}$ material de partida recuperado ${ }^{b}$ concentração de $0.023 \mathrm{M}^{\mathrm{c}}$ formação de vários produtos sem que tenha sido detectado o produto de interesse no bruto reacional. 
O substrato 150 da série J (Tabela 6) foi estudado nas mesmas condições mencionadas anteriormente. Inicialmente, uma solução do éster 150 em tolueno forneceu apenas a recuperação do material de partida (Tabela 6). A solução foi aquecida na temperatura de refluxo do tolueno e xileno, mas o material de partida permaneceu intacto. Nem mesmo o aquecimento em $165^{\circ} \mathrm{C}$ no solvente tolueno utilizando um tubo selado foi suficiente. A reação começou a evoluir em temperaturas a cima de $200^{\circ} \mathrm{C}$, fornecendo o produto de Diels-Alder 171 em $70 \%$ de rendimento ao se utilizar uma concentração de $0.023 \mathrm{M}$ do éster em xileno sob aquecimento de 250 ${ }^{\circ} \mathrm{C}$ em tubo selado após 48h (entrada 6, Tabela 6). Cabe a ressaltar, que o rendimento considerando o éster 150 não reagido, foi de 80\% (Esquema 56). A Figura 22 ilustra a formação dos produtos racêmicos endo-171 e exo-171 a partir de 150.

Tabela 6 Condições Diels-Alder estudadas a partir de 150.

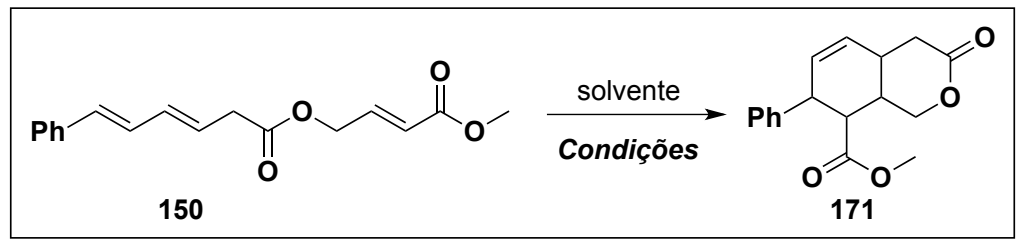

\begin{tabular}{|c|c|c|c|c|}
\hline Entrada & Solvente $^{e}$ & $\overline{\mathrm{T}\left({ }^{\circ} \mathrm{C}\right)}$ & Tempo & $(\%)$ \\
\hline 1 & benzeno & ambiente & $48 \mathrm{~h}$ & $\mathrm{MR}^{\mathrm{a}}$ \\
\hline 2 & benzeno & refluxo & $48 \mathrm{~h}$ & $\mathrm{MR}^{\mathrm{a}}$ \\
\hline 3 & tolueno & refluxo & $48 \mathrm{~h}$ & $\mathrm{MR}^{\mathrm{a}}$ \\
\hline $4^{b}$ & tolueno & 165 & $48 \mathrm{~h}$ & $\mathrm{MR}^{\mathrm{a}}$ \\
\hline $5^{b}$ & xileno & 200 & $48 \mathrm{~h}$ & $20 \%^{\mathrm{c}}$ \\
\hline $6^{b}$ & xileno & 250 & $48 \mathrm{~h}$ & $70 \%^{d}$ \\
\hline 7 & acetonitrila & refluxo & $2 \mathrm{~h}$ & $\mathrm{MR}^{\mathrm{a}}$ \\
\hline
\end{tabular}




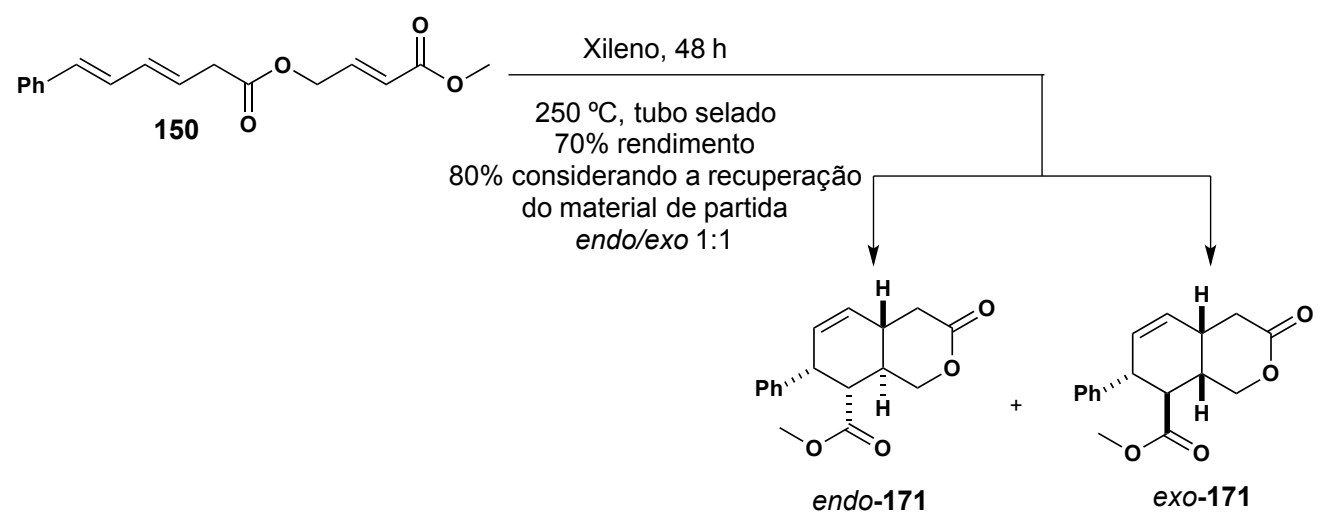

Esquema 56 Reação de Diels-Alder a partir de 150: produtos endo-171 e exo-171.
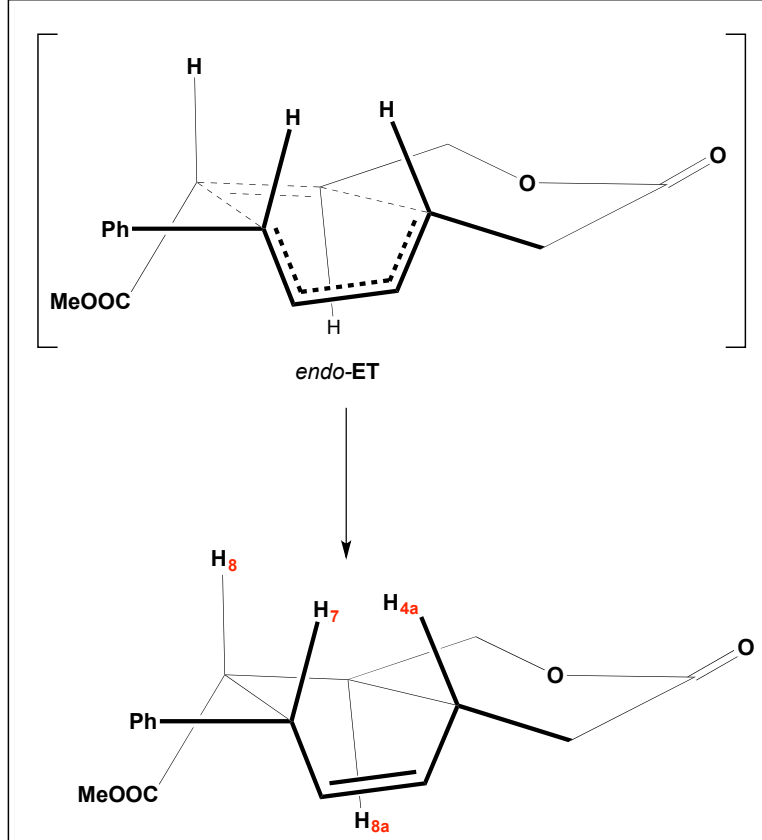

endo-171
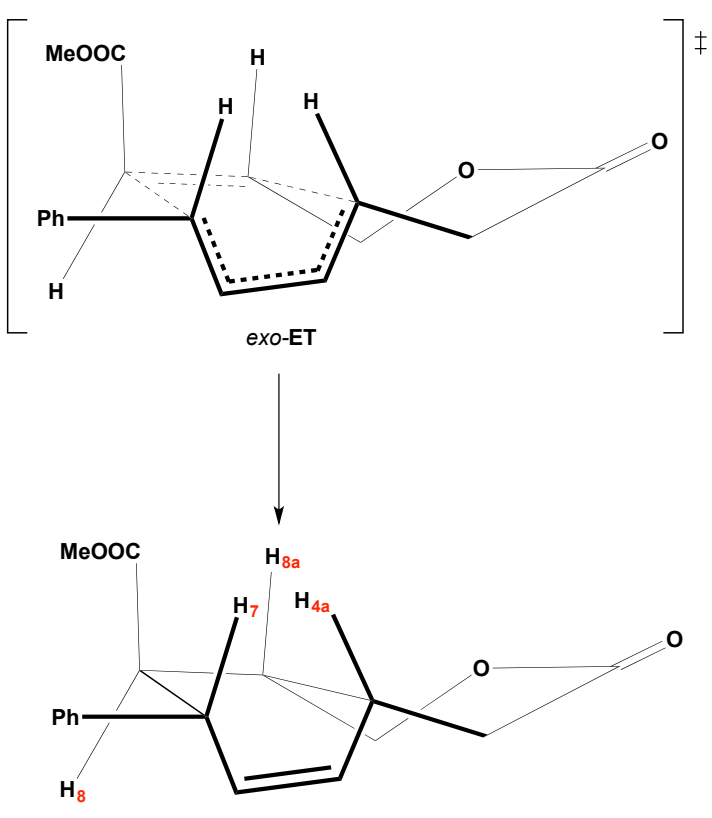

Figura 22. Formação dos produtos endo-171 e exo-171.

O espectro de $\mathrm{RMN}{ }^{1} \mathrm{H}$ do produto isolado por cromatografia flash em coluna de sílica revelou uma mistura de dois isômeros. Vários sistemas de eluentes foram testados em TLC em uma tentativa de separação sem sucesso. O cromatograma obtido pela análise de cromatografia gasosa acoplada à espectrometria de massas (Gas chromatography mass spectrometry - GC-MS) revelou uma proporção endo/exo (m/z 286) de 1:1 para 171 (Figura 23). Esta proporção foi também confirmada por análise de HPLC em coluna C18. 


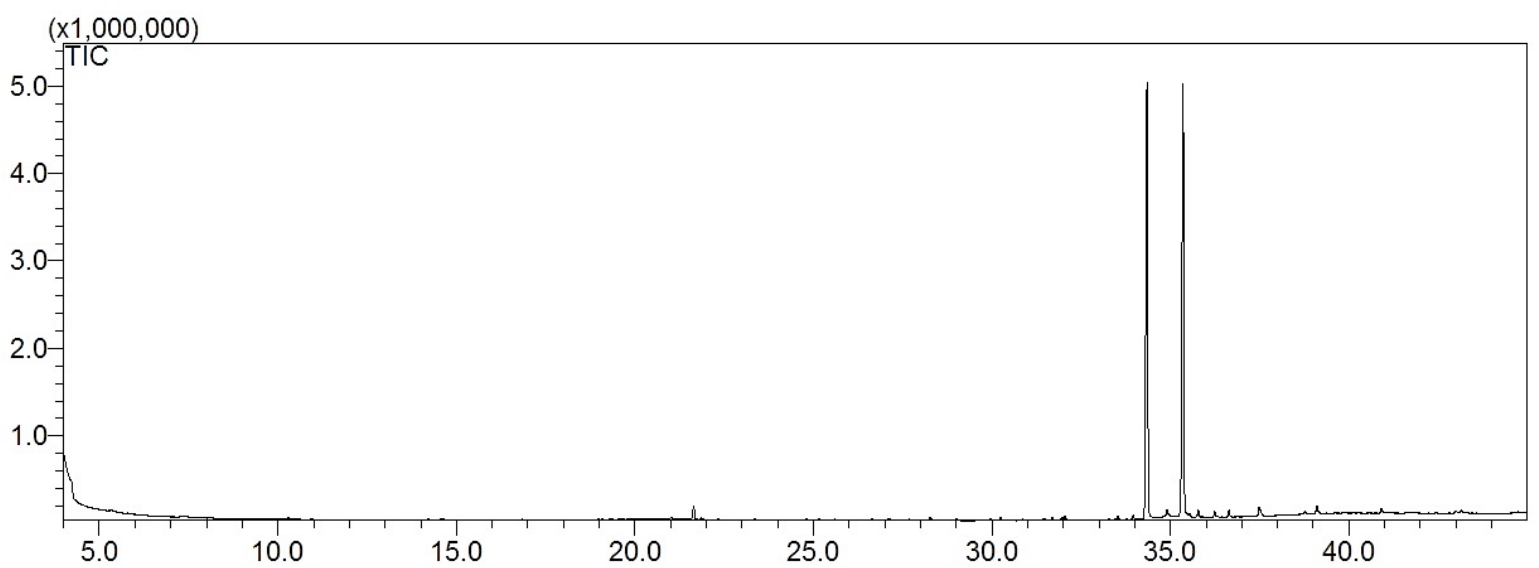

$(\mathrm{x} 1,000,000)$
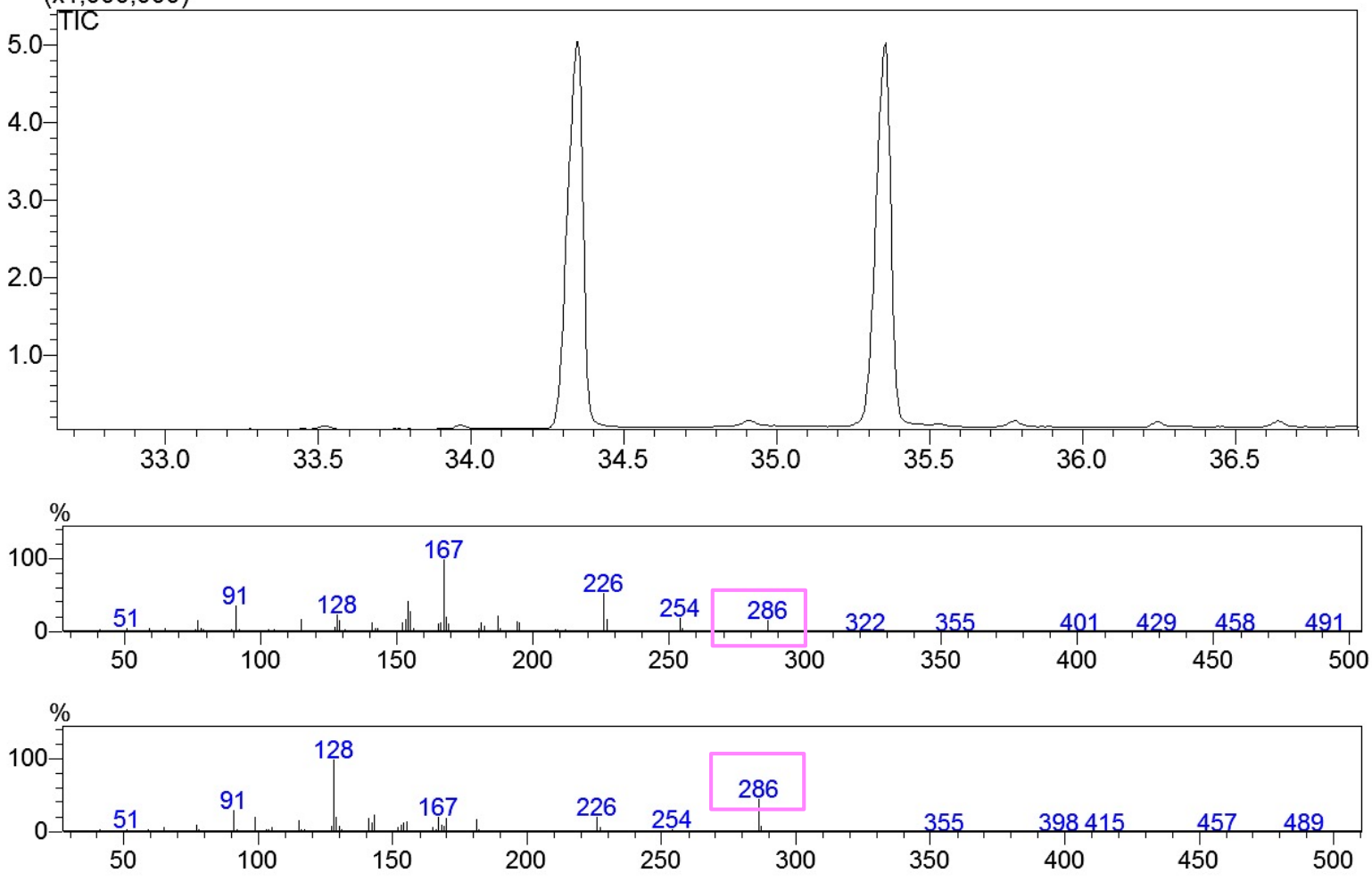

Figura 23 Análise de GC-MS: endo/exo 171 (m/z 286) em uma proporção de 1:1 
A estrutura do produto 171 foi determinada através da análise conjunta dos espectros de RMN de uma e duas dimensões tais como, ${ }^{1} \mathrm{H},{ }^{13} \mathrm{C}, \mathrm{COSY}{ }^{1} \mathrm{H}-{ }^{1} \mathrm{H}$ e HSQC ${ }^{1} \mathrm{H}-{ }^{13} \mathrm{C}$. A atribuição obtida (Figura 24) e o espectro de $\mathrm{RMN}{ }^{1} \mathrm{H} \mathrm{e}^{13} \mathrm{C}$ para produto 171 isolado por HPLC em sistema purificação em escala preparativa é comparado ao espectro de $\operatorname{RMN~}^{1} \mathrm{H}$ do éster $\beta, \lambda$-insaturado 150 na Figura 25. A separação dos isômeros endo/exo foi realizada por HPLC em uma coluna C18 utilizando um gradiente linear de $\mathrm{MeCN} / \mathrm{H}_{2} \mathrm{O} 50 \%$ em um fluxo de $1 \mathrm{~mL} \cdot \mathrm{min}^{-1}$.

A primeira evidência encontrada é a ausência dos hidrogênios do trieno 150 na região entre 6.95 e 5.89 ppm (Figura 26) e a presença de dois novos sinais olefínicos em 5.82 e 5.75 ppm referentes ao $\mathrm{H}_{6}$ e $\mathrm{H}_{5}\left(J_{\text {cis }}=9.9 \mathrm{~Hz}\right)$, respectivamente. A presença de sinais diastereotópicos em 2.38/2.92 ppm ( $\alpha$-carbonila $\mathrm{H}_{4}$ e $\mathrm{H}_{4}$ ) e 4.65/3.91 ppm (carbinólicos $\mathrm{H}_{1}$ e $\mathrm{H}_{1}$ ), bem como os hidrogênios em 2.47 e 2.22 ppm referentes aos $\mathrm{H}_{4 a}$ e $\mathrm{H}_{8 \mathrm{a}}$ na fusão dos anéis de 6 membros corroboram a estrutura. A estereoquímica relativa do produto 171 foi atribuída a partir da análise do espectro de RMN de ${ }^{1} \mathrm{H}$ com base nos valores das constantes de acoplamento entre $\mathrm{H}_{7}$ (3.96 ppm) e $\mathrm{H}_{8}$ (2.87 ppm) dos compostos isolados.

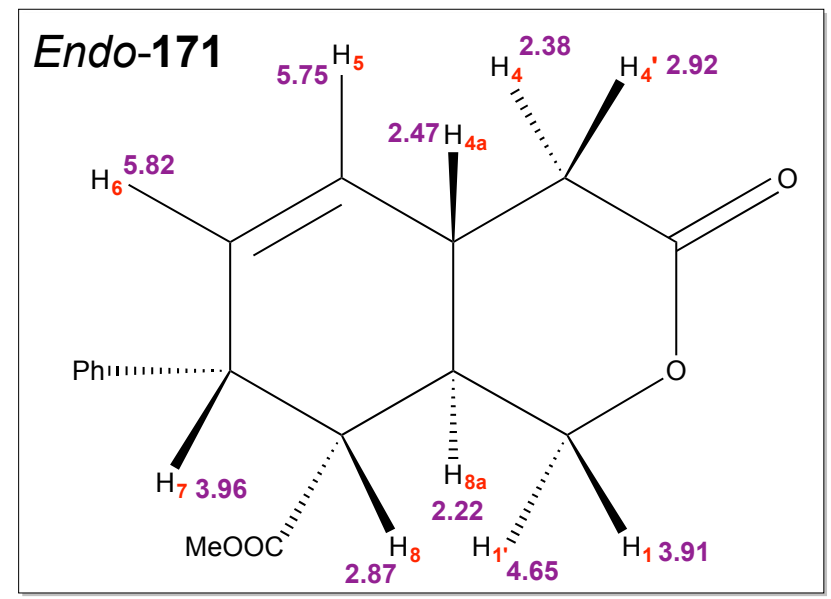

Figura 24 Atribuições da estrutura para o composto endo-171. 


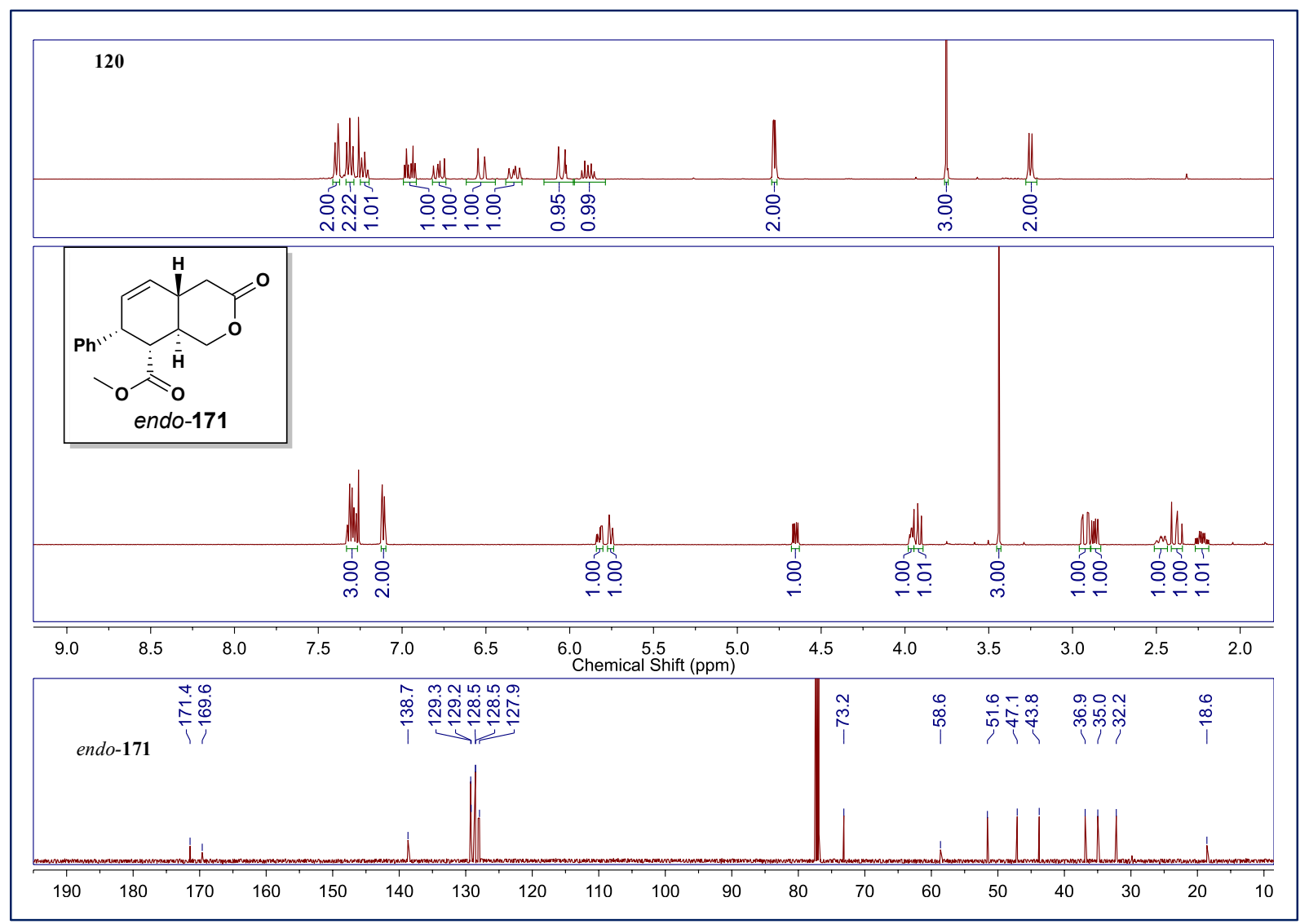

Figura 25 Espectro de ${ }^{1} \mathrm{H}$ e ${ }^{13} \mathrm{C}$ para o éster 150 e o produto de Diels-Alder 171.
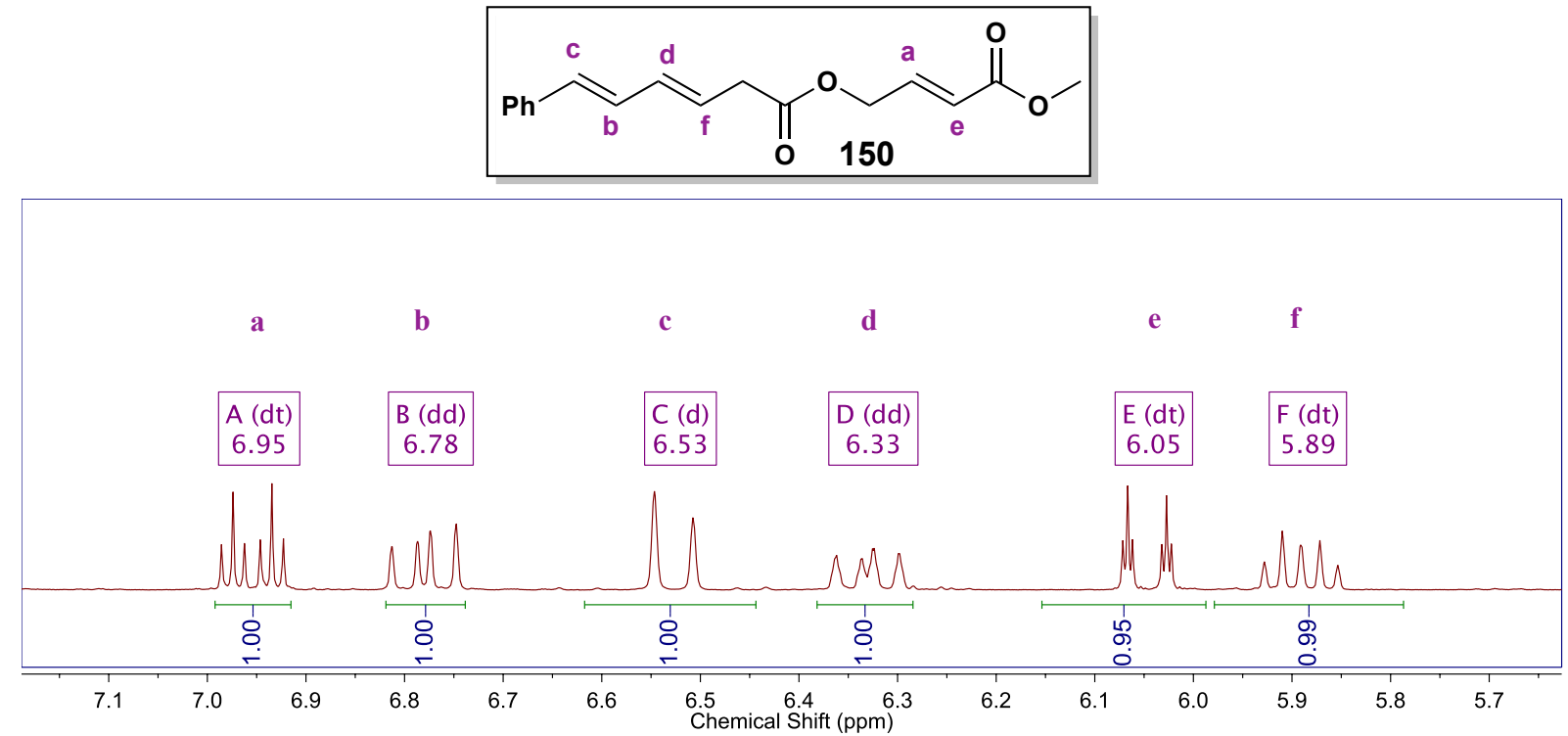

Figura 26 Expansão região dos hidrogênios olefínicos do espectro de $\mathrm{RMN}{ }^{1} \mathrm{H}$ do trieno 150. 
O isômero endo-171 apresenta uma conformação do tipo cadeira onde os substituintes fenila e COOMe ocupam posição axial e equatorial, respectivamente (Figura 27). Observou-se que o hidrogênio $\mathrm{H}_{7}$ apresenta uma constante de acoplamento de $6.6 \mathrm{~Hz}$ com hidrogênio $\mathrm{H}_{8}$, o que sugere um acoplamento do tipo equatorial-axial. Além disto, não foi possível detectar interação entre $0 \mathrm{H}_{8 \mathrm{a}}-\mathrm{H}_{4 a}$ a partir experimentos de nOe seletivo (irradiando em $\sigma_{\mathrm{H} 8 \mathrm{a}} 2.22 \mathrm{ppm}$ ). No caso do produto exO171, ambos substituintes fenila e COOMe ocupam posição equatorial, enquanto que os hidrogênios $\mathrm{H}_{7}$ e $\mathrm{H}_{8}$ possuem uma constante de acoplamento de $10.3 \mathrm{~Hz}$ que sugere um acoplamento trans-diaxial. Dados da literatura a partir de substratos similares corroboram com a elucidação realizada. ${ }^{150-152}$ A partir destas informações, pode-se concluir de maneira inequívoca a esteroquímica dos produtos isolados.
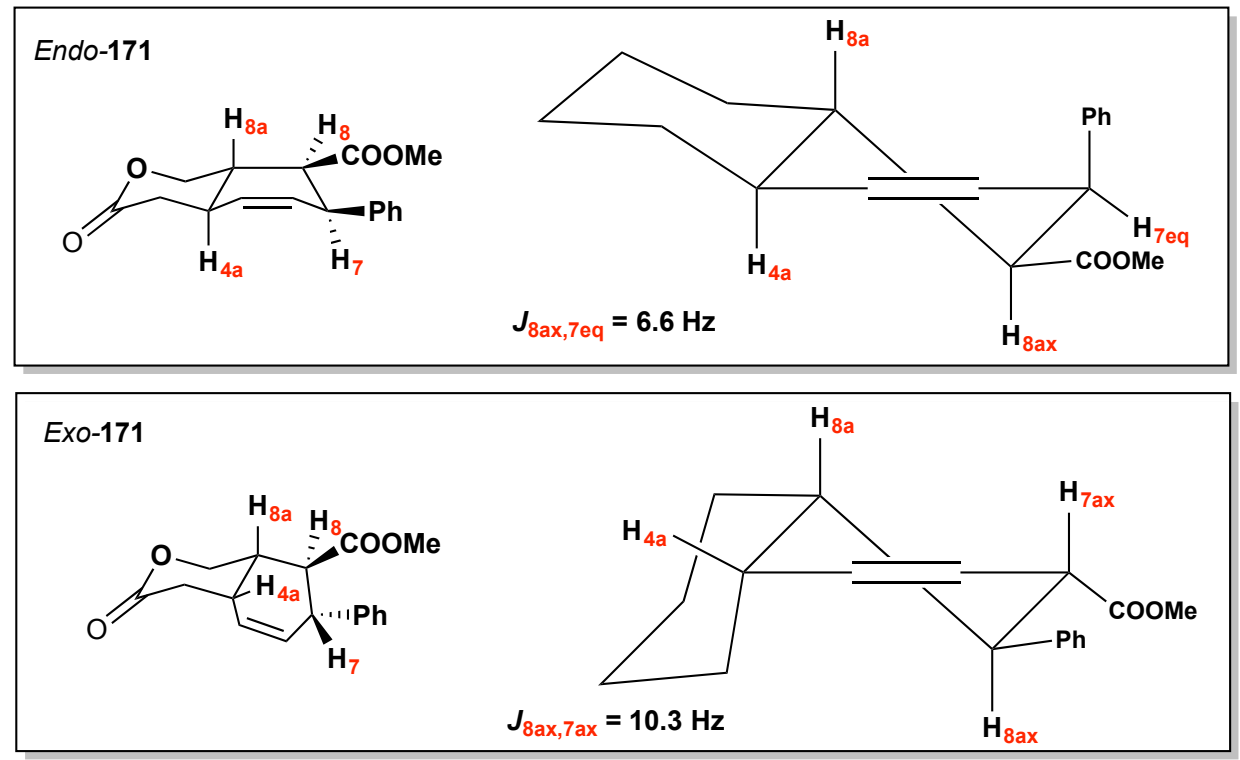

Figura 27 Análise esteroquímica relativa dos produtos endo-171 e exo-171.

Visando melhores seletividades entre os isômeros endo/exo, avaliou-se a reação utilizando ácidos de Lewis como catalisadores. Algumas condições foram testadas incluindo ácidos como $\mathrm{AlCl}_{3}, \mathrm{BF}_{3} . \mathrm{OEt}_{2}, \mathrm{SnCl}_{4}, \mathrm{NbCl}_{5}$ e $\mathrm{BCl}_{3}$ disponíveis no laboratório no momento do estudo. As entradas investigadas estão resumidas na Tabela 7. As condições avaliadas foram baseadas em procedimentos descritos na literatura para substratos similares. Por exemplo, na presença de $\mathrm{SnCl}_{4}$, a reação foi mantida em temperatura ambiente por $24 \mathrm{~h}$, recuperando-se o material de partida ao final do período reacional (Tabela 7, entrada 5). Em uma segunda tentativa, a reação foi iniciada em temperatura ambiente e aquecida a $50^{\circ} \mathrm{C}$ (em um tubo selado). 
Novamente, não houve consumo do material de partida após $12 \mathrm{~h}$ de agitação, tendo sido recuperado (entrada 6). O mesmo tipo de comportamento foi observado na presença de $\mathrm{BF}_{3} \mathrm{OEt}_{2}$ e de $\mathrm{AlCl}_{3}$ (entradas 1,2, 3 e 4). O material de partida foi convertido em produtos ao se utilizar $\mathrm{NbCl}_{5} \mathrm{BCl}_{3}$, entretanto, não foi possível detectar o cicloaduto 171 na mistura do bruto reacional (entradas 7 e 8). Um último substrato 153 foi estudado. Entretanto o material de partida permaneceu intacto após $48 \mathrm{~h}$ de reação em $280^{\circ} \mathrm{C}$ (Esquema 57).

Tabela 7 Condições da reação de Diels-Alder catalisada por ácido de Lewis.

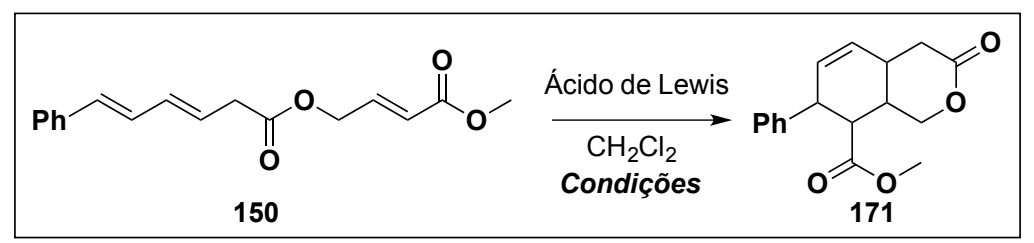

\begin{tabular}{cccccc}
\hline Entrada $^{\mathrm{b}}$ & Ácido de Lewis & Equiv. & Temperatura & Tempo & (\%) $\mathbf{1 3 6}$ \\
\hline $\mathbf{1}$ & $\mathrm{AlCl}_{3}$ & 0.1 & $0^{\circ} \mathrm{C}-\mathrm{t} . \mathrm{a}^{\mathrm{d}}$ & $12 \mathrm{~h}$ & $\mathrm{MR}^{\mathrm{c}}$ \\
$\mathbf{2}$ & $\mathrm{AlCl}_{3}$ & 0.3 & $0^{\circ} \mathrm{C}-\mathrm{t} . \mathrm{a}^{\mathrm{d}}$ & $12 \mathrm{~h}$ & $\mathrm{MR}^{\mathrm{c}}$ \\
$\mathbf{3}$ & $\mathrm{BF}_{3} . \mathrm{OEt}_{2}$ & 1.5 & $\mathrm{t} . \mathrm{a}$ & $48 \mathrm{~h}$ & $\mathrm{MR}^{\mathrm{c}}$ \\
$\mathbf{4}^{\mathrm{a}}$ & $\mathrm{BF}_{3} . \mathrm{OEt}_{2}$ & 1.5 & $50{ }^{\circ} \mathrm{C}$ & $24 \mathrm{~h}$ & $\mathrm{MR}^{\mathrm{c}}$ \\
$\mathbf{5}$ & $\mathrm{SnCl}_{4}$ & 1.0 & $0{ }^{\circ} \mathrm{C}-\mathrm{t} . \mathrm{a}^{\mathrm{d}}$ & $24 \mathrm{~h}$ & $\mathrm{MR}^{\mathrm{c}}$ \\
$\mathbf{6}$ & $\mathrm{SnCl}_{4}$ & 1.0 & $\mathrm{t} . \mathrm{a}-50^{\circ} \mathrm{C}$ & $12 \mathrm{~h}$ & $\mathrm{MR}^{\mathrm{c}}$ \\
$\mathbf{7}$ & $\mathrm{NbCl}_{5}$ & 0.4 & $0^{\circ} \mathrm{C}-\mathrm{t} . \mathrm{a}^{\mathrm{d}}$ & $12 \mathrm{~h}$ & $-{ }^{\mathrm{c}}$ \\
$\mathbf{8}$ & $\mathrm{BCl}_{3}$ & 0.2 & $0^{\circ} \mathrm{C}-\mathrm{t} . \mathrm{a}^{\mathrm{d}}$ & $12 \mathrm{~h}$ & $-{ }^{\mathrm{c}}$
\end{tabular}

${ }^{a}$ reação em tubo selado, temperatura do banho medida pelo termômetro ${ }^{\mathrm{b}} 20 \mathrm{mg}(0.068 \mathrm{mmol})$ de 150 foram solubilizados em $1.4 \mathrm{~mL}$ de $\mathrm{CH}_{2} \mathrm{Cl}_{2}$ na temperatura indicada previamente à adição do ácido de Lewis. ${ }^{\mathrm{C}}$ produto 171 não foi identificado no bruto reacional (antes e após work-up, por análise de TLC). ${ }^{d}$ temperatura de $0{ }^{\circ} \mathrm{C}$ no momento da adição do ácido de Lewis para atingir temperatura ambiente naturalmente.

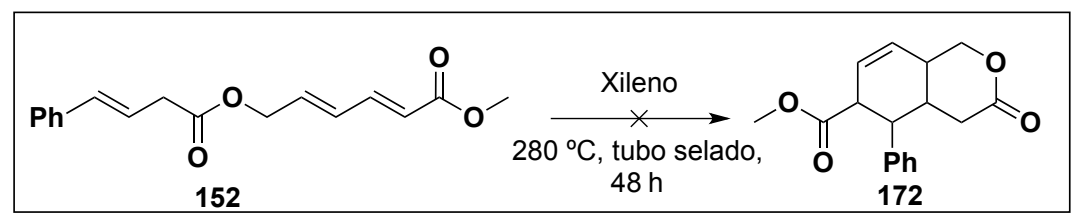

Esquema 57 Reação de Diels-Alder a partir do substrato 122. 


\subsection{Conclusões parciais}

Este capítulo dedicou-se ao estudo de reações de cicloadições [2+2] e [4+2] a partir de ésteres $\beta, \gamma$-insaturados provenientes de diazocetonas $\alpha, \beta$-insaturadas. A etapa de rearranjo de Wolff fotoquímico forneceu 13 substratos insaturados 141-153, entre eles, 9 substratos para o estudo de cicloadição [2+2] e 4 para Diels-Alder. Os ésteres $\beta, \gamma-$ insaturados 141-153 foram sintetizados a partir de 6 exemplos de diazocetonas e de 5 diferentes álcoois alílicos em $40-85 \%$ de rendimento. A reação ocorre de forma similar a descrita no capítulo 1, sendo possível utilizar lâmpadas de LED (18 W) e de Xenônio (300 W) em tempos variando entre 15 minutos (Xe) e 24 h (LED). Cabe ressaltar, que 5 novos exemplos de diazocetonas insaturadas $(53,112,113,114$ e 130) foram sintetizadas a partir de aldeídos como fenilglioxal, cinamaldeído e um aldeído protegido com TBS-128. Estas diazocetonas, especialmente 53, 113 e 130, podem abrir um leque de novas aplicações a serem exploradas. Os ésteres insaturados 141-149 foram submetidos em diferentes condições fotoquímicas de [2+2] na presença e ausência do fotossensibilizador tioxantona fornecendo misturas de isômeros com geometrias E/Z em proporção 1:1. Embora os produtos de cicloadição [2+2] não puderam ser obtidos, desenvolveu-se uma série de novas diazocetonas e de ésteres insaturados que podem vir a ser explorados futuramente pelo grupo de pesquisa do Prof. Antonio Burtoloso. Enquanto os substratos 151, 152 e 153 permaneceram intactos em condições térmicas de Diels-Alder $\left(110-280^{\circ} \mathrm{C}\right)$, o trieno 150 forneceu o produto de Diels-Alder $( \pm) \mathbf{1 7 1}$ em $70 \%$ de rendimento quando aquecido em tolueno a uma temperatura de $250^{\circ} \mathrm{C}$ em tubo selado. Experimentos de GC-MS, HPLC e RMN ${ }^{1} \mathrm{H}$ mostraram uma seletividade 1:1 dos produtos endo/exo. Os isômeros foram separados por HPLC em sistema preparativo. Melhores seletividades endo/exo foram exploradas fazendo o uso de diferentes ácidos de Lewis tais como $\mathrm{AlCl}_{3}, \mathrm{BF}_{3}$. OEt $2, \mathrm{SnCl}_{4}, \mathrm{NbCl}_{5}$ e $\mathrm{BCl}_{3}$. Na maioria dos casos, o material de partida foi recuperado. Este resultado indica que condições de temperatura associadas ao uso de ácidos de Lewis mais fortes podem vir a converter o éster no cicloaduto de interesse. 


\section{CAPÍTULO III}

\section{Diazocetonas insaturadas como reagentes para modificação de proteínas}

Este capítulo destina-se ao emprego das diazocetonas $\alpha, \beta$-insaturadas em sistemas mais complexos, por exemplo, como reagentes para a modificação específica de proteínas. Este trabalho foi realizado em colaboração com o Prof. Gonçalo Bernardes da Universidade de Cambridge, Reino Unido, como parte de um projeto BEPE/FAPESP. Compostos diazocarbonílicos insaturados foram empregados como aceptores de Michael pelo grupo do Prof. Antonio Burtoloso durante a síntese total do produto natural Preussina. ${ }^{60}$ Dentre os exemplos estudados no grupo, uma diazocetona em particular, 53, demonstrou-se extremamente reativa para adições de Michael (Esquema 58). Dessa forma, imaginou-se estes compostos como reagentes específicos para a ligação quimiosseletiva de cisteínas (Cis) ou lisinas (Lis) livres em proteínas nativas via adições 1,4. A inserção da funcionalidade diazocetona na superfície de uma proteína traria uma gama de transformações bioortogonais a serem exploradas. Após a instalação da diazocetona, reações mediadas por carbeno/carbenóides tais como rearranjo de Wolff, ciclopropanações e reações de inserção poderiam ser estudadas. 
Este capítulo foi dividido em duas seções, introduzindo a importância de se modificar proteínas de forma quimiosseletiva, os métodos desenvolvidos até o momento, e os resultados obtidos para a otimização reacional utilizando reagentes carbonilacrílicos mais simples. Para compreender o sistema e provar a sua seletividade, amidas e ésteres $\alpha, \beta$-insaturados foram propostos como modelos de um estudo aprofundado, incluindo cinética reacional, testes de estabilidade e aplicação na construção de proteínas e anticorpos funcionais (Esquema 58). Após definir as melhores condições para modificar as proteínas nativas e anticorpos utilizando reagentes carbonilacrílicos simples, a segunda seção é então voltada para o emprego e funcionalização dos seus derivados diazocarbonilacrílicos.

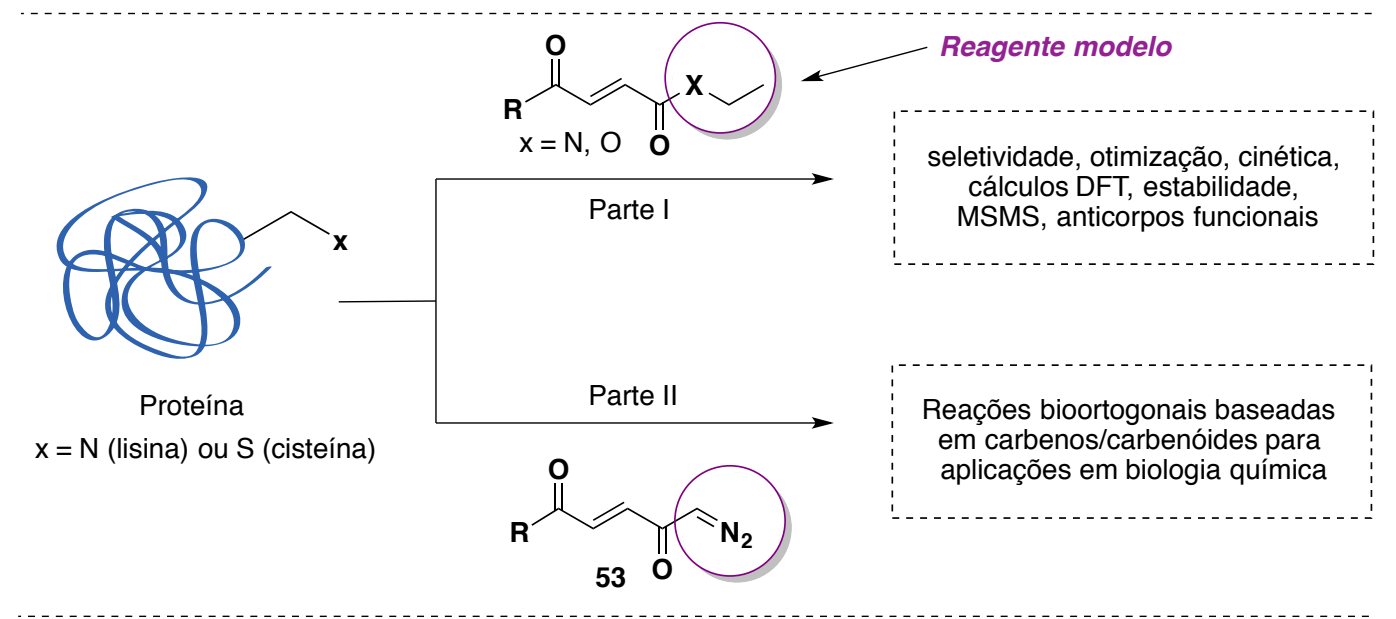

Esquema 58 Compostos carbonilacrílicos como reagentes para modificação específica de proteínas.

\subsection{Modificação de proteínas}

Ao longo de bilhões de anos de evolução, a natureza desenvolveu uma complexa máquina para anexar diversos grupos funcionais as proteínas - um processo chamado de modificações pós-translacionais (PTM). ${ }^{153}$ Estas proteínas modificadas desempenham funcionalidades químicas em importantes processos celulares, incluindo tráfego vesicular, diferenciação, migração e sinalização. ${ }^{153,154}$ Por exemplo, a ligação de carboidratos em proteínas, um processo conhecido como glicosilação, pode melhorar a solubilidade e modular interações ligante-receptor. ${ }^{154}$ Através da adição reversível de grupos fosfatos a serinas, treoninas ou resíduos de tirosinas, as enzimas podem permutar entre os estados ativos e inativos. De um modo semelhante, 
a formação de complexos entre duas ou mais proteínas podem ser controladas. ${ }^{154}$ Coletivamente, estes exemplos destacam como, através da introdução de pequenas modificações, a natureza muitas vezes redesenha a estrutura e função das proteínas para modular a diversidade biológica. ${ }^{153,154}$

Com inspiração na natureza, a comunidade científica tem desenvolvido ferramentas para modificar covalentemente proteínas em laboratório, instalando seletivamente diferentes alterações com variadas aplicações. ${ }^{153}$ Por exemplo, a circulação de meia-vida de uma proteína pode ser aumentada pela adição de unidades polietilenoglicol (PEG). A marcação de proteínas com compostos fluorescentes em células vivas permite a medida de parâmetros fisiológicos opticamente. Através da conjugação de anticorpos à fármacos citotóxicos, terapias anticâncer inovadoras com maior eficiência e redução de toxicidade podem ser obtidas. ${ }^{153,155-157}$ Acima de tudo, a modificação química de proteínas surgiu como uma ferramenta para a compreensão dos sistemas naturais, para a o preparo de conjugados terapêuticos com desempenhos melhorados, assim como a criação de novas proteínas com propriedades ou funções desejadas. ${ }^{158-166}$

\subsubsection{Estratégias para bioconjugação de proteínas}

Apesar do progresso na área da química de bioconjugação, a comunidade científica ainda enfrenta muitos desafios, não apenas impasses sintéticos, mas também dificuldades envolvendo seletividade e estabilidade dos conjugados obtidos. iv A quimiosseletividade e a suavidade do processo são quesitos essenciais para instalar precisamente modificações em locais pré-determinados, sem perturbar a estrutura, função e atividade das proteínas. ${ }^{160,167,168}$ Reatividade, acessibilidade e abundância de uma determinada cadeia lateral de aminoácidos são aspectos-chave necessários para conseguir a modificação seletiva de um certo resíduo sobre todos os outros. As primeiras metodologias descritas exibem pouca seletividade, oferecendo amostras heterogêneas com baixo controle sobre a posição de modificação. ${ }^{167}$

Entre todos os aminoácidos proteinogênicos disponíveis na superfície das proteínas, a cisteína continua a ser o resíduo de escolha devido à sua baixa

\footnotetext{
iv Pages 108 - 129: reproduced in part from Bernardim, B. et al. Stoichiometric and irreversible cysteineselective protein modification using carbonylacrylic reagents. Nature Communications. (7) 2016, 13128, doi: 10.1038/ncomms13128 with permission from Nature Publishing Group.
} 
abundância e a alta nucleofilicidade da cadeia sulfidrila. ${ }^{169} \mathrm{Na}$ verdade, a maioria dos conjugados de proteínas utilizados em testes clínicos, como por exemplo os conjugados de anticorpo-droga (Antibody Drug Conjugates - ADCs), são preparados utilizando métodos de bioconjugação de cisteínas. ${ }^{156,157}$ Vários reagentes de alquilação e aceptores de Michael têm sido e continuam a ser relatados para bioconjugação de cisteínas. ${ }^{169,170}$

\subsection{Reagentes carbonilacrílicos}

Apesar do grande desenvolvimento na área de bioconjugação de cisteínas, as maleimidas ainda são os reagentes mais utilizados. Este fato se deve principalmente à rápida cinética reacional, solubilidade em condições aquosas, reagentes facilmente sintetizados e o fato de que não requerer extensa engenharia genética da proteína alvo. Por exemplo, o ADC Brentuximab Vedotin, aprovado pela Food and Drug Administration (FDA) para tratamento de câncer, é preparado por conjugação de um fármaco-maleimida em resíduos de cisteína de um anticorpo. ${ }^{171}$ No entanto, é bem documentado que os conjugados formados passam por rápidas reações de troca com tióis biológicos presentes no plasma via reações de retro-Michael, conduzindo à liberação das maleimidas e causando toxicidade (Esquema 59, a). ${ }^{172,173}$ Um outro problema associado ao uso das maleimidas é a hidrólise natural da tio-succinimida em pH's fisiológicos, levando a formação de misturas heterogêneas de bioconjugados que prejudicam a ação farmacológica. No caso específico das maleimidas, as estratégias adotadas têm sido direcionadas ao aceleramento da velocidade de hidrólise da tio-succinimida formada a fim de gerar um derivado de cadeia aberta totalmente estável (Esquema 59, b). Isto foi demonstrado tanto por engenharia genética da sequência de aminoácido adjacente a cisteína ${ }^{172}$ ou por introdução química de um grupo amino sobre a estrutura maleimida (Esquema 59, b). ${ }^{174-176}$ Estas abordagens conduzem a conjugados que são mais estáveis in vivo, mas requerem extensa engenharia, uso de reagentes que resultam numa conjugação mais lenta, e que em muitas vezes fornecem misturas heterogêneas de conjugados hidrolisados vs conjugados não-hidrolisados. A substituição da olefina endocíclica por uma dupla ligação exocíclica também foi mostrado com fins de redução da reação de retroMichael. ${ }^{177}$ No entanto, a cinética mais lenta da reação de maleimidas exocíclicas com 
cisteínas requer um maior excesso de reagentes para alcançar conversões úteis em nível proteico.

Numa tentativa de proporcionar um método de bioconjugação de cisteínas que forneça compostos estáveis e resistentes a reações de retro-Michael, exploraram-se modelos carbonilacrílicos simples visando alta reatividade e seletividade em condições aquosas e um pH quase neutro (Esquema 59, c).

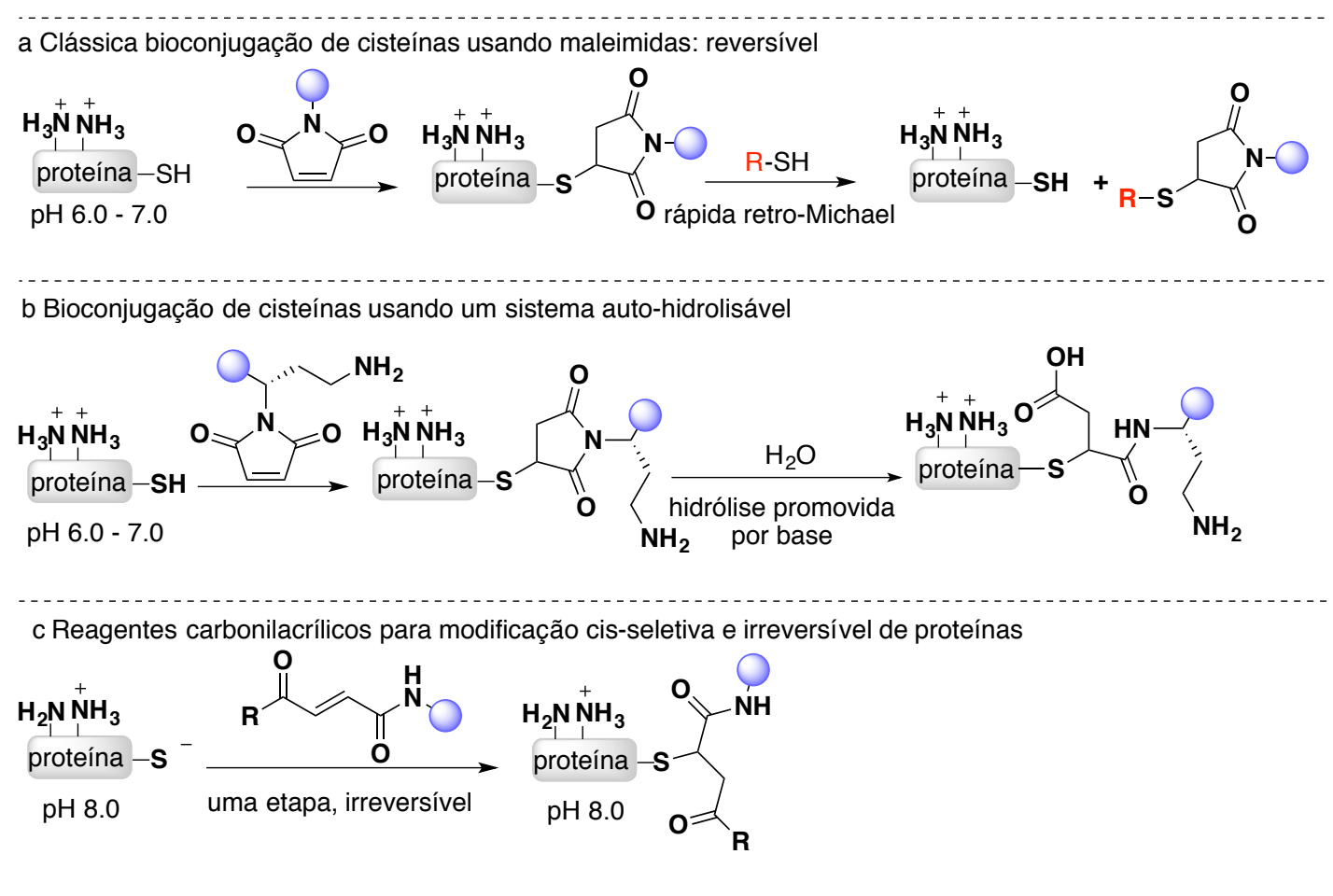

Esquema 59 Métodos para bioconjugação de cisteínas.

\subsubsection{Construção de modelos de aminoácidos}

O estudo foi iniciado pela reação do éster metílico do aminoácido cisteína protegido com Boc 173 com o reagente 3-benzoilacrilato 174 disponível comercialmente. Notavelmente, a reação ocorreu de forma completa (rendimento de 99\%), utilizando quantidades estequiométricas de 174 em menos de dois minutos à temperatura ambiente (Esquema 60). A reação pode ser realizada tanto em meio orgânico puro (MeCN ou DMF) quanto em meio aquoso (30\% de DMF em tampão de fosfato de sódio - $\mathrm{NaP}_{\mathrm{i}}, \mathrm{pH}$ 8.0, $50 \mathrm{mM}$ ), obtendo-se rendimentos equivalentes. Em um experimento de competição entre lisina e cisteína realizados sob as mesmas condições reacionais, apenas o aduto de enxofre é formado, permanecendo a lisina 
intacta (Esquema 60, b). Cabe ressaltar, que nas mesmas condições, o éster metílico do aminoácido Lisina protegido com Boc 177 é consumido após 1 hora (Esquema 60, c). Estes resultados indicam elevada quimiosseletividade do reagente carbonilacrílico 174 para adições de Michael em cisteínas.

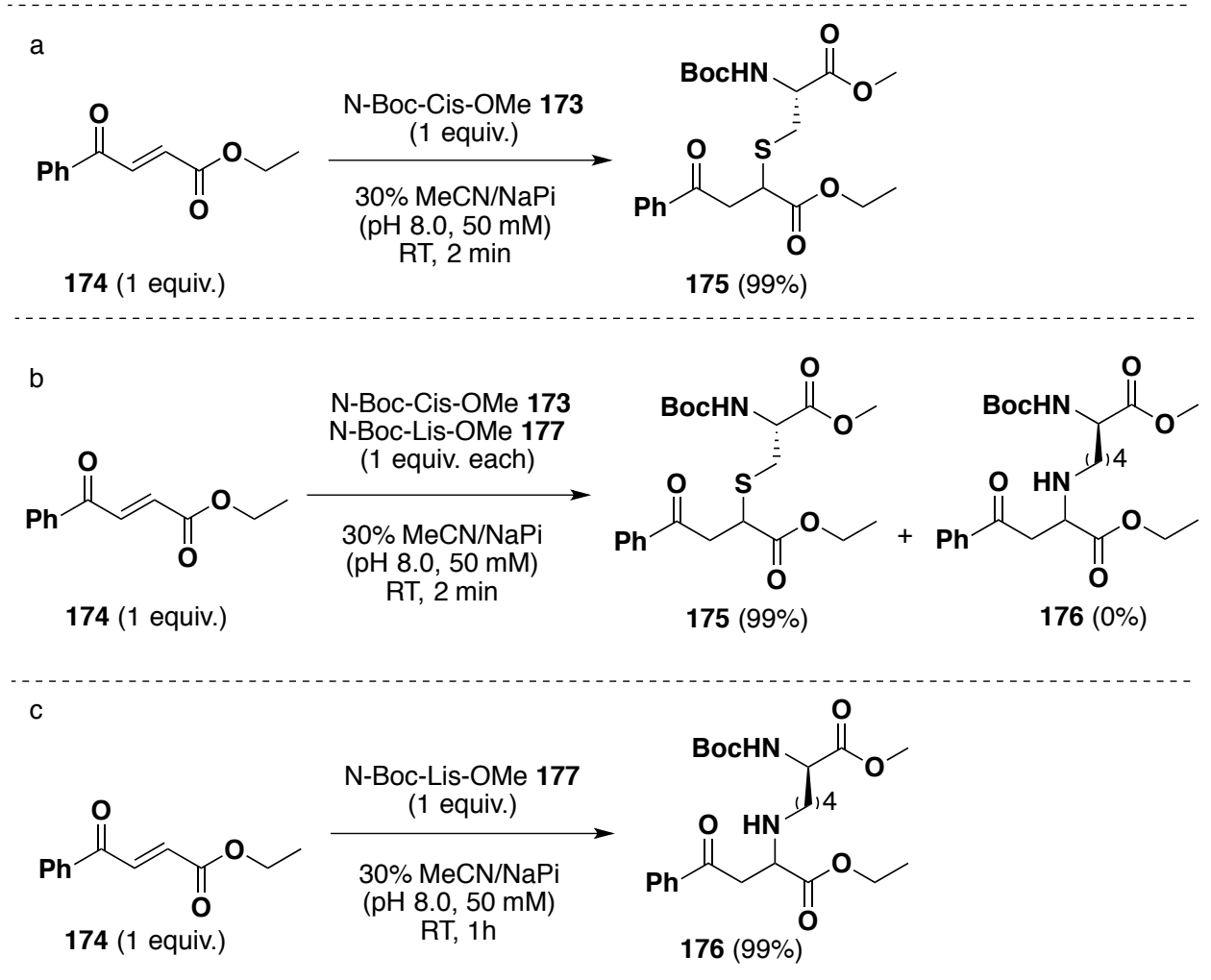

Esquema 60 Reação do éster carbonilacrílico 174 com cisteína 173 e lisina 174.

Considerando a simplicidade estrutural do éster 174, projetou-se uma série de variantes com a ajuda de cálculos mecânicos quânticos (QM), equilibrando reatividade e funcionalidade em ambas as extremidades da dupla ligação. ${ }^{\vee}$ Ésteres, cetonas e amidas 178-180 foram consideradas com o objetivo de encontrar um reagente altamente reativo que pode ser utilizado para conjugação rápida, seletiva e irreversível de proteínas (Figura 28). Um modelo abreviado para Cis (- $\mathrm{SMe}$ ) foi usado nos cálculos como um nucleófilo sulfidrila. A reatividade de diferentes reagentes carbonilacrílicos foi avaliada a partir da variação de energia $(\Delta \mathrm{E})$ entre o orbital molecular ocupado de maior energia (HOMO) do nucleófilo $\mathrm{SMe}^{-}$e o orbital molecular desocupado de menor energia (LUMO) do aceptor de Michael. ${ }^{178}$ Esta análise previu olefinas 1,2-trans di-

\footnotetext{
v Cálculos realizados pelo Prof. Dr. Gonzalo Jiménez-Osés do Departamento de Química da Universidad de La Rioja, Centro de Investigacioón en Síntesis Química, Spain.
} 
substituídas equipadas com uma metil cetona e um éster (178, $\Delta \mathrm{E}=4.5 \mathrm{eV})$, ou uma fenilcetona e uma amida (179, $\Delta \mathrm{E}=4.4 \mathrm{eV})$ com reatividade comparável a de $174(\Delta \mathrm{E}$ $=4.2 \mathrm{eV})$ e a da maleimida $(\Delta \mathrm{E}=4.3 \mathrm{eV})$. Uma outra informação importante extraída dos cálculos diz respeito a regiosseletividade da adição de Michael, considerando ambos carbonos da dupla ligação atuando na funcionalização 1,4. Além de previsível por estabilidade do intermediário formado (Esquema 61), exemplos de adição de Michael a partir de ésteres similares corroboram a entrada do nucleófilo na posição $\beta$ ' da olefina com $100 \%$ de seletividade (Esquema 61 ). ${ }^{179-186}$

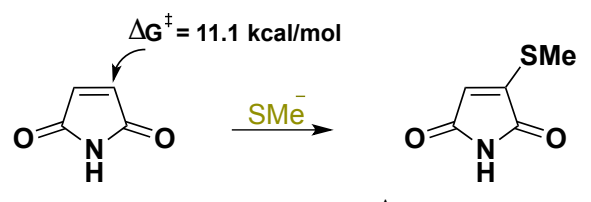

SUPER REATIVO
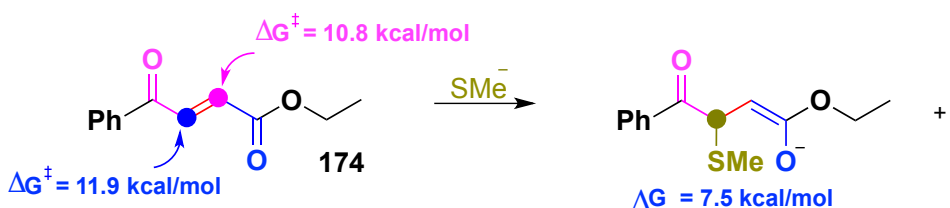

$\Delta \mathrm{G}=7.5 \mathrm{kcal} / \mathrm{mol}$

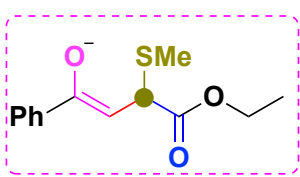

SUPER REATIVO
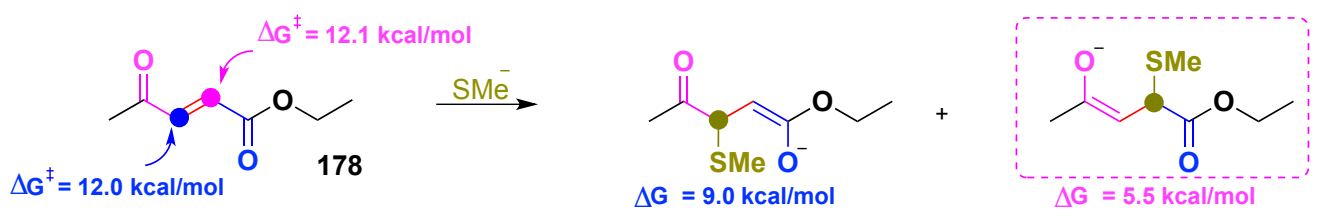

MUITO REATIVO
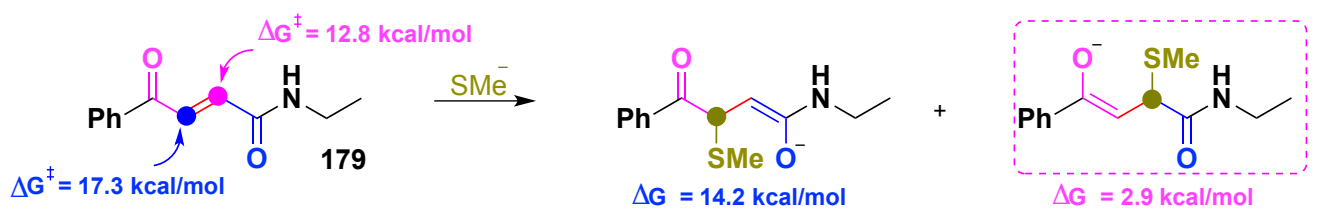

MUITO REATIVO
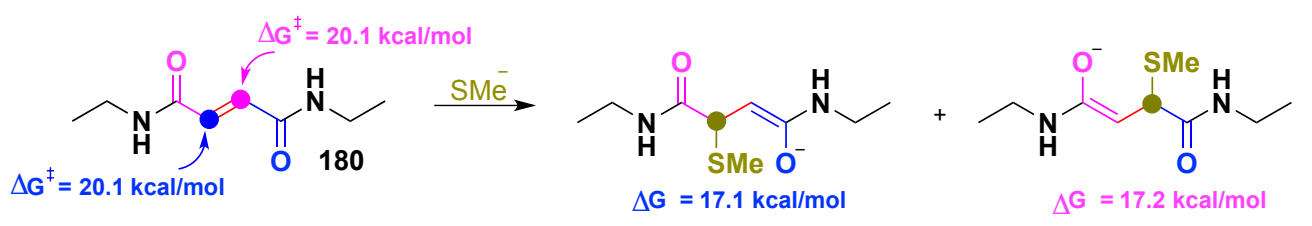

POUCO REATIVO

Figura 28 Adição conjugada de metil tiolato na maleimida e nos reagentes carbonilacrílicos. 

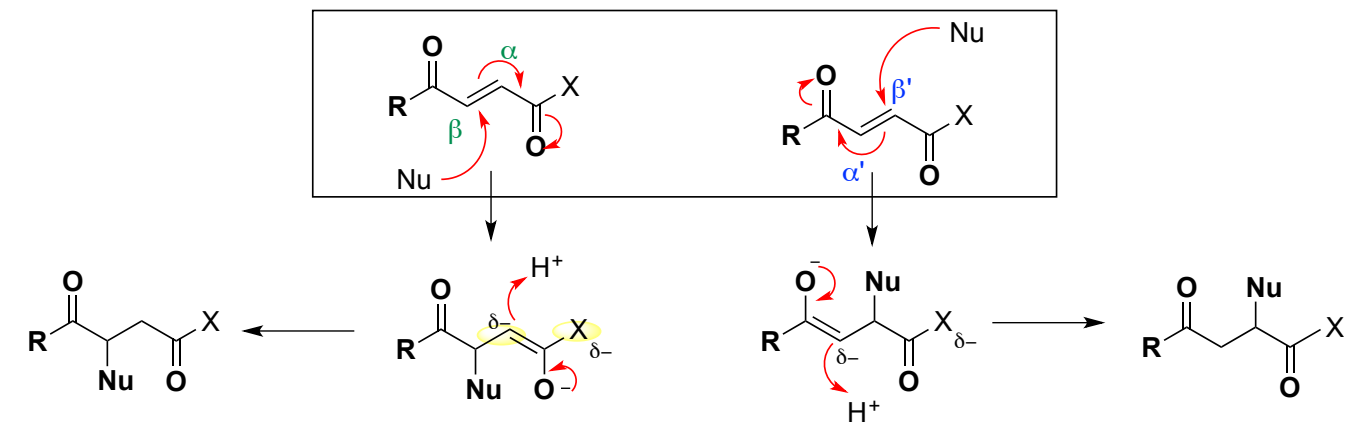

Esquema 61 Adição de Michael nas posições $\alpha$ e $\beta$ do reagente carbonilacrílico.

Outro refinamento dos cálculos através do estado de transição confirmou que 174, 178 e 179 estão dentro da mesma janela de reatividade quando comparada com a maleimida de referência (Figura 29). De nota, enquanto que uma amida é tolerada em um dos lados da ligação dupla, oferecendo grandes vantagens sintéticas para bioconjugação, a presença de amidas em ambas as extremidades da olefina, tal como em 180, $(\Delta E=5.1 \mathrm{eV})$, reduz a sua reatividade calculada em até 7 ordens de grandeza devido à sua incapacidade para estabilizar a carga negativa acumulada na carbonilacrilamida após a adição de tiolato. Os resultados experimentais corroboram as previsões, com derivados os carbonilacrílicos 178-180 levando a formação completa dos produtos 181-183 (Figura 29).

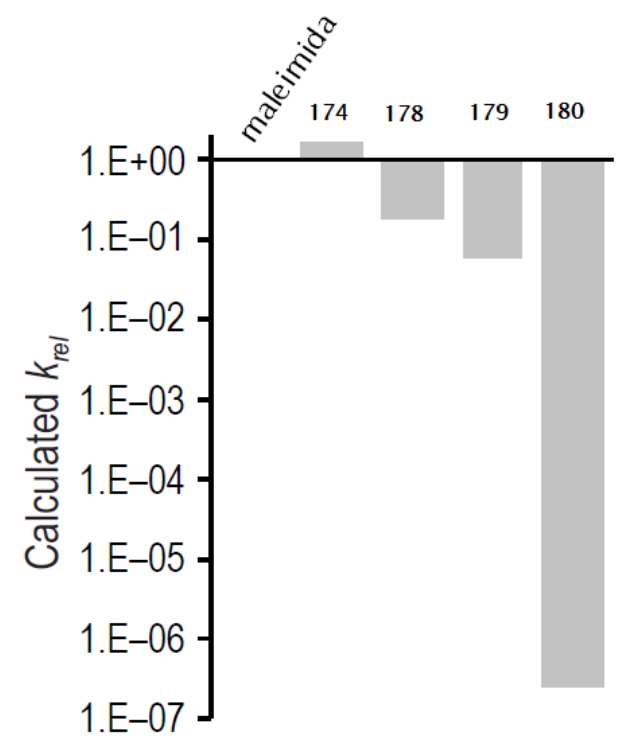

Figura 29 Velocidade de reação relativa calculada e resultados experimentais da adição de $\mathrm{SMe}^{-}$nos derivados carbonilacrílicos 174, 178-180. 


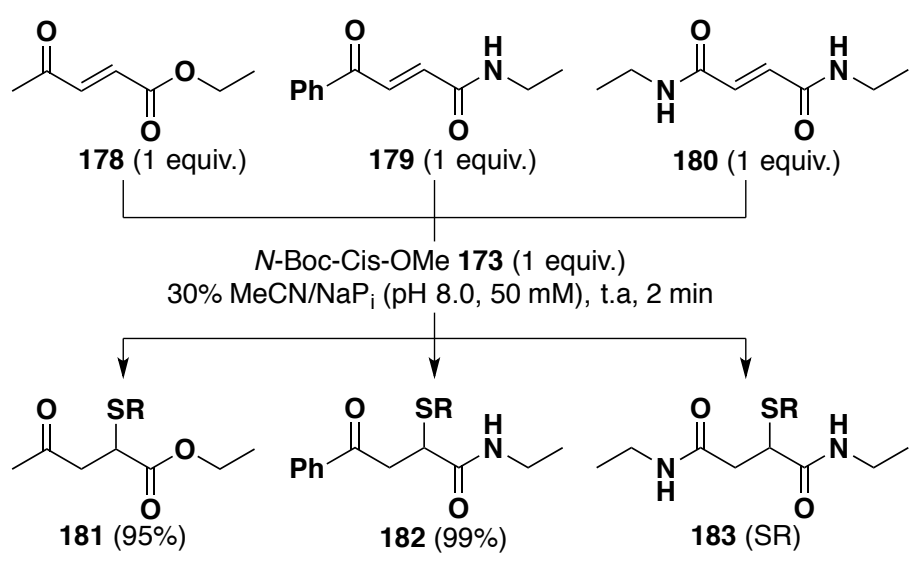

Esquema 62 Adição de N-Boc-Cis-OMe 173 nos reagentes carbonilacrílicos 178-180.

A cinética reacional foi avaliada utilizando a técnica de espectroscopia UV-VIS. Os espectros de UV dos compostos 174 (absorbância máxima 269) e 179 (absorbância máxima 275), em conjunto com os espectros dos correspondentes adutos de Michael 175 e 182 foram obtidos a temperatura ambiente em uma solução $0.075 \mathrm{mM}$ em 30\% MeCN/tampão de fosfato de sódio ( $\mathrm{pH}=8.0,50 \mathrm{mM}$ ) (Figura 30). ${ }^{\text {vi }}$ Após a adição da cisteína 173, a reação foi acompanhada pelo desaparecimento da absorbância máxima de ambos os compostos a cada 0.1 minutos (Figura 30). A determinação experimental da constante de velocidade de segunda ordem para o composto 174 (painel da esquerda) e 179 (painel da direita) foi realizada a partir da reta $\left(1 / \mathrm{C}-1 / \mathrm{C}_{0}\right)$ em função do tempo $\left(\mathrm{K}_{2}(\mathbf{1 7 4})=40,2 \mathrm{M}^{-1} \mathrm{~s}^{-1}\right.$ e $\mathrm{K}_{2}(\mathbf{1 7 9})=10,9 \mathrm{M}^{-1} \mathrm{~s}^{-1}$, Figura 30. O espectro de UV dos compostos 174 e 179, juntamente com os espectros dos adutos correspondentes 175 e 182 obtidos após a reação com 173, a variação da concentração do composto 174 com o tempo e a determinação experimental da constante cinética de segunda ordem para a adição de 173 ao composto 174 é apresentada na Figura 30.

\footnotetext{
vi Experimento realizado com o auxílio do Prof. Dr. Francisco Corzana do Departamento de Química da Universidad de La Rioja, Centro de Investigacioón en Síntesis Química, Spain.
} 

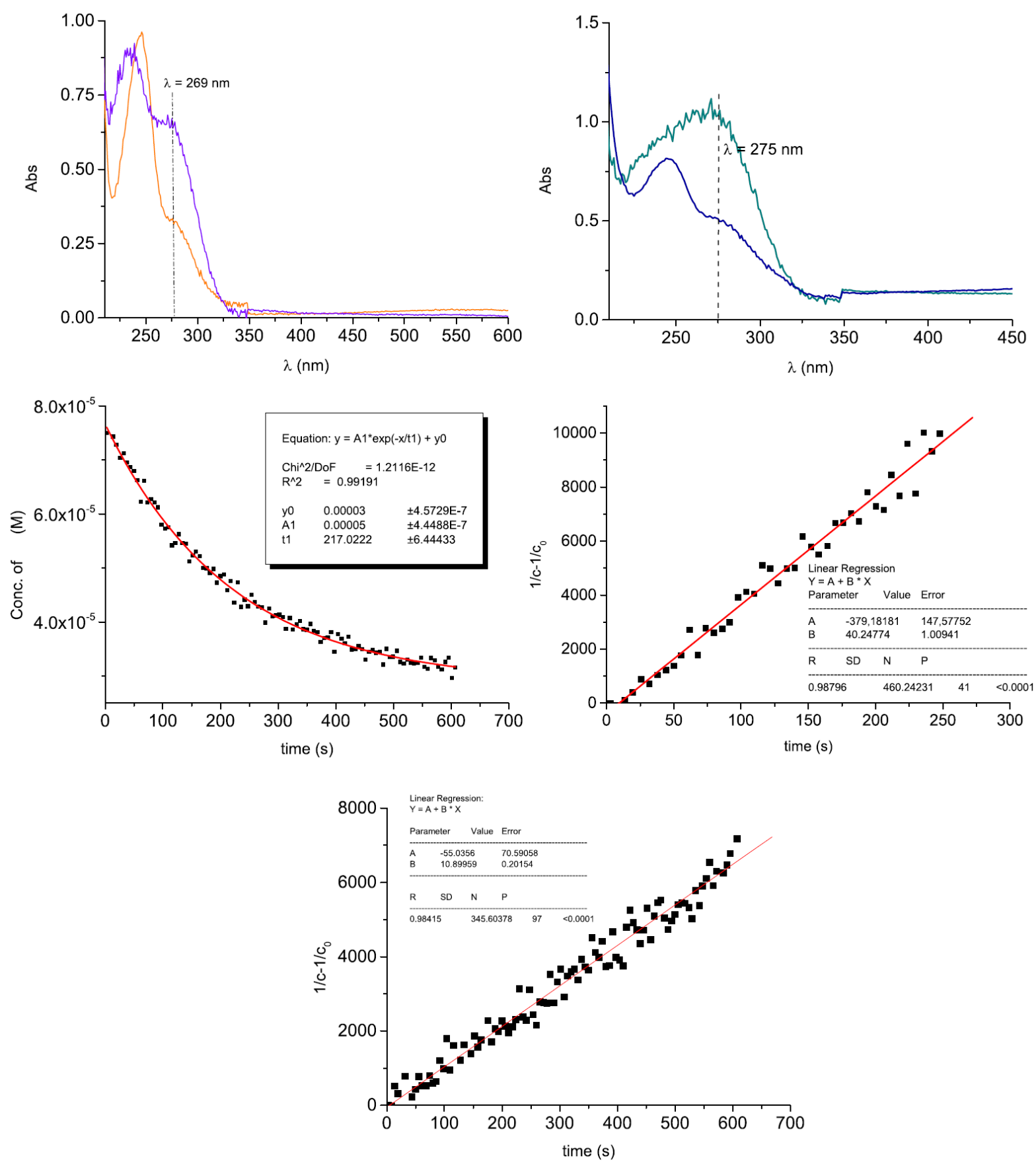

Figura 30 Determinação experimental da constante de velocidade de segunda ordem.

Um experimento de competição foi realizado pela técnica de $\mathrm{RMN}{ }^{1} \mathrm{H}$ para corroborar as constantes determinadas. Neste ensaio, 1 equivalente da cisteína 173 foi adicionada a uma solução $30 \%$ de $\mathrm{CD}_{3} \mathrm{CN} /$ tampão de fosfato de sódio deuterado $(\mathrm{pH} 8.0,50 \mathrm{mM})$ contendo uma mistura dos aceptores de Michael 174, 179 e Nmetilmaleimida em uma proporção inicial de 1:1:1. Após 10 minutos, um espectro de $\mathrm{RMN}^{1} \mathrm{H}$ foi obtido mostrando uma distribuição de produtos final de 1:0.22:0.58. A Nmetilmaleimida reagiu primeiramente (integral 0.22), seguido do derivado éster 174 
(integral 0.58) e por último a amida 179 (integral 1). Este resultado indica uma taxa de reação comparáveis entre 174, 179 e o derivado maleimida (Figura 31).

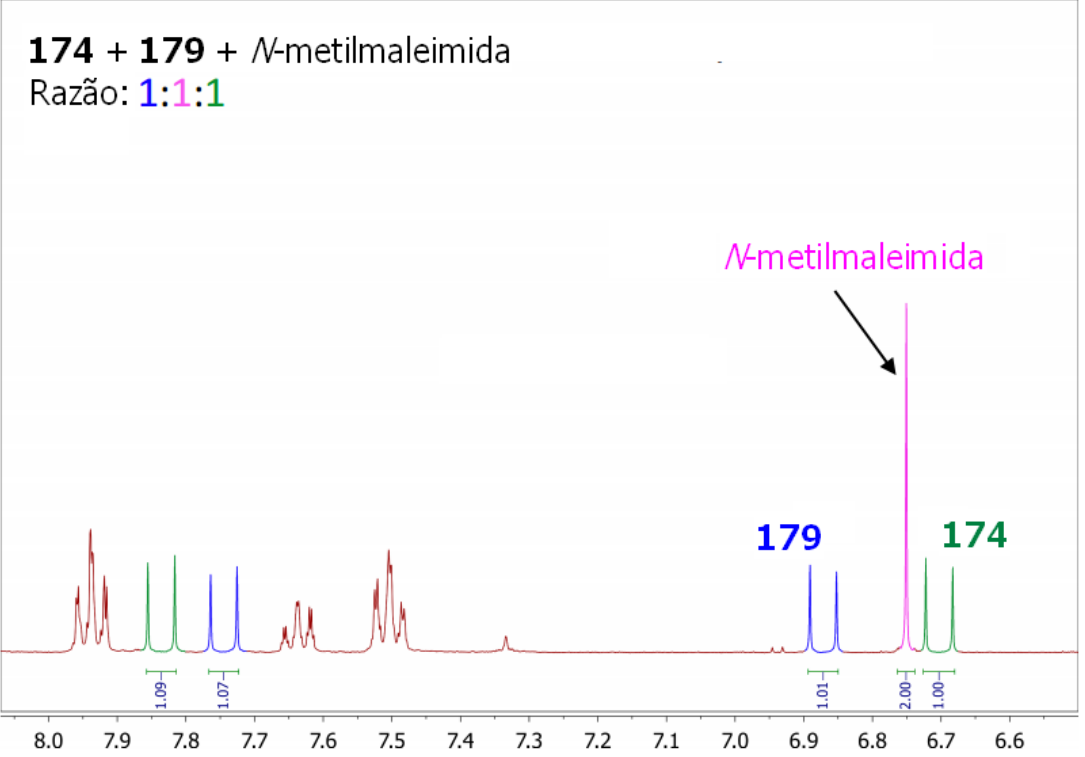

${ }^{1} \mathrm{H}$ RMN após adição de $\mathbf{1 7 3}$

Razão: 1:0.22:0.58

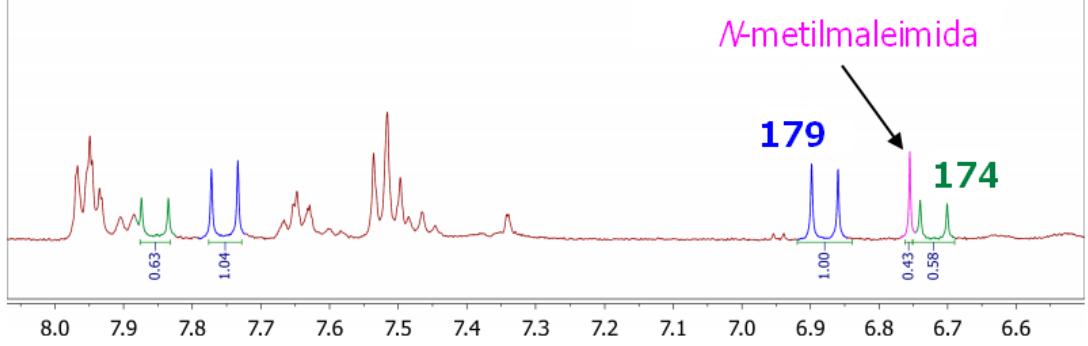

Figura 31 Experimento de competição de adição entre 174, 179 e N-metilmaleimida em 173. 
Em seguida, a estabilidade do tioéter 184 obtido por meio dos carbonilacrilatos 179 foi comparada com os 185 obtidos usando maleimidas 186 convencionais (Figura 35). Os adutos de Michael 184 e 185 foram preparados a partir da reação entre a amida 179 e da N-benzil maleimida 186 com 4-nitrotiofenol em 95 e 80\% de rendimento, respectivamente (Esquema 63).

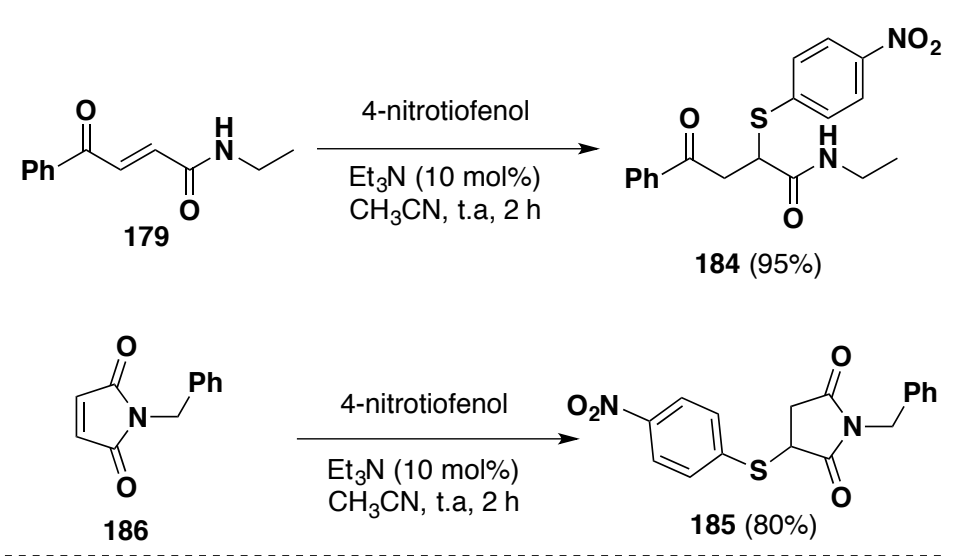

Esquema 63 Síntese dos tioéteres 184 e 185.

Utilizando um ensaio de UV-VIS, a cinética de degradação dos adutos cromogênicos 184 e 185 foi acompanhada. Demonstrou-se que em pH 7.4, o derivado 184 é completamente estável quando comparado com 185 (Figura 32). A absorbância do composto 184 é constante ao longo do tempo analisado, indicando que não há libertação de 4-nitrofenolato em solução $(\lambda=410 \mathrm{~nm})$. Por outro lado, para o composto 185, observou-se um aumento na absorbância ao longo do tempo. É importante notar que, embora ambos os compostos absorvam em $410 \mathrm{~nm}$, a tendência constante do derivado 184 contrasta com a liberação observada no caso do composto 185. O espectro do tiol $184\left(A_{0 h}=0.45 \mathrm{nM}, A_{5 h}=0.45 \mathrm{~nm}\right)$ e do $185\left(A_{0 h}=0.23 \mathrm{nM}, A_{5 h}=0.35\right.$ $\mathrm{nm}$ ) ao longo de 5 horas é apresentado na Figura 32. Além disso, a incubação de 182 com a nucleófilos biológicos naturais, como a glutationa 186 (GSH), não demonstrou qualquer clivagem $\mathrm{C}$-S ao longo de uma semana de incubação em pH fisiológico (avaliado por $\mathrm{RMN}^{1} \mathrm{H}$ e espectrometria de massas, figuras em anexo na seção experimental). 


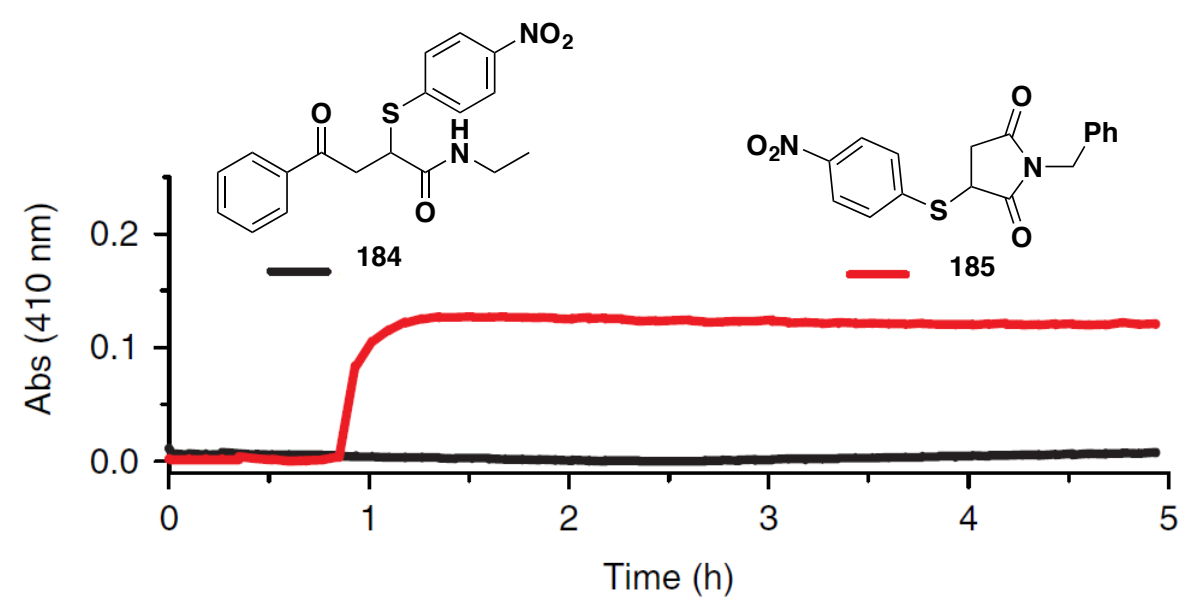

Figura 32 Comparação de estabilidade dos derivados 184 e 185.

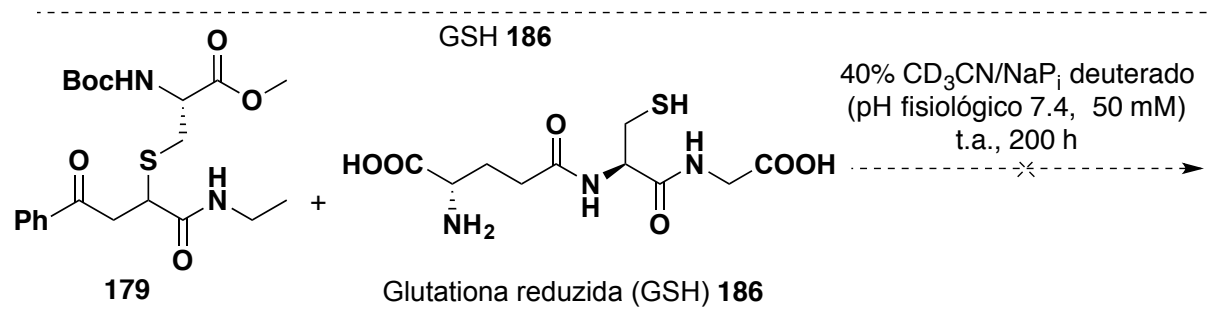

Esquema 64 Estabilidade do aduto de Michael 179 na presença de glutationa 186.

\subsubsection{Otimização da reação de bioconjugação de proteínas}

Com uma nova classe de reagentes aceptores de Michael irreversíveis, seletivos e com cinéticas rápidas, o trabalho foi então voltado para a sua aplicação em bioconjugação de proteínas. Os derivados 174, 178-180, foram inicialmente avaliados com a Annexina $V$, uma proteína utilizada para identificação e quantificação de células apoptóticas que contém uma cisteína livre na posição 316 (Tabela 8). ${ }^{187}$ Usando 25 equivalentes de 174, 178-180 em NaPi $\left(\mathrm{pH} \mathrm{8.0,50} \mathrm{mM)} \mathrm{durante} 27\right.$ horas a $25^{\circ} \mathrm{C}$, encontrou-se por análise de massas (LC-MS), que apenas 179 forneceu uma conversão moderada para o aduto tioéter correspondente. Ambos os ésteres 174 e 178 passaram por hidrólise parcial sob as condições testadas, enquanto que 180 não reagiu (dados e espectros apresentados na seção experimental). Com base nestes resultados, decidiu-se otimizar as condições reacionais usando a amida 179 e verificou-se que, para Annexina $\vee$, a conversão completa para o produto (> 95\%) pode 
ser obtida utilizando-se 50 equivalentes de 179 após 1 hora de reação em $37^{\circ} \mathrm{C}$, como confirmado pela análise de cromatografia líquida acoplada a um espectrômetro de massas (Figura 33). O teor total da proteína no cromatograma antes e após a reação de conjugação é analisado por espectrometria de massas e a concentração de proteína é analisada após purificação do conjugado por ensaio de Bradford. Estas análises, em conjunto, confirmam a conversão completa para formação de um único produto com rendimento $>95 \%$. Um exemplo desta análise é apresentado na seção experimental. Em condições idênticas (pH 8.0 e 50 equivalentes), a reação da Annexina $V$ com uma maleimida proporciona menos do que $50 \%$ do conjugado esperado com modificações adicionais na lisina.

Tabela 8 Bioconjugação de cisteínas em proteínas com 174, 178-180.

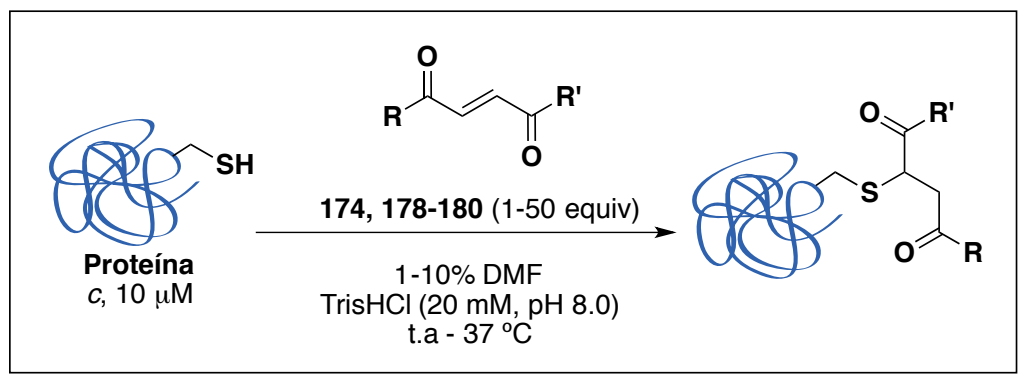

\begin{tabular}{cccccc}
\hline $\begin{array}{c}\text { Proteína } \\
(\mathbf{1 0} \boldsymbol{\mu M})\end{array}$ & Reagente & Equivalentes & $\begin{array}{c}\text { Temperatura } \\
\left({ }^{\circ} \mathbf{C}\right)\end{array}$ & $\begin{array}{c}\text { Tempo } \\
(\mathbf{h})\end{array}$ & $\begin{array}{c}\text { Conversão } \\
(\%)\end{array}$ \\
\hline Annexina V & $\mathbf{1 7 4}$ & 25 & 25 & 27 & $30^{b}$ \\
Annexina V & $\mathbf{1 7 8}$ & 25 & 25 & 27 & $30^{b}$ \\
Annexina V & $\mathbf{1 7 9}$ & 25 & 25 & 27 & 60 \\
Annexina V & $\mathbf{1 8 0}$ & 25 & 25 & 27 & 0 \\
Annexina V & $\mathbf{1 7 9}$ & 50 & 37 & 1 & $>95$ \\
C2Am & $\mathbf{1 7 9}$ & 25 & 25 & 1 & $>95$ \\
Albumina & $\mathbf{1 7 9}$ & 1 & 25 & 2 & $>95$ \\
\hline
\end{tabular}

${ }^{\mathrm{a}}$ Condições gerais de bioconjugação: Proteína (10 uM) em Tris-HCl $(\mathrm{pH} \mathrm{8,0,20} \mathrm{mM),} \mathrm{derivado} \mathrm{carbonilacrílico}$ 174, 178-180 (1-50 equivalentes) dissolvido em DMF (1-10\%). Reação em ependorfe durante o tempo indicado. ${ }^{b}$ A hidrólise do éster foi observada por LC-MS. O espectro é apresentado na parte experimental. 


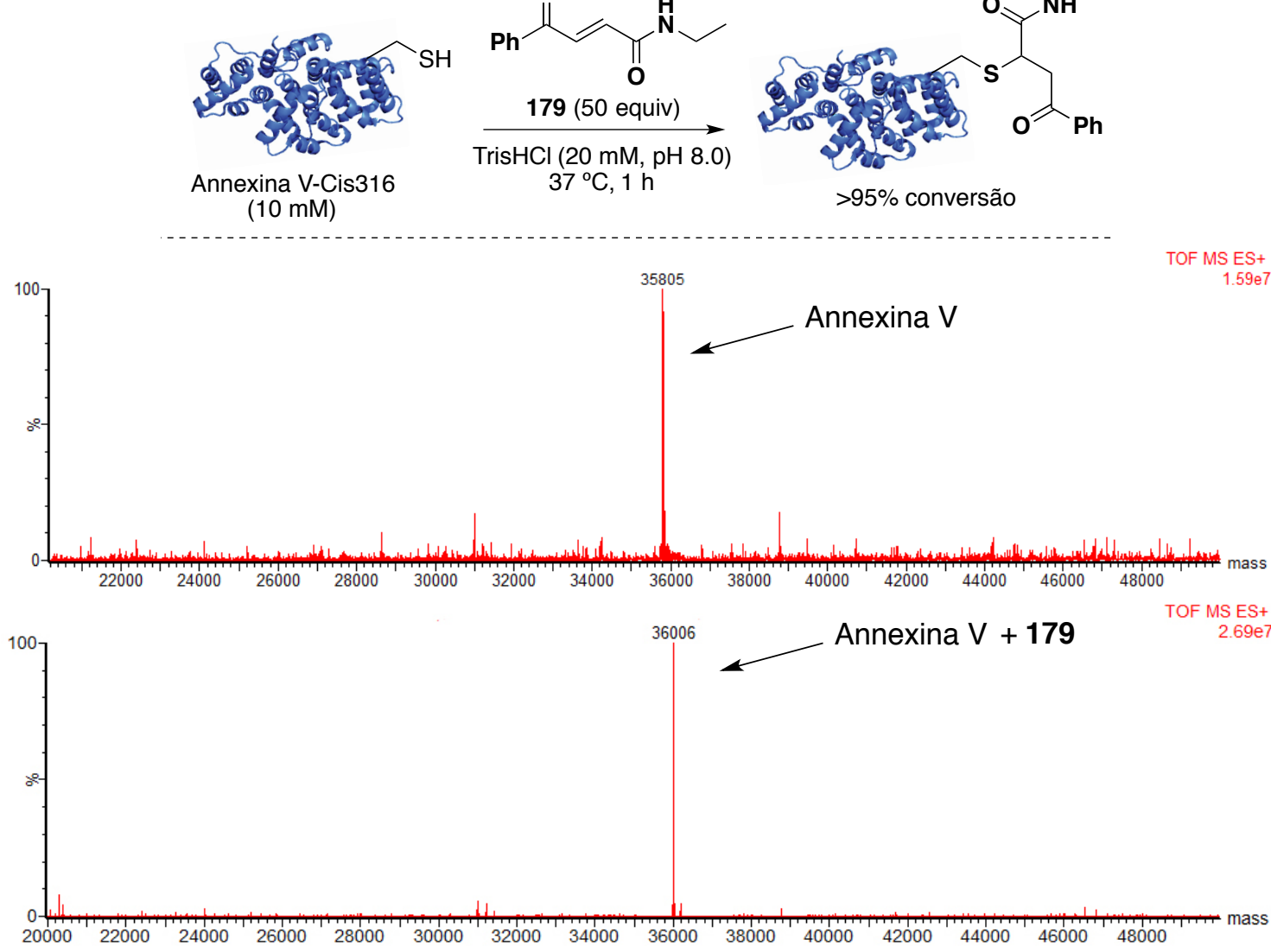

Figura 33 Reação de bioconjugação entre a Annexina $\vee$ e a amida 179.

Após estabelecer as condições reacionais com a Annexina $\mathrm{V}$, o escopo do método foi então avaliado com as proteínas C2Am e albumina (Figura 34). A C2Am é uma proteína que assim como a Annexina $V$ possui aplicação na identificação e quantificação de células apoptóticas. ${ }^{188}$ A albumina-Recombumina (Albumedix Ltd) é utilizada na entrega seletiva de fármacos (drug-delivery). ${ }^{189}$ Ambas as proteínas possuem uma cisteína livre na superfície (na posição 95 e 34, C2Am e Recombumina, respectivamente) e foram convertidas nos respectivos tio éteres correspondentes ao reagir com 179 (Figura 34). Interessantemente, no caso da albumina, a reação ocorreu em temperatura ambiente com apenas 1 equivalente de 179, quantidade suficiente para que ocorra uma completa conversão (<95\%). Este resultado demonstra a eficiência do presente método. Enquanto um leve excesso é necessário para a conversão da Annexina V (50 equivalentes) e da C2Am (25 equivalentes), quantidades estequiométricas de 179 podem levar ao conjugado dependendo da disponibilidade da cisteína na superfície da proteína. A análise do produto conjugado é realizada por LC-MS de forma similar ao apresentado para a Annexina $\mathrm{V}$. 

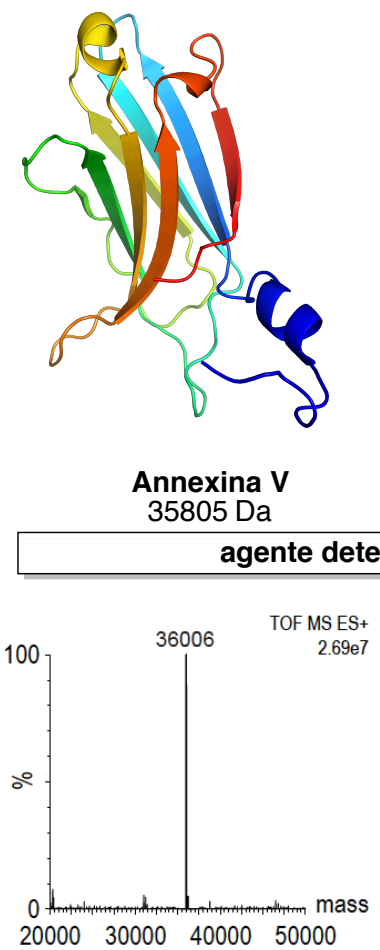

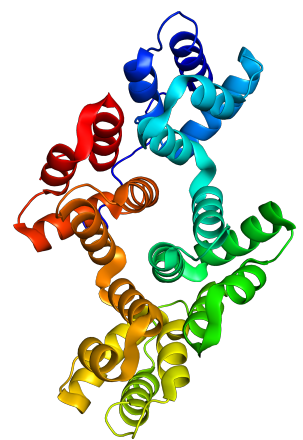

C2Am $16222 \mathrm{Da}$ optose

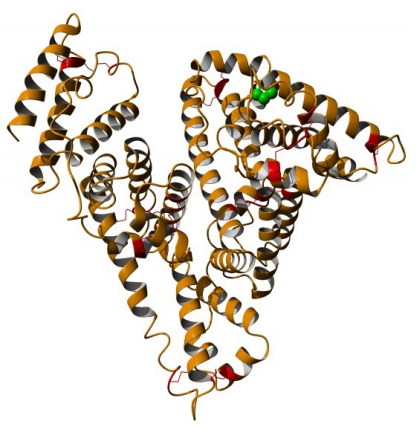

Recombumina $66439 \mathrm{Da}$

Figura 34 Proteínas avaliadas para bioconjugação com 179.

Apesar da alta seletividade encontrada nos modelos de aminoácidos para a cisteína, decidiu-se realizar análises complementares para comprovar a reação específica nos derivados biconjugados. O mapeamento dos peptídeos por MSMS após digestão da proteína com tripsina comprovou a reação específica na cisteína. $O$ espectro MS/MS do íon duplamente carregado ( $\mathrm{m} / \mathrm{z}$ 526.75) do peptído VPYCELGGK contendo a modificação da C2Am-179 no resíduo cisteína é apresentado na seção experimental. O C-terminal y dos fragmentos (y6-y8) são consistentes com a massa da modificação. Além disso, testes envolvendo o bloqueio prévio da cisteína e posterior reação com a amida 179 corroboram essa seletividade (Esquema 65). A reação da Annexina $\vee$ com 500 equivalentes do reagente cis-seletivo de Ellman's 187 forneceu o conjugado de Ellman's em rendimento superior a 95\%. A adição de 50 equivalentes da amida 179 nas mesmas condições reacionais otimizadas $(\mathrm{pH} 8.0$, $37^{\circ} \mathrm{C}, 1 \mathrm{~h}$ ) levou apenas a recuperação do material de partida sem qualquer evidência de adição de 179 no conjugado de Ellman's. Uma segunda reação foi realizada a partir do conjugado de Annexina $\vee$ bloqueado com o composto 179 (Esquema 65). A análise de LC-MS após a adição de 500 equivalentes do reagente de Ellman's 187 mostrou o conjugado carbonilacrílico intacto. Estes resultados, somados a análise de MSMS (espectro apresentado na parte experimental), confirmam a alta seletividade do reagente 179 em pH 8.0 para cisteínas. 

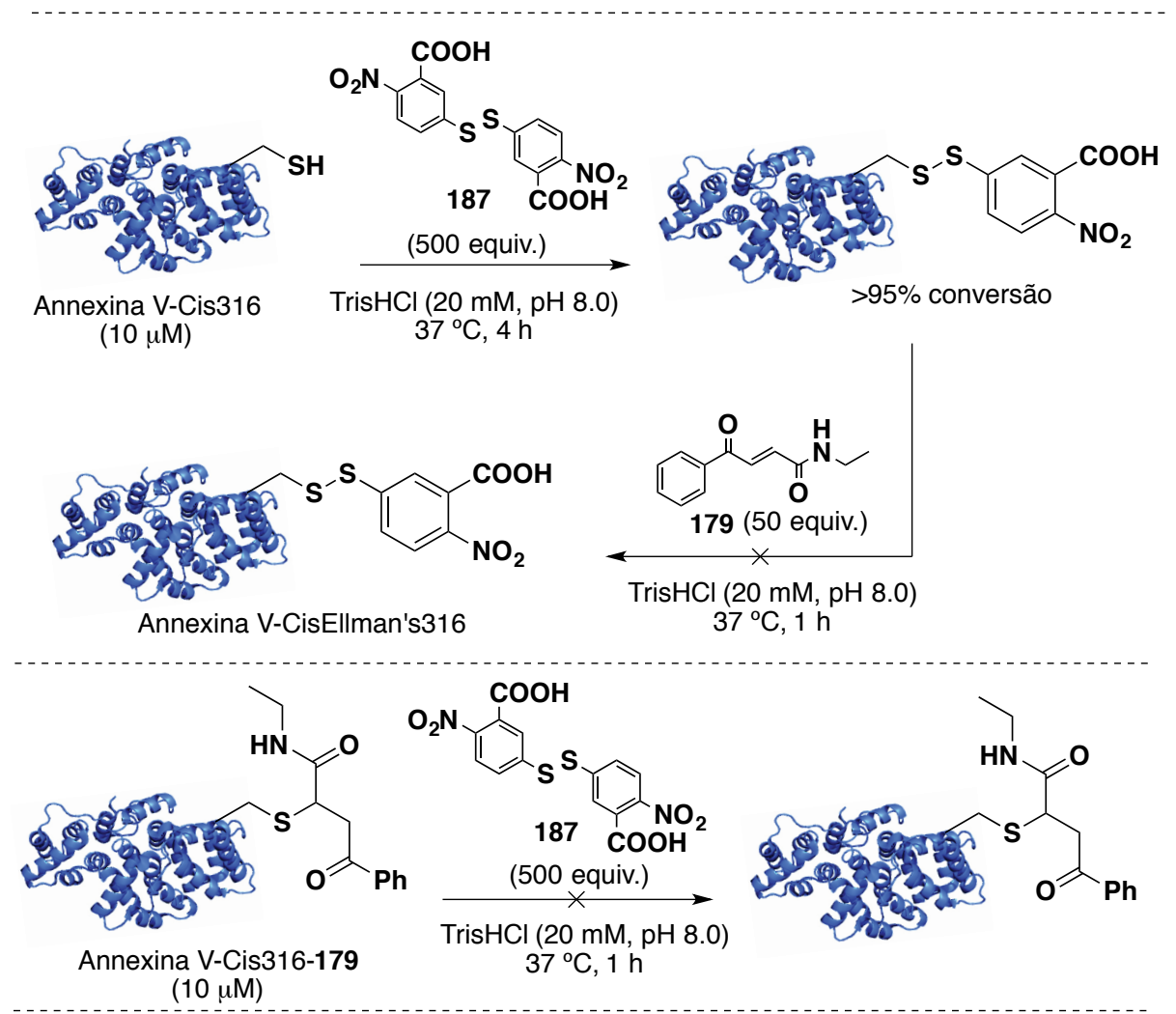

Esquema 65 Comprovação de seletividade através do reagente de Ellman's 187.

Um outro fator importante para demostrar a potencialidade do método é a estabilidade dos biconjugados obtidos. O conjugado de albumina-179 foi encubado na presença de plasma humano e do tiol biológico GSH 186 (glutationa) em $37^{\circ} \mathrm{C}$ por $48 \mathrm{~h}$ (Figura 35). Ambas as condições são conhecidas por fornecer misturas heterogêneas de conjugados hidrolisados/não hidrolisados e de retro-Michael quando acoplados a maleimidas. Análises de LC-MS comprovaram a estabilidade de albumina-179 sem deteç̧ão de produtos de degradação (espectro adicionado na seção experimental). Finalmente, estudos de ressonância plasmônica de superfície (Surface plasmon resonance - SPR) vii confirmaram que o conjugado de albumina-179 manteve sua capacidade de se ligar ao receptor $F c$ neonatal $(F c R n) .{ }^{190} \mathrm{~A}$ constante de dissociação $(\mathrm{Kd})$ encontrada para a albumina $(16.13 \mu \mathrm{M})$ e para a albumina-179 $(14.11 \mu \mathrm{M})$ indica completa a afinidade da proteína modificada pelo ligante sem a perda de suas propriedades e de sua funcionalidade (Figura 35 ).

\footnotetext{
vii Experimento de SPR com o receptor Fc neonatal foi realizado pela Ms. Elizabeth Perkins da Albumedix Ldt, Castle Boulevard, Nottingham, UK.
} 


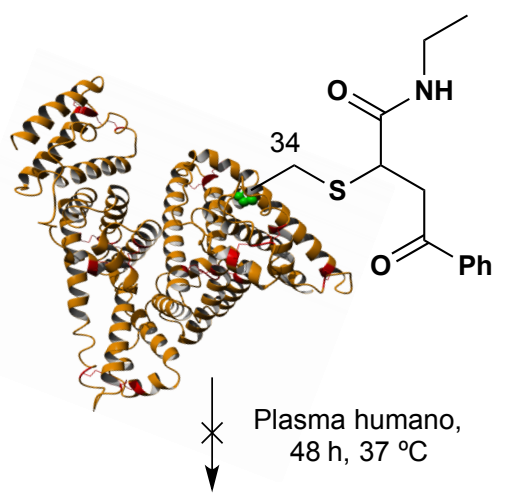

Sem degradação do conjugado

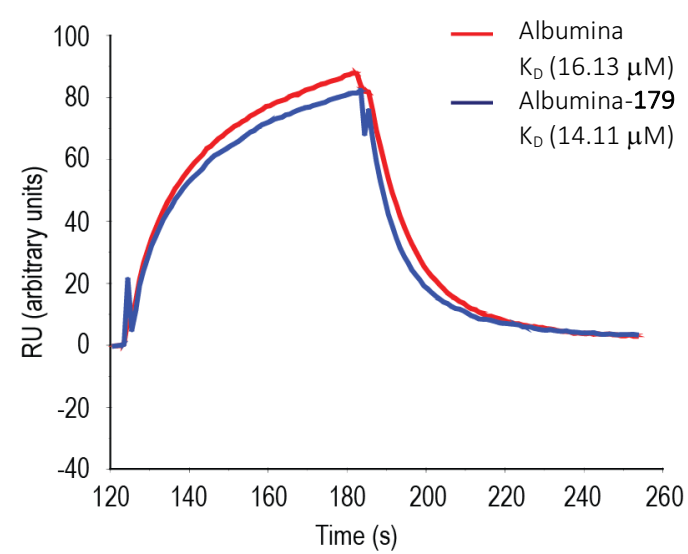

Figura 35 Análise da estabilidade do conjugado albumina-179 e avaliação das propriedades de ligação da albumina modificada e não modificada com do receptor neonatal FcRn via SPR.

Após encontrar um método geral para bioconjugação de 179 e explorar suas estabilidades e constantes cinéticas, decidiu-se modificar a estrutura do reagente carbonilacrílico a fim de incorporar diferentes grupos funcionais com variadas aplicações. Muitos dos reagentes de bioconjugação (fluoróforos, polietileno glicol PEG e fármacos) são encontrados comercialmente contendo um grupo amino livre que pode ser facilmente acoplado com ácidos carboxílicos. Por exemplo, os reagentes carbonilacrílicos 194 contendo um fluoróforo nitrobenzofurazano ( $\lambda_{\mathrm{ex}} \approx 465 \mathrm{~nm} \mathrm{e}$ $\lambda_{\mathrm{em}} \approx 539 \mathrm{~nm}$ ) e o derivativo PEG 195 foram sintetizados a partir do ácido carboxílico 191 na presença de $\mathrm{HOBt} / \mathrm{EDCl}$ em 65 e $45 \%$ de rendimento, respectivamente (Esquema 66). O cloridrato 190 foi sintetizado a partir do reagente comercial 4-cloro7-nitrobenzofurazano 188 após reação com N-Boc-etilenodiamina 189 e desproteção em meio ácido. O cloridrato 190 foi então tratado em meio básico para fornecer a amina 192 utilizada para fazer o acoplamento com o ácido 191.

Os reagentes carbonilacrílicos 194 e 195 foram incubados na presença da Annexina $\mathrm{V}, \mathrm{C} 2 \mathrm{Am}$ e albumina nas mesmas condições otimizadas $(\mathrm{pH} 8.0,1-50$ equivalentes, t.a $-37^{\circ} \mathrm{C}$ ) levando as proteínas funcionalizadas com conversão superior a 95\% após 1-2 h de reação (Esquema 67). Análises de gel SDS-PAGE (Sodium Dodecyl Sulphate-Polyacrylamide Gel Electrophoresis) comprovaram a fluorescência dos conjugados sintetizados. A Figura 36 ilustra um exemplo de gel obtido com a proteína C2Am modificada (linhas 3, 5 e 7) e não modificada (linhas 2, 4 e 6) fazendo o uso de diferentes reveladores (fluorescente, Ruby e Coomassie Blue). As figuras dos géis das proteínas Annexina $V$ e albumina são anexados na seção experimental. 


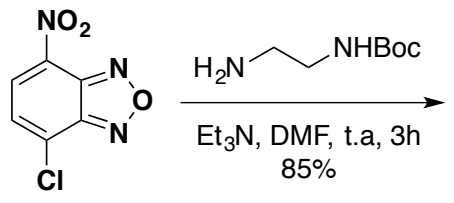

188

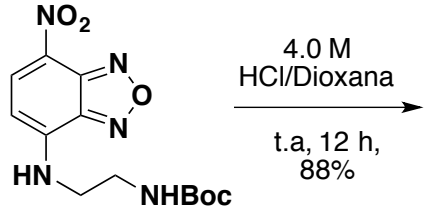

189

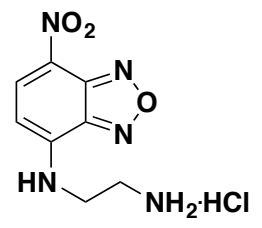

190

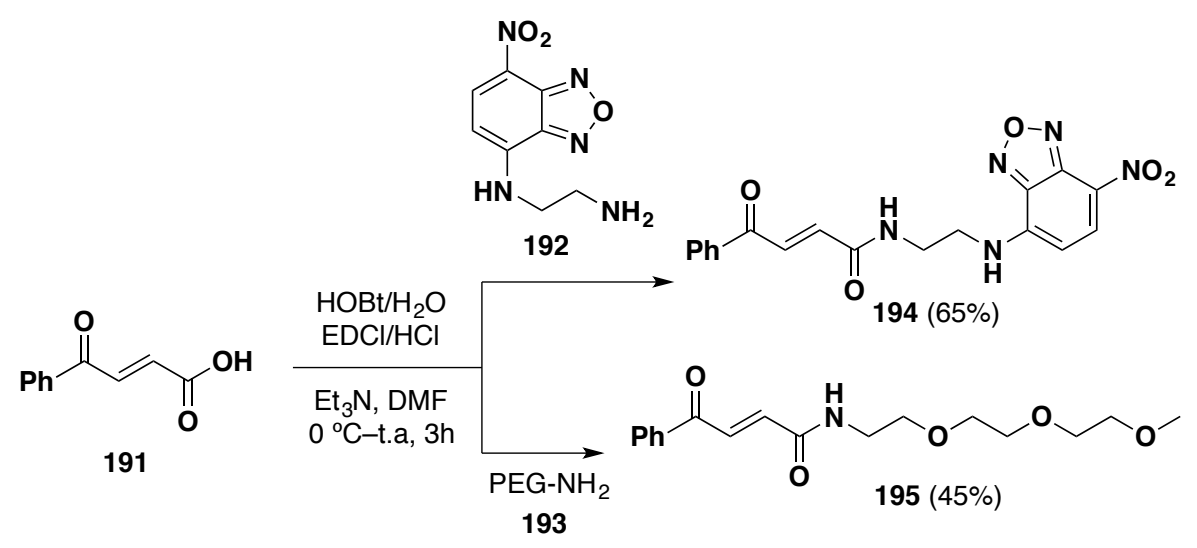

Esquema 66 Síntese dos reagentes carbonílacrílicos funcionalizados 194 e 195.

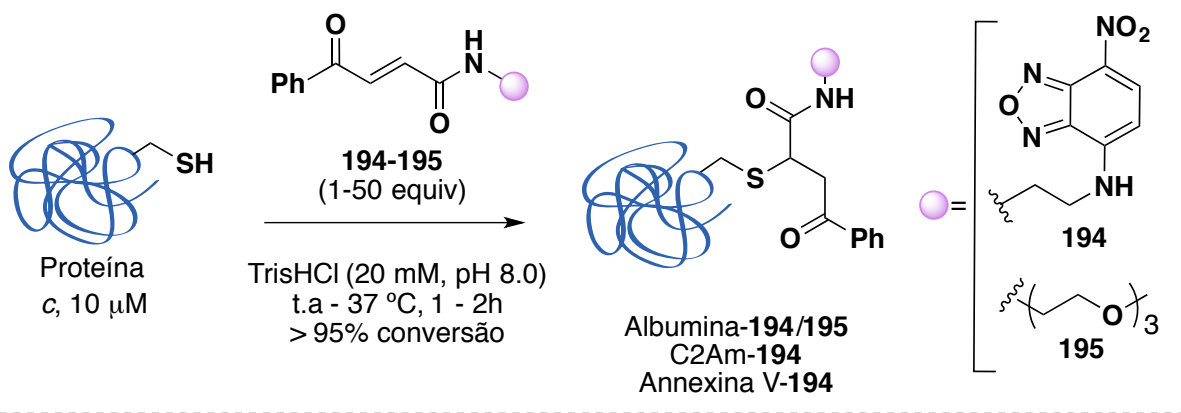

Esquema 67 Bioconjugação da Annexina V, C2Am e albumina com os reagentes 194 e 195.

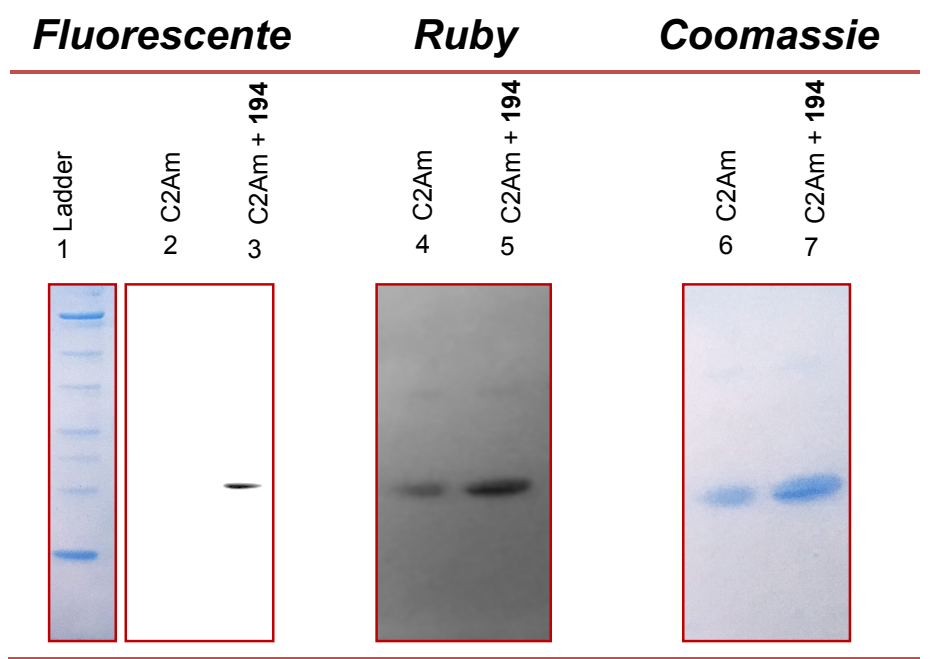

Figura 36 Análise SDS-PAGE do conjugado C2Am-194. 
A utilidade das proteínas funcionalizadas foi avaliada pela atividade do conjugado fluorescente Annexina V-194 em identificar e marcar células apoptóticas. A ligação da Annexina $V$ com as células em processo de morte celular ocorre na presença do receptor fosfatidilserina que é exposto na membrana celular em processo de apoptose. Muitas das estratégias de marcação fluorescente de proteínas a partir de maleimidas são ineficientes, uma vez que o anexo sintético ligado a proteína é perdido via reações de retro-Michael. ${ }^{177,191}$

As imagens fluorescentes obtidas pela leitura de microscopia das células apoptóticas e não apoptóticas após marcação com o conjugado Annexina V-194 são apresentadas na Figura 37. viii Um experimento controle foi realizado incubando-se a Annexina V-194 com as células HEK293 (Human Embryonic Kidney 293 cells) não apoptóticas (Figura 37, a). A análise de microscopia revela células de coloração azul com o uso do corante Hoechst, não sendo reveladas com o filtro fluorescente. Posteriormente, o mesmo conjugado foi adicionado ao meio após indução de apoptose celular com o fármaco actinomicina D (Figura 37, b). Neste caso, as células apoptóticas revelam em verde com o filtro FITC (isotiocianato de fluoresceína FITC com comprimentos de onda de excitação e emissão de aproximadamente $495 \mathrm{~nm} / 521$ $\mathrm{nm})$. A Figura 37 atesta a capacidade da Annexina V-194 quimicamente modificada de se ligar especificadamente ao receptor exposto na superfície celular durante a apoptose. Este resultado foi ainda confirmado após a pré-incubação das células apoptóticas com um excesso de Annexina $V$ não modificada (25x). Com a maior parte dos receptores bloqueados, a posterior adição do conjugado Annexina V-194 leva a leitura de um decréscimo significativo na intensidade de fluorescência (Figura 37, d).

Os resultados obtidos até o momento evidenciam a potencialidade do presente método. A reação fornece bioconjugados de proteínas estáveis, homogêneos e funcionais, retendo sua característica e propriedade biológica após a modificação.

viii O cultivo das células HEK293 e a indução de apoptose foi realizada em colaboração com o Dr. Bruno Oliveira da Universidade de Cambridge, UK. 


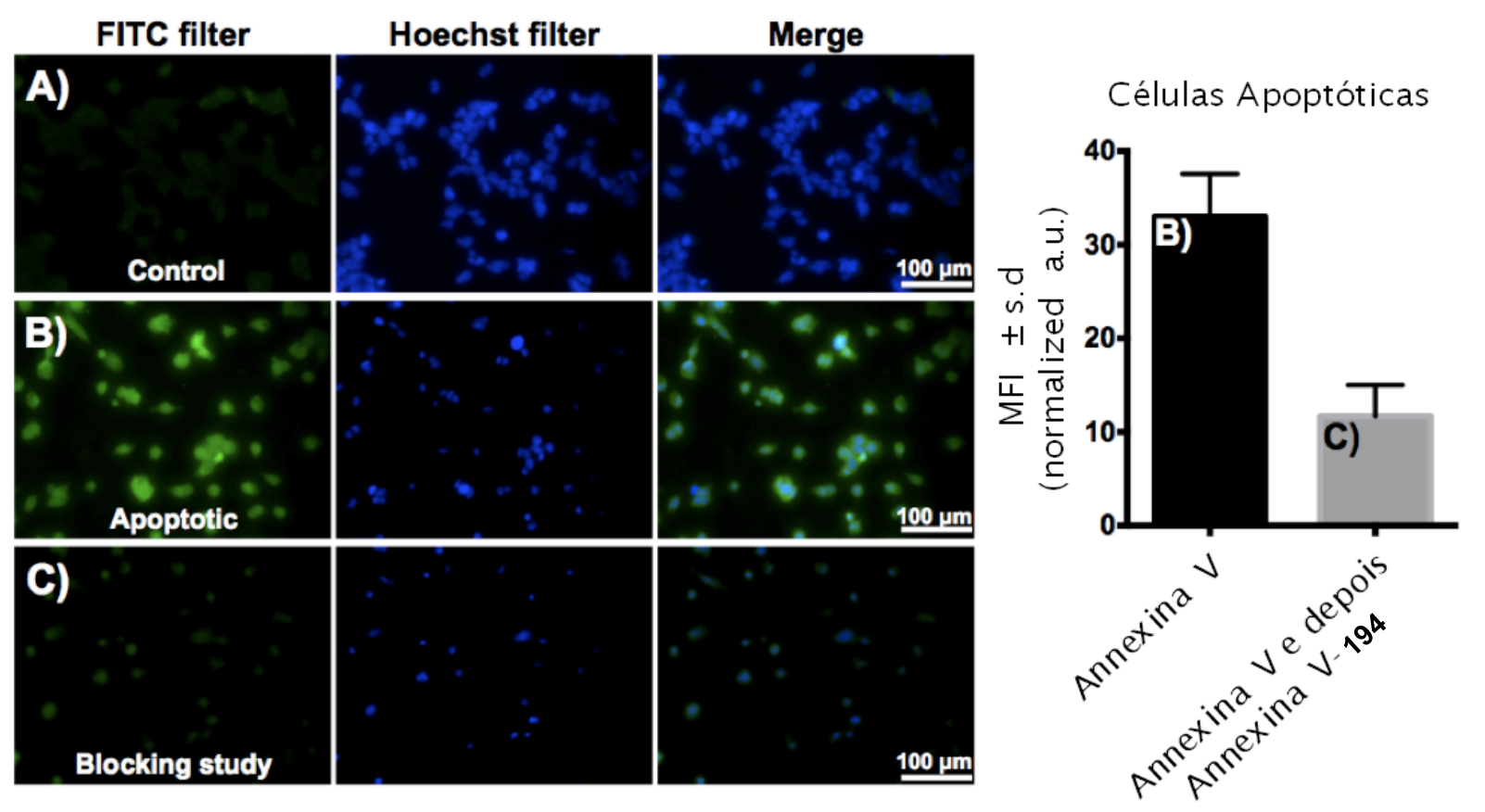

Figura 37 Imagens fluorescentes das células HEK293 apoptóticas e não apoptóticas (controle) após marcação com o conjugado Annexina V-194.

\subsubsection{Bioconjugação de anticorpos com derivados carbonilacrílicos}

Para expandir ainda mais a gama de aplicações, decidiu-se investigar a aplicação da metodologia desenvolvida para a modificação seletiva e funcional de anticorpos. Como substrato utilizou-se o Trastuzumab LC-V205C, um anticorpo amplamente usado para tratamento de câncer de mama. ${ }^{192}$ Previamente a conjugação com o reagente carbonilacrílico, o anticorpo foi tratado com o agente redutor TCEP (tris(2-carboxietil)fosfina) em temperatura ambiente para redução das pontes de disulfeto. Uma re-oxidação para reformar as pontes internas de dissulfeto foi realizada usando o ácido dehidroascórbico. Para a bioconjugação, as mesmas condições otimizadas foram aplicadas ( $\mathrm{pH} 8.0$, temperatura ambiente). Interessantemente, a reação foi completa com apenas 1 equivalente de 179 e de 194 com conversão superior a $95 \%$. A análise de espectrometria de massas mostrou apenas uma modificação da cadeia leve do anticorpo, enquanto que a cadeia pesada permaneceu não modificada. Este resultado indica uma completa re-oxidação das pontes internas de dissulfeto com a modificação ocorrendo apenas na cisteína livre. Enquanto maleimidas fornecem uma mistura de conjugados modificados (80-90\%) e não modificados $(10-20 \%),{ }^{172,174,193,194}$ este método forneceu um conjugado puro e quimicamente definido. 

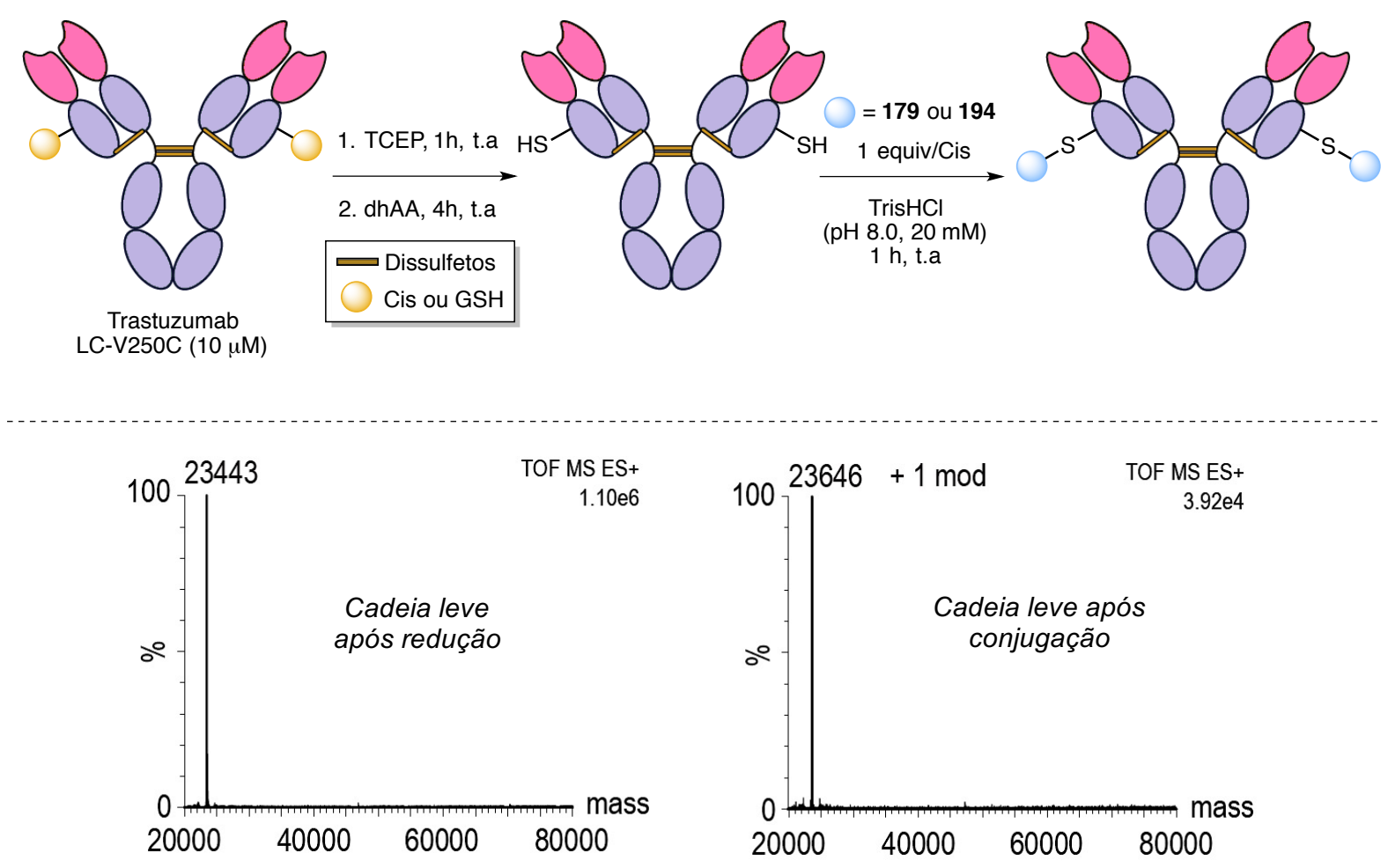

Figura 38 Bioconjugação quimioseletiva e equimolar do Trastuzumab com 179 e 194. Espectro de massas para a cadeia leve do anticorpo antes e após conjugação.

A capacidade de interação antígeno-anticorpo (Trastuzumab-HER2) foi verificada pela técnica de interferometria de biocamada (bio-layer interferometry - BLI) e pelo ensaio de imunoadsorção enzimática (enzyme-linked immunosorbent assay ELISA). ${ }^{\text {ix } O}$ teste de ELISA é realizado em placas de poliestireno de 96 poços podendo detectar e quantificar substâncias tais como peptídeos, proteínas, anticorpos e hormônios. De forma geral, os antígenos da amostra são ligados a superfície da placa de poliestireno. Em seguida, é aplicado um anticorpo específico sobre a superfície para que o mesmo possa ligar-se ao antígeno. Este anticorpo está ligado a uma enzima e, na etapa final, é adicionada uma substância contendo o substrato da enzima. A reação subsequente produz um sinal detectável via alteração de cor no substrato. A absorbância ou fluorescência dos poços de placas é então medida para determinar a presença e a quantidade de antígeno/anticorpo.

\footnotetext{
ix Ensaio de BLI e ELISA realizado em conjunto com a Dr. Nuria Martínez-Sáez da Universidade de Cambridge, UK.
} 
A interferometria bio biológica (BLI) é uma tecnologia para a medição de interações biomoleculares que analisa o padrão de interferência da luz branca refletida a partir de duas superfícies. Geralmente, uma camada de proteína imobilizada na ponta do biosensor e uma camada de referência interna. Qualquer alteração no número de moléculas ligadas à ponta do biosensor provoca uma alteração no padrão de interferência que pode ser medido em tempo real, proporcionando a capacidade de monitorar a especificidade de ligação com precisão.

Os resultados obtidos por ELISA e BLI mostram que o Trastuzumab-179 não perdeu sua capacidade de ligação com o antígeno HER2 após a modificação. Enquanto o anticorpo não modificado possui uma constante de dissociação $\left(K_{D}\right)$ de $14 \pm 1.4 \mathrm{nM}$, o Trastuzumab-179 possui um $\mathrm{K}_{\mathrm{D}}$ de $11 \pm 2.3 \mathrm{nM}$, apresentando total funcionalidade e atividade após as modificações realizadas. As constantes obtidas para o anticorpo modificado e não modificado podem ser observadas nos gráficos extraídos do experimento de BLI da Figura 39. Os gráficos referentes ao ensaio de ELISA estão anexados na seção experimental.

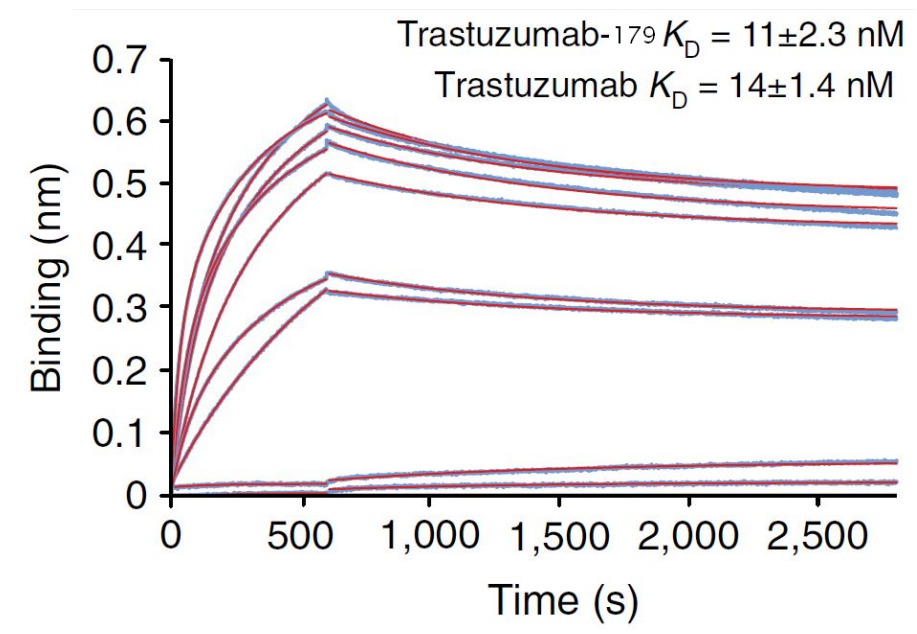

Figura 39 Curvas BLI para o Trastuzumab-179, não modificado e as constantes $\mathrm{K}_{\mathrm{D}}$ obtidas.

A especificidade anticorpo-antígeno para o conjugado modificado com 0 fluoróforo 194 foi ainda avaliada por citometria de fluxo. ${ }^{\times}$Nesta análise, utilizou-se as células SKBR3 e HepG2. Em oposição a super expressão do antígeno her2/c-erb-2 proveniente das células SKBR3, as células HepG2 expressam baixos níveis destes alvos. Estas duas linhas celulares foram incubadas com o anticorpo fluorescente-194

\footnotetext{
${ }^{x}$ Experimento de citometria de fluxo realizado pela Ms. Inês S. Albuquerque do Instituto de Medicina Molecular, Faculdade de Medicina, Universidade de Lisboa, Portugal.
} 
para quantificar a percentagem da população que foi revelada via citometria de fluxo em diferentes concentrações (10, 50 e $150 \mathrm{nM})$. Os resultados mostram que após o tratamento com o anticorpo modificado a $150 \mathrm{nM}$ por $1 \mathrm{~h},>90 \%$ das células SKBR3 são reveladas (filtro FITC), enquanto que somente $\sim 20 \%$ das células HepG2 são positivas para este marcador (Figura 40). Estes resultados estão de acordo com o que foi anteriormente publicado no que diz respeito à marcação de anticorpos anti-her2. ${ }^{192}$ Em concentrações mais elevadas, ambas as linhas celulares apresentaram níveis de coloração elevados, indicando ligação inespecífica do anticorpo. Em concentrações inferiores a $10 \mathrm{nM}$, não houve coloração observável. Estes resultados mostram claramente que o Trastuzumab-194 retém sua especificidade her2/cerb-2 em concentrações semelhantes às descritas na literatura anteriormente.

Em conjunto, todos estes resultados mostram que este novo método de bioconjugação fornece bioconjugados estáveis, funcionais e homogêneos utilizando quantidades equimolares dos reagentes carbonílacrílicos em apenas uma etapa. Neste momento, após a prova de conceito e de reatividade, os esforços foram voltados ao estudo dos derivados diazocarbonilacrílicos.

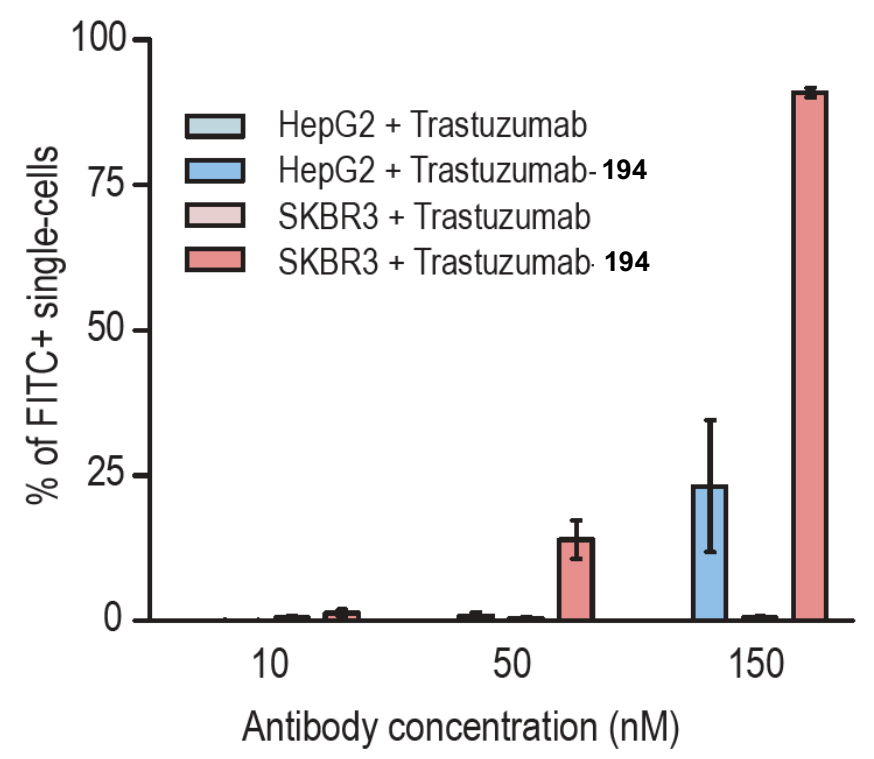

Figura 40 Percentagem de células reveladas (filtro FITC) após o tratamento das células com o Trastuzumab fluorescente e não fluorescente. 


\subsection{Reagentes diazocarbonilacrílicos}

A modificação química de proteínas pode ser conseguida a partir de aminoácidos naturais (por exemplo, Cis) ou via um aminoácido não natural contendo um grupo funcional de reatividade única. Azidas, alcinos, cetonas, alcenos e tetrazinas são exemplos de grupos que podem ser incorporados na superfície. Dependendo da aplicação, uma limitação das cadeias naturais é a modificação de proteínas purificadas, uma vez que muitas outras biomoléculas podem apresentar a mesma funcionalidade no caso de uma mistura complexa. Por outro lado, utilizando-se aminoácidos não naturais, reações seletivas a estes grupos funcionais permitem a modificação seletiva de proteínas individuais em misturas complexas, incluindo organismos vivos. ${ }^{195-197}$ Normalmente, grupos bioortogonais são incorporados em uma proteína seguido de modificações quimioseletivas. ${ }^{198}$ Esta abordagem é muitas vezes designada como "marcar e modificar", do inglês tag-and-modify. ${ }^{199}$

Como apresentado na introdução, o grupo diazo tem uma reatividade característica capaz de promover uma gama de aplicações em síntese orgânica. Este fato, somado a alta quimiosseletividade os revela potenciais e valiosos reagentes para química biológica. Enquanto diazoalcanos possuem baixa utilidade em bioquímica devido a sua pronunciada toxicidade, compostos diazo estabilizados pela deslocalização dos elétrons no carbono a para outro grupo funcional possuem compatibilidade e aplicabilidade em sistemas vivos. ${ }^{200} \mathrm{~A}$ presença de grupos diazo em produtos naturais como Kinamicina $D$, lomaiviticina $A / B$ e a sua pronunciada atividade antitumoral destaca sua participação em um contexto biológico. ${ }^{201}$ Raines e colaboradores publicaram em 2016 uma revisão destacando a importância do uso compostos diazo em biologia química. ${ }^{202}$

Apesar de extremamente versáteis, poucos exemplos de reações bioortogonais a partir de conjugados diazocarbonílicos são encontrados na literatura. Ésteres de $\mathrm{N}$ hidroxissuccinimida (NHS) contendo um grupo $\alpha$-diazocarbonílico foram utilizados como reagentes de conjugação de biomoléculas de complexidade variável. ${ }^{203-206} \mathrm{Um}$ exemplo de transformação a partir de uma diazo-proteína empregada em reações de cicloadição 1,3-dipolar com alcinos é apresentado no Esquema $68 .{ }^{206}$ 


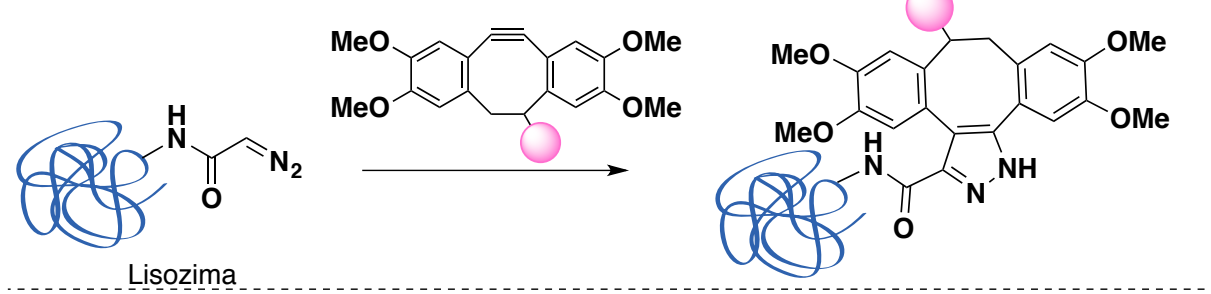

Esquema 68 Diazo-lisozima empregada em reações de cicloadição 1,3-dipolar com ciclooctinos.

No que se refere às reações catalisadas por metais, questões de solubilidade e estabilidade associadas aos catalisadores metálicos em solução aquosa podem resultar reações de inserção com água e com muitos dos grupos funcionais presentes nas superfícies das proteínas. Ajustando-se os parâmetros reacionais, a seletividade entre essas vias poderia ser alcançada. Apesar de muitas melhorias nas reações catalisadas por metais de transição em meios aquosos ou bifásicos, 207-217 abordagens de bioconjugação usando grupos diazo permanecem marginalmente exploradas. Chi-Ming Che e colaboradores relataram reações de inserção e ciclopropanação intermolecular usando um catalisador de metaloporfirina solúvel em água (Esquema 69). ${ }^{218}$ Outro exemplo foi reportado por Francis e Antos usando $\left[\mathrm{Rh}_{2}(\mathrm{OAc})_{4}\right]$ para a modificação de triptofano. (Esquema 69). ${ }^{219-221}$ É importante notar que nesses casos, o composto diazocarbonílico atua como reagente para proteínas nativas ou pré-funcionalizadas. Reações mediadas por carbenos/carbenóides em proteínas contendo a funcionalidade diazo na superfície não são descritas na literatura e representariam um avanço inestimável em biologia química. 


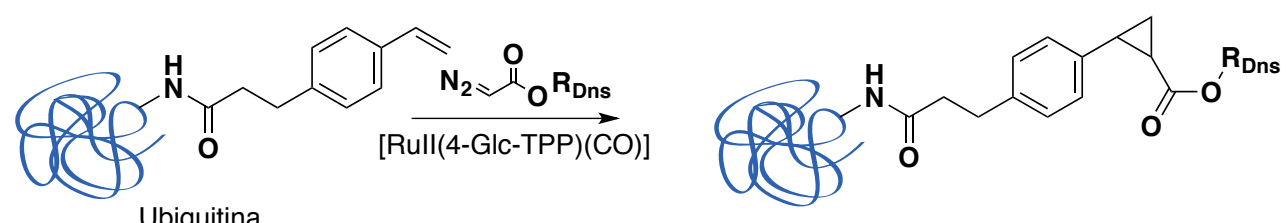

Ubiquitina

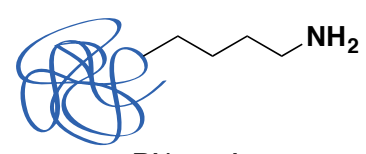

RNase A
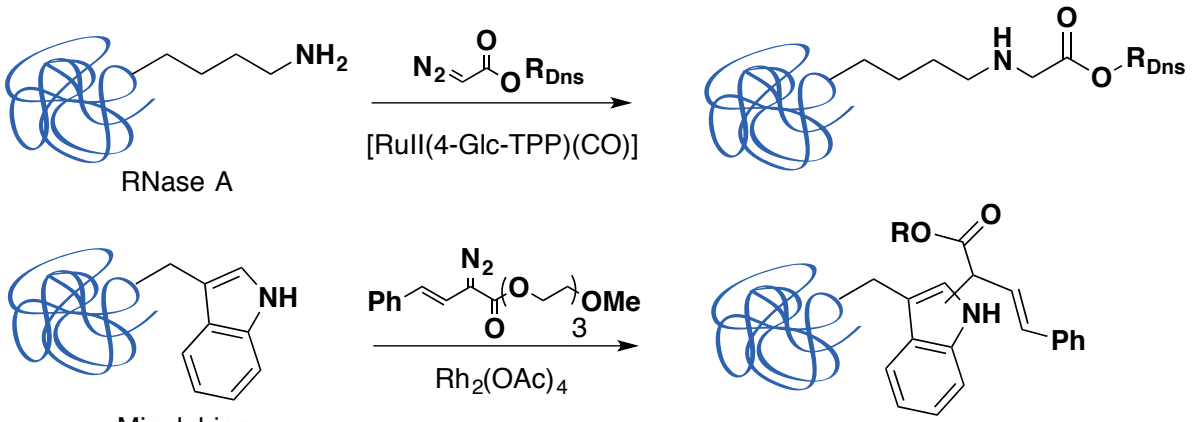

Mioglobina

Esquema 69 Exemplos de diazocompostos aplicados na modificação de proteínas.

A reação entre uma diazocetona como o exemplo 53, poderia levar a uma proteína contendo a funcionalidade diazo após adição de Michael seletiva para cisteínas. Reações mediadas por carbeno/carbenóide via cicloadições, rearranjo de Wolff ou ciclopropanações na presença de fluoróforos, fármacos ou açúcares poderia fornecer uma contribuição importante no desenvolvimento de reações bioortogonais com diferentes aplicações em química biologia. Após o estabelecimento de modelos carbonilacrílicos como reagentes diretos, irreversíveis e Cis-seletivos, a atenção foi então voltada para o estudo de seus derivados diazocarbonilacrílicos.

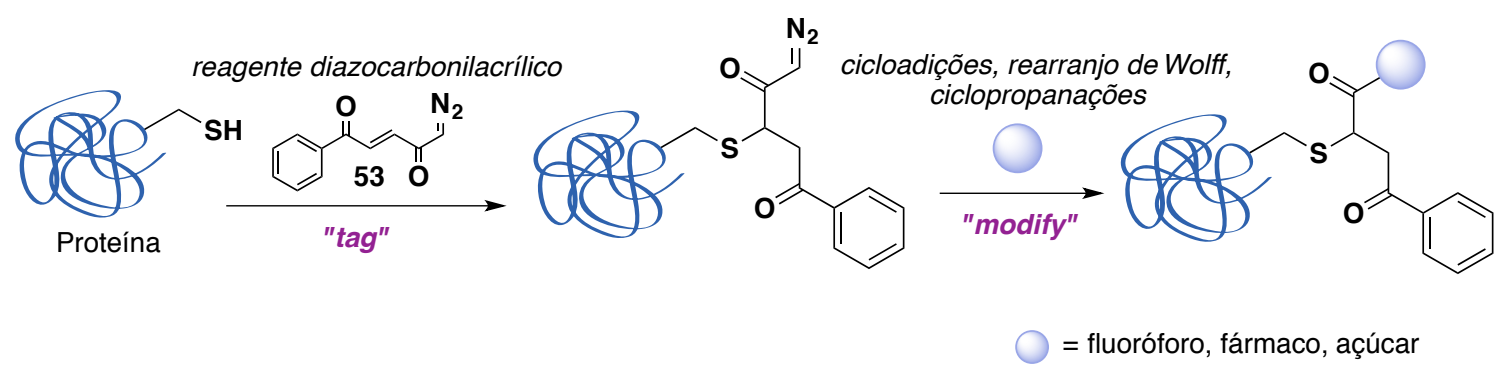

Esquema 70 Reações bioortogonais a partir de diazocompostos. 


\subsubsection{Adição de tio-Michael no reagente diazocarbonilacrílico}

A adição de quantidades estequiométricas do aminoácido N-Boc-Cis-OMe 173 em uma solução da diazocetona $\mathbf{5 3} \mathrm{em}$ acetonitrila forneceu o adulto de Michael 196 em um rendimento de $90 \%$ após 10 minutos de reação. O mesmo resultado foi obtido em meio aquoso a partir de uma solução de DMF a 30\% em tampão de fosfato de sódio ( $\mathrm{NaP}_{\mathrm{i}}$, pH 8.0, $50 \mathrm{mM}$ ) em temperatura ambiente (Esquema 71). Para evitar uma possível degradação da funcionalidade diazo, o tampão de TrisHCl $(\mathrm{pH} \mathrm{8.0,20} \mathrm{mM)}$ previamente utilizado foi substituído por $\mathrm{NaP}_{\mathrm{i}}(\mathrm{pH} 8.0,50 \mathrm{mM})$.

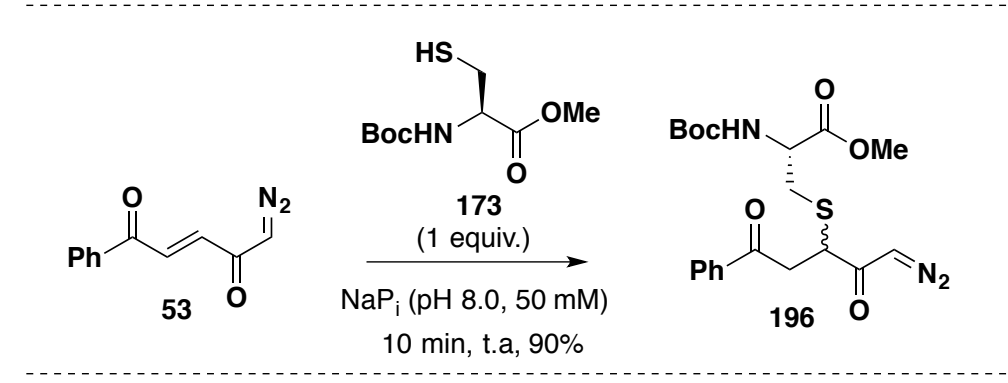

Esquema 71 Reação de adição de cisteína 173 na diazocetona 53.

O produto 196 foi confirmado pela análise de $\mathrm{RMN}{ }^{1} \mathrm{H}$ e de ${ }^{13} \mathrm{C}$. O espectro obtido é apresentado na Figura 41. A ausência dos sinais olefínicos em 7.89 e 7.01 pm confirmam a adição da cisteína 173. A presença do singleto $c$ característico do grupo de proteção Boc em 1.45 ppm $(9 \mathrm{H})$ e a metoxila $\boldsymbol{b}$ em 3.77 ppm $(3 \mathrm{H})$ corroboram a estrutura. Outro sinal importante é o singleto em 5.79 ppm $(1 \mathrm{H})$ referente ao hidrogênio $\alpha$-carboxila ligado ao grupo diazo. Análise de espectroscopia confirma a diazocetona pela banda em $2100 \mathrm{~cm}^{-1}$. O espectro de RMN ${ }^{13} \mathrm{C}$ apresenta sinais duplicados que podem ser resultado de uma mistura de diastereoisômeros ou de rotâmeros (sinais alargados são também observados no espectro de RMN ${ }^{1} \mathrm{H}$ ). Cabe ressaltar, que no caso da adição da cisteína $\mathbf{1 7 3}$ nos reagentes carbonílacrílicos 174,178-180, observou-se a formação de 175, 181-183 como uma mistura de diastereoisômeros que foi confirmada por experimentos de RMN de ${ }^{1} \mathrm{H} \mathrm{e}{ }^{13} \mathrm{C}$ em alta temperatura (DMSO-d a $90-100^{\circ} \mathrm{C}$ ). Análises adicionais (por exemplo por HPLC) para determinar a proporção diastereoisomérica não foram realizadas. 


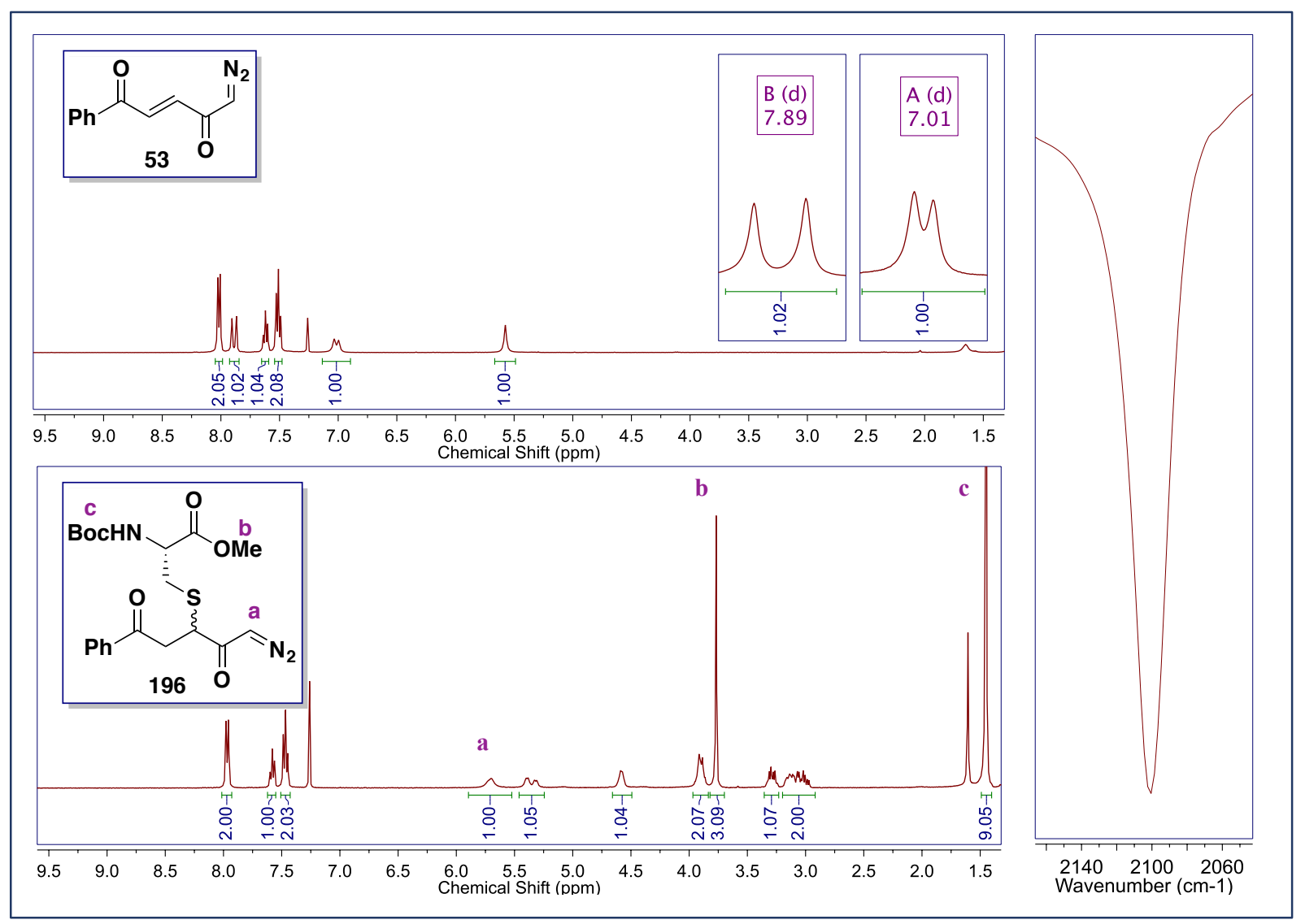

Figura 41 Espectro de $\mathrm{RMN}^{1} \mathrm{H}$ e de IV do aduto de Michael 196.

A reação de Michael foi também explorada a partir da diazocetona $\alpha, \beta$ insaturada 1 derivada do benzaldeído. A adição da cisteína 173 em uma solução da diazocetona 1 em acetonitrila forneceu apenas a recuperação dos materiais de partida. A reação foi acompanhada por RMN ${ }^{1} \mathrm{H}$ a cada $1 \mathrm{~h}$ em um período de $12 \mathrm{~h}$ (espectro adicionado nos anexos). Ao adicionar 50 mol\% de trietilamina, a reação evoluiu ao longo de $6 \mathrm{~h}$ até chegar em uma proporção 1:1.5 (material de partida:produto). A alíquota analisada ao final de $12 \mathrm{~h}$ revelou que o produto passou por uma reação de retro Michael, chegando em uma proporção final de 1:0.8 (Figura 42). A reação realizada em meio aquoso $\left(\mathrm{NaP}_{\mathrm{i}} \mathrm{pH} 8.0,50 \mathrm{mM}\right)$ ocorreu de forma bastante lenta, com uma conversão de apenas $5 \%$ ao final de $12 \mathrm{~h}$ (espectro adicionado nos anexos). Quando o pH reacional foi aumentado para 9.0, a reação chegou a $10 \%$ de conversão. Com estes resultados em mãos, decidiu-se focar no comportamento da diazocetona 53 como reagente para modificação seletiva de proteínas. 


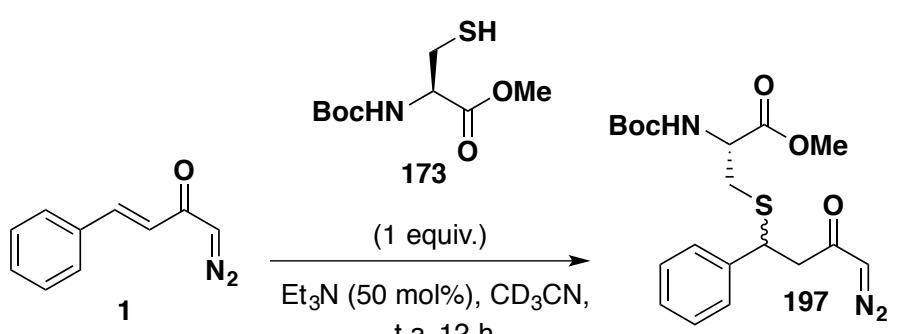

Esquema 72 Reação entre a diazocetona 1 e N-Boc-Cis-OMe 173 em acetonitrila.

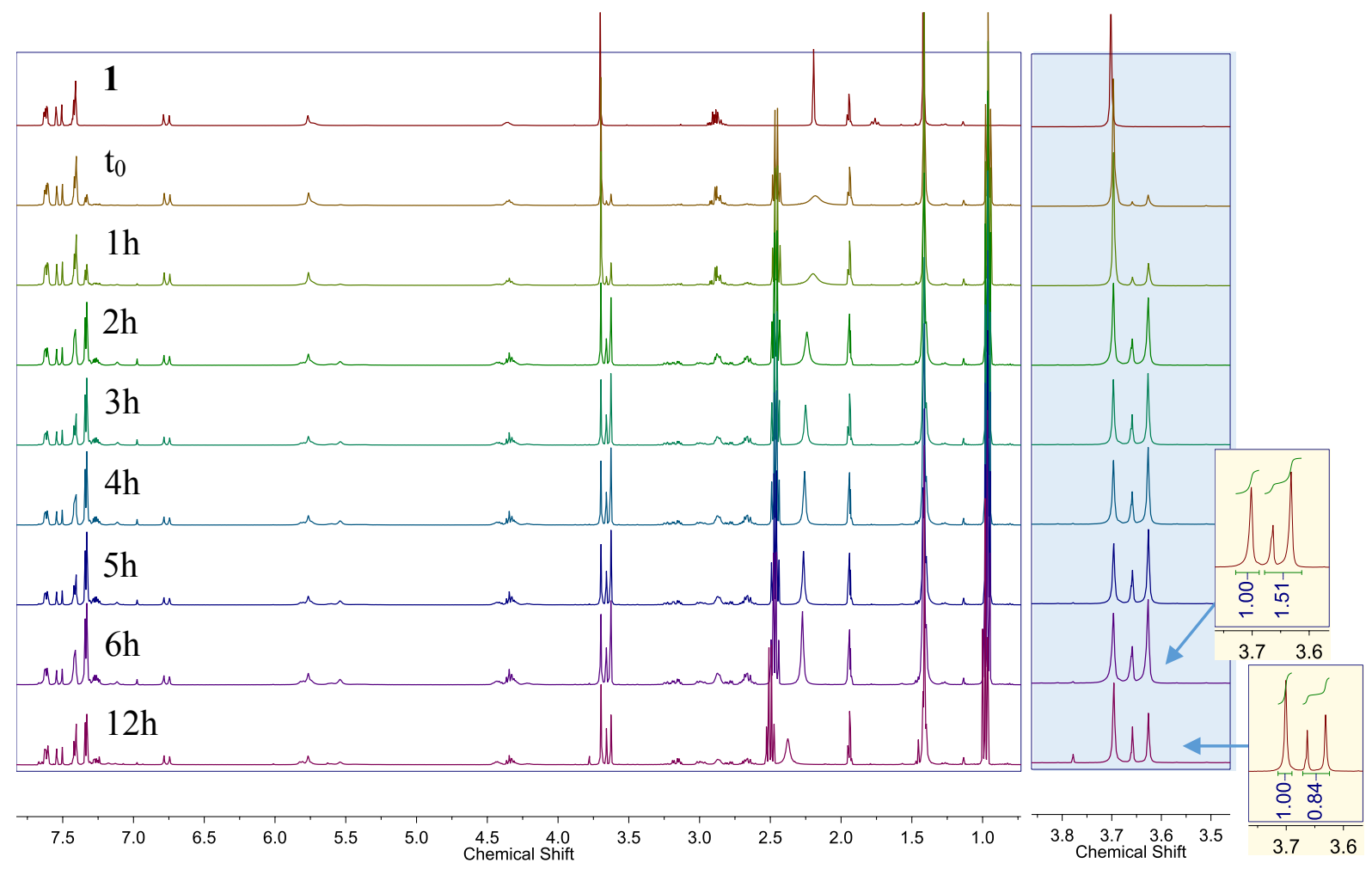

Figura 42 Espectro de RMN ${ }^{1} \mathrm{H}$ para a reação entre a diazocetona 1 e N-Boc-Cis-OMe 173.

\subsubsection{Bioconjugação de proteínas com o reagente diazocarbonilacrílico $\mathbf{5 3}$}

O reagente diazocarbonilacrílico 53 foi avaliado para a modificação da Annexina V. Em condições idênticas as aplicadas anteriormente utilizando-se 179, a conversão completa (> 95\%) pôde ser obtida com 50 equivalentes de $\mathbf{5 3}$ após 1 hora de reação em $37^{\circ} \mathrm{C}$, como confirmado por análise de espectrometria de massa por cromatografia líquida (Figura 43). Os testes químicos que envolveram o bloqueio da cisteína utilizando o reagente de Ellman's 187 previamente a reação com 53 mostraram uma completa seletividade para cisteínas. Os resultados estão em total concordância com os anteriores obtidos (Esquema 73). Todos os espectros de massas para cada transformação estão anexados na seção de anexos. 

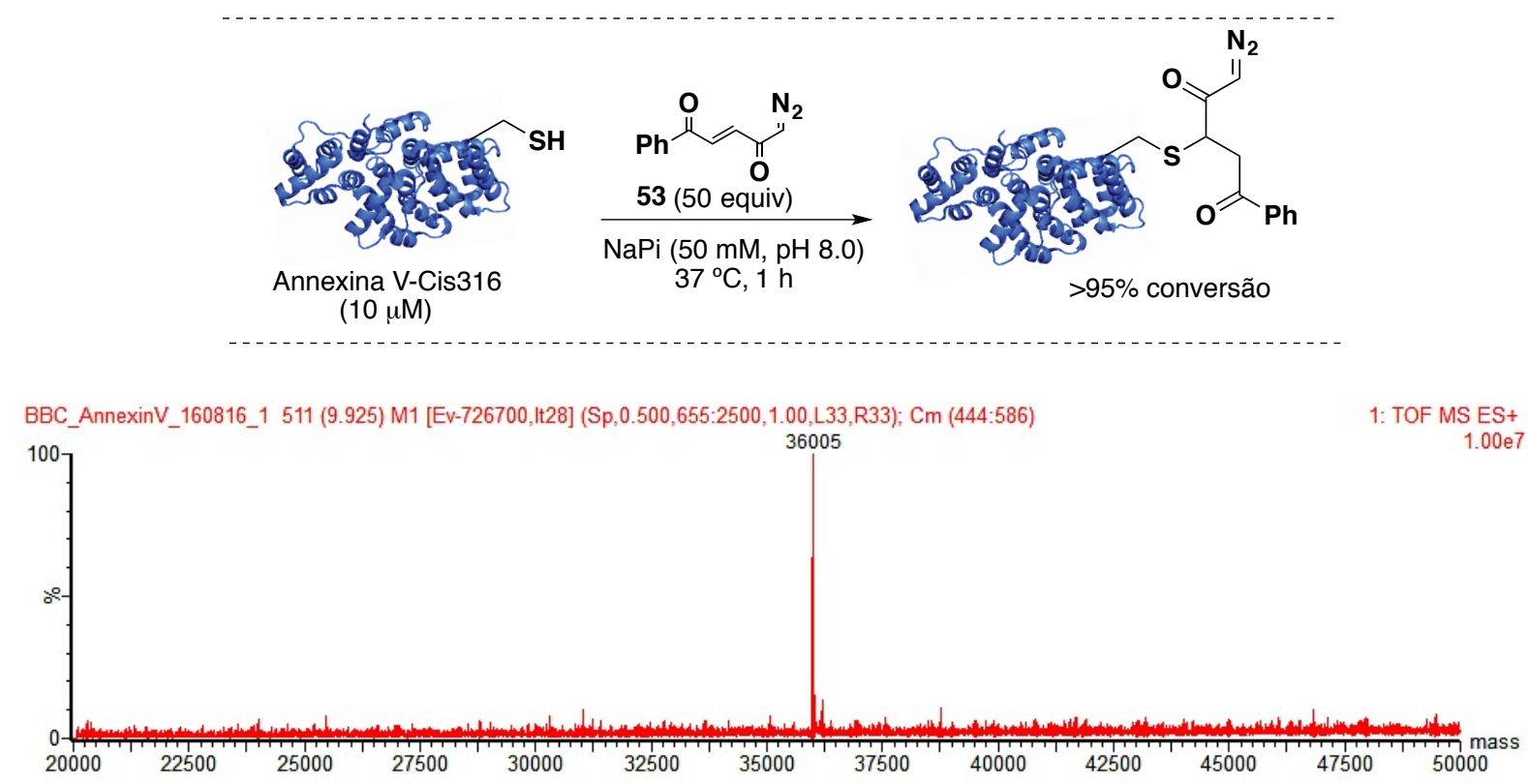

Figura 43 Bioconjugação da Annexina V com a diazocetona 53.
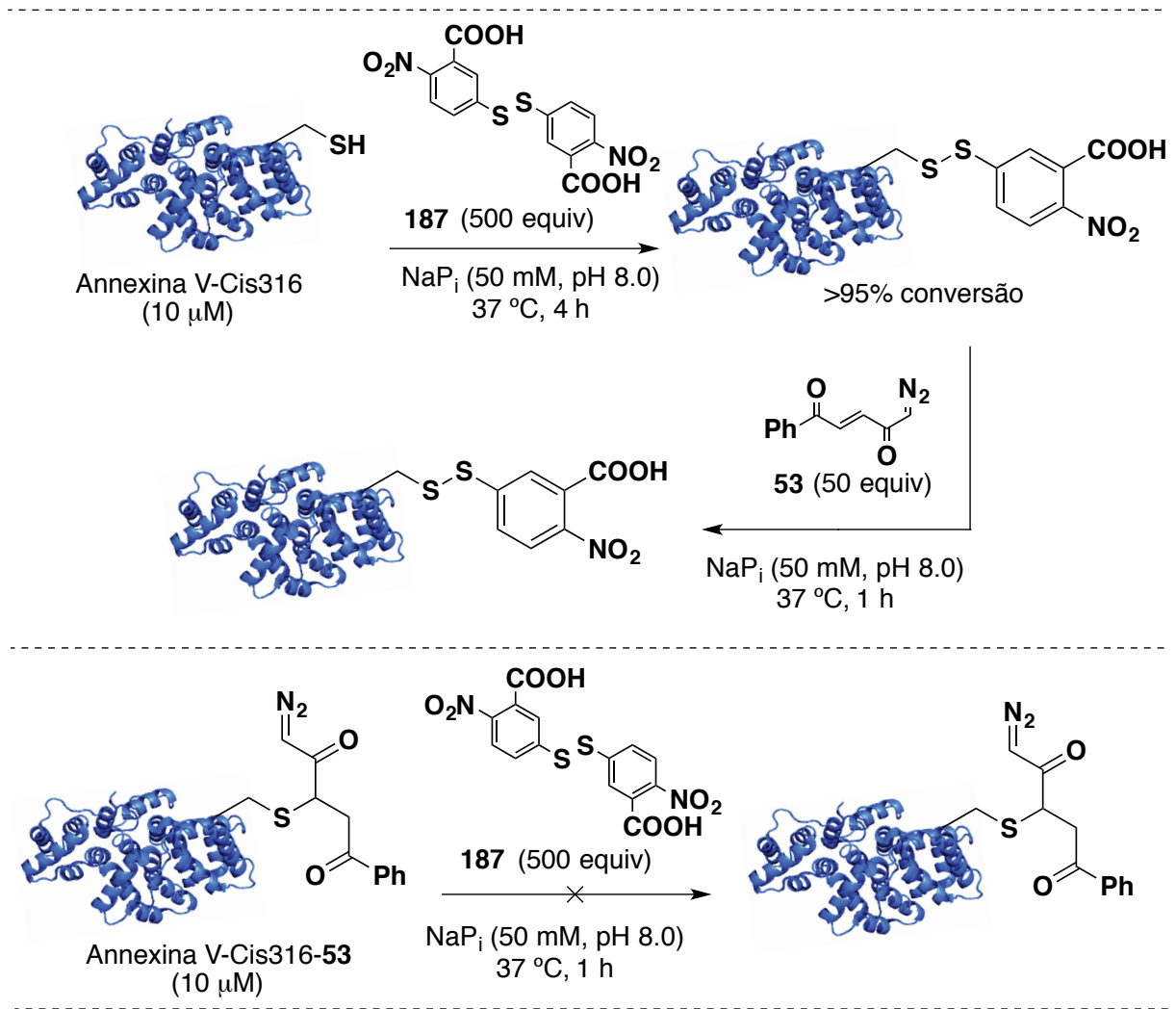

Esquema 73 Testes químicos de Ellman's com os conjugados de Annexina V-53. 


\subsubsection{Reações bioortogonais mediadas por carbeno/carbenóide}

Após bioconjugação da Annexina V com o reagente diazocarbonilacrílico 53, avaliou-se em seguida a sua aplicação em reações bioortogonais mediadas por carbeno/carbenoide. Realizou-se o rearranjo de Wolff catalisado por luz a partir do conjugado de Annexina $V$ utilizando 1000 equivalentes de benzilamina 32 e uma lâmpada de absorção em $350 \mathrm{~nm}$ durante 0.5 - $1 \mathrm{~h}$. A análise de LC-MS mostrou decomposição total da proteína.

A primeira tentativa metal-catalisada foi baseada em um catalisador biocompatível de ferro(III) - FeTPPCI - capaz de realizar reações de ciclopropanação eficientemente a partir de diazoacetato de etila na presença do microorganismo $E$. coli. ${ }^{217} \mathrm{O}$ conjugado de Annexina V-53 foi incubado com 0.1 - 20 equivalentes do catalisador FeTPPCI na presença de 1-1000 equivalentes de 4-vinilanisol 198 em $37^{\circ} \mathrm{C}$ durante 0.5 - $24 \mathrm{~h}$ (Tabela 9). A análise de massas sugere que o catalisador consegue deslocar eficientemente o grupo diazo pelo aparecimento de um pico de massa -28 (-N $\left.\mathrm{N}_{2}\right)$. Entretanto, estes resultados indicam que o carbenóide de Fe pode estar reagindo com alguma cadeia de aminoácidos lateral (exemplo Lis) antes de ser atacado pela olefina. Realizou-se a mesma reação na presença de 0.1 - 1000 equivalentes de benzilamina 199 (Esquema 74), apresentando espectros de massas com aspectos semelhantes. Estes resultados devem ser investigados profundamente com análises de MSMS e reações controle na ausência de olefina ou amina. Modelos de aminoácidos contendo a funcionalidade diazo poderiam fornecer dados para a melhor compreensão do sistema. Devido as questões de escala anteriormente mencionadas para o preparo da diazocetona 53, decidiu-se investigar uma rota alternativa para a obtenção do composto 196. Este aduto serviria como base para a otimização reacional em termos de catalisador, quantidade de nucléofilo necessária e tempo. 
Tabela 9 Condições testadas para a ciclopropanação da Annexina V-53.

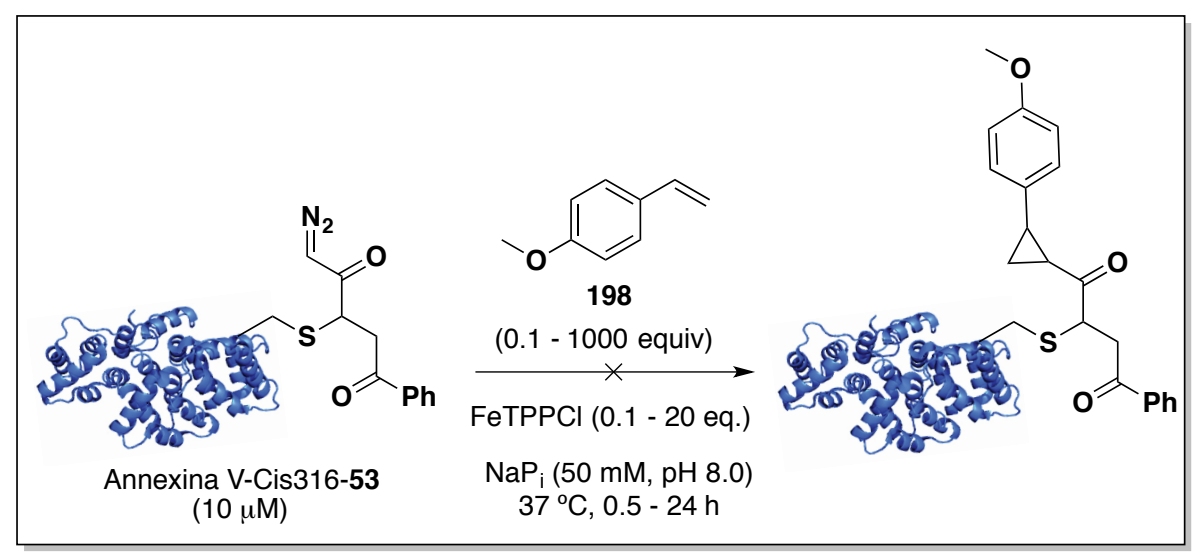

\begin{tabular}{ccccc}
\hline Annexina $\mathbf{V}(\mathbf{1 0} \boldsymbol{\mu M})$ & $\mathbf{1 9 8}$ & FeTPPCl & Tempo (h) & Conversão (\%) \\
\hline 1 & 1 & 0.1 & 3 & - \\
1 & 5 & 0.1 & 0.5 & - \\
1 & 5 & 0.1 & 24 & - \\
1 & 10 & 1 & 1 & - \\
1 & 50 & 20 & 0.5 & - \\
1 & 500 & 1 & 1 & - \\
1 & 1000 & 1 & 1 & - \\
\hline
\end{tabular}

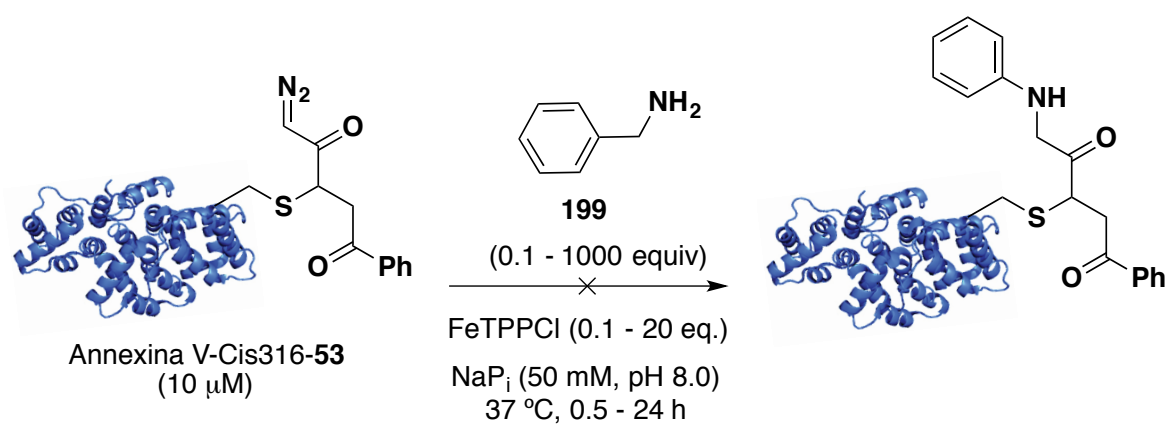

Esquema 74 Condições testadas para a inserção de benzilamina na Annexina V-53.

A reação de 1 equivalente do éster metílico Boc-Cis $173 \mathrm{com} 1$ equivalente do ácido trans-benzoilacrílico $191 \mathrm{em}$ temperatura ambiente forneceu o aduto $200 \mathrm{com}$ um rendimento quantitativo após $12 \mathrm{~h}$ de agitação vigorosa (Esquema 75). Foram avaliados diversos métodos de ativação de ácidos carboxílicos previamente a adição de diazometano no aduto 200, incluindo IBCF/NMM, TsCl, TBTU/DIPEA, CDI e o método clássico com cloreto de oxalila. Análises FTIR e RMN ${ }^{1} \mathrm{H}$ das amostras brutas mostraram que o aduto 201 não foi obtido a partir das condições estudadas, 
apresentando distribuições de produtos constituídas de éster metílico proveniente da esterificação direta do ácido carboxílico 200 com diazometano, assim como por subprodutos de decomposição.

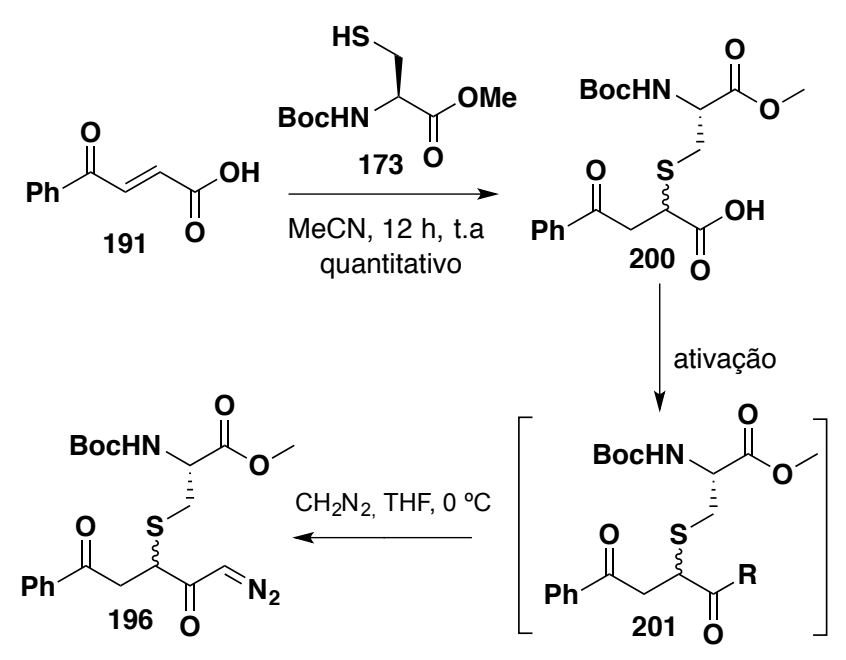

Esquema 75 Tentativa de obtenção do aduto 196 via acilacão do diazometano com ácido 201.

A falha na obtenção de $196 \mathrm{em}$ quantidades significativas de trabalho prejudicou o andamento da otimização da reação. Uma alternativa nesta rota seria a substituição do grupo de proteção da cisteína Boc por Cbz. Embora as reações mediadas por carbenos/carbenóides não puderam ser avaliadas em modelos de aminoácidos, a funcionalidade diazocetona foi instalada na superfície da proteína com sucesso em conversão superior a 95\%. A exposição deste conjugado a um catalisador de ferro levou a extrusão de nitrogênio, mostrando uma efetiva formação do intermediário reativo. Este resultado abre um leque de novas aplicações a serem exploradas, não somente ciclopropanações ou inserções, mas incluindo todas as reações pertinentes a funcionalidade diazo que sejam compatíveis com as biomoléculas. 


\subsection{Conclusões parciais}

Em resumo, um novo método de bioconjugação seletivo para cisteínas a partir de reagentes carbonilacrílicos foi desenvolvido. ${ }^{222} \mathrm{~A}$ reação ocorre em um elevado grau de seletividade fazendo o uso de quantidades estequiométricas de reagentes sinteticamente acessíveis. Três exemplos de proteínas (Annexina V, C2Am e albumina) foram convertidas em conjugados homogêneos em conversões superiores a $95 \%$. As proteínas modificadas apresentaram-se totalmente estáveis quando expostas a GSH e plasma sanguíneo, retendo a sua função biológica, como evidenciado pela deteç̧ão de células apoptóticas. A reatividade superior e a seletividade dos reagentes carbonilacrílicos permitiram o acesso a um anticorpo modificado totalmente homogêneo. O Trastuzumab foi reagido com quantidades equimolares de 179 e 194 após redução e oxidação das pontes de dissulfeto, fornecendo um conjugado totalmente funcional como evidenciado pela sua perfeita capacidade de interação anticorpo-antígeno. O método foi ainda estendido com sucesso para o reagente diazocarbonilacrílico 53. A reação ocorre em condições aquosas e diazo compatíveis com um elevado grau de seletividade para cisteínas. Diazocetonas mais simples, como o exemplo 1 derivado de benzaldeído passaram por retro-Michael nas condições estudadas ( $\mathrm{pH} 8.0$ - 9.0). A proteína Annexina $\mathrm{V}$ foi modificada com conversão superior a $95 \%$ usando 50 equivalentes da diazocetona 53 em pH $8.0\left(\mathrm{NaP}_{i} 50 \mathrm{mM}\right)$. Após a purificação da proteína, reações bioortogonais mediadas por carbeno/carbenoide foram investigadas. Análises de massas evidenciaram a perda de m/z $28\left(-\mathrm{N}_{2}\right)$ quando a Annexina $V$ contendo a diazocetona foi submetida a um catalisador de Fe(III) na presença de 1-1000 equivalentes de benzilamina ou vinilanisol. Este resultado se mostra promissor, indicando o sucesso na formação do carbenóide de ferro e o ataque instantâneo de um aminoácido vizinho da superfície da proteína (exemplo lisina) imediatamente após a sua formação. Como perspectivas nesta proposta, uma investigação profunda das reações de inserção, rearranjo de Wolff e ciclopropanação em modelos de aminoácidos (como por exemplo, o aduto 196) poderia fornecer dados importantes para a compreensão do sistema. $O$ uso das proteínas albumina e C2Am poderiam ser uma alternativa a Annexina como substratos a serem avaliados. Estes resultados abrem um leque de oportunidades na área de reações bioortogonais para futuras aplicações em biologia química. 


\section{Parte experimental}

\section{Experimental}

Todas as reações não aquosas foram realizadas sob uma atmosfera de argônio utilizando vidro seco em estufa $\left(150^{\circ} \mathrm{C}\right)$, salvo quando indicado. Uma vez removida da estufa, a vidraria foi resfriada sob vácuo e posteriormente a atmosfera trocada por argônio.

\subsection{Considerações gerais}

\section{Solventes e reagentes}

Todos os solventes foram secos e destilados antes da sua utilização por meio de procedimentos padrões. Os reagentes foram comprados na mais alta qualidade comercial, sendo utilizados sem purificação adicional; a menos que indicado de outra forma. 


\section{$\underline{\text { Aquecimento e resfriamento }}$}

Os balões reacionais foram aquecidos utilizando blocos controlados termostaticamente, banhos de areia ou de óleo. As temperaturas de reação são indicativas do ponto de referência do termostato ou termômetro, a menos que aquecida a refluxo, onde a temperatura indica a temperatura de refluxo do solvente. As reações indicadas como sendo realizadas a $0{ }^{\circ} \mathrm{C}$ referem-se a um banho de resfriamento externo de gelo/água, periodicamente substituído. As reações indicadas como sendo realizadas a $-20^{\circ} \mathrm{C}$ referem-se a um banho de arrefecimento externo de gelo/cloreto de sódio/água, periodicamente substituído. As reações indicadas como sendo realizadas a $-78{ }^{\circ} \mathrm{C}$ referem-se a um arrefecimento externo com gelo seco/acetona ou gelo seco/etanol (aproximadamente $-78^{\circ} \mathrm{C}$ ), mantido por adição de mais gelo seco.

\section{Cromatografia}

A cromatografia em coluna flash foi realizada utilizando sílica gel $60 \AA$ (0.040$0.063 \mu \mathrm{m}$ ) da SigmaAldrich ou Merck Millipore. As reações foram monitoradas por Cromatografia em Camada Fina (placa CCD, Fluka, matriz sílica gel, suporte de alumínio, com indicador fluorescente $254 \mathrm{~nm}$ e espessura de $200 \mu \mathrm{m}$ ), ou em placas de vidro Merck Silica gel 60 F254 de $1 \mathrm{~mm}$. A visualização pode ser tanto por radiação ultravioleta (254 nm) ou coloração com uma solução preparada por procedimentos conhecidos. A cromatografia em camada fina preparativa foi realizada utilizando placas de vidro preparadas em laboratório ou Analtech Uniplate Silica Gel GF UV254 $200 \times 200 \mathrm{~mm}$. O éter de petróleo ou hexano foi destilado e recolhido entre $40-60^{\circ} \mathrm{C}$, salvo indicação em contrário. Salvo quando especificado, todos os rendimentos referem-se a produtos isolados após purificação. As misturas de solventes empregadas nas análises por CCD e em purificações por cromatografia flash são apresentadas como volume/volume e em percentagens 


\section{Ressonância Magnética Nuclear}

Para as análises de RMN, foram utilizados equipamentos 400, 500 ou $600 \mathrm{MHz}$ Agilent RMN Spectrometer, 400 e $500 \mathrm{MHz}$ (IQSC-USP) ou Bruker $400 \mathrm{MHz}$ DPX400, Bruker $500 \mathrm{MHz}$ AVIII HD, Bruker Avance DRX-600 MHz (Univesity of Cambridge). Os deslocamentos químicos ( $\delta$ ) são referenciados em relação ao padrão interno TMS, tetrametilsilano $(0.00 \mathrm{ppm})$. Os espectros foram registados nos solventes indicados (DMSO- $\mathrm{d}_{6}, \mathrm{CDCl}_{3}, \mathrm{CD}_{3} \mathrm{CN}, \mathrm{MeOD}$ ou $\mathrm{D}_{2} \mathrm{O}$ ). As constantes de acoplamento $(J)$ são reportadas em $\mathrm{Hz}$. As multiplicidades são apresentadas como: s, singleto, d, dubleto, t, tripleto, q, quarteto, $\mathrm{m}$, multipleto; dd, duplo dupleto; sl; singleto largo. Os espectros de RMN ${ }^{13} \mathrm{C}$ foram registrados usando equipamentos de 100 ou $125 \mathrm{MHz}$. Os dados foram tratados utilizando o software MestreNova 10.0.

\section{Espectroscopia no infravermelho}

As análises de infravermelho foram realizadas em um espectrofotômetro com transformada de Fourier FTIR, BOMEN HARTMANN \& BRAUN modelo MB-102 e um Bruker, modelo Alpha, equipado com cristal de seleneto de zinco (IQSC-USP). Em Cambridge, o equipamento utilizado foi um Perkin-Elmer Spectrum One FTIR ATR. As amostras foram depositadas puras ou como películas finas por deposição de uma solução e deixando o solvente evaporar. Os espectros foram analisados no próprio software do fabricante e as figuras obtidas exportadas como PDF.

\section{Espectrometria de massas}

Os espectros de massa de alta resolução (HRMS) foram registrados em um Orbitrap FT-EM, QqTOF/EM - Microtof - modelo QIl e Waters Xevo G2-S QTOF. No departamento de Química da Universidade de Cambridge, as análises foram realizadas em um Waters Micromass LCT Premier (TOF MS ES+) e Waters Xevo G2$S$ QTOF (ESI+). Os valores obtidos estão todos dentro de $5.0 \mathrm{ppm}$ da massa calculada. Para a análise por UPLC - qTOF utilizou-se uma coluna Acquity UPLC BEH C18 (1.7 $\mu \mathrm{m}, 2.1 \times 100 \mathrm{~mm})$, em um fluxo: $0.5 \mathrm{~mL} / \mathrm{min}$ utilizando um gradiente de $\mathrm{MeCN}\left(+0.1 \% \mathrm{HCO}_{2} \mathrm{H}\right)$ em $\mathrm{H}_{2} \mathrm{O}\left(+0.1 \% \mathrm{HCO}_{2} \mathrm{H}\right)$, começando com $10 \%$ até $50 \%$ de $\mathrm{MeCN}\left(+0.1 \% \mathrm{HCO}_{2} \mathrm{H}\right)$ em 6 min; e de $50 \%$ até $98 \%$ de $\mathrm{MeCN}\left(+0.1 \% \mathrm{HCO}_{2} \mathrm{H}\right)$ em 3 
min, totalizando $9 \mathrm{mim}$. A detecção foi feita por MSE centroid durante $10 \mathrm{~min}$ em um intervalo de m/z 100-600. O modo de detecção: ESI (+) com um scan time de $0.2 \mathrm{~s} \mathrm{e}$ rampa de energia de colisão de 20-30 V.

\section{$\underline{\text { Reações fotoquímicas }}$}

As reações fotoquímicas foram realizadas em cubeta de quartzo de $1 \mathrm{~cm}$ de caminho óptico (3 mL). Células de quartzo de $10 \mathrm{~mL}$ e $15 \mathrm{~mL}$ foram também empregadas. Utilizou-se luz ultravioleta gerada por uma lâmpada de arco de Xenônio $300 \mathrm{~W}$ (operando em $260 \mathrm{~W}$ ), Osram 150 alojada em uma fonte Oriel Modelo 8500 Universal utilizando uma lente e quartzo como foco. A lâmpada de LED comercial branca é Philips Mestre LEDspot PAR 38 MV (18 W, 2700K, 50-60Hz typ, 90mA), nestes casos, o próprio balão ou frascos de vidro (pyrex) foram utilizados. Os espectros de emissão das lâmpadas são apresentados nos anexos.

\section{$\underline{\text { Reações de bioconjugação de proteínas }}$}

Para as reações de bioconjugação de proteínas, utilizou-se tubos de plástico eppendorf de 0.5 e $1.5 \mathrm{~mL}$. As reações foram aquecidas em um agitador mecânico em uma rotação de 700 rpm (PHMT - Grant Bio). A temperatura foi termostatizada em $37^{\circ} \mathrm{C}$ ou temperatura ambiente, conforme indicado. 


\subsection{Procedimento para o preparo do diazofosfonato 32}

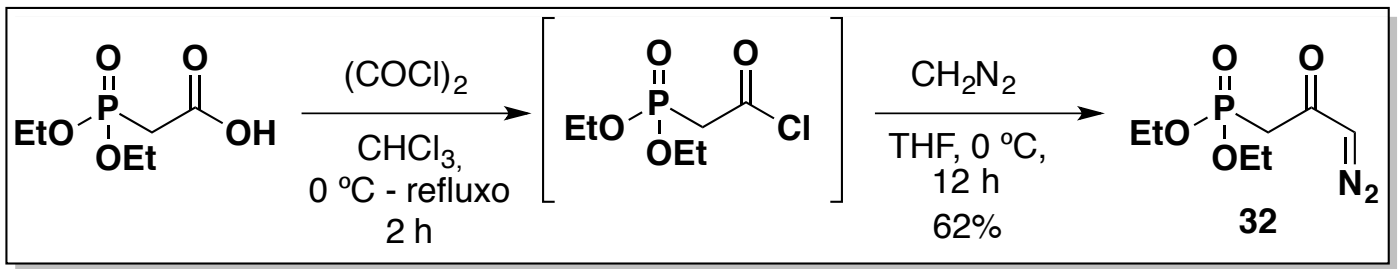

A um balão previamente seco foi adicionado o ácido 2-(dietóxifosforil)-acético $(6.0 \mathrm{~g}, 0.031 \mathrm{~mol}, 1$ equiv. $)$, seguido da adição de tolueno seco $(3 \times 15.0 \mathrm{~mL})$ para remoção azeotrópica de umidade. Em seguida, clorofórmio seco $(78.0 \mathrm{~mL})$ foi adicionado e o sistema resfriado a $0{ }^{\circ} \mathrm{C}$. Cloreto de oxalila recem destilado $(8.0 \mathrm{~mL}$, 0.093 mol, 3 equiv.) foi então adicionado gota a gota ao frasco reacional e a solução foi agitada em refluxo durante duas horas. Após este período, os solventes foram removidos em rota evaporador e o resíduo resultante foi dissolvido em THF seco (31.0 $\mathrm{mL}$ ) (Cuidado: O cloreto de ácido formado a partir do (dietilfosfono)ácido é muito instável e deve ser manuseado com cuidado durante estas operações para evitar a sua hidrólise). A solução de cloreto de ácido é canulada a uma solução $0.4 \mathrm{M}$, recém preparada, de diazometano etéreo (150.0 mL, 1.9 equiv.). A reação é agitada em $0{ }^{\circ} \mathrm{C}$ por $15 \mathrm{~min}$. Após este período, o solvente é removido em evaporador rotativo e o resíduo purificado por cromatografia flash ( $5 \%$ de $\mathrm{MeOH} / \mathrm{Et}_{2} \mathrm{O}$ ) para fornecer $\mathrm{o}$ diazofosfonato $32(4.20 \mathrm{~g}, 0.019 \mathrm{~mol}, 62 \%)$ como um óleo amarelo.

Fosfonato de dietil-(3-diazo-2-oxopropil) (32)

\begin{tabular}{|c|c|}
\hline $\mathbf{R}_{\mathbf{f}}$ & $0.27(10 \% \mathrm{MeOH} / \mathrm{AcOEt})$ ou $0.25\left(5 \% \mathrm{MeOH} / \mathrm{Et}_{2} \mathrm{O}\right)$ \\
\hline${ }^{1} \mathrm{H}$ RMN & $\left(400 \mathrm{MHz}, \mathrm{CDCl}_{3}\right) \delta 5.60\left(\mathrm{~s}, 1 \mathrm{H}, \mathrm{N}_{2} \mathrm{CH}\right), 4.23-4.10\left(\mathrm{~m}, 4 \mathrm{H}, \mathrm{OCH}_{2}\right), 2.95$ \\
\hline & $\left(\mathrm{d}, J=21.8 \mathrm{~Hz}, 2 \mathrm{H}, \mathrm{PCH}_{2}\right), 1.34\left(\mathrm{t}, J=7.1 \mathrm{~Hz}, 6 \mathrm{H}, \mathrm{CH}_{3}\right)$; \\
\hline${ }^{13} \mathrm{C}$ RMN & $\begin{array}{l}\left(50 \mathrm{MHz}, \mathrm{CDCl}_{3}\right) \delta 184.5,62.8\left(\mathrm{~d},{ }^{2} \mathrm{~J}_{\mathrm{C}, \mathrm{P}}=6,2 \mathrm{~Hz}\right), 56.6,41.5,38.9(\mathrm{~d}, \\
\left.{ }^{1} J_{\mathrm{C}, \mathrm{P}}=128 \mathrm{~Hz}\right), 16.2\left(\mathrm{~d},{ }^{3} J_{\mathrm{C}, \mathrm{P}}=6,0 \mathrm{~Hz}\right) ;\end{array}$ \\
\hline FTIR & $\left(\right.$ puro, $\left.\mathrm{cm}^{-1}\right) 2108,1633,1359,1249,1045,972$ \\
\hline
\end{tabular}




\subsection{Procedimento geral para a reação de Horner-Wadsworth-Emmons}

\subsection{Procedimento usando $\mathrm{NaOH} / \mathrm{EtOH}$}

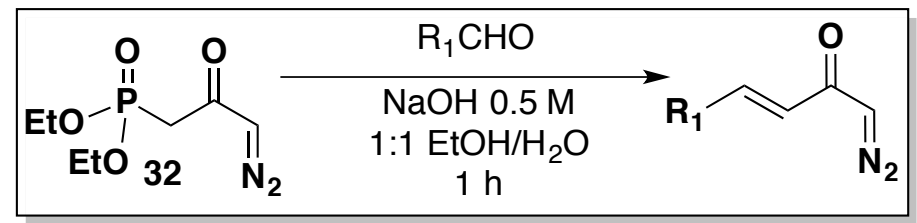

(E)-1-diazo-4-fenilbut-3-en-2-ona (1)

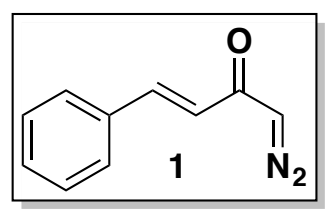

A uma solução de dietil (3-diazo-2-oxopropil) fosfonato ( $400 \mathrm{mg}, 1.81 \mathrm{mmol}, 1$ equiv.) em EtOH $(5 \mathrm{~mL})$ à temperatura ambiente foi adicionado $185 \mu \mathrm{L}$ de benzaldeído (1.81 mmol, 1 equiv.), seguido da adição de $3.6 \mathrm{~mL}$ de uma solução de $\mathrm{NaOH} 0.5 \mathrm{M}\left(\mathrm{H}_{2} \mathrm{O}\right.$ : $\mathrm{EtOH} 1: 1$ ) durante o período de 1 hora (via syringe-pump). Após este tempo, a mistura foi agitada na mesma temperatura por mais $30 \mathrm{~min}$ e, em seguida, terminada pela adição de solução saturada de $\mathrm{NaCl}(20 \mathrm{~mL})$, extração $\mathrm{com} \mathrm{CH}_{2} \mathrm{Cl}_{2}(3 \times 20 \mathrm{~mL})$ e secagem com $\mathrm{MgSO}_{4}$. Purificação por cromatografia em coluna flash $(5-10 \%$ de AcOEt/hexano) proporcionou a diazocetona insaturada 1 (281.3 mg, $1.45 \mathrm{mmol}, 80 \%$ ) como um sólido estável amarelo:

\section{(E)-1-diazo-4-fenilbut-3-en-2-ona (1)}

\begin{tabular}{|c|c|}
\hline$\overline{R_{f}}$ & 0.30 (25\% AcOEt/hexano); \\
\hline${ }^{1} \mathrm{H}$ RMN & $\begin{array}{l}\left(500 \mathrm{MHz}, \mathrm{CDCl}_{3}\right) \delta 7.59(\mathrm{~d}, J=15.8 \mathrm{~Hz}, 1 \mathrm{H}), 7.55-7.52(\mathrm{~m}, 2 \mathrm{H}), \\
7.40-7.36(\mathrm{~m}, 3 \mathrm{H}), 6.60(\mathrm{~d}, J=15.8 \mathrm{~Hz}, 1 \mathrm{H}), 5.44(\mathrm{~s}, 1 \mathrm{H}) ;\end{array}$ \\
\hline${ }^{13} \mathrm{C}$ RMN & $\begin{array}{l}\left(100 \mathrm{MHz}, \mathrm{CDCl}_{3}\right) \delta 184.2,140.7,134.4,130.3,128.9,128.2,123.6 \text {, } \\
56.2 ;\end{array}$ \\
\hline $\begin{array}{l}\text { FTIR } \\
\text { HRMS }\end{array}$ & $\begin{array}{l}\left.\text { (puro, } \mathrm{cm}^{-1}\right) 3070,2098,1636,1584,1450,1373,1149,973,759 ; \\
\text { (ESI) Calculado para } \mathrm{C}_{10} \mathrm{H}_{8} \mathrm{~N}_{2} \mathrm{NaO}[\mathrm{M}+\mathrm{Na}]^{+} 195.05288 \text {, encontrado } \\
\text { 195.0628; }\end{array}$ \\
\hline P.F & $58-62^{\circ} \mathrm{C}$ \\
\hline
\end{tabular}


Benzoato de metil (E)-4-(4-diazo-3-oxobut-1-en-1-il) (112)

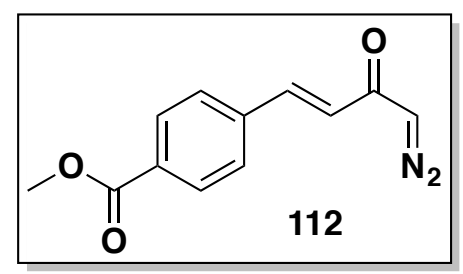

\begin{tabular}{|c|c|}
\hline & Benzoato metil (E)-4-(4-diazo-3-oxobut-1-en-1-il) (112) \\
\hline$(112)$ & $0.54 \mathrm{mmol}, 130 \mathrm{mg}, 40 \%$ como um sólido amarelo; \\
\hline $\mathbf{R}_{\mathbf{f}}$ & 0.10 (20\% AcOEt/hexano); \\
\hline${ }^{1} \mathrm{H}$ RMN & $\begin{array}{l}\left(400 \mathrm{MHz}, \mathrm{CDCl}_{3}\right) \delta 8.01(\mathrm{~d}, J=8.4 \mathrm{~Hz}, 2 \mathrm{H}), 7.61-7.50(\mathrm{~m}, 3 \mathrm{H}), 6.64 \\
(\mathrm{~d}, J=15.8 \mathrm{~Hz}, 1 \mathrm{H}), 5.45(\mathrm{~s}, 1 \mathrm{H}), 3.90(\mathrm{~s}, 3 \mathrm{H}) ;\end{array}$ \\
\hline${ }^{13} \mathrm{C}$ RMN & $\begin{array}{l}\left(125 \mathrm{MHz}, \mathrm{CDCl}_{3}\right) \delta 183.8,166.5,139.4,138.8,131.5,130.2,128.2 \\
126.6,56.8,52.4\end{array}$ \\
\hline FTIR & $\begin{array}{l}\text { (puro, } \mathrm{cm}^{-1} \text { ) 3096, 2952, 2927, 2100, 1720, 1639, 1566, 1434, 1280, } \\
\text { 1196, 1152, 1103, 754; }\end{array}$ \\
\hline HRMS & $\begin{array}{l}\text { (ESI) Calculado para } \mathrm{C}_{12} \mathrm{H}_{11} \mathrm{~N}_{2} \mathrm{O}_{3}{ }^{+}[\mathrm{M}+\mathrm{H}]^{+} 231.0764 \text {, encontrado } \\
\text { 231.0776; }\end{array}$ \\
\hline
\end{tabular}


(3E,5E)-1-diazo-6-fenilhexa-3,5-dien-2-ona (113)

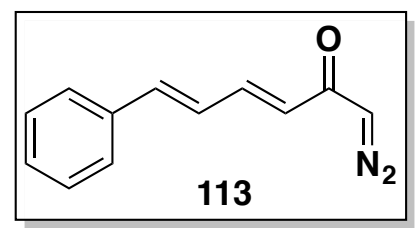

\section{(3E,5E)-1-diazo-6-fenilhexa-3,5-dien-2-ona (113)}

(113) $\quad 0.54 \mathrm{mmol}, 105 \mathrm{mg}, 30 \%$ como um sólido amarelo;

$\mathbf{R}_{\mathbf{f}} \quad 0.17$ (20\% AcOEt/hexano);

${ }^{1}$ H RMN $\quad\left(500 \mathrm{MHz}, \mathrm{CDCl}_{3}\right) \delta 7.47-7.43(\mathrm{~m}, 2 \mathrm{H}), 7.40-7.21(\mathrm{~m}, 4 \mathrm{H}), 6.94(\mathrm{~d}$, $J=15.6 \mathrm{~Hz}, 1 \mathrm{H}), 6.84(\mathrm{dd}, J=15.5,10.8 \mathrm{~Hz}, 1 \mathrm{H}), 6.16(\mathrm{~d}, J=15.0 \mathrm{~Hz}$, $1 \mathrm{H}), 5.37(\mathrm{~s}, 1 \mathrm{H})$;

${ }^{13}$ C RMN $\quad\left(126 \mathrm{MHz}, \mathrm{CDCl}_{3}\right) \delta 184.4,141.4,140.8,136.2,129.2,128.9,127.3$, 126.4, 125.6, 56.1;

FTIR (puro, $\left.\mathrm{cm}^{-1}\right)$ 3074, 2956, 2922, 2852, 2100, 1630, 1576, 1457, 1374, 1145, 1080, 987, 750, 694;

HRMS $\mathrm{ESI}^{+}(\mathrm{m} / \mathrm{z})$ Calculado para $\mathrm{C}_{12} \mathrm{H}_{11} \mathrm{~N}_{2} \mathrm{O}^{+}[\mathrm{M}+\mathrm{H}]^{+}$199.0866, encontrado 199.0873; 
(E)-5-(benzilóxi)-1-diazopent-3-en-2-ona (114)

Preparo do 2-(benzilóxi)acetaldeído

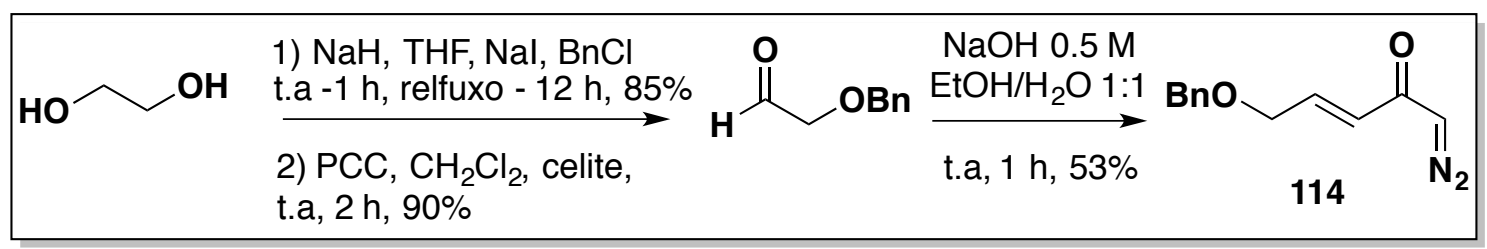

Uma solução de etileno glicol ( $9.0 \mathrm{~mL}, 0.161 \mathrm{~mol}, 5$ equiv.) em THF seco (32 mL) sob atmosfera de argônio foi adicionada via cânula a uma suspensão de $\mathrm{NaH}$ (60\% em óleo mineral, $1.41 \mathrm{~g}, 0.035 \mathrm{~mol}, 1.1$ equiv.) em THF seco (32 mL). A mistura foi agitada em temperatura ambiente por $1 \mathrm{~h}$, tempo que, todo o sólido foi dissolvido e uma camada oleosa de coloração amarela foi formada. A reação foi tratada com $\mathrm{Nal}$ ( $0.48 \mathrm{~g}, 0.0032 \mathrm{~mol}, 0.1$ equiv.) e cloreto de benzila ( $4.08 \mathrm{~g}, 0.032 \mathrm{~mol}, 1$ equiv.). A mistura foi aquecida em refluxo por $12 \mathrm{~h}$ e então deixada resfriar a temperatura ambiente. $\mathrm{H}_{2} \mathrm{O}$ e Et $\mathrm{t}_{2} \mathrm{O}$ foram adicionados e as camadas separadas. Após a extração com $\mathrm{Et}_{2} \mathrm{O}(2 \times 30 \mathrm{~mL})$ e lavagem com $\mathrm{H}_{2} \mathrm{O}$, a solução aquosa foi seca com $\mathrm{Na}_{2} \mathrm{SO}_{4} \mathrm{e}$ filtrada. A cromatografia em sílica ( $\left.\mathrm{Et}_{2} \mathrm{O} / \mathrm{Hexano}\right)$ 1:1 forneceu um líquido incolor em $85 \%$ de rendimento: ${ }^{1} \mathrm{H}$ RMN (500 MHz, $\left.\mathrm{CDCl}_{3}\right) \delta 7.38-7.27(\mathrm{~m}, 5 \mathrm{H}), 4.57(\mathrm{~s}, 2 \mathrm{H})$, $3.77(\mathrm{t}, J=4.5 \mathrm{~Hz}, 2 \mathrm{H}), 3.61(\mathrm{~d}, J=4.5 \mathrm{~Hz}, 2 \mathrm{H})$. Parte do álcool protegido (1.23 g, $0.0081 \mathrm{~mol}, 1$ equiv.) foi então oxidado em temperatura ambiente com PCC (3.25 g, 0.016 mol, 2 equiv.) na presença de Celite $(3.25 \mathrm{~g})$ em $\mathrm{CH}_{2} \mathrm{Cl}_{2}(10 \mathrm{~mL})$. Após $3 \mathrm{~h}$ de agitação vigorosa, a mistura foi diluída com $\mathrm{Et}_{2} \mathrm{O}(80 \mathrm{~mL})$ e agitada por um período adicional de $2.5 \mathrm{~h}$. Após, a mistura foi filtrada em Celite e evaporada em vácuo para fornecer o aldeído em 90\% de rendimento: $\mathrm{R}_{\mathrm{f}} 0.23$ (AcOEt/Hex 20\%); ${ }^{1} \mathrm{H}$ RMN (500 $\left.\mathrm{MHz}, \mathrm{CDCl}_{3}\right) \delta 9.73(\mathrm{t}, J=0.9 \mathrm{~Hz}, 1 \mathrm{H}), 7.39-7.33(\mathrm{~m}, 5 \mathrm{H}), 4.64(\mathrm{~s}, 2 \mathrm{H}), 4.10(\mathrm{~d}, J=$ $0.8 \mathrm{~Hz}, 2 \mathrm{H}) . \mathrm{O}$ aldeído foi utilizado diretamente na próxima etapa utilizando o protocolo geral com $\mathrm{NaOH}$. 114: $53 \%$ de rendimento após purificação em cromatografia flash, $\mathrm{R}_{\mathrm{f}} 0,29$ (AcOEt/Hex 20\%); ${ }^{1} \mathrm{H} \mathrm{RMN}\left(500 \mathrm{MHz}, \mathrm{CDCl}_{3}\right) \delta 7.43-7.29$ (m, 5H), 6.86 (dt, $J=15.5,4.1 \mathrm{~Hz}, 1 \mathrm{H}), 6.29(\mathrm{~d}, J=15.5 \mathrm{~Hz}, 1 \mathrm{H}), 5.33(\mathrm{~s}, 1 \mathrm{H}), 4.57(\mathrm{~s}, 2 \mathrm{H}), 4.20(\mathrm{dd}, J$ $=4.2,2.1 \mathrm{~Hz}, 2 \mathrm{H})$. 
6.3.2 Procedimento usando NaH/THF

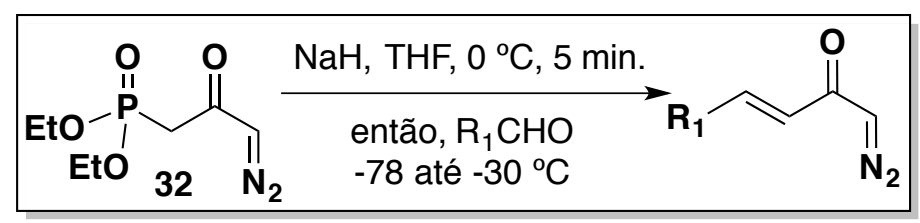

(E)-1-diazoept-3-en-2-ona (54)

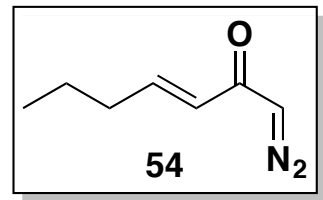

Em uma suspensão de $\mathrm{NaH}$ ( $60 \%$ em óleo mineral, 80.0 mg, 2.0 mmol, 2.2 equiv.) em THF seco $(6.0 \mathrm{~mL})$ sob atmosfera de argônio e temperatura de $0^{\circ} \mathrm{C}$, adicionou-se uma solução $0.15 \mathrm{M}$ em THF seco de dietil (3-diazo-2-oxopropil) fosfonato $32(400.0 \mathrm{mg}$, $1.8 \mathrm{mmol}, 2.0$ equiv.). A solução foi agitada durante $5 \mathrm{~min}$ na mesma temperatura e o sistema foi então resfriado a $-78^{\circ} \mathrm{C} \mathrm{e}$, em seguida, uma solução de $0.1 \mathrm{M}$ em THF seco de butiraldeído ( $65.5 \mathrm{mg}, 0.91 \mathrm{mmol}, 1.0$ equiv.) foi adicionado gota a gota. Após $1 \mathrm{~h}$, a temperatura foi deixada elevar-se naturalmente a $-30^{\circ} \mathrm{C}$, quando uma solução aquosa saturada de $\mathrm{NH}_{4} \mathrm{Cl}(25 \mathrm{~mL})$ foi adicionada a mistura reacional. Em seguida, a camada aquosa foi extraída com diclorometano $(3 \times 20 \mathrm{~mL})$, e as camadas orgânicas combinadas foram secas com $\mathrm{Na}_{2} \mathrm{SO}_{4}$, filtrada e evaporada em evaporador rotativo. A purificação por coluna de cromatografia flash (30\% AcOEt/hexano) forneceu a diazocetona 54 (82.0 mg, $0.59 \mathrm{mmol}, 64 \%$ ) como um óleo amarelo estável (método com $\mathrm{NaOH}$ fornece um rendimento de $50 \%$ ):

(E)-1-diazoept-3-en-2-ona (54)

\begin{tabular}{ll}
\hline $\mathbf{R}_{\mathbf{f}}$ & $0.30\left(20 \% \mathrm{AcOEt}_{/}\right.$hexano); \\
${ }^{1} \mathrm{H}$ RMN & $\left(400 \mathrm{MHz}, \mathrm{CDCl}_{3}\right) \delta 6.80(\mathrm{dt}, J=15.4,7.0 \mathrm{~Hz}, 1 \mathrm{H}), 5.98(\mathrm{~d}, J=15.5 \mathrm{~Hz}$, \\
& $1 \mathrm{H}), 5.29(\mathrm{~s}, 1 \mathrm{H}), 2.17(\mathrm{dq}, J=7.2,1.5 \mathrm{~Hz}, 2 \mathrm{H}), 1.48($ sext, $J=7.4 \mathrm{~Hz}$, \\
& $2 \mathrm{H}), 0.93(\mathrm{t}, J=7.4 \mathrm{~Hz}, 3 \mathrm{H}) ;$ \\
${ }^{13} \mathrm{C}$ RMN & $\left(100 \mathrm{MHz}, \mathrm{CDCl}_{3}\right) \delta 185.0,145.3,127.5,55.1,34.4,21.5,13.8 ;$ \\
FTIR & $\left(\right.$ puro, $\left.\mathrm{cm}^{-1}\right) 2962,2933,2100,1656,1606,1367,975 ;$ \\
HRMS & $(\mathrm{ESI})$ Calculado para $\mathrm{C}_{7} \mathrm{H}_{10} \mathrm{~N}_{2} \mathrm{NaO}\left[\mathrm{M}+\mathrm{Na}^{+} 161.0685\right.$, encontrado \\
& $161.0686 ;$ \\
\hline
\end{tabular}


( \pm ) Carboxilato de (E)-benzil-2-(4-diazo-3-oxobut-1-en-1-il)piperidina-1 (55)

Preparo do ( \pm )-N-Cbz-Pipecolinal 58

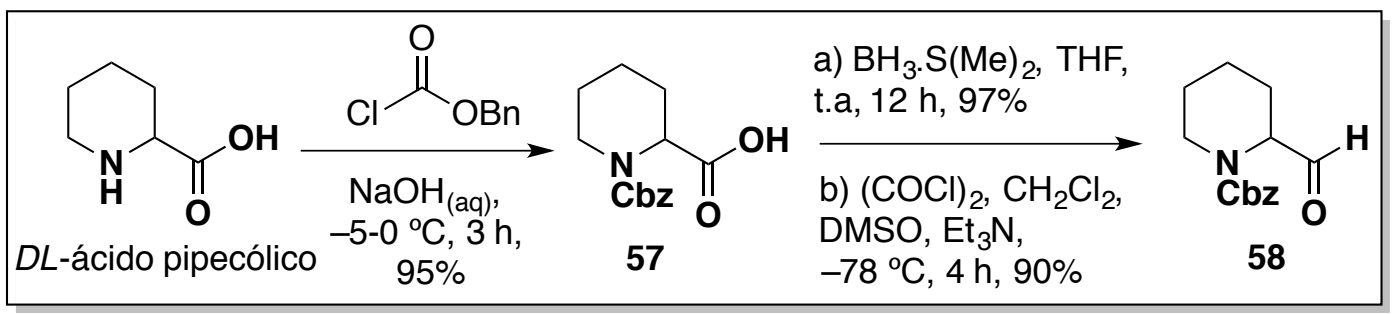

$\mathrm{O}$ aldeído $\mathrm{N}$-Cbz- $D L$-prolinal utilizado na etapa de Horner-Wadsworth-Emmons foi preparado a partir do $( \pm$ )ácido pipecólico protegido com $\mathrm{Cbz} 57$ após redução com $\mathrm{BH}_{3} \mathrm{SMe}_{2} / \mathrm{THF}(97 \%)^{223}$ e oxidação de Swern $(90 \%)^{101}$ conforme procedimento descrito e os dados espectroscópicos estão de acordo com os reportados. ${ }^{102,224} \mathrm{~A}$ reação de olefinação com o diazofostonato 32 foi finalizada em $-30^{\circ} \mathrm{C}$.

58: $R_{f} 0.23(40 \%$ AcOEt/Hexano).

58: ${ }^{1} \mathrm{H}$ RMN (400 MHz, $\left.\mathrm{CDCl}_{3}\right) \delta 9.61(\mathrm{~s}, 1 \mathrm{H}), 7.43-7.27(\mathrm{~m}, 5 \mathrm{H}), 5.22-5.11(\mathrm{~m}, 2 \mathrm{H})$, $4.79-4.64(\mathrm{~m}, 1 \mathrm{H}), 4.27-3.98(\mathrm{~m}, 1 \mathrm{H}), 3.09-2.81(\mathrm{~m}, 1 \mathrm{H}), 2.28-2.19(\mathrm{~m}, 1 \mathrm{H})$, $1.78-1.61(\mathrm{~m}, 3 \mathrm{H}), 1.53-1.34(\mathrm{~m}, 1 \mathrm{H}), 1.35-1.14(\mathrm{~m}, 1 \mathrm{H})$. 
( \pm ) Carboxilato de (E)-benzil-2-(4-diazo-3-oxobut-1-en-1-il)piperidina-1 (55)

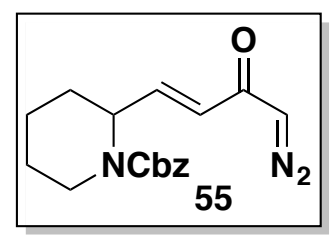

( \pm ) Carboxilato de (E)-benzil-2-(4-diazo-3-oxobut-1-en-1-il)piperidina-1 (55)

\begin{tabular}{|c|c|}
\hline$(55)$ & 1.46 mmol, 456 mg, 92\% como um óleo amarelo estável; \\
\hline $\mathbf{R}_{\mathbf{f}}$ & 0.33 (50\% AcOEt/hexano); \\
\hline${ }^{1}$ H RMN & $\begin{array}{l}\left(400 \mathrm{MHz}, \mathrm{CDCl}_{3}\right) \delta 7.47-7.30(\mathrm{~m}, 5 \mathrm{H}), 6.78(\mathrm{dd}, J=15.6,4.3 \mathrm{~Hz}, 1 \mathrm{H}), \\
5.91(\mathrm{~d}, J=14.9 \mathrm{~Hz}, 1 \mathrm{H}), 5.25(\mathrm{~s}, 1 \mathrm{H}), 5.16(\mathrm{~d}, J=12.3 \mathrm{~Hz}, 1 \mathrm{H}), 5.12 \\
(\mathrm{~d}, J=12.4 \mathrm{~Hz}, 1 \mathrm{H}), 5.03(\mathrm{~s}, 1 \mathrm{H}), 4.07(\mathrm{~d}, J=12.8 \mathrm{~Hz}, 1 \mathrm{H}), 2.88(\mathrm{t}, J= \\
11.4 \mathrm{~Hz}, 1 \mathrm{H}), 1.89-1.60(\mathrm{~m}, 4 \mathrm{H}), 1.52-1.36(\mathrm{~m}, 2 \mathrm{H}) ;\end{array}$ \\
\hline${ }^{13} \mathrm{C}$ RMN & $\begin{array}{l}\left(100 \mathrm{MHz}, \mathrm{CDCl}_{3}\right) \delta 183.8,155.6,142.8,136.6,128.5,128.3,128.0 \\
127.9,67.3,56.0,52.0,40.4,29.1,25.2,19.7\end{array}$ \\
\hline FTIR & $\begin{array}{l}\left(\text { puro, } \mathrm{cm}^{-1}\right) 3076,3029,2933,2852,2100,1693,1654,1606,1415 \\
\text { 1359, 1170; }\end{array}$ \\
\hline HRMS & $\begin{array}{l}\text { (ESI) Calculado para } \mathrm{C}_{17} \mathrm{H}_{19} \mathrm{~N}_{3} \mathrm{NaO}_{3}\left[\mathrm{M}+\mathrm{Na}^{+} 336.13186 \text {, encontrado }\right. \\
336.13092 ;\end{array}$ \\
\hline
\end{tabular}


Carbamato de (S,E)-tert-butil(8-diazo-2-metil-7-oxooct-5-en-4-il) (56)

Preparo do (S)-N-Boc-Leucinal 60

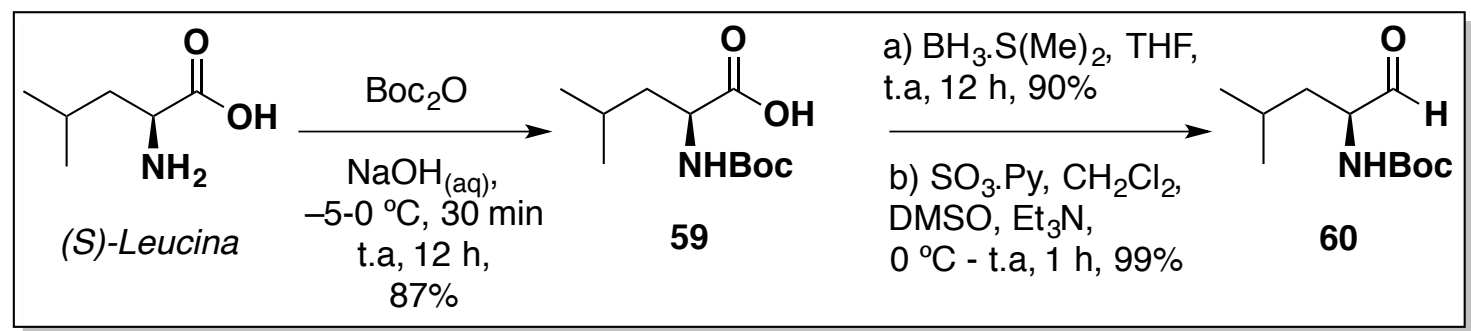

Obs.: Para fazer a redução do (S)-N-Boc-Leucina com borana, diluir o ácido em tolueno $(10 \mathrm{~mL})$ e remover o solvente em vácuo por 3 vezes. Sem este procedimento, a reação fornece rendimentos baixos (20-30\%). O N-Boc-L-Leucinal 60 foi preparado a partir do álcool correspondente $N$-Boc-L-Leucinol através da reação de oxidação de Parikh-Doering $\left(\mathrm{SO}_{3} \cdot \mathrm{Py}, \mathrm{CH}_{2} \mathrm{Cl}_{2}, \mathrm{DMSO} \mathrm{Et}_{3} \mathrm{~N}\right)^{104}$ e imediatamente utilizado na reação de olefinação. Todos os dados espectroscópicos estão de acordo com os descritos na literatura. Cuidado! A extração do aldeído deve ser cuidadosamente realizada em banho de gelo, resfriando todas as vidrarias, como por exemplo, o erlenmeyer, o funil de extração e o balão no qual o solvente será evaporado. Não aumentar a temperatura do banho do rota-evaporador durante a concentração do produto (acrescentar gelo no banho). Além destes cuidados, a reação de HWE foi finalizada em $-40{ }^{\circ} \mathrm{C}$ para evitar a racemização. Nestas condições, não foi possível verificar qualquer alteração na integridade do centro quiral.

60: $R_{f} 0.3$ (30\% AcOEt/Hexano).

60: ${ }^{1} \mathrm{H}$ RMN (500 MHz, $\left.\mathrm{CDCl}_{3}\right) \delta 9.59(\mathrm{~s}, 1 \mathrm{H}), 4.91(\mathrm{~s}, 1 \mathrm{H}), 4.25(\mathrm{~s}, 1 \mathrm{H}), 1.83-1.71$ (m, 1H), $1.70-1.61(\mathrm{~m}, 1 \mathrm{H}), 1.45(\mathrm{~s}, 9 \mathrm{H}), 1.38$ (ddd, J = 14.0, 9.3, $5.6 \mathrm{~Hz}, 1 \mathrm{H}), 0.97$ (dd, $J=6.6,3.0 \mathrm{~Hz}, 6 \mathrm{H}$ ). 
Carbamato de (S,E)-tert-butil(8-diazo-2-metil-7-oxooct-5-en-4-il) (56)

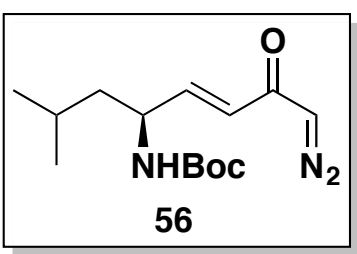

Carbamato de (S,E)-tert-butil(8-diazo-2-metil-7-oxooct-5-en-4-il) (56)

(56) $\quad 0.88 \mathrm{mmol}, 247 \mathrm{mg}, 83 \%$ como um sólido amarelo;

$\mathbf{R}_{\mathbf{f}} \quad 0.38(30 \%$ AcOEt/hexano);

${ }^{1} \mathrm{H}$ RMN $\left(500 \mathrm{MHz}, \mathrm{CDCl}_{3}\right) \delta 6.66(\mathrm{dd}, J=15.3,5.8 \mathrm{~Hz}, 1 \mathrm{H}), 6.06(\mathrm{~d}, J=15.3 \mathrm{~Hz}$, $1 \mathrm{H}), 5.32(\mathrm{~s}, 1 \mathrm{H}), 4.45(\mathrm{~s}, 1 \mathrm{H}), 4.30(\mathrm{~s}, 1 \mathrm{H}), 1.74-1.55(\mathrm{~m}, 2 \mathrm{H}), 1.43$ (s, 9H), 1.38 (t, J = 7.1 Hz, 1H), $0.92(\mathrm{~d}, J=6.6 \mathrm{~Hz}, 6 \mathrm{H})$;

${ }^{13}$ C RMN $\quad\left(125 \mathrm{MHz}_{2} \mathrm{CDCl}_{3}\right) \delta 184.4,155.2,144.7,126.2,79.9,55.9,50.1,44.1$, $31.1,29.8,28.5,24.9,22.8,22.4$;

FTIR (puro, $\mathrm{cm}^{-1}$ ) 3365, 3105, 2968, 2929, 2914, 2100, 1680, 1660, 1614, $1521,1367,1330,1284,1238,1172,1157,1105,1004,760$;

HRMS (ESI) Calculado para $\mathrm{C}_{14} \mathrm{H}_{23} \mathrm{~N}_{3} \mathrm{NaO}_{3}[\mathrm{M}+\mathrm{Na}]^{+} 304.16316$, encontrado 304.1646;

P.F $\quad 94-96^{\circ} \mathrm{C}$;

$[\alpha]_{D}^{23}-34.1\left(c 0.66, \mathrm{CHCl}_{3}\right)$;

HPLC Coluna CHIRALPAK® AD-H (tamanho de partícula: $5 \mu \mathrm{m}$; dimensão: $4.6 \mathrm{~mm} \times 250 \mathrm{~mm}$ ), $98: 2$ (hexano:isopropanol), $1.5 \mathrm{~mL} / \mathrm{min}, \lambda 254 \mathrm{~nm}$. 

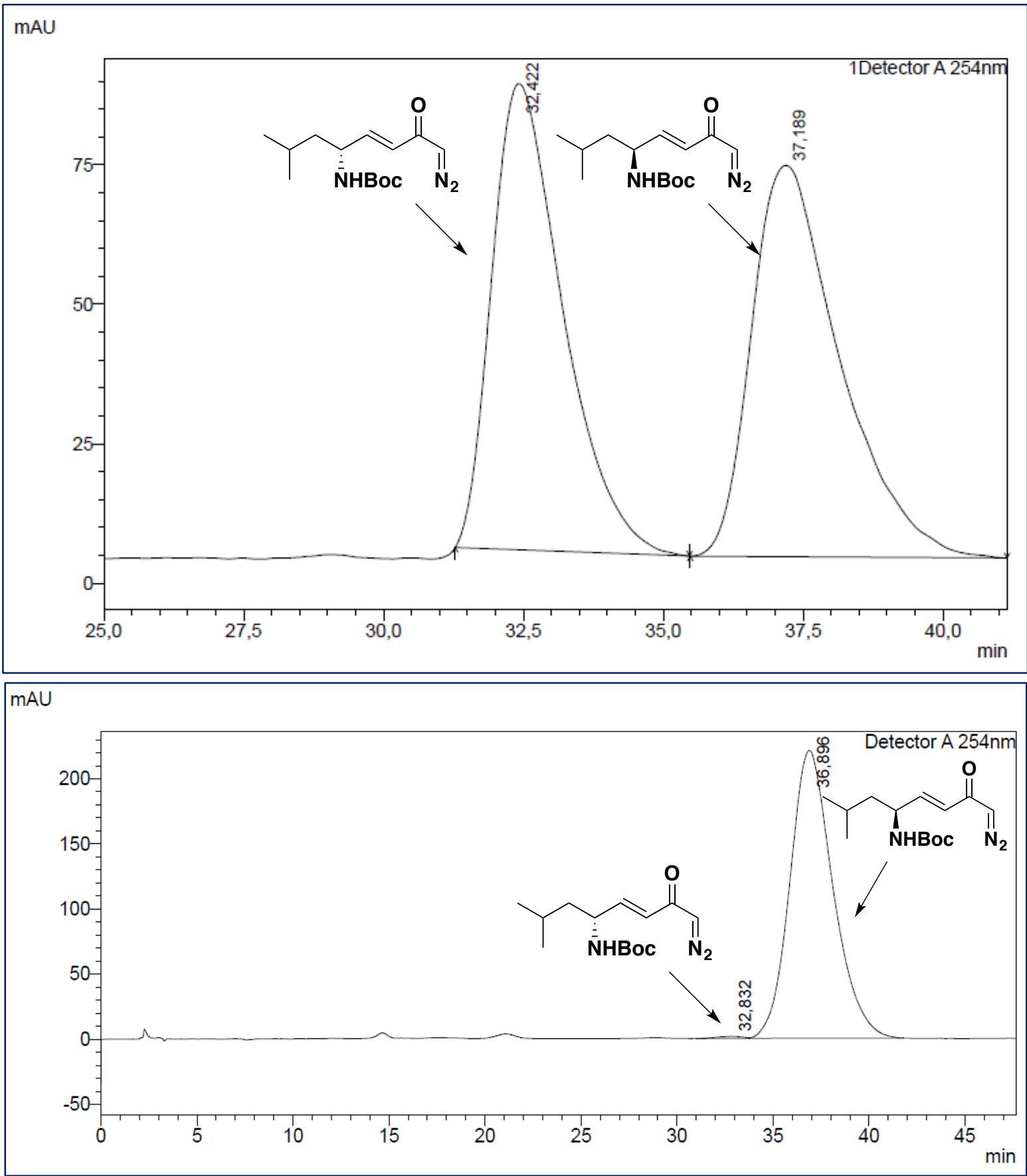

\begin{tabular}{|c|c|c|c|c|c|c|c|}
\hline \multirow{2}{*}{\multicolumn{8}{|c|}{ Detector A 254nm }} \\
\hline & & & & & & & \\
\hline Peak\# & et. Time & Area & Height & Conc. & Unit & Mark & Name \\
\hline 1 & 32,832 & 139235 & 1495 & 0,402 & & V & \\
\hline 2 & 36,896 & 34496772 & 220893 & 99,598 & & V & \\
\hline Total & & 34636007 & 222388 & & & & \\
\hline
\end{tabular}

Figura 44 Cromatograma obtido por análise HPLC para a diazocetona 56. 


\subsubsection{Procedimento usando DIPEA/LiCl}

Preparo fenilglioxal 121

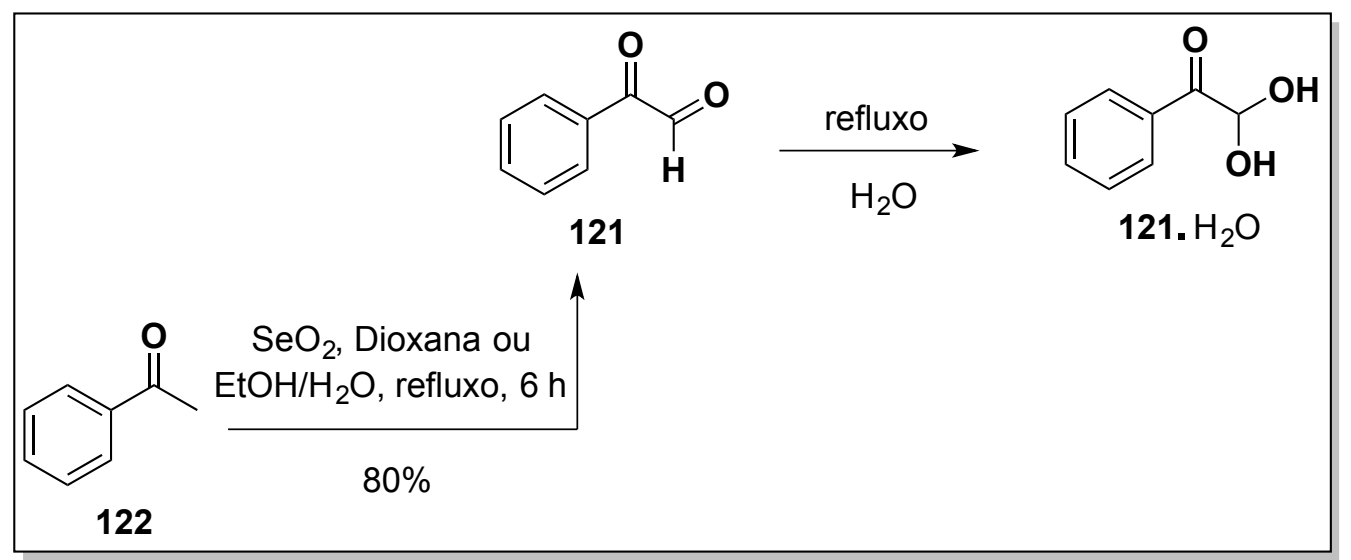

Em um balão de $250 \mathrm{~mL}$ foram adicionados $\mathrm{SeO}_{2}(9.0 \mathrm{~g}, 0.08 \mathrm{mmol}, 1$ equiv.) como um sólido, $\mathrm{EtOH}(50 \mathrm{ml})$ e $\mathrm{H}_{2} \mathrm{O}(4 \mathrm{~mL})$. A mistura foi aquecida a $50-55^{\circ} \mathrm{C}$ e agitada até que todo o sólido escuro de $\mathrm{SeO}_{2}$ fosse dissolvido. Após, um condensador de refluxo foi fixado e acetofenona $122(9.6 \mathrm{~mL}, 0.08 \mathrm{~mL}, 1$ equiv.) adicionada gota a gota a reação. Durante a adição da acetofenona, a reação passa de incolor para amarelo pardo, chegando em laranja, vermelho, bordô e por fim marrom escuro de acordo com adição. Após $2 \mathrm{~h}$ de refluxo, a solução se tornou mais clara com formação de um precipitado. A solução foi refluxada por mais $4 \mathrm{~h}$ até que o precipitado de selênio foi decantado e então filtrado. A filtração pode ser realizada em papel filtro, entretanto, recomenda-se o uso de Celite para evitar a contaminação da solução amarela com partículas de selênio. O solvente foi removido em vácuo e então destilado em pressão reduzida para fornecer o fenilglioxal 121 anidro como um óleo amarelo intenso em $80 \%$ de rendimento. $O$ bruto reacional pode também ser colunado em coluna $\left(R_{f} 0.25\right.$ AcOEt/Hex $40 \%$ ). Para armazenagem, utilizar um refluxo em água para levar a formação de 121. $\mathrm{xH}_{2} \mathrm{O}$. Os dados espectroscópicos estão de acordo com os descritos na literatura. ${ }^{225,226}$ 
(E)-5-diazo-1-fenilpent-2-ena-1,4-diona (53)

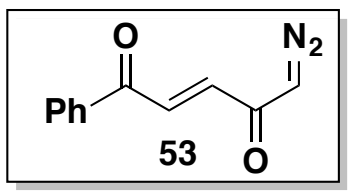

Em uma suspensão resfriada a $0^{\circ} \mathrm{C}$ e em atmosfera de argônio de $\mathrm{LiCl}(19 \mathrm{mg}$, $0.45 \mathrm{mmol}, 1.0$ equiv.) previamente seco em estufa (e em alto vácuo) em acetonitrila seca (3.8 mL) foi adicionado lentamente uma solução $0.1 \mathrm{M}$ de diazofosfonato $32 \mathrm{em}$ MeCN (100 mg, 0.45 mmol, 1.0 equiv.). Após, $80 \mu \mathrm{L}$ de DIPEA (0.45 mmol, 1 equiv.) foi adicionado lentamente. A solução passou de amarelo pardo para alaranjado claro. Após 5 minutos agitado na mesma temperatura, uma solução $0.1 \mathrm{M}$ do fenilaglioxal em MeCN (73.0 mg, $0.54 \mathrm{mmol}, 1.2$ equiv.) foi adicionada gota a gota na mistura reacional. A reação foi agitada em $0{ }^{\circ} \mathrm{C}$ por $24 \mathrm{~h}$ (na geladeira) e em seguida finalizada pela adição de $2 \mathrm{~mL}$ de $\mathrm{NH}_{4} \mathrm{Cl}$. O resíduo foi extraído com $\mathrm{CH}_{2} \mathrm{Cl}_{2}(2 \times 15 \mathrm{~mL})$ e seco com $\mathrm{MgSO}_{4}$. A purificação em coluna cromatográfica usando 5-50\% de AcOEt/Hexano forneceu a diazocetona $\mathbf{5 3} \mathrm{com} 60 \%$ de rendimento. $(E+Z=78 \%)$.

\begin{tabular}{|c|c|}
\hline \multicolumn{2}{|r|}{$(E)$-5-diazo-1-fenilpent-2-ena-1,4-diona (53) } \\
\hline $\mathbf{R}_{\mathbf{f}}$ & 0.50 (40\% AcOEt/hexano).; \\
\hline${ }^{1} \mathrm{H}$ RMN & $\begin{array}{l}\left(500 \mathrm{MHz}, \mathrm{CDCl}_{3}\right)(\delta 8.05-8.01(\mathrm{~m}, 2 \mathrm{H}), 7.90(\mathrm{~d}, J=15.2 \mathrm{~Hz}, 1 \mathrm{H}), 7.66 \\
-7.61(\mathrm{~m}, 1 \mathrm{H}), 7.55-7.50(\mathrm{~m}, 2 \mathrm{H}), 7.03(\mathrm{~d}, J=14.9 \mathrm{~Hz}, 1 \mathrm{H}), 5.58(\mathrm{~s}, \\
1 \mathrm{H}) ;\end{array}$ \\
\hline${ }^{13} \mathrm{C}$ RMN & $\begin{array}{l}\left(125 \mathrm{MHz}, \mathrm{CDCl}_{3}\right) \delta 189.6,182.8,136.9,136.8,133.8,132.0,128.9, \\
128.8,58.3\end{array}$ \\
\hline FTIR & $\begin{array}{l}\left.\text { (puro, } \mathrm{cm}^{-1}\right) \text { 3088, 2959, 2926, 2855, 2156, 2108, 1690, 1666, 1624, } \\
1599,1449,1379,1360,1290,1217,1146,1007,976,712\end{array}$ \\
\hline HRMS & $\begin{array}{l}\text { (ESI) Calculado para } \mathrm{C}_{11} \mathrm{H}_{9} \mathrm{~N}_{2} \mathrm{O}_{2}^{+}[\mathrm{M}+\mathrm{H}]^{+} 201.0659 \text { encontrado } \\
\text { 201.0599; }\end{array}$ \\
\hline
\end{tabular}


6.4 Procedimento geral para o rearranjo de Wolff na presença de aminas (lâmpada de Xe)

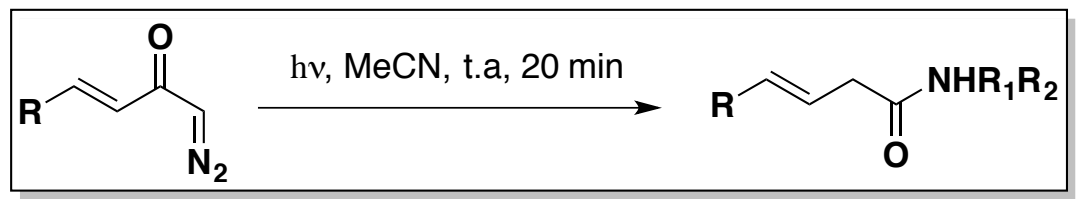

(E)-N-fenilhept-3-enamida (63)

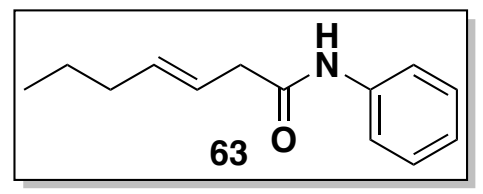

A uma solução de diazocetona $54(29.7 \mathrm{mg}, 0.215 \mathrm{mmol})$ em acetonitrila seca (10.0 mL) foi adicionada $20 \mu \mathrm{L}$ (1.0 equiv.) de anilina e então irradiada com uma lâmpada Osram 150 de Xenônio em forma de arco. A solução foi agitada durante 20 min a temperatura ambiente e em seguida, o solvente foi removido em evaporador rotativo. Purificação em cromatografia flash (30\% AcOEt/hexano) forneceu a amida 63 como um sólido branco (33.2 mg, $0.163 \mathrm{mmol}, 76 \%$ ):

(E)-N-fenilhept-3-enamida (63).

(63) 76\% como um sólido branco;

$\mathbf{R}_{\mathbf{f}} \quad 0.42(30 \%$ AcOEt/hexano);

${ }^{1} \mathrm{H}$ RMN $\left.500 \mathrm{MHz}, \mathrm{CDCl}_{3}\right) \delta 7.50(\mathrm{~d}, J=7.7 \mathrm{~Hz}, 2 \mathrm{H}), 7.39(\mathrm{t}, J=7.0 \mathrm{~Hz}, 3 \mathrm{H}), 7.10$ $(\mathrm{t}, J=7.4 \mathrm{~Hz}, 1 \mathrm{H}), 5.78-5.70(\mathrm{~m}, 1 \mathrm{H}), 5.67-5.58(\mathrm{~m}, 1 \mathrm{H}), 3.11(\mathrm{~d}, J$ $=7.0 \mathrm{~Hz}, 2 \mathrm{H}$ ), 2.10 (q, $J=6.9 \mathrm{~Hz}, 2 \mathrm{H}$ ), 1.46 (sext, $J=7.4 \mathrm{~Hz}, 2 \mathrm{H}$ ), 0.94 (t, J = 7.4 Hz, 3H);

${ }^{13}$ C RMN $\quad\left(125 \mathrm{MHz}, \mathrm{CDCl}_{3}\right) \delta 169.4,137.8,137.4,129.0,124.3,122.5,119.6$, 41.7, 34.6, 22.3, 13.7;

FTIR (puro, $\mathrm{cm}^{-1}$ ) 3300, 3197, 3138, 3026, 2958, 2927, 1658, 1600, 1546, 1498, 1442, 1327, 1251, 1176, 1112, 1080, 1031, 970, 754, 692;

HRMS (ESI) Calculado para $\mathrm{C}_{13} \mathrm{H}_{17} \mathrm{NNaO}[\mathrm{M}+\mathrm{Na}]^{+} 226.1202$, encontrado 226.1202;

P.F $\quad 33-35^{\circ} \mathrm{C}$; 
Carboxilato de (E)- benzil 2-(4-(benzilamino)-4-oxobut-1-en-1-il)piperidina-1 (61)

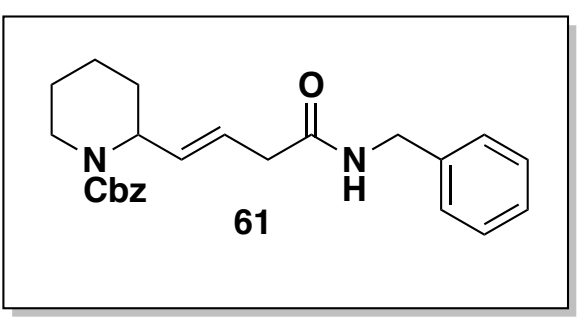

Carboxilato de (E)- benzil 2-(4-(benzilamino)-4-oxobut-1-en-1-il)piperidina-1 (61)

(61) Não foi necessária purificação, 98\% como um óleo incolor;

$\mathbf{R}_{\mathbf{f}} \quad 0.28$ (50\% AcOEt/hexano);

${ }^{1} \mathrm{H}$ RMN $\quad\left(500 \mathrm{MHz}, \mathrm{CDCl}_{3}\right) \delta 7.40-7.19(\mathrm{~m}, 10 \mathrm{H}), 5.95(\mathrm{~s}, 1 \mathrm{H}), 5.66-5.57(\mathrm{~m}$, 2H), $5.09-5.02(\mathrm{~m}, 2 \mathrm{H}), 4.84(\mathrm{~s}, 1 \mathrm{H}), 4.40(\mathrm{~d}, J=5.7 \mathrm{~Hz}, 2 \mathrm{H}), 3.99(\mathrm{~d}$, $J=13.1 \mathrm{~Hz}, 1 \mathrm{H}), 3.06-2.98(\mathrm{~m}, 2 \mathrm{H}), 2.86(\mathrm{t}, J=12.0 \mathrm{~Hz}, 1 \mathrm{H}), 1.76-$ $1.65(\mathrm{~m}, 2 \mathrm{H}), 1.63-1.52(\mathrm{~m}, 2 \mathrm{H}), 1.50-1.36(\mathrm{~m}, 2 \mathrm{H})$;

${ }^{13} \mathrm{C}$ RMN $\quad\left(100 \mathrm{MHz}, \mathrm{CDCl}_{3}\right) \delta 170.4,155.7,138.1,136.8,133.7,128.7,128.4$, $127.9,127.7,127.7,127.5,124.4,67.0,52.2,43.6,40.3,40.1,29.0$, 25.3, 19.4;

FTIR (puro, $\mathrm{cm}^{-1}$ ) 3510, 3307, 3064, 3032, 2937, 2858, 1693, 1654, 1540, 1423, 1263, 1170, 1091, 1029, 972, 916, 744, 698;

HRMS (ESI) Calculado para $\mathrm{C}_{24} \mathrm{H}_{28} \mathrm{~N}_{2} \mathrm{NaO}_{3}[\mathrm{M}+\mathrm{Na}]^{+} 415.1992$, encontrado 415.1990;

*escala de $0.215 \mathrm{mmol}$ para todos os exemplos seguintes. 
Carbamato de $(S, E)$-tert-butil (2-metil-8-oxo-8-(fenilamino)oct-5-en-4-il) (62).

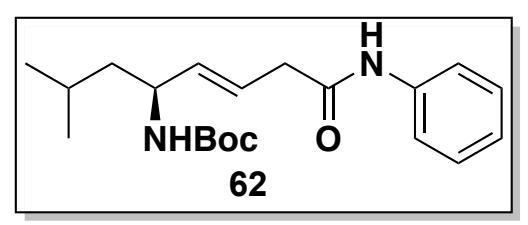

Carbamato de (S,E)-tert-butil (2-metil-8-oxo-8-(fenilamino)oct-5-en-4-il) (62)

\begin{tabular}{|c|c|}
\hline$(62)$ & $\begin{array}{l}\text { Purificação por cromatografia flash (30\% AcOEt/hexano), } 70 \% \text { como um } \\
\text { óleo incolor; }\end{array}$ \\
\hline $\mathbf{R}_{\mathbf{f}}$ & 0.43 (30\% AcOEt/hexano); \\
\hline${ }^{1}$ H RMN & $\begin{array}{l}\left(400 \mathrm{MHz}, \mathrm{CDCl}_{3}\right) \delta 8.09(\mathrm{~s}, 1 \mathrm{H}), 7.67(\mathrm{~d}, J=7.6 \mathrm{~Hz}, 2 \mathrm{H}), 7.35-7.27 \\
(\mathrm{~m}, 2 \mathrm{H}), 7.08(\mathrm{t}, J=7.4 \mathrm{~Hz}, 1 \mathrm{H}), 5.79(\mathrm{dt}, J=15.0,7.5 \mathrm{~Hz}, 1 \mathrm{H}), 5.56(\mathrm{dd}, \\
J=15.4,7.0 \mathrm{~Hz}, 1 \mathrm{H}), 4.56(\mathrm{~s}, 1 \mathrm{H}), 4.15-4.01(\mathrm{~m}, 1 \mathrm{H}), 3.15(\mathrm{~d}, J= \\
7.4 \mathrm{~Hz}, 2 \mathrm{H}), 1.69(\mathrm{sep}, J=6.7 \mathrm{~Hz}, 1 \mathrm{H}), 1.48-1.34(\mathrm{~m}, 11 \mathrm{H}), 0.94(\mathrm{dd}, \\
J=6.6,1.2 \mathrm{~Hz}, 6 \mathrm{H}) ;\end{array}$ \\
\hline${ }^{13} \mathrm{C}$ RMN & $\begin{array}{l}\left(100 \mathrm{MHz}, \mathrm{CDCl}_{3}\right) \delta 169.2,155.6,138.2,129.0,128.8,124.1,123.1, \\
120.1,79.6,51.7,40.9,28.41,28.3,24.6,22.5 ;\end{array}$ \\
\hline FTIR & $\begin{array}{l}\left.\text { (puro, } \mathrm{cm}^{-1}\right) \text { 3319, 2956, 2929, 2870, 1670, 1697, 1600, 1541, 1498, } \\
\text { 1442, 1367, 1311, 1249, 1249, 1172, 1026, 972, 750; }\end{array}$ \\
\hline HRMS & $\begin{array}{l}\text { (ESI) Calculado para } \mathrm{C}_{20} \mathrm{H}_{31} \mathrm{~N}_{2} \mathrm{O}_{3}\left[\mathrm{M}+\mathrm{H}^{+} \text {347.23292, encontrado }\right. \\
\text { 347.23260; }\end{array}$ \\
\hline$[\alpha]_{D}^{23}$ & $+18.8\left(\right.$ c $\left.0.1, \mathrm{CHCl}_{3}\right)$ \\
\hline HPLC & $\begin{array}{l}\text { Coluna: CHIRALPAK® AD-H (tamanho da partícula: } 5 \mu \mathrm{m} \text {; dimensão: } \\
4.6 \mathrm{~mm} \times 250 \mathrm{~mm} \text { ), } 95: 5 \text { (hexano:isopropanol), } 1,5 \mathrm{~mL} / \mathrm{min}, \lambda 254 \mathrm{~nm} \text {. }\end{array}$ \\
\hline
\end{tabular}



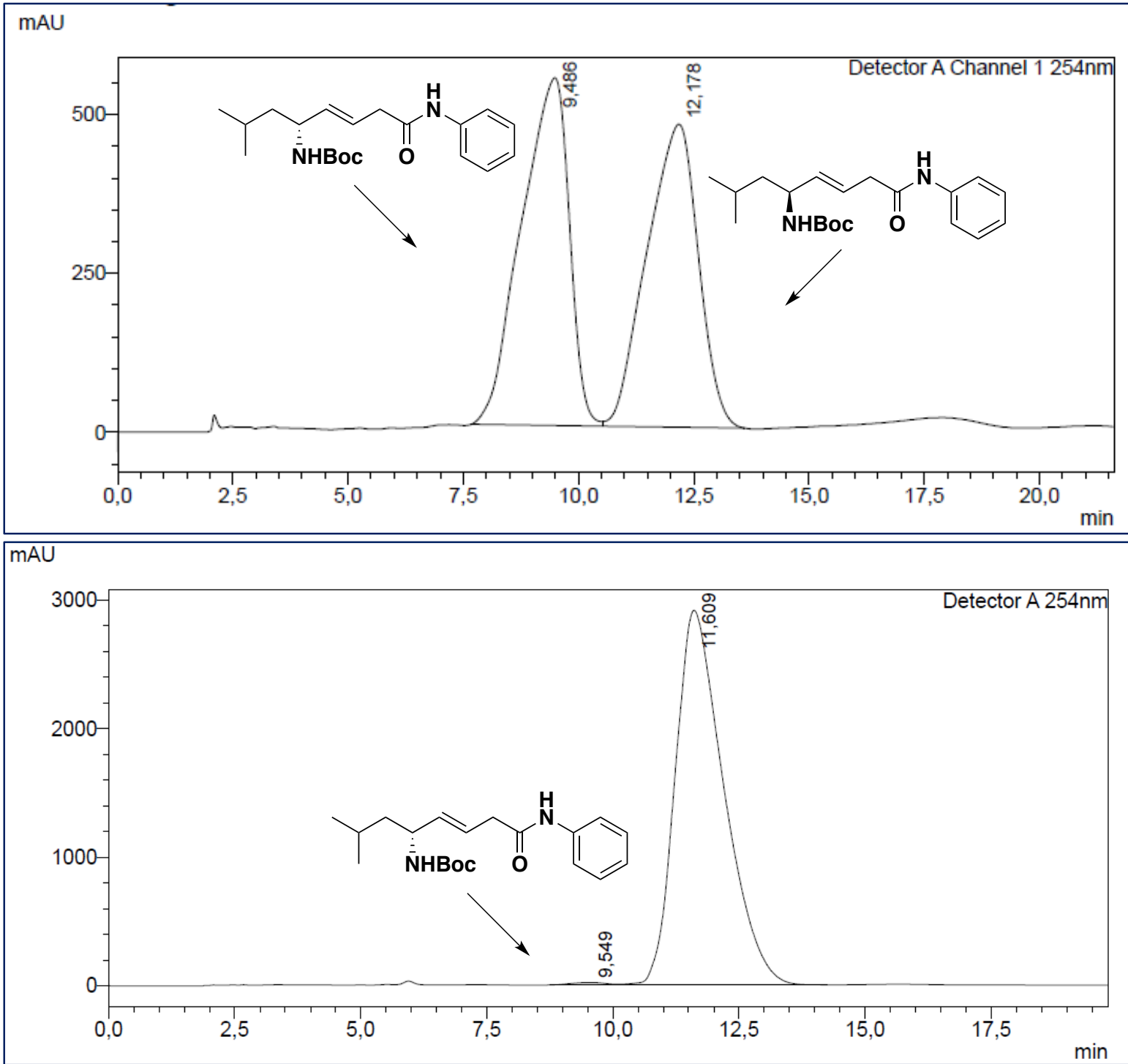

<Peak Table>

Detector A 254nm

\begin{tabular}{|r|r|r|r|r|r|r|r|}
\hline Peak\# & Ret. Time & \multicolumn{1}{c|}{ Area } & Height & \multicolumn{1}{c|}{ Conc. } & Unit & Mark & Name \\
\hline 1 & 9,549 & 975301 & 20099 & 0,496 & & & \\
\hline Total & 11,609 & 195578036 & 2915194 & 99,504 & & $\mathrm{~V}$ & \\
\hline
\end{tabular}

Figura 45 Cromatograma obtido por análise HPLC para a diazocetona 62. 
(E)-N-(4-metóxifenil)hept-3-enamida (64)

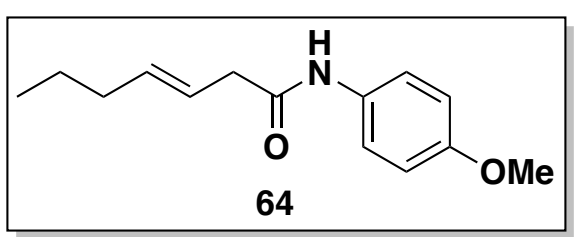

\section{(E)-N-(4-metóxifenil)hept-3-enamida (64)}

(64) Purificação por cromatografia flash (30\% AcOEt/hexano), 50\% como um sólido branco;

$\mathbf{R}_{\mathbf{f}} \quad 0.45$ (30\% EtOEt/hexano);

${ }^{1} \mathrm{H}$ RMN $\quad\left(500 \mathrm{MHz}, \mathrm{CDCl}_{3}\right) \delta 7.41-7.38(\mathrm{~m}, 2 \mathrm{H}), 7.27(\mathrm{~s}, 1 \mathrm{H}), 6.87-6.83(\mathrm{~m}$, $2 \mathrm{H}), 5.77-5.58(\mathrm{~m}, 2 \mathrm{H}), 3.78(\mathrm{~s}, 3 \mathrm{H}), 3.09(\mathrm{dd}, J=7.0,0.7 \mathrm{~Hz}, 2 \mathrm{H})$, 2.09 (q, $J=7.1 \mathrm{~Hz}, 2 \mathrm{H}), 1.45$ (sext, $J=7.4 \mathrm{~Hz}, 2 \mathrm{H}$ ), $0.94(\mathrm{t}, J=7.4 \mathrm{~Hz}$, $3 \mathrm{H})$;

${ }^{13}$ C RMN $\quad\left(125 \mathrm{MHz}, \mathrm{CDCl}_{3}\right) \delta 169.2,156.4,137.3,130.9,122.6,121.6,114.1$, 55.5, 41.4, 34.64, 22.3, 13.7;

FTIR (puro, $\mathrm{cm}^{-1}$ ) 3311, 2954, 2926, 1654, 1600, 1541, 1514, 1465, 1409, 1247, 1172, 1029, 964, 825;

HRMS (ESI) Calculado para $\mathrm{C}_{14} \mathrm{H}_{19} \mathrm{NNaO}_{2}\left[\mathrm{M}+\mathrm{Na}^{+}, 256.13082\right.$ encontrado 256.13080;

P.F $\quad 71-77^{\circ} \mathrm{C}$; 
(E)-N-benzilhept-3-enamida (65)

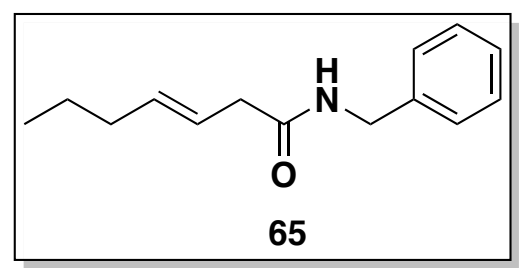

\section{(E)-N-benzilhept-3-enamida (65)}

(65) Não foi necessária purificação, 90\% de rendimento como um sólido branco;

$\mathbf{R}_{\mathbf{f}} \quad 0.13(20 \%$ AcOEt/hexano);

${ }^{1}$ H RMN (400 MHz, $\left.\mathrm{CDCl}_{3}\right) \delta 7.37-7.23(\mathrm{~m}, 5 \mathrm{H}), 5.95(\mathrm{~s}, 1 \mathrm{H}), 5.67-5.48(\mathrm{~m}$, $2 \mathrm{H}), 4.43(\mathrm{~d}, J=5.8 \mathrm{~Hz}, 2 \mathrm{H}), 2.99(\mathrm{~d}, J=7.4 \mathrm{~Hz}, 2 \mathrm{H}), 2.05(\mathrm{q}, J=7.4 \mathrm{~Hz}$, 2H), 1.38 (sext, $J=7.4 \mathrm{~Hz}, 2 \mathrm{H}$ ), 0.87 (t, $J=7.4 \mathrm{~Hz}, 3 \mathrm{H}$ );

${ }^{13}$ C RMN $\quad\left(100 \mathrm{MHz}, \mathrm{CDCl}_{3}\right) \delta 171.4,138.4,136.7,128.8,127.8,127.6,122.7$, 43.7, 40.7, 34.7, 22.4, 13.7;

FTIR (puro, $\mathrm{cm}^{-1}$ ) 3294, 3084, 3064, 3032, 2956, 2926, 2872, 1639, 1546, 1454, 1415, 1369, 1238, 1080, 1028, 964, 694;

HRMS (ESI) Calculado para $\mathrm{C}_{14} \mathrm{H}_{20} \mathrm{NNaO}[\mathrm{M}+\mathrm{Na}]^{+} 240.1359$, encontrado 240.1360

P.F $\quad 38-41^{\circ} \mathrm{C}$; 
(E)-N-ciclohexilhept-3-enamida (66)

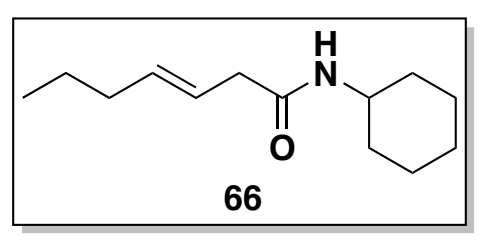

\section{(E)-N-ciclohexilhept-3-enamida (66)}

(66) Não foi necessária purificação, 95\% de rendimento como um sólido amarelo claro;

$\mathbf{R}_{\mathbf{f}} \quad 0.15$ (20\% AcOEt/hexano);

${ }^{1}$ H RMN $\quad\left(500 \mathrm{MHz} \mathrm{CDCl}_{3}\right) \delta 5.64-5.56(\mathrm{~m}, 1 \mathrm{H}), 5.54-5.45(\mathrm{~m}, 1 \mathrm{H}), 3.79-$ $3.69(\mathrm{~m}, 1 \mathrm{H}), 2.90(\mathrm{dd}, J=7.0,0.8 \mathrm{~Hz}, 2 \mathrm{H}), 2.03(\mathrm{q}, J=7.5 \mathrm{~Hz}, 2 \mathrm{H})$, $1.92-1.84(\mathrm{~m}, 2 \mathrm{H}), 1.71-1.63(\mathrm{~m}, 2 \mathrm{H}), 1.59(\mathrm{dq}, J=7.4,3.6 \mathrm{~Hz}, 1 \mathrm{H})$, $1.45-1.30(\mathrm{~m}, 4 \mathrm{H}), 1.20-1.05(\mathrm{~m}, 3 \mathrm{H}), 0.90(\mathrm{t}, J=7.4 \mathrm{~Hz}, 3 \mathrm{H})$;

${ }^{13}$ C RMN $\quad\left(125 \mathrm{MHz}, \mathrm{CDCl}_{3}\right) \delta 170.3,136.3,123.0,48.0,40.7,34.6,33.1,25.5$, 24.8, 22.3, 13.6;

FTIR (puro, $\mathrm{cm}^{-1}$ ) 3296, 3070, 2956, 2929, 2854, 1637, 1546, 1446, 1409, 1247, 1078, 970, 891;

HRMS (ESI) Calculado para $\mathrm{C}_{13} \mathrm{H}_{24} \mathrm{NO}[\mathrm{M}+\mathrm{H}]^{+} 210.1852$, encontrado 210.1859;

P.F $\quad 57-63^{\circ} \mathrm{C}$; 
(E)-N,N-dialilhept-3-enamida (67)

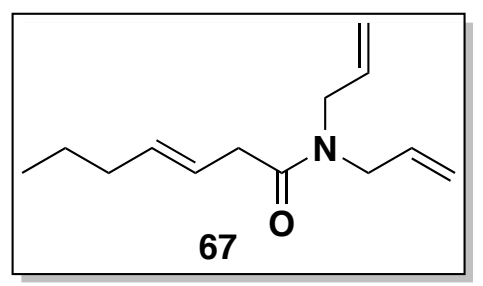

\section{(E)-N,N-dialilhept-3-enamida (67)}

(67) Não foi necessária purificação, 93\% de rendimento como um óleo incolor;

$\mathbf{R}_{\mathbf{f}} \quad 0.30$ (20\% AcOEt/hexano);

${ }^{1}$ H RMN (500 MHz, $\left.\mathrm{CDCl}_{3}\right) \delta 5.80-5.70(\mathrm{~m}, 2 \mathrm{H}), 5.61-5.48(\mathrm{~m}, 2 \mathrm{H}), 5.23-$ $5.08(\mathrm{~m}, 4 \mathrm{H}), 3.97(\mathrm{~d}, J=6.0 \mathrm{~Hz}, 2 \mathrm{H}), 3.87(\mathrm{dt}, J=4.8,1.6 \mathrm{~Hz}, 2 \mathrm{H}), 3.07$ (dd, $J=6.1,1.0 \mathrm{~Hz}, 2 \mathrm{H}), 2.04-1.98(\mathrm{~m}, 2 \mathrm{H}), 1.38$ (sext, $J=7.4 \mathrm{~Hz}$, $2 \mathrm{H}), 0.88(\mathrm{t}, \mathrm{J}=7.4 \mathrm{~Hz}, 3 \mathrm{H})$;

${ }^{13}$ C RMN $\quad\left(125 \mathrm{MHz}, \mathrm{CDCl}_{3}\right) \delta 171.6,133.8,133.3,133.0,123.1,117.2,116.7$, 49.2, 47.8, 37.5, 34.6, 22.3, 13.6;

FTIR (puro, $\mathrm{cm}^{-1}$ ) 3082, 2958, 2927, 2872, 1653, 1463, 1411, 1284, 1249, 1217, 1193, 1136, 1116, 993, 968, 921;

HRMS (ESI) Calculado para $\mathrm{C}_{13} \mathrm{H}_{21} \mathrm{NNaO}[\mathrm{M}+\mathrm{Na}]^{+} 230.1515$, encontrado 230.1519; 
Carboxilato de (E)-benzil2-(4-oxo-4-(fenilamino)but-1-en-1-il)piperidina-1 (68)

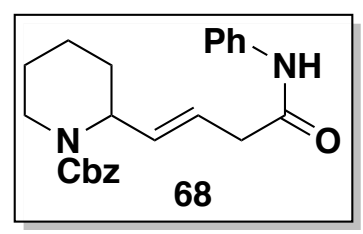

\section{Carboxilato de (E)-benzil2-(4-oxo-4-(fenilamino)but-1-en-1-il)piperidina-1 (68)}

(68) Não foi necessária purificação, 83\% como um óleo amarelo claro;

$\mathbf{R}_{\mathbf{f}} \quad 0.38$ (50\% AcOEt/hexano);

${ }^{1} \mathbf{H} \mathbf{R M N} \quad\left(400 \mathrm{MHz}, \mathrm{CDCl}_{3}\right) \delta 7.52(\mathrm{~d}, J=7.9 \mathrm{~Hz}, 2 \mathrm{H}), 7.37-7.27(\mathrm{~m}, 8 \mathrm{H}), 7.10$ (t, $J=7.9 \mathrm{~Hz}, 1 \mathrm{H}), 5.79-5.62(\mathrm{~m}, 2 \mathrm{H}), 5.13(\mathrm{~d}, J=4.3 \mathrm{~Hz}, 2 \mathrm{H}), 4.89-$ $4.83(\mathrm{~m}, 1 \mathrm{H}), 4.03(\mathrm{~d}, J=11.8 \mathrm{~Hz}, 1 \mathrm{H}), 3.15(\mathrm{~d}, J=6.5 \mathrm{~Hz}, 2 \mathrm{H}), 2.99(\mathrm{t}$, $J=11.8 \mathrm{~Hz}, 1 \mathrm{H}), 1.82-1.72(\mathrm{~m}, 2 \mathrm{H}), 1.69-1.61(\mathrm{~m}, 2 \mathrm{H}), 1.54-1.40$ $(\mathrm{m}, 2 \mathrm{H})$;

${ }^{13} \mathrm{C}$ RMN $\quad\left(125 \mathrm{MHz}, \mathrm{CDCl}_{3}\right) \delta 168.8,155.9,137.8,136.7,134.7,128.9,128.5$, $128.0,127.8,124.3,124.0,119.7,67.1,52.7,41.2,29.7,29.1,25.2$, 19.5

FTIR (puro, $\mathrm{cm}^{-1}$ ) 3506, 3311, 3062, 3034, 2926, 2854, 1693, 1674, 1600, $1544,1498,1442,1425,1344,1261,1172,1091,1029,972,906,756$, 696 ;

HRMS (ESI) Calculado para $\mathrm{C}_{23} \mathrm{H}_{27} \mathrm{~N}_{2} \mathrm{O}_{3}[\mathrm{M}+\mathrm{H}]^{+} 379.2016$, encontrado 379.2022; 
Carboxilato de (E)- benzil 2-(4-(diallilamino)-4-oxobut-1-en-1-il)piperidina-1 (69)

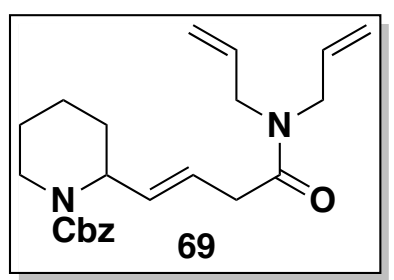

\section{Carboxilato de (E)- benzil 2-(4-(diallilamino)-4-oxobut-1-en-1-il)piperidina-1 (69)}

(69) Não foi necessária purificação, 98\% como um óleo incolor;

$\mathbf{R}_{\mathbf{f}} \quad 0.38(50 \%$ AcOEt/hexano);

${ }^{1} \mathbf{H}$ RMN $\quad\left(400 \mathrm{MHz}, \mathrm{CDCl}_{3}\right) \delta 7.37-7.27(\mathrm{~m}, 5 \mathrm{H}), 5.82-5.63(\mathrm{~m}, 3 \mathrm{H}), 5.56-$ $5.47(\mathrm{~m}, 1 \mathrm{H}), 5.24-5.08(\mathrm{~m}, 6 \mathrm{H}), 4.89(\mathrm{~s}, 1 \mathrm{H}), 4.08-3.95(\mathrm{~m}, 3 \mathrm{H}), 3.87$ - $3.82(\mathrm{~m}, 2 \mathrm{H}), 3.11(\mathrm{~d}, J=6.5 \mathrm{~Hz}, 2 \mathrm{H}), 2.92(\mathrm{td}, J=13.0,2.4 \mathrm{~Hz}, 1 \mathrm{H})$, $1.82-1.34(\mathrm{~m}, 6 \mathrm{H})$;

${ }^{13}$ C RMN (100 MHz, $\left.\mathrm{CDCl}_{3}\right) \delta 171.2155 .8,137.1,133.3,132.9,131.5,128.6$, $128.0,127.9,125.3,117.4,116.9,67.1,52.2,49.4,48.0,40.3,37.3$, 29.1, 25.7, 19.6;

FTIR (puro, $\mathrm{cm}^{-1}$ ) 3032, 2937, 2860, 1697, 1651, 1498, 1419, 1352, 1261, 1170, 1091, 1041, 993, 972, 923, 765, 744, 698;

HRMS (ESI) Calculado para $\mathrm{C}_{23} \mathrm{H}_{31} \mathrm{~N}_{2} \mathrm{O}_{3}[\mathrm{M}+\mathrm{H}]^{+} 383.2329$, encontrado 383.2336; 
Carboxilato de (E)-benzil 2-(4-(ciclohexilamino)-4-oxobut-1-en-1-il)piperidina-1 (70)

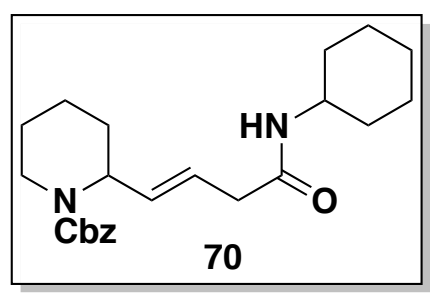

Carboxilato de (E)-benzil 2-(4-(ciclohexilamino)-4-oxobut-1-en-1-il)piperidina-1 (70)

(70) Não foi necessária purificação, 98\% como um óleo amarelo claro;

$\mathbf{R}_{\mathbf{f}} \quad 0.28(50 \%$ AcOEt/hexano);

${ }^{1}$ H RMN $\quad\left(500 \mathrm{MHz} \mathrm{CDCl}_{3}\right) \delta 7.38-7.27(\mathrm{~m}, 5 \mathrm{H}), 5.65-5.54(\mathrm{~m}, 2 \mathrm{H}), 5.48(\mathrm{~s}$, $1 \mathrm{H}), 5.13(\mathrm{~s}, 2 \mathrm{H}), 4.88-4.83(\mathrm{~m}, 1 \mathrm{H}), 4.03(\mathrm{~d}, \mathrm{~J}=13.0 \mathrm{~Hz}, 1 \mathrm{H}), 3.78-$ $3.68(\mathrm{~m}, 1 \mathrm{H}), 2.94(\mathrm{~d}, J=5.8 \mathrm{~Hz}, 2 \mathrm{H}), 1.91-1.82(\mathrm{~m}, 2 \mathrm{H}), 1.79-1.55$ $(\mathrm{m}, 8 \mathrm{H}), 1.55-1.29(\mathrm{~m}, 4 \mathrm{H}), 1.20-1.01(\mathrm{~m}, 3 \mathrm{H})$;

${ }^{13}$ C RMN (125 MHz, $\left.\mathrm{CDCl}_{3}\right) \delta 169.6,155.7,136.8,133.5,128.4,127.9,127.7$, $124.8,67.0,52.2,48.1,40.3,33.0,32.9,29.1,25.5,25.3,24.8,19.4$;

FTIR (puro, $\mathrm{cm}^{-1}$ ) 3305, 3064, 3034, 2933, 2854, 1699, 1651, 1543, 1448, 1423, 1352, 1336, 1261, 1170, 1091, 1041, 974, 734, 698;

HRMS (ESI) Calculado para $\mathrm{C}_{23} \mathrm{H}_{33} \mathrm{~N}_{2} \mathrm{O}_{3}[\mathrm{M}+\mathrm{H}]^{+} 385.2485$, encontrado 385.2483; 
(E)-N-(4-metóxifenil)-4-fenilbut-3-enamida (71)

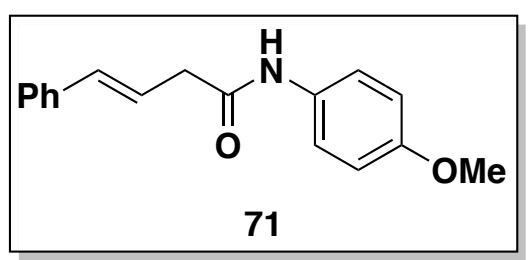

\section{(E)-N-(4-metóxifenil)-4-fenilbut-3-enamida (71)}

(71) Purificação por cromatografia flash (30\% AcOEt/hexano), 50\% como um sólido branco;

$\mathbf{R}_{\mathbf{f}} \quad 0.38$ (30\% AcOEt/hexano);

${ }^{1} \mathbf{H} \mathbf{R M N} \quad\left(500 \mathrm{MHz}, \mathrm{CDCl}_{3}\right) \delta 7.43-7.38(\mathrm{~m}, 4 \mathrm{H}), 7.34(\mathrm{t}, J=7.5 \mathrm{~Hz}, 2 \mathrm{H}), 7.30-$ $7.26(\mathrm{~m}, 2 \mathrm{H}), 6.87-6.83(\mathrm{~m}, 2 \mathrm{H}), 6.65-6.60(\mathrm{~m}, 1 \mathrm{H}), 6.38(\mathrm{dt}, J=15.8$, $7.3 \mathrm{~Hz}, 1 \mathrm{H}), 3.78(\mathrm{~s}, 3 \mathrm{H}), 3.31(\mathrm{dd}, J=7.3,1.2 \mathrm{~Hz}, 2 \mathrm{H})$;

${ }^{13} \mathrm{C}$ RMN $\quad\left(125 \mathrm{MHz}, \mathrm{CDCl}_{3}\right) \delta 168.6,156.5,136.4,135.3,130.7,127.9,126.4$, $121.9,121.9,116.4,114.0,55.4,41.7$

FTIR (puro, $\mathrm{cm}^{-1}$ ) 3288, 3197, 3140, 3082, 2931, 1654, 1606, 1558, 1512, 1411, 1298, 1247, 1170, 1033, 964, 829;

HRMS (ESI) Calculado para $\mathrm{C}_{17} \mathrm{H}_{17} \mathrm{NNaO}_{2}[\mathrm{M}+\mathrm{Na}]^{+} 290.11515$, encontrado 290.11545;

P.F $\quad 128-131^{\circ} \mathrm{C}$; 
(E)-N,4-difenilbut-3-enamida (72)

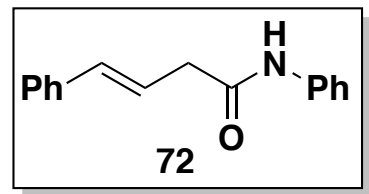

\section{(E)-N,4-difenilbut-3-enamida (72)}

\begin{tabular}{|c|c|}
\hline (72) & $\begin{array}{l}\text { Purificação por cromatografia flash (30\% AcOEt/hexano), } 64 \% \text { como um } \\
\text { sólido branco; }\end{array}$ \\
\hline $\mathbf{R}_{\mathbf{f}}$ & 0.42 (30\% AcOEt/hexano); \\
\hline${ }^{1} \mathrm{H}$ RMN & $\begin{array}{l}\left(500 \mathrm{MHz}, \mathrm{CDCl}_{3}\right) \delta 7.51(\mathrm{~d}, J=7.8 \mathrm{~Hz}, 2 \mathrm{H}), 7.41(\mathrm{~d}, J=7.4 \mathrm{~Hz}, 3 \mathrm{H}), \\
7.38-7.27(\mathrm{~m}, 5 \mathrm{H}), 7.12(\mathrm{q}, J=7.5 \mathrm{~Hz}, 1 \mathrm{H}), 6.63(\mathrm{~d}, J=15.9 \mathrm{~Hz}, 1 \mathrm{H}), \\
6.38(\mathrm{dt}, J=15.7,7.3 \mathrm{~Hz}, 1 \mathrm{H}), 3.33(\mathrm{dd}, J=7.3,0.8 \mathrm{~Hz}, 2 \mathrm{H}) ;\end{array}$ \\
\hline${ }^{13} \mathrm{C}$ RMN & $\begin{array}{l}\left(125 \mathrm{MHz}, \mathrm{CDCl}_{3}\right) \delta 168.8,137.6,136.4,135.4,129.0,128.8,128.0 \\
126.4,124.5,121.8,119.9,41.9\end{array}$ \\
\hline FTIR & $\begin{array}{l}\text { (puro, } \mathrm{cm}^{-1} \text { ) 3290, 3261, 3197, 3140, 3082, 3057, 3026, 2953, } 2922, \\
2850,1660,1647,1598,1550,1496,1442,1330,1307,1249,966,754 \\
690\end{array}$ \\
\hline HRMS & $\begin{array}{l}\text { (ESI) Calculado para } \mathrm{C}_{16} \mathrm{H}_{15} \mathrm{NNaO}[\mathrm{M}+\mathrm{Na}]^{+} 260.1046 \text {, encontrado } \\
260.1052 \text {; }\end{array}$ \\
\hline P.F & $87-91^{\circ} \mathrm{C}$ \\
\hline
\end{tabular}


(E)-N-benzil-4-fenilbut-3-enamida (73)

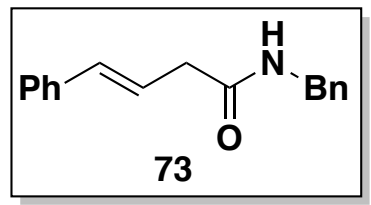

\section{(E)-N-benzil-4-fenilbut-3-enamida (73)}

(73) Purificação por cromatografia flash (30\% AcOEt/hexano), 64\% como um sólido branco;

$\mathbf{R}_{\mathbf{f}} \quad 0.23$ (30\% AcOEt/hexano);

'H RMN $\quad\left(500 \mathrm{MHz}, \mathrm{CDCl}_{3}\right) \delta 7.39-7.22(\mathrm{~m}, 10 \mathrm{H}), 6.54(\mathrm{~d}, J=15.8 \mathrm{~Hz}, 1 \mathrm{H}), 6.31$ (dt, $J=15.8,7.3 \mathrm{~Hz}, 1 \mathrm{H}), 5.96(\mathrm{~s}, 1 \mathrm{H}), 4.46(\mathrm{~d}, J=5.8 \mathrm{~Hz}, 2 \mathrm{H}), 3.21$ (dd, $J=7.3,1.2 \mathrm{~Hz}, 2 \mathrm{H}$ );

${ }^{13} \mathrm{C}$ RMN $\quad\left(125 \mathrm{MHz}, \mathrm{CDCl}_{3}\right) \delta 170.5,138.1,136.5,134.8,128.7,128.6,127.8$, $127.8,127.5,126.3,122.2,43.7,40.8$;

FTIR (puro, $\mathrm{cm}^{-1}$ ) 3238, 3055, 3035, 2954, 2922, 2875, 2850, 1633, 1548, 1411, 1238, 981, 968, 756, 698;

HRMS (ESI) Calculado para $\mathrm{C}_{17} \mathrm{H}_{18} \mathrm{NO}[\mathrm{M}+\mathrm{H}]^{+} 252.1383$, encontrado 252.1391;

P.F $\quad 125-129^{\circ} \mathrm{C}$ 
(E)-N-ciclohexil-4-fenilbut-3-enamida (74)

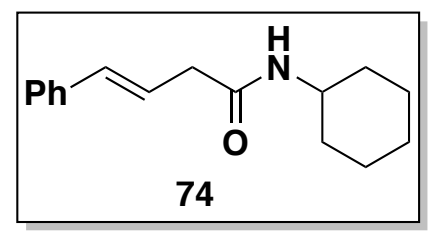

\section{(E)-N-ciclohexil-4-fenilbut-3-enamida (74)}

(74) Purificação por cromatografia flash (30\% AcOEt/hexano), 66\% como um sólido branco;

$\mathbf{R}_{\mathbf{f}} \quad 0.33$ (30\% AcOEt/hexano);

${ }^{1} \mathrm{H}$ RMN (400 MHz, $\left.\mathrm{CDCl}_{3}\right) \delta 7.41-7.36(\mathrm{~m}, 2 \mathrm{H}), 7.35-7.30(\mathrm{~m}, 2 \mathrm{H}), 7.28-$ $7.22(\mathrm{~m}, 1 \mathrm{H}), 6.53(\mathrm{~d}, \mathrm{~J}=15.9 \mathrm{~Hz}, 1 \mathrm{H}), 6.29(\mathrm{dt}, \mathrm{J}=15.8,7.3 \mathrm{~Hz}, 1 \mathrm{H})$, $5.47(\mathrm{~s}, 1 \mathrm{H}), 3.83-3.73(\mathrm{~m}, 1 \mathrm{H}), 3.13(\mathrm{dd}, J=7.3,1.3 \mathrm{~Hz}, 2 \mathrm{H}), 1.95-$ $1.86(\mathrm{~m}, 2 \mathrm{H}), 1.73-1.64(\mathrm{~m}, 2 \mathrm{H}), 1.61$ (ddd, $J=12.9,6.2,3.6 \mathrm{~Hz}, 1 \mathrm{H})$, $1.43-1.30(\mathrm{~m}, 2 \mathrm{H}), 1.19-1.04(\mathrm{~m}, 3 \mathrm{H})$;

${ }^{13} \mathrm{C}$ RMN $\quad\left(100 \mathrm{MHz}, \mathrm{CDCl}_{3}\right) \delta 169.6,136.7,134.5,128.6,127.7,126.3,122.7$, 77.3, 77.0, 76.7, 48.3, 41.1, 33.1, 25.5, 24.8;

FTIR (puro, $\mathrm{cm}^{-1}$ ) 3286, 3062, 3030, 2931, 2852, 1635, 1546, 1446, 1346, 1247, 960, 891, 690;

HRMS (ESI) Calculado para $\mathrm{C}_{16} \mathrm{H}_{21} \mathrm{NNaO}[\mathrm{M}+\mathrm{Na}]^{+}$266.1515, encontrado 266.1515;

P.F $\quad 89-96^{\circ} \mathrm{C}$; 
(E)-N,N-dialii-4-fenilbut-3-enamida (75)

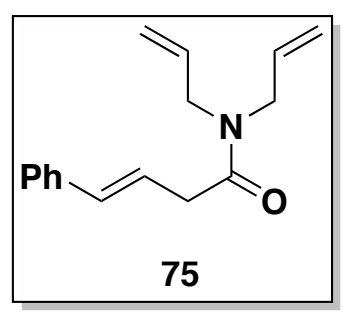

\section{(E)-N,N-dialil-4-fenilbut-3-enamida (75)}

\begin{tabular}{|c|c|}
\hline (75) & $\begin{array}{l}\text { Purificação por cromatografia flash (30\% AcOEt/hexano), } 63 \% \text { como um } \\
\text { óleo incolor; }\end{array}$ \\
\hline $\mathbf{R}_{\mathbf{f}}$ & 0.38 (30\% AcOEt/hexano); \\
\hline${ }^{1} \mathrm{H}$ RMN & $\begin{array}{l}\left(400 \mathrm{MHz}, \mathrm{CDCl}_{3}\right) \delta 7.39-7.34(\mathrm{~m}, 2 \mathrm{H}), 7.33-7.27(\mathrm{~m}, 2 \mathrm{H}), 7.24- \\
7.19(\mathrm{~m}, 1 \mathrm{H}), 6.46(\mathrm{~d}, J=16.1 \mathrm{~Hz}, 1 \mathrm{H}), 6.38(\mathrm{dt}, J=16.0,6.3 \mathrm{~Hz}, 1 \mathrm{H}), \\
5.85-5.73(\mathrm{~m}, 2 \mathrm{H}), 5.27-5.11(\mathrm{~m}, 4 \mathrm{H}), 4.01(\mathrm{~d}, J=6.0 \mathrm{~Hz}, 2 \mathrm{H}), 3.93 \\
(\mathrm{dt}, J=4.7,1.6 \mathrm{~Hz}, 2 \mathrm{H}), 3.30(\mathrm{dd}, J=6.3,0.9 \mathrm{~Hz}, 2 \mathrm{H}) ;\end{array}$ \\
\hline${ }^{13} \mathrm{C}$ RMN & $\begin{array}{l}\left(125 \mathrm{MHz}, \mathrm{CDCl}_{3}\right) \delta 171.0,137.0,133.2,132.9,132.6,128.5,127.4 \\
126.2,123.4,117.4,116.8,49.3,48.0,37.7\end{array}$ \\
\hline FTIR & $\begin{array}{l}\left.\text { (puro, } \mathrm{cm}^{-1}\right) \text { 3082, 3059, 3024, 2980, 2954, 2926, 2854, 1654, 1463, } \\
\text { 1448, 1413, 1217, 1193, 1132, 991, 966, 925, 742, 694; }\end{array}$ \\
\hline HRMS & $\begin{array}{l}\text { (ESI) Calculado para } \mathrm{C}_{16} \mathrm{H}_{20} \mathrm{NO}\left[\mathrm{M}+\mathrm{H}^{+} 242.1539 \text {, encontrado }\right. \\
\text { 242.1551; }\end{array}$ \\
\hline
\end{tabular}


Carbamato de tert-butil (S,E)-(8-(benzilamino)-2-metil-8-oxooct-5-en-4-il) (76)

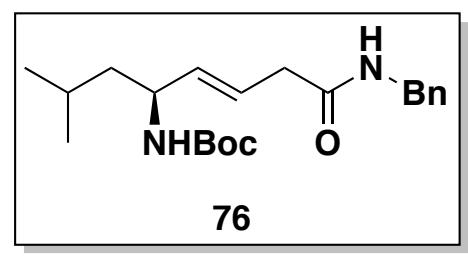

Carbamato de tert-butil (S,E)-(8-(benzilamino)-2-metil-8-oxooct-5-en-4-il) (76)

(76) Purificação por cromatografia flash (30\% AcOEt/hexano), 70\% como um óleo incolor;

$\mathbf{R}_{\mathbf{f}} \quad 0.30(30 \%$ AcOEt/hexano);

${ }^{1}$ H RMN $\left(500 \mathrm{MHz} \mathrm{CDCl}_{3}\right) \delta 7.33-7.21(\mathrm{~m}, 5 \mathrm{H}), 6.66(\mathrm{~s}, 1 \mathrm{H}), 5.74-5.67(\mathrm{~m}$, $1 \mathrm{H}), 5.45(\mathrm{dd}, J=15.4,7.0 \mathrm{~Hz}, 1 \mathrm{H}), 4.52-4.34(\mathrm{~m}, 3 \mathrm{H}), 4.01(\mathrm{q}, J=$ $7.2 \mathrm{~Hz}, 1 \mathrm{H}), 3.02$ (d, J = 7.4 Hz, 2H), $1.62(\mathrm{dq}, \mathrm{J}=13.5,6.7 \mathrm{~Hz}, 1 \mathrm{H})$, $1.35(\mathrm{~s}, 9 \mathrm{H}), 1.34-1.28(\mathrm{~m}, 2 \mathrm{H}), 0.89(\mathrm{dd}, J=6.6,5.1 \mathrm{~Hz}, 6 \mathrm{H})$;

${ }^{13} \mathrm{C}$ RMN $\quad\left(125 \mathrm{MHz}, \mathrm{CDCl}_{3}\right) \delta 170.8,155.4,138.5,137.1,128.5,127.6,127.2$, 123.8, 79.4, 51.4, 43.8, 43.5, 39.9, 28.3, 24.6, 22.4;

FTIR (puro, $\mathrm{cm}^{-1}$ ) 3342, 3032, 2981, 2954, 2929, 1678, 1637, 1525, 1367, 1294, 1170, 975;

HRMS (ESI) Calculado para $\mathrm{C}_{21} \mathrm{H}_{32} \mathrm{~N}_{2} \mathrm{NaO}_{3}[\mathrm{M}+\mathrm{Na}]^{+} 383.2305$, encontrado 383.2302;

$[\alpha]_{D}^{20}+17.3\left(c 0.1, \mathrm{CH}_{3} \mathrm{Cl}\right)$ 
Carbamato de tert-butil (S,E)-(8-(ciclohexilamino)-2-metil-8-oxooct-5-en-4-il) (77)
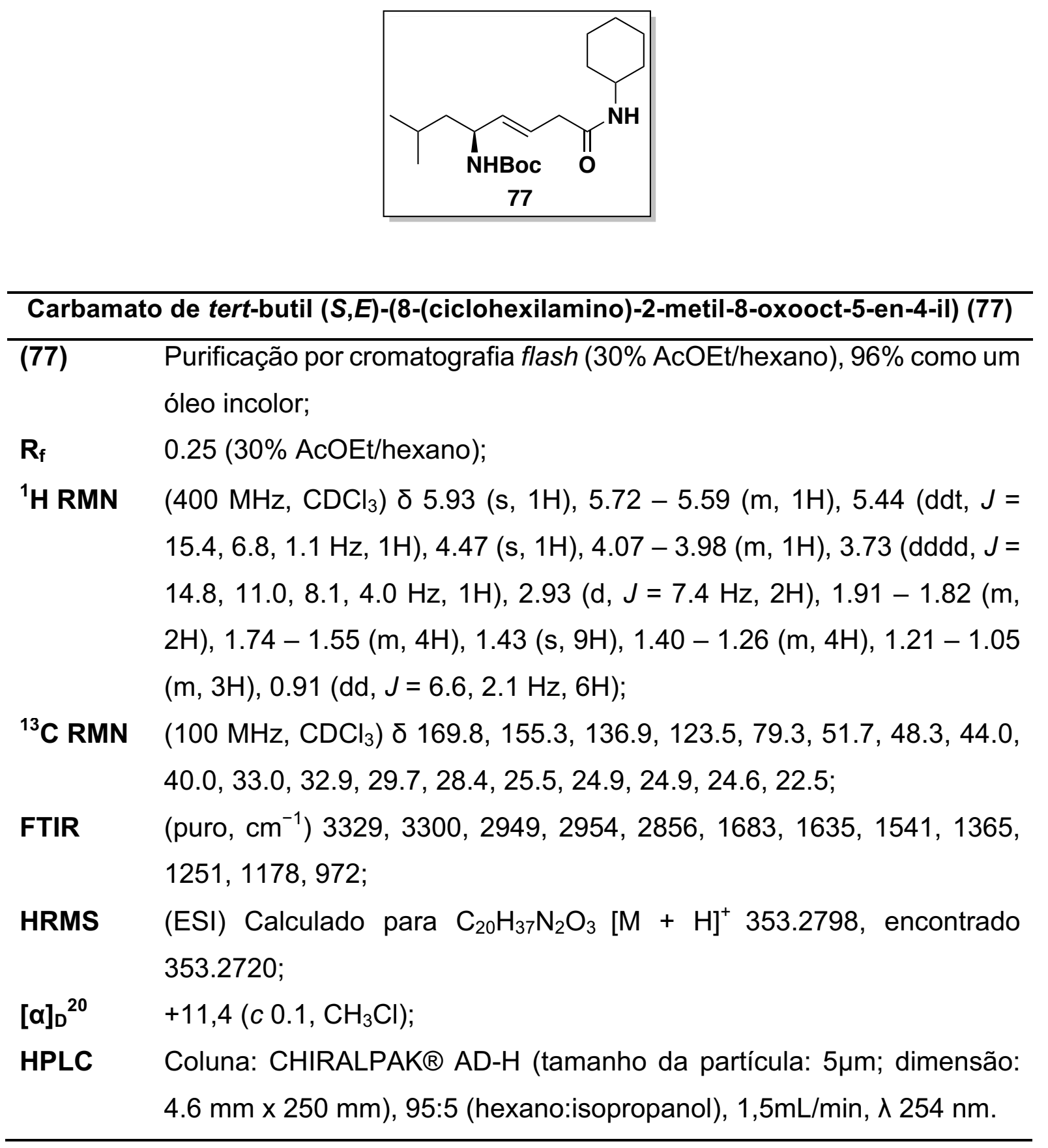
(S,E)-N-(2,2,6,6-Tetrametil-1-oxo-piperidin-4-il)-5- (tert-butóxicarbonilamino)-7metiloct-3-enamida (JP4-039)

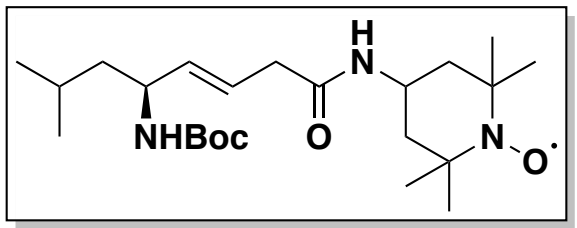

(S,E)-N-(2,2,6,6-Tetrametil-1-oxo-piperidin-4-il)-5- (tert-butóxicarbonilamino)-7metiloct-3-enamida (JP4-039)

\begin{tabular}{|c|c|}
\hline (JP4-039) & $\begin{array}{l}\text { O nucleófilo 4-amino-TEMPO foi adicionado como um sólido. } \\
\text { Purificação por cromatografia flash ( } 60 \% \text { AcOEt/hexano), } 65 \% \text { como } \\
\text { um sólido cor de pêssego; }\end{array}$ \\
\hline $\mathbf{R}_{\mathbf{f}}$ & 0.28 (60\% AcOEt/hexano); \\
\hline FTIR & $\begin{array}{l}\text { (puro, } \mathrm{cm}^{-1} \text { ) 3321, 2972, 2956, 2931, 2870, 1685, 1670, 1645, 1525, } \\
1458,1390,1317,1300,1244,1175,1043,972 ;\end{array}$ \\
\hline HRMS & $\begin{array}{l}\text { (ESI) Calculado para } \mathrm{C}_{23} \mathrm{H}_{42} \mathrm{~N}_{3} \mathrm{NaO}_{4}[\mathrm{M}+\mathrm{Na}]^{+} 447.3068 \text {, encontrado } \\
447.3071 \text {; }\end{array}$ \\
\hline$[\alpha]_{D}^{20}$ & $+35.3\left(c \quad 0.1, \mathrm{CH}_{2} \mathrm{Cl}_{2}\right)$ \\
\hline P.F & $51-60^{\circ} \mathrm{C}$ \\
\hline
\end{tabular}


6.4.2 Procedimento para redução do JP4-039 com ácido ascórbico

Carbamato de tert-butil (S,E)-(8-((1-hidroxi-2,2,6,6-tetrametilpiperidin-4il)amino)-2-metil-8-oxooct-5-en-4-il)

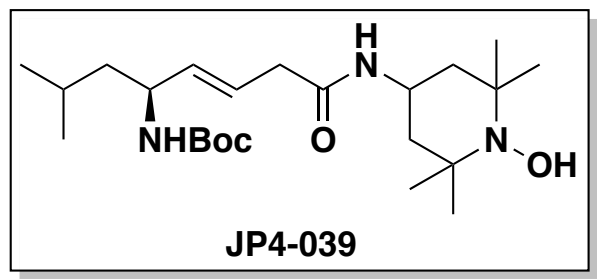

Para a análise de RMN, uma amostra do nitróxido JP4-039 (20.0 mg, 0.047 mmol) foi dissolvido em $\mathrm{MeOH}$ seco $(0.5 \mathrm{~mL})$ e ácido L-ascórbico $(8.3 \mathrm{mg}, 0.047 \mathrm{mmol})$ foi adicionado. A descoloração completa da solução ocorreu dentro de poucos segundos. Após agitação à temperatura ambiente durante $10 \mathrm{~min}$, o solvente foi removido sob vácuo. O resíduo resultante foi dissolvido em AcOEt e lavado com água. $A$ fase aquosa foi extraída duas vezes com AcOEt, e as camadas orgânicas combinadas foram secas $\left(\mathrm{Na}_{2} \mathrm{SO}_{4}\right)$, filtrou-se e concentrou-se em vácuo para se obter $16.1 \mathrm{mg}$ $(80 \%)$ da correspondente hidróxiamina como uma espuma branca:

\section{Carbamato de tert-butil (S,E)-(8-((1-hidroxi-2,2,6,6-tetrametilpiperidin-4-} il)amino)-2-metil-8-oxooct-5-en-4-il)

\begin{tabular}{ll}
\hline${ }^{1}$ H RMN & $\left(500 \mathrm{MHz}, \mathrm{CD}_{3} \mathrm{OD}\right) \delta 6.60(\mathrm{~s}, 1 \mathrm{H}), 5.69-5.61(\mathrm{~m}, 1 \mathrm{H}), 5.50(\mathrm{dd}, J=$ \\
& $15.3,6.0 \mathrm{~Hz}, 1 \mathrm{H}), 4.16-3.95(\mathrm{~m}, 2 \mathrm{H}), 2.88(\mathrm{~d}, \mathrm{~J}=6.9 \mathrm{~Hz}, 2 \mathrm{H}), 1.72(\mathrm{dt}$, \\
& $J=15.9,7.9 \mathrm{~Hz}, 2 \mathrm{H}), 1.66-1.54(\mathrm{~m}, 1 \mathrm{H}), 1.43(\mathrm{~s}, 9 \mathrm{H}), 1.43-1.26(\mathrm{~m}$, \\
& $4 \mathrm{H}), 1.17(\mathrm{~s}, 6 \mathrm{H}), 1.15(\mathrm{~s}, 6 \mathrm{H}), 0.91(\mathrm{~d}, \mathrm{~J}=5.7 \mathrm{~Hz}, 6 \mathrm{H}) ;$ \\
${ }^{13} \mathrm{C}$ RMN & $\left(125 \mathrm{MHz}, \mathrm{CD}_{3} \mathrm{OD}\right) \delta 173.3,157.9,136.6,124.3,79.9,59.9,51.7,45.9$, \\
& $45.2,42.2,40.7,32.7,28.8,25.9,23.1,22.6,20.3$. \\
\hline
\end{tabular}

- Os dados estão de acordo com os descritos na literatura. ${ }^{95,133}$ 


\subsection{Preparo das Diazocetonas para rearranjo de Wolff usando LED}

\section{1-Diazo-3-fenilpropan-2-ona (86)}

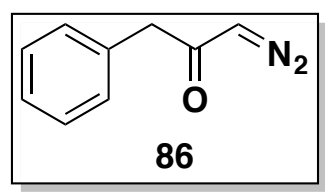

Uma solução de ácido fenil acético ( $6.90 \mathrm{mg}, 5 \mathrm{mmol}, 1$ equiv.) em $5 \mathrm{~mL}$ de benzeno seco e $5 \mathrm{ml}$ de cloreto de tionila ( $69 \mathrm{mmol}, 13$ equiv.) foi submetida a refluxo durante $1 \mathrm{~h}$. Após este período, a, solução incolor foi evaporada sob vácuo. O cloreto de ácido resultante foi dissolvido em $8 \mathrm{~mL}$ de éter e em seguida adicionado gota a gota sob agitação a $30-40 \mathrm{~mL}$ de uma solução etérea de diazometano $(0.4 \mathrm{M})$ em $0-5^{\circ} \mathrm{C}$. A solução amarela foi deixada em repouso à temperatura ambiente durante $1 \mathrm{~h} \mathrm{e}$, em seguida, purgada com argônio durante $30 \mathrm{~min}$. A evaporação do solvente seguida de purificação em sílica gel (25\% AcOEt / hexano) proporcionou a diazocetona 86 (480 mg, $3 \mathrm{mmol}$ ) como um óleo amarelo estável:

1-Diazo-3-fenilpropan-2-ona (86)

\begin{tabular}{ll}
\hline $\mathbf{R}_{\mathbf{f}}$ & $0.30\left(25 \% \mathrm{AcOEt}_{\text {/hexano }) ;}\right.$ \\
${ }^{1} \mathbf{H} \mathbf{R M N}$ & $\left(400 \mathrm{MHz}, \mathrm{CDCl}_{3}\right) \delta 3.61(\mathrm{~s}, 2 \mathrm{H}), 5.12(\mathrm{~s}, 1 \mathrm{H}), 7.19-7.37(\mathrm{~m}, 5 \mathrm{H}) ;$ \\
${ }^{13} \mathbf{C} \mathbf{R M N}$ & $(62.5 \mathrm{MHz}, \mathrm{CDCl}) \delta 48.0,54.8,127.2,128.8,129.3,134.5,192.7 ;$ \\
FTIR & $\left(\right.$ puro, $\left.\mathrm{cm}^{-1}\right) 3315,3084,2956,2926,2870,2117,1712,1654,1626$, \\
& $1420,1116,970 ;$ \\
\hline
\end{tabular}

- Os dados estão de acordo com os descritos na literatura. ${ }^{227}$ 
a-Diazoacetofenona (87)

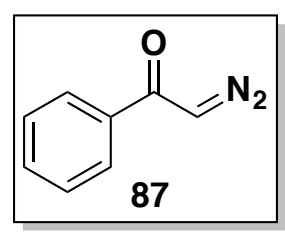

A uma solução a $-10^{\circ} \mathrm{C}$ de diazometano etéreo $(178 \mathrm{~mL}, 0.4 \mathrm{M})$ e trietilamina $(5.0 \mathrm{~mL}$, $35.6 \mathrm{mmol}, 1$ equiv.) foi adicionado cloreto de benzoíla (4.13 mL, $35.6 \mathrm{mmol}$, 1 equiv.) gota a gota com agitação durante um período de $30 \mathrm{~min}$. Após este tempo, a solução foi deixada aquecer até $0{ }^{\circ} \mathrm{C}$ e mantida na mesma temperatura durante $4 \mathrm{~h}$. Concentração sob pressão reduzida seguida de purificação em cromatografia flash forneceu a diazocetona 87 (4.44 g, $30.4 \mathrm{mmol})$ com $85 \%$ de rendimento como um sólido amarelo estável:

\section{a-Diazoacetofenona (87)}

\begin{tabular}{ll}
\hline $\mathbf{R}_{\mathbf{f}}$ & $0.30(25 \% \mathrm{AcOEt} / \mathrm{hexano}) ;$ \\
${ }^{1} \mathbf{H}$ RMN & $\left(400 \mathrm{MHz}, \mathrm{CDCl}_{3}\right) \delta 5.91(\mathrm{~s}, 1 \mathrm{H}), 7.44(\mathrm{t}, \mathrm{J}=7.5 \mathrm{~Hz}, 2 \mathrm{H}), 7.50-5.56$ \\
& $(\mathrm{~m}, 1 \mathrm{H}), 7.75(\mathrm{dd}, \mathrm{J}=8.3,1.3 \mathrm{~Hz}, 2 \mathrm{H}) ;$ \\
${ }^{13} \mathbf{C}$ RMN & $\left(100 \mathrm{MHz}, \mathrm{CDCl}_{3}\right) \delta 186.3,136.6,132.6,128.6,126.6,54.1 ;$ \\
FTIR & $\left(\right.$ puro, $\left.\mathrm{cm}^{-1}\right) 3088,2108,1728,1622,1575,1448,1367,1228,1145$, \\
& $702 ;$ \\
HRMS & $(\mathrm{ESI}) \mathrm{Calculado}$ para $\mathrm{C}_{21} \mathrm{H}_{32} \mathrm{~N}_{2} \mathrm{NaO}_{3}[\mathrm{M}+\mathrm{Na}]^{+} 383.2305$, encontrado \\
& $383.2302 ;$ \\
P.F & $48-50^{\circ} \mathrm{C} ;$ \\
\hline
\end{tabular}


Carbamato de (S)-benzil (1-diazo-5-metil-2-oxohexan-3-il) $(88)^{228}$

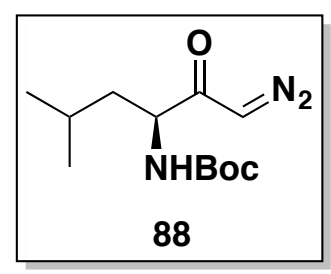

Cbz-L-leucina ( $1 \mathrm{~g}, 3.76 \mathrm{mmol}, 1$ equiv.) foi dissolvida em THF seco $(20 \mathrm{~mL})$ e a solução resultante foi resfriada a $0{ }^{\circ} \mathrm{C}$. À solução foram adicionados $\mathrm{N}$-metilmorfolina (NMM, $435 \mathrm{ml}, 3.95 \mathrm{mmol}, 1.05$ equiv.) e cloroformato de isobutila ( $515 \mu \mathrm{l}, 3.95 \mathrm{mmol}$, 1.05 equiv.), sucessivamente. A mistura foi agitada durante $15 \mathrm{~min}$ e em seguida, adicionada gota a gota a uma solução resfriada a $0{ }^{\circ} \mathrm{C}$ de $\mathrm{CH}_{2} \mathrm{~N}_{2}$ a $0.4 \mathrm{M} \mathrm{em} \mathrm{Et}_{2} \mathrm{O}$ $(70 \mathrm{~mL})$. A solução amarela foi deixada aquecer até à temperatura ambiente. A mistura reacional foi agitada por mais $2 \mathrm{~h}$ e, em seguida, concentrada sob pressão reduzida. O resíduo foi purificado por cromatografia em coluna de sílica gel $(20-30 \%$ de AcOEt/hexano) para se obter a diazocetona $88(0.93 \mathrm{~g}, 3.20 \mathrm{mmol}, 85 \%$ de rendimento) como um sólido amarelo;

\section{Carbamato de (S)-benzil (1-diazo-5-metil-2-oxohexan-3-il) (88)}

\begin{tabular}{ll}
\hline $\mathbf{R}_{\mathbf{f}}$ & $0.20(25 \%$ AcOEt/hexano); \\
${ }^{1} \mathbf{H}$ RMN & $\left(500 \mathrm{MHz}, \mathrm{CDCl}_{3}\right) \delta 7.38-7.28(\mathrm{~m}, 5 \mathrm{H}), 5.43(\mathrm{~s}, 1 \mathrm{H}), 5.34(\mathrm{~d}, \mathrm{~J}=7.3 \mathrm{~Hz}$, \\
& $1 \mathrm{H}), 5.11(\mathrm{~d}, \mathrm{~J}=12.0 \mathrm{~Hz}, 1 \mathrm{H}), 5.08(\mathrm{~d}, \mathrm{~J}=12.4 \mathrm{~Hz}, 1 \mathrm{H}), 4.26(\mathrm{~s}, 1 \mathrm{H})$, \\
& $1.75-1.63(\mathrm{~m}, 1 \mathrm{H}), 1.57(\mathrm{ddd}, \mathrm{J}=13.3,8.4,5.2 \mathrm{~Hz}, 1 \mathrm{H}), 1.50-1.41$ \\
& $(\mathrm{ddd}, \mathrm{J}=13.3,8.4,5.2 \mathrm{~Hz}, 1 \mathrm{H}), 0.94(\mathrm{~d}, \mathrm{~J}=6.5 \mathrm{~Hz}, 3 \mathrm{H}), 0.93(\mathrm{~d}, \mathrm{~J}=$ \\
& $6.4 \mathrm{~Hz}, 3 \mathrm{H}) ;$ \\
${ }^{13} \mathbf{C}$ RMN & $\left(125 \mathrm{MHz}, \mathrm{CDCl}_{3}\right) \delta 194.0,156.0,136.2,128.5,128.2,128.0,67.0,56.3$, \\
& $53.8,41.5,24.7,23.0,21.8 ;$ \\
FTIR & $\left(\mathrm{puro}, \mathrm{cm}^{-1}\right) 3315,3084,2956,2117,1712,1597,1541,1381,1247$, \\
& 1022,$761 ;$ \\
P.F & $71-72{ }^{\circ} \mathrm{C} ;$ \\
\hline
\end{tabular}


1-diazo-3,3-dimetilbutan-2-ona (99)

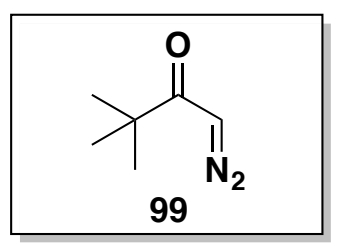

Em uma solução de diazometano $0.4 \mathrm{M}$ em éter $(100 \mathrm{~mL}, 40 \mathrm{mmol}, 4$ equiv.) resfriada em $0{ }^{\circ} \mathrm{C}$ foi adicionada uma solução $10 \mathrm{M}$ de cloreto de pivaloíla $(1.23 \mathrm{~mL}, 10 \mathrm{mmol}$, 1 equiv.) em éter ( $1 \mathrm{~mL}$ ) gota a gota. A solução foi agitada na mesma temperatura por $1 \mathrm{~h}$ e posteriormente por um período adicional $24 \mathrm{~h}$ em temperatura ambiente. Então o solvente removido em rota evaporador para fornecer o bruto da diazocetona 99 como um líquido amarelo que foi utilizado nas etapas seguintes sem necessidade de purificação (pureza $>99 \%$ determinada por RMN ${ }^{1} \mathrm{H}$ ).

1-diazo-3,3-dimetilbutan-2-ona (99)

\begin{tabular}{ll}
\hline${ }^{1}$ H RMN & $\left.500 \mathrm{MHz} \mathrm{CDCl}_{3}\right) \delta 5.41(\mathrm{~s}, 1 \mathrm{H}), 1.12(\mathrm{~s}, 9 \mathrm{H}) ;$ \\
${ }^{13}$ C RMN & $\left(126 \mathrm{MHz}_{\mathrm{CDCl}}\right) \delta 201.3,51.9,42.6,27.1 . ;$ \\
FTIR & $\left(\right.$ puro, $\left.\mathrm{cm}^{-1}\right) 3090,2968,2098,1623,1477,1341,1150,1007,897,806$, \\
& $704 ;$ \\
\hline
\end{tabular}

- Os dados estão de acordo com os reportados na literatura. ${ }^{229}$ 


\subsection{Procedimento geral para Rearranjo de Wolff usando lâmpada de LED}

\subsubsection{Método A: Usando os álcoois como solvente}

Em um frasco de $4 \mathrm{~mL}$, as diazocetonas 1, 86-88 $(0.174 \mathrm{mmol})$ foram dissolvidas em $3.5 \mathrm{ml}$ do álcool desejado. O frasco foi fechado com uma tampa e uma agulha adicionada (para ventilar o gás nitrogênio formado durante a reação). Em seguida, a solução amarela da diazocetona foi irradiada com uma lâmpada LEDspot PAR branca de18 $\mathrm{W}$ durante $24 \mathrm{~h}$ sob agitação magnética e à temperatura ambiente (evolução de gás nitrogênio observada, a solução tende a tornar-se incolor com o consumo da diazocetona). Depois disso, o solvente foi evaporado em evaporador rotativo. Purificação por cromatografia em coluna flash forneceu os seguintes ésteres e ácidos: 
(E)-metil 4-fenilbut-3-enoato (78)

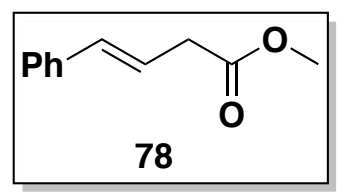

\section{(E)-metil 4-fenilbut-3-enoato (78)}

(78) Usando $\mathrm{MeOH}$ seco, 91\% de rendimento após purificação por cromatografia em coluna flash (5-10\% de AcOEt / hexano), como um óleo incolor. Rendimento de $100 \%$ por $\mathrm{RMN}^{1} \mathrm{H}$ quantitativo padrão de TMB;

$\mathbf{R}_{\mathbf{f}} \quad 0.38(10 \%$ AcOEt/hexano);

${ }^{1}$ H RMN $\left(500 \mathrm{MHz} \mathrm{CDCl}_{3}\right) \delta 7.38(\mathrm{dd}, J=8.4,1.2 \mathrm{~Hz}, 2 \mathrm{H}), 7.31(\mathrm{t}, J=7.6 \mathrm{~Hz}$, $2 \mathrm{H}), 7.25-7.21(\mathrm{~m}, 1 \mathrm{H}), 6.50(\mathrm{~d}, J=15.9 \mathrm{~Hz}, 1 \mathrm{H}), 6.31$ (ddd, $J=15.9$, 10.7, $5.8 \mathrm{~Hz}, 1 \mathrm{H}), 3.72(\mathrm{~s}, 3 \mathrm{H}), 3.26$ (dd, $J=7.1,1.5 \mathrm{~Hz}, 2 \mathrm{H}$ );

${ }^{13}$ C RMN $\quad\left(125 \mathrm{MHz}, \mathrm{CDCl}_{3}\right) \delta 172.0,136.8,133.5,128.5,127.5,126.3,121.6$, $51.90,38.2$; 
(E)-alil 4-fenilbut-3-enoato (79)

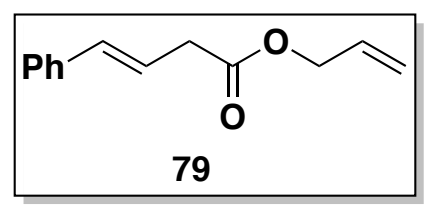

\section{(E)-alil 4-fenilbut-3-enoato (79)}

\begin{tabular}{|c|c|}
\hline (79) & $\begin{array}{l}\text { Usando álcool alílico, } 85 \% \text { de rendimento após purificação por } \\
\text { cromatografia em coluna flash (5-10\% de AcOEt/hexano), como um } \\
\text { óleo incolor; }\end{array}$ \\
\hline $\mathbf{R}_{\mathbf{f}}$ & 0.48 (10\% AcOEt/hexano); \\
\hline${ }^{1} \mathrm{H}$ RMN & $\begin{array}{l}\left(500 \mathrm{MHz}, \mathrm{CDCl}_{3}\right) \delta 7.37(\mathrm{dd}, J=8.2,1.0 \mathrm{~Hz}, 2 \mathrm{H}), 7.31(\mathrm{t}, J=7.6 \mathrm{~Hz}, \\
2 \mathrm{H}), 7.26-7.21(\mathrm{~m}, 1 \mathrm{H}), 6.51(\mathrm{~d}, J=15.9 \mathrm{~Hz}, 1 \mathrm{H}), 6.31(\mathrm{dt}, J=15.9, \\
7.1 \mathrm{~Hz}, 1 \mathrm{H}), 5.94(\mathrm{ddt}, J=17.2,10.4,5.8 \mathrm{~Hz}, 1 \mathrm{H}), 5.34(\mathrm{dd}, J=17.2, \\
1.5 \mathrm{~Hz}, 1 \mathrm{H}), 5.25(\mathrm{ddd}, J=10.4,2.6,1.3 \mathrm{~Hz}, 1 \mathrm{H}), 4.63(\mathrm{dt}, J=5.8,1.4 \\
\mathrm{Hz}, 2 \mathrm{H}), 3.28(\mathrm{dd}, J=7.1,1.4 \mathrm{~Hz}, 2 \mathrm{H}) ;\end{array}$ \\
\hline${ }^{13} \mathrm{C}$ RMN & $\begin{array}{l}\left(125 \mathrm{MHz}, \mathrm{CDCl}_{3}\right) \delta 171.2,136.8,133.5,132.0,128.5,127.5,126.3 \\
121.6,118.4,65.4,38.3\end{array}$ \\
\hline FTIR & $\begin{array}{l}\left.\text { (puro, } \mathrm{cm}^{-1}\right) \text { 3084, 3028, 2951, 2926, 2855, 1738, 1651, 1497, 1450, } \\
\text { 1371, 1285, 1240, 1155, 988; }\end{array}$ \\
\hline HRMS & $\begin{array}{l}\text { (ESI) Calculado para } \mathrm{C}_{13} \mathrm{H}_{16} \mathrm{O}_{2}[\mathrm{M}+\mathrm{H}]^{+} \text {203.10666, encontrado } \\
\text { 203.10692; }\end{array}$ \\
\hline
\end{tabular}


(E)-isopropil 4-fenilbut-3-enoato (81)

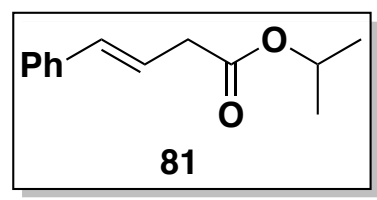

\section{(E)-isopropil 4-fenilbut-3-enoato (81)}

\begin{tabular}{|c|c|}
\hline (81) & $\begin{array}{l}\text { Usando } i \text {-PrOH seco, } 80 \% \text { de rendimento após purificação por } \\
\text { cromatografia em coluna flash (5-10\% de AcOEt/hexano), como um } \\
\text { óleo incolor; }\end{array}$ \\
\hline $\mathbf{R}_{\mathbf{f}}$ & 0.50 (10\% AcOEt/hexano); \\
\hline${ }^{1} \mathrm{H}$ RMN & $\begin{array}{l}\left(500 \mathrm{MHz}, \mathrm{CDCl}_{3}\right) \delta 7.38(\mathrm{dd}, J=8.4,1.2 \mathrm{~Hz}, 2 \mathrm{H}), 7.31(\mathrm{t}, J=7.6 \mathrm{~Hz}, \\
2 \mathrm{H}), 7.25-7.21(\mathrm{~m}, 1 \mathrm{H}), 6.49(\mathrm{~d}, J=15.9 \mathrm{~Hz}, 1 \mathrm{H}), 6.31(\mathrm{dt}, J=15.9, \\
7.1 \mathrm{~Hz}, 1 \mathrm{H}), 5.05(\text { hept}, J=6.3 \mathrm{~Hz}, 1 \mathrm{H}), 3.21(\mathrm{dd}, J=7.1,1.5 \mathrm{~Hz}, 2 \mathrm{H}), \\
1.26(\mathrm{~d}, J=6.3 \mathrm{~Hz}, 6 \mathrm{H}) ;\end{array}$ \\
\hline${ }^{13} \mathrm{C}$ RMN & $\begin{array}{l}\left(125 \mathrm{MHz}, \mathrm{CDCl}_{3}\right) \delta 171.1,136.9,133.2,128.5,127.4,126.2,122.0 \\
68.1,38.8,21.8\end{array}$ \\
\hline
\end{tabular}


(E)-tert-butil 4-fenilbut-3-enoato (84)

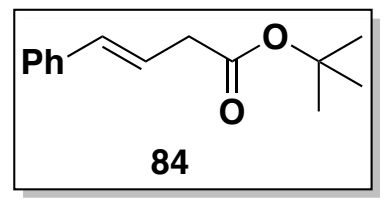

(E)-tert-butil 4-fenilbut-3-enoato (84)

(82) Usando $t$-BuOH seco, 63\% de rendimento após purificação por cromatografia em coluna flash (5-10\% de AcOEt / hexano), como um óleo incolor;

$\mathbf{R}_{\mathbf{f}} \quad 0.55(10 \%$ AcOEt/hexano);

${ }^{1}$ H RMN (500 MHz, $\left.\mathrm{CDCl}_{3}\right) \delta 7.37(\mathrm{~d}, J=7.3 \mathrm{~Hz}, 2 \mathrm{H}), 7.30(\mathrm{t}, J=7.6 \mathrm{~Hz}, 2 \mathrm{H})$, $7.25-7.20(\mathrm{~m}, 1 \mathrm{H}), 6.47(\mathrm{~d}, J=15.9 \mathrm{~Hz}, 1 \mathrm{H}), 6.29(\mathrm{dt}, J=15.9,7.1 \mathrm{~Hz}$, $1 \mathrm{H}), 3.16$ (dd, J = 7.1, 1.4 Hz, 2H), 1.47 (s, 9H);

${ }^{13}$ C RMN $\quad\left(125 \mathrm{MHz}, \mathrm{CDCl}_{3}\right) \delta 170.9,137.1,132.9,128.5,127.4,126.2,122.5$, 80.8, 39.7, 28.1; 
Acetato de metil-2-fenila (89) $)^{230}$

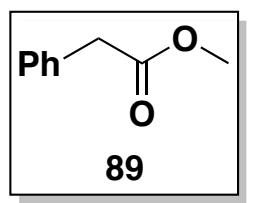

\section{Acetato de metil-2-fenila (89)}

(89) $81 \%$ de rendimento após purificação por cromatografia em coluna flash (5-10\% de AcOEt/hexano), como um óleo incolor: $R_{f} 0.40$ (10\% AcOEt/hexano);

${ }^{1} \mathbf{H}$ RMN $\quad\left(400 \mathrm{MHz}_{\mathrm{CDCl}}\right): \delta 7.32(\mathrm{~m}, 5 \mathrm{H}), 3.71(\mathrm{~s}, 3 \mathrm{H}), 3.62(\mathrm{~s}, 2 \mathrm{H})$;

- Os dados estão de acordo com os descritos na literatura. ${ }^{230}$ 
Acetato de alil-2-fenila (90)

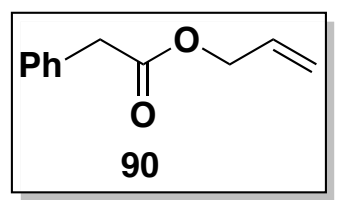

\section{Acetato de alil-2-fenila (90)}

(90) $75 \%$ de rendimento após purificação por cromatografia em coluna flash (5-10\% de AcOEt/hexano), como um óleo incolor;

$\mathbf{R}_{\mathbf{f}} \quad 0.50(10 \%$ AcOEt/hexano);

${ }^{1} \mathrm{H}$ RMN $\quad\left(400 \mathrm{MHz}, \mathrm{CDCl}_{3}\right) \delta 7.36-7.23(\mathrm{~m}, 5 \mathrm{H}), 5.90(\mathrm{ddt}, J=17.2,10.5,5.7$ $\mathrm{Hz}, 1 \mathrm{H}), 5.27$ (dd, $J=17.2,1.5 \mathrm{~Hz}, 1 \mathrm{H}), 5.21$ (dd, $J=10.4,1.3 \mathrm{~Hz}, 1 \mathrm{H})$, $4.59(\mathrm{dt}, \mathrm{J}=5.7,1.4 \mathrm{~Hz}, 2 \mathrm{H}), 3.65$ (s, 2H);

${ }^{13}$ C RMN $\quad\left(100 \mathrm{MHz}, \mathrm{CDCl}_{3}\right) \delta 171.2,133.9,132.0,129.2,128.6,127.1,118.2$, 65.4, 41.3;

FTIR (puro, $\mathrm{cm}^{-1}$ ): 3088, 3065, 3032, 2943, 1740, 1497, 1454, 1364, 1244, 1150, 991;

HRMS (ESI) Calculado para $\mathrm{C}_{11} \mathrm{H}_{12} \mathrm{O}_{2}[\mathrm{M}+\mathrm{Na}]^{+}$199.07295, encontrado 199.07320; 
Acetato de isopropil-2-fenila (91)

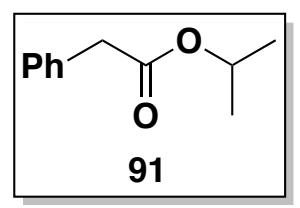

\section{Acetato de isopropil-2-fenila (91)}

(91) $63 \%$ de rendimento após purificação por cromatografia em coluna flash (5-10\% de AcOEt/hexano), como um óleo incolor;

$\mathbf{R}_{\mathbf{f}} \quad 0.50(10 \%$ AcOEt/hexano);

${ }^{1} \mathbf{H} \mathbf{R M N} \quad\left(500 \mathrm{MHz}, \mathrm{CDCl}_{3}\right) \delta 7.34-7.23(\mathrm{~m}, 5 \mathrm{H}), 5.01$ (hept, $\left.J=6.3 \mathrm{~Hz}, 1 \mathrm{H}\right)$, $3.58(\mathrm{~s}, 2 \mathrm{H}), 1.22(\mathrm{~d}, J=6.3 \mathrm{~Hz}, 6 \mathrm{H})$;

${ }^{13} \mathrm{C}$ RMN $\quad\left(125 \mathrm{MHz}, \mathrm{CDCl}_{3}\right) \delta 171.1,134.3,129.2,128.5,126.9,68.2,41.7,21.8$;

3-fenilpropanoato de alila (94)

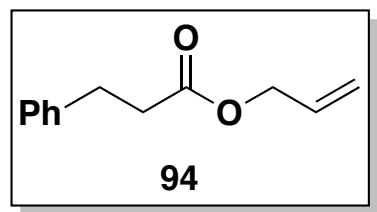

\section{3-fenilpropanoato de alila (94)}

(94) $89 \%$ de rendimento após purificação por cromatografia em coluna flash (5-10\% de AcOEt/hexano), como um óleo incolor;

$\mathbf{R}_{\mathbf{f}} \quad 0.50$ (10\% AcOEt/hexano);

${ }^{1}$ H RMN (500 MHz, $\left.\mathrm{CDCl}_{3}\right) \delta 7.31-7.27(\mathrm{~m}, 2 \mathrm{H}), 7.24-7.18(\mathrm{~m}, 3 \mathrm{H}), 5.90$ (ddt, $J=17.2,10.4,5.7 \mathrm{~Hz}, 1 \mathrm{H}), 5.29(\mathrm{dd}, J=17.2,1.5 \mathrm{~Hz}, 1 \mathrm{H}), 5.22(\mathrm{dd}, J=$ 10.4, $1.3 \mathrm{~Hz}, 1 \mathrm{H}), 4.58(\mathrm{dt}, J=5.7,1.4 \mathrm{~Hz}, 2 \mathrm{H}), 2.97(\mathrm{t}, J=7.6 \mathrm{~Hz}, 2 \mathrm{H})$, 2.67 (t, $J=7.6 \mathrm{~Hz}, 2 \mathrm{H}$ );

${ }^{13} \mathrm{C}$ RMN $\quad\left(125 \mathrm{MHz}, \mathrm{CDCl}_{3}\right) \delta 172.5,140.4,132.1,128.5,128.3,126.2,118.2$, $65.1,35.8,30.9$; 
3-fenilpropanoato de isopropila (95)

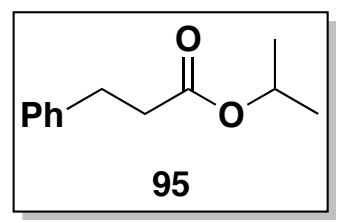

\section{3-fenilpropanoato de isopropila (95)}

(95) $70 \%$ de rendimento após purificação por cromatografia em coluna flash (5-10\% de AcOEt/hexano), como um óleo incolor;

$\mathbf{R}_{\mathbf{f}} \quad 0.50$ (10\% AcOEt/hexano);

${ }^{1} \mathrm{H}$ RMN $\quad\left(400 \mathrm{MHz}, \mathrm{CDCl}_{3}\right) \delta 7.31-7.24(\mathrm{~m}, 2 \mathrm{H}), 7.23-7.14(\mathrm{~m}, 3 \mathrm{H}), 5.00$ (hept, $J=6.3 \mathrm{~Hz}, 1 \mathrm{H}), 2.94(\mathrm{t}, J=7.6 \mathrm{~Hz}, 2 \mathrm{H}), 2.59(\mathrm{t}, J=7.8 \mathrm{~Hz}, 2 \mathrm{H}), 1.20(\mathrm{~d}$, $J=6.3 \mathrm{~Hz}, 6 \mathrm{H})$;

${ }^{13} \mathrm{C}$ RMN $\quad\left(100 \mathrm{MHz}, \mathrm{CDCl}_{3}\right) \delta 172.4,140.6,128.4,128.3,126.2,67.7,36.2,31.0$, 21.8;

3- fenilpropanoato de tert-butila (96)

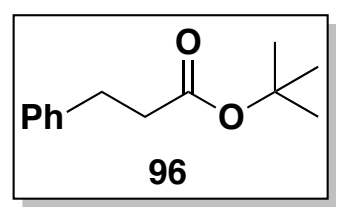

\section{3- fenilpropanoato de tert-butila (96)}

(96) $66 \%$ de rendimento após purificação por cromatografia em coluna flash (5-10\% de AcOEt/hexano), como um óleo incolor;

$\mathbf{R}_{\mathbf{f}} \quad 0.63$ (10\% AcOEt/hexano);

${ }^{1} \mathrm{H}$ RMN $\quad\left(500 \mathrm{MHz}, \mathrm{CDCl}_{3}\right) \delta 7.30-7.25(\mathrm{~m}, 2 \mathrm{H}), 7.21-7.16(\mathrm{~m}, 3 \mathrm{H}), 2.91(\mathrm{t}$, $J=7.7 \mathrm{~Hz}, 2 \mathrm{H}), 2.54(\mathrm{t}, J=7.7 \mathrm{~Hz}, 2 \mathrm{H}), 1.41(\mathrm{~s}, 9 \mathrm{H})$;

${ }^{13} \mathrm{C}$ RMN $\quad\left(125 \mathrm{MHz}, \mathrm{CDCl}_{3}\right) \delta 172.5,140.8,128.4,128.3,126.1,80.3,37.1,31.1$, 28.0; 
Hexanoato de (S)-alil-3-(((benziloxi)carbonil)amino)-5-metila (97)

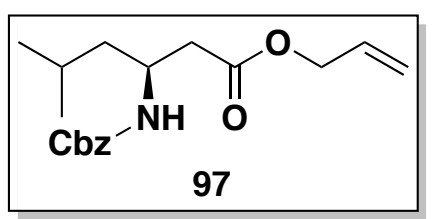

Hexanoato de (S)-alil-3-(((benziloxi)carbonil)amino)-5-metila (97)

(97) 62\% de rendimento após purificação por cromatografia em coluna flash (5-10\% de AcOEt/hexano), como um óleo incolor;

$\mathbf{R}_{\mathbf{f}} \quad 0.23(10 \%$ AcOEt/hexano);

${ }^{1}$ H RMN $\quad\left(500 \mathrm{MHz} \mathrm{CDCl}_{3}\right) \delta 7.38-7.28(\mathrm{~m}, 5 \mathrm{H}), 5.89$ (ddt, $J=16.3,10.7,5.8$ $\mathrm{Hz}, 1 \mathrm{H}), 5.30$ (dd, $J=17.2,1.4 \mathrm{~Hz}, 1 \mathrm{H}), 5.23$ (dd, $J=10.4,1.2 \mathrm{~Hz}, 1 \mathrm{H}$ ), $5.18-5.12(\mathrm{~m}, 1 \mathrm{H}), 5.09(\mathrm{~s}, 2 \mathrm{H}), 4.57$ (d, J = $5.3 \mathrm{~Hz}, 2 \mathrm{H}), 4.12-4.03$ (m, 1H), 2.56 (qd, $J=15.8,5.3 \mathrm{~Hz}, 2 \mathrm{H}), 1.72-1.58(\mathrm{~m}, 1 \mathrm{H}), 1.50$ (ddd, $J=14.6,7.5,4.3 \mathrm{~Hz}, 1 \mathrm{H}), 1.36-1.26(\mathrm{~m}, 1 \mathrm{H}), 0.93(\mathrm{~d}, J=6.7 \mathrm{~Hz}, 3 \mathrm{H})$, $0.91(\mathrm{~d}, \mathrm{~J}=6.7 \mathrm{~Hz}, 3 \mathrm{H})$;

${ }^{13}$ C RMN (125 MHz, $\left.\mathrm{CDCl}_{3}\right) \delta 171.2,155.7,136.6,131.9,128.5,128.0,128.0$, 118.5, 66.6, 65.2, 46.3, 43.5, 39.4, 24.9, 22.9, 22.1;

FTIR (puro, $\mathrm{cm}^{-1}$ ): 3339, 3034, 2957, 2870, 1825, 1732, 1717, 1531, 1456, 1306, 1263, 1233, 1179, 1115, 1001;

HRMS (ESI) Calculado para $\mathrm{C}_{18} \mathrm{H}_{26} \mathrm{O}_{4} \mathrm{~N}[\mathrm{M}+\mathrm{H}]^{+}$320.18563, encontrado 320.18604;

$[\alpha]_{\mathrm{D}}^{23} \quad-13.3\left(\right.$ c $\left.1.19 \mathrm{CHCl}_{3}\right) ;$ 
(S)-isopropil 3 - (((benziloxi)carbonil)amino)- 5 -methilhexanoato (98)

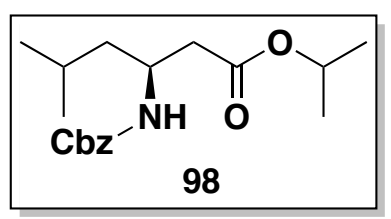

(S)-isopropil 3 - (((benziloxi)carbonil)amino)- 5 -methilhexanoato (98)

(98) $50 \%$ de rendimento após purificação por cromatografia em coluna flash (5-10\% de AcOEt/hexano), como um óleo incolor;

$\mathbf{R}_{\mathbf{f}} \quad 0.23(10 \%$ AcOEt/hexano);

${ }^{1}$ H RMN $\quad\left(500 \mathrm{MHz}, \mathrm{CDCl}_{3}\right) \delta 7.39-7.28(\mathrm{~m}, 5 \mathrm{H}), 5.20-5.12(\mathrm{~m}, 1 \mathrm{H}), 5.10(\mathrm{~d}, J$ $=12.7 \mathrm{~Hz}, 1 \mathrm{H}$ ), $5.07(\mathrm{~d}, J=12.7 \mathrm{~Hz}, 1 \mathrm{H}), 5.00$ (hept, $J=6.3 \mathrm{~Hz}, 1 \mathrm{H}$ ), $4.10-4.02(\mathrm{~m}, 1 \mathrm{H}), 2.49(\mathrm{qd}, J=15.5,5.3 \mathrm{~Hz}, 2 \mathrm{H}), 1.70-1.59(\mathrm{~m}, 1 \mathrm{H})$, $1.51-1.43(\mathrm{~m}, 1 \mathrm{H}), 1.35-1.24(\mathrm{~m}, 1 \mathrm{H}), 1.22(\mathrm{~d}, J=3.4 \mathrm{~Hz}, 3 \mathrm{H}), 1.21$ (d, $J=3.4 \mathrm{~Hz}, 3 \mathrm{H}), 0.93(\mathrm{~d}, J=5.8 \mathrm{~Hz}, 3 \mathrm{H}), 0.91(\mathrm{~d}, J=6.4 \mathrm{~Hz}, 3 \mathrm{H})$;

${ }^{13} \mathrm{C}$ RMN $\quad\left(100 \mathrm{MHz}, \mathrm{CDCl}_{3}\right) \delta 171.1,155.7,136.6,128.5,128.0,128.0,82.3,68.0$, $66.5,46.4,43.7,39.8,24.9,22.9,21.8,21.7$;

FTIR (puro, $\mathrm{cm}^{-1}$ ): $3021,2399,1729,1719,1514,1418,1217$;

HRMS (ESI) Calculado para $\mathrm{C}_{18} \mathrm{H}_{28} \mathrm{O}_{4} \mathrm{~N}[\mathrm{M}+\mathrm{H}]^{+}$322.20128, encontrado 322.20239;

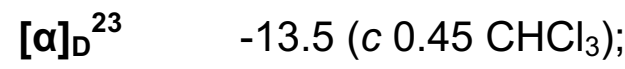


6.6.2 Método B: Usando acetato de etila como solvente

Em um frasco de $4 \mathrm{~mL}$, as diazocetonas 1,86-88 (0.174 $\mathrm{mmol})$ foram dissolvidas em $3.5 \mathrm{~mL}$ de AcOEt seco (acetonitrila também pode ser utilizada como solvente) seguido pela adição de 10 equivalentes do álcool ou amina desejado. A solução resultante foi irradiada com uma lâmpada LEDspot PAR branca de $18 \mathrm{~W}$ por $24 \mathrm{~h}$ sob agitação magnética à temperatura ambiente (evolução de gás nitrogênio observada). Em seguida, o solvente foi removido em evaporador rotativo. A purificação (quando indicada) por cromatografia em coluna flash forneceu os seguintes ésteres/ácidos/amidas: 
(E)-fenill 4-fenilbut-3-enoato (80)

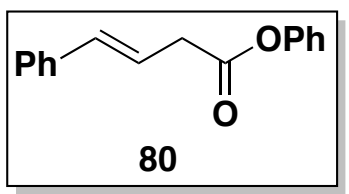

\section{(E)-fenill 4-fenilbut-3-enoato (80)}

(80) $63 \%$ de rendimento após purificação por cromatografia em coluna flash (5-10\% de AcOEt/hexano), como um sólido branco;

$\mathbf{R}_{\mathbf{f}} \quad 0.43(10 \%$ AcOEt/hexano);

${ }^{1} \mathrm{H}$ RMN $\quad\left(400 \mathrm{MHz}, \mathrm{CDCl}_{3}\right) \delta 7.42-7.29(\mathrm{~m}, 6 \mathrm{H}), 7.28-7.19(\mathrm{~m}, 2 \mathrm{H}), 7.14-$ $7.05(\mathrm{~m}, 2 \mathrm{H}), 6.60(\mathrm{~d}, J=15.9 \mathrm{~Hz}, 1 \mathrm{H}), 6.39(\mathrm{dt}, J=15.9,7.1 \mathrm{~Hz}, 1 \mathrm{H})$, 3.49 (dd, $J=7.1,1.4 \mathrm{~Hz}, 2 \mathrm{H})$;

${ }^{13} \mathrm{C}$ RMN $\quad\left(100 \mathrm{MHz}, \mathrm{CDCl}_{3}\right) \delta 167.0,150.7,136.7,134.0,129.4,128.6,127.7$, 126.3, 125.9, 121.5, 121.0, 38.4;

FTIR (puro, $\mathrm{cm}^{-1}$ ): 3061, 3028, 1755, 1593, 1493, 1362, 966, 937;

HRMS (ESI) Calculado para $\mathrm{C}_{16} \mathrm{H}_{15} \mathrm{O}_{2} \quad[\mathrm{M}+\mathrm{H}]^{+}$239.10666, encontrado 239.10663; 
(E)-1-fenoxi-5-fenilpent-4-en-2-ona (82)

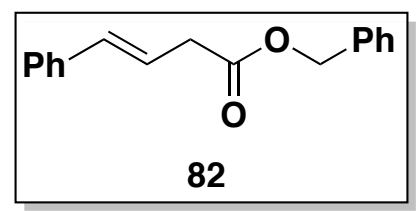

\section{(E)-1-fenoxi-5-fenilpent-4-en-2-ona (82)}

(80) $69 \%$ de rendimento como um óleo incolor após purificação por cromatografia em coluna flash (5-10\% de AcOEt/hexano);

$\mathbf{R}_{\mathbf{f}} \quad 0.48$ (10\% AcOEt/hexano);

${ }^{1} \mathbf{H}$ RMN $\quad\left(500 \mathrm{MHz}, \mathrm{CDCl}_{3}\right) \delta 7.39-7.29(\mathrm{~m}, 9 \mathrm{H}), 7.27-7.20(\mathrm{~m}, 1 \mathrm{H}), 6.51(\mathrm{~d}, J$ $=15.9 \mathrm{~Hz}, 1 \mathrm{H}), 6.32(\mathrm{dt}, J=15.9,7.1 \mathrm{~Hz}, 1 \mathrm{H}), 5.17(\mathrm{~s}, 2 \mathrm{H}), 3.31(\mathrm{dd}$, $J=7.1,1.4 \mathrm{~Hz}, 2 \mathrm{H})$;

${ }^{13} \mathrm{C}$ RMN $\quad\left(125 \mathrm{MHz}, \mathrm{CDCl}_{3}\right) \delta 171.4,136.8,135.8,133.6,128.6,128.5,128.3$, 128.2, 127.5, 126.3, 121.5, 66.6, 38.4;

FTIR (puro, $\mathrm{cm}^{-1}$ ): 3082, 3061, 3032, 2955, 2928, 1736, 1497, 1452, 1379, 1238, 1153, 966;

HRMS (ESI) Calculado para $\mathrm{C}_{17} \mathrm{H}_{16} \mathrm{O}_{2}[\mathrm{M}+\mathrm{Na}]^{+}$275.10425, encontrado 275.10446; 
Ácido (E)-4-fenilbut-3-enóico (83)

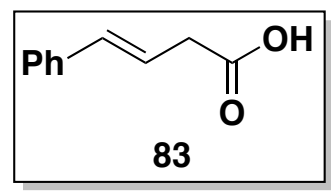

\section{Ácido (E)-4-fenilbut-3-enóico (83)}

\begin{tabular}{ll}
\hline (83) & $\begin{array}{l}\text { Rendimento quantitativo, sólido branco estável, não é necessária } \\
\text { qualquer purificação; }\end{array}$ \\
$\mathbf{R}_{\mathbf{f}}$ & $0.10(10 \% \mathrm{AcOEt} / \mathrm{Hexano}) ;$ \\
${ }^{1} \mathbf{H} \mathbf{R M N}$ & $\left(400 \mathrm{MHz}, \mathrm{CDCl}_{3}\right) \delta 7.36(\mathrm{~d}, J=7.2 \mathrm{~Hz}, 2 \mathrm{H}), 7.30(\mathrm{t}, J=7.4 \mathrm{~Hz}, 2 \mathrm{H})$, \\
& $7.25-7.20(\mathrm{~m}, 1 \mathrm{H}), 6.51(\mathrm{~d}, J=15.9 \mathrm{~Hz}, 1 \mathrm{H}), 6.27(\mathrm{dt}, J=15.9,7.1 \mathrm{~Hz}$, \\
& $1 \mathrm{H}), 3.29(\mathrm{dd}, J=7.1,1.4 \mathrm{~Hz}, 2 \mathrm{H}) ;$ \\
${ }^{13} \mathbf{C}$ RMN & $\left(100 \mathrm{MHz}, \mathrm{CDCl}_{3}\right) \delta 177.6,136.6,134.0,128.5,127.7,126.3,120.8$, \\
& $38.0 ;$ \\
\hline
\end{tabular}


$(+/-)-(E)-2-i s o p r o p i l-5-m e t i l c i c l o h e x i l$ 4-fenilbut-3-enoato (85)

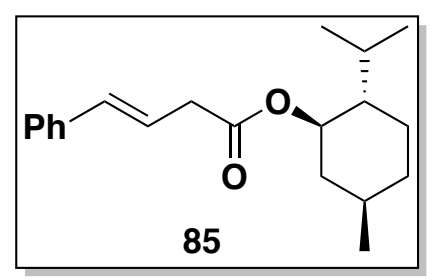

(+/-)-(E)-2-isopropil-5-metilciclohexil 4-fenilbut-3-enoato (85)

(85) $65 \%$ de rendimento como um óleo incolor após purificação por cromatografia em coluna flash (5-10\% de AcOEt/hexano);

$\mathbf{R}_{\mathbf{f}} \quad 0.63(10 \%$ AcOEt/hexano);

${ }^{1}$ H RMN $\quad\left(500 \mathrm{MHz}, \mathrm{CDCl}_{3}\right) \delta 7.37(\mathrm{dd}, J=8.2,1.0 \mathrm{~Hz}, 2 \mathrm{H}), 7.31$ (dd, $J=8.2,7.0$ $\mathrm{Hz}, 2 \mathrm{H}), 7.25-7.20(\mathrm{~m}, 1 \mathrm{H}), 6.50(\mathrm{~d}, J=15.9 \mathrm{~Hz}, 1 \mathrm{H}), 6.30(\mathrm{dt}, J=$ 15.8, 7.1 Hz, 1H), $4.72(\mathrm{td}, J=10.9,4.4 \mathrm{~Hz}, 1 \mathrm{H}), 3.23(\mathrm{~d}, J=7.6 \mathrm{~Hz}$, $2 \mathrm{H}), 2.04-1.98(\mathrm{~m}, 1 \mathrm{H}), 1.89(\mathrm{dtd}, J=14.0,7.0,2.7 \mathrm{~Hz}, 1 \mathrm{H}), 1.72-$ $1.64(\mathrm{~m}, 2 \mathrm{H}), 1.55-1.44(\mathrm{~m}, 1 \mathrm{H}), 1.44-1.36(\mathrm{~m}, 1 \mathrm{H}), 1.14-0.95(\mathrm{~m}$, $3 \mathrm{H}), 0.90$ (t, $J=6.7 \mathrm{~Hz}, 6 \mathrm{H}), 0.77(\mathrm{~d}, J=7.0 \mathrm{~Hz}, 3 \mathrm{H})$;

${ }^{13} \mathrm{C}$ RMN $\quad\left(125 \mathrm{MHz}, \mathrm{CDCl}_{3}\right) \delta 171.1,137.0,133.2,128.6,128.5,127.5,122.1$, 74.6, 47.0, 40.9, 38.8, 34.3, 31.4, 26.3, 23.5, 22.0, 20.7, 16.4;

FTIR (puro, $\mathrm{cm}^{-1}$ ): 3061, 3028, 2955, 2926, 2870, 1732, 1454, 1369, 1252, 1169, 1150, 984;

HRMS (ESI) Calculado para $\mathrm{C}_{20} \mathrm{H}_{28} \mathrm{O}_{2}[\mathrm{M}+\mathrm{Na}]^{+}$323.19815, encontrado 323.19772; 
2-fenilacetato de fenila (91)

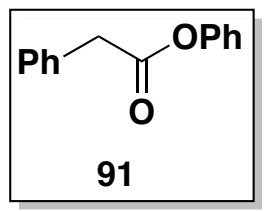

\begin{tabular}{ll}
\hline \multicolumn{1}{c}{ 2-fenilacetato de fenila (91) } \\
\hline $\mathbf{\text { (91) }}$ & $\begin{array}{l}62 \% \text { de rendimento como um óleo incolor após purificação por } \\
\text { cromatografia em coluna flash (5-10\% de AcOEt/hexano); }\end{array}$ \\
$\mathbf{R}_{\mathbf{f}}$ & $0.48(10 \% \mathrm{AcOEt} /$ hexano); \\
${ }^{1} \mathbf{H} \mathbf{R M N}$ & $\left(500 \mathrm{MHz}, \mathrm{CDCl}_{3}\right) \delta 7.42-7.29(\mathrm{~m}, 7 \mathrm{H}), 7.24-7.20(\mathrm{~m}, 1 \mathrm{H}), 7.09-$ \\
& $7.05(\mathrm{~m}, 2 \mathrm{H}), 3.87(\mathrm{~s}, 2 \mathrm{H}) ;$ \\
${ }^{13} \mathbf{C} \mathbf{R M N}$ & $\left(125 \mathrm{MHz}, \mathrm{CDCl}_{3}\right) \delta 167.0,150.7,133.5,129.4,129.3,128.7,127.3$, \\
& $125.8,121.4,41.4 ;$ \\
\hline
\end{tabular}

ácido 2-fenillacetico (93)

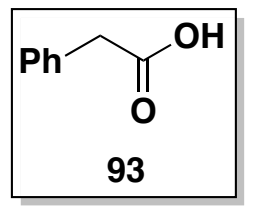

\begin{tabular}{ll}
\hline \multicolumn{1}{c}{ ácido 2-fenillacético (93) } \\
\hline $\mathbf{( 9 3 )}$ & $\begin{array}{l}78 \% \text { de rendimento como um óleo incolor após purificação por } \\
\text { cromatografia em coluna flash (20-40\% de AcOEt/hexano); }\end{array}$ \\
$\mathbf{R}_{\mathbf{f}}$ & $0.15\left(10 \% \mathrm{AcOEt}_{\text {hexano }) ;}\right.$ \\
${ }^{1} \mathbf{H ~ R M N}$ & $\left(400 \mathrm{MHz}, \mathrm{CDCl}_{3}\right) \delta 7.37-7.25(\mathrm{~m}, 5 \mathrm{H}), 3.66(\mathrm{~s}, 2 \mathrm{H}) ;$ \\
${ }^{13} \mathbf{C} \mathbf{R M N}$ & $\left(100 \mathrm{MHz}, \mathrm{CDCl}_{3}\right) \delta 177.7,133.2,129.4,128.6,127.3,41.0 ;$ \\
\hline
\end{tabular}


$N$-alil-2-fenilacetamida (100)

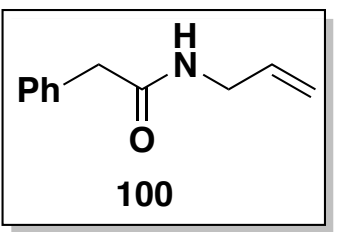

\begin{tabular}{|c|c|}
\hline \multicolumn{2}{|r|}{$N$-alil-2-fenilacetamida (100) } \\
\hline$(100)$ & $\begin{array}{l}\text { 93\% de rendimento, como um óleo incolor; não é necessária a } \\
\text { purificação em coluna; }\end{array}$ \\
\hline $\mathbf{R}_{\mathbf{f}}$ & 0.15 (10\% AcOEt/hexano); \\
\hline${ }^{1} \mathrm{H}$ RMN & $\begin{array}{l}\left(500 \mathrm{MHz}, \mathrm{CDCl}_{3}\right) \delta 7.34-7.26(\mathrm{~m}, 5 \mathrm{H}), 5.79-5.73(\mathrm{~m}, 1 \mathrm{H}), 5.71(\mathrm{~s}, \\
1 \mathrm{H}), 5.10-5.03(\mathrm{~m}, 2 \mathrm{H}), 3.87(\mathrm{dt}, J=5.8,1.6 \mathrm{~Hz}, 2 \mathrm{H}), 3.60(\mathrm{~s}, 2 \mathrm{H}) ;\end{array}$ \\
\hline FTIR & $\begin{array}{l}\left.\text { (puro, } \mathrm{cm}^{-1}\right): 3282,2956,2922,2853,1730,1641,1542,1495,1437 \\
1261,1074,918,722\end{array}$ \\
\hline
\end{tabular}

- Os dados estão em acordo com os descritos na literatura. ${ }^{231}$

$N$-ciclohexil-2-fenilacetamida (101)

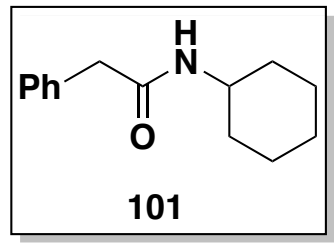

\section{$\mathrm{N}$-ciclohexil-2-fenilacetamida (101)}

(101) 96\% de rendimento após purificação por cromatografia em coluna flash (20-50\% de AcOEt/hexano), como um sólido branco;

${ }^{1} \mathrm{H}$ RMN $\quad\left(500 \mathrm{MHz}, \mathrm{CDCl}_{3}\right) \delta 7.31-7.25(\mathrm{~m}, 5 \mathrm{H}), 5.56(\mathrm{bs}, 1 \mathrm{H}), 3.80-3.69(\mathrm{~m}$, $1 \mathrm{H}), 3.55(\mathrm{~s}, 2 \mathrm{H}), 1.86-1.80(\mathrm{~m}, 2 \mathrm{H}), 1.66-1.56(\mathrm{~m}, 3 \mathrm{H}), 1.32-1.21$ $(\mathrm{m}, 2 \mathrm{H}), 1.11-0.98(\mathrm{~m}, 3 \mathrm{H})$;

- Os dados estão de acordo com os descritos na literatura. ${ }^{232}$ 
$N$-benzil-2-fenilacetamida (102)

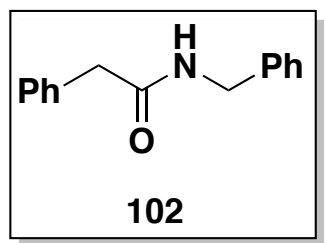

\begin{tabular}{|c|c|}
\hline \multicolumn{2}{|r|}{$\mathrm{N}$-benzil-2-fenilacetamida (102) } \\
\hline$(102)$ & $\begin{array}{l}99 \% \text { de rendimento como um sólido branco após purificação por } \\
\text { cromatografia em coluna flash ( } 20-50 \% \text { de AcOEt/hexano); }\end{array}$ \\
\hline${ }^{1} \mathrm{H}$ RMN & $\left(500 \mathrm{MHz}, \mathrm{CDCl}_{3}\right) \delta 7.32-7.18(\mathrm{~m}, 8 \mathrm{H}), 7.16-7.11(\mathrm{~m}, 2 \mathrm{H}), 4.34(\mathrm{~d}, J$ \\
\hline & $=5.8 \mathrm{~Hz}, 2 \mathrm{H}), 3.53(\mathrm{~s}, 2 \mathrm{H})$; \\
\hline
\end{tabular}

- Os dados estão de acordo com os descritos na literatura. ${ }^{233}$

$N$-butil-2-fenilacetamida (103)

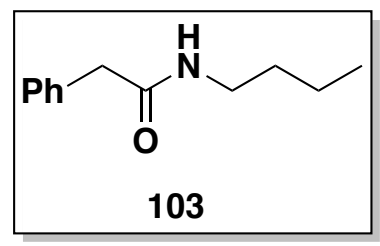

\begin{tabular}{|c|c|}
\hline \multicolumn{2}{|r|}{$N$-butil-2-fenilacetamida (103) } \\
\hline$(103)$ & $\begin{array}{l}95 \% \text { de rendimento como um sólido branco. Não é necessária a } \\
\text { purificação em coluna; }\end{array}$ \\
\hline${ }^{1} \mathrm{H}$ RMN & $\begin{array}{l}\left(500 \mathrm{MHz}, \mathrm{CDCl}_{3}\right) \delta 7.40-7.35(\mathrm{~m}, 2 \mathrm{H}), 7.33-7.25(\mathrm{~m}, 3 \mathrm{H}), 5.49(\mathrm{~s}, \\
1 \mathrm{H}), 3.58(\mathrm{~s}, 2 \mathrm{H}), 3.22(\mathrm{td}, J=7.3,5.8 \mathrm{~Hz}, 2 \mathrm{H}), 1.47-1.37(\mathrm{~m}, 2 \mathrm{H}), \\
1.33-1.22(\mathrm{~m}, 2 \mathrm{H}), 0.90(\mathrm{t}, J=7.3 \mathrm{~Hz}, 3 \mathrm{H}) ;\end{array}$ \\
\hline FTIR & $\left(\right.$ puro, $\left.\mathrm{cm}^{-1}\right): 3289,3085,2956,2928,2859,1639,1552,1494,1079$ \\
\hline
\end{tabular}

- Os dados estão de acordo com os descritos na literatura. ${ }^{234}$ 
N-alil-3,3-dimetilbutanamida (104)

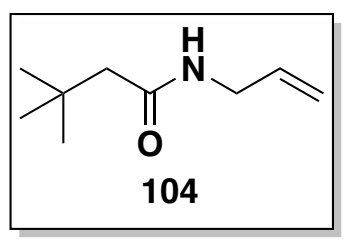

\begin{tabular}{ll}
\hline \multicolumn{1}{c}{$\boldsymbol{N}$-alil-3,3-dimetilbutanamida (104) } \\
\hline (104) & 93\% de rendimento como um óleo incolor. Não é necessária a \\
& purificação em coluna. \\
& $(500 \mathrm{MHz}, \mathrm{CDCl}) \delta 5.86(\mathrm{ddt}, \mathrm{J}=17.2,10.2,5.7 \mathrm{~Hz}, 1 \mathrm{H}), 5.52(\mathrm{~s}, 1 \mathrm{H})$, \\
& $5.25-5.17(\mathrm{~m}, 1 \mathrm{H}), 5.18-5.11(\mathrm{~m}, 1 \mathrm{H}), 3.90(\mathrm{tt}, \mathrm{J}=5.8,1.5 \mathrm{~Hz}, 2 \mathrm{H})$, \\
& $2.09(\mathrm{~s}, 2 \mathrm{H}), 1.07(\mathrm{~s}, 9 \mathrm{H}) ;$
\end{tabular}

3,3-dimetil-N-fenilbutanamida (105)

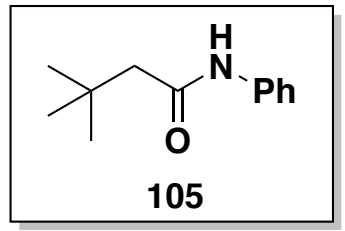

\begin{tabular}{|c|c|}
\hline & 3,3-dimetil-N-fenilbutanamida (105) \\
\hline$(105)$ & $\begin{array}{l}63 \% \text { de rendimento como um sólido branco após purificação por } \\
\text { cromatografia em coluna flash ( } 20-50 \% \text { de AcOEt/hexano); }\end{array}$ \\
\hline${ }^{1} \mathrm{H}$ RMN & $\begin{array}{l}\left(500 \mathrm{MHz}, \mathrm{CDCl}_{3}\right) \delta 7.35-7.28(\mathrm{~m}, 3 \mathrm{H}), 7.13-7.04(\mathrm{~m}, 2 \mathrm{H}), 2.20(\mathrm{~s}, \\
2 \mathrm{H}), 1.12(\mathrm{~s}, 9 \mathrm{H})\end{array}$ \\
\hline
\end{tabular}

- Os dados estão de acordo com os descritos na literatura. ${ }^{235}$ 
Carbamato de benzil (S)-(1-(alilamino)-5-metil-1-oxohexan-3-il) (106)

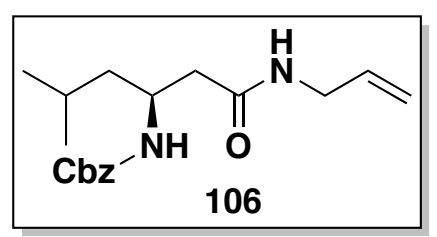

\begin{tabular}{|c|c|}
\hline \multicolumn{2}{|r|}{ Carbamato de benzil (S)-(1-(alilamino)-5-metil-1-oxohexan-3-il) (106) } \\
\hline$(\mathbf{1 0 6 )}$ & $\begin{array}{l}99 \% \text { de rendimento como um sólido branco. Não é necessária } \\
\text { purificação em coluna flash. }\end{array}$ \\
\hline $\mathbf{R}_{\mathbf{f}}$ & 0.20 (40\% AcOEt/Hexano); \\
\hline${ }^{1} \mathrm{H}$ RMN & $\begin{array}{l}\left(500 \mathrm{MHz}, \mathrm{CDCl}_{3}\right) \delta 7.41-7.29(\mathrm{~m}, 5 \mathrm{H}), 6.14(\mathrm{~s}, 1 \mathrm{H}), 5.81(\mathrm{ddt}, J= \\
17.1,10.2,5.6 \mathrm{~Hz}, 1 \mathrm{H}), 5.59(\mathrm{~d}, J=8.9 \mathrm{~Hz}, 1 \mathrm{H}), 5.21-5.07(\mathrm{~m}, 4 \mathrm{H}), \\
4.06-3.95(\mathrm{~m}, 1 \mathrm{H}), 3.92-3.77(\mathrm{~m}, 2 \mathrm{H}), 2.53-2.37(\mathrm{~m}, 2 \mathrm{H}), 1.73- \\
1.61(\mathrm{~m}, 1 \mathrm{H}), 1.62-1.51(\mathrm{~m}, 1 \mathrm{H}), 1.38-1.29(\mathrm{~m}, 1 \mathrm{H}), 0.94 \\
(\mathrm{t}, J=6.5 \mathrm{~Hz}, 6 \mathrm{H}) ;\end{array}$ \\
\hline HRMS & $\begin{array}{l}\text { (ESI) Calculado para } \mathrm{C}_{18} \mathrm{H}_{27} \mathrm{~N}_{2} \mathrm{O}_{3}{ }^{+}[\mathrm{M}+\mathrm{H}]^{+} 319.2016 \text {, encontrado } \\
319,2028 ;\end{array}$ \\
\hline FTIR & $\begin{array}{l}\text { (puro) } \mathrm{cm}^{-1}: 3305,2956,2922,2853,1732,1691,1641,1544,1436, \\
1378,1273,1115,1063,912\end{array}$ \\
\hline
\end{tabular}


Carbamato de benzil (S)-(5-metil-1-oxo-1-(fenilamino)hexan-3-il)) (107)

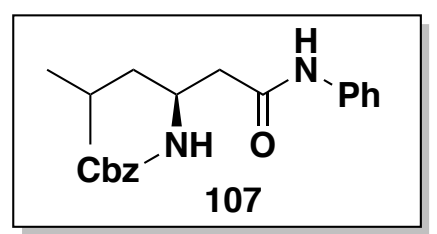

\section{Carbamato de benzil (S)-(5-metil-1-oxo-1-(fenilamino)hexan-3-il)) (107)}

(107) $\quad 70 \%$ de rendimento como um sólido branco após purificação por cromatografia em coluna flash (20-70\% de AcOEt/hexano);

$\mathbf{R}_{\mathbf{f}} \quad 0.45(40 \%$ AcOEt/Hexano);

${ }^{1}$ H RMN $\quad\left(500 \mathrm{MHz} \mathrm{CDCl}_{3}\right) \delta 7.80(\mathrm{~s}, 1 \mathrm{H}), 7.50(\mathrm{~d}, J=7.9 \mathrm{~Hz}, 2 \mathrm{H}), 7.39-7.28$ $(\mathrm{m}, 7 \mathrm{H}), 7.12(\mathrm{t}, J=7.4 \mathrm{~Hz}, 1 \mathrm{H}), 5.28(\mathrm{~s}, 1 \mathrm{H}), 5.11(\mathrm{~d}, J=2.8 \mathrm{~Hz}, 2 \mathrm{H})$, $4.28-4.18(\mathrm{~m}, 1 \mathrm{H}), 4.13-4.03(\mathrm{~m}, 2 \mathrm{H}), 2.64(\mathrm{dt}, J=15.5,8.8 \mathrm{~Hz}, 2 \mathrm{H})$, $1.75-1.67(\mathrm{~m}, 1 \mathrm{H}), 0.91(\mathrm{~s}, 6 \mathrm{H})$;

HRMS (ESI) Calculado para $\mathrm{C}_{21} \mathrm{H}_{27} \mathrm{~N}_{2} \mathrm{O}_{3}{ }^{+}[\mathrm{M}+\mathrm{H}]^{+}$355.2016, encontrado 355.2007;

FTIR (puro) $\mathrm{cm}^{-1}:$ 3312, 2956, 2922, 2853, 1691, 1662, 1600, 1545, 1463, 1378, 1271, 1117, 1065, 750; 
Carbamato de benzil (S)-(1-(butilamino)-5-metil-1-oxohexan-3-il) (108)

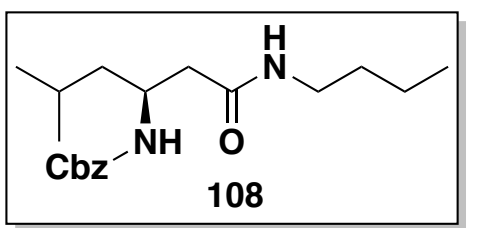

\section{Carbamato de benzil (S)-(1-(butilamino)-5-metil-1-oxohexan-3-il) (108)}

(108) 98\% de rendimento como um sólido branco após purificação por cromatografia em coluna flash (20-70\% de AcOEt/hexano);

$\mathbf{R}_{\mathbf{f}} \quad 0.20$ (40\% AcOEt/Hexano);

${ }^{1} \mathrm{H}$ RMN $\quad\left(500 \mathrm{MHz}, \mathrm{CDCl}_{3}\right) \delta 7.46-7.32(\mathrm{~m}, 5 \mathrm{H}), 6.04(\mathrm{~s}, 1 \mathrm{H}), 5.62(\mathrm{~d}, J=8.9$ $\mathrm{Hz}, 1 \mathrm{H}), 5.20-5.05(\mathrm{~m}, 2 \mathrm{H}), 4.01(\mathrm{td}, J=9.1,4.9 \mathrm{~Hz}, 1 \mathrm{H}), 3.31-3.13$ (m, 2H), $2.53-2.35(\mathrm{~m}, 1 \mathrm{H}), 1.78-1.27(\mathrm{~m}, 8 \mathrm{H}), 1.04-0.92(\mathrm{~m}, 10 \mathrm{H})$;

HRMS (ESI) Calculado para $\mathrm{C}_{19} \mathrm{H}_{31} \mathrm{~N}_{2} \mathrm{O}_{3}+[\mathrm{M}+\mathrm{H}]^{+} 335.2329$, encontrado 335,2331;

FTIR (puro) $\mathrm{cm}^{-1}: 3310,2957,2922,2853,1698,1644,1540,1463,1377$, $1266,1284,1119,1071,888,733$; 


\subsubsection{Método C: Usando álcoois alílicos em acetonitrila (LED ou Xenônio)}

1-10 equivalentes dos álcoois alílicos 154-159 foram adicionados a uma solução $0.022 \mathrm{M}$ das diazocetonas 1,54, 111-114 em MeCN em temperatura ambiente. A solução resultante foi irradiada com uma lâmpada LEDspot PAR branca de $18 \mathrm{~W}$ ou de arco de Xe $(260 \mathrm{~W})$ pelo tempo indicado sob agitação magnética à temperatura ambiente (evolução de gás nitrogênio observada). Em seguida, o solvente foi evaporado em evaporador rotativo. A purificação (quando indicada) por cromatografia em coluna flash forneceu os seguintes ésteres alílicos:

Obs.: O número de equivalentes, tempo e a lâmpada utilizada são indicados na descrição de cada composto, de acordo com o melhor rendimento obtido. Cabe ressaltar, que a reação pode ser realizada em ambas as lâmpadas, variando apenas o rendimento obtido e o tempo. Geralmente, a lâmpada de LED oferece reações mais limpas e rendimentos maiores, com reações completas em torno de 24 h. A lâmpada de Xenônio, entretanto, possui tempos de reação menores (30 min - 4 h).

Esclarecimento: Desde que a lâmpada seja desligada imediatamente após o total consumo da diazocetona, o isômero $Z$ durante a etapa de rearranjo de Wolff é formado apenas em quantidades traços ( $<5 \%)$. A caracterização do isômero $Z$ que é indicado na descrição de cada composto é referente ao produto de irradiação do éster puro em condições de fotocicloadição [2+2]. A razão E/Z obtida, neste caso, é de 1:1. 


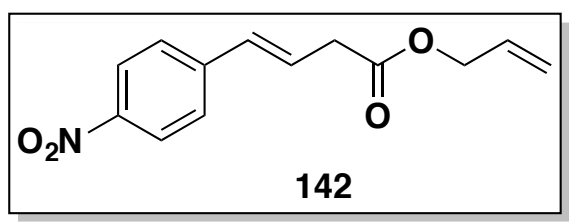

\section{but-3-enoato de alil (E)-4-(4-nitrofenila) (142)}

Obs.: $\quad$ Álcool alílico 156 puro 0.022 M, lâmpada de Xe (260 W), 4 h

(142) $44 \%$ de rendimento como um sólido amarelo pardo. Purificação em coluna flash usando gradiente de 5-20\% AcOEt/Hexano.

$\mathbf{R}_{\mathbf{f}} \quad$ Isômero E 0.34 (10\% AcOEt/Hexano);

$\mathbf{R}_{\mathbf{f}} \quad$ Isômero Z $0.36(10 \%$ AcOEt/Hexano $)$

${ }^{1} \mathbf{H}$ RMN Isômero E $\left(500 \mathrm{MHz}, \mathrm{CDCl}_{3}\right) \delta 8.18(\mathrm{~d}, J=8.8 \mathrm{~Hz}, 2 \mathrm{H}), 7.51$ (d, $J=8.7$ $\mathrm{Hz}, 2 \mathrm{H}), 6.59(\mathrm{~d}, J=16.1 \mathrm{~Hz}, 1 \mathrm{H}), 6.52(\mathrm{dt}, J=15.9,6.6 \mathrm{~Hz}, 1 \mathrm{H}), 5.95$ (ddt, $J=17.2,10.4,5.8 \mathrm{~Hz}, 1 \mathrm{H}$ ), 5.35 (dq, $J=17.2,1.5 \mathrm{~Hz}, 1 \mathrm{H}), 5.27$ $(\mathrm{dq}, J=10.4,1.3 \mathrm{~Hz}, 1 \mathrm{H}), 4.65(\mathrm{dt}, J=5.8,1.4 \mathrm{~Hz}, 2 \mathrm{H}), 3.35(\mathrm{dd}, J=$ 6.7, $1.0 \mathrm{~Hz}, 1 \mathrm{H})$.

${ }^{13}$ C RMN Isômero E $\left(126 \mathrm{MHz}, \mathrm{CDCl}_{3}\right) \delta 170.6,147.1,143.3,132.0,131.8,127.0$, 126.9, 124.1, 118.8, 65.8, 38.4;

${ }^{1} \mathbf{H}$ RMN Isômero Z $\left(500 \mathrm{MHz} \mathrm{CDCl}_{3}\right) \delta 8.21(\mathrm{~d}, J=8.8 \mathrm{~Hz}, 2 \mathrm{H}), 7.43(\mathrm{~d}, J=8.4$ $\mathrm{Hz}, 2 \mathrm{H}), 6.69$ (dt, $J=11.7,1.9 \mathrm{~Hz}, 1 \mathrm{H}), 6.10(\mathrm{dt}, J=11.6,7.5 \mathrm{~Hz}, 1 \mathrm{H})$, 5.92 (ddt, $J=17.2,10.4,5.8 \mathrm{~Hz}, 1 \mathrm{H}), 5.33(\mathrm{dq}, J=17.2,1.5 \mathrm{~Hz}, 1 \mathrm{H})$, 5.26 (dq, $J=10.4,1.2 \mathrm{~Hz}, 1 \mathrm{H}), 4.63$ (dt, $J=5.8,1.4 \mathrm{~Hz}, 2 \mathrm{H}$ ), 3.35 (dd, $J=7.6,1.8 \mathrm{~Hz}, 2 \mathrm{H})$;

FTIR (puro, $\mathrm{cm}^{-1}$ ) 3057, 2926, 2852, 1734, 1597, 1343, 1265, 1159, 987, 858, 732, 702;

HRMS $\mathrm{ESI}^{+}(\mathrm{m} / \mathrm{z})$ Calculado para $\mathrm{C}_{13} \mathrm{H}_{13} \mathrm{NNaO}_{4}{ }^{+}[\mathrm{M}+\mathrm{Na}]^{+}$270.0737, encontrado 270.0706; 
(E)-4-fenilbut-3-enoato cinâmico (143)

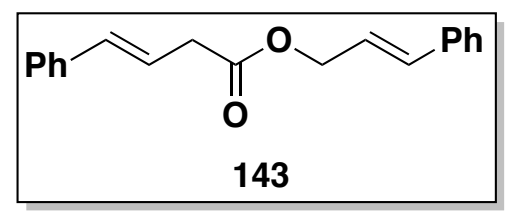

\section{(E)-4-fenilbut-3-enoato cinâmico (143)}

Obs.: 2 equiv. do álcool cinâmico 154, lâmpada de Xe (260 W); $1 \mathrm{~h}$

(143) $73 \%$ de rendimento como um sólido branco após purificação em coluna flash usando gradiente 5-20\% de AcOCEt/Hexano. A coluna pode ser realizada também em éter/éter petróleo 7-10\% para uma melhor separação dos isômeros.

$\mathbf{R}_{\mathbf{f}} \quad$ Isômero E 0.30 (5\% AcOEt/hexano);

$\mathbf{R}_{\mathbf{f}} \quad$ Isômero Z 0.35 (5\% AcOEt/hexano);

${ }^{1} \mathrm{H}$ RMN Isômero $E\left(400 \mathrm{MHz}, \mathrm{CDCl}_{3}\right) \delta 7.41-7.36(\mathrm{~m}, 4 \mathrm{H}), 7.35-7.27(\mathrm{~m}, 5 \mathrm{H})$, $7.25-7.20(\mathrm{~m}, 1 \mathrm{H}), 6.67(\mathrm{~d}, J=15.9 \mathrm{~Hz}, 1 \mathrm{H}), 6.52(\mathrm{~d}, J=15.9 \mathrm{~Hz}, 1 \mathrm{H})$, $6.31(\mathrm{dt}, J=15.9,6.8 \mathrm{~Hz}, 2 \mathrm{H}), 4.78$ (dd, $J=6.5,1.3 \mathrm{~Hz}, 2 \mathrm{H}), 3.30$ (dd, $J=7.1,1.4 \mathrm{~Hz}, 2 \mathrm{H})$;

Isômero Z $\left(500 \mathrm{MHz}, \mathrm{CDCl}_{3}\right) \delta 7.39-7.33(\mathrm{~m}, 4 \mathrm{H}), 7.31-7.28(\mathrm{~m}, 3 \mathrm{H})$, $7.25-7.22(\mathrm{~m}, 2 \mathrm{H}), 6.68(\mathrm{ddt}, J=17.7,11.5,1.9 \mathrm{~Hz}, 2 \mathrm{H}), 5.91$ (dt, $J=$ 11.5, 7.3 Hz, 1H), $5.83(\mathrm{dt}, J=11.7,6.7 \mathrm{~Hz}, 1 \mathrm{H}), 4.90$ (dd, $J=6.7,1.7$ $\mathrm{Hz}, 2 \mathrm{H}), 3.39$ (dd, $J=7.3,1.9 \mathrm{~Hz}, 2 \mathrm{H}$ ).

${ }^{13}$ C RMN $\quad\left(126 \mathrm{MHz}, \mathrm{CDCl}_{3}\right) \delta 171.5,136.9,136.3,134.5,133.7,128.7,128.7$, 128.2, 127.7, 126.8, 126.4, 123.1, 121.7, 65.5, 38.6;

FTIR (puro, $\mathrm{cm}^{-1}$ ) 3059, 3027, 2922, 2850, 1730, 1674, 1495, 1448, 1295, 1239, 1148, 962, 741, 689;

HRMS $\mathrm{ESI}^{+}(\mathrm{m} / \mathrm{z})$ Calculado $\mathrm{C}_{19} \mathrm{H}_{18} \mathrm{NaNO}_{2}{ }^{+}[\mathrm{M}+\mathrm{Na}]^{+} 301.1199$ encontrado 301.1215; 


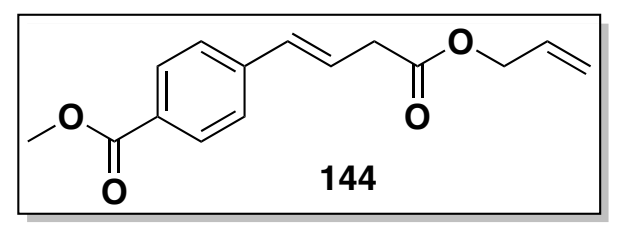

\section{benzoato de metil (E)-4-(4-(aliloxi)-4-oxobut-1-en-1-il) (144)}

Obs.: 10 equiv. do álcool alílico 156, lâmpada de Xe (260 W), 2 h e 20 min;

(144) $65 \%$ de rendimento como um sólido branco após purificação em coluna flash usando gradiente 5-10\% de AcOEt/Hexano;

$\mathbf{R}_{\mathbf{f}} \quad$ Isômero E 0.25 (5\% AcOEt/hexano);

$\mathbf{R}_{\mathbf{f}} \quad$ Isômero Z 0.31 (5\% AcOEt/hexano);

${ }^{1} \mathrm{H}$ RMN Isômero E $\left(500 \mathrm{MHz}, \mathrm{CDCl}_{3}\right) \delta 7.97(\mathrm{~d}, \mathrm{~J}=8.4 \mathrm{~Hz}, 2 \mathrm{H}), 7.42(\mathrm{~d}, J=8.0$ $\mathrm{Hz}, 2 \mathrm{H}), 6.54(\mathrm{~d}, J=15.9 \mathrm{~Hz}, 1 \mathrm{H}), 6.43(\mathrm{dt}, J=15.9,7.0 \mathrm{~Hz}, 1 \mathrm{H}), 5.93$ (ddt, $J=17.2,10.4,5.8 \mathrm{~Hz}, 1 \mathrm{H}$ ), 5.33 (dq, $J=17.2,1.5 \mathrm{~Hz}, 1 \mathrm{H}), 5.25$ (dq, $J=10.4,1.3 \mathrm{~Hz}, 1 \mathrm{H}), 4.63(\mathrm{dt}, J=5.8,1.4 \mathrm{~Hz}, 2 \mathrm{H}), 3.90(\mathrm{~s}, 3 \mathrm{H})$, 3.31 (dd, $J=7.0,1.3 \mathrm{~Hz}, 2 \mathrm{H}$ );

${ }^{1} \mathrm{H}$ RMN Isômero Z $\left(500 \mathrm{MHz}, \mathrm{CDCl}_{3}\right) \delta 8.06-7.98(\mathrm{~m}, 2 \mathrm{H}), 7.39-7.32(\mathrm{~m}, 2 \mathrm{H})$, $6.68(\mathrm{dt}, J=11.6,1.9 \mathrm{~Hz}, 1 \mathrm{H}), 6.02$ (dt, $J=11.6,7.4 \mathrm{~Hz}, 1 \mathrm{H}), 5.94$ (ddt, $J=17.2,10.4,5.8 \mathrm{~Hz}, 1 \mathrm{H}), 5.34(\mathrm{dq}, J=17.2,1.5 \mathrm{~Hz}, 1 \mathrm{H}), 5.27$ (dq, $J=$ 10.4, $1.3 \mathrm{~Hz}, 1 \mathrm{H}), 4.64$ (dt, $J=5.8,1.4 \mathrm{~Hz}, 2 \mathrm{H}), 3.38$ (dd, $J=7.4,1.9$ $\mathrm{Hz}, 2 \mathrm{H})$.

${ }^{13} \mathrm{C}$ RMN Isômero E $\left(126 \mathrm{MHz}, \mathrm{CDCl}_{3}\right) \delta 171.0,167.0,141.4,132.8,132.1,130.0$, 129.2, 126.3, 124.6, 118.7, 65.7, 52.2, 38.5;

FTIR (puro, $\mathrm{cm}^{-1}$ ) 2952, 1716, 1607, 1435, 1275, 1155, 1108, 970, 761;

HRMS $\mathrm{ESI}^{+}(\mathrm{m} / \mathrm{z})$ Calculado para $\mathrm{C}_{15} \mathrm{H}_{17} \mathrm{O}_{4}{ }^{+}[\mathrm{M}+\mathrm{H}]^{+} 261.1121$ encontrado 261.1120; 
but-2-enoato de metil (E)-4-(((E)-4-fenilbut-3-enoil)oxi) (145)

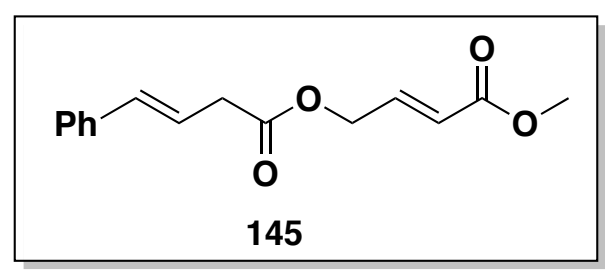

\begin{tabular}{|c|c|}
\hline & but-2-enoato de metil (E)-4-(((E)-4-fenilbut-3-enoil)oxi) (145) \\
\hline $\begin{array}{l}\text { Obs.: } \\
(145)\end{array}$ & $\begin{array}{l}2 \text { equiv. do álcool alílico 157, lâmpada de Xe }(260 \mathrm{~W}) \text {, } 1 \text { h e } 30 \text { min; } \\
50 \% \text { de rendimento após purificação em cromatografia flash usando } \\
\text { gradiente de } 10-20 \% \text { AcOEt/hexano. Os isômeros E/Z após a irradiação } \\
\text { não puderam ser separados em coluna. }\end{array}$ \\
\hline $\mathbf{R}_{\mathbf{f}}$ & 0.23 (10\% AcOEt/hexano); \\
\hline${ }^{1} \mathrm{H}$ RMN & $\begin{array}{l}\left(500 \mathrm{MHz}, \mathrm{CDCl}_{3}\right) \delta 7.39-7.36(\mathrm{~m}, 2 \mathrm{H}), 7.34-7.29(\mathrm{~m}, 2 \mathrm{H}), 7.26- \\
7.22(\mathrm{~m}, 1 \mathrm{H}), 6.96(\mathrm{dt}, J=15.8,4.7 \mathrm{~Hz}, 1 \mathrm{H}), 6.52(\mathrm{dt}, J=15.9,1.5 \mathrm{~Hz}, \\
1 \mathrm{H}), 6.30(\mathrm{dt}, \mathrm{J}=15.9,7.2 \mathrm{~Hz}, 1 \mathrm{H}), 6.05(\mathrm{dt}, J=15.8,1.9 \mathrm{~Hz}, 1 \mathrm{H}), 4.79 \\
(\mathrm{dd}, J=4.7,2.0 \mathrm{~Hz}, 2 \mathrm{H}), 3.75(\mathrm{~s}, 3 \mathrm{H}), 3.32(\mathrm{dd}, J=7.1,1.5 \mathrm{~Hz}, 2 \mathrm{H}) ;\end{array}$ \\
\hline${ }^{13} \mathrm{C}$ RMN & $\begin{array}{l}\left(126 \mathrm{MHz}, \mathrm{CDCl}_{3}\right) \delta 171.0,166.3,141.3,136.8,134.1,128.7,127.8, \\
\text { 126.5, 122.2, 121.2, 63.0, 51.9, 38.3; }\end{array}$ \\
\hline FTIR & $\begin{array}{l}\text { (puro, } \mathrm{cm}^{-1} \text { ) 3027, 2951, 2923, 2850, 1722, 1666, 1436, 1310, } 1274 \text {, } \\
\text { 1148, 964, 40, 692; }\end{array}$ \\
\hline HRMS & $\begin{array}{l}\mathrm{ESI}^{+}(\mathrm{m} / \mathrm{z}) \text { Calculado } \mathrm{C}_{15} \mathrm{H}_{16} \mathrm{NaO}_{4}{ }^{+}[\mathrm{M}+\mathrm{Na}]^{+} \text {283.0941, encontrado } \\
\text { 283.0957; }\end{array}$ \\
\hline
\end{tabular}


alil (E)-hept-3-enoato (146)

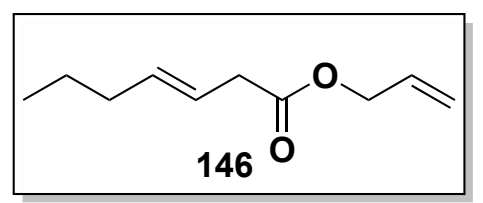

\section{alil (E)-hept-3-enoato (146)}

Obs.: $\quad 5$ equiv. do álcool alílico 157, lâmpada de Xe (260 W), $1 \mathrm{~h}$

(146) $70 \%$ de rendimento como um óleo incolor após purificação em AcOEt/Hexano $5-20 \%$. Não foi possível separar os isômeros E/Z por coluna após a irradiação. Cuidado! Produto volátil;

$\mathbf{R}_{\mathbf{f}} \quad 0.57$ (10\% AcOEt/hexano);

${ }^{1} \mathrm{H}$ RMN $\quad\left(400 \mathrm{MHz}, \mathrm{CDCl}_{3}\right) \delta 5.91(\mathrm{ddt}, J=17.1,10.4,5.7 \mathrm{~Hz}, 1 \mathrm{H}), 5.61-5.47$ (m, 2H), $5.35-5.27(\mathrm{~m}, 1 \mathrm{H}), 5.23(\mathrm{dq}, J=10.4,1.3 \mathrm{~Hz}, 1 \mathrm{H}), 4.58(\mathrm{dt}, J$ $=5.7,1.4 \mathrm{~Hz}, 2 \mathrm{H}), 3.05(\mathrm{~d}, J=5.6 \mathrm{~Hz}, 2 \mathrm{H}), 2.06-1.95(\mathrm{~m}, 2 \mathrm{H}), 1.39(\mathrm{~h}$, $J=7.3 \mathrm{~Hz}, 2 \mathrm{H}), 0.89(\mathrm{t}, J=7.4 \mathrm{~Hz}, 3 \mathrm{H})$;

${ }^{13} \mathrm{C}$ RMN $\quad\left(100 \mathrm{MHz}, \mathrm{CDCl}_{3}\right) \delta 172.0,134.9,132.3,121.7,118.3,65.3,38.2,34.7$, 22.4, 13.7;

HRMS $\mathrm{ESI}^{+}(\mathrm{m} / \mathrm{z})$ Calculado para $\mathrm{C}_{10} \mathrm{H}_{16} \mathrm{NaO}_{2}{ }^{+}[\mathrm{M}+\mathrm{Na}]^{+} 191.1043$ encontrado 191.1004; 
Carboxilato de benzil (E)-2-(4-(aliloxi)-4-oxobut-1-en-1-il)piperidina (147)

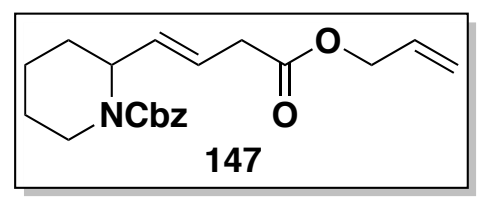

carboxilato de benzil (E)-2-(4-(aliloxi)-4-oxobut-1-en-1-il)piperidina (147)

Obs.: 10 equiv. do álcool alílico 156, lâmpada de Xe (260 W), 30 min;

(147) $50 \%$ de rendimento como um óleo incolor após purificação em AcOEt/Hexano 10-50\%. Não foi possível separar os isômeros E/Z por coluna após a irradiação;

$\mathbf{R}_{\mathbf{f}} \quad 0.25(10 \%$ AcOEt/hexano);

${ }^{1}$ H RMN $\quad\left(400 \mathrm{MHz} \mathrm{CDCl}_{3}\right) \delta 7.39-7.27(\mathrm{~m}, 5 \mathrm{H}), 5.91$ (ddt, $J=17.1,10.4,5.7$ $\mathrm{Hz}, 1 \mathrm{H}), 5.76-5.52(\mathrm{~m}, 2 \mathrm{H}), 5.31(\mathrm{dq}, J=17.2,1.5 \mathrm{~Hz}, 1 \mathrm{H}), 5.23$ (ddd, $J=10.4,2.6,1.3 \mathrm{~Hz}, 1 \mathrm{H}), 5.14(\mathrm{~d}, J=2.2 \mathrm{~Hz}, 2 \mathrm{H}), 4.90(\mathrm{~s}, 1 \mathrm{H}), 4.59$ (dt, $J=5.7,1.4 \mathrm{~Hz}, 2 \mathrm{H}), 4.03(\mathrm{~d}, J=13.6 \mathrm{~Hz}, 1 \mathrm{H}), 3.13-3.07(\mathrm{~m}, 2 \mathrm{H}), 2.91$ (td, $J=13.0,2.8 \mathrm{~Hz}, 1 \mathrm{H}), 1.82-1.59(\mathrm{~m}, 3 \mathrm{H}), 1.56-1.33(\mathrm{~m}, 3 \mathrm{H})$;

${ }^{13}$ C RMN $\quad\left(100 \mathrm{MHz} \mathrm{CDCl}_{3}\right) \delta 171.4,155.8,137.1,132.6,132.2,128.6,128.0$, $127.9,123.7,118.5,67.2,65.4,52.1,40.3,37.9,29.2,25.7,19.5$;

FTIR (puro, $\mathrm{cm}^{-1}$ ) 2953, 2858, 1735, 1692, 1418, 1320, 1255, 1158, 1070, 983, 918, 750;

HRMS $\mathrm{ESI}^{+}(\mathrm{m} / \mathrm{z})$ Calculado para $\mathrm{C}_{20} \mathrm{H}_{25} \mathrm{NNaO}_{4}{ }^{+}[\mathrm{M}+\mathrm{Na}]^{+} \quad 366.1676$ encontrado 366.1674; 
pent-3-enoato de (E)-4-metóxi-4-oxobut-2-en-1-il (E)-5-(benzilóxi) (148)

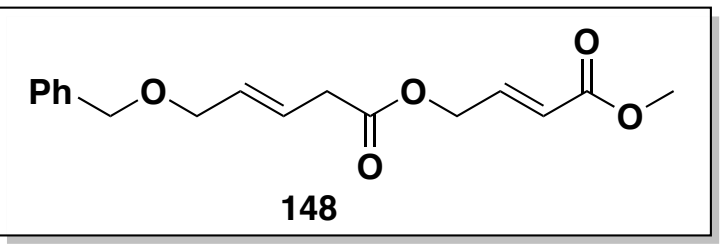

pent-3-enoato de (E)-4-metóxi-4-oxobut-2-en-1-il (E)-5-(benzilóxi) (148)

Obs.: 3 equiv. do álcool alílico 157, lâmpada de Xe (260 W), 2 h e 30 min,

(148) $53 \%$ de rendimento como um óleo incolor após purificação em 10-20\% AcOEt/Hexano. Não foi possível separar os isômeros $E / Z$ por coluna após a irradiação.

$\mathbf{R}_{\mathbf{f}} \quad 0.14$ (10\% AcOEt/hexano);

${ }^{1}$ H RMN $\quad\left(500 \mathrm{MHz}, \mathrm{CDCl}_{3}\right) \delta 7.37-7.31(\mathrm{~m}, 4 \mathrm{H}), 7.31-7.26(\mathrm{~m}, 1 \mathrm{H}), 6.94(\mathrm{dt}$, $J=15.8,4.7 \mathrm{~Hz}, 1 \mathrm{H}), 6.03(\mathrm{dt}, J=15.8,2.0 \mathrm{~Hz}, 1 \mathrm{H}), 5.86(\mathrm{dtt}, J=16.0$, 6.6, 1.2 Hz, 1H), 5.77 (dtt, $J=15.4,5.8,1.2 \mathrm{~Hz}, 1 \mathrm{H}$ ), 4.76 (dd, $J=4.7$, $2.0 \mathrm{~Hz}, 2 \mathrm{H}), 4.52(\mathrm{~s}, 2 \mathrm{H}), 4.03(\mathrm{dd}, J=5.7,1.2 \mathrm{~Hz}, 2 \mathrm{H}), 3.75(\mathrm{~s}, 3 \mathrm{H})$, $3.17(\mathrm{dd}, J=6.8,1.1 \mathrm{~Hz}, 2 \mathrm{H})$;

${ }^{13} \mathrm{C}$ RMN $\quad\left(126 \mathrm{MHz}, \mathrm{CDCl}_{3}\right) \delta 170.9,166.3,141.4,138.2,131.1,128.5,127.9$, $127.8,124.9,122.1,72.3,70.2,62.9,51.9,37.6$;

FTIR (puro, $\mathrm{cm}^{-1}$ ) 2952, 2925, 2852, 1721, 1666, 1436, 1310, 1275, 1154, 1098, 966, 736, 697;

HRMS $\mathrm{ESI}^{+}(\mathrm{m} / \mathrm{z})$ Calculado para $\mathrm{C}_{17} \mathrm{H}_{20} \mathrm{NaO}_{5}{ }^{+}[\mathrm{M}+\mathrm{Na}]^{+} 327.1203$ encontrado 327.1197 


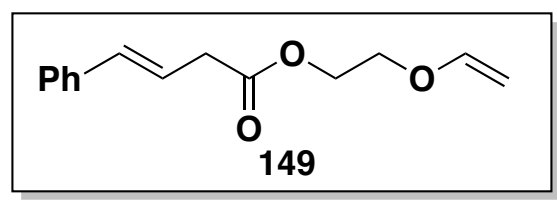

\section{2-(vinilóxi)etil (E)-4-fenilbut-3-enoato (149)}

Obs.: 5 equiv. do álcool alílico 159, lâmpada de LED, 24 h;

(149) $50 \%$ de rendimento como um óleo incolor após purificação em 10-20\% AcOEt/Hexano. Não foi possível separar os isômeros $E / Z$ por coluna após a irradiação.

$\mathbf{R}_{\mathbf{f}} \quad 0.37$ (10\% AcOEt/hexano);

${ }^{1}$ H RMN $\quad\left(400 \mathrm{MHz} \mathrm{CDCl}_{3}\right) \delta 7.40-7.36(\mathrm{~m}, 2 \mathrm{H}), 7.36-7.27(\mathrm{~m}, 2 \mathrm{H}), 7.27$ $7.21(\mathrm{~m}, 1 \mathrm{H}), 6.49(\mathrm{dd}, J=14.3,6.9 \mathrm{~Hz}, 2 \mathrm{H}), 6.31(\mathrm{dt}, J=15.9,7.1 \mathrm{~Hz}$, 1H), $4.40-4.33(\mathrm{~m}, 2 \mathrm{H}), 4.22(\mathrm{dd}, J=14.3,2.3 \mathrm{~Hz}, 1 \mathrm{H}), 4.06(\mathrm{dd}, J=$ 6.8, 2.3 Hz, 1H), $3.96-3.87(\mathrm{~m}, 2 \mathrm{H}), 3.30(\mathrm{dd}, J=7.1,1.5 \mathrm{~Hz}, 2 \mathrm{H})$.;

${ }^{13}$ C RMN $\quad\left(126 \mathrm{MHz}_{\mathrm{CDCl}}\right) \delta 171.6,151.5,136.9,133.7,128.6,127.7,126.4$, 121.5, 87.3, 65.8, 63.1, 38.3;

FTIR (puro, $\mathrm{cm}^{-1}$ ) 3028, 2955, 2928, 1733, 1619, 1452, 1321, 1252, 1159, 1101, 965, 824, 748, 695;

HRMS $\mathrm{ESI}^{+}(\mathrm{m} / \mathrm{z})$ Calculado para $\mathrm{C}_{14} \mathrm{H}_{17} \mathrm{NO}_{3}{ }^{+}[\mathrm{M}+\mathrm{H}]^{+} 233.1172$ encontrado 233.1164; 
(E)-4-metóxi-4-oxobut-2-en-1-il (3E,5E)-6-fenilhexa-3,5-dienoato (150)

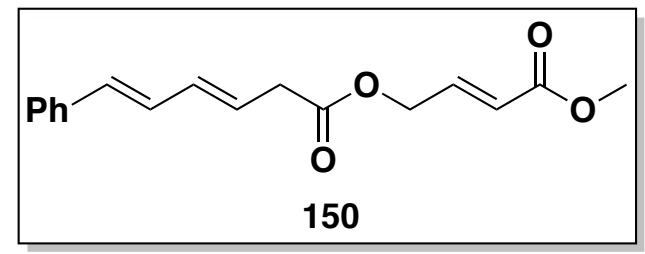

(E)-4-metóxi-4-oxobut-2-en-1-il (3E,5E)-6-fenilhexa-3,5-dienoato (150)

Obs.: $\quad 2$ equiv. do álcool alílico 157, lâmpada de Xe (260 W), 2 h e 30 min, 35\% 1.1 equiv. do álcool alílico 157, lâmpada de Xe (260 W), 3 h, $30 \%$ 1.1 equiv. do álcool alílico 157, lâmpada de LED (18 W), 24 h, 77\% O rendimento de $77 \%$ não foi reproduzido posteriormente, variando entre $40-60 \%$ nas mesmas condições;

(150) $\quad 30-77 \%$ de rendimento como um sólido branco após purificação em coluna flash usando $20-40 \%$ de AcOEt/Hexano.

$\mathbf{R}_{\mathbf{f}} \quad 0.31(20 \%$ AcOEt/hexano);

${ }^{1} \mathrm{H}$ RMN $\quad\left(400 \mathrm{MHz}, \mathrm{CDCl}_{3}\right) \delta 7.41-7.36(\mathrm{~m}, 2 \mathrm{H}), 7.31(\mathrm{t}, J=7.5 \mathrm{~Hz}, 2 \mathrm{H}), 7.25-$ $7.19(\mathrm{~m}, 1 \mathrm{H}), 6.95(\mathrm{dt}, J=15.8,4.7 \mathrm{~Hz}, 1 \mathrm{H}), 6.78$ (ddd, $J=15.7,10.4$, $0.8 \mathrm{~Hz}, 1 \mathrm{H}), 6.53(\mathrm{~d}, J=15.7 \mathrm{~Hz}, 1 \mathrm{H}), 6.33(\mathrm{dd}, J=15.2,10.4 \mathrm{~Hz}, 1 \mathrm{H})$, $6.05(\mathrm{dt}, J=15.8,2.0 \mathrm{~Hz}, 1 \mathrm{H}), 5.89(\mathrm{dt}, J=15.1,7.3 \mathrm{~Hz}, 1 \mathrm{H}), 4.78$ (dd, $J=4.7,2.0 \mathrm{~Hz}, 2 \mathrm{H}), 3.75(\mathrm{~s}, 3 \mathrm{H}), 3.25(\mathrm{dd}, J=7.3,1.4 \mathrm{~Hz}, 2 \mathrm{H}$ );

${ }^{13} \mathrm{C}$ RMN $\quad\left(101 \mathrm{MHz}, \mathrm{CDCl}_{3}\right) \delta 170.9,166.3,141.3,137.2,134.6,132.6,128.7$, $128.3,127.7,126.5,124.9,122.2,63.0,51.9,38.1$;

FTIR (puro, $\mathrm{cm}^{-1}$ ) 2952, 2925, 2853, 1720, 1667, 1449, 1276, 1018, 968, 753, 698 ;

HRMS $\mathrm{ESI}^{+}(\mathrm{m} / \mathrm{z})$ Calculado para $\mathrm{C}_{17} \mathrm{H}_{19} \mathrm{O}_{4}{ }^{+}[\mathrm{M}+\mathrm{H}]^{+}$287.1278, encontrado 287.1287; 
but-3-enoato de (2E,4E)-hexa-2,4-dien-1-il (E)-4-(4-nitrofenil) (151)

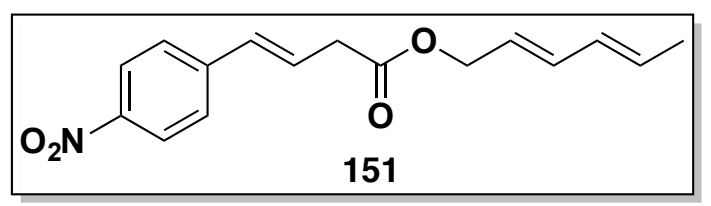

\begin{tabular}{|c|c|}
\hline & but-3-enoato de (2E,4E)-hexa-2,4-dien-1-il (E)-4-(4-nitrofenil) (151) \\
\hline Obs.: & 10 equiv. do álcool alílico 155, lâmpada de LED (18 W), 24 h \\
\hline (151) & $\begin{array}{l}40 \% \text { de rendimento como um sólido amarelo pardo após purificação em } \\
\text { coluna flash de } 10-20 \% \text { de AcOEt/Hexano; }\end{array}$ \\
\hline $\mathbf{R}_{\mathbf{f}}$ & 0.40 (10\% AcOEt/hexano); \\
\hline${ }^{1} \mathrm{H}$ RMN & $\begin{array}{l}\left(400 \mathrm{MHz}_{\mathrm{CDCl}}\right) \delta 8.17(\mathrm{~d}, J=9.0 \mathrm{~Hz}, 2 \mathrm{H}), 7.50(\mathrm{~d}, J=8.8 \mathrm{~Hz}, 2 \mathrm{H}) \text {, } \\
6.61-6.45(\mathrm{~m}, 2 \mathrm{H}), 6.33-6.22(\mathrm{~m}, 1 \mathrm{H}), 6.11-6.00(\mathrm{~m}, 1 \mathrm{H}), 5.83- \\
5.70(\mathrm{~m}, 1 \mathrm{H}), 5.64(\mathrm{dtq}, J=15.0,6.8,0.7 \mathrm{~Hz}, 1 \mathrm{H}), 4.63(\mathrm{~d}, J=6.7 \mathrm{~Hz}, \\
2 \mathrm{H}), 3.31(\mathrm{~d}, J=5.8 \mathrm{~Hz}, 2 \mathrm{H}), 1.77(\mathrm{~d}, J=6.1 \mathrm{~Hz}, 3 \mathrm{H}) ;\end{array}$ \\
\hline${ }^{13}$ C RMN & $\begin{array}{l}\left(101 \mathrm{MHz}, \mathrm{CDCl}_{3}\right) \delta 170.8,143.3,135.6,131.9,131.7,130.4,129.5, \\
127.0,127.0,124.1,123.3,65.7,38.5,18.3\end{array}$ \\
\hline FTIR & $\begin{array}{l}\text { (puro, } \mathrm{cm}^{-1} \text { ) 2923, 2852, 1731, 1658, 1598, 1514, 1340, 1154, 1108, } \\
989,969,858,803,744\end{array}$ \\
\hline HRMS & $\begin{array}{l}\mathrm{ESI}^{+}(\mathrm{m} / \mathrm{z}) \text { Calculado para } \mathrm{C}_{16} \mathrm{H}_{18} \mathrm{NO}_{4}{ }^{+}[\mathrm{M}+\mathrm{H}]^{+} 288.1230 \text {, encontrado } \\
288.1205 ;\end{array}$ \\
\hline
\end{tabular}


hexa-2,4-dienoato de metil (2E,4E)-6-(((E)-4-fenilbut-3-enoil)oxi) (152)

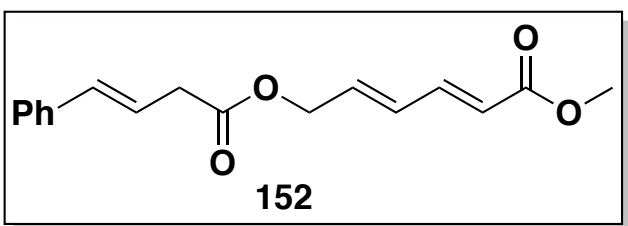

\section{hexa-2,4-dienoato de metil (2E,4E)-6-(((E)-4-fenilbut-3-enoil)oxi) (152)}

Obs.: 2 equiv. do álcool alílico 158, lâmpada de Xe (260 W), 1 h e 20 min,

(152) $52 \%$ de rendimento como um sólido branco após a purificação em coluna flash usando $10-20 \%$ de AcOEt/Hexano;

$\mathbf{R}_{\mathbf{f}} \quad 0.20$ (10\% AcOEt/hexano);

${ }^{1} \mathrm{H}$ RMN $\quad\left(400 \mathrm{MHz}, \mathrm{CDCl}_{3}\right) \delta 7.40-7.35(\mathrm{~m}, 2 \mathrm{H}), 7.34-7.19(\mathrm{~m}, 4 \mathrm{H}), 6.51$ (dt, $J=15.8,1.5 \mathrm{~Hz}, 1 \mathrm{H}), 6.44-6.35(\mathrm{~m}, 1 \mathrm{H}), 6.30(\mathrm{dt}, J=15.9,7.1 \mathrm{~Hz}$, $1 \mathrm{H}), 6.14(\mathrm{dtt}, J=15.4,5.9,0.8 \mathrm{~Hz}, 1 \mathrm{H}), 5.90(\mathrm{dt}, J=15.4,0.7 \mathrm{~Hz}, 1 \mathrm{H})$, $4.72(\mathrm{dd}, J=5.9,1.5 \mathrm{~Hz}, 2 \mathrm{H}), 3.75(\mathrm{~s}, 3 \mathrm{H}), 3.29(\mathrm{dd}, J=7.1,1.5 \mathrm{~Hz}$, $2 \mathrm{H})$;

${ }^{13}$ C RMN $\quad\left(101 \mathrm{MHz}, \mathrm{CDCl}_{3}\right) \delta 171.1,167.2,143.3,136.8,135.3,133.9,130.8$, $128.7,127.8,126.4,122.3,121.4,64.1,51.7,38.4$

FTIR (puro, $\mathrm{cm}^{-1}$ ) 3027, 2950, 1717, 1650, 1620, 1435, 1267, 1236, 1140, 999, 966;

HRMS $\mathrm{ESI}^{+}(\mathrm{m} / \mathrm{z})$ Calculado para $\mathrm{C}_{17} \mathrm{H}_{18} \mathrm{NaO}_{4}{ }^{+}[\mathrm{M}+\mathrm{Na}]^{+} 309.1097$, encontrado 309.1086; 
$(2 E, 4 E)$-hexa-2,4-dien-1-il (E)-4-fenilbut-3-enoato (153)

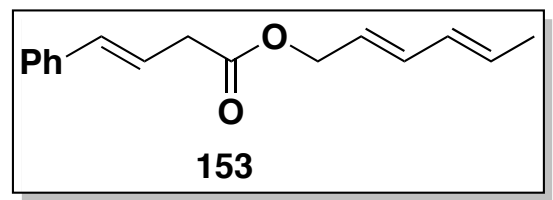

(2E,4E)-hexa-2,4-dien-1-il (E)-4-fenilbut-3-enoato (153)

Obs.: 10 equiv. do álcool alílico 155, lâmpada de LED (18 W), 24 h

(153) $65 \%$ de rendimento como um sólido branco após purificação em coluna usando gradiente de 5-10\% de AcOEt/Hexano;

$\mathbf{R}_{\mathbf{f}} \quad 0.57(10 \%$ AcOEt/hexano);

${ }^{1}$ H RMN (400 MHz, $\left.\mathrm{CDCl}_{3}\right) \delta 7.38-7.33(\mathrm{~m}, 2 \mathrm{H}), 7.29(\mathrm{t}, J=7.4 \mathrm{~Hz}, 2 \mathrm{H}), 7.24-$ $7.18(\mathrm{~m}, 1 \mathrm{H}), 6.48(\mathrm{~d}, J=15.9 \mathrm{~Hz}, 1 \mathrm{H}), 6.33-6.21(\mathrm{~m}, 2 \mathrm{H}), 6.04$ (ddd, $J=15.3,10.7,1.7 \mathrm{~Hz}, 1 \mathrm{H}), 5.73(\mathrm{dq}, J=13.5,6.7 \mathrm{~Hz}, 1 \mathrm{H}), 5.62$ (dtd, $J$ $=15.2,6.7,0.6 \mathrm{~Hz}, 1 \mathrm{H}), 4.60(\mathrm{~d}, J=6.7 \mathrm{~Hz}, 2 \mathrm{H}), 3.24(\mathrm{dd}, J=7.1,1.4$ $\mathrm{Hz}, 2 \mathrm{H}), 1.74$ (d, J = 7.3 Hz, 3H);

${ }^{13}$ C RMN $\quad\left(126 \mathrm{MHz}, \mathrm{CDCl}_{3}\right) \delta 171.3,136.8,135.1,133.5,131.4,130.4,128.5$, $127.5,126.3,123.5,121.7,65.3,38.5,18.1$;

FTIR (puro, $\mathrm{cm}^{-1}$ ) 3006, 2925, 2853, 1733, 1661, 1448, 1241, 1151, 988, 965, 745,692 ;

HRMS $\mathrm{ESI}^{+}(\mathrm{m} / \mathrm{z})$ Calculado para $\mathrm{C}_{16} \mathrm{H}_{19} \mathrm{O}_{2}{ }^{+}[\mathrm{M}+\mathrm{H}]^{+}$243.1380, encontrado 243.1370; 
Preparo álcoois alílicos 157 e 158
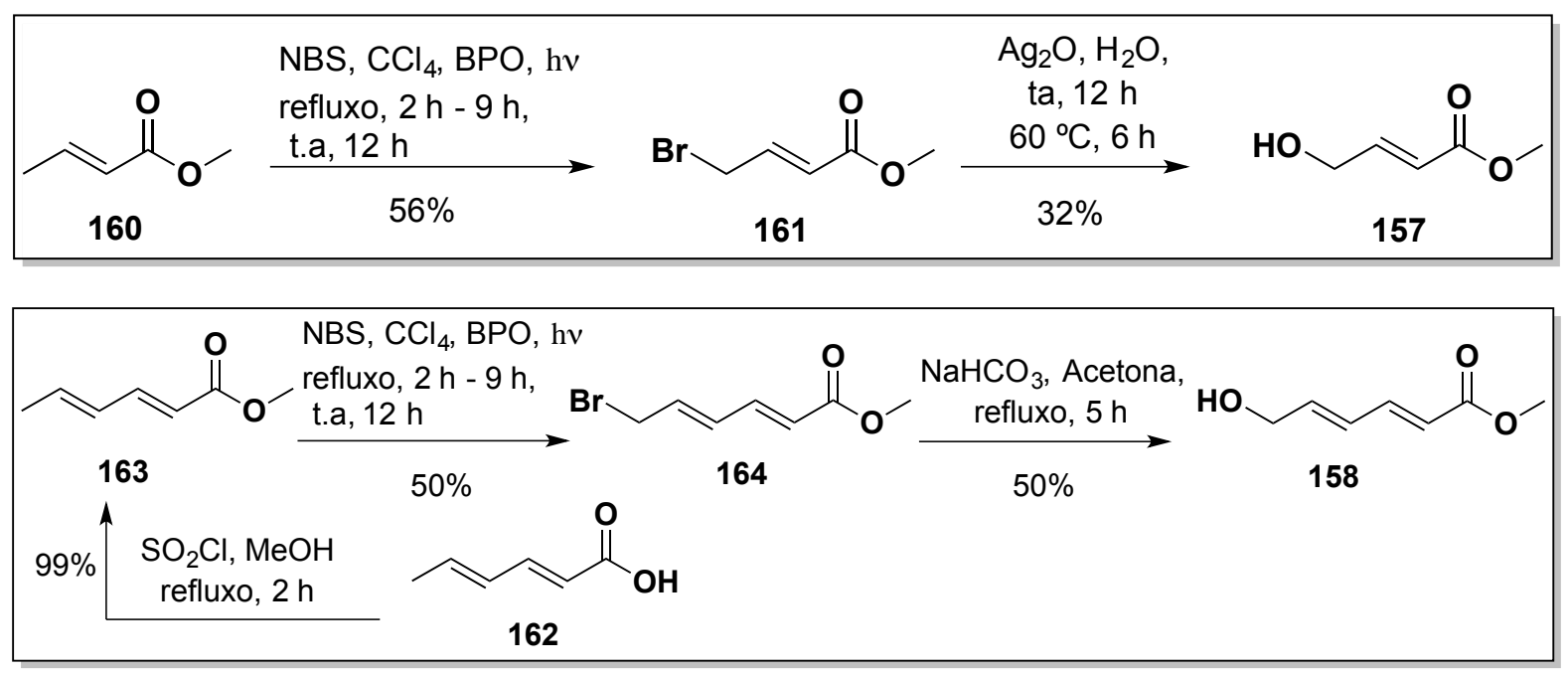

Em uma suspensão de metil crotonato 160 em refluxo ( $8.5 \mathrm{~g}, 85 \mathrm{mmol}, 1$ equiv.) em $40 \mathrm{~mL}$ de $\mathrm{CCl}_{4}$ foi adicionado NBS (16 g, $89 \mathrm{mmol}, 1.05$ equiv.) e peróxido de benzoíla em porções (10 mg, $0.041 \mathrm{mmol}, 0.004$ equiv.). Uma lâmpada CFL de $13 \mathrm{~W}$ foi equipada ao sistema e a solução irradiada sob refluxo por 9 h. Durante este tempo, peróxido de benzoíla foi adicionado (em pó) a mistura de 3 em 3 h (3 porções de 10 $\mathrm{mg}$ ). A solução foi agitada durante a noite e então resfriada a temperatura ambiente. Após, $\mathrm{H}_{2} \mathrm{O}$ foi adicionada (20 mL) e a solução extraída com hexano (2 x $\left.20 \mathrm{~mL}\right)$. As fases orgânicas combinadas foram secas com $\mathrm{Na}_{2} \mathrm{SO}_{4}$ e concentrada em vácuo para fornecer o brometo alílico como um líquido incolor. A purificação pode ser feita por cromatografia flash (6:1 hexano/AcOEt) ou por destilação em vácuo coletando as frações entre $95-98^{\circ} \mathrm{C}$ (20 Torr) para fornecer 161 como um óleo incolor $(9.5 \mathrm{~g}, 56 \%$ de rendimento): Cuidado! O produto possui um forte odor com características lacrimejantes.

161: ${ }^{1} \mathrm{H}$ RMN (400 MHz, $\left.\mathrm{CDCl}_{3}\right) \delta 7.02(\mathrm{dt}, J=15.4,7.4 \mathrm{~Hz}, 1 \mathrm{H}), 6.04(\mathrm{dt}, J=15.4$, $1.3 \mathrm{~Hz}, 1 \mathrm{H}), 4.01$ (dd, $J=7.4,1.3 \mathrm{~Hz}, 2 \mathrm{H}), 3.76(\mathrm{~s}, 3 \mathrm{H})$.

164: $1 \mathrm{H}$ RMN (500 MHz, $\mathrm{CDCl}_{3}$ ) $\delta 7.26$ (ddd, $J=15.4,10.9,0.7 \mathrm{~Hz}, 1 \mathrm{H}$ ), 6.39 (ddd, $J$ $=15.0,11.0,0.9 \mathrm{~Hz}, 1 \mathrm{H}$ ), 6.24 (dddd, $J=15.0,7.7,7.3,0.7 \mathrm{~Hz}, 1 \mathrm{H}), 5.94$ (dd, $J=15.4$, $0.8 \mathrm{~Hz}, 1 \mathrm{H}), 4.03$ (dd, $J=7.7,0.9 \mathrm{~Hz}, 2 \mathrm{H}), 3.76(\mathrm{~s}, 3 \mathrm{H})$. 


\section{Método com $\mathrm{Ag}_{2} \underline{\underline{O}}$}

O bromocrotonado 161 (500 mg, 2.79 mmol, 1 equiv.) foi adicionado em uma mistura de $\mathrm{Ag}_{2} \mathrm{O}$ (324 mg, $1.39 \mathrm{mmol}, 0.5$ equiv.) em $6 \mathrm{~mL}$ de $\mathrm{H}_{2} \mathrm{O}$ a temperatura ambiente. A mistura foi agitada vigorosamente por $12 \mathrm{~h}$ e então aquecida em $60^{\circ} \mathrm{C}$ por um período adicional de $6 \mathrm{~h}$. Após a filtração (pode ser feita tanto em Celite quanto em papel filtro), a água foi removida em sistema de vácuo e então o bruto purificado em coluna flash (40\% AcOEt/Hexano). O álcool alílico 157 foi obtido como um líquido incolor em 32\% de rendimento (104.6 $\mathrm{mg})$.

157: ${ }^{1} \mathrm{H}$ RMN (400 MHz, $\left.\mathrm{CDCl}_{3}\right) \delta 7.04(\mathrm{dt}, J=15.7,4.0 \mathrm{~Hz}, 1 \mathrm{H}), 6.11(\mathrm{dt}, J=15.7$, $2.1 \mathrm{~Hz}, 1 \mathrm{H}), 4.36(\mathrm{dd}, J=4.0,2.1 \mathrm{~Hz}, 2 \mathrm{H}), 3.75(\mathrm{~s}, 3 \mathrm{H})$.

\section{Método com $\mathrm{NaHCO}_{3}$}

Uma mistura de acetona (6 mL), solução aquosa saturada de $\mathrm{NaHCO}_{3}(4 \mathrm{~mL})$ e 0 brometo alílico 164 ( $0.5 \mathrm{~g}, 2.45 \mathrm{mmol}, 1$ equiv.) foi relfuxada por $5 \mathrm{~h}$. Após este período, $\mathrm{HCl} 5 \%$ foi adicionado e a acetona removida em vácuo. Um resíduo de 2 camadas foi obtido. A fase aquosa foi extraída com AcOEt (6 x $10 \mathrm{~mL})$ e a fase orgânica dissolvida em AcOEt $(50 \mathrm{~mL})$. As fases orgânicas combinadas foram concentradas para fornecer $155 \mathrm{mg}$ do álcool alílico 158 como um sólido branco em $50 \%$ de rendimento.

158: ${ }^{1} \mathrm{H}$ RMN $\left(\mathrm{CDCl}_{3}\right) \delta 7.30(\mathrm{dd}, J=15.3,11.1 \mathrm{~Hz}, 1 \mathrm{H}), 6.42(\mathrm{ddtd}, J=15.2,11.0$, 1.7, $0.7 \mathrm{~Hz}, 1 \mathrm{H}), 6.22$ (dtt, $J=15.4,5.0,0.7 \mathrm{~Hz}, 1 \mathrm{H}), 5.89(\mathrm{dt}, J=15.4,0.8 \mathrm{~Hz}, 1 \mathrm{H})$, 4.29 (dd, $J=5.0,1.7 \mathrm{~Hz}, 2 \mathrm{H}), 3.75(\mathrm{~s}, 3 \mathrm{H})$. 


\subsection{Reação de Diels-Alder a partir de 150}

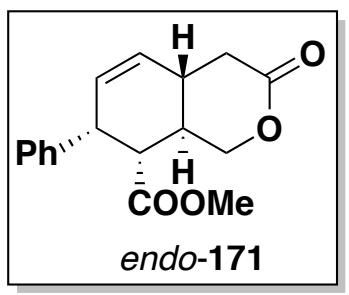

Uma solução do éster 150 (20 mg, $0.07 \mathrm{mmol}$ ) em xileno (3 mL) foi adicionada em um tubo selado e então argônio foi passado pelo sistema durante 30 minutos. A mistura foi aquecida em $230-250{ }^{\circ} \mathrm{C}$ (temperatura medida pelo banho de óleo) por $48 \mathrm{~h}$. Ao final deste período, o solvente é removido em vácuo para fornecer o resíduo bruto. $A$ purificação por cromatografia flash (50-70\% AcOEt/Hexano) forneceu $( \pm) \mathbf{1 7 1}$ como uma mistura endo/exo em proporção $1: 1$ (14.0 mg, $0.049 \mathrm{mmol}, 70 \%$ de rendimento). $3.8 \mathrm{mg}$ de 150 não reagido foi recuperado. A separação dos isômeros foi realizada por HPLC em sistema preparativo utilizando uma coluna C18.

\section{Endo-(171)}

$\mathbf{R}_{\mathbf{f}} \quad 0.34$ (40\% AcOEt/hexano);

${ }^{1}$ H RMN (500 MHz, $\left.\mathrm{CDCl}_{3}\right) \delta 7.33-7.27(\mathrm{~m}, 3 \mathrm{H}), 7.13-7.09(\mathrm{~m}, 2 \mathrm{H}), 5.82$ (ddd, $J=9.9,4.5,2.4 \mathrm{~Hz}, 1 \mathrm{H}), 5.75(\mathrm{dt}, J=10.0,1.7 \mathrm{~Hz}, 1 \mathrm{H}), 4.65$ (ddd, $J=$ 10.6, 4.7, $0.7 \mathrm{~Hz}, 1 \mathrm{H}), 3.96$ (ddd, $J=6.6,4.4,2.2 \mathrm{~Hz}, 1 \mathrm{H}), 3.92(\mathrm{t}, J=$ 11.4, 10.9, 1H), 3.44 (s, 3H), 2.93 (dd, $J=17.3,4.2 \mathrm{~Hz}, 1 \mathrm{H}), 2.87$ (dd, $J$ $=11.8,6.5 \mathrm{~Hz}, 1 \mathrm{H}), 2.51-2.43(\mathrm{~m}, 1 \mathrm{H}), 2.38(\mathrm{dd}, J=17.2,13.7 \mathrm{~Hz}$, $1 \mathrm{H}), 2.23$ (dd, $J=11.3,4.7 \mathrm{~Hz}, 1 \mathrm{H})$;

${ }^{13}$ C RMN (126 MHz, $\left.\mathrm{CDCl}_{3}\right) \delta 171.3,169.5,138.5,129.1,129.0,128.4,128.0$, 127.8, 73.0, 58.5, 51.4, 46.9, 43.6, 36.7, 34.8, 32.0, 18.4;

FTIR (puro, $\mathrm{cm}^{-1}$ ) 3027, 2952, 2920, 1732, 1492, 1454, 1435, 1289, 1262, 1200, 1033, 759, 703;

HRMS $\mathrm{ESI}^{+}(\mathrm{m} / \mathrm{z})$ Calculado para $\mathrm{C}_{17} \mathrm{H}_{19} \mathrm{O}_{4}{ }^{+}[\mathrm{M}+\mathrm{H}]^{+}$287.1278, encontrado 287.1279;

HPLC Coluna: Shim-Pack® VP-ODS (tamanho da partícula: $4.6 \mu \mathrm{m}$; tamanho de poro: $12 \mathrm{~nm}$, dimensão: $4.6 \mathrm{~mm}$ x $250 \mathrm{~mm}), 50: 50\left(\mathrm{MeCN}: \mathrm{H}_{2} \mathrm{O}\right), 1.0$ $\mathrm{mL} / \mathrm{min}, \lambda 220$ e $254 \mathrm{~nm}$. 
mAU

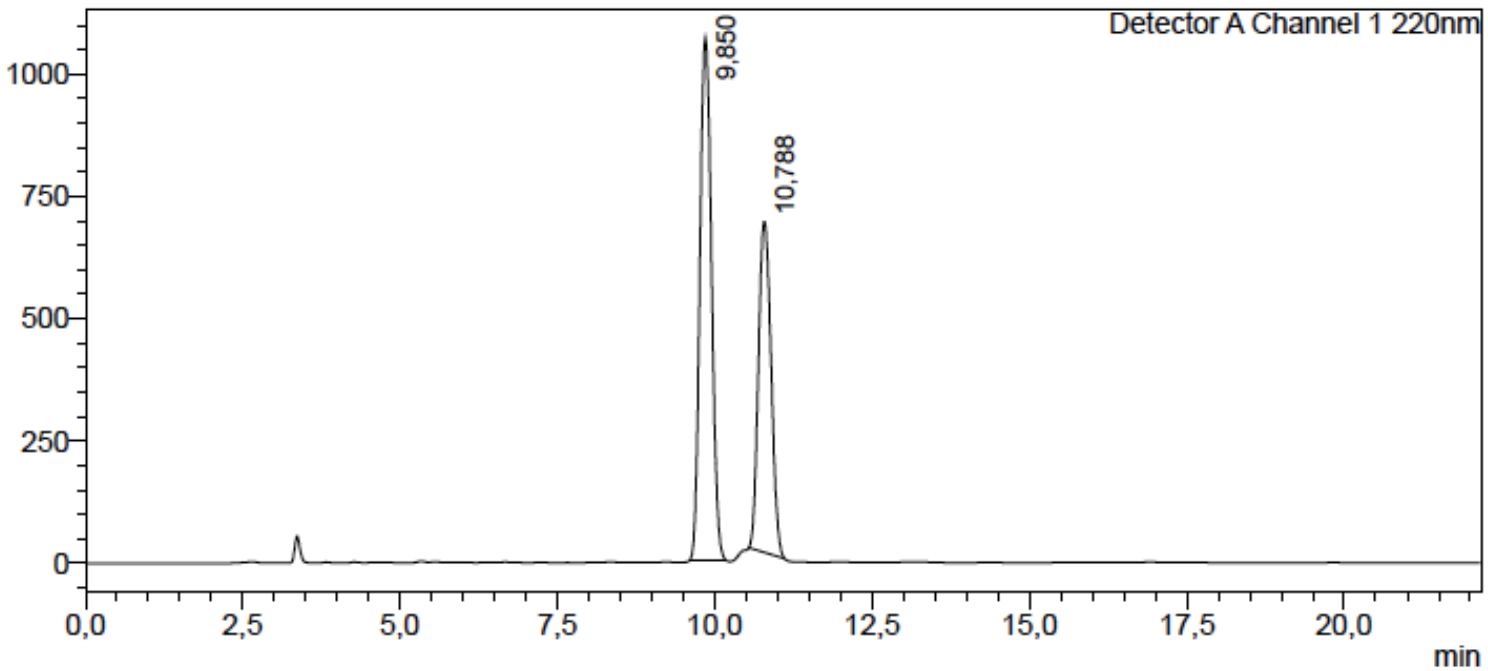

MAU

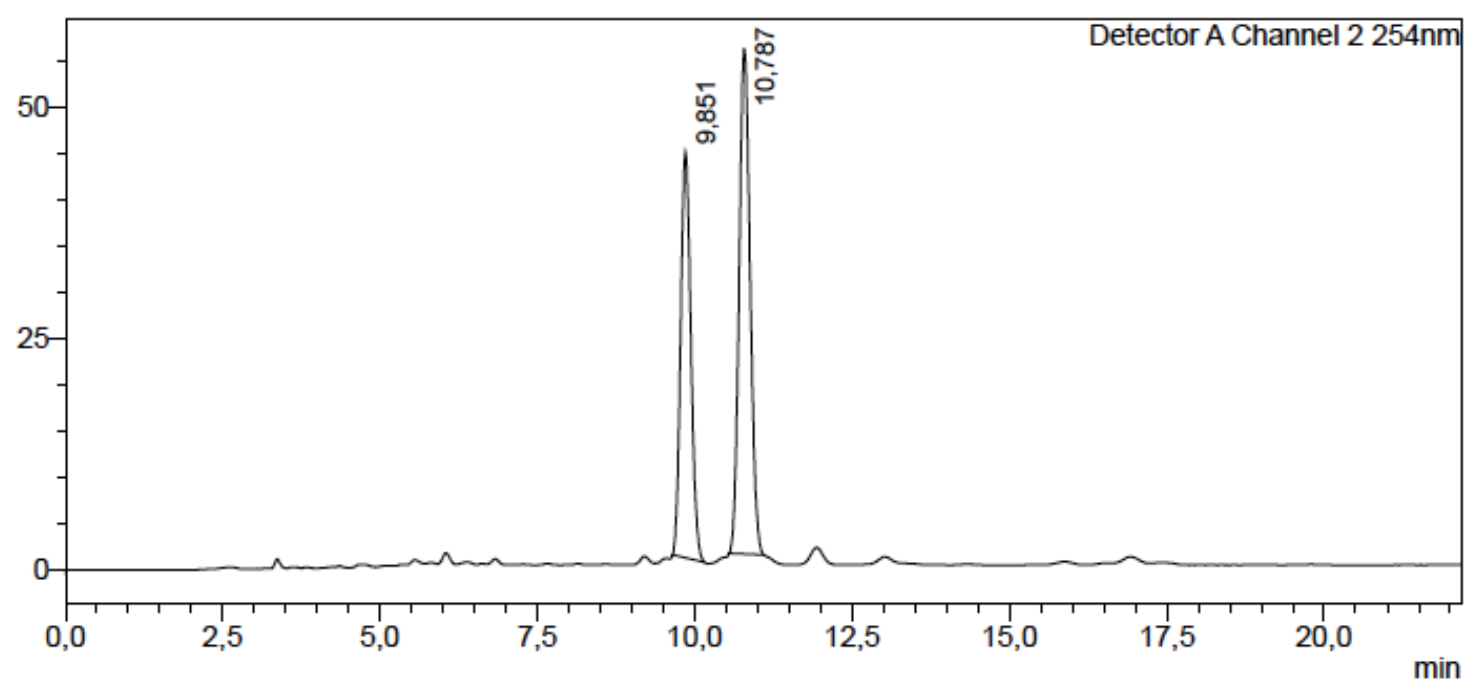

Figura 46 Cromatograma obtido para a separação dos isômeros endo/exo 171 por HPLC. 


\subsection{Síntese dos reagentes carbonilacrílicos}

(E)-etil 4-oxopent-2-enoato (174) ${ }^{236}$

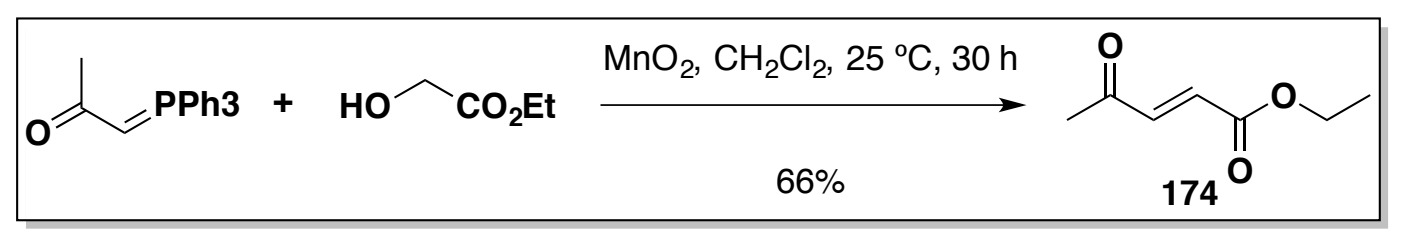

Em uma solução de 1-(trifenilfosforanilidena)-2- propanona $(2.10 \mathrm{~g}, 6.59 \mathrm{mmol}, 1.0$ equiv.) e glicolato de etila ( $0.75 \mathrm{~mL}, 7.92 \mathrm{mmol}, 1.2$ equiv.) em $\mathrm{CH}_{2} \mathrm{Cl}_{2}$ (22 MI) foi adicionado $\mathrm{MnO}_{2}(5.75 \mathrm{~g}, 65.9 \mathrm{mmol}, 10.0$ equiv.) e vigorosamente agitado em temperatura ambiente $\left(25^{\circ} \mathrm{C}\right)$ por $30 \mathrm{~h}$. A mistura foi filtrada em Celite e o filtrado concentrado usando rota evaporador. $\mathrm{O}$ resíduo foi diluído com $\mathrm{Et}_{2} \mathrm{O}(10 \mathrm{~mL})$ gelado, filtrado em Celite e lavado com $\mathrm{Et}_{2} \mathrm{O}(5 \mathrm{~mL})$. O filtrado foi concentrado em vácuo e purificado por cromatografia flash (5 - 20\% AcOEt em hexano) para fornecer o éster 174 (618 mg, $4.35 \mathrm{mmol}, 66 \%$ rendimento) como um óleo amarelho claro.

\section{(E)-etil 4-oxopent-2-enoato (174)}

\begin{tabular}{ll}
\hline $\mathbf{R}_{\mathbf{f}}$ & $0.40(1: 9 \mathrm{AcOEt} / \mathrm{h}$ exano); \\
${ }^{1} \mathrm{H}$ RMN & $\left(400 \mathrm{MHz}, \mathrm{CDCl}_{3}\right) \delta 6.98(\mathrm{~d}, J=16.2 \mathrm{~Hz}, 1 \mathrm{H}), 6.61(\mathrm{~d}, \mathrm{~J}=16.1 \mathrm{~Hz}, 1 \mathrm{H})$, \\
& $4.23(\mathrm{q}, J=7.1 \mathrm{~Hz}, 2 \mathrm{H}), 2.32(\mathrm{~s}, 3 \mathrm{H}), 1.29(\mathrm{t}, J=7.1 \mathrm{~Hz}, 3 \mathrm{H}) ;$ \\
${ }^{13} \mathrm{C} \mathbf{R M N}$ & $\left(100 \mathrm{MHz}, \mathrm{CDCl}_{3}\right) \delta 197.8,165.6,140.1,131.8,61.6,28.3,14.3 ;$ \\
FTIR & $\left(\right.$ puro, $\left.\mathrm{cm}^{-1}\right) 2986,1721,1701,1683,1641,1467,1424,1365,1290$, \\
& $1223,1181,1155,1096,1029,978,947,869 ;$ \\
HRMS & $\mathrm{ESI}^{+}(\mathrm{m} / \mathrm{z}):$ Calculado para $\mathrm{C}_{7} \mathrm{H}_{11} \mathrm{O}_{3}{ }^{+}[\mathrm{M}+\mathrm{H}]^{+} 143.0703$, encontrado \\
& $143.0698 ;$ \\
\hline
\end{tabular}


(E)-N-etil-4-oxo-4-fenilbut-2-enamida (179) ${ }^{237}$

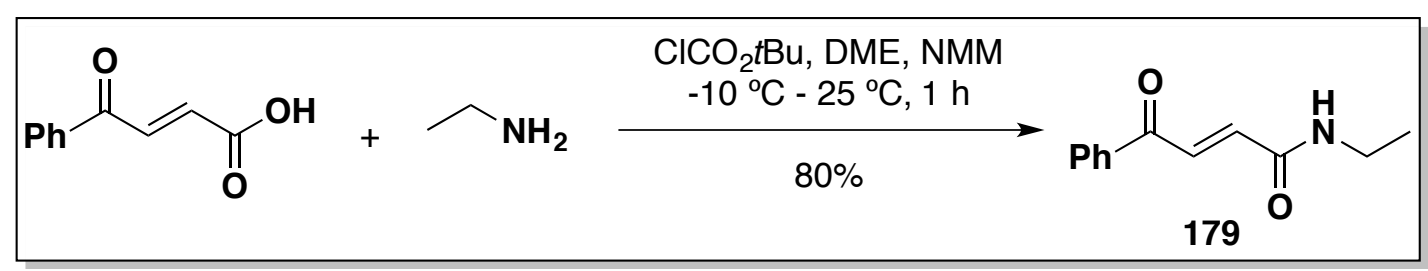

Sob atmosfera de argônio, $1.12 \mathrm{~g}$ do ácido 3-benzoilacrílico (6.4 mmol) foi dissolvido em dimetóxietano $(13 \mathrm{~mL})$ e a solução resfriada a $-10{ }^{\circ} \mathrm{C}$. Isobutilbloroformato $(1.18 \mathrm{~mL}, 7.7 \mathrm{mmol})$ foi adicionado a solução seguido de $N$-metilmorfolina $(0.85 \mathrm{~mL}$, $7.7 \mathrm{mmol})$. Após, uma solução $2 \mathrm{M}$ de etilamina em THF $(8.0 \mathrm{ml}, 16.0 \mathrm{mmol})$ foi adicionada e a mistura agitada na mesma temperatura por 15 min e em temperatura ambiente por um período adicional de $1 \mathrm{~h}$. $10 \mathrm{~mL}$ de $\mathrm{H}_{2} \mathrm{O}$ foi então adicionado ao balão reacional e a mistura extraída com $\mathrm{CH}_{2} \mathrm{Cl}_{2}(3 \times 15 \mathrm{~mL})$. As fases orgânicas combinadas foram lavadas com $10 \mathrm{~mL}$ de solução aquosa saturada de $\mathrm{NaOH}$ e $10 \mathrm{~mL}$ de $\mathrm{H}_{2} \mathrm{O}$ e secas usando $\mathrm{Na}_{2} \mathrm{SO}_{4}$. Após evaporação do solvente, o resíduo foi purificado por cromatografia flash (10 - 80\% AcOEt em hexano) para fornecer a amida pura 179 (1.04 g, $5.10 \mathrm{mmol}, 80 \%$ rendimento) como um sólido amarelo claro.

\section{(E)-N-etil-4-oxo-4-fenilbut-2-enamida (179)}

\begin{tabular}{ll}
\hline $\mathbf{R}_{\mathbf{f}}$ & $0.47(4: 1 \mathrm{AcOEt} /$ hexano $) ;$ \\
${ }^{1} \mathbf{H}$ RMN & $\left(400 \mathrm{MHz}, \mathrm{CDCl}_{3}\right) \delta 8.05-8.01(\mathrm{~m}, 2 \mathrm{H}), 7.97(\mathrm{~d}, \mathrm{~J}=15.0 \mathrm{~Hz}, 1 \mathrm{H}), 7.64$ \\
& $-7.57(\mathrm{~m}, 1 \mathrm{H}), 7.54-7.47(\mathrm{~m}, 2 \mathrm{H}), 6.95(\mathrm{~d}, \mathrm{~J}=15.0 \mathrm{~Hz}, 1 \mathrm{H}), 5.97(\mathrm{~s}$, \\
& $1 \mathrm{H}), 3.45(\mathrm{qd}, \mathrm{J}=7.3,5.7 \mathrm{~Hz}, 2 \mathrm{H}), 1.23(\mathrm{t}, \mathrm{J}=7.3 \mathrm{~Hz}, 3 \mathrm{H}) ;$ \\
${ }^{13} \mathbf{C}$ RMN & $\left(100 \mathrm{MHz}, \mathrm{CD}_{3} \mathrm{CN}\right) \delta 191.1,164.5,138.0,136.9,134.5,133.1,129.8$, \\
& $129.6,35.2,14.7 ;$ \\
FTIR & $\left(\right.$ puro, $\left.\mathrm{cm}^{-1}\right) 3258,1637,1593,1559,1447,1357,1324,1289,1196$, \\
& 1009,$977 ;$ \\
HRMS & $\mathrm{ESI}^{+}(\mathrm{m} / \mathrm{z}):$ Calculado para $\mathrm{C}_{12} \mathrm{H}_{14} \mathrm{NO}_{2}{ }^{+}[\mathrm{M}+\mathrm{H}]^{+} 204,1019$, encontrado \\
& $204.0995 ;$
\end{tabular}


$N^{1}, N^{4}$-dietilfumaramida (180)

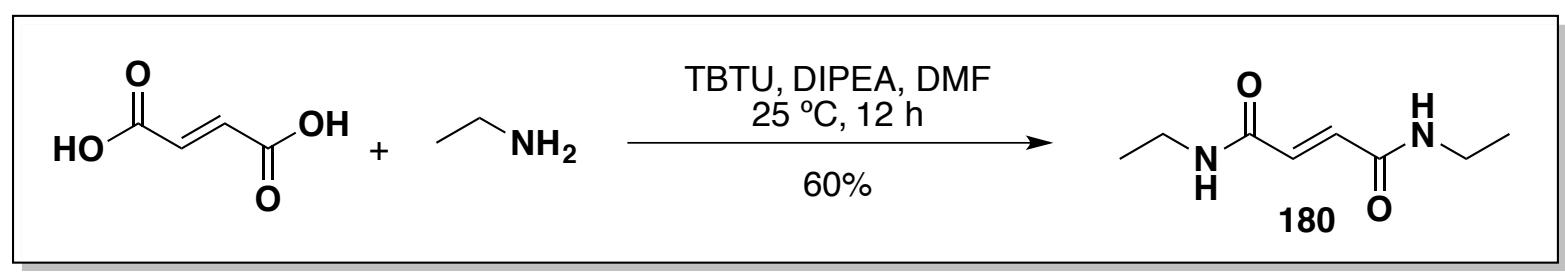

Ácido fumárico (1 g, $8.61 \mathrm{mmol}), \mathrm{N}$-N-diisopropil etil amina $(3.3 \mathrm{~mL}, 19.0 \mathrm{mmol}$, 2.2 equiv.) e TBTU ( $5.5 \mathrm{~g}, 17.0 \mathrm{mmol}, 2$ equiv.) foram dissolvidos em DMF (17 mL). Uma solução $2 \mathrm{M}$ de etilamina em THF ( $9.5 \mathrm{~mL}, 19.0 \mathrm{mmol}, 2.2$ equiv.) foi adicionada e a mistura reacional agitada em temperatura ambiente durante a noite $(12 \mathrm{~h})$. A reação foi diluída com água e extraída com $\mathrm{CH}_{2} \mathrm{Cl}_{2}(3 \times 20 \mathrm{~mL})$. As fases orgânicas combinadas foram secas com $\mathrm{Na}_{2} \mathrm{SO}_{4}$ e concentradas em vácuo. O resíduo foi purificado por cromatografia flash $\left(1-10 \% \mathrm{MeOH}\right.$ em $\mathrm{CH}_{2} \mathrm{Cl}_{2}$ ) para fornecer a fumaramida 180 ( $885 \mathrm{mg}, 5,2 \mathrm{mmol}, 60 \%$ rendimento) como um sólido branco.

\begin{tabular}{|c|c|}
\hline \multicolumn{2}{|r|}{$N^{1}, N^{4}$-dietilfumaramida (180) } \\
\hline $\mathbf{R}_{\mathbf{f}}$ & $0.29\left(2: 98 \mathrm{MeOH} / \mathrm{CH}_{2} \mathrm{Cl}_{2}\right)$ \\
\hline${ }^{1} \mathrm{H}$ RMN & $\begin{array}{l}\left(400 \mathrm{MHz}, \mathrm{DMSO}-d_{6}\right) \delta 6.74(\mathrm{~s}, 2 \mathrm{H}), 3.14(\mathrm{q}, J=7.3 \mathrm{~Hz}, 4 \mathrm{H}), 1.02(\mathrm{t}, J= \\
7.3 \mathrm{~Hz}, 6 \mathrm{H}) ;\end{array}$ \\
\hline${ }^{13} \mathrm{C}$ RMN & $\left.100 \mathrm{MHz}, \mathrm{DMSO}-d_{6}\right) \delta$ 164.6, 133.1, 34.4, 14.9; \\
\hline FTIR & $\begin{array}{l}\left(\text { puro, } \mathrm{cm}^{-1}\right) 3282.00,3068.18,2977.87,2936.84,2887.13,1622.83, \\
\begin{array}{l}1480.55,1405.59,1367.81,1317.23,1198.65,1144.83,1103.32, \\
1043.17,1013.02,992.01,981.76,923.03,910.08 ;\end{array}\end{array}$ \\
\hline HRMS & $\begin{array}{l}\mathrm{ESI}^{+}(\mathrm{m} / \mathrm{z}) \text { : Calculado para } \mathrm{C}_{8} \mathrm{H}_{15} \mathrm{~N}_{2} \mathrm{O}_{2}{ }^{+}[\mathrm{M}+\mathrm{H}]^{+} 171.1128 \text {, encontrado } \\
\text { 171.1205; }\end{array}$ \\
\hline
\end{tabular}




\subsection{Procedimento geral para a adição de Michael}

O tratamento dos derivados carbonilacrílicos com éster metílico de $\mathrm{N}$-(tertButóxicarbonil)-L-cisteína 173 em uma solução de $\mathrm{MeCN} / \mathrm{NaP}_{\mathrm{i}}$ (tampão de fosfato de sódio, pH 8.0, $50 \mathrm{mM}$ ) em temperatura ambiente por 2 minutos forneceu os adutos de cisteína:

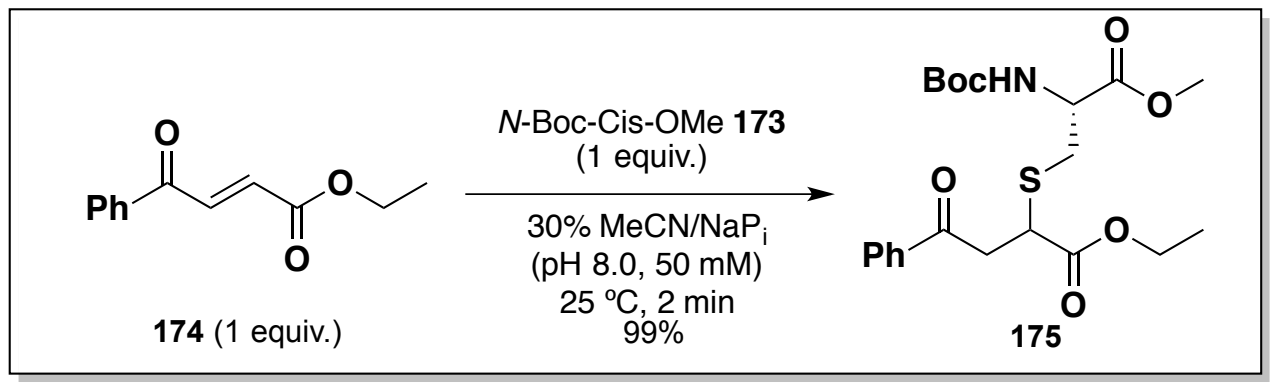

A uma solução de 173 (23.2 mg, $0.098 \mathrm{mmol}, 1$ equiv.) em $2 \mathrm{~mL}$ de uma solução de $\mathrm{NaP}_{\mathrm{i}}(\mathrm{pH}$ 8.0, $50 \mathrm{mM}$ ) contendo $30 \%$ de $\mathrm{MeCN}$ foi adicionada uma solução de 174 (20.0 mg, $0.098 \mathrm{mmol}, 1$ equiv.) em MeCN (0.5 mL) a temperatura ambiente. A reação foi acompanhada por TLC usando UV e ninhidrina como reveladores. Após 2 minutos, a reação foi concentrada em vácuo para fornecer o produto 175 como um óleo incolor em $99 \%$ de rendimento $(42.5 \mathrm{mg}, 0.097 \mathrm{mmol})$.

\section{(175)}

\begin{tabular}{|c|c|}
\hline $\mathbf{R}_{\mathrm{f}}$ & 0.11 (1:1 AcOEt/hexano); \\
\hline${ }^{1} \mathrm{H}$ RMN & $\begin{array}{l}\left(500 \mathrm{MHz}, \mathrm{DMSO}-\mathrm{d}_{6}, 100^{\circ} \mathrm{C}\right) \delta 7.97(\mathrm{~d}, J=7.3 \mathrm{~Hz}, 2 \mathrm{H}), 7.65(\mathrm{t}, J= \\
7.4 \mathrm{~Hz}, 1 \mathrm{H}), 7.53(\mathrm{t}, J=7.7 \mathrm{~Hz}, 2 \mathrm{H}), 6.86(\mathrm{~s}, 1 \mathrm{H}), 4.32-4.21(\mathrm{~m}, 1 \mathrm{H}), \\
4.19-4.10(\mathrm{~m}, 2 \mathrm{H}), 3.91-3.84(\mathrm{~m}, 1 \mathrm{H}), 3.68(\mathrm{~d}, J=2.5 \mathrm{~Hz}, 3 \mathrm{H}), 3.67 \\
-3.59(\mathrm{~m}, 1 \mathrm{H}), 3.46-3.29(\mathrm{~m}, 1 \mathrm{H}), 3.19-3.08(\mathrm{~m}, 1 \mathrm{H}), 3.06-2.98(\mathrm{~m}, \\
1 \mathrm{H}), 1.41(\mathrm{~s}, 9 \mathrm{H}), 1.22(\mathrm{t}, J=7.1 \mathrm{~Hz}, 3 \mathrm{H}) ;\end{array}$ \\
\hline${ }^{13} \mathrm{C}$ RMN & $\begin{array}{l}\text { (125 MHz, DMSO- } d_{6}, 100{ }^{\circ} \mathrm{C} \text {, diastereoisômero majoritário) } \delta \text { 196.4, } \\
170.7,170.5,154.5,135.8,132.8,128.1,127.3,78.2,60.2,60.2,53.7 \text {, } \\
53.2,51.3,41.6,40.9,40.6,40.3,32.5,32.2,27.6,13.2 \text {; }\end{array}$ \\
\hline FTIR & $\begin{array}{l}\left.\text { (puro, } \mathrm{cm}^{-1}\right) \text { 2981, 1712, 1684, 1597, 1581, 1501, 1449, 1392, 1366, } \\
\text { 1246, 1212, 1096, 1052, 1020, 1002, 988, 916, 857, 756; }\end{array}$ \\
\hline HRMS & $\begin{array}{l}\mathrm{ESI}^{+}(\mathrm{m} / \mathrm{z}) \text { : Calculado para } \mathrm{C}_{21} \mathrm{H}_{30} \mathrm{NO}_{7} \mathrm{~S}^{+}[\mathrm{M}+\mathrm{H}]^{+} 440.1737 \text {, encontrado } \\
440.1737\end{array}$ \\
\hline
\end{tabular}




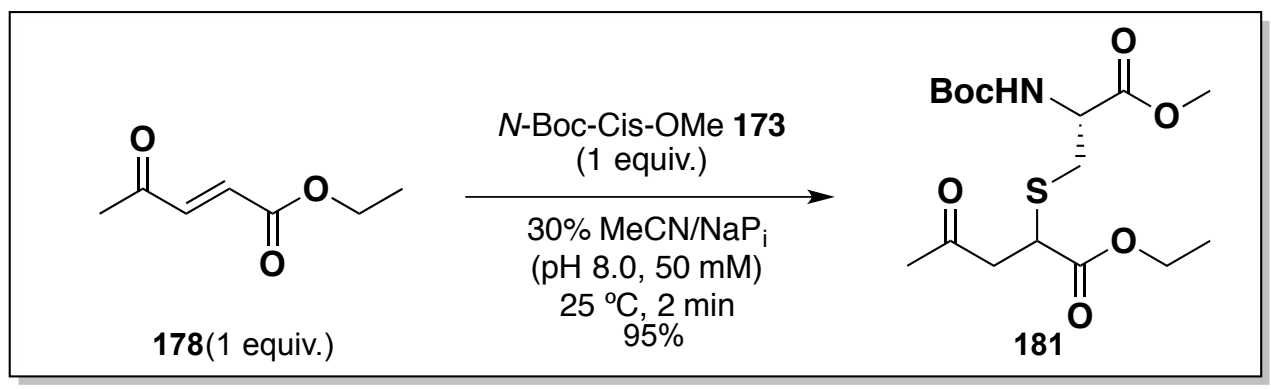

A uma solução do éster metílico de $N$-(tert-Butóxicarbonil)-L-cisteína 173 (16.5 mg, 0.070 mmol, 1 equiv.) em $1.4 \mathrm{~mL}$ de uma solução de $\mathrm{NaP}_{\mathrm{i}}(\mathrm{pH}$ 8.0, $50 \mathrm{mM}$ ) contendo $30 \%$ de MeCN foi adicionada uma solução de 178 (10.0 mg, 0.078 mmol, 1 equiv.) em $\operatorname{MeCN}(0.2 \mathrm{~mL})$ a temperatura ambiente. A reação foi acompanhada por TLC usando UV e ninhidrina como reveladores. Após 2 minutos, a reação foi concentrada em vácuo para fornecer o produto 181 como um óleo incolor em $95 \%$ de rendimento $(28.0 \mathrm{mg}$, $0.074 \mathrm{mmol})$.

\section{(181)}

\begin{tabular}{ll}
\hline $\mathbf{R}_{\mathbf{f}}$ & $0.40(1: 1 \mathrm{AcOEt} /$ hexano $) ;$ \\
${ }^{1} \mathbf{H}$ RMN & $\left(500 \mathrm{MHz}, 90^{\circ} \mathrm{C}, \mathrm{DMSO}-d_{6}\right) \delta 6.86(\mathrm{~s}, 1 \mathrm{H}), 4.31-4.16(\mathrm{~m}, 1 \mathrm{H}), 4.18-$ \\
& $4.04(\mathrm{~m}, 2 \mathrm{H}), 3.67(\mathrm{~s}, 3 \mathrm{H}), 3.09-3.03(\mathrm{~m}, 2 \mathrm{H}), 2.98-2.78(\mathrm{~m}, 2 \mathrm{H}), 2.11$ \\
& $(\mathrm{~s}, 3 \mathrm{H}), 1.40(\mathrm{~s}, 9 \mathrm{H}), 1.22(\mathrm{t}, \mathrm{J}=7.1 \mathrm{~Hz}, 3 \mathrm{H}) ;$ \\
${ }^{13} \mathbf{C}$ RMN & $\left(125 \mathrm{MHz}, \mathrm{DMSO}-d_{6}, 90{ }^{\circ} \mathrm{C}\right.$, diastereoisômero majoritário $) \delta 204.3$, \\
& $204.3,170.7,170.7,78.3,60.3,51.4,44.6,44.3,41.1,40.4,32.4,32.1$, \\
& $28.9,27.7,13.3 ;$ \\
& $\left(\right.$ puro, cm $\left.{ }^{-1}\right) 2979,1712,1508,1437,1392,1365,1319,1233,1095$, \\
FTIR & $1044,1018,860,779 ;$ \\
& $\mathrm{ESI}^{+}(\mathrm{m} / \mathrm{z}):$ Calculado para $\mathrm{C}_{16} \mathrm{H}_{28} \mathrm{NO}_{7} \mathrm{~S}^{+}\left[\mathrm{M}+\mathrm{H}^{+} 378.1581\right.$, encontrado \\
HRMS & $378.1585 ;$
\end{tabular}




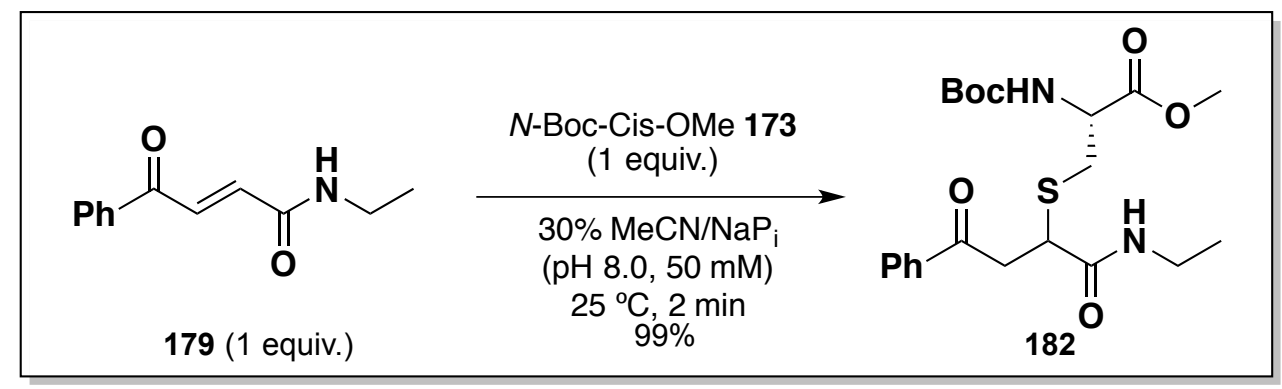

A uma solução do éster metílico de $N$-(tert-Butóxicarbonil)-L-cisteína 173 (23.2 mg, 0.098 mmol, 1 equiv.) em $2 \mathrm{~mL}$ de uma solução de $\mathrm{NaP}_{\mathrm{i}}(\mathrm{pH} 8.0,50 \mathrm{mM}$ ) contendo $30 \%$ de MeCN foi adicionada uma solução de 179 (20.0 mg, 0.098 mmol, 1 equiv.) em MeCN $(0.5 \mathrm{~mL})$ a temperatura ambiente. A reação foi acompanhada por TLC usando UV e ninhidrina como reveladores. Após 2 minutos, a reação foi concentrada em vácuo para fornecer o produto 182 como um óleo incolor em $95 \%$ de rendimento $(42.5 \mathrm{mg}$, $0.097 \mathrm{mmol})$.

\section{(182)}

\begin{tabular}{|c|c|}
\hline $\mathbf{R}_{\mathrm{f}}$ & 0.63 (4:1 AcOEt/hexano); \\
\hline${ }^{1} \mathrm{H}$ RMN & $\begin{array}{l}\left.500 \mathrm{MHz} \text {, DMSO-d6, } 100{ }^{\circ} \mathrm{C}\right) \delta 7.94(\mathrm{~d}, J=8.5 \mathrm{~Hz}, 2 \mathrm{H}), 7.73(\mathrm{~s}, 1 \mathrm{H}) \text {, } \\
7.63(\mathrm{t}, J=7.5 \mathrm{~Hz}, 1 \mathrm{H}), 7.52(\mathrm{t}, J=7.6 \mathrm{~Hz}, 2 \mathrm{H}), 6.77(\mathrm{~s}, 1 \mathrm{H}), 4.27-4.18 \\
(\mathrm{~m}, 1 \mathrm{H}), 3.88-3.79(\mathrm{~m}, 1 \mathrm{H}), 3.72-3.67(\mathrm{~m}, 1 \mathrm{H}), 3.66(\mathrm{~s}, 3 \mathrm{H}), 3.27(\mathrm{dt}, \\
J=17.4,4.9 \mathrm{~Hz}, 1 \mathrm{H}), 3.16-3.10(\mathrm{~m}, 2 \mathrm{H}), 3.10-3.04(\mathrm{~m}, 1 \mathrm{H}), 2.95- \\
2.91(\mathrm{~m}, 1 \mathrm{H}), 1.39(\mathrm{~s}, 9 \mathrm{H}), 1.06(\mathrm{t}, J=7.2 \mathrm{~Hz}, 3 \mathrm{H}) ;\end{array}$ \\
\hline${ }^{13} \mathrm{C}$ RMN & $\begin{array}{l}\text { (125 MHz, DMSO-d6, } 100{ }^{\circ} \mathrm{C} \text {, diastereoisômero majoritário) } \delta \text { 196.7, } \\
\text { 170.7, 169.4, 154.5, 136.3, 132.5, 128.0, 127.3, 78.2, 53.5, 51.2, 42.3, } \\
\text { 40.8, 33.3, 31.8, 27.6, 13.8; }\end{array}$ \\
\hline FTIR & $\begin{array}{l}\left.\text { (puro, } \mathrm{cm}^{-1}\right) \text { 2978, 1683, 1597, 1519, 1449, 1413, 1392, 1366, 1351, } \\
\text { 1248, 1217, 1052, 1019, 988, 912, 858; }\end{array}$ \\
\hline HRMS & $\begin{array}{l}\mathrm{ESI}^{+}(\mathrm{m} / \mathrm{z}) \text { : Calculado para } \mathrm{C}_{21} \mathrm{H}_{31} \mathrm{~N}_{2} \mathrm{O}_{6} \mathrm{~S}^{+}[\mathrm{M}+\mathrm{H}]^{+} \text {439.1897, } \\
\text { encontrado 439.1899; }\end{array}$ \\
\hline
\end{tabular}




\subsection{Estudos de seletividade}
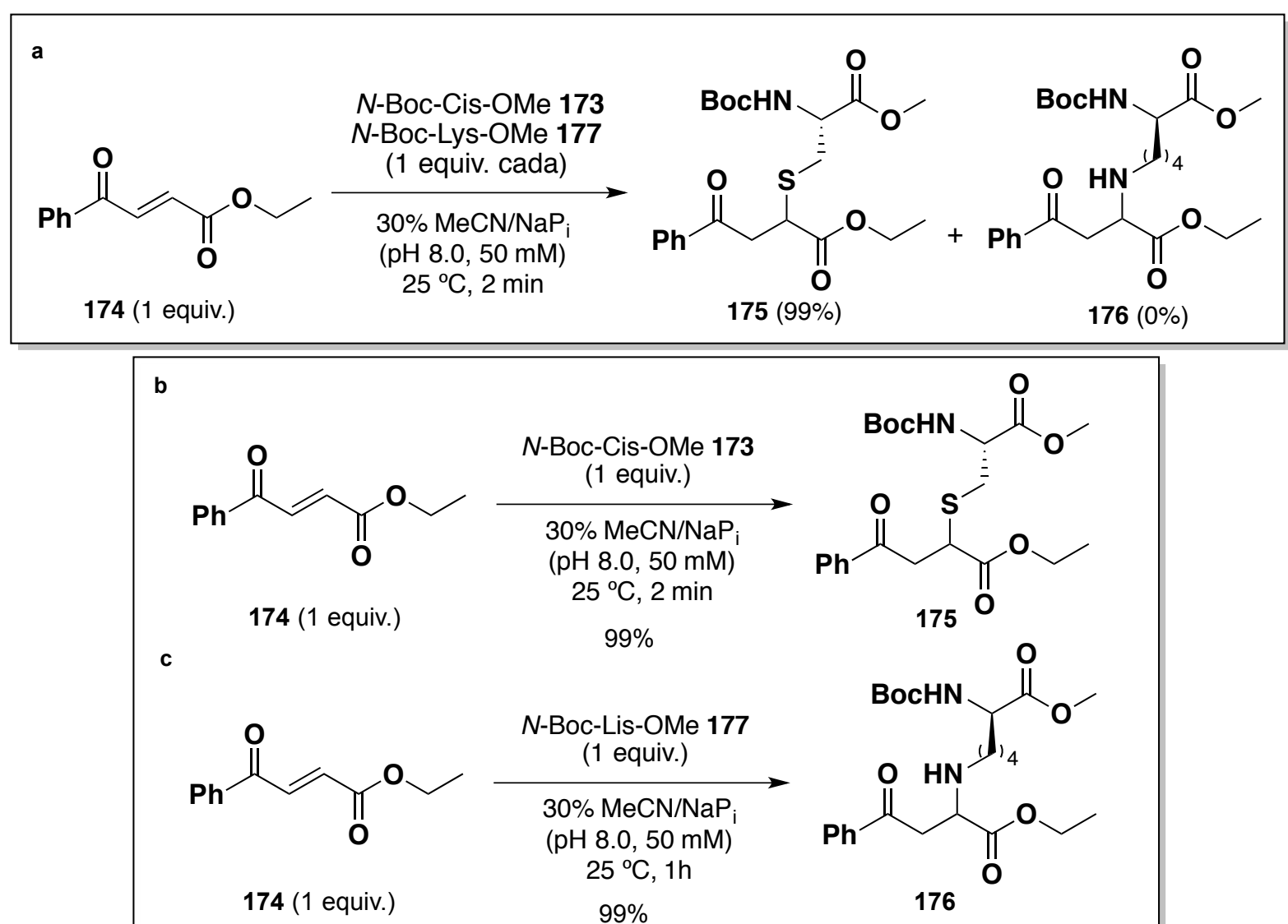

Uma mistura equimolar de N-Boc-Cisteína-OMe 173 (57,6 mg, 0.245 mmol, 1 equiv.) e N-Boc-Lisina-OMe 177 (63.7 mg, 0.245 mmol, 1 equiv.) em MeCN (0.05 M) ou em uma solução $30 \%$ de $\mathrm{MeCN} / \mathrm{NaP}_{\mathrm{i}}(50 \mathrm{mM})$ em pH $8(0.05 \mathrm{M})$ foi tratada com 174 (50.0 mg, $0.245 \mathrm{mmol}, 1$ equiv.) para fornecer somente o aduto de cisteína 175 seletivamente em $99 \%$ de rendimento isolado. A lisina permaneceu sem reagir (a). $O$ tratamento do composto 174 com uma solução do éster metílico de $N$-(tertButóxicarbonil)-L-cisteína 173 em NaP $(\mathrm{pH}$ 8.0, $50 \mathrm{mM}$ ) em temperatura forneceu o aduto de cisteína 175 em 99\% de rendimento após 2 min de reação (b). Em contraste, o tratamento de 174 com N-Boc-Lisina-OMe 177 nas mesmas condições reacionais requereu $1 \mathrm{~h}$ para o consumo total dos reagentes (c). 


\subsection{Experimento de competição entre 174,179, N-metilmaleimida}

Uma mistura equimolar dos compostos $174,179, N$-metilmaleimida em uma solução deuterada de $30 \% \mathrm{CD}_{3} \mathrm{CN} / \mathrm{NaP}_{\mathrm{i}}(\mathrm{pH} 8.0,50 \mathrm{mM}$ ) foi adicionada em um tubo de $\mathrm{RMN}$ e realizada a análise de RMN de ${ }^{1} \mathrm{H}$ em $20^{\circ} \mathrm{C}$ utilizando um equipamento de $400 \mathrm{MHz}$. O espectro confirmou a razão 1:1:1 da mistura. Após, 1 equiv. de 173 foi adicionada ao tubo reacional e um segundo espectro medido, mostrando uma razão final de 1:0.22:0.58 que corrobora as constantes cinéticas calculadas (Figura 47).

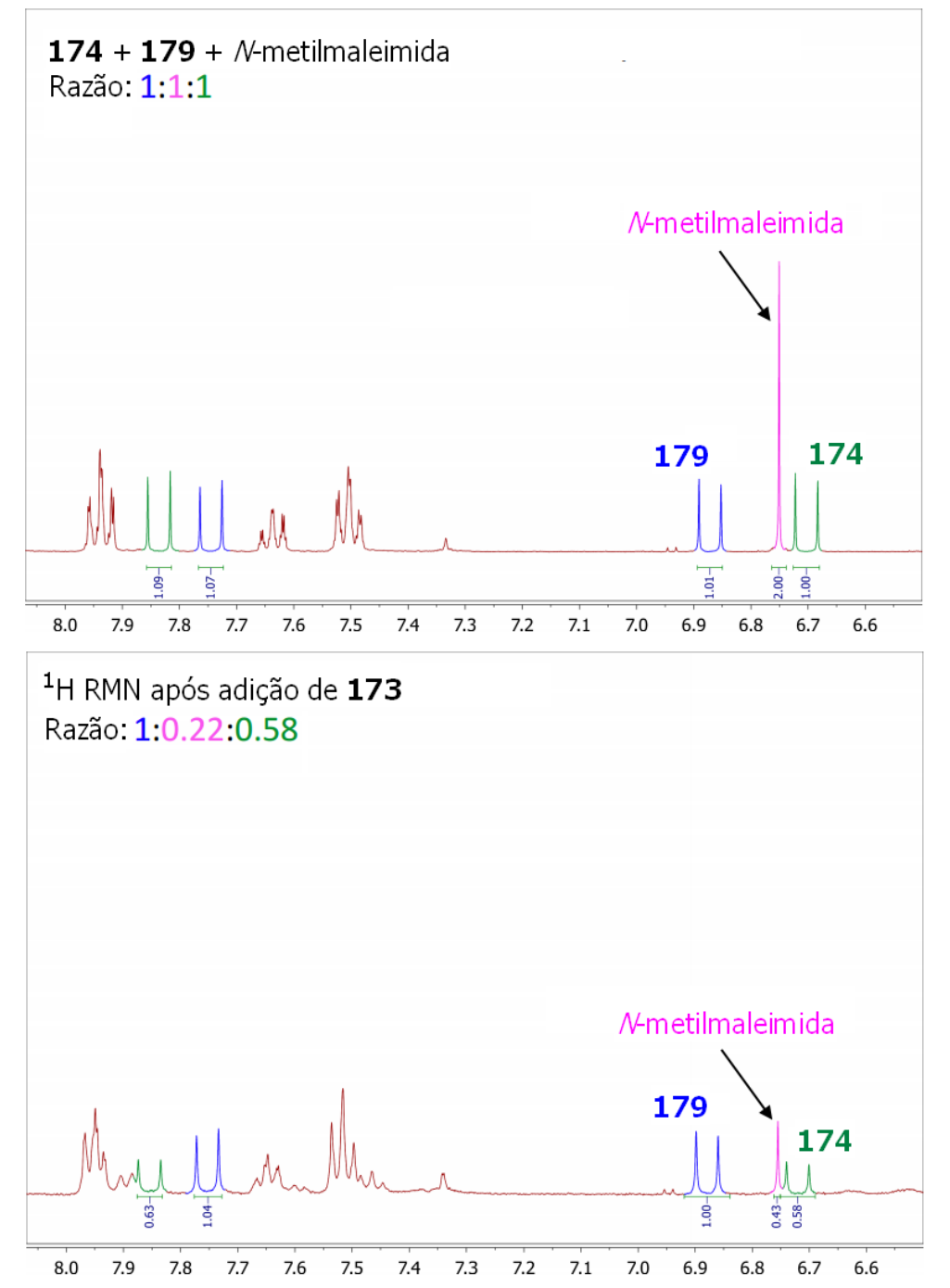

Figura 47 Experimento de competição entre 174, 179 e maleimida. 


\subsection{Estudos de estabilidade}

6.12.1 Estabilidade na presença de glutationa (GSH)

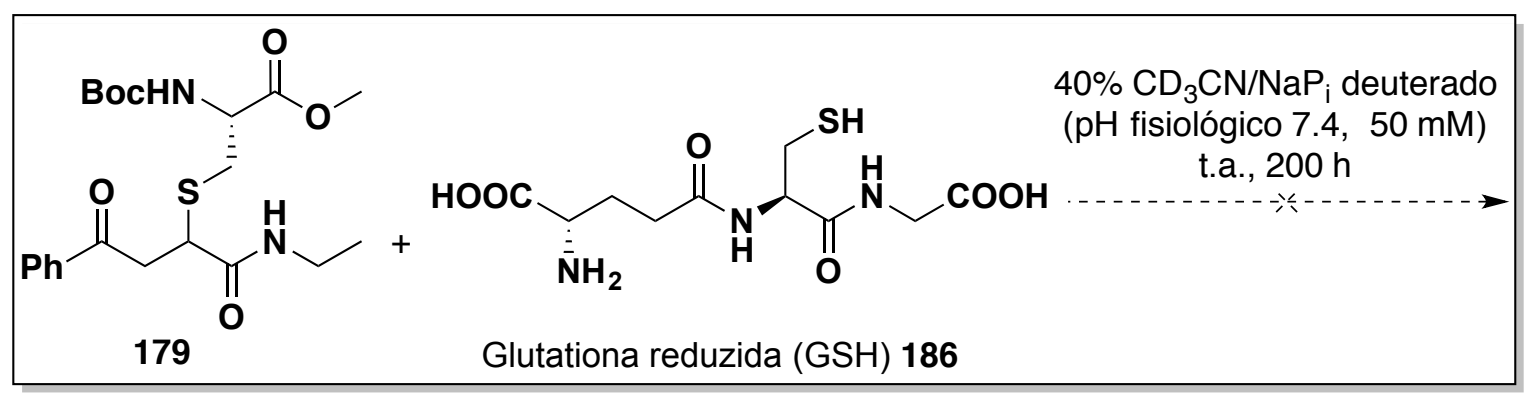

A reação foi realizada pelo tratamento de glutationa reduzida $(\mathrm{GSH}),(21 \mathrm{mg}$, $0.068 \mathrm{mmol}, 1.5$ equiv.) com o composto 182 (20mg, $0.046 \mathrm{mmol}, 1$ equiv.) em $2 \mathrm{~mL}$ de uma solução deuterada de tampão $\mathrm{NaPi}(50 \mathrm{mM})$ em pH fisiológico (7.4) contendo $40 \%$ de $\mathrm{CD}_{3} \mathrm{CN}$ em temperatura ambiente. Após 100 e $200 \mathrm{~h}$, uma alíquota de $0.5 \mathrm{~mL}$ foi coletada e analisada por RMN de ${ }^{1} \mathrm{H}$ (Figura 48) e por espectrometria de massas de alta resolução (Figura 49) de alta resolução (HRMS ESI ${ }^{+}(\mathrm{m} / \mathrm{z})$ : calculado para o aduto $\mathrm{GSH}+182 \mathrm{C}_{22} \mathrm{H}_{31} \mathrm{~N}_{4} \mathrm{O}_{8} \mathrm{~S}^{+}[\mathrm{M}+\mathrm{H}]^{+} 511.1857$ ou $\mathrm{C}_{22} \mathrm{H}_{30} \mathrm{~N}_{4} \mathrm{O}_{8} \mathrm{SNa}^{+}\left[\mathrm{M}+\mathrm{Na}^{+}\right.$ 533.1677). 


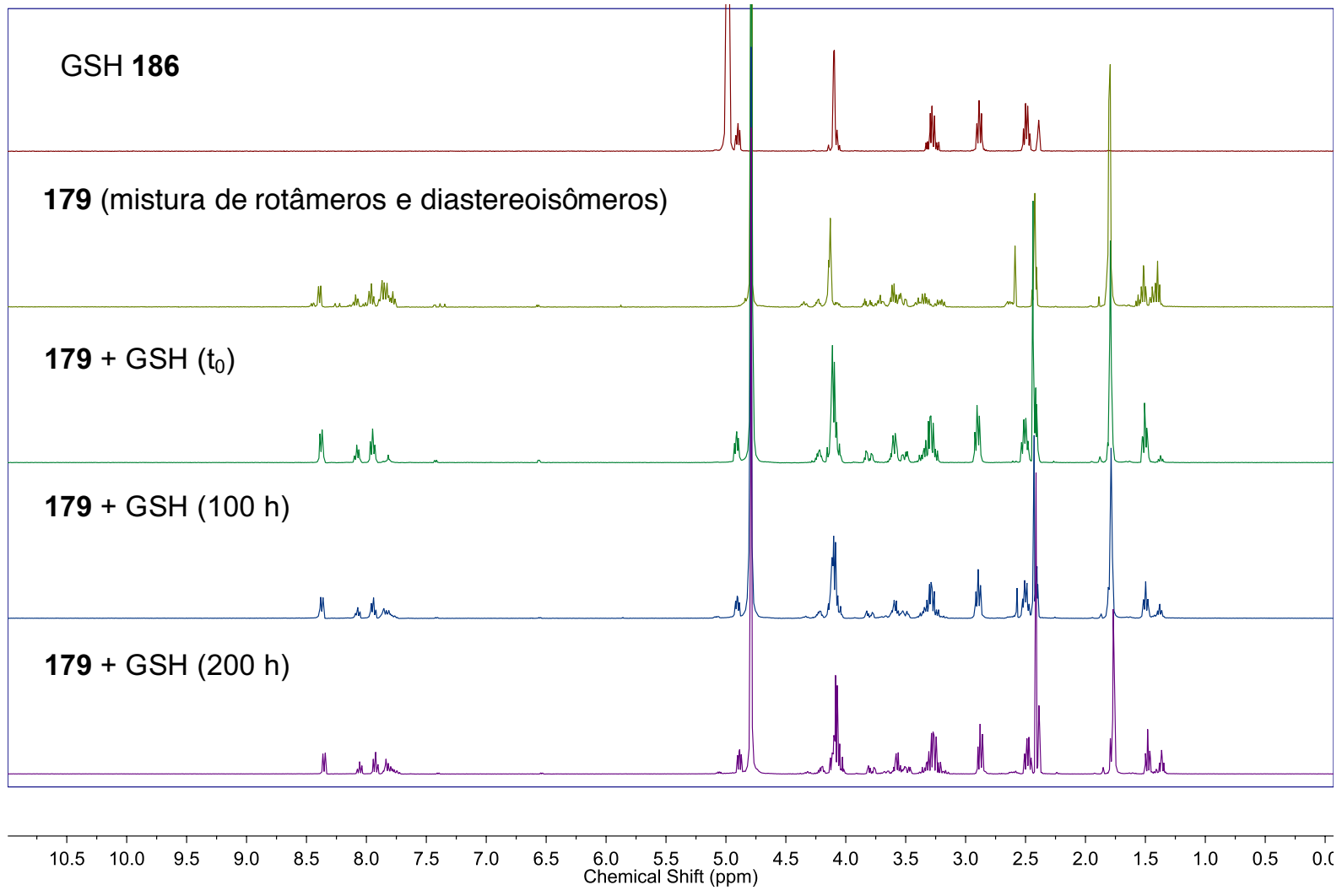

Figura 48 Estabilidade por RMN ${ }^{1} \mathrm{H}$ do aduto de Michael 179 na presença de GSH 186. 
1: TOF MS ES+ :511.186+533.168

1. 1e+002

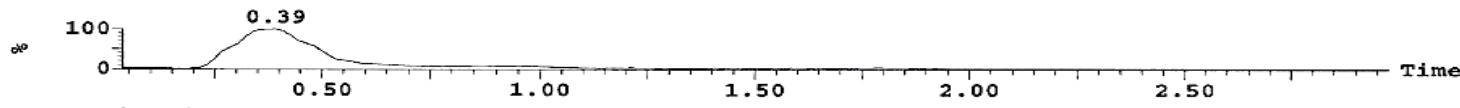

1: Combine $(8: 32-1: 10)$ $179+\mathrm{Na}^{+}$

$1.3 e+005$

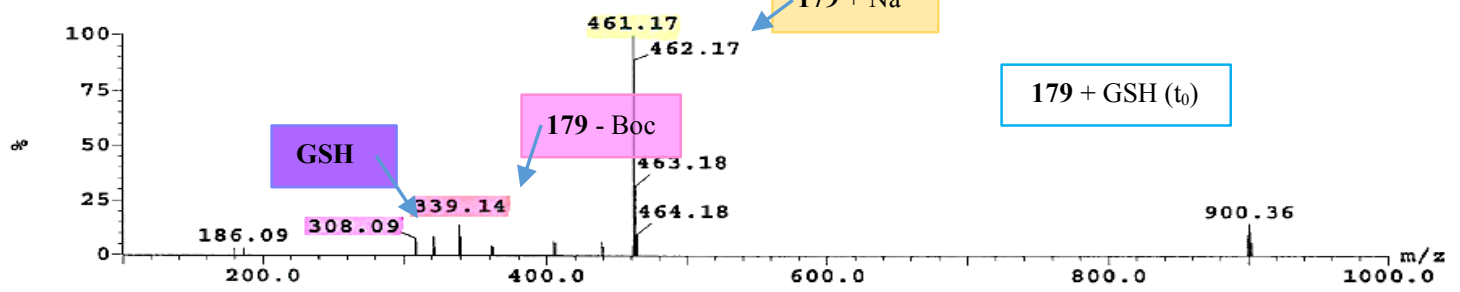

1: TOF MS ES+ : $511.186+533.168$

$1.1 e+002$

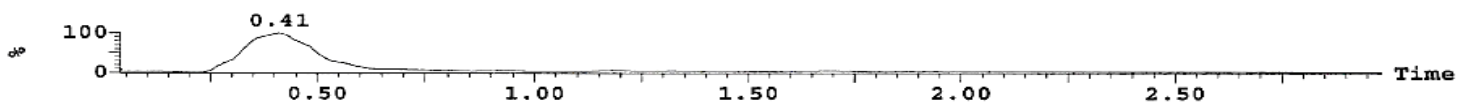

1: Combine $(8: 32-1: 10)$

$1.5 e+005$
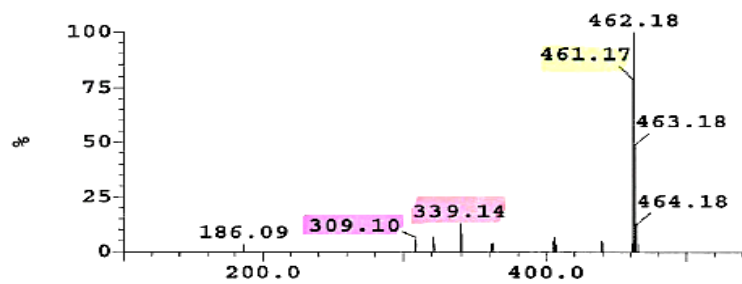

$179+\mathrm{GSH}(24 \mathrm{~h})$

1: TOF MS ES+ : $511.186+533.168$

$\infty \quad 100$

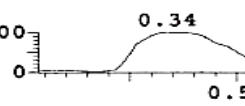

1: Combine $(8: 32-1: 11)$

1.00

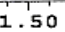

2.00

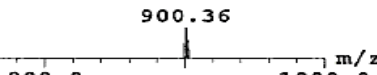

600.0
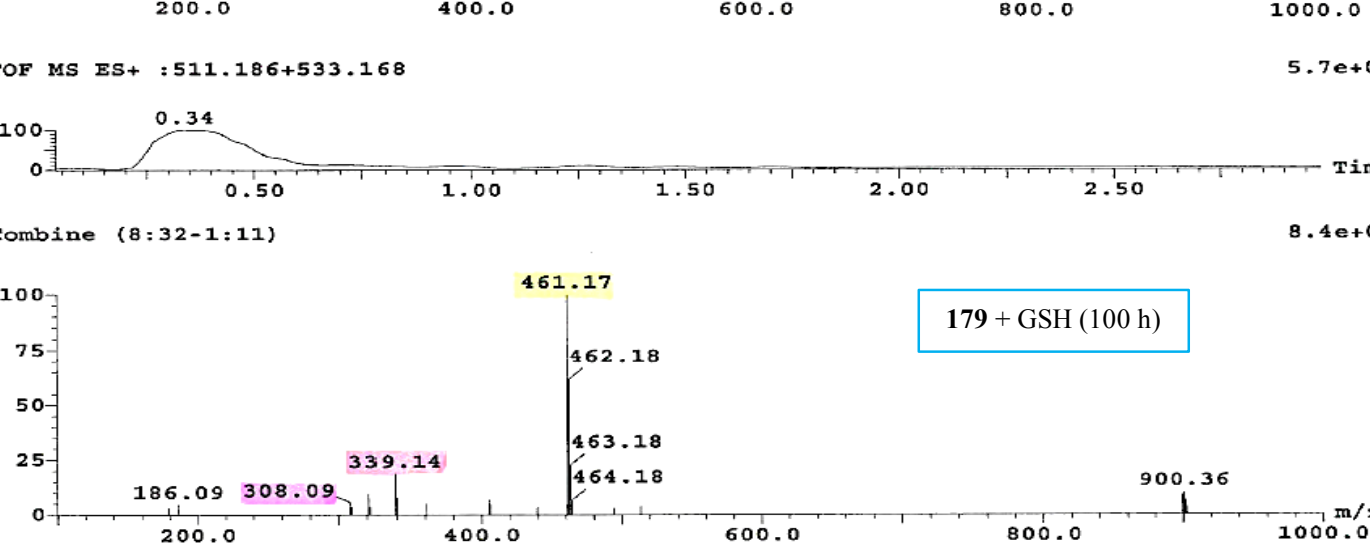

461.17

462.18

$179+\mathrm{GSH}(100 \mathrm{~h})$

200.0

4.63 .18

464.18
900.36

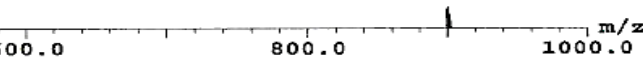

1: TOF MS ES+ :511.186+533.168

$2.6 e+001$

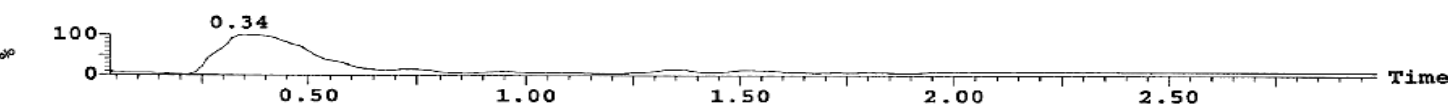

1: Combine $(8: 32-1: 10)$

$3.1 e+004$

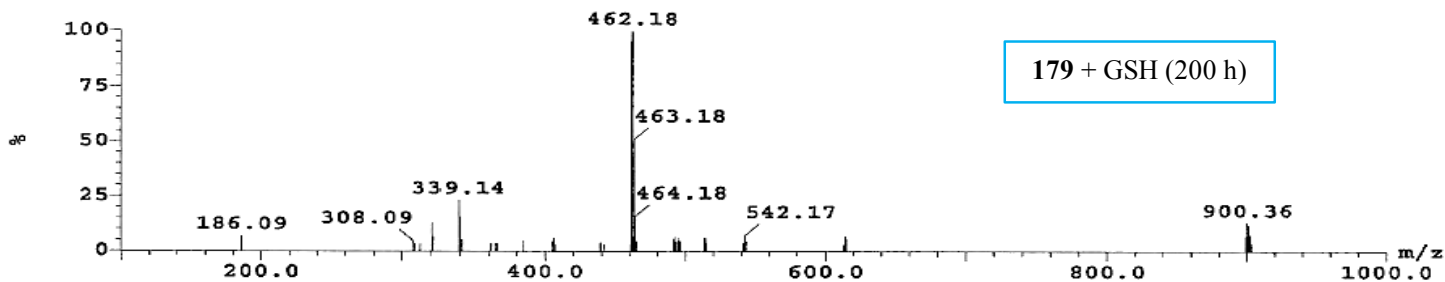

Figura 49 Estabilidade por HRMS do aduto de Michael 179 na presença de GSH 186. 
6.12.2 Análise de retro-Michael por UV-VIS

Preparo dos tióis cromogênicos para análise de retro-Michael

\section{N-etil-2-((4-nitrofenil)tio)-4-oxo-4-fenilbutanamida (184)}

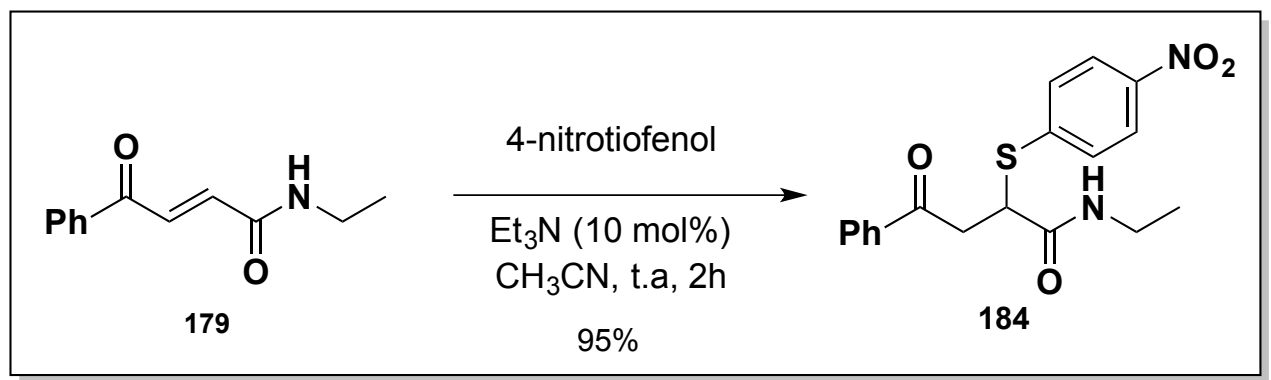

Uma solução de 179 (100.0 mg, 0.45 mmol, 1 equiv.), 4-nitrotiofenol (108.0 mg, $0.45 \mathrm{mmol}, 1$ equiv.) e trietilamina catalítica ( $7 \mu \mathrm{L}, 0.049 \mathrm{mmol})$ em acetonitrila anidra $(10 \mathrm{~mL})$ foi agitada em temperatura ambiente em atmosfera de nitrogênio. Após $2 \mathrm{~h}$, a reação foi concentrada em vácuo e o resíduo purificado por cromatografia flash (3:7, AcOEt/hexano) para fornecer o composto 184 (112 mg, 0. $32 \mathrm{mmol}, 70 \%$ ) como um sólido branco.

\begin{tabular}{|c|c|}
\hline & N-etil-2-((4-nitrofenil)tio)-4-oxo-4-fenilbutanamida (184) \\
\hline $\mathbf{R}_{\mathrm{f}}$ & 0.43 (3:7 AcOEt/hexano); \\
\hline${ }^{1} \mathrm{H}$ RMN & $\begin{array}{l}\left(500 \mathrm{MHz}, \mathrm{CDCl}_{3}\right) \delta 8.20-8.13(\mathrm{~m}, 2 \mathrm{H}), 7.97-7.91(\mathrm{~m}, 2 \mathrm{H}), 7.62- \\
7.56(\mathrm{~m}, 1 \mathrm{H}), 7.51-7.43(\mathrm{~m}, 4 \mathrm{H}), 6.57(\mathrm{~s}, 1 \mathrm{H}), 4.45(\mathrm{dd}, J=6.7,5.5 \mathrm{~Hz} \text {, } \\
1 \mathrm{H}), 3.92(\mathrm{dd}, J=18.0,6.7 \mathrm{~Hz}, 1 \mathrm{H}), 3.52(\mathrm{dd}, J=18.1,5.5 \mathrm{~Hz}, 1 \mathrm{H}), 3.37 \\
-3.24(\mathrm{~m}, 2 \mathrm{H}), 1.11(\mathrm{t}, \mathrm{J}=7.3 \mathrm{~Hz}, 3 \mathrm{H}) ;\end{array}$ \\
\hline${ }^{13} \mathrm{C}$ RMN & $\begin{array}{l}\left(125 \mathrm{MHz}, \mathrm{CDCl}_{3}\right) \delta 196.8,169.3,146.5,144.2,136.1,134.0,128.9, \\
\text { 128.9, 128.3, 124.4, 46.1, 41.2, 35.3, 14.8; }\end{array}$ \\
\hline FTIR & $\begin{array}{l}\text { (puro, } \mathrm{cm}^{-1} \text { ) 3271, 3097, 2985, 2903, 1682, 1637, 1595, 1577, 1517, } \\
\text { 1481, 1446, 1401, 1366, 1341, 1279, 1264, 1223, 1189, 1165, 1148, } \\
\text { 1114, 1082, 1010, 989.76; }\end{array}$ \\
\hline HRMS & $\begin{array}{l}\mathrm{ESI}^{+}(\mathrm{m} / z) \text { : calculado para } \mathrm{C}_{18} \mathrm{H}_{19} \mathrm{~N}_{2} \mathrm{O}_{4} \mathrm{~S}^{+}[\mathrm{M}+\mathrm{H}]^{+} 359.1060 \text {, encontrado } \\
359.1072 ;\end{array}$ \\
\hline
\end{tabular}


1-benzil-3-((4-nitrofenil)tio)pirrolidina-2,5-diona (185)

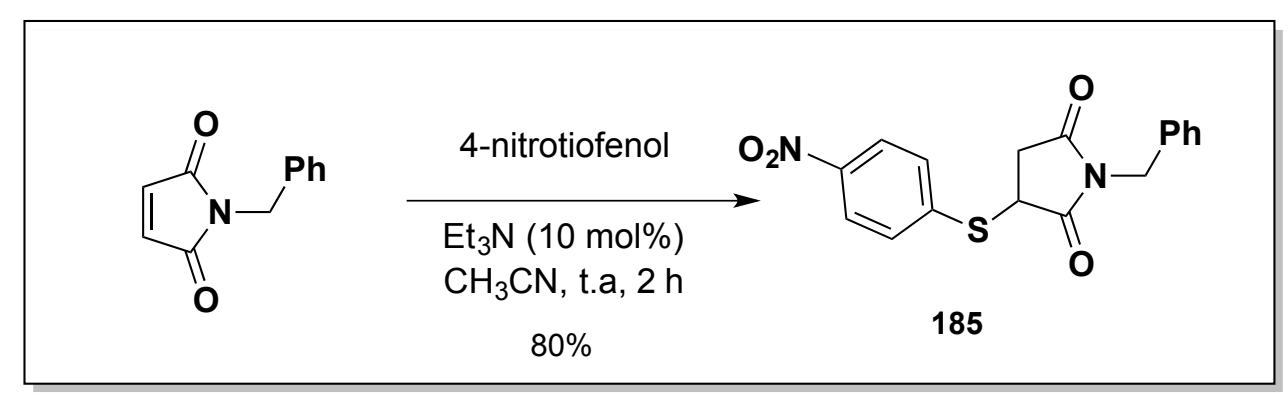

Uma solução de $N$-benzilmaleimida ( $150.0 \mathrm{mg}, 0.80 \mathrm{mmol}, 1$ equiv.), 4-nitrotiofenol (124.0 mg, $0.80 \mathrm{mmol}, 1$ equiv.) e trietilamina catalítica $(11 \mu \mathrm{L}, 0.08 \mathrm{mmol}) \mathrm{em}$ acetonitrila anidra $(10 \mathrm{~mL})$ foi agitada em temperatura ambiente em atmosfera de nitrogênio. Após $2 \mathrm{~h}$, a reação foi concentrada em vácuo e o resíduo purificado por cromatografia flash (3:7, AcOEt/hexano) para fornecer o composto 185 (178 mg, $0.52 \mathrm{mmol}, 65 \%)$ como um óleo incolor.

\begin{tabular}{ll}
\hline & 1-benzil-3-((4-nitrofenil)tio)pirrolidina-2,5-diona (185) \\
\hline $\mathbf{R}_{\mathbf{f}}$ & $0.37(3: 7 \mathrm{AcOEt} /$ hexano); \\
${ }^{1} \mathbf{H} \mathbf{R M N}$ & $\left(400 \mathrm{MHz}, \mathrm{CDCl}_{3}\right) \delta 8.08-7.97(\mathrm{~m}, 2 \mathrm{H}), 7.58-7.47(\mathrm{~m}, 2 \mathrm{H}), 7.37-$ \\
& $7.25(\mathrm{~m}, 5 \mathrm{H}), 4.65(\mathrm{~s}, 2 \mathrm{H}), 4.21(\mathrm{dd}, \mathrm{J}=9.4,4.3 \mathrm{~Hz}, 1 \mathrm{H}), 3.27(\mathrm{dd}, \mathrm{J}=$ \\
& $18.8,9.4 \mathrm{~Hz}, 1 \mathrm{H}), 2.67(\mathrm{dd}, \mathrm{J}=18.8,4.4 \mathrm{~Hz}, 1 \mathrm{H}) ;$ \\
${ }^{13} \mathbf{C} \mathbf{R M N}$ & $\left(101 \mathrm{MHz}, \mathrm{CDCl}_{3}\right) \delta 174.6,173.3,147.1,141.2,135.0,131.1,129.1$, \\
& $128.8,128.3,124.1,43.0,42.5,35.8$ \\
\hline
\end{tabular}

- Os dados estão de acordo com os reportados na literatura. ${ }^{177}$ 
Em uma solução de tampão $(165 \mu \mathrm{L})$ de $\mathrm{NaP}_{\mathrm{i}}(\mathrm{pH} 7.4,10 \mathrm{mM})$ em uma cubeta de quartzo foi adicionada uma solução do composto 184 (33 $\mu \mathrm{L}$ de uma solução $0.45 \mathrm{mM}$ em acetonitrila) e a mistura vigorosamente agitada. A absorbância em $410 \mathrm{~nm}$ correspondente ao ânion 4-nitrotiofenolato foi acompanhada a temperatura ambiente durante um período de $5 \mathrm{~h}$. O mesmo procedimento foi seguido para o composto 185. Cabe ressaltar, que embora ambos os compostos possuam uma absorbância inicial em $410 \mathrm{~nm}, 184-A_{0 h}=0.45 \mathrm{~nm}, A_{5 h}=0.45 \mathrm{~nm}$ e $185-A_{0 h}=0.23 \mathrm{~nm}, A_{5 h}=0.35 \mathrm{~nm}$, o comportamento de 185 claramente indica um aumento na absorbância ao longo do tempo em contraste com a estabilidade de 184 (Figura 50).
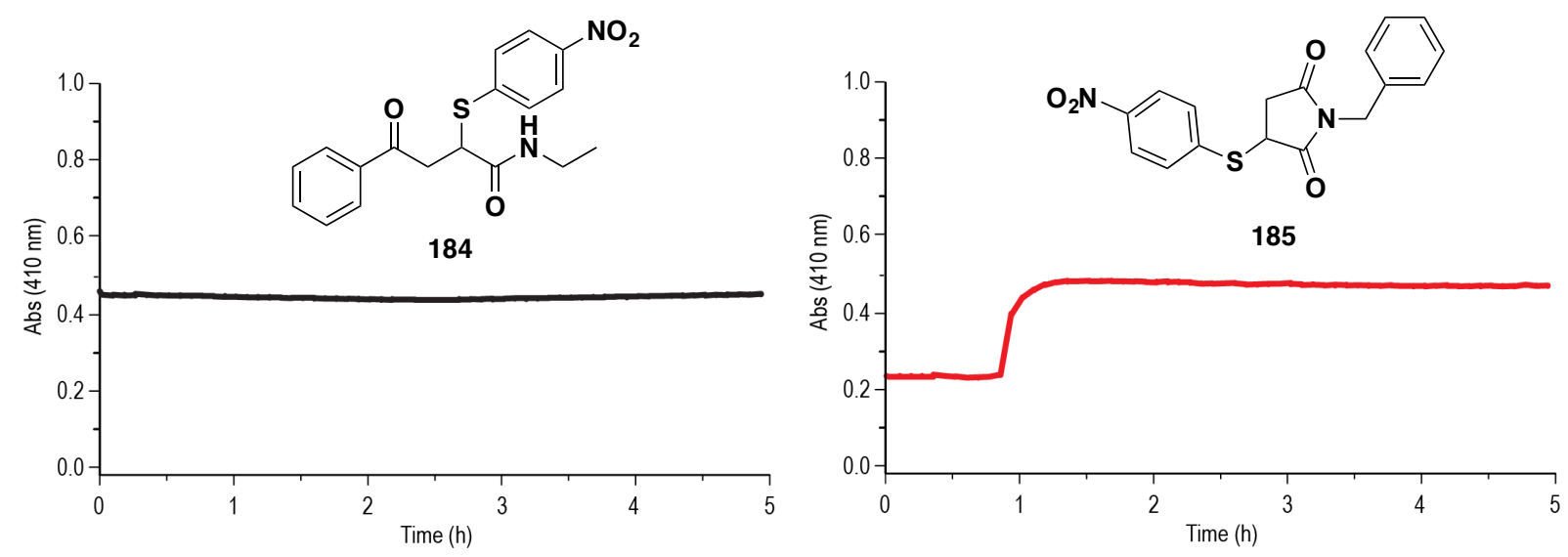

Figura 50 Comparação de estabilidade dos derivados cromogênicos 184 e 185. 


\subsection{Síntese dos derivados fluorescentes 194 e PEG 195}

\subsubsection{Síntese do derivado fluorescente 194}

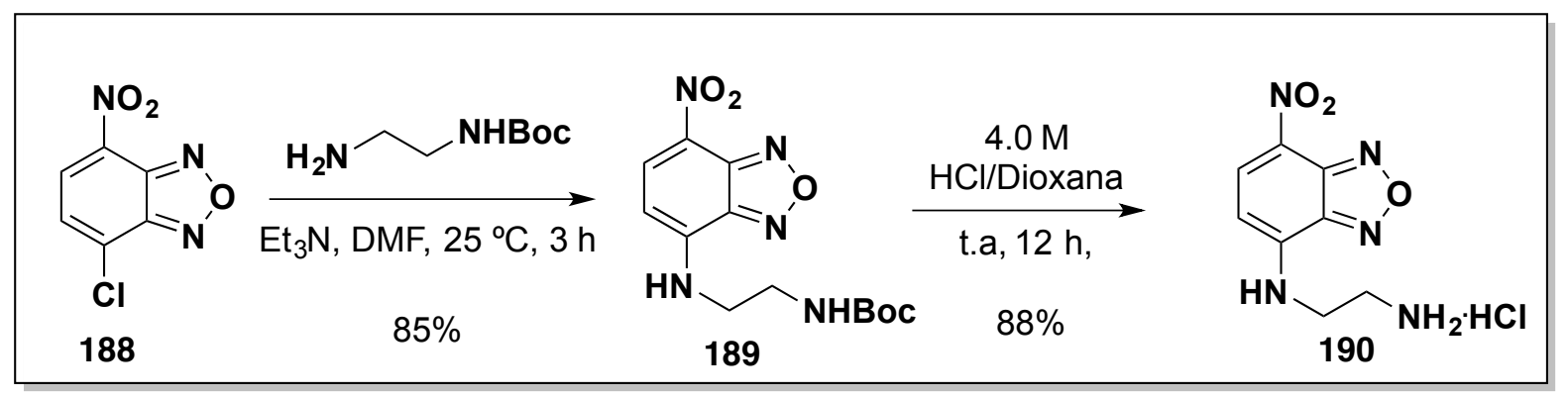

Carbamato de tert-butil (2-((7-nitrobenzo[c][1,2,5]oxadiazol-4-il)amino)etil) ${ }^{238}$ Em atmosfera de argônio, 4-cloro-7-nitrobenzofurazano - NBDCl 188 (199mg, $1.0 \mathrm{mmol}, 1$ equiv.) foi dissolvido em DMF anidro (6 mL). Após a adição de trietilamina (138 $\mu \mathrm{L}, 1.0 \mathrm{mmol}, 1$ equiv.) e $N$-Boc-1,2-diaminoetano (174 $\mu \mathrm{L}, 1.2 \mathrm{mmol}, 1.2$ equiv.), a mistura reacional foi agitada a temperatura ambiente por $3 \mathrm{~h}$. A reação foi acompanhada por TLC (1:1, AcOEt/hexano, usando UV e $\mathrm{KMnO}_{4}$ como reveladores) e finalizada pela adição de uma solução aquosa saturada de cloreto de amônio (30 mL). A mistura foi extraída com acetato de etila $(3 \times 40 \mathrm{~mL})$ e a fase orgânica lavada com água $(50 \mathrm{~mL})$, solução saturada de $\mathrm{NaCl}(50 \mathrm{~mL})$ e posteriormente seca com sulfato de magnésio. Após a remoção de solventes em pressão reduzida, o intermediário protegido com Boc 189 foi obtido como óleo marrom escuro (275 mg, $0.85 \mathrm{mmol}, 85 \%$ de rendimento):

$189{ }^{1} \mathrm{H}$ RMN (400 MHz, CDCl $) \delta 8.48(\mathrm{~d}, J=8.7 \mathrm{~Hz}, 1 \mathrm{H}), 8.01(\mathrm{br} \mathrm{s}, 1 \mathrm{H}), 6.16(\mathrm{~d}, J=$ $8.6 \mathrm{~Hz}, 1 \mathrm{H}), 5.09(\mathrm{br} \mathrm{s}, 1 \mathrm{H}), 3.59(\mathrm{br} \mathrm{s}, 4 \mathrm{H}), 1.46(\mathrm{~s}, 9 \mathrm{H}) ; \mathrm{HRMS} \mathrm{ESI}^{+}(\mathrm{m} / \mathrm{z})$ : calculado para $\mathrm{C}_{13} \mathrm{H}_{18} \mathrm{~N}_{5} \mathrm{O}_{5}{ }^{+}[\mathrm{M}+\mathrm{H}]^{+} 324.1302$, encontrado 324.1302 . 
$\boldsymbol{N}^{1}$-(7-nitrobenzo[c][1,2,5]oxadiazol-4-il)etano-1,2-diamina ${ }^{238} \mathrm{Em}$ atmosfera de argônio, o intermediário 189 (262 mg, $0.81 \mathrm{mmol}, 1$ equiv.) foi dissolvido em uma solução $4.0 \mathrm{M}$ de $\mathrm{HCl}$ em dioxana (6 mL). A solução foi protegida da luz (usando folha de alumínio) e agitada durante a noite (12h). Após confirmar a completa reação por TLC (9:1, $\mathrm{CH}_{2} \mathrm{Cl}_{2} / \mathrm{MeOH}$, usando UV e $\mathrm{KMnO}_{4}$ como reveladores), a solução foi evaporada em pressão reduzida e um sólido marrom escuro de 190 foi obtido e utilizado na próxima etapa ( $185.4 \mathrm{mg}, 0.71 \mathrm{mmol}, 88 \%$ de rendimento).

190: ${ }^{1} \mathrm{H}$ RMN (400 MHz, Metanol- $\left.d_{4}\right) \delta 8.54(\mathrm{~d}, J=8.7 \mathrm{~Hz}, 1 \mathrm{H}), 6.47(\mathrm{~d}, J=8.7 \mathrm{~Hz}$, $1 \mathrm{H}), 3.89(\mathrm{t}, J=6.2 \mathrm{~Hz}, 2 \mathrm{H}), 3.34(\mathrm{t}, J=6.3 \mathrm{~Hz}, 2 \mathrm{H})$; $\mathrm{HRMS} \mathrm{ESI}^{+}(\mathrm{m} / \mathrm{z})$ : calculado para $\mathrm{C}_{8} \mathrm{H}_{10} \mathrm{~N}_{5} \mathrm{O}_{3}{ }^{+}[\mathrm{M}+\mathrm{H}]^{+}$224.0778, encontrado 224.0784 . 


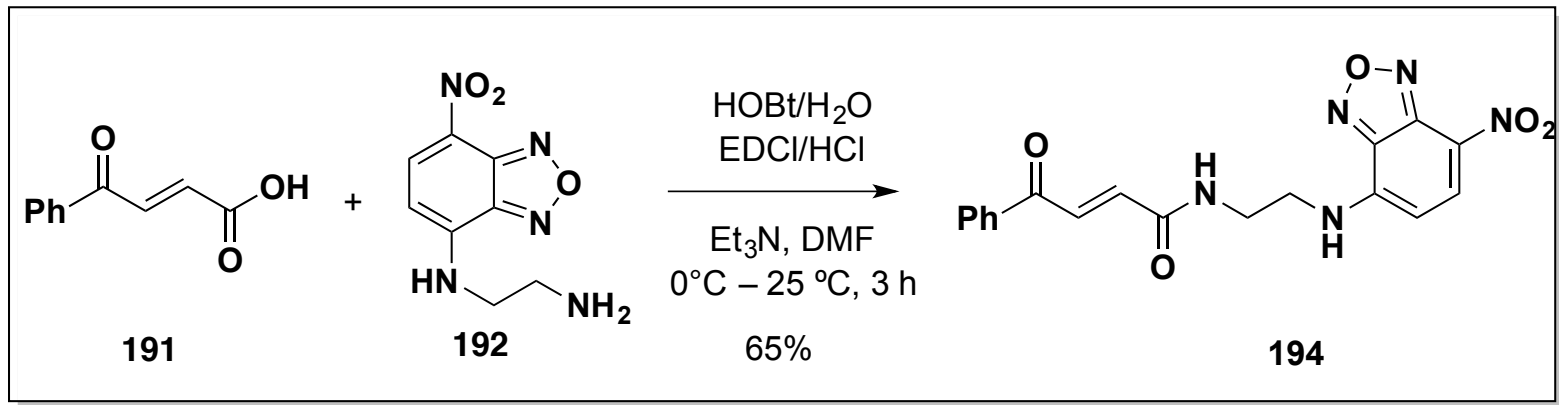

Em atmosfera de argônio, o ácido 3-benzoílacrílico 191 (108.0mg, 0.61 mmol, 1 equiv.) foi dissolvido em DMF anidro e então trietilamina (170 $\mu \mathrm{L}, 1.22 \mathrm{mmol}$, 2.0 equiv.) foi adicionada gota-a-gota. Esta solução foi resfriada com banho de gelo e então adicionado sequencialmente hidrato de 1-hidróxibenzotriazol (111.5 mg, $0.73 \mathrm{mmol}, 1.2$ equiv.), hidrocloreto de $N$-(3-Dimetilaminopropil)- $N$ '-etilcarbodiimida (140.0 mg, 0.73 mmol, 1.2 equiv.) e 192 (149.5 mg, 0.61 mmol, 1 equiv.). O balão foi excluído da luz (envolvido com papel de alumínio) e então a reação foi prolongada por $3 \mathrm{~h}$ em temperatura ambiente. Após análise por TLC (95:5, $\mathrm{CH}_{2} \mathrm{Cl}_{2} / \mathrm{MeOH}$, usando UV e $\mathrm{KMnO}_{4}$ como reveladores), a reação foi vertida em uma solução aquosa de $\mathrm{HCl}$ (0.5 M, $40 \mathrm{~mL})$ e extraída com $\mathrm{CH}_{2} \mathrm{Cl}_{2}(3 \times 40 \mathrm{~mL})$. As fases orgânicas combinadas foram lavadas com solução saturada de $\mathrm{Na}_{2} \mathrm{CO}_{3}(2 \times 40 \mathrm{~mL})$ e de $\mathrm{NaCl}(2 \times 40 \mathrm{~mL})$ e secas com sulfato de magnésio. A remoção dos voláteis em vácuo forneceu 0 composto 194 como um sólido amarelo escuro/marrom (151.0 mg, 0.40 mmol, 65\%). O produto foi obtido com excelente pureza por análise de ${ }^{1} \mathrm{H}$ RMN. Diversas tentativas de purificação usando cromatografia (sílica, sílica lavada com trietilamina e alumina) ou recristalização levaram a degradação.

(E)-N-(2-((7-nitrobenzo[c][1,2,5]oxadiazol-4-il)amino)etil)-4-oxo-4-fenilbut-2-enamida (194)

\begin{tabular}{ll}
\hline $\mathbf{R}_{\mathbf{f}}$ & $0.71\left(95: 5 \mathrm{CH}_{2} \mathrm{Cl}_{2} / \mathrm{MeOH}\right) ;$ \\
${ }^{1} \mathbf{H}$ RMN & $\left(500 \mathrm{MHz}, \mathrm{DMSO}-\mathrm{d}_{6}\right) \delta 8.80(\mathrm{t}, \mathrm{J}=5.8 \mathrm{~Hz}, 1 \mathrm{H}), 8.52(\mathrm{~d}, J=8.8 \mathrm{~Hz}, 1 \mathrm{H})$, \\
& $7.98(\mathrm{~d}, \mathrm{~J}=6.9 \mathrm{~Hz}, 2 \mathrm{H}), 7.74(\mathrm{~d}, \mathrm{~J}=15.3 \mathrm{~Hz}, 1 \mathrm{H}), 7.69(\mathrm{t}, \mathrm{J}=7.4 \mathrm{~Hz}$, \\
& $1 \mathrm{H}), 7.56(\mathrm{t}, \mathrm{J}=7.8 \mathrm{~Hz}, 2 \mathrm{H}), 6.91(\mathrm{~d}, \mathrm{~J}=15.3 \mathrm{~Hz}, 1 \mathrm{H}), 6.47(\mathrm{~d}, \mathrm{~J}=9.0$ \\
& $\mathrm{Hz}, 1 \mathrm{H}), 3.63(\mathrm{bs}, 2 \mathrm{H}), 3.56-3.47(\mathrm{~m}, 2 \mathrm{H}) ;$ \\
${ }^{13} \mathbf{C}$ RMN & $\left(125 \mathrm{MHz}, \mathrm{DMSO}-\mathrm{d}_{6}\right) \delta 189.8,164.1,145.4,144.6,137.9,136.5,136.1$, \\
& $133.8,132.1,129.0,128.6,128.2,99.3,45.7,29.0 ;$ \\
HRMS & $\mathrm{ESI}^{+}(\mathrm{m} / \mathrm{z}):$ Calculado para $\mathrm{C}_{18} \mathrm{H}_{16} \mathrm{~N}_{5} \mathrm{O}_{5}{ }^{+}\left[\mathrm{M}+\mathrm{H}^{+} 382,1146\right.$, encontrado \\
& $382.1133 ;$
\end{tabular}




\subsubsection{Síntese do derivado PEG 195}

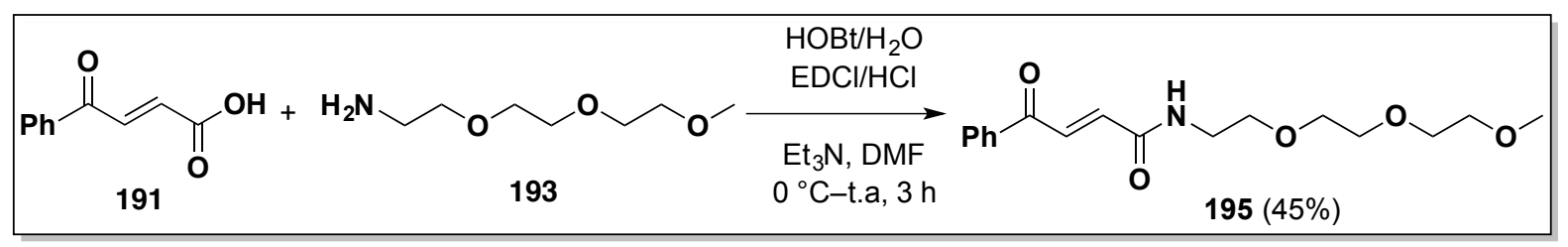

Em atmosfera de argônio, o ácido 3-benzoílacrílico 191 (50.0 mg, 0.28 mmol, 1 equiv.) foi dissolvido em DMF anidro e então trietilamina (78 $\mu \mathrm{L}, 0.56 \mathrm{mmol}, 2.0$ equiv.) foi adicionada. Esta solução foi resfriada com banho de gelo e então adicionado sequencialmente hidrato de 1-hidróxibenzotriazol (46.0 mg, $0.34 \mathrm{mmol}, 1.2$ equiv.), hidrocloreto de $N$-(3-Dimetilaminopropil)- $N$ '-etilcarbodiimida $(65.0 \mathrm{mg}, 0.34 \mathrm{mmol}$, 1.2 equiv.) e uma solução $0.3 \mathrm{M}$ de 2-(2-(2-Metóxietóxi)etóxi) etilamina 193 (45.0 mg, 0.28 mmol, 1 equiv.). O balão foi excluído da luz (envolvido com papel alumínio) e então a reação foi prolongada por $3 \mathrm{~h}$ em temperatura ambiente. Após análise por TLC (95:5, $\mathrm{CH}_{2} \mathrm{Cl}_{2} / \mathrm{MeOH}$, usando UV e $\mathrm{KMnO}_{4}$ como reveladores), a reação foi vertida em uma solução aquosa de $\mathrm{HCl}(0.5 \mathrm{M}, 20 \mathrm{~mL})$ e extraída com $\mathrm{CH}_{2} \mathrm{Cl}_{2}(3 \mathrm{x}$ $30 \mathrm{~mL}$ ). As fases orgânicas combinadas foram lavadas com solução saturada de $\mathrm{Na}_{2} \mathrm{CO}_{3}(2 \times 30 \mathrm{~mL})$ e de $\mathrm{NaCl}(2 \times 30 \mathrm{~mL})$ e secas com sulfato de magnésio. A remoção dos voláteis em vácuo forneceu o composto 195 como um óleo marrom (38.0 mg, $0.12 \mathrm{mmol}, 43 \%$ de rendimento) após purificação por cromatografia flash (95:5, $\left.\mathrm{CH}_{2} \mathrm{Cl}_{2} / \mathrm{MeOH}\right)$.

(E)-N-(2-(2-(2-metóxietóxi)etóxi)etil)-4-oxo-4-fenilbut-2-enamida 195

\begin{tabular}{ll}
\hline $\mathbf{R}_{\mathbf{f}}$ & $0.40\left(5 \% \mathrm{MeOH}_{\mathrm{CH}} \mathrm{Cl}_{2}\right) ;$ \\
${ }^{1} \mathbf{H}$ RMN & $(500 \mathrm{MHz}, \mathrm{CDCl}) \delta 8.04-8.00(\mathrm{~m}, 2 \mathrm{H}), 7.95(\mathrm{~d}, \mathrm{~J}=15.1 \mathrm{~Hz}, 1 \mathrm{H}), 7.62$ \\
& $-7.57(\mathrm{~m}, 1 \mathrm{H}), 7.49(\mathrm{dd}, \mathrm{J}=8.3,7.1 \mathrm{~Hz}, 2 \mathrm{H}), 7.01(\mathrm{~d}, \mathrm{~J}=15.0 \mathrm{~Hz}, 1 \mathrm{H})$, \\
& $6.94(\mathrm{~s}, 1 \mathrm{H}), 3.68-3.61(\mathrm{~m}, 8 \mathrm{H}), 3.63-3.54(\mathrm{~m}, 4 \mathrm{H}), 3.38(\mathrm{~s}, 3 \mathrm{H}) ;$ \\
${ }^{13} \mathbf{C}$ RMN & $\left(125 \mathrm{MHz}, \mathrm{CDCl}_{3}\right) \delta 189.8,164.1,137.0,135.5,133.6,133.0,128.8$, \\
& $128.8,71.9,70.5,70.4,70.2,69.5,59.0,39.7 ;$ \\
HRMS & $\mathrm{ESI}^{+}(\mathrm{m} / \mathrm{z}):$ Calculado para $\mathrm{C}_{17} \mathrm{H}_{23} \mathrm{NO}_{5} \mathrm{Na}^{+}[\mathrm{M}+\mathrm{Na}]^{+} 344.1468$, \\
& encontrado 344.1455; \\
\hline
\end{tabular}




\subsection{Método geral para análise de LC-MS}

A cromatografia líquida-espectrometria de massas (LC-MS) foi realizada em um espectrômetro Xevo G2-S-TOF acoplado a um sistema UPLC Acquity usando uma coluna Acquity UPLC BEH300 C4 $(1.7 \mu \mathrm{m}, 2.1 \times 50 \mathrm{~mm})$. Os solventes (A, água com $0.1 \%$ de ácido fórmico e $B, 71 \%$ de acetonitrila, $29 \%$ de água e $0.075 \%$ de ácido fórmico) foram utilizados como fase móvel em uma taxa de fluxo de $0.2 \mathrm{~mL} / \mathrm{min}$. $\mathrm{O}$ gradiente foi programado como se segue: $72 \%$ A até $100 \%$ B após 25 min e então $100 \%$ de B por 2 minutos. Após, $72 \%$ de A foi utilizado por 18 minutos. A fonte de electrospray foi operada com uma voltagem de capilaridade de $2.0 \mathrm{kV}$ e uma voltagem de cone de $40 \mathrm{~V}$. Nitrogênio foi utilizado como gás de desolvatação em um fluxo de $850 \mathrm{~L} / \mathrm{h}$. O espectro total de massa foi reconstruído a partir da série de íons utilizando um algoritmo MaxEnt pré-instalado no software MassLynx (v. 4.1 da Waters). Para obter a série de íons acima mencionada, os picos majoritários do cromatograma foram selecionados para integração e posterior análise. 


\subsection{Análise do produto de conjugação de proteínas usando LC-MS}

Uma análise típica de uma reação de conjugação por LC-MS é descrita na Figura 51 para a proteína albumina. $\mathrm{O}$ cromatograma dos íons totais, série de íons combinadas e o espectro deconvoluído são apresentados para a reação entre a albumina com 1 equivalente do composto (E)-N-etil-4-oxo-4-fenilbut-2-enamida 179. Análises idênticas foram realizadas para todas as reações de conjugação. Um espectro de LCMS foi coletado para todas as proteínas antes das reações com os compostos carbonilacrílicos.
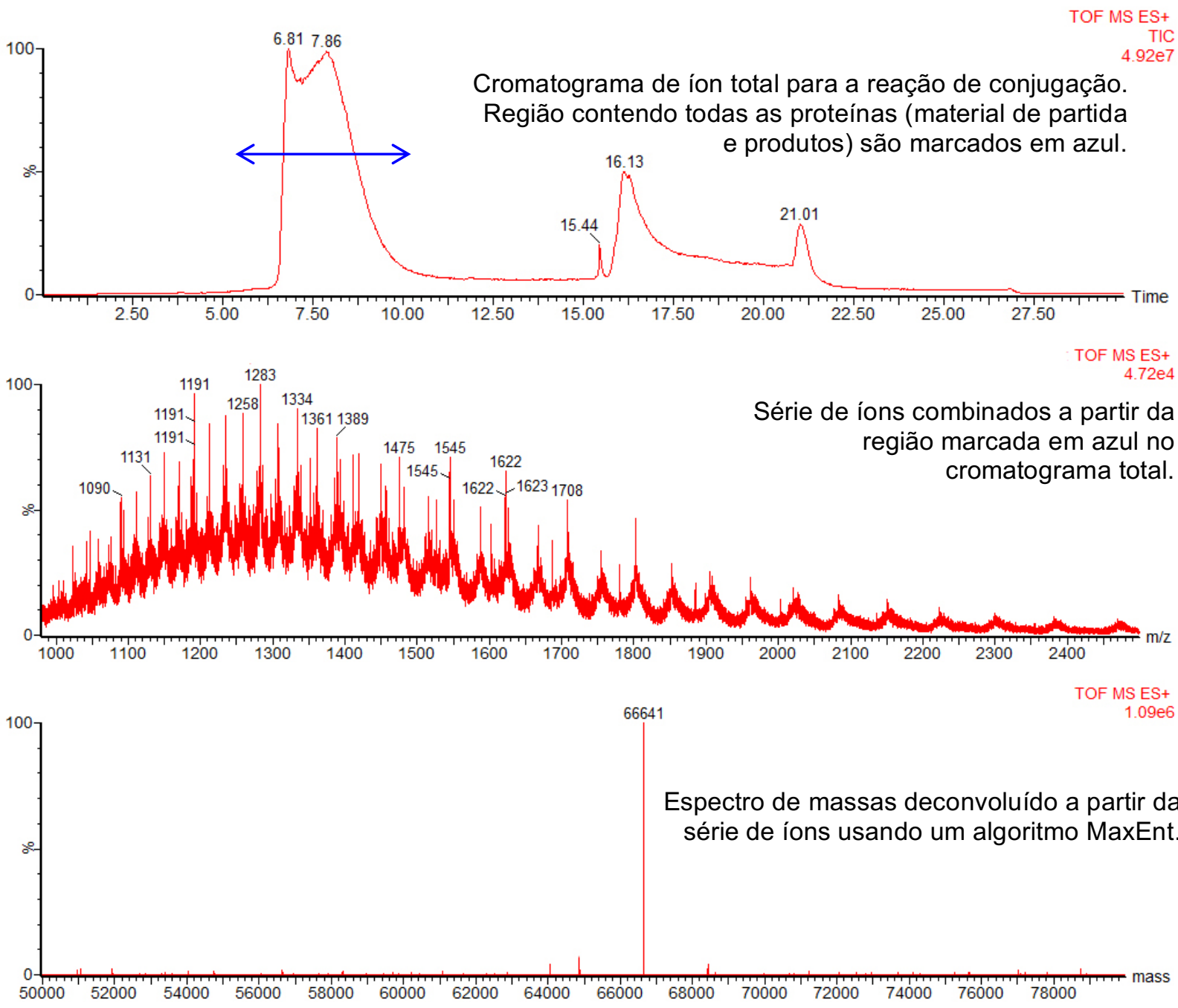

Figura 51 Análise de LC-MS obtida para as reações de bioconjugação (exemplo albumina). 


\subsection{Proteínas utilizadas: Annexina V, C2Am e albumina}

6.16.1 Annexina V-Cis316

Sequência:

AQVLRGTVTDFPGFDERADAETLRKAMKGLGTDEESILTLLTSRSNAQRQEISAAFK TLFGRDLLDDLKSELTGKFEKLIVALMKPSRLYDAYELKHALKGAGTNEKVLTEIIASR TPEELRAIKQVYEEEYGSSLEDDVVGDTSGYYQRMLVVLLQANRDPDAGIDEAQVE QDAQALFQAGELKWGTDEEKFITIFGTRSVSHLRKVFDKYMTISGFQIEETIDRETSG NLEQLLLAVVKSIRSIPAYLAETLYYAMKGAGTDDHTLIRVMVSRSEIDLFNIRKEFRK NFATSLYSMIKGDTSGDYKKALLLLㅌGEDD

Peso molecular $=35805 \mathrm{Da}$
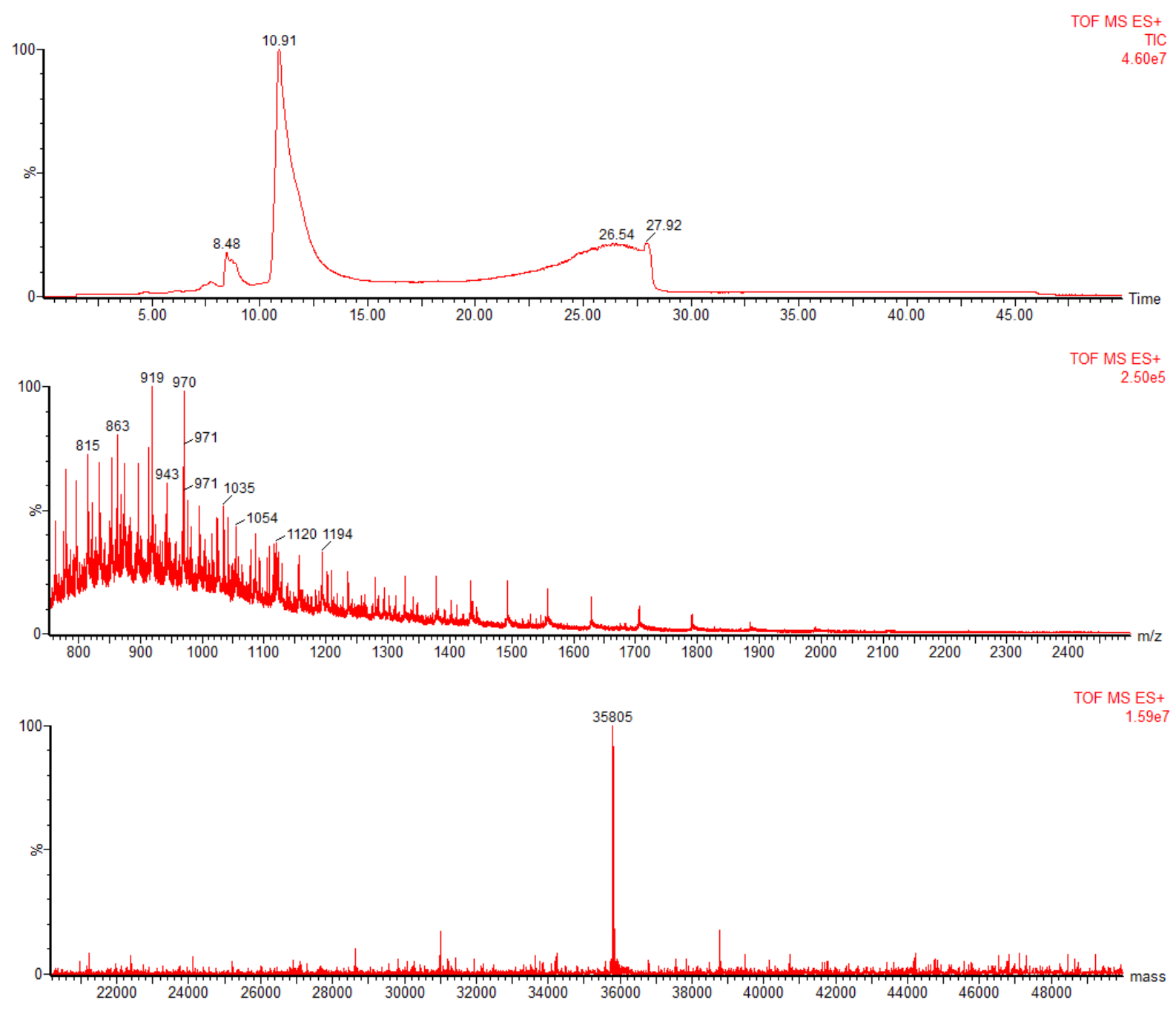

Figura 52 Análise LC-MS para a Annexina V-Cis316 


\subsubsection{C2Am-Cis78}

Sequência:

GSPGISGGGGGILDSMVEKLGKLQYSLDYDFQNNQLLVGIIQAAELPALDMGGTSD PYVKVFLLPDKKKKFETKVHRKTLNPVFNEQFTFKVPYCEELGGKTLVMAVYDFDRF SKHDIIGEFKVPMNTV DFGHVTEEWR DLQSAEK

Peso Molecular $=16222 \mathrm{Da}$
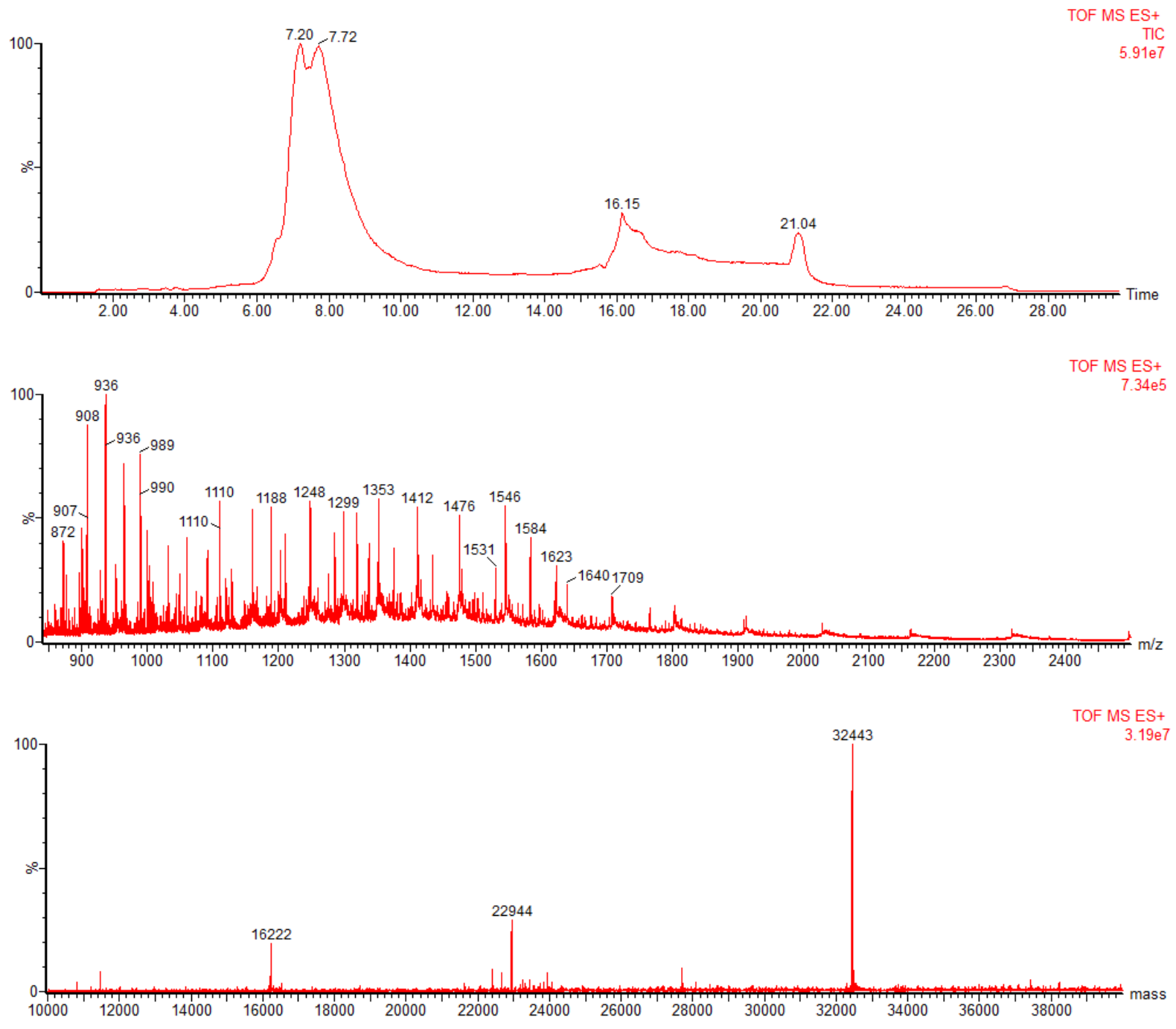

Figura 53 Análise LC-MS para a C2Am. 


\subsubsection{Albumina-Cis34}

Sequencia:

DAHKSEVAHRFKDLGEENFKALVLIAFAQYLQQ్PFEDHVKLVNEVTEFAKTCVADE SAENCDKSLHTLFGDKLCTVATLRETYGEMADCCAKQEPERNECFLQHKDDNPNL PRLVRPEVDVMCTAFHDNEETFLKKYLYEIARRHPYFYAPELLFFAKRYKAAFTECC QAADKAACLLPKLDELRDEGKASSAKQRLKCASLQKFGERAFKAWAVARLSQRFP KAEFAEVSKLVTDLTKVHTECCHGDLLECADDRADLAKYICENQDSISSKLKECCEK PLLEKSHCIAEVENDEMPADLPSLAADFVESKDVCKNYAEAKDVFLGMFLYEYARR HPDYSVVLLLRLAKTYETTLEKCCAAADPHECYAKVFDEFKPLVEEPQNLIKQNCEL FEQLGEYKFQNALLVRYTKKVPQVSTPTLVEVSRNLGKVGSKCCKHPEAKRMPCA EDYLSVVLNQLCVLHEKTPVSDRVTKCCTESLVNRRPCFSALEVDETYVPKEFNAE TFTFHADICTLSEKERQIKKQTALVELVKHKPKATKEQLKAVMDDFAAFVEKCCKAD DKETCFAEEGKKLVAASQAALGL

Peso molecular $=66472 ;$ com17 dissulfetos internos $=66439 \mathrm{Da}$ 

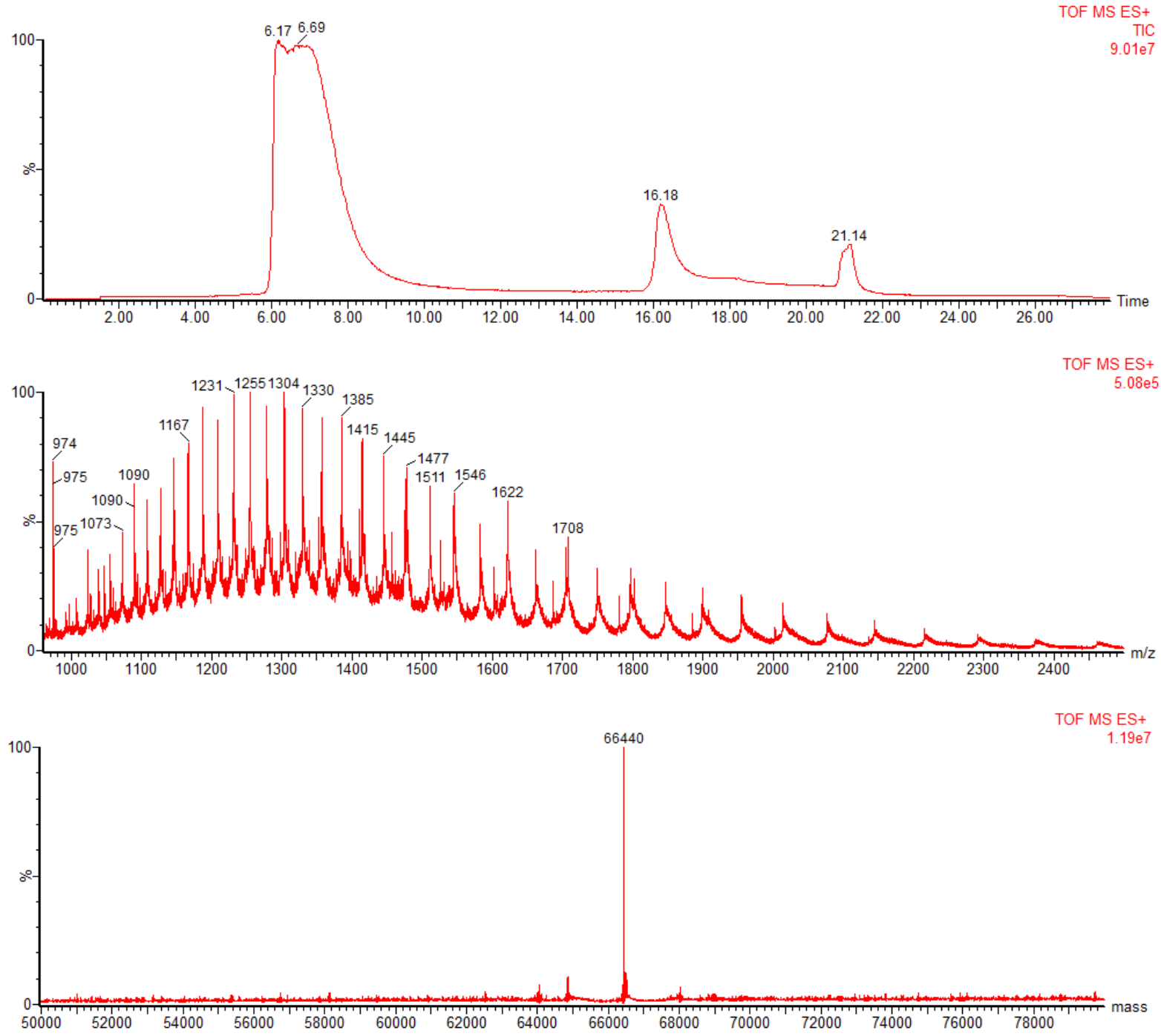

Figura 54 Análise LC-MS para a albumina. 


\subsection{Procedimento para a bioconjugação com Annexina V-Cis316}

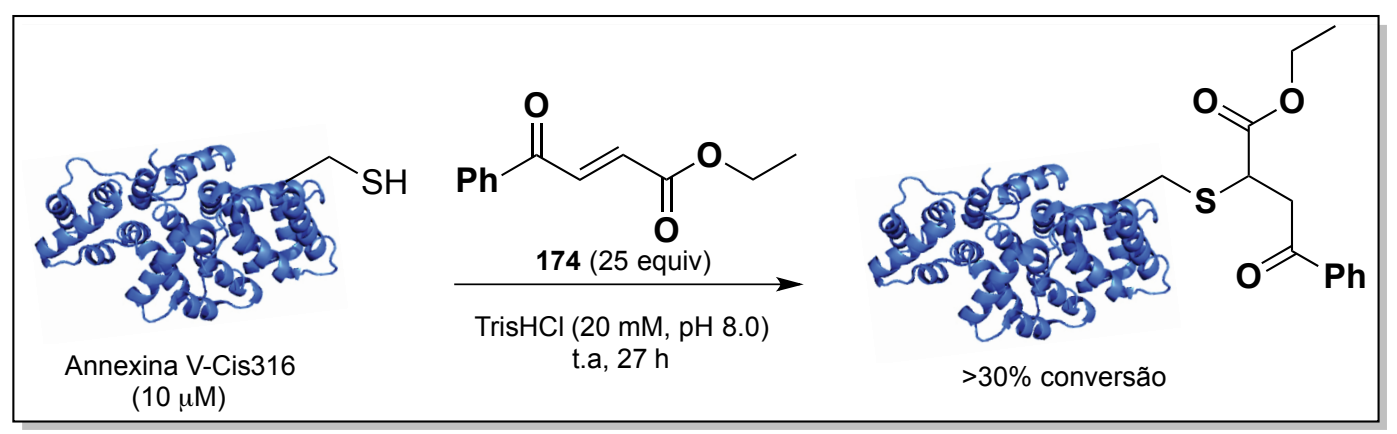

Em um ependorfe contendo $23.17 \mu \mathrm{L}$ de TrisHCl (20 mM, pH 8.0) foi adicionado uma alíquota de $14.40 \mu \mathrm{L}$ de uma solução estoque da Annexina V $(27.80 \mu \mathrm{M}, 400 \mathrm{nmol})$ e a mistura resultante foi agitada em vortex por 30 segundos. Após, uma solução $4.11 \mathrm{mM}$ de 174 (2.42 $\mu \mathrm{L}, 25$ equiv.) em DMF foi adicionada e a reação agitada por $27 \mathrm{~h}$ em temperatura ambiente. Após, uma alíquota de $10 \mu \mathrm{L}$ foi analisada por LC-MS e uma conversão de 50\% foi observada (massa calculada, 36010, massa observada, 36009).

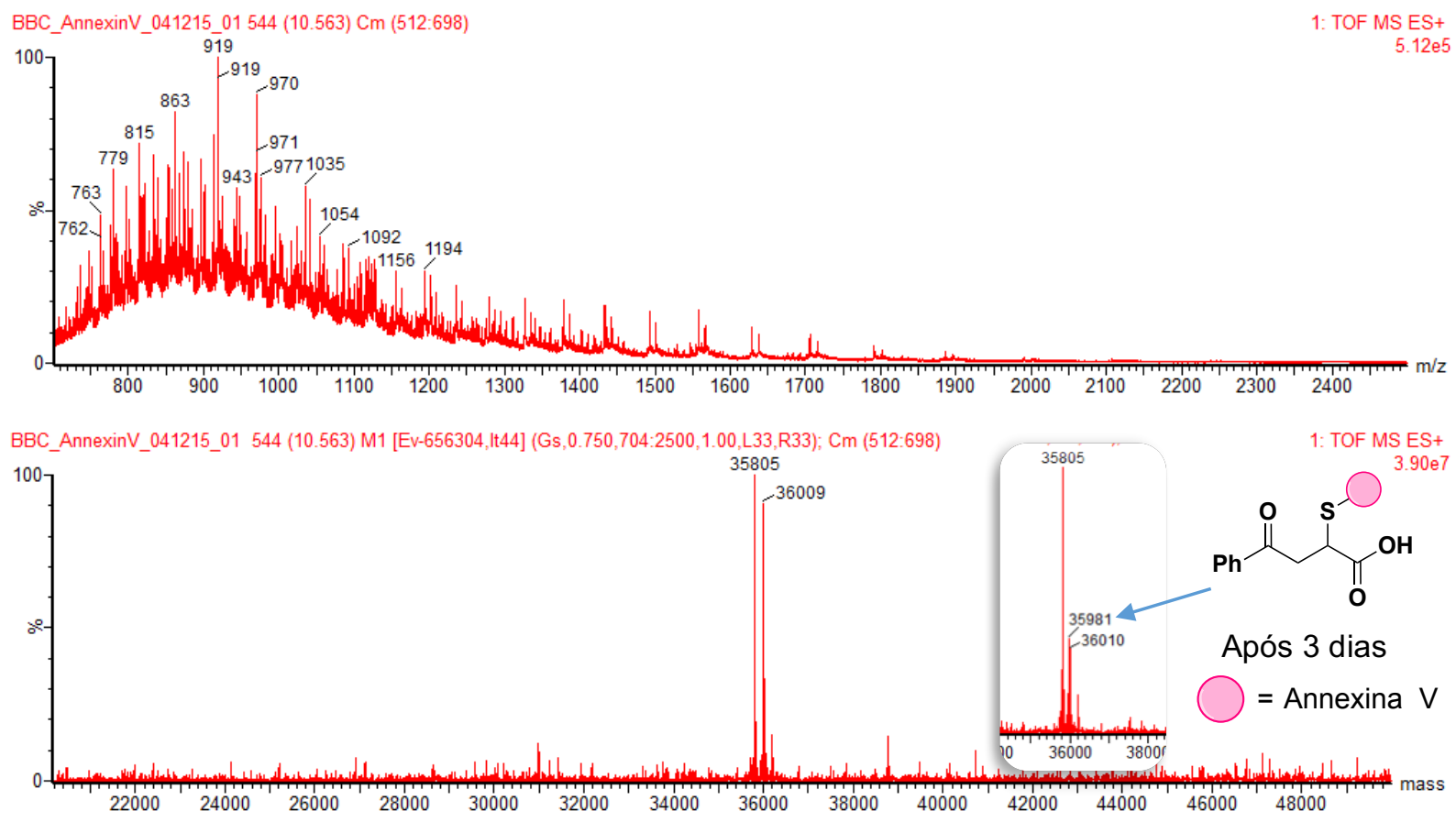

Figura 55 Análise LC-MS da reação entre a Annexina V e 174 após 27 h e 3 dias. 


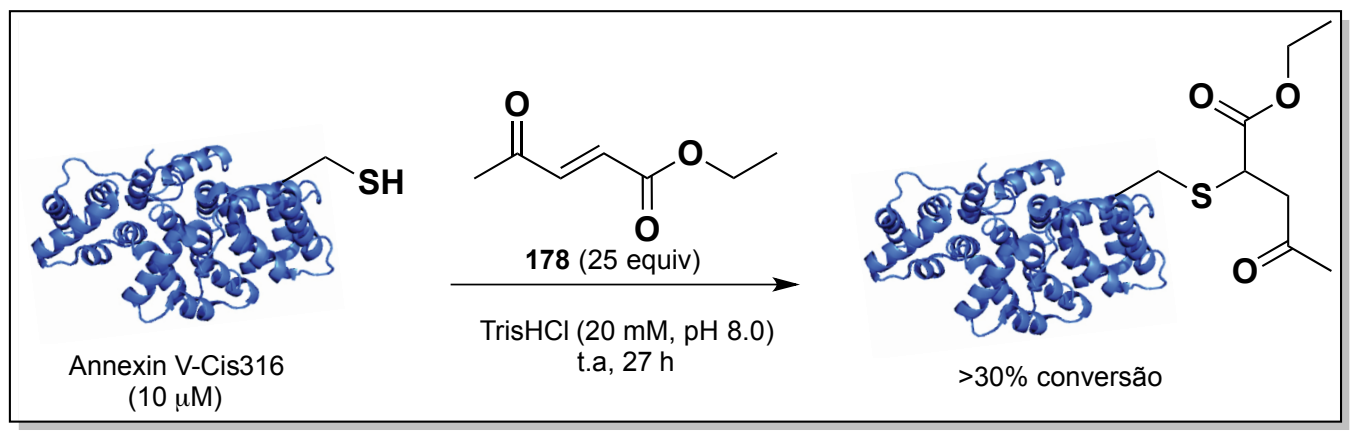

Em um ependorfe contendo $23.17 \mu \mathrm{L}$ de TrisHCl $(20 \mathrm{mM}, \mathrm{pH}$ 8.0) foi adicionado uma alíquota de $14.40 \mu \mathrm{L}$ de uma solução estoque da Annexina $\mathrm{V}(27.80 \mu \mathrm{M}, 400 \mathrm{nmol})$ e a mistura resultante foi agitada em vortex por 30 segundos. Após, uma solução $5.34 \mathrm{mM}$ de 178 (1.87 $\mu \mathrm{L}, 25$ equiv.) em DMF foi adicionada e a reação agitada por $27 \mathrm{~h}$ em temperatura ambiente. Após, uma alíquota de $10 \mu \mathrm{L}$ foi analisada por LC-MS e uma conversão de $30 \%$ foi observada (massa calculada, 35948, massa observada, 35947).
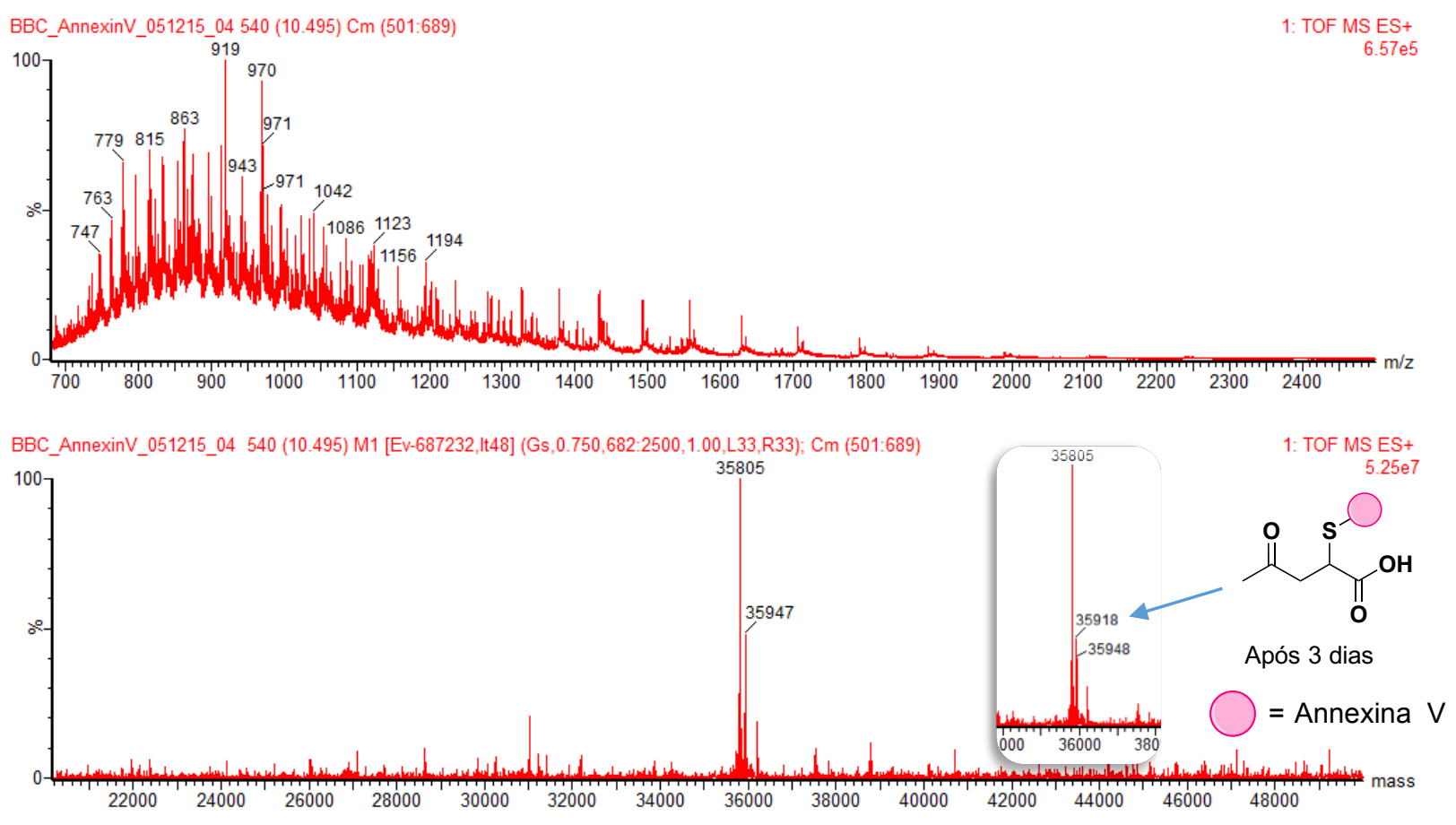

Figura 56 Análise LC-MS da reação entre a Annexina V e 178 após 27 h e 3 dias. 


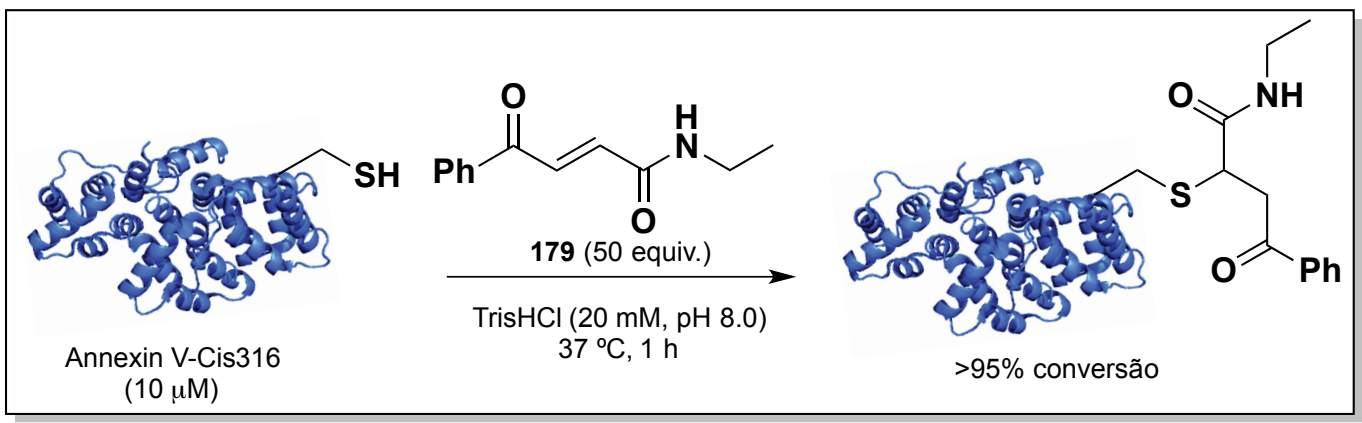

Em um ependorfe contendo $20.26 \mu \mathrm{L}$ de TrisHCl (20 mM, pH 8.0) foi adicionado uma alíquota de $14.40 \mu \mathrm{L}$ de uma solução estoque da Annexina $\mathrm{V}(27.80 \mu \mathrm{M}, 400 \mathrm{nmol})$ e a mistura resultante foi agitada em vortex por 30 segundos. Após, uma solução $3.74 \mathrm{mM}$ de 179 (5.34 $\mu \mathrm{L}, 50$ equiv.) em DMF foi adicionada e a reação agitada por $1 \mathrm{~h}$ em $37^{\circ} \mathrm{C}$. Após, uma alíquota de $10 \mu \mathrm{L}$ foi analisada por LC-MS e uma conversão completa ao produto esperado foi observada (massa calculada, 36009, massa observada, 36006).
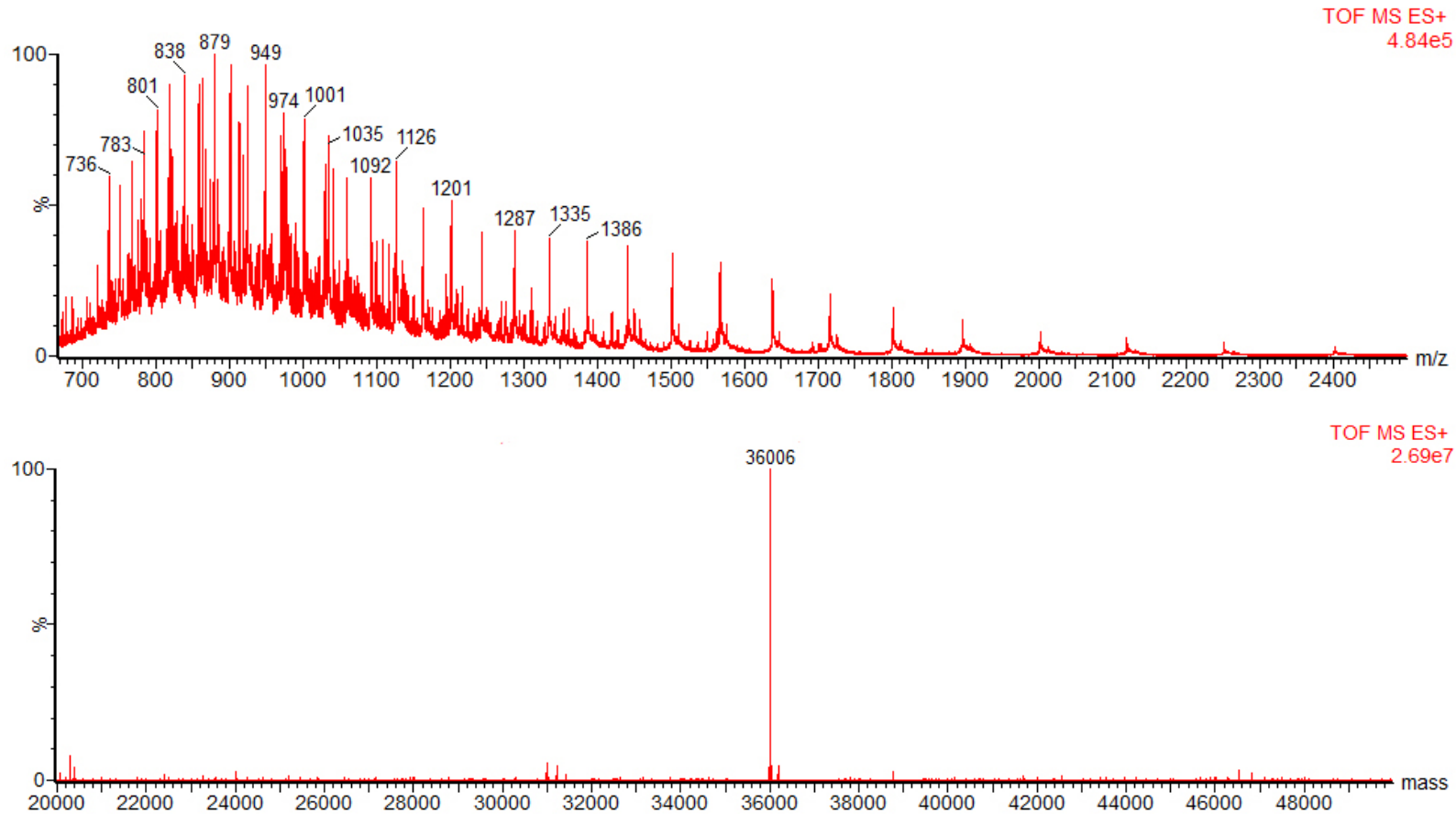

Figura 57 Análise LC-MS da reação entre a Annexina V e 179 após 27 h. 


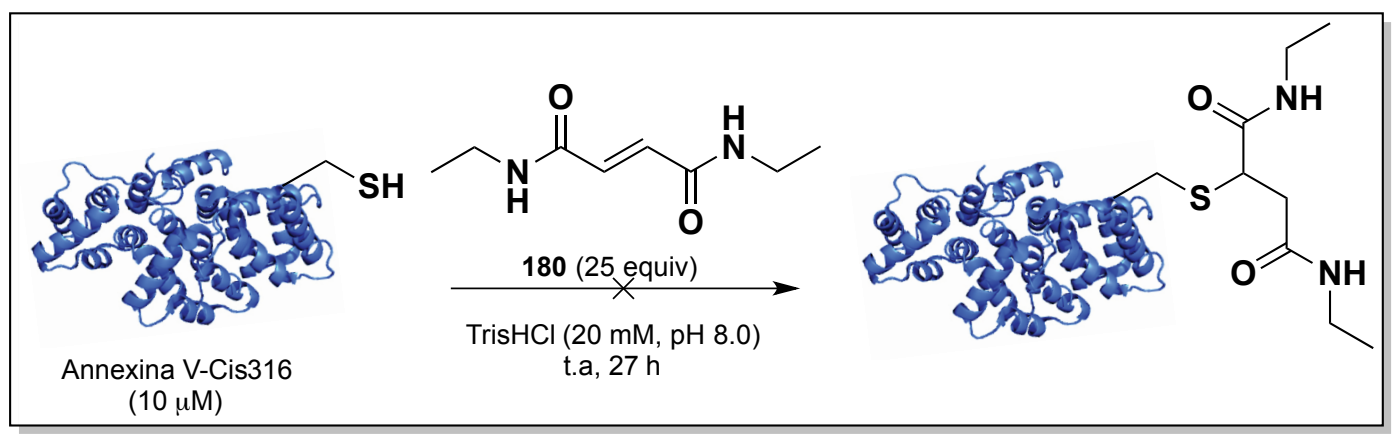

Em um ependorfe contendo $21.73 \mu \mathrm{L}$ de TrisHCl (20 mM, pH 8.0) foi adicionado uma alíquota de $14.40 \mu \mathrm{L}$ de uma solução estoque da Annexina $\mathrm{V}(27.80 \mu \mathrm{M}, 400 \mathrm{nmol}) \mathrm{e}$ a mistura resultante foi agitada em vortex por 30 segundos. Após, uma solução $2.58 \mathrm{mM}$ de 180 (3.87 $\mu \mathrm{L}, 25$ equiv.) em DMF foi adicionada e a reação agitada por $27 \mathrm{~h}$ em temperatura ambiente. Após, uma alíquota de $10 \mu \mathrm{L}$ foi analisada por LC-MS e apenas proteína de partida foi observada (massa calculada, 35805).

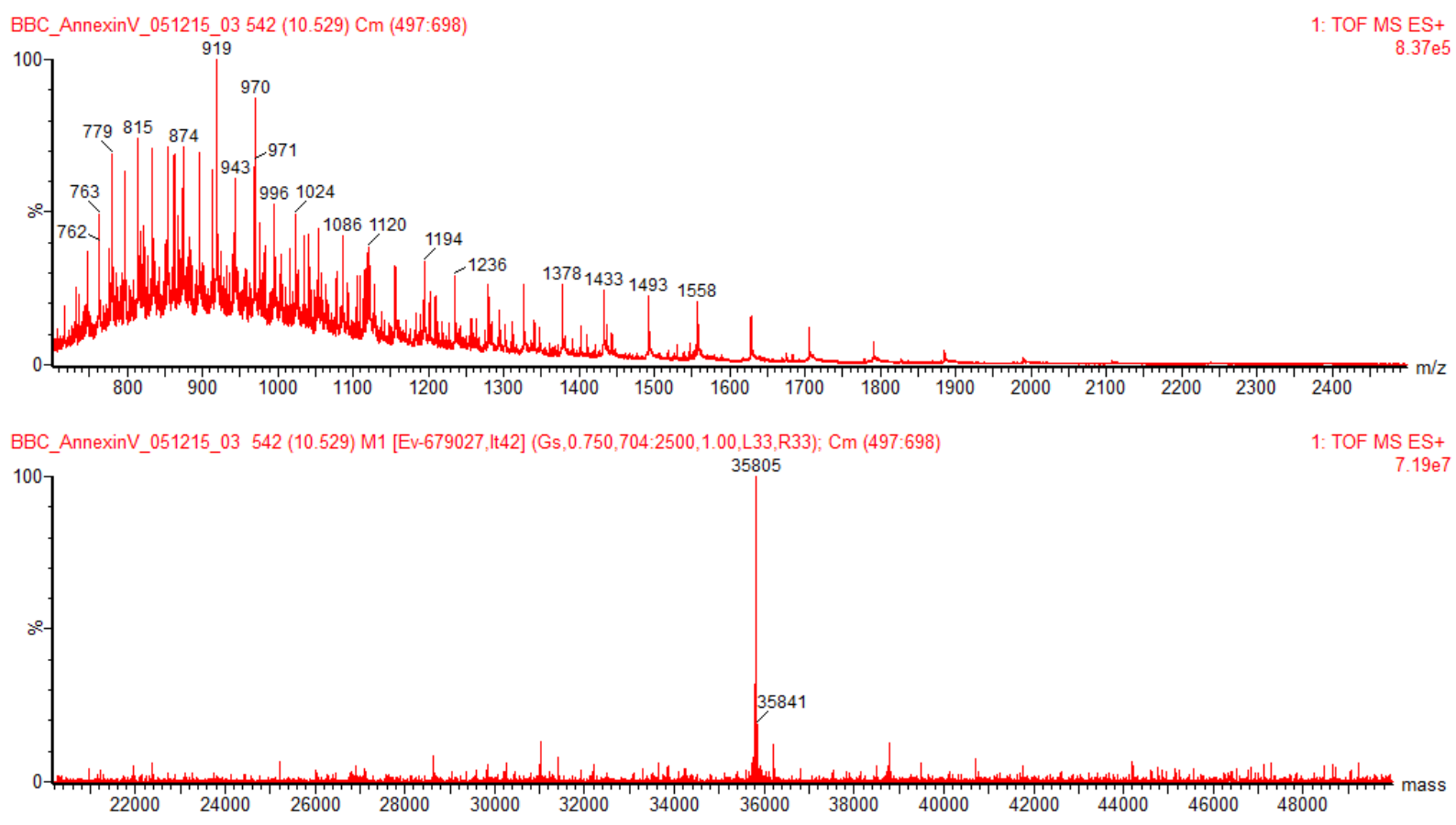

Figura 58 Análise LC-MS da reação entre a Annexina $\vee$ e 174 após 27 h. 


\subsection{Controles químicos}

6.18.1 Reação de Ellman's com Annexina V-Cis316

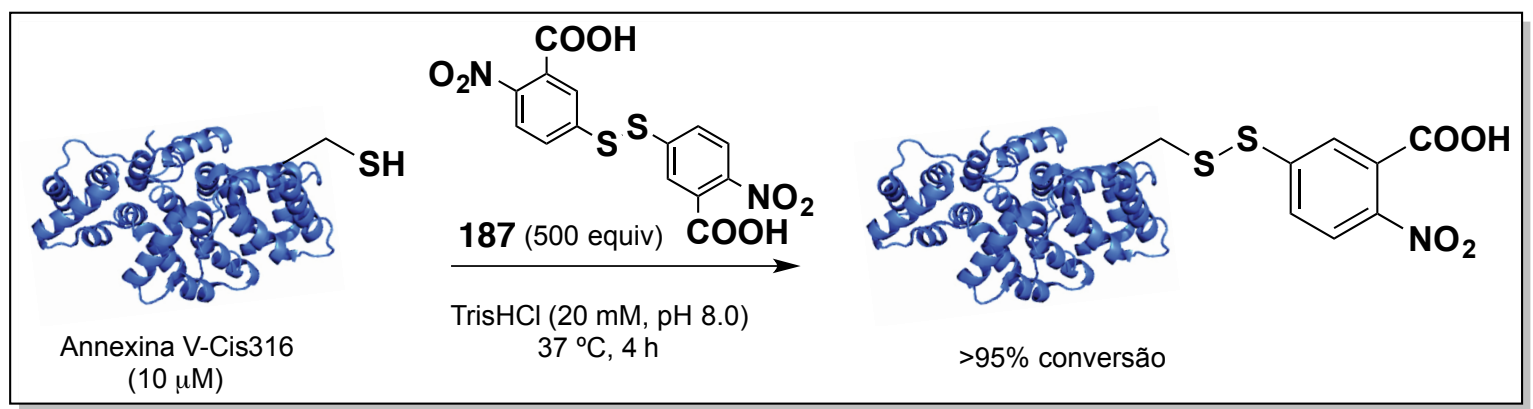

Uma alíquota de $14.4 \mu \mathrm{L}$ da Annexina V-Cis316 (27.8 $\mu \mathrm{M}, 400 \mathrm{nmol})$ em TrisHCl (20 mM, pH 8.0) foi transferida em um tubo ependorfe de $0.5 \mathrm{~mL}$. Uma alíquota de 4 $\mu \mathrm{L}$ do reagente de Ellman's 187 (50.5 mM, 200 umol, 500 equiv.) foi adicionada em temperatura ambiente e a mistura resultante agitada em vortex por 30 segundos. Após $4 \mathrm{~h}$ de agitação adicional em $37^{\circ} \mathrm{C}$, uma alíquota de $10 \mu \mathrm{L}$ foi analisada por LC-MS e uma conversão completa ao produto esperado foi observada (massa calculada, 36003, massa observada 36002). As moléculas de baixo peso molecular foram removidas da reação através de uma filtração em coluna Zeba Spin Desalting previamente equilibrada com TrisHCl (20 mM, pH 8.0). A amostra foi eluída via centrifugação (2 min, $1000 \mathrm{xg}$ ). A amostra foi utilizada na próxima etapa.

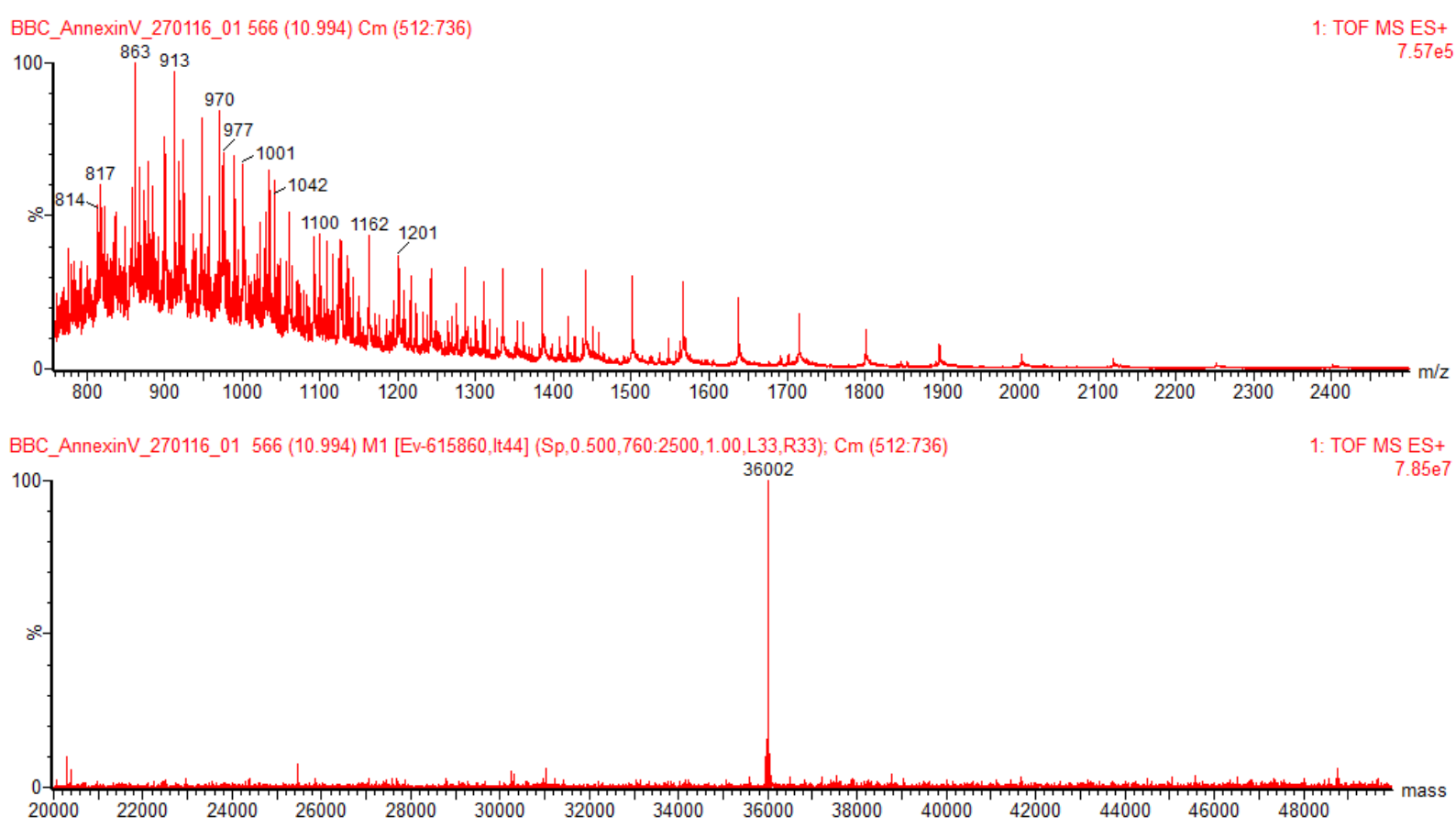

Figura 59 Análise LC-MS da reação entre Annexina V-Cis316 com o reagente de Ellman's 187. 


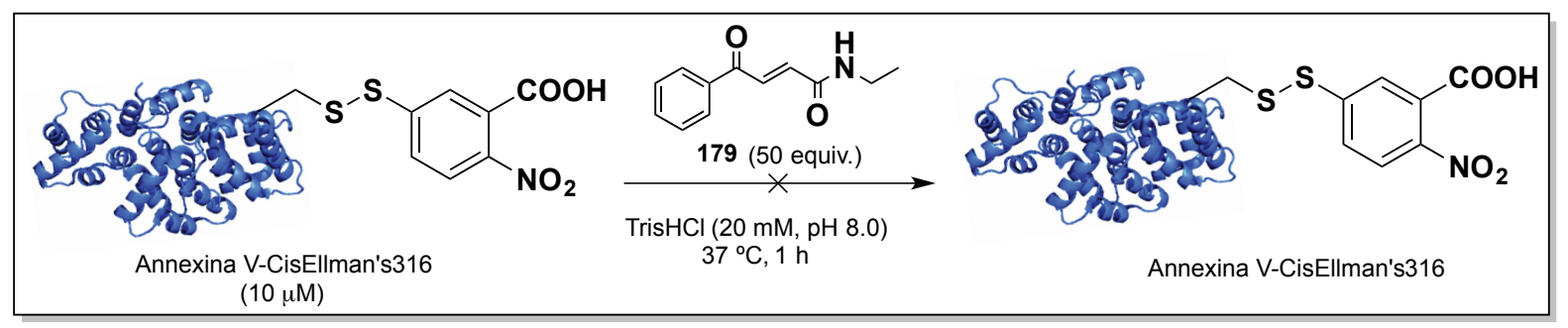

A uma alíquota de $26 \mu \mathrm{L}$ de Annexina V-CisEllman's $316(10 \mu \mathrm{M}, 260 \mathrm{nmol})$ em TrisHCl (20 mM, pH 8.0) foi transferida para um tubo ependorfe de $0.5 \mathrm{~mL}$. Uma alíquota de $4 \mu \mathrm{L}$ do composto 179 (3.72 mM, 50 equiv.) foi adicionada em temperatura ambiente e a mistura resultante agitada em vortex por 30 segundos. Após $1 \mathrm{~h}$ de agitação adicional em $37^{\circ} \mathrm{C}$, uma alíquota de $10 \mu \mathrm{L}$ foi analisada por LC-MS e não foi possível verificar reação. A amostra de proteína foi armazenada em $-20^{\circ} \mathrm{C}$.

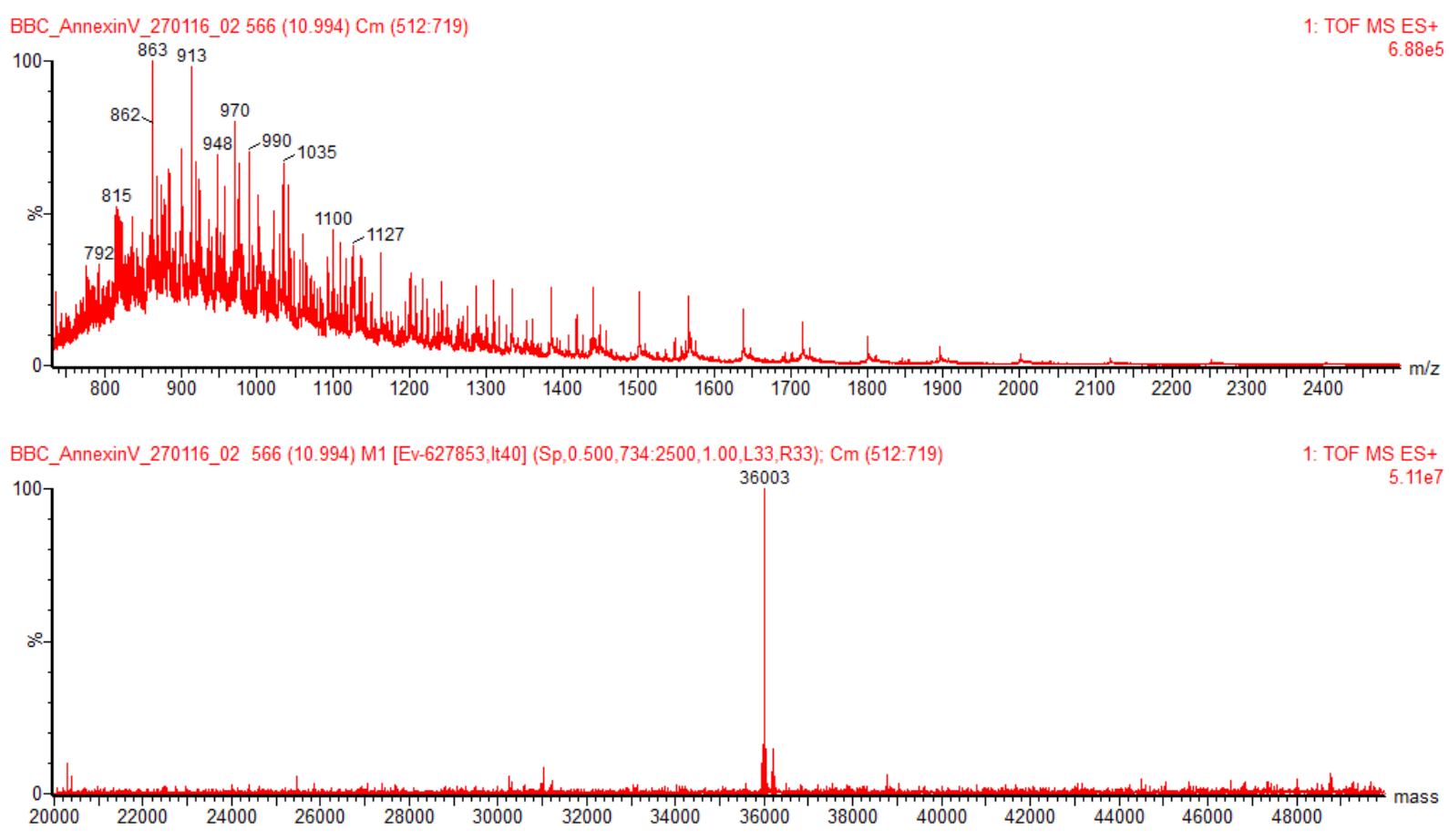

Figura 60 Análise de LC-MS da reação entre Annexina V-CisEllman's 316 com 179. 


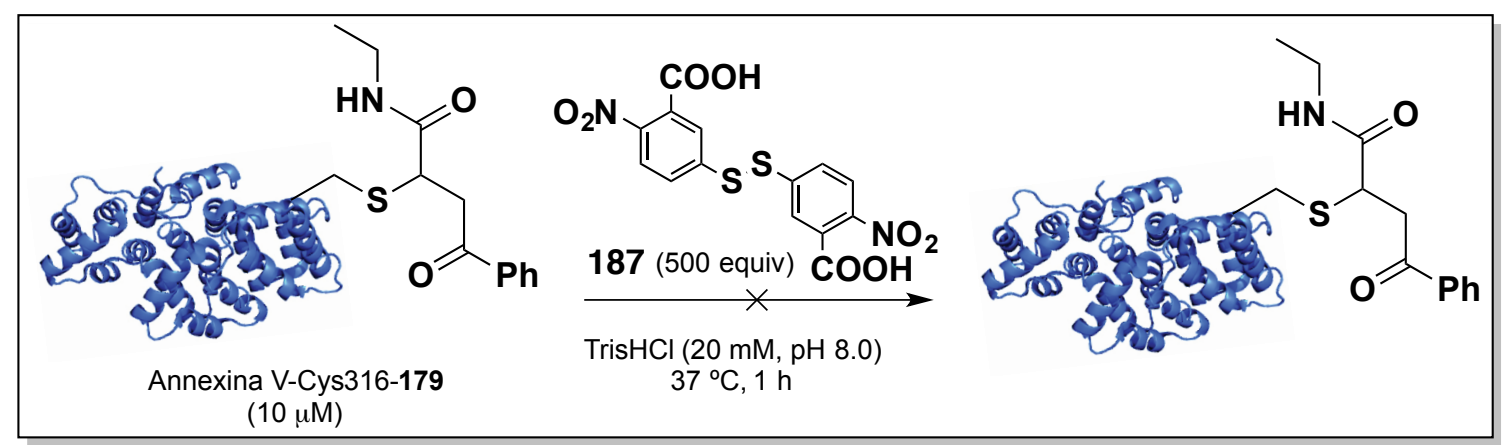

Uma alíquota de $13.5 \mu \mathrm{L}$ do conjugado de Annexina V-179 (10 $\mu \mathrm{M}, 135 \mathrm{nmol})$ em TrisHCl (20 mM, pH 8.0) foi transferido para um tubo ependorfe de $0.5 \mathrm{~mL}$. Uma alíquota de $1.5 \mu \mathrm{L}$ do reagente de Ellman's 187 (50.5 mM, 500 equiv.) foi adicionado em temperatura ambiente e a mistura resultante foi agitada em vortex por 30 segundos. Após $1 \mathrm{~h}$ de agitação adicional em $37^{\circ} \mathrm{C}$, uma alíquota de $10 \mu \mathrm{L}$ foi analisada por LC-MS e nenhuma alteração no espectro foi observada.

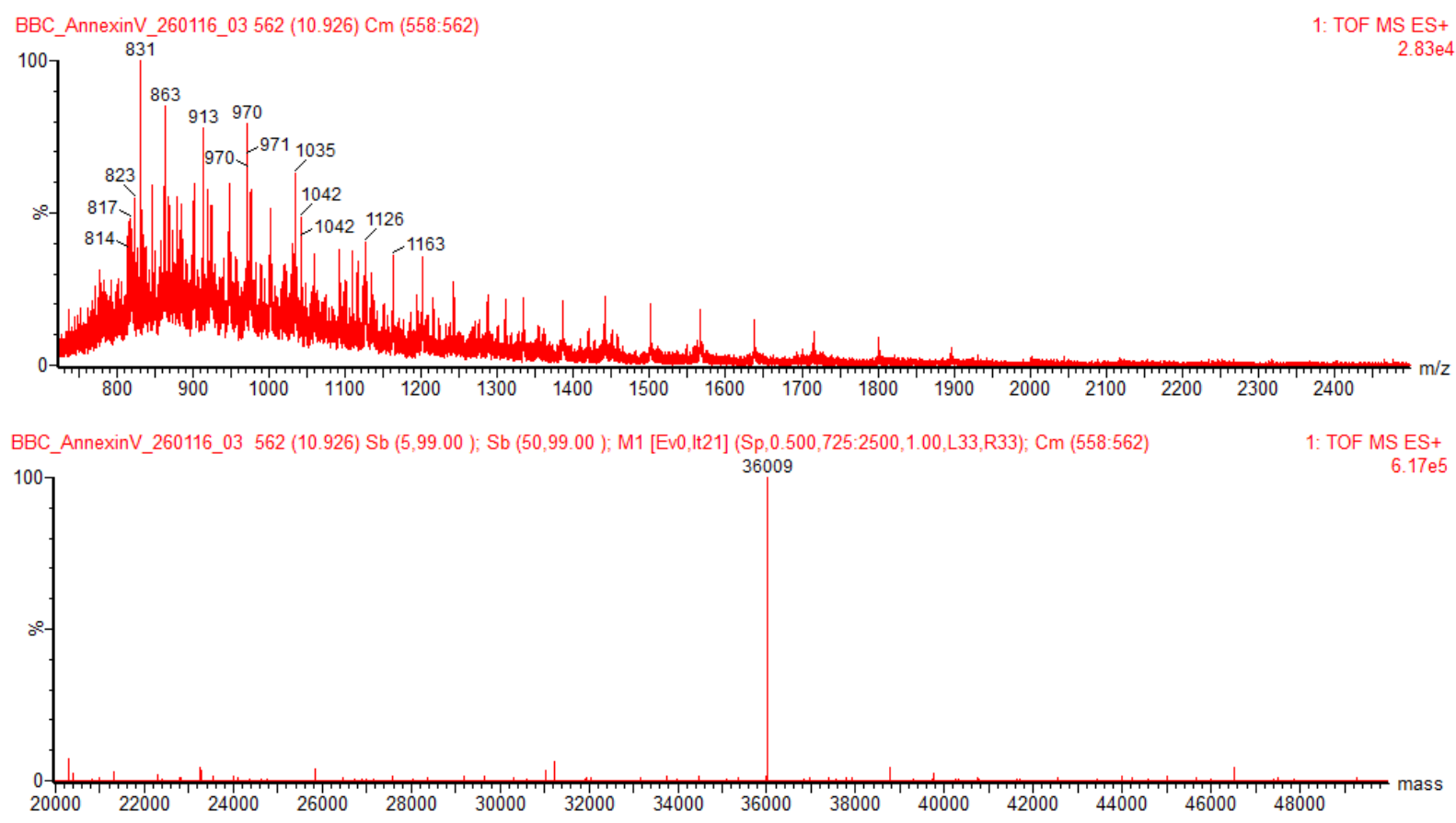

Figura 61 Análise LC-MS da reação entre Annexina V-Cis-179 com o reagente de Ellman's 187. 


\subsection{Procedimento para bioconjugação de C2Am-Cis78}

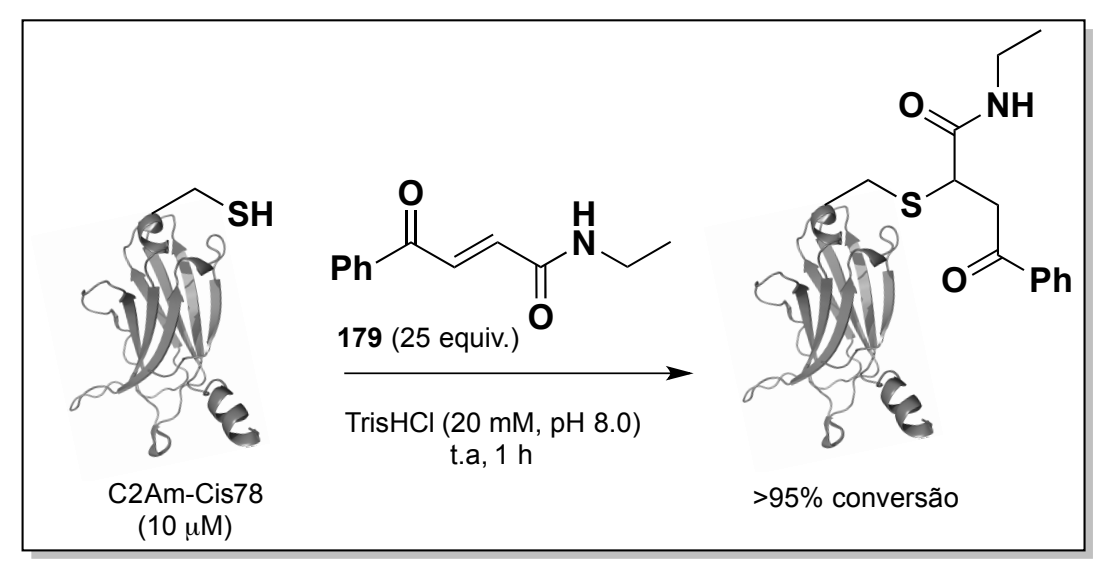

Em uma alíquota de $3.24 \mu \mathrm{L}$ de uma solução estoque da proteína $\mathrm{C}_{2} \mathrm{Am}(61.64 \mu \mathrm{M}$, $200 \mathrm{nmol}$ ) foi adicionada em um ependorfe contendo $15 \mu \mathrm{L}$ de TrisHCl $20 \mathrm{mM}$ em pH 8.0. TCEP (2.0 mmol, 10 equiv., $0.5 \mu \mathrm{L}$ de uma solução $40 \mathrm{mM}$ ) foi então adicionado e a reação agitada por 30 minutos em temperatura ambiente. Após, 25 equivalentes de uma solução de 179 em DMF (1.34 $\mu \mathrm{L}$ de uma solução estoque $3.74 \mathrm{mM})$ foi adicionado e a reação agitada por mais $1 \mathrm{~h}$ em temperatura ambiente. Ao final, uma alíquota de $10 \mu \mathrm{L}$ foi analisada por LC-MS e uma conversão completa ao produto esperado foi observada (massa calculada, 16425; massa observada, 16435).

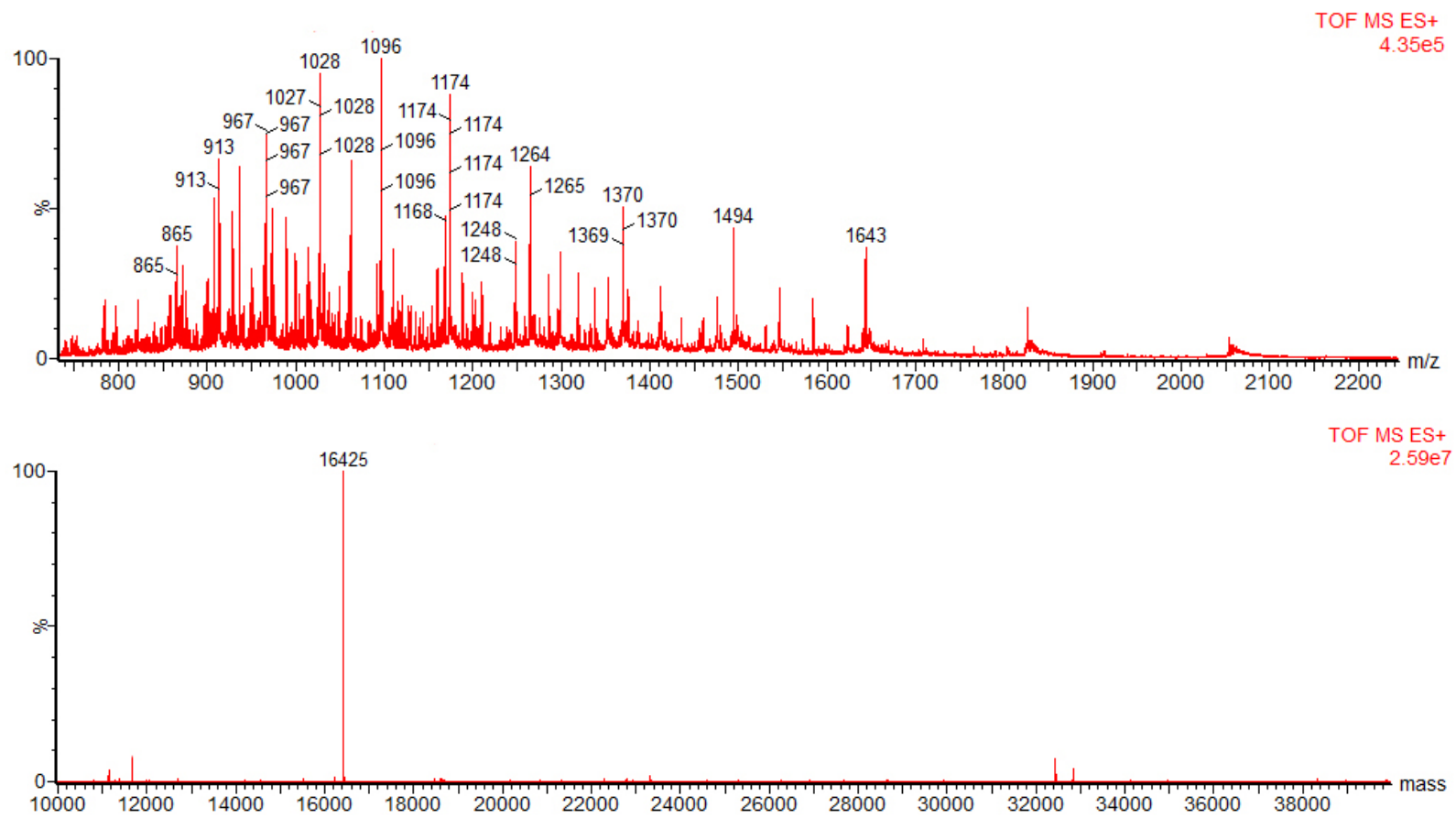

Figura 62 Análise LC-MS da reação da C2Am-Cis-78 com 179. 


\subsection{Análise de MS/MS do conjugado C2Am-179}

A solução de proteína foi reduzida, alquilada e digerida com tripsina durante a noite. Após a digestão, a solução foi pipetada em um vial e colocada em um amostrador automático de uma bomba de LC. Todos os experimentos de LC-MS/MS foram realizados em um sistema nanoUPLC Dionex Ultimate 3000 RSLC (Thermo Fisher Scientific Inc, Waltham, MA, USA) e um espectrômetro de massas QExactive Orbitrap (Thermo Fisher Scientific Inc, Waltham, MA, USA). A separação dos peptídeos foi realizada utilizando cromatografia de fase-reversa em um fluxo de $300 \mathrm{~nL} / \mathrm{min}$ e uma coluna de fase-reversa nano Easy-spray (Thermo Scientific PepMap C18, tamanho de partícula de $2 \mu \mathrm{m}$, tamanho de poro de 100A, $75 \mu \mathrm{m}$ i.d. x $50 \mathrm{~cm}$ de comprimento). Os peptídeos foram injetados em uma pré-coluna (Thermo Scientific PepMap 100 C18, tamanho de partícula de $5 \mu \mathrm{m}$, tamanho de poro de $100 \mathrm{~A}, 300 \mathrm{~nm}$ i.d. $\times 5 \mathrm{~mm}$ de comprimento) de um amostrador automático Ultimate 3000 contendo $0.1 \%$ de ácido fórmico por 3 minutos em um fluxo de $10 \mu \mathrm{L} / \mathrm{min}$. Após este período, a válvula da coluna foi girada para permitir a eluição dos peptídeos a partir da pré-coluna para a coluna analítica utilizando o solvente $\mathrm{A}$ (água $+0.1 \%$ de ácido fórmico) e o solvente B ( $80 \%$ de acetonitrila, $20 \%$ de água e $0.1 \%$ de ácido fórmico) como fase móvel. $O$ gradiente linear empregado foi de $2-40 \%$ de B em 30 minutos. O eluente LC foi desolvatado espectrômetro (Easy-spray, Thermo Fisher Scientific Inc.). Todos os valores de $\mathrm{m} / \mathrm{z}$ dos íons eluentes foram medidos em um analisador de massas do tipo Orbitrap, em uma resolução de 70000. Os dados adquiridos a partir de varredura (Top 20 íons) foram automaticamente isolados e fragmentados através de dissociação por alta energia de colisão (HCD) no analisador de massas do tipo quadrupolo. Os fragmentos resultantes foram medidos no analisador Orbitrap, com resolução de 17500. Íons peptídicos commestados de carga 2+ e acima foram selecionados para fragmentação. Após a corrida, a data foi processada usando Protein Dicoverer (version 1.4., ThermoFisher). Todos os MS/MS foram convertidos para arquivos mgf e os mesmos submetidos para a busca usando algoritmo Mascot (Matrix Science, London UK). Uma database contendo a sequencia da proteína $\mathrm{C}_{2} \mathrm{Am}$ foi utilizada. Uma tolerância de 5 ppm (MS) e $0.1 \mathrm{Da}$ (MS/MS) foi utilizada. A identificação dos peptídeos foi realizada com uma probabilidade maior de que $95 \%$. 


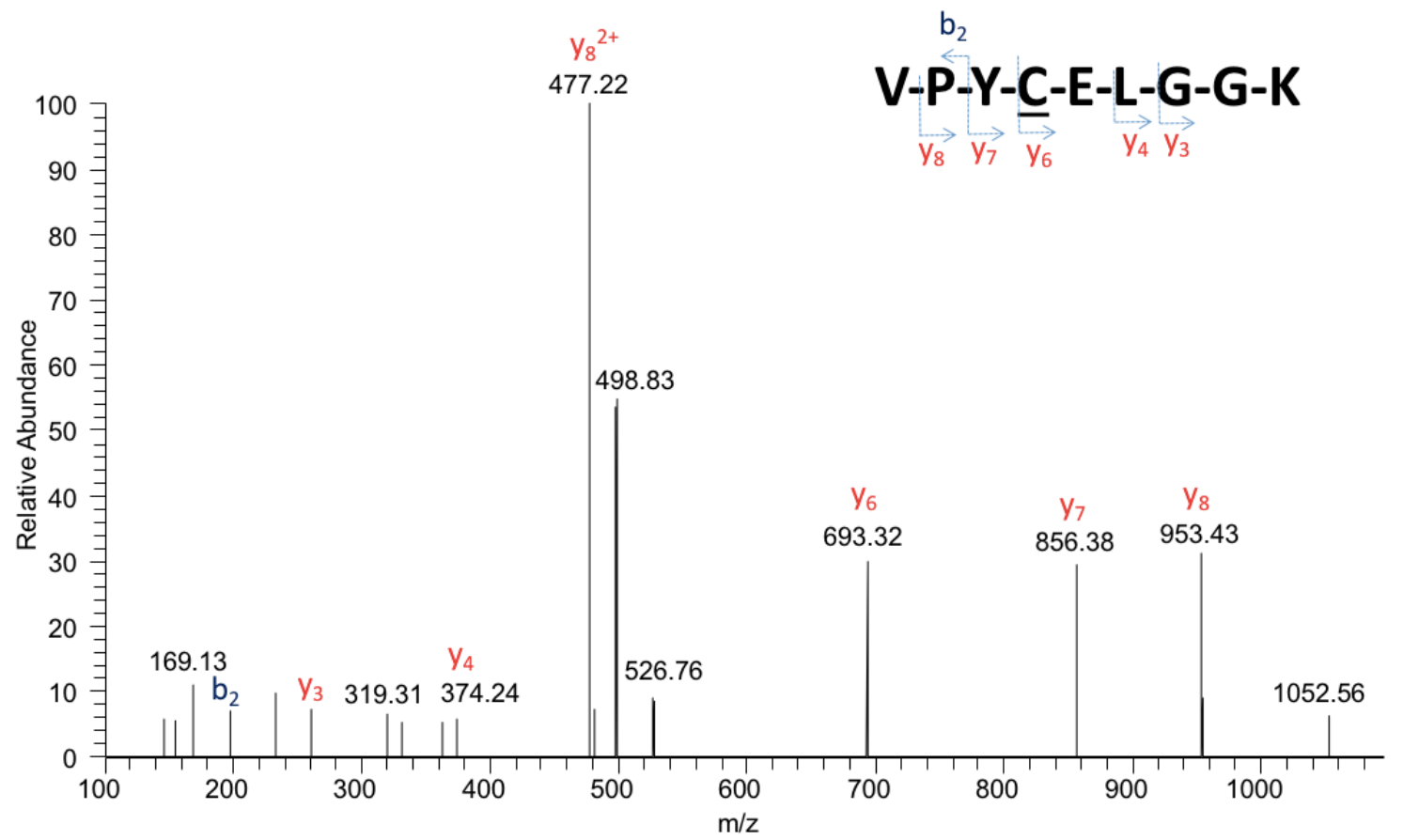

Figura 63 Análise de MSMS para o conjugado C2Am-179. 


\subsection{Procedimento para bioconjugação da Albumina-Cis34}

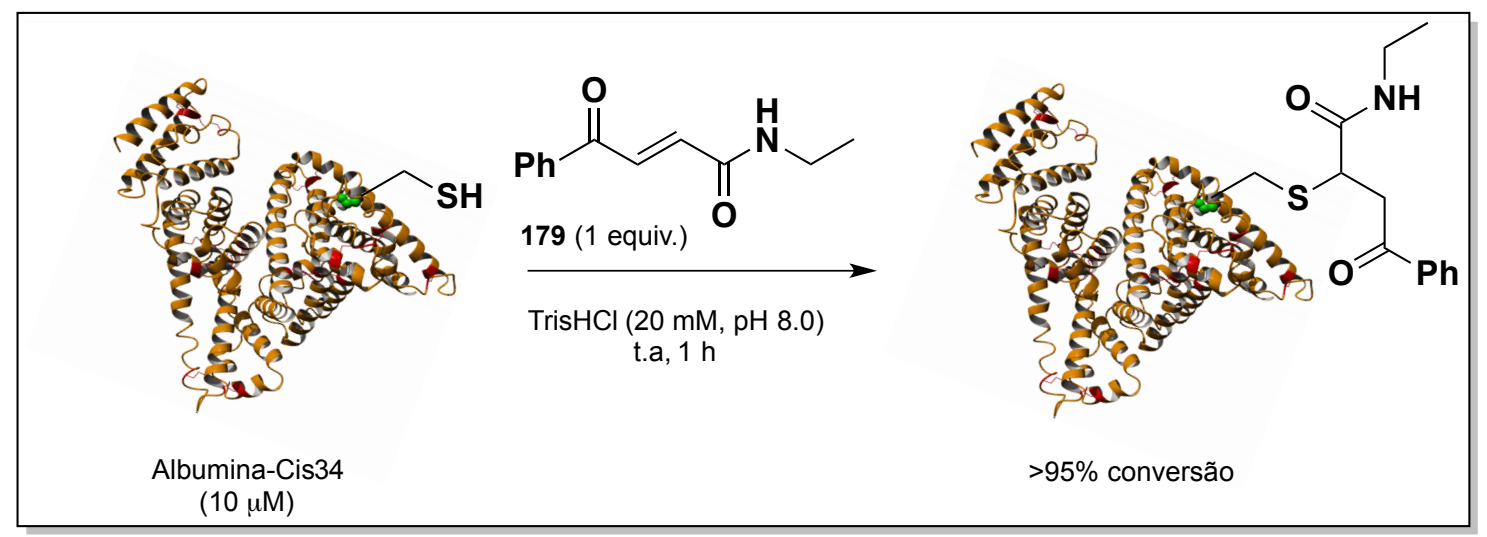

Em um ependorfe contendo $13.40 \mu \mathrm{L}$ de TrisHCl (20 mM, pH 8.0) foi adicionado $26.6 \mu \mathrm{L}$ de uma solução de Albumina (15.05 $\mu \mathrm{M}, 400 \mathrm{nmol})$ e a mistura resultante foi agitada em vortex por 30 segundos. Após, uma solução 3.74 mM de $179(0.10 \mu \mathrm{L}$, 1 equiv.) em DMF foi adicionada e a reação agitada por $2 \mathrm{~h}$ em temperatura ambiente. Ao final, uma alíquota de $10 \mu \mathrm{L}$ foi analisada por LC-MS e uma conversão total ao produto esperado foi observada (massa calculada, 66644; massa observada, 66641).

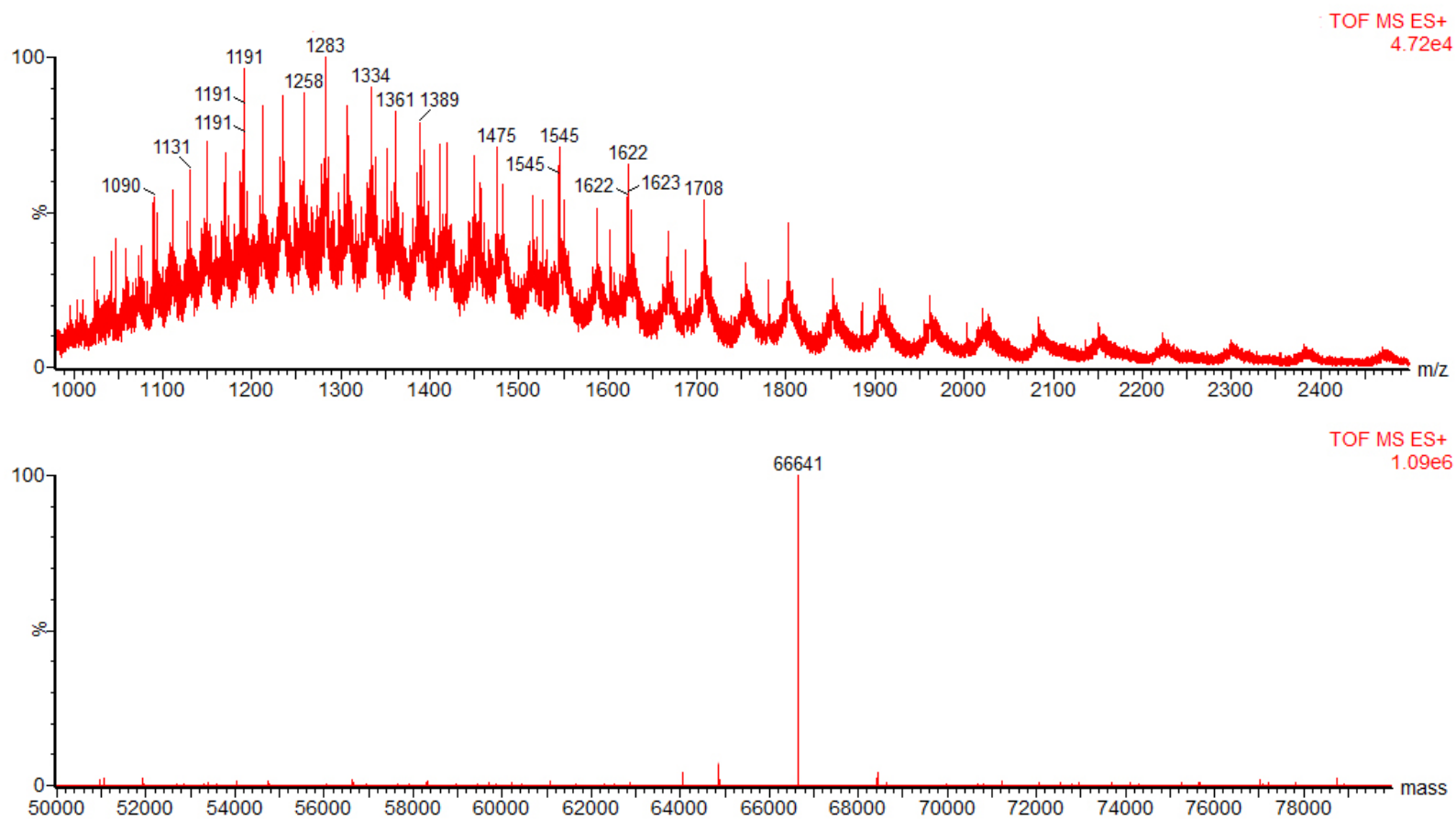

Figura 64 Análise LC-MS da reação da albumina com 179. 


\subsection{Estabilidade do conjugado albimina em plasma}

Uma alíquota de $20 \mu \mathrm{L}$ do conjugado albumina com $179(10 \mu \mathrm{M})$ em TrisHCl $(20 \mathrm{mM}$, $\mathrm{pH}$ 8.0) foi tratada com $2 \mu \mathrm{L}$ de plasma humano reconstituído (Sigma Aldrich) em temperatura ambiente e a mistura resultante agitada em vortex por 30 segundos. A mistura resultante foi então agitada em $37^{\circ} \mathrm{C}$ durante a noite. Após 1 e $24 \mathrm{~h}$, uma alíquota de $5 \mu \mathrm{L}$ de cada reação foi analisada por LC-MS (alíquota de $5 \mu \mathrm{L}$ diluída com $5 \mu \mathrm{L}$ de uma solução tampão TrisHCl $20 \mathrm{mM}$ em pH 8.0). Não foi detectada degradação do aduto. Um resultado similar foi encontrado quando o conjugado albumina foi incubado na presença de GSH (10 mM).

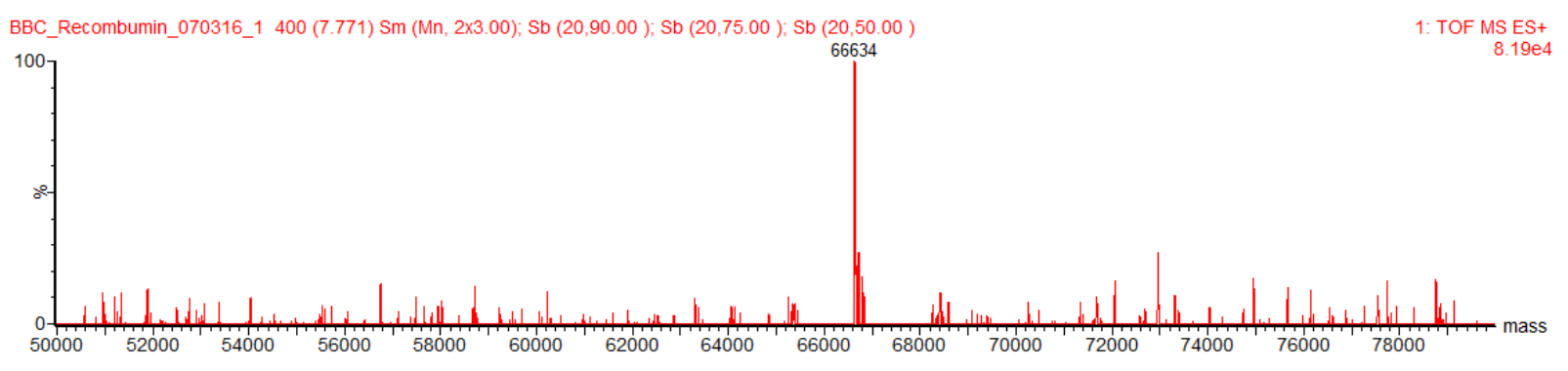

Figura 65 Estabilidade do conjugado de albumina-179 em plasma humano. 


\subsection{Afinidade de ligação da albumina-179 com o receptor FcRn}

\subsubsection{Resumo de Imobilização}

Instrumento: $\quad$ Biacore 3000

Chip: $\quad$ CM5

Tampão de corrida: $\quad$ HBS-EP (GE Healthcare)

Ligante:

shFcRn (BSP biotina) $760 \mu \mathrm{g} / \mathrm{mL}$ diluído para $10 \mu \mathrm{g} / \mathrm{mL}$

Tampão de diluição: $\quad$ tampão de Acetato de Sódio em pH 4.5 (GE Healthcare)

Método de acoplamento: EDC/NHS (acoplamento de amina)

Tampão de lavagem: $1 \mathrm{M}$ Etanolamina (GE Healthcare)

Caminho de fluxo: $\quad$ FC2

Nível de ligante: $\quad$ 1362RU

\subsubsection{Método de Immobilização}

A imobilização foi realizada utilizando um kit para acoplamento de aminas utilizando as instruções do fabricante (GE Heathcare). A proteína foi covalentemente ligada a superfície de um chip CM5 ativado com N-Hidróxisuccinimida/N-etil-N'-(-3dimetilamino-propil) carbodiimida (NHS/EDC diluído em 1:1), em uma taxa de fluxo de $5 \mu \mathrm{L} / \mathrm{min}$. A superfície de célula de referência foi ativada com NHS:EDC e desativada com etanolamina para controle negativo de ligação. A superfície do chip foi estabilizada pela passagem de um fluxo constante de tampão de corrida ( $5 \mu \mathrm{L} / \mathrm{min})$ HBS-EP (0.01 M HEPES, 3 mM EDTA, $0.15 \mathrm{M} \mathrm{NaCl}, 0.005 \%$ surfactante P20) em $\mathrm{pH} 7.4$ (GE Healthcare) e temperatura de $25^{\circ} \mathrm{C}$ por $\sim 2$ horas ou durante a noite. 


\subsubsection{Método de análise de ligação em pH 5.5}

A albumina foi diluída para $10 \mu \mathrm{M}$ (em tampão de corrida - $67 \mathrm{mM}$ fostato, $0.15 \mathrm{M}$ $\mathrm{NaCl}, 0.005 \%$ Tween 20 pH 5.5) e passada pelo receptor imobilizado shFcRn, em um fluxo contínuo (30 $\mu \mathrm{L} / \mathrm{min}$ ) por 1 minuto com intervalos de 2.5 minutos após a lavagem (com a solução de tampão de lavagem). A regeneração utilizando a solução de tampão HBS-EP em pH 7.4 por 12 segundos reestabeleceu a linha de base entre as injeções. Os sensogramas para os dados de ligação foram obtidos utilizando um software BIAevaluation 4.1 (BIAcore $A B$ ).

\subsubsection{Método para análise de cinética}

As albuminas foram diluídas (1:1) e fluídas no receptor shFcRN imobilizado para obter os dados cinéticos e confirmar os valores de $K_{D}$. A taxa de fluxo foi de $30 \mu \mathrm{L} / \mathrm{min}$ e o tempo de injeção foi de $60 \mathrm{~s}$ com um delay de $60 \mathrm{~s}$ antes da lavagem. Os parâmetros cinéticos foram extrapolados usando BIAevaluation 1:1 Langmuir model (BIAcore AB).

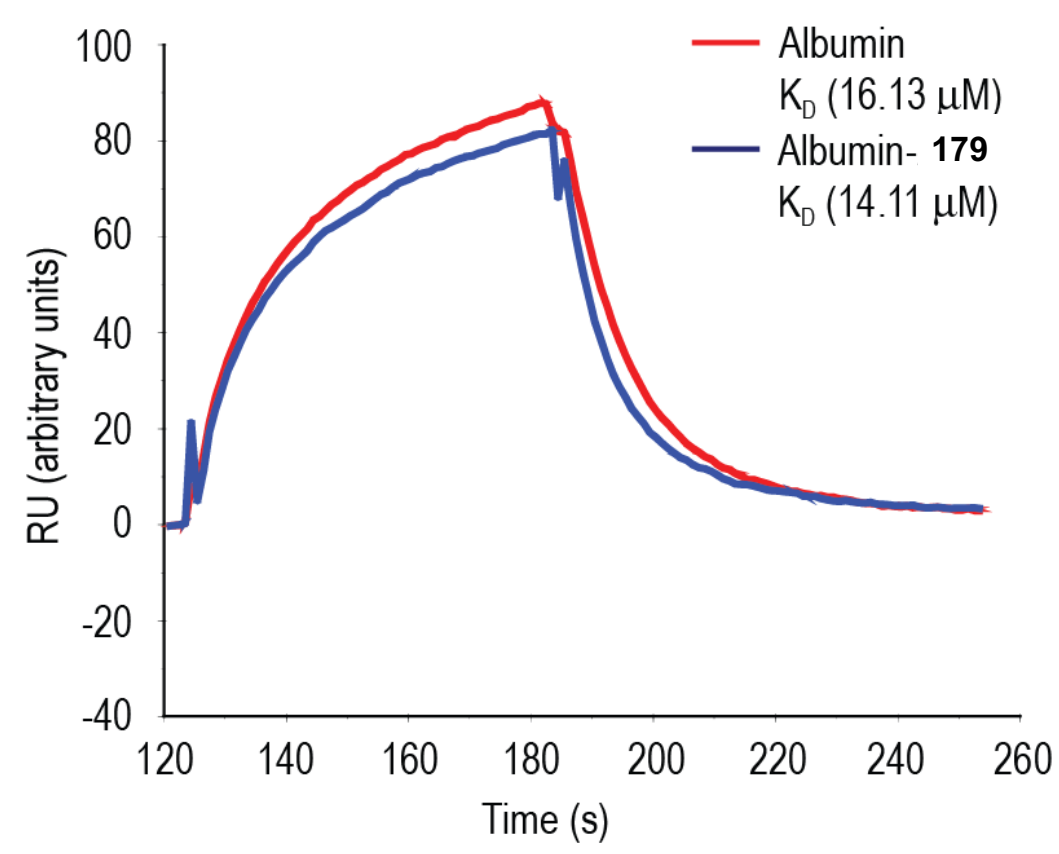

Figura 66 Experimento de SPR mostrando a afinidade de ligação da albumina não modificada e albumina-179 com o receptor FcRn. 


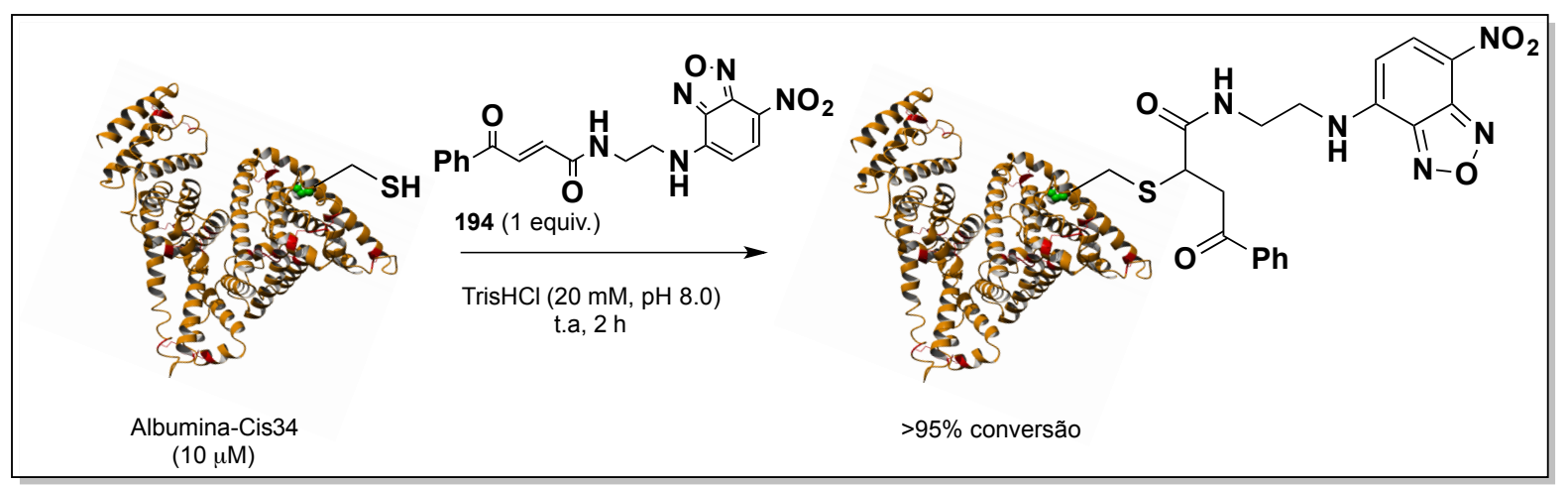

Em um ependorfe contendo $49.43 \mu \mathrm{L}$ de tampão TrisHCl (20 mM, pH 8.0) foi adicionado uma alíquota de $0.33 \mu \mathrm{L}$ de uma solução estoque de albumina (1505 $\mu \mathrm{M}$, $500 \mathrm{nmol}$ ) e a mistura resultante foi agitada em vortex por 30 segundos. Após, uma solução $4.19 \mathrm{mM}$ do composto $194(0.12 \mu \mathrm{L}$, 1 equiv.) em DMF foi adicionada e a reação agitada por $2 \mathrm{~h}$ em temperatura ambiente. Ao final, uma alíquota de $10 \mu \mathrm{L}$ foi analisada por LC-MS e uma conversão completa ao produto esperado foi observado (massa calculada, 66822; massa observada, 66821).

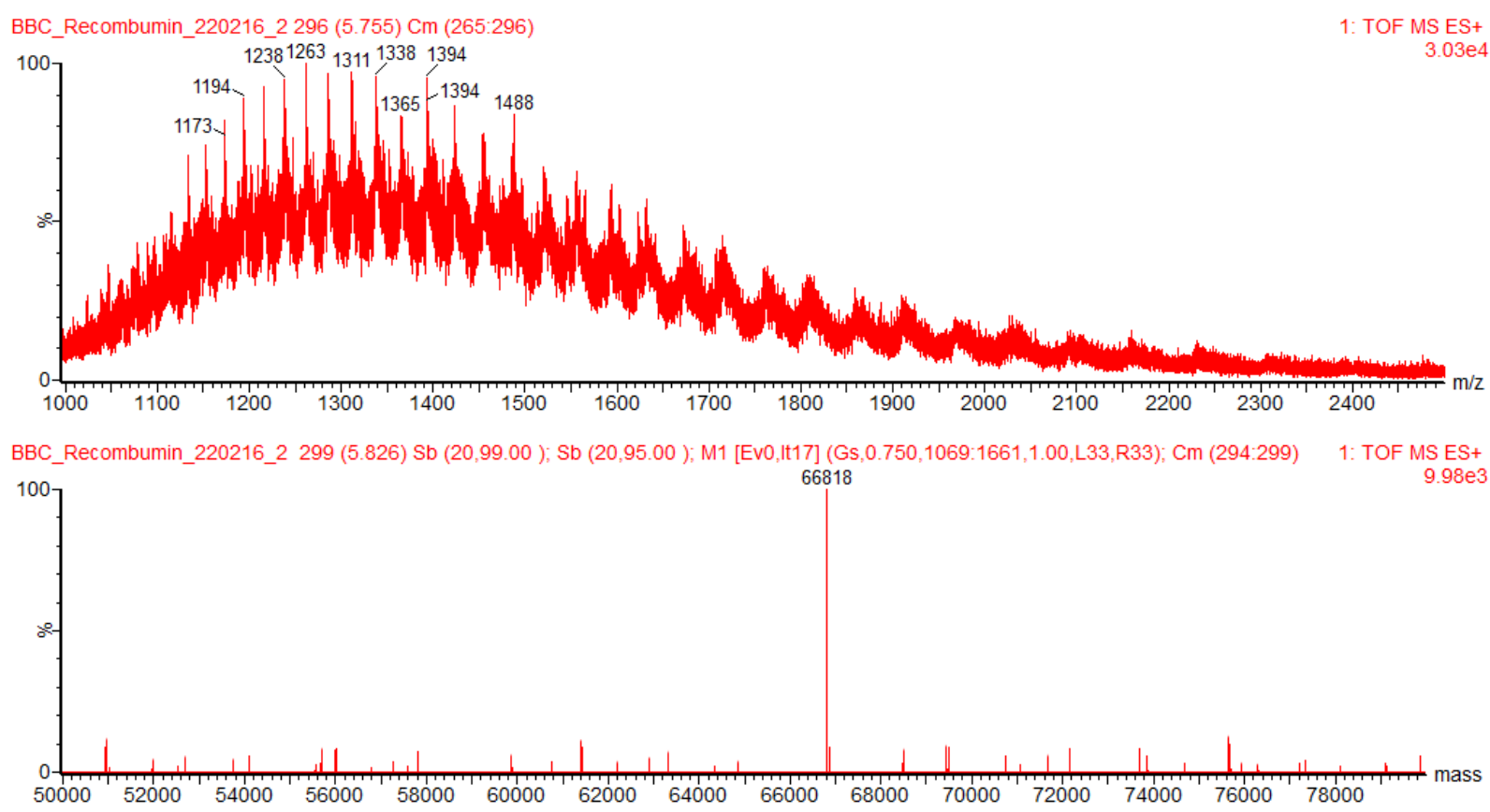

Figura 67 Reação da albumina com o fluorescente 194. 


\subsection{Reação de bioconjugação entre albumina e o reagente PEG 195}

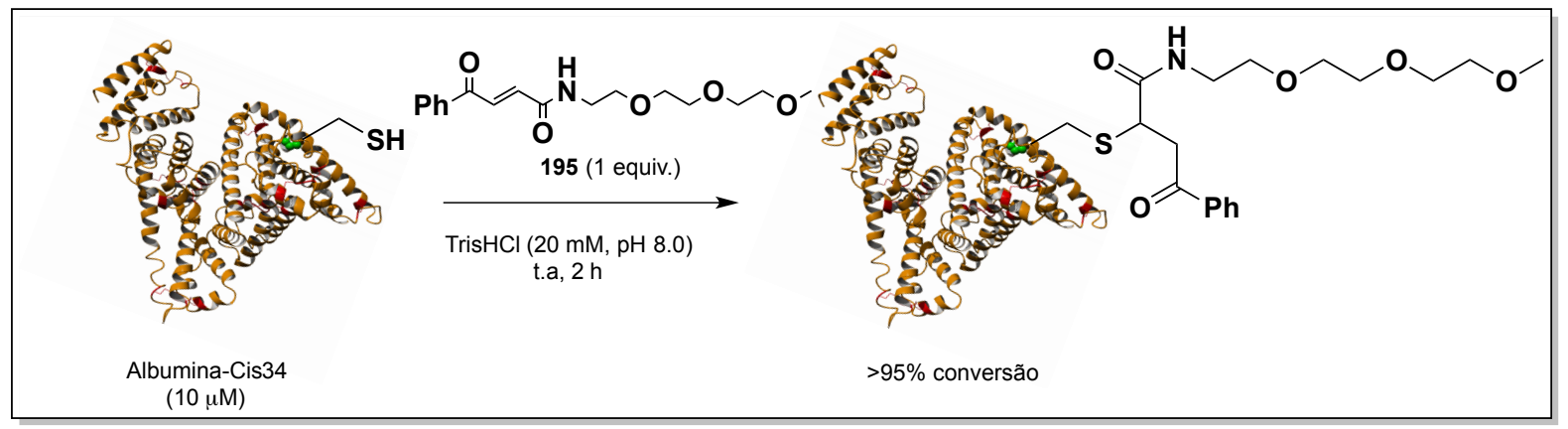

Em um ependorfe contento $13.18 \mu \mathrm{L}$ de tampão TrisHCl (20 mM, pH 8.0) foi adicionado $26.57 \mu \mathrm{L}$ de uma solução estoque de albumina (15.05 $\mu \mathrm{L}, 400 \mathrm{nmol})$ e a mistura resultante agitada em vortex por 30 segundos. Após, $2.74 \mu \mathrm{L}$ de uma solução estoque em DMF do composto 195 (0.13 $\mu \mathrm{L}, 1$ equiv.) foi adicionada e a mistura reacional agitada por $2 \mathrm{~h}$ em temperatura ambiente. No final, uma alíquota de $10 \mu \mathrm{L}$ foi analisada por LC-MS e uma conversão total ao produto esperado foi observada (massa calculada, 66762; massa observada, 66760).

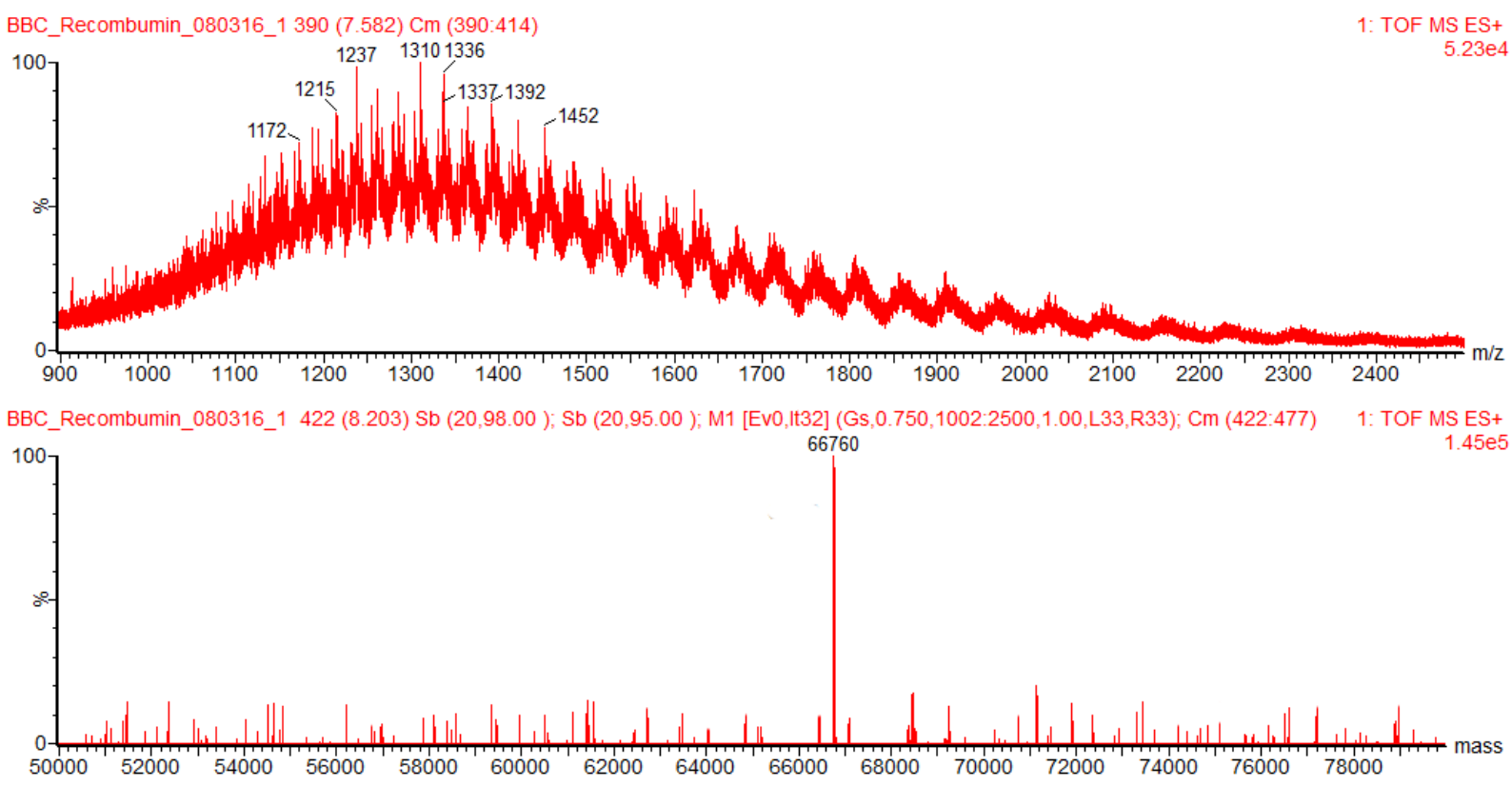

Figura 68 Reação da albumina com o reagente PEG-195. 


\subsection{Reação de bioconjugação entre C2Am e o reagente fluorescente 194}

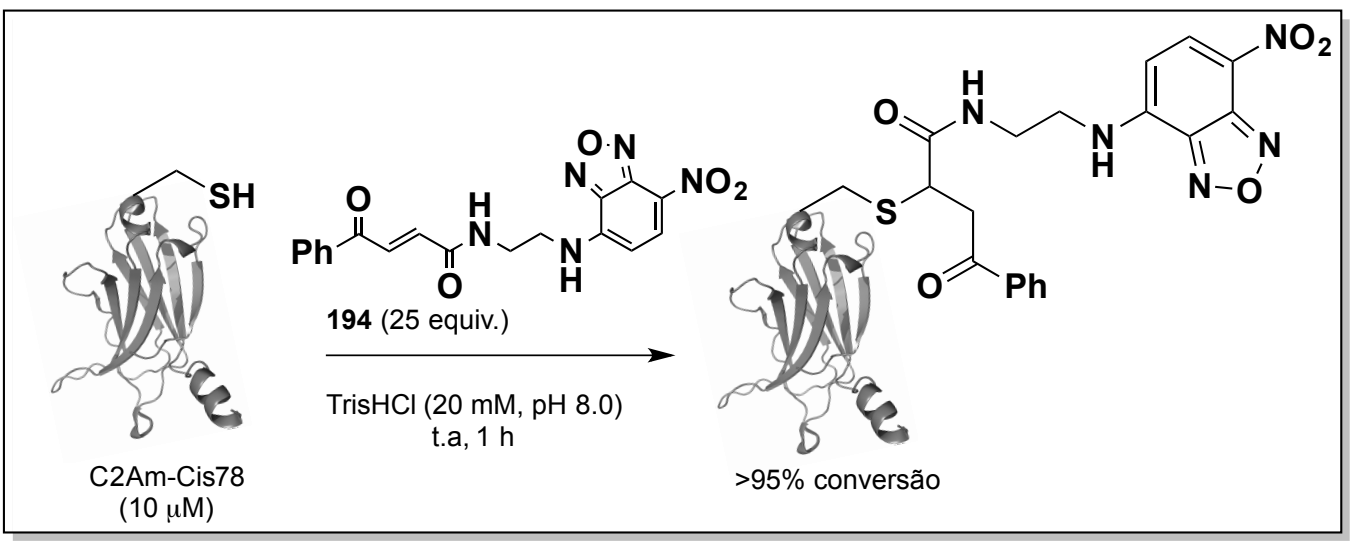

Uma alíquota de $6.49 \mu \mathrm{L}$ de uma solução estoque de $\mathrm{C}_{2} \mathrm{Am}(61.64 \mu \mathrm{M}, 400 \mathrm{nmol})$ foi adicionada a um ependorfe contendo $26.10 \mu \mathrm{L}$ de tampão TrisHCl (20 mM, pH 8.0). TCEP (20.0 mmol, 50 equiv., $5 \mu \mathrm{L}$ de uma solução $40 \mathrm{mM}$ ) foi adicionada e a reação agitada em vortex por $1 \mathrm{~h}$ em temperatura ambiente. Após, 25 equivalentes de uma solução de 194 em DMF (2.88 $\mu \mathrm{L}$ de uma solução estoque de $4.19 \mathrm{mM}$ ) foi adicionada e a reação agitada por $1 \mathrm{~h}$ em temperatura ambiente. No final, uma alíquota de $10 \mu \mathrm{L}$ foi analisada por LC-MS e uma conversão total ao produto esperado foi observada (massa calculada, 16603; massa observada, 16603).
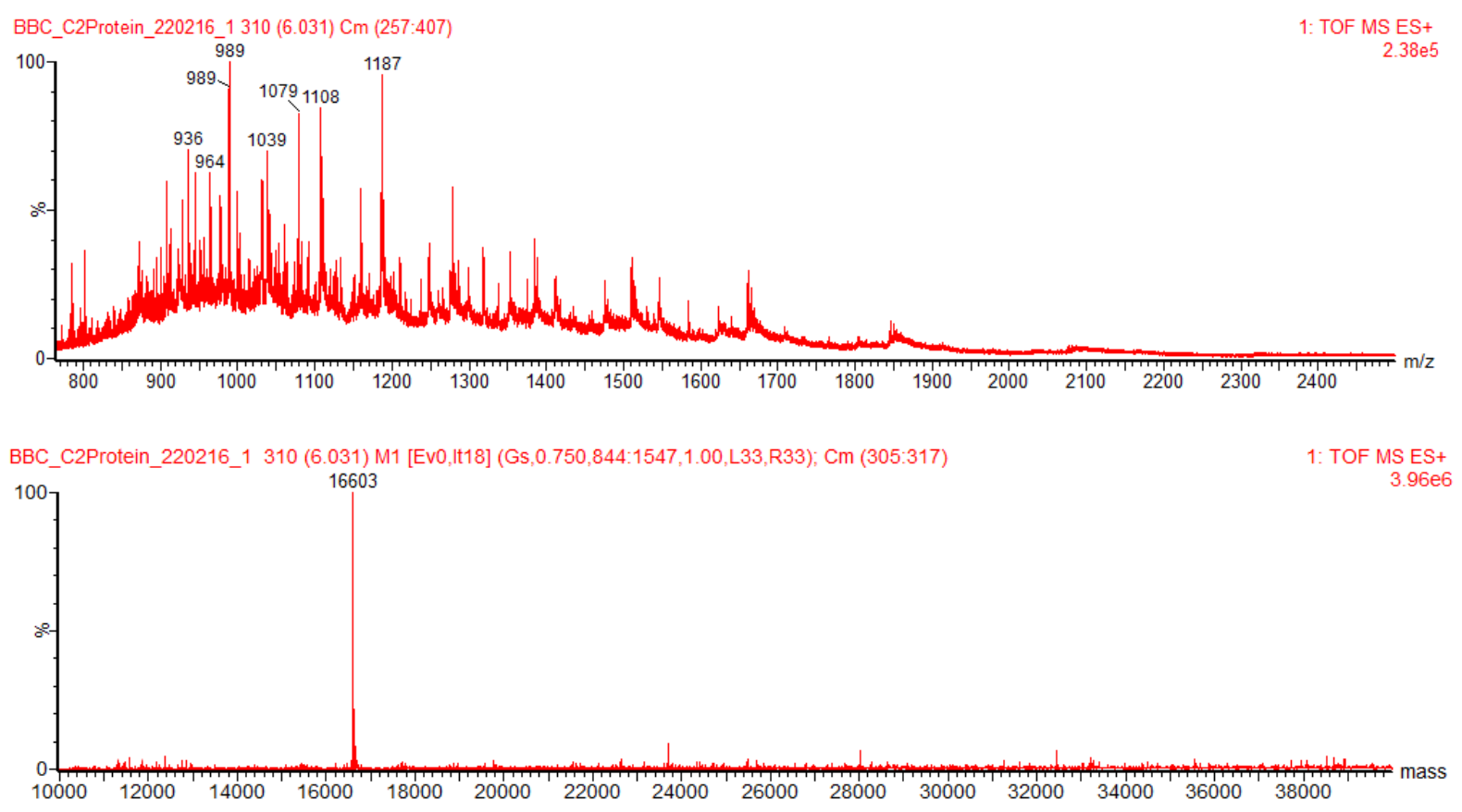

Figura 69 Reação da C2Am com o fluorescente 194. 


\subsection{Bioconjugação da AnnexinA V-Cis316 com o reagente fluorescente 194}

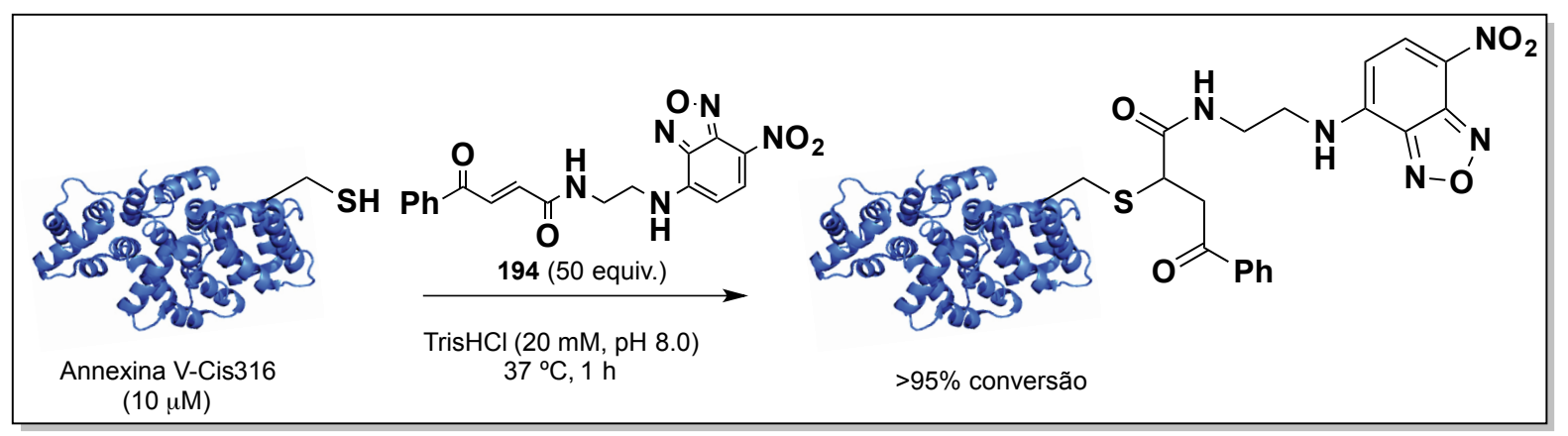

Em um ependorfe contendo $29.84 \mu \mathrm{L}$ de tampão TrisHCl (20 mM, pH 8.0) foi adicionado $14.40 \mu \mathrm{L}$ de uma solução estoque de Annexina $\mathrm{V}(27.8 \mu \mathrm{M}, 400 \mathrm{nmol})$ e a mistura resultante foi agitada em vortex por 30 segundos. Após, uma solução $4.19 \mathrm{mM}$ de 194 (4.76 $\mu \mathrm{L}, 50$ equiv.) em DMF foi adicionada e a reação agitada por $1 \mathrm{~h}$ em $37^{\circ} \mathrm{C}$. No final, uma alíquota de $10 \mu \mathrm{L}$ foi analisada por LC-MS e uma conversão total ao produto esperado foi observada (massa calculada, 36187; massa observada, 36185).
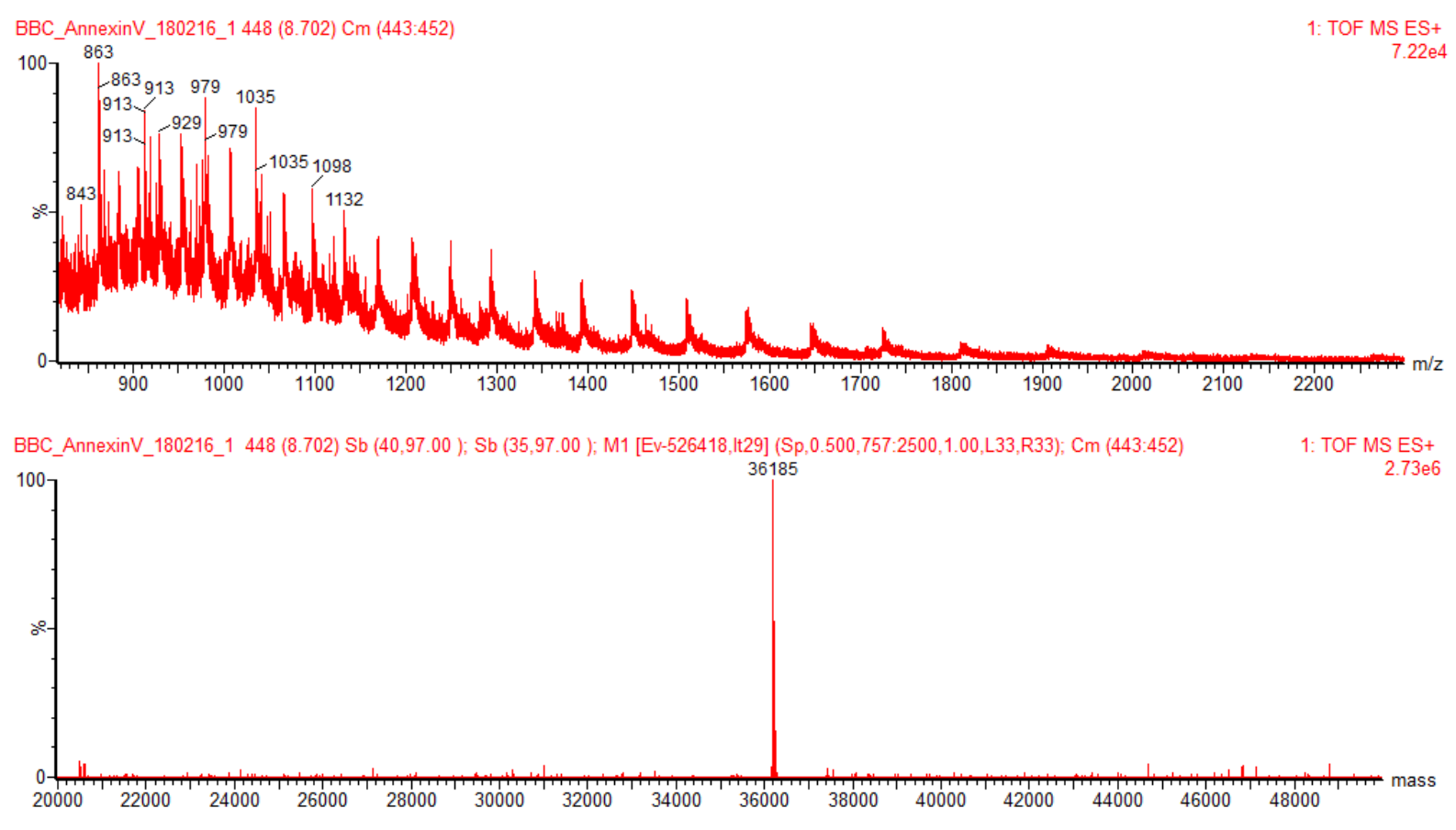

Figura 70 Reação da Annexina V com o fluorescente 194. 


\subsection{Procedimento para bioconjugação do Trastuzumab}

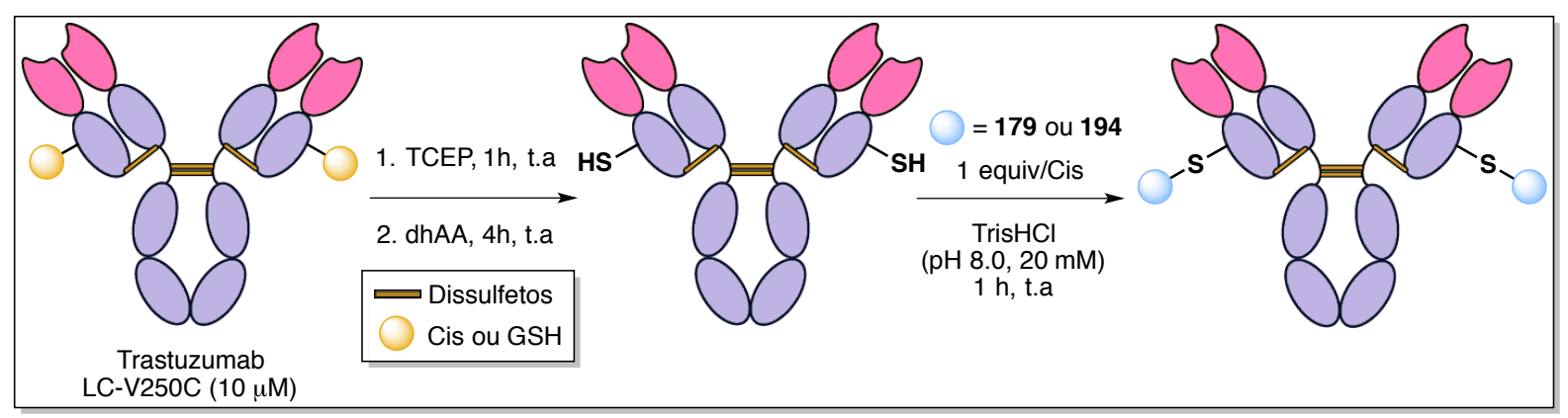

\subsubsection{Redução de dissulfetos}

A redução e oxidação do Trastuzumab foi realizada seguindo um procedimento do literatura. ${ }^{193}$ As pontes dissulfeto do Trastuzumab (15.33 $\mu \mathrm{L}, 1$ equiv., $400 \mathrm{nmol}$ ) foram reduzidas em condições brandas pela adição do agente redutor TCEP $(1 \mu \mathrm{L}, 4000 \mu \mathrm{M})$ em $23.46 \mu \mathrm{L}$ de solução de tampão TrisHCl (20 mM, pH 8.0) em temperatura ambiente por $1.5 \mathrm{~h}$. Os compostos de pesos moleculares menores foram removidos por uma filtração utilizando uma coluna Zeba Spin desalting equilibrada TrisHCl $(20 \mathrm{mM}$, pH 8.0) e eluída via centrifugação (2 min, 1500xg). A amostra foi analisada por LCMS (massa calculada, 23441; massa observada 23443). 


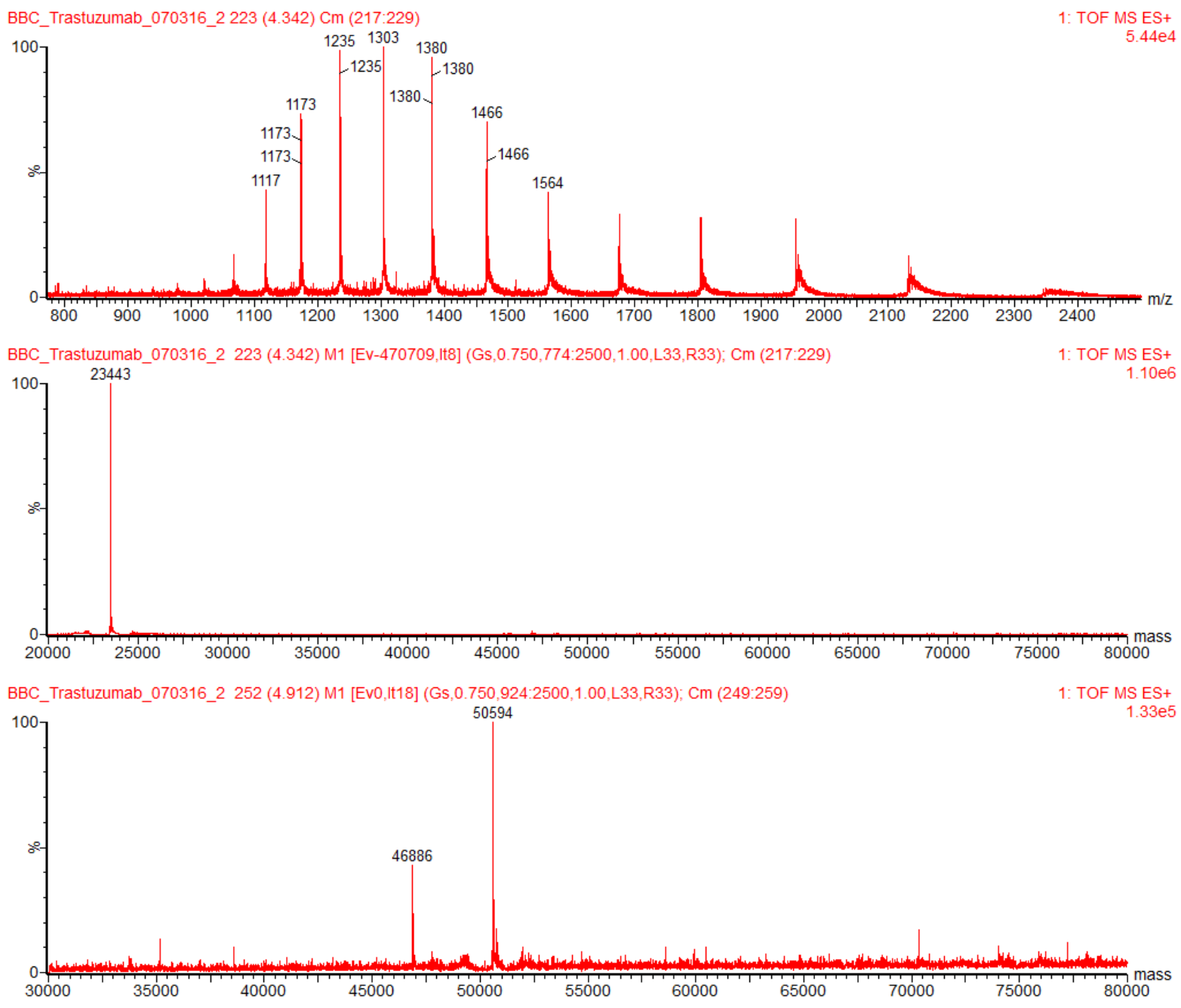

Figura 71 ESI-MS da cadeia pesada do trastuzumab (50594) após redução com 10 equiv. de TCEP.

\subsubsection{Re-oxidação dos dissulfetos}

Para reformar as pontes de dissulfeto internas, o Trastuzumab reduzido foi incubado com um excesso molar de 10x de dhAA (Sigma-Aldrich) por $4 \mathrm{~h}$ em temperatura ambiente. Após, uma alíquota de $5 \mu \mathrm{L}$ da mistura reacional foi analisada por LC-MS (alíquota de $5 \mu \mathrm{L}$ diluída com $5 \mu \mathrm{L}$ de uma solução de tampão de TrisHCl $(20 \mathrm{mM}$, $\mathrm{pH}$ 8.0). 


\subsubsection{Reação de bioconjugação com 179}

Em um ependorfe contendo $19.51 \mu \mathrm{L}$ do Trastuzumab reoxidado foi adicionado uma alíquota de $0.48 \mu \mathrm{L}$ de uma solução estoque em DMF de 179. A mistura reacional foi agitada em vortex por $1 \mathrm{~h}$ em temperatura ambiente. No final, uma alíquota de $10 \mu \mathrm{L}$ foi analisada por LC-MS e a completa conversão para o produto esperado foi observada (massa calculada, 23646; massa observada, 23646).

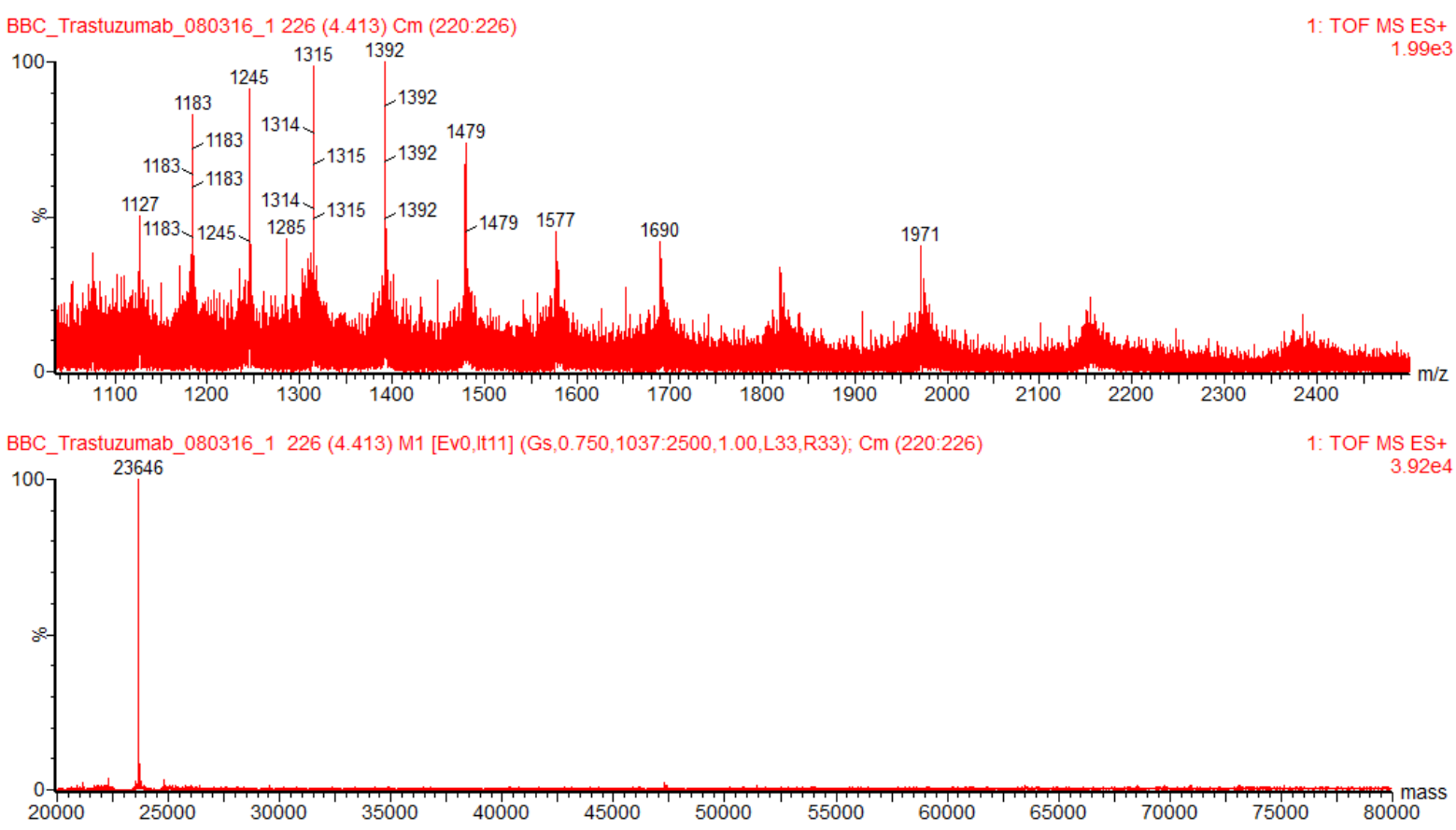

Figura 72 ESI-MS da cadeia leve do Trastuzumab após a reação com 179 por $1 \mathrm{~h}$ em RT.

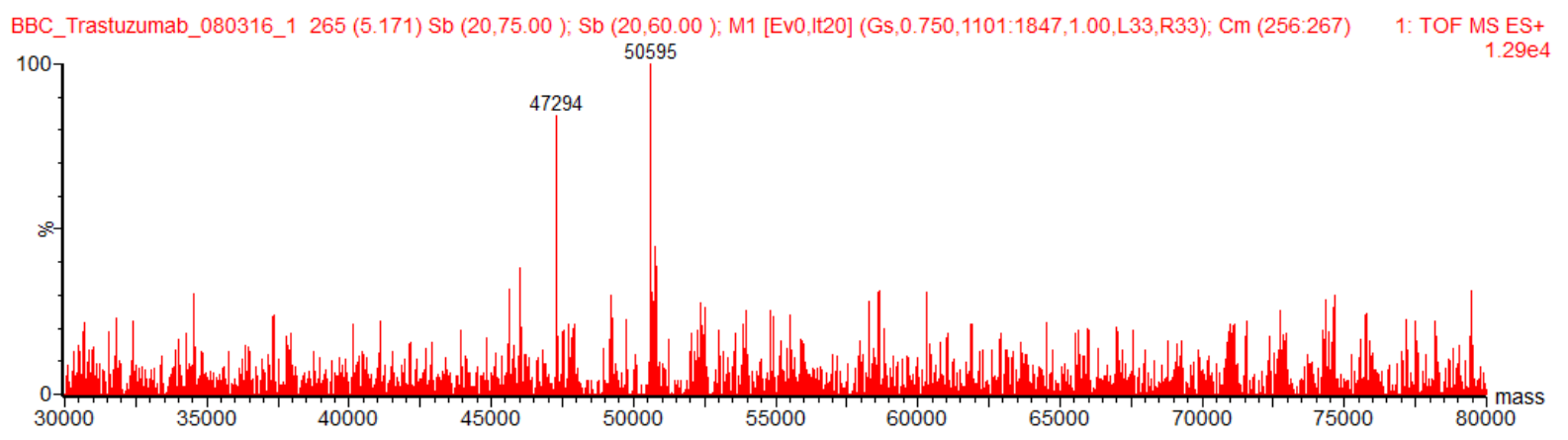

Figura 73 ESI-MS da cadeia pesada do Trastuzumab (50595) após a reação com 179 por 1 h em RT. 


\subsection{Citometria de fluxo}

\subsubsection{Condições de cultura de célula}

As células SKBR3 (ATCC® HTB-30 TM ) e HepG2 (ATCC® HB-8065 ${ }^{\mathrm{TM}}$ ) foram crescidas em um incubador umidificado em $37^{\circ} \mathrm{C}$ sob $5 \%$ de $\mathrm{CO}_{2}$ e divididas antes de atingir confluência utilizando TrypLE ${ }^{\mathrm{TM}}$ Express. Ambas as linhas celulares foram crescidas em DMEM média suplementado com 10\% de FBS, 2 mM GlutaMAX ${ }^{\mathrm{TM}}$, 10 mM HEPES, 1\% NEAA, $1 \mathrm{mM}$ piruvato de sódio, 100 unidades $/ \mathrm{mL}$ de penicillina e $100 \mu \mathrm{g} / \mathrm{mL}$ streptomicina. Todos os reagentes foram comprados de Gibco (Life Technologies, USA)

\subsubsection{Determinação da especificidade do Trastuzumab-194}

As células SKBR3 e HepG2 foram distribuídas em placas de 24 poços a uma concentração de 50000 células/poço e 30000 células/poço, respectivamente, e cultivadas durante $48 \mathrm{~h}$. As células foram separadas das placas e recolhidas em tubos de poliestireno de fundo redondo para citometria de fluxo. O meio de cultura foi removido e as células foram ressuspensas em meio suplementado com Trastuzumab ou Trastuzumab-194 (a 5, 10, 50, 150, 300 e 500 nM) e incubadas à temperatura ambiente, no escuro. Após $1 \mathrm{~h}$, as suspensões celulares foram centrifugadas a $400 \mathrm{~g}$ durante 4 minutos, o meio foi removido e as células foram ressuspensas em $300 \mu \mathrm{l}$ de uma solução de PBS suplementada com FBS a 10\%. As células foram mantidas no escuro até à análise. A aquisição foi realizada em um citômetro de fluxo LSR Fortessa (BD Biosciences, EUA) instalado com um laser de $488 \mathrm{~nm}$ e uma combinação de um filtro de 505 nm de 530/30 nm (combinação usada para detecção de FITC). 


\subsection{Experimento de ELISA}

A afinidade de ligação do anticorpo com o receptor HER2 foi determinada por ELISA, utilizando um kit de Trastuzumab (Herceptin ${ }^{\mathrm{TM}}$ ) ELISA Kit-96 poços fornecido por Generon. Os anticorpos foram pré-revestidos em micropoços. Diferentes concentrações de Trastuzumab-179 e Trastuzumab não modificado no tampão de amostra fornecido pelo kit foram pipetadas para dentro dos micropoços (20 nM, $0.06 \mathrm{nM}, 0.12 \mathrm{nM}, 0.25 \mathrm{nM}, 0.50 \mathrm{nM}, 1.00 \mathrm{nM}$ e $2.0 \mathrm{nM}$ ) e foram incubadas durante $1 \mathrm{~h}$ à temperatura ambiente. Em seguida, as soluções foram removidas e os poços lavados com a solução de lavagem três vezes. Em seguida, uma HRP (horseradish peroxidase) conjugada com IgG foi pipetada e incubada com as amostras. Depois de remover as soluções e de lavar novamente os micropoços com a solução de lavagem três vezes, adicionou-se a solução de TMB aos micropoços e a cor desenvolveu-se proporcionalmente à quantidade de Trastuzumab na amostra. $\mathrm{O}$ desenvolvimento da cor foi parado após $30 \mathrm{~min}$. A absorbância foi medida a $450 \mathrm{~nm}$. A absorbância foi corrigida subtraindo a média dos controles negativos.

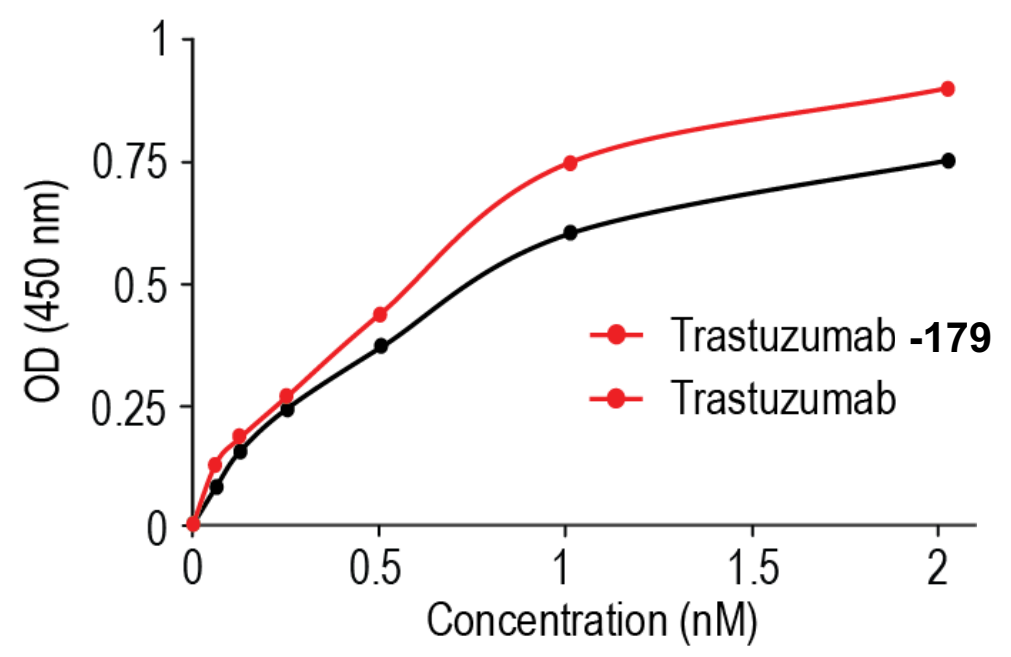

Figura 74 Determinação da atividade de ligação do anticorpo com o receptor HER2 por ELISA. 


\subsection{Experimento de BLI}

Biotinilação dos anticorpos. O Trastuzumab modificado e não modificado foi conjugado com biotina (Thermofisher Scientific) previamente ao experimento de BLI utilizando os biosensores estreptavidina (AS). Uma solução de Biotina-(PEG) ${ }_{4}-\mathrm{NHS}$ $(20 \mu \mathrm{L}, 200 \mu \mathrm{M})$ em PBS foi adicionada no correspondente anticorpo (20 $\mu \mathrm{L}, 20 \mu \mathrm{M}$ em PBS) e reagido em temperatura ambiente por $30 \mathrm{~min}$. O bruto da reação foi lavado com tampão PBS por 3 vezes para remover o excesso de NHS-(PEG)4-Biotina.

Bio-layer interferometry (BLI). Os ensaios de BLI foram realizados em um instrumento Octet Red (fortéBIO). A imobilização do ligante, reação de ligação, regeneração e as lavagens foram realizadas em microplacas de polipropileno de 96 poços. O Trastuzumab não modificado e com 179 (20 nM) foram imobilizados com os biosensores estreptavidina em PBS na presença de 0.1\% BSA e 0.02\% Tween em $30{ }^{\circ} \mathrm{C}$. Os ensaios de ligação foram realizados em $26^{\circ} \mathrm{C}, 1000 \mathrm{rpm}$ em PBS com $0.1 \%$ BSA e $0.02 \%$ Tween, com 600 s de associação e 2200 s de dissociação, utilizando diferentes concentrações do receptor HER2 para obter a corva de associação. Glicina em pH 2.0 foi utilizada como tampão de regeneração.
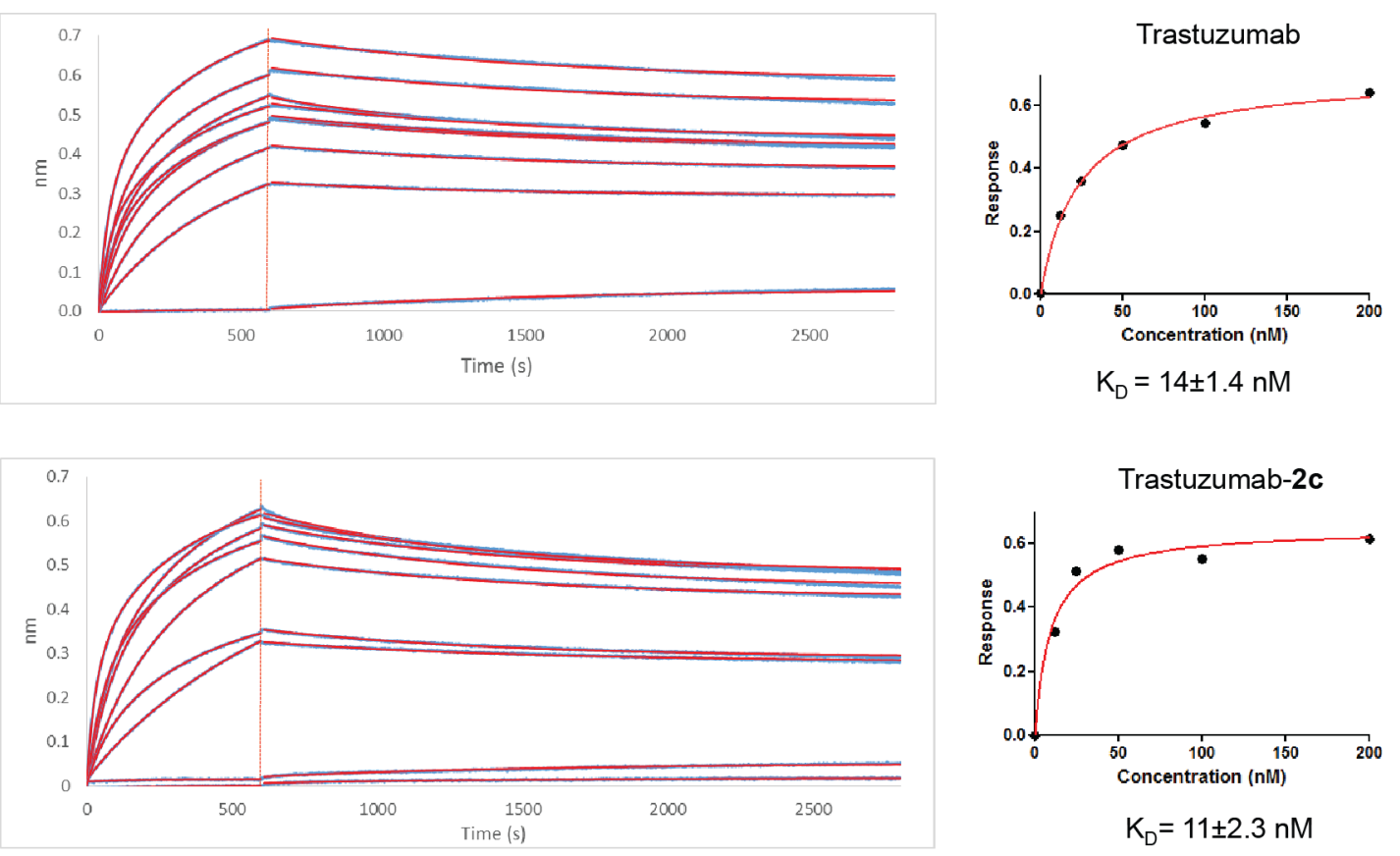

Figura 75 Determinação da constante de ligação $\left(K_{D}\right)$ do anticorpo. 


\subsection{Gel NuPAGE ${ }^{\circledR}$ Bis-Tris}

Uma solução contendo a proteína/anticorpo $(5.0 \mu \mathrm{L}$ em TrisHCl $20 \mathrm{mM}, \mathrm{pH}$ 8.0) foi adicionada a um tubo de plástico eppendorf. Tampão NuPAGE® LDS (4X, $2.5 \mu \mathrm{L})$, o agente redutor $\mathrm{NuPAGE}^{\circledR}(10 \mathrm{X}, 1 \mu \mathrm{L})$ e $\mathrm{H}_{2} \mathrm{O}(1.5 \mu \mathrm{L})$ foram então transferidos. A solução foi aquecida em $70^{\circ} \mathrm{C}$ por $10 \mathrm{~min}$. A solução aquecida foi adicionada ao mini gel NuPAGE ${ }^{\circledR}$ Bis-Tris $(10 \mathrm{~cm} \times 10 \mathrm{~cm})$ com uma concentração de poliacrilamida em um gradiente de 4-12\%. O sistema tampão aplicado foi de 1X SDS (tampão de corrida NuPAGE ${ }^{\circledR}$ MES SDS, 20X, pH 7.3, $50 \mathrm{~mL}$ para $950 \mathrm{~mL}$ de agua deionizada). Para as amostras reduzidas, $500 \mu \mathrm{L}$ do antioxidante $\mathrm{NuPAGE}^{\circledR}$ foi adicionado para cada $200 \mathrm{~mL}$ de tampão de corrida SDS 1X. Após $35 \mathrm{~min}$, as intensidades de fluorescência foram analisadas. $\mathrm{O}$ gel foi revelado com $0.5 \%$ de Ruby e agitado durante a noite em temperatura ambiente. Após a lavagem do gel, azul de coomassie $(0.5 \%)$ foi adicionado e o gel foi lido $2 \mathrm{~h}$ após agitar em temperatura ambiente. 
Fluorescente
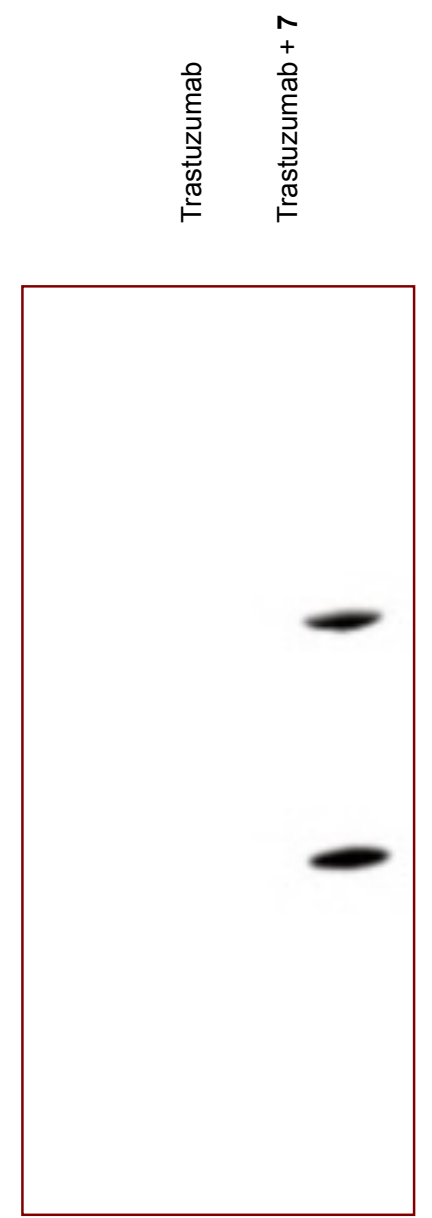

Ruby
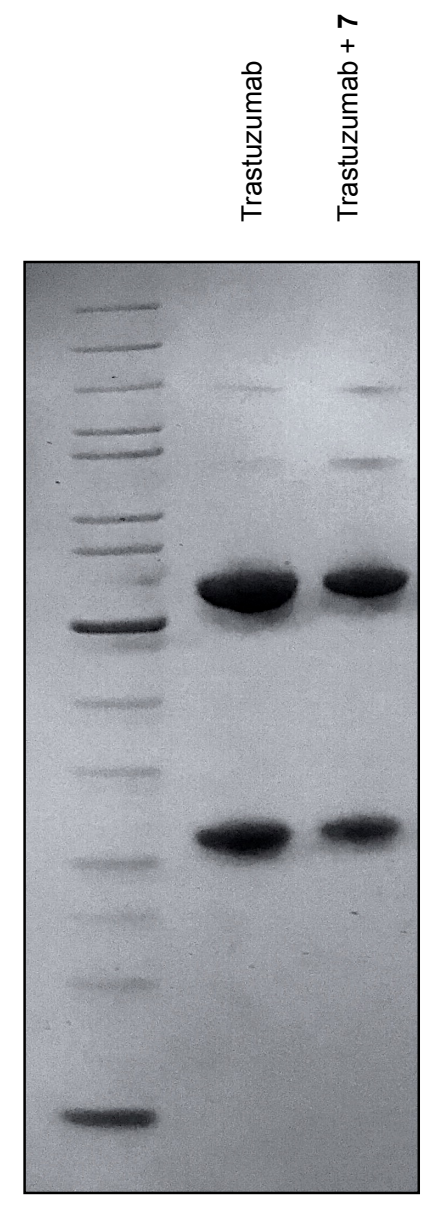

Coomassie

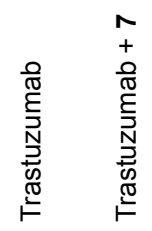

Figura 76 Análise SDS-PAGE do trastuzumab 194. 
Fluorescente
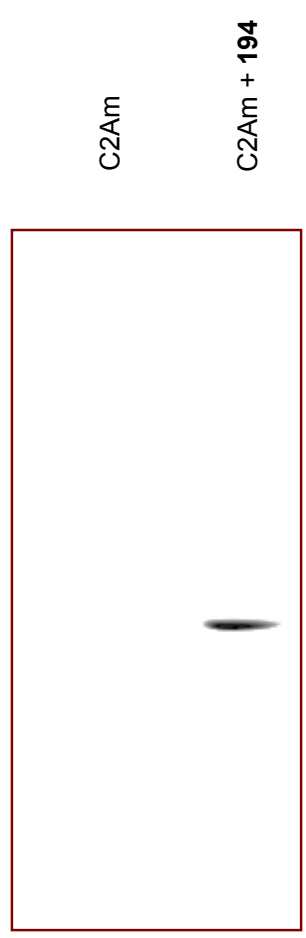

Ruby

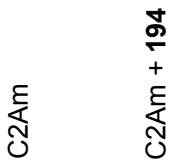

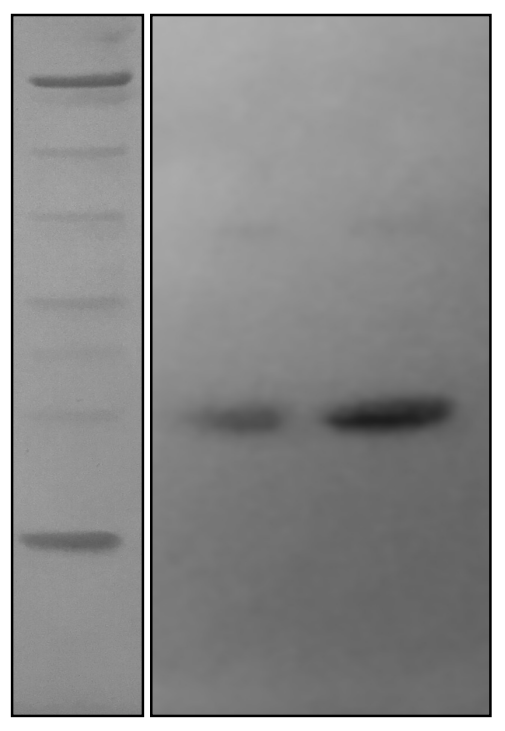

Coomassie

ह

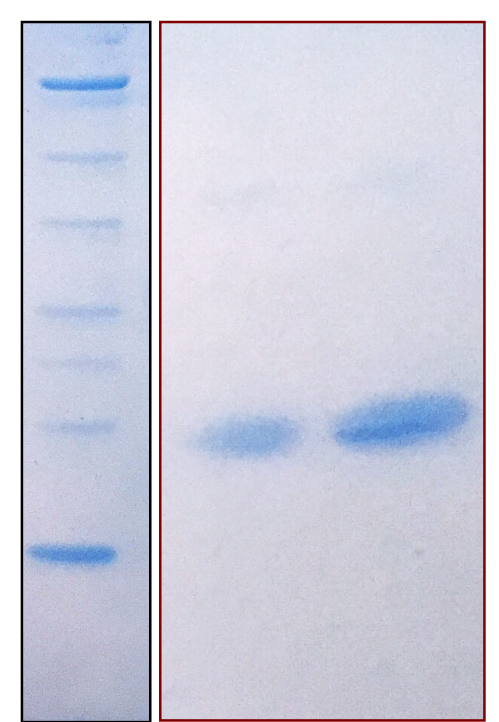

Figura 77 Análise SDS-PAGE do conjugado C2Am-194. 
Fluorescente
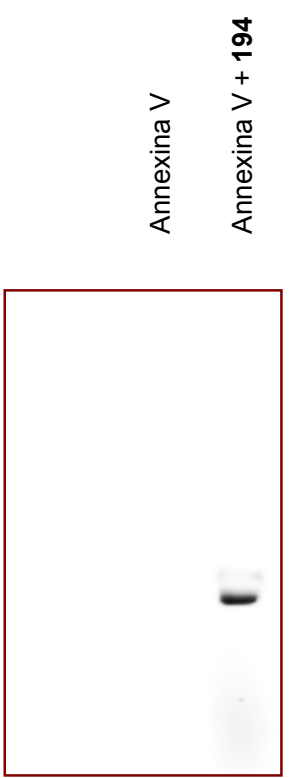

Ruby
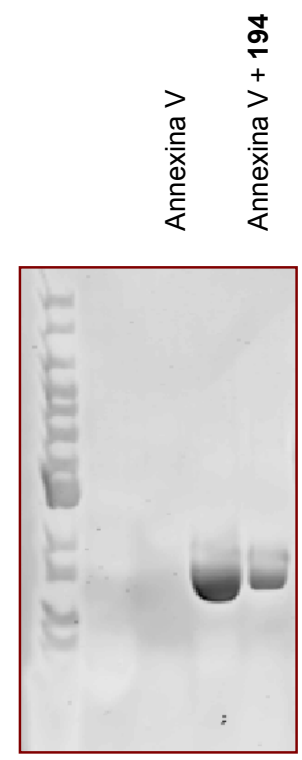

Coomassie
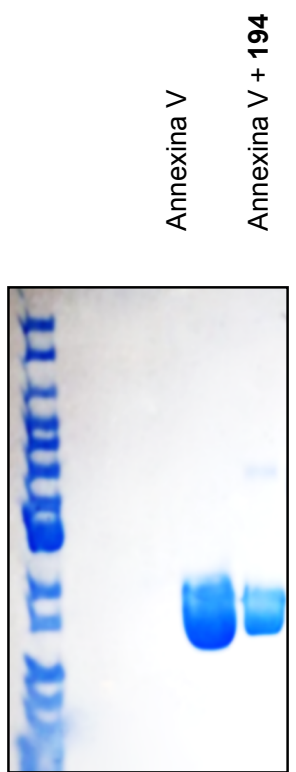

Figura 78 Análise SDS-PAGE do conjugado Annexina V-194. 
Fluorescente

Ruby

Coomassie

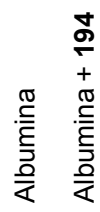

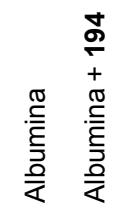

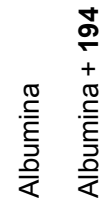
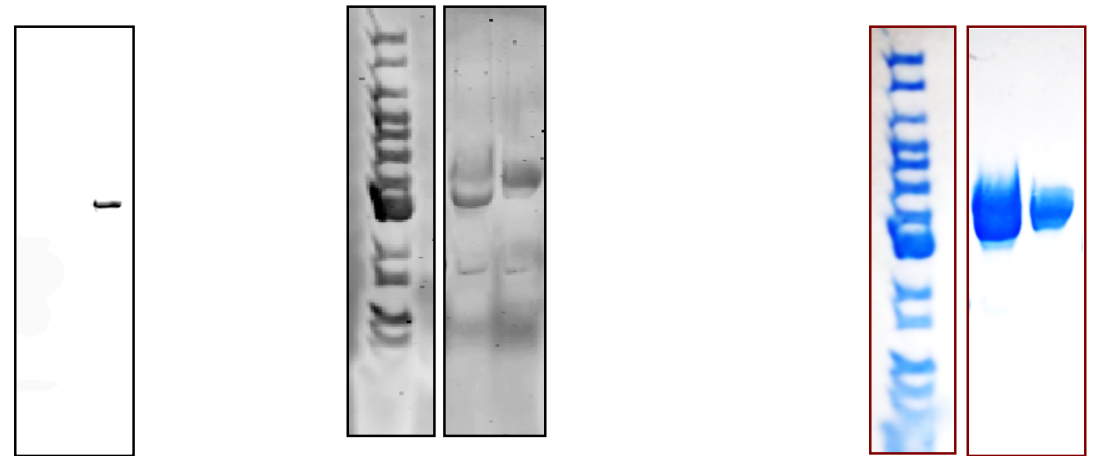

Figura 79 Análise SDS-PAGE do conjugado albumina-194. 


\subsection{Estudos de Microscopia}

As células HEK293 foram mantidas em $37^{\circ} \mathrm{C}$ em uma atmosfera umidificada $\left(5 \% \mathrm{CO}_{2}\right)$ com DMEM alta glicose (Gibco) suplementado com $10 \%$ de soro fetal bovino desativado (HI-FBS, Gibco) e 1X antibiótico-antimicótico (Gibco). Quando as células atingiram a densidade apropriada (70 - 80\% confluentes), o meio foi removido e as células colhidas com $0.25 \%$ Tripsina-EDTA. Em seguida, aplicou-se $200 \mu \mathrm{L}$ da suspensão com as células ( $\sim 000$ células) em cima de lamelas de vidro de $12 \mathrm{~mm}$ pré-revestidas com poli $D$-Lisina (Corning ${ }^{\mathrm{TM}}$ BioCoat $^{\mathrm{TM}}$ ) colocadas dentro de uma placa de 24 poços. Após $1 \mathrm{~h}$ de incubação para permitir a adesão das células, $200 \mu \mathrm{L}$ do meio foi adicionado nos poços. As células cresceram por um período adicional de $7 \mathrm{~h} \mathrm{em} 37^{\circ} \mathrm{C}$ antes da indução de apoptose pelo tratamento do meio com actinomicina $\mathrm{D}(2 \mu \mathrm{M})$ por $12 \mathrm{~h}$. Células de mesma densidade não tratadas com o agente apoptótico foram incluídas como controle. Após a indução, o meio foi removido e as células foram lavadas com D-PBS (Gibco). Em seguida, foram incubadas na presença de Annexina V-194 em $37^{\circ} \mathrm{C}$ por 20 minutos, em uma concentração de $0.2 \mu \mathrm{M}$ em $10 \mathrm{mM}$ de HEPES pH 7.4 suplementado com $140 \mathrm{Mm}$ de $\mathrm{NaCl}$ e $2.5 \mathrm{mM}$ de $\mathrm{CaCl}_{2}$. Ao mesmo tempo, os estudos de bloqueio prévio dos receptores foram realizados pré-incubando as células apoptóticas com um excesso de $25 x$ da Annexina $V$ não fluorescente $(5 \mu \mathrm{M}$, $37^{\circ} \mathrm{C}$ por $20 \mathrm{~min}$ ) antes da incubação com o conjugado 194 por um período adicional de $20 \mathrm{~min}$ em $37^{\circ} \mathrm{C}$. Para revelar o núcleo fluorescente do DNA, o corante Hoechst $33342\left(0.8 \mu \mathrm{g} / \mathrm{mL}\right.$, Sigma Aldrich, $15 \mathrm{~min}$ em $\left.37^{\circ} \mathrm{C}\right)$ foi utilizado. Após a marcação, as células foram lavadas com PBS 2 vezes. Finalmente, as células foram fixadas com uma solução de PBS contendo 4\% (m/v) de formaldeído por um período de $15 \mathrm{~min}$ em temperatura ambiente. A microscopia de fluorescência foi realizada utilizando um microscópio (Olympus IX-71) conectado com uma câmera digital F-view (Soft Imaging System). As imagens foram obtidas com os filtros FITC e Hoechst e analisadas utilizando um software Cell-F. A aquisição foi realizada e forma idêntica nos experimentos controle e de bloqueio prévio dos receptores. 


\subsection{Procedimento para o preparo do aduto 196.}

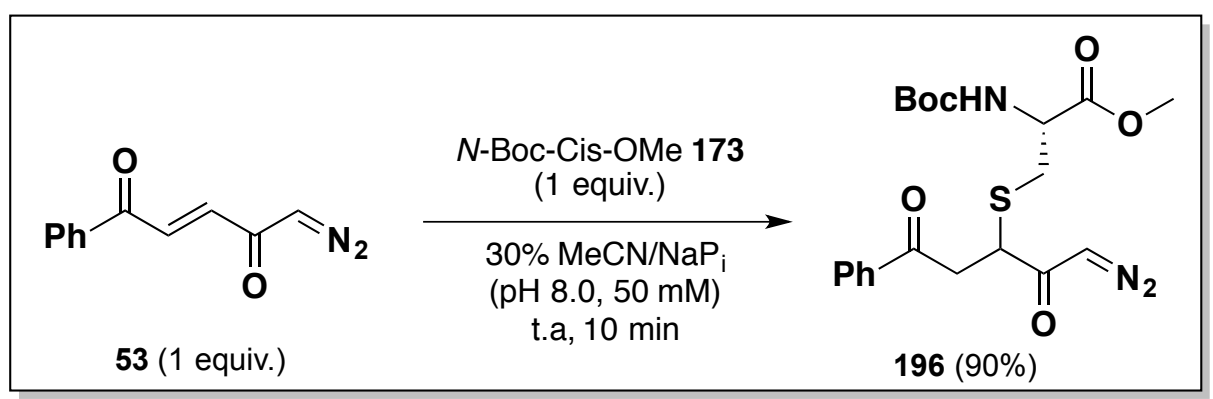

Em uma solução de $N$-(tert-Butoxicarbonil)-L-cisteína metil éster 173 (4.7 mg, 0.020 mmol, 1 equiv.) em $0.4 \mathrm{~mL}$ de tampão de fosfato de sódio $\mathrm{NaP}_{\mathrm{i}}(\mathrm{pH} 8.0,50 \mathrm{mM})$ contendo $30 \%$ of $\mathrm{MeCN}$ foi adicionada uma solução de etil (E)-5-diazo-1-phenilpent2-eno-1,4-diona 53 (4.0 mg, $0.020 \mathrm{mmol}, 1$ equiv.) em $\mathrm{MeCN}(0.1 \mathrm{~mL}$ ) temperatura ambiente. A reação foi monitorada por TLC. Após $10 \mathrm{~min}$, a mistura reacional foi concentrada em vácuo para fornecer 196 em 90\% de rendimento.

\section{(196)}

\section{$\mathbf{R}_{\mathbf{f}} \quad 0.40$ (4:6 AcOEt/hexano);}

${ }^{1} \mathrm{H}$ RMN $\quad\left(400 \mathrm{MHz}, \mathrm{CDCl}_{3} \delta 7.96(\mathrm{~d}, J=8.2 \mathrm{~Hz}, 2 \mathrm{H}), 7.57(\mathrm{t}, J=7.4 \mathrm{~Hz}, 1 \mathrm{H}), 7.46\right.$ $(\mathrm{t}, J=7.6 \mathrm{~Hz}, 2 \mathrm{H}), 5.69(\mathrm{~s}, 1 \mathrm{H}), 5.38(\mathrm{~d}, J=8.0 \mathrm{~Hz}, 1 \mathrm{H}), 4.64-4.42(\mathrm{~m}$, $1 \mathrm{H}), 3.97-3.80(\mathrm{~m}, 2 \mathrm{H}), 3.76(\mathrm{~s}, 3 \mathrm{H}), 3.35-3.21(\mathrm{~m}, 1 \mathrm{H}), 3.19-2.90$ $(\mathrm{m}, 2 \mathrm{H}), 1.44(\mathrm{~s}, 9 \mathrm{H})$;

${ }^{13}$ C RMN (100 MHz, $\mathrm{CDCl}_{3}$ diastereoisômero majoritário) $\delta$ 196.9, 191.1, 171.1, $155.1,136.1,133.6,128.7,128.2,80.4,55.3,53.5,52.8,40.9,32.9$, 29.7, 28.3;

FTIR (puro, $\mathrm{cm}^{-1}$ ): 3368, 2921, 2105, 1710, 1684, 1634, 1597, 1509, 1366, 1347, 1216, 1900, 1065, 985, 759;

HRMS (ESI) Calculado para $\mathrm{C}_{20} \mathrm{H}_{25} \mathrm{~N}_{3} \mathrm{NaO}_{6} \mathrm{~S}^{+}[\mathrm{M}+\mathrm{Na}]^{+} 458.1356$, encontrado 458.1368; 


\subsection{Procedimento para bioconjugação da Annexina V com a diazocetona 53}

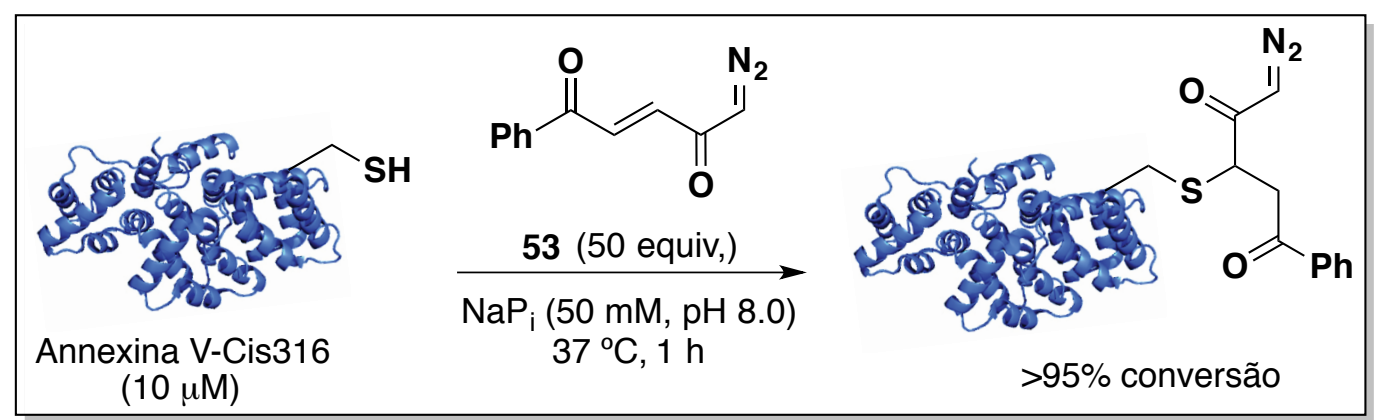

Em um ependorfe contendo $18.3 \mu \mathrm{L}$ de $\mathrm{NaP}_{\mathrm{i}}(50 \mathrm{mM}, \mathrm{pH}$ 8.0) foi adicionado uma alíquota de $11.70 \mu \mathrm{L}$ de uma solução estoque da Annexina $\mathrm{V}(34.30 \mu \mathrm{M}, 400 \mathrm{nmol}) \mathrm{e}$ a mistura resultante foi agitada em vortex por 30 segundos. Após, uma solução $3.74 \mathrm{mM}$ de 53 (10.0 $\mu \mathrm{L}, 50$ equiv.) em DMF foi adicionada e a reação agitada por $1 \mathrm{~h}$ em $37^{\circ} \mathrm{C}$. Após, uma alíquota de $10 \mu \mathrm{L}$ foi analisada por LC-MS e uma conversão completa ao produto esperado foi observada (massa calculada, 36009, massa observada, 36005).
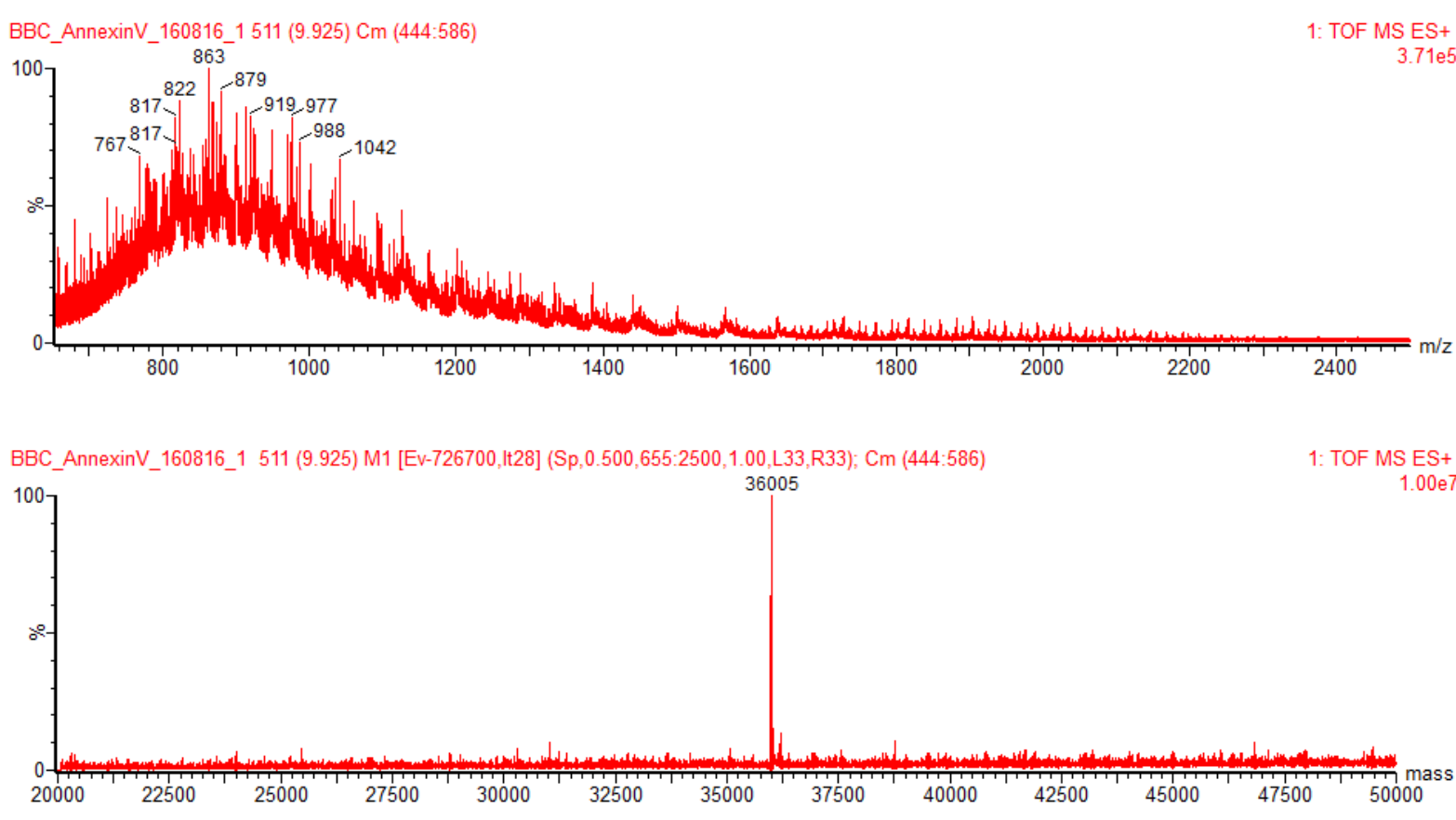

Figura 80 Bioconjugação da Annexina V-Cis316 com a diazocetona 53. 


\subsection{Reação do conjugado Ellman's-Annexina V com a diazocetona 53.}

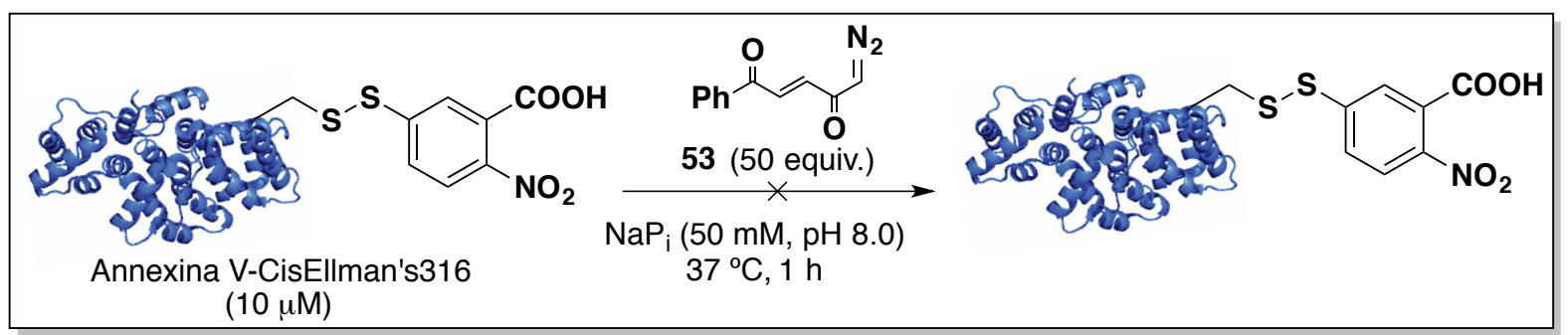

Uma alíquota de $22.5 \mu \mathrm{L}$ da Annexina V-Cys316-Ellman's (10 $\mu \mathrm{M}, 260 \mathrm{nmol})$ foi transferida para um tubo eppendorf de $0.5 \mathrm{~mL}$. Uma alíquota de $7.5 \mu \mathrm{L}$ de 53 (2.00 mM, 50 equiv.) foi adicionada em temperatura ambiente e a mistura reacional agitada em vortex por 30 segundos. Após $1 \mathrm{~h}$ de agitação adicional em $37^{\circ} \mathrm{C}$, uma alíquota de $10 \mu \mathrm{L}$ foi analisada por LC-MS. Não foi detectada mudança no espectro.
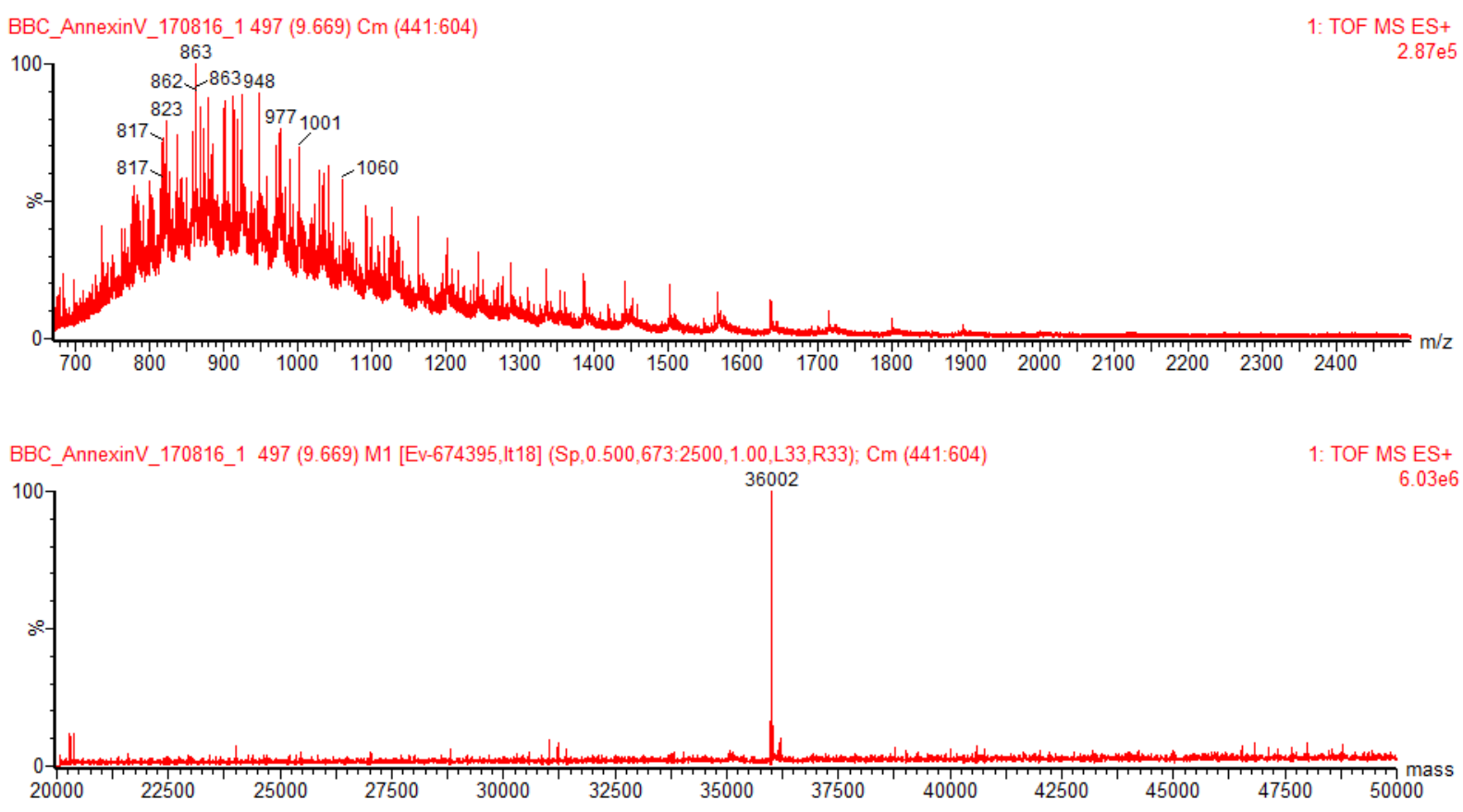

Figura 81 Reação do conjugado de Annexina V-CisEllman's-187 com a diazocetona 53. 


\subsection{Reação da Annexina V-88 com o reagente de Ellman's 187}

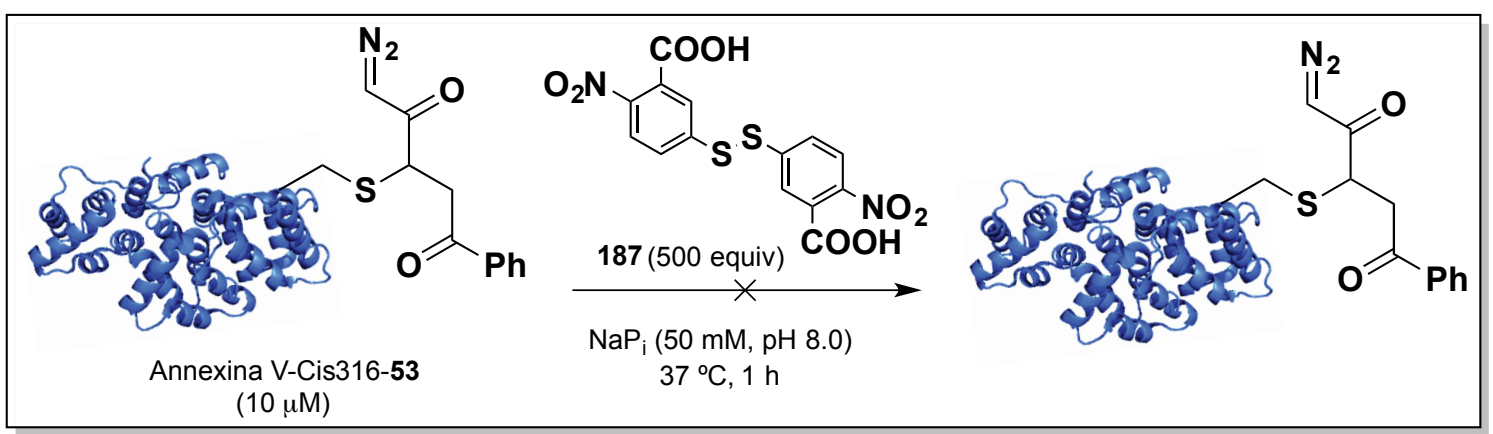

Uma alíquota de $13.5 \mu \mathrm{L}$ do conjugado de Annexina V-Cis316-53 (10 $\mu \mathrm{M}, 135 \mathrm{nmol})$ foi transferida para um tubo eppendorf de $0.5 \mathrm{~mL}$. Uma alíquota de $1.5 \mu \mathrm{L}$ do reagente de Ellman's 187 (50.5 mM, 500 equiv.) foi adicionada em temperatura ambiente e a mistura reacional resultante agitada em vortex por 30 segundos. Após um período adicional de agitação de $1 \mathrm{~h}$ em $37^{\circ} \mathrm{C}$, uma alíquota de $10 \mu \mathrm{L}$ foi analisada por LCMS e nenhuma alteração no espectro foi observada.

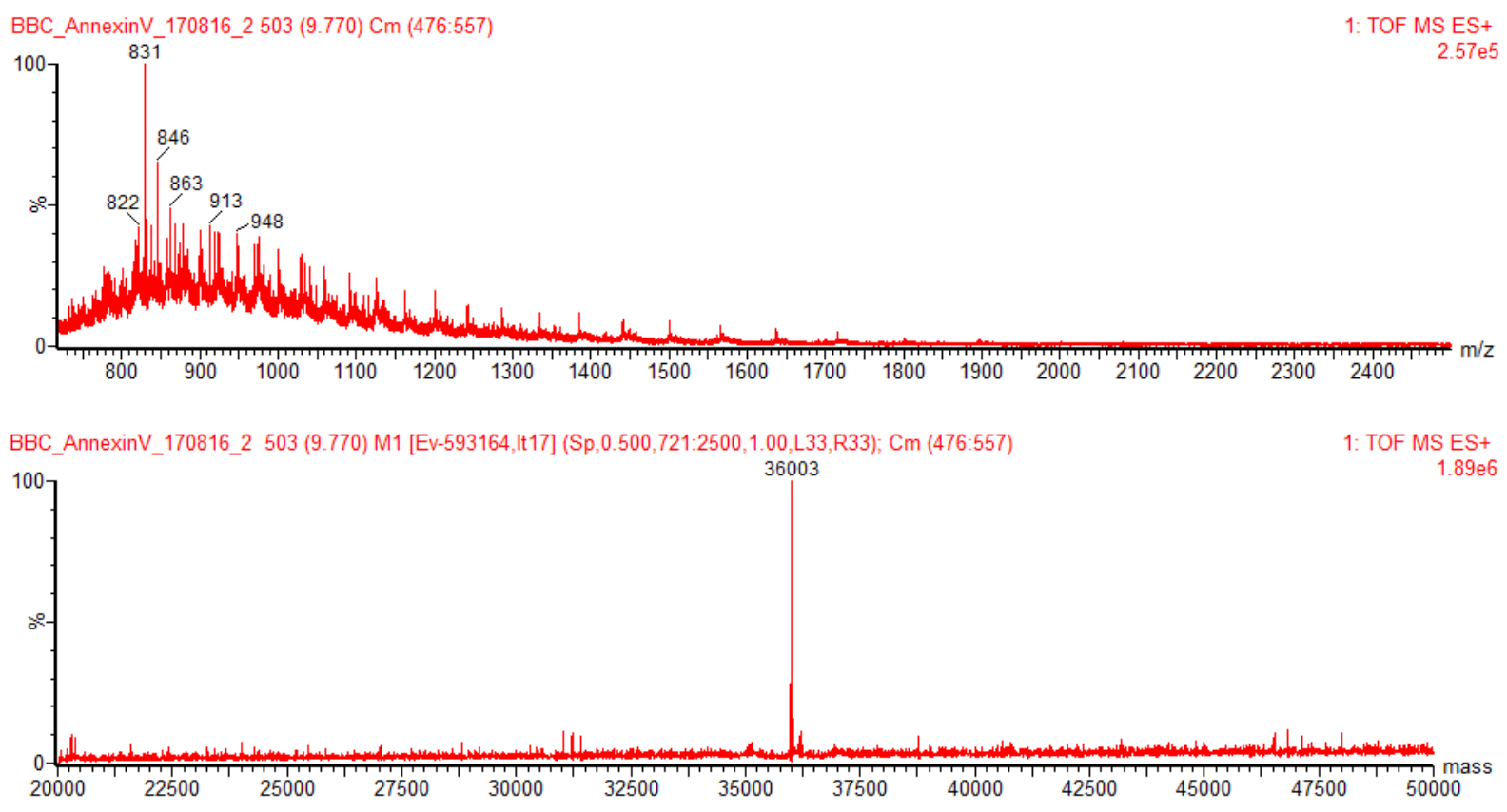

Figura 82 Reação do conjugado Annexina V-Cis316-53 com o reagente de Ellman's 187. 
6.37 Reações de adição de Michael acompanhadas por RMN ${ }^{1} \mathrm{H}$

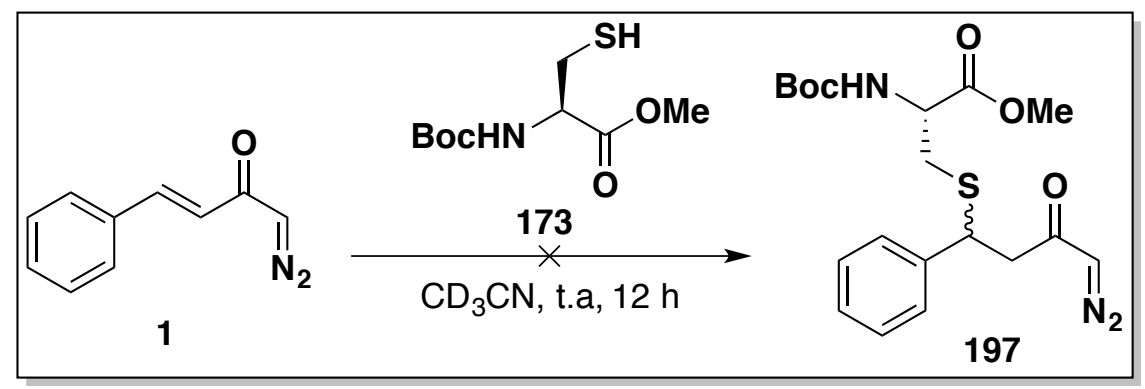

Uma solução da diazocetona 1 (5.0 mg, $0.029 \mathrm{mmol}) \mathrm{em} \mathrm{CD}_{3} \mathrm{CN}(0.7 \mathrm{~mL})$ foi reagida com 1 equivalente de $\mathrm{N}$-Boc-Cis-OMe $173(6.8 \mathrm{mg}, 0.029 \mathrm{mmol}$ ) em temperatura ambiente. Um espectro de $\mathrm{RMN}{ }^{1} \mathrm{H}$ foi coletado imediatamente no tempo zero da reação, e posteriormente de hora em hora, por um período de $12 \mathrm{~h}$. Não houve evolução da reação nas condições estudadas.

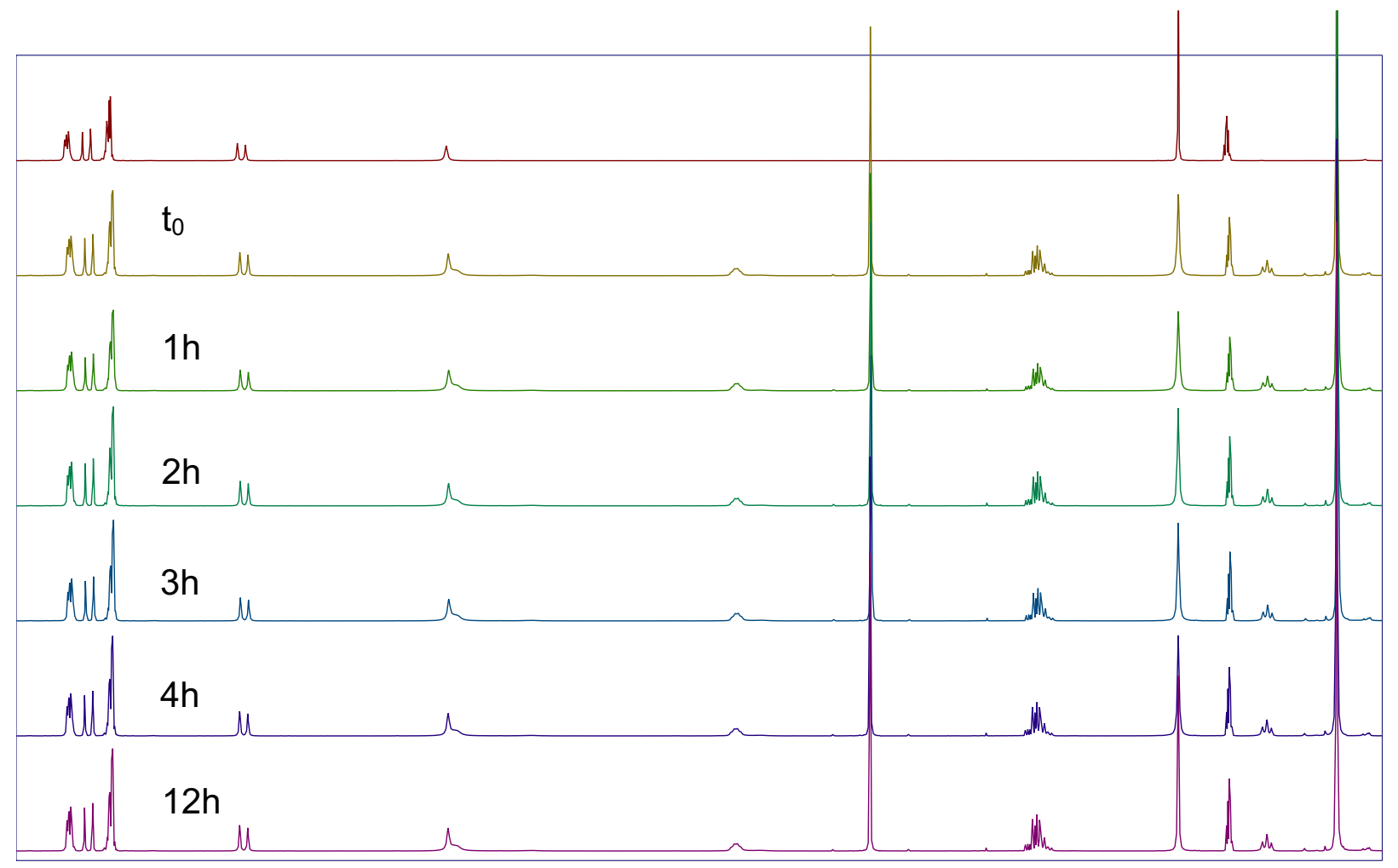

$\begin{array}{lllllllllllllllllllllllllllllllllllllllllll}.8 & 7.6 & 7.4 & 7.2 & 7.0 & 6.8 & 6.6 & 6.4 & 6.2 & 6.0 & 5.8 & 5.6 & 5.4 & 5.2 & 5.0 & 4.8 & 4.6 & 4.4 & 4.2 & 4.0 & 3.8 & 3.6 & 3.4 & 3.2 & 3.0 & 2.8 & 2.6 & 2.4 & 2.2 & 2.0 & 1.8 & 1.6 & 1.4 & 1.2\end{array}$

Figura 83 Espectros de $\mathrm{RMN}{ }^{1} \mathrm{H}$ para a adição de 173 na diazocetona $1 \mathrm{em} \mathrm{CDCl}_{3}$. 


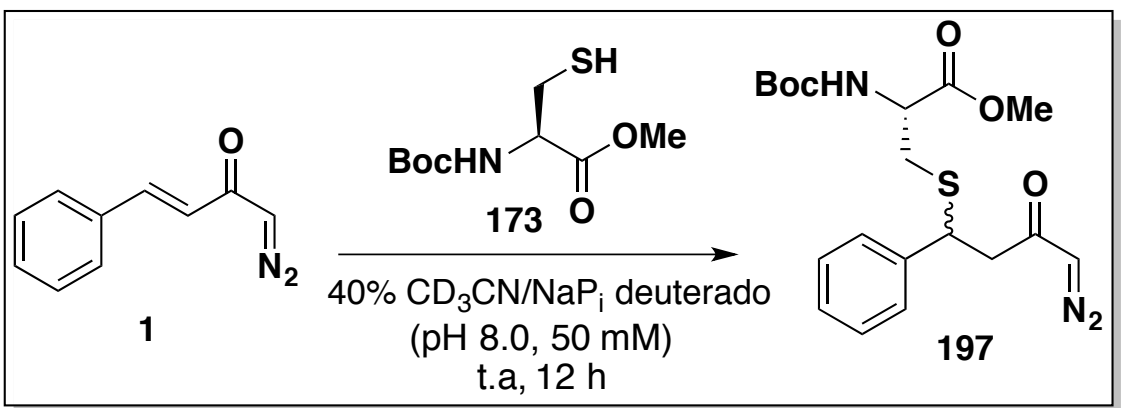

Uma solução da diazocetona 1 (5.0 mg, $0.029 \mathrm{mmol})$ em $0.7 \mathrm{~mL}$ de uma solução $40 \%$ de $\mathrm{CD}_{3} \mathrm{CN} / \mathrm{NaP}_{\mathrm{i}}$ deuterado (o tampão foi preparado com $\mathrm{D}_{2} \mathrm{O}$ ) foi reagida com 1 equivalente de $\mathrm{N}$-Boc-Cis-OMe $173(6.8 \mathrm{mg}, 0.029 \mathrm{mmol})$ em temperatura ambiente. Um espectro de $\mathrm{RMN}^{1} \mathrm{H}$ foi coletado imediatamente no tempo zero da reação, e posteriormente de hora em hora, por um período de $12 \mathrm{~h}$. O espectro abaixo é apresentado de 4 em 4 h. Uma pequena evolução de aproximadamente $5 \%$ foi observada.

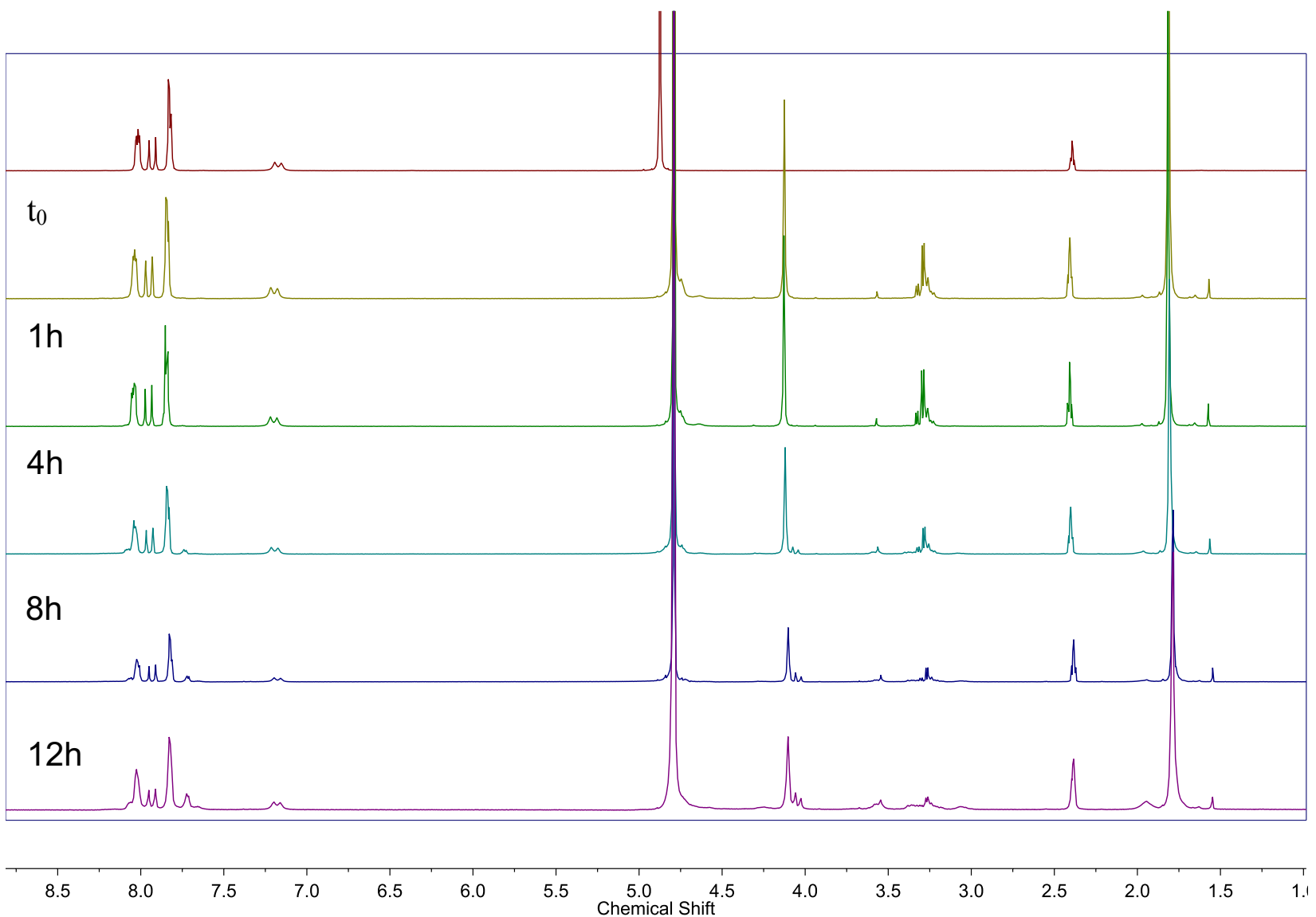

Figura 84 Espectros de $\mathrm{RMN}^{1} \mathrm{H}$ para a adição de 173 na diazocetona $1 \mathrm{em} \mathrm{CDCl}_{3} / \mathrm{NaP}_{\mathrm{i}}(\mathrm{pH}$ 8.0, 50 $\mathrm{mM}$ ) deuterado. 


\subsection{Cálculos DFT}

A otimização de geometria foi realizada com o programa Gaussian $09^{239}$ utilizando um funcional $^{240}$ de troca e correlação hídrido M06-2X com uma função de base de Pople 6-31+G(d,p). Efeitos de solvatação na água foram considerados implicitamente através do modelo ${ }^{241}$ IEF-PCM (integral equation formalism (IEF) - Polarizable continuum model (PCM)). A possibilidade de diferentes conformações foi levada em consideração em todas as estruturas. Análises de frequências vibracionais foram realizadas no mesmo nível de teoria usado das otimizações de geometria e a natureza dos estados estacionários foram determinadas caso a caso de acordo com um número apropriado de dos autovalores da matriz hessiana. As frequências não foram escalonadas. A aproximação quase harmônica (do inglês quase-harmonic approximation) de Trular et al. foi utilizada em substituição ao modelo do oscilador harmônico para o cálculo da contribuição vibracional na entalpia e entropia. ${ }^{242}$ Cálculos de coordenadas intrínseca de reação (do inglês intrisic reaction coordinate (IRC)) foram realizadas usando o modelo de Gonzalez e Schlegel ${ }^{243,244}$ com o intuito de assegurar que os estados de transição conectavam de fato os produtos e reagentes de modo apropriado. Energia livre de Gibbs $(\Delta G)$ foi usada para a discussão das estabilidades relativas nas estruturas consideradas. Coordenadas Cartesianas, energias eletrônicas, entropias, entalpias, energia livre de Gibbs e o menores valores calculados de frequências estão disponíveis abaixo. 

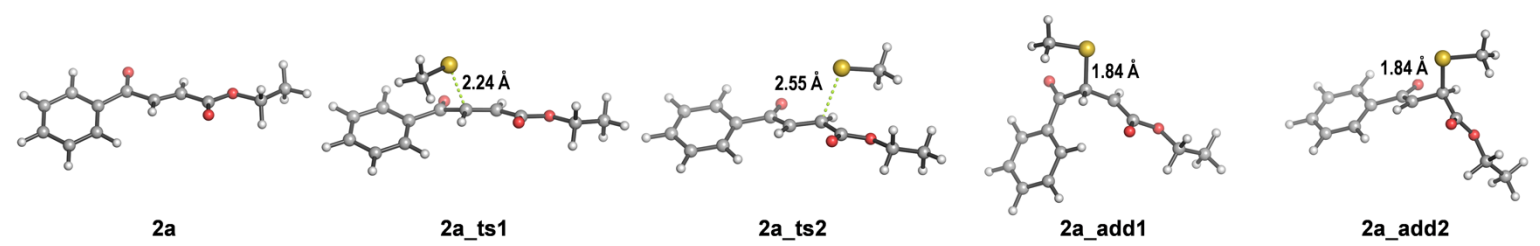

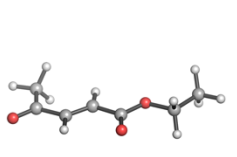

$\mathbf{2 b}$

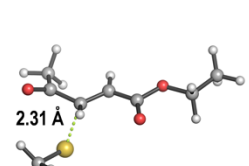

2b_ts 1

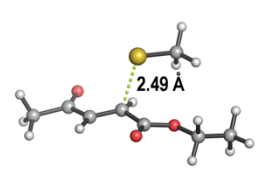

2b_ts2

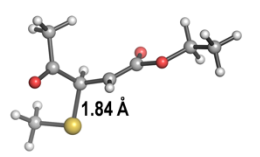

2b_add1

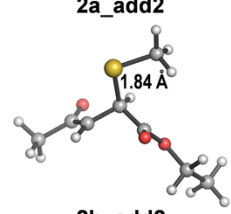

2b_add2

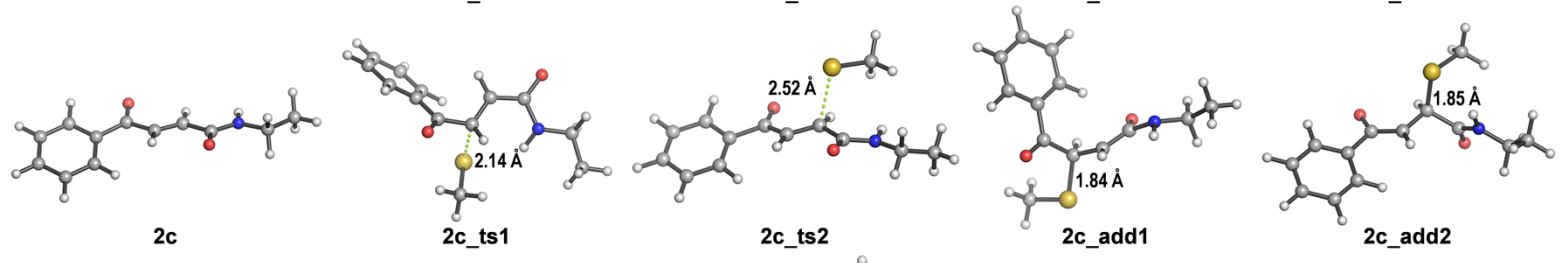

2c
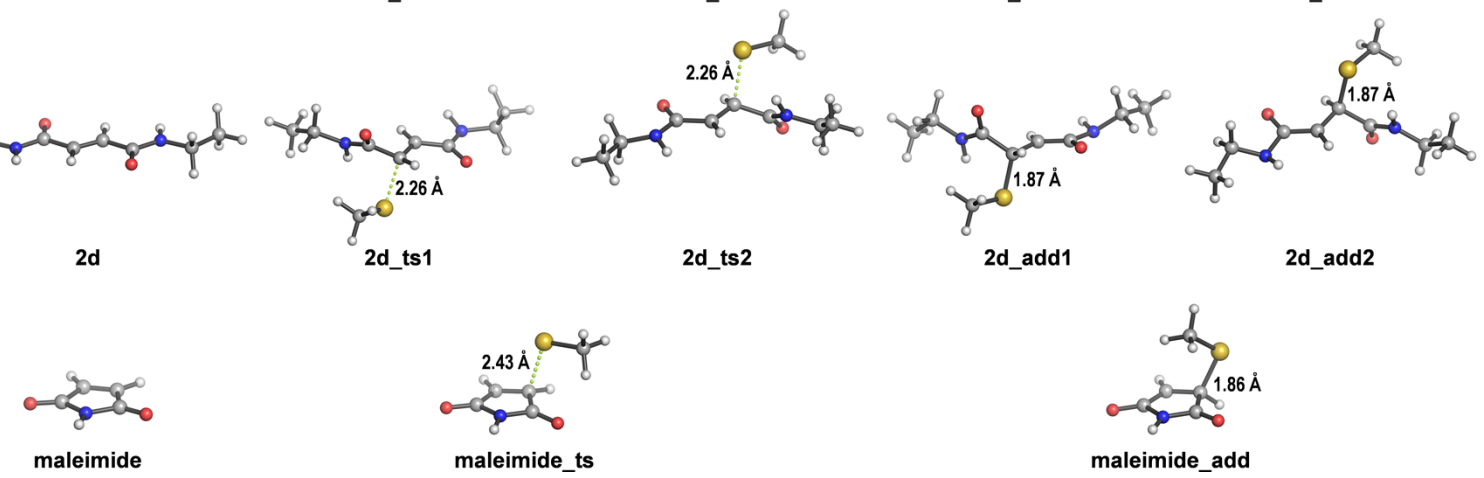

2d_add1

2d_add2

Figura 85 Estruturas calculadas (menor energia) para os compostos 174, 178-180 e maleimida. 
Tabela 10 Energias, entropias e frequências das estruturas calculadas de menor energia. ${ }^{a}$

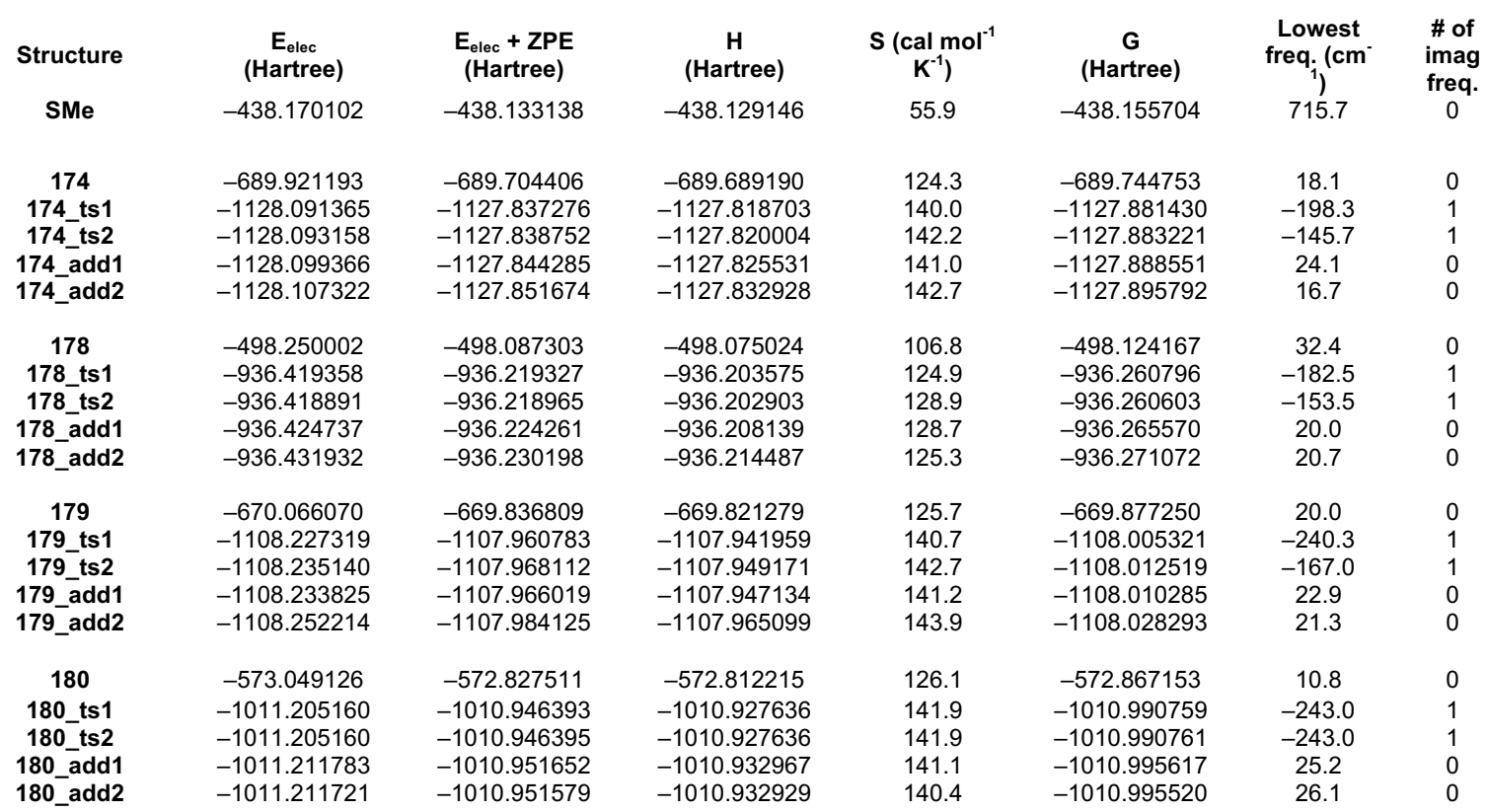

${ }^{a}$ Valores de energia calculados $\mathrm{PCM}_{\text {water }} / \mathrm{M} 06-2 \mathrm{X} / 6-31+G(\mathrm{~d}, \mathrm{p})$ level. 1 Hartree $=627.51 \mathrm{kcal} \mathrm{mol}^{-1}$. Correções em $298.15 \mathrm{~K}$. 


\section{Coordenadas cartesianas}

\section{Structure 174}

$\begin{array}{llll}1.079713 & 0.894107 & -0.075052\end{array}$

$\begin{array}{llll}-0.116645 & 0.011037 & -0.251271\end{array}$

$0.008814-1.007925-0.604077$

$\begin{array}{lll}-1.340121 & 0.473302 & 0.011181\end{array}$

$\begin{array}{llll}-1.501480 & 1.485914 & 0.367635\end{array}$

$-2.532726-0.397569-0.178831$

$\begin{array}{lll}-3.655758 & 0.248530 & 0.133705\end{array}$

$-4.885546-0.493230-0.013120$

$-4.970269-0.813488-1.054957$

$\begin{array}{llll}-4.826600 & -1.383298 & 0.618845\end{array}$

$\begin{array}{llll}-6.016214 & 0.422931 & 0.395651\end{array}$

$\begin{array}{llll}-6.045920 & 1.309661 & -0.241955\end{array}$

$\begin{array}{llll}-6.966452 & -0.106976 & 0.296403\end{array}$

$\begin{array}{lll}-5.902525 & 0.738314 & 1.435523\end{array}$

$-2.497023-1.546994-0.568302$

$2.431199 \quad 0.266844 \quad-0.004215$

$2.605653-1.101198 \quad 0.238282$

$\begin{array}{llll}3.553096 & 1.091958 & -0.161334\end{array}$

$\begin{array}{llll}3.889966 & -1.635638 & 0.324526\end{array}$

$\begin{array}{llll}1.751416 & -1.754117 & 0.382444\end{array}$

$\begin{array}{llll}4.832510 & 0.554208 & -0.088632\end{array}$

$3.4035112 .150771-0.345766$

$\begin{array}{llll}5.001650 & -0.811380 & 0.155731\end{array}$

$\begin{array}{llll}4.020726 & -2.694228 & 0.522394\end{array}$

$\begin{array}{llll}5.698419 & 1.194371 & -0.221383\end{array}$

$6.000754-1.231305 \quad 0.214950$

$0.942080 \quad 2.105974-0.001347$

\section{Estrutura 174 ts 1}

$0.884411-0.813302 \quad 0.741885$ $\begin{array}{lll}-0.272241 & -0.082960 & 0.137701\end{array}$

$\begin{array}{lll}-0.118434 & 0.330923 & -0.855902\end{array}$

$\begin{array}{lll}-1.571289 & -0.510212 & 0.439831\end{array}$

$\begin{array}{lll}-1.761723 & -1.137484 & 1.301413\end{array}$

$\begin{array}{lll}-2.662697 & -0.023464 & -0.326511\end{array}$

$\begin{array}{lll}-3.870369 & -0.531460 & 0.082571\end{array}$

$-5.019997-0.107849-0.651916$

$\begin{array}{lll}-5.100169 & 0.982990 & -0.605097\end{array}$

$-4.903848-0.388976-1.703801$

$\begin{array}{lll}-6.228774 & -0.777642 & -0.031607\end{array}$

$\begin{array}{lll}-6.336032 & -0.487427 & 1.016974\end{array}$

$\begin{array}{lll}-7.134386 & -0.480175 & -0.566687\end{array}$

$\begin{array}{llll}-6.137891 & -1.865863 & -0.084364\end{array}$

$\begin{array}{llll}-2.614408 & 0.767763 & -1.279282\end{array}$

$0.756524-1.497703 \quad 1.750875$

$\begin{array}{llll}0.390582 & 1.814202 & 1.128984\end{array}$

$\begin{array}{lll}1.512462 & 2.528032 & -0.117533\end{array}$

$\begin{array}{llll}1.550643 & 3.611758 & 0.016393\end{array}$

$2.523065 \quad 2.121252-0.028216$

$\begin{array}{llll}1.139472 & 2.321466 & -1.126211\end{array}$

$\begin{array}{llll}2.229609 & -0.699275 & 0.083620\end{array}$

$2.373252-0.536486-1.297657$

$\begin{array}{llll}3.371223 & -0.787898 & 0.888378\end{array}$

$3.645223-0.463869-1.866335$

$1.500434-0.482698-1.940656$

$\begin{array}{llll}4.639435 & -0.691945 & 0.324231\end{array}$

$\begin{array}{llll}3.247620 & -0.917834 & 1.959245\end{array}$

$4.778111-0.531478-1.056955$

$\begin{array}{llll}3.748892 & -0.350050 & -2.940655\end{array}$

$\begin{array}{llll}5.519817 & -0.742090 & 0.957093\end{array}$

$\begin{array}{llll}5.766891 & -0.461743 & -1.499369\end{array}$

\section{Estrutura 174 ts2}

$\begin{array}{llll}-1.521881 & 0.448869 & -0.534581\end{array}$

$\begin{array}{lll}-0.444623 & -0.313734 & 0.054246\end{array}$

$\begin{array}{llll}-0.654269 & -1.076498 & 0.794826\end{array}$

$\begin{array}{llll}0.855908 & -0.007664 & -0.244848\end{array}$

$\begin{array}{llll}1.949867 & -0.895367 & 0.226656\end{array}$

$3.054493-0.752408-0.519450$

$4.216591-1.475482-0.081893$

$\begin{array}{llll}4.469294 & -1.137521 & 0.928999\end{array}$

$\begin{array}{llll}3.976751 & -2.541289 & -0.037296\end{array}$

$5.326230-1.186076-1.068456$ $5.540263-0.114868-1.106801$ $6.235114-1.710633-0.763919$

$5.049984-1.524872-2.070122$

$\begin{array}{lll}1.859536 & -1.702175 & 1.134356\end{array}$

$\begin{array}{lll}-1.325270 & 1.441773 & -1.253037\end{array}$

$1.0815450 .638079-1.086548$

$\begin{array}{llll}1.931460 & 1.808081 & 1.182106\end{array}$

$\begin{array}{lll}3.271227 & 2.266915 & 0.027718\end{array}$

$\begin{array}{llll}4.176968 & 1.685405 & 0.217575\end{array}$

$\begin{array}{llll}2.963178 & 2.077312 & -1.006427\end{array}$

$\begin{array}{llll}3.511409 & 3.329372 & 0.120391\end{array}$

$\begin{array}{llll}-2.940170 & 0.031566 & -0.249913\end{array}$

$\begin{array}{llll}-3.959816 & 0.973717 & -0.432390\end{array}$

$\begin{array}{llll}-3.275567 & -1.261915 & 0.168921\end{array}$

$\begin{array}{llll}-5.288137 & 0.636644 & -0.187430\end{array}$

$\begin{array}{llll}-3.691525 & 1.971550 & -0.764409\end{array}$

$\begin{array}{llll}-4.606849 & -1.604271 & 0.401957\end{array}$

$\begin{array}{lll}-2.504135 & -2.014933 & 0.293437\end{array}$

$\begin{array}{lll}-5.614741 & -0.655202 & 0.230059\end{array}$

$-6.069222 \quad 1.378456-0.321826$

$\begin{array}{lll}-4.856731 & -2.612915 & 0.715543\end{array}$

$\begin{array}{llll}-6.650293 & -0.921470 & 0.417656\end{array}$

\section{Estrutura 174_add1}

$\begin{array}{llll}1.380760 & 0.648206 & 0.626944\end{array}$

$\begin{array}{llll}0.220194 & 1.285009 & -0.120369\end{array}$

$0.228686 \quad 0.953551-1.162180$

$\begin{array}{llll}-1.035106 & 0.806696 & 0.521736\end{array}$

$\begin{array}{lll}-1.176507 & 0.954270 & 1.586505\end{array}$

$\begin{array}{llll}-1.988028 & 0.128025 & -0.225749\end{array}$

$\begin{array}{lll}-3.093651 & -0.271396 & 0.520838\end{array}$

$\begin{array}{llll}-4.118056 & -0.961737 & -0.185434\end{array}$

$-4.496693-0.334596-1.000177$

$\begin{array}{llll}-3.712240 & -1.875308 & -0.634051\end{array}$

$\begin{array}{llll}-5.217516 & -1.285332 & 0.807101\end{array}$

$\begin{array}{lll}-5.625642 & -0.369935 & 1.244537\end{array}$

$\begin{array}{lll}-6.029163 & -1.820288 & 0.306424\end{array}$

$-4.835944-1.915346 \quad 1.615413$

$-1.951915-0.161933-1.448558$

$\begin{array}{lll}1.956770 & 1.210247 & 1.547243\end{array}$

$0.315065 \quad 3.121656-0.142326$

$\begin{array}{llll}1.952604 & 3.372680 & -0.891265\end{array}$

$2.073517 \quad 4.441383-1.076226$

$2.740625 \quad 3.032564-0.216787$

$2.0227392 .839953-1.842964$

$\begin{array}{llll}1.776374 & -0.752510 & 0.239218\end{array}$

$1.054588-1.516044-0.689507$

$2.929779-1.290104 \quad 0.823047$

$\begin{array}{llll}1.488410 & -2.798718 & -1.020328\end{array}$

$0.142105-1.128274-1.136847$

$\begin{array}{llll}3.363642 & -2.569407 & 0.485266\end{array}$

$3.479863-0.689665 \quad 1.540439$

$2.641962-3.326902-0.438344$

$0.921908-3.389080-1.733792$

$\begin{array}{llll}4.261980 & -2.974996 & 0.939965\end{array}$

$2.976472-4.325251-0.703124$ 
Estrutura 174_add2

$\begin{array}{lrrr}\text { C } & -1.192729 & -0.324172 & 0.664679 \\ \text { C } & -0.186168 & -0.344336 & -0.283906 \\ \text { H } & -0.386262 & -0.161203 & -1.333598 \\ \text { C } & 1.205124 & -0.719061 & 0.103878 \\ \text { C } & 2.178490 & 0.262996 & -0.515953 \\ \text { O } & 2.558336 & 1.193922 & 0.369533 \\ \text { C } & 3.398403 & 2.251938 & -0.131774 \\ \text { H } & 4.306533 & 1.807563 & -0.548213 \\ \text { H } & 2.866134 & 2.765348 & -0.937560 \\ \text { C } & 3.700044 & 3.176188 & 1.026653 \\ \text { H } & 4.222567 & 2.640446 & 1.822992 \\ \text { H } & 4.337382 & 3.995266 & 0.684704 \\ \text { H } & 2.778922 & 3.600752 & 1.433302 \\ \text { O } & 2.549903 & 0.264807 & -1.672438 \\ \text { O } & -1.050459 & -0.617417 & 1.902987 \\ \text { H } & 1.292404 & -0.667974 & 1.191949 \\ \text { S } & 1.591661 & -2.444216 & -0.410353 \\ \text { C } & 3.318965 & -2.572750 & 0.142128 \\ \text { H } & 3.957597 & -1.888371 & -0.421645 \\ \text { H } & 3.397034 & -2.359325 & 1.210663 \\ \text { H } & 3.650610 & -3.596182 & -0.040128 \\ \mathrm{C} & -2.590336 & 0.050728 & 0.210094 \\ \text { C } & -3.678845 & -0.383345 & 0.976480 \\ \text { C } & -2.849420 & 0.823802 & -0.930699 \\ \text { C } & -4.988325 & -0.079025 & 0.605284 \\ \text { H } & -3.475670 & -0.964635 & 1.870224 \\ \mathrm{C} & -4.156504 & 1.136157 & -1.302008 \\ \text { H } & -2.023931 & 1.203451 & -1.525127 \\ \text { C } & -5.233414 & 0.681950 & -0.538194 \\ \text { H } & -5.818222 & -0.433826 & 1.209779 \\ \text { H } & -4.334521 & 1.743163 & -2.184935 \\ \text { H } & -6.251104 & 0.926056 & -0.827388\end{array}$

\section{Estrutura 178}

$\begin{array}{llll}2.964902 & 0.056396 & -0.000075\end{array}$ $1.599268-0.544088-0.000051$ $1.562600-1.631046-0.000054$ $\begin{array}{llll}0.470007 & 0.167817 & -0.000054\end{array}$ $\begin{array}{llll}0.453266 & 1.253277 & -0.000051\end{array}$ $\begin{array}{lll}-0.850753 & -0.522852 & 0.000011\end{array}$ $\begin{array}{llll}-1.852513 & 0.355994 & 0.000447\end{array}$ $\begin{array}{lll}-3.188234 & -0.192305 & 0.000727\end{array}$ $\begin{array}{llll}-3.300176 & -0.822324 & -0.885602\end{array}$ $\begin{array}{lll}-3.300673 & -0.820422 & 0.888367\end{array}$ $\begin{array}{llll}-4.152929 & 0.971259 & -0.000784\end{array}$ $\begin{array}{llll}-4.012419 & 1.589775 & -0.890393\end{array}$ $\begin{array}{llll}-5.177690 & 0.592536 & -0.000649\end{array}$ $\begin{array}{llll}-4.012892 & 1.591669 & 0.887576\end{array}$ $\begin{array}{llll}-1.003408 & -1.726902 & -0.000154\end{array}$ $3.930976-0.688969-0.000335$ $\begin{array}{llll}3.115208 & 1.554904 & 0.000245\end{array}$ $\begin{array}{llll}2.634181 & 1.985243 & -0.882917\end{array}$ $\begin{array}{llll}2.634092 & 1.984780 & 0.883588\end{array}$ $\begin{array}{llll}4.174455 & 1.808735 & 0.000355\end{array}$
Estrutura 178_ts1

$\begin{array}{llll}2.032456 & 1.193717 & -0.385746\end{array}$ $\begin{array}{llll}0.887252 & 0.242802 & -0.418171\end{array}$

$\begin{array}{llll}-0.386700 & 0.633068 & -0.006403\end{array}$ $\begin{array}{llll}-0.543857 & 1.489458 & 0.638511\end{array}$ $\begin{array}{llll}-1.512798 & -0.179206 & -0.334587\end{array}$ $\begin{array}{llll}-2.688900 & 0.334559 & 0.140469\end{array}$ $\begin{array}{llll}-3.873176 & -0.410958 & -0.152659\end{array}$ $\begin{array}{llll}-3.985904 & -0.499709 & -1.237935\end{array}$ $\begin{array}{llll}-3.775713 & -1.421165 & 0.257517\end{array}$ $\begin{array}{lll}-5.040746 & 0.328392 & 0.466759\end{array}$ $\begin{array}{llll}-5.126994 & 1.334918 & 0.048979\end{array}$ $\begin{array}{lll}-5.970208 & -0.210326 & 0.265147\end{array}$ $\begin{array}{llll}-4.916295 & 0.409569 & 1.549806\end{array}$ $\begin{array}{llll}-1.507387 & -1.236763 & -0.974247\end{array}$ $\begin{array}{llll}2.901216 & 1.152287 & -1.252680\end{array}$ $\begin{array}{llll}2.052649 & 2.263597 & 0.680887\end{array}$ $\begin{array}{llll}1.463571 & 3.116124 & 0.323417\end{array}$ $\begin{array}{lll}1.617206 & 1.914672 & 1.618136\end{array}$ $\begin{array}{lll}3.078930 & 2.595734 & 0.842696\end{array}$ $0.950244-0.485389-1.224466$ $2.056808-1.106070 \quad 1.040449$ $3.218588-1.836484-0.155648$ $3.749250-1.041554-0.689831$ $\begin{array}{llll}3.951749 & -2.453428 & 0.369130\end{array}$ $\begin{array}{llll}2.694515 & -2.462000 & -0.883227\end{array}$

\section{Estrutura 178 ts2}

$\begin{array}{lll}3.020778 & -0.303935 & 0.437303\end{array}$ $\begin{array}{llll}1.813540 & -0.745298 & -0.216760\end{array}$ $1.885772-1.424272-1.060117$ $\begin{array}{llll}0.588046 & -0.258001 & 0.167878\end{array}$ $\begin{array}{llll}-0.652056 & -0.877541 & -0.367638\end{array}$ $\begin{array}{lll}-1.702028 & -0.652778 & 0.436105\end{array}$ $\begin{array}{llll}-2.979595 & -1.101864 & -0.044203\end{array}$ $-3.184029-0.599509-0.995790$ $\begin{array}{llll}-2.932264 & -2.178590 & -0.228297\end{array}$ $\begin{array}{llll}-4.006337 & -0.752970 & 1.010577\end{array}$ $\begin{array}{lll}-4.027829 & 0.325482 & 1.187543\end{array}$ $\begin{array}{lll}-4.997737 & -1.069766 & 0.677807\end{array}$ $\begin{array}{llll}-3.779178 & -1.258653 & 1.952449\end{array}$ $-0.722909-1.553338-1.378186$ $\begin{array}{llll}3.031906 & 0.541845 & 1.347200\end{array}$ $\begin{array}{llll}4.335736 & -0.890484 & -0.039360\end{array}$ $\begin{array}{llll}5.004126 & -1.035905 & 0.812052\end{array}$ $\begin{array}{llll}4.201553 & -1.833672 & -0.572546\end{array}$ $\begin{array}{llll}4.811911 & -0.176594 & -0.720701\end{array}$ $\begin{array}{llll}0.492926 & 0.267388 & 1.112534\end{array}$ $\begin{array}{llll}-0.125446 & 1.868637 & -0.918827\end{array}$ $\begin{array}{llll}-1.363709 & 2.404789 & 0.312284\end{array}$ $\begin{array}{lll}-2.356584 & 2.015027 & 0.074400\end{array}$ $\begin{array}{lll}-1.090303 & 2.040878 & 1.308720\end{array}$ $\begin{array}{lll}-1.415401 & 3.495991 & 0.351738\end{array}$ 
Estrutura 178_add1

$\begin{array}{llll}1.796938 & 1.265556 & -0.233621\end{array}$

$\begin{array}{lll}1.099096 & -0.030394 & 0.140007\end{array}$

$\begin{array}{lll}0.977496 & -0.061286 & 1.228428\end{array}$

$\begin{array}{llll}-0.254245 & 0.014525 & -0.478299\end{array}$

$\begin{array}{llll}-0.344730 & 0.170362 & -1.547495\end{array}$

$\begin{array}{llll}-1.390858 & -0.132495 & 0.306189\end{array}$

$\begin{array}{lll}-2.574255 & -0.064948 & -0.429420\end{array}$

$\begin{array}{lll}-3.785337 & -0.188079 & 0.306013\end{array}$

$\begin{array}{lll}-3.810534 & -1.151372 & 0.827650\end{array}$

$\begin{array}{lll}-3.842957 & 0.599385 & 1.065856\end{array}$

$\begin{array}{lll}-4.931404 & -0.075138 & -0.680272\end{array}$

$-4.874723-0.867503-1.431860$

$\begin{array}{llll}-5.887318 & -0.163856 & -0.156757\end{array}$

$\begin{array}{llll}-4.906950 & 0.890621 & -1.192764\end{array}$

$\begin{array}{lll}-1.467611 & -0.308763 & 1.547677\end{array}$

$\begin{array}{llll}2.517974 & 1.384897 & -1.211373\end{array}$

$\begin{array}{llll}1.509655 & 2.436954 & 0.677653\end{array}$

$0.515123 \quad 2.362099 \quad 1.121720$

$2.247019 \quad 2.415468 \quad 1.489075$

$\begin{array}{lll}1.617444 & 3.376959 & 0.134420\end{array}$

$2.038925-1.530977-0.360567$

$\begin{array}{llll}3.627017 & -1.227881 & 0.472292\end{array}$

$\begin{array}{llll}4.245123 & -2.118734 & 0.349001\end{array}$

$\begin{array}{llll}4.137849 & -0.371787 & 0.027295\end{array}$

$\begin{array}{llll}3.470306 & -1.052513 & 1.539648\end{array}$

\section{Estrutura 178_add2}

$\begin{array}{lll}-2.313140 & -1.208738 & -0.157813\end{array}$

$\begin{array}{llll}-1.417053 & -0.456316 & 0.580326\end{array}$

$\begin{array}{llll}-1.432818 & -0.478859 & 1.665723\end{array}$

$\begin{array}{llll}-0.429190 & 0.438734 & -0.092839\end{array}$

$\begin{array}{llll}0.943685 & 0.199690 & 0.500125\end{array}$

$1.650109-0.662494-0.244617$

$\begin{array}{llll}2.927889 & -1.067907 & 0.282368\end{array}$

$\begin{array}{llll}3.548019 & -0.177426 & 0.417041\end{array}$

$\begin{array}{llll}2.769423 & -1.527300 & 1.262257\end{array}$

$3.537079-2.037813-0.705363$

$3.677871-1.561467-1.678738$

$4.511331-2.370182-0.338701$

$\begin{array}{llll}2.897237 & -2.914600 & -0.831740\end{array}$

$\begin{array}{llll}1.365801 & 0.668661 & 1.538427\end{array}$

$-2.394432-1.233142-1.436949$

$\begin{array}{llll}-3.296004 & -2.091504 & 0.602223\end{array}$

$\begin{array}{lll}-3.169183 & -3.132905 & 0.287025\end{array}$

$-3.170393-2.031977 \quad 1.686675$

$\begin{array}{lll}-4.320570 & -1.799160 & 0.347768\end{array}$

$\begin{array}{lll}-0.402720 & 0.189245 & -1.156831\end{array}$

$\begin{array}{lll}-0.918838 & 2.205979 & 0.060337\end{array}$

$\begin{array}{llll}0.475398 & 3.014901 & -0.780882\end{array}$

$\begin{array}{llll}1.402950 & 2.865743 & -0.223063\end{array}$

$0.586682 \quad 2.629266-1.796996$

$\begin{array}{llll}0.259773 & 4.083483 & -0.829569\end{array}$
Estrutura 179

$\begin{array}{llll}1.099401 & 0.895235 & -0.050887\end{array}$ $\begin{array}{llll}-0.096578 & 0.015216 & -0.218416\end{array}$

$0.025206-1.013130-0.543495$

$\begin{array}{llll}-1.322935 & 0.485358 & 0.015993\end{array}$

$\begin{array}{llll}-1.462504 & 1.513015 & 0.344230\end{array}$

$\begin{array}{lll}-2.522577 & -0.390100 & -0.167600\end{array}$

$\begin{array}{llll}-4.964992 & -0.519128 & -0.026896\end{array}$

$\begin{array}{llll}-5.059219 & -0.877153 & -1.057553\end{array}$

$\begin{array}{llll}-4.938236 & -1.401582 & 0.621130\end{array}$

$\begin{array}{llll}-6.127474 & 0.388927 & 0.340727\end{array}$

$\begin{array}{llll}-6.164732 & 1.262407 & -0.316553\end{array}$

$\begin{array}{llll}-7.069129 & -0.153904 & 0.238885\end{array}$

$\begin{array}{lll}-6.042974 & 0.733376 & 1.375457\end{array}$

$\begin{array}{lll}-2.433602 & -1.561621 & -0.542968\end{array}$

$\begin{array}{lll}2.452414 & 0.266052 & 0.003492\end{array}$

$\begin{array}{lll}2.629687 & -1.099728 & 0.256050\end{array}$

$3.572870 \quad 1.087430-0.180471$

$\begin{array}{llll}3.914670 & -1.635307 & 0.325933\end{array}$

$\begin{array}{llll}1.776834 & -1.749488 & 0.420940\end{array}$

$\begin{array}{llll}4.852884 & 0.548608 & -0.124593\end{array}$

$\begin{array}{llll}3.421603 & 2.144683 & -0.372438\end{array}$

$\begin{array}{llll}5.024646 & -0.814674 & 0.130206\end{array}$

$\begin{array}{llll}4.047246 & -2.692129 & 0.532149\end{array}$

$\begin{array}{llll}5.717167 & 1.186299 & -0.278574\end{array}$

$\begin{array}{lll}6.024078 & -1.235498 & 0.176529\end{array}$

$\begin{array}{llll}0.969718 & 2.108659 & 0.029060\end{array}$

$\begin{array}{lll}-3.702486 & 0.197005 & 0.105305\end{array}$

$\begin{array}{lll}-3.718948 & 1.160440 & 0.412193\end{array}$

Estrutura 179 ts1

$\begin{array}{llll}-1.069484 & 0.717264 & -0.935574\end{array}$ $\begin{array}{llll}0.316289 & 0.312193 & -0.532842\end{array}$

$0.615204-1.074551-0.413799$

$\begin{array}{llll}-0.173586 & -1.807088 & -0.296212\end{array}$

$1.955102-1.552485-0.337138$

$\begin{array}{llll}4.319105 & -0.990861 & 0.073163\end{array}$

$\begin{array}{llll}4.373870 & -1.526701 & 1.032269\end{array}$

$\begin{array}{llll}4.644882 & -1.693653 & -0.697845\end{array}$

$\begin{array}{lll}5.231725 & 0.227373 & 0.101983\end{array}$

$\begin{array}{llll}4.908975 & 0.939888 & 0.868778\end{array}$

$\begin{array}{llll}6.258790 & -0.068397 & 0.330185\end{array}$

$\begin{array}{llll}5.225065 & 0.739869 & -0.864426\end{array}$

$2.283922-2.766990-0.378435$

$\begin{array}{lll}-1.227634 & 1.584675 & -1.787735\end{array}$

$1.035608 \quad 0.902989-1.104300$

$\begin{array}{lll}0.487109 & 1.533676 & 1.214107\end{array}$

$\begin{array}{llll}0.885946 & 3.088467 & 0.357617\end{array}$

$\begin{array}{llll}0.064970 & 3.380206 & -0.303201\end{array}$

$\begin{array}{lll}1.039463 & 3.875728 & 1.098137\end{array}$

$\begin{array}{llll}1.800341 & 2.983358 & -0.234170\end{array}$

$\begin{array}{llll}-2.267174 & 0.051159 & -0.320553\end{array}$

$\begin{array}{llll}-2.219707 & -0.600988 & 0.917880\end{array}$

$\begin{array}{llll}-3.476864 & 0.104301 & -1.022180\end{array}$

$\begin{array}{lll}-3.368469 & -1.187443 & 1.444242\end{array}$

$-1.289852-0.636132 \quad 1.475746$

$\begin{array}{llll}-4.622413 & -0.492196 & -0.501169\end{array}$

$\begin{array}{llll}-3.504258 & 0.613664 & -1.980218\end{array}$

$\begin{array}{llll}-4.569506 & -1.137971 & 0.734808\end{array}$

$\begin{array}{lll}-3.326606 & -1.682280 & 2.409244\end{array}$

$\begin{array}{lll}-5.553970 & -0.453584 & -1.056724\end{array}$

$-5.461929-1.600002 \quad 1.145505$

$2.954193-0.585268-0.223951$

$\begin{array}{llll}2.656315 & 0.263138 & 0.249909\end{array}$ 
Estrutura 179 ts2

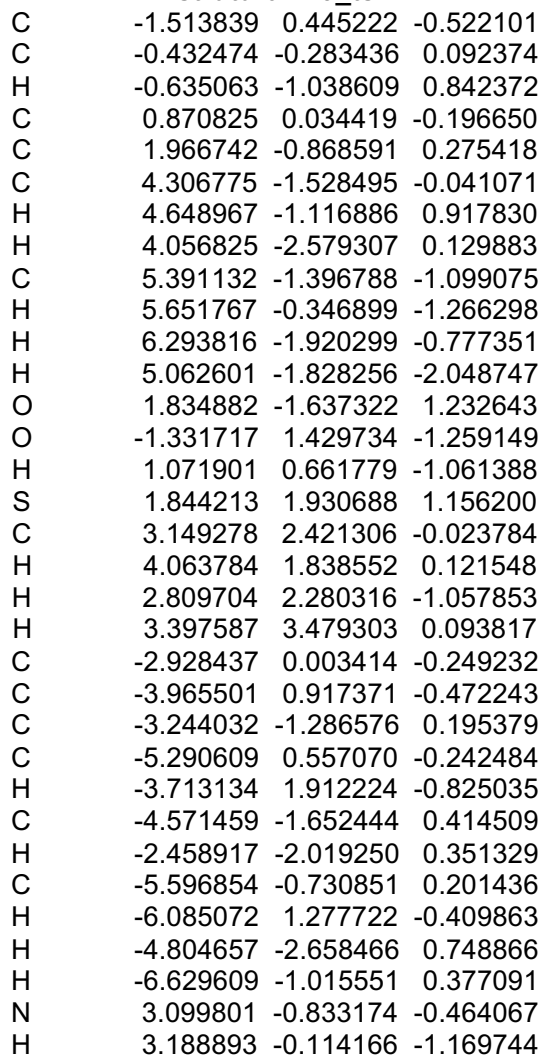

\section{Estrutura 179_add1}

$\begin{array}{llll}1.390421 & 0.654868 & 0.628154\end{array}$ $\begin{array}{llll}0.224253 & 1.275418 & -0.120211\end{array}$ $\begin{array}{llll}0.228058 & 0.939868 & -1.160704\end{array}$ $\begin{array}{lll}-1.020683 & 0.777141 & 0.527252\end{array}$

$\begin{array}{lll}-1.133823 & 0.909676 & 1.599713\end{array}$

$\begin{array}{lll}-1.957939 & 0.045512 & -0.204530\end{array}$

$\begin{array}{llll}-4.315113 & -0.670866 & -0.174286\end{array}$

$\begin{array}{llll}-4.730256 & 0.305855 & -0.473953\end{array}$

$-4.131487-1.232079-1.092260$

$\begin{array}{llll}-5.315775 & -1.405563 & 0.707151\end{array}$

$\begin{array}{lll}-5.499458 & -0.856373 & 1.636854\end{array}$

$\begin{array}{lll}-6.272953 & -1.518549 & 0.190901\end{array}$

$\begin{array}{llll}-4.941828 & -2.400079 & 0.967794\end{array}$

$-1.897441-0.197142-1.450371$

$\begin{array}{llll}1.956830 & 1.222177 & 1.552551\end{array}$

$\begin{array}{llll}0.292855 & 3.112899 & -0.145848\end{array}$

$\begin{array}{llll}1.928321 & 3.386646 & -0.891728\end{array}$

$2.036414 \quad 4.457171-1.074274$

$2.719217 \quad 3.054880-0.216374$

$2.007093 \quad 2.856649-1.844280$

$\begin{array}{llll}1.805650 & -0.740069 & 0.239437\end{array}$

$\begin{array}{llll}1.087051 & -1.517787 & -0.680233\end{array}$

$\begin{array}{llll}2.976264 & -1.255224 & 0.809178\end{array}$

$1.541579-2.792171-1.015614$

$0.162289-1.145954-1.117148$

$\begin{array}{llll}0.430494 & -2.526263 & 0.466417\end{array}$

$\begin{array}{llll}3.523795 & -0.643886 & 1.519335\end{array}$

$2.712295-3.298030-0.447992$

$0.977710-3.393788-1.721832$

$\begin{array}{llll}4.342282 & -2.914069 & 0.909805\end{array}$

$\begin{array}{llll}3.062823 & -4.289803 & -0.716834\end{array}$

$\begin{array}{lll}-3.040320 & -0.520024 & 0.516874\end{array}$

$\begin{array}{lll}-3.149334 & -0.097677 & 1.433297\end{array}$
Estrutura 179 add2

$\begin{array}{lll}-1.411328 & -0.758335 & 0.451206\end{array}$ $\begin{array}{llll}-0.226091 & -0.149340 & 0.083022\end{array}$ $\begin{array}{llll}-0.217361 & 0.779557 & -0.477063\end{array}$ $\begin{array}{llll}1.081246 & -0.805931 & 0.370782\end{array}$ $\begin{array}{llll}2.095318 & 0.215872 & 0.876639\end{array}$ $\begin{array}{llll}3.699247 & 1.983070 & 0.310913\end{array}$ $\begin{array}{llll}3.178271 & 2.759825 & 0.881390\end{array}$ $\begin{array}{llll}4.463105 & 1.556722 & 0.970574\end{array}$ $\begin{array}{llll}4.334978 & 2.570295 & -0.939387\end{array}$ $3.576725 \quad 3.010923-1.593329$ $\begin{array}{llll}5.045420 & 3.353244 & -0.666281\end{array}$ $4.873997 \quad 1.801474-1.501060$ $\begin{array}{llll}2.254808 & 0.400467 & 2.088701\end{array}$ $\begin{array}{lll}-1.510698 & -1.896891 & 1.031026\end{array}$ $0.945295-1.544546 \quad 1.165310$ $1.680360-1.724619-1.121083$ $\begin{array}{llll}3.228417 & -2.432043 & -0.479941\end{array}$ $3.028494-3.050050 \quad 0.398246$ $3.659428-3.056441-1.264125$ $3.939137-1.642330-0.222753$ $\begin{array}{lll}-2.708473 & -0.042208 & 0.128088\end{array}$ $\begin{array}{llll}-3.877420 & -0.802430 & 0.000512\end{array}$ $\begin{array}{llll}-2.801593 & 1.347608 & -0.033575\end{array}$ $\begin{array}{llll}-5.098655 & -0.201434 & -0.303570\end{array}$ $\begin{array}{llll}-3.807728 & -1.875782 & 0.145336\end{array}$ $\begin{array}{llll}-4.021461 & 1.953845 & -0.330989\end{array}$ $\begin{array}{llll}-1.918069 & 1.965769 & 0.094135\end{array}$ $\begin{array}{llll}-5.175970 & 1.181472 & -0.472261\end{array}$ $\begin{array}{llll}-5.991291 & -0.811859 & -0.406662\end{array}$ $\begin{array}{llll}-4.072774 & 3.032930 & -0.443611\end{array}$ $\begin{array}{llll}-6.125955 & 1.653983 & -0.702826\end{array}$ $\begin{array}{llll}2.750210 & 0.939723 & -0.049007\end{array}$ $2.6239090 .691167-1.023346$

\section{Estrutura 180}

$-1.860855-0.480712-0.001292$ $\begin{array}{llll}-0.590764 & 0.307304 & -0.000943\end{array}$ $\begin{array}{lll}-0.636935 & 1.393823 & 0.000610\end{array}$ $\begin{array}{llll}0.590759 & -0.307270 & -0.002505\end{array}$ $\begin{array}{llll}0.636910 & -1.393794 & -0.003997\end{array}$ $\begin{array}{llll}1.860849 & 0.480732 & -0.002157\end{array}$ $\begin{array}{llll}4.307986 & 0.364446 & -0.003629\end{array}$ $\begin{array}{llll}4.397556 & 1.001552 & -0.889951\end{array}$ $\begin{array}{llll}4.390850 & 1.016076 & 0.872571\end{array}$ $\begin{array}{llll}5.391517 & -0.701806 & 0.009042\end{array}$ $\begin{array}{llll}5.320189 & -1.342776 & -0.874416\end{array}$ $\begin{array}{llll}6.376341 & -0.230733 & 0.008684\end{array}$ $\begin{array}{llll}5.313474 & -1.328166 & 0.902312\end{array}$ $\begin{array}{llll}1.875148 & 1.714716 & -0.001221\end{array}$ $-1.875155-1.714660-0.003279$ $2.988847-0.254726-0.002453$ $2.924191-1.263962-0.005859$ $\begin{array}{llll}-2.924203 & 1.263951 & 0.002480\end{array}$ $\begin{array}{lll}-2.988838 & 0.254705 & 0.000702\end{array}$ $\begin{array}{llll}-4.307966 & -0.364505 & 0.000833\end{array}$ $-4.395140-1.007069-0.881699$ $\begin{array}{llll}-4.393204 & -1.010711 & 0.880892\end{array}$ $\begin{array}{llll}-5.391524 & 0.701788 & 0.004218\end{array}$ $\begin{array}{llll}-5.317833 & 1.337311 & -0.882951\end{array}$ $\begin{array}{lll}-6.376342 & 0.230705 & 0.004327\end{array}$ $\begin{array}{lll}-5.315868 & 1.333626 & 0.893848\end{array}$ 
Estrutura 180 ts 1

$1.579449-0.196323 \quad 0.915134$

$\begin{array}{llll}0.305914 & 0.513514 & 0.542114\end{array}$

$\begin{array}{lll}-0.788249 & -0.276245 & 0.165928\end{array}$

$\begin{array}{llll}-0.632130 & -1.239445 & -0.311467\end{array}$

$\begin{array}{llll}-2.121546 & 0.247322 & 0.263430\end{array}$

$\begin{array}{lll}-4.530104 & -0.274100 & 0.112959\end{array}$

$\begin{array}{lll}-4.709597 & -0.313622 & 1.197371\end{array}$

$\begin{array}{llll}-4.739782 & 0.750269 & -0.205525\end{array}$

$\begin{array}{llll}-5.448766 & -1.252569 & -0.604815\end{array}$

$\begin{array}{llll}-5.249074 & -2.282276 & -0.290546\end{array}$

$-6.493757-1.029279-0.376939$

$-5.310026-1.191271-1.688066$

$\begin{array}{llll}-2.406993 & 1.381853 & 0.713387\end{array}$

$\begin{array}{lll}2.052010 & -0.098776 & 2.053585\end{array}$

$\begin{array}{llll}0.091062 & 1.336907 & 1.217142\end{array}$

$1.100059 \quad 1.853383-1.101752$

$\begin{array}{llll}2.658261 & 2.398791 & -0.321885\end{array}$

$\begin{array}{llll}3.363470 & 1.565957 & -0.232692\end{array}$

$\begin{array}{llll}3.124612 & 3.182452 & -0.923319\end{array}$

$\begin{array}{llll}2.467221 & 2.801354 & 0.677505\end{array}$

$\begin{array}{llll}3.389327 & -1.683786 & 0.197026\end{array}$

$\begin{array}{llll}3.714207 & -2.580379 & -0.987745\end{array}$

$\begin{array}{llll}4.197161 & -0.959321 & 0.365071\end{array}$

$2.925733-3.322534-1.140928$

$\begin{array}{llll}-3.140429 & -0.569198 & -0.193235\end{array}$

$-2.907974-1.544016-0.332080$

$2.134414-0.982806-0.030453$

$\begin{array}{llll}1.837026 & -0.813442 & -0.984712\end{array}$

$3.290828 \quad-2.272746 \quad 1.113314$

$3.820577-1.993614-1.905403$

$\begin{array}{llll}4.654704 & -3.107437 & -0.813532\end{array}$

\section{Estrutura 180 ts2}

$\begin{array}{lll}2.121496 & 0.24 \overline{7} 281 & 0.263537\end{array}$

$\begin{array}{llll}0.788195 & -0.276294 & 0.166164\end{array}$

$\begin{array}{llll}0.632043 & -1.239547 & -0.311116\end{array}$

$\begin{array}{lll}0.305965 & 0.513560 & 0.542155\end{array}$

$\begin{array}{lll}-1.579540 & -0.196190 & 0.915186\end{array}$

$\begin{array}{llll}-3.389392 & -1.683741 & 0.197045\end{array}$

$\begin{array}{lll}-3.290811 & -2.272766 & 1.113283\end{array}$

$\begin{array}{llll}-4.197285 & -0.959361 & 0.365161\end{array}$

$\begin{array}{llll}-3.714225 & -2.580267 & -0.987792\end{array}$

$-2.925709-3.322367-1.141033$

$-4.654693-3.107391-0.813620$

$\begin{array}{llll}-3.820626 & -1.993439 & -1.905406\end{array}$

$\begin{array}{llll}-2.052057 & -0.098671 & 2.053665\end{array}$

$\begin{array}{lll}2.406960 & 1.381892 & 0.713273\end{array}$

$\begin{array}{lll}-0.091193 & 1.337093 & 1.217052\end{array}$

$\begin{array}{llll}-1.099989 & 1.852975 & -1.101988\end{array}$

$\begin{array}{llll}-2.657797 & 2.399111 & -0.321894\end{array}$

$\begin{array}{lll}-2.466361 & 2.801895 & 0.677333\end{array}$

$\begin{array}{llll}-3.124064 & 3.182750 & -0.923419\end{array}$

$\begin{array}{llll}-3.363216 & 1.566513 & -0.232273\end{array}$

$\begin{array}{lll}4.530060 & -0.274235 & 0.113096\end{array}$

$\begin{array}{llll}5.448702 & -1.252458 & -0.605039\end{array}$

$\begin{array}{llll}4.739592 & 0.750225 & -0.205179\end{array}$

$6.493699-1.029268-0.377092$

$\begin{array}{llll}-2.134558 & -0.982618 & -0.030428\end{array}$

$\begin{array}{llll}-1.837162 & -0.813270 & -0.984684\end{array}$

$3.140364-0.569352-0.192981$

$2.907876-1.544187-0.331663$

$\begin{array}{llll}4.709716 & -0.313998 & 1.197475\end{array}$

$\begin{array}{llll}5.249001 & -2.282276 & -0.291137\end{array}$

$5.309947-1.190774-1.688265$
Estrutura 180_add1

$\begin{array}{lll}1.491360 & -0.309105 & 0.842074\end{array}$

$\begin{array}{llll}0.397112 & 0.630928 & 0.347774\end{array}$

$\begin{array}{llll}-0.771831 & -0.130340 & -0.153907\end{array}$

$\begin{array}{llll}-0.603640 & -0.950458 & -0.846902\end{array}$

$\begin{array}{lll}-2.068265 & 0.292937 & 0.140338\end{array}$

$\begin{array}{lll}-4.384956 & -0.538882 & 0.237391\end{array}$

$\begin{array}{llll}-4.241351 & -1.087571 & 1.183443\end{array}$

$\begin{array}{llll}-4.729114 & 0.462681 & 0.502165\end{array}$

$\begin{array}{llll}-5.427671 & -1.249582 & -0.614480\end{array}$

$\begin{array}{llll}-5.091337 & -2.254540 & -0.891584\end{array}$

$-6.368570-1.351155-0.066831$

$-5.620104-0.689854-1.534583$

$\begin{array}{llll}-2.383691 & 1.258320 & 0.903809\end{array}$

$\begin{array}{lll}1.588275 & -0.600700 & 2.040299\end{array}$

$\begin{array}{llll}0.093863 & 1.242558 & 1.201371\end{array}$

$\begin{array}{llll}1.040878 & 1.820339 & -0.942050\end{array}$

$2.436355 \quad 2.577812-0.052432$

$\begin{array}{llll}3.207960 & 1.834199 & 0.164561\end{array}$

$\begin{array}{llll}2.861876 & 3.354620 & -0.689846\end{array}$

$\begin{array}{llll}2.091387 & 3.032380 & 0.879228\end{array}$

$\begin{array}{llll}-3.132835 & -0.402537 & -0.497311\end{array}$

$\begin{array}{llll}-2.824129 & -1.288896 & -0.884006\end{array}$

$\begin{array}{llll}3.348965 & -1.797957 & 0.246225\end{array}$

$\begin{array}{llll}2.899133 & -2.668322 & 0.735990\end{array}$

$\begin{array}{llll}4.030782 & -1.337749 & 0.970721\end{array}$

$\begin{array}{llll}4.101722 & -2.216531 & -1.007094\end{array}$

$4.569875-1.352645-1.488543$

$\begin{array}{llll}4.887736 & -2.930221 & -0.751741\end{array}$

$3.428547-2.692275-1.726253$

$2.298175-0.849284-0.090305$

$2.222251-0.502060-1.039280$

\section{Estrutura 180_add2}

$\begin{array}{llll}2.055596 & 0.129108 & 0.360794\end{array}$ $\begin{array}{llll}0.763736 & -0.214175 & -0.035451\end{array}$

$0.589512-1.080368-0.667752$

$\begin{array}{llll}-0.395769 & 0.609194 & 0.385709\end{array}$

$\begin{array}{lll}-1.550915 & -0.271031 & 0.850075\end{array}$

$\begin{array}{llll}-3.432968 & -1.707464 & 0.205542\end{array}$

$\begin{array}{llll}-3.038339 & -2.577744 & 0.740958\end{array}$

$\begin{array}{llll}-4.131900 & -1.203156 & 0.882793\end{array}$

$\begin{array}{llll}-4.138900 & -2.136902 & -1.071051\end{array}$

$-3.449570-2.657486-1.742235$

$-4.962074-2.814375-0.834861$ $-4.550902-1.271860-1.599388$

$\begin{array}{lll}-1.715932 & -0.525064 & 2.049535\end{array}$

$\begin{array}{lll}2.380587 & 1.149697 & 1.044995\end{array}$

$\begin{array}{lll}-0.110194 & 1.234042 & 1.236106\end{array}$

$\begin{array}{llll}-0.920322 & 1.781144 & -0.968979\end{array}$

$\begin{array}{llll}-2.325812 & 2.623121 & -0.176529\end{array}$

$\begin{array}{llll}-2.009944 & 3.092005 & 0.758379\end{array}$

$\begin{array}{llll}-2.683586 & 3.396670 & -0.857993\end{array}$

$\begin{array}{lll}-3.139274 & 1.919832 & 0.021009\end{array}$

$\begin{array}{llll}-2.334142 & -0.805626 & -0.105424\end{array}$

$\begin{array}{llll}-2.198750 & -0.491287 & -1.059195\end{array}$

$2.806042-1.415986-0.721477$

$\begin{array}{llll}4.410054 & -0.196128 & -0.283654\end{array}$

$\begin{array}{llll}4.364465 & 0.513812 & -1.126728\end{array}$

$\begin{array}{lll}4.726722 & 0.372885 & 0.592456\end{array}$

$\begin{array}{llll}5.416931 & -1.295406 & -0.593106\end{array}$

$5.106071-1.879569-1.466021$

$\begin{array}{llll}6.399694 & -0.867844 & -0.809621\end{array}$

$\begin{array}{llll}5.514957 & -1.978580 & 0.255745\end{array}$

$\begin{array}{lll}3.100324 & -0.769839 & 0.004178\end{array}$ 
Estrutura maleimida

C $\quad \begin{array}{llll}0.666400 & 1.268488 & -0.000161\end{array}$

$\begin{array}{lllll}\text { C } & 0.666336 & 1.268481 & 0.000155\end{array}$

$\begin{array}{lll}1.144111 & -0.157311 & 0.000023\end{array}$

$\begin{array}{llll}1.1 .144125 & -0.157279 & -0.000081\end{array}$

$-0.000153-1.954748-0.000190$

$\begin{array}{llll}1.353107 & 2.103957 & 0.000218\end{array}$

$-0.000016-0.942973-0.000095$

$\begin{array}{lll}-2.284949 & -0.561691 & 0.000159\end{array}$

$2.285048-0.561640 \quad 0.000010$

$\begin{array}{llll}-1.353172 & 2.103976 & -0.000335\end{array}$

\section{Estrutura maleimida ts}

$\begin{array}{lll}-0.149348 & -0.17937 \overline{7} & 1.149359\end{array}$

$\begin{array}{lll}-1.332339 & -0.856683 & 0.937447\end{array}$

$\begin{array}{llll}-2.015889 & -0.244899 & -0.178317\end{array}$

$\begin{array}{lll}-0.162914 & 1.041975 & 0.275370\end{array}$

$\begin{array}{lll}-1.550360 & 1.559457 & -1.239208\end{array}$

$\begin{array}{lll}-1.684478 & -1.753504 & 1.425263\end{array}$

$\begin{array}{llll}-1.242833 & 0.872881 & -0.564489\end{array}$

$\begin{array}{llll}0.566752 & 2.021903 & 0.319685\end{array}$

$\begin{array}{lll}-3.069578 & -0.542820 & -0.742031\end{array}$

$\begin{array}{llll}0.473578 & -0.207335 & 2.031604\end{array}$

$1.608118-1.102023-0.258390$

$\begin{array}{llll}2.986082 & 0.084468 & -0.415220\end{array}$

$\begin{array}{llll}3.747236 & -0.076055 & 0.351958\end{array}$

$3.455813-0.010237-1.397900$

$2.597218 \quad 1.104308-0.319115$

\section{Estrutura maleimida_add}

$\begin{array}{llll}0.346249 & 0.087045 & 0.974072\end{array}$

$\begin{array}{lll}-0.766590 & -0.899055 & 0.937692\end{array}$

$\begin{array}{llll}-1.754526 & -0.472559 & 0.075196\end{array}$

$\begin{array}{lll}-0.156330 & 1.237814 & 0.085026\end{array}$

$\begin{array}{llll}-1.895200 & 1.383194 & -1.063647\end{array}$

$\begin{array}{llll}-0.779361 & -1.837368 & 1.473618\end{array}$

$\begin{array}{lll}-1.326793 & 0.823522 & -0.441905\end{array}$

$\begin{array}{llll}0.406825 & 2.310883 & -0.120487\end{array}$

$\begin{array}{lll}-2.861750 & -0.933000 & -0.310136\end{array}$

$\begin{array}{lll}0.615768 & 0.485695 & 1.958527\end{array}$

$\begin{array}{lll}1.987994 & -0.499611 & 0.319520\end{array}$

$1.493700-0.917727-1.373862$

$0.557994-1.482951-1.342806$

$1.366659-0.017467-1.979715$

$2.278171-1.538159-1.808719$ 


\section{Referências}

1 CURTIUS, T. Ueber die einwirkung von salpetriger säure auf salzsauren glycocolläther. Berichte der deutschen chemischen Gesellschaft, v. 16, n. 2, p. 2230-2231, 1883.

2 WOLFF, L.; KRÜCHE, R. Über diazoanhydride (1,2,3-oxydiazole oder diazoxyde) und diazoketone. Justus Liebigs Annalen der Chemie, v. 394, n. 1, p. 23-59, 1912.

3 WOLFF, L. Ueber diazoanhydride. Justus Liebigs Annalen der Chemie, v. 325, n. 2, p. 129-195, 1902.

4 ARNDT, F.; EISTERT, B.; PARTALE, W. Diazo-methan und o-nitroverbindungen, II.: $\mathrm{N}$-oxy-isatin aus o-nitro-benzoylchlorid. Berichte der deutschen chemischen Gesellschaft (A and B Series), v. 60, n. 6, p. 1364-1370, 1927.

5 REGITZ, M. New methods of preparative organic chemistry. Transfer of diazo groups. Angewandte Chemie International Edition in English, v. 6, n. 9, p. 733-749, 1967.

6 YE, T.; MCKERVEY, M.A. Organic synthesis with a-diazo carbonyl compounds. Chemical Reviews, v. 94, n. 4, p. 1091-1160, 1994.

7 REGITZ, M.; MAAS, G. Diazo compounds: properties and synthesis. Orlando, Florida: Academic Press, 1987. 608 p.

8 DOYLE, M.P.; MCKERVEY, M.A.; YE, T. Modern catalytic methods for organic synthesis with diazo compounds: from cyclopropanes to ylides. New York: WileyInterscience, 1998. 652 p.

9 SINGH, G.S. Reactions of organic nitrogen compounds with carbenoids and diarylketenes from diazoalkanes and diazocarbonyls. Current Organic Synthesis, v. 2, n. 3, p. 377-391, 2005.

10 FERREIRA, V.F. Synthesis of heterocyclic compounds by carbenoid transfer reactions. Current Organic Chemistry, v. 11, n. 2, p. 177-193, 2007.

11 ZHANG, Z.; WANG, J. Recent studies on the reactions of a-diazocarbonyl compounds. Tetrahedron, v. 64, n. 28, p. 6577-6605, 2008.

12 GILLINGHAM, D.; FEI, N. Catalytic $\mathrm{X}-\mathrm{H}$ insertion reactions based on carbenoids. Chemical Society Reviews, v. 42, n. 12, p. 4918-4931, 2013.

13 MAAS, G. New syntheses of diazo compounds. Angewandte Chemie International Edition, v. 48, n. 44, p. 8186-8195, 2009.

14 GRUNDMANN, C. Ein neues verfahren zur überführung von carbonsäuren in aldehyde. Justus Liebigs Annalen der Chemie, v. 524, n. 1, p. 31-48, 1936.

15 WOTIZ, J.H.; BUCO, S.N. The arnt-eistert synthesis of unsaturated acids. The Journal of Organic Chemistry, v. 20, n. 2, p. 210-214, 1955.

16 MOORE, J.A. The reactions of alpha, beta-unsaturated acid chlorides with diazomethane. The Journal of Organic Chemistry, v. 20, n. 11, p. 1607-1612, 1955. 
17 ROSENQUIST, N.R.; CHAPMAN, O.L. A general method for the synthesis of reactive alpha,beta-unsaturated diazomethyl ketones: allenyl diazomethyl ketone and vinyl diazomethyl ketone. The Journal of Organic Chemistry, v. 41, n. 20, p. 33263327, 1976.

18 REGITZ, M.; MENZ, F.; LIEDHEGENER, A. Reaktionen CH-aktiver verbindungen mit aziden, XXVIII 1) synthese $\alpha . \beta$-ungesättigter diazoketone durch entformylierende diazogruppen-übertragung. Justus Liebigs Annalen der Chemie, v. 739, n. 1, p. 174184, 1970.

19 REGITZ, M.; HECK, G. Synthesen und einige Umsetzungen des 2-Diazo- und des 2-Hydroxy-indandions-(1.3). Chemische Berichte, v. 97, n. 5, p. 1482-1501, 1964.

20 REGITZ, M. Reaktionen aktiver methylenverbindungen mit aziden, i. eine neue synthese für $\alpha$-diazo- $\beta$-dicarbonylverbindungen aus benzolsulfonylaziden und $\beta$ diketonen. Justus Liebigs Annalen der Chemie, v. 676, n. 1, p. 101-109, 1964.

21 HARMON, R.E.; SOOD, V.K.; GUPTA, S.K. A new synthesis of $\alpha, \beta$-unsaturated diazo-ketones: an improved synthesis of 4-diazo-3-oxo-1-phenyl-1-butene (diazomethyl styryl ketone). Synthesis, v. 1974, n. 08, p. 577-578, 1974.

22 DANHEISER, R.L.; MILLER, R.F.; BRISBOIS, R.G.; PARK, S.Z. An improved method for the synthesis of .alpha.-diazo ketones. The Journal of Organic Chemistry, v. 55, n. 6 , p. 1959-1964, 1990.

23 DANHEISER, R.L.; MILLER, R.F.; BRISBOIS, R.G. Detrifluoroacetylative diazo group transfer: (e)-1-diazo-4-phenyl-3-buten-2-one. Organic Syntheses, v. 73, p. 134, 1996.

24 DOYLE, M.P.; DOROW, R.L.; TERPSTRA, J.W.; RODENHOUSE, R.A. Synthesis and catalytic reactions of chiral $\mathrm{N}$-(diazoacetyl)oxazolidones. The Journal of Organic Chemistry, v. 50, n. 10, p. 1663-1666, 1985.

25 ALLER, E.; MOLINA, P.; LORENZO, Á. N-Isocyanotriphenyliminophosphorane; a convenient reagent for the conversion of acyl chlorides into alpha-diazoketones. Synlett, v. 4 , p. $526-528,2000$.

26 BETHÄUSER, W.; REGITZ, M.; THEIS, W. Über die reaktivität von 4-phenyl-1,2,4triazolin-3,5-dion mit diazoverbindungen. Tetrahedron Letters, v. 22, n. 27, p. 25352538, 1981.

27 FANG, F.G.; PRATO, M.; KIM, G.; DANISHEFSKY, S.J. The aza-robinson annulation: An application to the synthesis of iso-A58365A. Tetrahedron Letters, v. 30, n. 28, p. 3625-3628, 1989.

28 CLARK, J.S.; HODGSON, P.B.; GOLDSMITH, M.D.; STREET, L.J. Rearrangement of ammonium ylides produced by intramolecular reaction of catalytically generated metal carbenoids. Part 1. Synthesis of cyclic amines. Journal of the Chemical Society, Perkin Transactions 1, n. 24, p. 3312-3324, 2001.

29 CECCHERELLI, P.; CURINI, M.; MARCOTULLIO, M.C.; ROSATI, O.; WENKERT, E. A new, general cyclopentenone synthesis. The Journal of Organic Chemistry, v. 55, n. 1, p. 311-315, 1990. 
30 FRANCK-NEUMANN, M.; GEOFFROY, P.; WINLING, A. Tricarbonyl iron complexes bearing a free diazo group. II diene and trimethylenemethane diazoketone complexes as precursors of highly reactive ketocarbenes and diazonium cations. Tetrahedron letters, v. 36, n. 45, p. 8213-8216, 1995.

31 DANHEISER, R.L.; BRISBOIS, R.G.; KOWALCZYK, J.J.; MILLER, R.F. An annulation method for the synthesis of highly substituted polycyclic aromatic and heteroaromatic compounds. Journal of the American Chemical Society, v. 112, n. 8 , p. 3093-3100, 1990.

32 LOEBACH, J.L.; BENNETT, D.M.; DANHEISER, R.L. (Trialkylsilyl)vinylketenes: synthesis and application as diene components in Diels-Alder cycloadditions. The Journal of Organic Chemistry, v. 63, n. 23, p. 8380-8389, 1998.

33 CAINELLI, G.; GIACOMINI, D.; GALLETTI, P.; QUINTAVALLA, A. Synthesis of novel 4-(2-oxoethylidene)azetidin-2-ones by a Lewis acid mediated reaction of acyldiazo compounds. European Journal of Organic Chemistry, v. 2003, n. 9, p. 1765-1774, 2003.

34 IHARA, E.; FUJIOKA, M.; HAIDA, N.; ITOH, T.; INOUE, K. First synthesis of poly(acylmethylene)s via palladium-mediated polymerization of diazoketones.

Macromolecules, v. 38, n. 6, p. 2101-2108, 2005.

35 KAPFERER, T.; BRÜCKNER, R. Asymmetric dihydroxylation of $\beta, \gamma$-unsaturated carboxylic esterswith trisubstituted $\mathrm{C}=\mathrm{C}$ bonds - enantioselective syntheses of trisubstituted $y$-butyrolactones. European Journal of Organic Chemistry, v. 2006, n. 9, p. 2119-2133, 2006.

36 DENG, Y.; LEE, Y.R.; NEWMAN, C.A.; WULFF, W.D. Aziridinyl vinyl ketones from the asymmetric catalytic aziridination reaction. European Journal of Organic Chemistry, v. 2007, n. 13, p. 2068-2071, 2007.

37 SOSA, J.R.; TUDJARIAN, A.A.; MINEHAN, T.G. Synthesis of alkynyl ethers and low-temperature sigmatropic rearrangement of allyl and benzyl alkynyl ethers. Organic Letters, v. 10, n. 21, p. 5091-5094, 2008.

38 CAO, P.; SUN, X.-L.; ZHU, B.-H.; SHEN, Q.; XIE, Z.; TANG, Y. Multistep one-pot wittig/nazarov reaction for construction of cyclopentenone with diazo compounds and acid chlorides. Organic Letters, v. 11, n. 14, p. 3048-3051, 2009.

39 ZHANG, X.; GUO, X.; YANG, L.P.; HU, W.H. Rh(II) and Zn(II) co-catalyzed multicomponent reaction for the synthesis of vicinal diols. Chinese Chemical Letters, v. 20, n. 11, p. 1299-1302, 2009.

40 WANG, C.-D.; LIU, R.-S. Silver-catalyzed [3+2]-cycloaddition of benzynes with diazocarbonyl species via a postulated $(1 \mathrm{H}$-indazol-1-yl)silver intermediate. Organic \& Biomolecular Chemistry, v. 10, n. 45, p. 8948-8952, 2012.

41 QIAN, Y.; JING, C.; LIU, S.; HU, W. A highly enantioselective four-component reaction for the efficient construction of chiral $\beta$-hydroxy- $\alpha$-amino acid derivatives.

Chemical Communications, v. 49, n. 26, p. 2700, 2013. 
42 WANG, P.; LIAO, S.; WANG, S.R.; GAO, R.-D.; TANG, Y. Reaction of trisubstituted alkenes with iron porphyrin carbenes: facile synthesis of tetrasubstituted dienes and cyclopentadienes. Chemical Communications, v. 49, n. 67, p. 7436-7438, 2013.

43 XU, X.; XU, X.; ZAVALIJ, P.Y.; DOYLE, M.P. Dirhodium(ii)-catalyzed formal $[3+2+1]$-annulation of azomethine imines with two molecules of a diazo ketone. Chemical Communications, v. 49, n. 27, p. 2762-2764, 2013.

44 DANHEISER, R.L.; CHA, D.D. Total synthesis of the host defense stimulant maesanin. Tetrahedron Letters, v. 31, n. 11, p. 1527-1530, 1990.

45 SHANAHAN, C.S.; TRUONG, P.; MASON, S.M.; LESZCZYNSKI, J.S.; DOYLE, M.P. Diazoacetoacetate enones for the synthesis of diverse natural product-like scaffolds. Organic Letters, v. 15, n. 14, p. 3642-3645, 2013.

46 PINHO, V.D.; BURTOLOSO, A.C.B. Preparation of $\alpha, \beta$-unsaturated diazoketones employing a Horner-Wadsworth-Emmons reagent. The Journal of Organic Chemistry, v. 76, n. 1, p. 289-292, 2011.

47 ROSSET, I.G.; BURTOLOSO, A.C.B. Preparation of Z- $\alpha, \beta$-unsaturated diazoketones from aldehydes. Application in the construction of substituted dihydropyridin-3-ones. The Journal of Organic Chemistry, v. 78, n. 18, p. 9464-9470, 2013.

48 TEICHERT, A.; JANTOS, K.; HARMS, K.; STUDER, A. One-pot homolytic aromatic substitutions/hwe olefinations under microwave conditions for the formation of a small oxindole library. Organic Letters, v. 6, n. 20, p. 3477-3480, 2004.

49 ANDO, K. Practical synthesis of Z-unsaturated esters by using a new HornerEmmons reagent, ethyl diphenylphosphonoacetate. Tetrahedron Letters, v. 36, n. 23, p. 4105-4108, 1995.

50 ANDO, K. Highly selective synthesis of z-unsaturated esters by using new horner-emmons reagents, ethyl (diarylphosphono)acetates. The Journal of Organic Chemistry, v. 62, n. 7, p. 1934-1939, 1997.

51 ANDO, K. Z-Selective horner-wadsworth-emmons reaction of a-substituted ethyl (diarylphosphono)acetates with aldehydes. The Journal of Organic Chemistry, v. 63, n. 23, p. 8411-8416, 1998.

52 ANDO, K. Convenient preparations of (diphenylphosphono)acetic acid esters and the comparison of the z-selectivities of their horner-wadsworth-emmons reaction with aldehydes depending on the ester moiety. The Journal of Organic Chemistry, v. 64, n. 22, p. 8406-8408, 1999.

53 STILL, W.C.; GENNARI, C. Direct synthesis of Z-unsaturated esters. A useful modification of the horner-emmons olefination. Tetrahedron Letters, v. 24, n. 41, p. 4405-4408, 1983.

54 DA SILVA PRADO, V.; BURTOLOSO, A. An improved procedure for the preparation of [bis(2,2,2-trifluoroethyl)phosphono]acetic acid. Synthesis, v. 2010, n. 02, p. 361-363, 2010. 
55 BURTOLOSO, A.C.B.; DIAS, R.M.P.; BERNARDIM, B. $\alpha, \beta-$-Unsaturated diazoketones as useful platforms in the synthesis of nitrogen heterocycles. Accounts of Chemical Research, v. 48, n. 4, p. 921-934, 2015.

56 BERNARDIM, B.; PINHO, V.D.; BURTOLOSO, A.C.B. $\alpha, \beta$-unsaturated diazoketones as platforms in the asymmetric synthesis of hydroxylated alkaloids. Total synthesis of 1-deoxy-8,8a-diepicastanospermine and 1,6-dideoxyepicastanospermine and formal synthesis of Pumiliotoxin 251D. The Journal of Organic Chemistry, v. 77, n. 21, p. 9926-9931, 2012.

57 BERNARDIM, B.; LORDELLO, L.; BURTOLOSO, A.C.B. $\alpha, \beta$-Unsaturated diazoketones as versatile building blocks for the synthesis of hydroxylated piperidines, indolizidines and quinolizidines. Current topics in medicinal chemistry, v. 13, n. 17, p. 2099-2103, 2013.

58 PINHO, V.D.; BURTOLOSO, A.C.B. Total synthesis of (-)-indolizidine 167B via an unusual Wolff rearrangement from an $\alpha, \beta$-unsaturated diazoketone. Tetrahedron Letters, v. 53, n. 7, p. 876-878, 2012.

59 KAWAMURA, M.Y.; TALERO, A.G.; SANTIAGO, J.V.; GARAMBEL-VILCA, E.; ROSSET, I.G.; BURTOLOSO, A.C.B. Six-step syntheses of (-)-1-deoxyaltronojirimycin and (+)-1-deoxymannonojirimycin from N-Z-O-TBDPS-I-serinal. The Journal of Organic Chemistry, v. 81, n. 21, p. 10569-10575, 2016.

60 ROSSET, I.G.; DIAS, R.M.P.; PINHO, V.D.; BURTOLOSO, A.C.B. Three-step synthesis of $( \pm)$-preussin from decanal. The Journal of Organic Chemistry, v. 79, n. 14, p. $6748-6753,2014$.

61 NEWMAN, M.S.; BEAL, P.F. An improved Wolff rearrangement in homogeneous medium. Journal of the American Chemical Society, v. 72, n. 11, p. 5163-5165, 1950.

62 KIRMSE, W. 100 years of the Wolff rearrangement. European Journal of Organic Chemistry, v. 2002, n. 14, p. 2193-2256, 2002.

63 KURTI, L.; CZAKO, B. Strategic applications of named reactions in organic synthesis. New York: Academic Press, 2005. 864 p.

64 BURDZINSKI, G.; PLATZ, M.S. Ultrafast time-resolved studies of the photochemistry of diazo carbonyl compounds. Journal of Physical Organic Chemistry, v. 23, n. 4, p. 308-314, 2010.

65 KAPLAN, F.; MELOY, G.K. The structure of diazoketones. A study of hindered internal rotation1,2. Journal of the American Chemical Society, v. 88, n. 5, p. 950956, 1966.

66 ZELLER, K.-; BLOCHER, A.; HAISS, P. Oxirene participation in the photochemical Wolff rearrangement. Mini-Reviews in Organic Chemistry, v. 1, n. 3, p. 291-308, 2004.

67 MEIER, H.; ZELLER, K.-P. Die Wolff-umlagerung von a-diazocarbonylverbindungen. Angewandte Chemie, v. 87, n. 2, p. 52-63, 1975.

68 PADWA, A.; LAYTON, R. The photochemical decomposition of $\alpha-$ diazoacetophenone in hydroxylic solvents. Tetrahedron Letters, v. 6, n. 26, p. 21672170, 1965. 
69 JONES, M.; ANDO, W. Formation of cyclopropanes via the photosensitized decomposition of aliphatic .alpha.-diazo ketones. Journal of the American Chemical Society, v. 90, n. 8, p. 2200-2201, 1968.

70 CANDEIAS, N.R., TRINDADE, A.F.; GOIS, P.M.P.; AFONSO, C.A.M. The Wolff rearrangement. In: KNOCHEL, P.; MOLANDER, G. A. (Ed.). Comprehensive Organic Synthesis II. 2 ed. Amsterdam: Elsevier, 2014. v.1, p. 944-991.

71 TOMIOKA, H.; OKUNO, H.; IZAWA, Y. Mechanism of the photochemical Wolff rearrangement. The role of conformation in the photolysis of alpha.-diazo carbonyl compounds. The Journal of Organic Chemistry, v. 45, n. 26, p. 5278-5283, 1980.

72 TOMIOKA, H.; OKUNO, H.; KONDO, S.; IZAWA, Y. Direct evidence for ketocarbene-ketocarbene interconversion. Journal of the American Chemical Society, v. 102, n. 23, p. 7123-7125, 1980.

73 ABDEL-WAHAB, A.-M.A.; AHMED, S.A.; DUERR. H. Carbene formation by extrusion of nitrogen. In: HORSPOOL, W.M.; LENCI, F. (Ed.). CRC handbook of organic photochemistry and photobiology. 2 ed. Boca Raton: CRC, 2003. v.1. p.1 - 37

74 BACHMANN, W.E., STRUVE, W.S. The Arndt-Eistert synthesis. In: ORGANIC reactions. New York: John Wiley, 2011. v.1, p. 38-62

75 HORNER, L.; SPIETSCHKA, E. Über lichtreaktionen VI: addukte aus azoverbindungen und ketenen. Chemische Berichte, v. 89, n. 12, p. 2765-2768, 1956.

76 DARKINS, P.; MCCARTHY, N.; ANTHONY, M.; MCKERVEY; O'DONNELL, K.; YE, T.; WALKER, B. First synthesis of enantiomerically pure $\mathrm{N}$-protected $\beta$-amino- $\alpha$-keto esters from $\alpha$-amino acids and dipeptides. Tetrahedron: Asymmetry, v. 5, n. 2, p. 195198, 1994.

77 TILEKAR, J.N.; PATIL, N.T.; DHAVALE, D.D. Synthesis of C1-C6 segment of carbonolide B: Wolff rearrangement of sugar a-diazo ketones. Synthesis, v. 2000, n. 03, p. 395-398, 2000.

78 COOPER, J.; KNIGHT, D.W.; GALLAGHER, P.T. Total synthesis of (-)-a-kainic acid. Journal of the Chemical Society, Perkin Trans. 1, n. 5, p. 553-559, 1992.

79 WENKERT, E.; DECORZANT, R.; NÄF, F. A novel access to ionone-type compounds: (E)-4-oxo- $\beta$-ionone and (E)Oxo- $\beta$-irone via metal-catalyzed intramolecular reactions of $\alpha$-diazo ketones with furans. Helvetica Chimica Acta, v. 72, n. 4, p. 756766, 1989.

80 GRIECO, P.A.; HON, Y.S.; PEREZ-MEDRANO, A. Convergent, enantiospecific total synthesis of the novel cyclodepsipeptide $(+)$-jasplakinolide (jaspamide). Journal of the American Chemical Society, v. 110, n. 5, p. 1630-1631, 1988.

81 LEVIN, S.; NANI, R.R.; REISMAN, S.E. Enantioselective total synthesis of (+)Salvileucalin B. Journal of the American Chemical Society, v. 133, n. 4, p. 774-776, 2011.

82 WIBERG, K.B.; SNOONIAN, J.R.; LAHTI, P.M. Ring contraction of a two-carbon bridged spiropentane. Tetrahedron Letters, v. 37, n. 46, p. 8285-8288, 1996. 
83 RAO, V.B.; WOLFF, S.; AGOSTA, W.C. Synthesis of methyl 1methyltetracyclo[4.3.1.03,10.08,10]decane-7-carboxylate, a derivative of[4.4.4.5]fenestrane. Journal of the Chemical Society, Chemical Communications, n. 5, p. 293-294, 1984.

84 RAO, V.B.; GEORGE, C.F.; WOLFF, S.; AGOSTA, W.C. Synthetic and structural studies in the [4.4.4.5]fenestrane series. Journal of the American Chemical Society, $v$. 107, n. 20, p. 5732-5739, 1985.

85 LOWE, G.; RIDLEY, D.D. Synthesis of $\beta$-lactams by photolytic Wolff rearrangement. Journal of the Chemical Society, Chemical Communications, n. 10, p. 328-329, 1973.

86 UEDA, K.; TODA, F. Wolff rearrangement of 2-diazo-3,4bis(diphenylmethylene)cyclobutmone into 1,2-bis (diphenylmethylene) cyclopropmes. Chemistry Letters, v. 4, n. 7, p. 779-780, 1975.

87 BASKAR, R. Cancer and radiation therapy: current advances and future directions. International Journal of Medical Sciences, v. 9, n. 3, p. 193-199, 2012.

88 HOYE, A.T.; DAVOREN, J.E.; WIPF, P.; FINK, M.P.; KAGAN, V.E. Targeting mitochondria. Accounts of Chemical Research, v. 41, n. 1, p. 87-97, 2008.

89 KANAI, A.; ZABBAROVA, I.; AMOSCATO, A.; EPPERLY, M.; XIAO, J.; WIPF, P. Mitochondrial targeting of radioprotectants using peptidyl conjugates. Organic \& Biomolecular Chemistry, v. 5, n. 2, p. 307-309, 2007.

90 BALABAN, R.S.; NEMOTO, S.; FINKEL, T. Mitochondria, oxidants, and aging. Cell, v. 120 , n. 4 , p. $483-495,2005$.

91 FRANTZ, M.-C.; SKODA, E.M.; SACHER, J.R.; EPPERLY, M.W.; GOFF, J.P.; GREENBERGER, J.S.; WIPF, P. Synthesis of analogs of the radiation mitigator JP4-039 and visualization of BODIPY derivatives in mitochondria. Organic \& Biomolecular Chemistry, v. 11, n. 25, p. 4147-4153, 2013.

92 JIANG, J.; KURNIKOV, I.; BELIKOVA, N.A.; XIAO, J.; ZHAO, Q.; AMOSCATO, A.A.; BRASLAU, R.; STUDER, A.; FINK, M.P.; GREENBERGER, J.S.; WIPF, P.; KAGAN, V.E. Structural requirements for optimized delivery, inhibition of oxidative stress, and antiapoptotic activity of targeted nitroxides. Journal of Pharmacology and Experimental Therapeutics, v. 320, n. 3, p. 1050-1060, 2007.

93 KAGAN, V.E.; WIPF, P.; STOYANOVSKY, D.; GREENBERGER, J.S.; BORISENKO, G.; BELIKOVA, N.A.; YANAMALA, N.; SAMHAN ARIAS, A.K.; TUNGEKAR, M.A.; JIANG, J.; TYURINA, Y.Y.; JI, J.; KLEIN-SEETHARAMAN, J.; PITT, B.R.; SHVEDOVA, A.A.; BAYIR, H. Mitochondrial targeting of electron scavenging antioxidants: regulation of selective oxidation vs random chain reactions. Advanced Drug Delivery Reviews, v. 61, n. 14, p. 1375-1385, 2009.

94 SKODA, E.M.; DAVIS, G.C.; WIPF, P. Allylic amines as key building blocks in the synthesis of (E)-alkene peptide isosteres. Organic Process Research \& Development, v. 16, n. 1, p. 26-34, 2012. 
95 FRANTZ, M.-C.; PIERCE, J.G.; PIERCE, J.M.; KANGYING, L.; QINGWEI, W.; JOHNSON, M.; WIPF, P. Large-Scale asymmetric synthesis of the bioprotective agent JP4-039 and analogs. Organic Letters, v. 13, n. 9, p. 2318-2321, 2011.

96 BERHANE, H.; EPPERLY, M.; DIXON, T.M.; CAO, S.; SHIELDS, D.; WIPF, P.; LI, S.; GAO, X.; GUINAN, E.; GREENBERGER, J.S. Oral delivery of mitochondrial targeted GS-nitroxide JP4-039 protects fanconi Anemia (FA) D2 -/- mice from irradiation mucositis. International Journal of Radiation Oncology Biology Physics, v. 84, n. 3, Supplement, p. S677-S678, 2012.

97 BERNARD, M.E.; KIM, H.; BERHANE, H.; EPPERLY, M.W.; FRANICOLA, D.; ZHANG, X.; HOUGHTON, F.; SHIELDS, D.; WANG, H.; BAKKENIST, C.J.; FRANTZ, M.-C.; FORBECK, E.M.; GOFF, J.P.; WIPF, P.; GREENBERGER, J.S. GS-nitroxide (JP4-039)-mediated radioprotection of human fanconi anemia cell lines. Radiation Research, v. 176, n. 5, p. 603-612, 2011.

98 JIANG, J.; BELIKOVA, N.A.; HOYE, A.T.; ZHAO, Q.; EPPERLY, M.W.; GREENBERGER, J.S.; WIPF, P.; KAGAN, V.E. A mitochondria-targeted nitroxide/hemigramicidin $S$ conjugate protects mouse embryonic cells against gamma irradiation. International Journal of Radiation Oncology Biology Physics, v. 70, n. 3, p. 816-825, 2008.

99 RWIGEMA, J.-C.M.; BECK, B.; WANG, W.; DOEMLING, A.; EPPERLY, M.W.; SHIELDS, D.; GOFF, J.P.; FRANICOLA, D.; DIXON, T.; FRANTZ, M.-C.; WIPF, P.; TYURINA, Y.; KAGAN, V.E.; WANG, H.; GREENBERGER, J.S. Two strategies for the development of mitochondrion-targeted small molecule radiation damage mitigators. International Journal of Radiation Oncology Biology Physics, v. 80, n. 3, p. 860868, 2011.

100 WIPF, P.; XIAO, J.; JIANG, J.; BELIKOVA, N.A.; TYURIN, V.A.; FINK, M.P.; KAGAN, V.E. Mitochondrial targeting of selective electron scavengers: synthesis and biological analysis of hemigramicidin-TEMPO conjugates. Journal of the American Chemical Society, v. 127, n. 36, p. 12460-12461, 2005.

101 OMURA, K.; SWERN, D. Oxidation of alcohols by "activated" dimethyl sulfoxide. a preparative, steric and mechanistic study. Tetrahedron, v. 34, n. 11, p. 1651-1660, 1978.

102 MINATO, D.; NAGASUE, Y.; DEMIZU, Y.; ONOMURA, O. Effecient kinetic resolution of racemic amino aldehydes by oxidation with $\mathrm{N}$-iodosuccinimide.

Angewandte Chemie International Edition, v. 47, n. 49, p. 9458-9461, 2008.

103 YANG, X; ZOU, X; FU, Y; MOU, K; FU, G; MA, C; XU, P. Synthesis of $\beta$-secretase inhibitors containing a hydroxyethylene dipeptide isostere. Synthetic Communications, v. 37, n. 1, p. 9-24, 2007.

104 PARIKH, J.R.; DOERING, W. V. E. Sulfur trioxide in the oxidation of alcohols by dimethyl sulfoxide. Journal of the American Chemical Society, v. 89, n. 21, p. 55055507, 1967.

105 SEIKALY, H.R.; TIDWELL, T.T. Addition reactions of ketenes. Tetrahedron, v. 42, n. 10, p. 2587-2613, 1986. 
106 ANDRAOS, J.; KRESGE, A.J. The mechanism of the reaction of diphenylketene with bases in aqueous solution: nucleophilic attack versus general base catalysis of ketene hydration. Journal of the American Chemical Society, v. 114, n. 14, p. 56435646, 1992.

107 SEKI, H.; GEORG, G.I. Three-component synthesis of cyclic enaminones via ketene cyclization. Organic Letters, v. 13, n. 9, p. 2147-2149, 2011.

108 PRESSET, M.; COQUEREL, Y.; RODRIGUEZ, J. Microwave-assisted Wolff rearrangement of cyclic 2-diazo-1,3-diketones: an eco-compatible route to $\alpha$ carbonylated cycloalkanones. The Journal of Organic Chemistry, v. 74, n. 1, p. 415418, 2009.

109 LUCAS, N.C. DE; NETTO-FERREIRA, J.C.; ANDRAOS, J.; SCAIANO, J.C. Nucleophilicity toward ketenes: rate constants for addition of amines to aryl ketenes in acetonitrile solution. The Journal of Organic Chemistry, v. 66, n. 15, p. 5016-5021, 2001.

110 SHI, B.-F.; MAUGEL, N.; ZHANG, Y.-H.; YU, J.-Q. Pdll-catalyzed enantioselective activation of $\mathrm{C}(\mathrm{sp} 2)-\mathrm{H}$ and $\mathrm{C}(\mathrm{sp} 3)-\mathrm{H}$ bonds using monoprotected amino acids as chiral ligands. Angewandte Chemie International Edition, v. 47, n. 26, p. 4882-4886, 2008.

$111 \mathrm{KOCH}, \mathrm{K}$; PODLECH, J. Exceptionally simple homologation of protected $\alpha$ - to $\beta$ amino acids in the presence of silica gel. Synthetic Communications, v. 35, n. 21, p. 2789-2794, 2005.

112 FENG, J.M.; CHEN, S.P.; TANG, L.J.; ZHANG, J.T.; WANG, X.J.; HUANG, S.P. Study on synthesis of (S)-methyl 3-(((benzyloxy)carbonyl) amino)-7-hydroxyheptanoate. Advanced Materials Research, v. 781-784, p. 1187-1189, 2013.

113 WEIBEL, J.-M., BLANC, A., PALE, P. Sigmatropic rearrangements and related processes promoted by silver. In: HARMATA, M.; WENDER, P.A. (Ed.) Silver in organic chemistry. New York: John Wiley, 2010. p. 83-116.

114 THOMPSON, J.L.; DAVIES, H.M.L. Enhancement of cyclopropanation chemistry in the silver-catalyzed reactions of aryldiazoacetates. Journal of the American Chemical Society, v. 129, n. 19, p. 6090-6091, 2007.

115 SUDRIK, S.G.; CHAKI, N.K.; CHAVAN, V.B.; CHAVAN, S.P.; CHAVAN, S.P.; SONAWANE, H.R.; VIJAYAMOHANAN, K. Silver nanocluster redox-couple-rromoted nonclassical electron transfer: an efficient electrochemical Wolff rearrangement of $\alpha$ diazoketones. Chemistry - A European Journal, v. 12, n. 3, p. 859-864, 2006.

116 SUDRIK, S.G.; SHARMA, J.; CHAVAN, V.B.; CHAKI, N.K.; SONAWANE, H.R.; VIJAYAMOHANAN, K.P. Wolff rearrangement of a-diazoketones using in situ generated silver nanoclusters as electron mediators. Organic Letters, v. 8, n. 6, p. 1089-1092, 2006.

117 MA, B.; CHEN, F.-L.; XU, X.-Y.; ZHANG, Y.-N.; HU, L.-H. $\alpha$-diazo $\beta-K e t o$ ester as precursor to aromatic $\mathrm{C}-\mathrm{H}$ insertion and Wolff rearrangement with different directing groups. Advanced Synthesis \& Catalysis, v. 356, n. 2-3, p. 416-420, 2014. 
118 LOVELY, C.J. Silver carbenoids. In: HARMATA, M.; WENDER, P.A. (Ed.). Silver in organic chemistry. New York: John Wiley, 2010. p. 229-257.

119 ROSATI, R.L.; KAPILI, L.V.; MORRISSEY, P.; RETSEMA, J.A. Cephalosporins to carbapenems: 1-oxygenated carbapenems and carbapenams. Journal of Medicinal Chemistry, v. 33, n. 1, p. 291-297, 1990.

120 MASCITTI, V.; COREY, E.J. Total synthesis of ( \pm )-pentacycloanammoxic acid. Journal of the American Chemical Society, v. 126, n. 48, p. 15664-15665, 2004.

121 PINHO, V.D.; GUTMANN, B.; KAPPE, C.O. Continuous flow synthesis of $\beta$-amino acids from $\alpha$-amino acids via Arndt-Eistert homologation. RSC Advances, v. 4, n. 70, p. 37419-37422, 2014.

122 BOERNER, L.J.K.; DYE, D.F.; KÖPKE, T.; ZALESKI, J.M. Expansion and contraction: Shaping the porphyrin boundary via diradical reactivity. Coordination Chemistry Reviews, v. 257, n. 2, p. 599-620, 2013.

123 CHIANG, Y.; KRESGE, A.J.; POPIK, V.V. Scavenging of intermediates formed in photolysis of $\alpha$-diazocarbonyl compounds and hydroxycyclopropenones. Implication on the mechanism of the photo-Wolff reaction. Journal of the American Chemical Society, v. 121, n. 25, p. 5930-5932, 1999.

124 ALLEN, A.D.; CHENG, B.; FENWICK, M.H.; GIVEHCHI, B.; HENRY-RIYAD, H.; NIKOLAEV, V.A.; SHIKHOVA, E.A.; TAHMASSEBI, D.; TIDWELL, T.T.; WANG, S. Ketene reactions with the aminoxyl radical TEMPO: preparative, kinetic, and theoretical studies. The Journal of Organic Chemistry, v. 66, n. 8, p. 2611-2617, 2001.

125 ZIMMERMAN, H.E.; WANG, P. An unusual abnormal Wolff rearrangement. Canadian Journal of Chemistry, v. 81, n. 6, p. 517-524, 2003.

126 VASKE, Y.S.M.; MAHONEY, M.E.; KONOPELSKI, J.P.; ROGOW, D.L.; MCDONALD, W.J. Enantiomerically pure trans- $\beta$-lactams from $\alpha$-amino acids via compact fluorescent light (CFL) continuous-flow photolysis. Journal of the American Chemical Society, v. 132, n. 32, p. 11379-11385, 2010.

127 NIKOLAEV, V.A.; GALKINA, O.S.; SIELER, J.; RODINA, L.L. Surprising secondary photochemical reactions observed on conventional photolysis of diazotetrahydrofuranones. Tetrahedron Letters, v. 51, n. 20, p. 2713-2716, 2010.

128 WILLUMSTAD, T.P.; HAZE, O.; MAK, X.Y.; LAM, T.Y.; WANG, Y.-P.; DANHEISER, R.L. Batch and flow photochemical benzannulations based on the reaction of ynamides and diazo ketones. Application to the synthesis of polycyclic aromatic and heteroaromatic compounds. The Journal of Organic Chemistry, v. 78, n. 22, p. 1145011469, 2013.

129 NICOLAOU, K.C.; BARAN, P.S.; ZHONG, Y.-L.; CHOI, H.-S.; YOON, W.H.; HE, Y.; FONG, K.C. Total synthesis of the CP molecules CP-263,114 and CP-225,917- Part 1: synthesis of key intermediates and intelligence gathering. Angewandte Chemie International Edition, v. 38, n. 11, p. 1669-1675, 1999.

130 KNOWLES, J.P.; ELLIOTT, L.D.; BOOKER-MILBURN, K.I. Flow photochemistry: Old light through new windows. Beilstein Journal of Organic Chemistry, v. 8, p. 20252052, 2012. 
131 EVANS, D.L. High-luminance LEDs replace incandescent lamps in new applications. In: SCHUBERT, E.F. Light-emitting diodes: research, manufacturing, and applications. San Jose, CA: SPIE. Digital, Library, 1997. v.3002, p. 142-153.

132 PRAT, D.; HAYLER, J.; WELLS, A. A survey of solvent selection guides. Green Chemistry, v. 16, n. 10, p. 4546-4551, 2014.

133 BERNARDIM, B.; BURTOLOSO, A.C.B. A two-step synthesis of the bioprotective agent JP4-039 from N-Boc-I-leucinal. Tetrahedron, v. 70, n. 20, p. 3291-3296, 2014.

134 BERNARDIM, B.; HARDMAN-BALDWIN, A.M.; BURTOLOSO, A.C.B. LED lighting as a simple, inexpensive, and sustainable alternative for Wolff rearrangements. RSC Advances, v. 5, n. 18, p. 13311-13314, 2015.

135 PADWA, A.; KENNEDY, G.D.; WANNAMAKER, M.W. Cycloaddition reactions of strained ring systems. Photosensitized [2 + 2] cycloadditions of 2-(acyloxy)-substituted cyclopropenes. The Journal of Organic Chemistry, v. 50, n. 25, p. 5334-5341, 1985.

136 FUSON, R.C.; GRAY, H.; GOUZA, J.J. Acyloins from t-Butylglyoxal. Journal of the American Chemical Society, v. 61, n. 8, p. 1937-1940, 1939.

137 ISHIHARA, K.; YANO, T.; FUSHIMI, M. Asymmetric intramolecular Cannizzaro reaction of anhydrous phenylglyoxal. Journal of Fluorine Chemistry, v. 129, n. 10, p. 994-997, 2008.

138 MARUYAMA, K.; MURAKAMI, Y.; YODA, K.; MASHINO, T.; NISHINAGA, A. Catalysis by cobalt Schiff's base complexes in highly selective conversion of arylglyoxals to a-aryl-a-hydroxyacetic esters. Journal of the Chemical Society, Chemical Communications, n. 21, p. 1617-1618, 1992.

139 YOUNG, R.M.; DAVIES-COLEMAN, M.T. Microwave-assisted selenium dioxide oxidation of aryl methyl ketones to aryl glyoxals. Tetrahedron Letters, v. 52, n. 31, p. 4036-4038, 2011.

140 WANG, P.; TAO, W.-J.; SUN, X.-L.; LIAO, S.; TANG, Y. A highly efficient and enantioselective intramolecular cannizzaro reaction under TOX/Cu(II) catalysis. Journal of the American Chemical Society, v. 135, n. 45, p. 16849-16852, 2013.

141 HUISGEN, R. 1,3-Dipolar cycloadditions. Concerted nature of 1,3-dipolar cycloadditions and the question of diradical intermediates. The Journal of Organic Chemistry, v. 41, n. 3, p. 403-419, 1976.

142 CHANDRASEKHAR, S.; SARKAR, S. Methylenephenylsulfone appended acetals and ketals: New class of carbonyl protective groups cleavable by DBU. Tetrahedron Letters, v. 39, n. 16, p. 2401-2404, 1998.

143 SARABIA GARCÍA, F.; PEDRAZA CEBRIÁN, G.M.; HERAS LÓPEZ, A.; LÓPEZ HERRERA, F.J. Reactions of monosaccharide derivatives with diazocarbonyl compounds. Reactivity and synthetic applications. Tetrahedron, v. 54 , n. 24, p. $6867-$ 6896, 1998.

144 ŠVENDA, J.; HILL, N.; MYERS, A.G. A multiply convergent platform for the synthesis of trioxacarcins. Proceedings of the National Academy of Sciences of the United States of America, v. 108, n. 17, p. 6709-6714, 2011. 
145 JOLY, G.D.; JACOBSEN, E.N. Catalyst-controlled diastereoselective heteroDiels-Alder reactions. Organic Letters, v. 4, n. 10, p. 1795-1798, 2002.

146 WOHL, A. Bromierung ungesättigter Verbindungen mit N-Brom-acetamid, ein Beitrag zur Lehre vom Verlauf chemischer Vorgänge. Berichte der deutschen chemischen Gesellschaft (A and B Series), v. 52, n. 1, p. 51-63, 1919.

147 ZIEGLER, K.; SCHENCK, G.; KROCKOW, E.W.; SIEBERT, A.; WENZ, A.; WEBER, H. Die synthese des cantharidins. Justus Liebigs Annalen der Chemie, v. 551, n. 1, p. 1-79, 1942.

148 KLESSINGER, M.; MICHL, J. Excited states and photochemistry of organic molecules. New York: Wiley-VCH, 1995. 537 p.

149 BACH, R.D.; DMITRENKO, O. Strain energy of small ring hydrocarbons. Influence of C-h bond dissociation energies. Journal of the American Chemical Society, v. 126, n. 13, p. 4444-4452, 2004.

150 SCALABRINO, G.; SUN, X.-W.; MANN, J.; BARON, A. A convergent approach to the marine natural product eleutherobin: synthesis of key intermediates and attempts to produce the basic skeleton. Organic \& Biomolecular Chemistry, v. 1, n. 2, p. 318-327, 2003.

151 MA, K.; LIAO, D.; YANG, S.; LI, X.; LEI, X. Studies towards the synthesis of the functionalized $\mathrm{C} 3-\mathrm{C} 14$ decalin framework of alchivemycin A. Organic Chemistry Frontiers, v. 3, n. 2, p. 251-258, 2016.

152 RAMANATHAN, M.; TAN, C.-J.; CHANG, W.-J.; TSAI, H.-H.G.; HOU, D.-R. Synthesis of the decalin core of codinaeopsin via an intramolecular Diels-Alder reaction. Organic \& Biomolecular Chemistry, v. 11, n. 23, p. 3846-3854, 2013.

153 KRALL, N.; CRUZ, F.P. DA; BOUTUREIRA, O.; BERNARDES, G.J.L. Siteselective protein-modification chemistry for basic biology and drug development. Nature Chemistry, v. 8, n. 2, p. 103-113, 2016.

154 WALSH, C.T.; GARNEAU-TSODIKOVA, S.; GATTO, G.J. Protein Posttranslational Modifications: The Chemistry of Proteome Diversifications.

Angewandte Chemie International Edition, v. 44, n. 45, p. 7342-7372, 2005.

155 AGARWAL, P.; BERTOZZI, C.R. Site-specific antibody-drug conjugates: the nexus of bioorthogonal chemistry, protein engineering, and drug development.

Bioconjugate Chemistry, v. 26, n. 2, p. 176-192, 2015.

156 CHARI, R.V.J.; MILLER, M.L.; WIDDISON, W.C. Antibody-drug conjugates: an emerging concept in cancer therapy. Angewandte Chemie International Edition, v. 53, n. 15, p. 3796-3827, 2014.

157 CHUDASAMA, V.; MARUANI, A.; CADDICK, S. Recent advances in the construction of antibody-drug conjugates. Nature Chemistry, v. 8, n. 2, p. 114-119, 2016.

158 HACKENBERGER, C.P.R.; SCHWARZER, D. Chemoselective ligation and modification strategies for peptides and proteins. Angewandte Chemie International Edition, v. 47, n. 52, p. 10030-10074, 2008. 
159 KENT, S.B.H. Total chemical synthesis of proteins. Chemical Society Reviews, v. 38, n. 2, p. 338-351, 2009.

160 SPICER, C.D.; DAVIS, B.G. Selective chemical protein modification. Nature Communications, v. 5, p. 4740, 2014.

161 SCHMALTZ, R.M.; HANSON, S.R.; WONG, C.-H. Enzymes in the synthesis of glycoconjugates. Chemical Reviews, v. 111, n. 7, p. 4259-4307, 2011.

162 TASDELEN, M.A.; YAGCI, Y. Light-induced click reactions. Angewandte Chemie International Edition, v. 52, n. 23, p. 5930-5938, 2013.

163 LANG, K.; CHIN, J.W. Cellular incorporation of unnatural amino acids and bioorthogonal labeling of proteins. Chemical Reviews, v. 114, n. 9, p. 4764-4806, 2014.

164 VILLALONGA, M.L.; DÍEZ, P.; SÁNCHEZ, A.; GAMELLA, M.; PINGARRÓN, J.M.; VILLALONGA, R. Neoglycoenzymes. Chemical Reviews, v. 114, n. 9, p. 4868-4917, 2014.

165 WALLAT, J.D.; ROSE, K.A.; POKORSKI, J.K. Proteins as substrates for controlled radical polymerization. Polymer Chemistry, v. 5, n. 5, p. 1545-1558, 2014.

166 BOUTUREIRA, O.; BERNARDES, G.J.L. Advances in chemical protein modification. Chemical Reviews, v. 115, n. 5, p. 2174-2195, 2015.

167 STEPHANOPOULOS, N.; FRANCIS, M.B. Choosing an effective protein bioconjugation strategy. Nature Chemical Biology, v. 7, n. 12, p. 876-884, 2011.

168 BOUTUREIRA, O.; BERNARDES, G.J.L. Advances in chemical protein modification. Chemical Reviews, v. 115, n. 5, p. 2174-2195, 2015.

169 CHALKER, J.M.; BERNARDES, G.J.L.; LIN, Y.A.; DAVIS, B.G. Chemical modification of proteins at cysteine: opportunities in chemistry and biology. Chemistry An Asian Journal, v. 4, n. 5, p. 630-640, 2009.

170 TODA, N.; ASANO, S.; BARBAS, C.F. Rapid, stable, chemoselective labeling of thiols with julia-kocieński-like reagents: a serum-stable alternative to maleimide-based protein conjugation. Angewandte Chemie International Edition, v. 52, n. 48, p. 1259212596, 2013.

171 SENTER, P.D.; SIEVERS, E.L. The discovery and development of brentuximab vedotin for use in relapsed Hodgkin lymphoma and systemic anaplastic large cell lymphoma. Nature Biotechnology, v. 30, n. 7, p. 631-637, 2012.

172 SHEN, B.-Q.; XU, K.; LIU, L.; RAAB, H.; BHAKTA, S.; KENRICK, M.; PARSONSREPONTE, K.L.; TIEN, J.; YU, S.-F.; MAI, E.; LI, D.; TIBBITTS, J.; BAUDYS, J.; SAAD, O.M.; SCALES, S.J.; MCDONALD, P.J.; HASS, P.E.; EIGENBROT, C.; NGUYEN, T.; SOLIS, W.A.; FUJI, R.N.; FLAGELLA, K.M.; PATEL, D.; SPENCER, S.D.; KHAWLI, L.A.; EBENS, A.; WONG, W.L.; VANDLEN, R.; KAUR, S.; SLIWKOWSKI, M.X.; SCHELLER, R.H.; POLAKIS, P.; JUNUTULA, J.R. Conjugation site modulates the in vivo stability and therapeutic activity of antibody-drug conjugates. Nature Biotechnology, v. 30, n. 2, p. 184-189, 2012. 
173 BALDWIN, A.D.; KIICK, K.L. Tunable degradation of maleimide-thiol adducts in reducing environments. Bioconjugate Chemistry, v. 22, n. 10, p. 1946-1953, 2011.

174 LYON, R.P.; SETTER, J.R.; BOVEE, T.D.; DORONINA, S.O.; HUNTER, J.H.; ANDERSON, M.E.; BALASUBRAMANIAN, C.L.; DUNIHO, S.M.; LEISKE, C.I.; LI, F.; SENTER, P.D. Self-hydrolyzing maleimides improve the stability and pharmacological properties of antibody-drug conjugates. Nature Biotechnology, v. 32, n. 10, p. 1059$1062,2014$.

175 FONTAINE, S.D.; REID, R.; ROBINSON, L.; ASHLEY, G.W.; SANTI, D.V. Longterm stabilization of maleimide-thiol conjugates. Bioconjugate Chemistry, v. 26, n. 1, p. 145-152, 2015.

176 TUMEY, L.N.; CHARATI, M.; HE, T.; SOUSA, E.; MA, D.; HAN, X.; CLARK, T.; CASAVANT, J.; LOGANZO, F.; BARLETTA, F.; LUCAS, J.; GRAZIANI, E.I. Mild method for succinimide hydrolysis on adcs: impact on adc potency, stability, exposure, and efficacy. Bioconjugate Chemistry, v. 25, n. 10, p. 1871-1880, 2014.

177 KALIA, D.; MALEKAR, P.V.; PARTHASARATHY, M. Exocyclic olefinic maleimides: synthesis and application for stable and thiol-selective bioconjugation. Angewandte Chemie International Edition, v. 55, p. 1432-1435, 2015.

178 FUKUI, K.; YONEZAWA, T.; SHINGU, H. A molecular orbital theory of reactivity in aromatic hydrocarbons. The Journal of Chemical Physics, v. 20, n. 4, p. 722-725, 1952.

179 LV, X.; ZHANG, Y.; ZHOU, L.; WANG, X. Facile and efficient conjugate additions of $\beta$-dicarbonyl compounds and nitroalkanes to 4-aryl-4-oxobut-2-enoates. Journal of the Serbian Chemical Society, v. 76, n. 7, p. 947-954, 2011.

180 DAS, U.; CHEN, Y.-R.; TSAI, Y.-L.; LIN, W. Organocatalytic enantioselective direct vinylogous michael addition of $Y$-substituted butenolides to 3-aroyl acrylates and 1,2diaroylethylenes. Chemistry - A European Journal, v. 19, n. 24, p. 7713-7717, 2013.

181 JI, J.; LIN, L.; ZHOU, L.; ZHANG, Y.; LIU, Y.; LIU, X.; FENG, X. N,N'-dioxidescandium(III)-catalyzed asymmetric michael addition of $\beta, \gamma$-unsaturated butenolides to $\alpha, \beta$-unsaturated $\gamma$-keto esters. Advanced Synthesis \& Catalysis, v. 355, n. 14-15, p. 2764-2768, 2013.

182 KANG, Q.; ZHANG, Y. N-Heterocyclic carbene-catalyzed aza-Michael addition. Organic \& Biomolecular Chemistry, v. 9, n. 19, p. 6715-6720, 2011.

183 LU, H.-H.; WANG, X.-F.; YAO, C.-J.; ZHANG, J.-M.; WU, H.; XIAO, W.-J. Highly enantioselective organocatalytic Michael addition of nitroalkanes to 4-oxo-enoates.

Chemical Communications, n. 28, p. 4251-4253, 2009.

184 SHEN, J.; NGUYEN, T.T.; GOH, Y.-P.; YE, W.; FU, X.; XU, J.; TAN, C.-H. Chiral bicyclic Guanidine-Catalyzed Enantioselective Reactions of Anthrones. Journal of the American Chemical Society, v. 128, n. 42, p. 13692-13693, 2006.

185 WANG, Z.; YAO, Q.; KANG, T.; FENG, J.; LIU, X.; LIN, L.; FENG, X. Highly diastereo- and enantioselective Michael addition of 3-substituted benzofuran-2(3H)-ones to 4-oxo-enoates catalyzed by lanthanide(III) complexes. Chemical Communications, v. 50, n. 38, p. $4918-4920,2014$. 
186 ZHAO, S.; LIN, J.-B.; ZHAO, Y.-Y.; LIANG, Y.-M.; XU, P.-F. Hydrogen-bonddirected formal $[5+1]$ annulations of oxindoles with ester-linked bisenones: facile access to chiral spirooxindole $\delta$-lactones. Organic Letters, v. 16, n. 6, p. 1802-1805, 2014.

187 LOGUE, S.E.; ELGENDY, M.; MARTIN, S.J. Expression, purification and use of recombinant annexin $\mathrm{V}$ for the detection of apoptotic cells. Nature Protocols, v. 4, n. 9, p. 1383-1395, 2009.

188 ALAM, I.S.; NEVES, A.A.; WITNEY, T.H.; BOREN, J.; BRINDLE, K.M. Comparison of the $\mathrm{C} 2 \mathrm{~A}$ domain of synaptotagmin-i and annexin- $v$ as probes for detecting cell death. Bioconjugate Chemistry, v. 21, n. 5, p. 884-891, 2010.

189 KRATZ, F.; ELSADEK, B. Clinical impact of serum proteins on drug delivery. Journal of Controlled Release, v. 161, n. 2, p. 429-445, 2012.

190 ANDERSEN, J.T.; DALHUS, B.; VIUFF, D.; RAVN, B.T.; GUNNARSEN, K.S.; PLUMRIDGE, A.; BUNTING, K.; ANTUNES, F.; WILLIAMSON, R.; ATHWAL, S.; ALLAN, E.; EVANS, L.; BJØRÅS, M.; KJAERULFF, S.; SLEEP, D.; SANDLIE, I.; CAMERON, J. Extending serum half-life of albumin by engineering neonatal $F c$ receptor (FcRn) binding. Journal of Biological Chemistry, v. 289, n. 19, p. 13492-13502, 2014.

191 ISHII, Y.; LEHRER, S.S. Effects of the state of the succinimido-ring on the fluorescence and structural properties of pyrene maleimide-labeled alpha alphatropomyosin. Biophysical Journal, v. 50, n. 1, p. 75-80, 1986.

192 MERLIN, J.-L.; BARBERI-HEYOB, M.; BACHMANN, N. In vitro comparative evaluation of trastuzumab (Herceptin $\AA$ ) combined with paclitaxel (Taxol $®$ ) or docetaxel (Taxotere $\AA$ ) in HER2-expressing human breast cancer cell lines. Annals of Oncology, v. 13, n. 11, p. $1743-1748,2002$.

193 JUNUTULA, J.R.; RAAB, H.; CLARK, S.; BHAKTA, S.; LEIPOLD, D.D.; WEIR, S.; CHEN, Y.; SIMPSON, M.; TSAI, S.P.; DENNIS, M.S.; LU, Y.; MENG, Y.G.; NG, C.; YANG, J.; LEE, C.C.; DUENAS, E.; GORRELL, J.; KATTA, V.; KIM, A.; MCDORMAN, K.; FLAGELLA, K.; VENOOK, R.; ROSS, S.; SPENCER, S.D.; LEE WONG, W.; LOWMAN, H.B.; VANDLEN, R.; SLIWKOWSKI, M.X.; SCHELLER, R.H.; POLAKIS, P.; MALLET, W. Site-specific conjugation of a cytotoxic drug to an antibody improves the therapeutic index. Nature Biotechnology, v. 26, n. 8, p. 925-932, 2008.

194 LYON, R.P.; BOVEE, T.D.; DORONINA, S.O.; BURKE, P.J.; HUNTER, J.H.; NEFF-LAFORD, H.D.; JONAS, M.; ANDERSON, M.E.; SETTER, J.R.; SENTER, P.D. Reducing hydrophobicity of homogeneous antibody-drug conjugates improves pharmacokinetics and therapeutic index. Nature Biotechnology, v. 33, n. 7, p. 733-735, 2015.

195 PATTERSON, D.M.; NAZAROVA, L.A.; PRESCHER, J.A. Finding the right (bioorthogonal) chemistry. ACS Chemical Biology, v. 9, n. 3, p. 592-605, 2014.

196 SLETTEN, E.M.; BERTOZZI, C.R. Bioorthogonal chemistry: fishing for selectivity in a sea of functionality. Angewandte Chemie International Edition, v. 48, n. 38, p. 6974-6998, 2009.

197 CHEN, X.; WU, Y.-W. Selective chemical labeling of proteins. Organic \& Biomolecular Chemistry, v. 14, n. 24, p. 5417-5439, 2016. 
198 LIM, R.K.V.; LIN, Q. Bioorthogonal chemistry: recent progress and future directions. Chemical Communications, v. 46, n. 10, p. 1589-1600, 2010.

199 CHALKER, J.M.; BERNARDES, G.J.L.; DAVIS, B.G. A "Tag-and-modify" approach to site-selective protein modification. Accounts of Chemical Research, v. 44, n. 9, p. 730-741, 2011.

200 MCGRATH, N.A.; ANDERSEN, K.A.; DAVIS, A.K.F.; LOMAX, J.E.; RAINES, R.T. Diazo compounds for the bioreversible esterification of proteins. Chemical Science, v. 6, n. 1, p. 752-755, 2014.

201 HE, H.; DING, W.-D.; BERNAN, V.S.; RICHARDSON, A.D.; IRELAND, C.M.; GREENSTEIN, M.; ELLESTAD, G.A.; CARTER, G.T. Lomaiviticins A and B, potent antitumor antibiotics from micromonospora lomaivitiensis. Journal of the American Chemical Society, v. 123, n. 22, p. 5362-5363, 2001.

202 MIX, K.A.; ARONOFF, M.R.; RAINES, R.T. Diazo compounds: versatile tools for chemical biology. ACS Chemical Biology, v. 11, n. 12, p. 3233-3244, 2016.

203 FRISCOURT, F.; FAHRNI, C.J.; BOONS, G.-J. Fluorogenic strain-promoted alkyne-diazo cycloadditions. Chemistry - A European Journal, v. 21, n. 40, p. 1399614001, 2015.

204 ZHOU, W.; HSIEH, P.-H.; XU, Y.; O'LEARY, T.R.; HUANG, X.; LIU, J. Design and synthesis of active heparan sulfate-based probes. Chemical Communications, v. 51, n. 55, p. 11019-11021, 2015.

205 ANDERSEN, K.A.; ARONOFF, M.R.; MCGRATH, N.A.; RAINES, R.T. Diazo groups endure metabolism and enable chemoselectivity in cellulo. Journal of the American Chemical Society, v. 137, n. 7, p. 2412-2415, 2015.

206 JOSA-CULLERÉ, L.; WAINMAN, Y.A.; BRINDLE, K.M.; LEEPER, F.J. Diazo group as a new chemical reporter for bioorthogonal labelling of biomolecules. RSC Advances, v. 4, n. 94, p. 52241-52244, 2014.

207 IWASA, S.; TAKEZAWA, F.; TUCHIYA, Y.; NISHIYAMA, H. Asymmetric cyclopropanation in protic media conducted by chiral bis(hydroxymethyldihydrooxazolyl)pyridine-ruthenium catalysts. Chemical Communications, n. 1, p. 5960, 2001.

208 WURZ, R.P.; CHARETTE, A.B. Transition metal-catalyzed cyclopropanation of alkenes in water: catalyst efficiency and in situ generation of the diazo reagent. Organic Letters, v. 4, n. 25, p. 4531-4533, 2002.

209 IWASA, S.; TSUSHIMA, S.; NISHIYAMA, K.; TSUCHIYA, Y.; TAKEZAWA, F.; NISHIYAMA, $H$. Catalytic asymmetric cyclopropanation of alkenes with diazoesters in protic and biphasic media. Tetrahedron: Asymmetry, v. 14, n. 7, p. 855-865, 2003.

210 CANDEIAS, N.R.; GOIS, P.M.P.; AFONSO, C.A.M. Rh(II) catalysed intramolecular $\mathrm{C}-\mathrm{H}$ insertion of diazo substrates in water: a simple and efficient approach to catalyst reuse. Chemical Communications, n. 3, p. 391-393, 2005. 
211 CANDEIAS, N.R.; GOIS, P.M.P.; AFONSO, C.A.M. Rh(II)-catalyzed intramolecular $c-h$ insertion of diazo substrates in water: scope and limitations. The Journal of Organic Chemistry, v. 71, n. 15, p. 5489-5497, 2006.

212 ESTEVAN, F.; LLORET, J.; SANAÚ, M.; ÚBEDA, M.A. Enantio- and diastereocontrol in intermolecular cyclopropanation reaction of styrene catalyzed by dirhodium(II) complexes with bulky ortho-metalated aryl phosphines: catalysis in water as solvent. study of a (+)-nonlinear effect. Organometallics, v. 25, n. 21, p. 4977-4984, 2006.

213 LIAO, M.; WANG, J. Highly efficient [2,3]-sigmatropic rearrangement of sulfur ylide derived from Rh(II) carbene and sulfides in water. Green Chemistry, v. 9, n. 2, p. 184188, 2007.

214 AVIV, I.; GROSS, Z. Iron(III) corroles and porphyrins as superior catalysts for the reactions of diazoacetates with nitrogen- or sulfur-containing nucleophilic substrates: synthetic uses and mechanistic insights. Chemistry - A European Journal, v. 14, n. 13, p. 3995-4005, 2008.

215 NICOLAS, I.; MAUX, P.L.; SIMONNEAUX, G. Synthesis of chiral water-soluble metalloporphyrins ( $\mathrm{Fe}, \mathrm{Ru}$,): new catalysts for asymmetric carbene transfer in water. Tetrahedron Letters, v. 49, n. 40, p. 5793-5795, 2008.

216 BORDEAUX, M.; TYAGI, V.; FASAN, R. Highly diastereoselective and enantioselective olefin cyclopropanation using engineered myoglobin-based catalysts. Angewandte Chemie International Edition, v. 54, n. 6, p. 1744-1748, 2015.

217 WALLACE, S.; BALSKUS, E.P. Interfacing microbial styrene production with a biocompatible cyclopropanation reaction. Angewandte Chemie, v. 127, n. 24, p. 72127215, 2015.

218 HO, C.-M.; ZHANG, J.-L.; ZHOU, C.-Y.; CHAN, O.-Y.; YAN, J.J.; ZHANG, F.-Y.; HUANG, J.-S.; CHE, C.-M. A water-soluble ruthenium glycosylated porphyrin catalyst for carbenoid transfer reactions in aqueous media with applications in bioconjugation reactions. Journal of the American Chemical Society, v. 132, n. 6, p. 1886-1894, 2010.

219 ANTOS, J.M.; FRANCIS, M.B. Selective tryptophan modification with rhodium carbenoids in aqueous solution. Journal of the American Chemical Society, v. 126, n. 33, p. 10256-10257, 2004.

220 ANTOS, J.M.; FRANCIS, M.B. Transition metal catalyzed methods for siteselective protein modification. Current Opinion in Chemical Biology, v. 10, n. 3, p. 253-262, 2006.

221 ANTOS, J.M.; MCFARLAND, J.M.; IAVARONE, A.T.; FRANCIS, M.B. Chemoselective tryptophan labeling with rhodium carbenoids at mild $\mathrm{pH}$. Journal of the American Chemical Society, v. 131, n. 17, p. 6301-6308, 2009. 
222 BERNARDIM, B.; CAL, P.M.S.D.; MATOS, M.J.; OLIVEIRA, B.L.; MARTÍNEZSÁEZ, N.; ALBUQUERQUE, I.S.; PERKINS, E.; CORZANA, F.; BURTOLOSO, A.C.B.; JIMÉNEZ-OSÉS, G.; BERNARDES, G.J.L. Stoichiometric and irreversible cysteineselective protein modification using carbonylacrylic reagents. Nature Communications, v. 7, p. $13128,2016$.

223 FOOTE, M. K. Quinazoline Derivatives. GB n. US2010/0168143A1, 01 jul. 2010.

224 BERNARDIM DE SOUZA, Barbara. Síntese de indolizidinas e quinolizidinas diidroxiladas a partir de diazocetonas alfa,beta-insaturadas. 2013. $238 \mathrm{f}$.

Dissertação (Mestrado em Química Orgânica e Biológica) - Instituto de Química de São Carlos, Universidade de São Paulo, São Carlos, 2013.

225 ZHOU, Q.-Q.; YUAN, X.; XIAO, Y.-C.; DONG, L.; CHEN, Y.-C. Aminocatalytic asymmetric Diels-Alder reaction of phosphorus dienophiles and 2,4-dienals.

Tetrahedron, v. 69, n. 48, p. 10369-10374, 2013.

226 BHELLA, S.S.; ELANGO, M.; ISHAR, M.P.S. Design, synthesis and conformational analysis of turn inducer cyclopropane scaffolds: microwave assisted amidation of unactivated esters on catalytic solid support to obtain y-turn mimic scaffolds. Tetrahedron, v. 65, n. 1, p. 240-246, 2009.

227 GANGJEE, A.; YANG, J.; IHNAT, M.A.; KAMAT, S. Antiangiogenic and antitumor agents: Design, synthesis, and evaluation of novel 2-amino-4-(3-bromoanilino)-6benzylsubstituted pyrrolo[2,3-d]pyrimidines as inhibitors of receptor tyrosine kinases. Bioorganic \& Medicinal Chemistry, v. 11, n. 23, p. 5155-5170, 2003.

228 ZHENG, Y.; XU, J. Synthesis of enantiopure free and N-benzyloxycarbonylprotected 3-substituted homotaurines from naturally occurring amino acids.

Tetrahedron, v. 70, n. 34, p. 5197-5206, 2014.

229 KIM, K.S.; KIMBALL, S.D.; MISRA, R.N.; RAWLINS, D.B.; HUNT, J.T.; XIAO, H.Y.; LU, S.; QIAN, L.; HAN, W.-C.; SHAN, W.; MITT, T.; CAI, Z.-W.; POSS, M.A.; ZHU, H.; SACK, J.S.; TOKARSKI, J.S.; CHANG, C.Y.; PAVLETICH, N.; KAMATH, A.; HUMPHREYS, W.G.; MARATHE, P.; BURSUKER, I.; KELLAR, K.A.; ROONGTA, U.; BATORSKY, R.; MULHERON, J.G.; BOL, D.; FAIRCHILD, C.R.; LEE, F.Y.; WEBSTER, K.R. Discovery of aminothiazole inhibitors of cyclin-dependent kinase 2: synthesis, $x$-ray crystallographic analysis, and biological activities. Journal of Medicinal Chemistry, v. 45, n. 18, p. $3905-3927,2002$.

230 YAMAMOTO, N.; OBORA, Y.; ISHII, Y. Iridium-catalyzed oxidative methyl esterification of primary alcohols and diols with methanol. The Journal of Organic Chemistry, v. 76, n. 8, p. 2937-2941, 2011.

231 LI, J.; LEAR, M.J.; HAYASHI, Y. Sterically demanding oxidative amidation of asubstituted malononitriles with amines using $\mathrm{O}_{2}$. Angewandte Chemie International Edition, v. 55, n. 31, p. 9060-9064, 2016.

232 XIE, P.; XIA, C.; HUANG, H. Palladium-catalyzed oxidative aminocarbonylation: a new entry to amides via $\mathrm{C}-\mathrm{H}$ activation. Organic Letters, v. 15, n. 13, p. 3370-3373, 2013. 
233 NIELSEN, D.U.; NEUMANN, K.; TAANING, R.H.; LINDHARDT, A.T.; MODVIG, A.; SKRYDSTRUP, T. Palladium-catalyzed double carbonylation using near stoichiometric carbon monoxide: expedient access to substituted ${ }^{13} \mathrm{C}_{2}$-labeled phenethylamines. The Journal of Organic Chemistry, v. 77, n. 14, p. 6155-6165, 2012.

234 LI, J.; SUBRAMANIAM, K.; SMITH, D.; QIAO, J.X.; LI, J.J.; QIAN-CUTRONE, J.; KADOW, J.F.; VITE, G.D.; CHEN, B.-C. AlMe 3 -promoted formation of amides from acids and amines. Organic Letters, v. 14, n. 1, p. 214-217, 2012.

235 ZHANG, Z.; LIU, Y.; LING, L.; LI, Y.; DONG, Y.; GONG, M.; ZHAO, X.; ZHANG, Y.; WANG, J. Pd-Catalyzed carbonylation of diazo compounds at atmospheric pressure: a catalytic approach to ketenes. Journal of the American Chemical Society, v. 133, n. 12, p. 4330-4341, 2011.

236 ABBASOV, M.E.; HUDSON, B.M.; TANTILLO, D.J.; ROMO, D. Acylammonium salts as dienophiles in diels-alder/lactonization organocascades. Journal of the American Chemical Society, v. 136, n. 12, p. 4492-4495, 2014.

237 DIWISCHEK, Florian. Development of synthesis pathways and characterization of cerulenin analogues as inhibitors of the fatty acid biosynthesis of Mycobacterium tuberculosis and of efflux pump resistant Candida albicans. 2008. $225 \mathrm{f}$. Doctoral Thesis - Julius-Maximilians-Universität Würzburg, Würzburg, Germany, 2008.

238 OOHASHI, T.; KAKUTA, H. Lysine Oligomer Derivative and Cartilage Tissue Marker Made Thereof. JP n. EP2826785A1, 21 jan. 2015.

239 FRISCH, M.J.; TRUCKS, G.W.; CHEESEMAN, J.R.; SCALMANI, G.; CARICATO, M.; HRATCHIAN, H.P.; LI, X.; BARONE, V.; BLOINO, J.; ZHENG, G.; VREVEN, T.; MONTGOMERY, J.A.; PETERSSON, G.A.; SCUSERIA, G.E.; SCHLEGEL, H.B.; NAKATSUJI, H.; IZMAYLOV, A.F.; MARTIN, R.L.; SONNENBERG, J.L.; PERALTA, J.E.; HEYD, J.J.; BROTHERS, E.; OGLIARO, F.; BEARPARK, M.; ROBB, M.A.; MENNUCCI, B.; KUDIN, K.N.; STAROVEROV, V.N.; KOBAYASHI, R.; NORMAND, J.; RENDELL, A.; GOMPERTS, R.; ZAKRZEWSKI, V.G.; HADA, M.; EHARA, M.; TOYOTA, K.; FUKUDA, R.; HASEGAWA, J.; ISHIDA, M.; NAKAJIMA, T.; HONDA, Y.; KITAO, O.; NAKAI, H. Gaussian 09. Wallingford: Gaussian, 2009. Programa de computador.

240 ZHAO, Y.; TRUHLAR, D.G. The M06 suite of density functionals for main group thermochemistry, thermochemical kinetics, noncovalent interactions, excited states, and transition elements: two new functionals and systematic testing of four M06-class functionals and 12 other functionals. Theoretical Chemistry Accounts, v. 120, n. 1-3, p. 215-241, 2007.

241 SCALMANI, G.; FRISCH, M.J. Continuous surface charge polarizable continuum models of solvation. I. General formalism. The Journal of Chemical Physics, v. 132, n. 11, p. $114110,2010$.

242 RIBEIRO, R.F.; MARENICH, A.V.; CRAMER, C.J.; TRUHLAR, D.G. Use of solutionphase vibrational frequencies in continuum models for the free energy of solvation. The Journal of Physical Chemistry B, v. 115, n. 49, p. 14556-14562, 2011.

243 GONZALEZ, C.; SCHLEGEL, H.B. An improved algorithm for reaction path following. The Journal of Chemical Physics, v. 90, n. 4, p. 2154-2161, 1989.

244 GONZALEZ, C.; SCHLEGEL, H.B. Reaction path following in mass-weighted internal coordinates. The Journal of Physical Chemistry, v. 94, n. 14, p. 5523-5527, 1990. 


\section{Anexos}

São anexos os espectros de $\mathrm{RMN}{ }^{1} \mathrm{H},{ }^{13} \mathrm{C}$ e os espectros de FTIR referente aos compostos apresentados nesta tese. 


\section{Anexos}
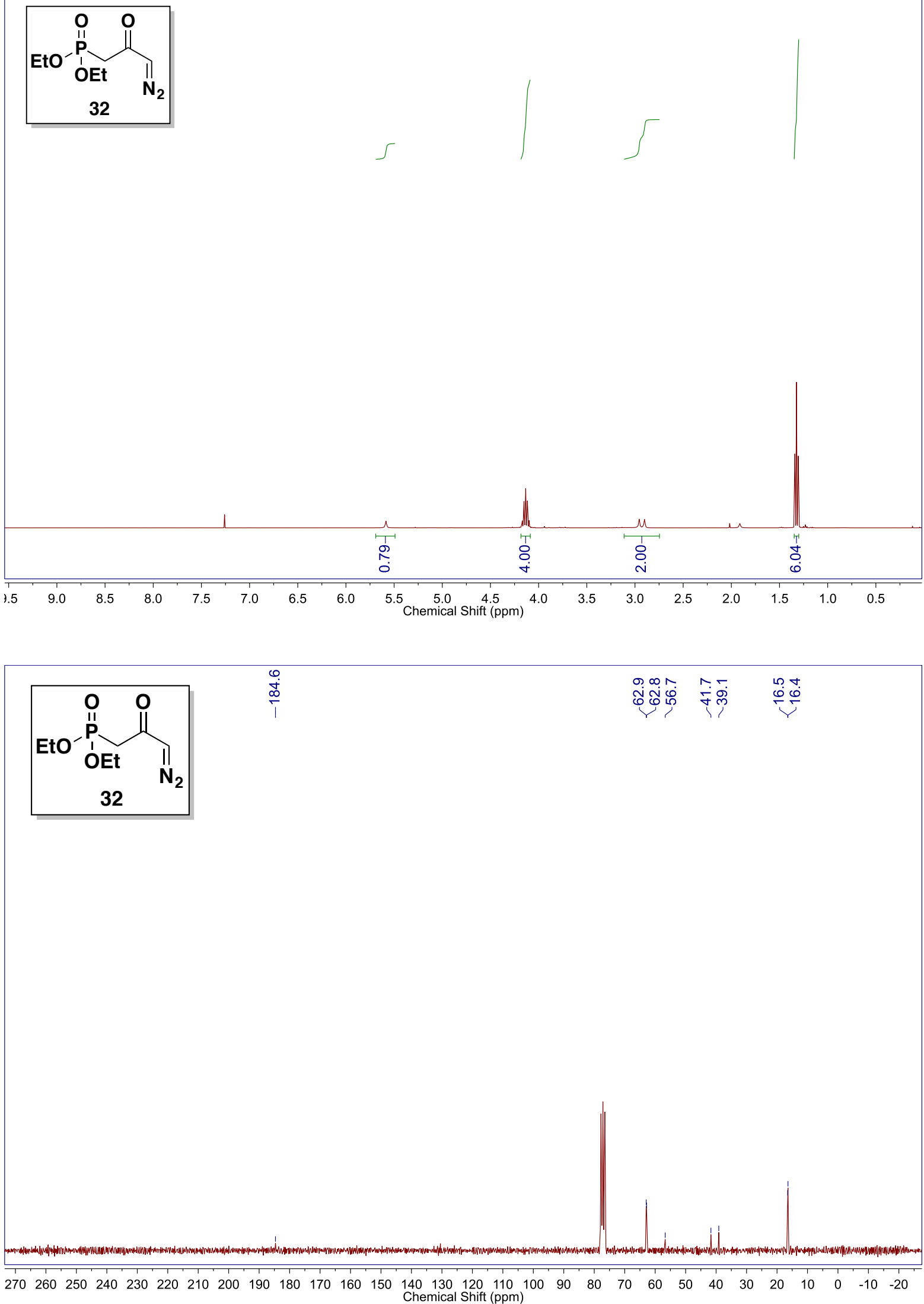

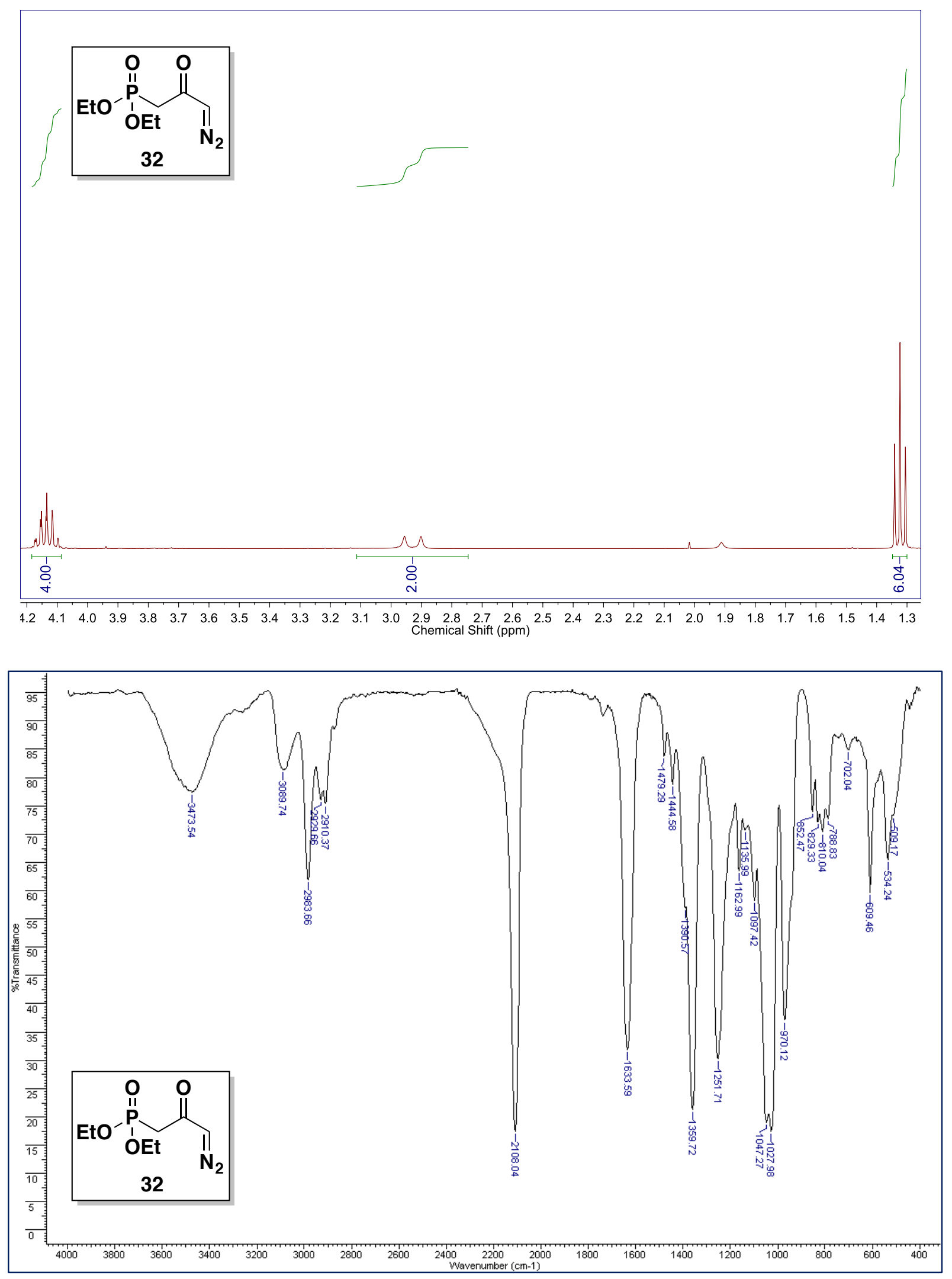

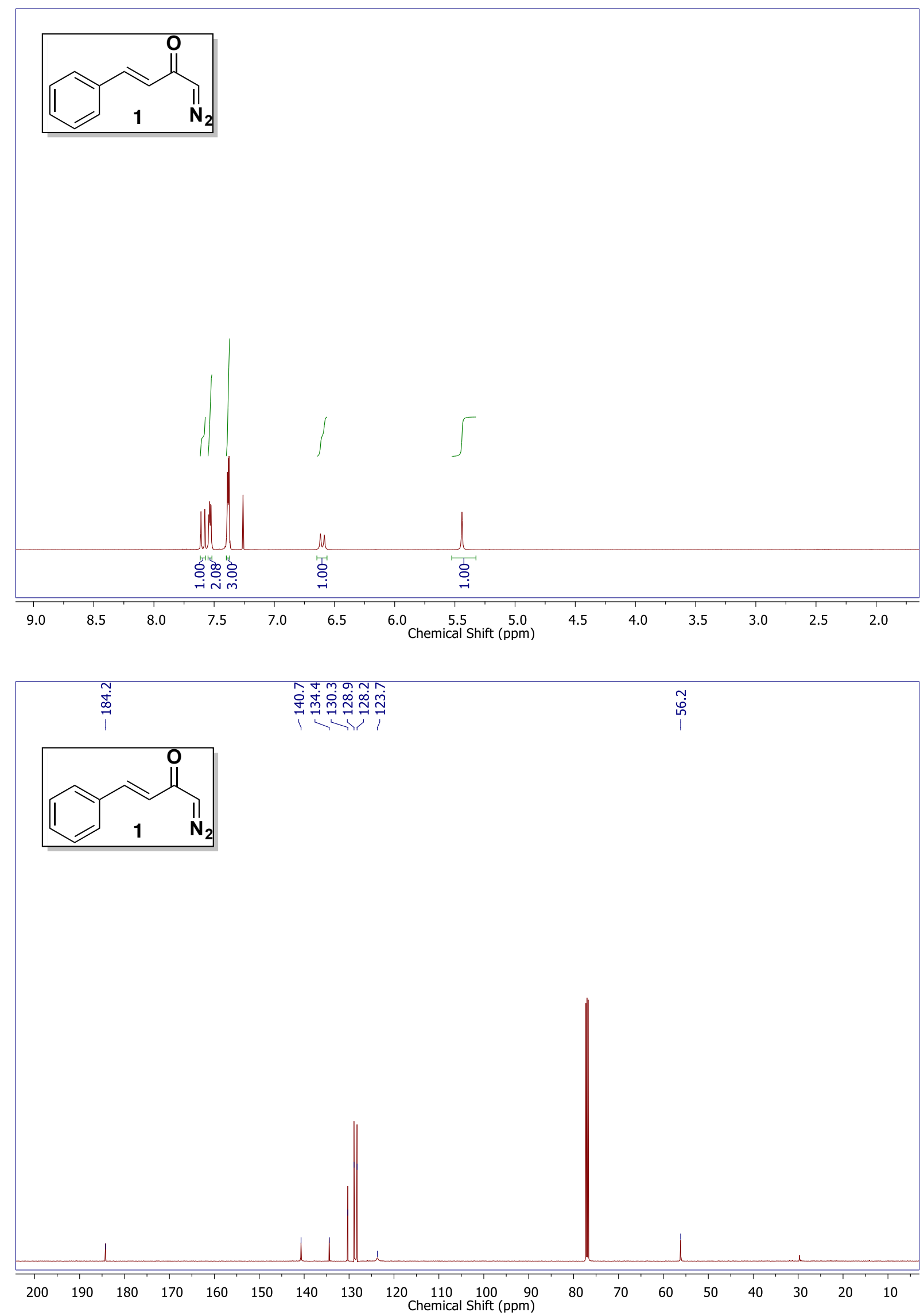


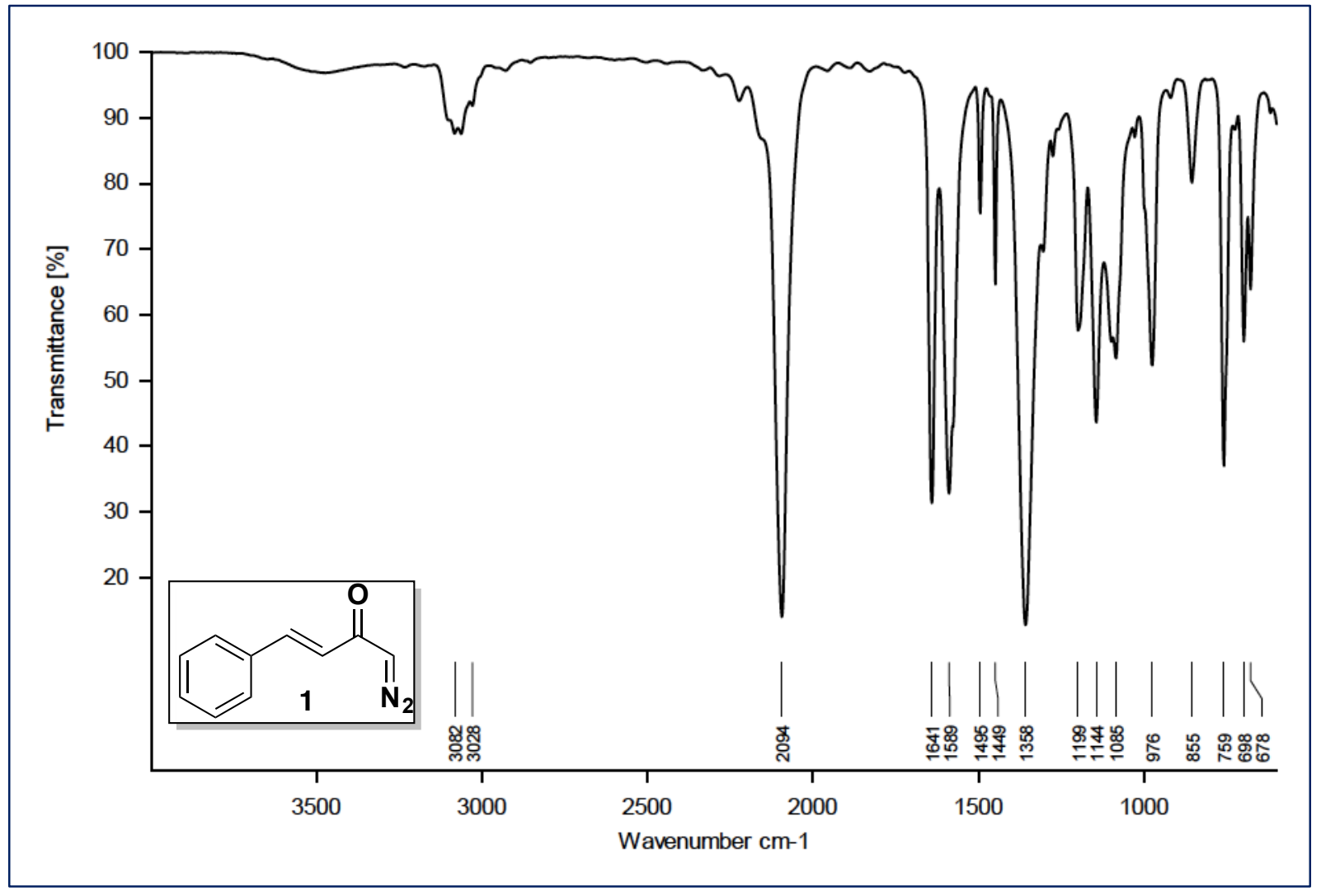



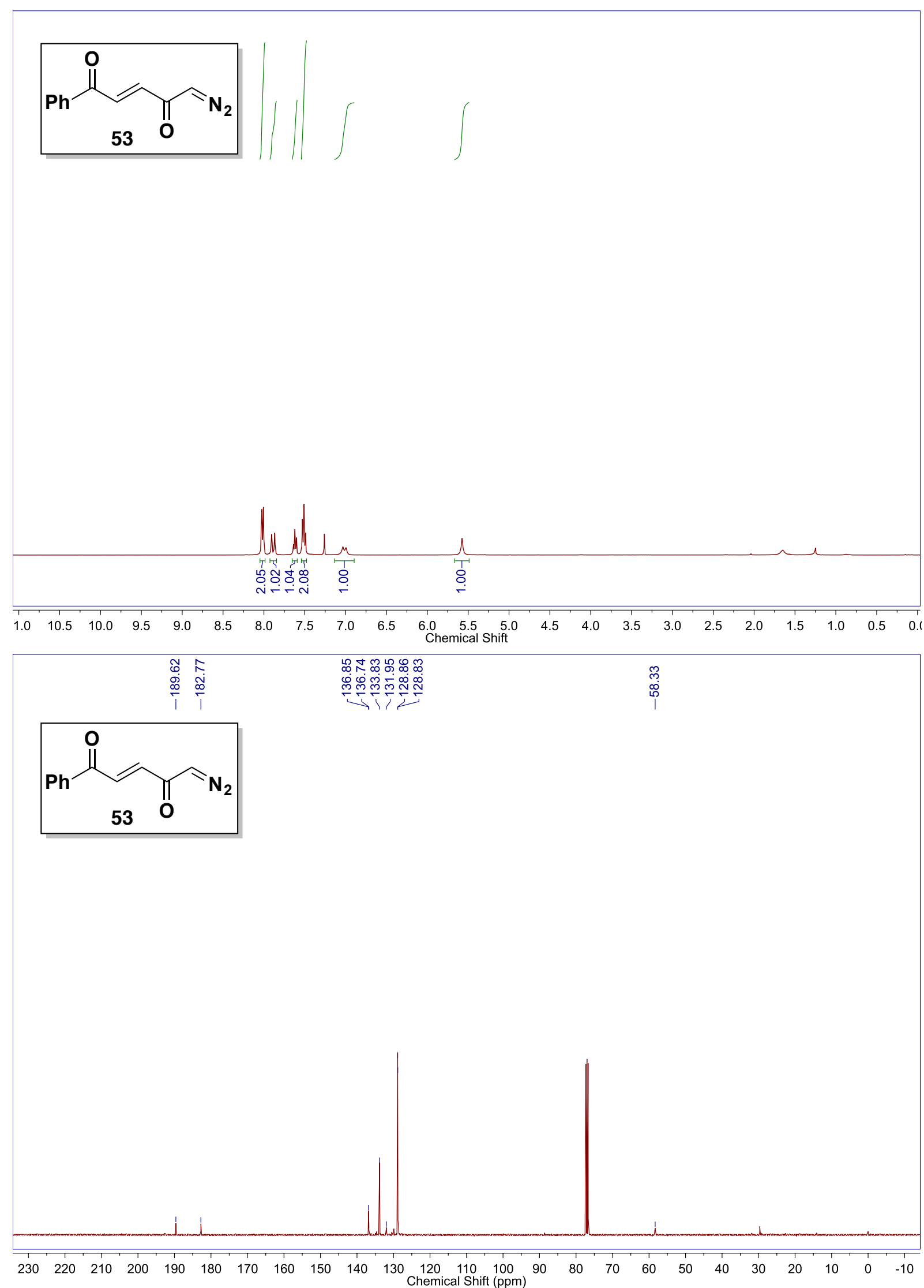

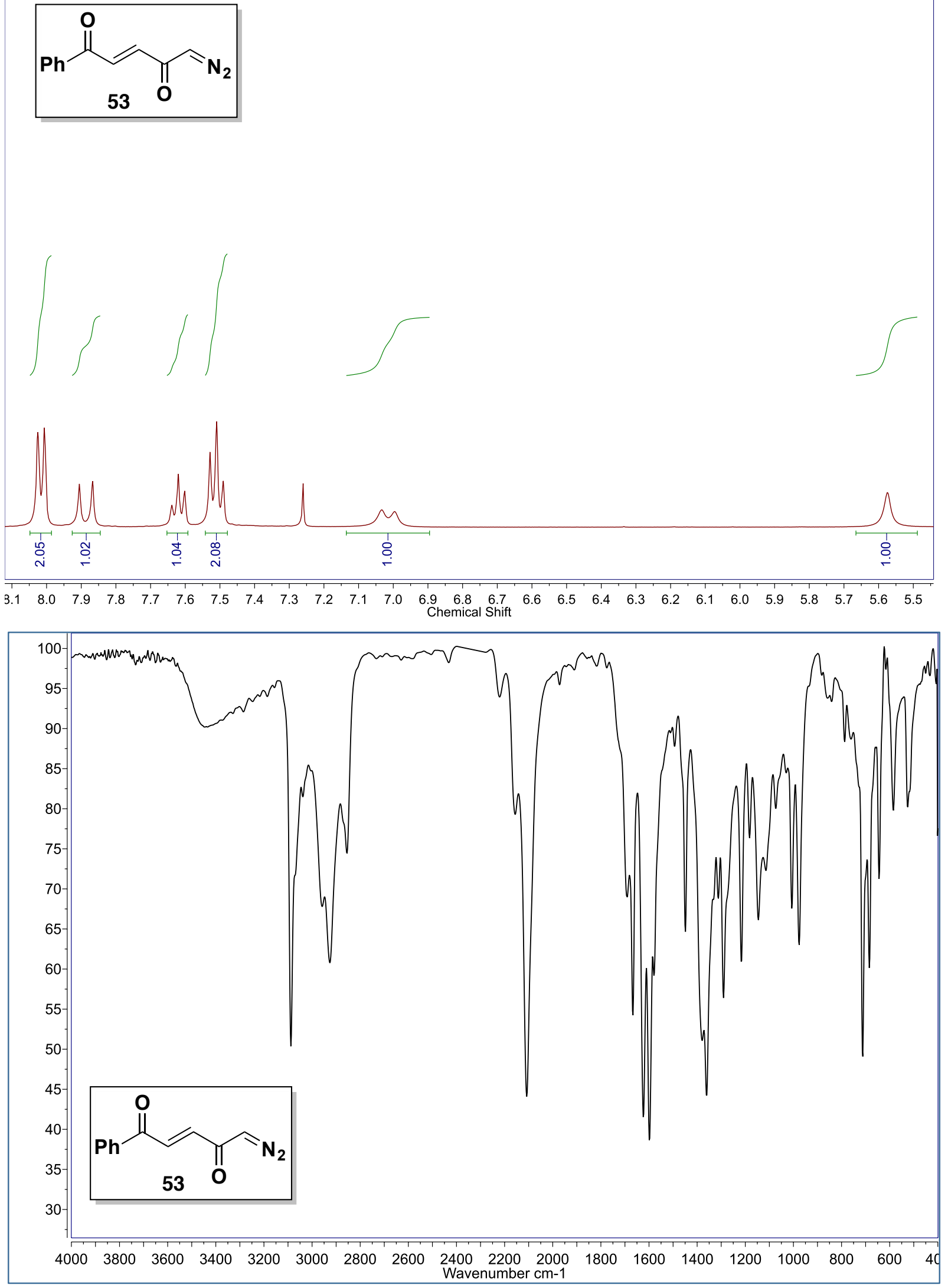

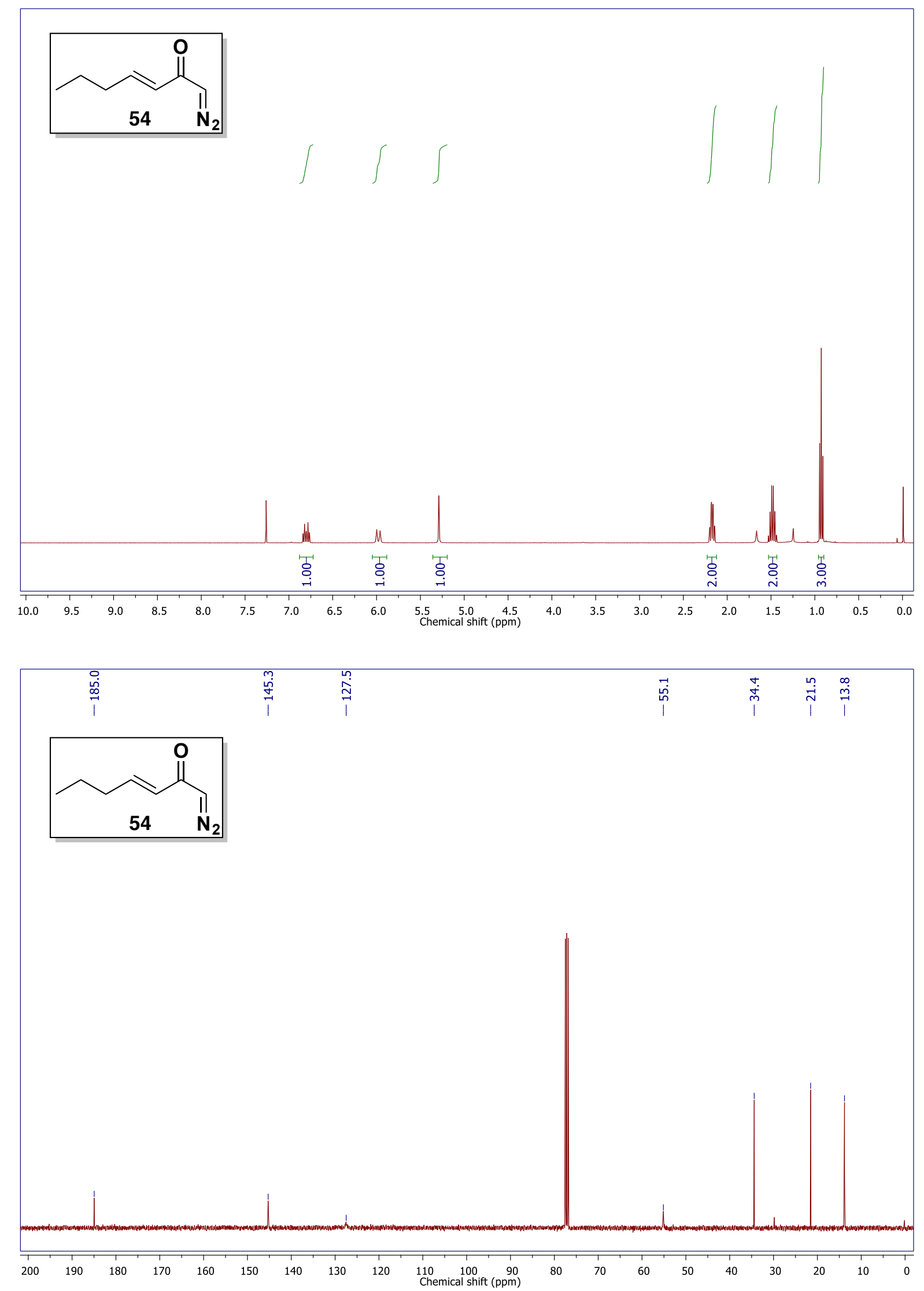

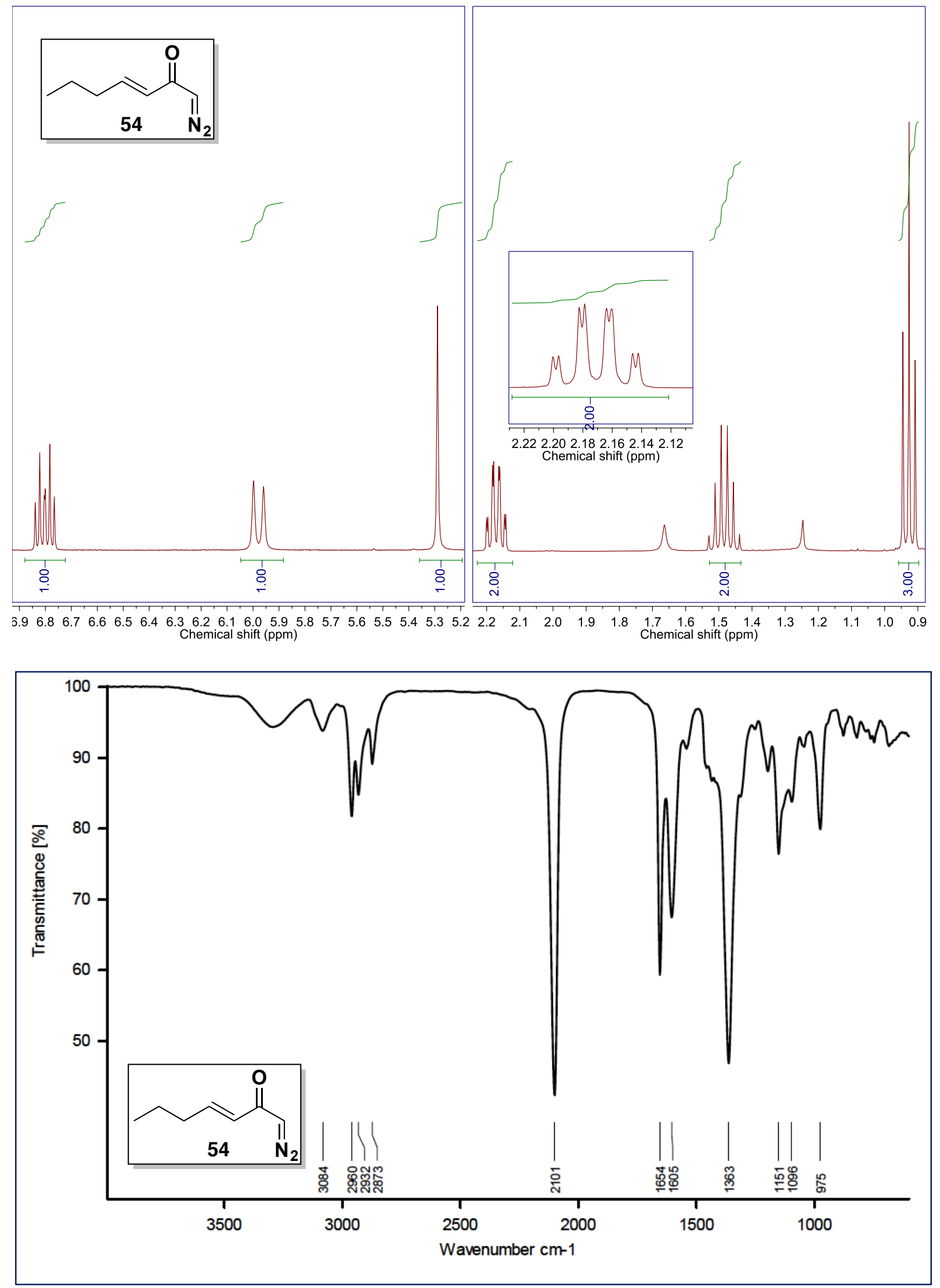

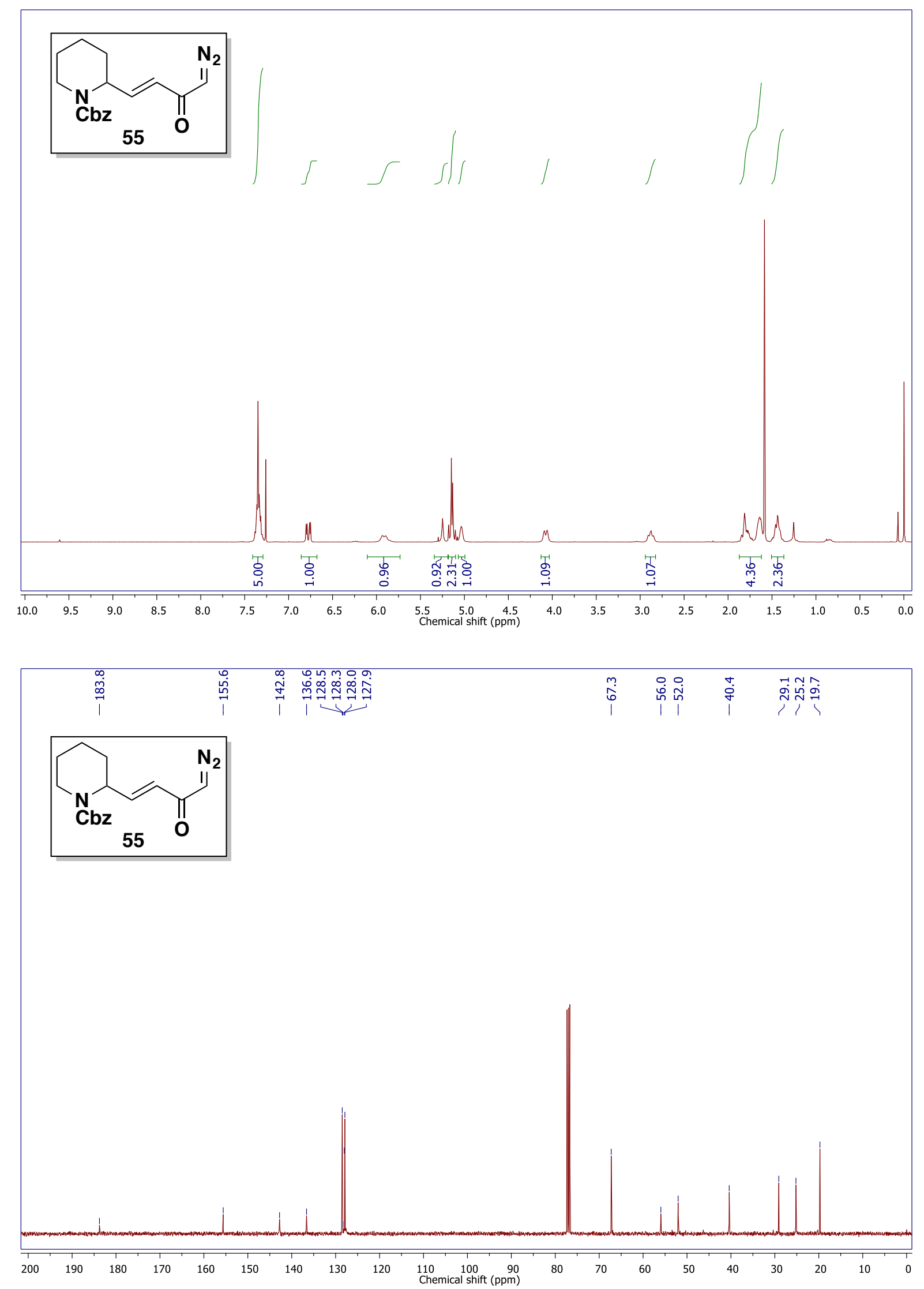

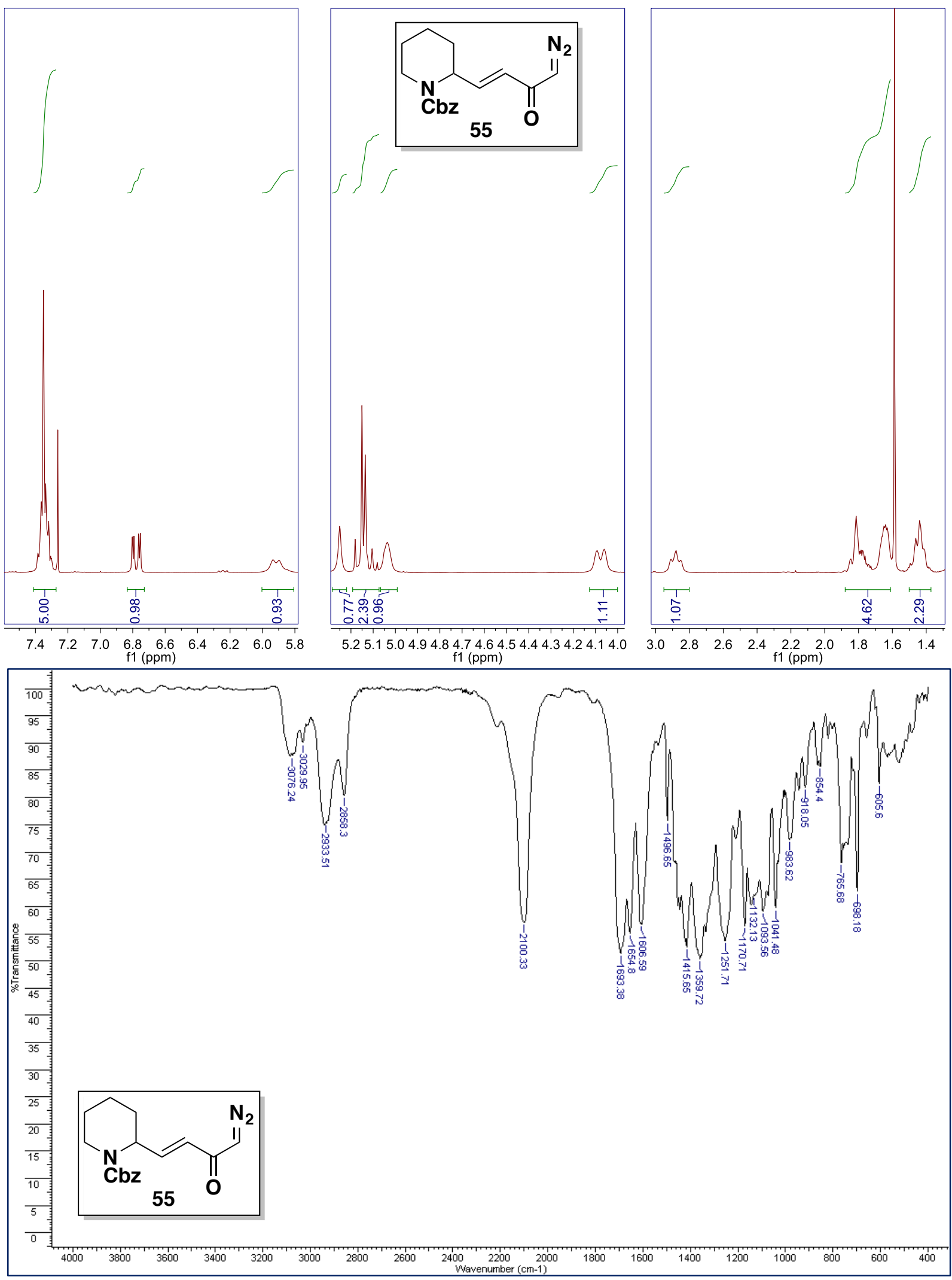

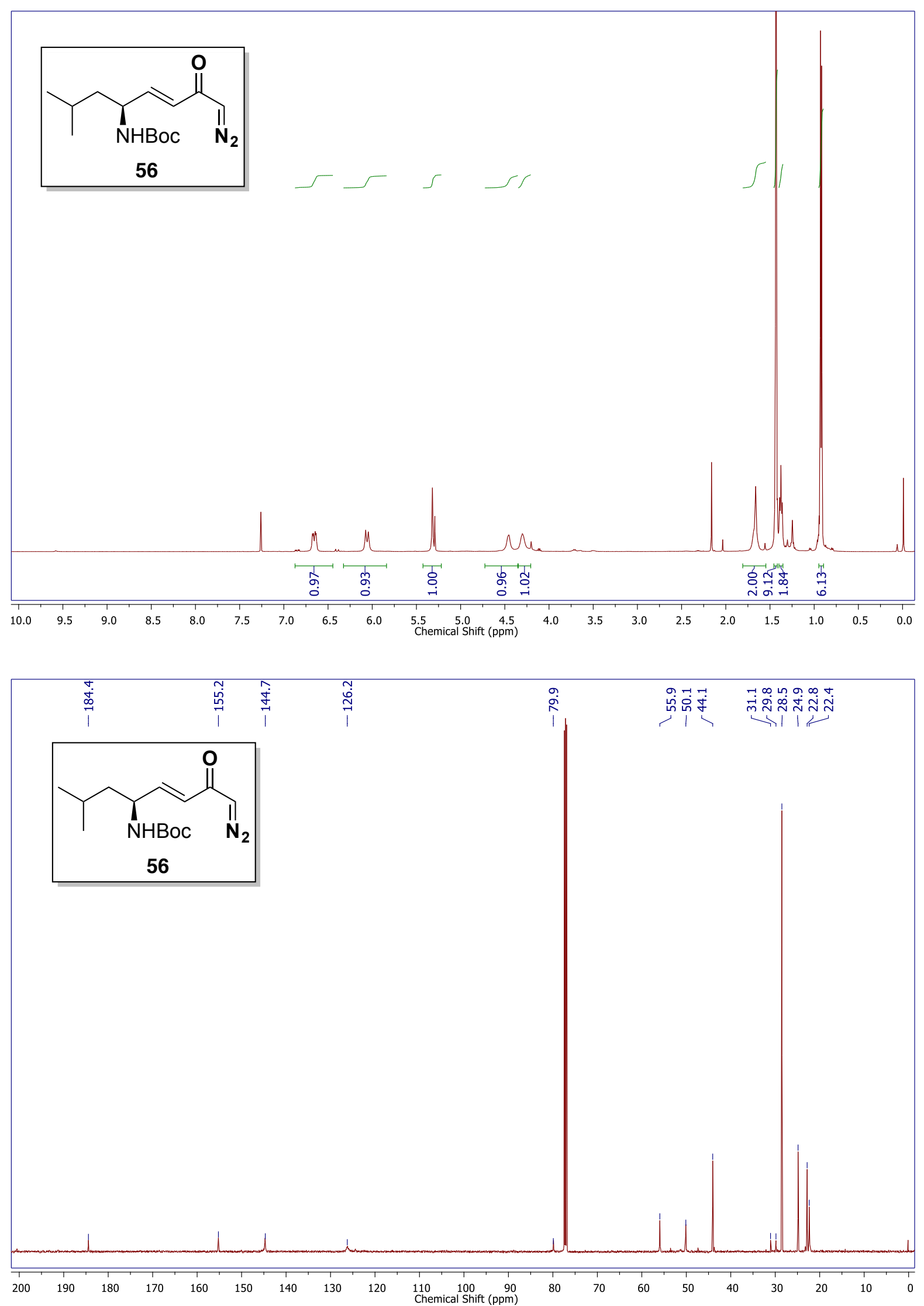

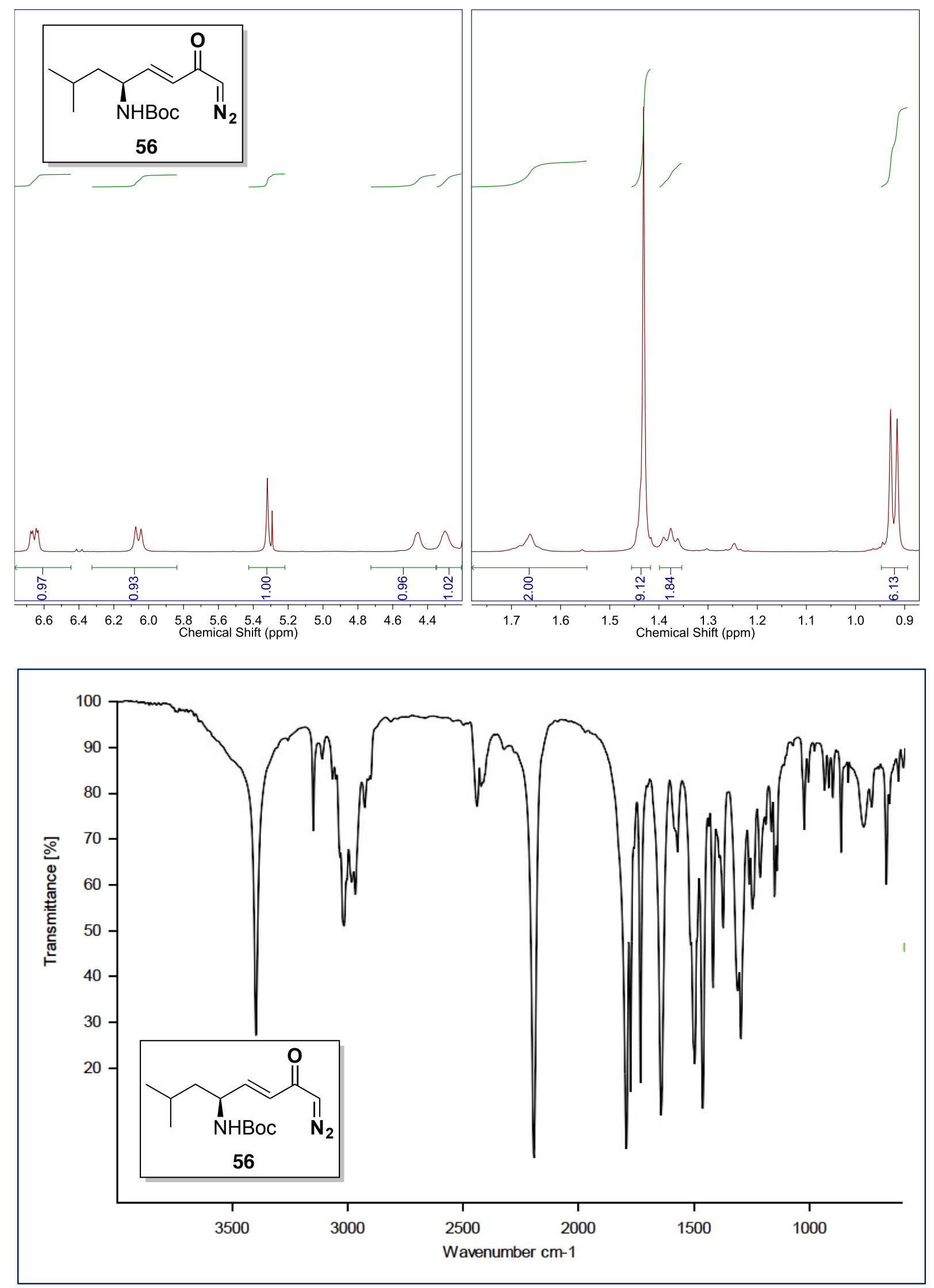

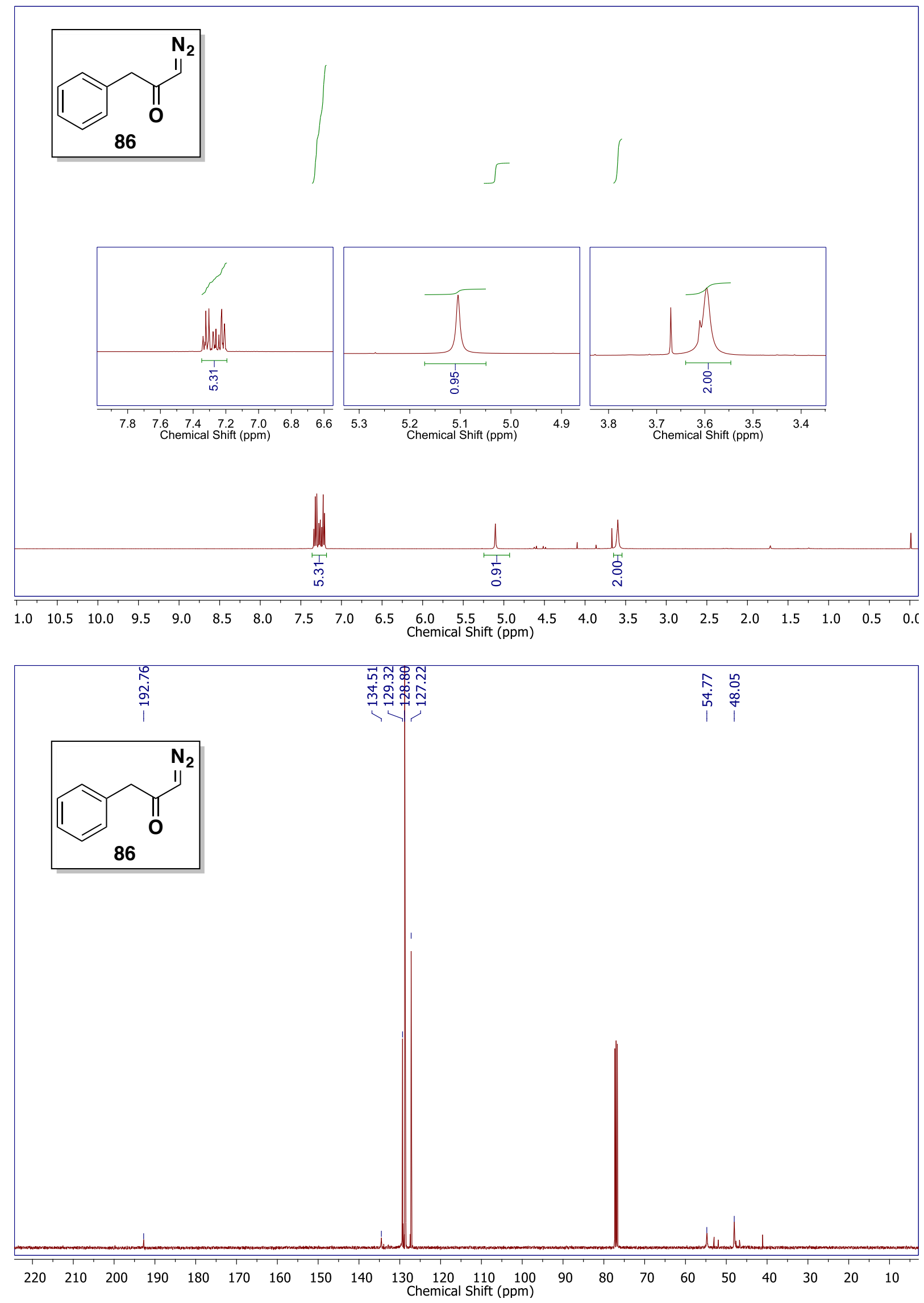


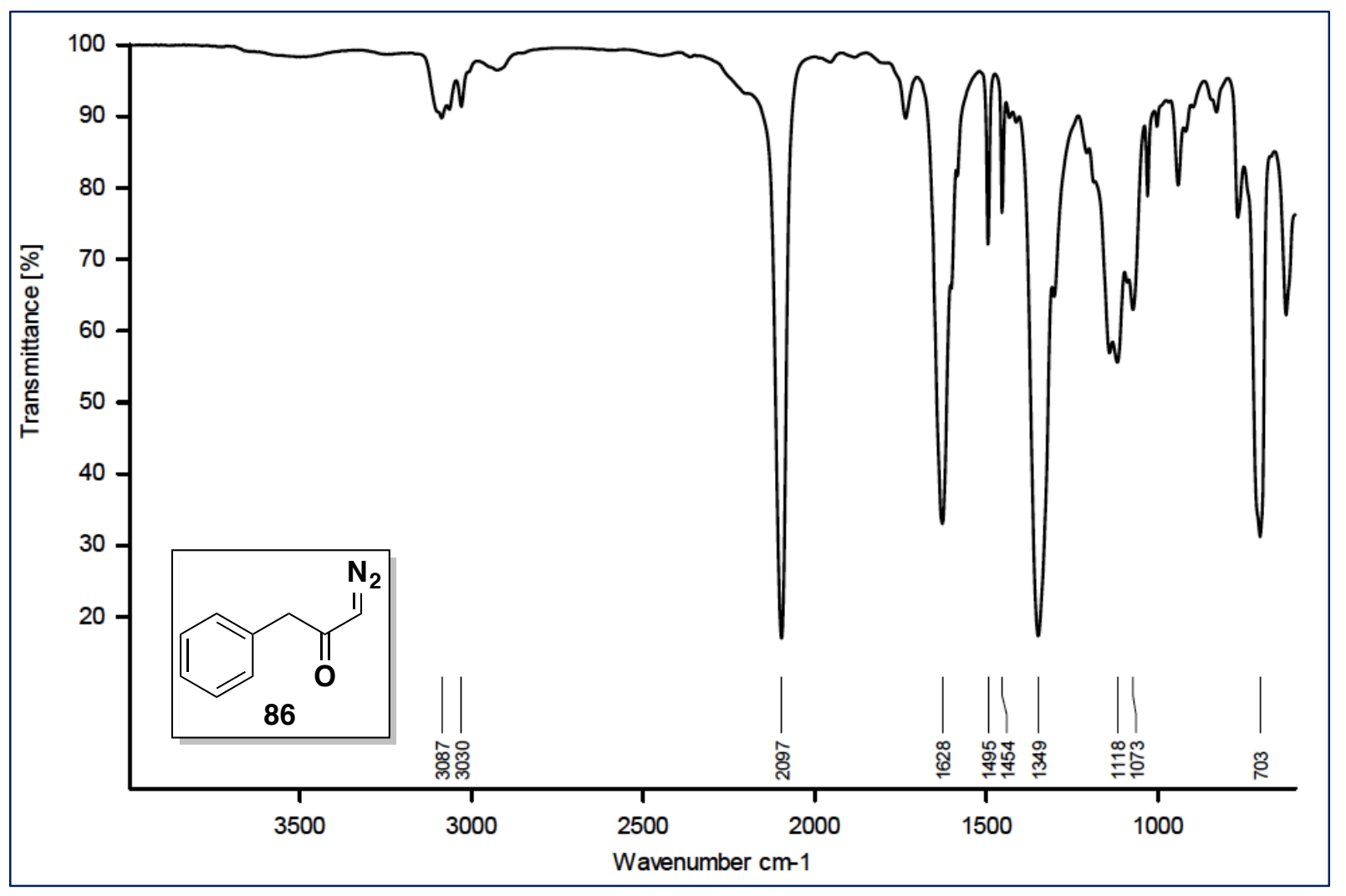



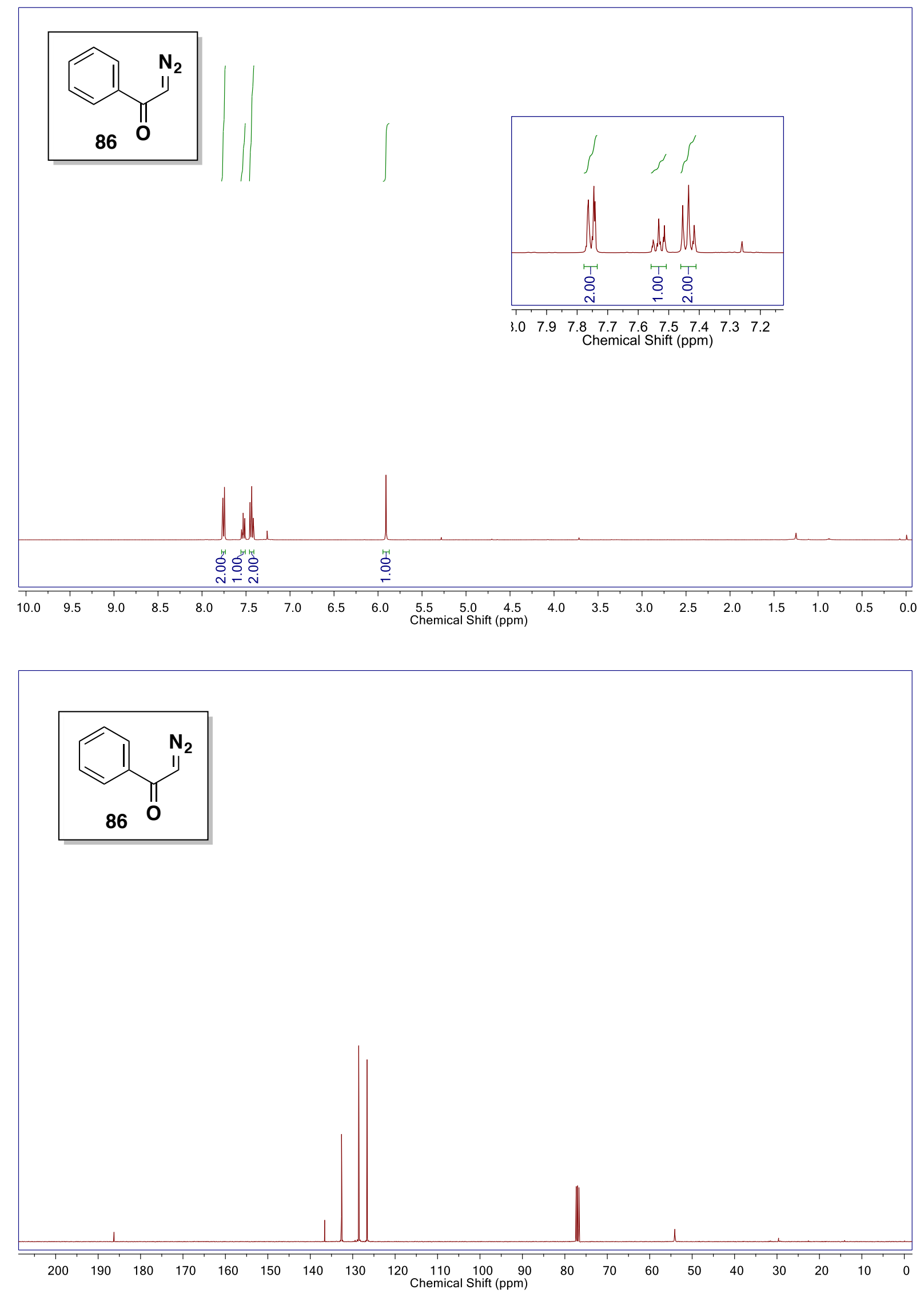


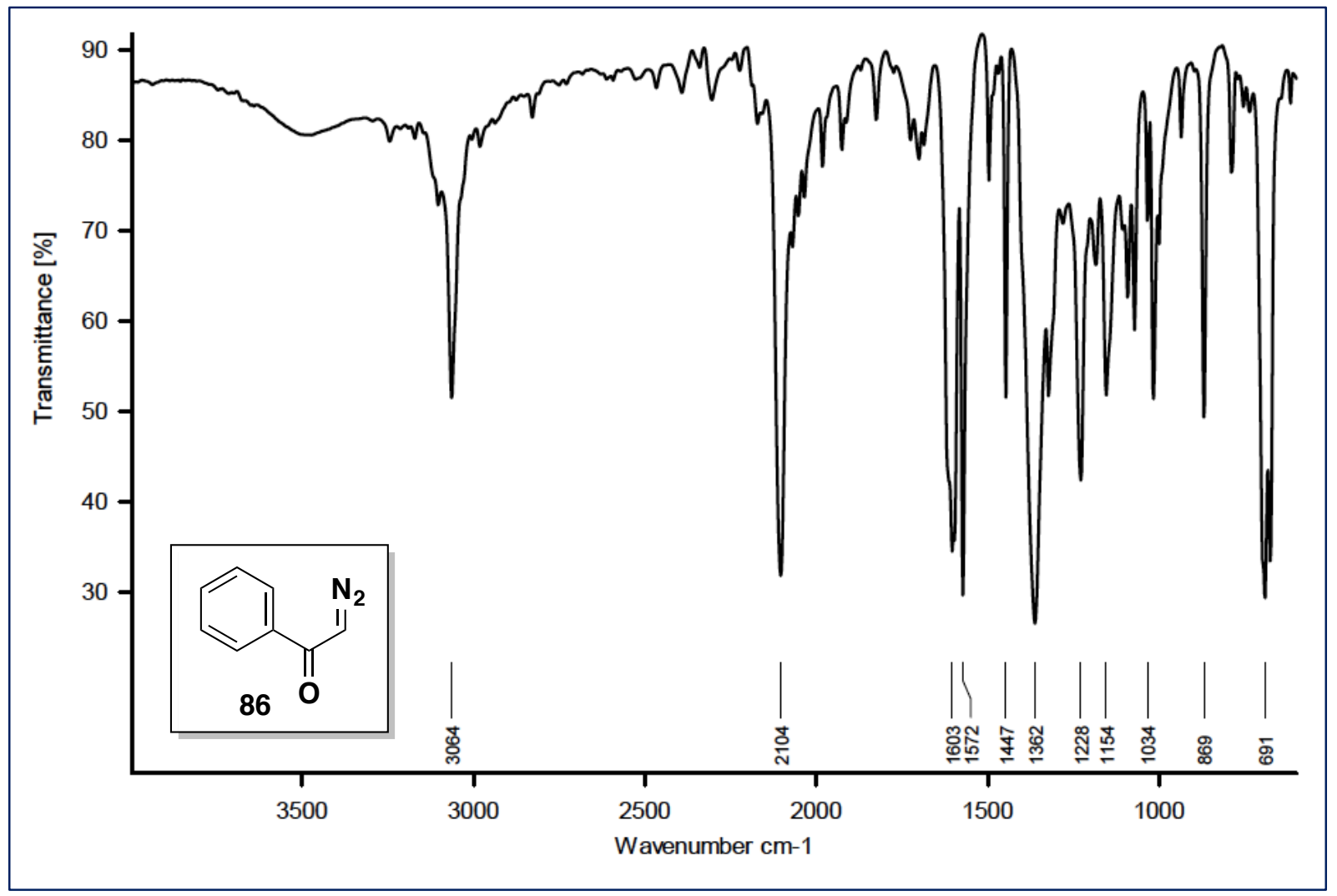



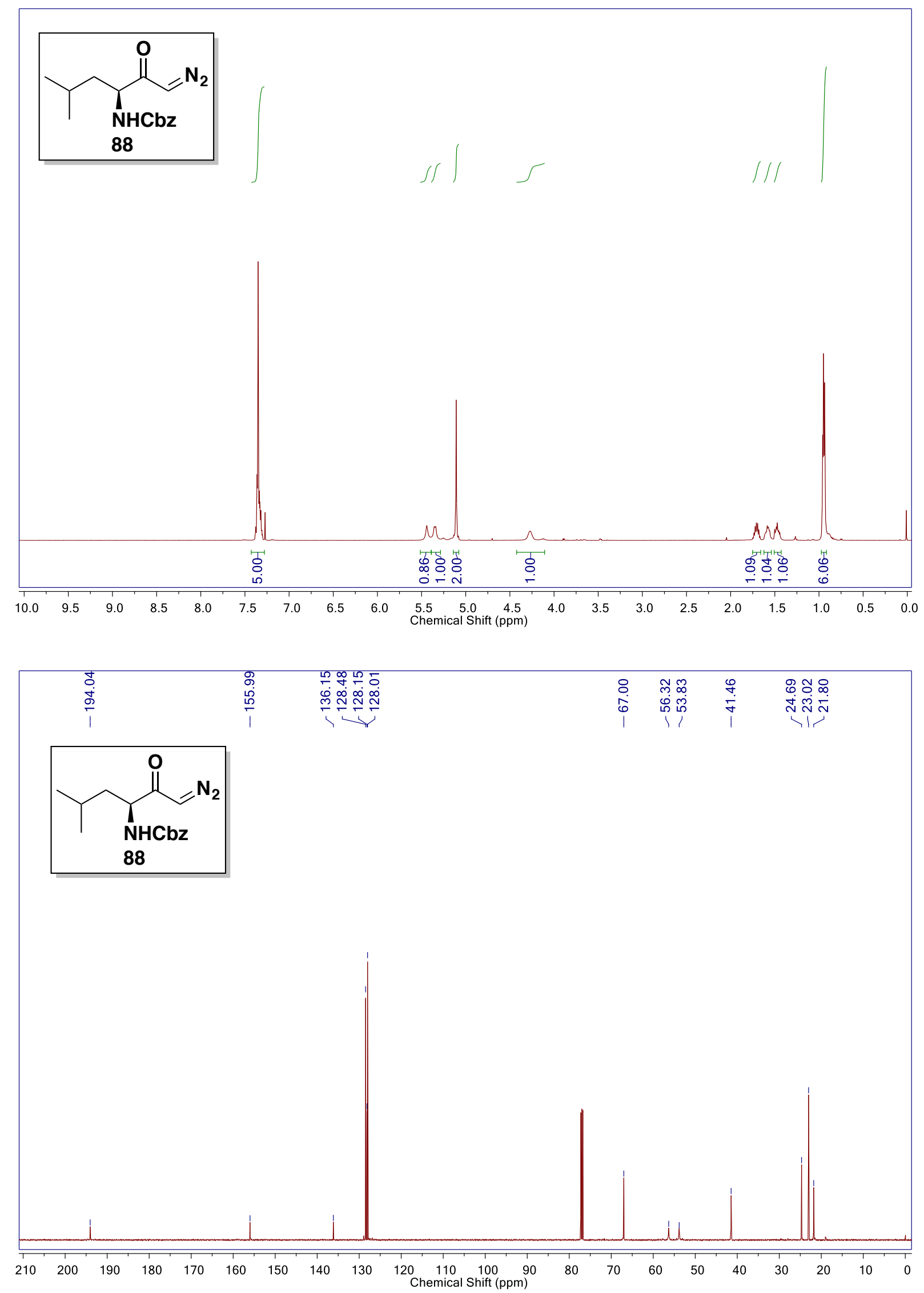

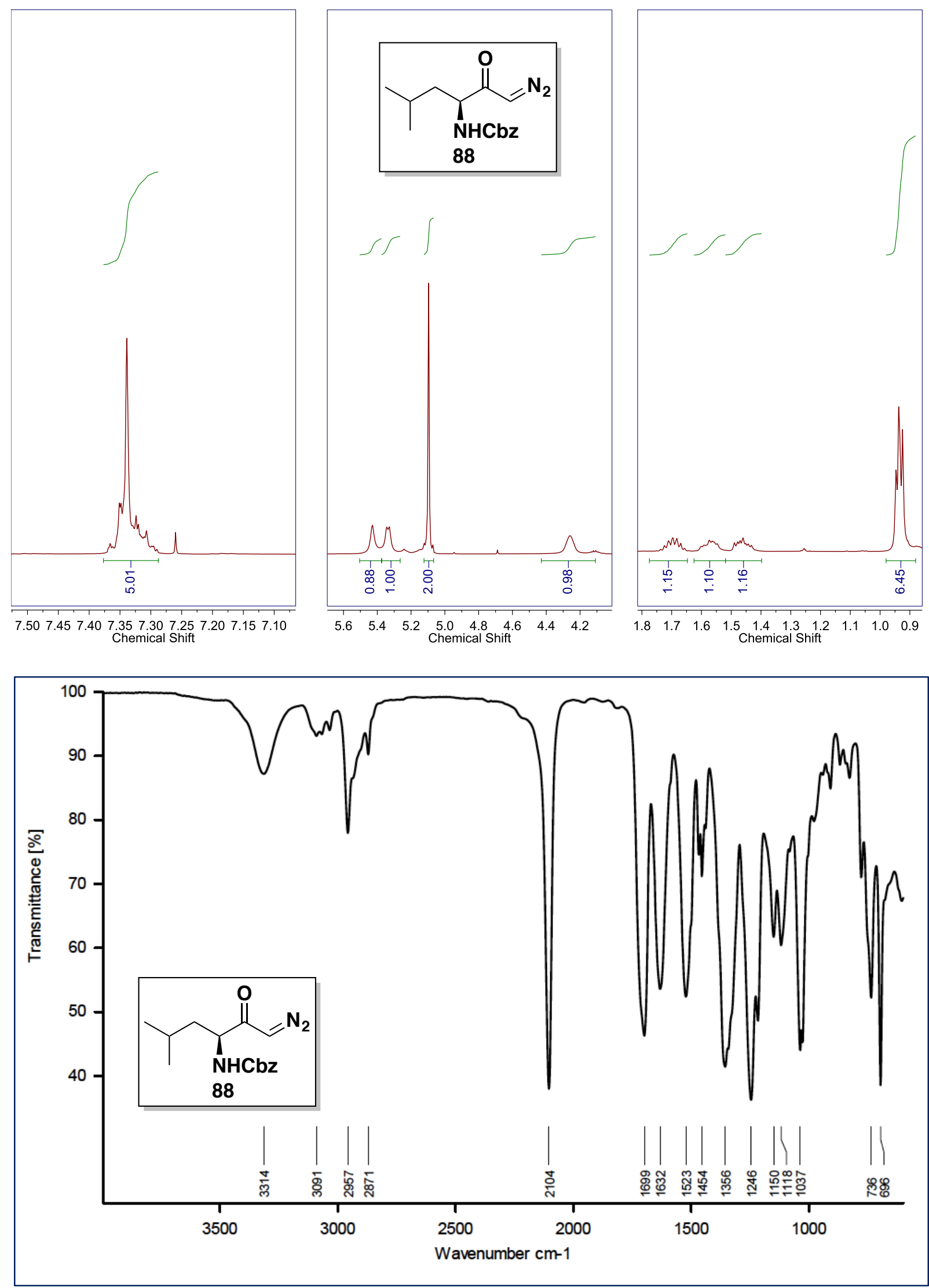

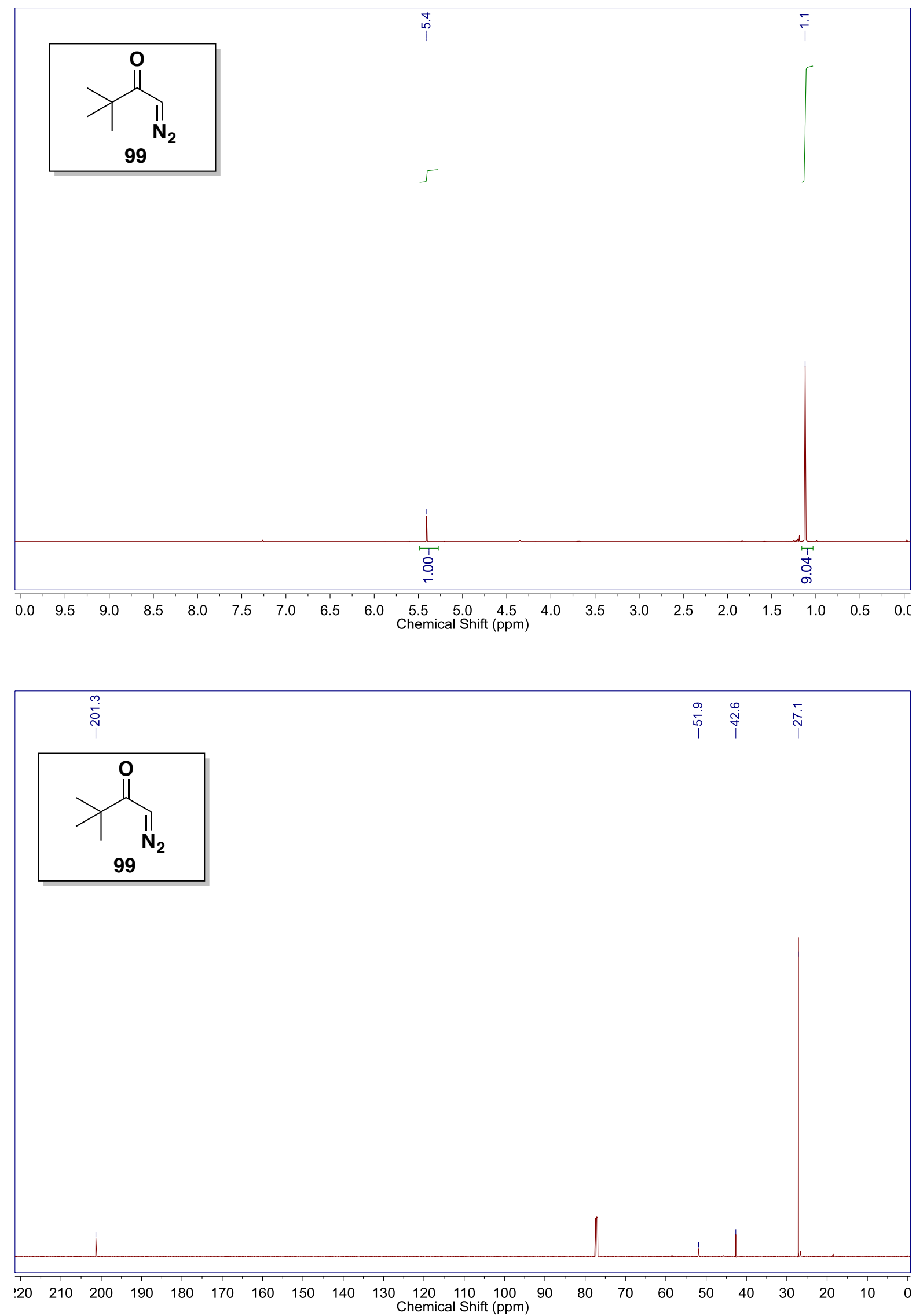


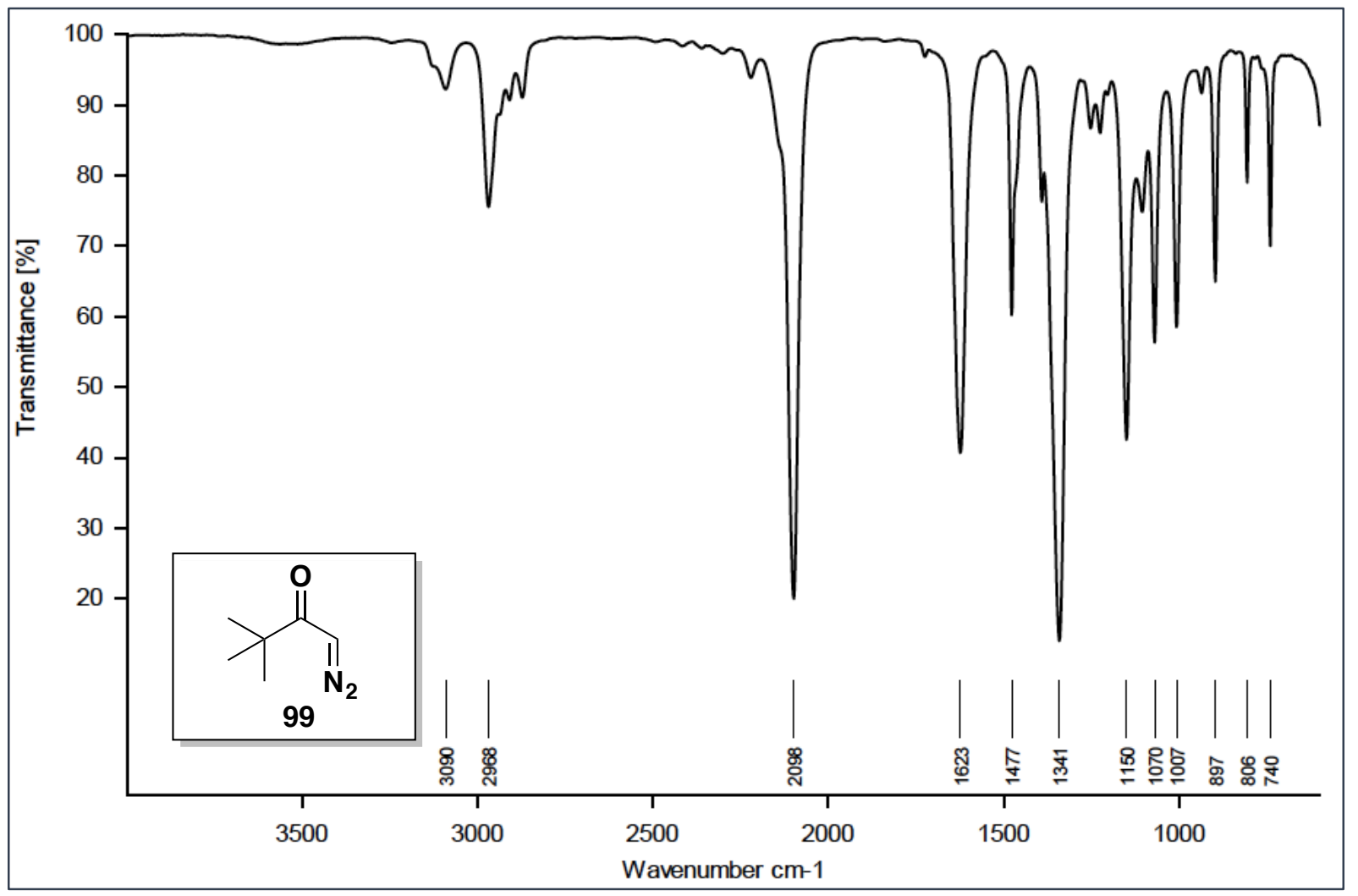



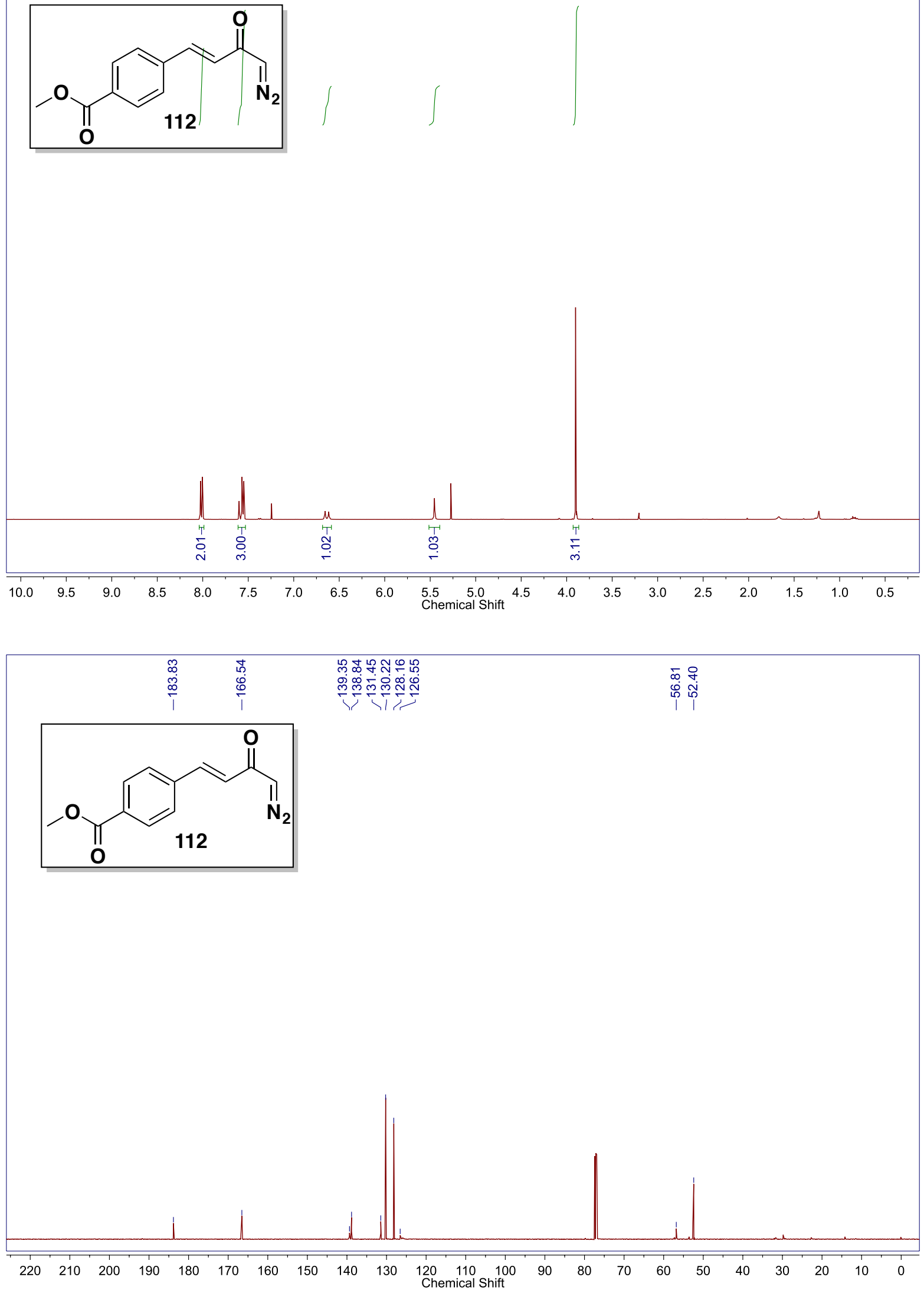

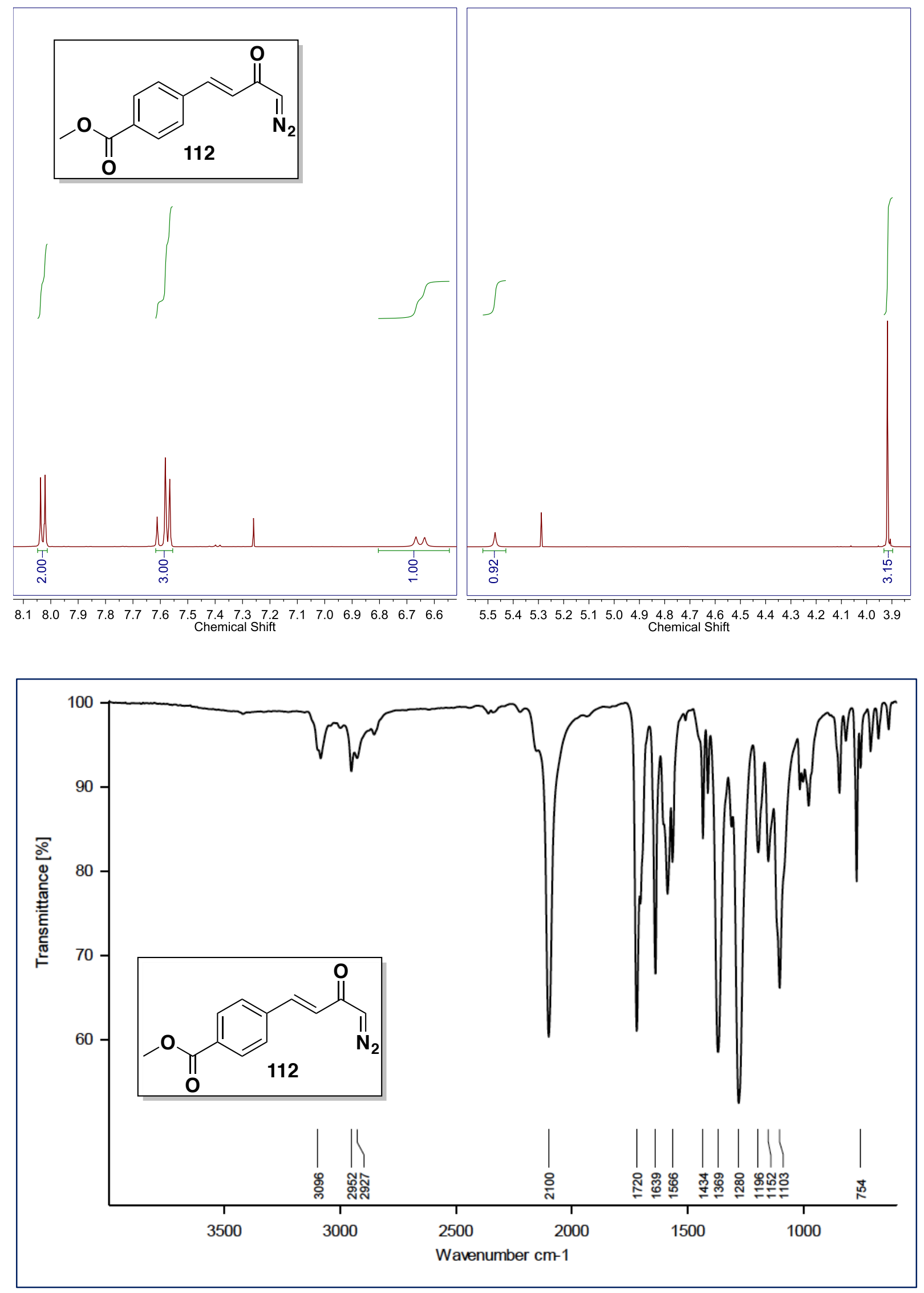

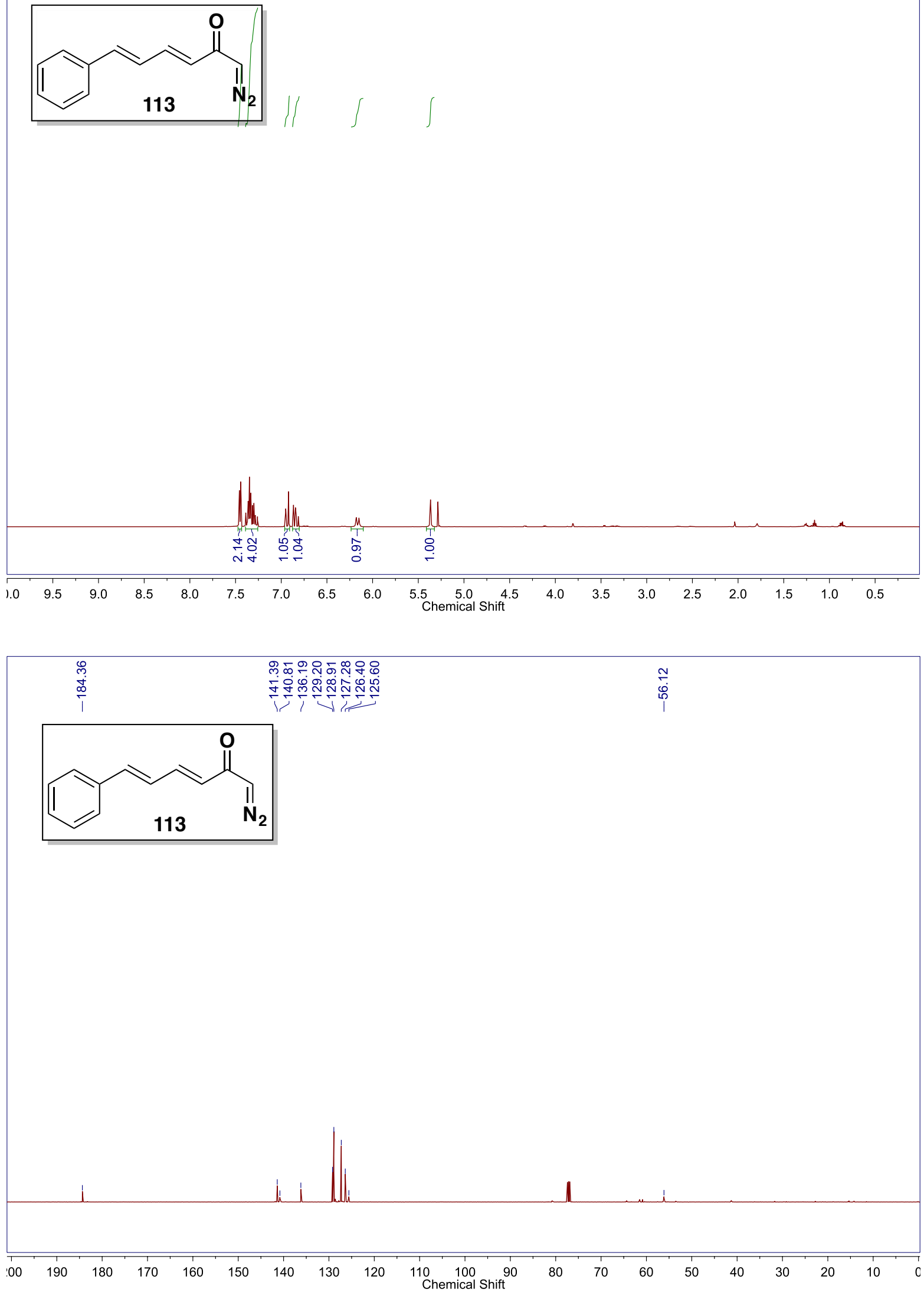

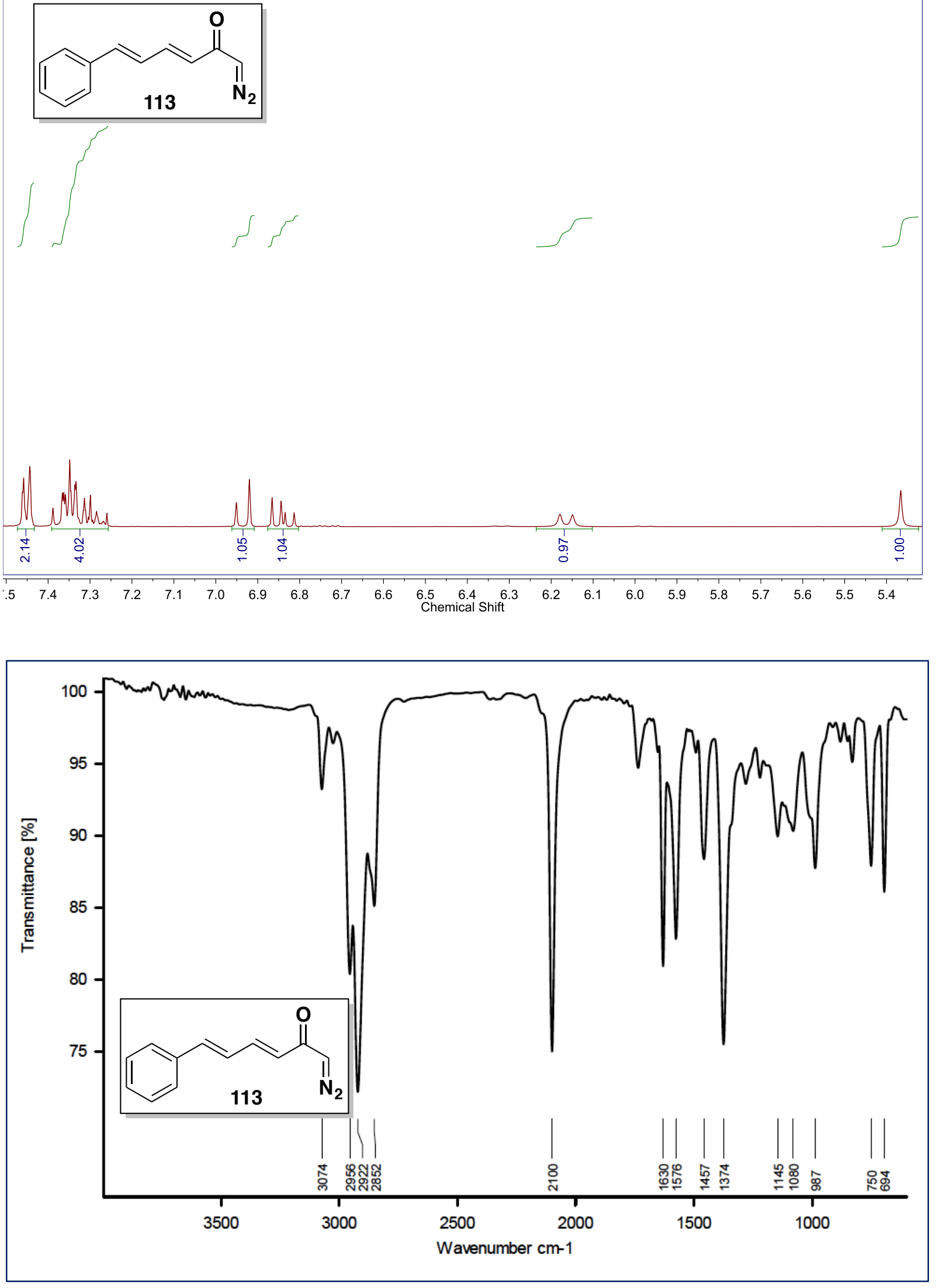

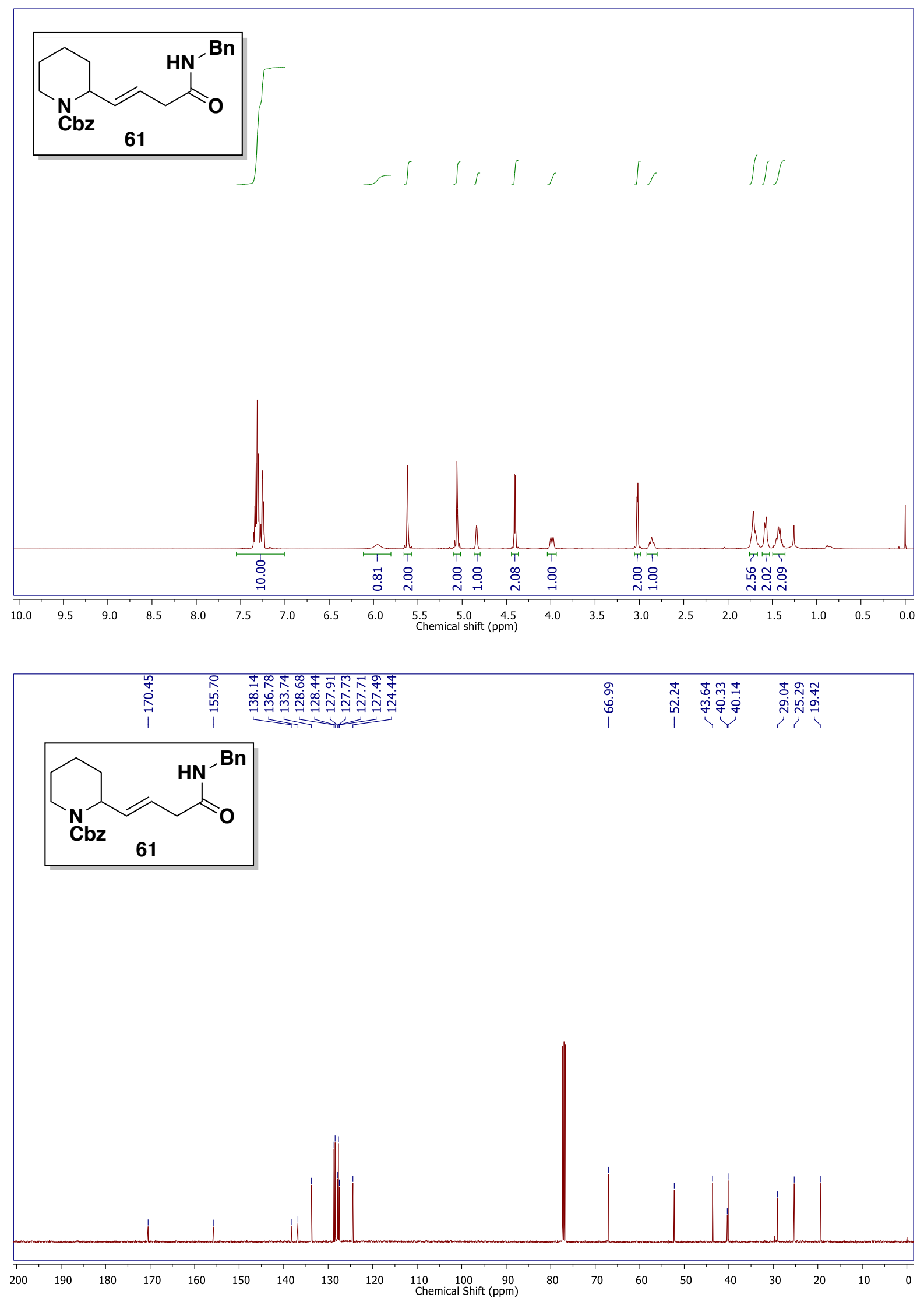

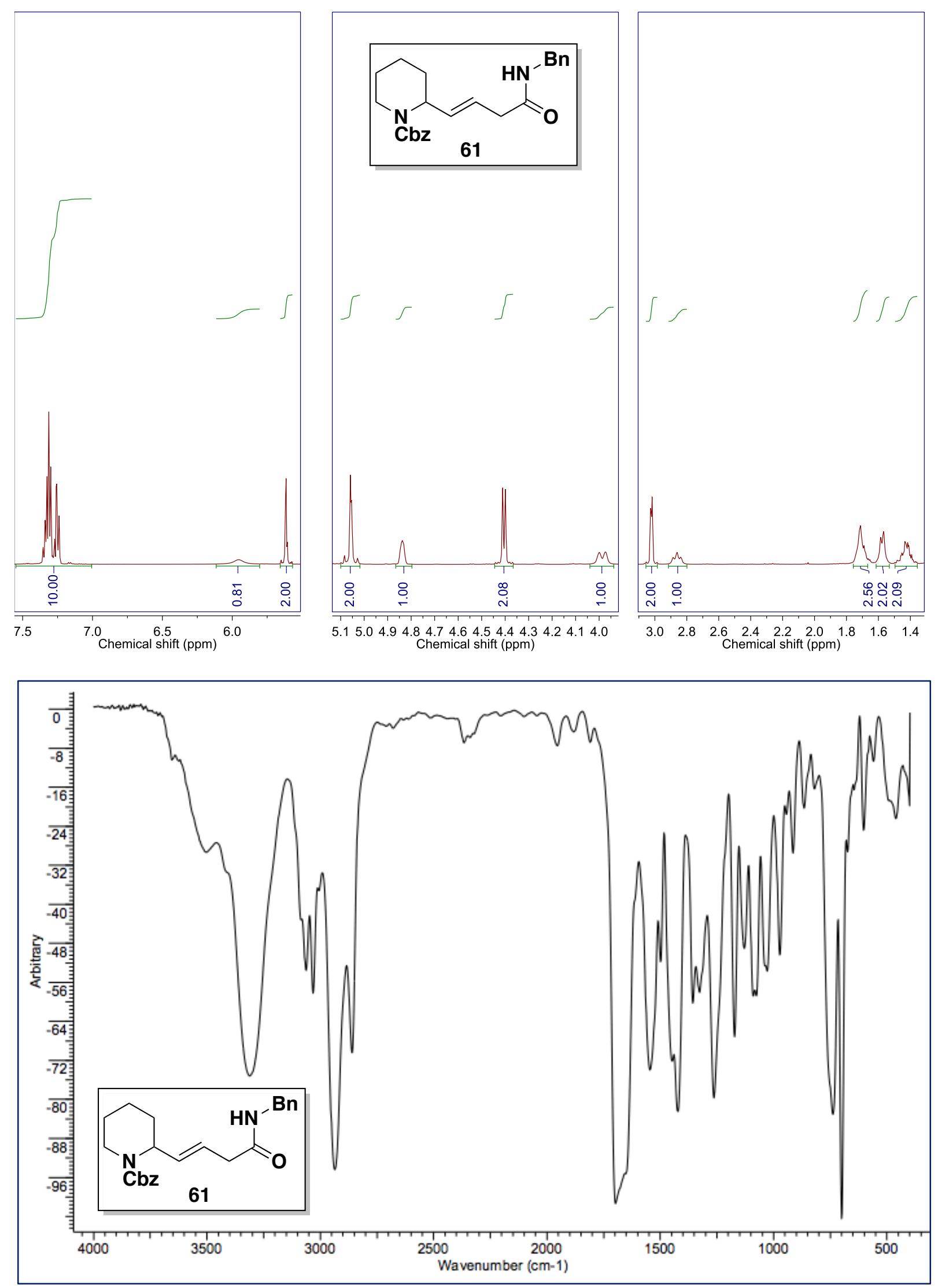

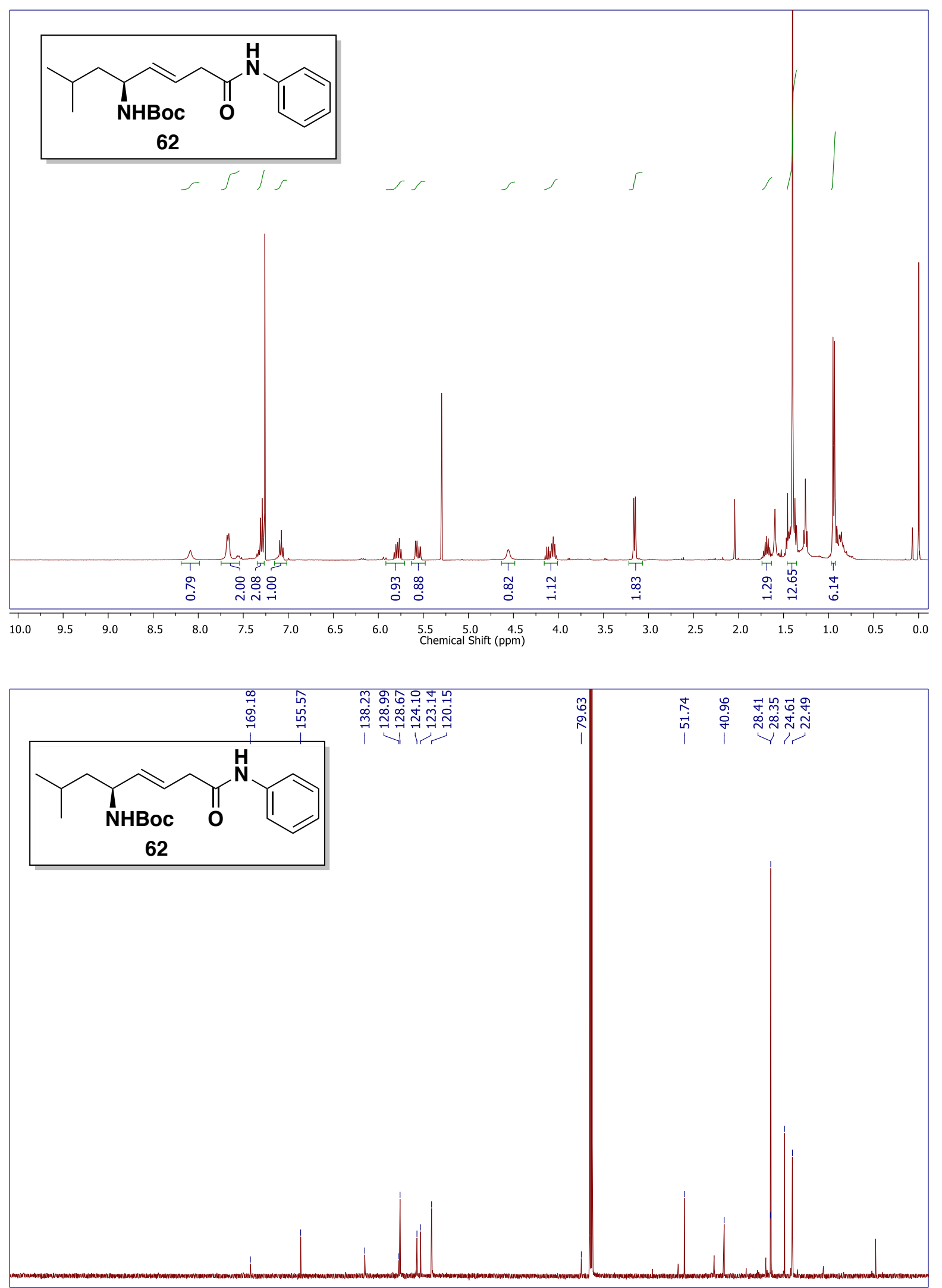

$\begin{array}{llllllllllllllllllllllllllll}230 & 220 & 210 & 200 & 190 & 180 & 170 & 160 & 150 & 140 & 130 & 120 & 110 & 100 & 90 & 80 & 70 & 60 & 50 & 40 & 30 & 20 & 10 & 0 & -10\end{array}$ 


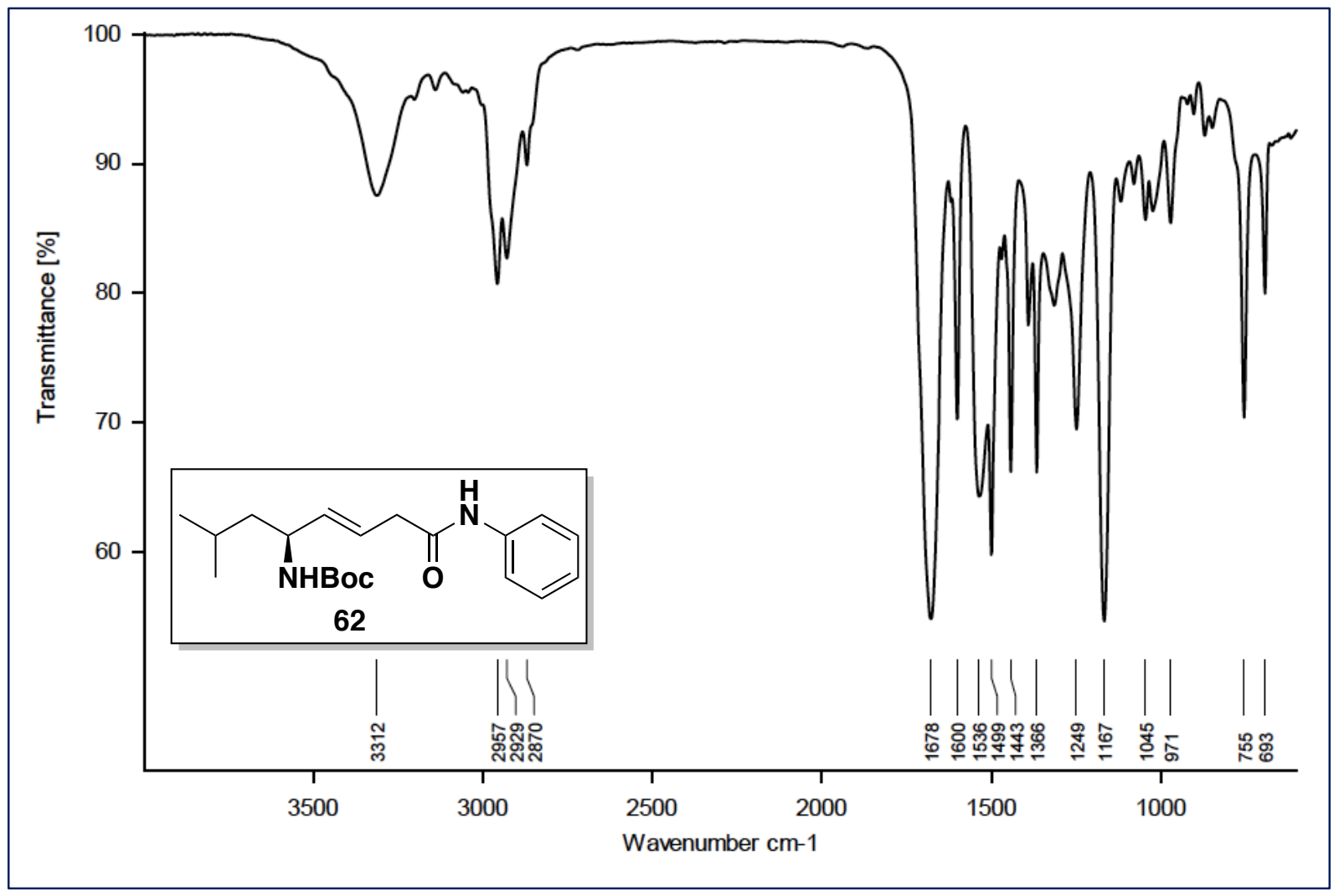



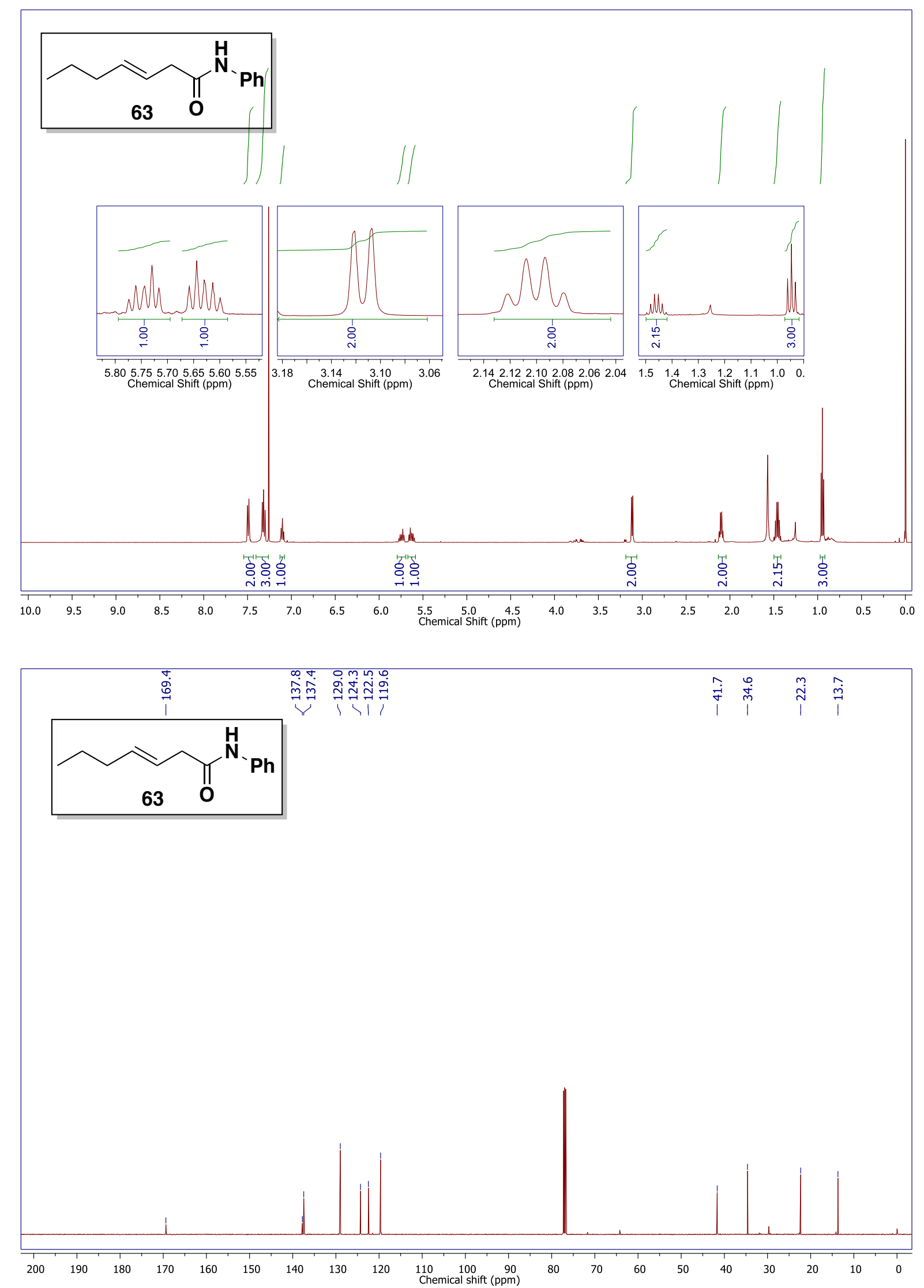


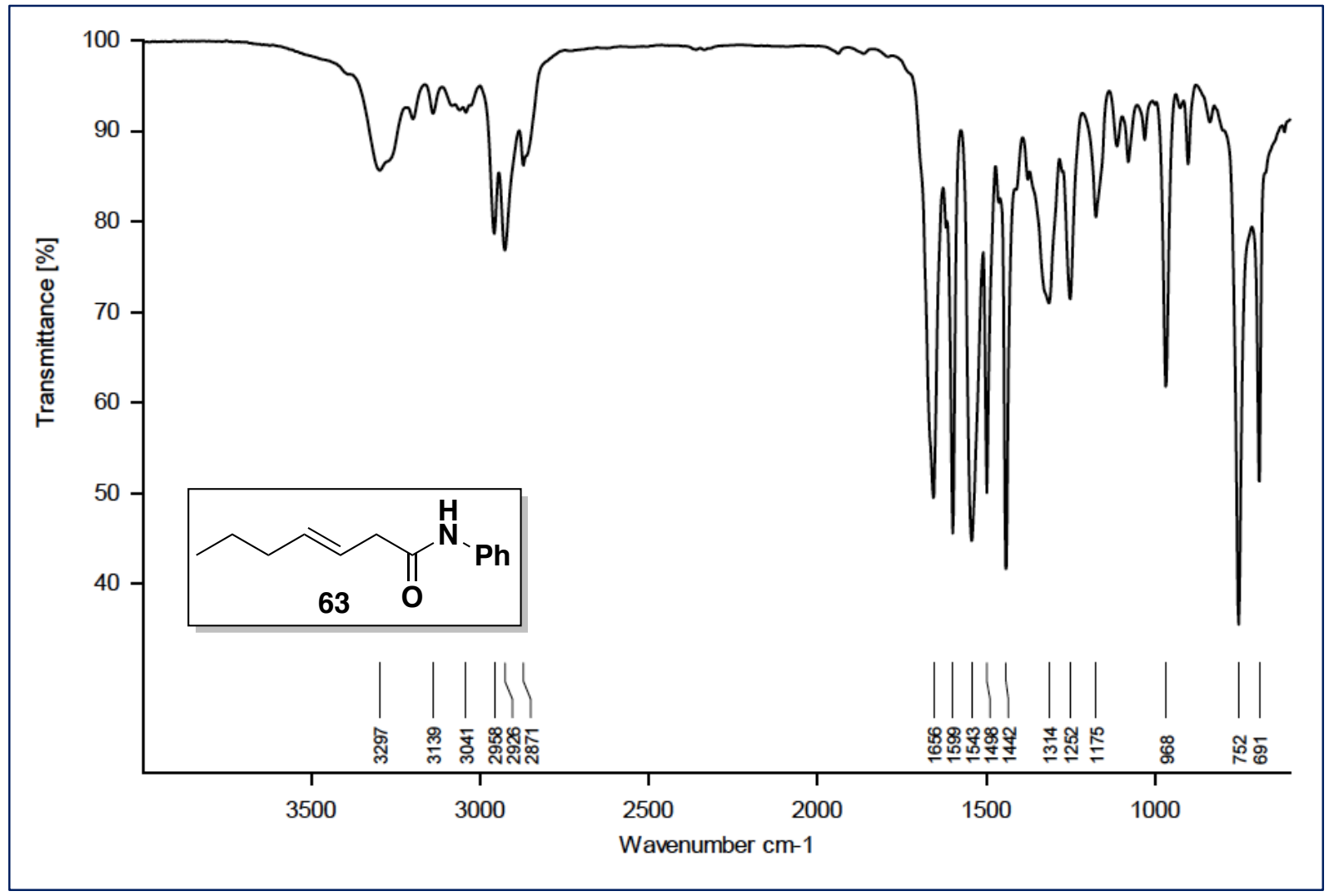


341
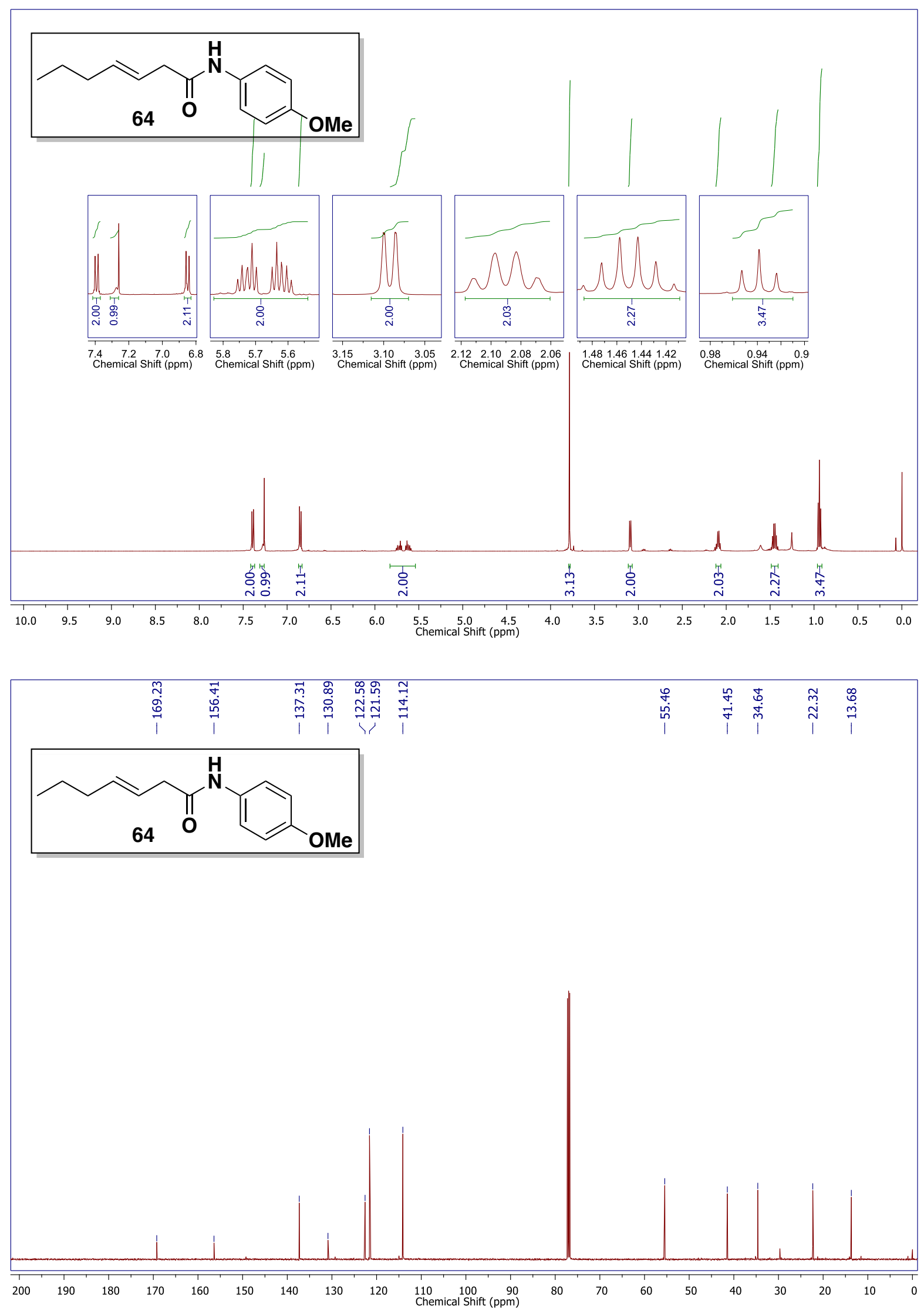


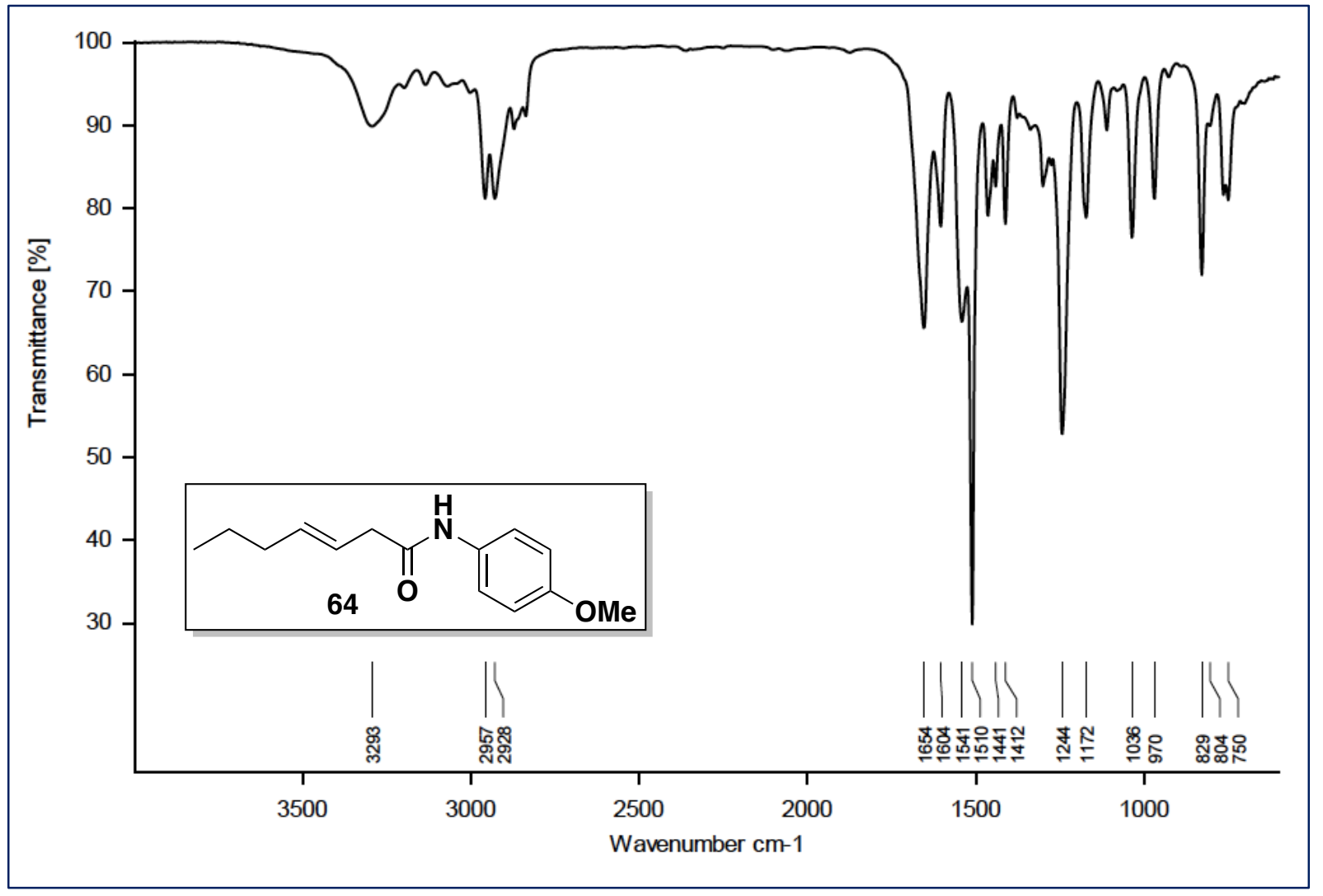



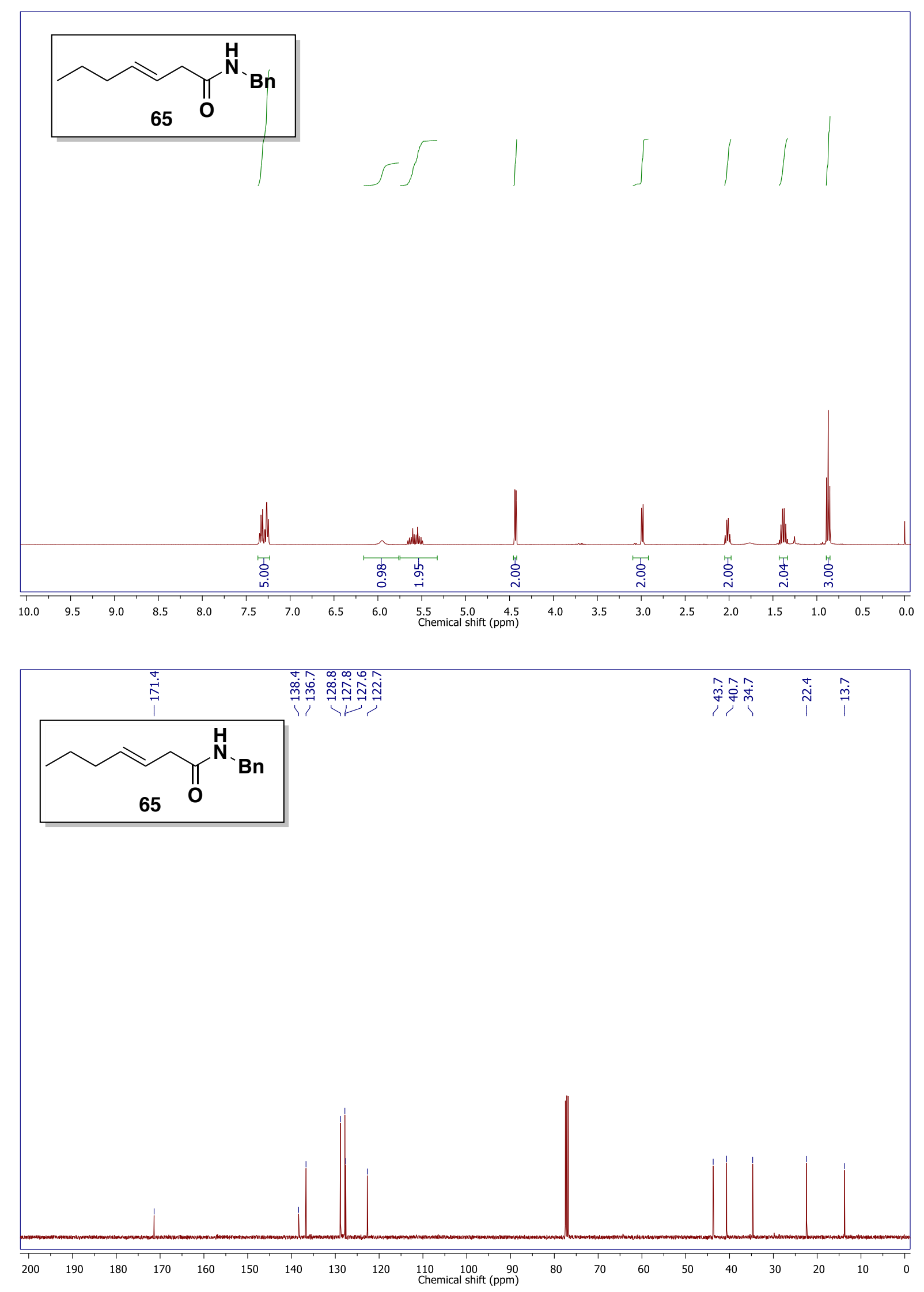


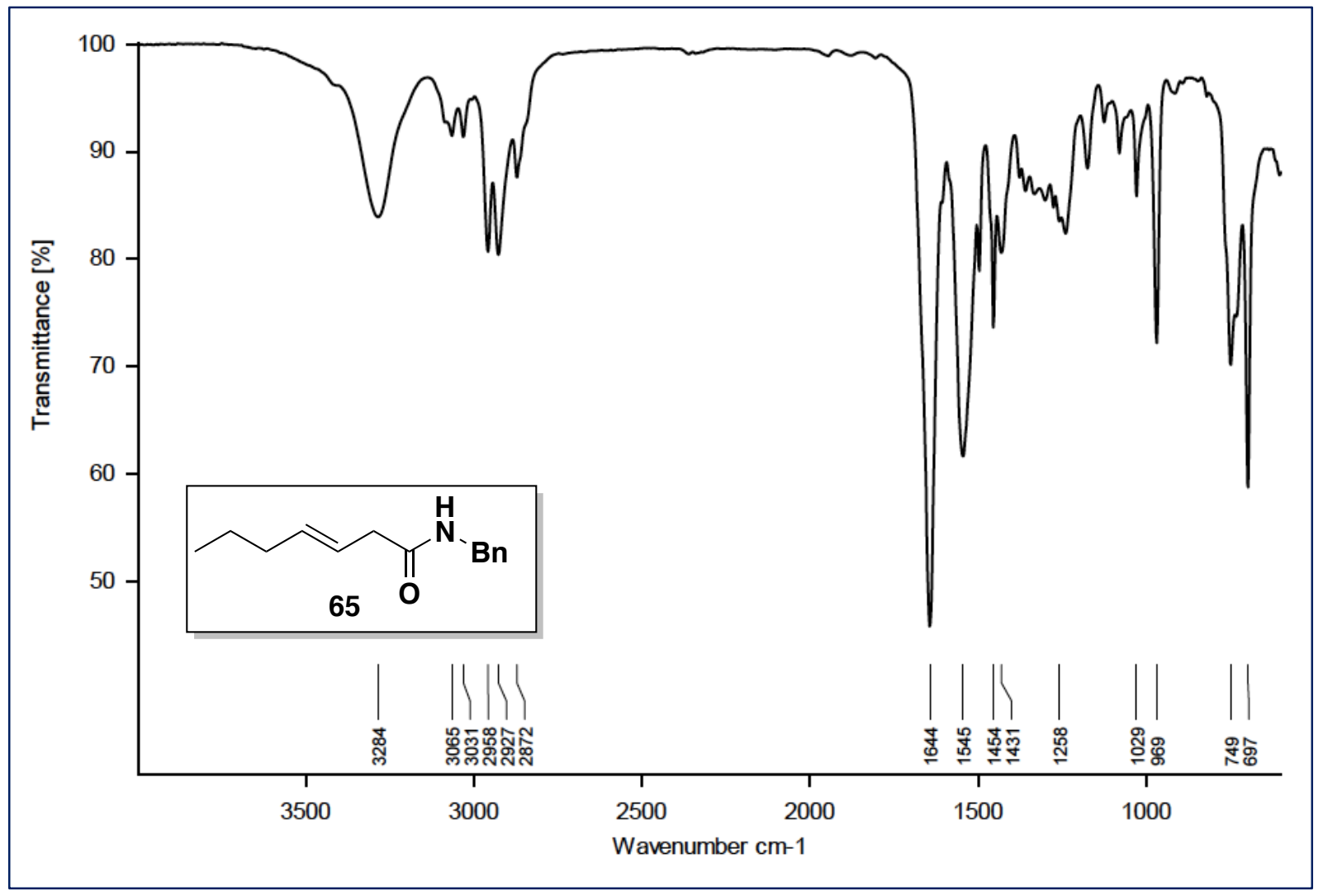



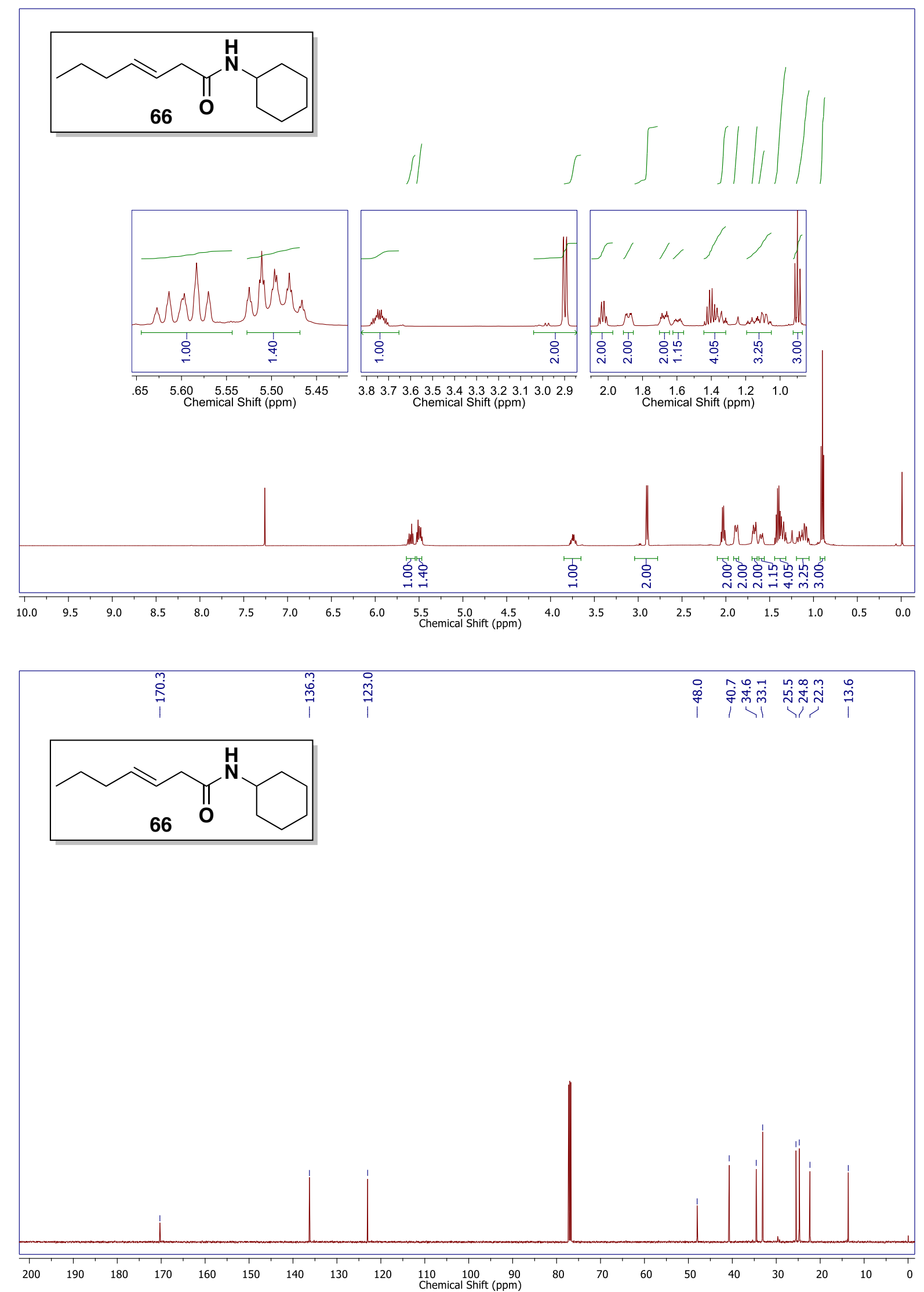


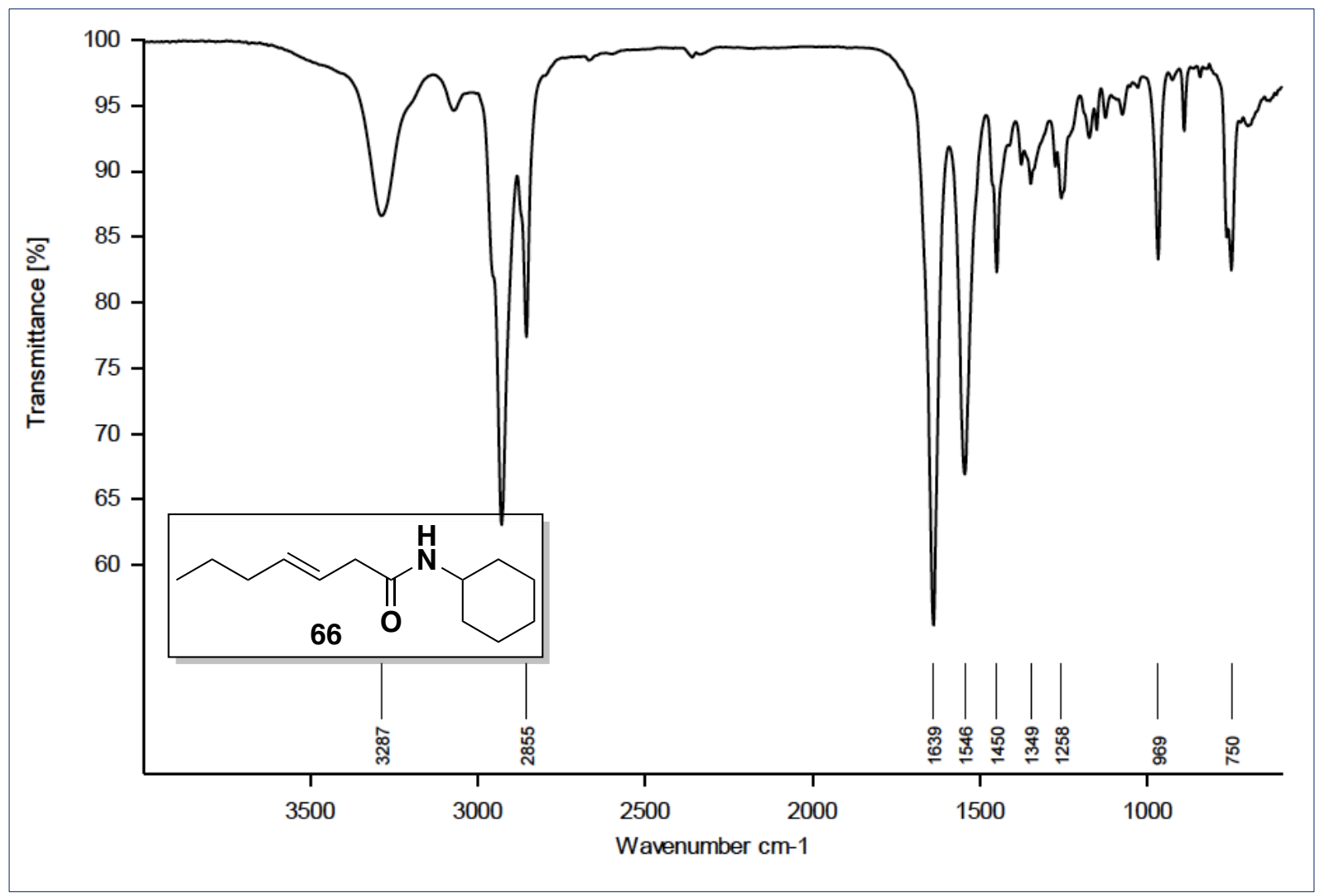



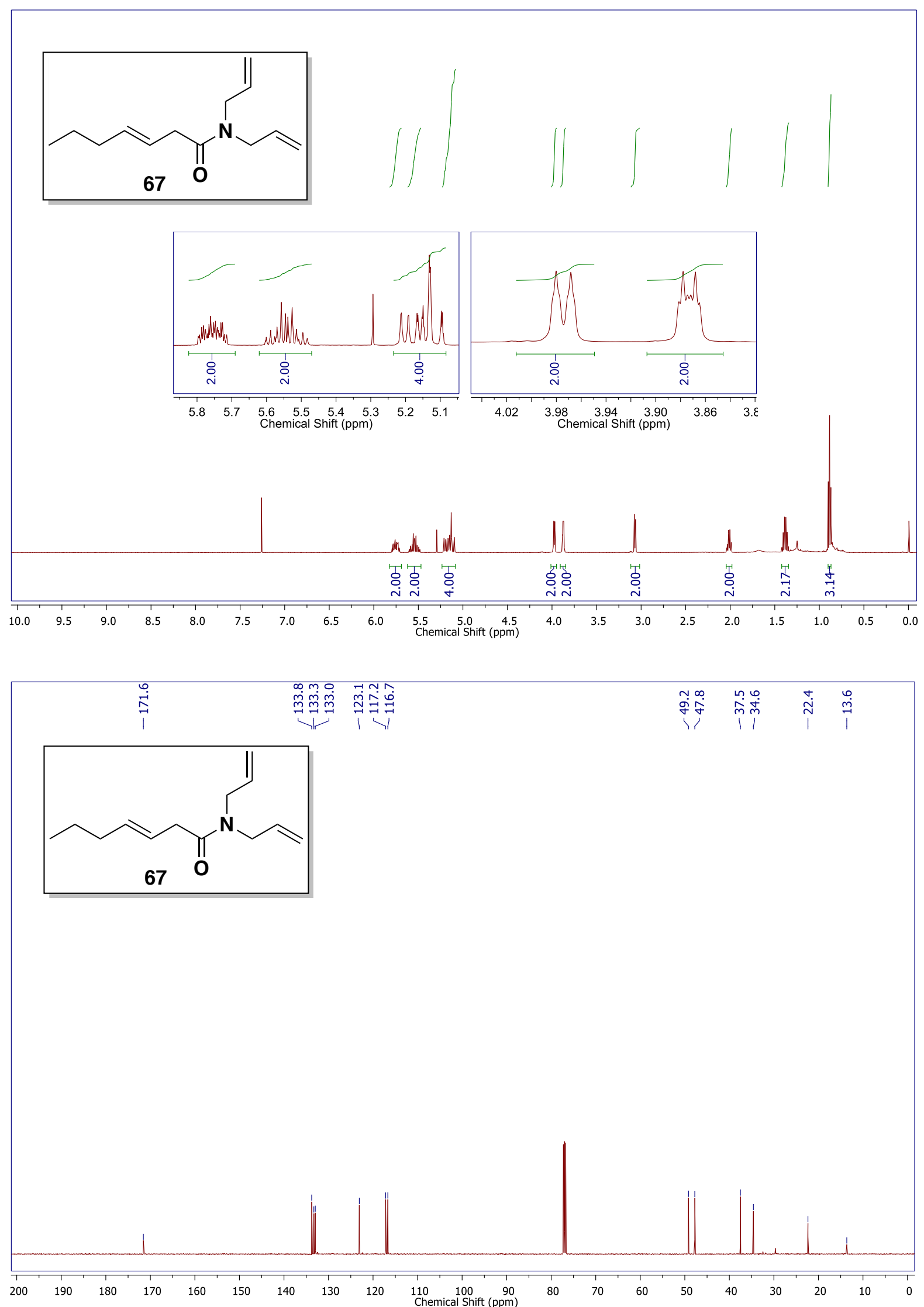


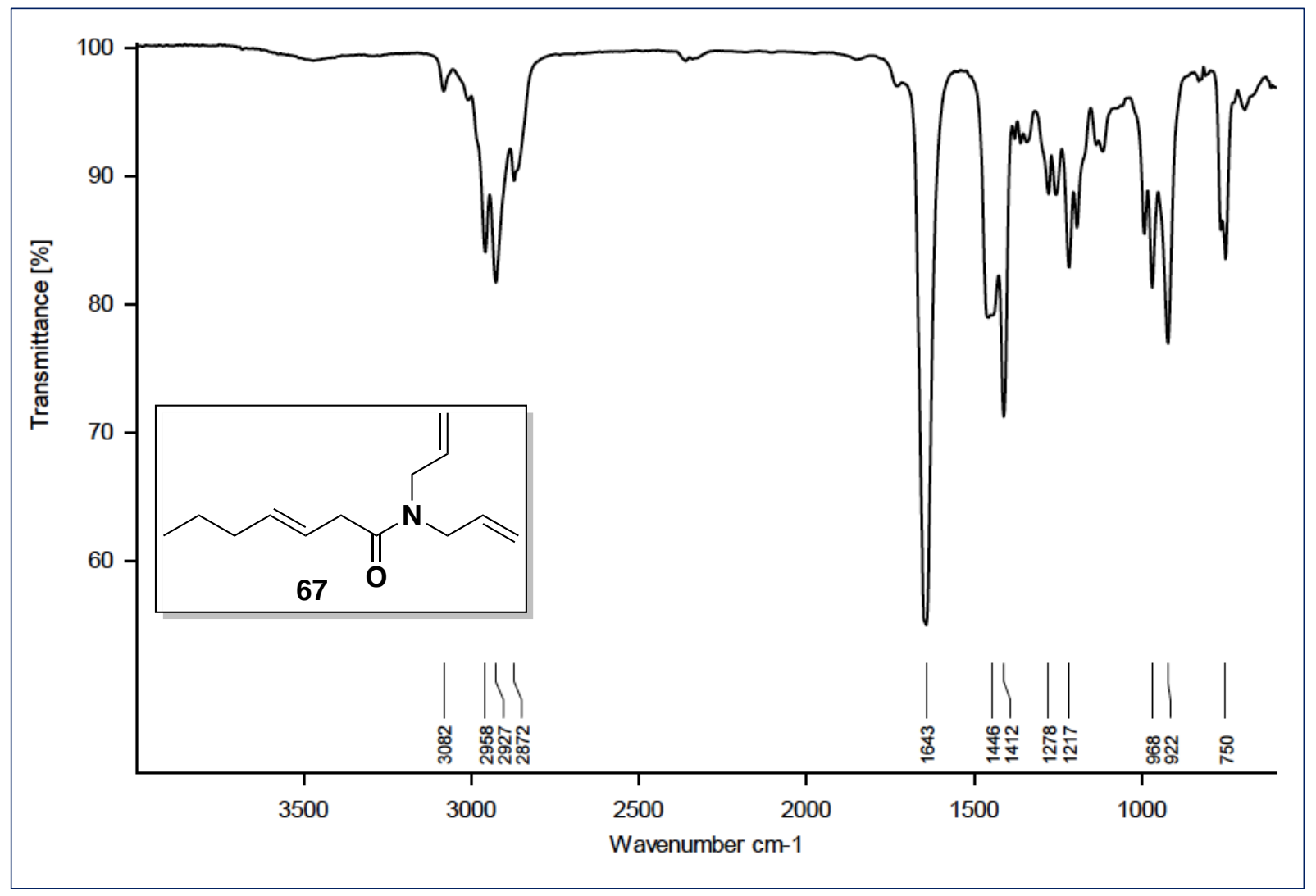



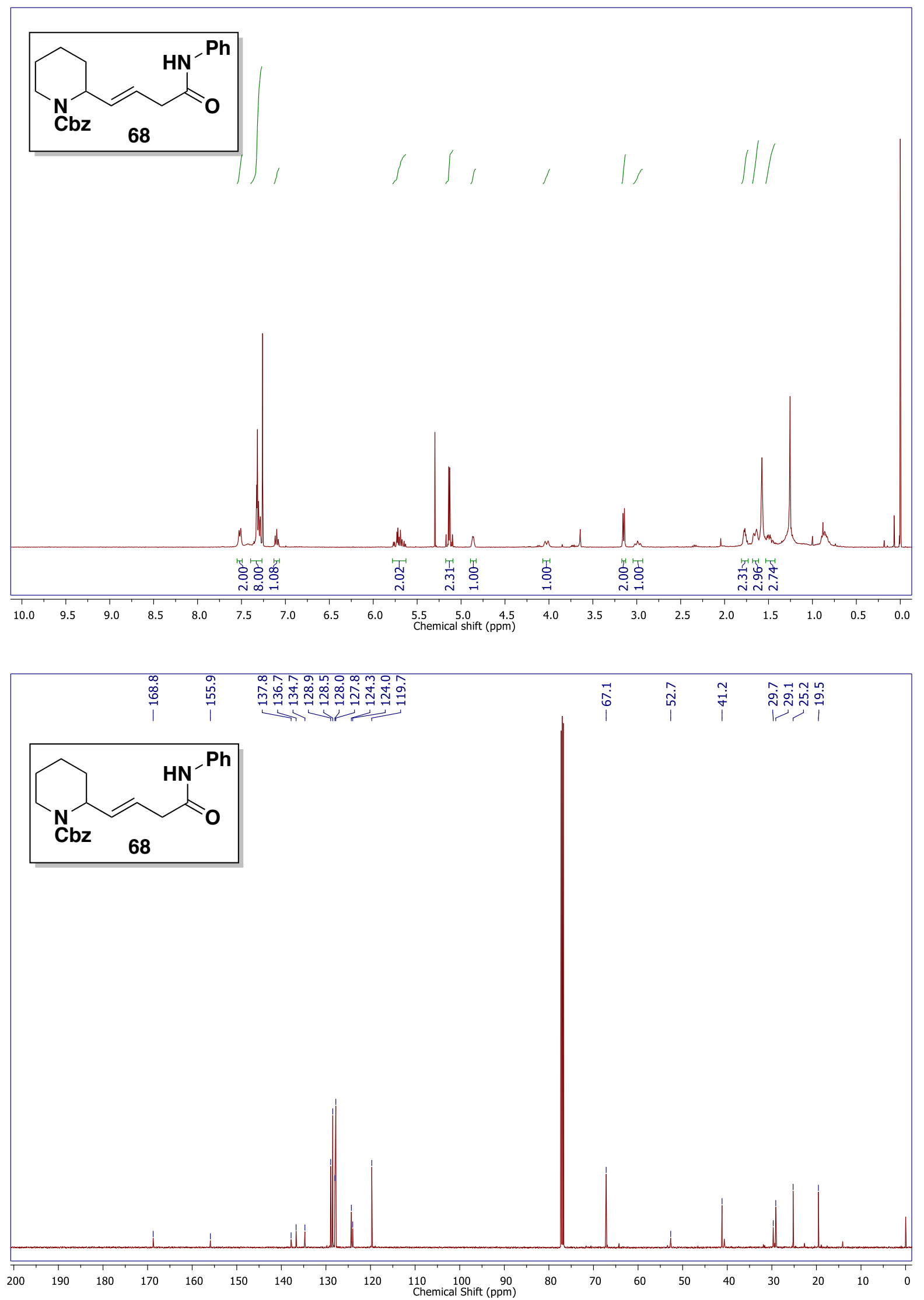


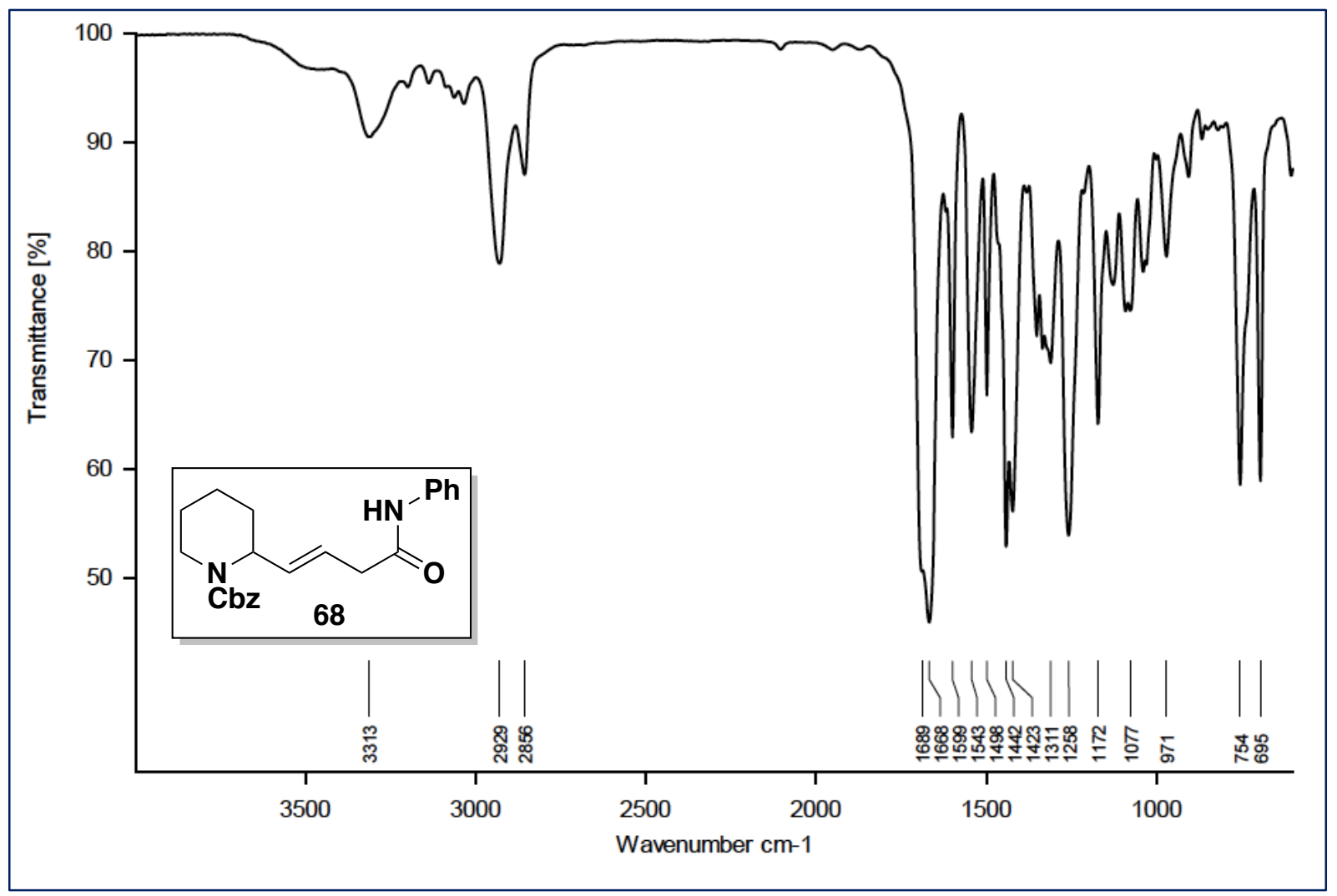



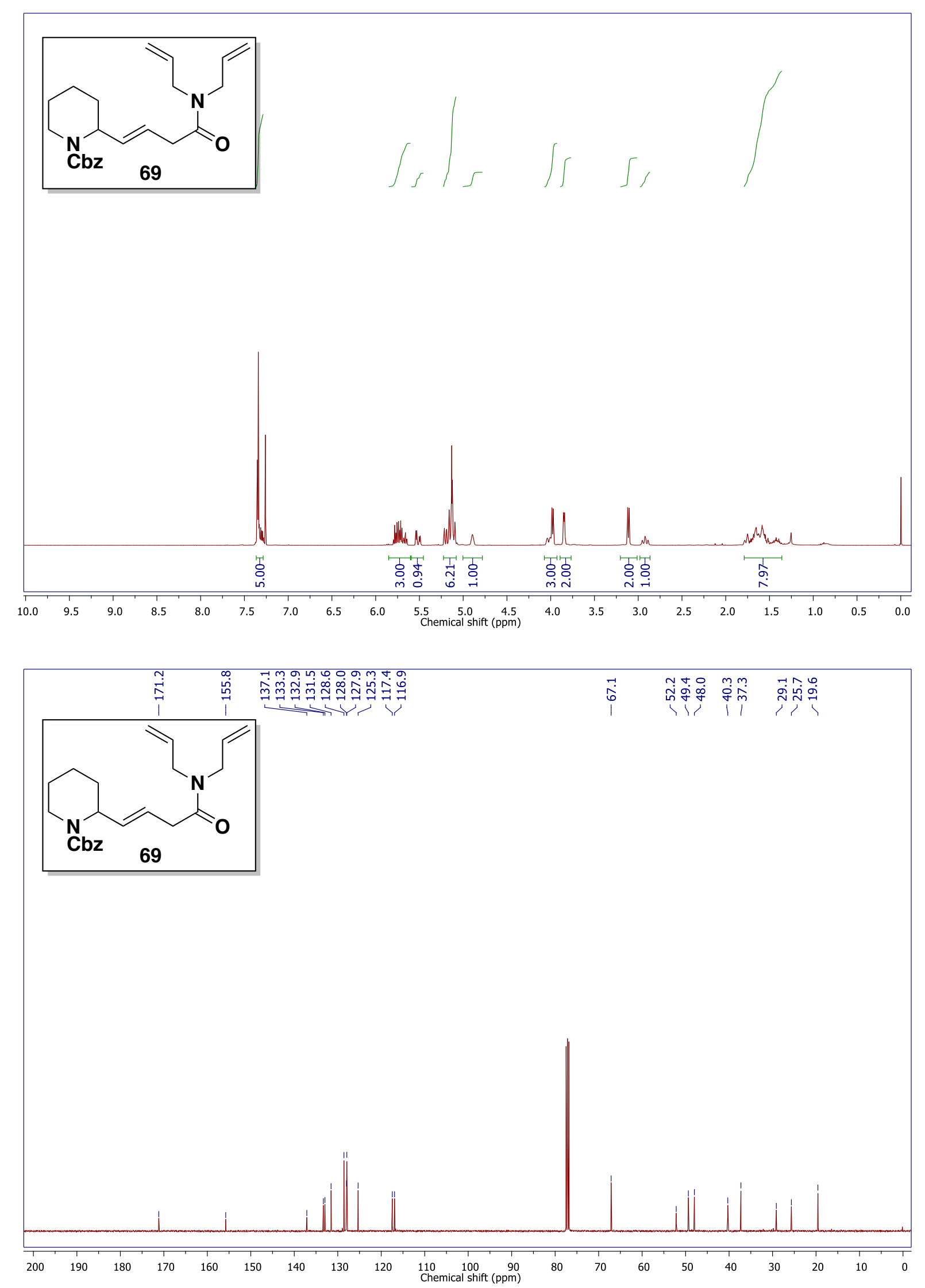


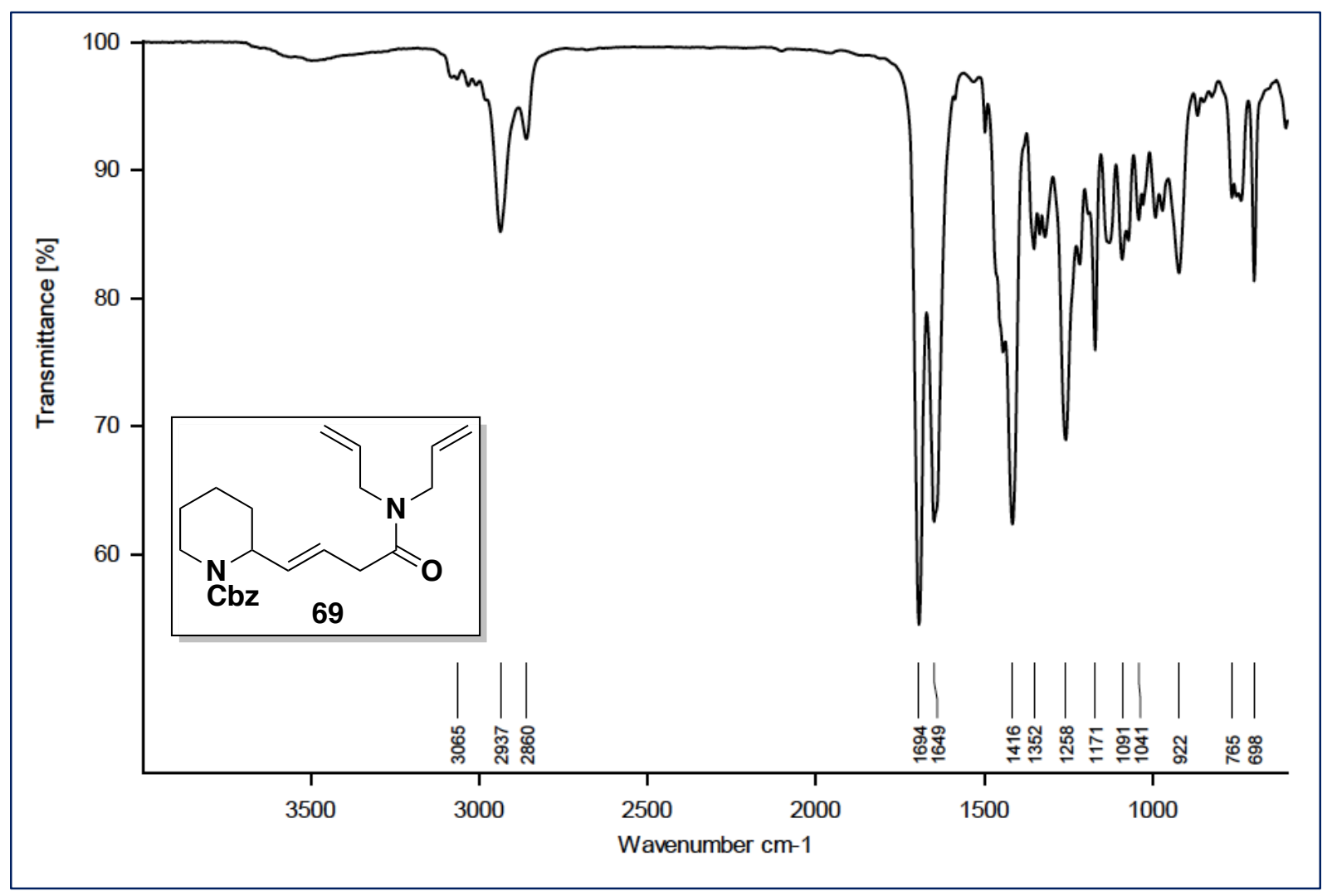



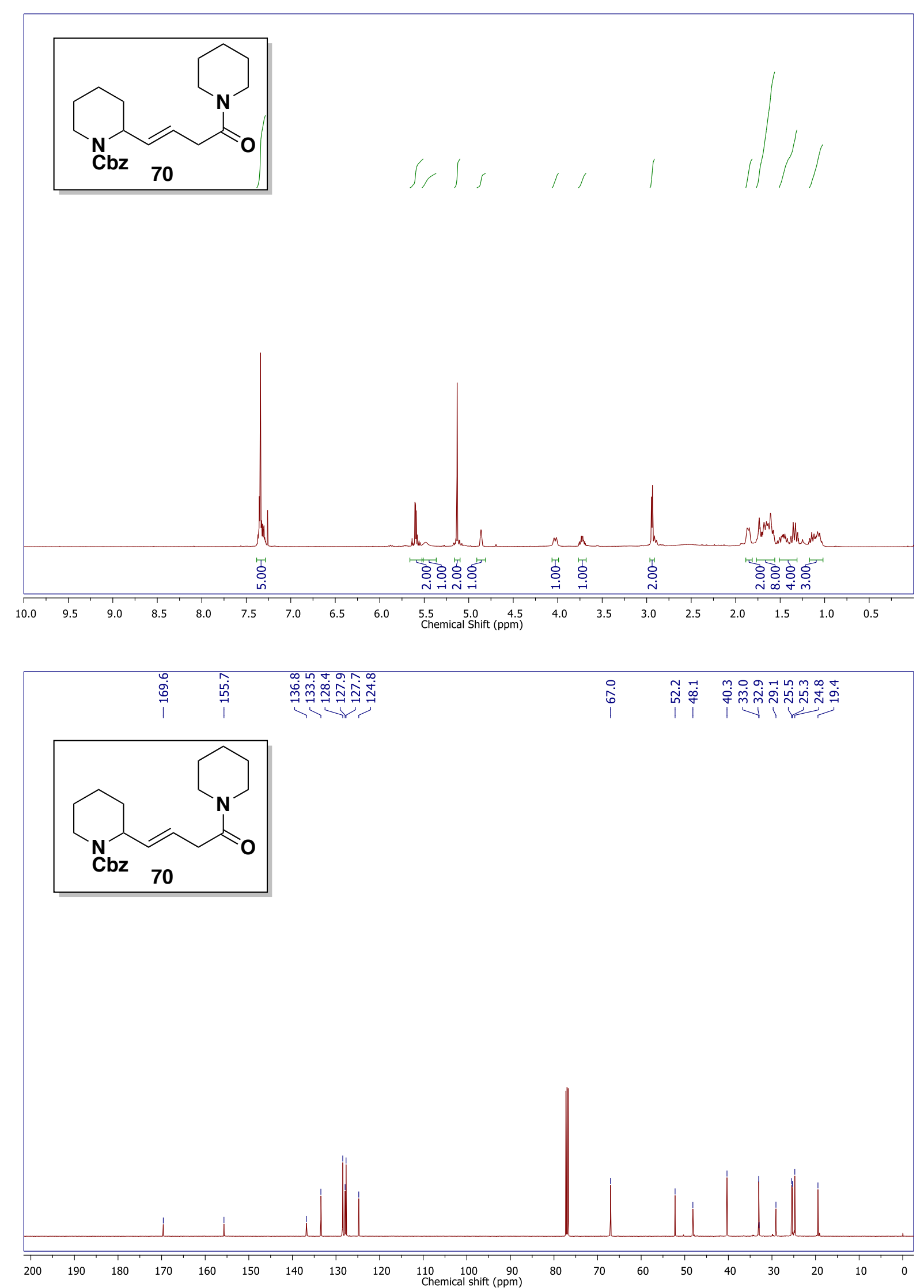


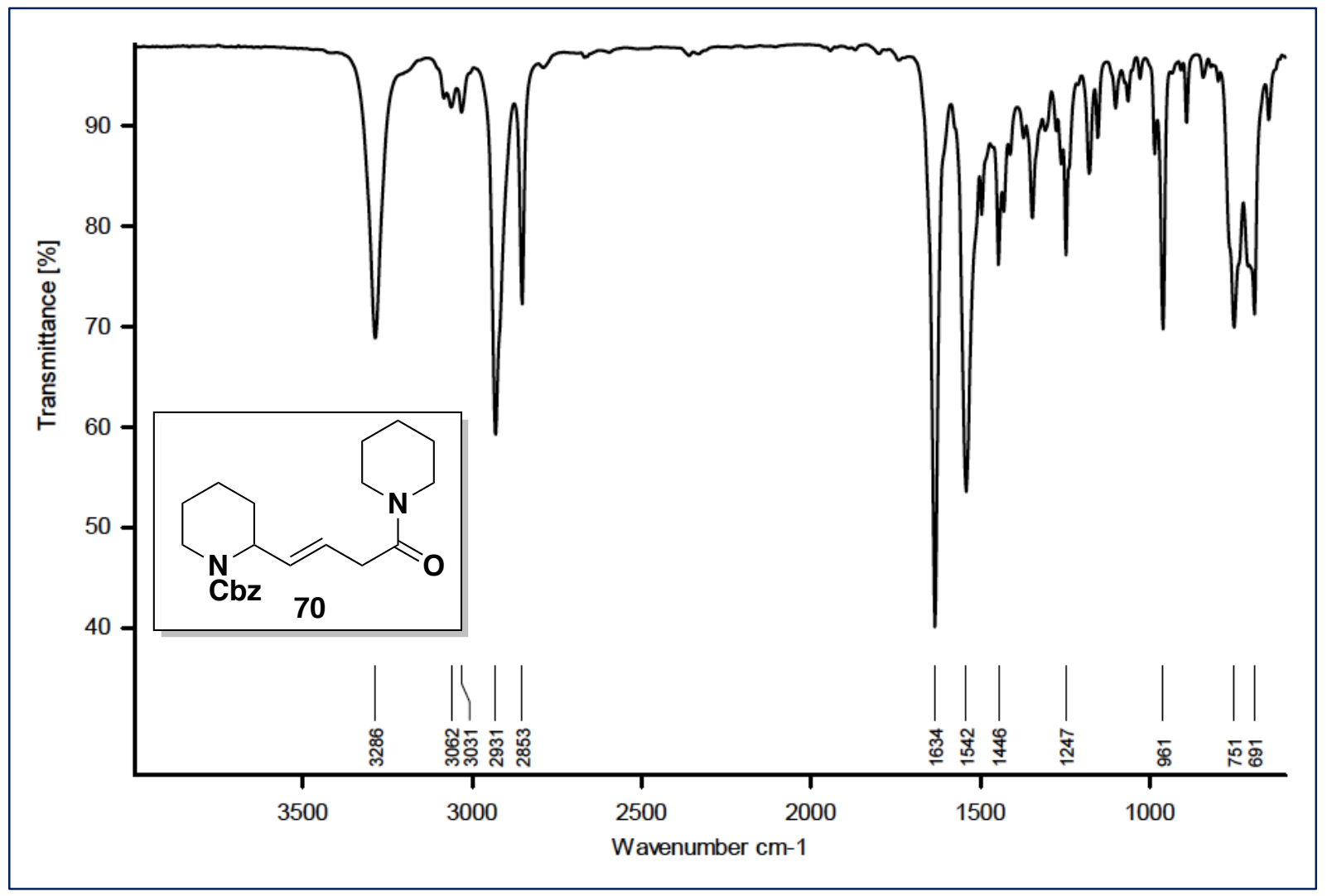



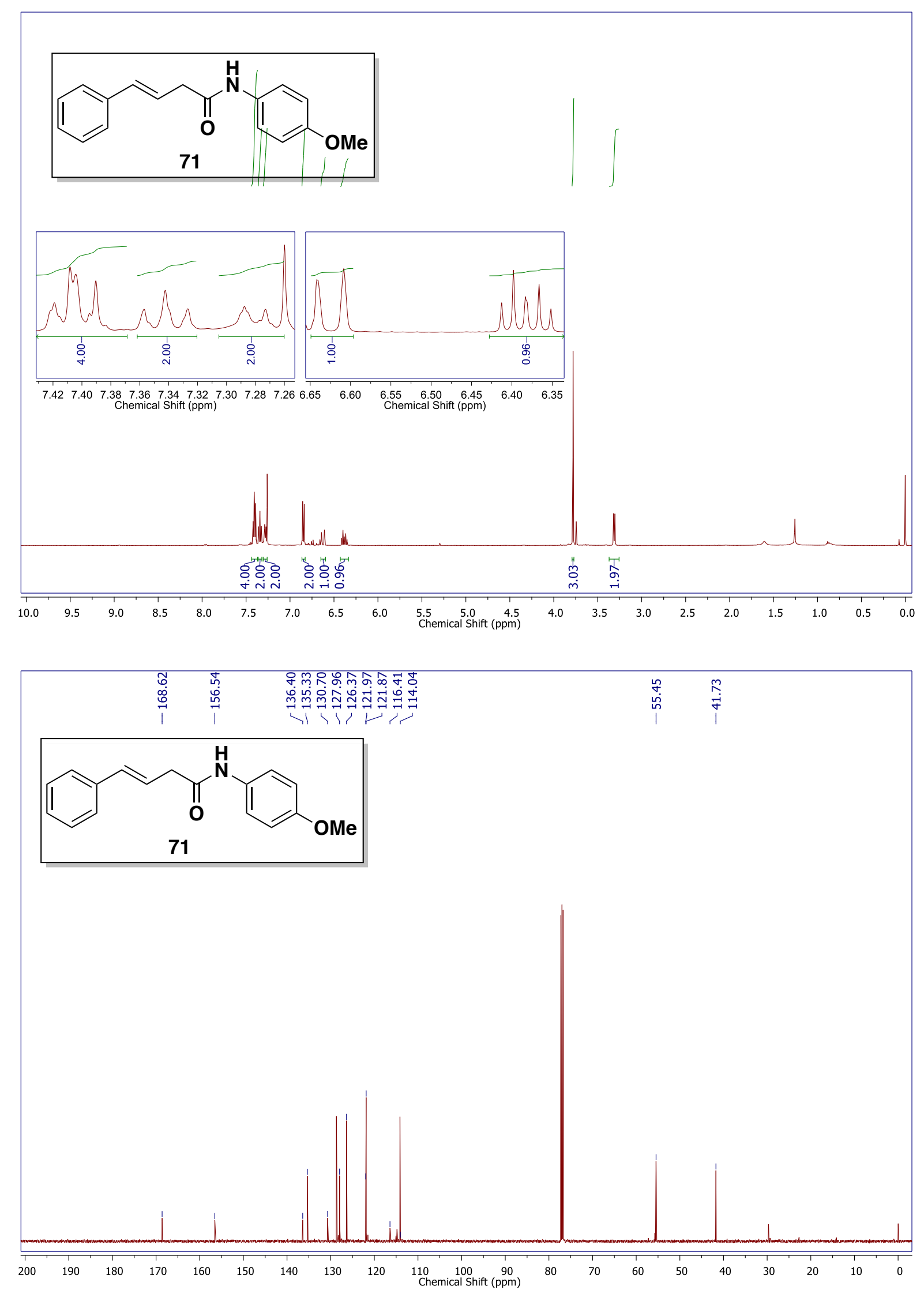


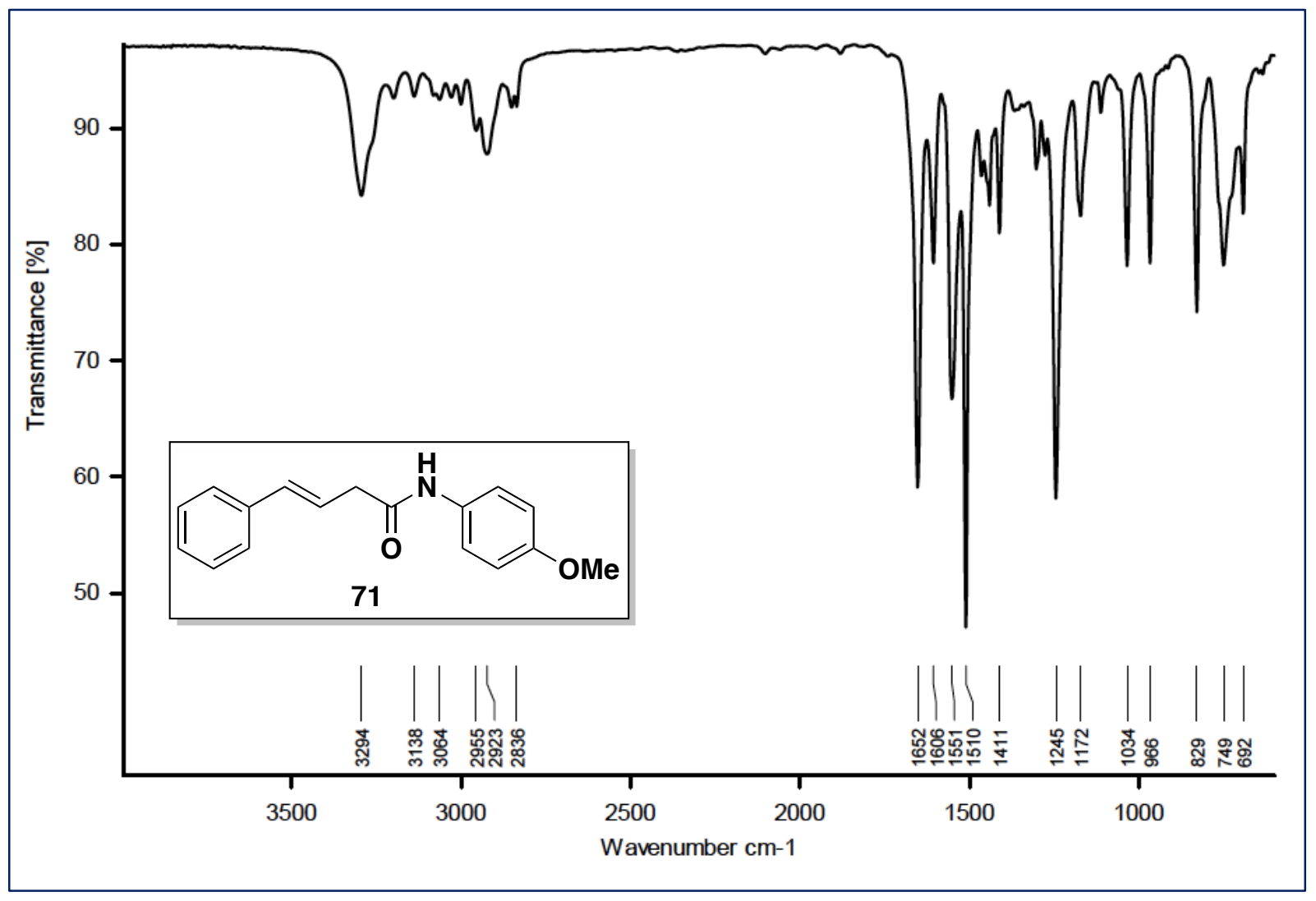



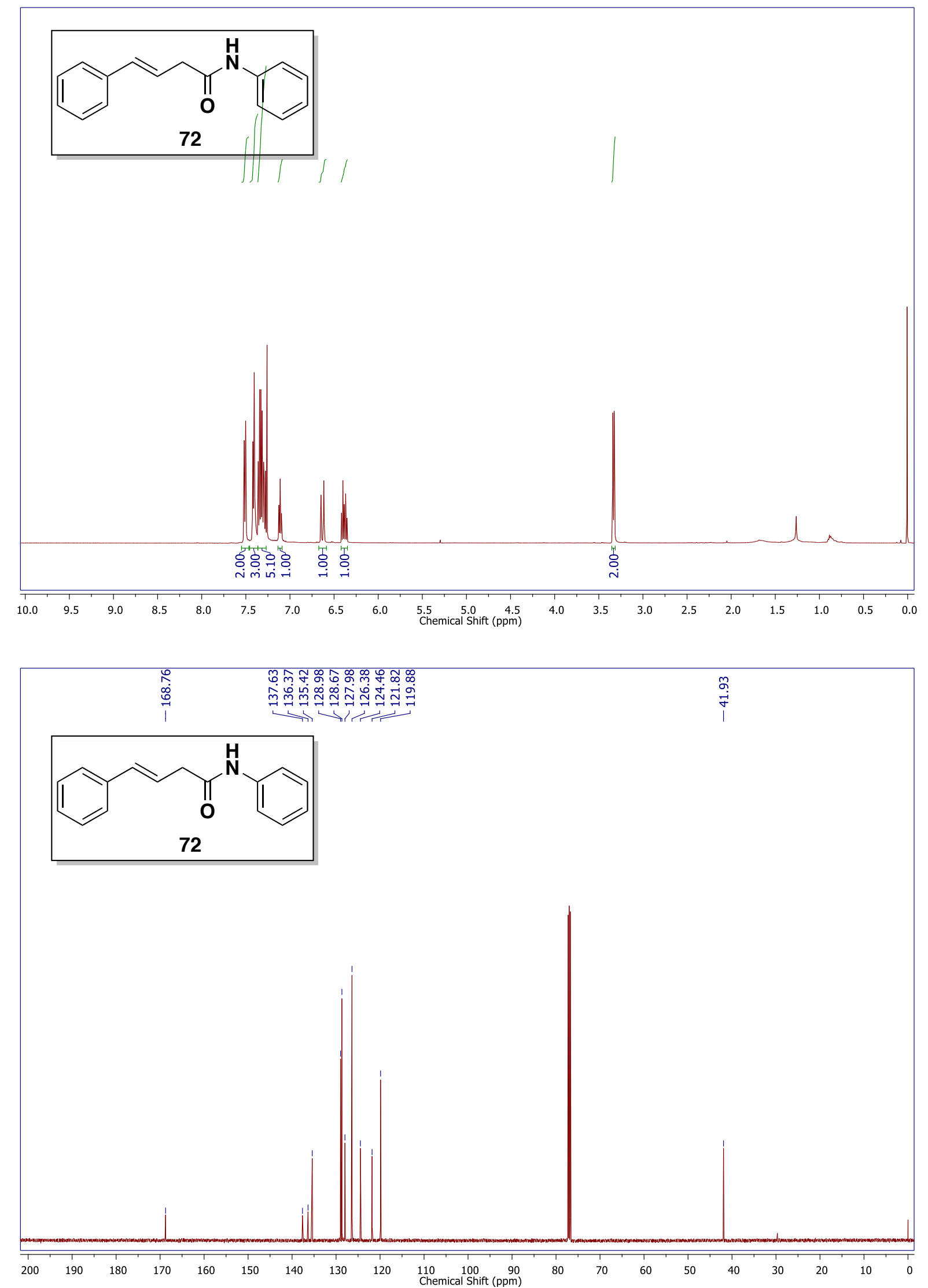


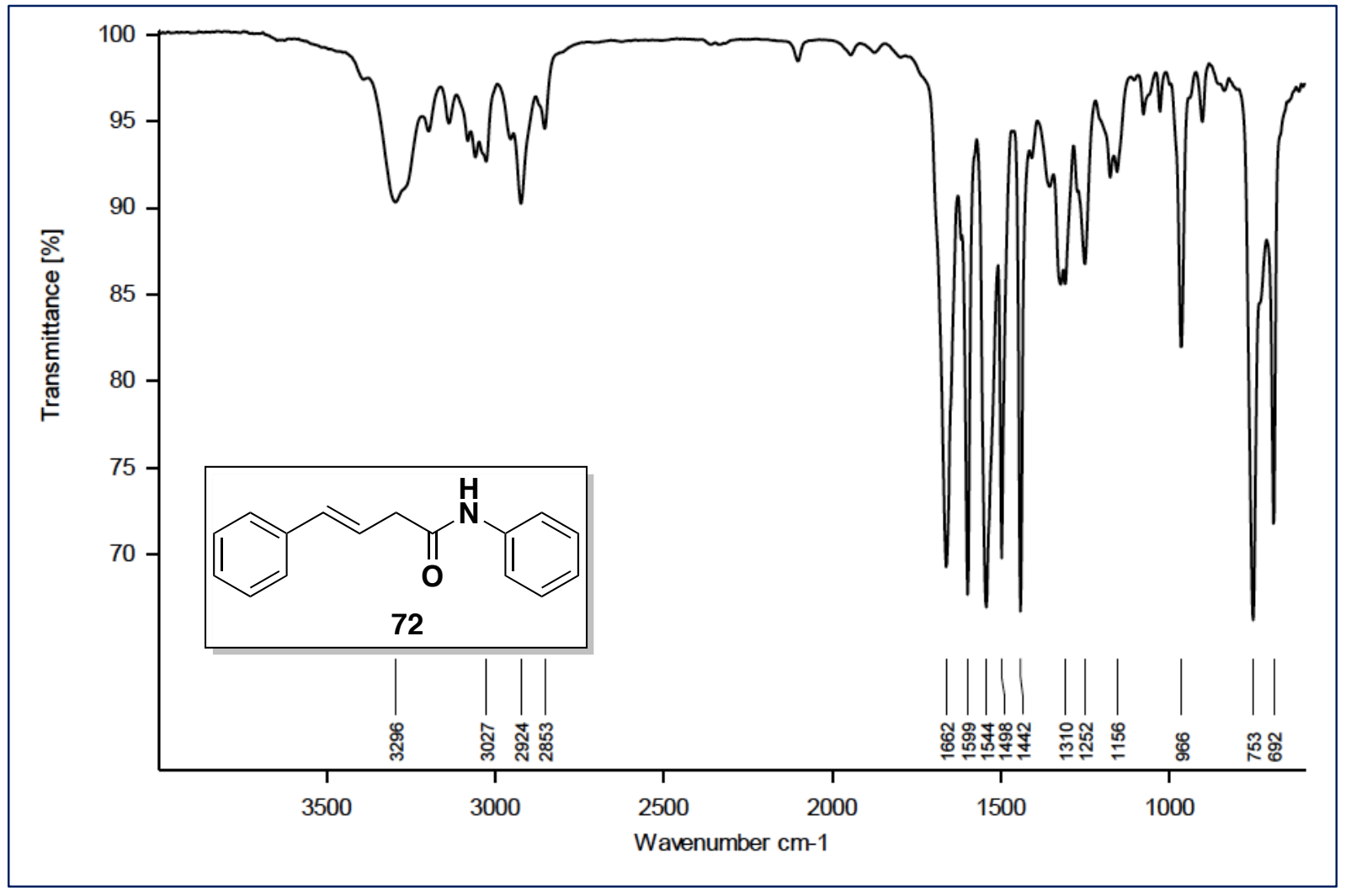



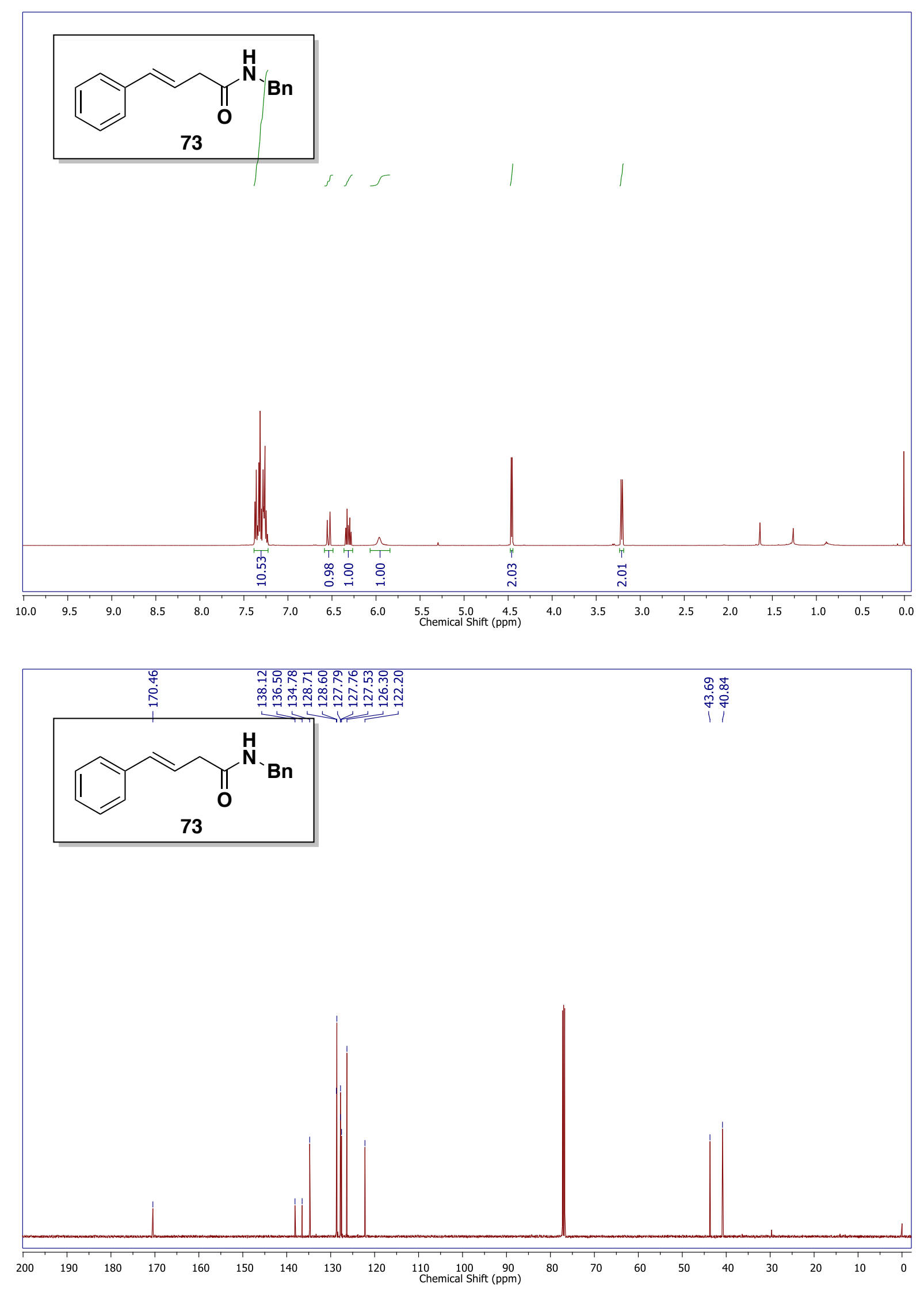


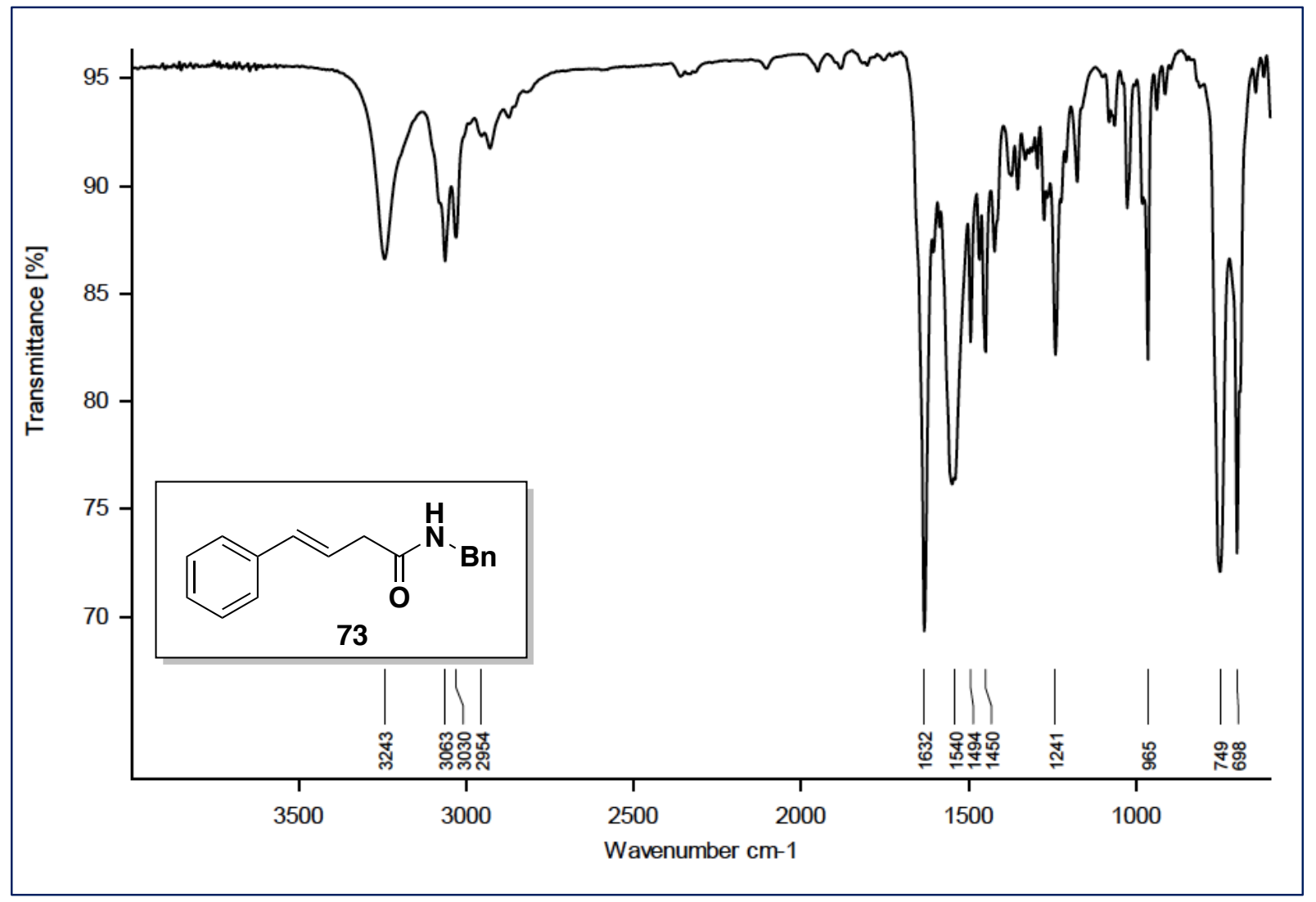



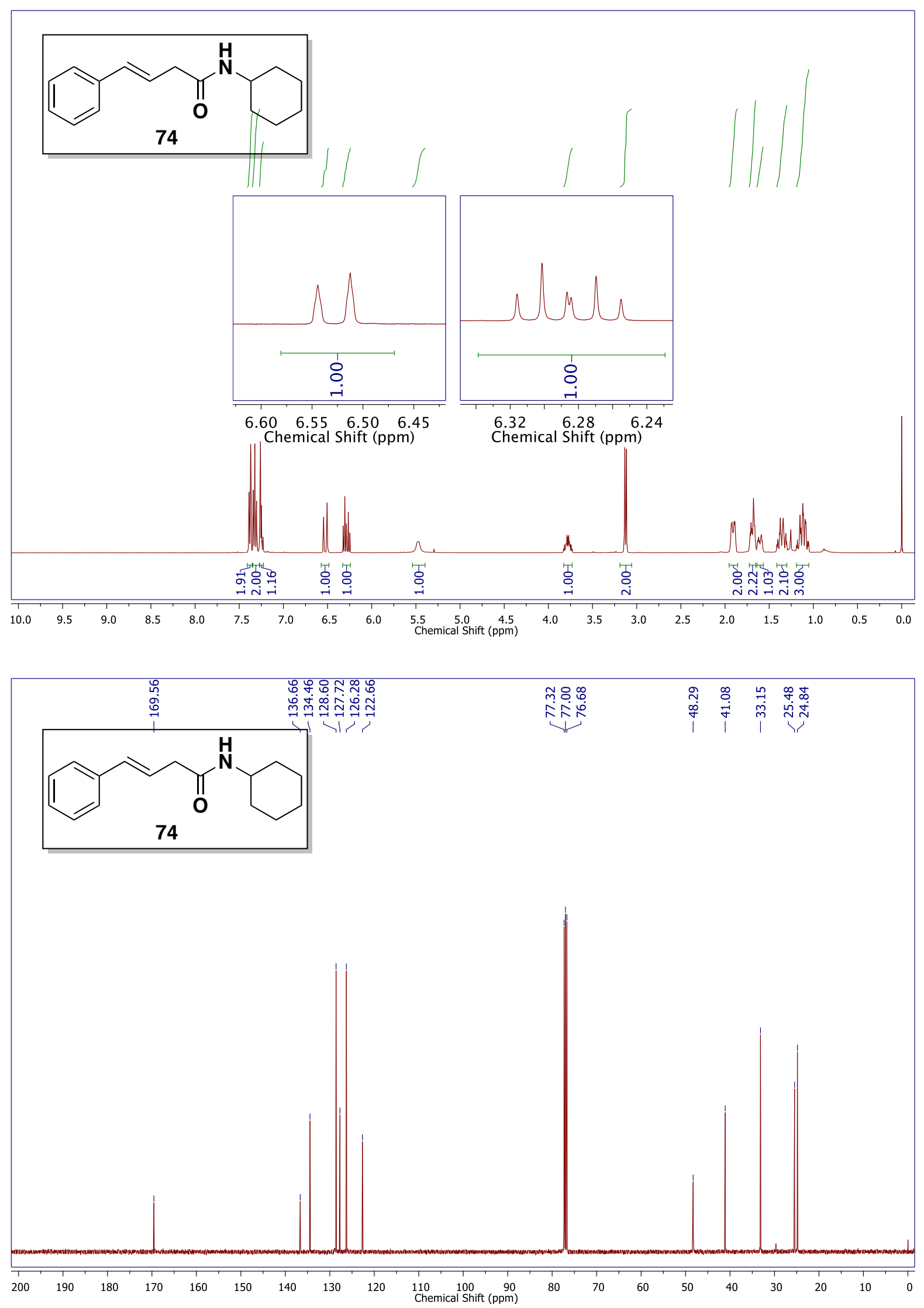


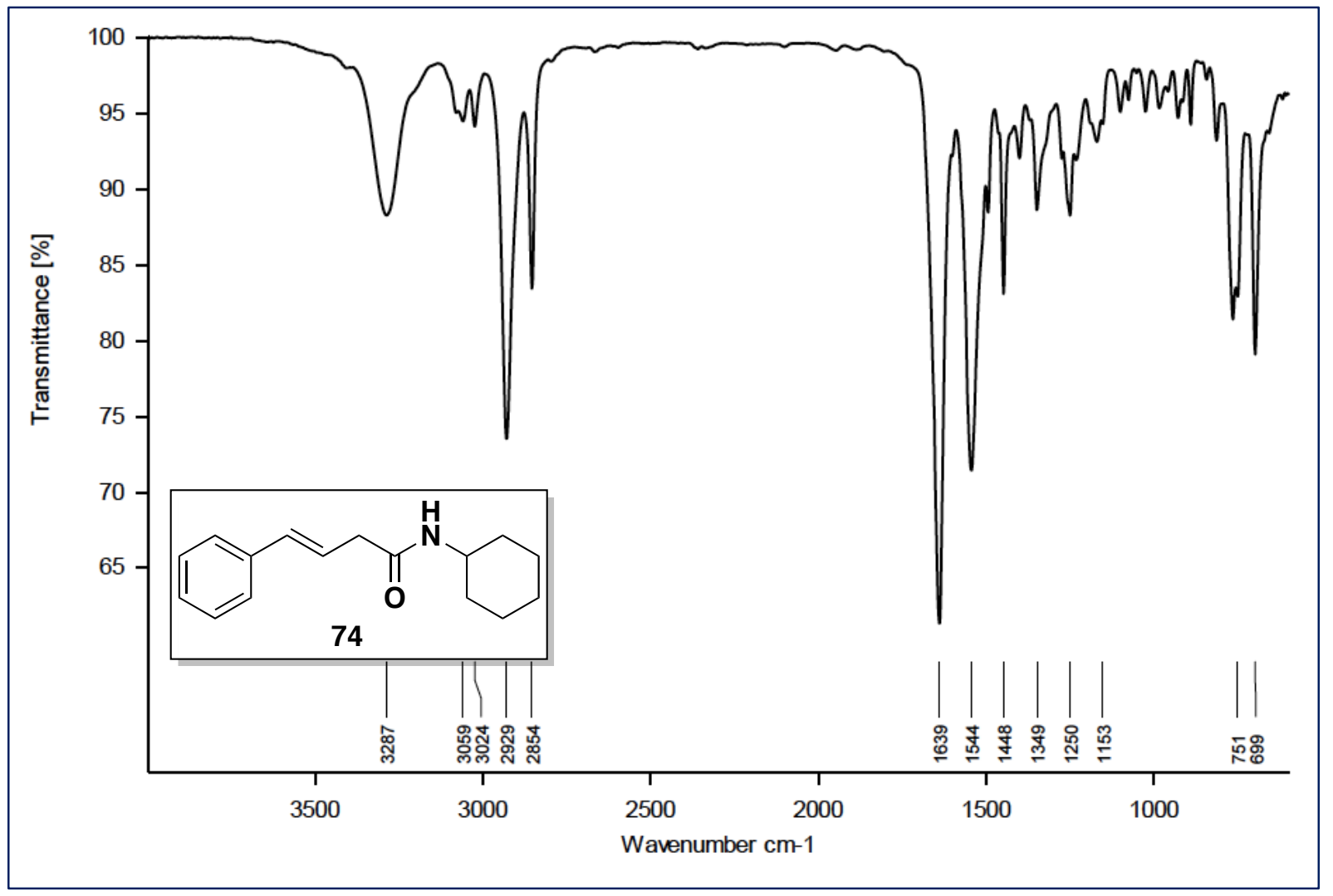



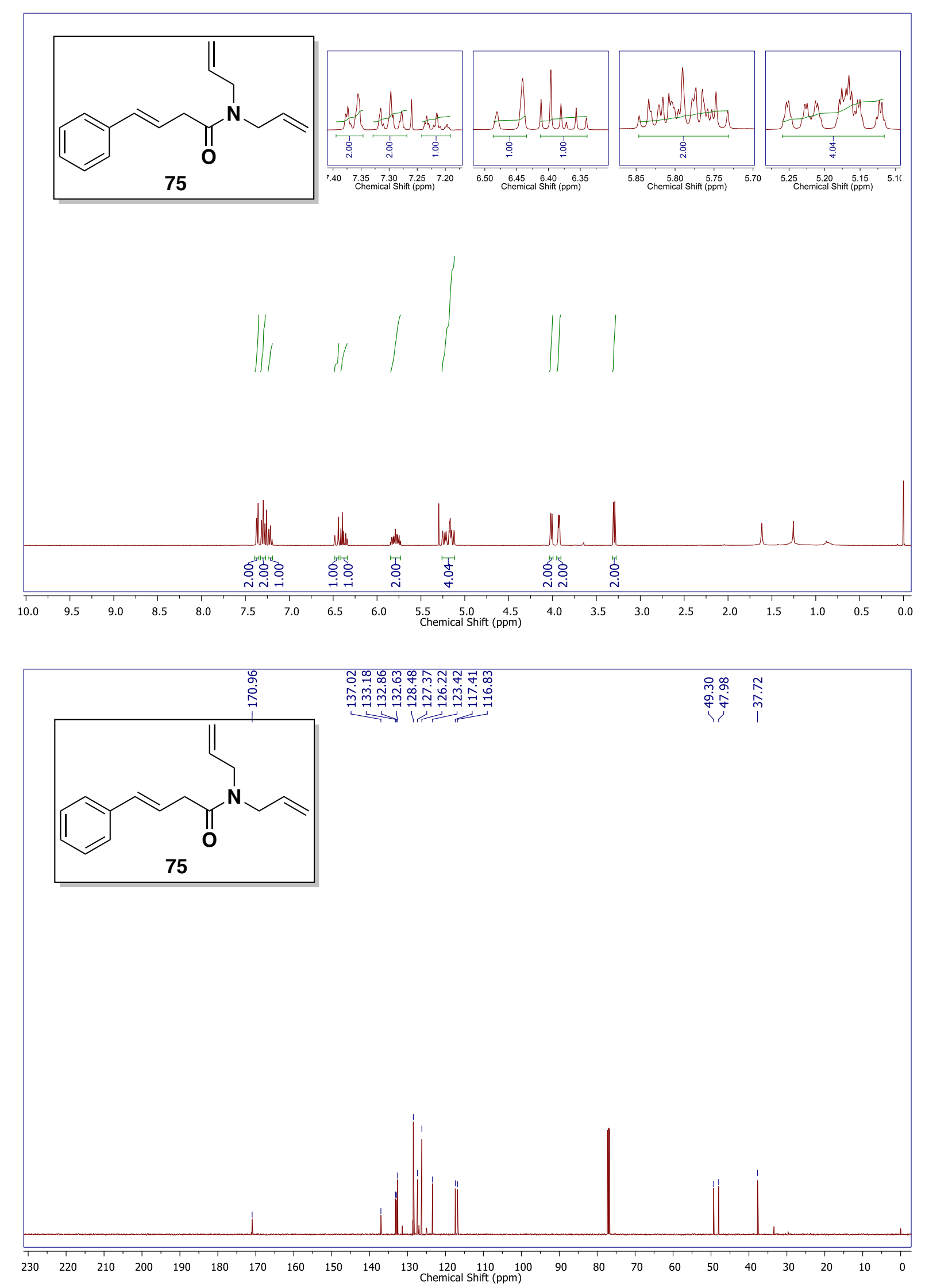


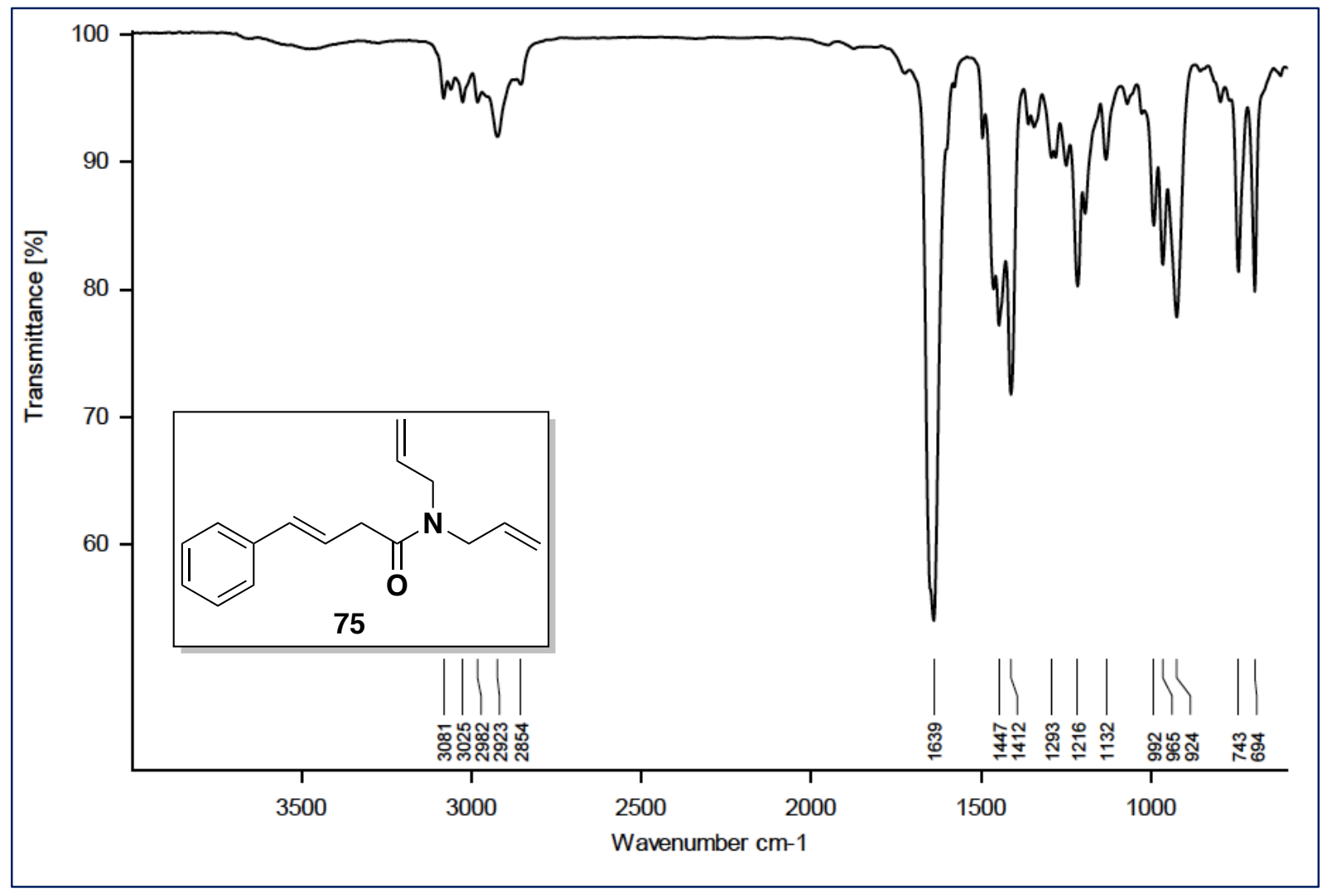



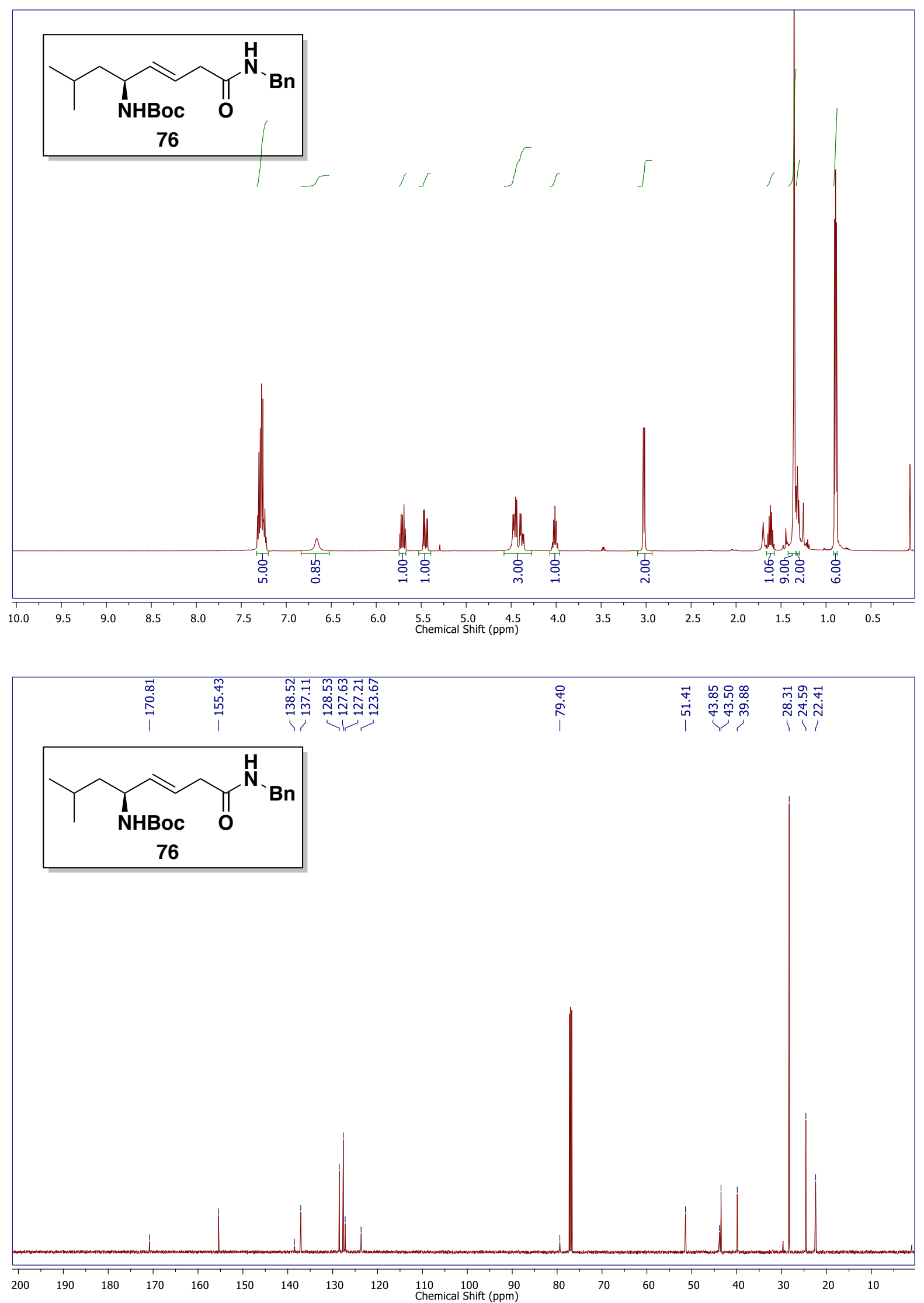


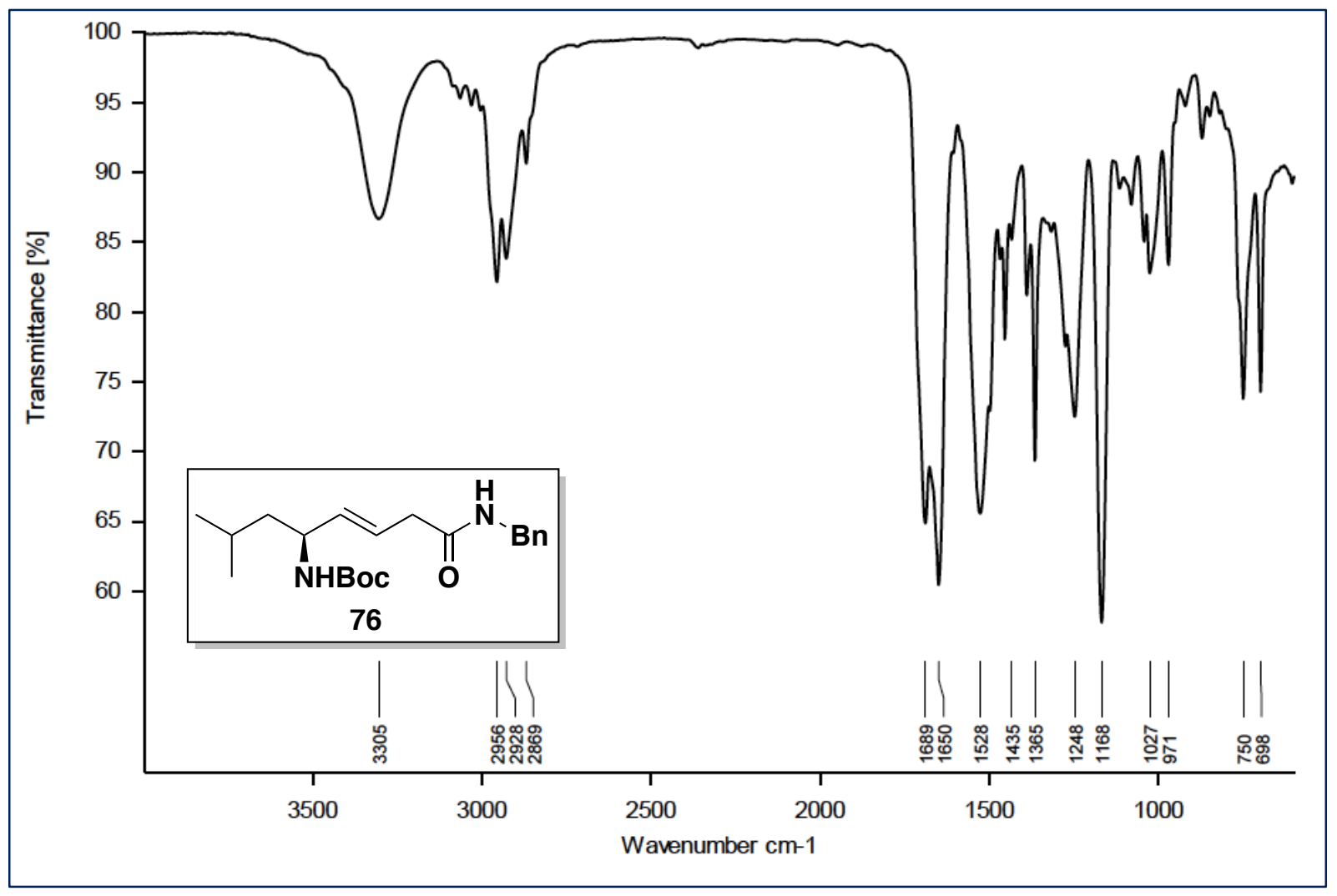



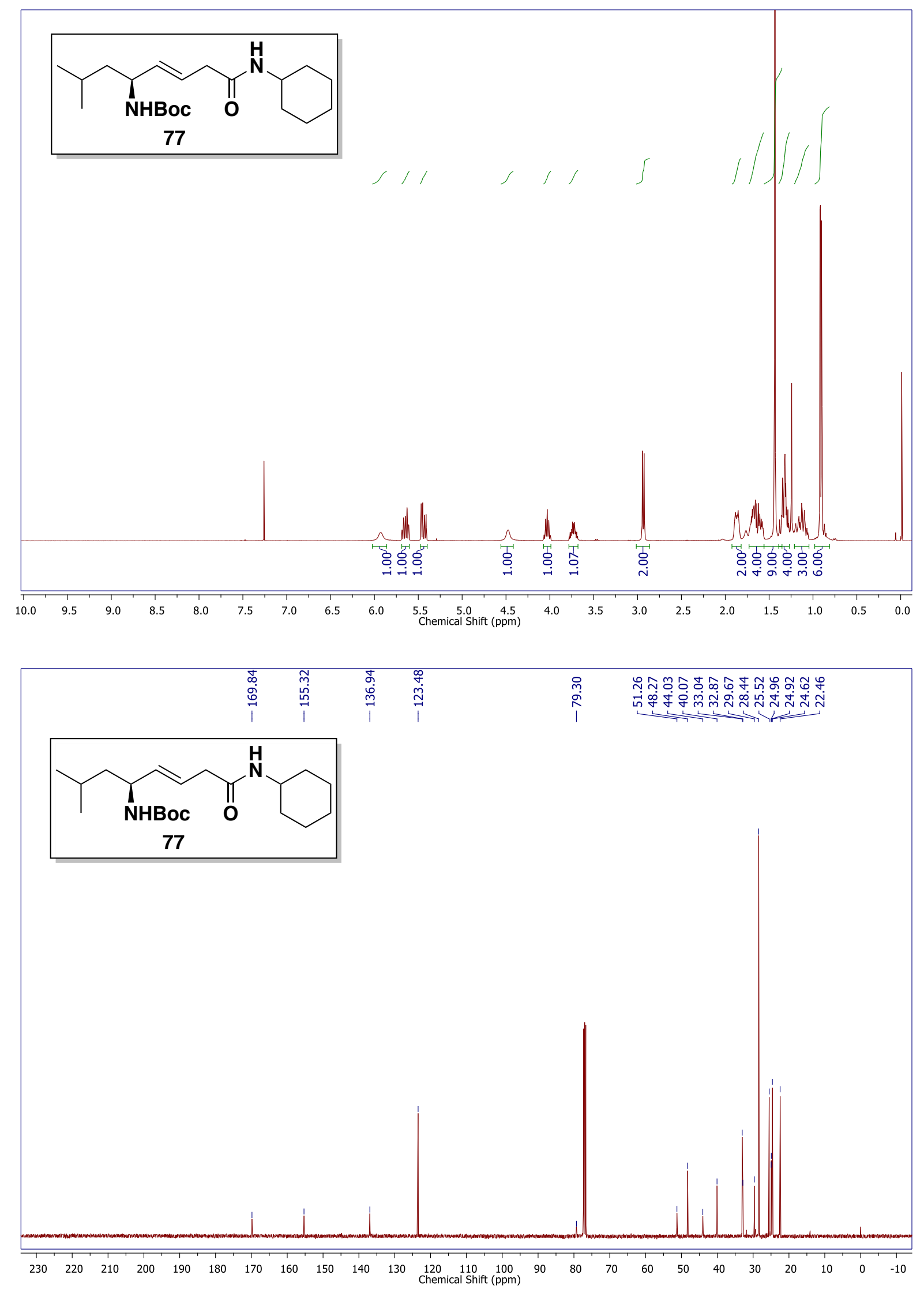


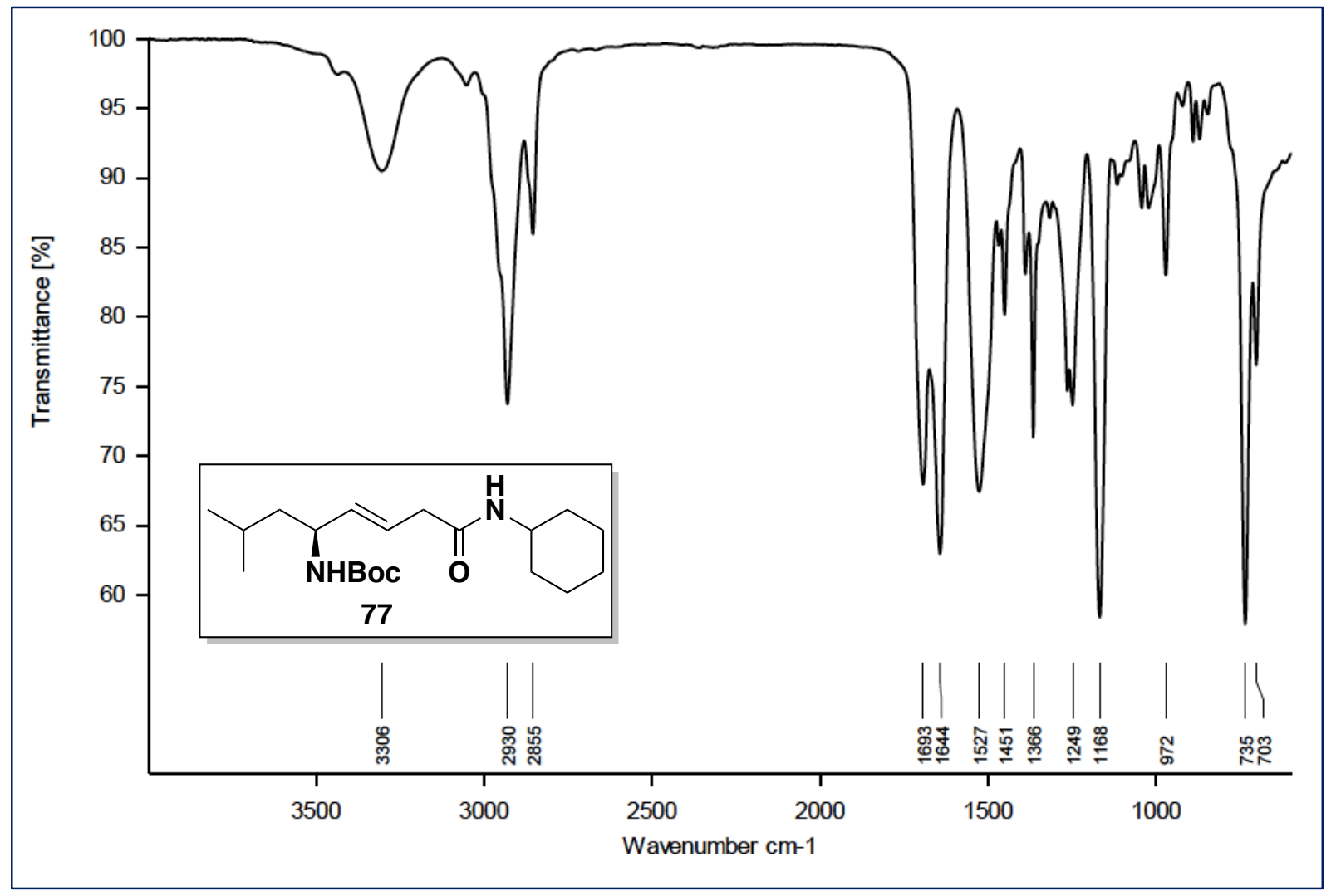



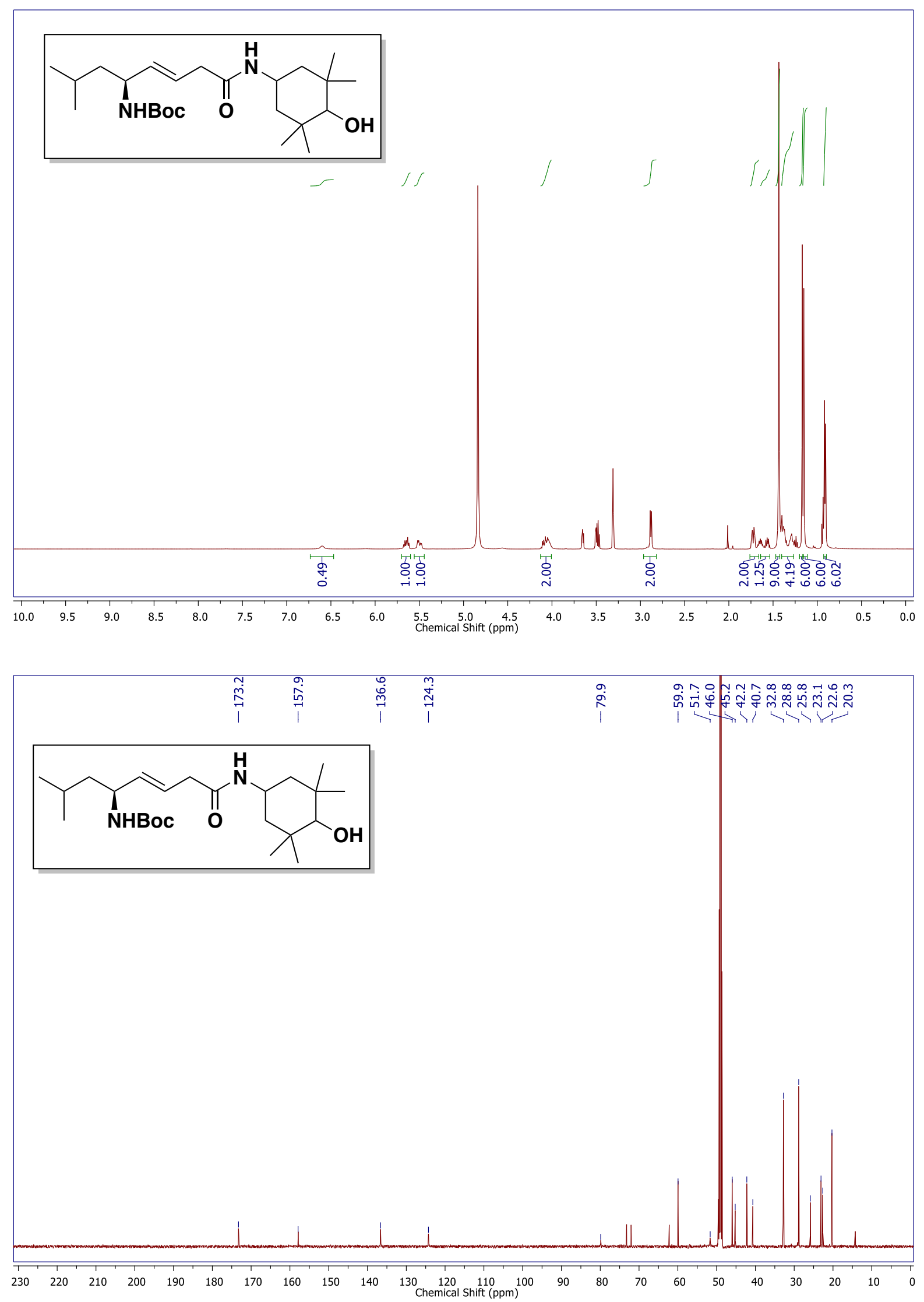


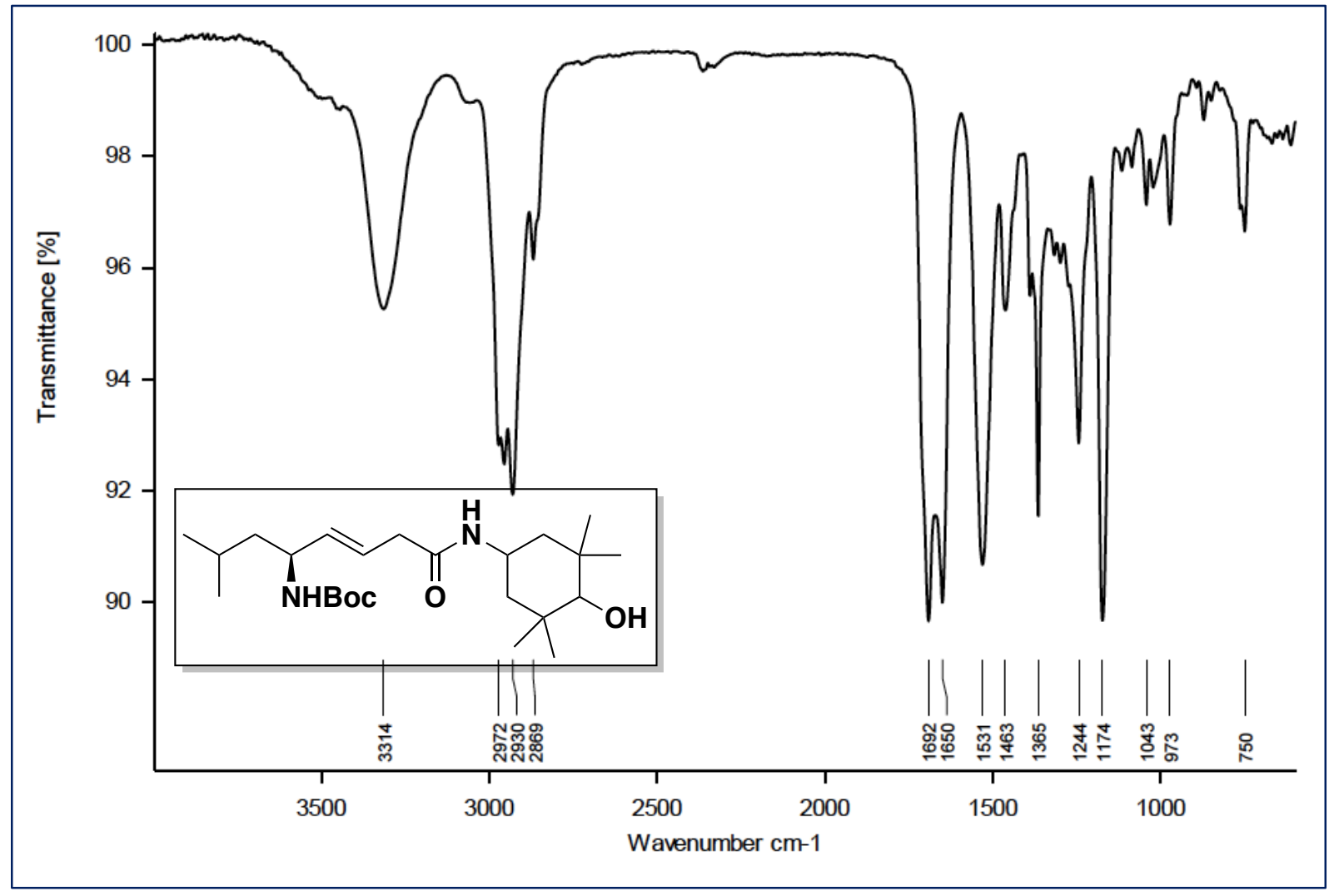



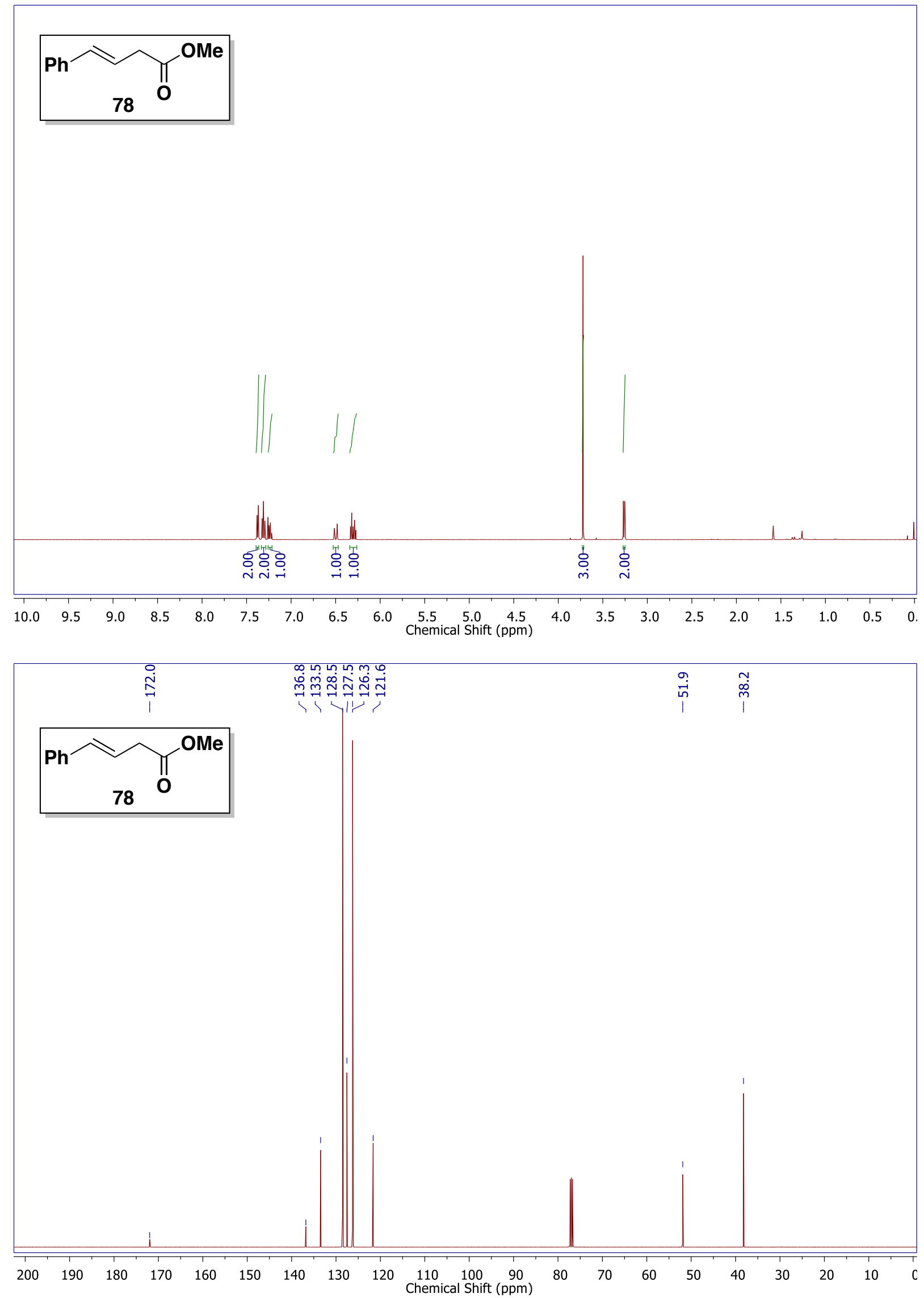

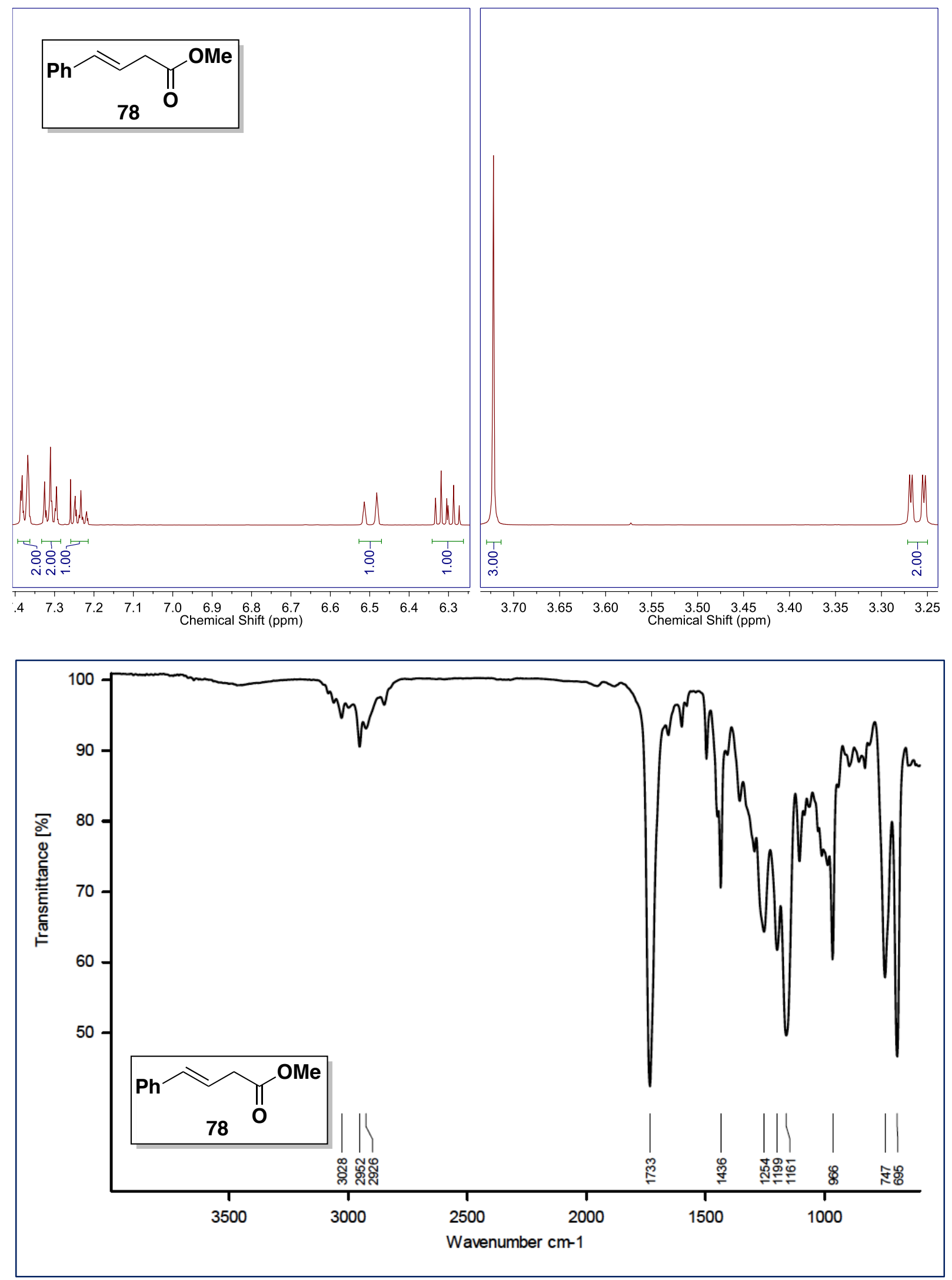

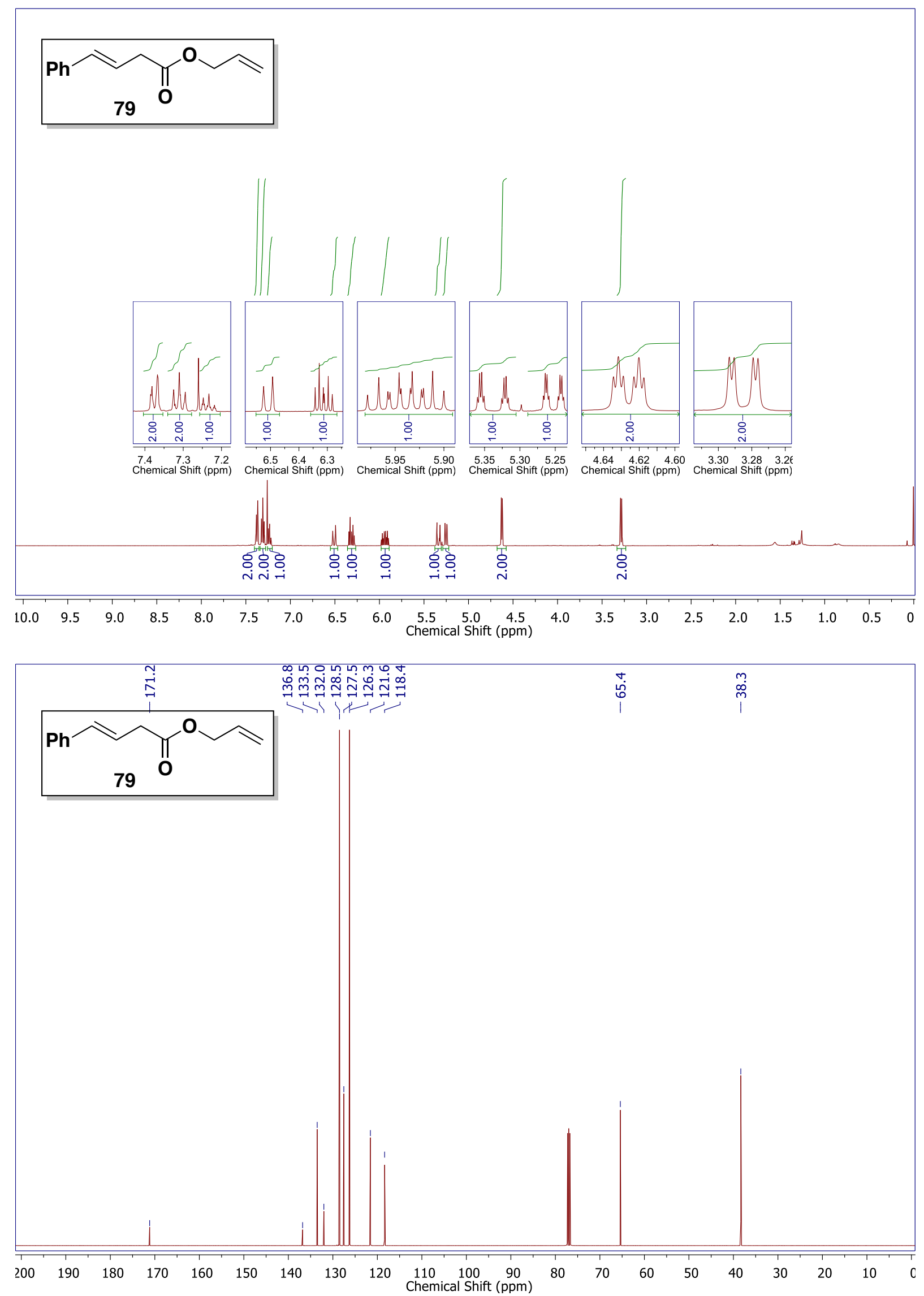

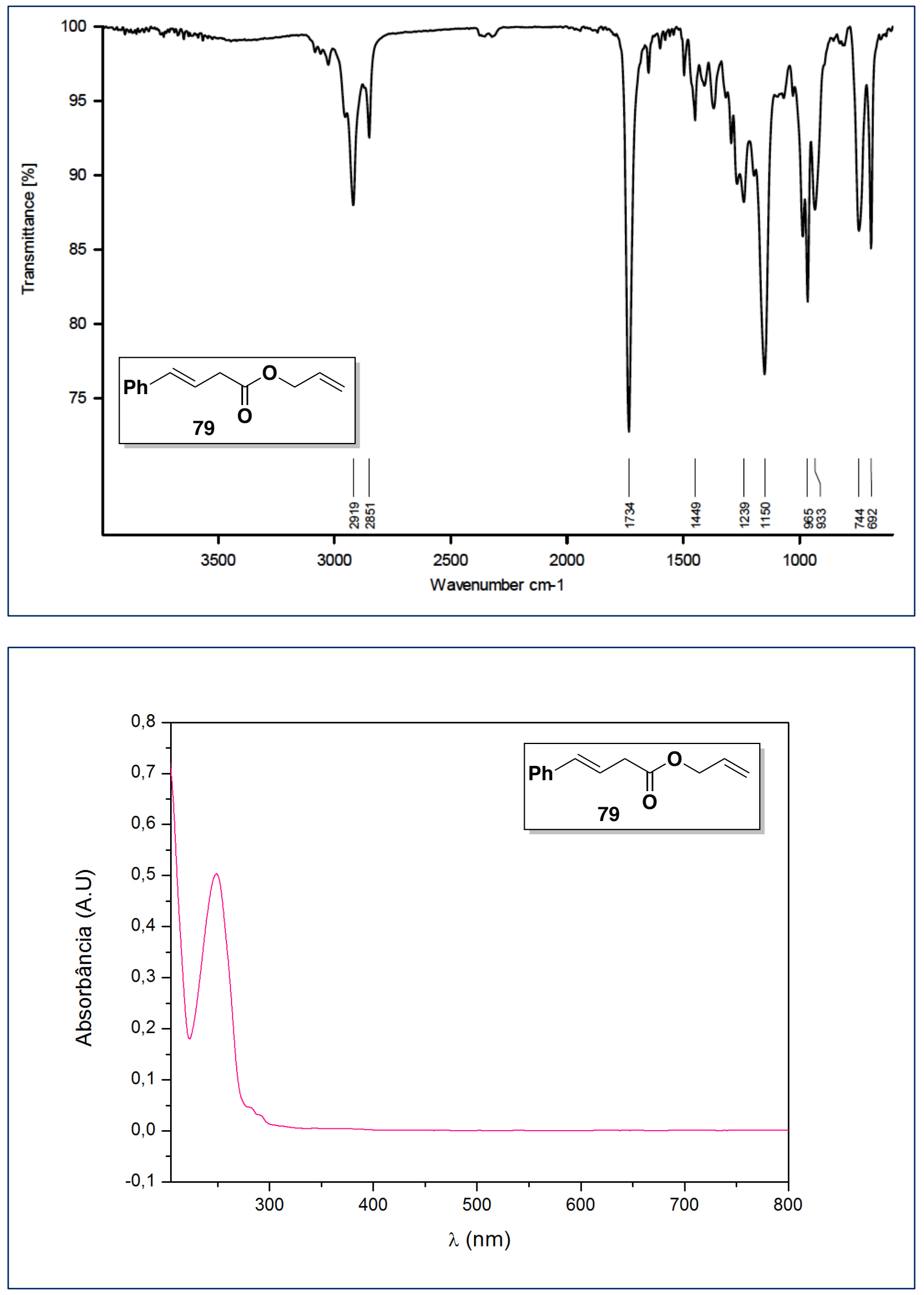

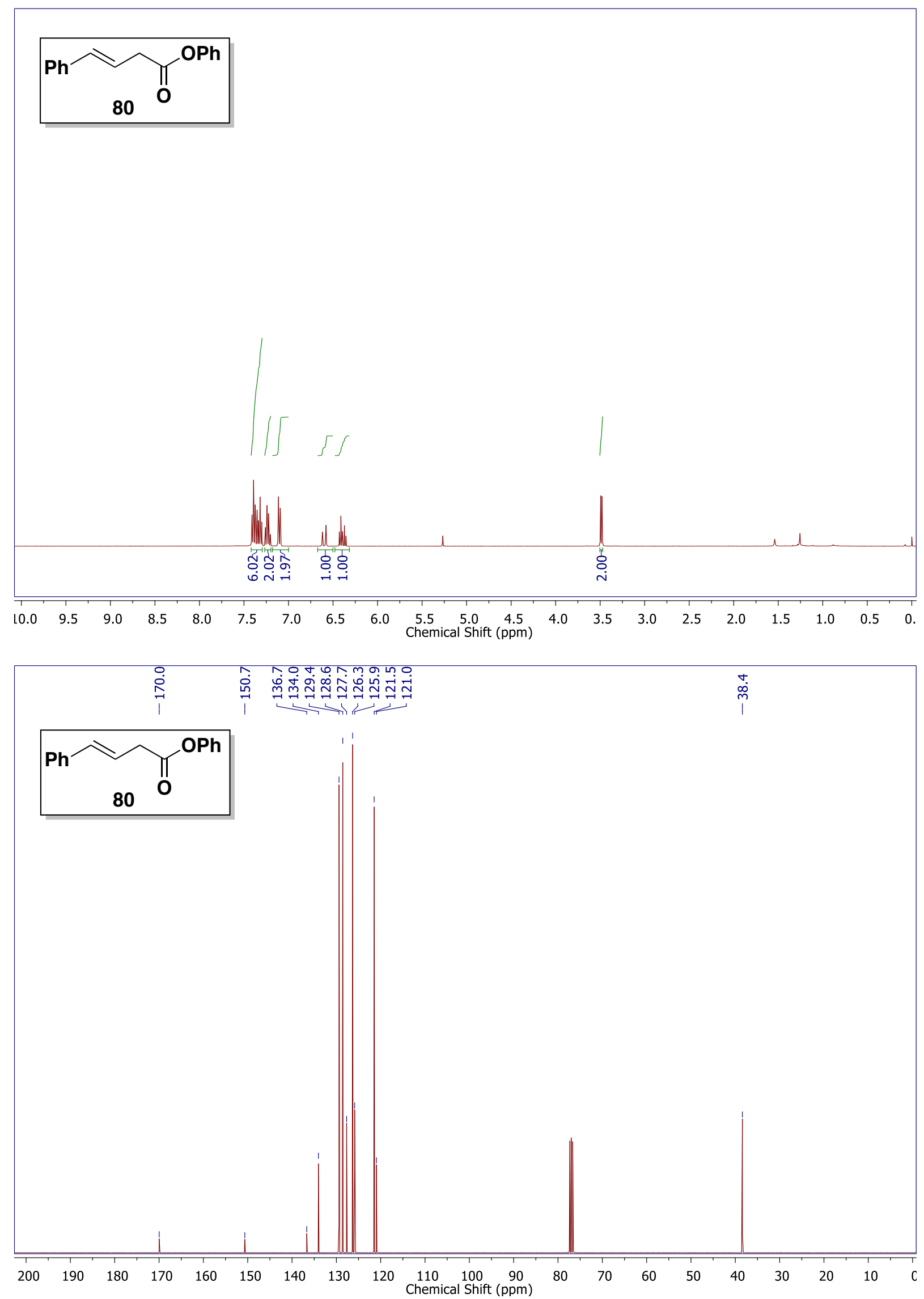


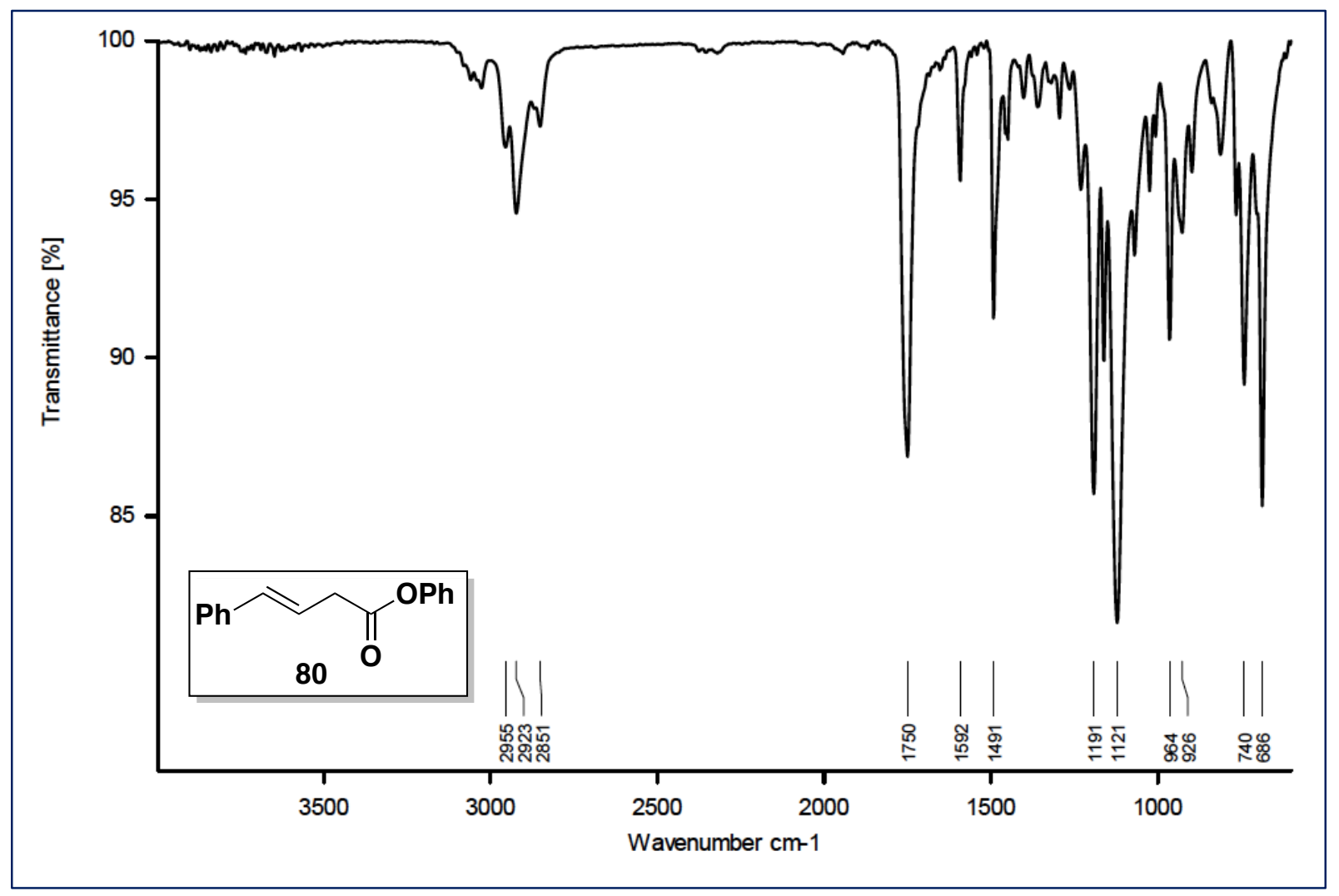



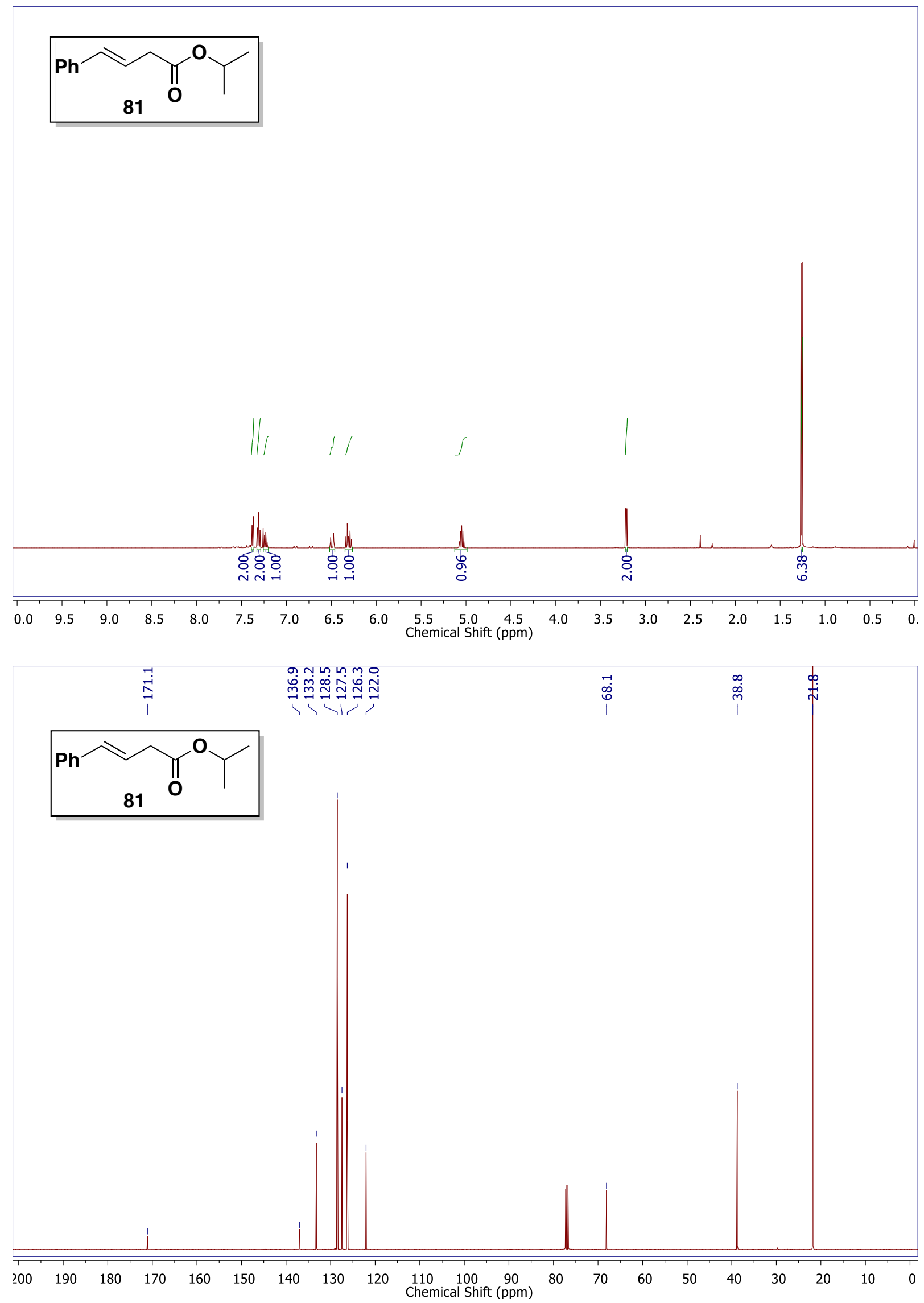


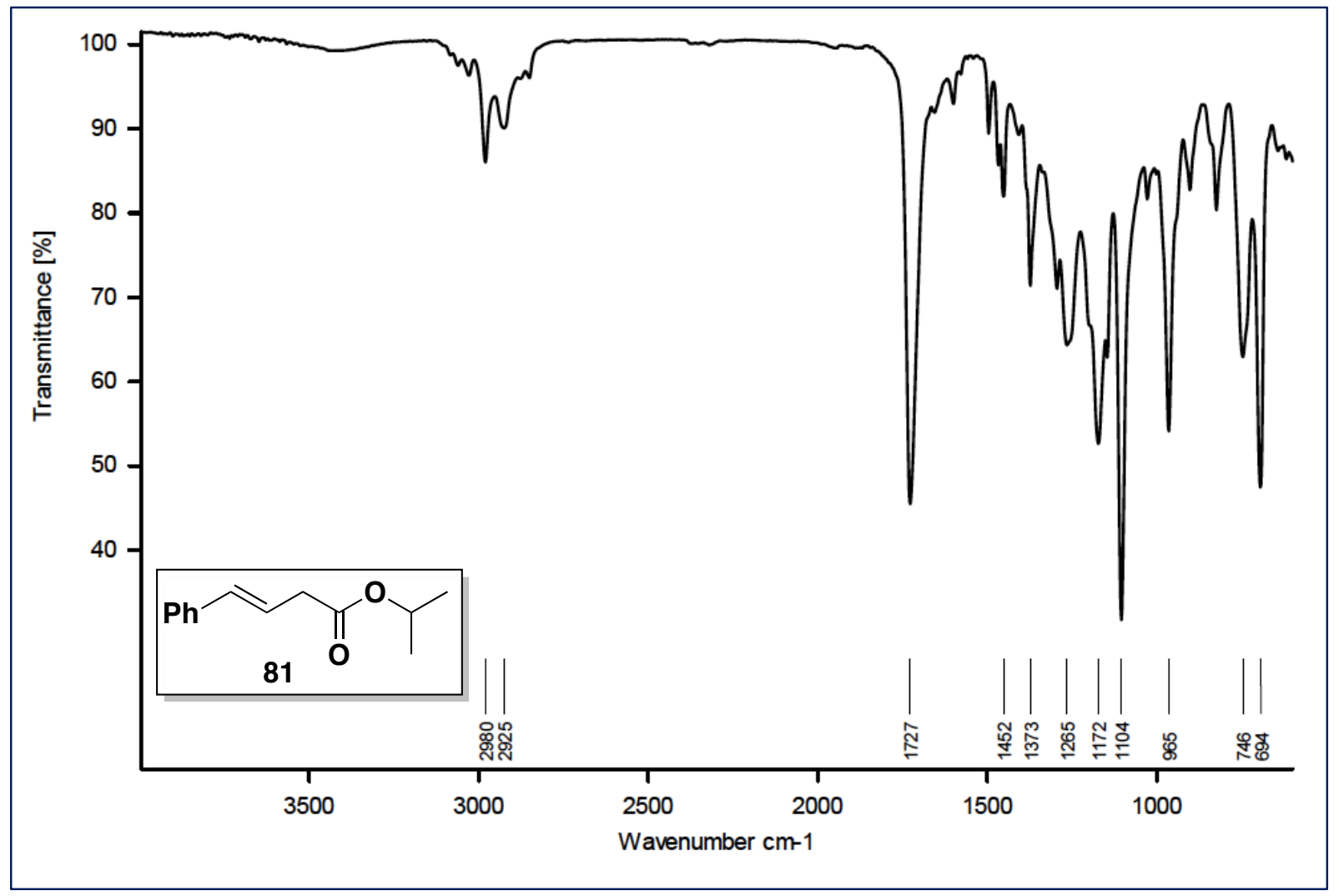


${ }_{82}^{\mathrm{Ph}} \prod_{\mathrm{Bn}}^{0}$
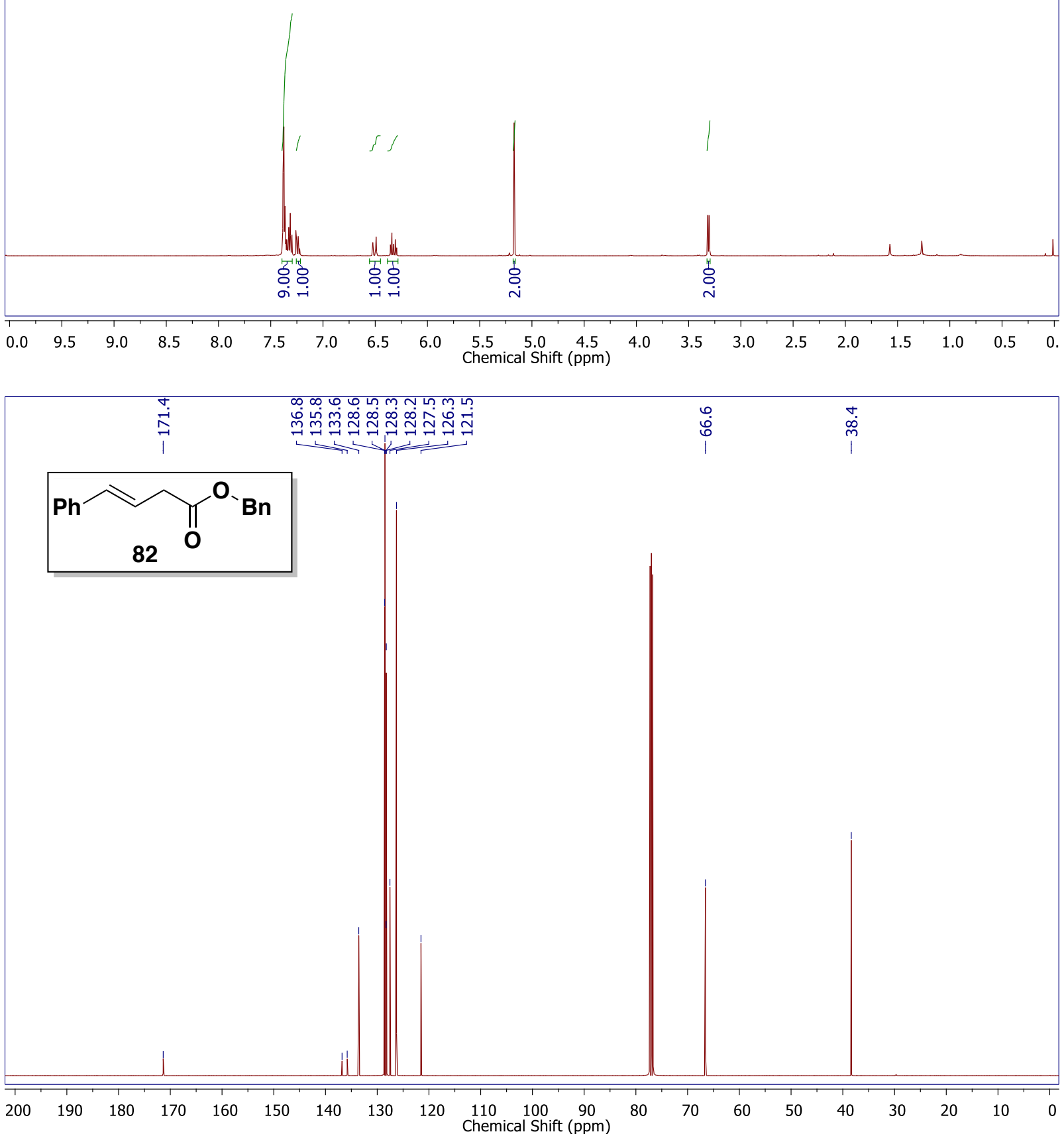

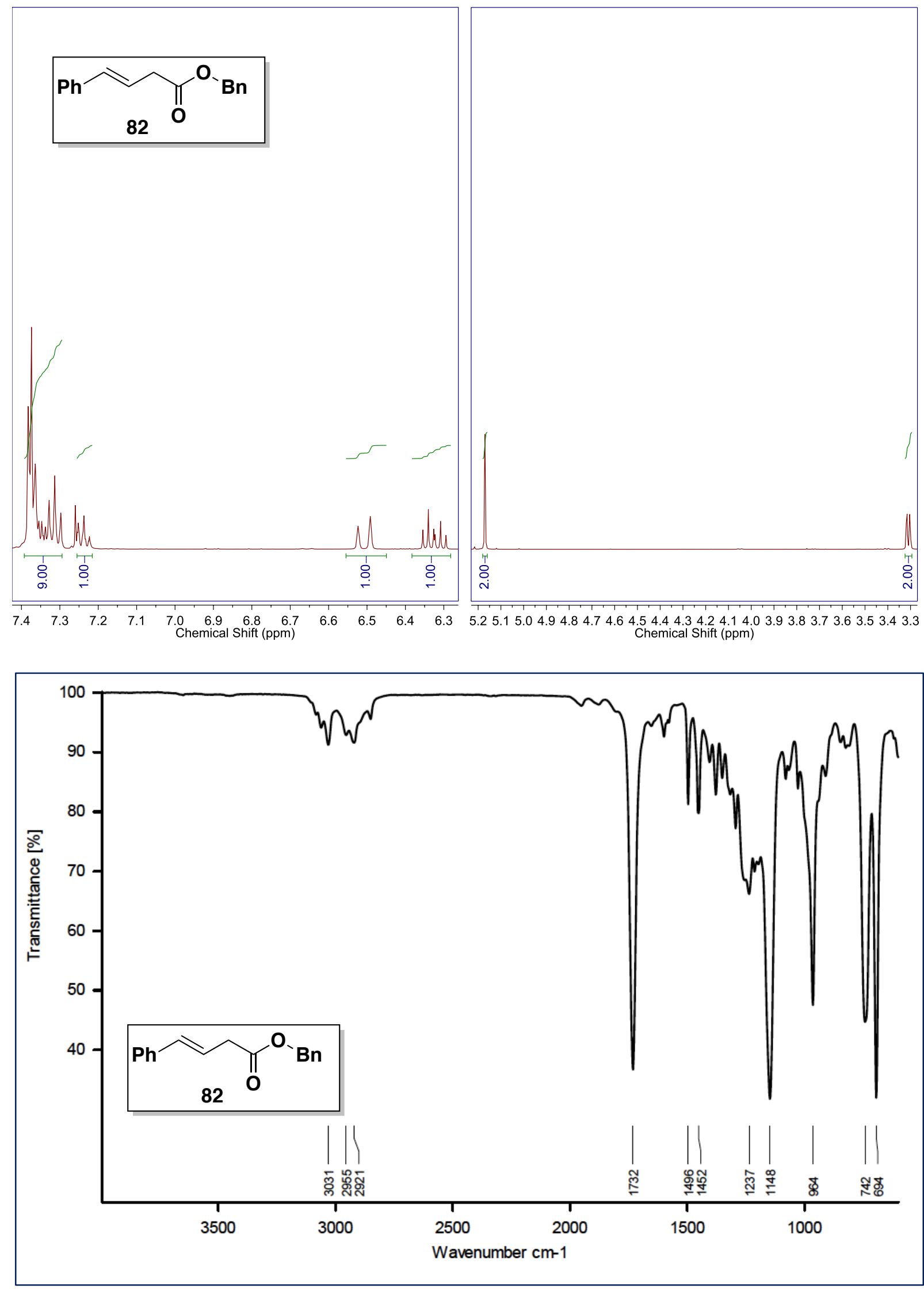

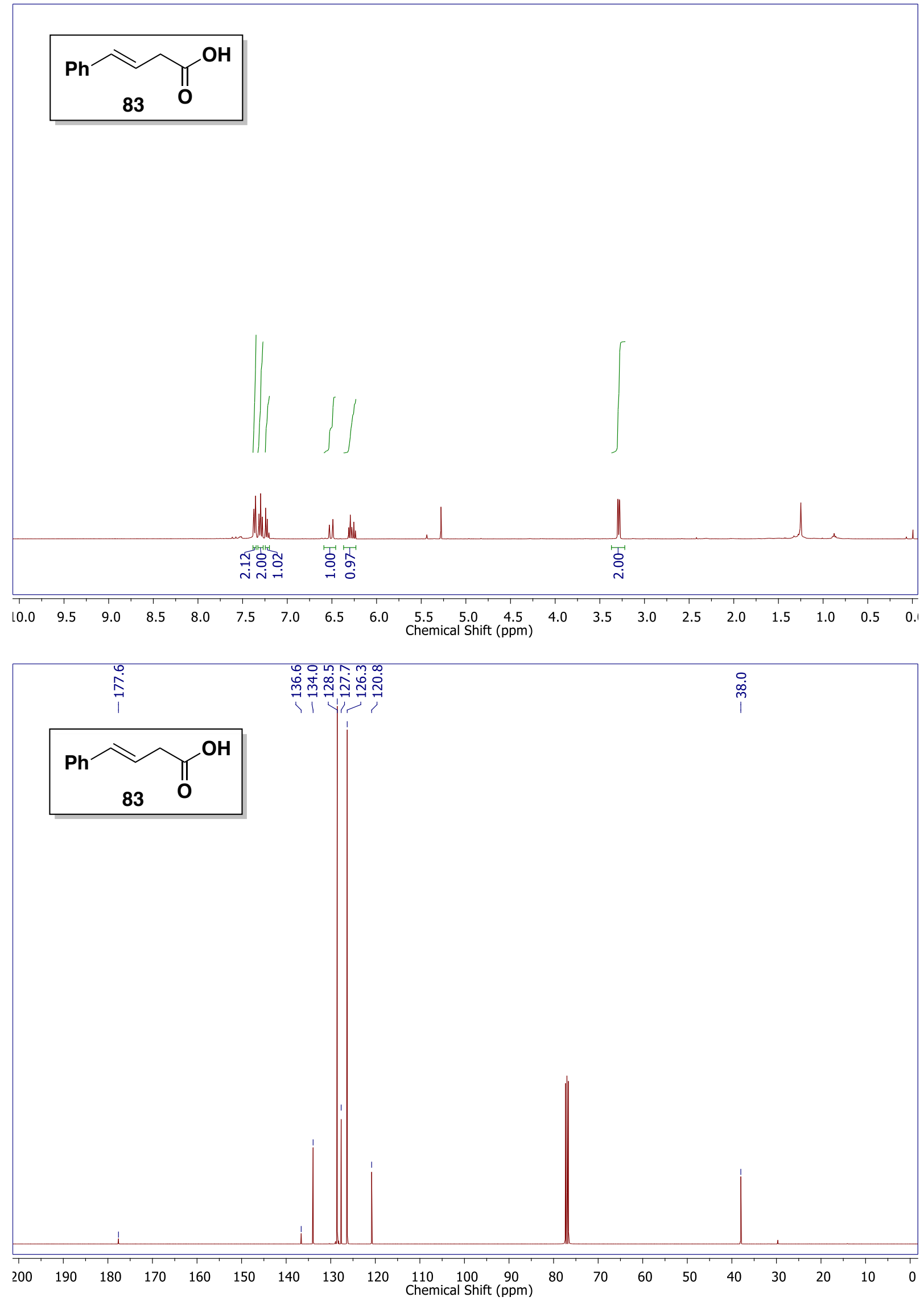

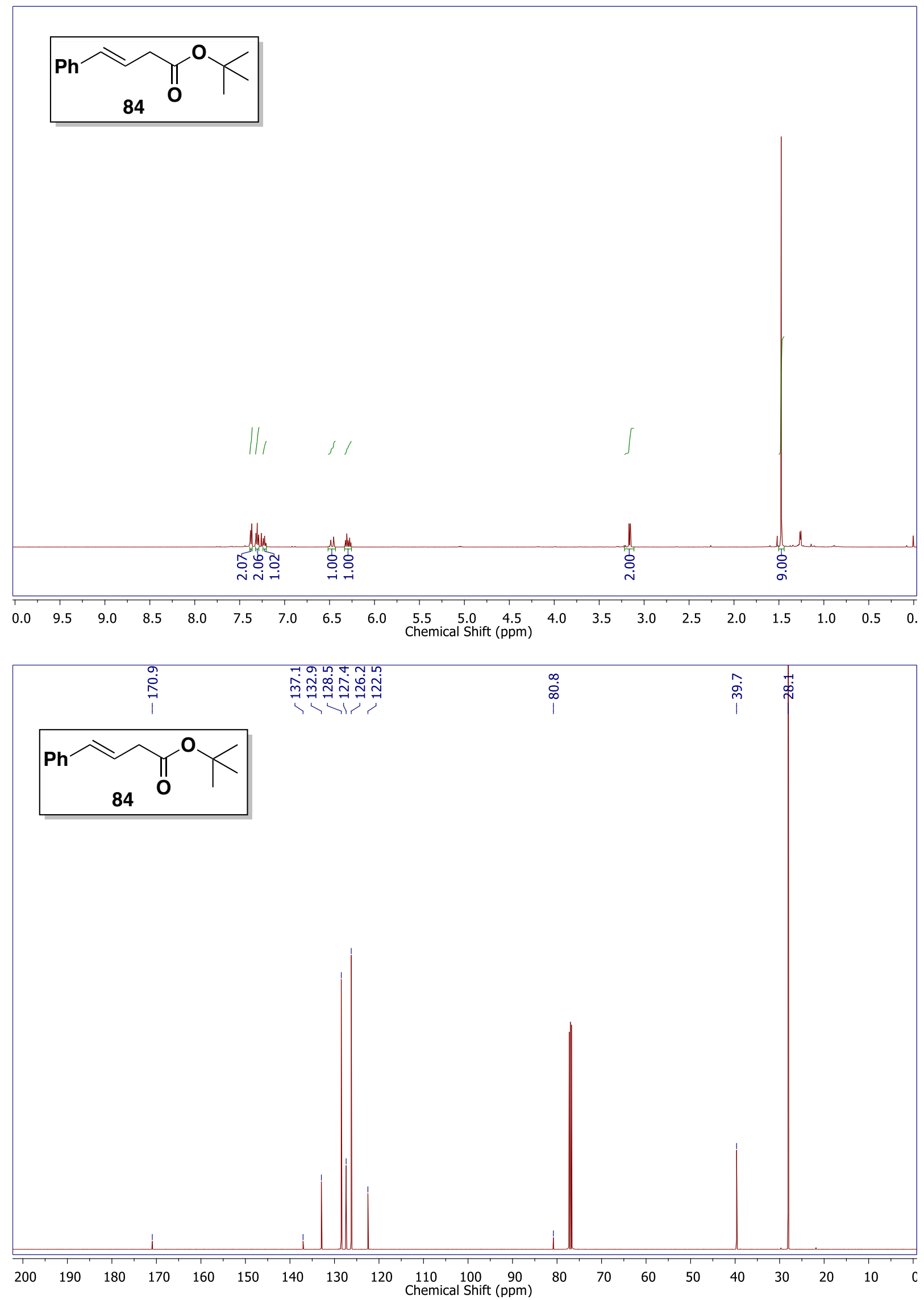


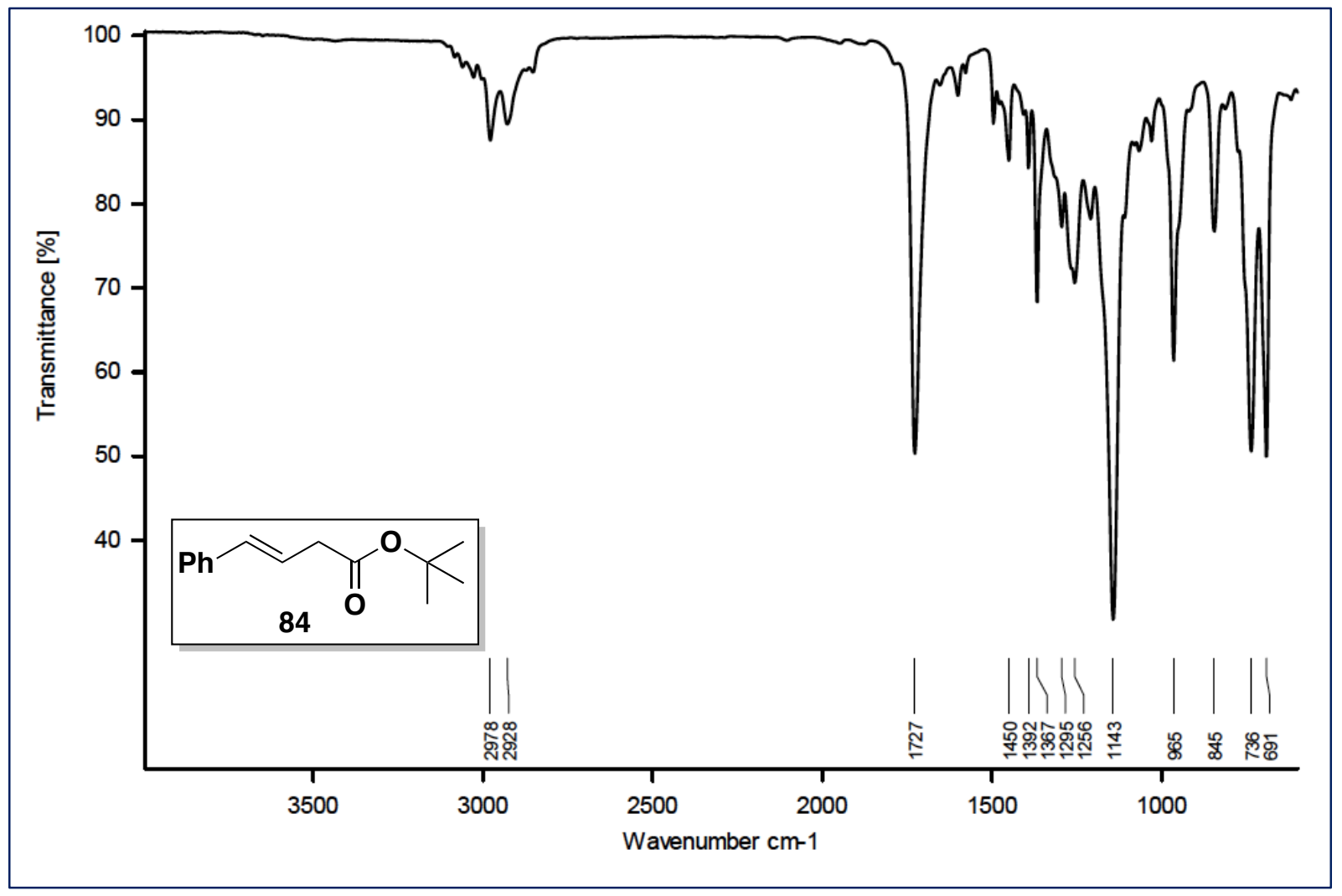



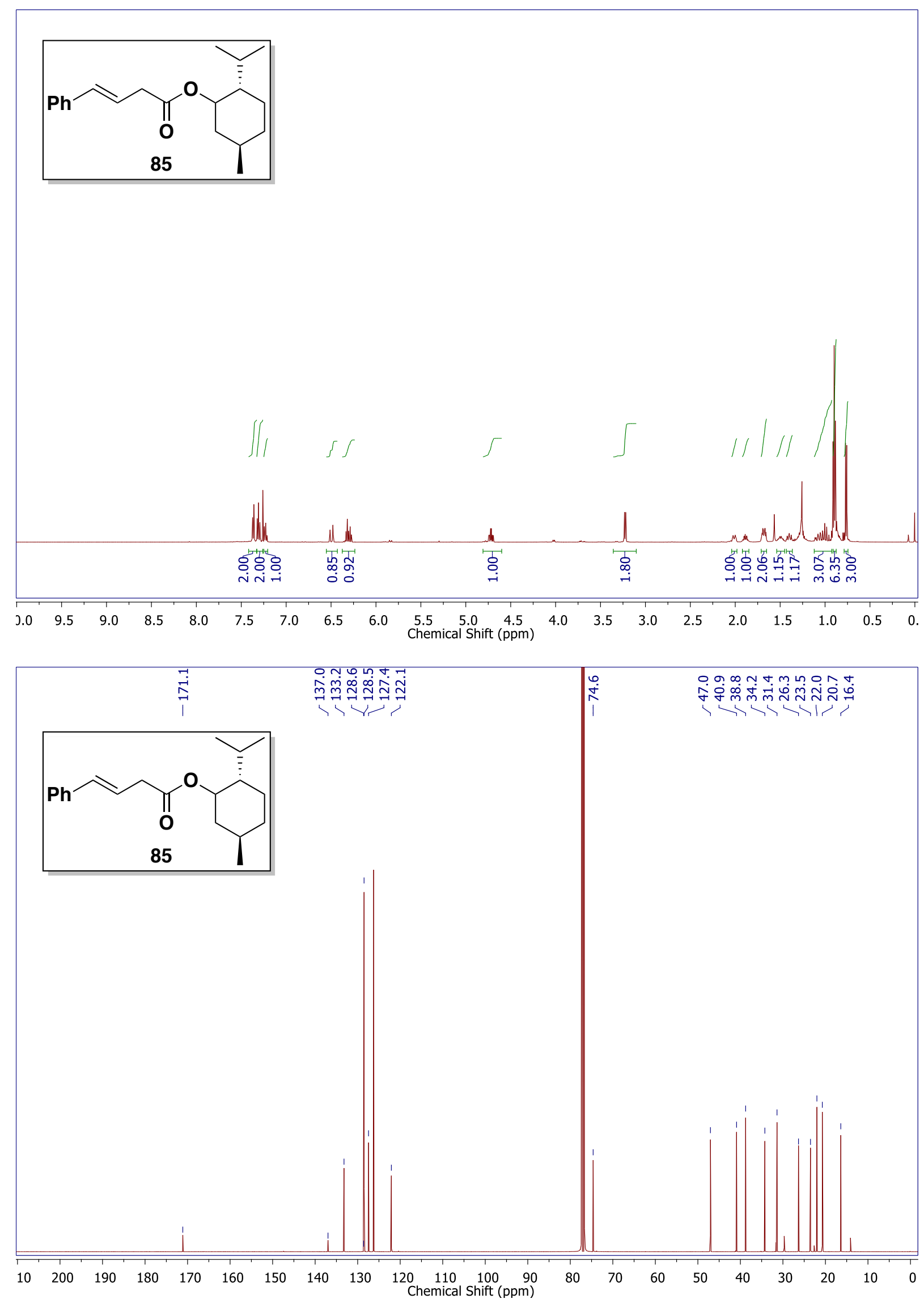


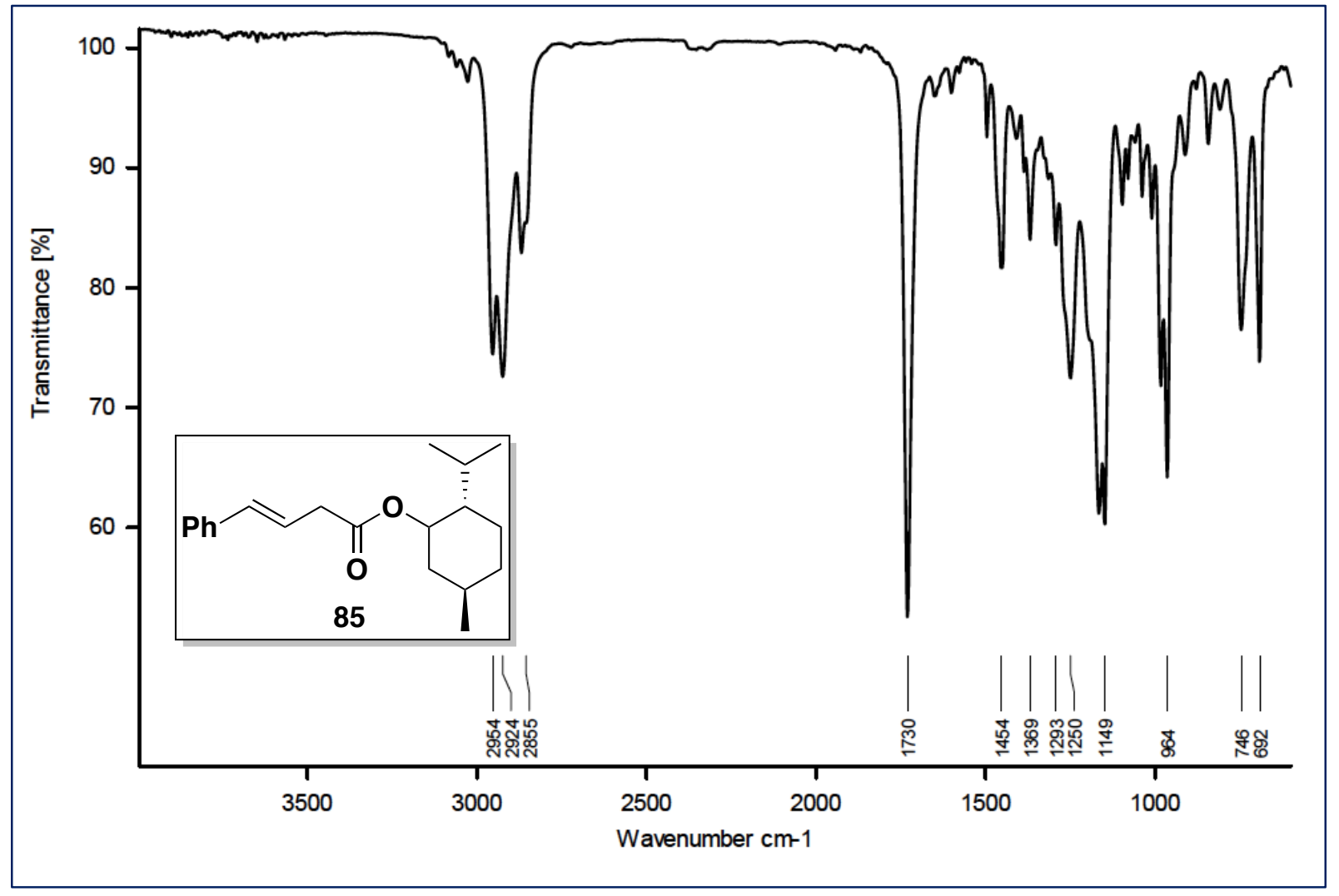



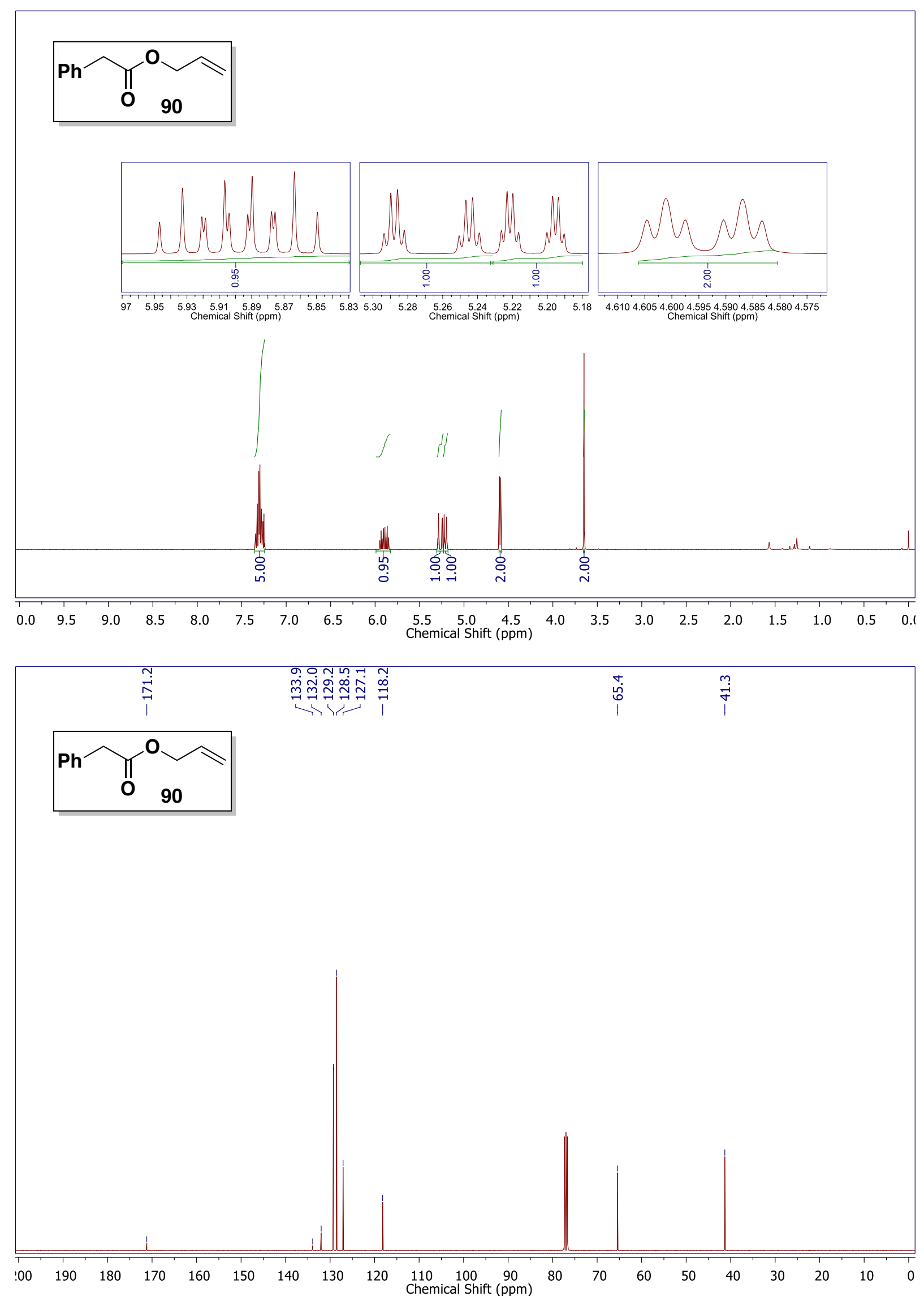


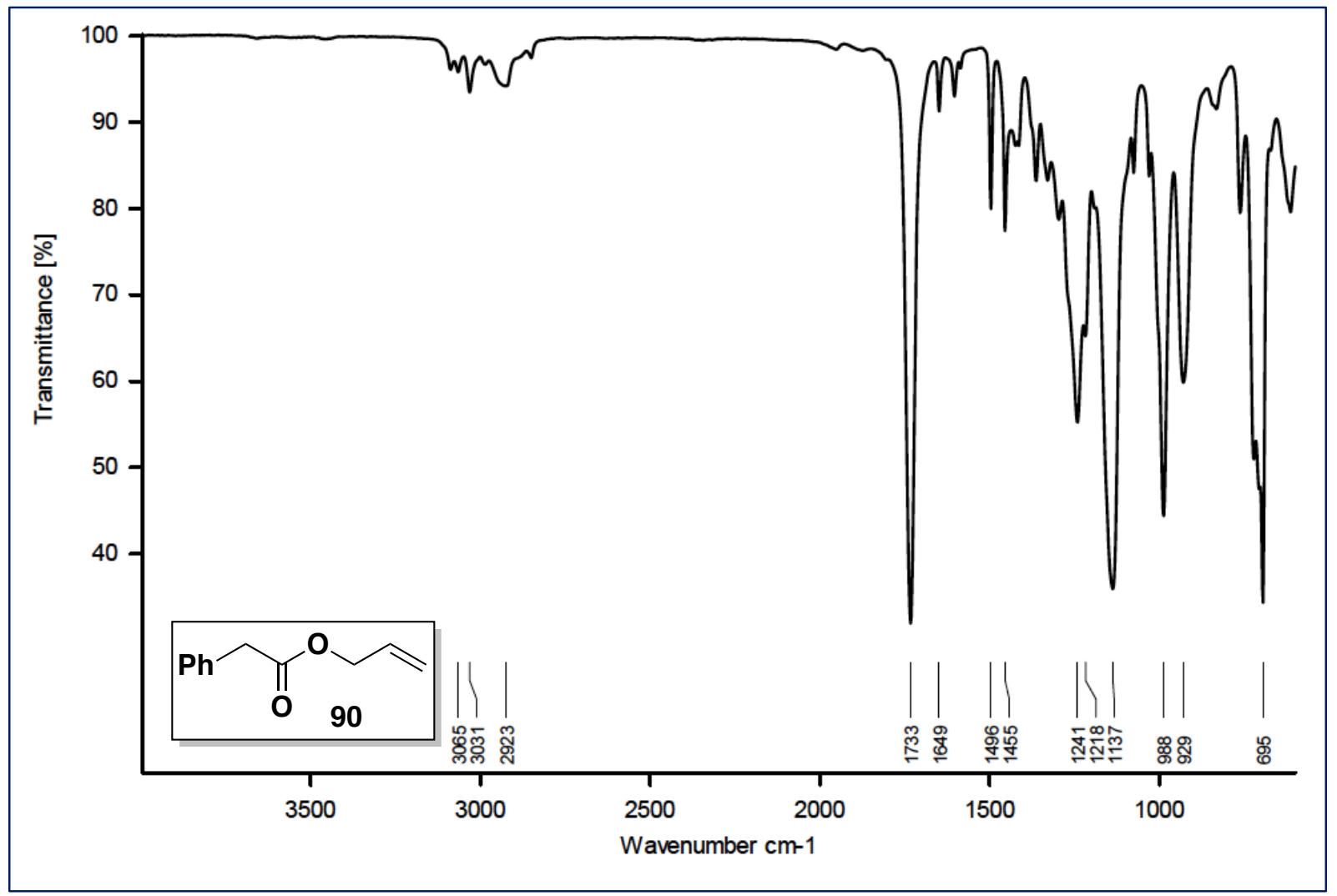



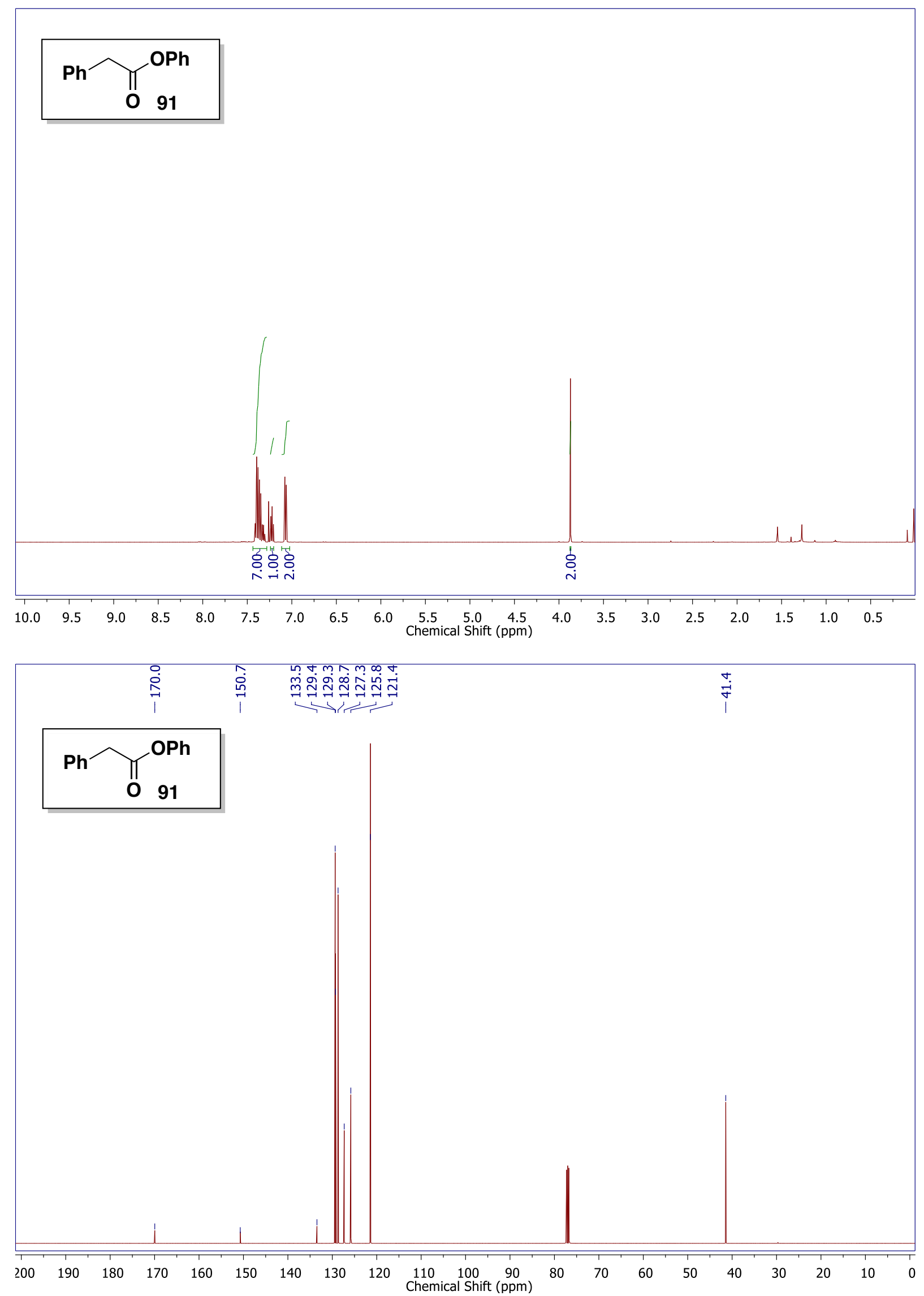


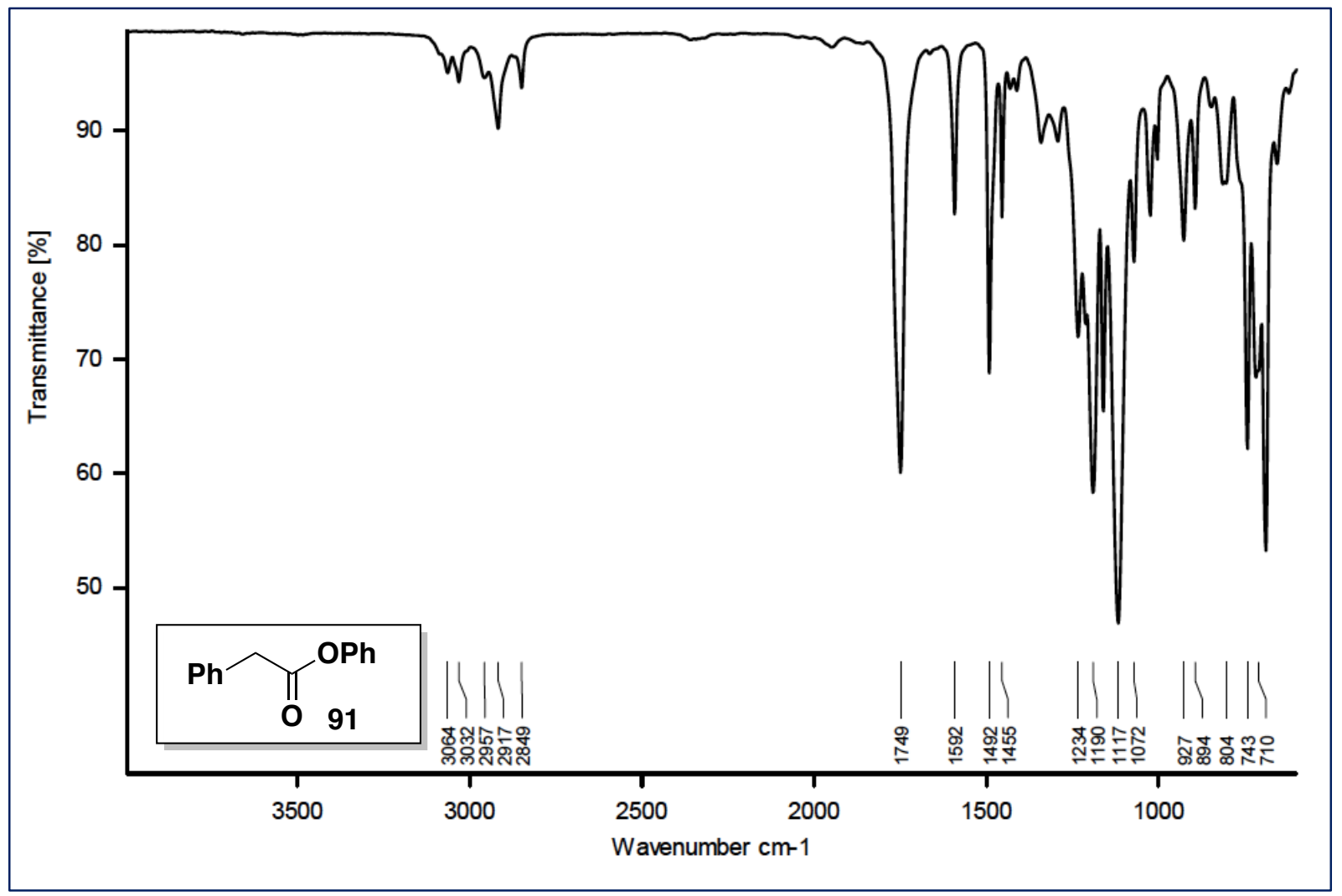



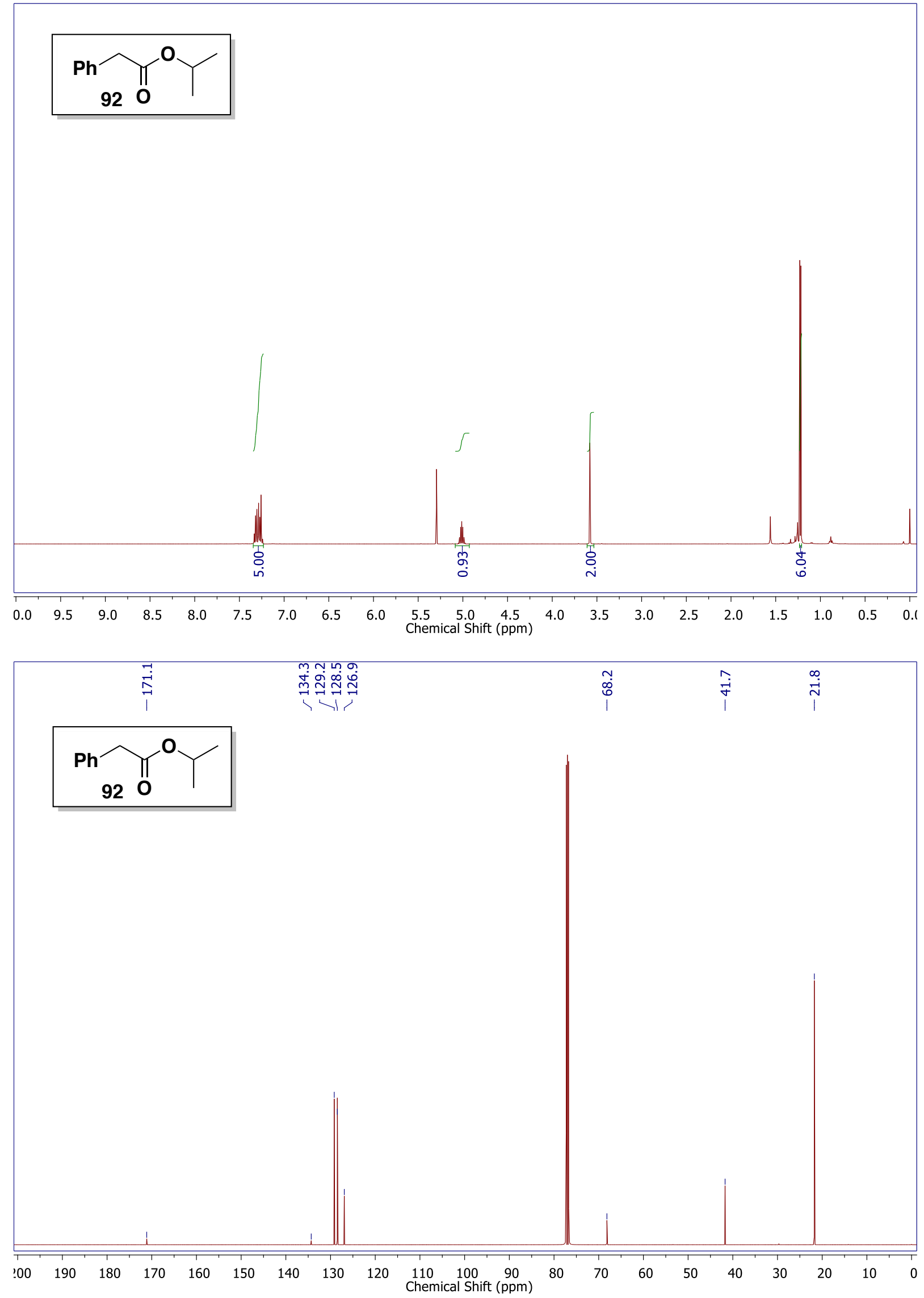


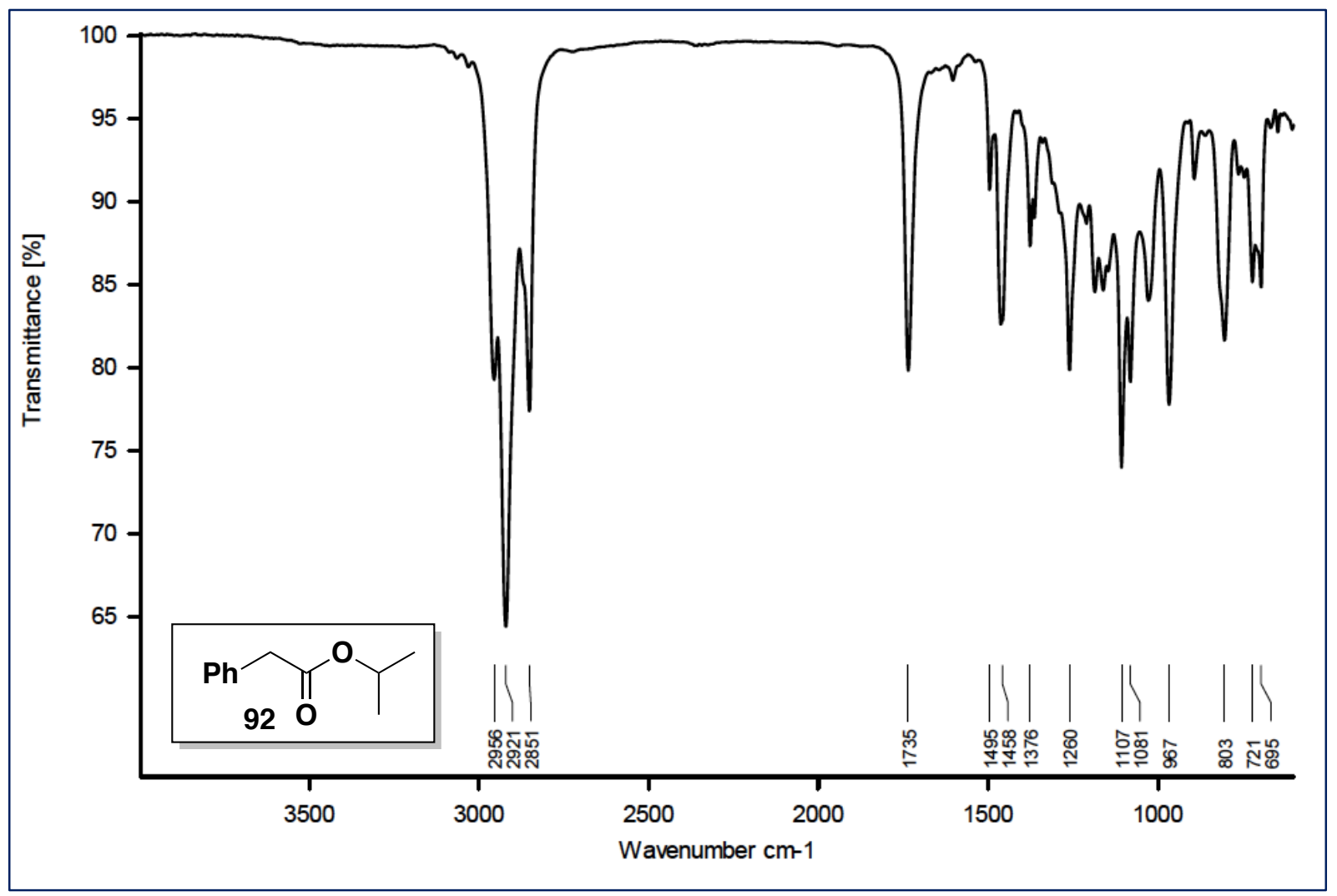



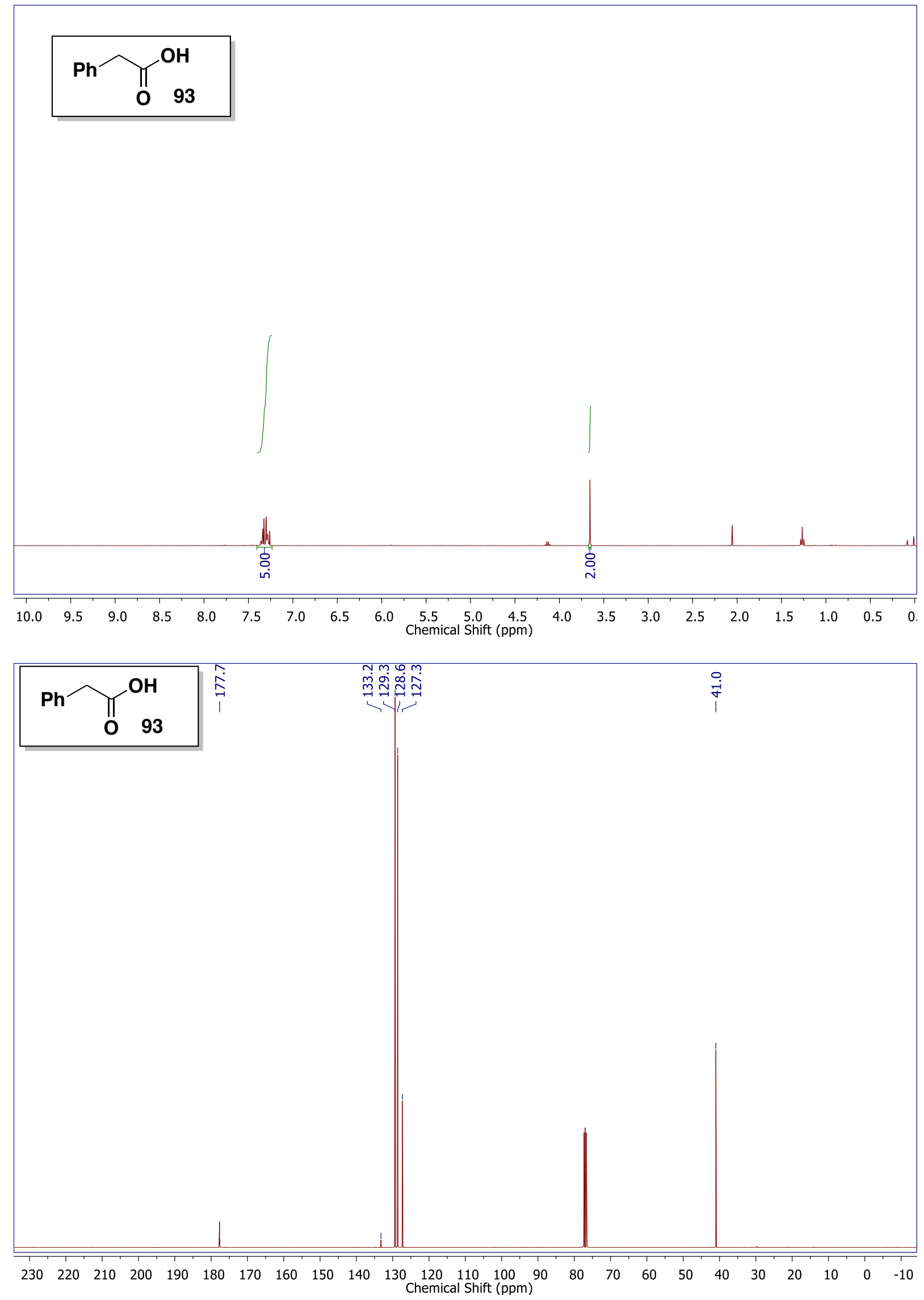


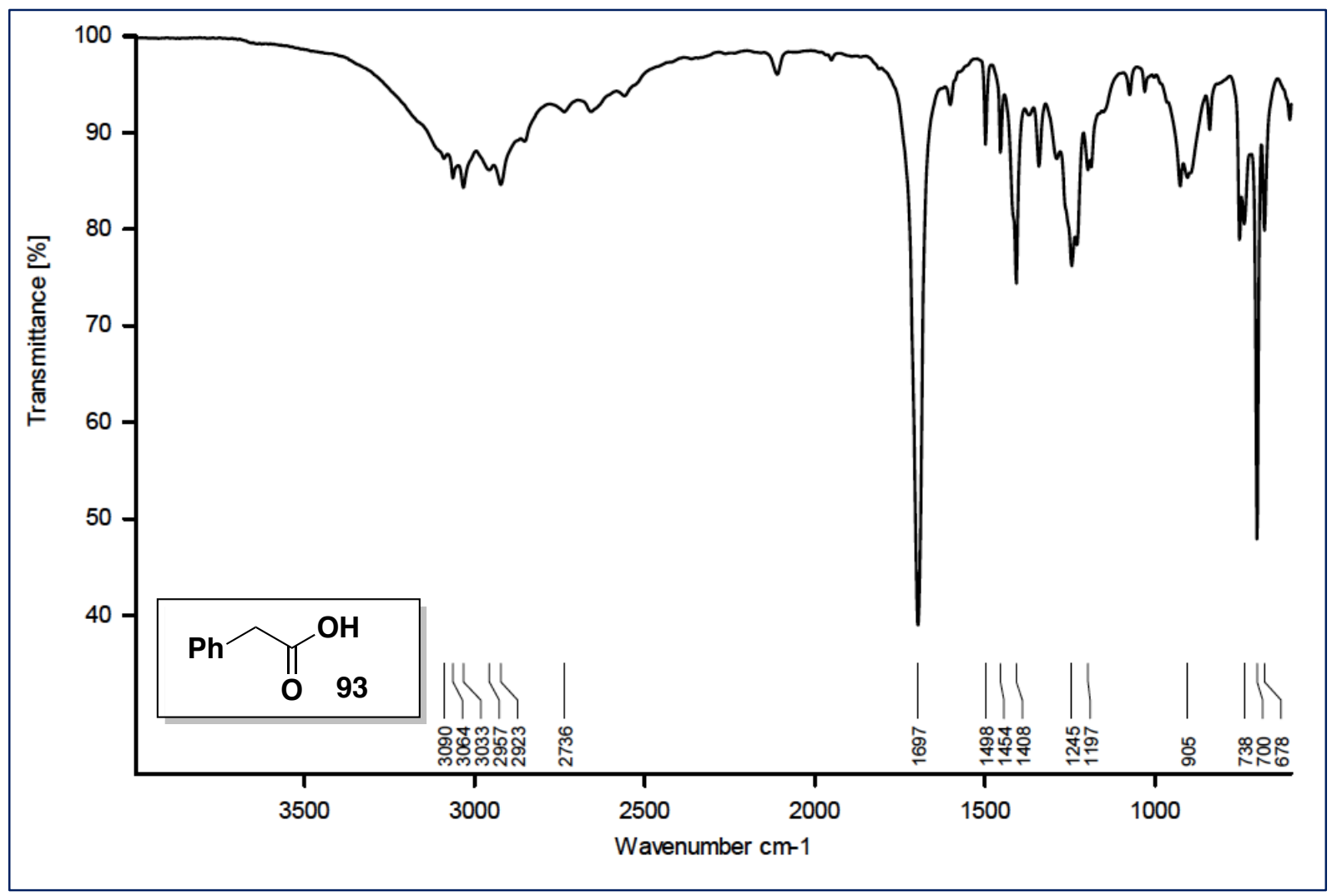



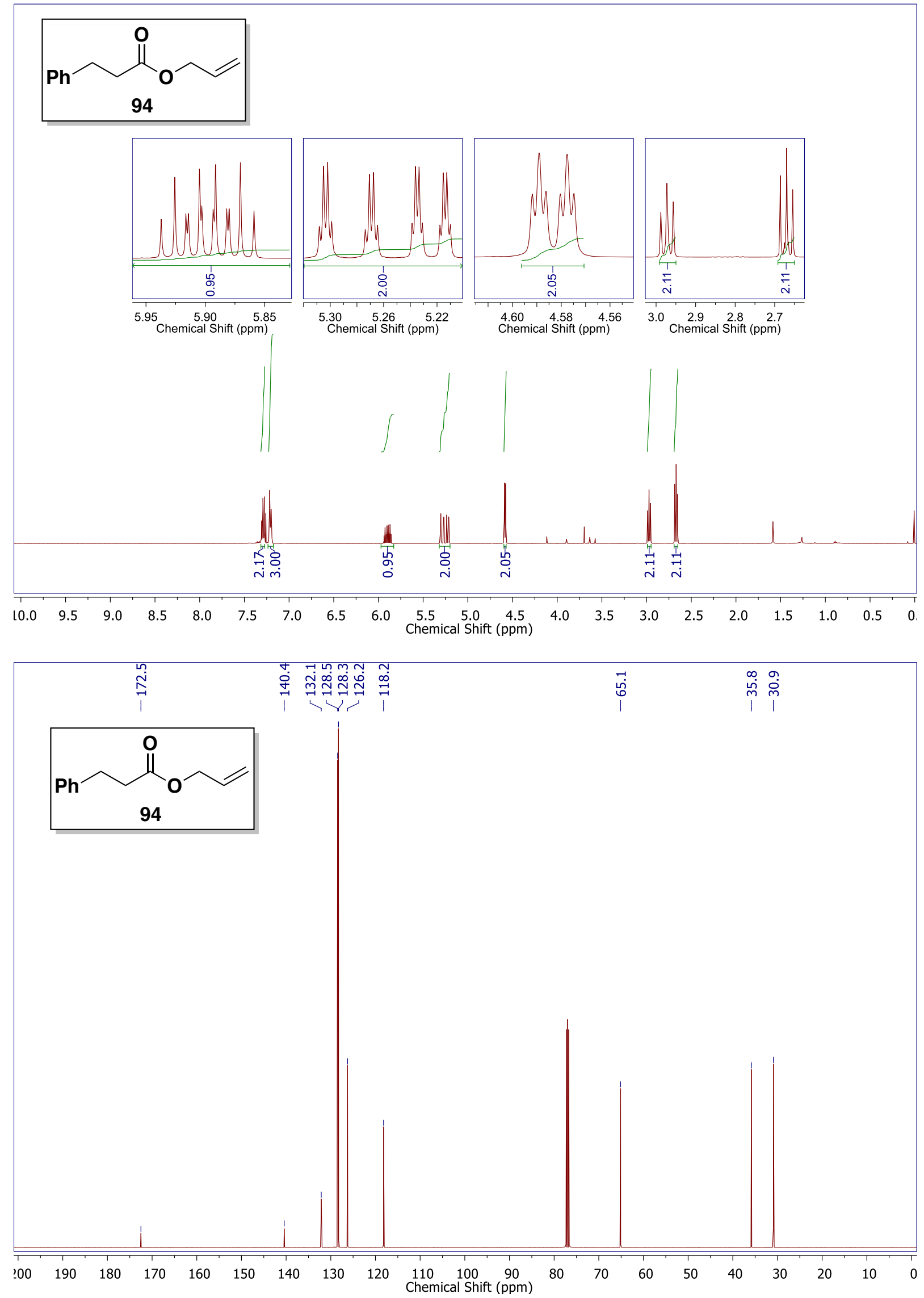


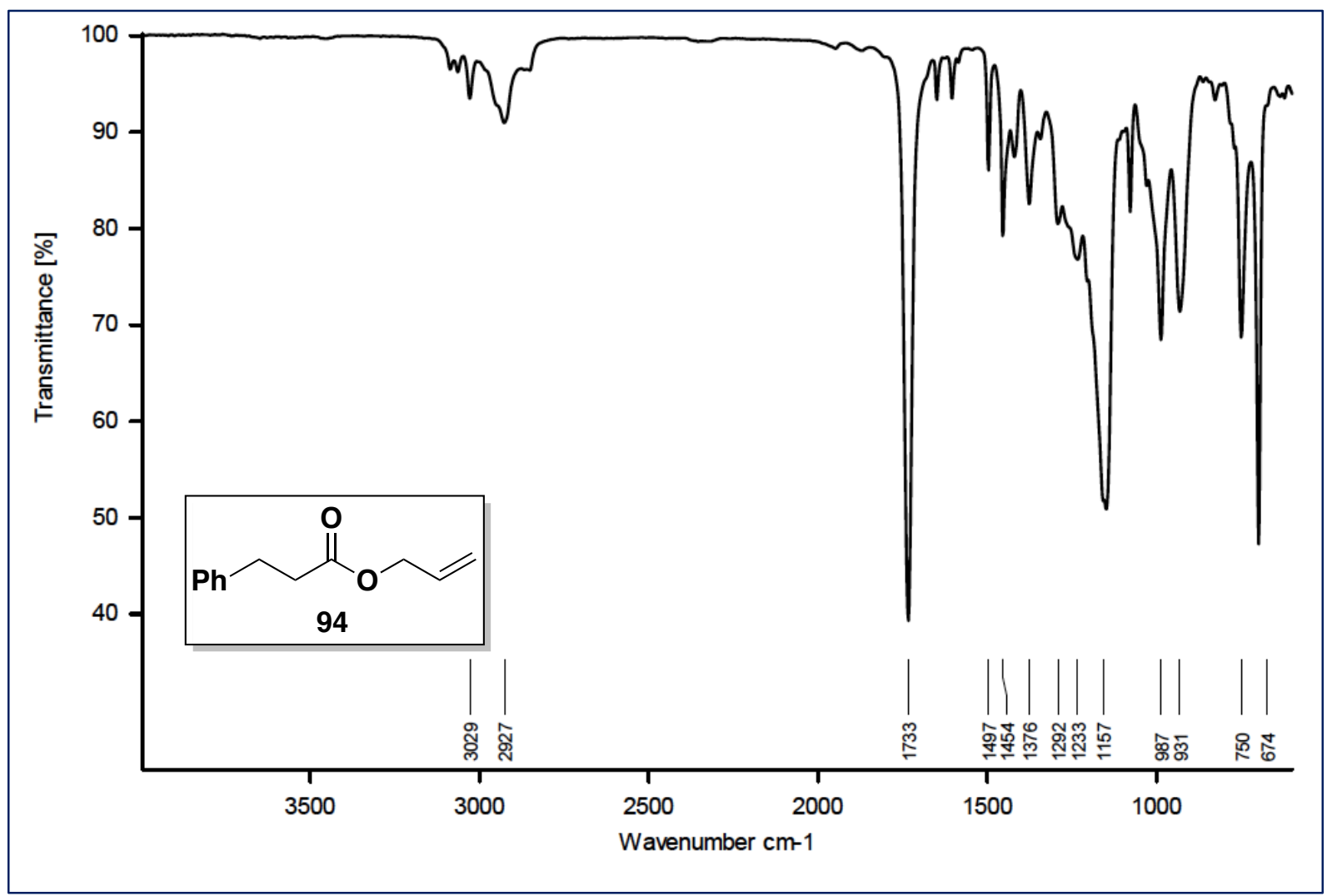



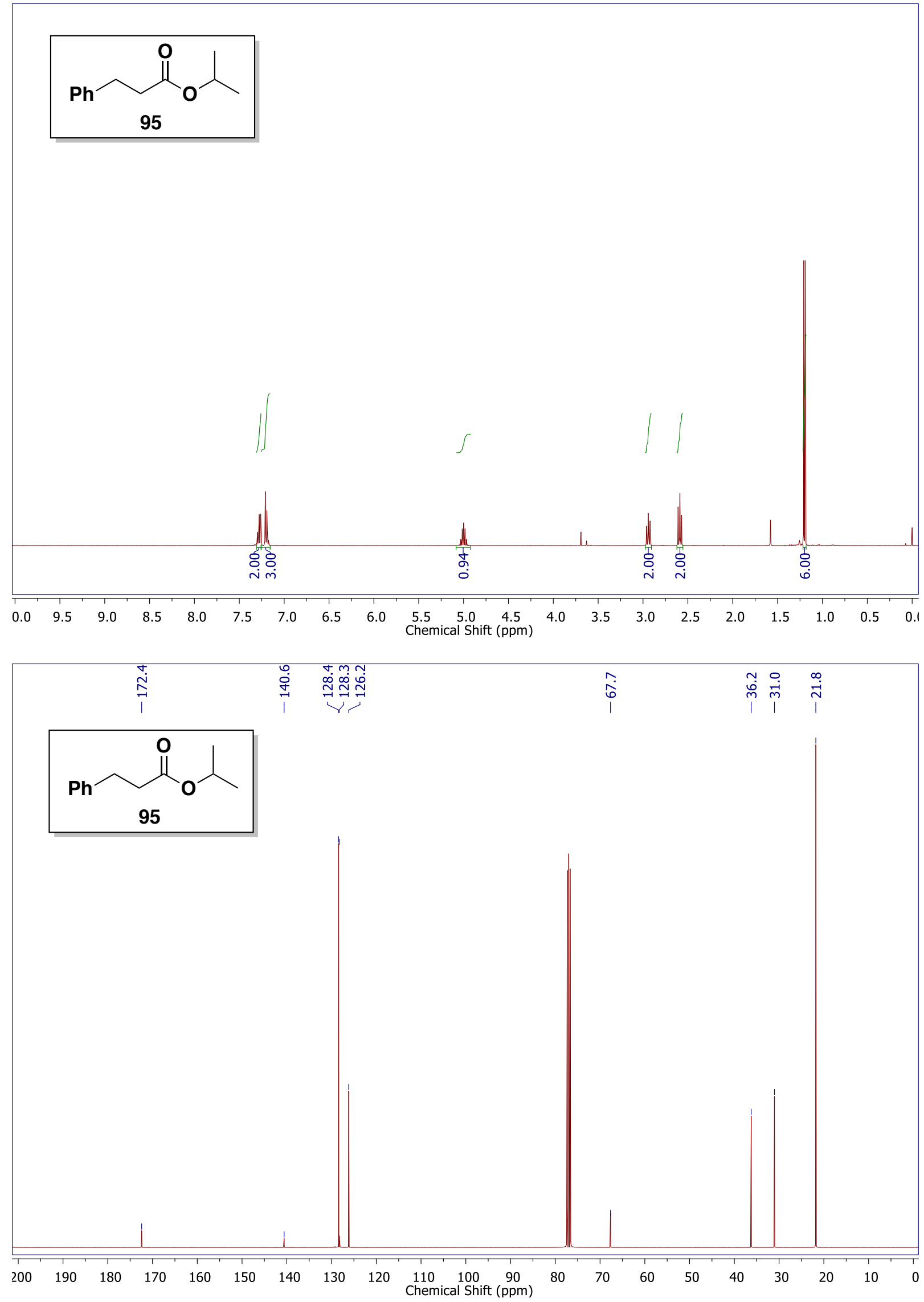


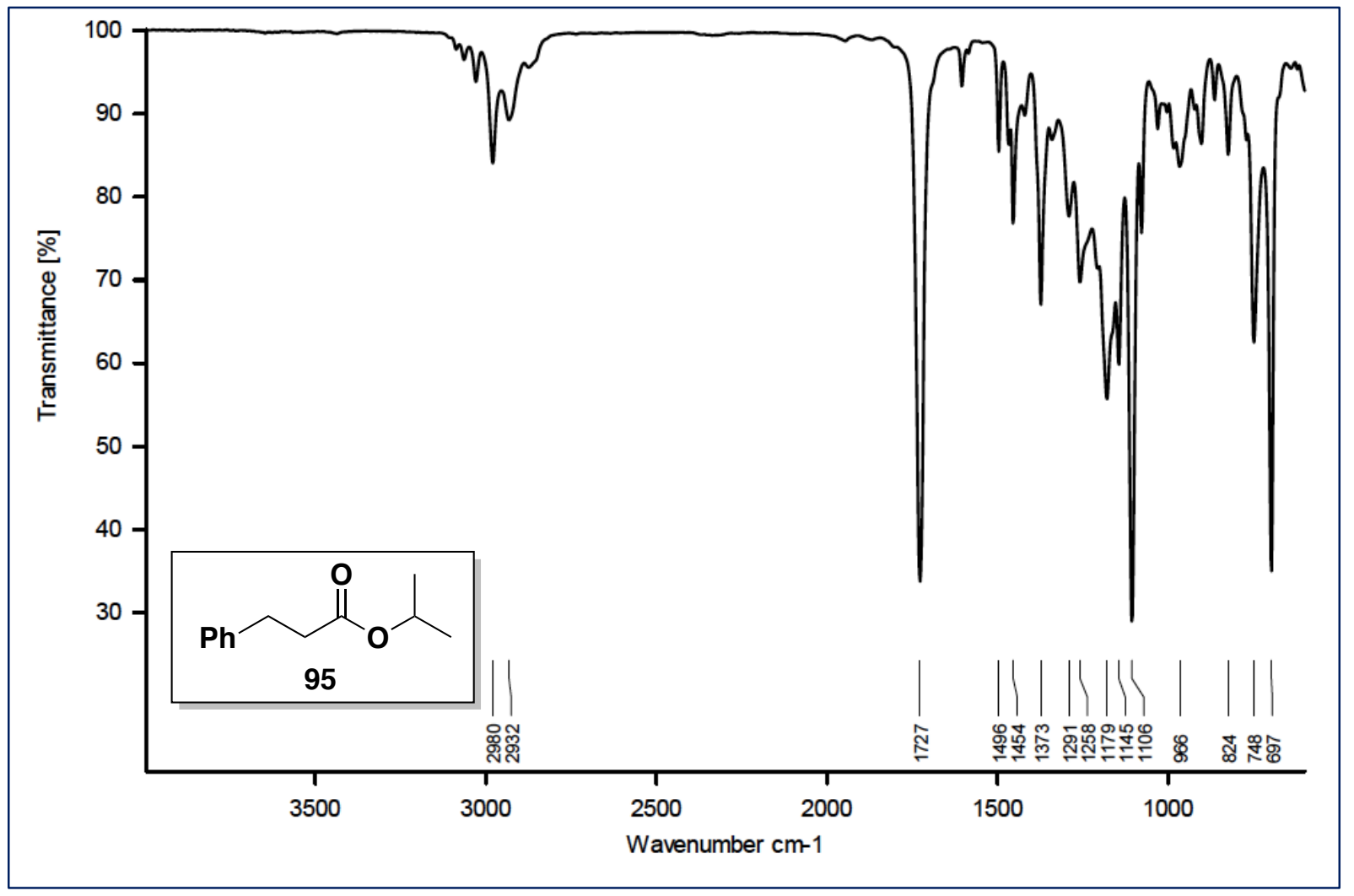



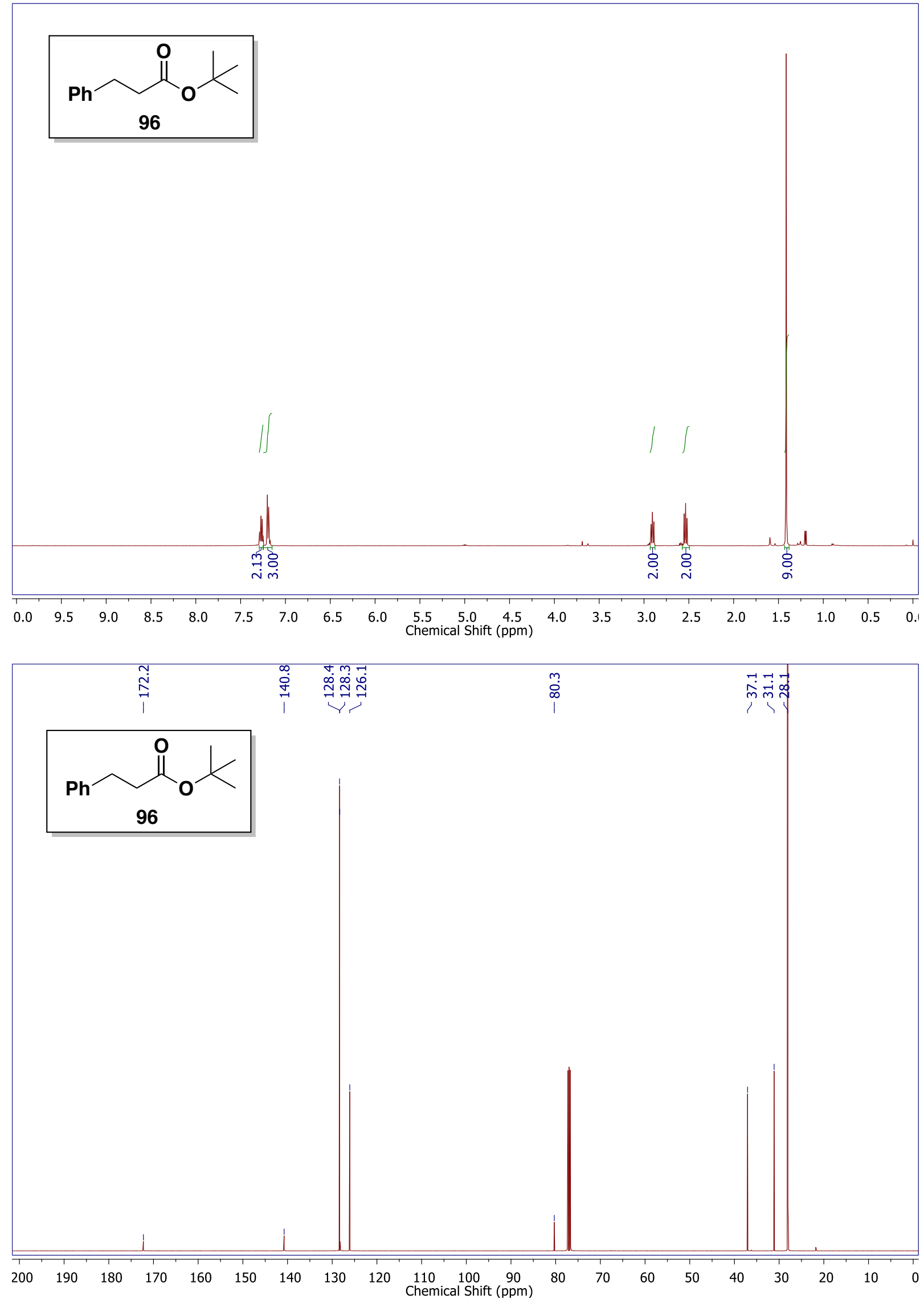


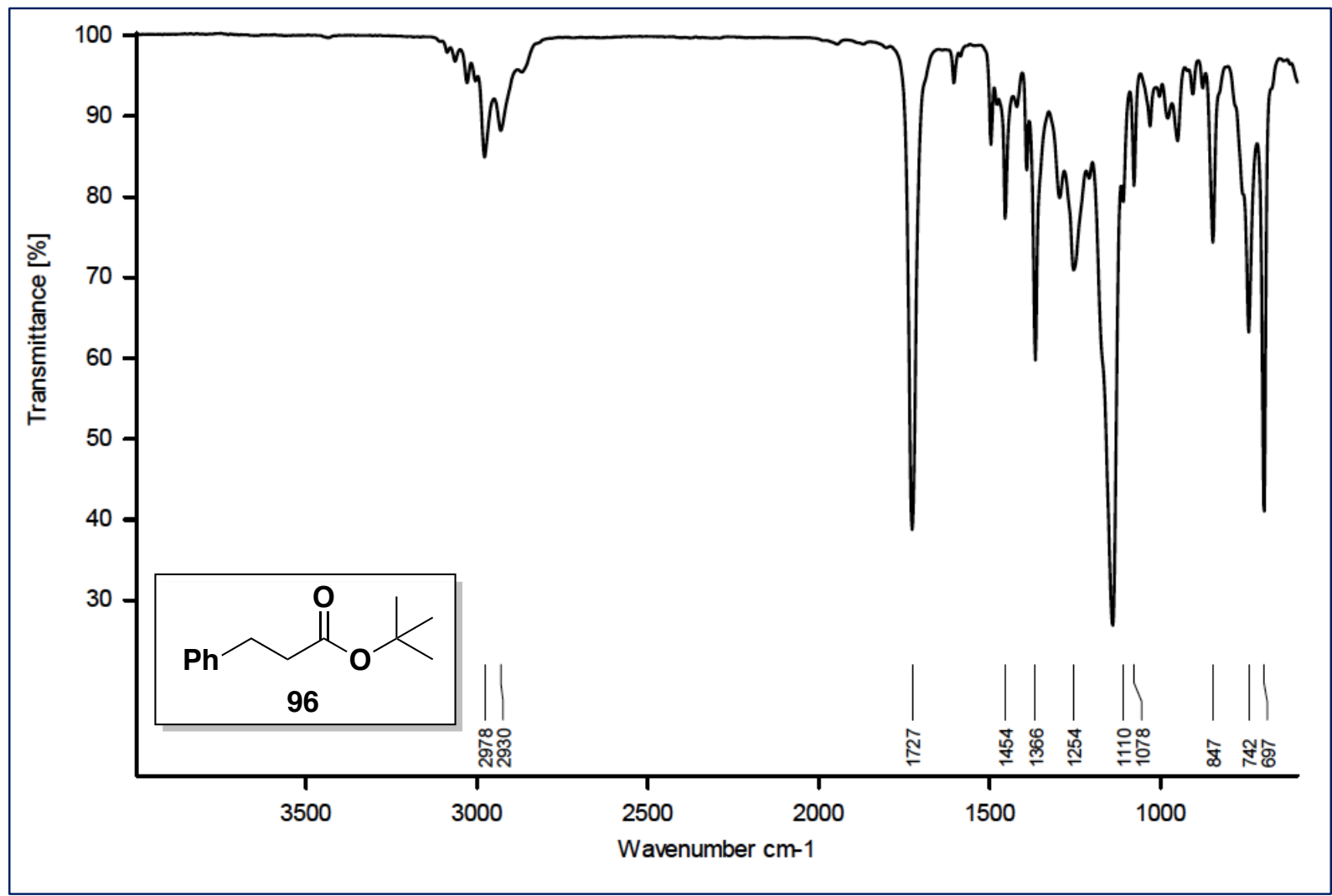



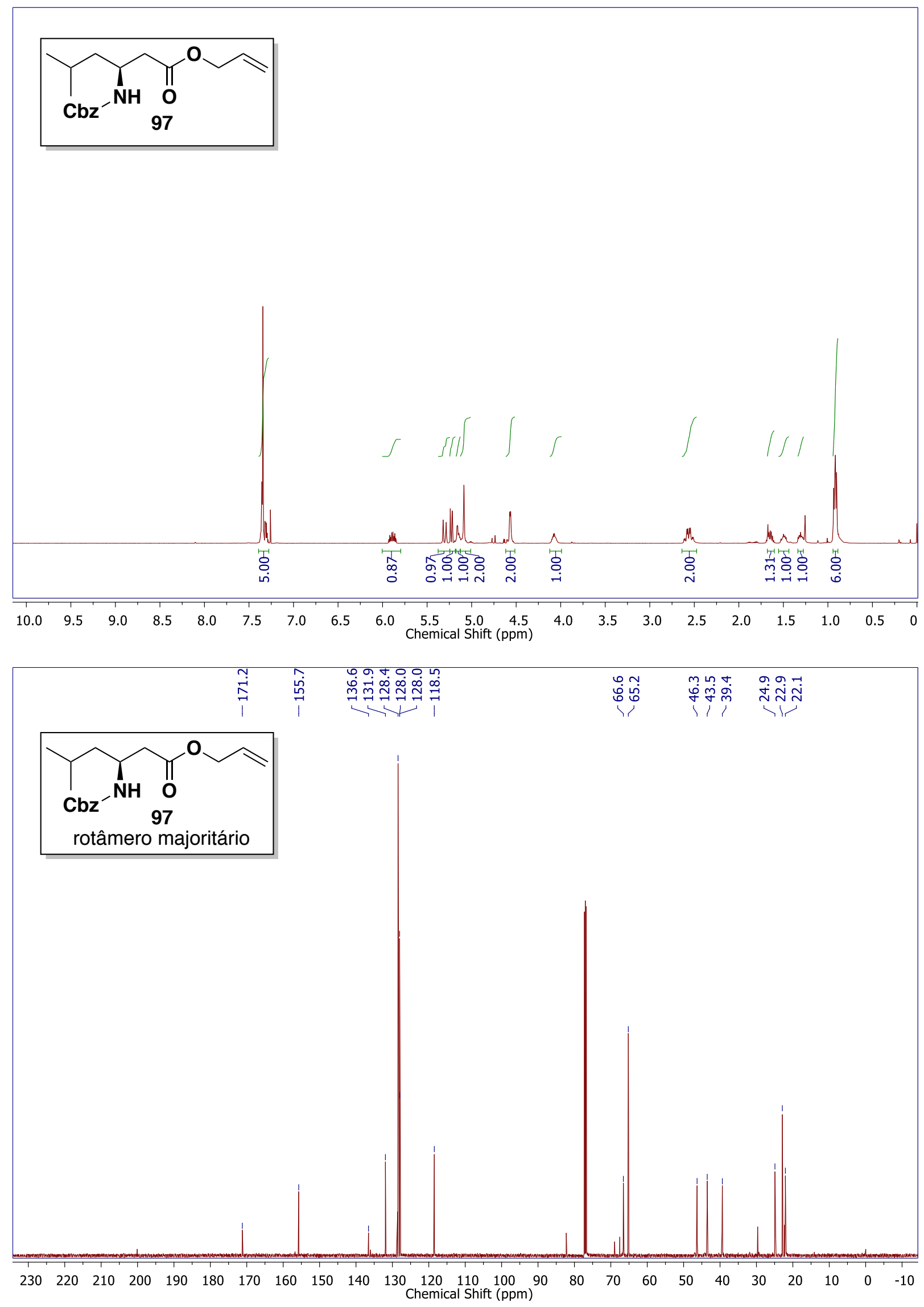

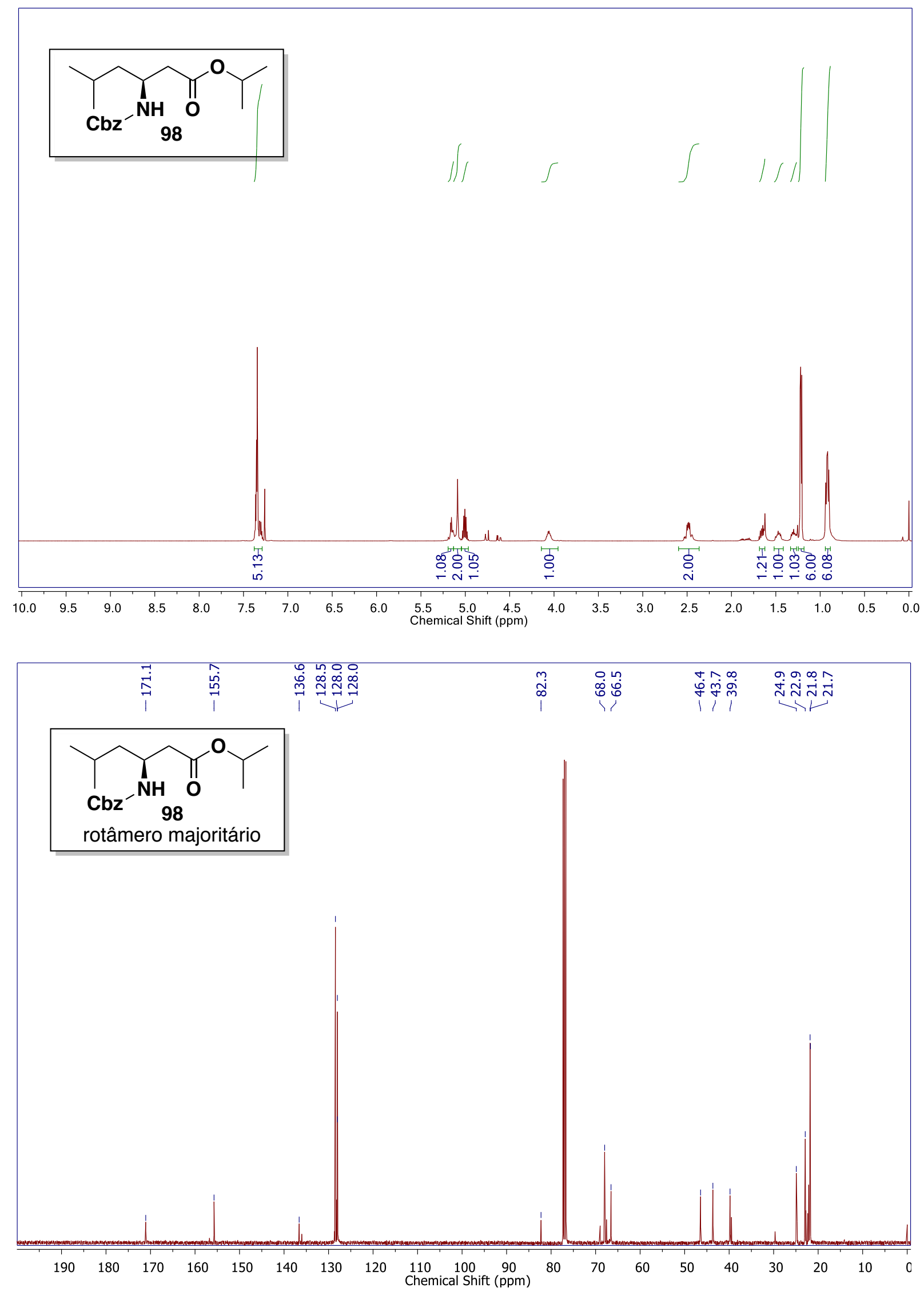

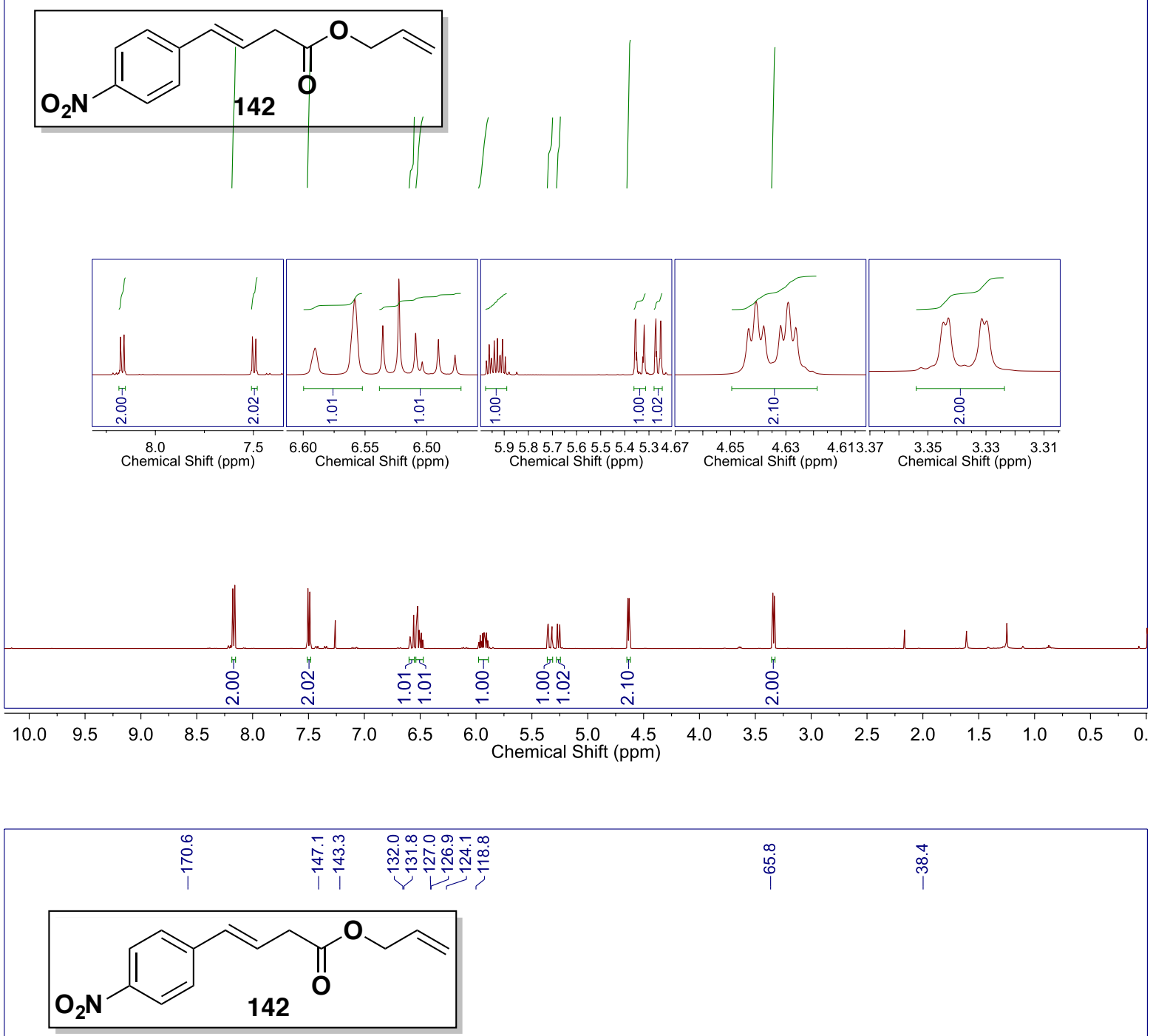

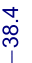

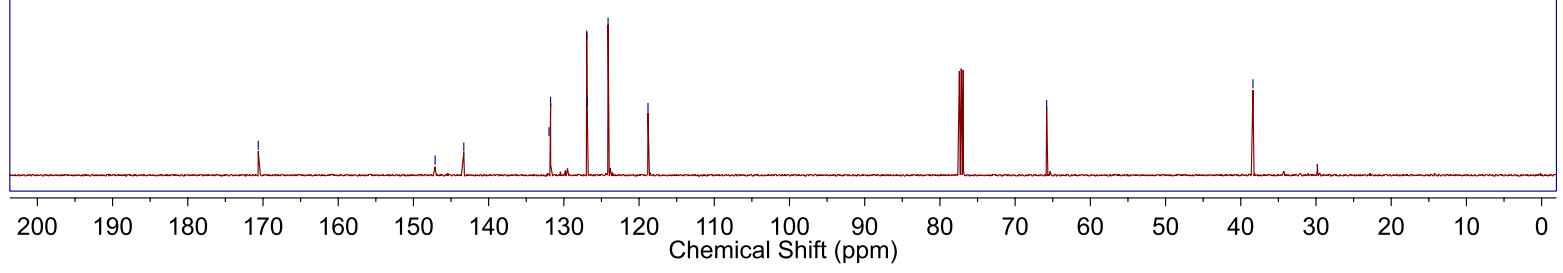



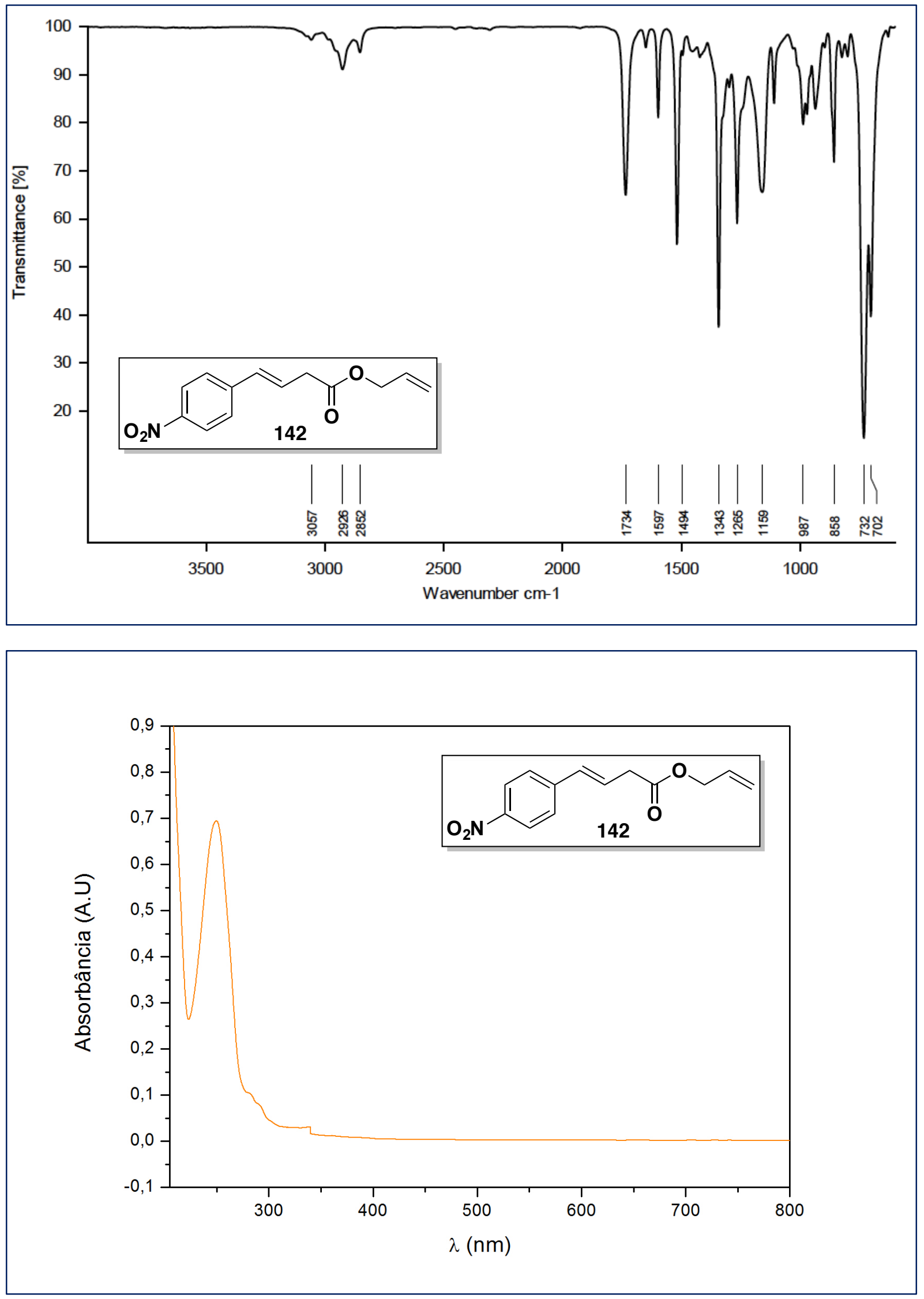

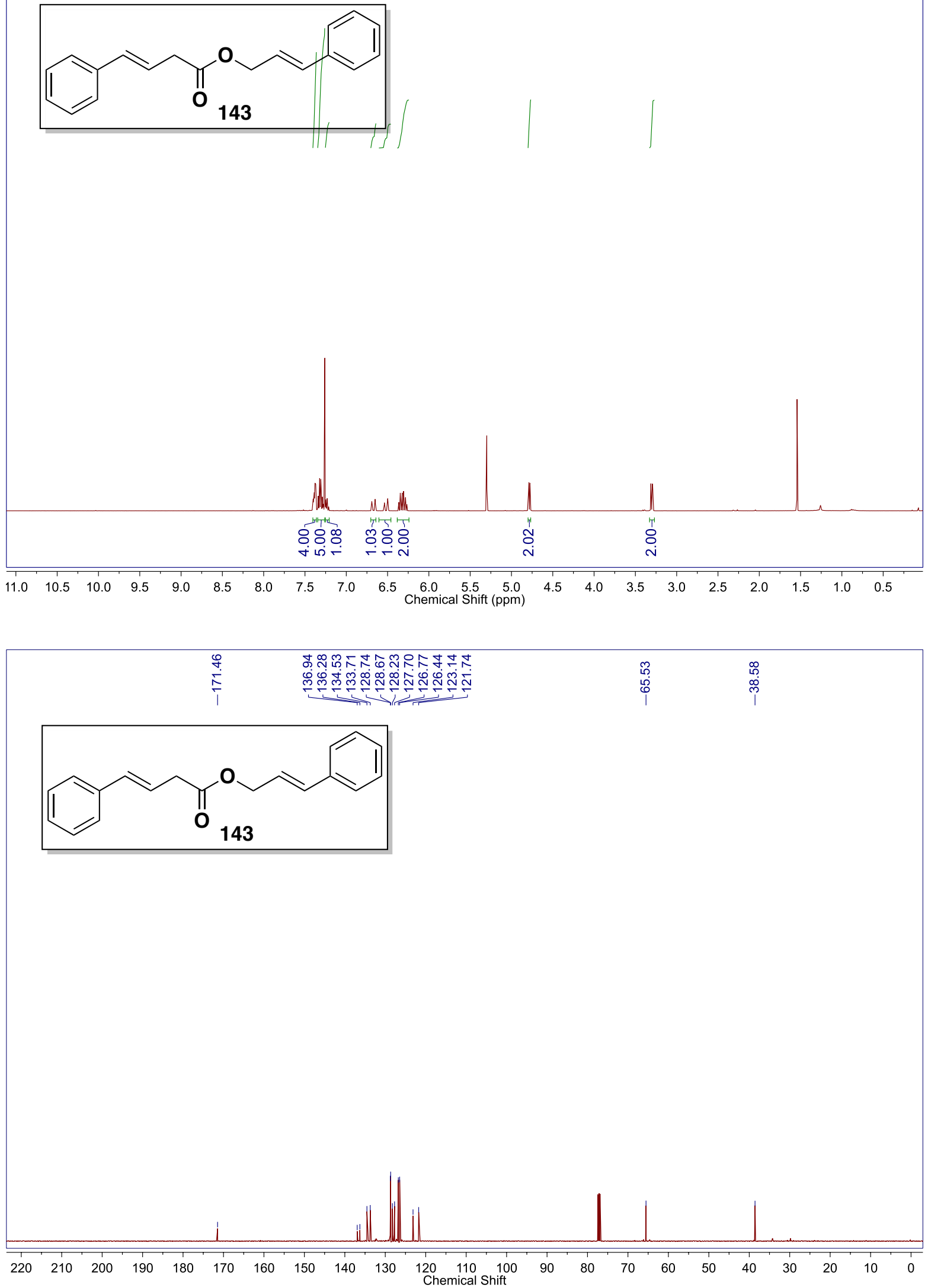

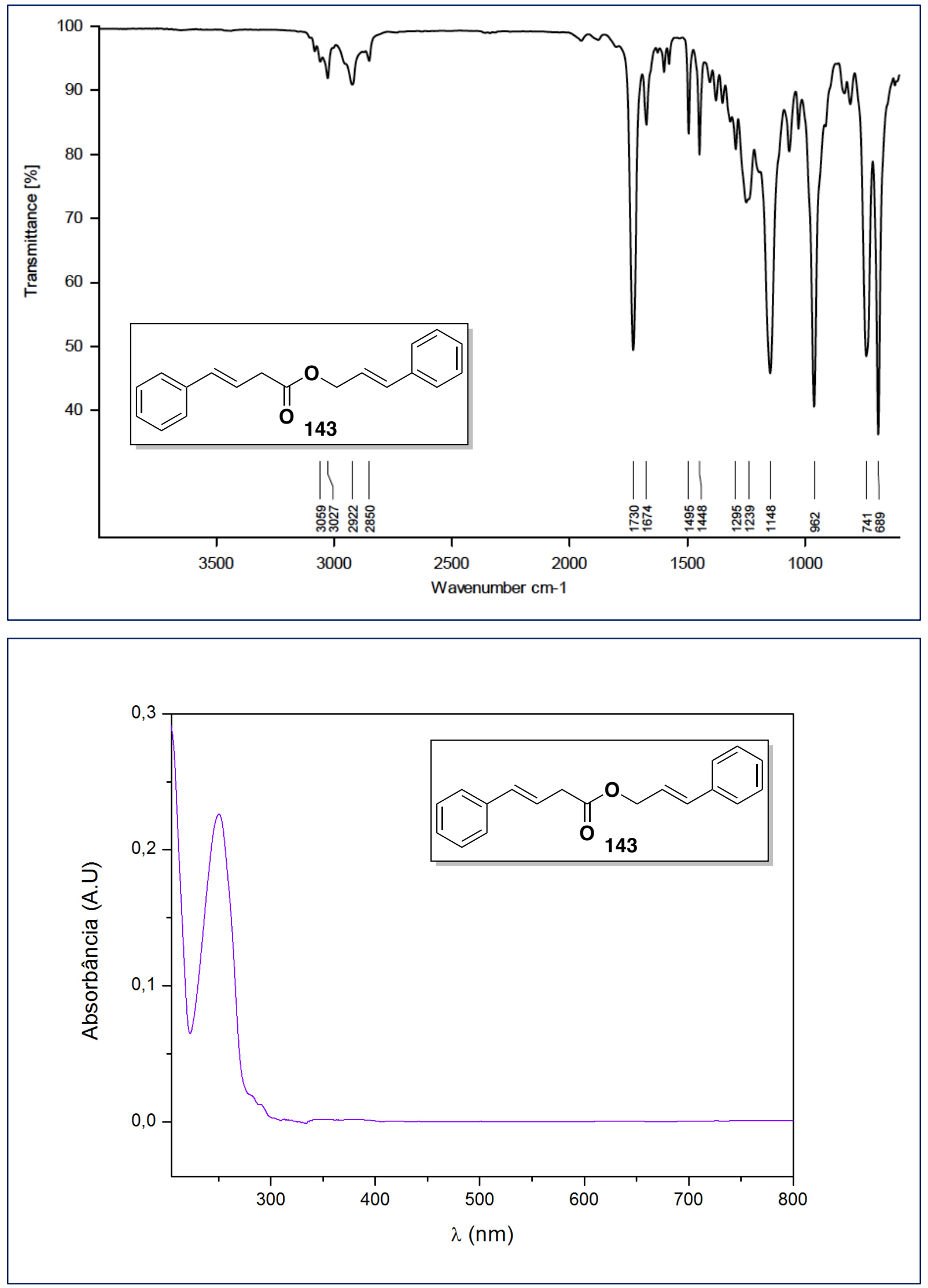

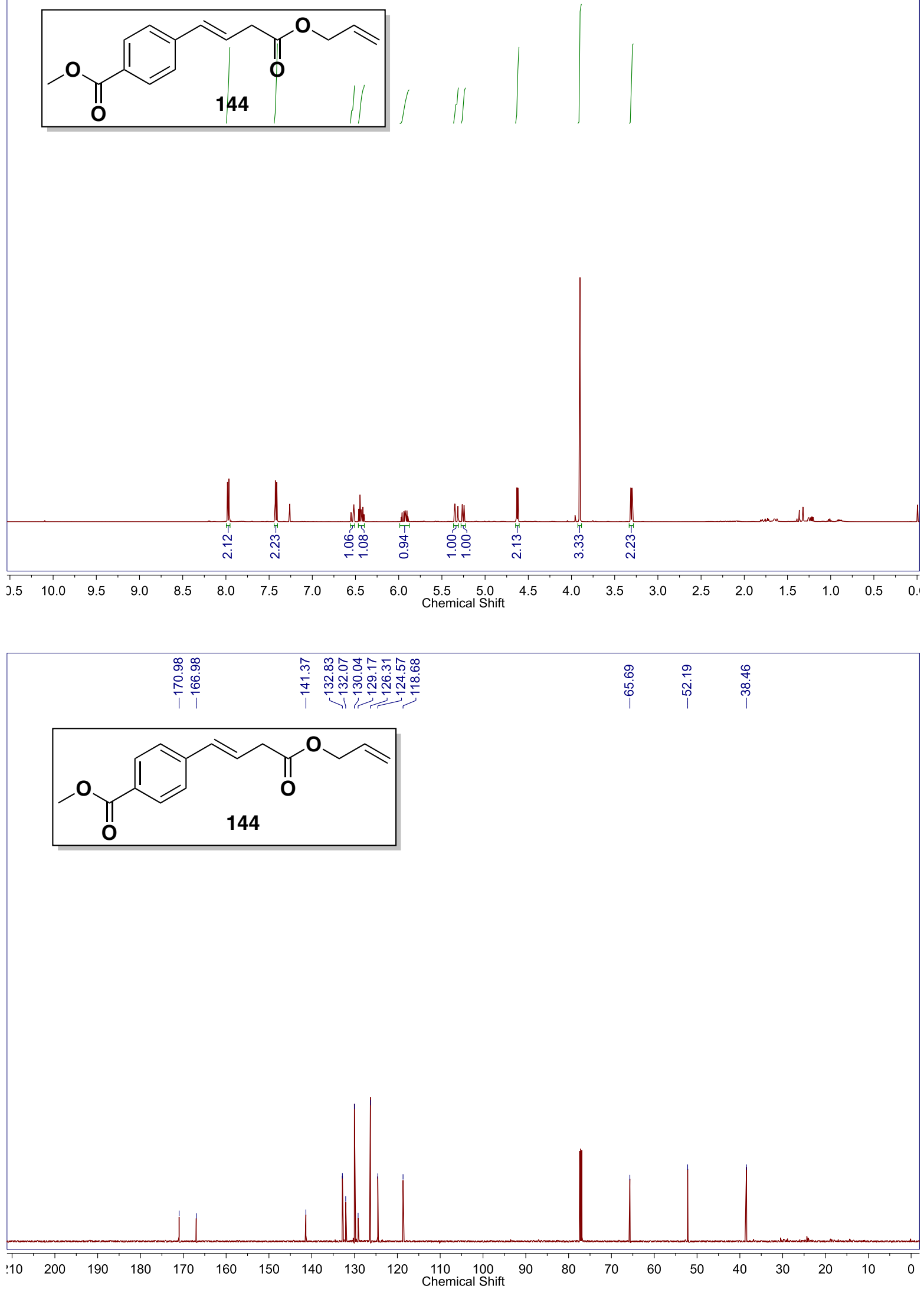

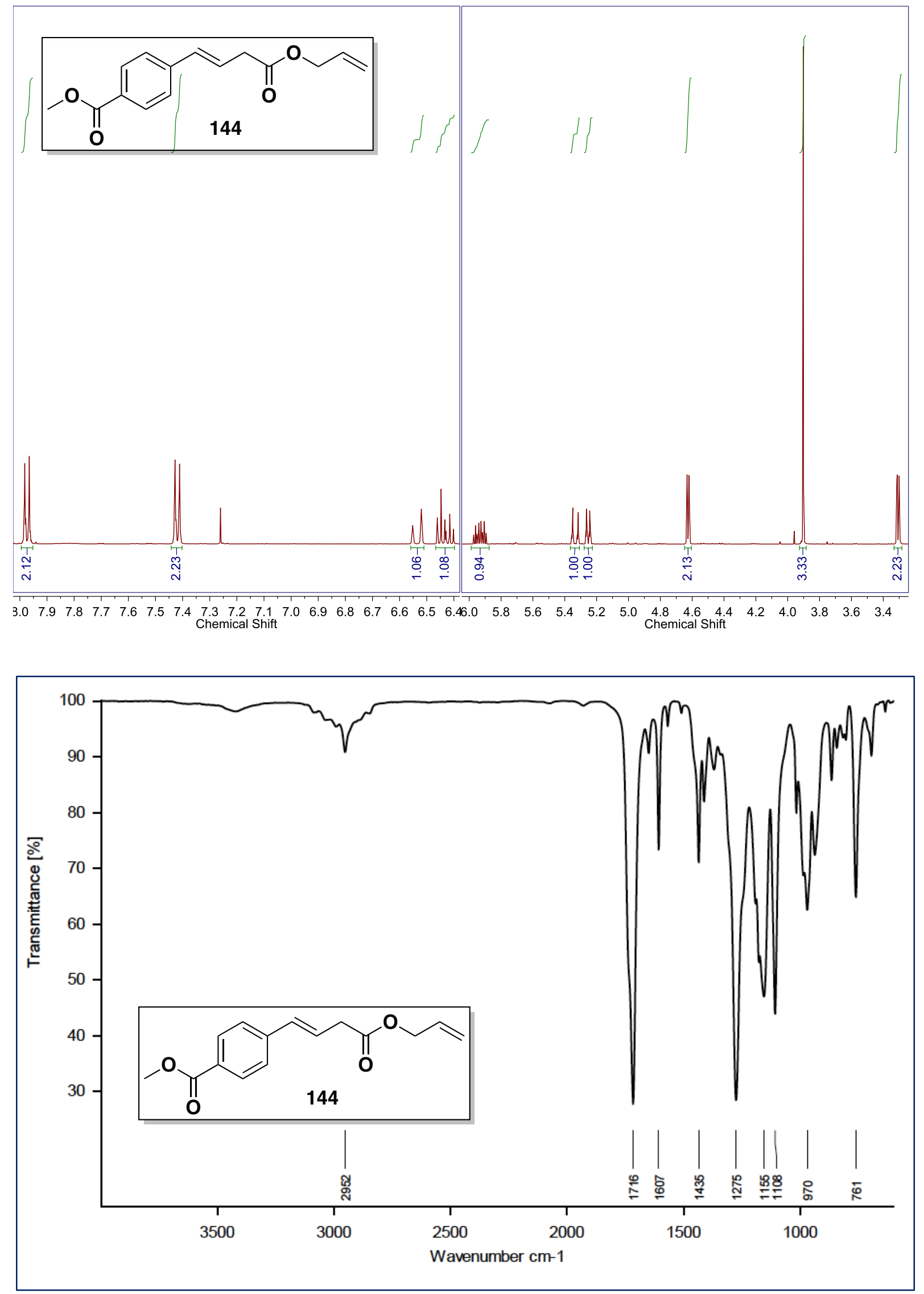

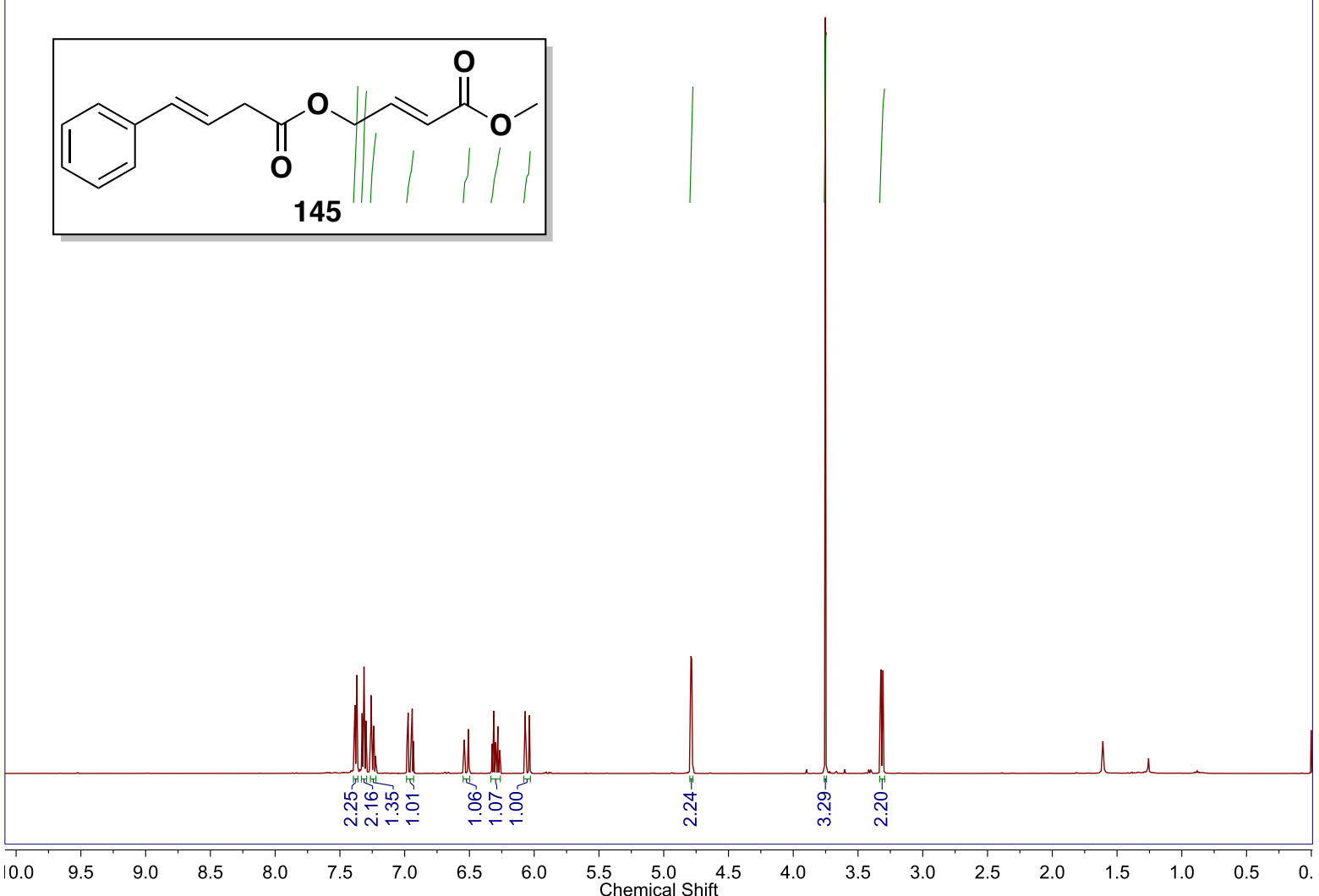

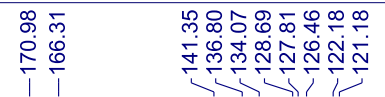

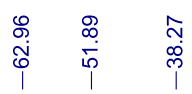
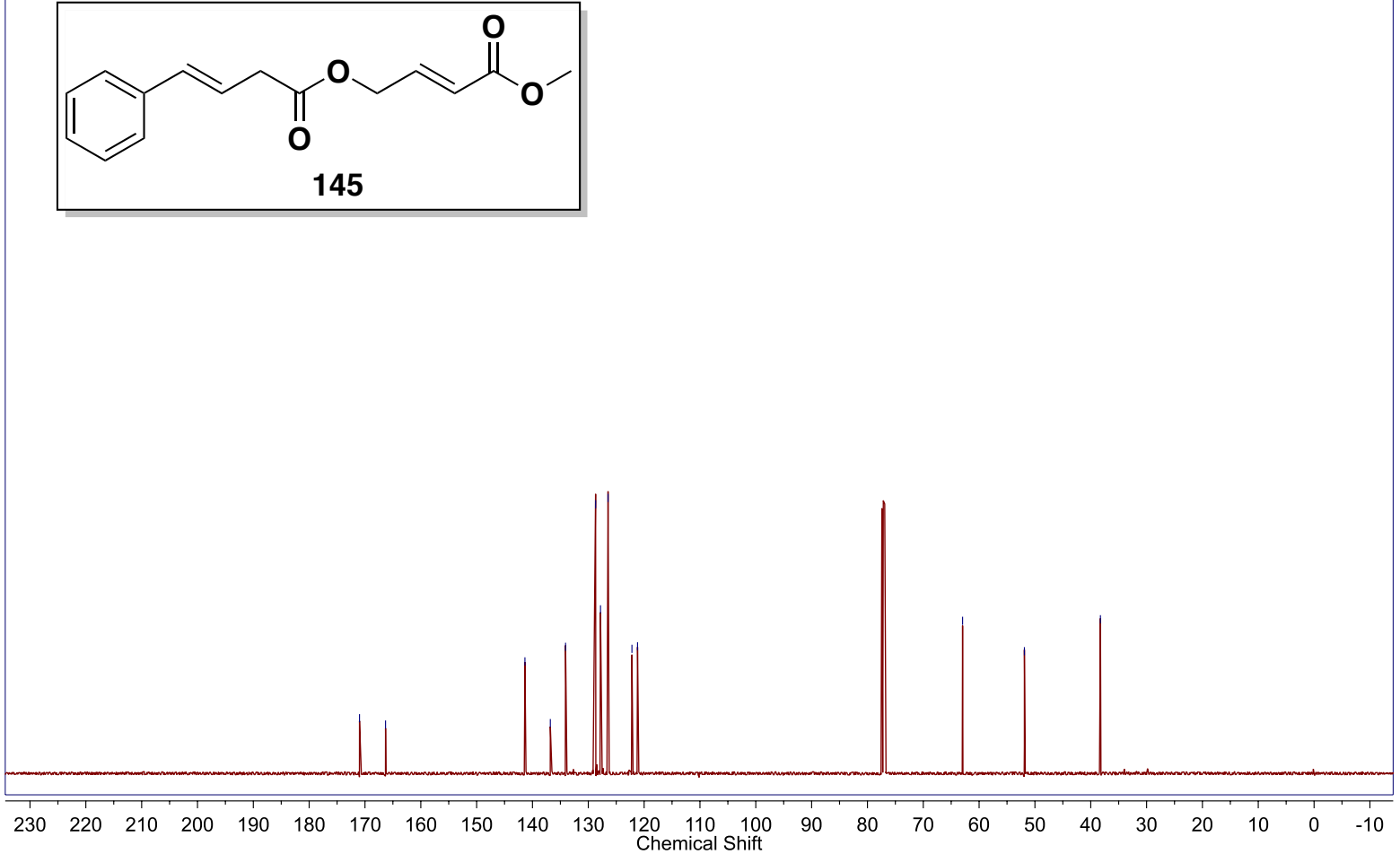

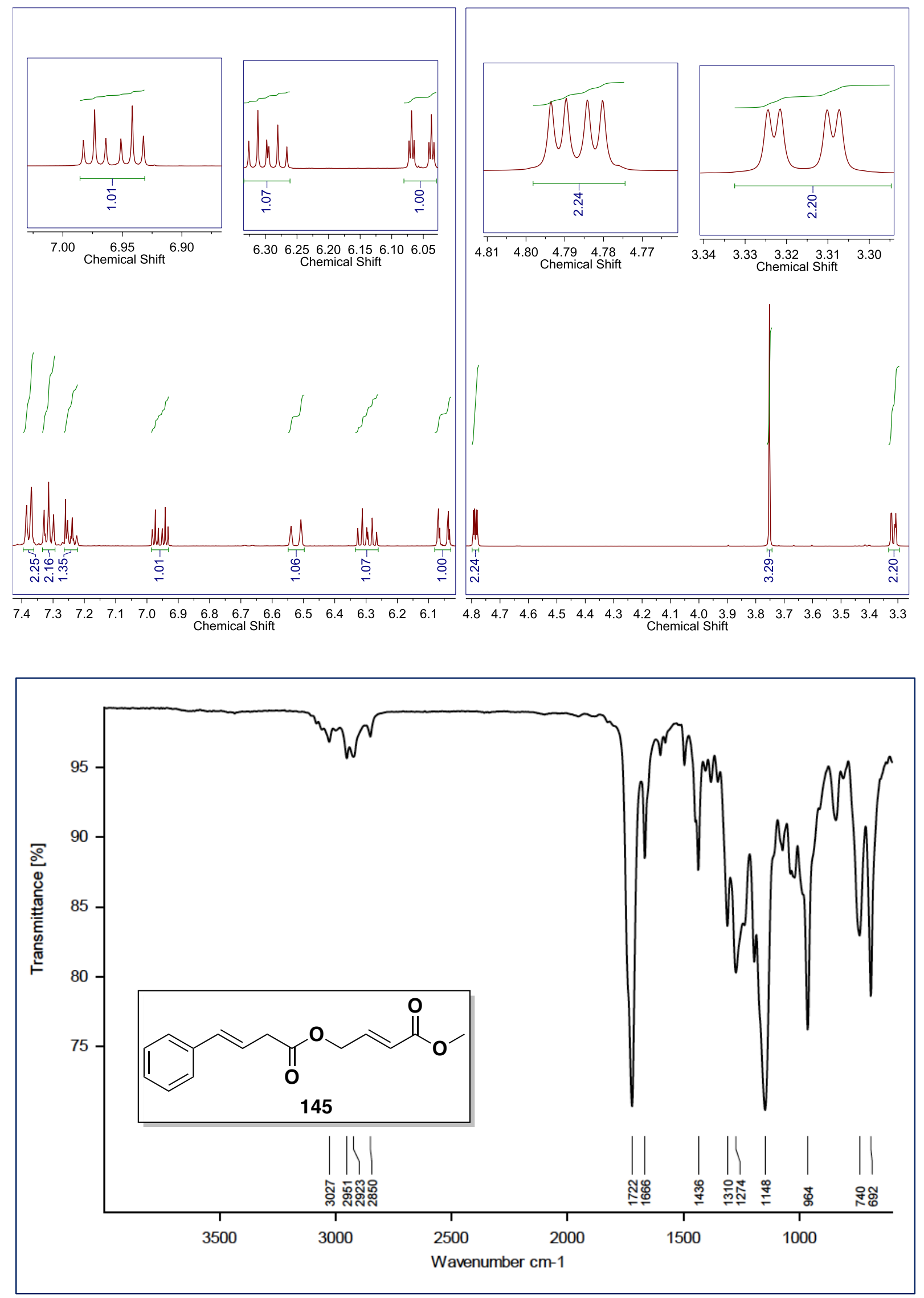

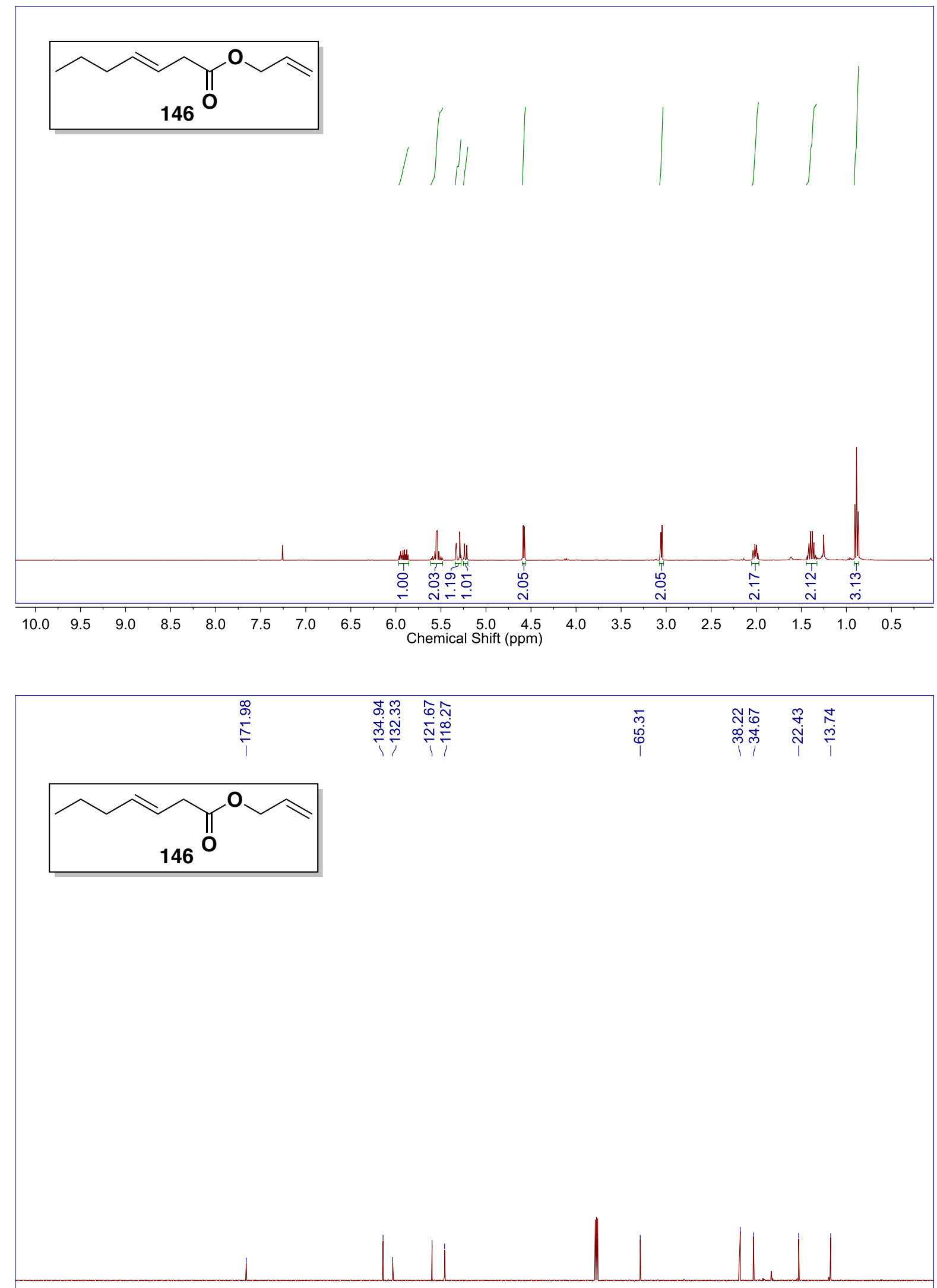

$\begin{array}{lllllllllllllllllllllllllll}230 & 220 & 210 & 200 & 190 & 180 & 170 & 160 & 150 & 140 & 130 & 120 & 110 & 100 & 90 & 80 & 70 & 60 & 50 & 40 & 30 & 20 & 10 & 0 & -10\end{array}$ 

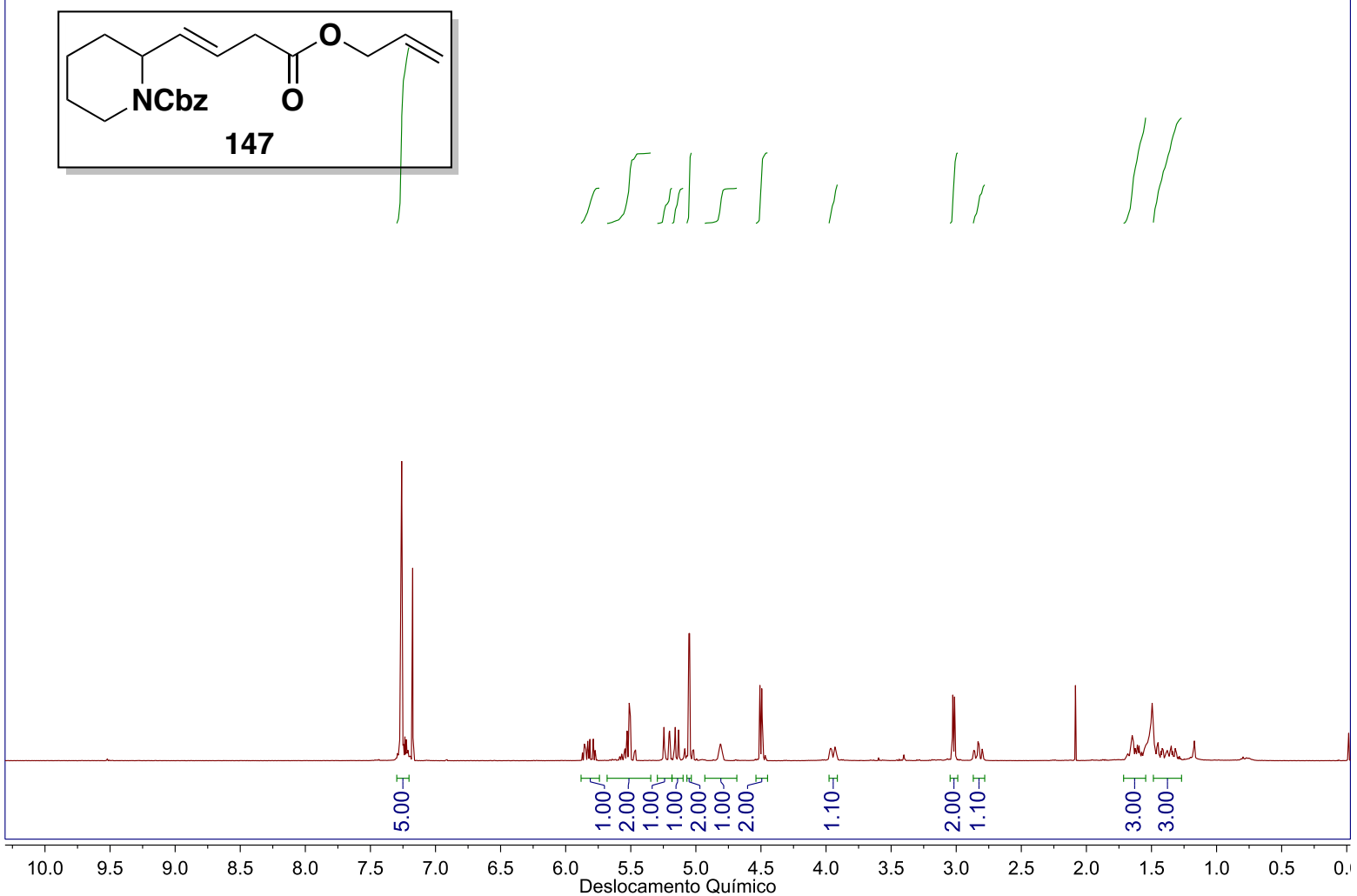

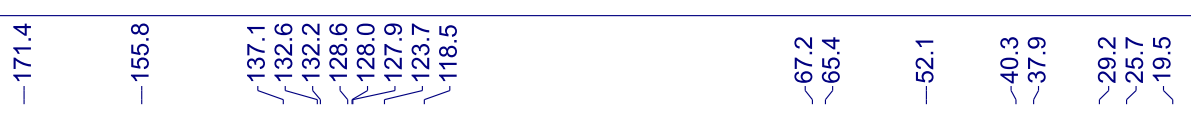
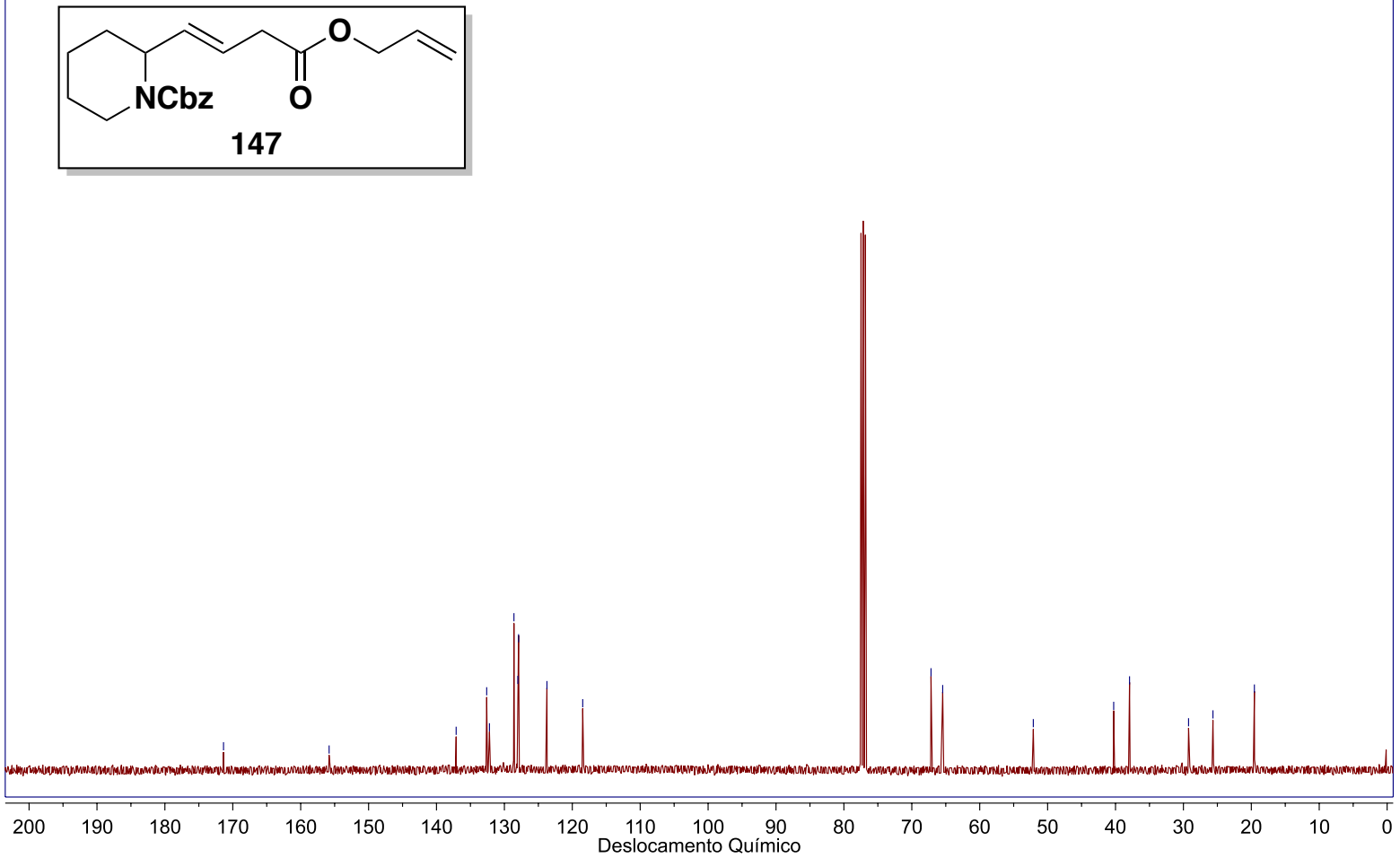


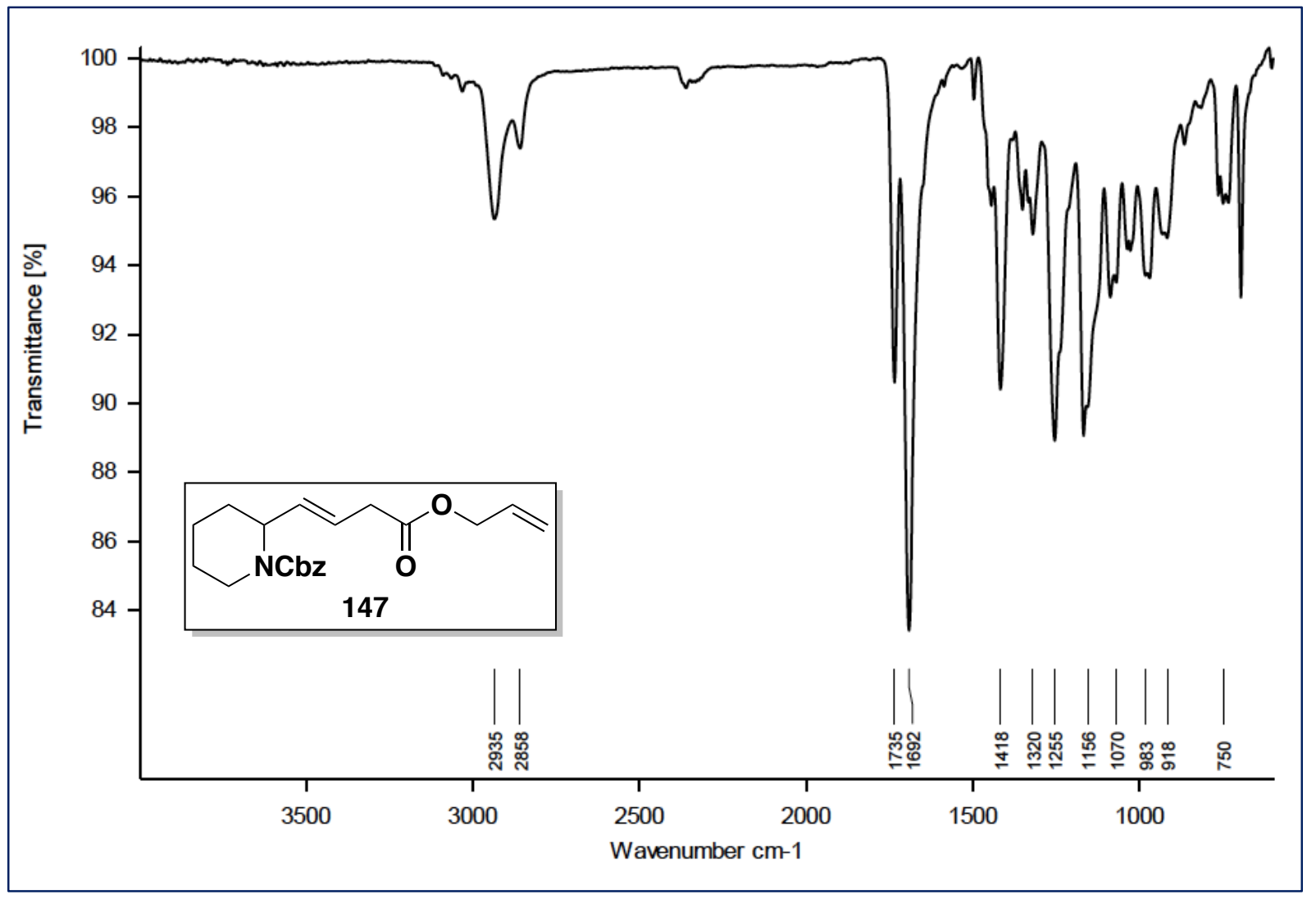



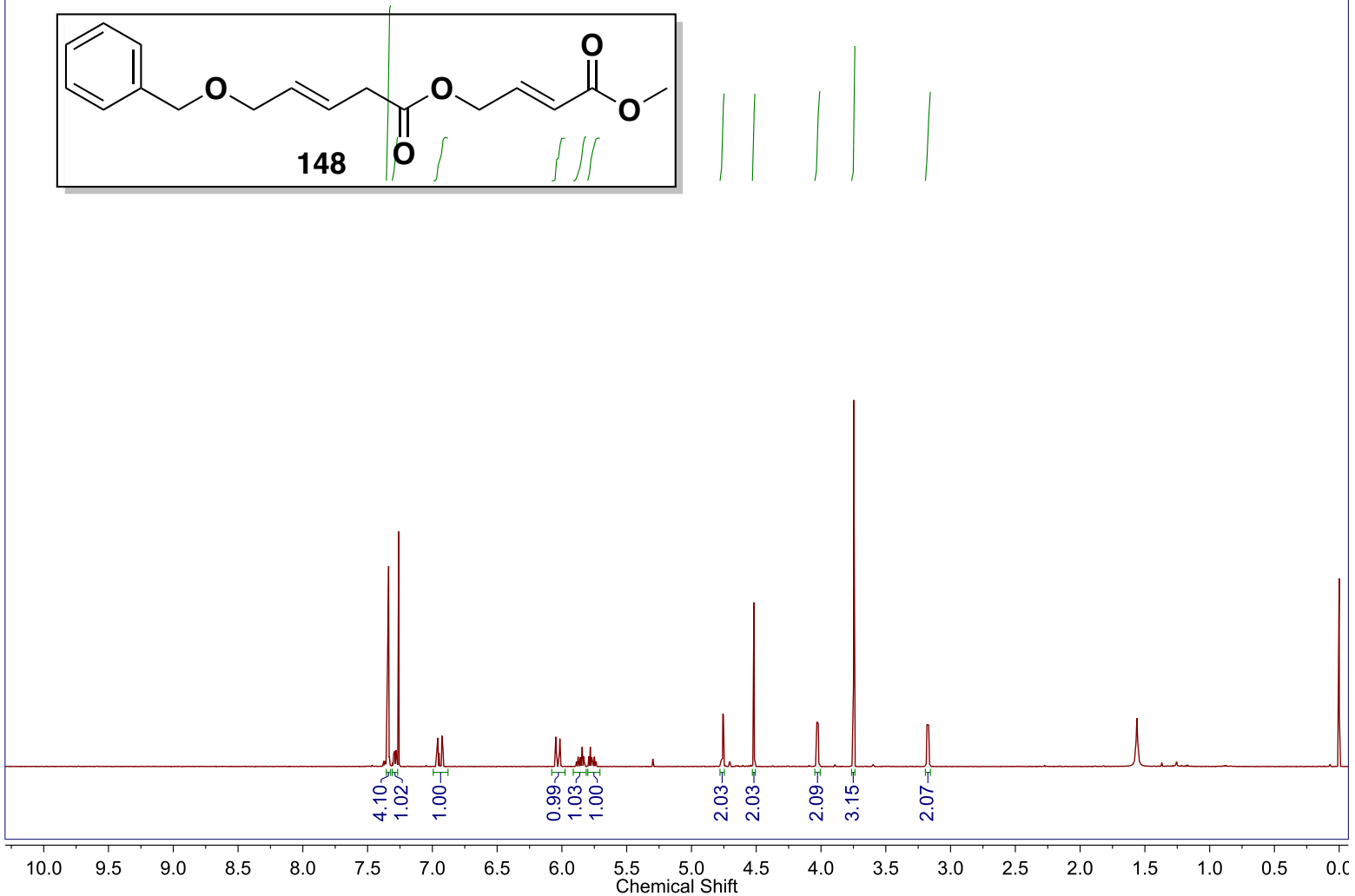

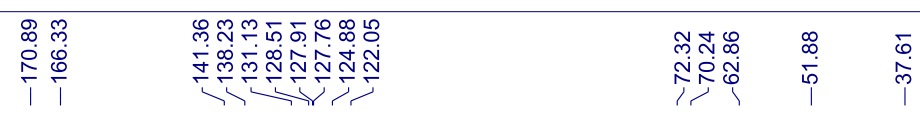
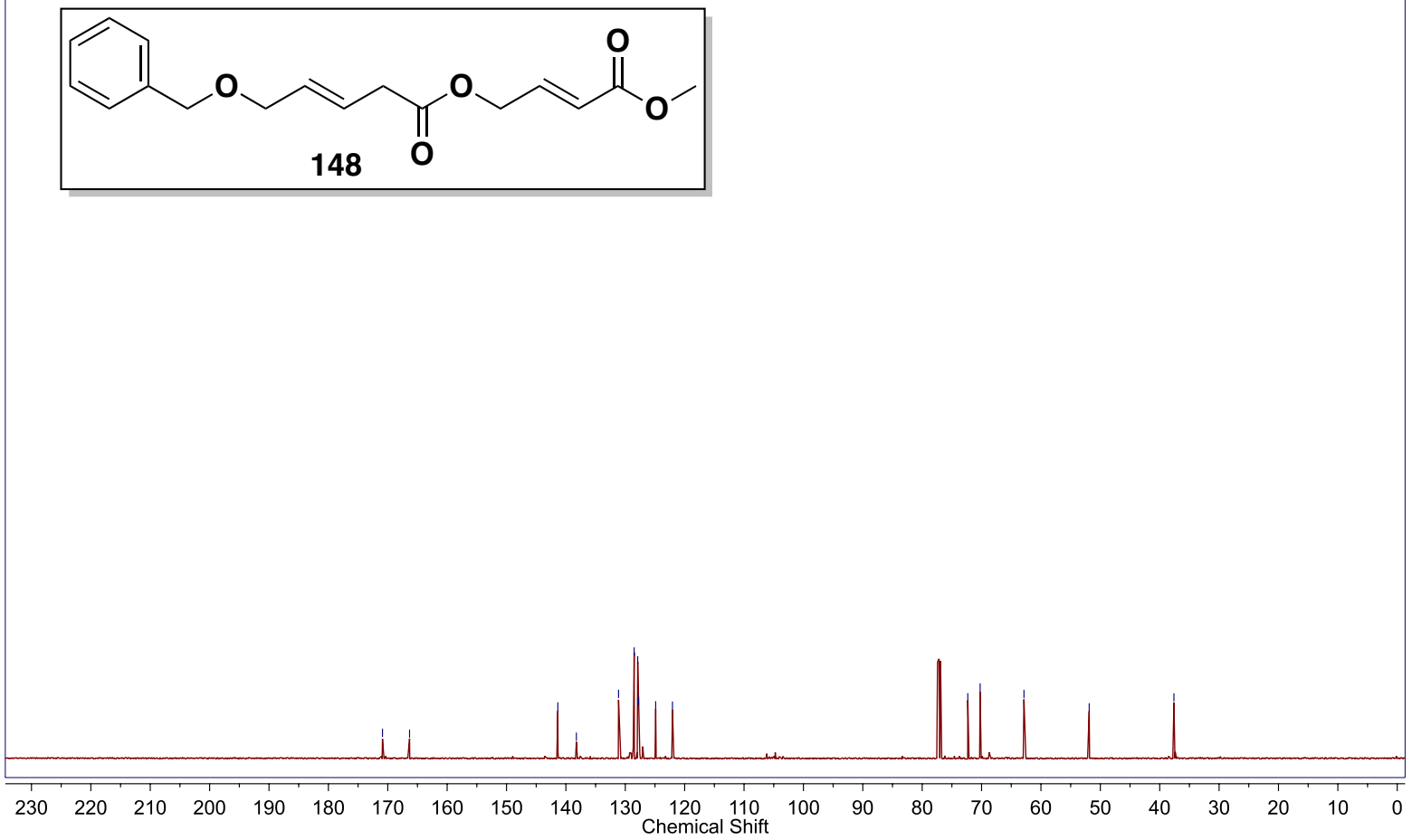


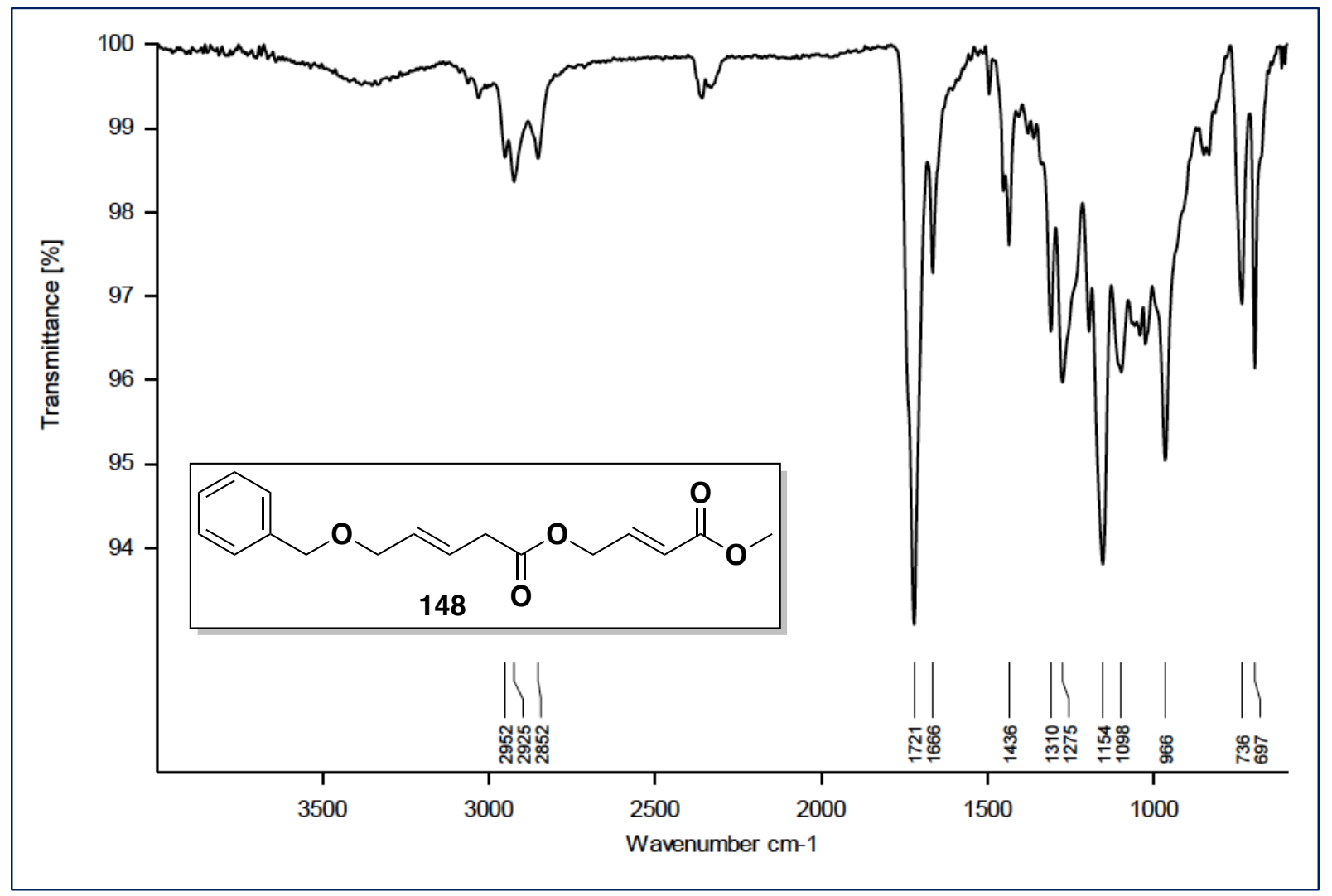



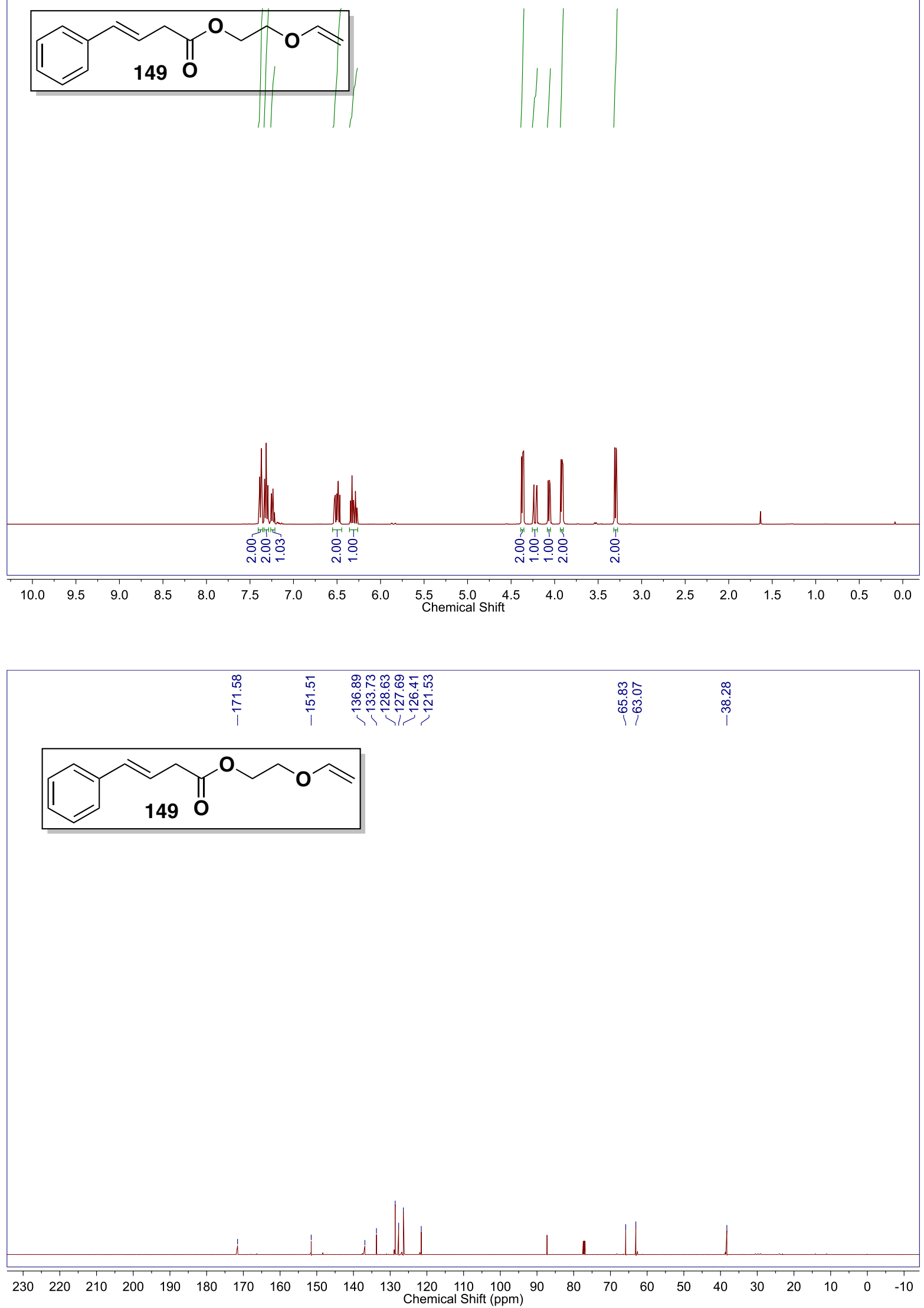

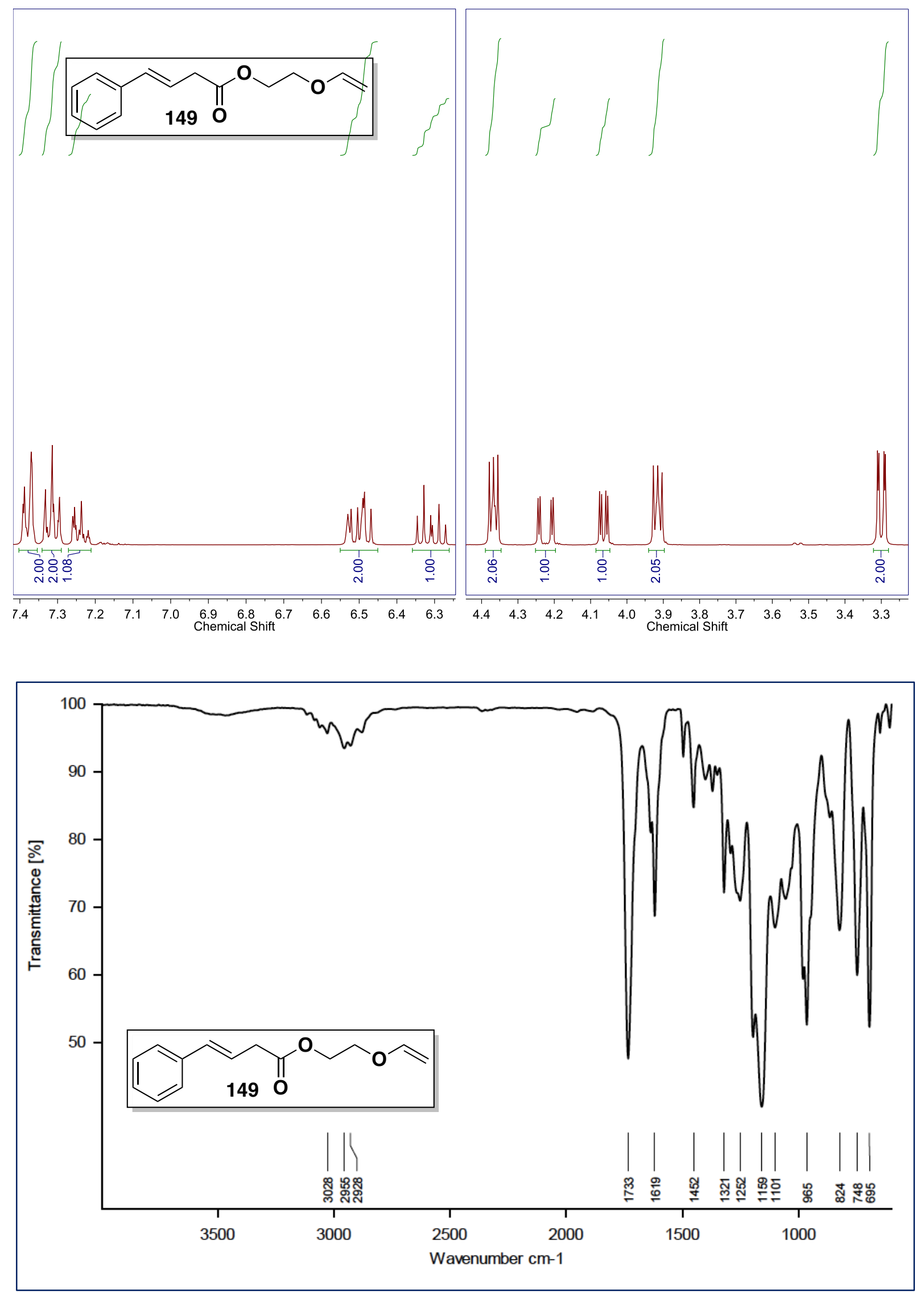

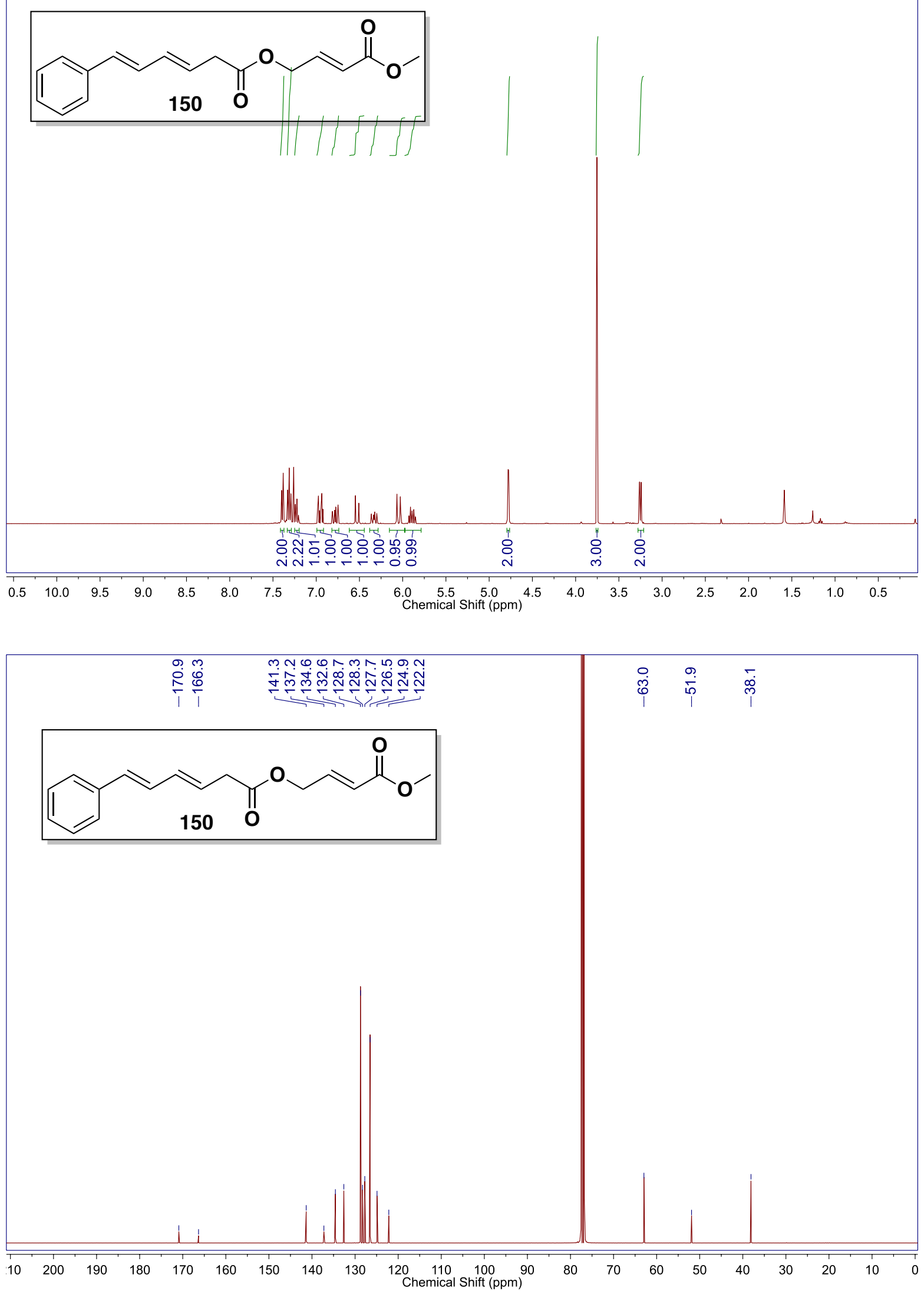

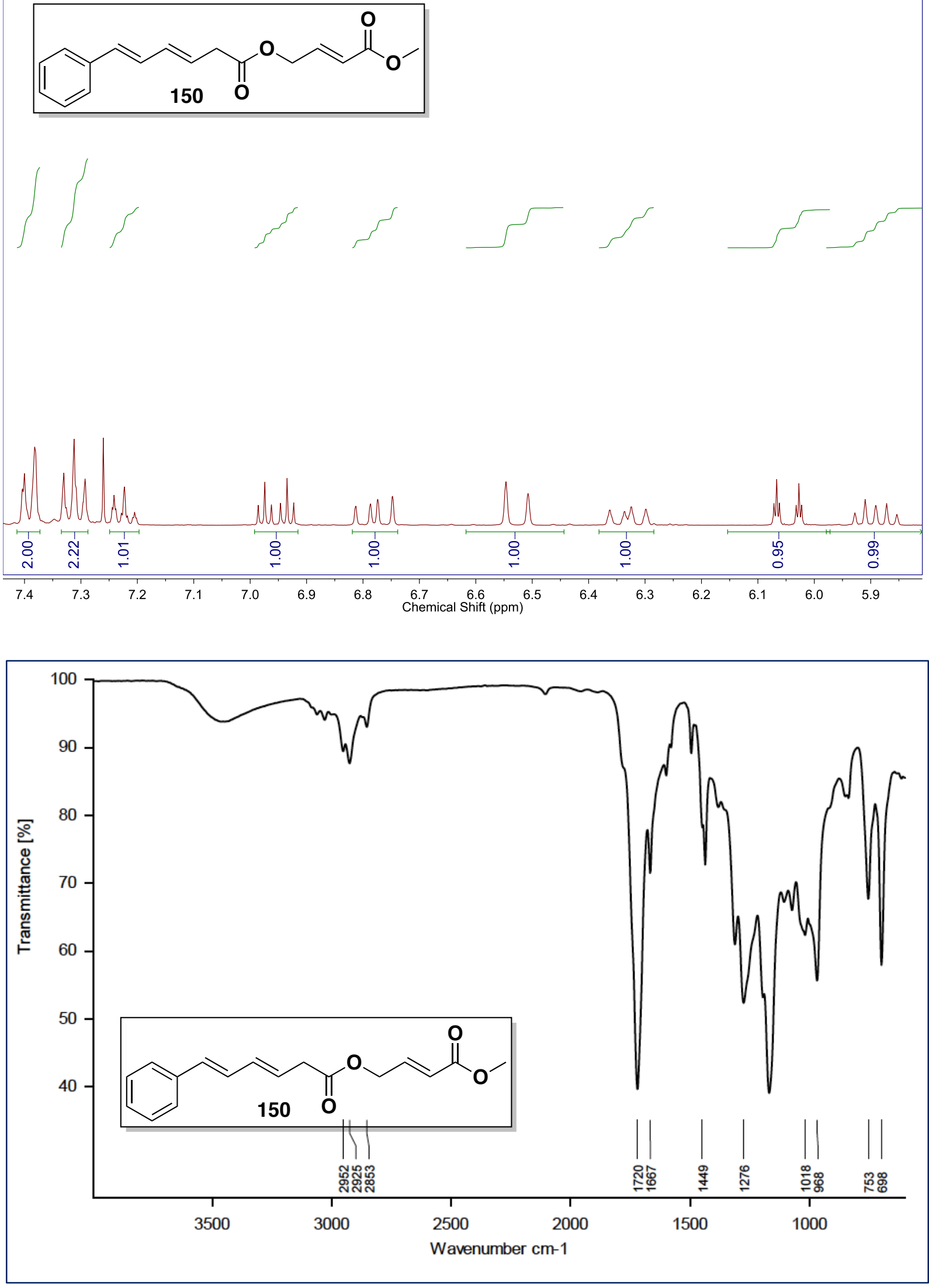

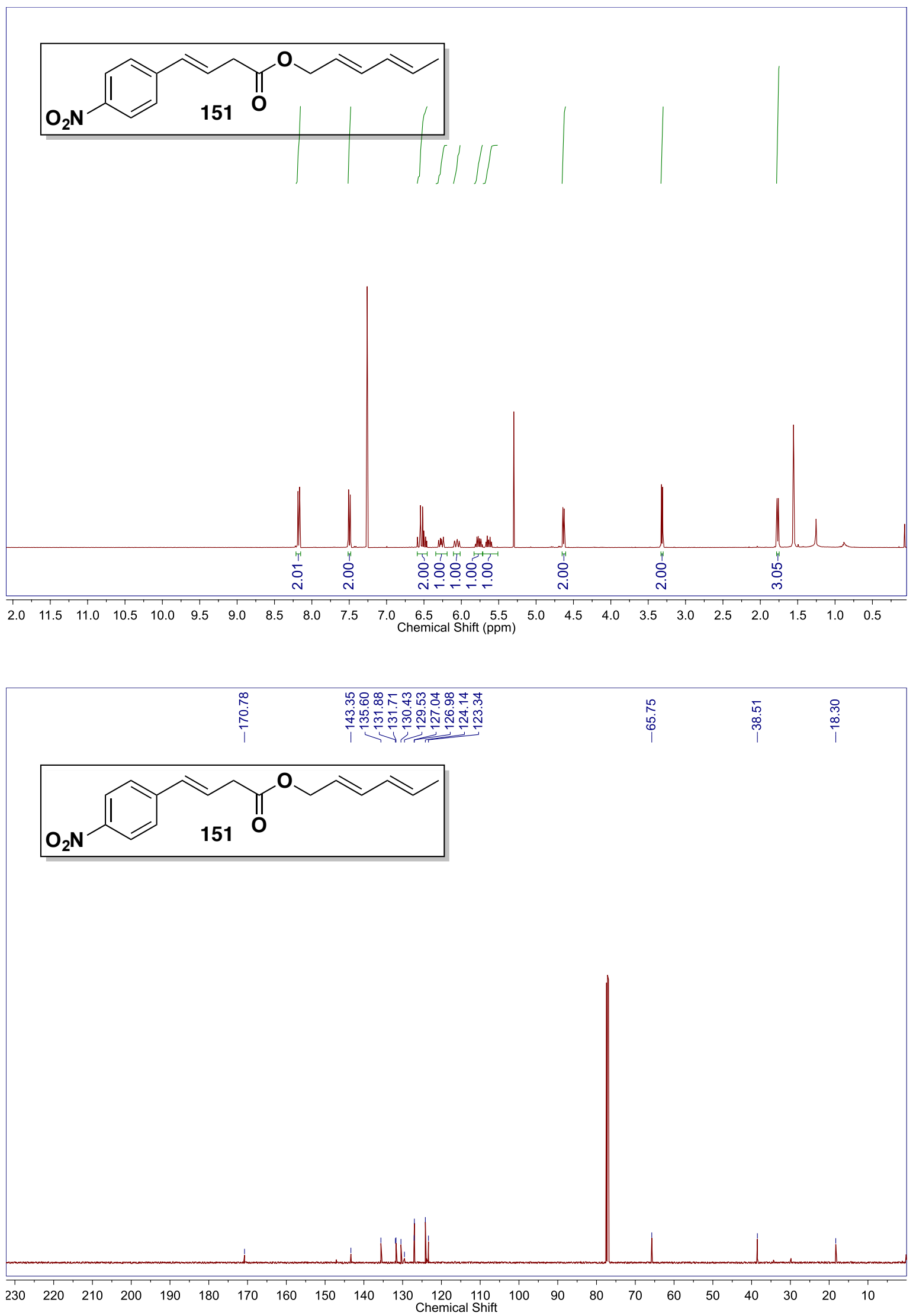

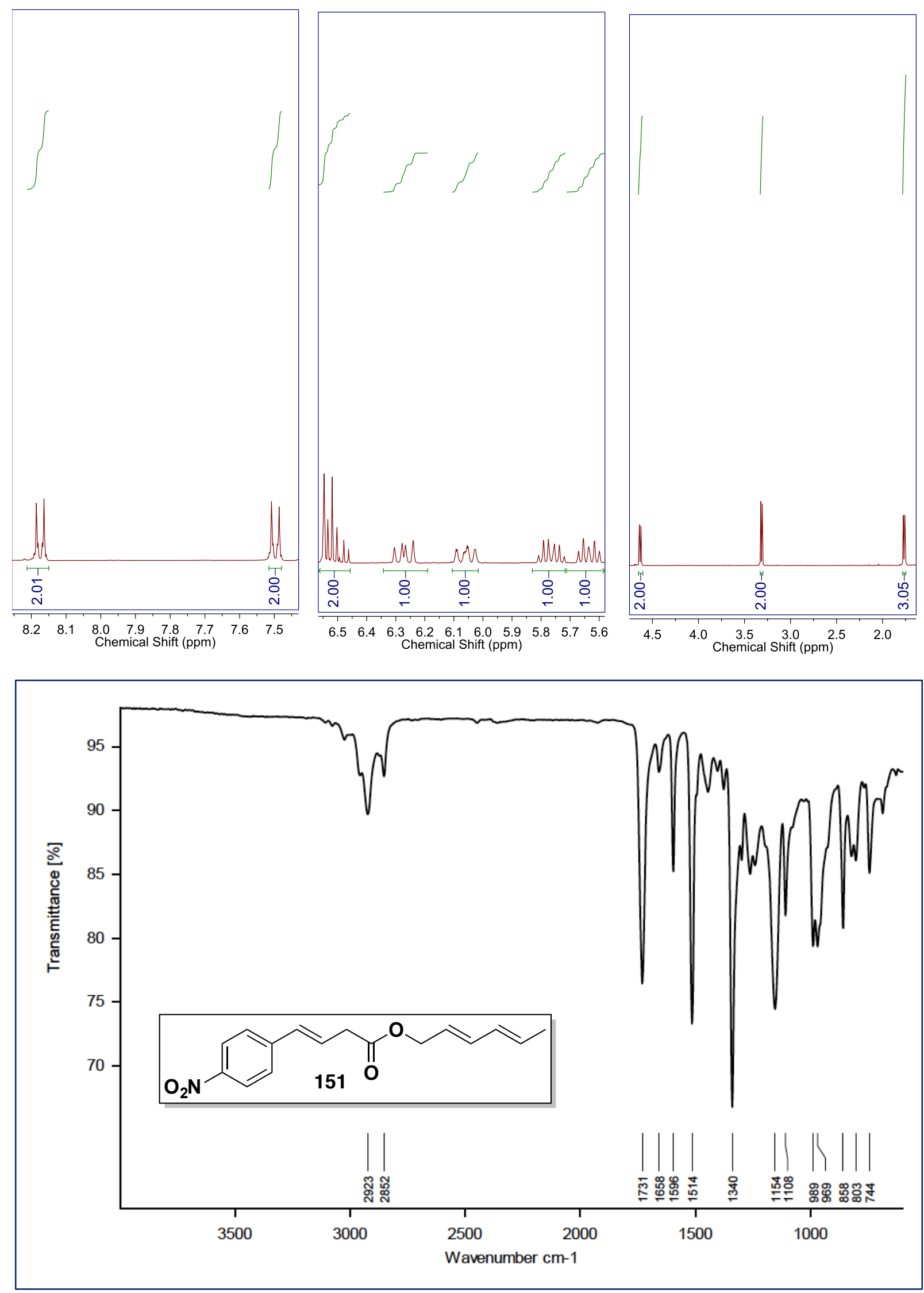

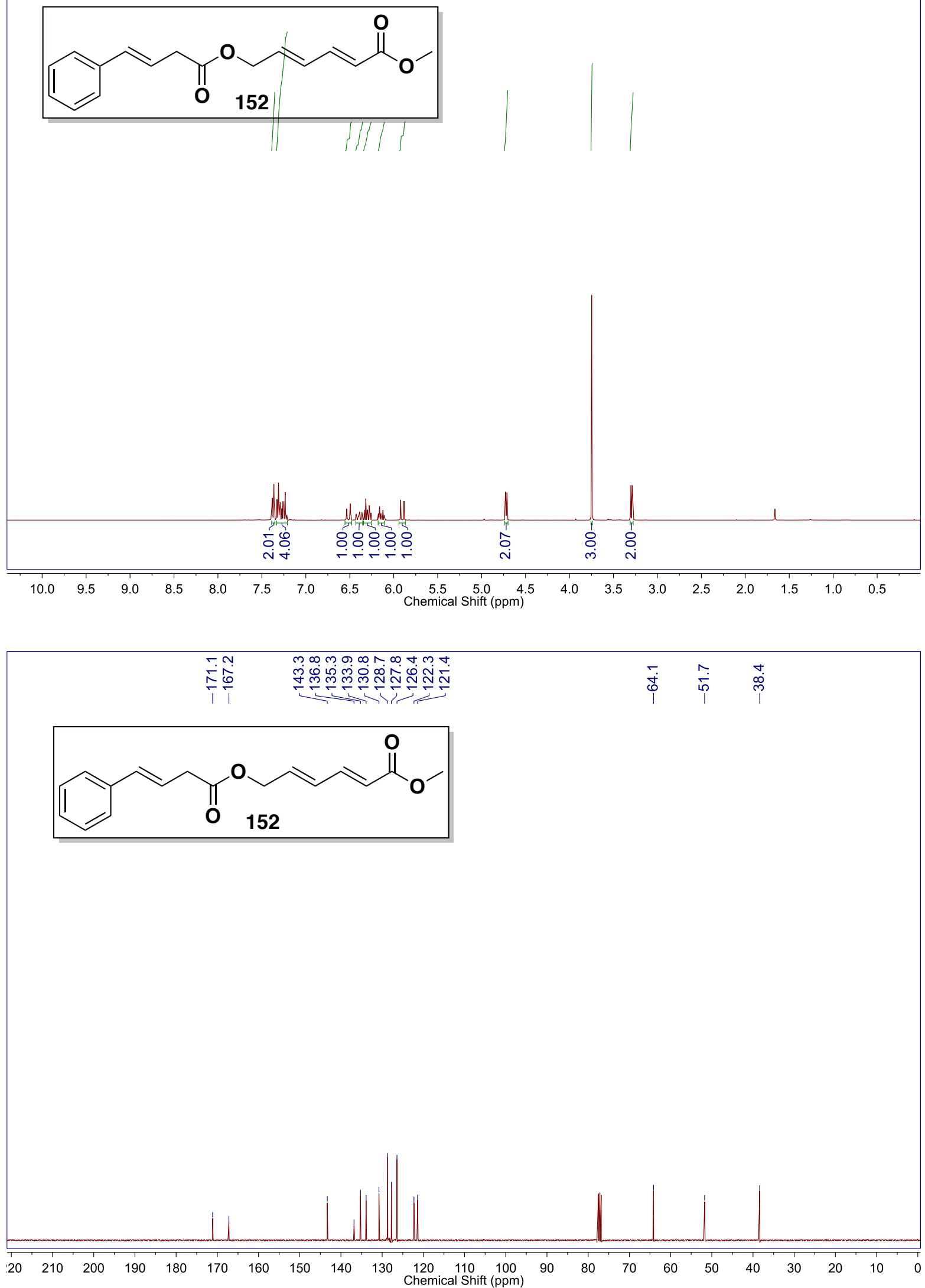

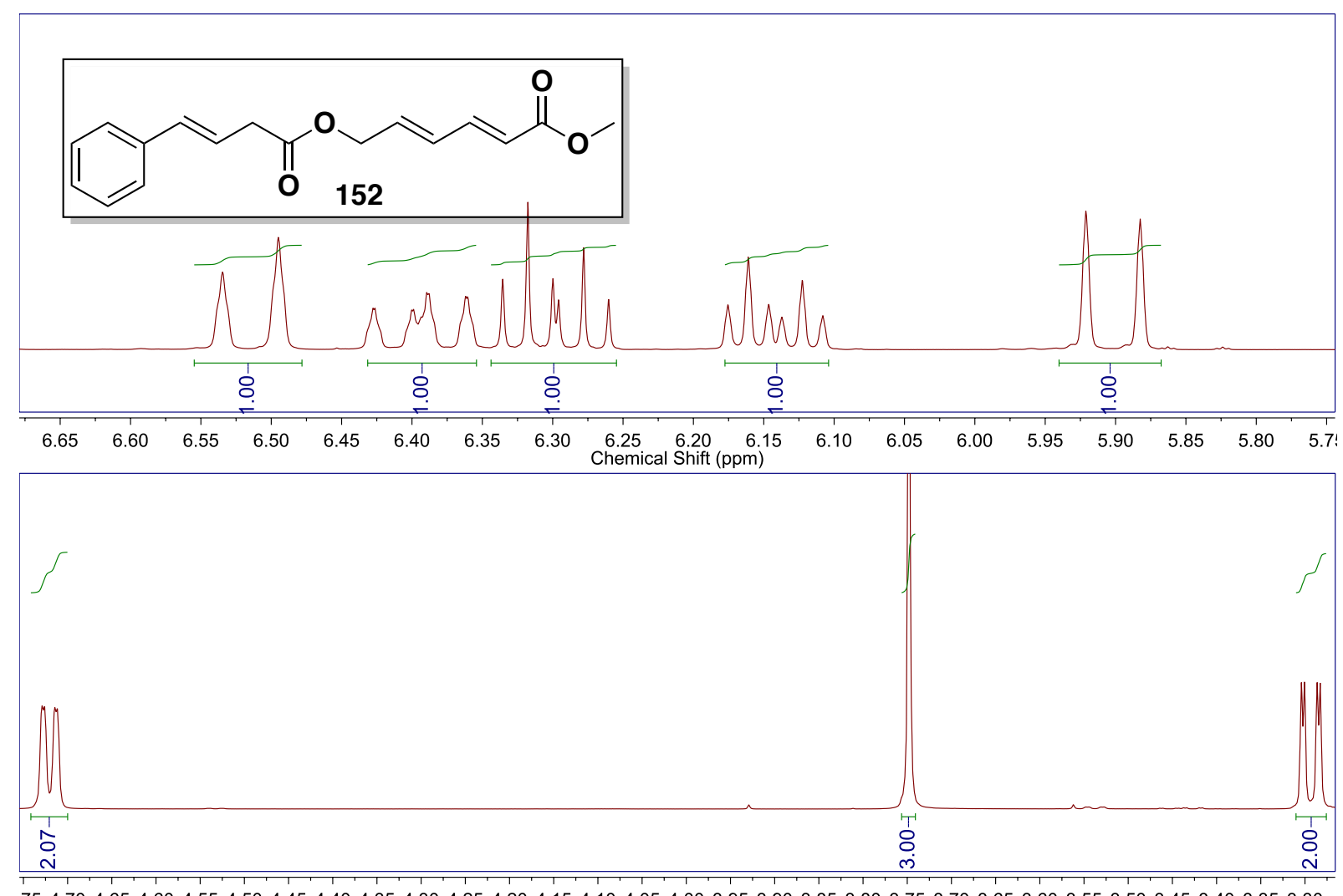

754.704 .654 .604 .554 .504 .454 .404 .354 .304 .254 .204 .154 .104 .054 .003 .953 .903 .853 .803 .753 .703 .653 .603 .553 .503 .453 .403 .353 .30 Chemical Shift (ppm)

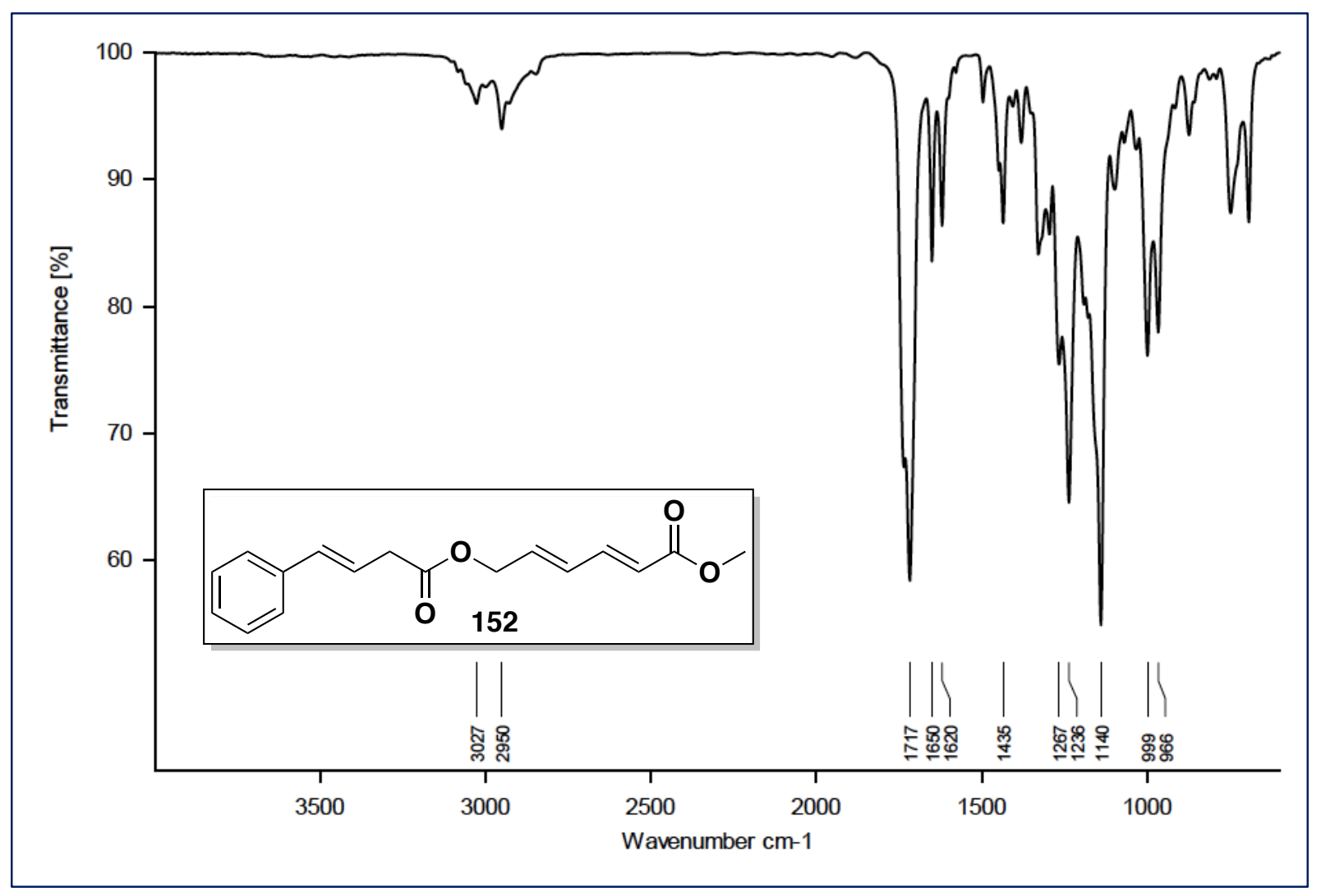



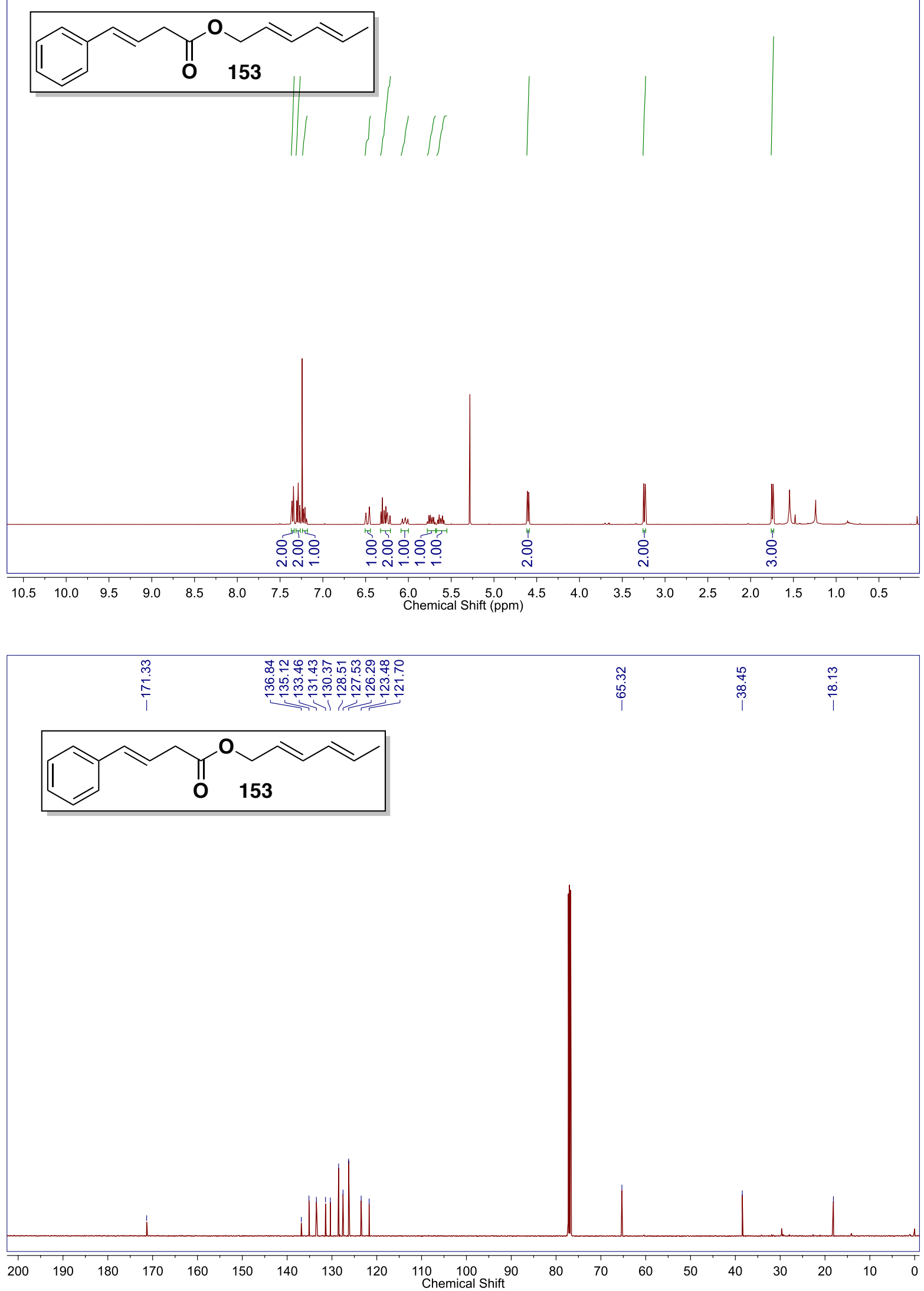

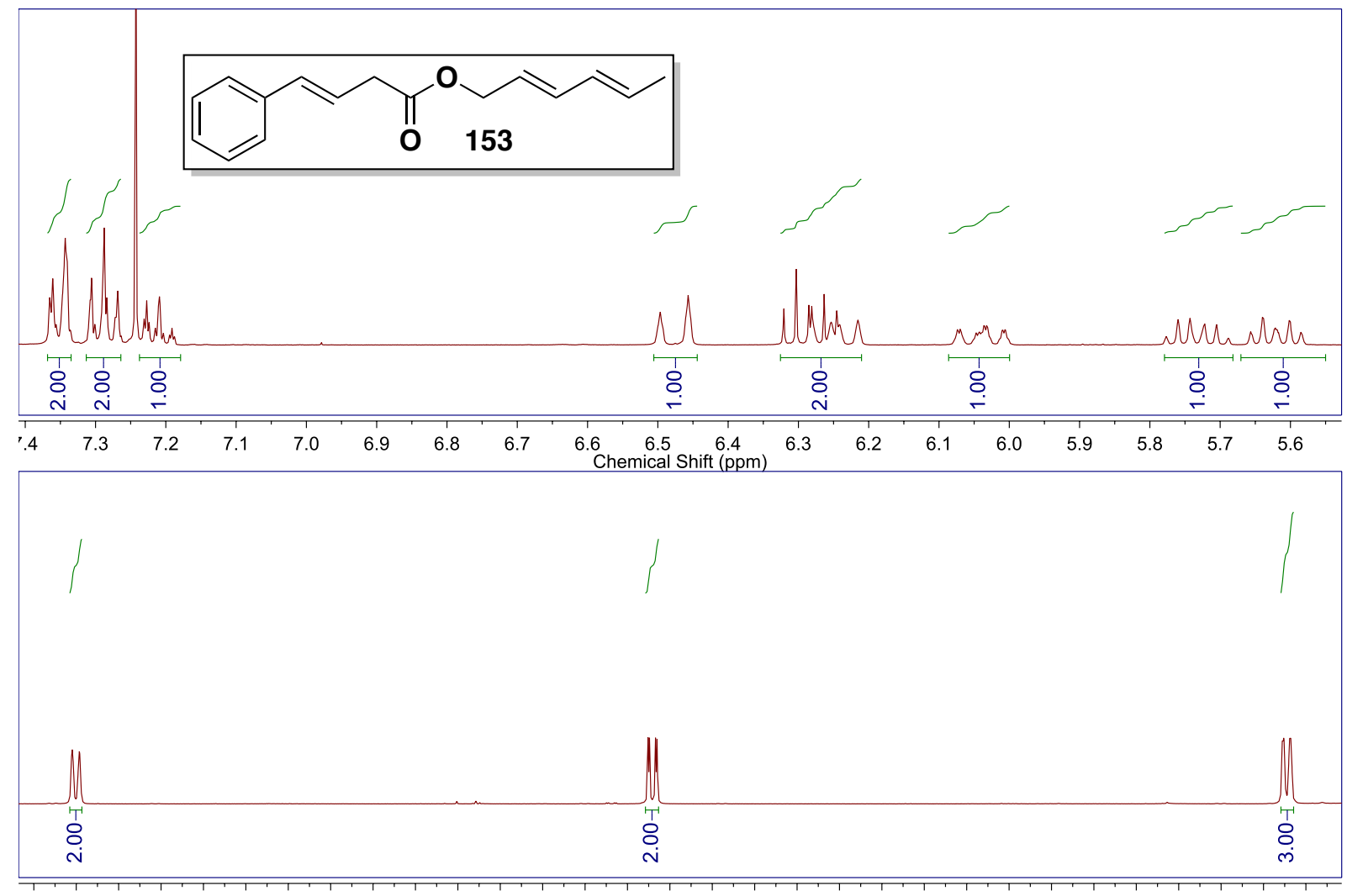

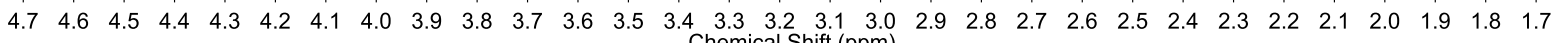
Chemical Shift (ppm)

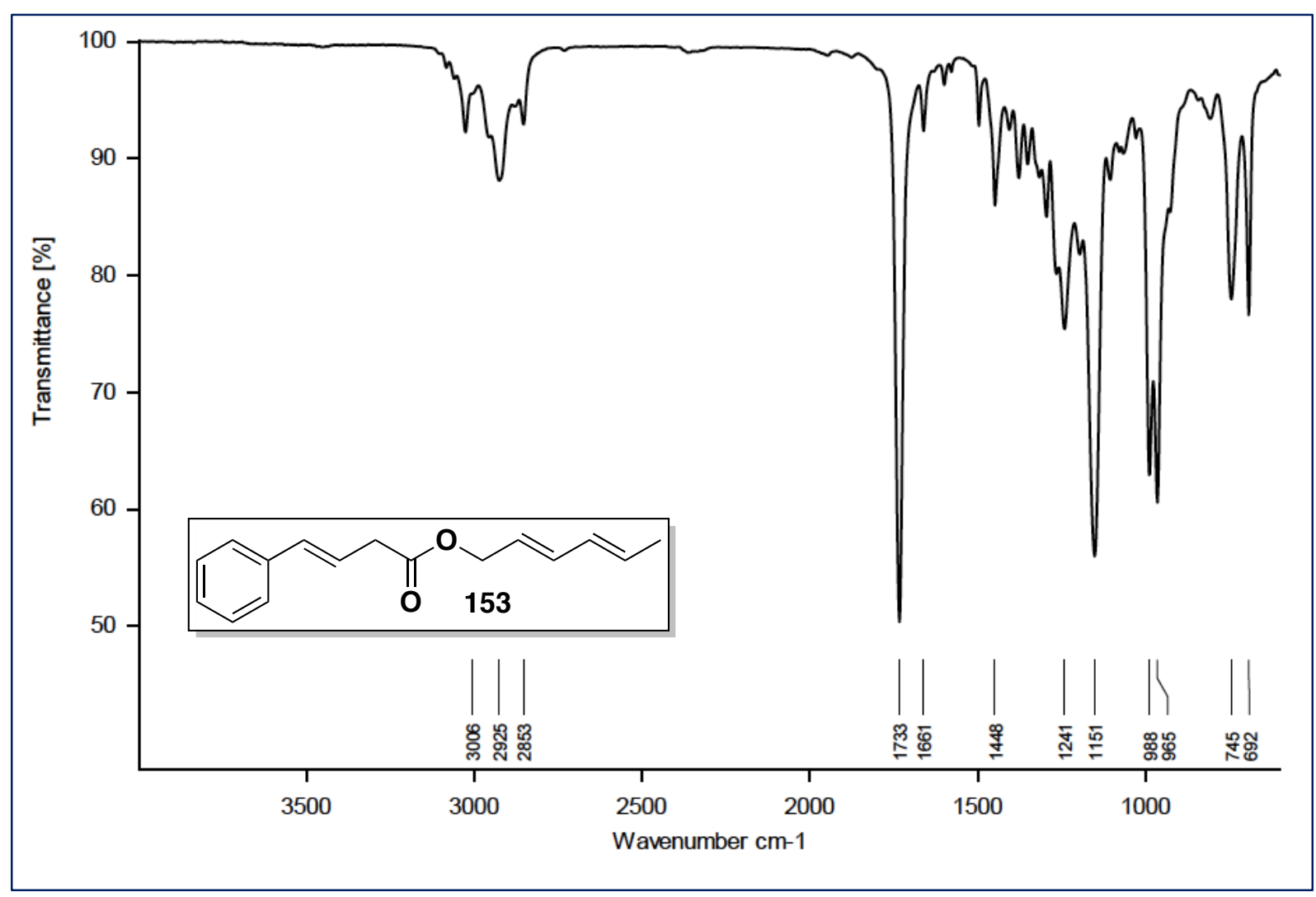



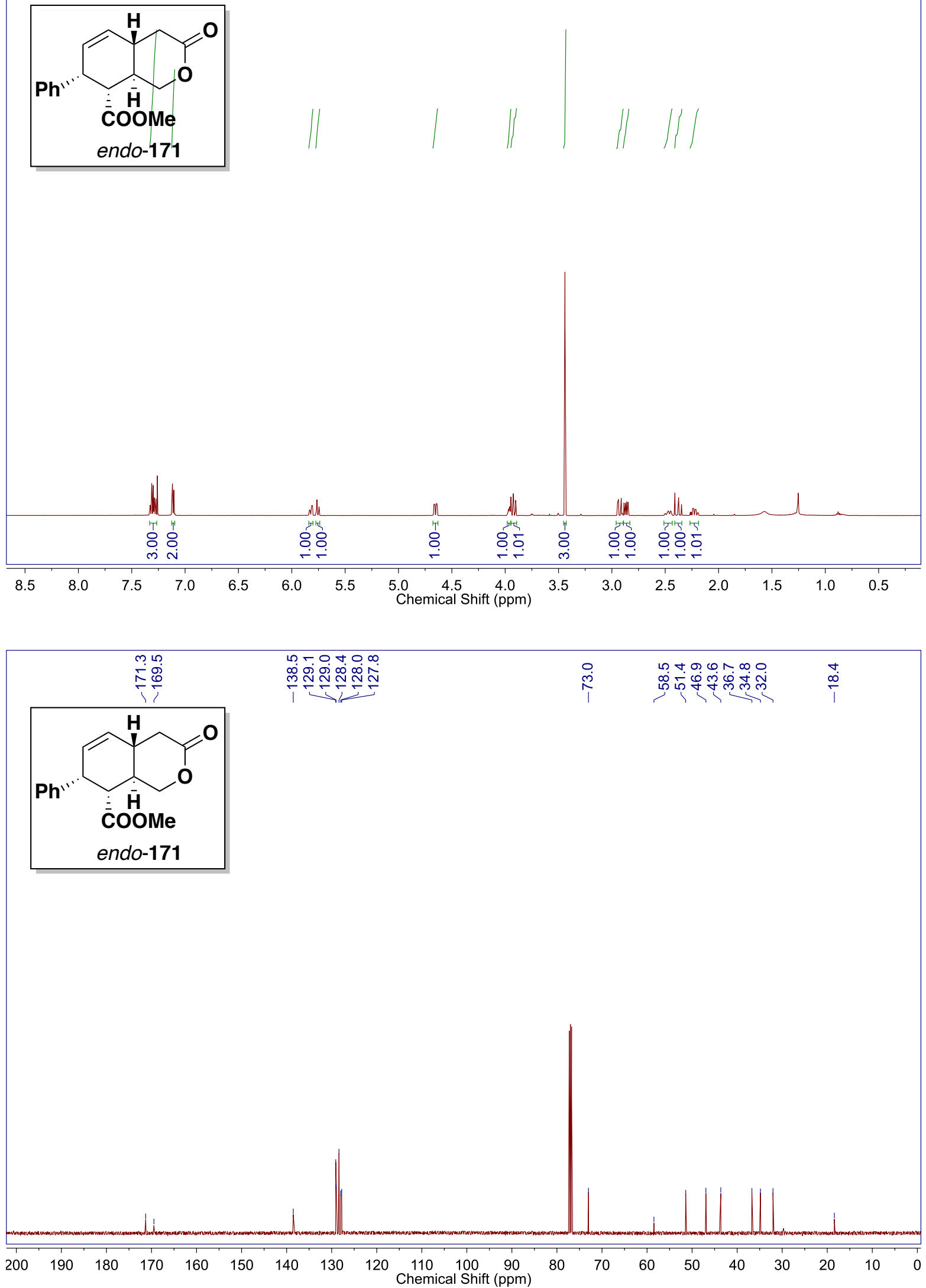

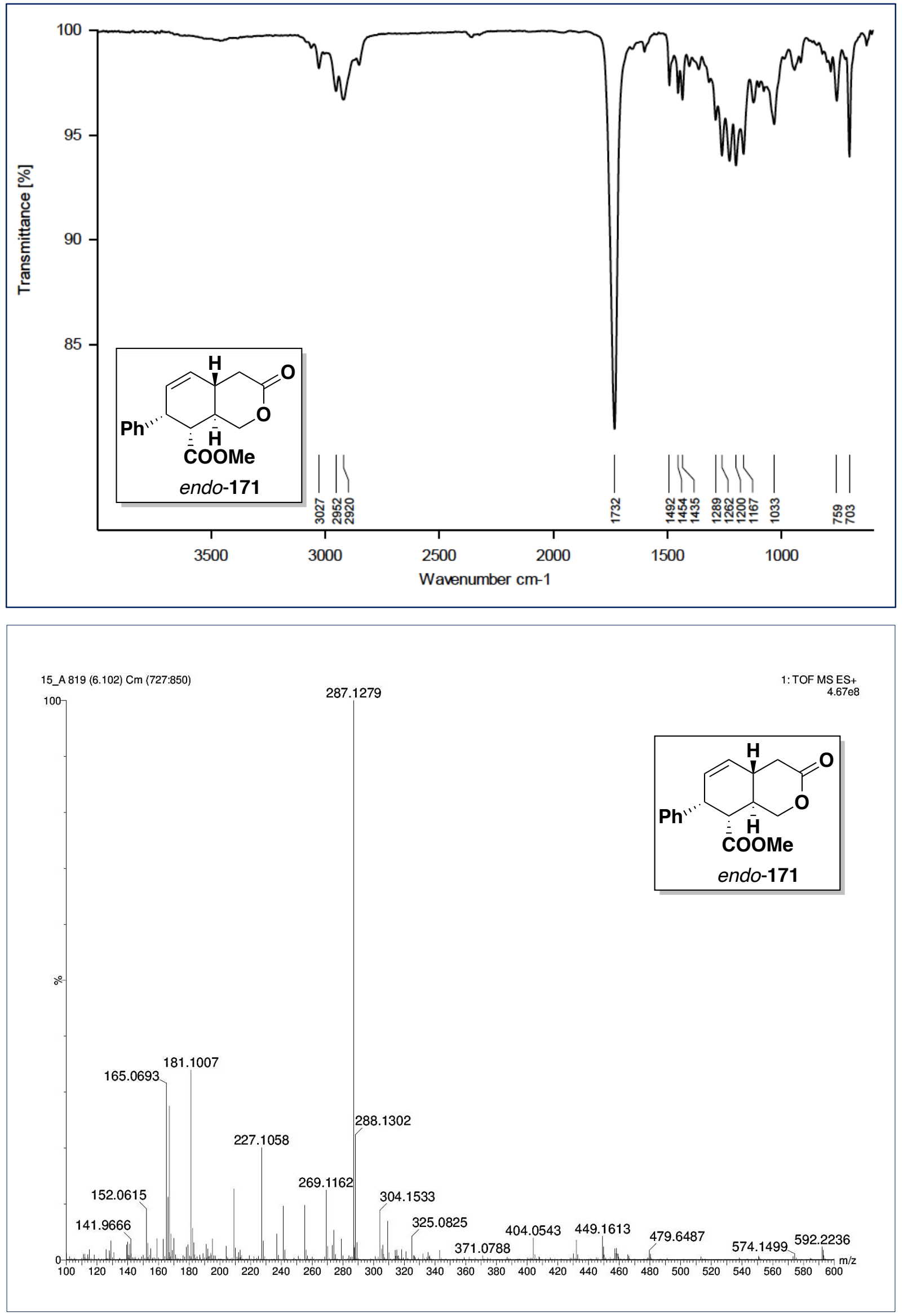


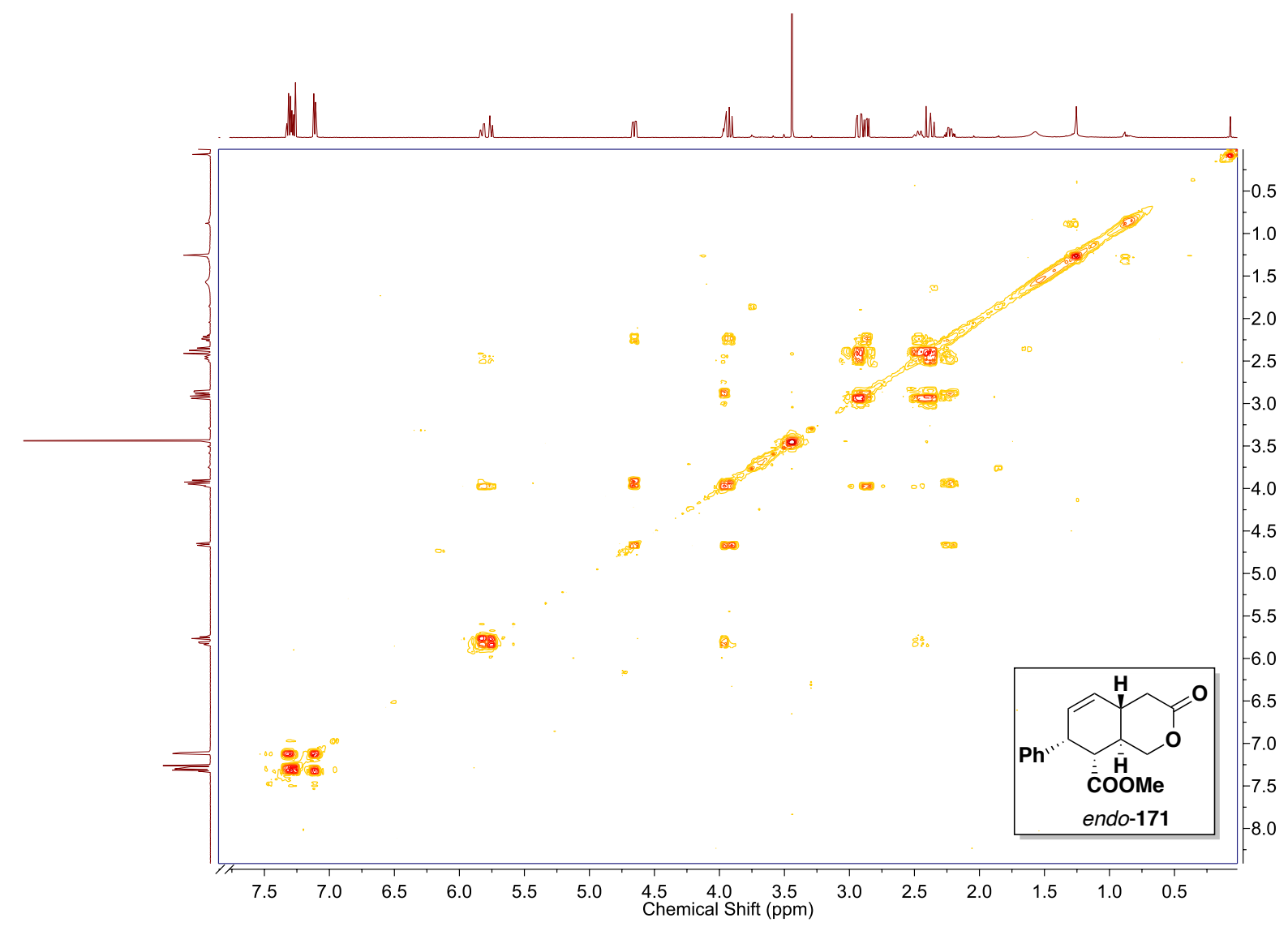



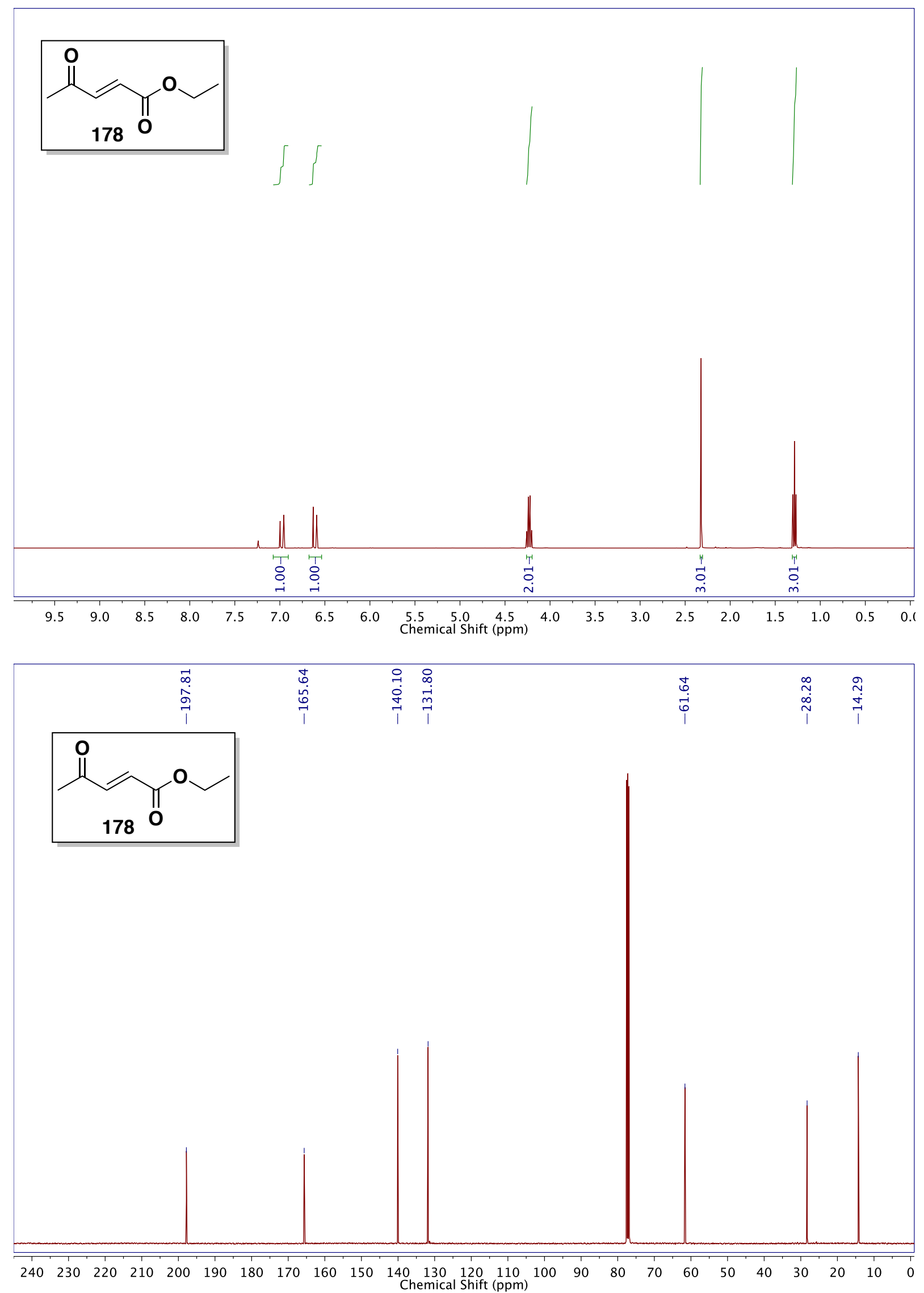


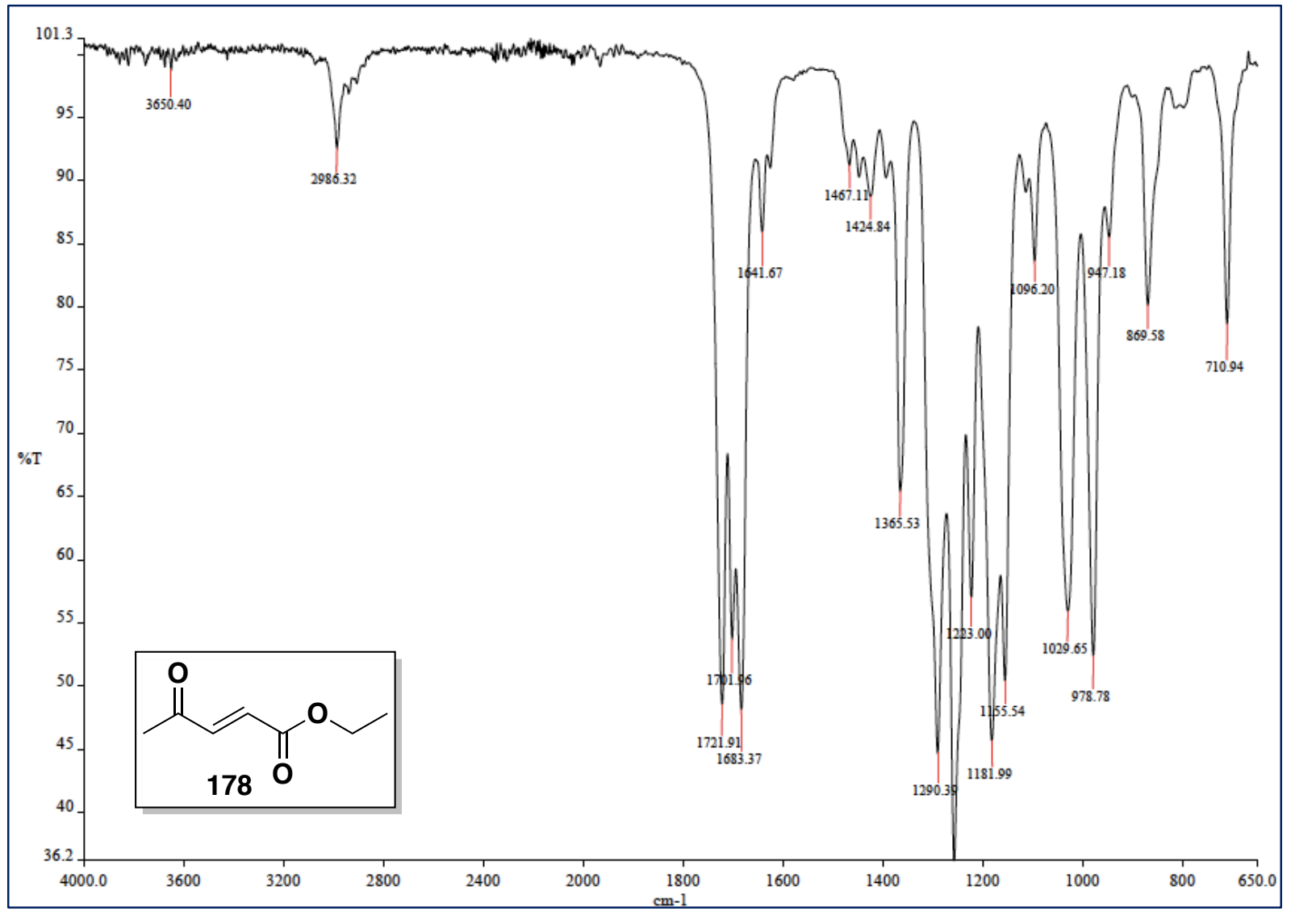



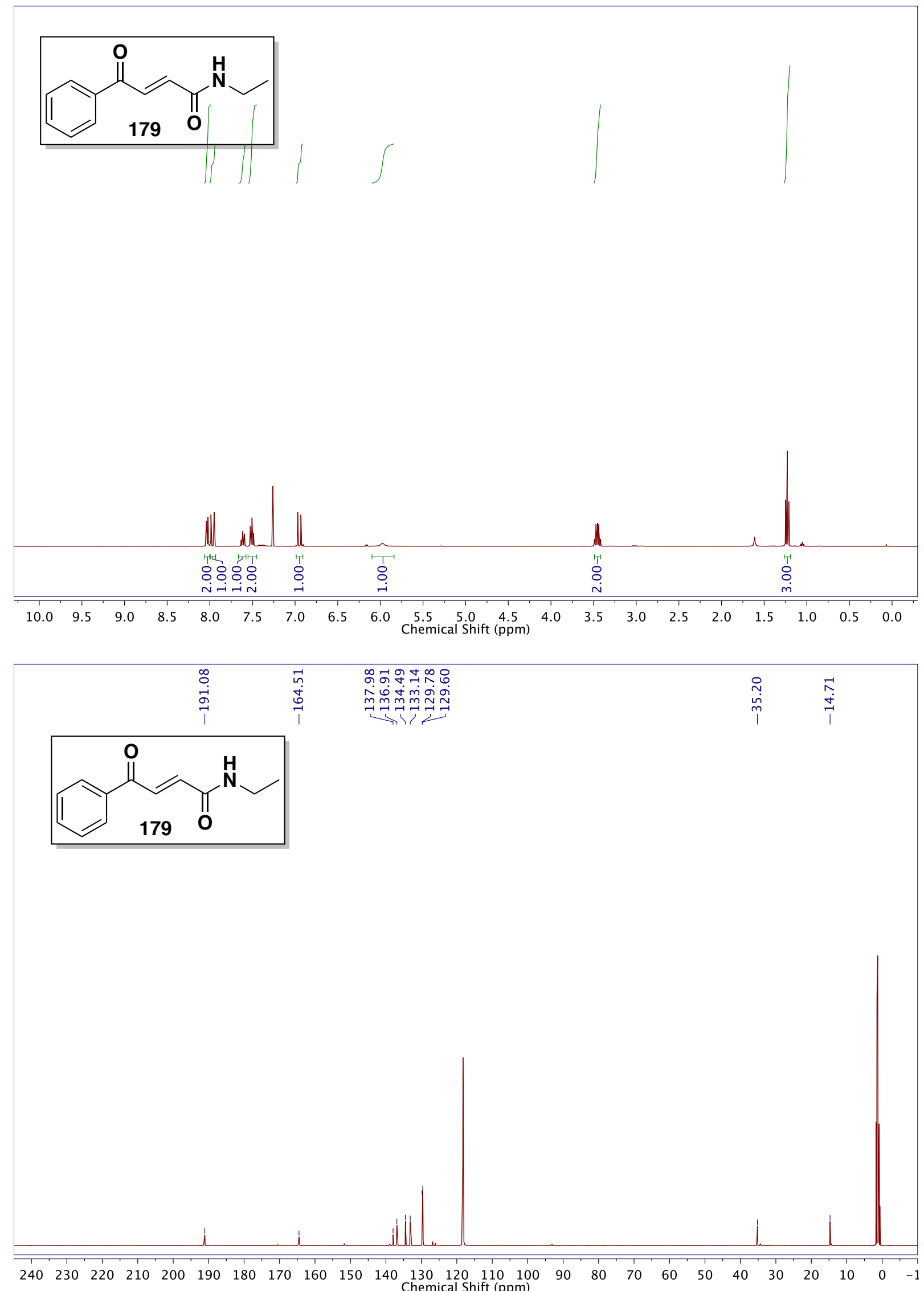


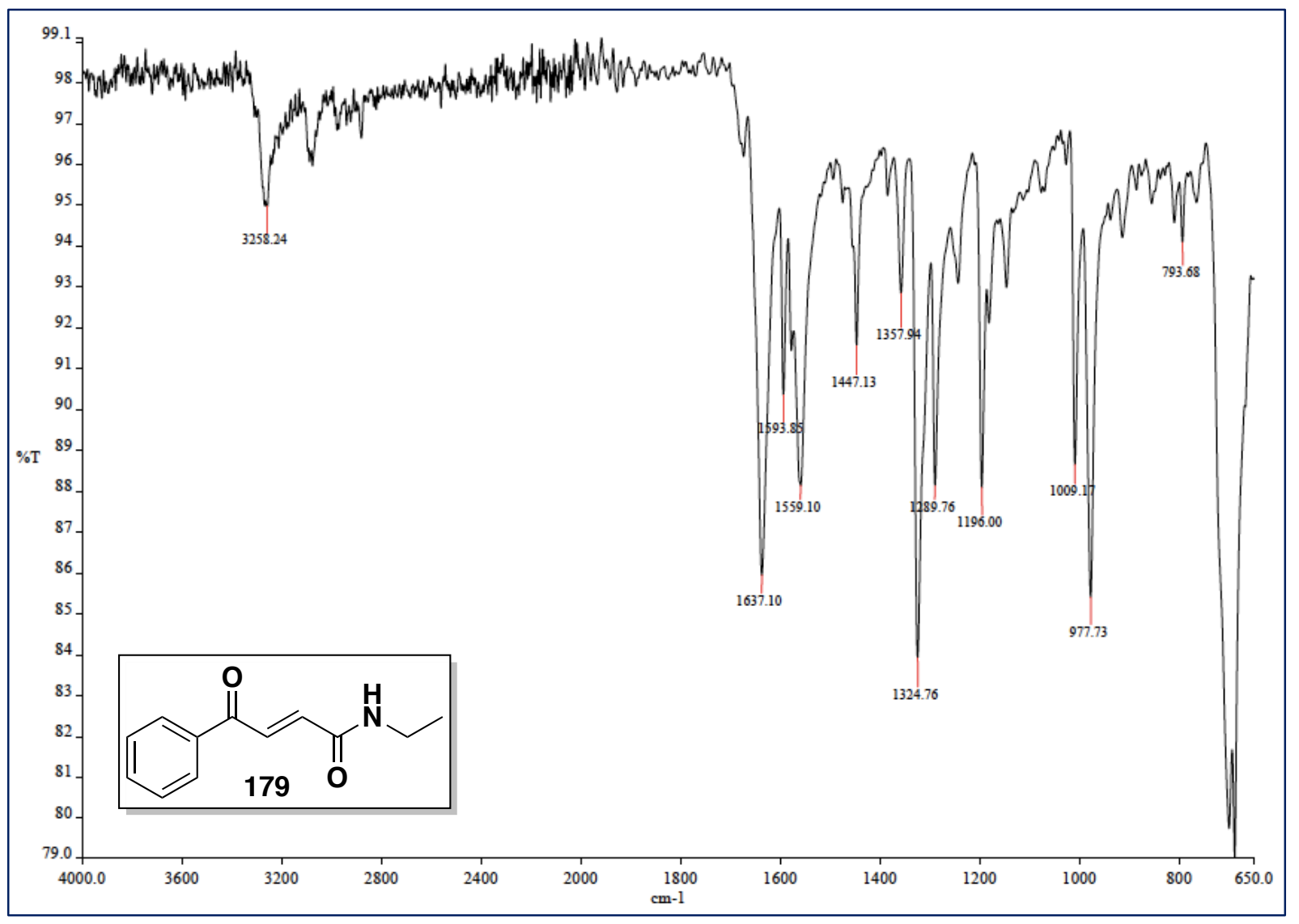



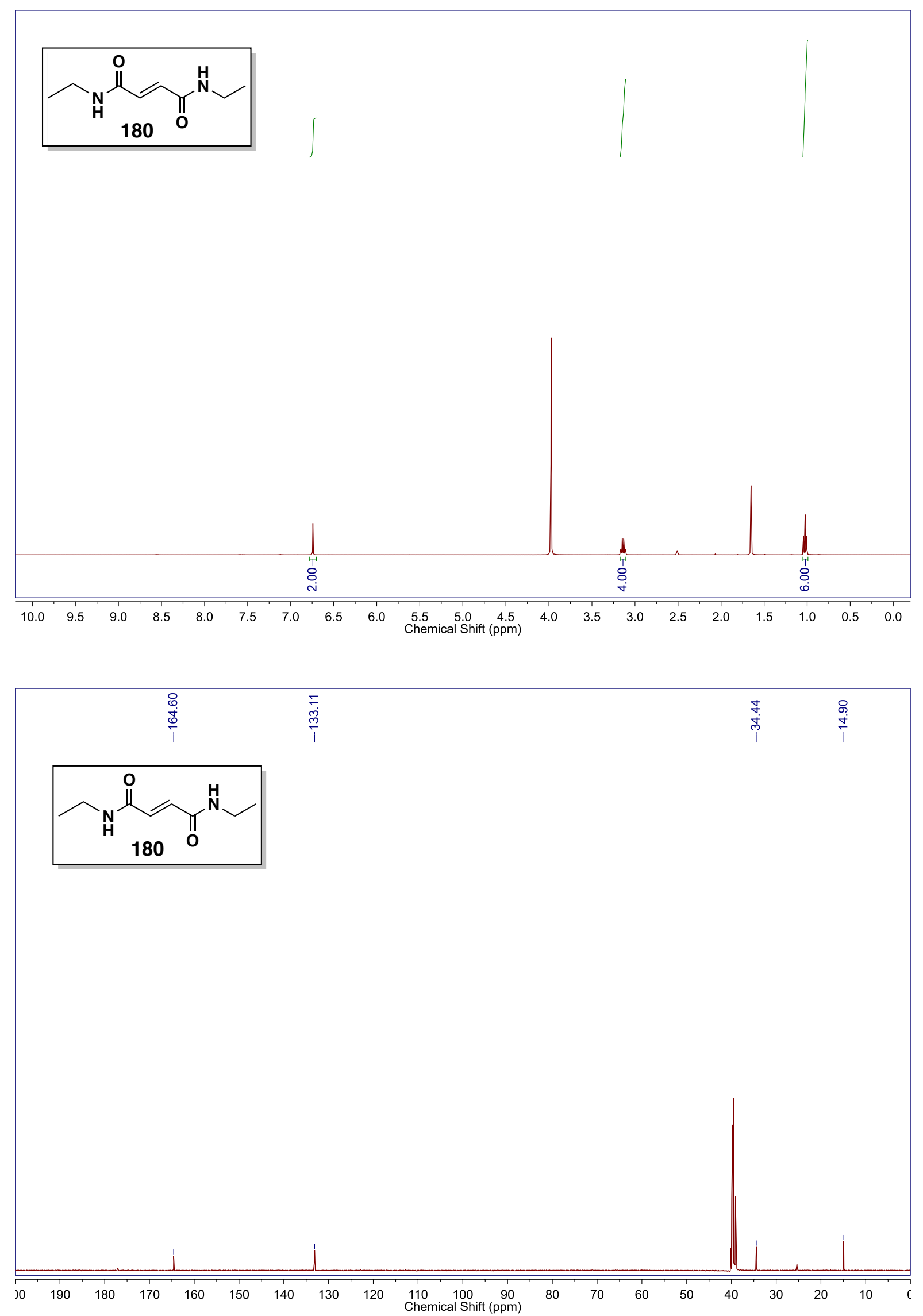


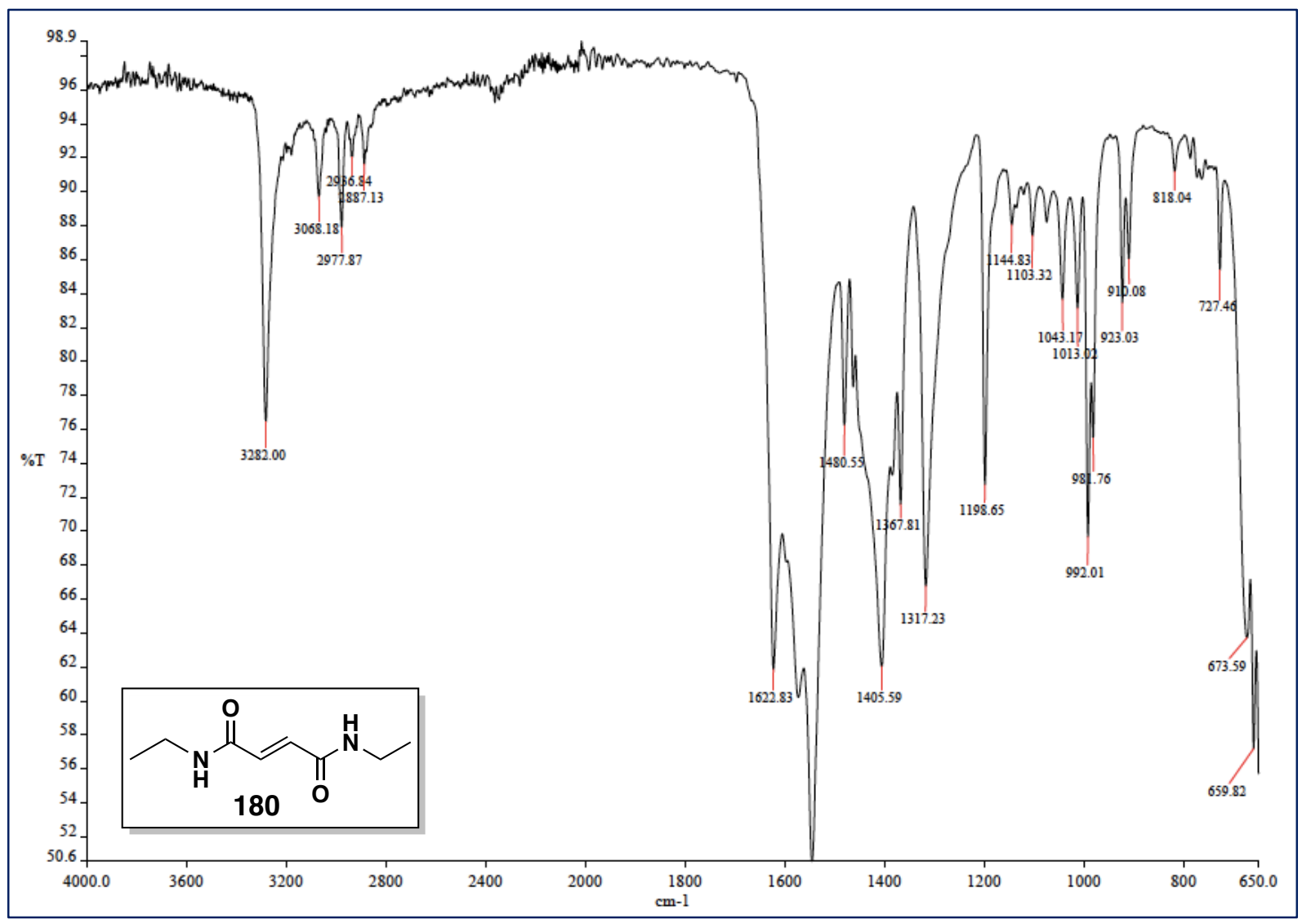



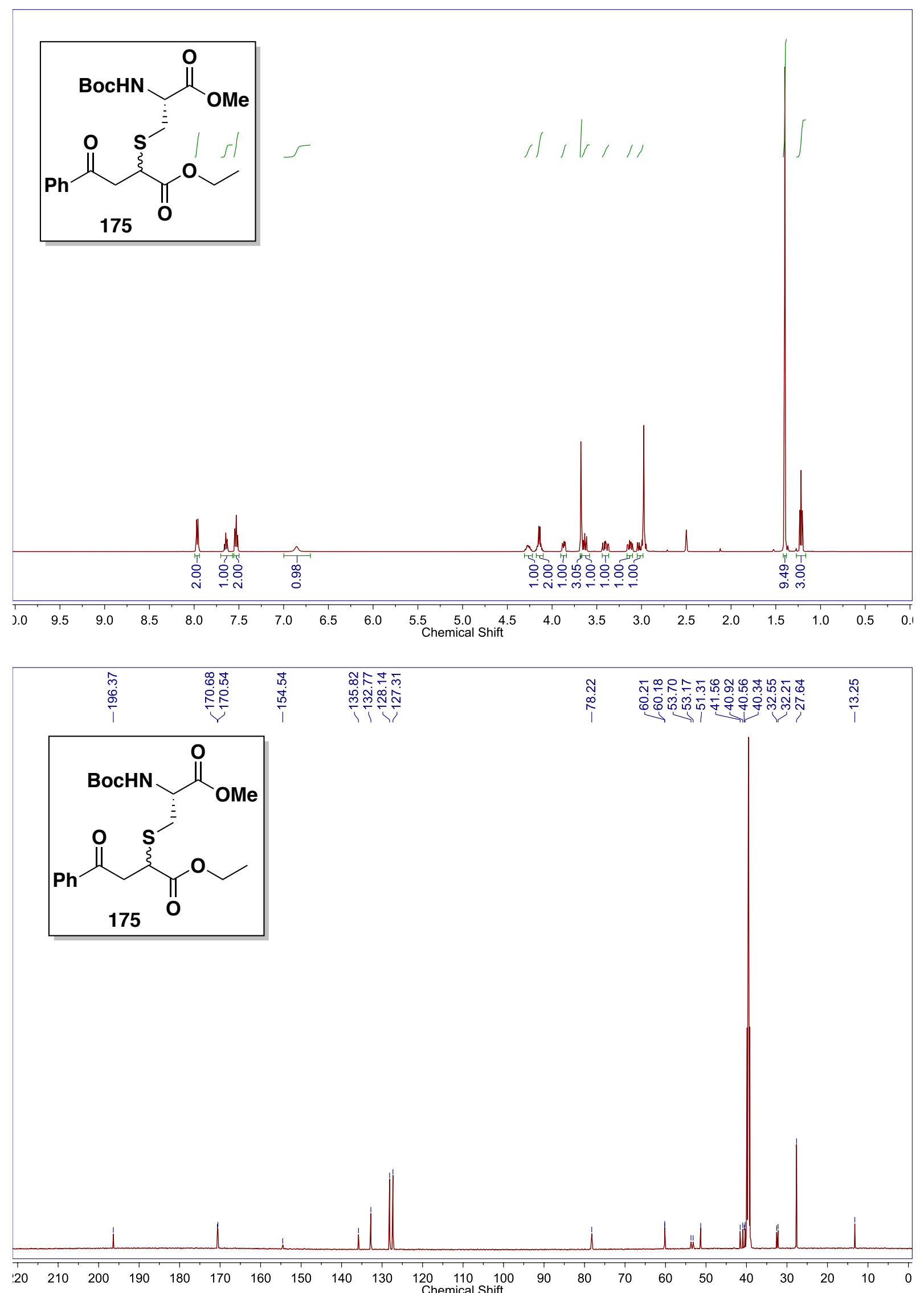


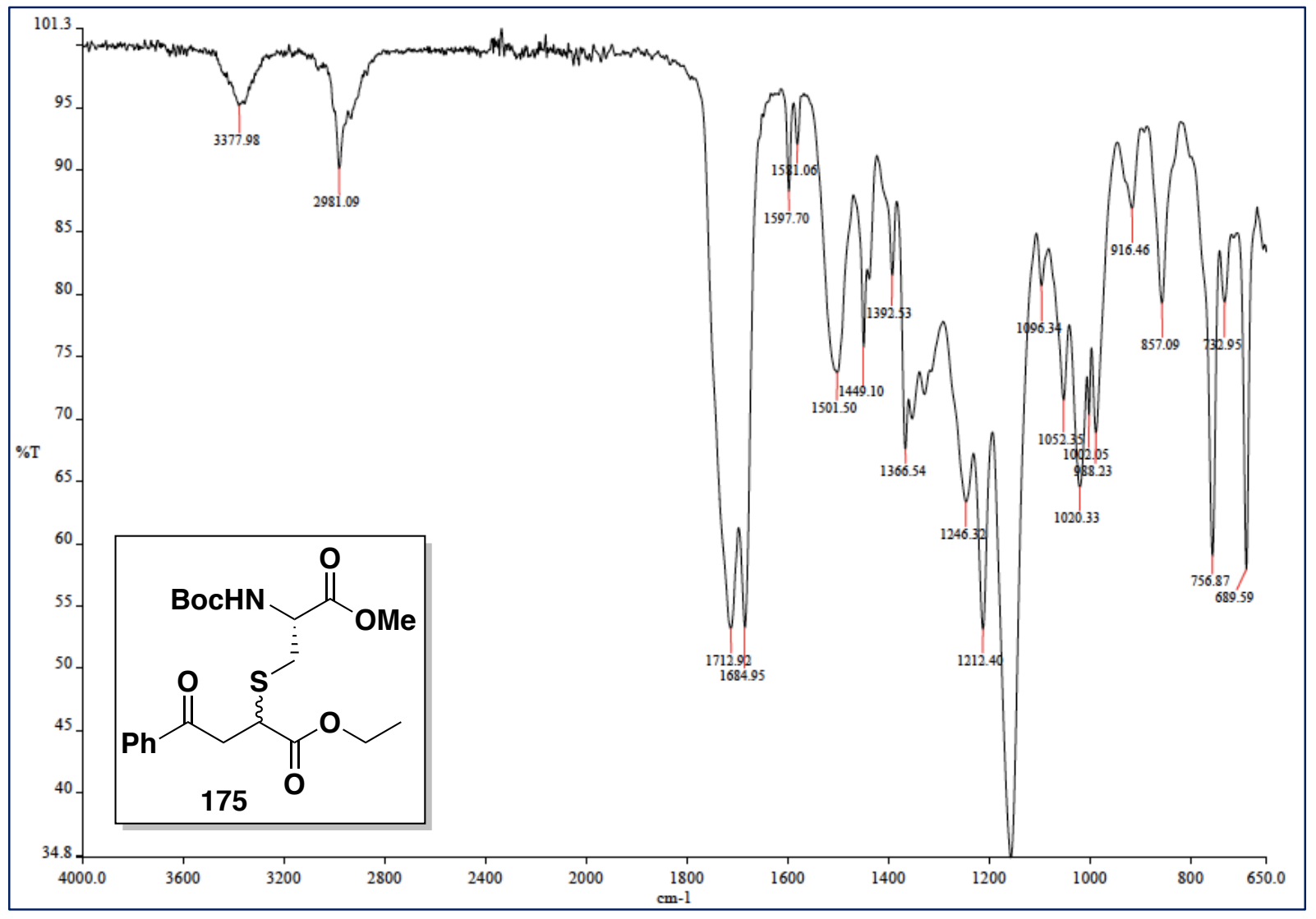



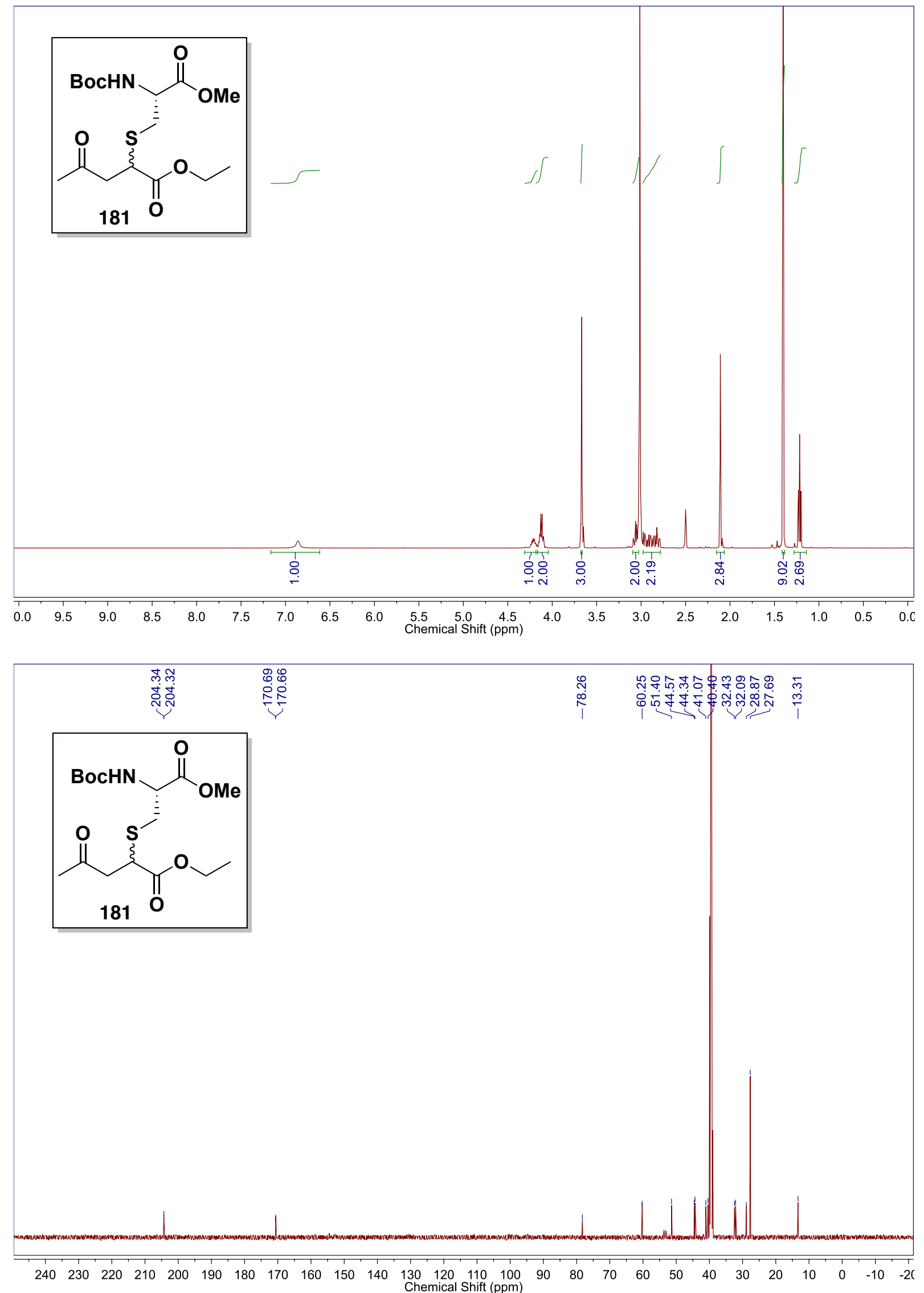


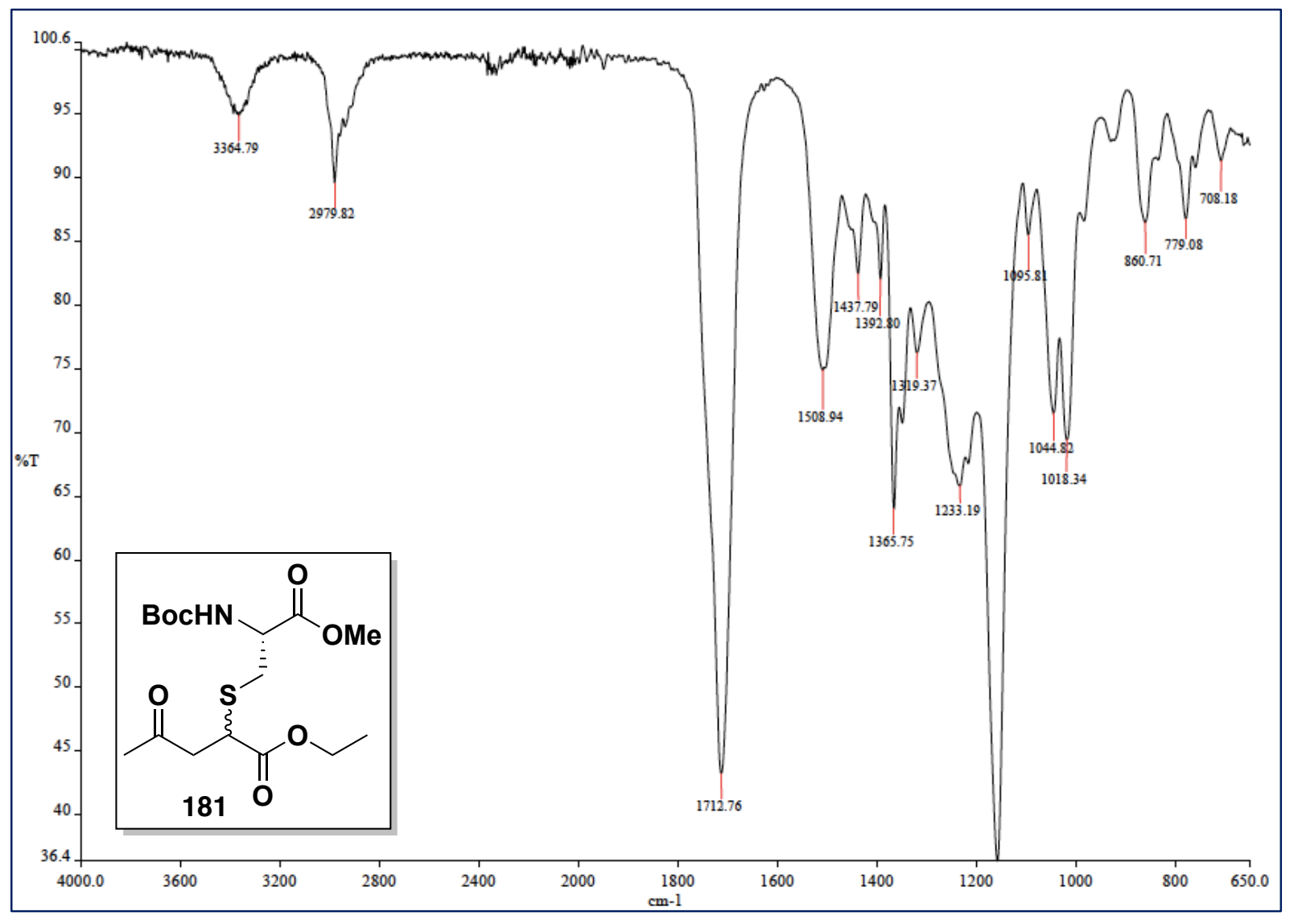



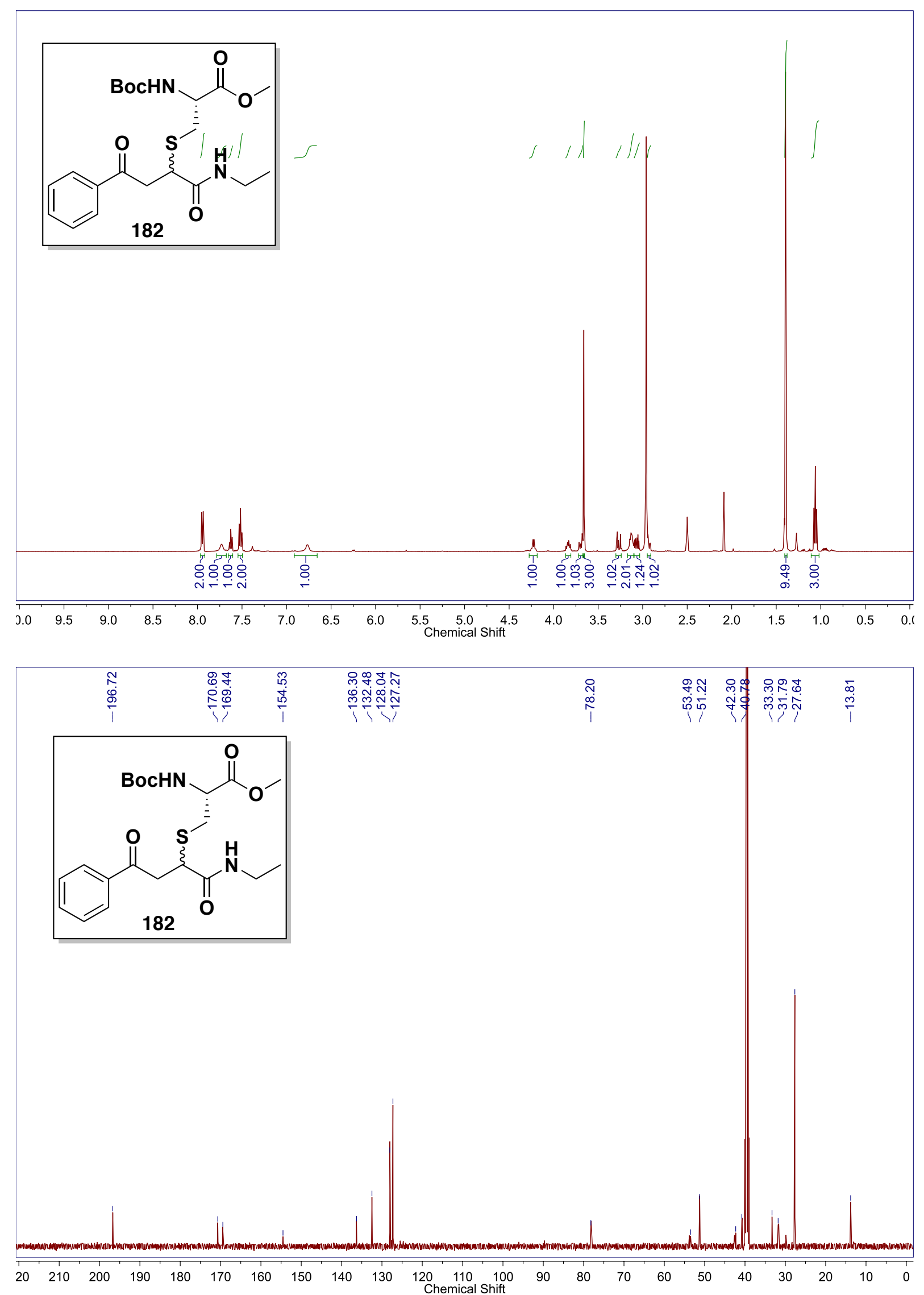


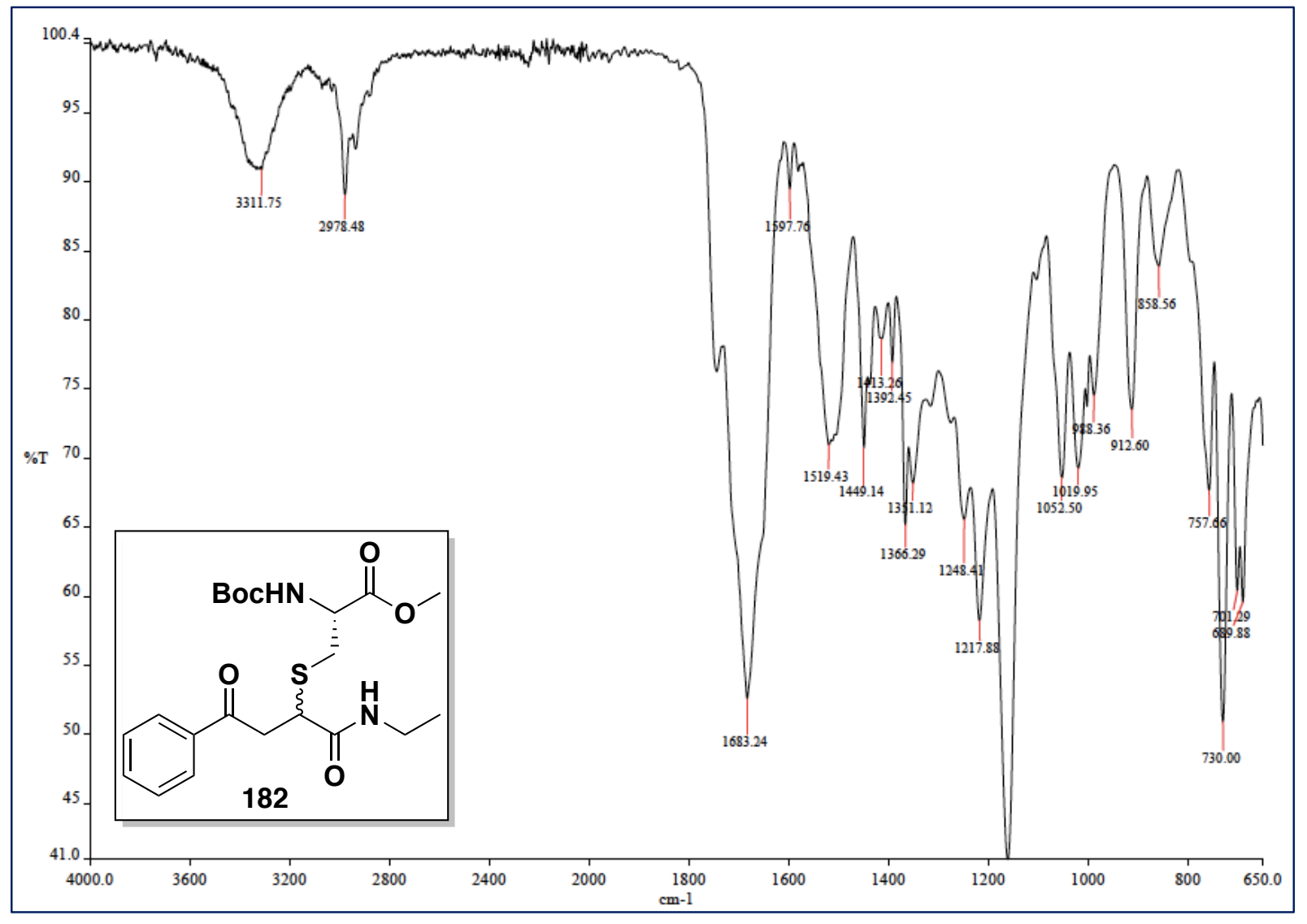



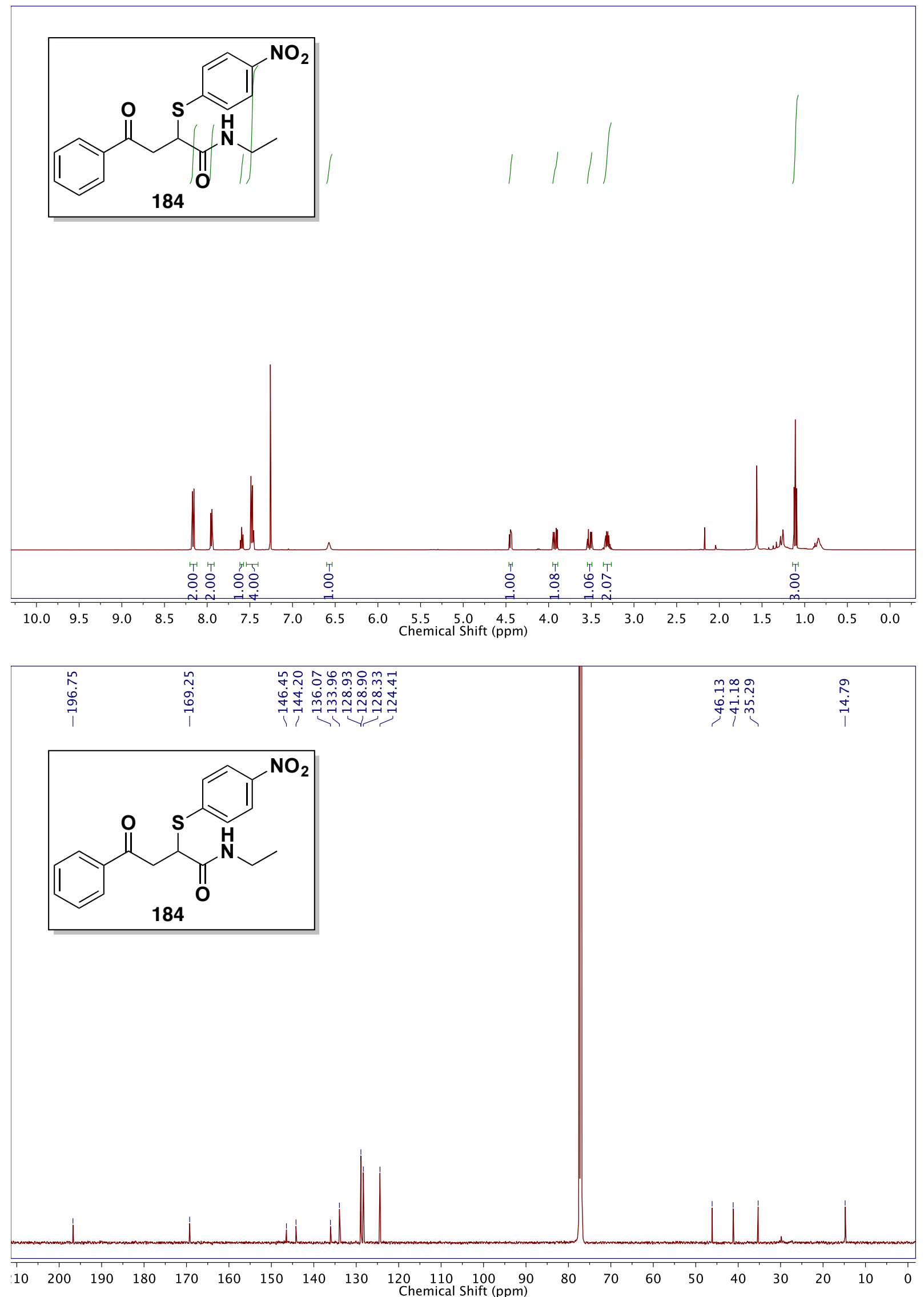


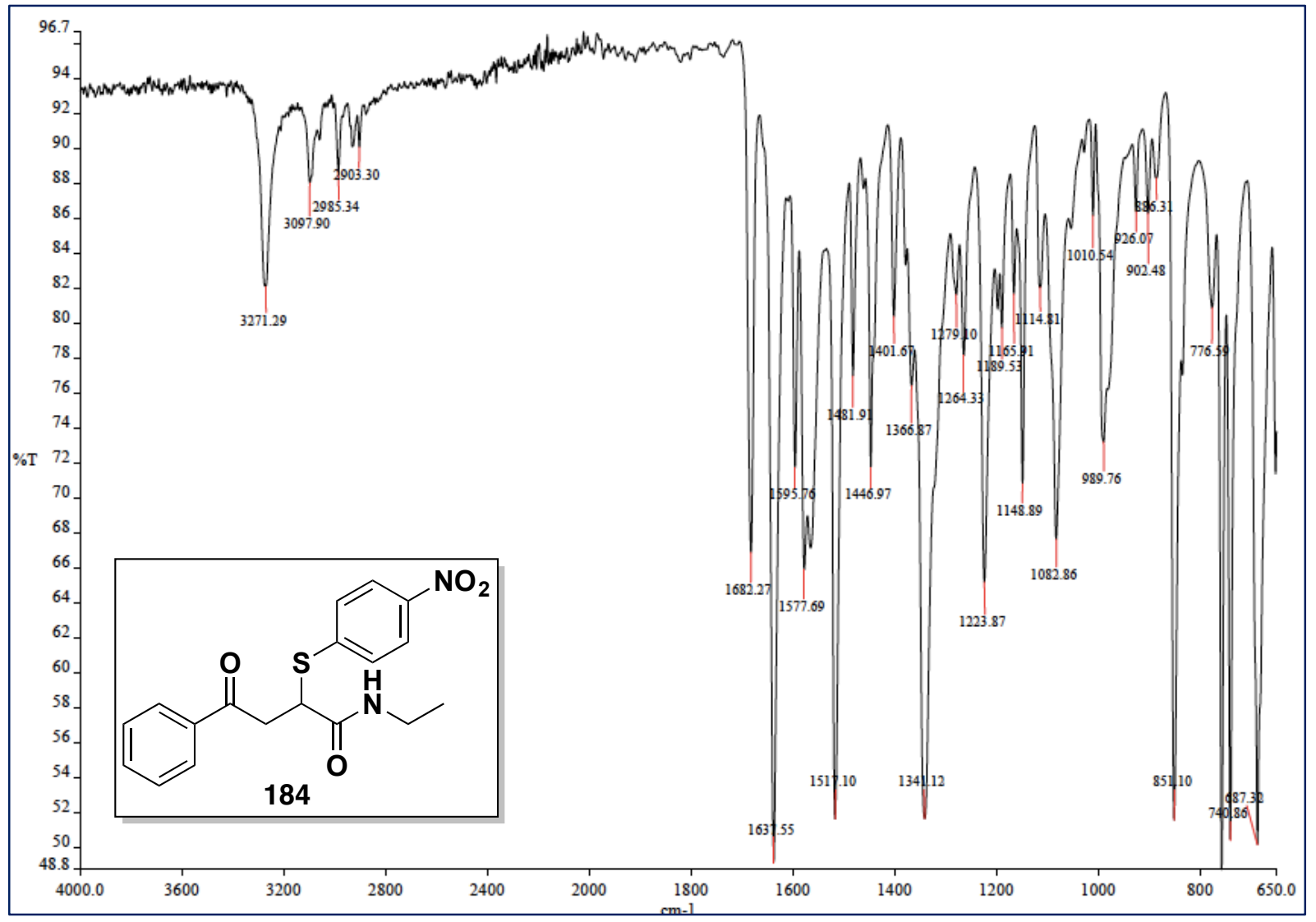



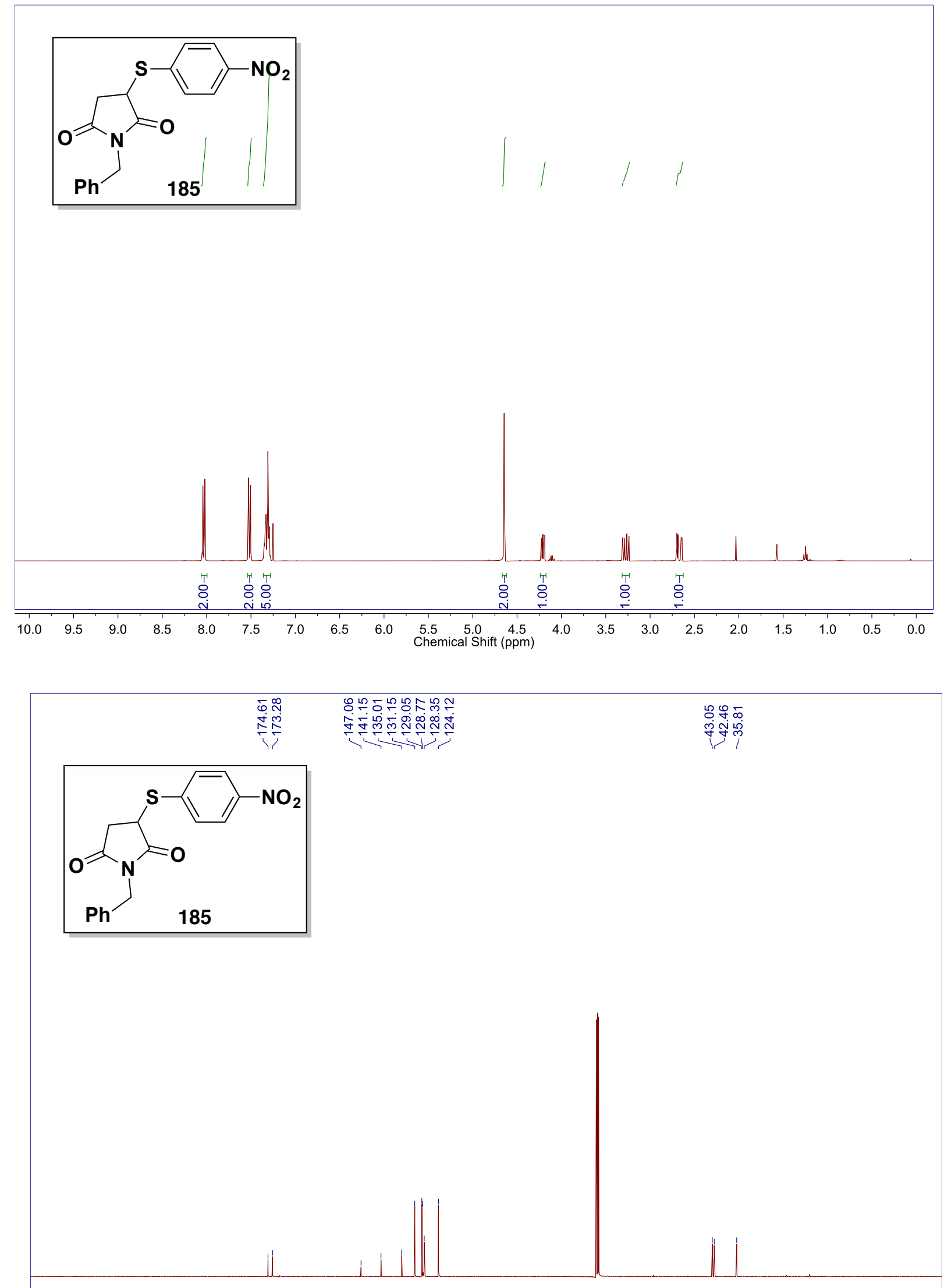

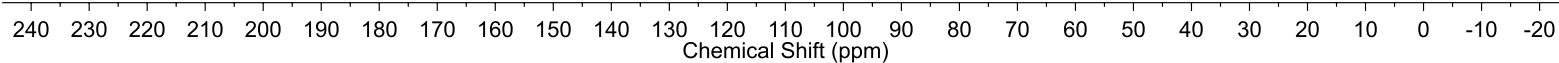



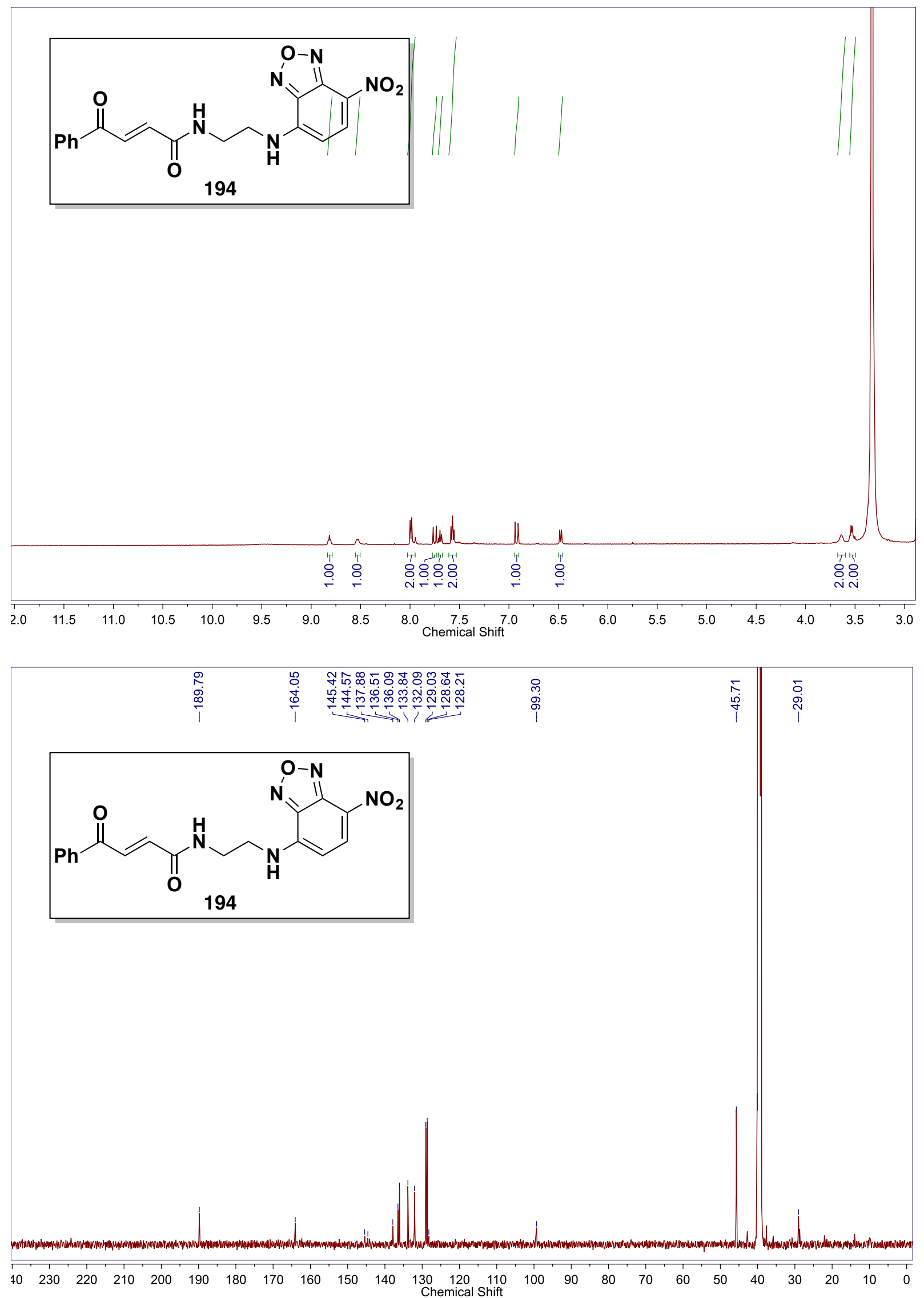

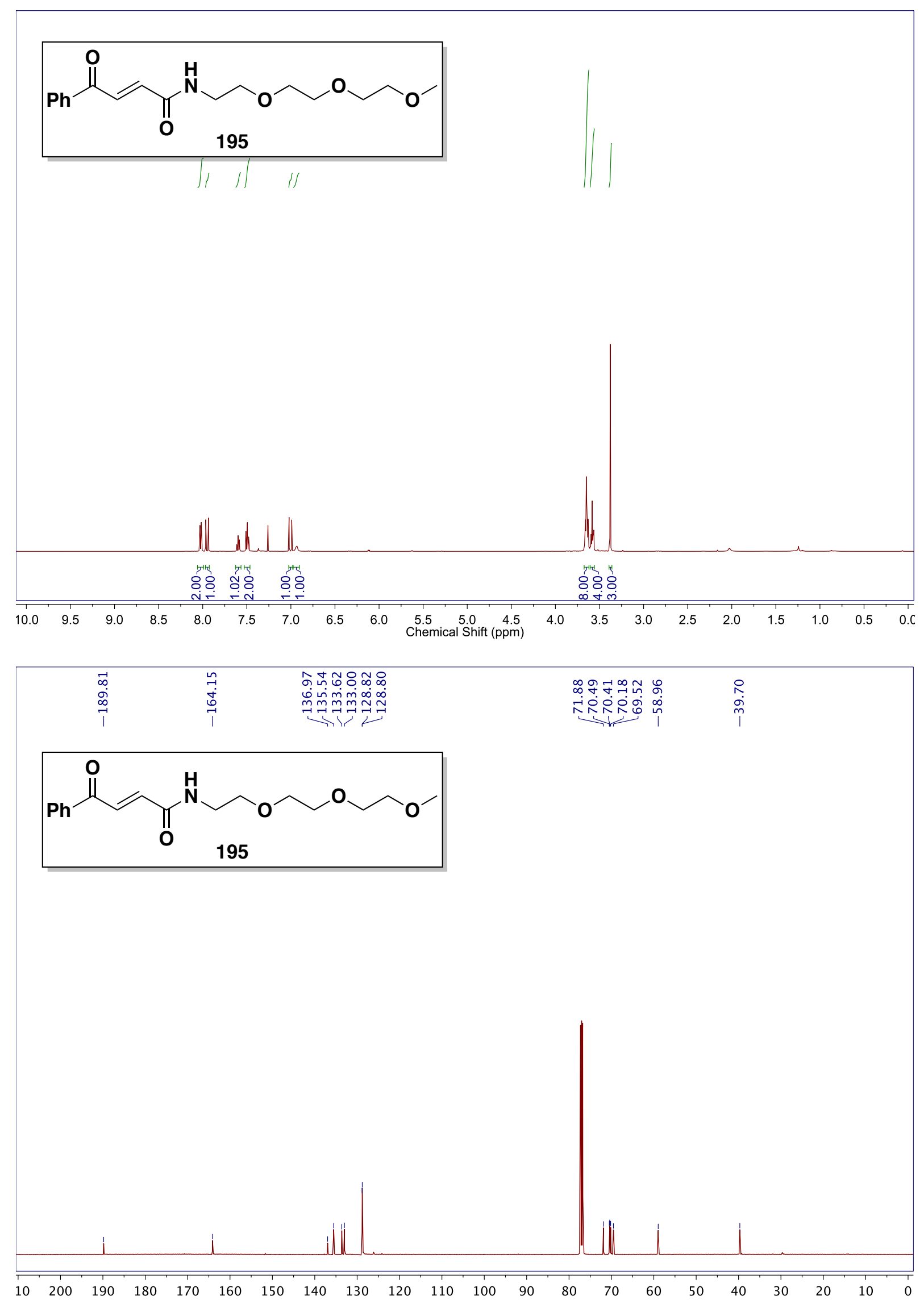

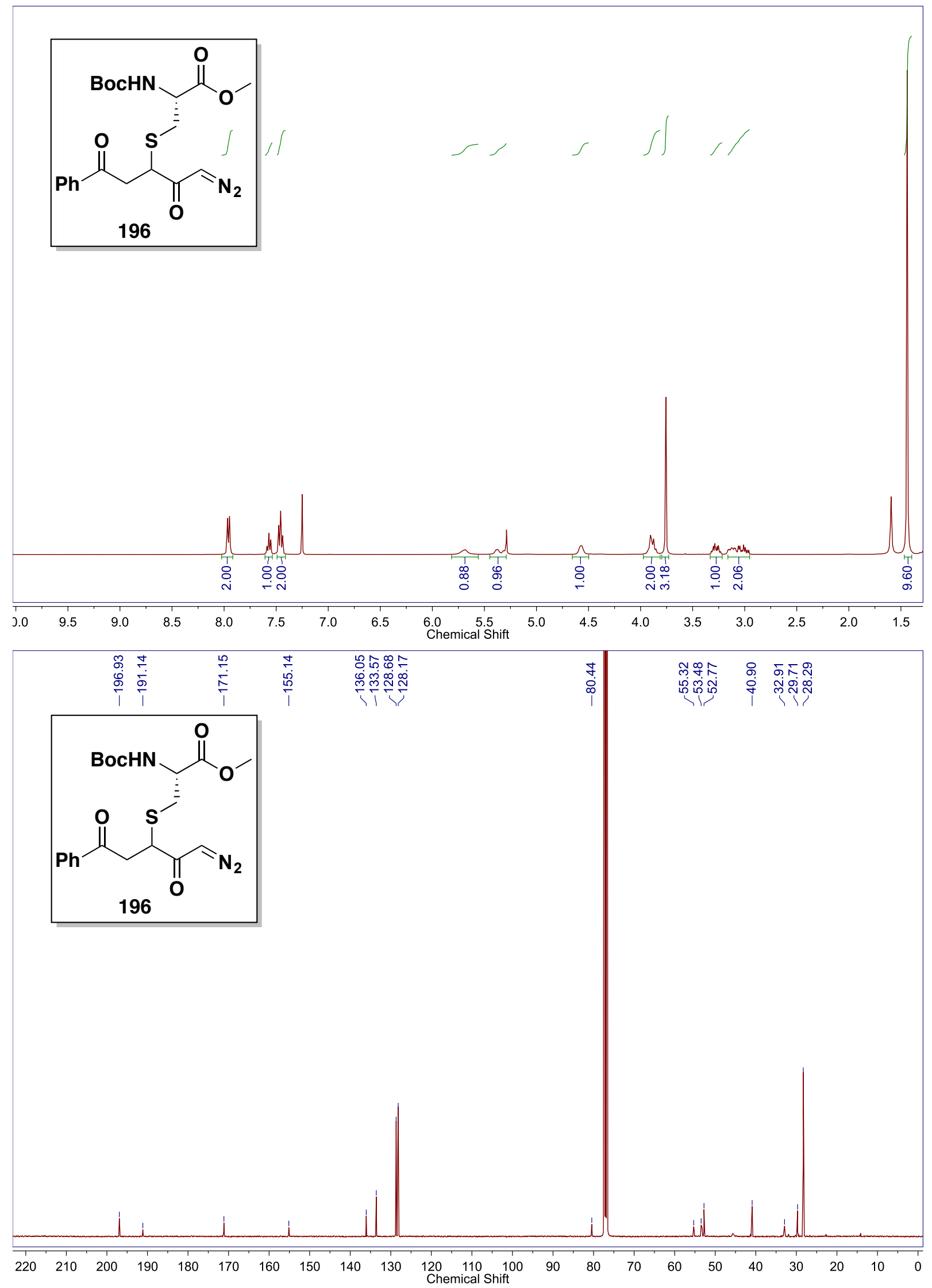


\section{Espectro de distribuição lâmpada de LED}

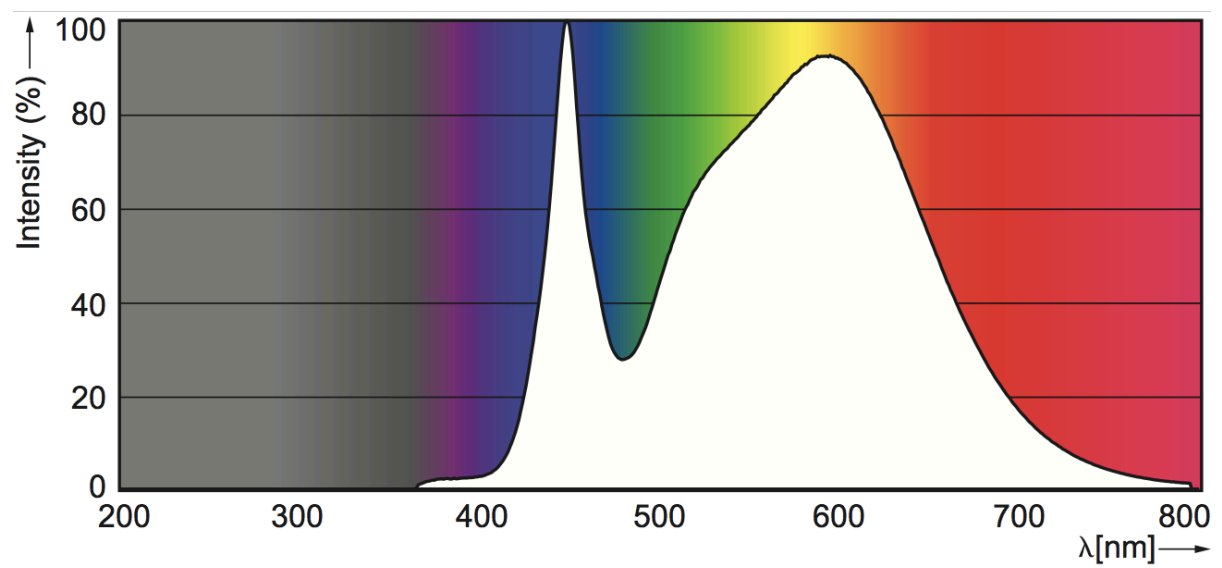

Fonte: dados fornecidos pelo fabricante no arquivo de especificação detalhada do produto. Website: http://www.lighting.philips.com/main/prof/led-lamps-and-systems/led-lamps/master-ledspot-par Mais detalhes: http://www.p4c.philips.com/cgi-bin/zip.pl?p=ZFI\&locale=en_AA\&d=adam\&ids=ADAM20160215152019698\&filename=ZFI-files.zip (C) 2017 Philips Lighting Holding B.V.

\section{Espectro de distribuição lâmpada de Xenônio}

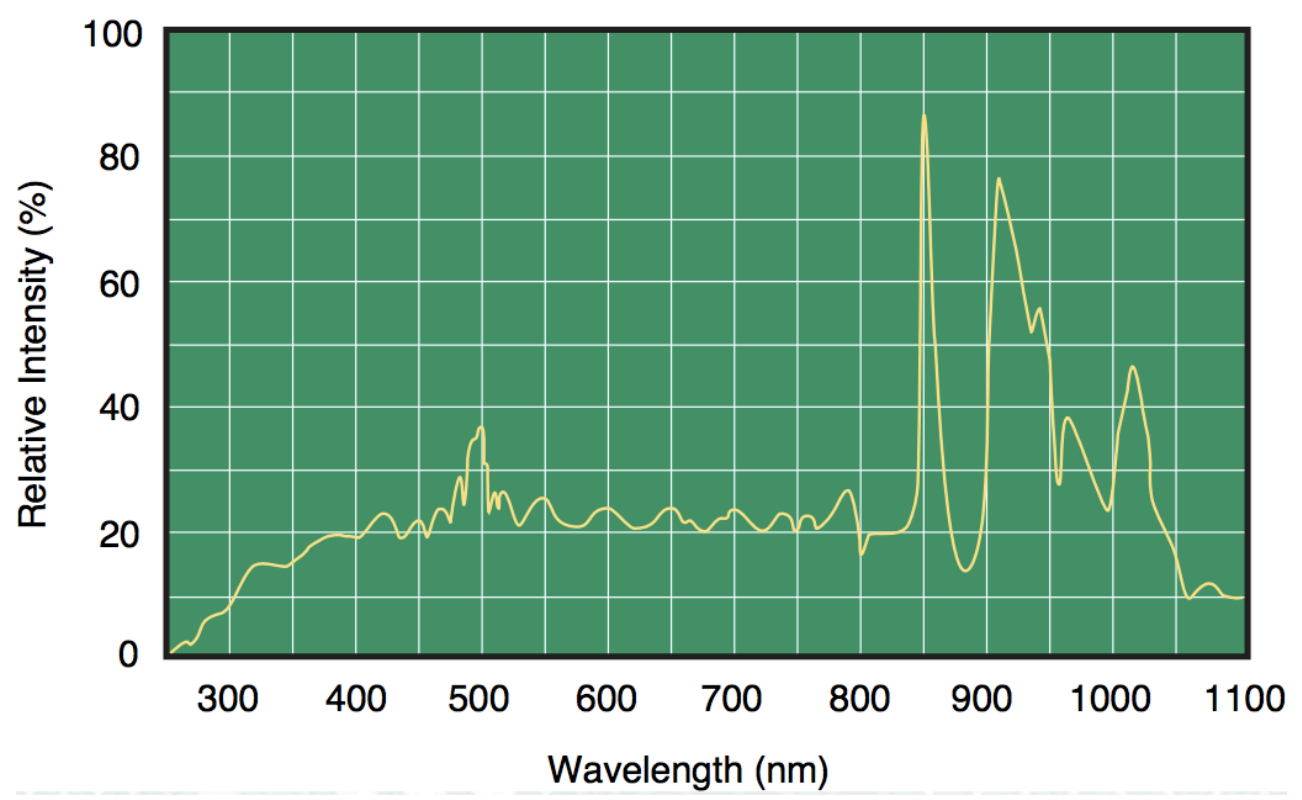

Fonte: dados fornecidos pelo fabricante no arquivo de especificação detalhada do produto.

Website: http://www.ushio.com/files/specifications/xenon-short-arc-uxl.pdf Mais detalhes: https://www.ushio.co.jp/documents/en/products/light_source/UXL302_O_E.pdf (C) 2006 USHIO America, Inc. 